\title{
REFERENCE
}

\section{HANDBOOK OF ANCIENT AFRO-EURASIAN ECONOMIES}

Edited by Sitta von Reden

VOLUME 1: CONTEXTS

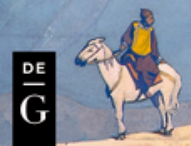


Sitta von Reden (ed.)

Handbook of Ancient Afro-Eurasian Economies

Volume 1: Contexts 



\section{Handbook of Ancient Afro-Eurasian Economies}

Volume 1: Contexts

Edited by

Sitta von Reden

In cooperation with

Mamta Dwivedi, Lara Fabian, Kathrin Leese-Messing, Lauren Morris, and Eli J. S. Weaverdyck 


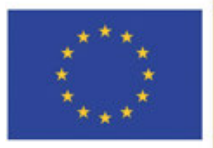

This project has received funding from the European Research Council (ERC) under the European Union's Horizon 2020 research and innovation programme (grant agreement No 742645).

ISBN 978-3-11-060451-1

e-ISBN (PDF) 978-3-11-060774-1

e-ISBN (EPUB) 978-3-11-060494-8

\section{(cc) BY-NC-ND}

This work is licensed under a Creative Commons Attribution-NonCommercial-NoDerivatives 4.0 International License. For details go to http://creativecommons.org/licenses/by-nc-nd/4.0/.

\section{Library of Congress Control Number: 2019946355}

\section{Bibliographic information published by the Deutsche Nationalbibliothek} The Deutsche Nationalbibliothek lists this publication in the Deutsche Nationalbibliografie; detailed bibliographic data are available on the Internet at http://dnb.dnb.de.

(C) 2020 Sitta von Reden and the chapters' contributitors. Published by Walter de Gruyter GmbH, Berlin/Boston

This book is published with open access at www.degruyter.com.

Cover illustration: Remember/ Помни, by Nicholai Roerich (1924), Roerich Museum (New York) (c) Bridgeman Images (Berlin).

Typesetting: Meta Systems Publishing \& Printservices GmbH, Wustermark Print and binding: CPI books $\mathrm{GmbH}$, Leck

www.degruyter.com 


\title{
Acknowledgements
}

This handbook is based on the interdisciplinary research project "Beyond the Silk Road: Economic Development, Frontier-Zones, and Inter-Imperiality in the AfroEurasian Weorld Region (300 BCE to $300 \mathrm{CE}$ ), " and made possible through the award of an Advanced Grant by the European Research Council from 2017 to 2022 (ERCADG 742645). Further particulars about our research can be found on our website www.basar.uni-freiburg.de. We wish to thank the European Research Council and the anonymous readers of the proposal for their financial support and helpful comments. We are also grateful to our scientific advisors, Anthony Barbieri-Low, Peter Eich, Enno Giele, Herrmann Kulke, Rachel Mairs, Bryan Miller, Richard Payne, Himanshu Prahba Ray, Armin Selbitschka, Michael Speidel, Soeren Stark, Miguel John Versluys, and Josef Wiesehöfer, for their advice and encouragement especially during the early stages of this project.

At the University of Freiburg we benefitted from the help and expertise of Marco Ferrario and Milinda Hoo, while Peter Palm, Berlin, drew all the maps for this volume. Special thanks go to Alison Weaverdyck who corrected the English of the nonnative speakers, and to Mark Marsh-Hunn who added last-minute support. Clara Hillebrecht has been our incessant assistant during the entire period of research for the first volume, while she, Benedict Lerbs, and Stephan Neitmann have helped to prepare the manuscript for publication. Last but not least we thank Florian Hoppe at de Gruyter Press for suggesting and encouraging the publication of the results of this project in the form of a handbook, and for his patient advice in any editorial matter.

\author{
Mamta Dwivedi \\ Lara Fabian \\ Tsang Wing $M a$ \\ Kathrin Leese-Messing \\ Lauren Morris \\ Sitta von Reden \\ Eli Weaverdyck
}

○ Open Access. (C) 2020 published by De Gruyter. (c) BY-NC-ND This work is licensed 



\section{Contents}

Acknowledgements $-\mathrm{v}$

List of Contributors - $-\mathbf{x i}$

Transliteration and Orthography - xiii

Abbreviations - $\mathbf{x v}$

Sitta von Reden

Introduction: Ancient Economies and Global Connections - 1

\section{Part I: Empires}

Sitta von Reden

Introduction -13

Sitta von Reden

1 The Hellenistic Empires - 15

Lauren Morris

2 Central Asian Empires - 53

Mamta Dwivedi

3 Early Historic South Asia - 95

Kathrin Leese-Messing

4 The Qin and Han Empires - 129

Ursula Brosseder

5 The Xiongnu Empire - 195

Lara Fabian

6 The Arsakid Empire - 205

Eli J. S. Weaverdyck

7 The Roman Empire - 241 


\section{Part II: Evidence}

Sitta von Reden

Introduction -307

8 Graeco-Roman Evidence - 311

Eli J. S. Weaverdyck

8.A Material Evidence - 311

Eli J. S. Weaverdyck

8.B Transmitted Texts -343

Sitta von Reden

8.C Documentary Sources - 357

Lauren Morris

9 Evidence for Central Asia - 381

10 Evidence for Early South Asia — 423

Mamta Dwivedi

10.A Indic Sources -423

Sitta von Reden

10.B Graeco-Roman Indography - 469

Josef Wiesehöfer

11 Evidence for Arsakid Economic History - 477

12 Qin and Han Evidence -497

Kathrin Leese-Messing

12.A Transmitted Texts -497

Tsang Wing $\mathrm{Ma}$

12.B Excavated Texts -529

Kathrin Leese-Messing

12.C Material Evidence: Lacquerware $-\mathbf{5 5 7}$ 


\section{Part III: Historiographies}

Lara Fabian

Introduction $-\mathbf{5 7 7}$

Lara Fabian

13 Russian Perspectives on Eurasian Pasts - 581

Tsang Wing Ma

14 The Qin and Han Economies in Modern Chinese and Japanese Historiographies -619

Mamta Dwivedi

15 Trends in Economic History Writing of Early South Asia - 641

Lauren Morris

16 Constructing Ancient Central Asia's Economic History — 669

Sitta von Reden and Michael Speidel

17 Economy, Frontiers, and the Silk Road in Western Historiographies of Graeco-Roman Antiquity - 693

Index -729 



\section{List of Contributors}

Ursula Brosseder is an archaeologist at the University of Bonn, spezializing in the archaeology of Inner Asia and Mongolia from the Bronze Age to the Late Iron Age and beyond. Having received her Ph.D. from Freie Universität Berlin, she has focused on the Xiongnu Empire and long-distance exchanges in the Eurasian steppe world. From 2015, she has been Principle Investigator of a research project centering on bioarchaeological investigations of cemeteries in Central Mongolia. Together with Bryan Miller, she edited Xiongnu Archaeology - Multidisciplinary perspectives of the first Steppe Empire in Inner Asia (2011). She has been an associate member of the BaSaR project since 2017.

Mamta Dwivedi, as a student of ancient history, was awarded her Ph.D. from Jawaharlal Nehru University (New Delhi) in 2016. Her research interest includes economic thought and monetary systems in early historic South Asia. She joined the BaSaR project in September 2017 and since then has developed an interest in questions of connectivity and economic history in South Asia.

Lara Fabian is an archaeologist working in the Circumpontic and Caspian zones, focusing on the responses of communities living at the juncture of the Roman, Arsakid, and 'Sarmatian' mobile pastoralist worlds. She earned a Ph.D. in the Art and Archealogy of the Mediterranean World graduate group from the University of Pennsylvania in 2018. Her dissertation examined the history, archaeology, and archaeological historiography of Caucasian Albania in the eastern Caucasus, and she has ongoing fieldwork in Azerbaijan. She joined the BaSaR project in October 2017.

Kathrin Leese-Messing is a Sinologist with research interests in ancient and early medieval Chinese historiography as well as cultural and economic history. She earned her Ph.D. from the University of Munich (LMU) in 2014 with a dissertation published as Tradition im Wandel. Historiographiegeschichtliche Studien zu Chen Shous 陳壽 Sanguo zhi 三國志 (Tradition in Transition. Studies on Chen Shou's Sanguo zhi and its Place in the History of Chinese Historiography). She joined the BaSaR project in September 2017.

Tsang Wing Ma, Assistant Professor of History at the University of Macau, is an historian of ancient China. He completed his doctoral dissertation under the title "Scribes in Early Imperial China" at the University of California, Santa Barbara in 2017. His works appear in T'oung Pao, Bulletin of Institute of History and Philology Academia Sinica, Journal of Chinese Studies, and Jianbo, including "Scribes, Assistants, and the Materiality of Administrative Documents in Qin-Early Han China: Exacavated Evidence from Liye, Shuihudi, and Zhangjiashan." He joined the BaSaR project from 2017 to 2018.

Lauren Morris is an archaeologist particularly interested in the urban archaeology, numismatics, and history of pre-Islamic Central Asia, especially under the Kushans. 
First studying at the University of Sydney, she wrote her doctoral dissertation on the Begram hoard (Afghanistan) at the University of Munich (LMU). She joined the BaSaR project in October 2017.

Sitta von Reden is Professor of Ancient History at the University of Freiburg. Her research concentrates on classical Greek and Hellenistic history with a special focus on Egypt. She has published in Greek and Roman economic history, including Money in Ptolemaic Egypt (2007), Money in Classical Antiquity (2010) and Die Antike Wirtschaft (2015). A comparative history of Hellenistic Empires, edited together with C. Fischer-Bovet, is forthcoming. She is Principal Investigator of the BaSaR project.

Michael A. Speidel, currently Research Professor and 'Polonez' Fellow at the Institute of Archaeology of the University of Warsaw, is an ancient historian. He has widely published on various subjects of Roman imperial history, including long distance trade and foreign relations. He is an associate member of the BaSaR project.

Eli J. S. Weaverdyck is an archaeologist and historian of ancient Rome with research interests in economic history, landscape archaeology, the social history of the Roman army, and spatial analysis methods. He earned his Ph.D. from the University of California, Berkeley in 2016 with a dissertation titled "Isolation or Integration? A Spatial Analytical Approach to the Local Impact of the Roman Army on the Northern Frontier.” He joined the BaSaR project in September 2017.

Josef Wiesehöfer is retired Professor of Ancient History at the University of Kiel. His main scholarly interests lie in the history of the ancient Near East (especially pre-Islamic Iran) and its relations with the Graeco-Roman worlds, and in the history of scholarship. His publications include Ancient Persia. From 550 BC to 650 AD (1996, 3rd. ed. 2001), Iraniens, Grecs et Romains (2005), and as editor The Arsacid Empire: Sources and Documentation (1998). Together with S. Müller he has edited Parthika. Greek and Roman Authors' Views of the Arsacid Empire (2017). 


\section{Transliteration and Orthography}

In developing standards for orthography and transliteration for this volume, we have tried to strike a balance between readability and consistency, while also preserving standard practices in the diverse disciplines from which the research emerges.

For Chinese, Hanyu pinyin is used, with texts transliterated according to other systems standardized according to this system. For Indic languages, the conventions of the International Alphabet for Sanskrit Transliteration have been used, and diacritics retained. Modern place names within the South Asian region, however, have been rendered without diacritics, following conventional English-language spellings (thus Sanchi rather than Sãñ̄ī). Cyrillic names and terms are transcribed according to the widely used modified ALA-LC Romanization system without diacritics (e.g., piatichlenka instead of piatichlenka).

Personal names, toponyms, and terminology from the Graeco-Roman world are generally rendered in forms that preserve their original orthography as much as possible (e.g., Antiocheia rather than Antioch; Dionysos instead of Dionysus). However, in cases where a word has a generally accepted English spelling, we have followed that convention (Carthage rather than Karthago; Cyrene rather than Kyrene). We have also allowed multiple spellings of certain names and terms, where cross-disciplinary consistency clashed with disciplinary conventions. Thus, we kept Śaka alongside Saka and Kuṣanna alongside Kushan.

Ә Open Access. (C 2020 published by De Gruyter. (c) BY-NC-ND This work is licensed 



\section{Abbreviations}

Ancient literary works from the Greek and Latin corpora are cited in full upon first reference, and then abbreviated according to the conventions of the Oxford Classical Dictionary, third edition. Corpora of epigraphic and numismatic evidence are abbreviated using the same conventions. Papyri, ostraca and tablets are cited according to the Checklist of Greek, Latin, Demotic and Coptic papyri, ostraca and tablets (https://papyri.info/docs/checklist).

Ancient transmitted works from the Chinese tradition are cited according to Sinological norms, such that Shiji 15.685 refers to Shiji chapter 15, page 685 in the Zhonghua shuju edition. These sources are listed under the title of the work in chapter bibliographies. 



\section{Sitta von Reden}

\section{Introduction: Ancient Economies and Global Connections}

The purpose of this three-volume handbook is twofold. First, it aims to provide a tool for interdisciplinary research on ancient economies during the imperial period of the third century BCE to the third century CE. Second, it aims to suggest ways of approaching the connectivity of the Afro-Eurasian region from a new economic perspective. It is widely acknowledged that the expansion of relationships between the Afro-Eurasian empires in antiquity was accompanied by the movement of large amounts of goods: fine textiles, leather items, pearls, ivory, dies, spices, drugs, unguents, animals, and much more. The visibility of such items in places far away from their origin leaves no doubt. Yet the mechanisms by which these goods were mobilized in their areas of production or extraction, and the exchange systems through which they spread into distant locations, are far less certain. We argue that the notion of Silk Road trade based on nineteenth-century perceptions of caravan trade, national economies, and markets is ill-suited to analyzing the nature and dynamics of the connectivity of ancient empires. ${ }^{1}$ The chapters of this handbook aim to globalize ancient history without presuming a context that make ancient inter-imperial economic connections a precursor of modern globalization. ${ }^{2}$

Over the last 15 years, scholarship has seen a proliferation of comparative research on ancient empires. ${ }^{3}$ The question of connections across Eurasia, in contrast, has suffered relative neglect or has been locked within the flawed notion of the Silk Road. This handbook attempts to shift the problem of connections into a framework that has been developed in world history and world systems theory. It starts from the uncontroversial fact that while ancient imperial courts and historiographers invented empires as 'one' and universal, they were neither culturally homogenous nor fully self-sufficient. ${ }^{4}$ The complicated levels of interdependence of imperial and local economies, as well as the diversity of social and ecological landscapes within which exchanges took place, make it hard to approach empires as socio-political 'containers' engaging with other such containers via international trade. The concept of inter-imperiality, in contrast, brings into focus local economic and ecological heterogeneity, peripheries, as well as imperial coevolution and global (inter)depen

1 Christian 2000; Rhezakani 2010; Chin 2013. Hansen 2012, 7-8 and Galli 2017 for the commercial background of the nineteenth-century Silk Road concept.

2 Osterhammel 2011; Jennings 2011 for different approaches to globalization in historical perspective.

3 Morris and Scheidel 2009; Scheidel 2009; 2015; Bang and Bayly 2011; Gehler and Rollinger 2014; Monson and Scheidel 2015.

4 Barkey 2008; Burbank and Cooper 2010; Düring and Stek 2018.

Ә Open Access. (c) 2020 Sitta von Reden, published by De Gruyter. (c) BY-NC-ND This work is licensed under the Creative Commons Attribution-NonCommercial-NoDerivatives 4.0 License.

https://doi.org/10.1515/9783110607741-001 
dency structures. ${ }^{5}$ It focuses attention on regions and landscapes at the edges and in between empires as nodes of exchange and interaction. ${ }^{6}$ Much recent historical and archaeological research has established ancient imperial peripheries and frontier zones as distinct regions of economic activity and connectivity. ${ }^{7}$ Frontier zones are strongly affected by, and affect, imperial development and the fiscal-military politics of nearby or overarching empires. At the same time, frontier zone economies have their own logics, develop special economic opportunities as a result of their location, and in turn have important effects on imperial consolidation. ${ }^{8}$ In the context of inter-imperial exchange, they are not peripheral but central. The focus on frontier zone processes allows us to analyze long-distance trade within the AfroEurasian inhabited world, giving due recognition to the fact that this trade was mediated and often shaped by local or at most regional exchange networks with profound imperial impact.

The chronological frame we have chosen for the handbook aims to slice out a historically meaningful period in ancient world history. ${ }^{9}$ The centuries between 300 BCE and 300 CE form a distinct period of dynamic empire formation and transformation in the Afro-Eurasian zone. ${ }^{10}$ The Hellenistic Empires forming in the aftermath of the conquests of Alexander the Great at the end of the fourth century BCE for the first time created imperial connections between the Greek mainland, Egypt, the Red Sea, and western and Central Asia as far as northern India and the Pamir mountains. At roughly the same time, the Qin and Han dynasties formed the first multiethnic empire in East Asia, while the Mauryans developed what might be called imperial corridors through the Indian subcontinent. In a process of imperial coevolution, the Xiongnu in the Inner Asian steppe promoted greater degrees of political cohesion alongside the Qin and Han, while the Arsakids (Parthians) emerged as a new imperial power independent of the Seleukids, spreading from the Central Asian steppe into western Asia in the course of the third century BCE. The end of the period is marked by significant imperial transformation across Afro-Eurasia, which profoundly affected the nature of connectivity. Explicit textual references to long-distance commercial trade along overland routes reaching from China via Sogdiana into Central Asia to markets in northern Mesopotamia and the Mediterranean increase in the fourth century CE. ${ }^{11}$ Before that time, similarly explicit evidence concentrates on the maritime routes between India, the Arabian Peninsula and Egypt, and between the Persian Gulf and Syria via the Euphrates and Palmyra. ${ }^{12}$

5 L. Doyle 2014a; 2014b; see also Turchin 2009.

6 Sahadeo 2011.

7 Cherry 2007; Düring and Stek 2018, 3-6 with further bibliography.

8 Rodseth and Parker 2005; Reger 2017; Boozer 2018.

9 Bentley 1996; McKeon 2012; Brosseder 2015, 200-203.

10 Turchin 2009 within a different argument.

11 Hansen 2012, 19-21; Kolb and Speidel 2017.

12 Young 2001; Evers 2016; Cobb 2018. 
This discrepancy is not accidental, we argue, but the consequence of geopolitical, imperial, and religious change. From the time of the fourth century CE onward, the Roman Empire and the integration of its frontier zones changed significantly. By the fifth and sixth centuries, the imperial world of the Mediterranean and western Asia had transformed into what has been called a "commonwealth of kingdoms," or "empires of faith." 13 They marked the beginning of new social and religious orders, a greater mobility of people, and new forms of identity emerging from religious rather than imperial ideologies of belonging. ${ }^{14}$ In East, South, and Central Asia, the imperial context changed likewise, though in different ways, with the fall of the Han dynasty, the decline of the Kushan Empire, and the subsequent fragmentation of Central Asia. Yet, the mobility of religious groups and Buddhist forms of ritual expression and art drove new common identities, exchange, and interaction between Indian, Central Asian, and Chinese communities. ${ }^{15}$ The imperial world of the previous period was conducive to global connections, too, but in very different ways.

Imperial formations strongly influence local economies and the flow of resources and agrarian surplus. Empires are defined as multiethnic political entities, usually created by conquest, held together by a fiscal-tributary regime, and dominated by a political center that exerts some form of power over its constituencies and far distant peripheries. ${ }^{16}$ Despite their relatively loose control over regions and local populations, empires create - like more tightly integrated states - a certain degree of institutional stability through administrative and material infrastructures, protection, access to adjudication, and sometimes common coinages. ${ }^{17}$ However, being less well integrated than modern nation-states, imperial polities are better approached in terms of overlapping local, regional, and trans-regional exchange networks rather than as national market economies governed by effective state policy, regulation of coinage, and cohesive structures of contractual law. ${ }^{18}$ At the same time, the ability of hegemonic emperors to concentrate resources through oppressive fiscal-military regimes leads to the growth of nodes of consumption in the form of spectacular imperial courts and royal cities, large imperial armies, and a gradual increase of administrative institutionalization as a result of tribute extraction and

13 Fowden 1993; Sarris 2011.

14 Beautifully described by Brown 2018.

15 Neelis 2010; 2012.

16 Classically formulated by M. Doyle 1986, and comparative studies in, e.g., Alcock et al. 2001; Burbank and Cooper 2010; Cline and Graham 2011; Bang and Bayly 2011; Hurlet 2008; Gehler and Rollinger 2014; Stek and Düring 2018.

17 Allsen 2011.

18 Ristvet 2018 for the term network empire. The development of more integrated market economies in the course of empire consolidation and greater degrees of state integration has been discussed intensely in connection with the Roman Empire and its long-term development from the second century BCE to the third century CE; see, e.g., Eich and Eich 2005; Scheidel 2015. 
imperial governance. Effective extraction of tribute, as Shmuel Eisenstadt has famously argued, mobilizes resources and agricultural surplus that otherwise are locked into the claims and consumption regimes of local aristocracies, religious institutions, and other rural or urban hierarchies. ${ }^{19}$ In many imperial formations, the disposable economic surplus may not increase through increased productivity and technological change, but through the mobilization of local resources and their subsequent entry into larger circuits of exchange. It has been suggested therefore that the organizing principles of the economies of tributary empires are likely to have differed from the political economies of nation-states. ${ }^{20}$ Production regimes were influenced by fiscal extraction and imperial consumption rather than by market forces. And capital accumulation was not achieved by capital investment and productive credit, but by what Subrahanjaman and Bayly have called "portfolio capitalism”: entrepreneurial strategies of making agricultural surplus disposable through market institutions, which were mobilized by fiscal demand. ${ }^{21}$

The emphasis on particular principles of imperial economies does not dispute the potential of ancient empires to increase productivity, to stimulate market exchange, credit, and private economic initiative, leading to better economic performance. It does not dispute the interest of local governments and private economic agents in improving management structures, technology, and institutional infrastructures. But it calls for the need to understand such developments as processes demanding explanation, rather than simply being taken for granted in a grand narrative of market development and global commercial trade. It is our contention that frontier zone development had important feedback effects on the empires in the Afro-Eurasian region, that it stimulated inter-imperial connectivity, as well as local, regional, and imperial economic development.

This handbook proceeds in three steps in order to develop these various lines of thought in the framework of interdisciplinary research. In the first volume we discuss historical, evidentiary, and historiographic contexts that are indispensable for understanding trans-imperial connectivity. These contexts provide an introduction to historical discussions and a foundation for comparative analyses. Moreover, they develop transparent and reflexive lines of inquiry about how evidentiary and historiographic discrepancies have affected historical understanding, particularly in a trans-regional and interdisciplinary setting. One of the big challenges of interdisciplinary work is the question of how to cut across disciplinary boundaries. Collaborative volumes tend to produce parallel demonstrations with little dialog between individual contributions. Single-author publications, by contrast, have a basis in one field combined with limited expertise in others. In order to overcome some of these obstacles, the chapters of this volume have been written by an inter-

19 Eisenstadt (1963) 2010, xvi, 33-68.

20 Bang 2007; 2008.

21 Bang 2007, 25; Subrahanjaman and Bayly 1988. 
disciplinary team that has collaborated on a daily basis. By providing in-depth analyses, each of which being targeted at readers who are external to that particular field, we aim to provide a foundation for more informed interdisciplinary dialog.

The first section of the volume provides contextual information about the AfroEurasian world zone in the form of historical overviews. The pioneering studies of ancient global trade, still resonating in more recent work, attributed to particular empires specific functions in the movement of goods from East to West: China and India, with their wealth in precious resources consumed as luxuries elsewhere, were the suppliers; the elites of the Hellenistic and Roman Empires were the consumers; and the poorly documented polities and mobile pastoralist spaces of Inner and Central Asia were attributed the sad role of having been mere transit zones. ${ }^{22}$ With our discussions of these empires, we aim to open the debate about their functions by outlining each empire as a heterogeneous socio-political space that filled multiple roles in exchange circuits of various kinds and scales.

Ancient empires, moreover, are known to us through very uneven sorts and volumes of evidence. The second context presented in this volume is, therefore, a series of chapters that discuss the different types of evidence and the methodologies of interpretation that have been brought to bear on economic history across the region. Discrepancies between the evidentiary bodies lie behind many of the false assumptions that underpin modern accounts of ancient Afro-Eurasian connectivity. Working with this material requires bringing together very separate textual traditions and archaeologies in order to overcome imbalances in the data, a process that requires great care. The final part of the first volume situates ancient economic histories and Silk Road studies within a third context: that of particular historiographical and disciplinary traditions. Not only have different scientific communities approached economic history differently, but these histories have played different roles in processes of national identity formation and the national self-positioning in local or imperial pasts. Tracing several discourses concerning the study of AfroEurasian economic history helps to explain the divergent nature of contemporary conversations about this space, while also contextualizing the work of previous generations of scholars and increasing its legibility and reconsideration within our own frameworks.

In the second volume we identify economic structures and developments that allowed resources, goods, and capital to concentrate as well as to spread into frontier zones. Over the last generations, economic history, archaeology, and anthropology have seen a large amount of theoretical work which has increased our understanding of economic development in vastly different social and ecological settings. We will use these insights in order to develop models of explanation and

22 Chase-Dunn and Hall 1977, 149-187; Cameron and Neal 1986, 20-43. Examples of more recent work include Fitzpatrick 2011 and many studies on Indo-Roman trade; Chakravarti 2015 for discussion. 
methods of analysis that are suitable for comparative research at a global scale. We start from nodes of acquisition and consumption that are visible in the archaeological and textual records in the form of households, temples, cities, and capitals, as well as armies that were stationed in some cases permanently in imperial frontier zones. Taking into consideration the diversity of social systems, ecologies, and evidence across the ancient Afro-Eurasian world region, our investigation will be divided into "actors" and "tools" that stimulated extraction, concentration, and circulation. As actors we define administrative systems, social groups, and individuals as much as institutions and landscapes. These actors deployed or acted upon certain tools of extraction, concentration and circulation: money, markets, technology, legal systems, and physical infrastructures. Through these broad categories of analysis we hope to compare and explain different kinds and scales of economic development across the Afro-Eurasian empires without underprivileging regions that have left notoriously difficult evidence.

In the third volume, we will analyze frontier zones and borderlands as sites of social and imperial encounters as well as network formation. ${ }^{23}$ Much recent work has been devoted to analyzing frontiers and borderlands as distinct spaces. They are recognized as specific sites of imperial encounter and interaction in the form of negotiation and appropriation, but also resistance and violence. ${ }^{24}$ Combining recent research foci and the expertise of the researchers collaborating on this handbook, the volume will focus on a particular selection of frontier zones, such as the Egyptian Eastern Desert, Syria, the Ponto-Caspian zone, the Hindu Kush, forested Central India, and the Hexi corridor. While the second volume considers forms of economic development in frontier zones, the chapters of the third volume take a more complex approach to borderland processes. Borderlands and frontiers often form along and across open boundaries between agrarian, pastoral, and coastal communities, as well as along and across different ecologies that require different economic and social strategies. ${ }^{25}$ Such dividing lines suggest, both theoretically and empirically, more complicated scenarios for the movements of goods than is captured by the idea of trade from empire to empire. The second part of this volume will thus turn to the nature of exchange networks within and across imperial frontiers, and their connections to local, regional, and imperial hinterlands. Although, given the structure of available datasets, formal network approaches are only occasionally applicable, we nevertheless favor network perspectives as they are less loaded with economic presumptions than market concepts. ${ }^{26}$ Networks and markets are two spatial

23 Boozer 2018, 209-214 for a discussion of the concepts of frontier zone and borderland, often used interchangeably. Brosseder 2015 for the different anthropological models and network theories that have been applied to long-distance exchange in recent archaeological and anthropological research.

24 Ristvet 2018.

25 Stek and Düring 2018, 357-358.

26 Brosseder 2015, 209-210. 
expressions of exchange that relate small intensive and large extensive circuits of exchange together, often under particular local social, military, religious, and administrative circumstances. ${ }^{27}$ There is no doubt that much exchange in frontier zones took the form of trade via marketplaces, as markets provide a unique degree of condensation of interaction, as well as great opportunities for institutional and fiscal control. Yet the concept of the market - so closely related to the debates over national economies - underrepresents the social dimensions of exchange, the heterogeneity of its motivations, and its social complexity. ${ }^{28}$ The profound importance of inter-imperial exchange for empire formation and transformation will emerge against the backdrop of these complications in a combination of micro-perspectives and their relevance to understanding larger circuits of exchange connecting vast geographical distances.

\section{References}

Alcock, S. E. 2001. Empires: Perspectives from archaeology and history. Cambridge: Cambridge University Press.

Allsen, T. T. 2011. “Premodern empires.” In J. H. Bentley (ed.), The Oxford handbook of world history, 361-379. Oxford: Oxford University Press.

Bang, P. F. 2007. "Trade and empire: In search for organizing concepts for the Roman economy." Past and Present 195, 3-54.

-. 2008. The Roman bazaar: A comparative study of trade and markets in a tributary empire. Cambridge: Cambridge University Press.

Bang, P. F., and C. A. Bayly, eds. 2011. Tributary empires in world history. Cambridge: Cambridge University Press.

Barkey, K. 2008. Empire of difference: The Ottomans in comparative perspective. Cambridge: Cambridge University Press.

Bentley, J. H. 1996. "Cross-cultural interaction and periodization in world history." American Historical Review 101.3, 749-770.

Boozer, A. L. 2018. "The archaeology of imperial borderlands: A view from Roman Egypt and Sudan." In B. S. Düring and T. D. Stek (eds.), The archaeology of imperial landscapes: A comparative study of empires in the ancient Near East and Mediterranean world, 206-239. Cambridge: Cambridge University Press.

Brosseder, U. 2015. "A study on the complexity and dynamics of interaction and exchange in Late Iron Age Eurasia." In J. Bemmann and M. Schmauder (eds.), Complexity of interaction along the Eurasian steppe zone in the first millennium CE, 199-332. Bonn: Vor- und frühgeschichtliche Archäologie, Rheinische Friedrich-Wilhelms-Universität Bonn.

Brown, P. 2018. "Commerce, diplomacy, and cultural contacts along the Silk Road in Late Antiquity." In N. Di Cosmo and M. Maas (eds.), Empires and exchanges in Eurasian Late Antiquity: Rome, China, Iran, and the steppe, ca. 250-750, 96-107. Cambridge: Cambridge University Press.

27 See the contributions in Knappett 2013; Leidwanger and Knappett 2018.

28 Classically, Granovetter 1985; also Bang 2008. 
Burbank, J., and F. Cooper. 2010. Empires in world history. Power and the politics of difference. Princeton, NJ: Princeton University Press.

Chakravarti, R. 2017. "Examining the hinterland and foreland of the port of Muziris in the wider perspective of the subcontinent's long-distance networks." In K. S. Mathew (ed.), Imperial Rome, Indian Ocean regions and Muziris, 307-338. London: Routledge.

Cameron, R., and L. Neal. 1986. A concise history of the world. Oxford: Oxford University Press.

Chase-Dunn, C., and T. D. Hall. 1977. Rise and demise: Comparing world systems. Boulder, CO: Westview.

Cherry, J. 2007. "The frontier zones." In W. Scheidel, I. Morris, and R. Saller (eds.), The Cambridge economic history of the Greco-Roman world, 720-741. Cambridge: Cambridge University Press.

Chin, T. 2013. "The invention of the Silk Road, 1877." Critical Inquiry 40, 194-219.

Christian, D. 2000. "Silk roads or steppe roads? The silk roads in world history." Journal of World History 11, 1-26.

Cline, E. H., and M. W. Graham. 2011. Ancient empires: From Mesopotamia to the rise of Islam. Cambridge: Cambridge University Press.

Cobb, M. A. 2018. Rome and the Indian Ocean trade from Augustus to the early third century CE. Leiden: Brill.

Doyle, L. 2014a. "Inter-imperiality." Interventions 16.2, 159-96.

-. 2014b. "Dialectics in the longue durée: The IIPEC model of inter-imperial economy and culture." Globalizations 11.5, 689-709.

Doyle, M. 1986. Empires. Ithaka, NY: Cornell University Press.

Düring, B. S., and T. D. Stek. 2018. "Ancient empires on the ground: Provincial and peripheral perspectives." In B. S. Düring and T. D. Stek (eds.), The archaeology of imperial landscapes: A comparative study of empires in the ancient Near East and Mediterranean world, 1-20. Cambridge: Cambridge University Press.

Eich, A., and P. Eich. 2005. "War and state-building in Roman Republican times." Scripta Classica Israelica 24, 1-34.

Eisenstadt, S. (1963) 2010. The political systems of empires. New Brunswick: Transaction Publishers.

Evers, K. G. 2017. Worlds apart trading together: The organisation of long-distance trade between Rome and India in antiquity. Oxford: Archaeopress.

Fitzpatrick, M. P. 2011. "Provincializing Rome: The Indian Ocean trade network and Roman imperialism." Journal of World History 22, 27-54.

Fowden, G. 1993. Empire to commonwealth: Consequences of monotheism in Late Antiquity. Princeton, NJ: Princeton University Press.

Galli, M. 2017. "Beyond frontiers: Ancient Rome and the Eurasian trade networks." Journal of Eurasian Studies 8, 3-9.

Gehler, M., and R. Rollinger, eds. 2014. Imperien und Reiche in der Weltgeschichte. Vol. 1, Imperien des Altertums, mittelalterliche und frühneuzeitliche Imperien. Wiesbaden: Harrassowitz.

Granovetter, M. 1985. "Economic action and social structure: The problem of embeddedness." American Journal of Sociology 91, 481-510.

Hansen, V. 2012. The Silk Road: A new history. Oxford: Oxford University Press.

Hurlet, F., ed. 2008. Les empires: Antiquité et Moyen Âge: Analyse comparée. Rennes: Presses Universitaires de Rennes.

Jennings, J. 2011. Globalizations and the ancient world. Cambridge: Cambridge University Press.

Knappett, C., ed. 2013. Network analysis in archaeology: New approaches to regional interaction. Oxford: Oxford University Press. 
Kolb, A., and M. Speidel. 2017. "Imperial Rome and China: Communication and information transmission." In M. D. Elizalde and J. Wang (eds.), China's development from a global perspective, 28-57. Newcastle upon Tyne: Cambridge Scholars Publishing.

Leidwanger, J., and C. Knappett. 2018. "Maritime networks, connectivity, and mobility in the ancient Mediterranean." In J. Leidwanger and C. Knappett (eds.), Maritime networks in the ancient Mediterranean world, 1-21. Cambridge: Cambridge University Press.

Manning, J. G., and I. Morris. 2005. "Introduction." In J. G. Manning and I. Morris (eds.), The ancient economy: Evidence and models, 1-44. Stanford, CA: Stanford University Press.

McKeown, A. 2012. "What are the units of world history?" In D. Northrop (ed.), A companion to world history, 79-94. Oxford: Wiley-Blackwell.

Monson, A., and W. Scheidel, eds. 2015. Fiscal regimes and the political economy of premodern states. Cambridge: Cambridge University Press.

Morris, I., R. Saller, and W. Scheidel. 2007. "Introduction." In W. Scheidel, I. Morris, and R. Saller (eds.), The Cambridge economic history of the Greco-Roman world, 1-14. Cambridge: Cambridge University Press.

Morris, I., and W. Scheidel, eds. 2009. The dynamics of ancient empires: State power from Assyria to Byzantium. Oxford: Oxford University Press.

Neelis, J. 2010. Early Buddhist transmission and trade network: Mobility and exchange within and beyond the northwestern borderlands of South Asia. Leiden: Brill.

-. 2012. "Overland shortcuts for the transmission of Buddhism." In S. E. Alcock, J. Bodel, and R. J. A. Talbert (eds.), Highways, byways and road systems in the pre-modern world, 1232. Malden, MA: Wiley-Blackwell.

Osterhammel, J. 2011. "Globalizations." In J. H. Bentley (ed.), The Oxford handbook of world history, 89-104. Oxford: Oxford University Press.

Reger, G. 2017. "Romans in the Egyptian desert: From desert space to Roman place." In P. Derron and S. von Reden (eds.), Économy et ínégalité: Ressources, échanges et pouvoir dans l'antiquite classique, 115-144. Vandoeuvres: Fondation Hardt.

Rezakhani, K. 2010. "The road that never was: The Silk Road and trans-Eurasian exchange." Comparative Studies of South Asia, Africa and the Middle East 30, 420-433.

Ristvet, L. 2018. "Negotiation, violence, and resistance: Urartu's frontiers in the Iron Age Caucasus." In B. S. Düring and T. D. Stek (eds.), The archaeology of imperial landscapes: A comparative study of empires in the ancient Near East and Mediterranean world, 175-205. Cambridge: Cambridge University Press.

Rodseth, L., and Parker, B. J. 2005. "Introduction: Theoretical considerations in the study of frontiers." In B. J. Parker and L. Rodseth (eds.), Untaming the frontier in anthropology, archaeology, and history, 3-21. Tuscon, AZ: University of Arizona Press.

Sarris, P. 2011. Empires of faith. The fall of Rome and the rise of Islam. Oxford: Oxford University Press.

Subrahmanyam, S., and C. A. Bayly. 1988. "Portfolio capitalists and the political economy of early modern India." Indian Economic and Social History Review 4, 401-424.

Scheidel, W., ed. 2009. Rome and China: Comparative perspectives on ancient world empires. Oxford: Oxford University Press.

-. 2013. "Studying the state." In P. F. Bang and W. Scheidel (eds.), The Oxford handbook of the state in the Ancient Near East and Mediterranean, 5-60. Oxford: Oxford University Press.

-, ed. 2015. State power in ancient China and Rome. Oxford: Oxford University Press.

Sahadeo, J. 2011. "The accidental traders: Marginalization and opportunity from the Southern Republics to late Soviet Moscow." Central Asia Survey 30.3/4, 521-540.

Stek, T. D., and Düring, B. S. 2018. "Towards a patchwork perspective on ancient empires." In B. S. Düring and T. D. Stek (eds.), The archaeology of imperial landscapes: A comparative study of empires in the ancient Near East and Mediterranean world, 351-362. Cambridge: Cambridge University Press. 
Turchin, A. 2009. “A theory for formation of large empires." Journal of Global History 4, 191-217. Young, G. K. 2001. Rome's eastern trade: International commerce and imperial policy, 31 BC$A D$ 305. London: Routledge. 
Part I: Empires 



\section{Sitta von Reden \\ Introduction}

'Empire' is a historical phenomenon, a frame of mind, a modern concept, and a theme for cross-cultural comparison. ${ }^{1}$ Yet not only is the term imperium Roman, but also imperial ideas and modern concepts of empire are inextricably linked with the Roman model so influential for the development of Western political traditions and thought. It is thus not accidental that the term empire seems well-suited to the Roman case, while it is more controversial among scholars of other historical traditions. Historians of Han China, where comparison with Rome has the longest historiographical pedigree, point to fundamental differences in the conceptions of the rise and the cosmological self-understanding of both empires. Hellenistic historians struggle over the question whether the unceasing competition between the rival Hellenistic kingdoms sits well with the notion of universal empire. The mobility of the Xiongnu makes it hard to identify a political core or centralized governance structures. We know equally little about the precise nature of the Arsakid political organization. In Indian history, moreover, empire comes with particular historiographical baggage, and seems a rather inappropriate term for the partial integration of the subcontinent under successive dynasties.

Yet despite its problems, empire is still the best term to be applied to territorially extensive, multi-ethnic, or composite political spaces with variable degrees of political integration and ideological penetration. In circumscribing a wide variety of political formations with an equally wide variety of sociopolitical substructures, it has proved immensely useful for comparative purposes. Concomitantly, it has received a large degree of theoretical reflection that has helped to reduce essentializing overtones. In contrast to concepts of state, it carries fewer presumptions about institutional consolidation and political integration, and has tamed successfully the terms of imperial decline and collapse into more fluid notions of transition and transformation. Even where constituents break away and form into new political entities, or imperial cores are taken over violently, imperial memories have lasting effects on political spaces, and pre-figure the paths of new political formations. ${ }^{2}$ Each of the following chapters will give abundant examples of the diversity of imperial expressions and memories that can be found in the historical evidence.

The chapters that follow are targeted at an interdisciplinary audience. We have kept comparative efforts at a minimum in order not to flatten historical differences and articulations of particular disciplinary discourses. The main purpose of these contributions is to provide structural contexts and historical narratives that we deem to be essential for understanding the economic developments, frontier zone

1 Scheidel 2015, 232.

2 Burbank and Cooper 2010, 8.

○ Open Access. (C) 2020 Sitta von Reden, published by De Gruyter. (c) BY-NC-ND This work is licensed under the Creative Commons Attribution-NonCommercial-NoDerivatives 4.0 License. 
landscapes, and inter-imperial connections we investigate in the next two volumes. Yet the variable degrees of academic attention that the spaces we cover have received in global scholarship have led to discrepancies in the ways these chapters proceed. Given that the histories of the Hellenistic and Roman Empires have frequently been written and re-written, these two accounts were challenged by the goal of communicating established narratives without eliding controversies and alternative approaches. In other cases, the structures of the imperial spaces are more elusive, and the histories that are given here are rather to be read as contributions to ongoing disciplinary debates.

\section{References}

Scheidel, W. 2015. "Introduction." In W. Scheidel (ed.), State power in ancient China and Rome, 3-10. Oxford: Oxford University Press.

Burbank, J., and F. Cooper. 2010. Empires in world history. Power and the politics of difference. Princeton NJ: Princeton University Press. 


\section{Sitta von Reden}

\section{The Hellenistic Empires}

\section{Introduction}

The Hellenistic Empires that emerged in the aftermath of the Macedonian conquest of the Achaemenid Empire (ca.550-330 BCE) laid the foundation for the connectivity of Asia, Egypt, and the Mediterranean for many centuries to come. Although often referred to as kingdoms, they are best understood as empires dominating a vast and heterogeneous political and economic space. ${ }^{1}$ The ideological goal of their kings was world dominion, yet the degree of their control over regions, resources, and local polities was uneven, and their styles of rule responsive to various micro- and macro-traditions. ${ }^{2}$

Looking at the Hellenistic kingdoms as parts of a dynamic imperial space alters our perspectives on their territoriality, frontier zones, and temporality. From the time of Alexander's campaigns onward, the Hellenistic Empires were in constant transformation. They gained some coherence through fiscal-administrative practices, military regimes, and political ideologies. But they remained fragmented due to their mutual competition and by the continuity of local power regimes, hierarchies, and economic practices that influenced local land and people. The Hellenistic imperial world was also polycentric, both in terms of the continuity of local power centers and in terms of the distribution of royal capitals that were built in various parts of the Hellenistic Empires. ${ }^{3}$ Given the polycentricity of the Hellenistic Empires, what constituted imperial cores and peripheries is arguable. The cities of the Aegean and

1 Ma 2013; Thonemann 2013; Fischer-Bovet forthcoming for chapter-length accounts of the Hellenistic Empires. Companion volumes such as Erskine 2003; Bugh 2006; Weber 2007 cover many aspects discussed in this chapter. Particularly influential studies include Koenen 1993; Ma 1999; Manning 2003; Capdetray 2007; Kosmin 2014, 2018. This chapter is indebted to all these works.

2 Macro-traditions refer to long-term imperial memories and models (Persian, Hellenistic, Roman, etc.), and micro-traditions to local memories and continuities. Their complex relationship is at the center of research on the Hellenistic period, see numerous articles by Pierre Briant published since the 1970s, some being translated in Briant 2017a, 429-610; Koenen 1993; Sherwin-White and Kuhrt 1993; and, more recently, Manning 2010; Moyer 2011; Ma 2013; Strootman 2014a, 2014b; Strootman and Versluys 2017; Fischer-Bovet forthcoming.

3 Kosmin 2014, 93-120. The cores of the Seleukid Empire were Syria and Babylonia; Egypt had its core in the delta and Lower Egypt, but rival courts existed temporarily in Cyprus and Cyrene. The Antigonid West had old Macedonia at its core, but Athens maintained some symbolic centrality in the Greek world.

Note: I am grateful to Peter Eich, Christelle Fischer-Bovet, and Andrew Monson for helpful discussion and comments on this chapter. Special thanks to Jennifer Gates-Foster, Christelle FischerBovet, and Milinda Hoo for letting me see forthcoming work.

Ә Open Access. (C) 2020 Sitta von Reden, published by De Gruyter. (c) BY-NC-ND This work is licensed under the Creative Commons Attribution-NonCommercial-NoDerivatives 4.0 License.

https://doi.org/10.1515/9783110607741-003 


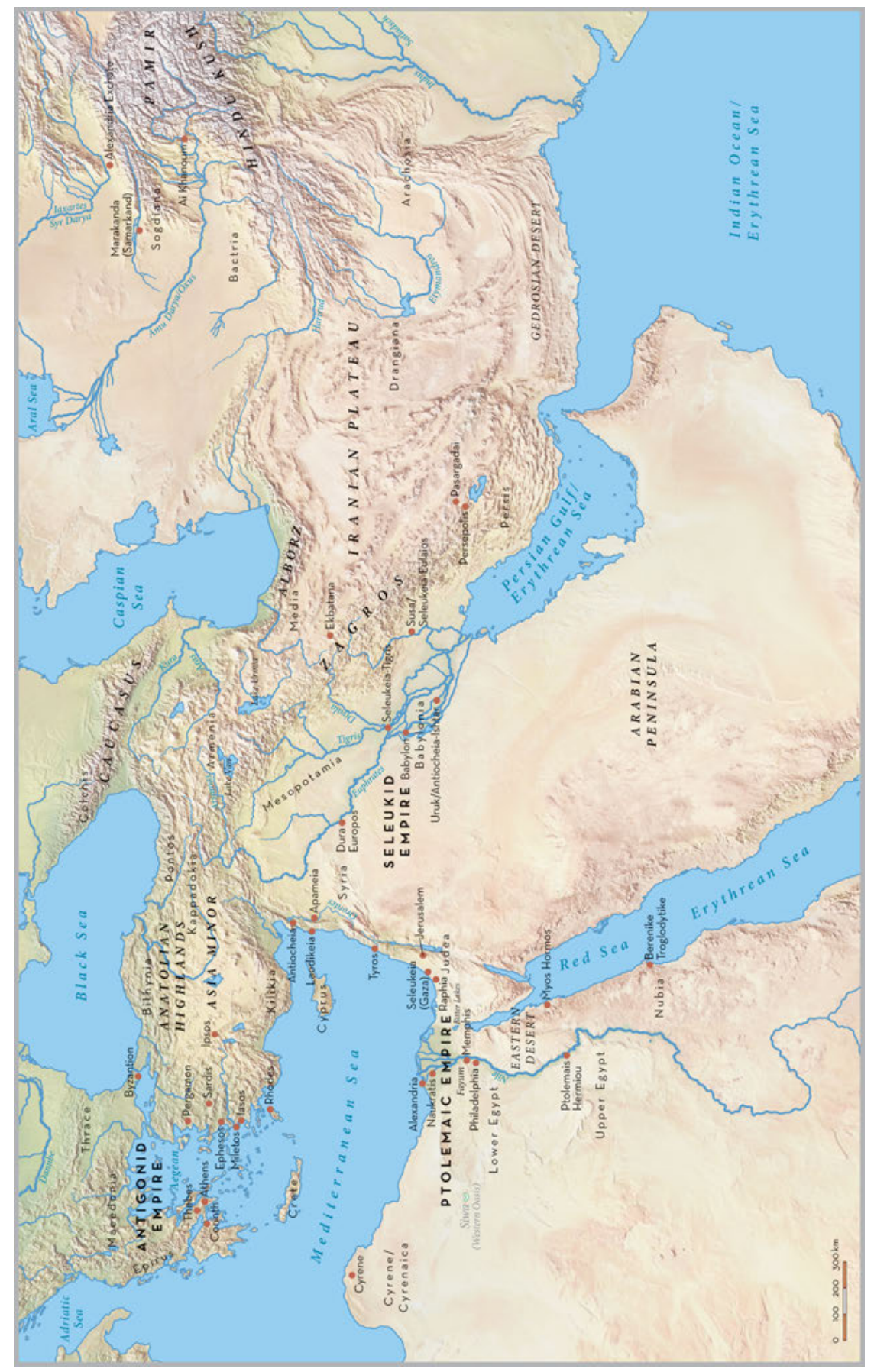

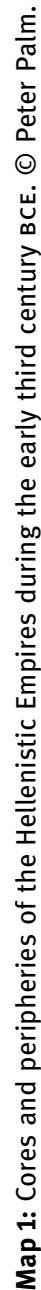


Asia Minor, for example, temporarily formed an outer circle of the Ptolemaic Empire, thus being peripheral to its core. Yet culturally and symbolically, they were the very core of the Hellenistic world, as kings defined themselves as Macedonians and Greeks. Many Greek immigrants in the new Seleukid and Ptolemaic Empires came from these regions. The same holds true for Thrace and Southern Syria in that both lay between two Hellenistic spheres of influence. They were geographically at the border of two Hellenistic Empires, but economically and culturally they were by no means marginal.

The societies of the Hellenistic Empires had several cultural layers. Neither the conquerors nor the conquered populations were culturally or ethnically pure entities moving in and out of foreign domination. What we call Greek, Persian, Egyptian, or Iranian are convenient but misleading shortcuts for a transcultural mix of traditions, languages, material culture, social practices, and political systems that converged in special circumstances. Representations in Greek iconography or language were not necessarily produced by Greeks. Public inscriptions in one particular or several languages, and artifacts in either one or a mixture of styles, were statements about the intended addressees, affiliations, and self-positioning within a repertoire of imperial possibilities. Vassal or client kings who adopted Greek coinages (Hellenistic or Athenian, even), or used Greek as the official language, did not necessarily speak Greek among themselves, or regarded themselves as Greeks, but placed themselves deliberately or by necessity within a particular imperial orbit. I present two examples.

In the centuries preceding the Macedonian expansion into Asia and Egypt, the dynastic predecessors of Philip and Alexander had deliberately positioned themselves as Greeks. They constructed mythical descent from Herakles, adopted Greek as the language of official communication, and issued coinages based on the Athenian weight standard. When Alexander's successors established themselves as kings over Asia and Egypt, they continued to emphasize their belonging to what we now call classical Greek culture. They collected Greek literature, adopted Athenian law and legal practice, listened to Greek philosophers, and made Greek education a focus of court culture and cultural patronage. Yet the Macedonians had never lived in city-states (poleis), nor had they shared typically Greek civic values so strongly associated with Greek poleis, such as equality and freedom. Nevertheless, poleis with civic institutions became major instruments of administrative and ideological control of the Hellenistic Empires, especially in Asia, but also in Egypt and Macedonia itself. ${ }^{4}$

Another example is Egypt. In the eyes of both ancient and modern observers, Egypt seemed and seems rather resilient to cultural change. Temple iconographies and inscriptions were highly conventional and formulaic well into the Ptolemaic period. They emphasized conquest as the condition of peace, the return of the di-

4 Ma 2013; Clancier and Gorre forthcoming. 
vine images (statues) as a sign of benevolent rule, and pharaonic support of temple building activity as the condition for general prosperity. The Ptolemies, too, were represented in these terms, having expelled the Persian foe, returned the statues to the Egyptian temples, and supported the indigenous cults and temples. ${ }^{5}$ Yet not only the Ptolemies, but also the Persians, had respected the Egyptian gods, and just like the Ptolemies, they had transformed the country administratively and culturally in cooperation with local priesthoods. ${ }^{6}$ When the Macedonians conquered Egypt, they encountered several political, administrative, and cultural traditions to which they added further. And when the Romans conquered Egypt 300 years later, once again, being Egyptian or being Greek were fairly artificial administrative labels sliding over much more complex social realities. ${ }^{7}$

Because of the diverse motivations and social practices that caused Hellenism to spread, it is also problematic to use the term Hellenization as an active pursuit of the Graeco-Macedonian ruling elites. The fact that the Greek Alexander historians lamented Alexander's adoption of Persian rituals and intermarriage with Bactrian and Persian aristocracies shows that Greeks had cultivated other expectations of the conquest than what had happened in its aftermath, namely interaction and entanglement, rather than segregation and revenge. ${ }^{8}$ Despite coercion and control, the Hellenistic ruling apparatus incorporated and responded to long-lasting local cultural practices that continued to resonate in the emerging Hellenistic tradition. ${ }^{9}$

\section{The Macedonian Takeover}

The story of Alexander III's campaign is too well known to be in need of much elaboration here. A war against Persia had been planned under Alexander's father Philip II, and the Corinthian League formed by the Greek cities in mainland Greece and the Aegean had agreed to it. Macedonian imperial ambitions had developed rapidly from the mid-fourth century onward. Philip's armies had created military corridors in Thrace, Thessaly, and Illyria. He had married into several royal families to secure these and other territories. And there had been attempts to negotiate cooperation and confederations especially with the important cities of Corinth, Thebes, and Athens. The Corinthian League gave their support to the war, propagated as a pan-Greek revenge against the Persian invasion during the Persian Wars of the early

\footnotetext{
5 Briant (2003) 2017c.

6 Lloyd 2000, 383-384.

7 Bowman 1996, 121-186.

8 Badian 1965.

9 Moyer 2011; Strootman 2014a, 2014b; Koenen 1993 for transcultural ideas of Ptolemaic kingship; numerous agrarian and administrative practices went back to Persian, Pharaonic, or Greek precedence; Briant (1994) 2017b; Manning 2003; Thonemann 2013.
} 
fifth century BCE. Yet Philip was assassinated before the campaign started, probably in reaction to his seventh marriage that could have impaired Alexander's dynastic succession.

Alexander ascended to the throne in 336 BCE. In 334, his army crossed the Hellespont that separated Macedonian Thrace from Persian Lydia. Within two years, the Greek cities in Asia Minor were 'liberated' from the Persians, the Phoenician cities in Syria captured, and Egypt and Libya transformed into a Graeco-Macedonian satrapy (Persian administrative unit). Alexander's troops pushed into Babylonia, Persis, and Media where the former Persian residences were located. They plundered the rich treasuries of Babylon, Susa, and Persepolis, installed Greek satraps, burned down the citadel of Persepolis, and pursued the Persian king Darius III who had fled to the Median capital of Ekbatana.

The rule of the last Persian king, Darius III, had been anything but stable, much to the advantage of Alexander, who cooperated with disaffected local elites and their armies. One of the pretenders was Bessos, a relative of Darius and royal satrap of Bactria. Though Bessos claimed the empire for himself, his ambitions served Alexander's interests. It was Bessos who finally killed Darius when he took refuge from Alexander in Ekbatana. Yet, rather than negotiating with the usurper, Alexander aligned himself with his opponents by offering royal burial to Darius. Bessos fled to Bactria, where he proclaimed himself King of Kings, Artaxerxes V. Losing the support of his own generals, Bessos was delivered to Alexander and executed in Ekbatana in 329 BCE. The conquest of Bactria and Sogdiana still proved difficult and violent, despite some cooperation of local military elites. It seems that it was only through marriage into a leading Bactrian family that Alexander eventually gained control over the powerful central Asian kingdoms. ${ }^{10}$

Marrying a Bactrian princess was not the only gesture by which he achieved convergence to Persian political practice. Already in Egypt, Alexander had had proclaimed himself son of Ammon Zeus by the oracle of Siwa. This combined Macedonian ideas of divine kingship with Persian concepts of the King of Kings being the substitute of god, as well as integrating the Egyptian notion of the pharaoh endowed with divine $K a$. It had great appeal to local populations, kings, and priests, whose claims over land and income were thereby confirmed. However, many Greeks resented the idea of a divine kingship. This was partly because it implied a degree of hierarchy irreconcilable with civic equality, but more importantly it involved a degree of military expansionism not all Alexander's generals were willing to support. Alexander's rejection of Darius's peace offer in 330 BCE had already provoked criticism among a military exhausted by warfare. Internal discontent increased as Alexander made his armies march farther east and began to adopt elements of Persian dress and court ritual. The link between expansionism and resentment is amply

10 Although Arrian calls her a captive of war (Arrian Anabasis [Arr. Anab.] 4. 19-20), later her father Oxyartes was installed satrap of Paropamisos (6. 15). 
proved by the increase of conspiracies against Alexander during the far-eastern campaigns. In their course, a whole level of generals was exchanged for personnel that were more loyal. These new generals were the contenders for Alexander's succession and transported the idea of a universal empire to the next military generation.

In 327 BCE, the armies turned south and, crossing the Hindu Kush, marched down to the western Indus valley. The region seems to have had an ambiguous status under the Persians as either satrapy or vassal kingdom. ${ }^{11} \mathrm{~A}$ Macedonian satrap was installed here, while the area south of the Hydaspes, under control of an Indian king called Poros in Greek sources, became a vassal kingdom after several indecisive battles in 326 всE. Alexander and his armies were able to develop further Macedonian corridors in northern India along the Indus valley down to the city of Patala (see ch. 3, map 1, this volume), occupying two more short-lived satrapies bordering the Thar Desert. In 325 BCE, Alexander was ruler of a space that, in terms of satrapal administration, was more or less coextensive with the Achaemenid Empire. It excluded, however, northern parts beyond the Lesser Caucasus, and the steppe regions along the western and eastern coasts of the Caspian Sea. No Hellenistic king ever attempted to expand beyond these ecological boundaries. ${ }^{12}$

\section{Ecologies and Climates}

When Alexander died in 323 BCE, the Macedonian Empire stretched across a vast and heterogeneous ecological space (see map 1). Fertile alluvial plains were interlaced with mountain ranges and desert zones, neither easily subjected to social and political control, nor very suitable for economic exploitation. In the west, the empire included the densely populated Mediterranean micro-ecologies of the Aegean and Asia Minor characterized by Greek poleis, for which dry farming, private property rights, a specific relationship between town and countryside, and political regionalism were typical. In the south, it stretched into the populous country of Egypt, which for millennia had been dominated by the Nile ecology that produced immensely rich agricultural yields under the condition of artificial irrigation. Traditionally, this land was controlled through institutional landownership by the temples and the pharaoh. In the north, the empire included the fertile Pontic region (never conquered by Macedonian armies), partly settled by Greek-speaking populations since the seventh century BCE. Its northernmost frontier was adjacent to and in some connection with populations of the steppe belt, a socio-ecological zone that

11 Briant 2002, 754-757.

12 There were expeditions along the Iaxartes and into the steppe of Inner Asia in the early years of Seleukos I, but these seem to have been explorations rather than attempts at conquest, Kosmin 2014, 72-73. 
was traditionally alien to the Greek way of life. In the east, it approached the natural border of the Pamir and Himalaya, while farther south it reached southwest down into the Indus Valley.

The ecological micro-systems of the Asian landmass are too numerous to be surveyed here. Yet with six of the seven administrative complexes (Great Satrapies) of the Achaemenid Empire located in Asia, these offer a useful guide to understanding the Asian landmass as an imperial as well as economic landscape. ${ }^{13}$ Though highly diverse and disconnected in themselves, they nevertheless seem to have formed networks of populations that were grouped together into administrative entities, arguably long before even the Persian expansion. ${ }^{14}$ These were, firstly, Persis and eastern Iran, the heartland of the Achaemenid dynasty. Secondly, Media spanned across large parts of the Zagros Mountains, forming the western border of Sogdiana and Bactria. This was a land of mountains and valleys along the axis of the mountain range, with one major transverse river valley forming a major line of communication between Babylon and Ekbatana. Thirdly, Lydia stretched across Anatolia with its Mediterranean and Black Sea temperate climate, on the one hand, and pocketed micro-ecologies ranging from fertile river valleys to high mountain ranges in eastern Anatolia, on the other. Fourthly, Mesopotamia and Babylonia were situated along the rivers Euphrates and Tigris, which watered wide and very fertile alluvial plains providing great opportunities for cereal agriculture under artificial irrigation. Their economic potential, both in terms of agrarian fertility and strategic position as a contact zone between the Persian Gulf and Syria, was fully exploited by the early Seleukids. ${ }^{15}$ It made Syria and Babylonia the core region of their empire, both politically and economically (see map 2 and 3). There was, fifthly, Arachosia, with the core region in southern Afghanistan, including the Gedrosian Desert in the south, Drangiana in the northwest, and the lower Indus valley in the east. Much of this region was covered by arid desert zones, but Arachosia itself was agriculturally fertile, and though Drangiana was mostly a poor desert zone, it had some fertile plains along the river Etymandros. Finally, Greater Bactria comprised the kingdoms of Bactria (roughly the area of central and northern Afghanistan), Sogdiana in the north, and Aria in the southwest. ${ }^{16}$ It is a region of semiarid mountain zones, interlaced with fertile river valleys that are potentially very productive if irrigated successfully. The great potential and power of Bactria must be seen in its location adjacent to the steppe and its strategic position as a communication line of roads and infrastructures linking Mesopotamia, Iran, and northern India. ${ }^{17}$ Administratively,

13 Also Morris, ch. 2, this volume.

14 Jacobs 1994; Jacobs 2011; and Morris, ch. 2, this volume. See Aperghis 2004, 35-51 for a bold survey of local geographies and estimated population densities.

15 Fabian, ch. 6, this volume for the importance of this route for the Arsakids ruling this space thereafter.

16 Morris, ch. 2, this volume.

17 Mairs 2014 with Strabo Geography (Strab.) 11. 11. 1 on the fertility of Bactria; for the connections of the Steppe with Gandhara, Morris, ch. 2, this volume. 
the Far Eastern satrapies reached across the Hindu Kush down to the upper Indus valley, once again connecting mountain ecologies with fertile agricultural areas. ${ }^{18}$ As Morris argues below, the Hindu Kush posed a far less severe socio-ecological dividing line than the Alexander historiography wants us to believe in its attempt to stylize Alexander's Hindu Kush crossing as a truly heroic achievement. Nevertheless, the satrapies of the northwestern Indus valley were soon ceded to the king of the new Mauryan Empire that formed shortly after the Macedonian conquest. Though these satrapies were lost, relationships between the Mauryan and Seleukid kings remained friendly, and the boundary uncontested.

\section{Empires in the Making}

The formation of the Hellenistic Empires after Alexander's conquests and death continued to be an immensely violent process. The ambition of becoming the ruler of the entire empire that Alexander had left gave rise to six Wars of the Successors (321-272 BCE) and remained the goal of all contenders who eventually occupied parts of it. ${ }^{19}$ The story of these wars is a series of indecisive victories and defeats, changing military alliances, dynastic marriages, assassinations, and intrigues. Yet this story helps to understand Hellenistic history as prefigured by internal competition and ever-in-flux zones of conflict and internal frontiers. Because of the continuous competition and warfare between the successor kings and allies among the constituent polities, Hellenistic imperialism was essentially inward looking. ${ }^{20}$

After Alexander's premature death, the succession was unresolved. His mentally handicapped half-brother Philip III Arrhidaios and his yet unborn half-Bactrian son, Alexander (IV), were the two dynastic heirs, but unfit for government when the succession was to be settled. However, as succession in the Macedonian monarchy was largely dynastic, the two heirs were appropriated for rival claims to legitimate succession. Their assassination in 317 and 309 respectively, despite making little difference to actual politics, changed the rules of the game and remade legitimacy to mean a combination of military success, support of armies, and local acceptance.

18 Kulke and Rothermund 2018, 13.

19 Meadows 2012; Hauben and Meeus 2014; Strootman 2014b; Fischer-Bovet 2019 with special emphasis on the Ptolemaic ambitions in southern Anatolia. For an emphasis on the alternative territorial designs of the Seleukids, Tuplin 2009; Kosmin 2014.

20 Bugh 2006. The main sources for the history of the Wars of the Successors are Diodoros ([Diod.] 17 and 18); several Lives of Plutarch (Plut.), and the Alexander historiographies of Arrian, Curtius Rufus, and pseudo-Kallisthenes. 
There were several contenders for succession. Among the older generation of Alexander's father, the most important ones were Antigonos Monophthalmos ("the one-eyed”), Perdikkas, Antipatros (followed by his son Kassandros), and Polyperchon. All belonged to the Macedonian aristocracy, had institutional ties of friendship with Philip II and Alexander, and occupied top ranks in Macedonia or the imperial army. A second group of aspirants were the generals of Alexander's generation. These were, to name but the most prominent, Lysimachos, who had become satrap of Thrace after Alexander's death; Eumenes, in charge of the northeastern Anatolian satrapies; Ptolemy, satrap of Egypt; and Seleukos, military governor (chiliarch) of the troops in Macedonia.

Perdikkas seems to have been the strongest contender at first, as he was elected commander of the imperial army in the first meeting of the generals after Alexander's death. He suggested they hold off on further action until Alexander's child was born. This plan would have put him in the position of trustee of the dynastic successor as soon as the baby was born. Yet opposition formed around Antipatros, who claimed dynastic succession for Arrhidaios, and the infantry armies. Antipatros was also an ancestral enemy of Olympias, Alexander's mother, who had forged a marriage between Alexander's sister Kleopatra and Perdikkas, with dynastic intentions in mind. Possession of Alexander's body was another strong symbol for legitimate succession, and armed conflict became inevitable when Ptolemy captured it for burial in Alexandria. Rebuffed by this arrogant act, Perdikkas marched against Ptolemy, while Antipatros pursued Perdikkas into Asia Minor. Yet before war broke out, Perdikkas was killed by members of his own army, leaving Ptolemy in possession of Alexander's corpse, and Antipatros the new leader of the imperial army. However, his ambitions were cut short by his own unforeseen, though natural death just two years later.

Antipatros's position now passed on to his sons, Kassandros and Polyperchon. Polyperchon revived the Corinthian League to gain the support from the Greek cities. But Kassandros joined forces with Antigonos, military governor of Asia, against Polyperchon and the Macedonian Perdikkas-Olympias alliance. Olympias, still striving for the succession of Alexander IV, had Arrhidaios and his wife murdered in 317 BCE. But she was executed by Kassandros in retaliation. The death of Olympias, Philip III, and his wife allowed Kassandros to strengthen his position in Macedonia, which was consolidated by his marriage to Thessalonike, a daughter of Philip II and heiress of the kingdom. ${ }^{21}$ Meanwhile, Antigonos fought several wars to solidify his position in Asia. In 316, he controlled much of Asia, and according to one ancient source, was proclaimed King of Asia in Persepolis. ${ }^{22}$ Yet his position created a new opposition joining Lysimachos of Thrace, Ptolemy of Egypt, Kassandros of Macedo-

21 In principle, any male offspring of a Macedonian king was entitled to the inheritance of the kingdom; see Ogden 1999; Strootman 2014b.

22 Diod. 19. 14. 1. 
nia, and Seleukos who had captured the city of Babylon and installed himself as governor of Babylonia with the help of Ptolemy's troops. Another war raged inconclusively until 311, when finally a settlement was reached, confirming each of the contenders in their present position. Seleukos ordered the building of the new capital of Seleukeia-Tigris close to Babylon (see map 2) and systematically began to reconquer the Median and Bactrian Satrapies that had defected from Macedonian control. However, Antigonos's ally and son, Demetrios, defeated Ptolemy's brother in Cyprus in a battle said to have destroyed one-third of the large Ptolemaic army. ${ }^{23}$ Having reached the height of his power, Kassandros had Alexander IV killed in 309, extinguishing the male line of the Argead (Alexander's) family.

Antigonos and Demetrios forcefully expanded their position in the following years. Demetrios liberated Athens from Kassandros, a success for which he and his father were proclaimed by the Athenians as Savior Gods (theoi soteres). Demetrios's ambitions at that time may well have been captured by a painting with which the Athenians are said to have honored their new ruler showing him striding over the oikoumene (the entire inhabited world). ${ }^{24}$ When Antigonos once again defeated Ptolemy off Cyprus, it forced Ptolemy to abandon Cyprus and Syria-Phoenicia, and Antigonos's armies proclaimed him and Demetrios kings (306 BCE). Lysimachos, Seleukos, Ptolemy, and Kassandros, now in Macedonia, quickly followed suit. Yet the idea of universal empire remained - Antigonos invaded Egypt, and Demetrios besieged Rhodes, a close ally of Ptolemy. Both campaigns failed.

Father and son were more successful in Greece where they liberated Athens from renewed occupation by Kassandros. Yet, instead of withstanding his opponents, Kassandros took sides with Antigonos to fight against Seleukos and Lysimachos at Ipsos in 301 BCE. Antigonos was killed in battle. When Kassandros died shortly thereafter from an infectious disease, followed by one of his sons, Demetrios invaded Macedonia. He killed the other two sons of Kassandros and was proclaimed king. Demetrios's ambitions, however, made him enemy not only of Lysimachos, but also Pyrrhos of Epiros, who was a successful general linked with the Argead family through his mother. In 287 BCE, the Macedonian elite withdrew their support from Demetrios, who had created offense by his un-militaristic behavior and (possibly Persian) style of dress. ${ }^{25}$ Pyrrhus and Lysimachos divided Macedonia between themselves, though Pyrrhus was driven out, leaving Lysimachos in charge of all Macedonia. Antigonos Gonatas, son of Demetrios, was able to keep control over Greece, while Demetrios himself fled with his navy to Asia Minor. He was captured by Seleukos and kept in exile for the rest of his life.

Now, Lysimachos and Seleukos fought for universal empire. They met in battle at the plain of Kurupedion in Lydia (281 BCE) where Lysimachos lost his life. Seleu-

23 Fischer-Bovet 2014, 53.

24 Athenaios Deipnosophistae (Ath.) 12. 536a with Strootman 2014b, 216.

25 Plut. Life of Demetrios (Demetr.) 41. 
kos crossed the Hellespont into Europe as victor, but was murdered by Ptolemy Karaunos, a dispossessed son of Ptolemy of Egypt. Ptolemy Karaunos was proclaimed king of Macedonia, which put him in a good position to retaliate against his father in Egypt. Before he had the opportunity, he was killed during an invasion of the Celts in 279 вCE, leaving the Macedonian kingdom without a head. This was a catastrophic situation in a polity with few institutionalized state structures. The best option for the Macedonian military was to proclaim Antigonos Gonatas king of Macedonia, a decision that had some dynastic justification. Moreover, Antigonos Gonatas had successfully defeated the Celts threatening Thrace and stood a good chance of restoring Macedonian hegemony over Thessaly and the southern Peloponnese, traditionally areas of strong Macedonian influence. ${ }^{26}$

The territorial situation of the early 270s BCE shaped the imperial history of the next two centuries: the Antigonids presided over Greater Macedonia, including Thrace, Thessaly and, at times, the Greek city leagues, the Seleukids were kings of Asia, and the Ptolemies held the Egyptian empire, including Cyprus, Kyrenaika, and Syria and Phoenicia. Yet major zones of conflict and unresolved imperial domination remained. The Greek cities in the mainland, the Aegean, and Asia Minor continued to regard themselves as allies rather than subjects of the Macedonians and forged changing alliances in order to regain independence. Syria and Phoenicia (including major Levantine harbour towns up to the city of Tyros, see map 2) remained contentious possessions because of their position between the Seleukid and Ptolemaic spheres of influence, as was Thrace between the Seleukid and Antigonid spheres of influence. Smaller kingdoms on what soon became peripheries of the Seleukid Empire developed either full or partial independence: Bithynia and Pontos on the southern Black Sea coast, Kappadokia and Armenia in western Anatolia and northern Iran; the kingdom of Pergamon in Asia Minor; Parthia, Media, and the Persian heartlands in the Middle East; Bactria in Central Asia, as well as the south Asian satrapies of Gandhara, Paropamisadai, and east Gedrosia (see ch. 2, map 1, this volume). The latter were ceded to the newly emerging Mauryan king early in the reign of Seleukos I. ${ }^{27}$ According to Graeco-Roman historiography, a treaty was negotiated in which the relationships were to remain friendly, 500 war elephants given in exchange for the land, and a daughter of Seleukos's family given in marriage to the allied king. ${ }^{28}$

The fierce military competition in the 50 years after Alexander's death shows several challenges of the imperial succession. First, the rapid conquest of vast territories left the Macedonian Empire without a center. On the surface, this was due to the lack of a dynastic heir fit for rule. Yet more fundamentally, there was an unresolved conflict between several potential imperial cores - Macedonia, Anatolia, Syria, Babylonia, and Egypt. All were too rich in resources and too powerful locally

26 Strootman 2014b, 144.

27 Morris, ch. 2, this volume.

28 Plut. Alex. 62. 4; Strab. 15. 2. 9. Kosmin 2014, 32-37, 227-228 for discussion. 


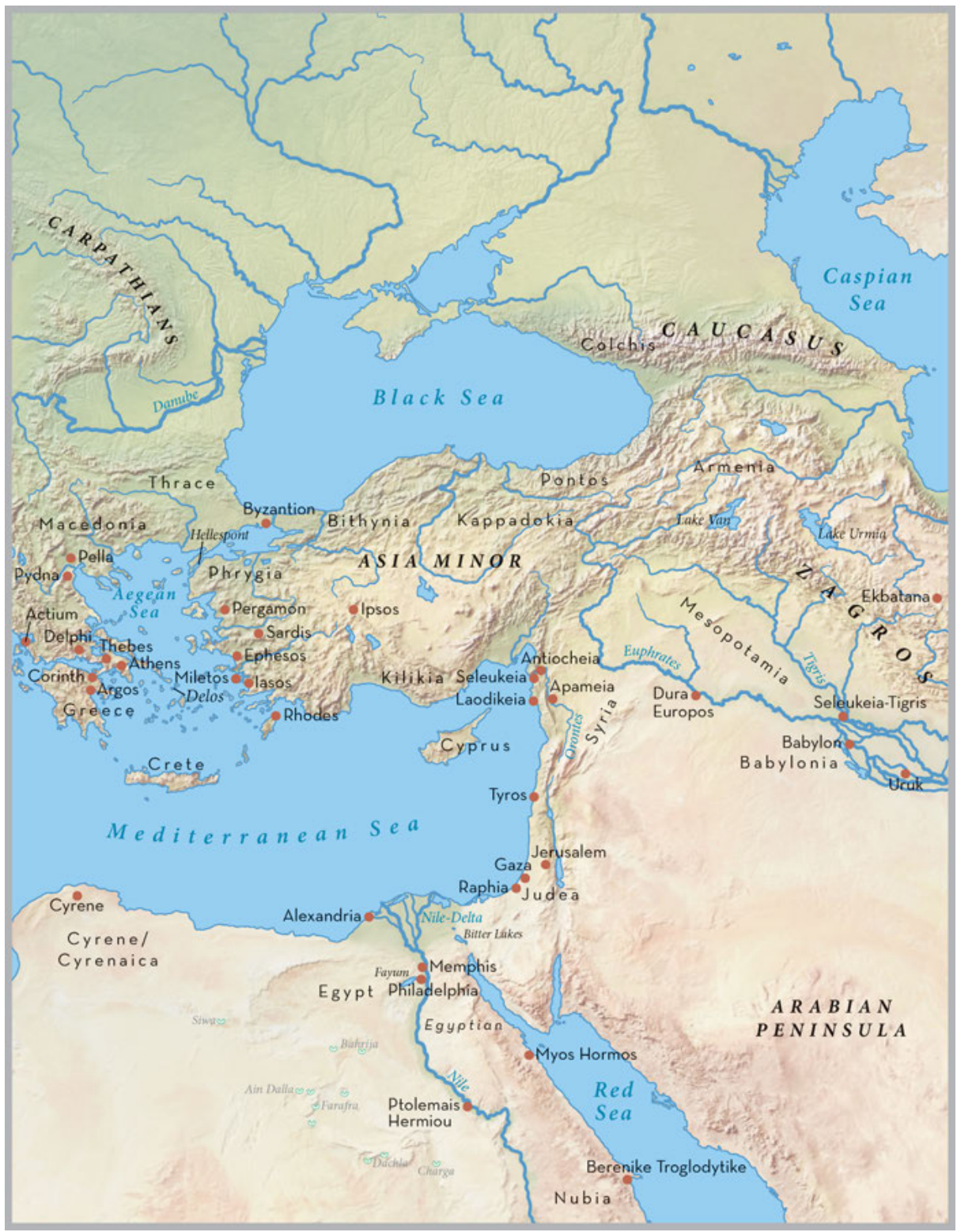

Map 2: Main cities of the core regions of the Hellenistic Empires. ๑ Peter Palm.

to be subordinated to an uncontested core. At the same time, each was too weak to become such a center itself. One monolithic Hellenistic Empire could not have been ruled from Pella, Alexandria, or Babylon/Seleukeia-Tigris alone. Nevertheless, none of the successors was content with a segment of Alexander's empire. Universal rule was built into the ideology of kingship, despite the insurmountable problems that 
putting this ideal into political practice caused. So despite the power of the military elite that had gained the victories for Alexander, dynastic aspirations continued to be a powerful force in the conflicts over succession. Marriage alliances, kinship, and family intrigue played vital, and eventually lethal, parts in these conflicts, not only in the first 15 years after Alexander's death but throughout the Hellenistic period. As a consequence, all Hellenistic dynasties and many smaller courts of peripheral kingdoms were related by marriage ties. Multiple marriages created ambiguous lines of succession and conflict between royal offspring over claims to kingship. This imposed a dynastic burden on all Hellenistic monarchies, which made them vulnerable to internecine violence and fragmentation. ${ }^{29}$

\section{Monarchy and Administration}

Scholars of the Hellenistic period are amazed by the multiplicity of strategies employed by the Hellenistic kings in order to maintain and expand their empires. Military conquest and coercion were one strategy, but others included negotiation with local elites by means of religious politics, benefactions, land development, foundation of settlements and cities, as well as marriage alliances. Once again, the search for Greek, Macedonian, or Persian precedents is not very helpful. Imperial administration was a multidimensional mix of imperial macro- and local micro-traditions, Greek political language, and cosmopolitan discourse. Most regions of the Hellenistic Empires maintained their local socio-political character, but tinged with the transcultural influence that came with foreign domination, mobility, and warfare. The great royal cities along the Mediterranean coast - such as Alexandria in Egypt and the Seleukid four-city network of Antiocheia-Orontes, Seleukeia-Pieria, Laodikeia, and Apameia (see map 2) - may have appeared Greek by their architectural styles, concentration of Greek-speaking populations, Greek institutions and buildings such as gymnasia, theaters, and libraries. ${ }^{30}$ Yet archaeology brings to light increasing amounts of material remains that reveal local or transcultural styles. Some buildings, such as the Serapeion in Alexandria, were deliberate hybrids. ${ }^{31}$

Most kings seem to have pursued a seemingly paradoxical strategy of positioning themselves as culturally Greek by means of language, coinage, social entourage, and types of warfare; but at the same time being adaptive to some local practices of warfare (especially elephant warfare) and to forms of politics that must be regard-

29 Ogden 1999, 128-129.

30 For Hellenistic foundations, Cohen 2006, 2013.

31 The mixed urban styles of Hellenistic cities and capitals are well demonstrated by the archaeology and underwater discoveries in Alexandria (Goddio 1998) and Ai Khanum in Bactria (Bernard 2012). 
ed as typically local rather than typically Greek or Macedonian. ${ }^{32}$ For example, both the Seleukids and the Ptolemies held congregations with major local priesthoods who controlled populations and agrarian revenue. They published multilingual official communications, granted financial concessions to local cities and temples, and developed physical infrastructures from which not only the administration, but also local economies benefited..$^{33}$ And they practiced some degree of religious syncretism in order to strengthen the religious legitimacy of their rule. ${ }^{34}$ In the Aegean, they communicated with Greek cities and League representatives, granted land to cities, and made substantial financial benefactions in support of local cults and festivals. ${ }^{35}$ Concentrating on one role of the Hellenistic kings always risks neglecting the other, while separating the two ignores the duplicity of power on which Hellenistic Empires rested. The kings needed to protect and expand their 'spear-won country' (doriktetos $g e)^{36}$ by means of armies dominated by Greek-speaking mercenaries and Greek military techniques. But in order to finance the wars and manpower, they needed to extract tribute from mostly non-Greek agrarian populations. The latter was possible only through the cooperation of local elites who provided the logistics and fiscal infrastructures. ${ }^{37}$

Despite these multiple responses to local practices and traditions, the Hellenistic Empires created a common symbolic system and new Hellenistic macro-tradition that lasted well into the Roman Empire and beyond. Symbolic and institutional coherence emerged partly because of adaptations to the existing Persian macro-tradition, but also because Hellenism became a cultural parameter that was open to all who were willing to cooperate. Greeks soon formed what has been termed an ethnoclass, a status group not necessarily ethnically Greek, but sharing material culture, rituals, values, interests, and loyalty to the regime through education and integration. ${ }^{38}$ Greek was the administrative language, Greek coinage was a major means of payment, and members of the Greek ethno-class dominated the fiscal-military regime. These common parameters permit us to recognize the Hellenistic Empires as a connected space despite considerable local diversity. In the next sections, I shall discuss several institutions and practices that created such coherence: the monar-

32 Ma 2013.

33 A famous example is the Pithom canal first constructed by Darius and later reopened by Ptolemy II. The priesthood of Tjeku (Pithom) praised the king for the benefaction, which increased their local revenues; Mueller 2006, Appendix II for a translation of the Pithom stele.

34 Derow and Bagnall 2004, no. 164 (Kanopos Decree); Derow and Bagnall 2004, no. 165 (Rosetta Stone); for comparable evidence from the Borsippa Cylinder recording benefactions of Antiochos I, Kuhrt and Sherwin-White 1991; Pfeiffer and Klinkott forthcoming; Ma 2013.

35 Ma 1999, esp. 179-214; Thonemann 2013; for a comprehensive collection of texts on royal benefactions, Bringmann and Steuben 1995.

36 Diod. 18. 39. 5.

37 Monson 2015, 170-171. Valuable case studies for Egypt can be found in Lewis (1986) 2001.

38 Briant 1988; Ma 2013. 
chical military-administrative apparatus, settlement politics, administrative language, and coinage. This coherence fostered mobility, exchange, and interaction at a global scale. Through a shared official language, shared coinages, and shared urban cultures, merchants, mercenaries, settlers, and itinerants moved around the Hellenistic imperial space with a certain ease. ${ }^{39}$

\section{V.1 Monarchy}

Hellenistic monarchy developed from preexisting monarchical traditions in Macedonia, Persia, and Egypt, and the socio-political dynamics created by two generations of military conquest. Victory was the key to political legitimacy and military rank, and so to social status. At the top of this military social hierarchy stood the king, followed by his generals and the ranks of the armies. Military rank became the structuring principle of the social order of the Hellenistic kingdoms, and the soldiery a group with a particular social identity and coherence. ${ }^{40}$

Yet Hellenistic monarchy was also a political order that had to respond to particular internal tasks, such as creating peace, generating income, and distributing this income. At the top of this hierarchy, again, stood the king, but this time as benefactor, friend, savior, and protector. In this role, he communicated via memoranda (hypomnemata) and prescripts (prostagmata) in the first person with local constituencies, and the language of friendship formed the governing principle. ${ }^{41}$ Within this personalized system, the entourage played an important role. Its members were the representatives of the monarchy, agents of the king's prestige, and managers of the royal relationships with cities, local elites, and populations. Friends (philoi) filled the position of local governors (strategoi or hoi epi tōn pragmatōn) and garrison leaders (phrouarchoi, or equivalent titles). The entourage, forming some kind of court, was ranked according to degrees of intimacy with the king, ranging from 'kinsmen,' 'bodyguard,' and 'most honored friend,' to 'first friend,' and lesser titles. ${ }^{42}$ In the course of the Hellenistic period, these personal designations routinely came to be attached to high-ranking administrative officers as court titles, showing a degree of institutionalization and formalization that came along with the gradual development of state structures in the Hellenistic Empires. ${ }^{43}$ From the second century onward, they also became open to people with no apparent Greek

\footnotetext{
39 Walbank 1981, 66-67.

40 Fischer-Bovet 2014.

41 Gehrke 2008, 46; Ma 2013, 336.

42 Mooren 1977; Moyer 2011; similar court titles are found in the Seleukid and Ptolemaic courts, but not so in Antigonid Macedonia, John Ma 2011, 526.

43 Mooren 1977 dates the first evidence for institutionalized honorific court titles to Ptolemy V, while Lanciers 2018 has adduced convincing evidence for their emergence in the 210s under Ptolemy IV.
} 
or Macedonian roots - a process that can best be observed in Egypt. ${ }^{44}$ Throughout the Hellenistic period, the friends formed a hierarchical and exclusive group of cultural Hellenes that reproduced their status through Greek education, Greek forms of entertainment, music, games, and athletic contests, as well as the orchestration of the ruler cults. The culture and learning of the courtiers, their ceremonies, and rituals spread to local metropoleis and towns where Greek and local elites emulated it as a means of integrating themselves into the wider group of the dominating ethno-class.

The second characteristic of Hellenistic monarchy was the royal interaction with local constituencies: cities, temples, and populations. This interaction was partly coercive and tributary in nature, as the next section will show. But in order to create stable structures of authority and legitimacy, it also took more benevolent forms. Gift-giving and offers of protection were the most important means by which the kings created relationships with, and loyalty among, different social bodies. Gifts were sent to sanctuaries at Delphi, Olympia, or Delos in order to enhance royal prestige within the symbolic centers of the Hellenistic Empires. Gifts in the form of subsidies or tax relief were given to cities who reciprocated with crowns, statues, and cultic honors. Local temples received financial contributions (suntaxeis), tax relief, and support for construction work, as well as grants of income from land and customs dues, in return for ritual services that stabilized the kingdom. Negotiations and concessions are best known from the multilingual stelai (the most famous being the Rosetta Stone) that the Egyptian priests erected at the end of ritual gatherings (sunodoi) between kings and priests. Other recipients of gifts were high officials entering the administrative apparatus, and provincial military officers who were rewarded with land and gift estates (doreiai). In return, the kings gained loyal followers, economic prosperity, and increased tax income. ${ }^{45}$

Ruler cult was a third characteristic of Hellenistic monarchy and closely connected to the kings' role as benefactors. Religious cults had been devoted to kings in Greece, Persia, and Egypt before, yet the immediate model was Alexander. ${ }^{46} \mathrm{Al}$ exander had become a religious figure in Egypt immediately after his visit to the oracle of Siwa (which had confirmed him as a son of Zeus), while numerous Greek and non-Greek cities offered him cults spontaneously on the occasion of a victory, sometimes on the demand of generals and the king's friends. The successor kings immediately latched onto this ritual. A cult for Demetrios and Antigonos was set up in Athens when they liberated the city from Kassandros. Ptolemy II introduced a cult for his deceased father and his father's wife Berenike, who were worshipped as Savior Gods (Soteres) from about 278 BCE. Soon afterward, he set up a cult for his

44 Fischer-Bovet 2014.

45 There are some indications that large gift estates formed distinct tax districts for whose income the estate owner was responsible.

46 Jones 2010; Mitchell 2013. 
own deceased sister-wife, Arsinoe. Not only was this cult henceforth celebrated in all Egyptian temples with revenues of one of the largest taxes in Egypt (the so-called apomoira); but Arsinoe being associated with the mother goddess of Aphrodite equalling the Egyptian goddess Isis, became the most popular cult-figure in the entire Ptolemaic world. ${ }^{47}$ In dating formulas, Ptolemy put his own cultic name Philadelphos ('sister-loving [god]') alongside the title of the Alexander priest who was eponymous for each year, and thus both circulated together as part of all official documents throughout the country. ${ }^{48}$ In Seleukid Asia, essentially the same thing happened. Kings received cults by cities spontaneously, while they were divinized officially after their death. From the late third century onward, living kings started to have themselves divinized, as we learn from dating formulas and official letters requesting that priests for the living king be elected. ${ }^{49}$ In the Antigonid kingdom controlling much of the Greek world in the mainland and Aegean, no official ruler cult was established, but spontaneous cults sprang up in Greek cities in honor of individual kings.

Ruler cults and the divine status of the kings and queens consolidated the cosmological role of the Hellenistic monarchies. It elevated the kings and queens to god-like figures who were in control of natural fecundity, procreation, prosperity, and the Nile inundations. The king (pharaoh) as a divine figure also legitimized local Egyptian priesthoods' claims to income from land and people. ${ }^{50}$ In combination with the king's and queen's role as benefactors, the ruler cult formed a major means of communication between local cities and royal centers. The kings and queens were far away, but their sacred districts, priesthoods, and statues were present, as were the libations, sacrifices, and festivals taking place in their names. ${ }^{51}$ The celebrations of festivals and cults were powerful means of building identity and community in the Hellenistic world. Local social life was attached to their figures and rendered the experience of empire a matter of joyful festivity and song.

The power of cults also helped to build dynastic continuity, a major problem in any monarchy, but in particular in the Hellenistic Empires where multiple marriages created ambiguous lines of succession. The problem of dynastic succession was greatest in the Asian and Egyptian empires, while in Antigonid Macedonia, the violent fight over the succession of Alexander seems to have put an end to the conflicts over succession once and for all. In the Asian and Egyptian empires, however, the Seleukids and Ptolemies established new royal dynasties with Alexander as their founder. This dynastic origin was widely disseminated through coinage minted in Alexander's name and carrying his image. Eponymous priesthoods were established

47 Koenen 1993.

48 Chaniotis 2003.

49 Chaniotis 2003, 473; Lanciers 1993.

50 As for example expressed in the Pithom stele, Mueller 2006, Appendix.

51 Chaniotis 2007, 139-140. 
in his name, while numerous stories developed about his divine origin and heroic status acquired by conquest. Local Egyptian myth-making gave him a double descent as the son of Philip II of Macedonia and of Nektanebo, the last native pharaoh of Egypt. ${ }^{52}$ The dynastic cult was most strongly developed in Egypt. Dynastic festivals were celebrated regularly, and dynastic succession expressed explicitly on early Ptolemaic coinage. ${ }^{53}$ For fear of dynastic trouble, Ptolemy II even married his own sister Arsinoe shortly before her death. Brother-sister marriage was practiced henceforth roughly every other generation in the Ptolemaic dynasty, although this did not solve dynastic frictions. Multiple marriages aiming to confirm territorial possessions and diplomatic friendship fostered internecine warfare and alienated the royal houses internally. Both ancient and modern commentators regard the dynastic problems of the Hellenistic royal houses as one of the main reasons for the Hellenistic monarchies' incapacity to respond successfully to military and political challenges in the long-term.

\section{V.2 Administration}

The administration of the empire was linked to the person of the king but gradually developed into an institutional apparatus governing in his name. The intimate relationship between the king and his administration had conceptual, ideological, and economic dimensions. Conceptually, the administration was just another aspect of the king's pragmata (affairs). Ideologically, the empire was the king's personal household, just as regional administrations were regarded as parts of this household. ${ }^{54}$ In principle, all land was royal land. It could be ceded or given to others, but some of it was cultivated by the king's own royal tenants. Like a good landlord, the king was personally interested in his land and agrarian development. Economically, benefactions to local elites and temples, land donations, and land development created incentive structures for the mobilization of local resources and people.

This form of rule was not just a Macedonian invention. At the time of conquest, the Macedonian satraps took over the administrative systems of the Achaemenid Empire and only gradually changed these structures as a matter of practice. The Achaemenids, on their part, also had not interfered radically with preexisting administrative practices, authority structures, and agrarian systems. ${ }^{55}$ Yet they eventually established a centralized system of foreign authority to which the local constituencies responded. They had created roads and land registers, standard weights,

52 Alexander Romance I, 1-30; Stephens 2003, 64-73.

53 For dynastic cult, Hölbl 2001, 77-124, 160-177 in place of numerous other studies. For the distinction between dynastic and ruler cult, see Pfeiffer 2008.

54 Gehrke 2008, 48, 57-59.

55 Briant 2002, 411. 
measures, and some coinages, and probably also the practice of differentiating between royal land and other types of land. ${ }^{56}$

Keeping the diversity of local structures in mind, some general principles of the Hellenistic administration can be observed. Two qualifications need to be made, nevertheless. First, due to the excellent papyrological evidence from rural Egypt, ${ }^{57}$ we are much better informed about this than any other part of the Hellenistic World, including Alexandria and the Greek cities with their exceptional historiographical tradition. Egypt was as typical or atypical for the rest of the Hellenistic world as any other part of it, but it had developed particularly cohesive state structures and a highly developed administrative system over 2,000 years. Its agricultural rhythm was determined by the Nile inundation, its agrarian income dependent on changing field sizes, and the local administration heavily involved in the maintenance of the dyke system. All of this created specific administrative structures, similar perhaps only to those of Babylonia for which we lack comparable evidence. The second problem is administrative language. Having to find Greek terms for local institutions and offices, the conquerors had at their disposal a limited linguistic repertoire that had developed in the Greek and Macedonian context. Administrative terminology thus obscured substantial socio-economic differences and created a degree of coherence and familiarity that will have been greater in linguistic than in practical terms.

To judge from the Egyptian evidence, the basis of Hellenistic administration was the district. All of Egypt was divided into what the Greeks called nomoi, regional divisions dating back to the Old Kingdom. The nome reflected the continuity of local agrarian organization regardless of the shift of domination in the political centers. ${ }^{58}$ At the top of the nome was a nomarchos ('head of the nome') who supervised agricultural production and the dyke system, as well as fulfilling some judicial functions. An oikonomos was in charge of the nome income in cash and in kind, while a checking clerk (basilikos grammateus) keeping records worked at his side. They had their subordinates in the topos (tax district) and the komos (village). The tax income, carefully pre-assessed on the basis of a sowing schedule and plot sizes each year, was collected, recorded, and countersigned in storehouses (thesauroi) to which the Ptolemies added banks (trapezai) with very similar accounting systems. Yet while the in-kind income was collected by the nome administration itself, all monetary taxes were auctioned off to tax farmers. Though not collecting the taxes themselves, they guaranteed a fixed total sum and kept a sharp eye on its efficient collection. The dioiketes stood at the center of the royal administration. He was in charge not only of finances, but also of the coordination of the economy and the

56 Briant 2002, 410-421.

57 Von Reden, ch. 8 C, this volume.

58 Derow and Bagnall 2004, 285-286; Thonemann 2013 for Attalid Asia Minor; Capdetrey 2007, 227-267 for the Seleukid administration. 
correspondence of the empire. The royal mints and the treasury (to basilikon) were also under his control. ${ }^{59}$ People could submit legal matters, often emerging from tax collection practices but also from other conflicts, in the form of petitions directly to the king. The petitions were decided on in the king's name and sent back for execution to the heads of the nome.

Alongside the nome administration, the Ptolemies developed a parallel structure that resulted from their military presence and the cleruchic system. Rather than keeping their soldiers under arms, they gave them land lots (kleroi) that provided them with an income for themselves and their families. The allotments varied in size according to military rank and achievement, giving a military social order to the immigrant population of the nome. Military cleruchs belonging to the same garrison under an eponymous commander (hegemon or phrouarchos) formed communities that served many informal social and economic purposes as well. At the top of the military hierarchy in the nome was a strategos, who not only had military functions, but supervised the cleruchs, their land, and filled judicial functions, much in the same way as the nomarch. Both must have worked closely hand in hand at first, but in the course of the third century, the strategoi took over the role of the nomarchs, and eventually replaced them. This is quite a remarkable fact, as the strategoi were direct royal appointees, whereas nomarchs had been subordinate to the dioiketes, who had replaced the former satrap and thus been part of the satrapal structure that the Ptolemies took over. There must have been a military superstructure in the capital as well, but not much detail is known. ${ }^{60}$

In the Seleukid Empire, we encounter similar administrative principles and institutions with two important exceptions. Both led to rather different administrative hierarchies and geographies. ${ }^{61}$ First, Egypt under Achaemenid rule had been a single satrapy to which the Ptolemies added just some regions in Cyrene, Cyprus, Syria, and temporarily, Asia Minor. ${ }^{62}$ Thus, the royal economy of Egypt was equivalent to that of one satrapy, while in the Seleukid Empire, the king was on top of several satrapies. So in Asia, we find dioiketai cooperating with strategoi at a regional (satrapal) level and acting in conjunction with oikonomoi and phrouarchoi, who in Egypt were subordinates of the dioiketes. ${ }^{63}$ There is evidence, nevertheless, for administrative heads (hoi epi tōn pragmatōn) and subdivisions of the satrapies (hyp-

59 Von Reden 2007, 79-152; Capdetrey 2007, 306-331.

60 Fischer-Bovet 2014.

61 See most comprehensively, Capdetrey 2007; also Ma 2000, 122-139; and Aperghis 2004, 263-295 for a survey of the most important administrative documents.

62 Syria and Phoenicia, Cyprus and Cyrene were closely integrated into the Egyptian administration, while the cities of Asia Minor maintained their own fiscal institutions and coinages, see Bagnall 1976.

63 Aperghis 2004, 269-274 with examples from Palestine (when under Seleukid control), Kappadokia, and the city of Iasos in Asia Minor. 
archiai, toparchiai and oikonomiai). ${ }^{64}$ The second major difference was that the Seleukids tended to settle their soldiers in cities rather than the country side. Higher military personnel and civil beneficiaries who received large plots of land as gift estates attached their holdings to the land that belonged to the cities. ${ }^{65}$ This seems to have led to special administrative districts (hyparchiai or oikonomiai) attested in the Greek poleis of Asia Minor and the former Lydian capital Sardis. These administrative districts, much like the toparchies in Egypt, seem to have been in charge of the revenue from the cities and their hinterland. In second-century inscriptions from Ai Khanum, too, several oikonomoi are documented as delivering tax money to the treasury, suggesting that though the city was not the capital of the Bactrian kingdom, it was the center of several districts. It is best to conclude that while administrative institutions and some principles of collecting revenue were comparable throughout the Hellenistic world, administrative geographies and hierarchies could vary depending on the established structures of the fiscal unit. In the second century, local variation increased even further as a result of weakening central authority and the reemergence of local authority structures. ${ }^{66}$

\section{Settlement and Cities}

The Hellenistic period was a time of urban growth and development. ${ }^{67}$ Alexander is well known for the large number of cities he founded in the course of his campaigns. Many were attributed to him later, and the early successors, most notably Seleukos and Antiochos, followed his practice. Urban foundations not only served to settle and resettle veteran soldiers, civil immigrants, indigenous populations, and personnel in charge of military control and tax collection, but also created an imperial landscape marked by settlement and urbanization. Several hundred new cities emerged in the first century of the Hellenistic period, forming part of an urban development that reached from the Mediterranean coasts through Iran to central Asia and northern India. Some of these cities are still visible, such as Alexandria in Egypt, Samarkand in modern Uzbekistan, and Ai Khanum in Afghanistan.

Parts of the material culture of these cities were recognizably Greek, such as gymnasia, theater buildings, and libraries that became part of the representational quarters of royal cities. We also find portrait sculpture, votive offerings, vase paintings, and pottery of typically Greek iconography and manufacture. For a long time,

64 Capdetrey 2007, 257-265 with some alternative nomenclature for satrapal subdivisions.

65 Aperghis 2004, 99-107 (land grants) and 148-153 (revenue from cities).

66 Well shown by Thonemann 2013 for the Attalid kingdom after 188 BCE, and Manning 2003 for Egypt.

67 Billows 2003; Kosmin 2014, 183-221; Mairs and Fischer-Bovet forthcoming; Cohen 2006, 2013 for a survey. 
archaeologists have latched on to the Greek remains, emphasizing the Hellenizing influence of Greek urbanization in Asia and Egypt. Yet with increasing sensitivity to transcultural practices, larger amounts of non-Greek artifacts, as well as objects of mixed styles, are being identified in Hellenistic urban sites, suggesting various types of convergence, interaction, and segregation. Ai Khanum is a particularly instructive place for analyzing Greek and local social and cultural interaction, including common use of temples and sanctuaries by worshippers belonging to different religious communities. ${ }^{68}$ Alexandria in Egypt, a truly multicultural space where people of various origins met and settled, also offers opportunities for studying growing degrees of cultural interaction, as the number of artifacts and buildings of Egyptianizing styles increased in the course of time. ${ }^{69}$

On closer inspection, a very heterogeneous picture of Hellenistic urbanization emerges. First, very few of the sites were actually new foundations. Some big cities, such as the royal residences of the Seleukids, do seem to have been new foundations (e.g., Seleukeia-Tigris, Seleukeia-Pieria, and Antiocheia-Orontes). Yet Alexandria in Egypt incorporated a local village, Rhakotis, which continued to be remembered in the mythographies of the city. ${ }^{70}$ Moreover, many cities were refounded to accommodate the cult for a new dynastic founder and to receive a dynastic name. ${ }^{71}$ Thus, Susa became Seleukeia-Eulaios, Uruk became Antiocheia-Ishtar, Gaza became another Seleukeia, and Jerusalem only just escaped the fate of becoming another Antiocheia. ${ }^{72}$

Foundations also differed in size and organization. Scholars have attempted to classify Hellenistic foundations, distinguishing between large primary, mediumsized secondary, and small tertiary urban centers, as well as between villages from large to small. ${ }^{73}$ Archaeological surveys of selected Hellenistic settlements suggest that there were indeed certain categories of urban foundations. The sumptuous royal capitals of Seleukeia-Pieria, Antiocheia-Orontes, Laodikeia, Apameia in north Syria and Ptolemais Hermiou (Upper Egypt) were all in the range of 205 to 280 ha in size, while secondary urban sites such as Dura-Europos on the Euphrates, Philadelphia in the Fayum, and Berenike Troglodytike on the Red Sea, measured between 50 and 70 ha. As the evidence for urban areas is generally too scanty and fraught with archaeological problems, it would be unwise to speak of a coherent strategy of Hellenistic city foundations. Yet it is still possible to argue that settlement sizes were

68 Hoo forthcoming, with further literature.

69 Goddio 1998; Ashton 2004.

70 von Reden and Strootman forthcoming.

71 Sherwin-White and Kuhrt 1993, 161. Seleukos I is said to have founded 9 Seleukeias, 16 Antiocheias, 5 Laodikeias, 3 Apameias and 1 Stratonikeia, see Kosmin 2014, 183-184 and map 3, below. The number of known Ptolemaic foundations include 24 Arsinoes, 19 Ptolemaeis, 13 Berenikes, 5 Philoteras, 5 Kleopatreis, and 4 Euergeteis, see Mueller 2006, 14.

72 One of the reasons for the Maccabean revolt, see Billows 2003, 198.

73 Grainger 1990, 91-99; Mueller 2006, 89-106. 
planned in relation to their function and location, their importance in wider regional urban networks, and their role in controlling agrarian land, communication lines, and local populations. ${ }^{74}$

Some Hellenistic cities developed from mid-sized urban sites to gigantic cities largely by cramming more people into the urban space and developing new hinterlands for the supply of urban demand. There is abundant evidence that the Fayum in Egypt, for example, supplied Alexandria with food and other agricultural products. The Seleukid and Ptolemaic capitals developed into urban centers far bigger than any of the biggest towns in the Classical period. Athens, Syracuse, and Miletus once the largest poleis in the classical period had about 100,000 to 125,000 free inhabitants. Antiocheia-Orontes and Seleukeia-Tigris, in contrast, reached populations on the order of 300,000, while the population of Alexandria, the biggest town in the Mediterranean before Rome, numbered an estimated half million inhabitants by the mid-third century BCE. Many secondary cities and local metropoleis still reached population numbers of 50-100,000 people, while Berenike Troglodytike at the Red Sea or Ai Khanum are estimated to have had populations on the order of 20,000-30,000. The vast majority of new settlements, however, was in the category of large to small villages numbering about 5,000 inhabitants. ${ }^{75}$

There were also different types of political organization. Our evidence unfortunately is too limited to construct a typology of Hellenistic cities, but we know that many communities were organized, or organized themselves as poleis with citizen bodies usually drawn from the Greek ethno-class and a set of well-functioning civic institutions: councils, magistracies, and popular assemblies. Yet not all Hellenistic foundations were Greek poleis with citizen bodies and civic institutions. Out of the 49 cities known to have been founded by Alexander and the early Ptolemies in Egypt, just two cities were organized as poleis: Alexandria and Ptolemais Hermiou, the second Ptolemaic administrative center founded by Ptolemy I for the administration of Upper Egypt. The Seleukids founded many more cities, the majority of which are believed to have been organized as poleis. Other cities, such as Jerusalem, gradually developed Greek civic structures in the course of the Hellenistic period, a trend that has been termed 'poliadization' or 'polification' by modern scholars. ${ }^{76}$ The process of poliadization meant not just the development of civic institutions, but also the adoption of a more comprehensive civic model in terms of architecture, socio-political behavior, education, and urbanization.

Archaeological research has brought to light the spatial politics of Hellenistic settlement and urbanization. It is obvious that Alexandria and the Seleukid Tetrapolis of capitals on the Mediterranean coasts marked the orientation of Hellenistic

74 Mueller 2006, 85-184 for city sizes and discussion. Alexandria quickly outgrew the size of any of the other capitals, e.g., Monson 2012, 40-41.

75 Kosmin 2014, 189.

76 Clancier 2017 (for Babylonia); Thonemann 2013 (for the cities of Asia Minor). 


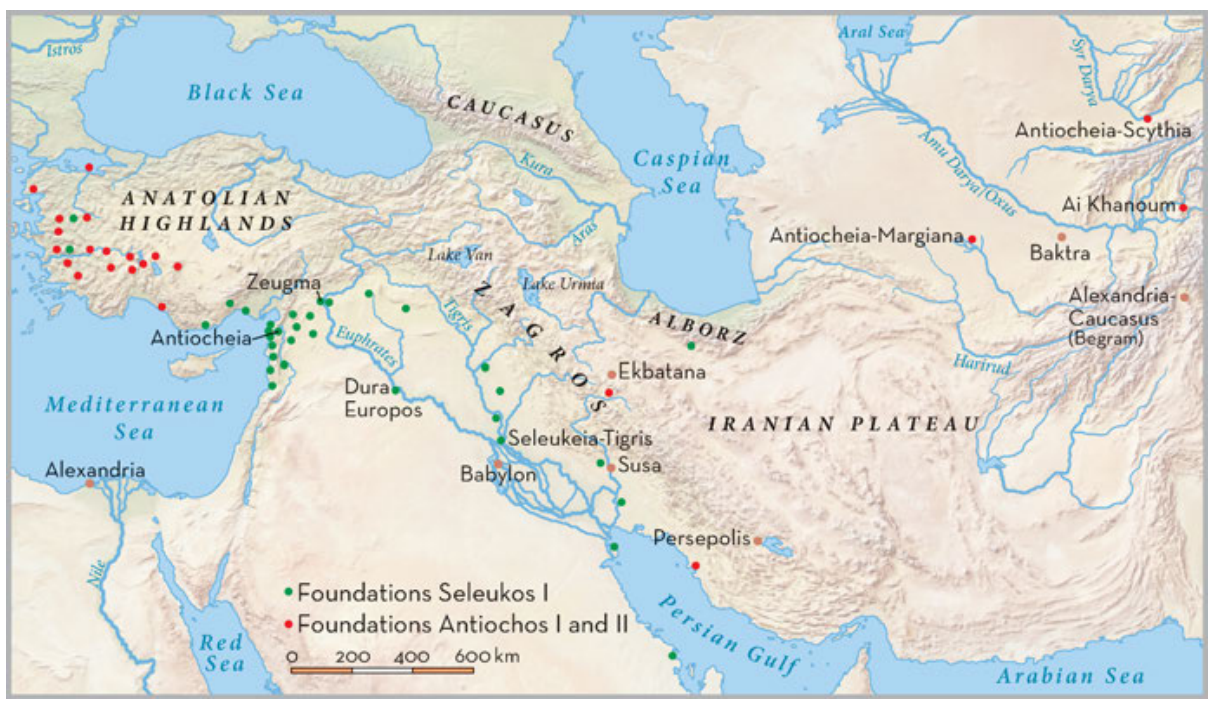

Map 3: City foundations under Seleukos I and Antiochos I and II (after Kosmin 2014, map 8). (C) Peter Palm.

rulers toward the Mediterranean. The choice of Seleukeia-Tigris as Seleukid capital instead of using the major Persian residence in Persepolis was also a sign of the western gravity of Seleukid imperial politics. ${ }^{77}$ It was part of a new Seleukid geography for which the development of the Persian Gulf, its riverine connections into northern Iran and Syria, as well as the agrarian development of the Tigris valley, played a crucial economic role. Yet smaller settlements add to the picture. West of the Euphrates, 87 Seleukid settlements are attested and just 35 in the larger expanse between the Euphrates and Sogdiana. All but a dozen of these eastern foundations, moreover, were located in the lower middle Tigris and Gulf region, areas that were marginal during the Achaemenid period, but became centers of strategic economic development under the early Seleukids.

A similar combination of urban, strategic, and economic development can be observed in northern Syria. The development of northern Syria was a direct result of the Seleukid loss of southern Syria to the Ptolemies and the fragmentation of the Levantine coast between the late fourth to the early second century BCE.

The Ptolemies, too, pursued an urbanization policy, if at a smaller scale. ${ }^{78}$ One focus of new settlement was the Fayum Oasis in Lower Egypt, just 45 miles away from the former capital of Memphis. Ptolemy II tripled the area of cultivation by draining Lake Moeris (modern Birket Qarun). The Fayum not only became a center

77 Kosmin 2014, 188-195 for this and the following.

78 Müller 2006; Fischer-Bovet in Mairs and Fischer-Bovet forthcoming. 
of Greek settlement, but also a center of agrarian development and innovation. Another focus of economic development and settlement was the Eastern Desert and the Red Sea coast. On the northwestern stretch of this coast, two important harbor towns, Myos Hormos and Berenike Troglodytike, were founded and linked by caravan routes to the Nile. Substantial forts with large capacities for grain storage and water supply have been excavated along these routes, demonstrating substantial Ptolemaic interest in this area. ${ }^{79}$ At the northern tip of the Red Sea, Ptolemy II also reopened a canal that linked the Bitter Lakes via Heroonpolis (Pithom/Tjeku) with the eastern branch of the Nile delta (see ch. $8 \mathrm{C}$, map 2, this volume). Where the canal connected with the sea, a city called Arsinoe was founded, and the opening of the canal was celebrated in grand style by the priesthood of Pithom/Tjeku. ${ }^{80}$ Above all, the urban and infrastructural development of the Red Sea coast and its linkage with the Nile served as the means to transport a supply of war elephants from Nubia and the East African coast to Alexandria. But in time, it acquired further economic functions and laid the foundation for the thriving trade between Egypt, the Arabian Peninsula, and India.

The largest number of new settlements were founded in Egypt, but Ptolemaic foundations spread throughout the provinces of Cyrene, Cyprus, and Asia Minor. Small settlements and garrisoned fortresses suggest that they served as nodal points for the control of local taxation and administration, as well as for the control of networks of communication in areas of imperial and economic interest. ${ }^{81}$

\section{Language and Institutions}

Greek language, but also Greek political terminology in the Hellenistic kingdoms, created a sense of cultural homogeneity that was greater in appearance than in practice. As far as language was concerned, written documents increasingly used a common Greek dialect (koine) that replaced numerous local dialects of Greek (i.e., Doric, Aeolic, Ionic etc.) as well as local administrative languages. The Hellenistic koine was a slightly modified version of the Attic dialect, which shows the cultural role of Athens in the formation of Hellenistic culture. ${ }^{82}$ It is difficult to estimate how far the use of Greek spread down the social scale (many Egyptian priests learnt Greek and fixed religious texts and Egyptian literature in Greek writing), but Greek language offered access to the administration and to Greek legal practice, which was favored by many indigenous inhabitants. ${ }^{83}$

79 Sidebotham and Gates-Foster 2019.

80 Mueller 2006, Appendix II; Tuplin 1991 for the previous Achaemenid canal that had silted up.

81 Mueller 2006, 41-84; Kosmin 2014, 183-221.

82 Billows 2003. Continuing Athenian influence can be seen in the Athenian weight standard of most Hellenistic coinages, Athenian legal traditions in Hellenistic law, and the emulation of Athens as educational center by many Hellenistic capitals, especially Alexandria.

83 Clarysse and Thompson 2009, 36-89. 
Moving from language to terminology, there was a rather distinct political and administrative terminology in use throughout the kingdoms. This creates the impression of a certain administrative homogeneity derived from some common model. Hellenistic kings called their own realms basileiai, kingdoms, and their political activities, which included religious and military affairs, ta pragmata (business). Court titles such as philos ('friend'), sungenes ('kinsmen'), somatophylax ('bodyguard'), protos philos ('first friend') and some others were used across the Ptolemaic and Seleukid courts (see above). The cities in which kings and courts resided, the metropoleis of local administration and urban living, and city foundations with Greek-style civic organizations were all called poleis despite their socio-political diversity. Not only were there different types of poleis within the Mediterranean world - the poleis of Cyprus, for example, had been ruled by kings before the Macedonian conquest - but the Phoenician cities, Judaea, Babylon, Memphis, as well as many local cities had their own urban organization, political structures, and economic systems despite all being called poleis in Greek administrative terminology. ${ }^{84}$ Local administrators and supervisors of temples, without any clear definition of their tasks and authority, were included in the large category of epistatai (prefects), as local governors in pre-Hellenistic Macedonia had been called. Strategoi are regularly found as top royal appointees in the military administration with shifting profiles and tasks. Phoros was the general term for land tax, ekphoria for rents (although the two imposts could overlap in practice). We have similar titles for a range of other taxes, such as the enkuklion ('sales tax'), ennomion ('pasture tax') and tele (a very general category of surcharges and market taxes). Many standard taxes, moreover, were called according to the fractions of the total on which they were levied (e.g., dekate ('the tenth'); tetarte ('the fourth'); pentekoste ('the fiftieth') despite the fact that different quantities were extracted under these titles. ${ }^{85}$

The degree to which the royal administration of the Hellenistic Empires could be regarded as a coherent system is shown by the pseudo-Aristotelian Oikonomika. It was written within the Aristotelian school during the early years of the Hellenistic period and attempted to put the relationship between imperial, satrapal, polis, and household administration into a coherent system. According to pseudo-Aristotle, the four types of administration are part of a hierarchy in which the royal administration stands at the apex. Royal administration is responsible for the most important economic affairs, such as imports, exports, coinage, prices, and the revenues from the local satrapies. The satraps, in turn, are in charge of local taxation and land use. Autonomous cities are free to look after the civic revenues, while private citizens deal with their private income from agriculture, industries, and credit. ${ }^{86}$

84 For the different types of cities in the Hellenistic period, Billows 2003; Kosmin 2014; Mairs and Fischer-Bovet forthcoming.

85 Monson 2015 for the dekate.

86 Pseudo-Aristotele Oikonomika (Arist. [Oec.]) 2. 1. 1-6. 
The treatise represents a Greek perspective on the late Persian administrative tradition. ${ }^{87}$ It ignores the difference of agrarian systems and fiscal practices across a vast imperial space, but created a common language of economic administration that nurtured unity and coherence in an otherwise impenetrable range of local diversity.

\section{Coinage}

Greek coinages were both a means of exchange and a means of communication. This led to fierce academic controversy over the political vis-à-vis economic function of Greek coins. ${ }^{88}$ Hellenistic coinage reflects commercial and fiscal functions as well as different governance structures in different parts of the Hellenistic Empires. Kings could tolerate non-imperial forms of money, un-coined metal, pre-Hellenistic coinages, and several forms of in-kind payment. They could also grant monetary autonomy to local polities, which created identity through coinage. Yet all kings also produced their own imperial coinages. They were the ones most widely accepted, allowed monetary taxation to run effectively, and were most suitable for applying fiscal revenue to military and urban expenditure. ${ }^{89}$ This part of the monetary policy facilitated and encouraged commercial exchange. While imperial coinages were issued to pay for mercenaries, warfare, urban development, and monetary benefactions, it was probably also the single most visible symbol of foreign domination and imperial rule. Hellenistic coins reached into every corner of the Hellenistic Empires and deep down the social scale of the population. They were not only an instrument of taxation, but also a means of payment to public workers and civil administrators, to whom coins transmitted the public image of the rulers, their success, and ruling ideologies. The impact of Greek coinage on local polities and populations can best be gleaned from the fact that many kingdoms that politically and administratively broke away from Graeco-Macedonian control maintained recognizably Greek-style coinages, only adapting portraiture and symbolic repertoire to their own images and needs. ${ }^{90}$

Alexander had paid his mercenaries with Macedonian coins minted in large quantities in the fourth century BCE. Philip II had deliberately adapted his coinage to the weight standard of the dominant Athenian currency, but had added gold and bronze coins. ${ }^{91}$ Both small denominations in bronze and high-value pieces in gold had been unusual among Greek poleis. Achaemenid wealth, among which was the

87 Lowry 1987.

88 Howgego 1995, 39-61 for the debate.

89 Von Reden 2007.

90 Morris, ch. 2; Fabian, ch. 6, this volume.

91 Thonemann 2015 for a lively and up-to-date account of the impact of coinage on the Hellenistic Empires. 
vast treasury of Persepolis captured in 330 BCE, poured large quantities of additional precious metal into the hands of the Macedonian victors, which was then minted into coinage and spread the message of Alexander's victories when spent on campaign. ${ }^{92}$ The number of Greek mints in Asia increased substantially in the late fourth century BCE, and at the same time, first steps were undertaken to introduce Macedonian coinage into Egypt. ${ }^{93}$ City buildings, garrisons, and mercenaries began to be paid for in Macedonian coinage. It has been estimated that between 333 and 290 BCE, Alexander's royal mints struck 60 million tetradrachms (40,000 talents), 66 million drachms (11,000 talents) and 12 million gold staters (each worth 20 silver drachms = 40,000 talents), totaling an estimated 91,000 talents of silver. ${ }^{94}$ These are vast quantities in comparison to the tribute of the Athenian Empire in the fifth century BCE that totaled on average 500 talents per year at its peak.

Immediately after Alexander's death, most Hellenistic mints minted so-called posthumous Alexander coinages using an iconography that Alexander had adopted on some issues in 333/2 BCE. It showed Herakles with a lion scalp on the front side (obverse) and a seated Zeus on the back (reverse). On the reverse, the coins carried the legend "[coin of] Alexander." Posthumous Alexander coinages were minted in all Hellenistic royal mints except Egypt until the second century BCE. Several local coinages, former Persian coins, Babylonian shekels, as well as royal issues produced to commemorate particular events and victories added to the volume of coinage in circulation. Kings and cities in Antigonid Greece and Seleukid Asia created a large repertoire of designs on their coins (showing royal portraits or Alexander in attire that symbolized military, royal, or divine status), but their coinages followed the basic model set by the posthumous Alexander coinage. On the obverse was a royal or divine portrait looking right, and on the reverse a seated or standing divinity engaged in some military activity. ${ }^{95}$ The adaptation of the Alexander coins engaged deliberately and intentionally with the time of Alexander's conquest, which increasingly became a monetary macro-tradition influencing the imperial space across individual empires and kingdoms. It also created a numismatic koine that was recognizable to all users as a common language of communication and exchange. It built confidence in, and adherence to, a monetary system that was backed by royal authority and protected every individual's capacity to own monetary wealth. It was a powerful means of imperial integration that also enhanced the economic power of the central royal authority. The Seleukid and Antigonid kings accepted a large degree of local minting, and payment in local species, within their spheres of influence, but the large amount of Alexander coinage and royal issues based on his model left no doubt about the imperial dominance of monetary circulation.

92 Thonemann 2015, 15; with de Callataÿ 2005.

93 Lorber 2012.

94 De Callataÿ 2011, 23.

95 Thonemann 2015. 

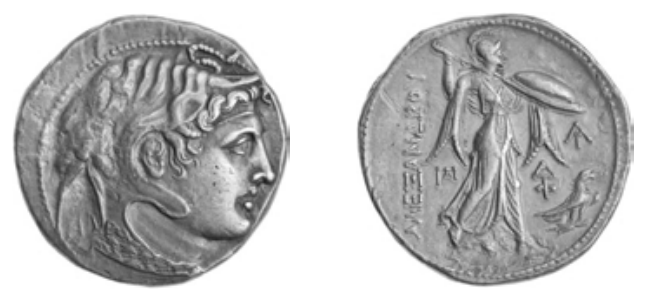

Fi. 1: Silver tetradachm of Ptolemy I Soter (306 BCE), obv. Head of Alexander with elephant scalp, Ammon's horn, and Dionysos head band. Rev. standing Athena. Diameter 28 mm., $14.93 \mathrm{~g}$. ANS 1957.172.2019. (C) American Numismatic Society.
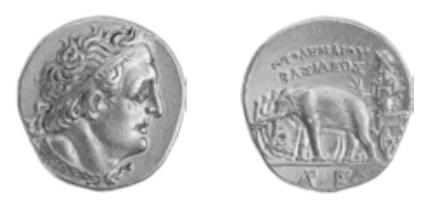

Fig. 2: Gold stater of Ptolemy I Soter (299/295 BCE), obv. Head of Ptolemy I. Rev. Alexander leading elephant quadriga. Diameter 18 mm., 7.1 g. ANS 1967.152.621. (C) American Numismatic Society.

The Ptolemies of Egypt created their own coinage and monetary system. ${ }^{96}$ As early as 320 BCE, Ptolemy I had developed a distinct iconography on his coinage, replacing the Herakles type of the central Macedonian mint with a portrait of Alexander with elephant scalp (symbolizing his Indian conquests), carrying a Dionysos headband (also refering to the Indian campaign), and a ram's horn that symbolized that he had been accepted as son of Zeus Ammon by the oracle of Siwa (fig.1). Ptolemy also gradually diverted from the Attic weight standard of the Macedonian coinage to a lighter standard that may have been inspired by Rhodes, one of Alexandria's most significant commercial partners. ${ }^{97}$ But the reduction in weight and the silver gained from the reduction were also an important source of revenue, as it was made equivalent to Attic-standard coins. From about 300 всE onward, when Ptolemy I had become king of Egypt, he put his own portrait on the gold and silver coinages and reduced their weight standard once again (fig. 2). All foreign coins to be used in Egypt had to be exchanged for Ptolemaic coins in Alexandria and the ports at a relationship of value of $1: 1 .^{98}$

Until far into the Roman period, Egypt formed a closed currency system. It not only marked the core of the Ptolmaic Empire as a distinct monetary zone, but also allowed the Ptolemies a larger degree of monetary control of Egypt. For not only

96 Le Rider 1986; Le Rider and de Callataÿ 2006; von Reden 2007, 31-57.

97 Lorber 2012 for the connection with the Rhodian standard.

98 The evidence is purely numismatic, and unmistakable as Egyptian coin hoards no longer contain non-Egyptian coinage, Le Rider 1986. 
were Egyptian gold and silver denominations less valuable than their other Hellenistic equivalents, but Ptolemy II also created a bronze coinage that had entirely fiduciary value. This allowed a degree of monetization in the Egyptian countryside that would have been impossible with the means of precious metal coinage alone. ${ }^{99}$ While the motivations for these monetary manipulations were most likely financial, their implementation was feasible only because the unusually strong state structure that the Ptolemies inherited from their Pharaonic predecessors. ${ }^{100}$

\section{The Dynamics of the Hellenistic Empires}

The end of the Wars of the Successors gives a false impression of imperial stability during the Hellenistic period. While the kings recognized each other in their imperial centers, their imperial reach remained contested. As was noted above, universal empire was built into the royal ideology of Hellenistic rulers. In the course of imperial development, it became the most important symbol of legitimacy vis-à-vis both Greek and local populations. Images of foreign domination, such as captives of war, exotic animals, and other trophies, passed in royal processions through the capitals on the occasion of dynastic festivals and victories, while coinages, inscriptions, and pictorial representations spread the message throughout the country. ${ }^{101}$ Imperial propaganda of victory was often more glorious than the territorial gain or political advantage that was actually achieved, but its universal presence (also finding its way into Hellenistic historiography) suggests that gaining and maintaining empire were inseparably linked. There was never a turn from military expansion to peaceful state-building in the Hellenistic world. Both went hand in hand and deteriorated simultaneously in tandem with the increasing decline of the spatial and political cohesion of the Hellenistic monarchies.

The first period of the Hellenistic Empires that lasted until the 220s BCE was characterized by systematic empire building in which the kings forcefully expanded and consolidated their power intheir spheres of influence. By about 250 вCE, both the Ptolemaic and Seleukid Empires had reached their maximum imperial expanse, although the Seleukids had already lost the satrapies of Bactria and Parthia to local kings in 255 and 247 BCE respectively. ${ }^{102}$ Yet the Ptolemies controlled territories all along the Eastern Mediterranean coast from Kyrenaika to Southern Anatolia, Cyprus, and Thrace, with a few enclaves in Crete, mainland Greece, and the Aegean,

99 Von Reden 2019.

100 Von Reden 2007; Manning 2010. The kingdom of Pergamon temporarily experimented with a lighter coinage, the so-called kistophoroi, but it had a more limited impact and design; Thonemann 2015, 77-82.

101 Thonemann 2015; Rice 1983 for a grand procession in honor of the deceased Ptolemies celebrated quinquennially in Alexandria.

102 Fischer-Bovet 2014, 7-11 for this and the following chronologial scheme. 
as well as Lower Nubia. The Seleukids' imperial power extended from Anatolia and northern Syria to Central Asia. ${ }^{103}$ Most of the imperial structures that are regarded as typical for the Hellenistic period developed in these 60 years: colonization, land development, and the foundation of new settlements and cities; the gradual transformation of fiscal structures, economic development, expansion of trade, and forms of adjudication of law based on classical Greek models; royal representation in capitals, as well as ritualized communication and exchange with local elites; the development of Hellenistic court life and cultural politics in the form of literary and scientific patronage, athletic games, libraries, and museums; and the development of a ruler cult and ritual as a means of creating dynastic continuity and legitimacy.

The next 60 years from ca. 220 to ca. 160 BCE saw intensive warfare between the Ptolemaic and Seleukid Empires, starting with the temporary conquest of Syria and Phoenicia by Antiochos III during the Fourth Syrian War (219-217 BCE), and the victory of Ptolemy IV who recuperated the lost Syrian territories in the battle of Raphia in 217 BCE. Antiochos then started a campaign, reminiscent of Alexander's, through Armenia, Media, Parthia, Bactria and northern India, but its success was short-lived. Shortly after Antiochos's death in 187 BCE, these areas were lost again to local kings. The Fifth Syrian War (202-197 BCE) ended with the definitive loss of these territories by the Ptolemies to the Seleukids, while during the Sixth Syrian War (170-168 BCE) Antiochos IV temporarily invaded Egypt, only to withdraw after an ultimatum was set by the Roman Popilius Laenas. ${ }^{104}$ In this period, the Hellenistic imperial space rapidly fell under the spell of the new power of Rome. From the last decade of the third century onward, Rome had become an increasingly dominant factor in the Eastern Mediterranean. ${ }^{105}$ This had been triggered by the Roman aggression against Illyrian piracy in the Adriatic Sea, which led to two Roman wars against the Illyrian queen. As this was part of the Antigonid imperial orbit, Philip responded by allying with Rome's enemy, Hannibal of Carthage, which led to the first military confrontation between Rome and Macedonia in 215-205 BCE. This first Macedonian War also involved the kingdom of Illyria, Pergamon in Asia Minor, the Aetolian League in central Greece, and the Peloponnese. Simultaneously, the Greek cities entered into a dangerous internecine war that was also settled by Roman interference. The second Macedonian War ended with the defeat of the last Antigonid King, Philip V, at the battle at Cynoscephalae (197 BCE), which put the Roman general Titus Quinctius Flamininus in the position of declaring the Greek cities free and autonomous in 196 BCE. The Attalid kings of Pergamon became loyal allies of the Roman senate, and in 188 BCE were rewarded with large amounts of formerly Seleukid territory that Antiochos III had to cede to the Romans after the spectacular victo-

103 Ager 2003, 37-50.

104 Ma 2000; Mittag 2006; Feyel and Graslin 2014.

105 Derow 2003, and Weaverdyck, ch. 7, this volume. 
ries of the Romans and their allies in Syria, Asia Minor, and Greece. The small kingdom of the Attalid dynasty, in control of the territory around the city of Pergamon since 283/2 BCE, gained a large territorial expanse stretching across the rich and densely populated river valleys of northwestern Asia Minor, Phrygia, and the southern Pontic Coast. ${ }^{106}$ Within one generation, Rome had risen to be an aggressive military factor, protector state, and arbitrator within the imperial Hellenistic space. A third war between Rome and Macedonia ended with a crushing defeat of the Macedonians at Pydna (168 всE). This led to the fragmentation of the kingdom into four independent but separate regions. Large numbers of slaves from Illyria, Epiros, central Greece, and the Peloponnese were deported to Rome. Ptolemies and Seleukids changed the nature of the control over their remaining territories. ${ }^{107}$ Relationships with local elites and the distribution of revenue were renegotiated, as the famous decree on the Rosetta Stone suggests. ${ }^{108}$ In most areas, we see the reemergence of independent local social structures and the devolution of tributary and administrative tasks to local elites. ${ }^{109}$ Internal secessions ensued, and were successfully repressed in the case of the Theban revolt in Upper Egypt (204-185 BCE), but not so in the case of the Maccabean revolt in Judaea (167-160 BCE).

The years from ca. 160 to 30 ВсE are characterized by extended dynastic conflicts, which weakened the cohesion of the Hellenistic Empires in both their cores and the peripheries. Concomitantly, there was further growth of Roman power, which also mobilized increasing resources and ambition within Rome itself. ${ }^{110}$ Further expansion of the Parthians into Media, Elymais, and the important region of Babylonia threatened the Seleukids from the east. ${ }^{111}$ The dynamic expansion of the Pontic king Mithridates VI (120-63 BCE) into Bithynia, Kappadokia, Galatia, Paphlagonia, Asia Minor, and the Greek mainland not only reduced the Seleukid sphere of influence in northwestern Asia, but also triggered a final phase of Roman imperial expansion into the Hellenistic world under Sulla, Lucullus, and Pompey. By 129 BCE, Seleukid possessions were reduced to the territory of northern Syria before becoming a Roman province in 63 вСE.

In 148 всE Macedonia had been made the first Roman province in the Hellenistic imperial space, followed by the Peloponnese, central Greece, and Thessaly, which became the province of Achaia in 146 BCE. The aggressive expansion, and increasing popularity of Mithridates VI, a rather typical Hellenistic king who, though descending from the Achaemenid royal family, presented himself as a typi-

106 Thonemann 2013, 2-3.

107 Manning 2003, 43-54.

108 Derow and Bagnall 2004, 165; see also n. 50 above.

109 Thonemann 2013 for the Attalid kingdom. In Egypt, the most striking evidence for the reemergence of local autonomy and power is the Ptolemaic local bronze coinage, which reverted to Egyptian standards of weight and value, Faucher and Lorber 2010.

110 Weaverdyck, ch. 7, this volume.

111 Derow 2003 for the following. 
cal Greek benefactor and defender of Greek interests against the Roman barbarians, led to the confrontation between Mithridates and three Roman legions under Sulla in Greece. Mithridates's retreat and the Roman advance into Asia during the second and third Mithridatic Wars (83/2 BCE and 74-63 BCE) involved almost all parts of the Hellenistic world and caused massive human and financial losses. It eventually ended with the reorganization of Asia under Pompey in 63 BCE. Bithynia, Pontos, Kilikia, and Syria became Roman provinces, while treatises of friendship and submission were concluded with the kings of Armenia, Kappadokia, Kolchis, and Galatia.

The Ptolemies, too, gradually lost their peripheral territories. In 94 BCE, Rome had seized Kyrenaika according to the will of Ptolemy Apion, and Cyprus in 58 BCE. Soon after, however, thanks to her remarkable alliances with Julius Caesar and Marc Antony, Kleopatra VII was able to reestablish the empire, if at the cost of Egyptian independence. After the final defeat of Kleopatra and Antony at Actium in 31 BCE, Egypt became a Roman province in 30 BCE.

\section{$X$ Decline and Transformation}

This is not the place to discuss the reasons for the loss of the Hellenistic Empires to the Romans. Polybios and subsequent historiography put much emphasis on the dynastic and moral decline of the Hellenistic courts. The luxury and debauchery of the kings bewildered Roman armies, magistrates, visitors, and envoys, known for their austerity. Some modern scholars suspect that the Ptolemies turned mad in the course of their repeated incest. ${ }^{112}$ Yet, strong rulers such as Ptolemy VIII and Kleopatra VII argue against this suspicion.

More convincing is the argument that Roman expansion in the Eastern Mediterranean was an extraneous shock. ${ }^{113}$ The military machine Rome had been able to develop in the course of the third century was simply more powerful than that of the Hellenistic armies, and became increasingly so the more the Romans were able to tap Hellenistic financial resources. ${ }^{114}$ Access to manpower, as well as agrarian and monetary revenue that paid for armies, fleets, and campaigns were crucial to imperial power in the Hellenistic world. Some extraordinarily wealthy regions, such as Babylonia, Media, and Egypt (including Cyprus and Cyrene), had been indispensable for imperial success. Transportation routes and nodal cities that connected

112 From the marriage between Ptolemy II and his full sister Arsinoe II, brother-sister marriages were frequent among the Ptolemies, probably in order to act against the problem of unclear lines of succession. This marriage policy, however, was not successful, as the dynastic conflicts surrounding the reigns of Ptolemy VIII and Kleopatra II suggest, Hölbl (1993) 2001, 194-203, 222-256. 113 Fischer-Bovet 2014.

114 Weaverdyck, ch. 7, this volume. The capture of foreign treasuries was indispensable for further conquest, de Callataÿ 1989; Taylor 2014. 
these regions were similarly important. This explains the strategic importance of Syria-Phoenicia and its coastal harbor towns, of the Euphrates and the Tigris as riverine routes, the Aegean islands connecting Northern Greece and the Propontic coast with the Western Asian coast and Egypt, and the Pontos region that linked the Black Sea with Kilikia. Above all, the city leagues of central Greece, the Peloponnese, and Macedonia may have functioned as symbolic centers for Hellenistic rulers and their followers who drew identity and cultural orientation from them. The loss of these regions to the Romans and the Arsakids respectively cut the courts off from their lifelines.

Finally, there was the problem of imperial expansion turned inward. As was mentioned several times in this chapter, all Hellenistic rulers, including new contenders in Asia Minor, Pontos, and Armenia, were spurred by the ideological drive for universal empire. For this goal, alliances were created and negotiated, probably always to the advantage of the highest bidder. Those potential allies who promised to make available most revenue, troops, and transportation routes were won over by means of benefactions, promises of friendship, and protection. In this fiercely competitive sphere, no single Hellenistic ruler was able to develop stable alliances in the long-term (Egypt, Cyrene, and Cyprus perhaps being an exception). Dynastic conflicts and changing marriages added to the instability of the Hellenistic Empires. Eventually, the new powers from the West (Rome) and East (Parthia) seem to have struck the best deals in this ever-changing imperial space.

Yet approaching the imperial transformation of the Hellenistic Empires in terms of decline is a misleading perspective in the context of world history. Under Hellenistic influence, structures developed that outlived the rule of the Hellenistic kings. Greek continued to function as common language in the eastern Roman provinces. Hellenistic elites, although gradually adopting Roman habits, continued to fill the most important administrative positions under the Roman Empire. Greek and Greek-style coinages remained the dominant media of payment and exchange in Egypt and in many regions of Asia that lay beyond the Roman fiscalmilitary regime based on Roman coinage. The greatest Hellenistic capitals, Alexandria and Antiocheia-Orontes, continued to be the uncontested metropoleis of the Eastern Mediterranean. The development of productive economic regions such as the Fayum, the Eastern Desert, north Syria, and the Tigris valley provided the foundations for the economic prosperity and vibrant trade of subsequent centuries. Ruler cults and political generosity (euergetism) remained important elements of political identity- and community-building in the Eastern Mediterranean under Roman rule. It is thus with some justification that scholars suggest that the Hellenistic World did not decline culturally before the Arabian conquests of Asia and Egypt in the seventh century CE. 


\section{References}

Ager, S. L. 2003. "An uneasy balance: From the death of Seleukos to the battle of Raphia." In Erskine (2003), 35-50.

Allsen, T. T. 2011. "Premodern empires.” In J. H. Bentley (ed.), The Oxford handbook of world history, 361-378. Oxford: Oxford University Press.

Aperghis, G. G. 2004. The Seleukid royal economy: The finances and financial administration of the Seleukid Empire. Cambridge: Cambridge University Press.

Ashton, S.-A. 2004. "Ptolemaic Alexandria and Egyptian tradition." In A. Hirst and M. S. Silk (eds.), Alexandria: Real and imagined, 15-40. Aldershot: Ashgate.

Badian, E. 1965. "The administration of the empire." Greece and Rome 12.2, 166-182.

Bagnall, R. S. 1976. The administration of the Ptolemaic possessions outside Egypt. Leiden: Brill.

Barkey, K. 2008. Empire of difference: The Ottomans in comparative perspective. Cambridge: Cambridge University Press.

Bernard, P. 2012. "Aï Khanum: A Greek colony in post-Alexandrian Central Asia, or how to be Greek in an Oriental milieu." In J. Aruz and E. Valtz Fino (eds.), Afghanistan: Forging civilizations along the Silk Road, 42-53. New York, NY: Metropolitan Museum of Art.

Billows, R. 2003. "Cities." In Erskine (2003), 196-215.

Bowman, A. K. 1996. Egypt after the Pharaohs, 332 BC-AD 642: From Alexander to the Arab conquest. 2nd ed. Berkeley, CA: University of California Press.

Briant, P. 1988. "Ethno-classe dominante et populations soumises dans l'empire achéménide: Le cas de l'Égypte." In A. Kuhrt and H. Sancisi-Weerdenburg (eds.), Achaemenid history. Vol. 3, 137-173. Leiden: Nederlands Instituut voor het Nabije Oosten.

-. 2002. From Cyrus to Alexander: A history of the Persian Empire. Winona Lake, IN: Eisenbrauns.

-. 2017a. Kings, countries, peoples: Selected studies on the Achaemenid Empire. A. Kuhrt (trans.). Stuttgart: Franz Steiner.

-. (1994) 2017b. "Greco-Hellenistic sources, Persian and Macedonian institutions: Continuities, changes and "bricolages." In Briant (2017a) 498-525. Originally published as "Institutions perses et institutions macédoniennes: Continuités, changements et bricolages."

-. (2003) 2017c. "When kings write history: The Persian period in Ptolemaic inscriptions." In Briant (2017a), 247-258. Originally published as "Quand les rois écrivent l'histoire: La domination achéménide vue à travers les inscriptions officielles lagides."

Bringmann, K., and H. von Steuben, eds. 1995. Schenkungen hellenistischer Herrscher an griechische Städte und Heiligtümer. Vol. 1, Zeugnisse und Kommentare. Berlin: AkademieVerlag.

Bugh, G. R., ed. 2006. The Cambridge companion to the Hellenistic world. Cambridge: Cambridge University Press.

Capdetrey, L. 2007. Le pouvoir séleucide: Territoire, administration, finances d'un royaume hellénistique, 312-129 avant J.-C. Rennes: Presses universitaires de Rennes.

Chaniotis, A. 2003. "The divinity of Hellenistic rulers." In Erskine (2003), 431-445.

-. 2007. "Mythos und Religion." In Weber (2007), 139-157.

Clancier, P., and G. Gorre. Forthcoming. "The integration of indigenous elites and the development of poleis in the Ptolemaic and Seleucid Empires." In C. Fischer-Bovet and S. von Reden (eds.), Comparing the Ptolemaic and Seleukid Empires. Cambridge: Cambridge University Press.

Clancier, P. 2017. "The polis of Babylon: A historical approach.” In B. Chrubasik and D. King (eds.), Hellenism and the local communities of the Eastern Mediterranean: 400 BCE-205 CE, 53-82. Oxford: Oxford University Press.

Clarysse, W., and D. J. Thompson. 2009. Counting the people in Hellenistic Egypt. 2nd ed. Vol. 2, Historical studies. Cambridge: Cambridge University Press. 
Cohen, G. M. 2006. The Hellenistic settlements in Syria, the Red Sea Basin, and North Africa. Berkeley, CA: University of California Press.

-. 2013. The Hellenistic settlements in the East from Armenia and Mesopotamia to Bactria and India. Berkeley, CA: University of California Press.

Davies, J. 2013. "Corridors, cleruchies, commodities and coins: The pre-history of the Athenian Empire." In A. Slawisch (ed.), Handels- und Finanzgebaren in der Ägäis im 5. Jh. v. Chr. I Trade and finance in the 5th c. BC Aegean world, 43-66. Istanbul and Vienna: Ege Yayınları and Phoibos.

de Callataÿ, F. 1989. "Les trésors achéménides et les monnayages d’Alexandre: Espèces immobilisées et espèces circulantes?" Revue des Études Anciennes 91, 259-276.

-. 2005. "L'instauration par Ptolémée ler Sôter d'une économie monétaire fermée." In F. Duyrat and 0. Picard (eds.), L'exception égyptienne? Production et échanges monétaires en Égypte hellénistique et romaine: Actes du colloque d'Alexandrie, 13-15 avril 2002, 117-134. Cairo: Institut Français d’Archéologie Orientale.

-. 2011. "Quantifying monetary production in Greco-Roman times: A general frame." In F. de Callataÿ (ed.), Quantifying monetary supplies in Greco-Roman times, 7-29. Bari: Edipuglia.

Derow, P. 2003. "The arrival of Rome: From the Illyrian Wars to the Fall of Macedon." In Erskine (2003), 51-70.

Derow, P., and R. S. Bagnall. 2004. The Hellenistic period: Historical sources in translation. 2nd ed. Malden, MA: Blackwell.

Erskine, A., ed. 2003. A companion to the Hellenistic world. Malden, MA: Blackwell.

Faucher, T., and C. Lorber. 2010. "Bronze coinage of Ptolemaic Egypt in the second century BC." American Journal of Numismatics 22, 35-80.

Feyel, C., and L. Graslin-Thomé, eds. 2014. Le projet politique d'Antiochos IV: Journées d'études franco-allemandes, Nancy 17-19 juin 2013. Nancy and Paris: ADRA and De Boccard.

Fischer-Bovet, C. 2014. Army and society in Ptolemaic Egypt. Cambridge: Cambridge University Press.

-. Forthcoming. "The Ptolemaic and Seleucid Empires." In P. F. Bang, C. A. Bayly, and W. Scheidel (eds.), The Oxford world history of empire, XX-XX, Oxford: Oxford University Press.

Gehrke, H.-J. 2008. Geschichte des Hellenismus. 4th ed. Munich: Oldenbourg.

Goddio, F. 1998. Alexandria: The submerged royal quarters. London: Periplus.

Grainger, J. D. 1990. The cities of Seleukid Syria. Oxford: Clarendon.

Hauben, H., and A. Meeus, eds. 2014. The Age of the Successors and the creation of the Hellenistic kingdoms (323-276 BC). Leuven: Peeters.

Hölbl, G. (1993) 2001. A history of the Ptolemaic Empire. London: Routledge. Originally published as Geschichte des Ptolemäerreiches.

Hoo, M. Forthcoming. Eurasian localisms: Towards a translocal approach to Hellenism and inbetweenness in central Eurasia, C. 300 BCE-1 CE. Stuttgart: Franz Steiner.

Howgego, C. 1995. Ancient history from coins. London: Routledge.

Jacobs, B. 1994. Die Satrapienverwaltung im Perserreich zur Zeit Darius' III. Wiesbaden: Reichert.

-. 2011. "Achaemenid satrapies." Encyclopaedia Iranica, online edition. http:// www.iranicaonline.org/articles/achaemenid-satrapies.

Jones, C. P. 2010. New heroes in antiquity: From Achilles to Antinoos. Cambridge, MA: Harvard University Press.

Koenen, L. 1993. "The Ptolemaic king as a religious figure." In A. Bulloch, E. S. Gruen, A. A. Long, and A. Stewart (eds.), Images and ideologies: Self-definition in the Hellenistic world, 25-115. Berkeley, CA: University of California Press.

Kosmin, P. 2014. The land of the elephant kings: Space, territory, and ideology in the Seleucid Empire. Cambridge, MA: Harvard University Press.

Kuhrt, A., and S. M. Sherwin-White. 1991. "Aspects of Seleucid royal ideology: The cylinder of Antiochus I from Borsippa." Journal of Hellenic Studies 111, 71-86. 
Kulke, H., and D. Rothermund. 2018. Geschichte Indiens: Von der Induskultur bis heute. 3rd ed. Munich: C. H. Beck.

Lanciers, E. 1993. “Die Opfer im hellenistischen Herrscherkult und ihre Rezeption bei der einheimischen Bevölkerung der hellenistischen Reiche.” In J. Quaegebeur (ed.), Ritual and sacrifice in the ancient Near East: Proceedings of the international conference organized by the Katholieke Universiteit Leuven from the 17th to the 20th of April 1991, 203-223. Leuven: Peeters.

-. 2018. "The emergence of Ptolemaic honorific court titles." Ancient Society 48, 49-82.

Le Rider, G. 1986. “Les Alexandres d'argent en Asie Mineure et dans l’Orient séleucide au Ille siècle av. J.-C. (c. 275-c. 225): Remarques sur le système monétaire des Seleucides et des Ptolémées." Journal des Savants 1/3, 3-57.

Le Rider, G., and F. de Callataÿ. 2006. Les Séleucides et les Ptolémées: L'héritage monétaire et financier d'Alexandre le Grand. Monaco: Éditions du Rocher.

Lewis, N. (1986) 2001. Greeks in Ptolemaic Egypt: Case studies in the social history of the Hellenistic world. Oakville, CT: American Society of Papyrologists.

Lloyd, A. B. 2000. “The Late Period (664-332 BC).” In I. Shaw (ed.), The Oxford history of ancient Egypt, 364-387. Oxford: Oxford University Press.

Lorber, C. 2012. “The coinage of the Ptolemies.” In W. E. Metcalf (ed.), The Oxford handbook of Greek and Roman coinage, 211-234. Oxford: Oxford University Press.

Lowry, S. T. 1987. The archaeology of economic ideas: The classical Greek tradition. Durham: Duke University Press.

Ma, J. 2000. Antiochos III and the cities of western Asia Minor. Oxford: Oxford University Press.

-. 2011. "Court, king and power in Antigonid Macedonia.” In R. J. Lane Fox (ed.), Brill's companion to ancient Macedon: Studies in the archaeology and history of Macedon, $650 B C-300 A D$, 521-543. Leiden: Brill.

-. 2013. "Hellenistic Empires." In P. F. Bang and W. Scheidel (eds.), The Oxford handbook of the state in the ancient Near East and Mediterranean, 324-357. Oxford: Oxford University Press.

Mairs, R. 2014. The Hellenistic Far East: Archaeology, language, and identity in Greek Central Asia. Berkeley, CA: University of California Press.

Mairs, R., and C. Fischer-Bovet. Forthcoming. "Reassessing Hellenistic settlement policies: The Seleukid Far East and Ptolemaic Red Sea Basin, Egypt and Nubia." In C. Fischer-Bovet and S. von Reden (eds.), Comparing the Ptolemaic and Seleucid Empires. Cambridge: Cambridge University Press.

Manning, J. G. 2003. Land and power in Ptolemaic Egypt: The structure of land tenure 332-30 $B C E$. Cambridge: Cambridge University Press.

-. 2010. The last Pharaohs: Egypt under the Ptolemies, 305-30 BC. Princeton, NJ: Princeton University Press.

Meadows, A. 2012. “Ptolemaic possessions outside Egypt.” In R. S. Bagnall, K. Brodersen, C. B. Champion, A. Erskine, and S. R. Huebner (eds.), The encyclopedia of ancient history. Vol. 10, 5625-5629. Malden, MA: Wiley-Blackwell.

Mitchell, L. 2013. The heroic rulers of archaic and classical Greece. London: Bloomsbury. Mittag, P. F. 2006. Antiochos IV. Epiphanes: Eine politische Biographie. Berlin: Akademie-Verlag. Monson, A. 2015. “Hellenistic empires.” In A. Monson and W. Scheidel (eds.), Fiscal regimes and the political economy of premodern states, 169-207. Cambridge: Cambridge University Press.

Mooren, L. 1977. La hiérarchie de cour ptolémaïque: Contribution à l'étude des institutions et des classes dirigeantes à l'époque hellénistique. Leuven: Katholieke Universiteit Leuven.

Moyer, I. S. 2011. Egypt and the limits of Hellenism. Cambridge: Cambridge University Press.

Mueller, K. 2006. Settlements of the Ptolemies: City foundations and new settlement in the Hellenistic world. Leuven: Peeters.

Ogden, D. 1999. Polygamy, prostitutes and death: The Hellenistic dynasties. London: Duckworth. 
Pfeiffer, S. 2008. Herrscher- und Dynastiekulte im Ptolemäerreich: Systematik und Einordnung der Kultformen. Munich: C. H. Beck.

Pfeiffer, S., and H. Klinkott. Forthcoming. "Legitimizing the foreign king in the Ptolemaic and Seleucid Empires: The role of local elites and priests." In C. Fischer-Bovet and S. von Reden (eds.), Comparing the Ptolemaic and Seleucid Empires. Cambridge: Cambridge University Press.

Rice, E. 1983. The grand procession of Ptolemy Philadelphus. Oxford: Oxford University Press. Sherwin-White, S., and A. Kuhrt. 1993. From Samarkhand to Sardis: A new approach to the Seleucid Empire. Berkeley, CA: University of California Press.

Sidebotham, S. E., and J. Gates-Foster. 2019. The archaeological survey of the desert roads between Berenike and the Nile Valley: Expeditions by the University of Michigan and the University of Delaware to the Eastern Desert of Egypt, 1987-2015. Boston, MA: American Schools of Oriental Research.

Stephens, S. A. 2003. Seeing double: Intercultural poetics in Ptolemaic Alexandria. Berkeley, CA: University of California Press.

Strootman, R. 2014a. "Hellenistic imperialism and the ideal of world unity." In C. Rapp and H. A. Drake (eds.), The city in the classical and post-classical world: Changing contexts of power and identity, 38-61. Cambridge: Cambridge University Press.

-. 2014b. "'Men to whose rapacity neither sea nor mountain sets a limit': The aims of the Diadochs." In H. Hauben and A. Meeus (eds.), The Age of the Successors and the creation of the Hellenistic kingdoms (323-276 BC), 307-322. Leuven: Peeters.

Strootman, R., and M. J. Versluys, eds. 2017. Persianism in antiquity. Stuttgart: Franz Steiner. Taylor, M. J. 2014. "Sacred plunder and the Seleucid Near East." Greece and Rome 61, 222-241. Thompson, D. J. 1984. "Agriculture." In F. W. Walbank, A. E. Astin, M. W. Frederiksen, and R. M. Ogilvie (eds.), The Cambridge ancient history. Vol. 7.1, 363-370. Cambridge: Cambridge University Press.

Thonemann, P. 2013. “The Attalid state, 188-133 BC.” In P. Thonemann (ed.), Attalid Asia Minor: Money, international relations, and the state, 1-47. Oxford: Oxford University Press.

-. 2015. The Hellenistic world: Using coins as sources. Cambridge: Cambridge University Press. Tuplin, C. 1991. "Darius' Suez Canal and Persian imperialism." In A. Kuhrt and H. SancisiWeerdenburg (eds.), Achaemenid history. Vol. 6, 237-283. Leiden: Nederlands Instituut voor het Nabije Oosten.

-. 2009. "The Seleucids and their Achaemenid predecessors: A Persian inheritance?" In S. M. R. Darbandi and A. Zournatzi (eds.), Ancient Greece and ancient Iran: Cross-cultural encounters: 1st international conference, Athens, 11-13 November 2006, 109-136. Athens: National Hellenic Research Foundation.

von Reden, S. 2007. Money in Ptolemaic Egypt: From the Macedonian conquest to the end of the third century $B C$. Cambridge: Cambridge University Press.

-. 2019. "Monetization of the countryside." In K. Vandorpe (ed.), A companion to Greco-Roman and Late Antique Egypt, 217-232. Malden, MA: Wiley-Blackwell.

von Reden, S., and R. Strootman. Forthcoming. "Imperial metropoleis and foundation myths: Ptolemaic and Seleucid capitals compared." In C. Fischer-Bovet and S. von Reden (eds.), Comparing the Ptolemaic and Seleucid Empires. Cambridge: Cambridge University Press.

Walbank, F. W. 1981. The Hellenistic world. London: Fontana.

Weber, G., ed. 2007. Kulturgeschichte des Hellenismus: Von Alexander dem Großen bis Kleopatra. Stuttgart: Klett-Cotta. 


\section{Lauren Morris}

\section{Central Asian Empires}

\section{Introduction: Central Asia as an Imperial Space}

\section{I.1 From Imperial Frontier to Center: 300 BCE-300 CE}

During the mid to late first millennium BCE, Central Asia underwent enormous political and cultural change. Through the military campaigns of the Achaemenid kings Cyrus II and Darius I, Central Asia came to form the empire's northeastern frontier by the late sixth century всE. ${ }^{1}$ As with the rest of the Achaemenid Empire, this space was subdivided into dahyava (countries) - preexisting cultural units refigured as satrapal administrative units - from which taxes, military personnel, and laborers could be levied. Bactria was an especially resource-rich and significant country, whose satraps were often drawn from the Achaemenid royal family, but it was also unruly and prone to revolt. ${ }^{2}$ Here, the Achaemenid administration further developed the irrigation systems that had existed since the Bronze Age, ${ }^{3}$ and introduced the use of Aramaic as a chancellery language; the use of Elamite has been additionally attested in Arachosia. ${ }^{4}$

Between 329 and 327 BCE, Alexander the Great campaigned in Central Asia for two difficult years in the pursuit of Bessos (the satrap of Bactria who had murdered the king Darius III), all the while adapting himself to Persian modes of rule and largely preserving administrative structures he found in place. ${ }^{5}$ One important cultural ramification of Alexander's conquests was the introduction of demobilized Greek and Macedonian soldiers into the population through the foundation of new settlements with a strong military component. ${ }^{6}$ Garrisons were established within existing cities or as new outposts, existing cities were refounded, and new foundations were also established, such as Alexandria Eschate on the Jaxartes (mod. Syr

\footnotetext{
1 On Achaemenid Central Asia, see generally Briant 1984. Pre-Achaemenid forms of state control or development in this space are unclear, especially since Sancisi-Weerdenburg 1988 cast doubt on the existence of the Median 'Empire.'

2 Wu 2017; Henkelman 2018.

3 Gardin 1998, 185; Mairs 2014, 38-39.

4 See discussion and bibliography in Morris, ch. 9, this volume.

5 On Alexander in Bactria, see Holt 1988.

6 On prior deportations of Greek communities to Bactria during the Achaemenid period, see Martinez-Sève 2012, 372. On the foundations and settlement policies of Alexander in Central Asia, consult the discussions in Fraser 1996; Fischer-Bovet and Mairs forthcoming.
}

Note: Thanks are due to Olivier Bordeaux, Omar Coloru, and Gunnar Dumke for their comments on earlier versions of this chapter.

Ә Open Access. (ㄷ 2020 Lauren Morris, published by De Gruyter. (c) BY-NC-ND This work is licensed under the Creative Commons Attribution-NonCommercial-NoDerivatives 4.0 License.

https://doi.org/10.1515/9783110607741-004 


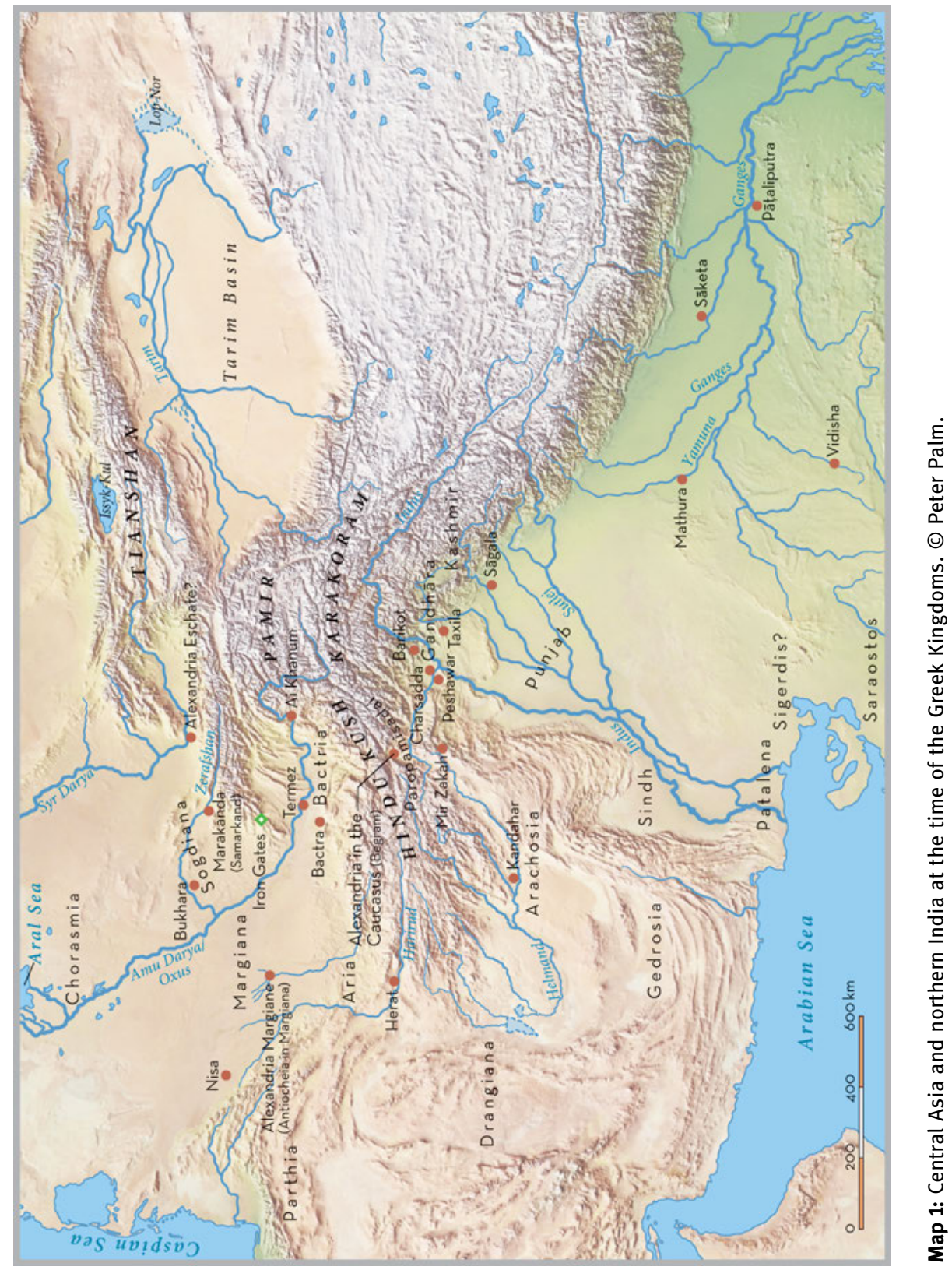


Darya) River. ${ }^{7}$ Although two settler revolts followed in 325 and 323 BCE, ${ }^{8}$ GraecoMacedonian occupation likely continued to some degree.

Following Alexander's death in 323 BCE and the first wars of his successors, Seleukos I led a campaign in ca. 305 BCE into Central Asia. An unsuccessful military venture across the Hindu Kush against the Mauryans resulted in a treaty: Arachosia, the Paropamisadai, Gandhāra, and northwest India were ceded to Chandragupta Maurya along with a Seleukid princess, in exchange for five hundred war elephants. ${ }^{9}$ Seleukos appointed his son Antiochos I as co-regent in ca. 294 BCE with a particular concern for Bactria, due in part to the region's strategic significance but also Antiochos's own family ties; his mother, Apama, was the daughter of the Sogdian noble Spitamenes, who had been a prominent antagonist during Alexander's campaigns. Seleukid rule in Central Asia further culturally and economically integrated this space into the wider Hellenistic world. In Bactria and Sogdiana, the Greek language came into wider use, garrisons and larger settlements were founded and refounded (such as Antiocheia in Margiana), new settlers were introduced, and monetization began through the establishment of royal mints striking gold, silver, and copper coinage to the Attic standard used throughout the Hellenistic East. ${ }^{10}$

Then, in the mid-third century BCE, a new geopolitical phenomenon occurred, which shaped the following centuries in this space. Bactria was transformed from an eastern imperial frontier to become the locus of two new successive Central Asian 'empires': that of the Greek Kingdoms (map 1), and the Kushan Empire (map 2). ${ }^{11}$ The rule of the Greek Kingdoms (са. 250 BCE-10 CE) is usually regarded to begin with the secession of Diodotos I, the former Seleukid satrap of Bactria. He and subsequent kings ruling in Bactria are conventionally referred to as 'Graeco-Bactrian.' After the southern conquests of Demetrios I (са. 200-180 BCE), the subsequent Greek kings thought to have ruled in Arachosia, the Paropamisadai, Gandhāra, and the Punjab are now usually referred to as 'Indo-Greek.' ${ }^{12}$ So much about these kingdoms remains unclear. Strabo, drawing on the now-lost Parthika of Apollodoros of Artemita (ca. 50 BCE), provided the most informative account surviving today. He described an independent Greek polity which had emerged from the agricultural prosperity of Bactria to become a far-reaching and multiethnic political entity:

The Greeks who caused Bactria to revolt grew so powerful on account of the fertility of the country that they became masters, not only of Ariana, but also of India, as Apollodorus of

\footnotetext{
7 The site of which remains archaeologically unconfirmed, see Holt 1988, 54-59.

8 See further in Holt 1988, 70-87.

9 For this episode, see Karttunen 1997, 260-263.

10 On Seleucid Central Asia, see Holt 1999, 21-29; Capdetrey 2007, 79-81; Martinez-Sève 2012, 375376. For more on the Seleukid Empire, see von Reden, ch. 1, this volume.

11 There are many orthographic variants for 'Kushan' in scholarship, and preferences differ according to disciplinary, historical, and methodological positionality. 'Kushan' is in widest use, but 'Kuṣāṇa' or 'Kušān' are also commonly seen.

12 For more on these terms, see below.
} 
Artemita says: and more tribes were subdued by them than by Alexander - by Menander in particular (at least if he actually crossed the Hypanis towards the east and advanced as far as the Imaüs), for some were subdued by him personally and others by Demetrius, the son of Euthydemus the king of the Bactrians; and they took possession, not only of Patalena, but also, on the rest of the coast, of what is called the kingdom of Saraostus and Sigerdis. In short, Apollodorus says that Bactriana is the ornament of Ariana as a whole; and, more than that, they extended their empire [arche, i.e., sovereignty or dominion] even as far as the Seres and the Phryni. ${ }^{13}$

Whether the Greek Kingdoms may be properly defined as a premodern empire as understood in current scholarship has not been extensively debated. ${ }^{14}$ Indeed, the Graeco-Bactrian polity has been described as an empire by a range of authorities over time without explicitly justifying the choice. ${ }^{15}$ Likewise, the Indo-Greeks under Menander have also been described as "an Indian empire with a small Greek ruling caste." 16 Yet, a recent treatment engaging with current discourse about premodern empires prudently does not commit to this definition in respect to the Graeco-Bactrians and Indo-Greeks - largely because of the scarcity of the available (literary) sources - despite generally fulfilling the criteria discussed by the authors. ${ }^{17}$ Thus, although relatively short-lived and still structurally obscure, the Greek Kingdoms nonetheless appear to bear qualities of premodern empires and it is seen as productive in the present context to approach them as such.

Greek rule in Bactria collapsed in the mid-second century BCE from a combination of internal stresses - dynastic conflict, and discord from local elites and populations - and external pressures created by the eastward expansion of the Arsakid Empire and the migration of nomadic groups into and through southern Central Asia. A nomadic confederacy called the Yuezhi 月氏 (or Da [Great] Yuezhi 大月氏) in Chinese sources had arrived in Bactria after the mid-second century BCE, usually identified by scholars as the Tocharoi/Tochari mentioned in Greek and Latin sources, ${ }^{18}$ although the connection is not directly proven. Becoming sedentarized, the Kushan clan attained power among the Yuezhi and established a ruling dynasty conventionally beginning with the king Kujula Kadphises. From the beginning of their rule into the mid-second century $\mathrm{CE}$, Kushan power rapidly expanded into an empire (ca. 50-350 CE) by military conquest, first into northwest India, then finally across the Gangetic plain. The heartland of Bactria-Tokharistan was lost in ca. $230 \mathrm{CE}$ to the Sasanians, who subsequently established the so-called Kushano-Sasanian

13 Strabo 11. 11. 1, trans. Jones. For more on Strabo and Apollodoros in reference to Central Asia, see Morris, ch. 9, this volume.

14 For discourse on premodern empires especially in respect to the Hellenistic world, see von Reden, ch. 1, this volume.

15 Such as Tarn 1938, 409; Bernard 1994, 98, 100, 115; Mairs 2014, 165.

16 Tarn 1938, 258-260.

17 Hoo and Wiesehöfer forthcoming.

18 Strabo 11 .8. 2; Justinus Epitome (Just. Epit.) prol. 42; Ptolemy Geographia (Ptol. Geog.) 6. 11. 6. 
kingdom. Kushan control over Gandhāra and the northern Punjab ended about a century later.

Many facets of Bactria's transformation into a locus of new imperial power require future interrogation, foremost the question of why the Kushan imperial project was more stable and wide-reaching than the Greek one. Some general observations may nonetheless be offered here. First, at this time, certain regions surrounding the core of Bactria - the Paropamisadai, Arachosia, and Gandhāra - were repeatedly subject to its political control. Although Margiana was only briefly under Greek rule before falling to the Arsakids in the second century BCE, it retained varying economic and cultural ties to Bactria, as did the virtually independent Chorasmia and Sogdiana. It should also not be forgotten that the iranophone peoples of Central Asia included both sedentary populations practicing agriculture and mobile pastoralist populations (nomads) living in desert-steppe areas and mountain piedmonts; these populations existed in something of a state of symbiosis. ${ }^{19}$ Connectivity between Bactria, northern India, and the Tarim Basin states also gradually increased during this period. Bactria and Gandhāra were host to exciting cultural innovations, especially in the realms of material culture and religion. Although many museum catalogs and edited volumes concerned with such material frequently cast this space as a "crossroads," 20 this descriptor is flawed for implicitly characterizing Central Asia as a junction between real cultural entities. Indeed, the connectivity, prosperity, and innovation of this period may be associated with Central Asia's development as a new imperial center, even a global core region.

No discussion about Central Asia in antiquity can avoid the customary lament over the state of the art. The available transmitted literary sources are famously poor. ${ }^{21}$ The study of the Greek Kingdoms and the Kushan Empire exists on the fringes of different larger disciplines which do not always speak well to each other, and the existing scholarship can be difficult to navigate. ${ }^{22}$ Little should be taken as common knowledge, and radically significant new evidence sometimes emerges to change prevailing historical narratives. ${ }^{23}$ The continuing reinterpretation of older evidence has also been crucial. This is seen in the sustained struggles to establish relative chronologies of kingship sequences and absolute dates for the historical eras inaugurated by rulers throughout this period, which have enormously hampered scholarly progress of the twentieth century. ${ }^{24}$ Recent achievements in the in-

19 Recent treatments on the nomads of Central Asia in this period include Rapin 2007; Abdullaev 2007.

20 Such as Allchin et al. 1997; Hiebert and Cambon 2011.

21 See Morris, ch. 9, this volume.

22 For further discussion, see Morris, ch. 16, this volume.

23 The most salient case of this is the discovery of the Bactrian-language Rabatak inscription in 1993, discussed further below.

24 For the political and cultic significance of reckoning time in new eras from the Hellenistic period onward, see most recently Kosmin 2018. 
terpretation of literary, epigraphic, and numismatic evidence appear to have finally fixed some dates, approved by wide scholarly consensus. ${ }^{25}$ The beginning of the Greek (Yavana) era probably commenced in $175 \mathrm{BCE},{ }^{26}$ perhaps instituted to mark a co-regency between the Graeco-Bactrian king Antimachos I and the Indo-Greek king Apollodotos I. ${ }^{27}$ The Azes (an Indo-Scythian king) era seems to have been established in 47 вCE and, judged from the affinity of the Arsakid and Azes calendrical systems, may have been a reinauguration of the Arsakid era of 248 BCE (year 1 of Azes = year 201 in Arsakid era). ${ }^{28}$ The date of year 1 of Kanishka, i.e., the Kushan era, has been a particularly contentious subject of modern historiography. ${ }^{29}$ Falk's reading of the Yavanajātaka of Sphujiddhvaja, a third-century Sanskrit astronomical text, noted a formula for converting a year in the Kushan era into a Śaka-era date, the latter being an important historical era of India beginning in $78 \mathrm{CE}$. This study indicated that the two eras are not the same, and has fixed the beginning of year 1 of the Kanishka era in $127 \mathrm{CE} .^{30}$ The Kanishka era appears to be now equivalent with year 301 of the Greek era, indicating a reinauguration of this older era. ${ }^{31}$

Despite the clear historical interest in considering the Greek Kingdoms and the Kushan Empire together, the trajectories of current scholarship on these polities have differed profoundly. Usually restricted to the realm of specialists, the study of political history remains a central occupation of research into the Graeco-Bactrians, especially through the vast numismatic record they left behind. ${ }^{32}$ However, recent years have seen renewed interest in the cultural encounter prompted by Greek rule in Central Asia and northwest India, mobilizing a range of theoretical frameworks to explore its dynamics and implications. ${ }^{33}$ Quite differently, the Kushans have long been associated with the growth of Buddhism into Central Asia and the Tarim Basin in the first centuries CE, and the flourishing of the Gandhāran (sometimes described as Graeco-Buddhist) idiom of sculptural art. Thus, much scholarship dealing with the Kushans exists in the orbits of Buddhist and religious studies, as well as art history. Otherwise, the Kushans frequently appear in scholarship dealing with longdistance trade in antiquity. Here, they are usually framed as middlemen, and their empire's prosperity is repeatedly associated with their putative control of longdistance trade routes. The Begram hoard - which contained over 400 objects largely from the Roman Mediterranean, India, and Han China - has been central to this

25 Consult, conveniently, the discussion and further bibliography in Cribb 2018b; Baums 2018.

26 Falk and Bennett 2009, 208.

27 Rapin 2010.

28 Falk and Bennett 2009, 209-211.

29 See the range of positions represented in Basham 1968.

30 Falk 2001.

31 Falk and Bennett 2009, 208-211.

32 Foundational historical works are Tarn 1938; Narain 1957. Recent numismatically conversant treatments are Coloru 2009; Widemann 2009.

33 See, for example, relevant contributions in Kouremenos et al. 2011; Mairs 2014. 
belief. ${ }^{34}$ As new evidence emerges and the old continues to be critically reviewed, future scholarship will undoubtedly nuance these receptions.

The remainder of this chapter more sharply defines the Central Asian space and its environments and resources, and then presents essential contextual historical information on the Greek Kingdoms and the Kushan Empire. This includes a presentation of their political histories in broad strokes, their notions of kingship, patterns of settlement and urbanism under their rules, their respective militaries, and the administrative systems they mobilized.

\section{I.2 The Central Asian Space: A Geopolitical and Cultural Perspective}

The term 'Central Asia' emerged in the nineteenth century simultaneously in France and Russia, overlapping in part with what had been previously known as Tartary. ${ }^{35}$ As this encompasses an incredibly diverse space without indisputable physical geographical boundaries, Central Asia has become a polyvalent and contested spatial designation, shaped by colonialist and imperialist perspectives as well as modern notions of the political, ethnic, geographic, and cultural characteristics of this space. Indeed, the most extensive study of the concept of Central Asia clarifies that our current situation is one of "terminological chaos." 36

In current anglophone usage, this space is most recognizably identified in the five former Soviet republics of Kazakhstan, Uzbekistan, Tajikistan, Kyrgyzstan, and Turkmenistan, which have been known collectively as Tsentral'naia Aziia since the 1990s. This space had been known as Turkestan under the Russian Empire, demarcated in the early postrevolutionary decades into new Soviet Republics (1924-1936). In the Soviet era they were collectively termed Sredniaia Aziia i Kazakhstan (Middle Asia and Kazakhstan, see also the German Mittelasien). The Russian and German terms translated as Central Asia (Tsentral'naia Aziia, Zentralasien) are traditionally broader, corresponding or overlapping with spaces sometimes called Central Eurasia or Inner Asia in English. Problematically, Central Asia as used in English (as in French, Asie centrale) does not make clear differentiations. It may equally refer to the Soviet Sredniaia Aziia, the present autonomous Chinese region of Xinjiang, and even Inner Asia or Central Eurasia. Definitions of this space still vary wildly in historical scholarship. ${ }^{37}$ For example, the definition adopted for the UNESCO volumes on the history of Central Asia included Afghanistan, China, north India, northeast

34 See further discussion in Morris, ch. 16, this volume.

35 On the origins of the term 'Central Asia' and its early development, see Gorshenina 2014, 283384.

36 Gorshenina 2014, 539-544.

37 Gorshenina 2014, 519-538. 
Iran, Mongolia, Pakistan, as well as Sredniaia Aziia. ${ }^{38}$ Now, most archaeologists working on Central Asia in antiquity tend to adopt a minimalist definition, following the former Soviet Republics but with a northern extent drawn at the Eurasian steppe belt in Kazakhstan, and southern extent along the Kopet Dagh and Hindu Kush ranges.

As the term 'Central Asia' remains inherently malleable, I have elected to use a similar definition of this space, but explicitly informed by its geopolitical and cultural situation in antiquity. Thus, 'Central Asia' is used here to refer to the core territory of Bactria and its adjacent regions (without insisting on fixed boundaries), including the Hindu Kush. Multiple conceptions of this space have been transmitted to us, constructed variously with regard to physical geography as well as ethno-cultural and political-administrative considerations, which do not overlap perfectly. The picture is complicated as the limits of certain spatial entities, such as Bactria, seem to have shifted over time.

The most developed historical geography of relevance is that of Achaemenid administrative geography, particularly Jacobs's reconstruction of a hierarchy of putative great, main, and minor satrapies (Groß-, Haupt- und Kleinsatrapien) at the time of Darius III. ${ }^{39}$ Thus the Great Satrapies of Bactria and Arachosia are subdivided into Main Satrapies which are assumed to be the standard units of imperial administration presented in the dahyava list of Darius I's trilingual Bisitun Inscription. ${ }^{40}$ The Great Satrapy of Arachosia thus perhaps included the Central Main Satrapy of Arachosia - with its capital at Kandahar, the putative location of Alexandria in Arachosia - in addition to Drangiana, Gedrosia, Sattagydia, and India. The Great Satrapy of Bactria is thought to have extended from the Hindu Kush at least to the Jaxartes (mod. Syr Darya). This included the Central Main Satrapy Bactria itself subdivided into a Central Minor Satrapy of Bactria with its capital at Bactra (later known as Balkh) - in addition to Sogdiana, Gandhāra, Aria, and the lands of the Dahae, Massagetae, and Amyrgians.

It is particularly interesting that this reconstruction connects the administration of Gandhāra with Bactria, across the Hindu Kush, rather than northwest India. Additionally, in the Elamite and Babylonian versions of the Bisitun inscription, Gandhāra is instead rendered Parrubaresana/Paruparesanna, that is, Paropamisos/ Paropamisadai and all variants in Greek. ${ }^{41}$ The latter may have been a minor satrapy of Gandhāra, perhaps its western center of gravity. ${ }^{42}$ While the Hindu Kush obviously physically restricted movement, it is mistaken to regard this massif as an impervious political or cultural boundary during the period of study. ${ }^{43}$

38 Miroshnikov 1992.

39 As in Jacobs 1994.

40 See, e.g., the Old Persian version, DBp I.12-17, in Schmitt 1991.

41 DBp I.16; DBe I.13; DBb 6.

42 Jacobs 1994, 217-220; Jacobs 2011.

43 See similar observations in Thapar 2003, 39-40. 
The names of the Main Satrapies are retained here as regional reference points, even if their boundaries and political affinities shifted over time. Presumably, their seats of regional government remained important centers, such as at Bactra and Old Kandahar, although new centers and administrative subdivisions were developed later. A specific example of a changing space may be cited in the case of Bactria, the northern frontier of which is a longstanding point of dispute. Some scholars maintain that literary sources place this frontier between Bactria and Sogdiana at the Oxus River, a perspective underlined most vocally by Rapin who nonetheless concedes that this frontier shifted north over time. ${ }^{44}$ Others consider the frontier to be located at the Hissar Range, and refer to the space between there and the right bank of the Oxus as Northern Bactria. ${ }^{45}$ This conception of Bactria overlaps with an important regional topoynm of the Kushan period, Tokharistan (the land of the Tocharoi/Tochari), which was certainly in use by ca. $137 \mathrm{CE},{ }^{46}$ but probably inaugurated rather earlier. For the Kushan period, it is more appropriate to refer to this space as Bactria-Tokharistan.

Other exogenous ethno-linguistic perspectives considered Central Asia as an eastern Iranian space, for example, in the case of the Ar(e)iane/Ariana variously described in classical sources. ${ }^{47}$ In the early Hellenistic period, Eratosthenes (cited by Strabo), considered Ariana - stretching between the Caspian Gates and Carmania to the Indus River, and from the Hindu Kush to the Arabian Sea - to constitute a single ethnos. ${ }^{48}$ Strabo notes that this definition should also include part of Persia and Media as well as the Bactrians and Sogdians "for these speak approximately the same language," ${ }^{49}$ although this alleged linguistic unity has been dismissed as imaginary. ${ }^{50}$

Some final words about the potentialities of imperial control across Central Asia are due. First, the diverse environments of this space did not have equal settlement or economic potential. While sedentary urban life was concentrated around river basins and irrigated plains, much space between these centers was either sparsely populated or virtually uninhabitable. A helpful analogy to visualize this has been proposed in respect to the spatial designation of 'Turko-Persia.' As the analogy goes, cartographies of states and empires in modernity tend to resemble monolithic "processed American cheese" with a uniform distribution and clear boundaries filled in with a single color on the map. However, Turko-Persia rather illustrated the "Swiss cheese model of the polity" where uniformity of landscape or control thereof is not assumed, and ruling strategies are concentrated around holes of different shapes

\footnotetext{
44 Rapin 2007.

45 For further details, see Staviskij 1986, 50-55.

46 Silver dish of Nukunzuk, line 4, in Sims-Williams 2015, 257.

47 For Ariana and the history of the idea of Iran, see Shahbazi 2005, 105-106.

48 Strabo 15. 2. 8; 2. 1. 31.

49 Strabo 15. 2. 8, trans. Jones.

50 Panaino 2015.
} 
and sizes, while nominal sovereignty could be asserted over peoples in marginal areas (i.e., desert, steppe, and mountains) within the boundaries of the state. ${ }^{51}$ Environment and climate may also shape power structures in other ways, for example in the development of seasonal capitals between which the court would travel. Historically, Kapisa and Kabul (located in the ancient Paropamisadai) have served as the location of a summer highland capital for multiple powers who also had winter lowland bases to the east at Jalalabad, Peshawar, or Taxila. ${ }^{52}$

\section{I.3 Environment, Climate, and Natural Resources}

The environment of Central Asia is very diverse, encompassing oasis, desert, mountain, and steppe landscapes. Its climatic and ecological zones are accordingly varied, but the lowlands in the most part have a semiarid steppe climate with low rainfall occurring mostly in winter and spring. Although the region's climate appears to have been relatively stable for the last five thousand years, climate variations have been documented through proxy records, including a humid period between ca. 0-410 CE. ${ }^{53}$ Sedentary settlement was clustered around piedmonts and river plains composed of fertile loess, and sustained by runoff from the high mountains of the region. These river plains supported denser flora, particularly tugaidense riparian forests thriving in arid regions in addition to agricultural cultivation, which flourished since at least the Bronze Age through the installation of artificial irrigation systems. These systems continued to be developed and extended throughout the Hellenistic and Kushan periods. ${ }^{54}$ On these irrigated plains, or where dry farming was possible, the main food resources cultivated appear to have been grains such as wheat, barley, and millet, i.e., both summer and winter crops. The agricultural output of Bactria was famously outstanding, a point emphasized in multiple Greek and Latin texts. ${ }^{55}$ Meat and secondary animal products could be obtained through hunting and pastoralism practiced along a spectrum of mobility. ${ }^{56}$ Comparably, mountainous regions, such as those of the Paropamisadai and Arachosia encompassed a great diversity of ecotopes created by rapid altitude changes. Lowland valleys, like Laghman and Jalalabad at less than 1,000 m above sea level, are relatively warm year-round and in modern times produce wet rice and citrus crops. However, the highlands (mod. Kabul at 1,800 m, Ghazni at 2,200 m, and Gar-

51 Barfield 2010, 67-68.

52 Barfield 2010, 53.

53 See Gentelle 1989, 61-79; Yang et al. 2009.

54 The available data is uneven. A synthesis of data from the Chalcolithic to the Iron Age is to be found in Francfort and Lecomte 2002. The ample data for east Bactria are presented in Gentelle 1989, 81-106.

55 See further in Morris, ch. 9, this volume.

56 See, for example, the analysis of faunal remains at the Achaemenid period site of Kyzyltepa in north Bactria, indicating that the local economy included a market-oriented pastoral component, in Wu et al. 2015. 
dez at 2,300 $\mathrm{m}$ ) have cold winters which have traditionally supported the cultivation of wheat, barley, grapes, and fruit and nut trees. In a parallel manner to the 'vertical archipeligo' model of the Andes, the close proximity of such diverse ecotopes was likely attractive to the states wishing to exploit them. ${ }^{57}$

Central Asia is host to rich metal deposits including silver, gold, tin, copper, and lead, and to precious and semiprecious stones, including lapis lazuli and garnet. Although direct evidence for the location of mines and their operation during antiquity is lacking, ${ }^{58}$ they were likely economically significant and possibly controlled by imperial monopoly. Somewhat better documented is the case of lapis lazuli, which was found in Badakhshan and had been exploited and distributed through wide networks of exchange since the third millennium BCE. The most important sources were the Kokcha valley and Sar-i Sang, although archaeological research has not been undertaken at the ancient mining works. ${ }^{59}$ However, at Ai Khanum, a Graeco-Bactrian city which lay downstream at the Kokcha's junction with the Panj, a bag-shaped deposit of roughly $75 \mathrm{~kg}$ of unworked lapis was found abandoned in one of the rooms of the treasury, ${ }^{60}$ suggesting some kind of state involvement with the stone's exploitation.

No archaeometallurgical research has yet proven the precise sources of gold, silver, and copper used in the production of Graeco-Bactrian, Indo-Greek and $\mathrm{Ku}$ shan coinage. However, gold deposits are located in Badakhshan and the upper Indus. Potential sources of silver include the galena deposits in Panjshir valley and Farenjal in the Ghorband valley, both in the central Hindu Kush. The major copper deposit of Mes Aynak in the modern Logar province was certainly exploited from the late Kushan period, although earlier exploitation is also expected. The Zarkashan-Anguri formation, located in Arachosia, may have been a major source of copper, iron, gold, and tin. ${ }^{61}$

\section{The Greek Kingdoms of Central Asia}

The Greek Kingdoms of Central Asia existed from ca. 250 BCE until 10 CE (map 1), emerging on the frontier of Seleukid rule in Bactria, with the last kings ruling in the eastern Punjab. These kings - basileis like their Hellenistic counterparts - were perhaps 45 in number, known mostly from coins. Only eight are mentioned in transmitted texts. ${ }^{62}$ It has become conventional to describe these kings as either 'Graeco-

57 Barfield 2010, 52.

58 A project dedicated to ancient mining and resource use in Afghanistan has been established by the Deutsches Archäologisches Institut, see Thomalsky et al. 2013.

59 Bernard 1978.

60 Rapin 1992, 50.

61 For further information on all deposits, see Thomalsky et al. 2013.

62 Bordeaux 2018, 29, n. 28. 
Bactrian' or 'Indo-Greek,' designations which are partly geographical, chronological, and numismatic. The convention is most justified from a numismatic perspective. Graeco-Bactrian coinage developed out of Seleukid coinage and was struck to the Attic weight standard current in the Hellenistic east (tetradrachm of $16.80 \mathrm{~g}$ ), while Indo-Greek coinage was struck to a lower standard (tetradrachm of $9.80 \mathrm{~g}$ ). ${ }^{63}$ The design of Indo-Greek coinage also differs. The names and titles of kings are usually given in Gāndhārī on the reverse of coins, sometimes Indic deities or symbols are depicted, and copper coins were often struck from square flans. The precise implications of these numismatic changes for the political and cultural orientation of the Greek Kingdoms remains an open question. In fact, some later Indo-Greek kings who certainly did not politically control Bactria also minted coinage of a Graeco-Bactrian style and weight; explanatory hypotheses suggest that these coins may have been intended for commercial exchange with Bactria, or as used as tribute payments for antagonistic neighbors. ${ }^{64}$

Indeed, from the available evidence thus far, it appears that the Greek Kingdoms were modelled foremost on the political and administrative structures current in other Hellenistic monarchies, especially that of their Seleukid predecessors. ${ }^{65}$ It is accordingly important to be aware of the possibility of political complexity that is not explicitly visible in our limited sources. Although the reconstruction of the sequence and territorial association of these kings seems exceedingly fragmented and disconnected, the possibility of coregencies and even alliances between kings must be taken into account, as well as inter- and intra-dynastic conflict (fig. 1). This is made plain by the first lines of the Asangorna parchment, an unprovenanced tax receipt from Bactria. This features a dating formula according to multiple kings: "In the reign of God Antimachos and Eumenes and Antimachos ... year 4, month of Olöus, in Asangorna."66 This date appears to be given in the Greek era discussed above, possibly inaugurated to commemorate an alliance made between Antimachos I and Apollodotos I, meaning this document would have been drawn up in 171 вCE. ${ }^{67}$ Indeed, recent analysis with infrared photography has proposed to reconstruct the lacuna to read "[and] Apollodotus" although this reading has yet to be adequately debated and accepted in scholarship. ${ }^{68}$ Numismatic evidence indicates that Antimachos I ruled in Bactria, while Antimachos II ruled in the Indo-Greek realms (as did Apollodotos I). Eumenes is otherwise unknown. Essentially, while the terms Graeco-Bactrian and Indo-Greek are retained here for lucidity, they are obviously problematic vis-à-vis their ethno-cultural baggage, as well as for obscuring the political and administrative organization of the period.

63 Bopearachchi 1991, 13.

64 Bopearachchi 1990.

65 For which see von Reden, ch. 1, this volume.

66 Rea, Senior, and Hollis 1994; see also Bernard and Rapin 1994.

67 Rapin 2010.

68 Jakobsson and Glenn 2018. 


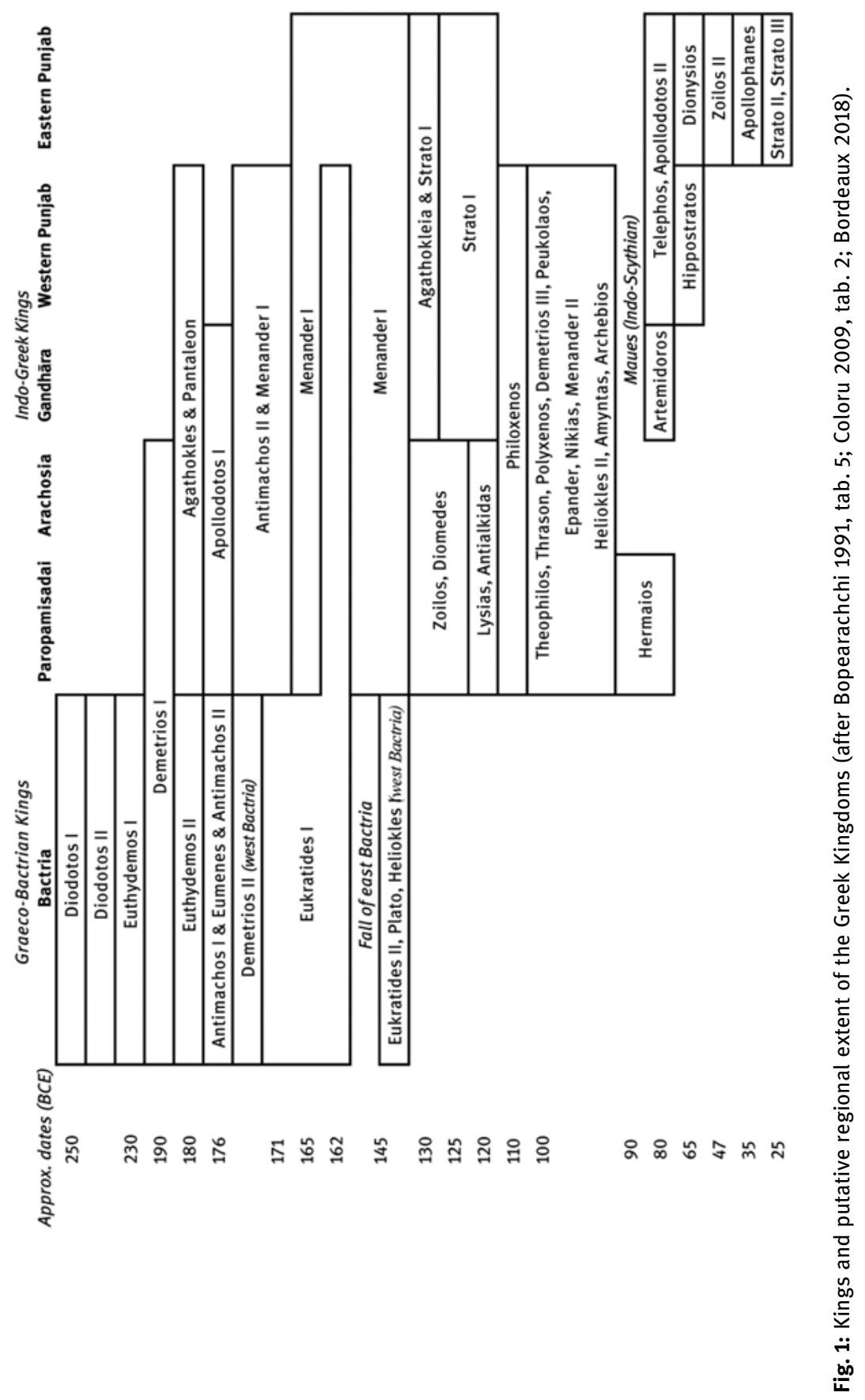




\section{II.1 Political History}

In the mid-third century BCE, Diodotos I, the Seleukid satrap of Bactria, reportedly revolted and established an independent kingdom. ${ }^{69}$ The precise date, between ca. 250-235 BCE, and nature of the Bactrian secession remains a subject of dispute. ${ }^{70}$ Diodotos I was succeeded by a homonymous son, who was reported by Justin to have made an alliance with Arsakes, the founder of the Arsakid dynasty. This alliance apparently ended conflict between Parthia and Bactria and helped the other former Seleukid satrapy to likewise revolt. ${ }^{71}$

The Diodotids appear to have been overthrown by Euthydemos I (ca. 230190 BCE), who Polybios described as being a native of Magnesia. ${ }^{72}$ The Hellenistic historian provided further details about a certain historical episode of conflict between the Seleukids and Graeco-Bactrians. In his grand eastern campaigns, the Seleukid king Antiochos III defeated Euthydemos in a battle near the Arius River (mod. Harirud) in 208 BCE, and Euthydemos retreated to his capital at Bactra, where he was besieged for two years. ${ }^{73}$ During the siege, Euthydemos justified his actions to a Seleukid messenger as action taken against the original rebels, underlining his faculty as the last line of defense against approaching hordes of nomads. The siege concluded with a peace agreement, ratified in person by Euthydemos's son Demetrios I. This recognized Euthydemos's legitimacy, giving also a daughter of Antiochos III to Demetrios in marriage, while Antiochos III received Euthydemos's elephants and grain rations for his troops. ${ }^{74}$ Demetrios (ca. 190-180 BCE) enacted the first major southward expansion of Graeco-Bactrian territory. Likely in imitation of Alexander the conqueror, he was represented on his coins as a bust wearing the scalp of an elephant. ${ }^{75}$ His conquests included at least part of Arachosia, and possibly coincided with the foundation of a new city, Demetrias. ${ }^{76}$

69 Just. Epit. 41. 4. 3-5.

70 Holt's interpretation based on Diodotid coinage is most generally accepted. Holt concluded the secession was a gradual process beginning around 250 BCE, with Diodotos I first minting coins with his own portrait in Antiochos II's name, followed by complete independence in the reign of Diodotus II (Holt 1999, 87-125). Jakobsson proposed alternatively that the coins minted in the name of Antiochos were issued by a hitherto unknown Graeco-Bactrian king named Antiochos, a son of Diodotos I, who ruled after Diodotos II. This would imply Diodotos I's secession was sudden, ruling between ca. 255-250 вCE (Jakobsson 2010).

71 Just. Epit. 41.4. See also the discussion in Fabian, ch. 6, this volume.

72 Polybios (Polyb.) 11. 34. On Antiochos III's eastern campaign, see von Reden, ch. 1, this volume.

73 Polyb. 10. 49.

74 Polyb. 11. 34. 8-10.

75 See von Reden, ch. 1, fig. 1, this volume. The elephant scalp iconography was widely adopted by other kings.

76 Mentioned only in the Parthian-era Greek itinerary text Stathmoi Parthikoi 19, of Isidoros of Charax. 
Demetrios was succeeded by Euthydemos II (са. 180-177 вСE). ${ }^{77}$ Euthydemos II's coinage has many similarities with certain issues of two contemporary Indo-Greek kings, Pantaleon (ca. 180-175 вCE) and Agathokles (са. 180-174 вCE), who are thought to have ruled in Arachosia and the Paropamisadai. Agathokles also minted Graeco-Bactrian weight and style coins. Some political arrangement between the three kings has been inferred. ${ }^{78}$ Pantaleon and Agathokles perhaps expanded their control into Gandhāra, issuing the first Indo-Greek rectangular copper coins, with bilingual legends and depictions of Brahmanical deities rather than royal portraits. $^{79}$

Euthydemus II's reign seems to have been brought to a premature close by Antimachos I Theos (ca. 177-171 всE). Antimachos and Agathokles minted special series of commemorative or 'pedigree' coins in silver, depicting portraits of prior rulers. This has been interpreted to indicate their political rivalry ${ }^{80}$ As discussed above, it is possible that an alliance was made between Antimachos I and the Indo-Greek king Apollodotus I (ca. 174-160 BCE). An apparent co-regency between Antimachos I and (his sons?) Eumenes and Antimachos II is documented in 171 BCE. During this time, a certian Demetrios II (ca. 174-171 BCE) may have ruled in east Bactria. ${ }^{81}$

Then, an usurper, Eukratides I (ca. 171-145 BCE), wrested power in Bactria. The Indo-Greek king Menander I (ca. 165-130 BCE) perhaps emerged shortly after in the Paropamisadai, and it is possible that during this early period, Antimachos II ruled in Arachosia subordinately to him. ${ }^{82}$ Eukratides's early reign appears to have been marked by violent conflict, as Justin mentioned his wars with Sogdians, Drangians, and Indians. ${ }^{83}$ Yet, his campaign into the Indic borderlands, probably in the $160 \mathrm{~s}$ BCE, seems to have been successful. Its material outcome appears to be visible in the finds at the treasury of Ai Khanum, with luxury objects representing the capture of booty or even extraction of tribute. ${ }^{84}$ A Hellenistic phase at Marakanda-Afrasiab in Sogdiana is thought to be associated with a brief reconquest by Eukratides, although the evidence is not conclusive. ${ }^{85}$ The immense prosperity of Eukratides's reign is indicated by his prolific coinage and the enactment of a new building program at Ai Khanum, but it was short lived. Justin reported that, on the king's return from India, he was killed by his son, who drove his chariot through his father's blood and ordered the body to be cast out unburied. ${ }^{86}$

77 Either the younger son of Euthydemus I (Narain 1957, 23; Bopearachchi 1991, 55) or the elder son of Demetrios I (Coloru 2009, 195).

78 Bopearachchi 1991, 56.

79 Bopearachchi 1991, 57; Coloru 2009, 203-206.

80 Bopearachchi 1991, 61; Coloru 2009, 200-202.

81 Coloru 2009, 208.

82 Bordeaux 2018, 140-141.

83 Just. Epit. 41. 6.

84 Rapin 1992, 281-287.

85 Lyonnet 2012, 167.

86 Just. Epit. 41. 6. 
As a result of Eukratides's southeast expansion, conflict with Menander seems to have broken out. Menander probably also enacted an eastward program of conquest, as well as eventually reconquering the territory lost to Eukratides. Later Buddhist tradition places the capital of Menander at Sāgala (probably mod. Sialkot) in the Punjab. ${ }^{87}$ Of all the Indo-Greeks, it is supposed that Menander's conquests were most extensive, if their precise limits remain uncertain. Later Indic literary tradition, foremost the Yugapurāna, seems to reflect a memory of a Yavana (here, Indo-Greek) invasion across the Gangetic plain. According to this text, the Indo-Greeks invaded Sāketa and Pātaliputra in an alliance with the Pañcalas and Māthuras. Having overthrown Pātaliputra, leaving all desolate and in disorder, they returned to their own realm as conflict had broken out there. ${ }^{88}$ Equally difficult to validate is the claim presented in Strabo that the Greeks of Bactria took possession of Patalene, the kingdom of Saraostos, and Sigerdis, which perhaps also reflected the state of expansion under Menander. ${ }^{89}$

The subsequent political history of the Greek Kingdoms is more poorly attested. In Bactria, Eukratides's campaigns might have spread power and resources too thinly. Internal pressures, such dynastic conflict and possibly a local uprising, in combination with external ones, such as the Arsakid conquests of the western provinces and nomadic migrations into Bactria, caused the royal abandonment of Ai Khanum in ca. 145 BCE, marking the end of Greek control over the important region of east Bactria. ${ }^{90}$ Plato and Heliokles I (ca. 143-130 BCE) appear to have been the last Greek rulers of west Bactria. The first nomadic group that migrated into Bactria during the second century BCE were perhaps the Saka/Sai, displaced by the arrival of the Yuezhi (Tochari/Tocharoi?), although the archaeological identification of these groups remains problematic. ${ }^{91}$

After Menander's probably violent death in ca. 130 BCE, Greek power in the Paropamisadai, Arachosia, Gandhāra, and the Punjab seems to have become more fragmented. Bopearachchi's numismatic study still provides the basis for the chronology and location of the kings, but the picture continues to be reassessed through

87 Milindapañha 1.2, a paracanonical Buddhist text that relates a fictitious dialog between king Menander and a Buddhist sage. Its first book was likely composed between 100 BCE-200 CE. For further discussion, see Morris, ch. 9, this volume.

88 Yugapurāṇa, 47-48; 56-57. See a parallel in Patañjali’s commentary on Pānini's grammar, providing similar information in the form of a grammatical example (Mahābhāysa 3.2.11). The Yugapurāna is a Sanskrit text of uncertain age, concerned with the decline of the dharma, which 'prophesizes' the Yavana invasion in the Kali Yuga (the age of strife). This should be compared to a wider tradition about foreign invasions into India's northern plains within Buddhist prophecies of decline, for which see Nattier 1991.

89 Strabo 11. 11. 1, discussed in Coloru 2009, 241.

90 For historiographical discussion on the treatment of the fall of Greek Bactria in modern scholarship, see Mairs 2014, 146-176. For the palatial abandonment of Ai Khanum and its later occupation, see Martinez-Sève 2018.

91 See Abdullaev 2007. 
ongoing research. Coloru has observed that Indo-Greek rule at this point appears to have been divided into two large blocs governed by dynasties often in mutual conflict. Hypothetically, the western bloc might have comprised the Paropamisadai, Arachosia, and western Gandhāra. The eastern bloc perhaps included eastern Gandhāra to the region surrounding Sāgala, with the Sutlej River marking a frontier with Sunga territory. ${ }^{92}$

Zoilos and Diomedes are thought to have ruled in Arachosia and the Paropmisadai after ca. 130 BCE, while joint issues of Strato I and Agathokleia (perhaps Strato's wife) have been placed in eastern Gandhāra and the Punjab, followed by sole issues of Strato. ${ }^{93}$ Afterward, Antialkidas and Lysias perhaps ruled jointly in the Paropamisadai and Arachosia. ${ }^{94} \mathrm{~A}$ unique document of diplomatic relations from this period is the Heliodoros pillar, an inscribed stone column topped with a sculpture of Garuda (the mount of Vishnu) erected in ca. 113 BCE in Vidisha (Madhya Pradesh). The two Prakrit inscriptions written in the Brāhmī script describe the pillar's establishment by Heliodoros of Taxila, a devotee to the god Vasudeva and the Yona (Greek) ambassador from mahārāja Amtalikita (i.e., Antialkidas) sent to Bhāgabhadra, who was either a local ruler or member of the Śunga dynasty. ${ }^{95}$

Around the beginning of the first century BCE, Philoxenos might have briefly reunified the western and eastern blocs, followed by the rule of several coeval kings. Hermaios (са. 90-70 вСE) was the last Indo-Greek king to rule in the Paropamisadai. His coinage was posthumously imitated in this region until the conquest of the Kushan king Kujula Kadphises. The authority responsible for striking these imitations remains unclear; perhaps it was the Yuezhi. 96

Between ca. 90 всE and 10 CE, Arachosia, Gandhāra, and the Punjab developed as spaces of intensified political competition and diversity. Explication of the absolute chronology, political organization, and familial relations and alliances between rulers of this period remains a work in progress. ${ }^{97}$ Indo-Greek kings ruled over a declining space in the east. Maues - the first of the so-called Indo-Scythian (Saka) kings - appears to have taken control of Taxila, with his dynasty ruling over Arachosia and Gandhāra thereafter. ${ }^{98}$ Apollodotos II perhaps regained control over part of Gandhāra to the eastern Punjab, a space then divided by Hippostratos and Dionysios, while the Indo-Scythian king Azes followed Hippostratos at Taxila. IndoGreek rule ended with the reigns of Zoilos II, Apollophanes, Strato II, and Strato III

\footnotetext{
92 Coloru 2009, 245.

93 Coloru 2009, 246.

94 Coloru 2009, 247.

95 Discussed further in Mairs 2014, 117-133.

96 Bopearachchi and Rahman 1995, 37-38.

97 For one recent exposition, see Errington and Curtis 2007, 57-66.

98 A familial relationship between Maues and the Indo-Greek Artemidoros has been postulated from the interpretation of a Gāndhārī legend of a rare copper series of Artemidoros, but for a critical discussion thereof see Bopearachchi 2008, 28-34.
} 
in the eastern Punjab. At the turn of the first century CE, another dynasty initiated by the king Gondophares emerged in Arachosia and Gandhāra. This dynasty is conventionally referred to as the Indo-Parthian dynasty, due to the similarity between their own and Arsakid coins, although their political affiliation remains unclear. The Indo-Parthians ruled much of Gandhāra and Arachosia until the Kushan invasion of Kujula Kadphises. During this period, other local rulers and dynasties were entangled with regional political affairs and patronage of Buddhism: the IndoScythian Kșatrapas; the Apracarājas, kings of the Apraca royal house in Bajaur who had repeated connections with Indo-Scythian rulers; and the neighboring Odi dynasty in Swat. 99

\section{II.2 Kingship}

The logic and challenges of Graeco-Bactrian and Indo-Greek kingship appear to have been similar to those of Hellenistic monarchies, so only characteristics specific to the Central Asian milieu are noted here. ${ }^{100}$ In a political context of apparently constant violence and turmoil, the Graeco-Bactrian kings were compelled to communicate their legitimacy to a competitive peer group - the small Graeco-Macedonian settler class - as well as the Bactrian aristocracy who had allied with the conquerors. ${ }^{101}$ Strategies of communication included royal displays of resources, such as Eukratides I's building program at Ai Khanum, ${ }^{102}$ and propagandistic displays of a king's military achievements, most clearly seen on coinage. For example, the ideological justification of rule over spear-won land (doriktetos chora) ${ }^{103}$ is reflected in some of Eukratides I's coinage, as on types where he is depicted in a helmet with cuirass (instead of the usual mantle), or on the new type he initatied depicting the spear-throwing king from behind. ${ }^{104}$ This type was repeated by subsequent kings, in addition to Eukratides's epithet megas ('the great') and his choice of the Dioscuri as reverse deities. These references to Eukratides's military campaigns communicated a distinctively martial royal identity which was evidently attractive.

The choice to depict certain deities on the reverses of coins were perhaps intended to communicate dynastic legitimacy, such as the Diodotid use of Zeus with thunderbolt, or wider familial associations, such as Euthydemos II's depiction of Apollo on his nickel and copper coinage in reference to the Seleukids. ${ }^{105}$ Likewise,

99 For more on the Apracarājas, see Falk 1998, and for the kings of Oḍi, see von Hinüber 2003.

100 Further discussion on Hellenistic kingship is found in von Reden, ch. 1, this volume.

101 See further in Bernard 1981.

102 Martinez-Sève 2015.

103 For the significance of spear-won land, see von Reden, ch. 1, this volume.

104 Bopearachchi 1991, Eukratides I series 8.

105 Bopearachchi 1991, 56. For a different perspective, see Coloru 2009, 195. 
the commemorative issues of Antimachos I and Agathokles may be interpreted as attempts to convey legitimacy, used by both kings to connect themselves with past sovereigns of Hellenistic Central Asia. ${ }^{106}$

Gaining the acceptance of wider subject groups was an important task that involved new cultural and linguistic challenges, and to this end, the 'religious policy' of the Greek kings of Central Asia appear to have been similar to that of their Seleukid contemporaries. They depicted or referenced popular local deities on their coins, used sanctuaries of local and syncretic deities as platforms for showcasing royal power, and most probably developed royal cults. ${ }^{107}$ On Indo-Greek coinage, this manifested in the use of bilingual legends and the portrayal of Indic symbols and deities; most vividly, certain issues of Agathokles depicted the Brahmanical deities Balarāma-Saṃkarṣana and Vāsudeva-Kṛṣna. Of course, such strategies are not evidence for any ruler's adherence to local religions. Whether Menander converted to Buddhism remains a matter of debate, but for political purposes he might have supported the Buddhist community in some way; the use of the symbol of the wheel on some of his copper coins may be read as an attempt to communicate with his Brahmanical and Buddhist subjects. ${ }^{108}$

\section{II.3 Settlement, Fortifications, and Urbanism}

While Greek and Latin literary sources mention the names of numerous foundations of the Hellenistic period in Central Asia, the admittedly uneven archaeological evidence indicates that it was more common for preexisting cities and settlements to be developed and renamed during this period, rather than for new foundations to be established. ${ }^{109}$ Under Alexander, the Seleukids, and the early Graeco-Bactrians, new fortifications and garrisons were probably added to all major urban centers, including Marakanda-Afrasiab and Bactra, and smaller fortresses were created, like Kurganzol in northern Bactria, and Kampyrtepa, which was located at a strategic crossing point on the Oxus. The latter became more significant in the Graeco-Bactrian period, incorporating a residential area. ${ }^{110}$ A network of border fortifications across the Hissar Range was also developed possibly as early as the Seleukid period and maintained under the Graeco-Bactrians. This included the Iron Gate wall near Derbent, and Uzundara, a fortress located on top of the Suzitag controlling a second

\footnotetext{
106 Antimachos I depicted portraits and legends naming Diodotos I and Euthydemos I, while Agathokles depicted Alexander the Great, Antiochos II, Diodotos I, Diodotos II, Euthydemos I, Demetrios I, and Pantaleon.

107 Martinez-Sève 2010.

108 Coloru 2009, 242-244.

109 Leriche 2007, 138. Consult also Cohen 2013; Mairs and Fischer-Bovet forthcoming.

110 Martinez-Sève 2012, 376. On Kurganzol, see Sverchkov 2014. On Graeco-Bactrian Kampyrtepa, see Bolelov 2018, 11-18.
} 
route between Bactria and Sogdiana. ${ }^{111}$ In other cases, preexisting settlements in the Kugitang piedmont and the Surkhan Darya valley appear to have been abandoned in the early Hellenistic period and not developed again until the Kushan period. ${ }^{112}$

$\mathrm{Ai}$ Khanum remains the only extensively excavated Graeco-Bactrian city. Its origins are somewhat obscure; it is possible that the site was occupied in the Achaemenid period (e.g., with a garrison), although no archaeological layers from this time were detected during excavations. ${ }^{113}$ The city proper is generally regarded as a colonial Hellenistic-period foundation, perhaps established by the Seleukids, but developed profoundly by the Graeco-Bactrian kings into a royal residence and the capital of east Bactria. ${ }^{114}$ The city was home to only a small settler population, and had strong militaristic elements including fortifications and an arsenal, but also prestigious monumental and public buildings including temples, a palace with a treasury, and a heroon (sanctuary for a hero). During the reign of Eukratides, the Greek civic institutions of a theater and gymnasion were constructed, which remain by far the easternmost attested examples of both. However, it should be emphasized that Ai Khanum is thus far unique in the archaeological record of Central Asia, and thus should not be seen as a typical case of Graeco-Bactrian urbanism.

\section{II.4 Military}

The ability to mobilize and finance an effective army was central to the success of Graeco-Bactrian and Indo-Greek kings. Expansion by conquest was an important for a king's legitimacy, and the possibility of civil and external warfare was constantly looming. The structure, organization, tactics, and arms of the armies of the Greek Kingdoms seem to reflect those of the wider Hellenistic world, although direct information is scarce. ${ }^{115}$ A small standing infantry drawn initially from the Graeco-Macedonian settler community is to be expected, stationed at the numerous archaeologically attested military installations described previously, including forts, garrisons in larger fortified settlements, and the Iron Gate wall. By analogy with infantries of other Hellenistic states, they were probably composed of phalanx units armed with sarissa pikes. ${ }^{116}$

Some innovations are also visible to us. For example, finds of iron armor elements for a human and horse at Ai Khanum indicate that heavy-armored cavalry was in use by around the mid-second century всЕ. ${ }^{117}$ The nature and power of the

111 A discussion of the Iron Gate wall excavations is found in Rapin 2007. The latest report on excavations at Uzundara is Dvurechenskaia 2015.

112 Augustinová et al. 2018, 130.

113 Martinez-Sève 2015, 21-22.

114 For this and the following, Martinez-Sève 2015, 26-41; Martinez-Sève 2014.

115 A survey is provided in Nikonorov 1997, 38-49.

116 Nikonorov 1997, 38.

117 Bernard 1980, 452-459. 
army would have changed significantly with the integration of new local fighting forces and with access to elephants through conquests into Arachosia, Gandhāra, and the Indic borderlands. Further forces were likely also mobilized in times of need. Phalanx soldiers might have been supplemented by mercenaries from the local population serving as lightly armed auxiliary troops. Polybios numbers Euthydemos's cavalry for the battle of Arius at 10,000 horsemen, ${ }^{118}$ which probably was comprised of a substantial portion of indigenous Bactrian nobles. ${ }^{119}$ It is also likely that the Graeco-Bactrians took advantage of the manpower of the nomadic groups living within and beyond their frontiers by hiring them as mercenaries. The Amphipolis parchment appears to refer to such a payment of coined silver to "Scythian" mercenaries. ${ }^{120}$

\section{II.5 Administration}

The data available on administrative practice in the Greek Kingdoms thus far indicates continuity from structures established and developed in Achaemenid and Seleukid periods of rule in Central Asia, as well as parallels with contemporary developments in the eastern Hellenistic kingdoms. ${ }^{121}$ Evidence of administrative practice in the Achaemenid period is thus important. The continuing study of recently edited documents from Bactria written in Official Aramaic - including tally-sticks as well as letter orders from the archive of Akhvamazda (presumably the satrap residing in Bactra) - indicates the replication of practices from the imperial center in the northeastern frontier, in addition to high mobility between the two. ${ }^{122}$

Although Strabo stated that "the Greeks who took possession of the region divided it into satrapies," 123 the shape of these administrative units remains unknown. Several offices familiar from the Hellenistic world are attested. The title strategos survived beyond Greek rule at Taxila into the first century CE, as did the title of meridarches, a civil provincial governor, attested in Gandhāra, in Swat during the Indo-Greek period, and later in Taxila. ${ }^{124}$

Financial administration is likely to have followed Seleukid practices, to the extent that the Asangorna parchment has been considered an indirect source for Seleukid administration. ${ }^{125}$ Within this text, Menodotos - a tax-gatherer or account-

118 Polyb. 10. 49. 1.

119 Polyb. 10. 49. 1. On the indigenous Bactrian cavalry in this conflict, see Leriche 1985.

120 Mairs 2014, 150.

121 Aperghis 2004, 283; Coloru 2009, 265-268; Mairs 2014, 55-56. For more on practices in the Hellenistic kingdoms, see von Reden, ch. 1, this volume.

122 Henkelman 2018. See further discussion and bibliography in Morris, ch. 9, this volume.

123 Strabo 11. 11. 2, trans. Jones.

124 Coloru 2009, 265-266.

125 Aperghis 2004, 283-283. 
ant (logeutes) - acknowledges receipt from another individual (whose name is not fully preserved) of payments due from a purchase. A hierarchy of officials above Menodotos is seen: He acted in the presence of an official, who was sent out by two further officials (a Demonax and a Simos), all under the agency of Diodoros, the controller of revenues (epi tôn prosodôn). ${ }^{126}$ A second text of the Graeco-Bactrian period, the Amphipolis parchment, records a payment of a sum, explicitly, of 100 drachms of coined silver, to Scythians (mercenaries?) and another fragmentary text notes that Archises had received something (a payment?) for transport, with some reference to stone. ${ }^{127}$ Finally, a glimpse into the granular processes within the palatial treasury of Ai Khanum is provided by a corpus of notations applied to ceramic vessels with ink or incised post-firing. ${ }^{128}$ These texts often describe the contents of the vessels (coins, olive oil, incense, and cinnamon), and transactions taken with revenue or commodities by officials (who are mentioned only by name), variously transferring, counting, and sealing the described contents. Coined money is represented conspicuously, counted in round sums of Greek drachms (500) and Indian kārșāpaṇas (10,000). ${ }^{129}$ In sum, it is evident that Graeco-Bactrian rule was supported by a sophisticated administrative system.

\section{The Kushan Empire}

The Kushan Empire (map 2, ca. 50-350 CE) emerged from the Kushan clan within the Yuezhi confederacy of nomads in Bactria-Tokharistan (map 3). The absolute chronology for the Kushan kings, which remains a work in progress, as used here follows Cribb's reconstruction (fig. 2) ${ }^{130}$ Through military expansion, by the middle of the second century CE, this empire appears to have stretched between BactriaTokharistan's northern frontier at the Hissar range and the city of Śrī-Campā on the Ganges, although the real extent of Kushan rule and its precise nature is not yet clear. The heartland of Bactria-Tokharistan was lost to the Sasanian king Ardashir I in ca. $230 \mathrm{CE}$, and the so-called Kushano-Sasanian kingdom was established there. Kushan power in Gandhāra and the northern Punjab appears to have ended about a century later.

Although 'Kushan' seems to operate as a dynastic name and is usually treated as such in scholarship, its origins and meaning are obscure. It might rather have functioned as a title, deriving from the clan name of the yabgu (see below) of the Guishuang 貴霜 (Kushan) when Bactria was under Yuezhi rule, or a place name

126 For a general discussion, Mairs 2014, 46-54.

127 Clarysse and Thompson 2007; Mairs 2014, 54.

128 Rapin and Grenet 1983; see further discussion in Morris, ch. 9, this volume.

129 Mairs 2014, 50.

130 As in Jongeward et al. 2015. 


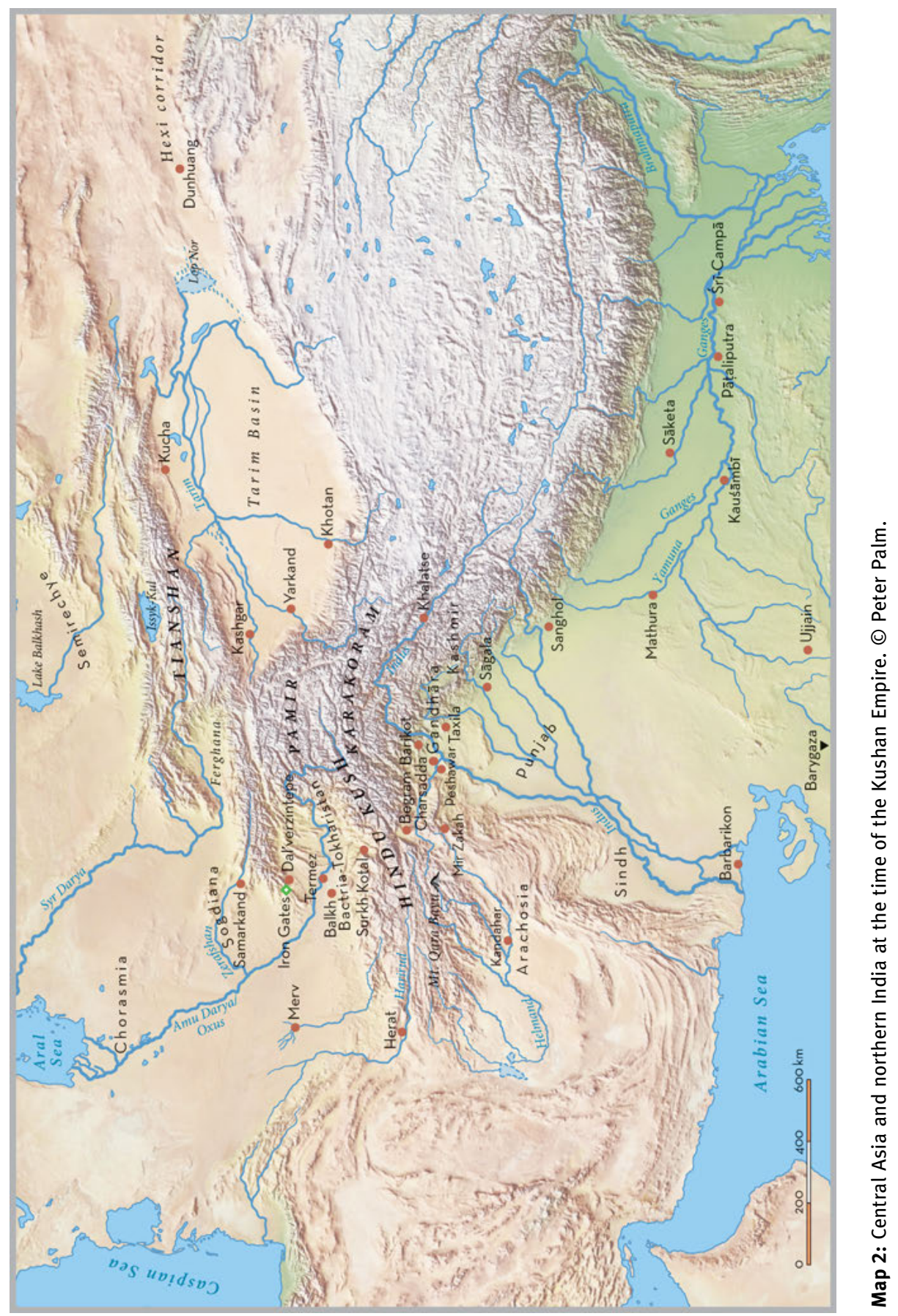


associated with the clan that is no longer known. ${ }^{131}$ Epigraphic texts and coin legends known thus far associate 'Kushan' with the names of all kings from Kujula Kadphises to Vasudeva II, except for Vima Kadphises, who is nonetheless explicitly named as Kanishka's father in the Rabatak inscription. ${ }^{132}$ The last three kings, Mahi to Kipunadha, are only known from their coins, but as they minted types distinct to the Kushans, they are appropriately considered as Kushan kings.

\section{III.1 Political History}

The origins of the Kushans are found in the Yuezhi, a confederacy of nomadic pastoralists. Although the matter is more complicated, Chinese sources conflated the two: “All the kingdoms call [their king] the Guishuang 貴霜 (Kushan) king, but the Han call them by their original name, Da Yuezhi."133 Prior to their migration into Bactria, the history of the Yuezhi is only tenuously known from Chinese historical sources, ${ }^{134}$ which place their earliest known home in the Gansu corridor. ${ }^{135}$ Multiple sources recount their conflicts with other nomadic confederacies - especially the attacks made by the Xiongnu on the Yuezhi from the late third century BCE - which instigated the latter's gradual migration to Bactria, although their exact route remains a matter of contention. ${ }^{136}$ The Yuezhi appear to have arrived here after the mid-second century BCE, after which their court was visited by the Han ambassador Zhang Qian in 128 BCE who unsuccessfully sought a military alliance with the Yuezhi against the Xiongnu. ${ }^{137}$

At some point during their time in Bactria, Yuezhi rule was split between five yabgus, i.e., 'allied princes.' 138 The realms and seat of governance of each Yuezhi yabgu were listed first in the Hanshu (Documents of the Han), ${ }^{139}$ and have been tentatively located by Grenet within northern Bactria by comparing the attested Chi-

131 Cribb 2018a, 4; see also remarks in Falk 2015, 11.

132 Rabatak lines 13-14, edition and trans. in Sims-Williams 2004.

133 Hou Hanshu 88.2921, trans. Hill 2015, 1: § 13.

134 See the presentation and discussion of sources in Falk 2015, especially $\S 1-3$. The frequently made equation between the Yuezhi and the Yuzhi 禺氏 - traders of white jade in the mountains bordering Khotan - is speculative. On the interpretation of Chinese sources in this historical context, see Morris, ch. 9, this volume.

135 Shiji 123.3162; Hanshu 96A.3891.

136 See the sources collected in Falk 2015, § 9-28.

137 Zhang Qian's report is described in Shiji 123. For further discussion see Morris, ch. 9, this volume.

138 Rendered as xihou 翕侯 in Chinese sources, thought to be equivalent to the later Turkic title yabgu. Whether this title existed among the Yuezhi prior to their arrival in Bactria is not known. On its interpretation, see Sims-Williams and de la Vaissière 2007.

139 Hanshu 96A.3891. See this and later sources collected in Falk 2015, § 44-46. 


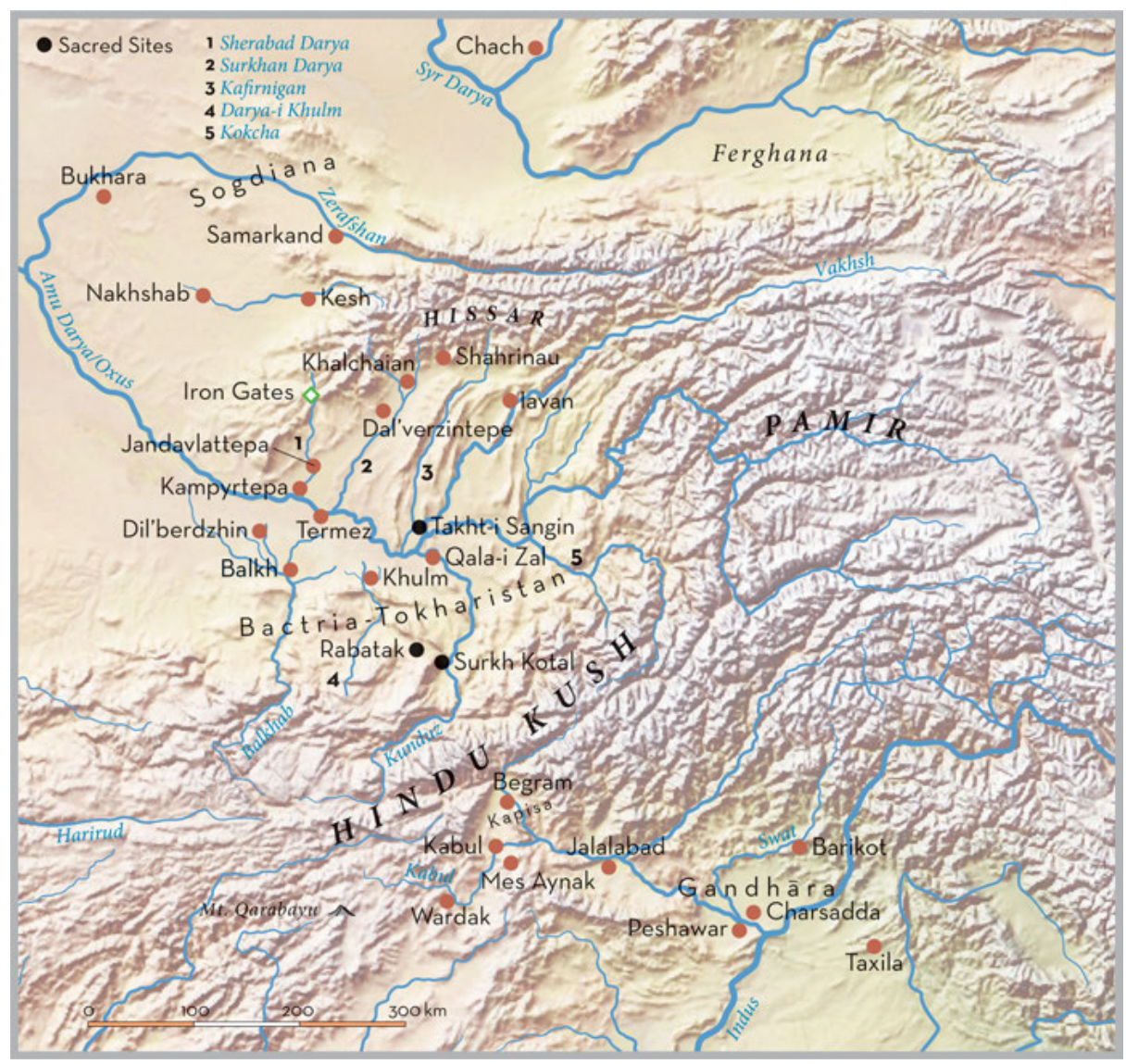

Map 3: Important settlements and sacred sites of Kushan Bactria-Tokharistan and surroundings. (C) Peter Palm.

nese toponyms with historical toponyms of other languages and time periods. ${ }^{140}$ Thus the yabgu of Xiumi with its seat at the town Hemo probably ruled in Karategin (in the upper Vakhsh); the yabgu of Shuangmi with its seat at the town of Shuangmi, probably ruled in Hisar (a realm including Khalchaian and Dal'verzintepe); the yabgu of the Guishuang (Kushan) with its seat at the town of Huzao, seems to have ruled in Wakhshu or Wakhshab (Vakhsh River, near to Takht-i Sangin); the yabgu of Xidun with its seat at Bomao, probably ruled the Kafirnigan valley; and the yabgu of Gaofu seems to have had its seat at Gaofu/Dumi, modern Termez.

Relatively early in their time in Bactria, it appears that the Yuezhi struck imitation coins of Eukratides I and Heliokles I, i.e., some of the last Graeco-Bactrian

140 Grenet 2006; Falk 2015, § 48. For a different reconstruction, see Falk 2014. 
kings ruling in west Bactria. These were followed by the enigmatic silver coinage of 'Heraios' (misread from an apparent title in the Greek legend turannountos eiaou korranou). These depict a distinctive bust of a moustachioed and diademed ruler on the obverse, and on the reverse the same ruler in Central Asian-Iranian dress on horseback, with a bow hanging from the saddle (ch. 9, fig. 4). This coinage seems to have emanated from the realm thought to have been ruled by the Kushan yabgu, and the issuing authority is thought to have been a pre-imperial Kushan yabgu, or perhaps the first known Kushan king, Kujula Kadphises, who came to power in ca. $50 \mathrm{CE} .{ }^{141}$ At the end of the pre-imperial period, the Arsakid king Vardanes I reportedly sought refuge in the plains of the Bactrians during a power struggle with his brother Gotarzes II, before regaining authority and leading a successful campaign against Gotarzes's Dahae (a nomadic group) army. ${ }^{142}$ This event may help to interpret the painted clay sculptures of Khalchaian, which is a Yuezhi temple or ceremonial pavilion of contested date (perhaps mid-first century CE). Several figures have similar physiognomy and dress to that on the 'Heraios' coins, and the sculptural program, which includes a mounted battle scene, appears to celebrate a victory over a Saka group. ${ }^{143}$ The central sculptural panel includes an individual clearly identifiable as an Arsakid or Parthian noble, which Grenet has hypothesized may constitute a portrait of Vardarnes I, although an earlier date and different historical circumstances remain possible. ${ }^{144}$

The beginnings of the Kushan Empire remain shrouded in mystery, best known from their pithy retelling in Hou Hanshu (Documents of the Later Han), compiled in the fifth century $\mathrm{CE}$ :

More than a hundred years later, the prince [xihou/yabgu] of Guishuang, named Qiujiuque [Kujula Kadphises], attached and exterminated the four other xihou. He established himself as king, and his dynasty was called that of Guishuang. He invaded Anxi and took the Gaofu region. He also defeated the whole of the kingdoms of Puda, and Jibin. Qiujiuque was more than eighty when he died. ${ }^{145}$

Thus, Kujula seized power among the Yuezhi, and captured at least Kapisa, Gandhāra, and Taxila; the toponyms given in this account are difficult to precisely locate. ${ }^{146}$ The Hou Hanshu also provides information about the entanglement of the Kushans in the military and diplomatic activities of Ban Chao (Han protector-general of the Western Regions), which also sheds light on the Kushans' own diplomatic relations during this period. Reportedly, Ban Chao attacked Yarkand in 84 CE. Then, the king

141 See discussions in Falk 2015, § 57; Cribb 2018a, 11-14.

142 Tacitus Annales (Tac. Ann.) 9. 8-10.

143 Bernard 1987.

144 Grenet 2000; Olbrycht 2015, 347-349.

145 Hou Hanshu 88.2921, trans. after Hill 2015, 1: § 13.

146 See Hill 2015, 2: appendices D, F, G. For a numismatic perspective on Kujula's conquests, see Jongeward et al. 2015, 24. On the identification of Central Asian toponyms and ethnonyms in Chinese texts, see Morris, ch. 9, this volume. 


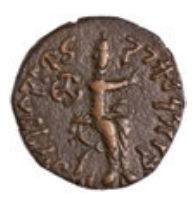

ANS 1973.56.220

Kujula Kadphises (ca. 50-90)

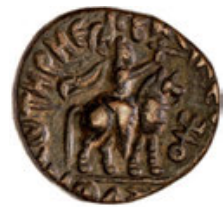

ANS 1944.100.59469

Vima Taktu (ca. 90-113)

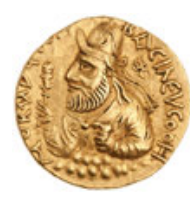

ANS 1944.100.30162 Vima Kadphises (ca. 113-127)

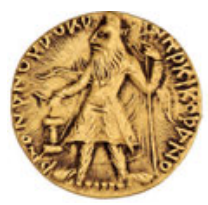

ANS 1944.100.30743

Kanishka I (ca. 127-151)

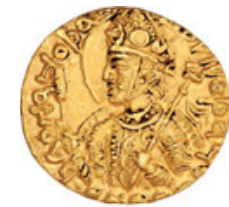

ANS 1986.149.12

Huvishka (ca. 151-190)

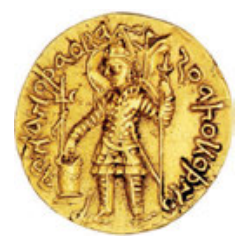

ANS 1944.100.63827

Vasudeva I (ca. 190-230)

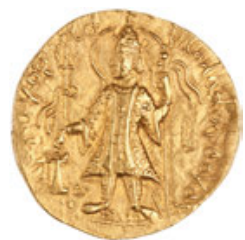

ANS 1967.154.11

Kanishka II (ca. 230-247)

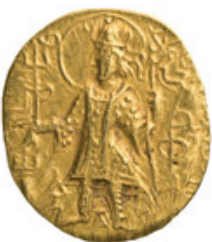

ANS 2012.31.3

Vasishka (ca. 247-267)

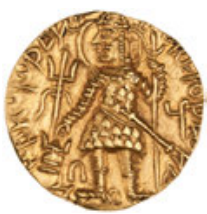

ANS 1944.100.59445

Kanishka III (ca. 267-270)

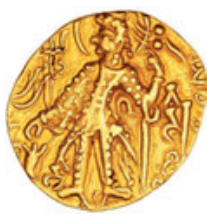

ANS 1944.100.63831

Vasudeva II

(ca. 267-300)

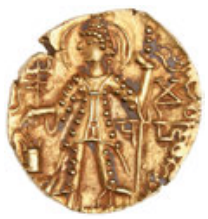

ANS 2012.2.1 Mahi (ca. 300-305)

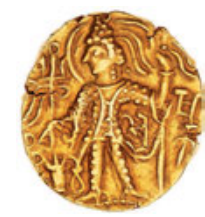

ANS 1944.100.48107 Saka

(ca. 305-335)

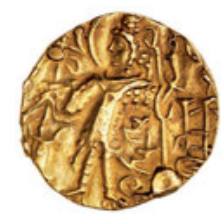

ANS 1944.100.59428 Kipunadha (ca. 335-350)

Fig. 2: The Kushan kings. All photographs $\odot$ American Numismatic Society.

of Kashgar revolted, receiving military help from the Kangju 康居 (another nomadic group controlling Chach and much of Sogdiana). The Kushans and the Kangju were newly linked by a recent marriage, so Ban Chao sent gifts of silk stuffs to Kujula and persuaded him to convince the Kangju to discontinue their support for the king of Kashgar. ${ }^{147}$ When Ban Chao defeated Yarkand, the Kushans sent an envoy with tribute of precious stones, antelopes, and lions; however, their request for a Han princess in marriage was rejected, prompting animosity toward the Han thereafter. ${ }^{148}$

147 Hou Hanshu 47.1579-1580.

148 Hou Hanshu 3.158; Hou Hanshu 47.1580. 
In Kujula's final years, he also appears to have initiated the new 'Soter Megas' copper coinage - with the legend basileus basileuon [sic] soter megas ('king of kings, great savior') - which was struck to a reduced Attic standard. The majority of this coinage however appears to have been minted by Kujula's son and successor, Vima Taktu. ${ }^{149}$

Vima Taktu continued attempts to expand Kushan rule through conquest. Chinese historical sources mention a failed military enterprise into the Tarim Basin in $90 \mathrm{CE}$. Vima Taktu reportedly led a force of 70,000 to attack Ban Chao west of Kucha. Short on provisions, Vima sent envoys with gold, silver, pearls, and jade to the king of Kucha to request aid, but Ban Chao laid an ambush to kill the envoys. Vima then sent an envoy to Ban Chao in a gesture of peace, and thereafter the Kushans reportedly paid tribute to the Han every year. ${ }^{150}$ Vima's exploits in the southeast were more successful. He conquered Tianzhu 天箨 (northwest India up to Mathura) and installed a general in charge of its administration, which reportedly made the Kushans extremely rich. ${ }^{151}$ Vima appears to have consolidated his control in the Mathura region by establishing a devakula (house of the gods) at Măț. This poorly documented structure was furnished with over life-sized sculptures of the Kushan kings (some accompanied with inscriptions) and also deities, although the precise religious beliefs and practices involved remain unclear. ${ }^{152}$ Vima Taktu also established a trilingual inscription on a boulder on a ridge of Mount Qarabayu, perhaps intended as a proclamation of power or boundary marker. The languages used were Bactrian (the native spoken idiom of the country written in a modified Greek alphabet), Gāndhārī, and the so-called 'unknown language' in the undeciphered 'unknown script.'153

Vima Taktu's successor, Vima Kadphises, is best known for introducing a regular gold coinage, struck to a new unit (ca. $8.0 \mathrm{~g}$ ) conventionally referred to as the dinar. ${ }^{154}$ On these coins, Vima Kadphises established distinctive and innovative designs reflecting Kushan royal identity. ${ }^{155} \mathrm{~A}$ single rock inscription at Khalatse (near to Leh, see map 2) dated to $112 \mathrm{CE}$ bears his name. ${ }^{156}$ Between the years of 114120 CE, i.e., during Vima Kadphises's reign, the Kushans also reportedly have become entangled with dynastic problems of Kashgar. The king of Kashgar's maternal uncle, Chenpan, was exiled to the Kushans, who are said to have become very fond

149 Cribb 2014; Jongeward et al. 2015, 5.

150 Hou Hanji 13; Hou Hanshu 47.1580. For the interpretation of Vima Taktu's name in these texts, see Falk 2015, § 74-75.

151 Hou Hanshu 88.2921.

152 For a summary of the excavations, see Rosenfield 1967, 140-142. For the inscription on the base of the statue of Vima Taktu, Falk 2015, § 88.

153 Fussman 1974, 2-50; Sims-Williams 2012, 76-77. See further in Morris, ch. 9, this volume.

154 See further in Morris, ch. 16, this volume.

155 Jongeward et al. 2015, 7, 53.

156 Edition in Falk 2015, § 91. 
of him. When the king of Kashgar died without an heir and a young relative was installed on the throne, Kushan soldiers escorted Chenpan back to Kashgar where he was made king. ${ }^{157}$

Vima Kadphises was succeeded by his son, Kanishka I, who is relatively well known to history through memories and legends in later Buddhist texts relating his conquests, supernatural powers, wickedness, and his (historically dubious) conversion to and personal patronage of Buddhism. ${ }^{158}$ Thankfully, two contemporary Bactrian inscriptions provide more concrete insight into Kanishka's accession and Indian conquests. The Rabatak foundation inscription was discovered by chance at an unexcavated bagolango (image temple) in 1993, and is packed with historical information that revolutionized Kushan studies. ${ }^{159}$ This inscription mentions Kanishka's inauguration of a new era (year $1=127 \mathrm{CE}$ ) and notes that the king was busy pacifying "all India” for the first six years of his reign. ${ }^{160}$ Here "all India" is conceived as the famous urban centers of the Gangetic plain that were captured, including Sāketa, Kauśāmbī (Kaushambi), Pāțaliputra (Palibothra), until Śri-Campā. ${ }^{161}$ The inscription on the silver dish of Nukunzuk records that the king returned from India to Bactria-Tokharistan in ca. 137 CE. ${ }^{162}$

The historicity of Kanishka's other military campaigns and extent of power, transmitted in later texts, is difficult to pin down. The seventh-century cE Chinese Buddhist pilgrim Xuanzang reported that he had learned that Kanishka had enlarged his territory into the Tarim Basin. ${ }^{163}$ A fifth-century CE Chinese Buddhist text described an attack from the king of Anxi (the Arsakids), from which Kanishka emerged victorious. ${ }^{164}$ The same text gives a moralizing and mythologized account of the king's end, in which his ministers - sick of Kanishka's insatiable desire for conquest - smothered him to death after he fell ill. ${ }^{165}$

Yet Kanishka was not just a conqueror. The Rabatak inscription is an unequivocal representation of Kanishka's interest in new material and symbolic expressions

\footnotetext{
157 Hou Hanshu 88.2927.

158 See discussion in Rosenfield 1967, 28-39. A range of evidence, especially epigraphic, disputes the traditional association of the Kushans with Buddhism and its expansion. As Fussman (2015, 153) stated plainly, “The Surkh Kotal and Rabatak inscriptions prove beyond doubt that Kanișka was no Buddhist, and, judging by their coinage, no Kushan Emperor was ever a Buddhist."

159 The first publication is Sims-Williams and Cribb 1996. Refer now to the third edition and translation in Sims-Williams 2004.

160 Rabatak, lines 2, 19.

161 Rabatak, lines 5-6.

162 Silver dish of Nukunzuk, line 4; edition and trans. in Sims-Williams 2015, 257.

163 Xuanzang Da Tang Xiyu ji, Taishō Tripițaka, vol. 51, no. 2087, 1.0873c23; trans. Zürcher 1968, 377.

164 Fu Fazang Yinyuan zhuan, Taishō Tripițaka, vol. 50, no. 2058, 5.316b16-18; trans. Zürcher 1968, 386.

165 Fu Fazang Yinyuan zhuan, Taishō Tripițaka, vol. 50, no. 2058, 5.317a4-18; trans. Zürcher 1968, 387.
} 
of his royal and dynastic authority. This is not only seen in his inauguration of a new regnal era, but in the central part of the Rabatak inscription, which records Kanishka's order for a karalrang (a high officer, discussed below) to establish a temple to a pantheon of gods (a number of which being Zoroastrian in origin), to be fitted with the images of these gods, and the images of Kanishka and past kings. The foundation act recalls Vima Taktu's establishment of the devakula at Māt, and that of the bagolango of Surkh Kotal. ${ }^{166}$ Kanishka's reign also marks the abandonment of Greek as an imperial official language and its replacement by the Bactrian language. This is indicated in the Rabatak inscription, which states that Kanishka "issued a Greek edict (and) then he put it into Aryan,"167 and likewise Kanishka's coin legends began to be inscribed in Bactrian exclusively. Thus, Kanishka's reign appears to see a conscious revival of an Iranian vocabulary of power. ${ }^{168}$

The dimensions of the Kushan Empire appear to have crystallized in the reign of king Huvishka, yet some political problems encountered during his reign may be inferred. For example, the weight standard of his coinage dropped, ${ }^{169}$ and the main inscription at Surkh Kotal refers to Nukunzuk the karalrang's installation of a well at the sanctuary, an act framed as a pious response to an enemy attack. ${ }^{170}$ Similarly little is known about the reign of Huvishka's successor, Vasudeva I, but some indications of diplomatic activities during his rule are available. Most significantly, Vasudeva appears to have sent envoys with tribute to the Chinese capital in $230 \mathrm{CE},{ }^{171}$ possibly seeking assistance in anticipation of the Sasanian foe.

Nonetheless, a crushing blow was struck to the empire with the loss of BactriaTokharistan to Sasanian invaders under Ardashir I in ca. $230 \mathrm{CE}$, followed by the installation of the so-called Kushano-Sasanians (ca. 230-365 CE) whose kings called themselves Kushanshah. The Kushano-Sasanians were possibly a semiautonomous cadet branch of the Sasanian royal house, perhaps named 'Kushan' for ruling over an area of former Kushan control. ${ }^{172}$ While these kings bore names from the Sasanian world - Ardashir, Peroz, Hormizd, Varahran - their coinage mingled Sasanian and Kushan designs. The process and chronology of the Sasanian/Kushano-Sasanian advance across the former Kushan realm still requires further clarification. It would appear that Bactria-Tokharistan was invaded by the Sasanian king Ardashir I in ca. $230 \mathrm{CE}$, establishing a homonymous Kushano-Sasanian Ardashir at Bactra. Expansion into Kapisa might have begun around ca. 260 CE under the Kushano-

166 See the discussion of the Kushan pantheon in Grenet 2015.

167 Rabatak, lines 3-4; trans. Sims-Williams 2004. "Aryan" here does seem to simply designate the Bactrian language, but was a politically, ideologically, and ethnically charged term used in a parallel manner in Darius I's Bisitun inscription (Panaino 2015, 96-101).

168 As proposed already in Fussman 1977.

169 Jongeward et al. 2015, 89-90.

170 Surkh Kotal 4 M, trans. Sims-Williams 2012, 78-79.

171 Sanguo zhi 3.97; trans. Zürcher 1968, 371. See also the sources discussed in Falk 2015 § 112-116.

172 Rezakhani 2017, 72-73. 
Sasanian king Peroz I. ${ }^{173}$ The trilingual inscription of Shapur I (240-270 CE) at Ka'ba-i Zartosht (Naqsh-i Rustam, Fars, Iran) described the Kushanshahr as reaching "as far as Peshawar," 174 and Gandhāra appears to have remained a contended space between the Kushano-Sasanians and Kushans for almost a century thereafter. The Sasanian rock relief of Rag-i Bibi in northern Afghanistan (ca. $25 \mathrm{~km}$ southeast of Surkh Kotal), which depicts a figure identified as Shapur I hunting rhinoceros, attests to a direct Sasanian presence in this territory. ${ }^{175}$

The historical record pertaining to the Kushan kings after Vasudeva is poor and contested. Indeed, we only know that the last three Kushan kings were named Mahi, Șaka, and Kipunadha, due to the Brāhmī inscriptions on their coins. A plausible reconstruction suggests that the Kushan realm gradually constricted in the wake of the expansion of burgeoning Kushano-Sasanian and Gupta power. The presence of both the Kushano-Sasanians and Kushans in Gandhāra and the northern Punjabwas finally wiped out through the expansion of the Kidirate Huns from Bactria-Tokharistan. ${ }^{176}$

\section{III.2 Kingship}

The logic of Kushan kingship has not been comprehensively treated in scholarship, but some general remarks may be offered. The Kushan monarchy appears to have been absolute and hereditary. The origins and legitimacy of the dynasty's kingship were regarded to derive from the Iranian goddess Nana, the head of the Kushan pantheon. More light on the conferral of kingship is shed by an unprovenanced painting on cotton of an investiture scene. The king in the center, perhaps a depiction of Huvishka, is depicted here accompanied by two figures to his left - perhaps representing military and civil estates - while the figures to his right appear to be Zoroastrian priests, preparing to solemnize a service to the sacred fire. A putto flies above, presenting an untied diadem. Although the central part of the scene is missing, it has been tentatively reconstructed to depict the investiture of the crown prince, to whom the king hands over a bow and quiver. ${ }^{177}$

The Kushans drew on multiple vocabularies of power in their expressions of kingship, stemming from Iranian, Greek, and Indic worlds. In particular, the Central Asian-Iranian tradition was central to articulations of royal imagery. Kushan royal costume - the caftan, felt boots, and a cap - recalled the traditional dress of the region, and the Kushans also drew heavily on Arsakid royal iconography, as the

173 According to the reconstruction proposed in Jongeward et al. 2015, 197-198.

174 ShKZ I:24; trans. Huyse 1999.

175 Grenet et al. 2007.

176 See the extended discussion in Cribb and Bracey forthcoming.

177 Marshak and Grenet 2006; Grenet 2015, 225-226. 
predominant imperial power in the Iranian world of that time. ${ }^{178}$ On the other hand, some elements of Kushan royal imagery appear to recall the nomadic heritage of the dynasty. ${ }^{179}$ From late in the reign of Kujula Kadphises, the Kushans referred to themselves as 'King of Kings' in the languages of their empire: in Greek basileus basileon, Bactrian shaonano shao, as well as the Gāndhārī maharaya rayatiraya and Sanskrit mahārāja rājātirāja ('great king, King of Kings'). This title of Achaemenid origin had been previously introduced into the numismatic and epigraphic repertoire of Gandhāra by the Indo-Scythian king Maues, and its use by the Kushans was perhaps influenced by contemporary Arsakid usage.

A variety of epithets were also attached to the Kushan kings, perhaps the most contested being the Bactrian bagopouro, equivalent to the Gāndhārī and Sanskrit devaputra ('son of god'). Scholars disagree as to whether this epithet actually indicated the king's divinization. ${ }^{180}$ Opinions likewise diverge as to the interpretation of the bagolango/devakula sanctuaries. Although frequently described as dynastic temples, they were fitted with both images of the gods of the Kushan pantheon and the Kushan kings. Whether the kings were in fact worshipped within a dynastic cult remains an open question. ${ }^{181}$ The Kushans were tolerant of the many religions current in their empire, which solidified the legitimacy of their rule among their subject populations. This approach is most visible in the occasional depiction of Indic and Greek deities on their coins, and donations made by officials and lay followers in Buddhist contexts seeking to confer merit on the king. ${ }^{182}$

A crucial piece of the puzzle - the nature of the socio-political structures which bound the king to his inner circle and upper officials (see below) - remains obscure. The inscription of the silver dish of Nukunzuk may hold a clue. Here, Nukunzuk began by describing himself as a marego ('servant, slave') to Vima Kadphises in his former position as a (lower) official, an amboukao. He then framed his subsequent promotion under Kanishka I in similar terms of servitude: "he established me (as) equal(?) with (his) father's and with (his) grandfather's servants [maregano], with the foremost (people)." ${ }^{183}$ This calls to mind the high-ranking men described as servants (O. Pers. bandaka) of Darius I, mentioned in the Bisitun inscription, who were chosen by the king as generals against those who rebelled against him. ${ }^{184}$ These noblemen were apparently 'bound' to the king, a relationship perhaps sealed

178 Sinisi 2017.

179 Grenet 2012, 12-17.

180 See Verardi 1983; Panaino 2009.

181 Compare most recently Shenkar 2017 with Grenet 2015, 209-210.

182 For religion under the Kushans, see Fussman 2015; Grenet 2015. Skinner 2017 approaches donative spheres, especially Buddhist, as central to imperial stability.

183 Silver dish of Nukunzuk, line 2; trans. Sims-Williams 2015, 257.

184 Throughout DBp; edition and trans. in Schmitt 1991. I thank Frantz Grenet for drawing this to my attention. 
with an oath. ${ }^{185}$ The information provided about Darius's bandaka indicates that they were drawn variously from (at least) noble families and satraps, and were not always Persians. Yet, multiple sources for the comparative Kushan case may be hypothesized. For example, the institution of the comitatus (as it was known in Latin sources) - a loyal war band of friends sworn to defend their lord to the death has been analyzed as a crucial component of the 'Central Eurasian Culture Complex,' key to the success of nomads in warfare, and a central and enduring structure in their rule. ${ }^{186}$

\section{III.3 Settlement and Urbanism}

Two principle problems pervade research on Kushan-era settlement and urbanism: first, the relevant archaeological documentation is of uneven coverage; and second, the extent of imperial control is unclear and difficult to determine archaeologically. Indeed, widespread material cultural phenomena in northern India of the early historic period - such as baked bricks, red stamped ware, and terracotta figurines have been traditionally characterised as 'Kuṣāna,' making it difficult to assess any specific characteristics of Kushan urbanism. ${ }^{187}$ Kushan imperial control may be more safely postulated from the presence of inscriptions mentioning Kushan kings and substantial site or surface finds of copper coins. Thus, for example, from Vima Taktu's Dasht-i Nawur inscription and the copper Kushan coins in the collection of Kandahar Museum, ${ }^{188}$ it may be inferred that Arachosia - a politically contested space between the fourth century BCE to the mid-first century CE - came under some form of Kushan control or influence. Yet, this mountainous and sparsely settled region remains largely archaeological terra incognita.

The most intensive research on settlement patterns and urban archaeology of the Yuezhi-Kushan period has been conducted across disparate micro-regions of the Kushan Empire's heartland, Bactria-Tokharistan. ${ }^{189}$ In north Bactria, the number and coverage of sites increased, and former military colonies and fortresses became regional hubs, such as Kampyrtepa, or even urban centers, like Dal'verzintepe and Termez. Another urban center, although only partly archaeologically documented, is believed to have been established also at Shakhrinau, in addition to a possible regional hub at Garav Kala (Iavan). The number of sites in east Bactria seem to have receded, but a new urban center in central Bactria was created, the unexcavated Qala-i Zal. Bactra was refortified, and the apparent former military colony

185 Eilers and Herrenschmidt 1989.

186 Beckwith 2009, 12-25.

187 Pons 2016; Prasad 1973.

188 MacDowall and Ibrahim 1978, 68.

189 For the following, see Leriche 2007. For the main sites of Bactria-Tokharistan's Kushan period, see also Staviskij 1986, 261-279. 
Dil'berdzhin was developed into an urban site. The expansion of Buddhism during this period also affected the archaeological landscape, seen in the construction of new Buddhist monasteries and monuments around old urban centers such as Bactra and Begram, and the new center of Termez. ${ }^{190}$

\section{III.4 Military}

Expansion by military conquest was the foundation of the Kushan imperial project, so much that it came to the attention of outside commentators; the author of the Periplus Maris Erythraei (first century CE) knew the 'Bactrians' only as a “very war-

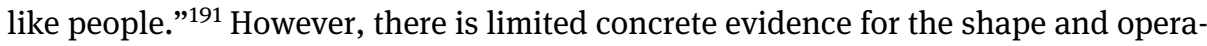
tion of the Kushan army. ${ }^{192}$

The Khalchaian sculptures (discussed above) depict the Yuezhi vividly as light horsemen armed with bows against an opponent using armored horsemen. The Kushans probably drew on their nomadic heritage through an intensive use of light cavalry units. The use of elephant units may be inferred from the iconography of Huvishka's coinage, which sometimes depicts the ruler holding an elephant goad or riding an elephant. Nikonorov has postulated the existence of a professional order of 'horsemen' forming a military class of light- and heavy-armed mounted troops in the royal army, led by a high dignitary entitled 'chief of cavalry.'193

The size of the Kushan army is also not clear from our sources. The Hanshu recorded that the Kushans possessed 100,000 men who could bear arms, ${ }^{194}$ and the force led by Vima Taktu against Ban Chao comprised either 70,000 horsemen or 70,000 soldiers, according to two different Chinese historical chronicles. ${ }^{195}$ These sources give rough and probably stylized figures, and therefore hardly constitute reliable evidence for the manpower that the Kushans could mobilize for any given campaign.

\section{III.5 Administration}

Although direct evidence remains limited, we may speculate that the Kushan Empire was supported by a complex administrative system. Epigraphic evidence attests to offices held by the intermediaries between the king and his subjects, if the nature of their roles and the hierarchy remains unclear. Bactrian-language inscriptions mention one of the highest offices, the title of karalrang ('lord of the marches,' 'mar-

190 See generally Fussman 2015.

191 PME 47.

192 The only extended treatment is Nikonorov $1997,56-68$.

193 Nikonorov 1997, 56.

194 Hanshu 96A.3890, repeated in Hou Hanshu 88.2920.

195 Hou Hanji 13; Hou Hanshu 47.1580. 
grave'). ${ }^{196}$ This is equivalent to the later attested Middle Persian kanarang, a title given to the Sasanian northeastern frontier province warden. ${ }^{197}$ A similar function may be inferred for the Kushan context, although the epigraphic evidence only documents karalrangs establishing or enriching bagolangos. The Surkh Kotal inscription clarifies the high status of this position, as Nukunzuk the karalrang is also described as "the lord's favorite, who is most dear to the king ... the second-incommand(?)."198 The fact that two individuals, Pyash and Shafar, are associated in the Rabatak inscription with the title karalrang indicates that the position might have existed for multiple frontier provinces. The function of other titles mentioned in the Bactrian inscriptions, such as amboukao and hasht-walg, are not yet clear. However, in the epigraphic record, we witness most likely the same Nukunzuk rise from an amboukao under the reign of Vima Kadphises, to hasht-walg under Kanish$\mathrm{ka}$, and finally reaching karalrang in the reign of Huvishka. ${ }^{199}$ This indicates a hierarchy of high offices, as well as mobility between them.

Other documented offices look more familiar to us. The titles of kșatrapa ('satrap') and mahākșatrapa ('great satrap'), which are clearly of Iranian origin, are attested already in Gandhāra in the mid-first century всE. ${ }^{200}$ Yet, when attached to the names of various Indo-Scythians from Jalalabad to Ujjain in the following centuries, these titles appear to variously indicate nobility, regional governance, or indepdendent rule. ${ }^{201}$ Nonetheless, the use of the title in clear contexts of Kushan rule may indicate a governing office. A unique legend on a 'bull and camel' coin issued by Vima Taktu (usually attributed to Kashmir), appears to name a descendant of the king as mahākșatrapa. ${ }^{202}$ Likewise, a Gāndhārī-inscribed reliquary casket from Manikyala stupa (east of Taxila) refers to a kșatrapa of Kapisa, the son of another $k$ satrapa; ${ }^{203}$ thus perhaps this office could be hereditary. With the advent of the Kushan invasion of India, professional titles of Iranian origin begin to appear in inscriptions in Epigraphical Hybrid Sanskrit. ${ }^{204}$ There are numerous examples, such as the titles hamārakāra and gañja-hāmārakara, which denote an account-keeper of the treasury. Another term, kharāsalerapati, has been explained as "chief of the army chiefs."205

As documentary texts from the Achaemenid and Kushano-Sasanian periods in Bactria have recently materialized, it is probably just a matter of time before similar

\footnotetext{
196 For example, in Rabatak, lines 7-8, 15-16; Surkh Kotal 4 M, lines 20-25.

197 The etymology first proposed in Henning 1965, 77-79.

198 Surkh Kotal 4 M, lines 6-9; trans. Sims-Williams 2012, 79.

199 Silver dish of Nukunzuk, lines 1-2; Rabatak, lines 16-17; Surkh Kotal 4 M, line 7.

200 On the etymology of kṣatrapa, see Salomon 1974, 12-14.

201 Falk 2010, 74, 78.

202 Falk 2010, 78, Fig. 3.

203 CKI 150 in Baums and Glass, 2002-.

204 See Falk 2010, 78.

205 Falk 2010, 78; Falk 2015, 121-122.
} 
material from the Kushan period is discovered. The later Bactrian-language corpus may also yield indirect information about practices in the Kushan period. ${ }^{206}$ There is limited evidence that Bactrian was used in lower level bureaucratic documentation in the mid-second century CE, as it was found written on slivers of papyri in an apparent archive at Kampyrtepa. ${ }^{207}$

\section{Conclusion}

This chapter has argued that from 300 BCE to 300 CE, Central Asia (as defined here) underwent a significant geopolitical transition. Drawing from rich resources, an unruly history, and new political ambitions, the rulers of Bactria transformed Central Asia from an eastern imperial frontier - as it was under the Achaemenids, Alexander and the Seleukids - into a new imperial space. Bactria was thus the locus of power of the independent Greek Kingdoms, followed by the Kushan Empire. These two polities, although still historically obscure, may be understood and productively compared and analyzed as premodern empires. This chapter has more sharply defined the Central Asian imperial space and presented essential historical information about its two empires during the period of study, including their political history, conceptions of kingship, patterns of settlement and urbanism, military, and administration, as far as they are understood in current scholarship.

\section{References}

Abdullaev, K. 2007. "Nomad migration in Central Asia." In J. Cribb and G. Herrmann (eds.), After Alexander: Central Asia before Islam, 73-98. Oxford: Oxford University Press.

Allchin, F. R., B. Allchin, N. Kreitman, and E. Errington, eds. 1997. Gandharan art in context: EastWest exchanges at the crossroads of Asia. Cambridge and New Delhi: Ancient India and Iran Trust by Regency Publications.

Aperghis, G. G. 2004. The Seleukid royal economy: The finances and financial administration of the Seleukid Empire. Cambridge: Cambridge University Press.

Augustinová, A., L. Stančo, L. Damašek, M. Mrva, and S. Shaydullaev. 2018. "Archaeological survey of the oases of Zarabag, Karabag and Kampyrtepa in the piedmont of the Kugitang mountains, South Uzbekistan - Preliminary report for the season 2016." Studia Hercynia 21.1, 104-148.

Barfield, T. 2010. Afghanistan: A cultural and political history. Princeton, NJ: Princeton University Press.

Basham, A. L., ed. 1968. Papers on the date of Kanișka: Submitted to the conference on the date of Kaniṣka, London, 20-22 April, 1960. Leiden: Brill.

206 See Morris, ch. 9, this volume.

207 Rtveladze 2012, 234-240. For more, Morris, ch. 9, this volume. 
Baums, S. 2018. "A framework for Gandhāran chronology based on relic inscriptions." In W. Rienjang and P. Stewart (eds.), Problems of chronology in Gandhäran art: Proceedings of the first international workshop of the Gandhäran Connections Project, University of Oxford, 23rd-24th March, 2017, 53-70. Oxford: Archaeopress.

Baums, S., and A. Glass. 2002-. Catalog of Gāndhārī texts. https://gandhari.org/catalog.

Beckwith, C. I. 2009. Empires of the Silk Road: A history of Central Eurasia from the Bronze Age to the present. Princeton, NJ: Princeton University Press.

Bernard, P. 1978. "Les mines de lapis-lazuli du Badakhshan.” In P. Bernard and H.-P. Francfort (eds.), Études de géographie historique sur la plaine d'Aï Khanoum (Afghanistan), 49-51. Paris: Éditions du Centre national de la recherche scientifique.

-. 1980. "Campagne de fouilles 1978 à Aï Khanoum (Afghanistan)." Comptes rendus des séances de l'Académie des Inscriptions et Belles-Lettres 124.2, 435-459.

-. 1981. "Problèmes d'histoire coloniale grecque à travers l'urbanisme d'une cité hellénistique d'Asie Centrale (Ai Khanoum)." In Deutsches Archäologisches Institut (ed.), 150 Jahre Deutsches Archäologisches Institut, 1829-1979: Festveranstaltungen und internationales Kolloquium, 17.-22. April 1979 in Berlin, 108-120. Mainz: Philipp von Zabern.

-. 1987. "Les nomades conquérants de l'empire gréco-bactrien: Réflexions sur leur identité ethnique et culturelle." Comptes rendus des séances de l'Académie des Inscriptions et Belles-Lettres 131.4, 758-768.

-. 1994. "The Greek Kingdoms of Central Asia." In J. Harmatta, B. N. Puri, and G. F. Etemadi (eds.), History of civilizations of Central Asia: The development of sedentary and nomadic civilizations: $700 B C$ to $A D$ 250, 96-126. Paris: UNESCO Publishing.

Bernard, P., and C. Rapin. 1994. "Un parchemin gréco-bactrien d'une collection privée." Comptes rendus des séances de l'Académie des Inscriptions et Belles-Lettres 138.1, 261-294.

Bolelov, S. B., ed. 2018. Кампыртепа - кушанская крепость на Оксе. Археологические исследования 2001- 2010 гг. [Kampyrtepa - Kushan fortress on the Oxus: Archaeological investigations 2001-2010]. Москва: Нестор-Истоия.

Bopearachchi, O. 1990. "Graeco-Bactrian issues of later Indo-Greek kings." Numismatic Chronicle 150, 79-103.

-. 1991. Monnaies gréco-bactriennes et indo-grecques: Catalogue raisonné. Paris: Bibliothèque nationale.

-. 2008. "Was Indo-Greek Artemidoros the son of Indo-Scythian Maues? Amluk Dara hoard revisited." Nomismatika Khronika 27, 25-36.

Bopearachchi, O., and A. Rahman. 1995. Pre-Kushana Coins in Pakistan. Karachi: Iftikhar Rasul.

Bordeaux, 0. 2018. Les Grecs en Inde: Politiques et pratiques monétaires (IIle s. a.C.-ler s. p.C.). Bordeaux: Ausonius.

Briant, P. 1984. L'Asie centrale et les royaumes proche-orientaux du premier millénaire (c. VIIle-IVe siècles avant notre ère). Paris: Éditions Recherche sur les civilisations.

Capdetrey, L. 2007. Le pouvoir séleucide: Territoire, administration, finances d'un royaume hellénistique (312-129 avant J.-C.). Rennes: Presses Universitaires de Rennes.

Clarysse, W., and D. J. Thompson. 2007. "Two Greek texts on skin from Hellenistic Bactria." Zeitschrift für Papyrologie und Epigraphik 159, 273-279.

Cohen, G. M. 2013. The Hellenistic settlements in the East from Armenia and Mesopotamia to Bactria and India. Berkeley, CA: University of California Press.

Coloru, 0. 2009. Da Alessandro a Menandro. Il regno greco di Battriana. Pisa: Fabrizio Serra.

Cribb, J. 2014. "The Soter Megas coins of the first and second Kushan kings, Kujula Kadphises and Wima Takto." Gandhāran Studies 8, 79-122.

-. 2018a. "Kujula Kadphises and his title Kushan Yavuga." Sino-Platonic Papers 280, 1-20.

-. 2018b. "Numismatic evidence and the date of Kanișka I." In W. Rienjang and P. Stewart (eds.), Problems of chronology in Gandhäran art: Proceedings of the first international workshop 
of the Gandhāran Connections Project, University of Oxford, 23rd-24th March, 2017, 7-34. Oxford: Archaeopress.

Cribb, J., and R. Bracey. Forthcoming. Kushan coins: A British Museum catalogue and type corpus. London: British Museum.

Dvurechenskaia, N. D. 2015. “Предварительные материалы археологических работ 2014 г. на крепости Узундара" [Preliminary materials of archaeological works of 2014 at the Uzundara fortress]. Проблемы истории, филологии, культуры 47, 124-133.

Eilers, W., and C. Herrenschmidt. 1989. "Banda 'servant.”' In Encyclopaedia Iranica. Vol. 3.7, 682685. Available online at http://www.iranicaonline.org/articles/banda-servant.

Errington, E., and V. S. Curtis. 2007. From Persepolis to the Punjab: Exploring ancient Iran, Afghanistan and Pakistan. London: British Museum.

Falk, H. 1998. "Notes on some Apraca dedicatory texts." Berliner Indologischen Studien 11/12, 85-108.

-. 2001. "The yuga of Sphujiddhvaja and the era of the Kușânas." Silk Road Art and Archaeology 7, 121-136.

-. 2010. "Names and titles from Kuṣāṇa times to the Hūṇas: The Indian material." In M. Pfisterer, M. Alram, M. Inaba, and D. Klimburg-Salter (eds.), Coins, art and chronology. Vol. 2, 73-89. Vienna: Österreichische Akademie der Wissenschaften.

-. 2014 [2018]. "The five Yabghus of the Yuezhi." Bulletin of the Asia Institute 28, 1-43.

-, ed. 2015. Kushan histories: Literary sources and selected papers from a symposium at Berlin, December 5 to 7, 2013. Bremen: Hempen.

Francfort, H.-P., and O. Lecomte. 2002. "Irrigation et société en Asie centrale des origins à l'époque achéménide." Annales 57.3, 625-663.

Fraser, P. M. 1996. Cities of Alexander the Great. Oxford: Clarendon.

Fussman, G. 1974. "Documents épigraphiques kouchans." Bulletin de l'École française d'Extrême Orient 61, 1-76.

-. 1977. "Le renouveau iranien dans l'empire kouchan." In Le plateau iranien et l'Asie centrale des origines à la conquête islamique: Leurs relations à la lumière des documents archéologiques, Paris, 22-24 mars 1976, 313-322. Paris: Centre national de la recherche scientifique.

-. 2015. "Kushan power and the expansion of Buddhism beyond the Soleiman mountains." In Falk (2015), 153-202.

Gardin, J.-C. 1998. Prospections archéologiques en Bactriane orientale (1974-1978). Vol. 3, Description des sites et notes de synthèse. Paris: Éditions Recherche sur les civilisations.

Gentelle, P. 1989. Prospections archéologiques en Bactriane orientale (1974-1978). Vol. 1, Données paléogéographiques et fondements de l'irrigation. Paris: De Boccard.

Gorshenina, S. 2014. L'Invention de l'Asie centrale: Histoire du concept de la Tartarie à l'Eurasie. Geneva: Droz.

Grenet [Grene], F. 2000. “Новая гипотеза о датировке рельефов Халчаяна” [New hypothesis on the dating of the Khalchaian reliefs]. Вестник древней истории, nо. 2, 130-135.

-. 2006. "Nouvelles données sur la localization des cinq yabghus des Yuezhi: Arrière plan politique de l'itinéraire des marchands de Maès Titianos." Journal asiatique 294, 325-341.

-. 2012. "The nomadic element in the Kushan Empire." Journal of Central Eurasian Studies 3, $1-22$.

-. 2015. "Zoroastrianism among the Kushans." In Falk (2015), 203-240.

Grenet, F., J. Lee, P. Martinez, and F. Ory. 2007. "The Sasanian relief at Rag-i Bibi (Northern Afghanistan)." In J. Cribb and G. Herrmann (eds.), After Alexander: Central Asia before Islam, 243-267. Oxford: Oxford University Press.

Henkelman, W. F. M. 2018. "Bactrians in Persepolis - Persians in Bactria." In J. Lhuillier and N. Boroffka (eds.), A millennium of history: The Iron Age in southern Central Asia (2nd and 
1st millennia BC): Proceedings of the conference held in Berlin (June 23-25, 2014): Dedicated to the memory of Viktor Ivanovich Sarianidi, 223-255. Berlin: Reimer.

Henning, W. B. 1965. "Surkh-Kotal und Kaniska.” Zeitschrift der Deutschen Morgenländischen Gesellschaft 115.1, 75-87.

Hiebert, F., and P. Cambon. 2011. Afghanistan: Crossroads of the ancient world. London: British Museum.

Hill, J. E. 2015. Through the Jade Gate - China to Rome: A study of the silk routes 1st to 2nd centuries CE. New updated and expanded edition. 2 vols. Self-published, CreateSpace.

Holt, F. L. 1988. Alexander the Great and Bactria: The formation of a Greek frontier in Central Asia. Leiden: Brill.

-. 1999. Thundering Zeus: The making of Hellenistic Bactria. Berkeley, CA: University of California Press.

Hoo, M., and J. Wiesehöfer. Forthcoming. “An empire of Graeco-Bactrians and Indo-Greeks?” In M. Gehler and R. Rollinger (eds.), Empires to be remembered. Vienna: Österreichische Akademie der Wissenschaften.

Huyse, P. 1999. Corpus Inscriptionum Iranicarum. Part 3, vol. 1, texts 1, Die dreisprachige Inschrift Šābuhrs I. an der Ka'ba-i Zardušt (ŠKZ). 2 vols. London: School of Oriental and African Studies.

Jacobs, B. 1994. Die Satrapienverwaltung im Perserreich zur Zeit Darius' III. Wiesbaden: Reichert.

-. 2011. "Achaemenid satrapies." Encyclopaedia Iranica, online edition. http:// www.iranicaonline.org/articles/achaemenid-satrapies.

Jakobsson, J. 2010. “Antiochus Nicator, the third king of Bactria?” Numismatic Chronicle 170, 17-33.

Jakobsson, J., and S. Glenn. 2018. “New research on the Bactrian tax-receipt." Ancient History Bulletin 32.1/2, 61-71.

Jongeward, D., J. Cribb, and P. Donovan. 2015. Kushan, Kushano-Sasanian, and Kidarite coins: A catalogue of coins from the American Numismatic Society. New York, NY: American Numismatic Society.

Karttunen, K. 1997. India and the Hellenistic world. Helsinki: Finnish Oriental Society.

Kosmin, P. J. 2018. Time and its adversaries in the Seleucid Empire. Cambridge, MA: Belknap Press of Harvard University Press.

Kouremenos, A., S. Chandrasekaran, R. Rossi, and J. Boardman. 2011. From Pella to Gandhara: Hybridisation and identity in the art and architecture of the Hellenistic East. Oxford: Archaeopress.

Leriche, P. 1985. "Structures politiques et socials dans la Bactrian et la Sogdiane hellénistiques." In H. Kreissig and F. Kühnert (eds.), Antike Abhängigkeitsformen in den griechischen Gebieten ohne Polisstruktur und den römischen Provinzen: Actes du colloque sur l'esclavage, léna 29 september-2 octobre 1981, 65-79. Berlin: Akademie-Verlag.

-. 2007. "Bactria, land of a thousand cities." In J. Cribb and G. Herrmann (eds.), After Alexander: Central Asia before Islam, 121-153. Oxford: Oxford University Press.

Lyonnet, B. 2012. "Questions on the date of the Hellenistic pottery from Central Asia (Ai Khanoum, Marakanda and Koktepe).” Ancient Civilizations from Scythia to Siberia 18, 143-173.

MacDowall, D. W., and M. Ibrahim. 1978. "Pre-Islamic coins in Kandahar Museum.” Afghan Studies 1, 67-77.

Mairs, R. 2014. The Hellenistic Far East: Archaeology, language, and identity in Greek Central Asia. Oakland, CA: University of California Press.

Fischer-Bovet, C., and R. Mairs. Forthcoming. "Reassessing Hellenistic settlement policies: The Seleukid Far East and Ptolemaic Red Sea Basin, Egypt and Nubia." In C. Fischer-Bovet and S. von Reden (eds.), Comparing the Ptolemaic and Seleukid Empires. Cambridge: Cambridge University Press. 
Marshak, B., and F. Grenet. 2006. "Une peinture kouchane sur toile." Comptes rendus des séances de l'Académie ses Inscriptions et Belles-Lettres 150.2, 947-963.

Martinez-Sève, L. 2010. "Pouvoir et religion dans la Bactriane hellénistique: Recherches sur la politique religieuse des rois séleucides et gréco-bactriens." Chiron 40, 1-27.

-. 2012. "Les Grecs d'extrême Orient: Communautés grecques d'Asie Centrale et d'Iran." Pallas 89, 367-391.

-. 2014. "The spatial organization of Ai Khanoum, a Greek city in Afghanistan." American Journal of Archaeology 118.2, 267-283.

-. 2015. "Ai Khanoum and Greek domination in Central Asia." Electrum 22, 17-46.

-. 2018. "Ai Khanoum after 145 BC: The post-palatial occupation." Ancient Civilizations from Scythia to Siberia 24, 354-419.

Miroshnikov, L. I. 1992. "Appendix: A note on the meaning of the term 'Central Asia' as used in this book." In A. H. Dani and V. M. Masson (eds.), History of civilizations of Central Asia. Vol. 1, 467-470. Paris: UNESCO Publishing.

Narain, A. K. 1957. The Indo-Greeks. Oxford: Clarendon.

Nattier, J. 1991. Once upon a future time: Studies in Buddhist prophecy of decline. Berkeley, CA: Asian Humanities Press.

Nikonorov, V. P. 1997. The armies of Bactria 700 BC-450 AD. 2 vols. Stockport: Montvert.

Olbrycht, M. J. 2015. "Arsacid Iran and the nomads of Central Asia - Ways of cultural transfer." In J. Bemmann and M. Schmauder (eds.), Complexity of interaction along the Eurasian steppe zone in the first millennium CE, 333-390. Bonn: Vor- und frühgeschichtliche Archäologie, Rheinische Friedrich-Wilhelms-Universität Bonn.

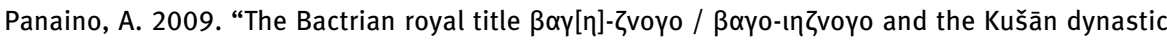
cult." In W. Sundermann, A. Hintze, and F. de Blois (eds.), Exegisti monumenta: Festschrift in honour of Nicholas Sims-Williams, 331-346. Wiesbaden: Harrassowitz.

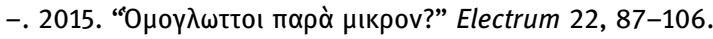

Pons, J. 2016. "Kushan dynasty VI, Archeology of the Kushans: In India." In Encyclopaedia Iranica, online edition. http://www.iranicaonline.org/articles/kushan-dynasty-06-archeology-india.

Prasad, K. 1973. "The Kushana towns in India: Problems and methods." Proceedings of the Indian History Congress 34, 32-40.

Rapin, C. 1992. Fouilles d'Aï Khanoum. Vol. 8, La trésorerie du palais hellénistique d'Aï Khanoum: L'apogée et la chute du royaume grec de Bactriane. Paris: De Boccard.

-. 2007. "Nomads and the shaping of Central Asia." In J. Cribb and G. Herrmann (eds.), After Alexander: Central Asia before Islam, 29-72. Oxford: Oxford University Press.

-. 2010. "L'ère yavana d'après les parchemins Gréco-Bactriens d'Asangorna et d'Amphipolis." In K. Abdullaev (ed.), Традиции Востока и Запада в античной культуре Средней Азии. Сборник статей в честь Поля Бернара / The Traditions of East and West in the antique cultures of Central Asia: Papers in honour of Paul Bernard, 234-252. Tashkent: "Noshirlik yog'dusi."

Rapin, C., and F. Grenet. 1983. "Inscriptions économiques de la trésorerie hellénistique d’Aï Khanoum: L'onomastique iranienne à Aï Khanoum." Bulletin de correspondence hellénique 107, 315-381.

Rea, J. R., R. C. Senior, and A. S. Hollis. 1994. "A tax receipt from Hellenistic Bactria.” Zeitschrift für Papyrologie und Epigraphik 104, 261-280.

Rezakhani, K. 2017. ReOrienting the Sasanians: East Iran in Late Antiquity. Edinburgh: Edinburgh University Press.

Rosenfield, J. M. 1967. The dynastic arts of the Kushans. Berkeley, CA: University of California Press.

Rtveladze, E. V. 2012. Великий индийский путь: из истории важнейших торговых дорог Евразии [The Great Indian Road: From the history of the most important trade routes of Eurasia]. Санкт-Петербург: Нестор-Истоия. 
Salomon, R. 1974. “The Kșatrapas and Mahākṣatrapas of India.” Wiener Zeitschrift für die Kunde Südasiens 18, 5-25.

Sancisi-Weerdenburg, H. 1988. "Was there ever a Median Empire?” In A. Kuhrt and H. SancisiWeerdenburg (eds.), Achaemenid History. Vol. 3, 197-212. Leiden: Nederlands Instituut voor het Nabije Oosten.

Schmitt, R. 1991. Corpus Inscriptionum Iranicarum. Part 1, vol. 1, texts 1, The Bisitun inscriptions of Darius the Great: Old Persian text. London: School of Oriental and African Studies.

Shahbazi, A. S. 2005. "The history of the idea of Iran." In V. S. Curtis and S. Stewart (eds.), Birth of the Persian Empire, 100-111. London: I. B. Tauris.

Shenkar, M. 2017. “Royal regalia and the 'divine kingship' in the pre-Islamic Central Asia.” Parthica 19, 55-74.

Sims-Williams, N. 2004. "The Bactrian inscription of Rabatak: A new reading." Bulletin of the Asia Institute 18, 53-68.

-. 2012. "Bactrian Historical Inscriptions of the Kushan Period.” The Silk Road 10, 76-80.

-. 2015. "A new Bactrian inscription from the time of Kanishka." In Falk (2015), 255-264.

Sims-Williams, N., and J. Cribb. 1996. “A new Bactrian inscription of Kanishka the Great.” Silk Road Art and Archaeology 4, 75-142.

Sims-Williams, N., and É. de la Vaissière. 2007. "Jabḡuya, i: Origin and Early History." In Encyclopaedia Iranica. Vol. 14.3, 314-315. Available online at http://www.iranicaonline.org/ articles/jabguya.

Sinisi, F. 2017. "Royal imagery on Kushan coins: Local tradition and Arsacid influences." Journal of the Economic and Social History of the Orient 60, 818-927.

Skinner, M. C. 2017. "Marks of empire: Extracting a narrative from the corpus of Kuṣāna inscriptions." PhD diss., University of Washington.

Staviskij, B. J. 1986. La Bactriane sous les Kushans: Problèmes d'histoire et de culture. Paris: Maisonneuve.

Sverchkov, L. M. 2014. Курганзол - Крепость Александра на юге Узбекистана [Kurganzol: A fortress of Alexander in south Uzbekistan]. Ташкент: SMI-ASIA.

Tarn, W. W. 1938. The Greeks in Bactria and India. Cambridge: Cambridge University Press.

Thapar, R. 2003. The Penguin history of early India: From the origins to AD 1300. London: Penguin.

Thomalsky, J., B. Bräutigam, M. Karaucak, and S. Kraus. 2013. "Early mining and metal production in Afghanistan: The first year of investigations." Archäologische Mitteilungen aus Iran und Turan 45, 199-230.

Verardi, G. 1983. "The Kuṣāṇa emperors as Cakravartins: Dynastic art and cults in India and Central Asia: History of a theory, clarifications and refutations." East and West 33, 225-295.

von Hinüber, 0. 2003. Beiträge zur Erklärung der Senavarma-Inschrift. Stuttgart: Steiner.

Widemann, F. 2009. Les successeurs d'Alexandre en Asie centrale et leur héritage culturel: Essai. Paris: Riveneuve.

Wu, X. 2017. "Land of the unrule-ables: Bactria in the Achaemenid period." In K. O. Weber, E. Hite, L. Khatchadourian, and A. T. Smith (eds.), Fitful histories and unruly publics: Rethinking temporality and community in Eurasian archaeology, 258-287. Leiden: Brill.

Wu, X., N. F. Miller, and P. Crabtree. 2015. “Agro-pastoral strategies and food production on the Achaemenid frontier in Central Asia: A case study of Kyzyltepa in southern Uzbekistan." Iran 53, 93-117.

Yang, B., J. Wang, A. Bräuning, Z. Dong, and J. Esper. 2009. "Late Holocene climatic and environmental changes in arid central Asia." Quaternary International 194.1-2, 68-78.

Zürcher, E. 1968. "The Yüeh-chih and Kanișka in the Chinese sources.” In A. L. Basham (ed.), Papers on the date of Kanișka: Submitted to the conference on the date of Kaniṣka, London, 20-22 April, 1960, 346-390. Leiden: Brill. 



\section{Early Historic South Asia}

\section{Geography, Climate, and the Human Landscape}

The geographical borders of pre-nation-states or polities are difficult to chart out clearly. Yet it is more often than not that geography shapes political and cultural entities. South Asia forms one such entity, having physiographical markers that define the space both geographically and culturally. ${ }^{1}$ This space is bounded by the Balochistan highlands to the west, the Swat valley in the northwest, the Himalayas in the north, the meridional mountain chain of Indochina in the east, and the peninsular region in the south. The peninsular south is surrounded by the Arabian Sea in the west, the Bay of Bengal in the east, and the Indian Ocean in the south. An extensive coastline of $11,104 \mathrm{~km}$ in total surrounds the Indian subcontinent (map 1). ${ }^{2}$

Three physiographic divisions mark the mainland of the subcontinent: the Himalayas, the Indo-Gangetic Plains, and the peninsula. ${ }^{3}$ The Himalayas are young tectonic mountains with various glacial snow formations. Melting glacial deposits form three perennial river systems, the Indus, the Ganga, and the Brahmaputra, with various distributaries and tributaries. These river systems inundate the northern plains and form deposits of fertile alluvial soil. The Indus River system flows into the Arabian Sea, while the Ganga and the Brahmaputra flow into the Bay of Bengal. The alluvial plains are bordered by the Aravali and Vindhya Ranges in the south. The Aravali plateaus are the oldest physiographical formations, and it is here that the Deccan plateau and peninsular India begin.

Peninsular India is characterized by smaller zones, such as the lava trap topography with black soil in the western and upper Deccan, ${ }^{4}$ granite areas in the eastern region, and red soil in the southern peninsula. ${ }^{5}$ There are also pockets of alluvial soil zones in the Narmada, Tapti, Mahanadi, Godavari, Kaveri, and Krishna River valleys. ${ }^{6}$

\footnotetext{
1 South Asia comprises the modern states of India, Pakistan, Nepal, Bhutan, Bangladesh, and Sri Lanka. It is located between $5^{\circ}$ and $37^{\circ} \mathrm{N}$. The areal expanse of the subcontinent is more than 4.2 million sq km (Spate and Learmonth [1954] 2007; Xue and Yanai 2005, 115).

2 The total coastline area includes the coastline of the modern nations of India $(7,500 \mathrm{~km}$, including the islands), Pakistan (1,365 km), Sri Lanka (1,585 km), and Bangladesh (654 km), (Snead 2010b, 1059; 2010a, 1078; Nayak and Hanamgond 2010, 1065; Swan 2010, 1072).

3 Spate and Learmonth (1954) 2017, 6-7; Tandon et al. 2014, 3.

4 The black soil, also called the regur type, is rich in ferromanganesian and aluminum compounds because of the volcanic lava content (Randhawa 1980, 8).

5 This region consists of the oldest rock constitution containing prevalent crystalline schists and ferromanganesian minerals (Randhawa 1980, 8).

6 Spate and Learmonth (1954) 2017, 16.
}

Note: I would like to thank Professor H. P. Ray for her suggestions and comments on this chapter.

Ә Open Access. (c) 2020 Mamta Dwivedi, published by De Gruyter. (c) BY-NC-ND This work is licensed under the Creative Commons Attribution-NonCommercial-NoDerivatives 4.0 License.

https://doi.org/10.1515/9783110607741-005 


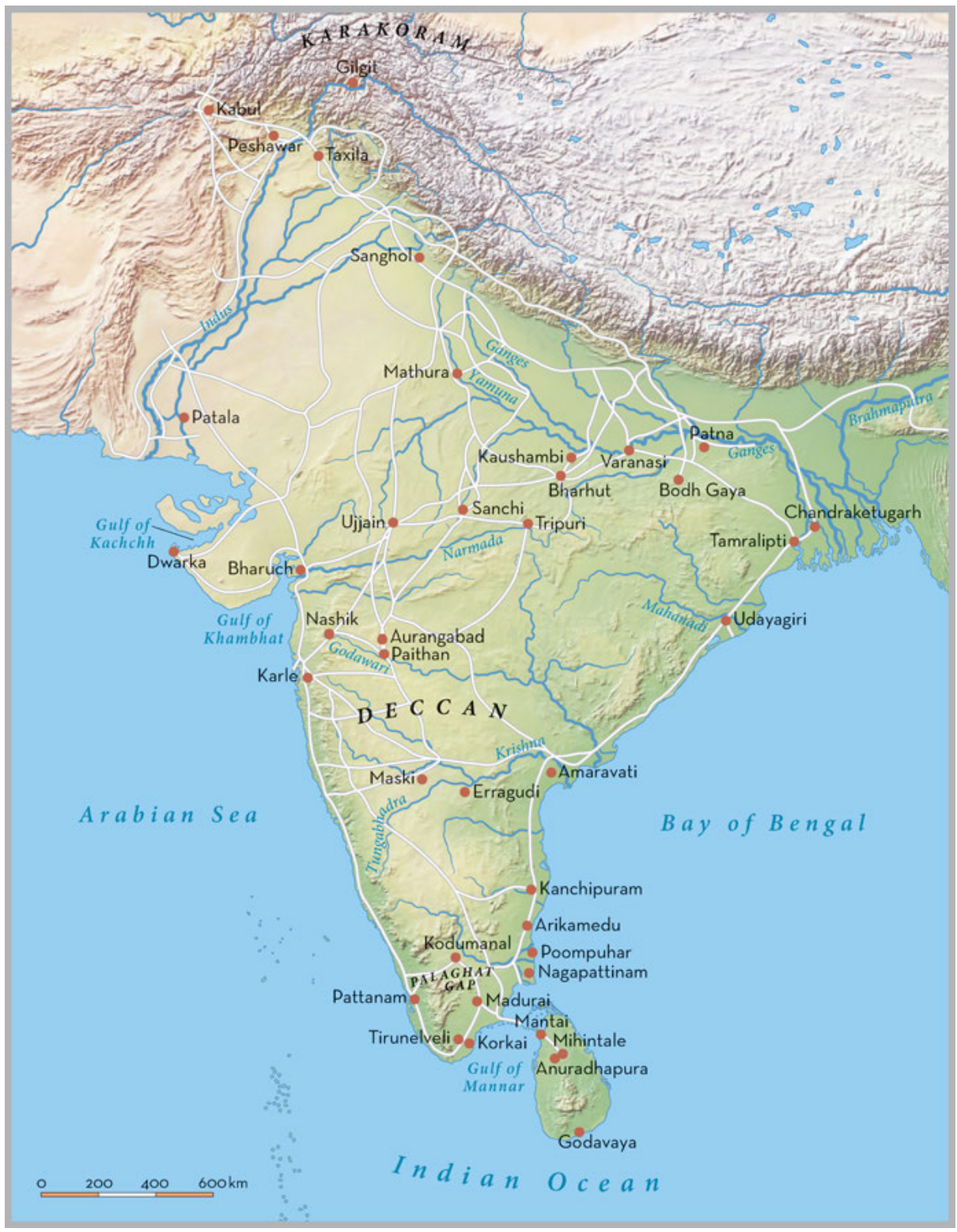

Map 1: Major cities and routes in early historic South Asia (after Chandra 1977; Neelis 2011). (c) Peter Palm. 
Offshore, the South Asian region includes the following main islands: Lakshadweep off the west coast, Andaman-Nicobar Islands in the Bay of Bengal, ${ }^{7}$ and Sri Lanka in the Indian Ocean. The Sri Lankan hinterland consists of alluvial tracts, lagoons, and coastal regions. ${ }^{8}$

The climate of the subcontinent varies considerably. The subcontinent has six major ecological zones: rainy tropical, humid subtropical, tropical savanna, mountain, arid desert, and steppe grassland. ${ }^{9}$ The extreme north has a temperate climate, while the northeastern regions, the central part, and the south are influenced by the tropical monsoon. The southernmost part of the mainland and Sri Lanka have an equatorial climate. Seasonal changes in temperature and rainfall throughout the subcontinent depend on the monsoon. ${ }^{10}$ In most regions, 80 percent of the rainfall is the result of the southwestern monsoon, lasting for four months from June to September. The northernmost regions, by contrast, experience precipitation during the winter, while parts of the southeastern coast, the islands in the Bay of Bengal, and northeastern Sri Lanka have rainfall during the retreating monsoon from September to January. ${ }^{11}$

The diversity of the topography, soil type, climate, and rainfall are one explanation for the diversity of vegetation in South Asia. ${ }^{12}$ The other is the human impact on the landscape. Apart from archaeobotanical finds, early historical literary texts mention a great variety of agricultural crops and methods of cultivation. ${ }^{13}$ Arguably, the particularly long tradition of local domestication combined with the dispersion and adoption of grains via land and sea routes since the third and second millennia BCE account for the greater variety of grain crops in early historic South Asia than in any other world region. ${ }^{14}$ Double-cropping in the form of winter and summer crops, and multicropping (growing more than one crop in a single season) were common practices in the subcontinent as early as 3000 BсE. ${ }^{15}$ Rice, millet, mustard, sesame, cotton, hemp, and some pulses formed the main crops of the summer cultivation cycle, irrigated by the monsoon rain from July to August. ${ }^{16}$ Winter cropping included wheat, barley, pulses (horse gram, mung bean, pea, chickpea, grass pea), flax, and safflower. Winter crops were watered by the winter rainfall in the northwest and by residual soil moisture or river irrigation in other regions.

7 Nayak and Hanamgond 2010, 1066.

8 Swan 2010, 1073.

9 McColl 2014, 453.

10 Singhvi and Krishnan 2014.

11 Dash 2005, 509; Xue and Yanai 2005, 115; Randhawa 1980, 21.

12 The types of vegetation include the temperate Himalayan type, the tropical thorn forest, the dry deciduous forest, the tropical evergreen rain forest, and the mangrove and beach forest. For a detailed account of the division of vegetation types, see Randhawa 1980, 25-43.

13 Randhawa 1980; Raychaudhuri and Roy 1993; Srinivasan 2016.

14 Murphy and Fuller 2017, 6; Fuller et al. 2011.

15 Murphy and Fuller 2017, 8; Petrie and Bates 2017, 83-84, 89.

16 Petrie and Bates 2017, 89; Murphy and Fuller 2017. 


\section{Political Formations in Early South Asia}

Henige suggests that the study of political chronology can be placed into a typological continuum. At one end are those incontrovertibly documented societies about which there is no dispute over timing and sequence. As we move back in time or to areas of restricted literacy and documentation, problems of chronology become more numerous and refractory. In these cases, the available evidence makes it virtually impossible to be certain about the timing and sequence of even the known events. ${ }^{17}$

The chronology of early India fits the latter end of this continuum. Since it was the British who first wrote histories of the subcontinent in the eighteenth and nineteenth centuries, all early political chronologies of Indian history are based on the Christian calendar and relate to Hellenistic events. For the colonial rulers, the only authentic sources of history were Greek historiographies. The Purānas, in contrast, were condemned as being mythological. ${ }^{18}$ Thus, the date for the reign of Candragupta (Chandragupta) Maurya (ca. 320 BCE) is derived from references to him in the accounts of the immediate successors of Alexander of Macedonia in the Indian satrapies (ca. 325 BCE onward). This was followed by dates of five Hellenistic rulers mentioned in Rock Edicts (RE) II and XIII of Aśoka (ca. 268-231 BCE). ${ }^{19}$ Also, the dates commonly found on Indic inscriptions of the Samvat and Saka eras are attributed to $56 \mathrm{BCE}$ and $78 \mathrm{CE}$ based on the chronology of the Indo-Scythian rulers. ${ }^{20}$ Given that the dating of Buddhist and Hindu texts is also highly controversial, historical chronologies and sequences are often only relative in nature and must be treated with utmost caution.

The period between 300 BCE and 300 CE is marked by a variety of political formations: (1) so-called empires; (2) satrapies and independent monarchies; and (3) janapadas (coin-issuing communities in the Indo-Gangetic divide). ${ }^{21}$ The period begins with the emergence of the Maurya dynasty (ca. 320-185 BCE), generally regarded as the first empire of South Asia, followed by a period of fragmentation and foreign domination. It ends with the rise of the Guptas (320-550 CE), another indigenous dynasty with its center in the northern alluvial plains. Scholars variously consider the post-Mauryan period as a phase of invasions, confrontations, interactions, innovations, and urban development prompted by external influences from

17 Henige 1986, 58.

18 Ray and Potts 2007.

19 Antiochos II Theos (261-246 BCE), Ptolemy II of Egypt (285-247 BCE), Antigonos II Gonatas of Macedonia (278-239 вСE), Magas of Cyrene (300-258 вCE), and Alexander II of Epiros (272-258 вCE). 20 Bhandare 2006, 69.

21 The janapadas here are used in the meaning Shrimali suggests. He finds janapada has connotations of both monarchical and non-monarchical forms of political organization, and implies both the communal and territorial aspect of a polity (Shrimali 1985, 3-4). 
the northwest into the northern part of the subcontinent. ${ }^{22}$ Western influences resulted in the emergence of satrapies and monarchies usually referred to as IndoGreek, Indo-Parthian, Indo-Scythian or Śaka, and Kuṣāna. ${ }^{23}$ Among the local polities in the post-Mauryan phase, the most prominent were the local gana-samghas in the Indo-Yamuna divide; the dynastic rule of Sungas in the north, Sātavāhanas and Kalinga in the Deccan and Odisha; and the kingdoms of Cola, Cera, and Pāṇdyas in the peninsular south.

The historiography of the period under consideration is influenced by two traditions, one emphasizing imperial unity, the other local autonomy. ${ }^{24}$ The first focuses on imperial state formation explained by surplus production and the concomitant emergence of social hierarchy and political organization. This approach explains history in terms of the rise and fall of empires, the emergence and fall of cities and cultures, and the dynamics of political vacuums created and filled. It originated in early nineteenth-century scholarship, which searched for empires as markers of early civilization. ${ }^{25}$ By the middle of the twentieth century, the tradition transformed into concepts of state formation and urbanization and was strongly influenced by Marxist historiographic models introduced into Indian historiography by D. D. Kosambi. ${ }^{26}$ Thus in the Indian context, the study of empire is strongly associated with concepts of state formation and unifying processes. An empire is understood as a well-developed, centralized state that is territorially expansive.

Within the imperial approach, the subcontinent is constructed as one historical unit in which different areas played their parts. The northwest is described as a region ever riddled by incessant invasions and imperial endeavors. ${ }^{27}$ The northern alluvial plains are regarded as the nucleus of civilization and state formation, while the Deccan and the southern peninsula played catch-up. ${ }^{28}$ The state of the Mauryan dynasty, with its center at Magadha (modern Bihar), came to be considered the first and archetypical Indian empire. This characterization of the Mauryan dynasty owes much to the idea of the Mauryan state as a unifier of South Asia under one ruler,

22 Basham (1954) 1986; Thapar 2003; Chakravarti 2016; U. Singh 2008.

23 See Morris, ch. 2, this volume.

24 Chakravarti 2012, 14.

25 The late eighteenth- and early nineteenth-century Indologists like William Jones and James Mill were familiar with the king named Candragupta of Mauryas from references in ancient Greek sources as a contemporary of the successors of Alexander of Macedonia. Also, Aśoka was known from the Sri Lankan Pali chronicles of the fourth and sixth centuries CE. With the successful decipherment of Kharoșţī and Brāhmī scripts by James Prinsep in the 1830s, the discovery of Aśoka as an Indian emperor was made. The deciphering of the scripts also enabled the identification of the Kuṣāṇas as a ruling dynasty of early India (Prinsep 1838; 1858; Dwivedi 2015, 208-210).

26 Kosambi 1956. Gurukkal (2008) describes the tradition as influenced by the "Kosambi effect."

27 Prakash 1964; 1971.

28 Seneviratne 1981; Champakalakshmi 1996; Thapar 2003; Basu Majumdar 2017. 
no doubt inspired by the colonial idea of ruling and governing India as a single imperial unit. ${ }^{29}$

Since the nineteenth century, the identification of the Mauryas as an empire, particularly under Aśoka, has been based on identifying the criteria for imperial status and arguing that the Mauryas fulfilled them. An empire is defined as a uniform territory divided into centers and peripheries; it is marked by the introduction of a uniform script and state-issued coinage; there is evidence for royal patronage of art leading to representative monuments; and it has a state ideology. ${ }^{30}$ To demonstrate Mauryan imperial homogeneity, scholars have pointed to the ubiquity of northern black polished ware (NBPW) throughout the subcontinent, which in turn was labled Mauryan pottery. They saw the rock edicts as marking the territorial expanse of Aśoka's sphere of influence (see ch.10.A, map 1), and his policy of dhamma (Buddhist ethical teachings) as the unifying ideology. ${ }^{31}$ In this approach, Aśoka stands at the core of the Mauryan dynasty as the ideal emperor. The deciphering of Brāhmī and Kharoșthī scripts by James Prinsep in the early 1830s enabled the attribution of the titles devānampiya and piyadasi to Aśoka. ${ }^{32}$ Since then, Aśoka has remained an important historical figure, both to be studied and admired. ${ }^{33}$

Any other political formation was understood in terms of being part of the process of incipient state formation. Where the influence of the Mauryan imperial state formation process could not be identified, it was suggested that these polities remained uninfluenced by Magadha. ${ }^{34}$ The imperial model also fostered ideas of urbanization and so-called secondary state formation in imperial vicinities, and the establishment of long-distance trade routes and religious contacts as part of the imperializing process. Secondary state formation and secondary urbanization were the explanatory models for the rise of complex state-like polities and cities in areas adjacent to the imperial centers in the middle Ganga valley as well as in Sri Lanka. ${ }^{35}$ Finally, the spread of the imperial state was associated with the processes of what may be called Sanskritization and Brahmanization. Complex imperial state formation in this model was influenced by orthodox Brahmanical ideas vis-à-vis heterodox republican ideas that were prevalent in areas farther away from the Ganga valley. ${ }^{36}$

29 Chattopadhyaya 2015, 3-4.

30 Thapar 2003; 2006; (1961) 2013. For criticism, see Morrison 1995; 1997; M. Smith 2005; Ray 1986; 2008.

31 Thapar 2003; (1961) 2013; Allchin 1995; U. Singh 2008; Chakravarti 2016.

32 Prinsep 1838. In Sanskrit devānāmpriya means 'beloved of the gods' and priyadarśin, 'he who regards everyone with affection.'

33 For an account of scholarly interest in Aśoka and the Mauryan dynasty, see Lahiri 2015.

34 Thapar 2003, 158.

35 The suggested regions of impact are Bengal, Odisha, the Deccan, and the southern peninsula, as well as Sri Lanka, Thapar 2003, 211; Basu Majumdar 2017; Chakravarti 2017, 333-338.

36 The influence of Brahmanical ideals on the emergence of complex state structures is ascribed to the complex and hierarchical 'Brahmanical' social institutions, which contrast with simpler egali- 
The second method for studying this region calls for examining socio-cultural aspects of South Asia beyond the question of state formation and political expansion. These approaches explain early historical India in terms of autonomous spaces and consider regional social variations instead of uniform processes of state formation. ${ }^{37}$ They use fluid concepts of historical orbits, ${ }^{38}$ and describe the political space "as networks of resource acquisition in which territories and boundaries are porous, permeable, flexible, and selectively defended." 39 The identification of certain geographical areas as cradles of civilization and starting points of political development is rejected in favor of approaching regions as more than either perennial nuclear regions or backward and tribal parts of the subcontinent. The search for imperial structures and centralization is largely abandoned in favor of studying areas and political formations in relation to their specific social, economic, and political contexts. ${ }^{40}$ The new perspective also focuses on power nodes and social functionaries that used to be overlooked, such as merchants, small landowners, and religious agents. ${ }^{41}$ This method denounces the compartmentalized view of political geographies and advocates for the possibility of a more continuous ecological and cultural divide between the northern and southern polities of the subcontinent.

\section{II.1 Political Scenarios in South Asia}

\section{II.1.1 The Mauryas and the North}

At the time of Alexander's invasion of the subcontinent, the Nandas ruling at Magadha were a formidable political power with a grand standing army. It was in 321/ 20 BCE that the Nandas were usurped by Candragupta Maurya (known as Sandrokottos to the Greek historians) who founded the Maurya dynasty. ${ }^{42}$ Control over the northwestern region of the subcontinent under the Mauryas is credited to Candragupta and is based on the record of the gift of Arachosia, Gedrosia, and Paropami-

tarian political models found in regions west of the Yamuna and identified as more 'heterodox' (Thapar 1978). In the Deccan and southern regions, the polities are considered tribal until Brahmanical ideas were spread through the process of secondary state formation and the propagation of Vedic-Śastric-Purānic ideas (Sahu 2001). This idea does not find any support in the archaeological evidence. The archaeological sites of Mathura, Kaushambi, Varanasi, and others exhibit a mixed archaeological assemblage with common and shared iconographies.

37 Chattopadhyaya 2003a.

38 Chakrabarti 2010a.

39 M. Smith 2005, 835.

40 Lahiri 2015, 172.

41 M. Smith 2005, 836; Ray 2008, 11.

42 The date for Mauryan accession depends on the two debated dates of the Buddha's parinirvāṇa (death), 486 and 483 BCE. 
sadai (Kandahar, south Balochistan, and Kabul) that Seleukos Nikator made in exchange for 500 elephants. ${ }^{43}$ It is also possible that Candragupta Maurya had the chance of retaining some regions controlled by the Nanda rulers, possibly with the exception of Kalinga. ${ }^{44}$ Candragupta Maurya's grandson, Aśoka (r. 268-232 BCE) is regarded as the first ruler to have united the subcontinent under one rule, after which he adopted a pacifist policy changing bherighoșa to dhammaghoșa - from announcements of war to propagation of dhamma (Buddhist teaching) - as declared in RE IV. Aśoka is also known to have added the Kalinga region to the Mauryan sphere of influence after a battle recorded in RE XIII, which expresses remorse for the losses suffered in war. ${ }^{45}$

The Maurya dynasty ended with the assassination of the last king Brihadratha by his minister Pusyamitra Sunga, who established a new dynasty centered in Magadha. The legend of his accession, however, is debatable as it is drawn from a romantic play of the fourth century CE. ${ }^{46}$ The post-Mauryan period is identified in the imperial approach as a phase of political upheaval when kingdoms that sprang up were in constant conflict. The Ś ungas are said to have campaigned against their southern neighbors in the Deccan, against the Hellenistic Greeks in the northwest, and against the Kalinga in the southeast. ${ }^{47}$ The political activities in the post-Mauryan period, moreover, are considered to be the result of polities emerging to fill in the vacuum created by the decline of the empire. The northwest and west experienced the presence of Indo-Greek kingdoms and Seleukid satrapies. ${ }^{48}$ After the Mauryas, only the Kuṣananas in the first century CE were able to claim a large part of the north under their rule, as mentioned in the Rabatak inscription. ${ }^{49}$

The northwestern region was occupied by the janapadas and gana-samghas (political conglomerates) who are known by their coin issues as Yaudheyas, Ârjun-

43 Chakravarti 1986, 49.

44 In the west, at Junagarh (Gujarat), Candragupta Maurya is also noted to have commissioned the construction of Sudarśana Lake, which was then repaired at the time of Aśoka and then again in 150 CE by Rudradāman, a Śaka ruler. In the east, in modern Odisha, a post-Mauryan eulogistic rock inscription ascribed to Khāravela refers to a water tank constructed by one of the Nanda rulers. It is possible that Kalinga was controlled by the Nandas but was perhaps lost by early Mauryas and was conquered by Aśoka (Jayaswal and Banerji 1929). The extent of the Kalinga region in the early historic period is not clear. The region might have included areas of the present states of Odisha, Chhatisgarh, Telangana, and Andhra Pradesh.

45 However, the war with Kalinga referred to in RE XIII is not mentioned in the major rock edicts found in Odisha (at the Dhauli and Jagauda sites), a part of the traditional Kalinga region itself. Guruge (1994, 54-55) questions the historical reliability of the content of RE XIII as it has as many as eight versions found in different regions, however none near Odisha.

46 The Mālavikā-Agnimitram is a Sanskrit play in the kāvya tradition authored by Kālīdāsa stationed at the court of the Guptas.

47 Thapar 2003, 210.

48 For discussion of Indo-Greek, Indo-Parthian, and Kuṣāna rule, see Morris, ch. 2, this volume.

49 For the Rabatak inscription see, Sims-Williams and Cribb 1995. See also, Morris, ch. 2, this volume. 
āyanas, Trigartas, Kuṇindas, Śibis, and some other names. ${ }^{50}$ They are often regarded as tribal kingdoms filling the vacuum created by the end of the Mauryan rule. Yet one finds references to these gana-samghas in the pre-Mauryan grammatical work by Pānini, and they are also mentioned in the Alexander historiography. ${ }^{51}$ In the Indian grammatical tradition, these groups are identified as śastropajivi-samgha and $\bar{a} y u d h a j \bar{i} v \bar{\imath}$ (a group living by the profession of arms or warfare). ${ }^{52}$ They are also mentioned in the Mahābhārata and the fourth-century CE inscriptions of Samudragupta. Coin issues suggest that the three communities of Yaudheyas, Ārjunāyanas, and Kuṇindas formed an alliance to eventually defeat the Kuṣāṇas in the northern region. They issued coins or seals commemorating their victory with the legend yaudheya-ganasya-jaya (victory of the Yaudheya alliance). ${ }^{53}$ Similarly, an inscription ascribed to the dynasty of the Vākātaka (third to fourth centuries CE), suggests that the imperial Nāgas of Kāntipuri (identified as modern Mirzapur district of Uttar Pradesh) ousted Kuṣāṇas from the Āryāvarta region. ${ }^{54}$

\section{II.1.2 Politics in the Deccan}

Scholars who write the early history of South Asia give relatively less space to the history of the peninsula because there is less evidence for a well-developed territorial state system. Many scholars suggest that the political formations in the Deccan and the south were secondary state formations, adopting administrative institutions under the influence of the Mauryan metropolitan state's administrative structures. ${ }^{55}$ An example of a region supposedly experiencing secondary state formation is the central India region (present Chhattisgarh), a land corridor of primarily forested areas communicating between the southern and northern regions. While travelers frequented it over centuries, its particular landscape formed a territorial zone favoring a particular kind of settlement. Inscriptions from the Sitabenga and Jogimara caves in this region, dating to the late third or early second centuries BCE, refer to military and administrative offices that might have shared features with offices attested in the territorial polities (mahājanapadas) of the Ganga valley during the preMauryan period. ${ }^{56}$ Yet the idea of a southward influence over land is problematic when one looks at the archaeological evidence, sculptural and architectural remains, and the history of maritime activities. ${ }^{57}$

50 Handa 2007; Shrimali 1985; Gupta 1996; Agrawal 1953, 457; Allan 1936.

51 E.g., Arrian Indica 5.

52 Handa 2007, 149.

53 Altekar and Majumdar (1946) 1986, 23-33; S. Ghosh 2012, 49-51.

54 Jayaswal 1933, 5. However, this has been contested by Altekar and Majumdar (1946) 1986, 2528.

55 Seneviratne 1981; Thapar 2003, 60, 211; Chattopadhyaya 2003b; Basu Majumdar 2017.

56 Basu Majumdar 2017, 123. For the inscription and translation see H. Sastri 1925-1926, 152-156.

57 Maloney 1970; Ray 1986; 2003; 2008; Morrison 1995; 1997; Abraham 2003. 
The upland areas of peninsular India were home to iron-using megalithic communities in the first millennium BCE. Iron Age megalithic sites span the centuries from 1200 BCE to $300 \mathrm{CE}$ and extend across all regions of peninsular India with the exception of the western Deccan (modern Maharashtra). Of the thousands of sites discovered so far, more than 65 percent are in Karnataka and Tamil Nadu. ${ }^{58}$

The larger megalithic sites were not only found at the locations of Aśokan inscriptions, but also distributed along major routes of communication. These routes are known to have continued in the subsequent post-Mauryan periods. Perhaps the most interesting is the stretch extending from the Palghat (Palakkad) Gap and Coimbatore to the Kaveri delta. ${ }^{59}$ An analysis of site dimensions indicates that there were at least 26 large settlements, each capable of supporting a population of approximately 1,000 residents. 14 of these were concentrated in the Coimbatore-Madurai uplands. ${ }^{60}$ One especially significant site is Kodumanal on the northern bank of the river Noyyal, a tributary of the Kaveri. The site straddles the ancient route running eastward along the Kaveri from the Palghat Gap to Karur and Uraiyur. The site dates from the late Iron Age to the early historical periods (ca. third century BCE to third century $\mathrm{CE}$ ) and has provided evidence of early writing dated to the pre-Mauryan period. ${ }^{61}$

The Ândhras in the west and the Kalingas in the east rose to power after the decline of the Mauryas in the late third century BCE. Khāravela was the most recognized ruler of Kalinga. He assumed the title of Kalingädhipati ('king of Kalinga') and Kalinga-cakravartin ('unchallenged ruler of the Kalinga'). ${ }^{62}$ There are no clear references to clashes between Khāravela and the Āndhras, although a eulogistic inscription praising Khāravela refers to expeditions against the Bhojakas and the Raț̣hikas (Rāșț̣ikas). ${ }^{63}$ He apparently aimed at expanding his rule over Bhäratavarșa, successfully pushed a yavana king out of Rājagriha, made the ruler of Magadha bow to him and broke the formidable conglomeration of the southern states. ${ }^{64}$

The Ândhras are mentioned in Aśoka's RE XIII as one of the followers of dham$m a$ (Buddhist teachings). In the early historical context, Āndhra refers to the Sātavā-

58 Moorti had studied more than 1,900 megalithic sites (1994, 4-5). Recently the number of known sites has increased to 3,000 (Menon 2018).

59 Moorti 1994; also Ray 1994a, ch. 2.

60 Ray 1994a, tab. 2.6.

61 Apart from Kodumanal, the discovery of sherds with Tamil-Brāhmī inscriptions (dated to the fifth century BCE) has also been reported at Adichanallur (Tamil Nadu) and Anuradhapura (Sri Lanka) (Rajan 2015; Allchin 2006).

62 Sastri and Srinivasachari 1970, 148.

63 Jayaswal and Banerji 1929. The Bhojakas and Ratthikas are considered to be the ancestors of the Mahābhojas and the Mahārathis, who had marital alliances with the Sātavāhanas (Raychaudhuri [1923] 1972, 259; Ray 1986, 165).

64 Rājagriha and Magadha are mentioned separately in the inscription and it is possible that the latter is to be identified with Pāțaliputra, which had become the capital of Magadha under Ajātaśatru of the Haryanka dynasty in the fifth century всE. 
hanas in the Deccan, an identification that is based on the Purānic texts mentioning the Sātavāhanas as Āndhras and Āndhrabhṛtyas. However, the Sātavāhanas do not mention the Āndhra connection in their inscriptions. ${ }^{65}$ The dynasty was probably founded by Simuka, though the date is not clear. Scholars variously ascribe his accession as occurring between 230 and 100 все. ${ }^{66}$ By the third ruler, identified as Śrī Sātkarṇi in the first century BCE, the dynasty had emerged as a political power. It is probably under his rule that the Sātavāhanas defeated the Sungas in 75 BCE and the Kānvas in 30 всE. ${ }^{67}$ The Nanaghat cave inscription issued by Sātkarṇi's queen Nāganikā (?) praises him as the lord of the Dakșināpatha ('route to the south' or the Deccan) whose cakra (chariot wheels or army) were unstoppable. ${ }^{68}$

The epigraphic and numismatic evidence reveal political clashes of the Sātavāhanas with both Indo-Scythians and Western Kșatrapas. ${ }^{69}$ Toward the end of the second century CE, the Sātavāhanas had extended their domination of western India to the Krishna delta in the south. From the mid-third century, there were various political units that appear in the sources. The upper Deccan was taken by the Vākațakas, whose dynasty appears in many later sources as contemporary to the early Guptas, and the lower Deccan saw the emergence of the Kālacuri-Cedi dynasty. Further south to the Krishna valley, another dynasty, the Ikșvākus, appears prominently in the third and fourth century. ${ }^{70}$

\section{II.1.3 The 'Tamilakam' of the Sangam Period}

Sources that refer to the southern polities are RE II and XIII, found in Siddhapura and Brahmagiri (Maski and Teragudi). These mention the Cola, the Pāṇya, the Satiyaputra (Kośars of Tulanāọu), the Keralaputra (Ceras), and the Tambapanni (Skt. Tamraparṇi, i.e., Sri Lanka) as southern neighbors. Of these, the polities of the Cola, Ceras, and Pānḍyas were most influential, and their dynastic monarchies are regarded as kingdoms or secondary states. ${ }^{71}$ For understanding the political situation in the far south, the Sangam literature has also been identified as an important source. This is a corpus of literature written in the Tamil language and dated to the

65 Ray 1986, 173.

66 The date is based on the date of death of Aśoka, as other polities only rise after the collapse of the Mauryas. However, the discontinued settlement pattern in the archaeological assemblage shows Sātavāhanas could not be contemporaneous with the Mauryas. See further, N. K. A. Sastri (1955) 1995, 93-94; Ray 1986.

67 Dhavalikar 1996, 135-136.

68 “... apratihatacakrasya dakśināpathapate.” Inscription no. 82 in Sircar 1965, 186-190. See also below for the Dakșināpatha.

69 Cribb 2000.

70 Subbarayalu 2014.

71 Chakravarti 2017. 
second and third centuries CE. ${ }^{72}$ Its geographical scope is the ancient Tamilakam (the modern states of Tamil Nadu, Kerala, and parts of Andhra Pradesh and Karnataka).

The Colas were situated in the lower Kaveri valley, and their residential city was at Uraiyur. Their origin is traced back to a mythical ruler whose name is not recorded. Karikāla (190 CE) might have been one of their most powerful and expansionist kings. He gained many victories in different regions, but the idea that his conquests extended up to the Himalayas in the north is probably exaggerated. ${ }^{73}$

The Ceras had their seat at Karuvur or Vanji and controlled the western part of the Kaveri valley as well as the southern part of the western coast. There is also a reference to the Elimalai kingdom, headed by a ruler named Nannan, situated in the Konkanam region on the west coast near Tulunād. ${ }^{74}$ After his death, this region is said to have merged with the Cera kingdom. ${ }^{75}$ His son, Nedun, assuming the title of imayavaramban, is connected with victories over several rulers as well as a naval victory along the Malabar Coast in which he captured yavanas (western or Greekspeaking people). ${ }^{76}$ Another king, Senguțuvan, is credited with some exploits in the sea, but no further details are known. ${ }^{77}$

The Pāṇdyas, with their capital at Maturai (Madurai), controlled the Thamirabarani-Vaigai valley. They were well known to Greek geographers and historians mainly for their connection with sea pearls. ${ }^{78}$ Not surprisingly, the Vaigai River delta was called the greatest emporium of trade in India. ${ }^{79}$ The Pāndyas are also often ascribed a northern origin and are associated with the Pāṇạas of the itihāsa-kāvya tradition, which is part of the Mahābhārata epos. Based on the Mahābhārata tradition, the Pāndyas are ascribed a pre-Mauryan origin, having traveled from the northwest of the subcontinent to the south via the sea. ${ }^{80}$

The nature of these various polities is debated. The Sangam texts refer to battles in their praise of victory and death, and refer to the Colas, Ceras, and Pāṇdyas as the three most prominent kingdoms. Their rulers are called the three crowned kings (ventar/vendar) among many more chieftains. ${ }^{81}$ Yet lacking tributary structures, the

72 Dwivedi ch. 10.A, this volume.

73 N. K. A Sastri (1955) 1995, 124.

74 Girija 1976.

75 Girija 1976, 57.

76 N. K. A Sastri (1955) 1995, 118; see also below for the term yavana.

77 N. K. A Sastri (1955) 1995, 118.

78 Periplus Maris Erythraei (PME) 59; Ptolemy Geographia (Ptol. Geog.) 7. 1. 10-11; 1. 13. 1; Pliny Naturalis historia (Plin. HN) 6. 17. 23; Aelian De natura animalium, 15. 9. See also Maloney 1970, 604.

79 Maloney 1970, 604.

80 Maloney 1970, 603-604.

81 Champakalakshmi (1996, 26-28) translates the terms ventar/vendar as 'chiefs' rather than 'kings' because to her the Sangam period is characterized by pre-state polities and the vendars are 
Sangam polities are often considered to be tribal. On the other hand, based on the fact that the texts do refer to capital cities with fortified settlements, guarded posts, and standing armies with a commander (enādi), they can also be called kingdoms. There are references to victories over seven such crowned kings with the result of the conqueror taking the title of overlord (adhirāja). Yet kingship and kingdoms as developed political concepts should be taken more as rhetoric in the epic tradition than as developed political concepts. The Sangam polities appear as a conglomeration of the Cola, Cera, and Pāṇdyas rather than individual monarchies. The Hathigumpha inscription of the Kalinga king Khāravela refers to a league of Tamil states lasting for more than a century and posing a threat to Kalinga. ${ }^{82}$ This was possible, as the Sangam kings were constantly at war with each other. ${ }^{83}$ Yet alliances, periodic exactions, patronage of agriculturists, and intensification of production do not require state structures. They can equally be regarded as features of a pre-state society. ${ }^{84}$ The peninsula thus exhibits a varied socio-political character that requires us to understand its complexity and diversity without dividing it into fixed evolutionary structures. It should rather be seen in contextualized situations of continuous interactions. ${ }^{85}$

\section{II.1.4 Sri Lanka}

In the early historiographical tradition, Sri Lanka is identified as Tamraparṇi or Tambapanni and Sinhala. ${ }^{86}$ The history of settlement and the establishment of kingdoms was derived mainly from the fourth- to fifth-century CE Buddhist chronicles of the Pali Theravāda tradition, also referred to as the Sinhalese tradition. These texts provide a chronology of rulers up to the third century CE. ${ }^{87}$ They ascribe the establishment of monarchy in Sri Lanka to King Vijāya, who came with an influx of migrants from the north and established a base at Anuradhapura in the sixth or fifth centuries BCE. Other detailed accounts identify the historical rulers Devānampiya Tissa (250-210 BCE) and Dutṭhagāmani (161-137 BCE). ${ }^{88}$ An inscription from Mihintale records another ruler, identified as King Uttiya (207-197 BCE), the successor

found in the fertile agricultural tracts of the Marudam tinai. N. K. A. Sastri, however, takes the term ventar/vendar to refer to monarchies ([1955] 1995, 117).

82 Jayaswal and Banerji 1929.

83 For Sangam warfare, see Chakravarti 1986, 106.

84 Gurukkal 1993, 11.

85 Gurukkal 1995, 239-240; Abraham 2008, 67-73. See also Bauer 2015 for a study of political complexity in megalithic societies.

86 The fifth-century Chinese Buddhist pilgrim Faxian refers to the region as Sinhala in his accounts (Peeble 2006, 19).

87 Peebles 2006, 13.

88 Peebles 2006, 14. 
of Devānampiya Tissa, a contemporary of Aśoka. ${ }^{89}$ The adoption of the title devānampiya ('beloved of gods') has been interpreted as an attempt to imitate Aśoka, who also adopted this title. However, as Ray has pointed out, in Sri Lanka it appears in conjunction with the title mahārāja, which is not typical for the subcontinent. The Minvila inscription of king Kuṭakaṇna Tissa, moreover, refers to this king as belonging to the Devānampiya kula, or family of Devānampiya, indicating the dynastic aspect of the title. ${ }^{90}$

Again, there is much debate over whether the Sri Lankan rulers mentioned in the Buddhist chronicles represented monarchical state formation processes, and accordingly, whether they were ethnically and politically linked to peninsular and northern India. Brāhmī inscriptions, such as the one discovered at Mihintale near Anuradhapura, provide significant evidence running contrary to the idea of monarchical state structures, as well as peninsular influences. ${ }^{91}$ They mention kinship titles, royal titles, and titles of functionaries that diverge significantly from those in north and peninsular India. They attest a variety of local chieftains and administrative officers (superintendent of horses, superintendent of roads, superintendent of storehouses at sea ports, accountants, cavalry officers, and so on) that suggest a rather differentiated and articulate structure of authority. Scholars have also argued that the emergence of a more centralized polity in the late third and early second centuries BCE should not be viewed as a response to Mauryan influence, but as an indigenous development. Buddhism was introduced in Sri Lanka in a climate of political fragmentation, but it helped to unify the different chiefdoms and eventually led to the emergence of the kingdom of Anuradhapura in the second century BCE under king Dutțhagāmani. The disappearance of inscriptions of smaller chiefdoms after the first century BCE is indicative of the expanding power and authority of Anuradhapura over the island, but also reveals them as signs of local diversity before this period. ${ }^{92}$

\section{II.2 Ideas of Kingship, Administration, and Warfare}

Ideas of kingship are represented variably in the literary sources. The Kautilizy Arthaśāstra $(K A)$ is one of the most elaborate treatises of economic and political administration. ${ }^{93}$ It is difficult to ascribe it to one single period or kingdom, but it certainly can be used as evidence for a highly developed idea of administration and political organization. The $K A$ represents the state or political organization as an organic entity with seven parts (saptānga): svāmī ('king'), amātya ('ministers'), ja-

89 Ray 2003, 147.
90 Ray 2003, 147.
91 Ray 2003, 147.
92 Ray 2003, 148-149.
93 Dwivedi, ch. 10.A, this volume. 
napada ('countryside/subjects'), durga ('fort/city'), kośa ('treasury'), daṇ̂ ('army/ police'), and mitra ('ally'). ${ }^{94}$ The state is not only supposed to regulate and gather wealth and resources from within its territory, but also to expand its arable land into new areas and into neighboring kingdoms. Expansion may be achieved through alliances with neighboring states or through warfare and other strategies. The rule or administration of the king is to be based on danda, which can be variously interpreted as literally the imperial rod, but also army, punishment, or state apparatus of enforcement.

The $K A$ 's idea of a ruler is that of a vijigișu (the 'would-be controller'), ${ }^{95}$ who must instill within himself an expansionist nature, as the acquisition of land (prith$v y \bar{a}$ läbhe) is one of the most important parts of administration. ${ }^{96}$ Expansionist kings are of three types, the righteous, greedy, or "demonical" conqueror. ${ }^{97}$ The righteous conqueror (dharmavijayin) is satisfied with submission by his subjects, the greedy king (lobhavijayin) with seizures of land and goods, while the demonical conqueror (asuravijayin) also takes sons, wives, and lives. ${ }^{98}$

Buddhist texts, too, talk about important qualities of a king. The Tesakuna Jāta$k a$ refers to five strengths (balāni) that make a successful king: physical strength, wealth, ministers, high birth, and intellect. ${ }^{99}$ The territory of a state should comprise a capital, towns, villages, countryside, and border areas. ${ }^{100}$ The definition of power is also similar to Kautiliya's, referring to an army and treasure as powers of might, as well as the power of knowledge and the power of valor. ${ }^{101}$

According to the $K A$, the appointment of the king was to end the confusion arising out of anarchy (aräjaka) in which the stronger exploits the weaker. ${ }^{102}$ The title of devānampiya ('beloved of god') is found not only in relation to Aśoka and the Sri Lankan king Tissa, but also in the Nagarjuni hill cave inscription in relation to his grandson Daśaratha. ${ }^{103}$ Similar titles are seen in the inscriptions of the Kuṣāṇa kings, such as mahārāja ('great king'), rājatirāja ('King of Kings'), and devaputra ('son of god'). These rulers followed the practice of assuming grand titles from previous Indo-Greeks, who themselves borrowed it from the Achaemenid rulers. ${ }^{104}$

94 Kauțilìya Arthaśāstra (KA) 6. 1. A similar definition is found in the Tirukural (381), where six limbs of the king are mentioned and refer to army, subjects, wealth, ministers, ally, and fort. The dating of the Tirukural has been difficult and the suggested dates vary from the early Common Era to as late as the ninth century (Kennedy 1976, 2).

$95 K A$ 6. 2. 13.

$96 K A$ 1. 1. 1.

$97 K A$ 11. 1. 10.

$98 K A$ 11. 1. 11-16.

99 Gokhale 1966, 17.

100 Gokhale 1966, 17.

101 KA 6. 2. 33.

102 KA 1. 13. 5; MS 7. 20.

103 Thapar (1961) 2013, 348-349.

104 See Falk 2010; Morris, ch. 2, this volume. 
However, emphasis on divinity of the king is also found in the Indic literary tradition. One of the earliest references comes from the Manusmrti $(M S),{ }^{105}$ one of the earliest dharmaśāstras dated between the second and third centuries CE. ${ }^{106}$ In the Sangam literature, we find a reference to the king as the center and embodiment of administration, encapsulated in the titles ko, mannan, vendan, and iraivan. Ko is also suggested to have meant god or 'god incarnate.'107

The idea of royal paternalism is also attested in various sources. ${ }^{108}$ Rājadharma ('duties of the king') are found in early Hindu political and economic treatises, the $K A$ and the $M S$. The $K A$ refers to the king's happiness (sukham), but his welfare (hita) lies in the happiness and welfare of the people. ${ }^{109}$ Like a father, the king helps initial settlers with various exemptions and grants favors. ${ }^{110}$ A reckless king, by contrast, can lose his position as a result of his people's anger and revolt (janapadakopa). ${ }^{111}$ Buddhism also has the concept of political society as a family presided over by a morally elevated father figure. ${ }^{112}$ The Buddhist universal monarch, the cakkavatti (cakravarti), is considered the beloved of the subjects. ${ }^{113}$ The statement of the Aśokan edict at Dhauli that "all men are my children" goes in the same direction, though in the imperial historiographical tradition this statement has been mistaken as some kind of paternal despotism. ${ }^{114}$

Standing armies are frequently mentioned in the sources, and the military campaigns in northern India are well known. The $K A$ gives a detailed account of methods and tactics of warfare and siege, various ranks and their duties, training, army organization, salaries, camping, transport of armies, and the duties of the army commander. ${ }^{115}$ The army traditionally was fourfold, comprised of foot soldiers, horsemen, chariots, and elephant forces. Apart from the standing army, the king could deploy additional "hereditary troops, hired troops, corporate troops, troops supplied by the ally, troops supplied by the enemy, and tribal troops."116 The pur-

105 Manusmrti (MS) 7. 4. The king is further equated with the gods Fire, Wind, Sun, Moon, Yama, Kubera, and Indra (MS 7. 7). Apart from association with Kubera, the deity of wealth, the king is also elevated to a higher socio-ritual position, and in his "benevolence lies Padmā, the goddess of prosperity" (MS 7. 11). A verse very similar to that in $M S 7.4$ is also cited in $M S 5$. 96 , where the king is mentioned as the embodiment of the 'eight guardians' (așțānām lokapāla) and thus is considered pure at all times (Jayaswal 1924, 55).

106 Olivelle 2005, 25.

107 Subramanian 1966, 40.

108 Bandopadhyaya 1927, 64. See also Thapar (1961) 2013, 121.

$109 K A$ 1. 19. 34.

$110 K A$ 2. 1. 17-18.

$111 K A$ 1. 13. 20.

112 Gokhale $(1966,21)$ in reference to Majjhima Nikāya 3. 176.

113 Gokhale 1966, 21.

114 Thapar (1961) 2013, 121.

115 KA 2. 33. 6-10.

116 KA 9. 2. 1, trans. Olivelle 2013, 352. 
pose and conditions for the recruitment of these groups are also explained. ${ }^{117}$ The arms were to be returned to the royal armory, the horses and elephants to the royal stables. ${ }^{118}$ The elephants had three mounted archers and a mahout. Greeks showed a great interest in the use of elephants in the army, and there are references to the importance of elephants in the indigenous military. ${ }^{119}$ The $K A$ refers to officers of horses, elephants, chariots, and infantry (aśvādhyakșa, hastyadhyakșa, rathādhyakșa, and pattyadhyakșa). ${ }^{120}$ The Buddhist text Dīgha Nikāya refers to the wheeltreasure, the elephant-treasure, and the horse-treasure as parts of the seven jewels of an empire. ${ }^{121}$ It is believed that it was because of this form of military machine that it was possible for the Mauryas to subdue most of the northern region. ${ }^{122}$

Even in various works of Greek Indography, the military strength of Indian rulers is praised. Plutarch mentions that Candragupta Maurya subdued India with an army of 80,000 horses, 200,000 foot soldiers, 8,000 chariots, and 6,000 elephants. ${ }^{123}$ Pliny mentions walled towns of the eastern Deccan, and that the rulers of the powerful tribe Andarae (probably referring to the Āndhras/Sātavāhanas) ${ }^{124}$ maintained an army of 100,000 infantry, 2,000 cavalry, and 1,000 elephants. ${ }^{125}$ In the southern context, a similar picture has been suggested, with a fourfold army ox-drawn chariots, elephants, cavalry, and infantry. ${ }^{126}$

War drums were symbols of sovereignty and an important part of warfare. Each ruler and chieftain had a war drum among his insignia. ${ }^{127}$ The symbolism of war drums is clearly attested in a reference to the change in Aśoka's policy toward conquest and expansion. His expansionist policy is referred to as bherighoșa, literally meaning the 'sound of the war drums,' i.e., declaration of war. ${ }^{128}$ In the Sangam texts, there are also references to capturing the war drums of different groups as a sign of control over them.

117 KA 9. 2. 13-20.

118 Trautmann 2009, 233.

119 Trautmann 2009.

120 KA 2. 30. 1-2. 33. 11.

121 Ghoshal (1959) 1995, 77.

122 Trautmann 2009, 233.

123 Plutarch Life of Alexander 62. 3; Majumdar 1960, 192-193, 198; see also Chakravarti 1986, 48.

124 Aiyangar 1941, 46.

125 Plin. HN 6. 22. 67; see von Reden, ch. 10.B, this volume.

126 N. K. A. Sastri (1955) 1995, 133.

127 U. Singh 2008, 385.

128 In RE IV, Aśoka claims the replacement of bherighoṣa with dhammaghoṣa ('call of dhamma'). It is understood as a change in policy that is from aggressive conquest to dhamma. The term dham$m a$ in this context is understood by some scholars as the spread of Buddhism, while others understand it as moral governance, righteousness, and social ethics. See V. A. Smith (1901) 1920, 29-31; Raychaudhuri (1923) 1972, 170-178; Basham 1986, 56-58; Thapar 2003, 200-204. 


\section{II.3 Regions, Networks, and Connectivity}

The Sanskrit textual sources refer to the northern region as the Āryāvarta, the abode of the noble, expanding from the Himalayas in the north to Vindhyas in the south. ${ }^{129}$ Within this the Ganga-Yamuna region is considered the Madhyadeśa ('Middle Country'), expanding toward the river Sarasvatī in the west. ${ }^{130}$ Within the period of our concern, epigraphic sources also refer to the subcontinent as Jambudvipa (literally 'the island of rose apple') ${ }^{131}$ and Bhäratavarșa ('land of the descendants of King Bharat'). ${ }^{132}$ The region south from the Vindhya Ranges to the river Krishna was known as the Drāviḍadeśa, which in the Graeco-Roman Periplus Maris Erythraei $(P M E)$ and Ptolemy's Geographia is frequently referred to as Dachinabades and Limyrike (Dimirike), the hinterland of Barygaza (Bharuch). ${ }^{133}$ The southernmost region of present Tamil Nadu and Kerala are identified as the Tamilakam, which is a linguistic rather than a geopolitical entity. ${ }^{134}$

Literary sources do not only identify geographical regions, but also networks and corridors. Such corridors of travel and communication appear in texts from the sixth to fifth centuries BCE onward. ${ }^{135}$ Of interest here are the Uttaräpatha ("northward route') and the Dakșināpatha ('southward route'). The term Uttarāpatha is found in one of the earliest surviving Sanskrit grammatical texts, Pāninini’s Aștāadhyā$y \bar{\imath}$, dated between the fifth and fourth centuries BCE. ${ }^{136}$ The route certainly facilitated long-distance journeys through networks of roads toward northerly regions with multiple functions and associations depending on geographical contexts. ${ }^{137}$ The networking routes are said to have filled important roles for administrative purposes. They were hubs, semiautonomous regional centers, and clusters of cultic activi-

129 Here the Sanskrit/traditional textual sources include a wide array of normative texts (the śāstras, pertaining to general livelihood, morality, legality, and administrative matters), grammatical texts, and the itihāsa-kāvya tradition commonly considered related to the epic tradition.

130 MS 2. 21-22. The river Sarasvatī has not been located, and it is mostly understood as part of a mythical geography. See also, Chattopadhyaya 2015, 23.

131 RE I from Maski refers to the subcontinent as Jambudvipa. Sircar points out that this could have been a reference to the Aśokan Empire, which in Dhauli RE V is called prithvi ('the entire earth'). This may be an exaggeration, however. The concept of Jambudvipa is also seen in Buddhist Visuddhimagga, Vinaya texts, and the Purānas, which identify Jambudvipa as the region between the Himalayas and the southern sea (Law 1955, 8-9; Sircar [1979] 2000, 62, 66-68, 84; Thapar [1961] 2013, 26).

132 Jayaswal and Banerji 1929; Bhattacharyya 2009, 21-22.

133 PME 51; Ptol. Geog. 7. 1. 8; 1. 7. 6; 7. 1. 85; Casson 1989, 213; Chakravarti 2016, 187.

134 Abraham 2003, 207-208, 212; 2008, 53.

135 Chandra 1953, 45-68.

136 For the commodities procured along the northern route, Auttarapathika, see Agrawal 1953, 244.

137 Neelis 2013, 14. 
ties. ${ }^{138}$ It is also suggested that the network was used by both regional and foreign political units for expansion into northern India. ${ }^{139}$ This interpretation is based on an understanding of the routes as part of an imperial communication network, described by Megasthenes as royal roads with pillars to mark distances, extending from Susa in Iran to Palibothra (Pataliputra, modern Patna in Bihar) under the Mauryas. ${ }^{140}$ The two Aramaic edicts of Aśoka from Laghman mention the term KRPTY (karapathi), which is considered to mean 'royal roads.'141

The $K A$ explains "the east and the west trade routes" further by talking about "the route to the Himavat" (possibly a reference to the Uttarāpatha) and the route to the south (the Dakșinapatha). ${ }^{142}$ The reference is made within a debate about which trade route is better. The $K A$ emphasizes the benefits of trade to the south. The author expresses a clear preference for land routes, and here in particular wheel tracks rather than footpaths. ${ }^{143}$ Among different kinds of water paths, he prefers coastal and riverine routes over the open sea. The influence of topography on the routes is most prominent in peninsular India. Because of the varied terrain and smaller stretches of alluvial soil, the agricultural tracts were relatively smaller in comparison to those of the northern plains. Yet the uneven distribution of the rich mineral resources in the peninsular region necessitated an internal exchange system. The $K A$ explicitly refers to the profitable trade in minerals in the Deccan. ${ }^{144}$ Sanskrit Buddhist texts divide India into three parts, Madhyadeśa, Uttarāpatha, and Dakșināpatha, where the two latter terms are not seen as routes but as regions. ${ }^{145}$

The interaction of different ecological zones stands out clearly in the Sangam literature. The texts are strongly aware of the geographical and ecological divisions of the southern Indian region. Central to this perception is the notion of tinai. ${ }^{146}$ The five tinais are first mentioned in Tolkappiyam, the earliest extant Tamil text, where they form zones characterized by particular landscapes and occupations: the Kurinji (areas with hilly terrain), Mullai (pastures and woodlands), Palai (arid stretches), Neidal (littorals), and Marudam (agrarian tracts). Tinais also had their

138 Thapar 2003, 196; Fussman 1987-1988, 66-68; Neelis 2013, 14.

139 Neelis 2013, 14.

140 Megasthenes ad Strabo 15. 1. 11; 15. 1. 50; see also Neelis 2013; von Reden, ch. 10.B, this volume.

141 Chakravarti 2017, 309. For the inscriptions, see Mukherjee 1984.

142 KA 7. 12. 22-26. The route to the Himavat, or the Haimavatapatha, in Kautiliya's Arthaśāstra $(K A)$ has been identified as the route from Balk to Taxila based on the items that are said to have been traded in the region, such as horses, woolen cloths, hides, and furs (Chandra 1977, 5, 78, 79). For the Skt. text and translation of the $K A$, see Kangle (1960-65) 2014, vols. 1 and 2 respectively

$143 K A$ 7. 12. 13-26.

$144 K A$ 7. 12. 13-26.

145 Law 1955, 14. Based on the PME, De Romanis (2012) also discusses the possible evolution of the term Dakșināpatha from a hodonym (name of a road) to a choronym (name of a region).

146 For discussion on Sangam literature, see Dwivedi, ch. 10.A, this volume. 
own heroes and deities, and thus formed some kind of identity group. ${ }^{147}$ Yet the precise meaning of the term tinai can only be conjectured, as the semantic field of the term ranges from 'space,' 'land,' and 'abode,' to 'genre,' 'genealogy,' and 'situation.' ${ }^{148}$ Thus, some scholars take them as ecological zones that harbored differentiated economic activities. The littoral zone was associated with fishery and pearl diving, while agricultural groups that were always under the threat of attack by raiders from the Palai areas occupied the fertile Marudam. In this approach, the fertile agricultural tracts of Marudam created a prerequisite for state-like political formations, as particular ecological pockets had access to urban centers and the inland capitals of chieftains. ${ }^{149}$ Other scholars regard them as just mythopoeic categories, or semiotic tools for organizing a lyrical landscape with no background in a real world. ${ }^{150}$ However, regardless of whether the tinais are considered as real ecological zones in southern India or as mere mythopoetic concepts, Sangam poetry provides us with an insight into how early writers conceptualized and represented regions, occupations, and polities in ecological terms.

The knowledge of geography or place names of the southern region in northern Sanskrit texts does not indicate a gradually increasing awareness of southern geography in the post-Mauryan period. Rather, the Indo-Sri Lankan coast was already well known in pre-Mauryan times. ${ }^{151}$ If we believe the Roman geographer Strabo, Sri Lanka (Taprobane in Greek) was known to Alexander's pilot Onesikritos when the Macedonian army was stationed near the river Indus. ${ }^{152}$ It is also remarkable that early sources refer to Sri Lanka as Tamraparṇī. ${ }^{153}$ The Tamraparnī River (now Thamirabarani) near the coast of the southern peninsula may represent a close connection between the riverine and maritime routes to Sri Lanka, connecting coastal ports with inland riverine ports. ${ }^{154}$

The early historical donative records, found throughout the subcontinent, are also an interesting source for understanding social, economic, and ecological connectivity. Donative texts on stone were not the result of any "royal decree but constructed through the generosity of the common man, by a process of collective do-

147 Gurukkal 1993, 7.

148 Champakalakshmi 1996; Chakravarti 2016; Devadevan 2006, 200.

149 Champakalakshmi 1996, 28-32; Gurukkal 1995.

150 Devadevan 2006; Selby 2008.

151 Maloney 1970, 606; Ray 2003; 2008; Abraham 2003; 2008.

152 Strabo 15. 1. 14-15; Maloney 1970, 606. Sri Lanka was also known to Arrian (second century CE). On the knowledge of Sri Lankan natural phenomena by Arrian, see Ray 2003, 168-172.

153 Aśokan RE II and XIII, as discussed above, and the KA 2. 11. 1-2.

154 The similarity of archaeological assemblage even in the megalithic phase between South Indian and Sri Lankan sites, such as Adichanallur and Pomparippu, has often been suggested (Kennedy 1974, 24). Further, there have been studies about the cosmopolitan nature of Anuradhapura from the fourth century onward. It is situated in the North-Central province of the island and transformed from an Iron Age village into a metropolis due to extensive development of irrigation facilities (Coningham, Manuel, and Shoebridge 2017). 
nation that is attested by the masses." "155 The donations or gifts, referred to as dāna, include anything from single railing pillars, cross bars, sculptures, and stone to images of the Buddha, Bodhisattvas, Jain Tìrthankaras, and Hindu deities. The donors often identified themselves with their and their ancestors' names, references to their home city or region, and their occupations. It is interesting that most of the donors were monks, nuns, and laypersons. ${ }^{156}$ Donative records from Mathura mostly refer to the occupations of the donors, such as perfume merchants, courtesans, blacksmiths, goldsmiths, ivory workers, performers, rich merchants, travelling merchants, and others. ${ }^{157}$ Studies of the donative inscriptions from the Sanchi stūpa have been used to identify kinship relations. The references to kinship ties of the donors along with references to their occupation and places of origin have been used to understand the complexity of identities as a characteristic of urban societies. Individuals occupied many roles, vis-à-vis their religious, economic, political, and regional affiliations. ${ }^{158}$ Similarly, donative inscriptions from areas near Anuradhapura have been used to understand the limited role of kings in patronage of religious structures, water body management, and administration. Like in other parts of the subcontinent, Anuradhapura also demonstrates the importance of social dynamics as opposed to state-driven developments. ${ }^{159}$

\section{II.3.1 Foreigners in Local Texts}

References to outsiders are commonly found in Indic texts and are often identified with the term yavana. References to rulers like Antiochos of Syria, Ptolemy of Egypt, Antigonos of Macedonia, Megas of Cyrene, and Alexander of Epiros as yona-läja in RE II and XIII have been mentioned above. In RE V, Aśoka includes yavanas among his subjects at the northwestern border. ${ }^{160}$ RE XIII refers to kingdoms situated along his borders and includes the country of the yavanas. ${ }^{161}$ The presence of yavanas in the northwest is also associated with the presence of the bilingual Aśokan edict at Kandahar in Greek and Aramaic. ${ }^{162}$ Another piece of epigraphic evidence comes from Khāravela's Hathigumpha inscription dated to the second century BCE. Here, the king is eulogized for having defeated and pushed back a certain yavana-rāja

155 Dehejia 1992, 35.

156 U. Singh 1996.

157 V. L. Singh 2005; Bhattacharya 2008, 495-500. For the inscriptions from Mathura, see, Lüders 1912.

158 Basant 2009; U. Singh 1996.

159 Coningham 1995.

160 Sircar (1979) 2000, 15; 22-23; 31-33.

161 Ray 1988, 312.

162 Sircar (1979) 2000, 113. 
out of Rājagṛha to Mathura. ${ }^{163}$ There are, furthermore, records of donations made by yavanas in central and western India, for example, the records of a gift at Sanchi by a yona living in Setapatha, of gifts at Karle by yavanas living in Dhenukākata, by the Vìtasamgata from the unidentified place Umehanakata, and at Junnar by a yavana from Gata. ${ }^{164}$

While most of the epigraphic records are post-Aśokan, references to yavanas are also found in pre-Aśokan Sanskrit grammatical works. ${ }^{165}$ From around 500 BCE onward, yavanas appear to have been included in the category of people who spoke a mlecchas bhāṣa.$^{166}$ The areas where these people lived were designated as mleccha deśa and included frontier zones such as the countries where the yavanas and kâmbojas lived. Subsequently, rich mythologies emerged, giving the yavanas a local northern Indian origin. ${ }^{167}$

In Tamil texts, references to Graeco-Roman outsiders or strangers are attested rather late. The term yavanar seems to have been triply imported. It is the Tamilized form of yavana deriving from the Sanskritized version of 'Ionian,' in turn entering Sanskrit/Prakrit through the Old Persian term Yauna denoting Ionian Greeks, who were conquered by Cyrus in the sixth century всE. ${ }^{168}$ Originally denoting Greeks or Romans, the word came to refer to any unfamiliar being, foreigner, or stranger. In the context of Tamil literature it occurs for the first time in the Puranānūru (ca. $350 \mathrm{CE}$ ) where the yavanars are described as wine merchants coming in boats. It is interesting that while Greek and Roman trade is attested in earlier texts, the term yavanar enters Tamil literature much later, though with no conspicuous description. It comes "very much in passing and almost offhand, as if the 'Greeks' were a part of the ordinary daily existence." 169

\section{II.3.2 Inland Networks}

Indic connections to the north and beyond the Himalayas are clear in the material and architectural remains. This is often studied in connection to the Gandhāran material culture and spread of Buddhism. The expansion of Indic traditions beyond the Indus is associated with the legendary account of colonization of Khotan by Kunāla, a son of Aśoka. By the fourth century CE Khotan had become a center for

163 Jayaswal and Banerji 1929.

164 Ray 1988, 314-315.

165 Karttunen 2015, 42.

166 The term mleccha refers to 'non-Vedic,' 'barbaric,' 'non-ārya,' an outcast, or a foreigner. Mleccha bhāṣā means the language of the mlecchas.

167 Ray 1988, 321-322.

168 Ray 1988, 312; Selby 2008, 82.

169 Selby 2008, 83. 
the diffusion of northwestern Prakrit. ${ }^{170}$ The accounts of a Chinese Buddhist monk, Faxian (fourth to fifth century CE) refers to the Gomativihāra of Khotan, famous for housing 3,000 monks, where Sanskrit manuscripts of medical knowledge and other types of texts were reproduced and translated. ${ }^{171}$ The Kharoșthī documents from Niya also refer to a monetary denomination of masa (Skt. māṣaka) and other Sanskritized names in the context of Buddhist vihāras that point to a prolonged connection with Indic traditions. ${ }^{172}$

Routes through the Swat valley are considered the most common and conventional connections between the Indian subcontinent and Central Asia. This region is considered as a corridor toward the Indus and then into the mainland for contact and invasions. Other than this corridor, scholars point to another overland route along the Karakorum highway connecting Kashmir with Kashgar, including the sites of Gilgit, Chilas, Skardu, etc., based on the rock engravings and epigraphic material. ${ }^{173}$ This route is identified as the Jibin (Kashmir) route in the Chinese sources of the Han period. It was suggested this route would be a shorter way to directly connect Kashgar to the subcontinent in comparison to the route from Kashgar to Kabul and then to the Peshawar-Taxila region. ${ }^{174}$

Material remains in archaeological contexts have also been used as evidence for interregional connections within mainland India. Raw materials as well as finished products of agate, steatite, carnelian, ivory, gold, copper, and iron have been used to chart inland communication between northern and southern regions. ${ }^{175}$ Archaeological assemblages of various megalithic sites contain material remains that have been used to identify connectivity between inland and coastal areas, so much so that recent studies have questioned the concept of 'hinterland' and 'foreland.'176 The distribution of Buddhist sites and their contextualization in their respective geographic settings has also allowed the identification of different passes and arterial routes (map 1). ${ }^{177}$

170 Sastri and Srinivasachari 1970, 229.

171 Sastri and Srinivasachari 1970, 229.

172 Hansen 2017, 83-93.

173 Inscriptions in Kharoșthī, Brāhmī, Chinese and Sogdian have been reported along with rock engravings of stupa worship and horses brought for trade (Jettmar 1989; Neelis 2000; Chakravarti 2017, 311-314).

174 Chakravarti 2017, 313. For a discussion on problems of identification of such toponyms as modern regions, see Morris, ch. 9, sec. II.3, this volume.

175 Lahiri (1992) has illustrated the distribution of various raw materials in different parts of the subcontinent. She explains the possible distributive networks from the Bronze age up to 200 BCE. Chakrabarti and Lahiri (1996) charted out the distribution of copper sources as well as their find spots in the subcontinent, which allows one to identify channels of communication.

176 Bauer 2016.

177 Ray 1994a; 1994b; Chakrabarti 2005; 2010b; Neelis 2011. 


\section{II.3.3 Maritime Networks}

South Asia has a long history of maritime connections to both western and eastern regions of the Indian Ocean. ${ }^{178}$ The transmission of flora and fauna from the African continent and Southeast Asia dates back to the second and first millennia BCE. ${ }^{179}$ Maritime networks involving coastal centers in Gujarat (western India) date back to the third millennium всE, while Tamil maritime connections can be traced to the first millennium BCE. A third region of maritime activity was that of the Bay of Bengal, although it contrasts with the other two as having more extensive inland and riverine connections. ${ }^{180}$ Here, the location of coastal ports may not have responded to maritime trade, but rather to the location of resources in the hinterland. ${ }^{181}$ The connection of regional coastal routes with the hinterland via river is confirmed by the distribution of rouletted ware (RW) in Bangladesh and West Bengal. ${ }^{182}$

In the Indian context, trade and exchange are often part of the ritual and social roles of communities and not the consequence of settled agricultural life associated with surplus production and state formation. ${ }^{183}$ Trading activity, including seafaring in the Indian Ocean and Arabian Sea, must be dissociated from the question of state formation and the great empires as prime movers of trade. ${ }^{184}$ If one considers that the vast majority of produce shipped between and through Indian ports consisted of local subsistence products rather than luxuries, the role of small-scale entrepreneurs in multitude comes into view. ${ }^{185}$ The vast majority of pottery found in coastal sites along the Indian littoral is now identified as being of local origin, although many varieties of coarse ware are still difficult to place precisely. ${ }^{186}$

South Asia's role in the maritime networks of the western Indian Ocean is usually studied in connection with trade in the Arabian Sea, Persian Gulf, and the Red Sea. ${ }^{187}$ The Periplus Maris Erythraei (mid-first century CE), with its extensive record of travel and navigation through ancient ports, is one of the most commonly used

178 Among the large amount of literature devoted to Indian Ocean trade, see the most recent volumes by De Romanis and Maiuro (2015); Mathew (2017); Cobb 2018.

179 Fuller et al. 2011.

180 Ray 2003, 20.

181 Most of the early western sources refer to the already existing ports. There is hardly any indication that the activities of the traders either established or enhanced the trading stations (Ray 2003, 23-24).

182 Schenk 2006; Tomber 2008, 45-46.

183 For discussion see, A. Ghosh 1973; Ray 1994 .

184 For a discussion on internal and external impetuses for the development of trade in India and urbanization and secondary state formation, see Chakravarti 2017, 333-338.

185 Ray 2003 82-125; Fuller et al. 2011. The non-luxury items may include food stuffs, inexpensive textiles, spices, medicines, and ritual commodities (Seland 2014, 386).

186 On the misattribution of conical amphorae and rouletted ware in particular, see Tomber 2008, 44-45. See Dwivedi, ch. 10.A, this volume for the history of rouletted ware.

187 Mathew 2017; De Romanis and Maiuro 2015; Seland 2014, 368. 
sources for the study of maritime activity in this region. ${ }^{188}$ As a result, port sites on the western coast of the mainland and in Sri Lanka have been studied through the lens of Roman trade with India, most prominently at the sites of Arikamedu and Pattanam (alleged Muziris). More recently, Roman and Indian traders have been considered as just two players active along the long-established routes of trade and exchange from East Africa to Sri Lanka via Arabia, southern Iran, and the Indian subcontinent. ${ }^{189}$ Recent archaeology focuses more carefully on the identification and analysis of South Asian artifacts at sites across the Arabian Sea. One example is the discovery of Indian pottery dating back to centuries long before the Common Era from sites in southern Arabia (Khor Rori), the Arabian Gulf (Mleiha), and the Red Sea (Berenike and Myos Hormos). ${ }^{190}$ Finds of grain from Mleiha and ed-Durr in Umm al Qaiwain, early Indian coins of Ujjain and and the Sātavāhanas, and inscriptions in Tamil-Brāhmī script are also important markers of connectivity. ${ }^{191}$ Indian pottery found in the port towns on the Red Sea coast are now considered as relating to Indian communities settling there, rather than as representing Roman imports of ceramics or their contents. ${ }^{192}$ This is particularly true for rouletted and other fine wares that are represented in small numbers (ca. 20 vessels) in Myos Hormos and Berenike. ${ }^{193}$

Southeast Asian connections with South Asia based on the similarity of religiopolitical concepts has been a topic of discussion since the colonial period. The 'Indianization' or 'Indicization' of Southeast Asia, including the spread of Buddhism, was considered a form of colonization undertaken by the South Asian empires and states, especially during the first millennium CE. ${ }^{194}$ However, archaeological, epigraphical, and socio-anthropological research has pointed to maritime connections with Southeast Asia as early as the second millennium BCE. Furthermore, shared seafaring technology, suggesting that the development of boat-building techniques in India were influenced by Southeast Asian practices, indicates transfers of knowledge. ${ }^{195}$ Another type of shared knowledge was that of metallurgy. Bimetallic artifacts of bronze and iron from sites in South Asia, east Java, and Vietnam date back to the first millennium BCE, and are still evident in the beginning of the Common Era. Glass, pottery, and carnelian beads also appear as common remains linking South and Southeast Asia over long periods of time. ${ }^{196}$

\footnotetext{
188 Ray 2011; Seland 2014.

189 Fitzpatrick 2011, 30.

190 Reddy 2016, 55-68.

191 Reddy 2016, 71-72; Haerinck 1998, 293-296.

192 Tomber 2008, 74; Thomas 2012, 180.

193 Tomber 2008,74.

194 For an overview of the argument and criticisms, see Mabbet 1977; M. Smith 1999; Winzeler 1981, 459-466; Ray 1996, 422-431.

195 Fuller et al. 2011, 551-553.

196 Ray 2003, 120-123.
} 
Knowledge of a place called Suvarnabhūmi (literally 'the land of gold') in Southeast Asia, including its location, is another issue in the debate on Indian maritime contacts and networks. ${ }^{197}$ Buddhist Jätakas, some of which date to the third century BCE, refer to overseas voyages toward the seaports of Suvarnabhūmi. ${ }^{198}$ The $K A$ also refers to an incense from a region named Svarnabhūmī. ${ }^{199}$ Further, the prevalence of Brāhmī inscriptions of the South Indian variety in Borneo, Myanmar, Java, and Malaysia makes the connectivity obvious. Also, Sanskrit inscriptions and political structures based (it has been suggested) on the principles of the dharmaśāstras and the $K A$ are considered to be the result of cultural and economic influences. ${ }^{200}$

The attribution of Suvarṇabhūmi to a geo-political entity was an important factor in debates surrounding the spread of Buddhism in nineteenth- and twentiethcentury scholarship. However, extensive gold mines in the Philippines, Borneo, western Burma, western Sumatra, the Malaysian and Thai peninsulas, central Vietnam, Cambodia, and Laos confirm the reputation of Suvarnabhūmi as a 'land of gold. ${ }^{201}$ High-value artifacts of South Asian provenance used in a ritual context, moreover, have been discovered in sites of peninsular and central Thailand and coastal Vietnam. Rouletted ware and beads found in coastal sites in Myanmar, Thailand, Vietnam, Malaysia, and Indonesia show that maritime trade between these regions and South Asia was established by the third century BсE. ${ }^{202}$ The presence of merchants is evident from merchant seals found at U Thong and Chansen. Small stone seals from Palembang are inscribed in Sanskrit with the verse: "This successful journey is for the welfare and happiness for all human beings."203

\section{Conclusion}

Understanding the political development and chronology of early India is a complex matter due to a scarcity of dated texts and a complicated archaeological situation. Discrepancies and contradictions between literary and archaeological evidence exacerbate the problems. ${ }^{204}$ While the northwestern region is understood by many scholars as primarily Buddhist and its polities inspired by the gana-samgha (repub-

197 For this and the following, see Ray and Mishra 2018.

198 Ray and Mishra 2018, 1-4.

199 KA 2. 11. 96.

200 Sastri and Srinivasachari 1970, 230-231.

201 Bennet 2009; Ray and Mishra 2018, 4-6.

202 Jahan 2010, 5.

203 Guy 2014, 8, quoted in Ray and Mishra 2018, 9.

204 The inherent contradiction lies in the different ways in which each field is used: archaeological data are commonly used to corroborate theories derived from literary sources. The role of archaeology in history writing and the problems associated with it have been discussed in several essays in Ray and Sinopoli 2004. 
lican-style polities), archaeological and architectural remains run contrary to this perspective.

Early historic South Asia exhibits a variety of political formations. There were polities with tendencies toward monarchical rule, elaborate administrative structures, and expansionist military apparatuses. There were also political conglomerations and lineage-based polities coexisting with the kingdoms and often outliving the monarchical structures. The dynamics of subjugation, coexistence, and alliance do not allow one to chart fixed political developments in a cohesive unity spanning the Indian subcontinent and Sri Lanka. Nevertheless, the idea of dynamic unity has resulted in scholars understanding the political scenario of South Asia differently. While one group of scholars regards the degree of ecological diversity as an adequate condition for one region (the Ganga-Yamuna valley) to emerge as a nucleus region with a level of surplus production and resource concentration that enabled the control of other regions, the alternate view sees the diversity and complexity of ecologies and social structures as hindering the formation of empire-like structures. However, if empire is to be understood as more than a central state, military apparatus, and dominant political and religious influence, other, perhaps more helpful, aspects come into perspective. If we define empires more flexibly as a political context of connectivity and interaction (of ideological, religious, cultural, and economic forms), the history of the South Asian region appears as a dynamic entity with connections and interactions both within the region and with the wider world. South Asia provides an example of an interesting relationship between ritual, economic, and social aspects of society in which polities, monuments, and institutions developed through factors other than either the purely political or the purely economic.

\section{References}

Abraham, S. A. 2003. “Chera, Chola, Pandya: Using archaeological evidence to identify the Tamil kingdoms of the early historic South India." Asian Perspectives 42.2, 207-223.

-. 2008. "Inland capitals, external trade: The socio-political landscape of Late Iron Age/Early Historic Tamil South India.” In G. R. Parker and C. M. Sinopoli (eds.), Ancient India in its wider world, 52-78. Ann Arbor, MI: University of Michigan.

Agrawal, v. S. 1953. India as known to Pānini: A study of the cultural material in the Ashțādhyāyī. Lucknow: University of Lucknow.

Aiyangar, S. K. 1941. Ancient India and South Indian history and culture. Vol. 1, Ancient India. Poona: Oriental Book Agency.

Allan, J. 1936. Catalogue of coins of ancient India in the British Museum. London: British Museum. Allchin, F. R. 1995. “The Mauryan state and empire.” In F. R. Allchin (ed.), The archaeology of early historic South Asia: The emergence of cities and states, 187-221. Cambridge: Cambridge University Press.

-. 2006. “The inscriptions and graffiti." In R. A. E. Coningham (ed.), Anuradhapura: The British-Sri Lankan excavations at Anurādhapura Salgaha Watta 2. Vol. 2, 431-455. Oxford: Archaeopress.

Altekar, A. S., and R. C. Majumdar. 1986. The Vākāṭaka-Gupta age. Delhi: Motilal Banarsidass. 
Bandopadhyaya, N. C. 1927. Kautilya: Or an exposition of his social ideals and political theory. Calcutta: Cambray.

Basant, P. K. 2009. "Urbanism and society in early India." In B. D. Chattopadhyaya (ed.), History of science, philosophy and culture in Indian civilization. Vol. 2.5, 73-92. Delhi: Pearson Longman.

Basham, A. L. (1954) 1986. The wonder that was India: A survey of the history and culture of the Indian sub-continent before the coming of the Muslims. 2nd ed. Calcutta: Rupa.

Basu Majumdar, S. 2017. "State formation and religious processes of Chhattisgarh (from first century BC to eighth century AD." Studies in People's History 4.2, 119-129.

Bauer, A. M. 2015. Before Vijayanagara: Prehistoric landscapes and politics in the Tungabhadra basin. New Delhi: Manohar.

-. 2016. "Provincializing the littoral in Indian Ocean heritage: Coastal connections and interior contexts of the southern Deccan." In H. P. Ray (ed.), Bridging the Gulf: Maritime cultural heritage of the western Indian Ocean, 101-119. New Delhi: Manohar.

Bennett, A. T. N. 2009. "Gold in early Southeast Asia." ArcheoSciences 33, 99-107.

Bhandare, S. 2006. "Numismatics and history: The Maurya-Gupta interlude in the Gangetic plain." In P. Olivelle (ed.), Between the empires: Society in India 300 BCE to 400 CE, 67-111. Oxford: Oxford University Press.

Bhattacharya, G. 2008. "Who were the donors of early Mathura sculptures? What was their social status?" In G. Sengupta and S. Chakraborty (eds.), Archaeology of early historic South Asia, 495-502. New Delhi: Pragati.

Bhattacharyya, N. N. 2009. “India: Its regions and peoples." In B. D. Chattopadhyaya (ed.), History of science, philosophy and culture in Indian civilization. Vol 2.5, 21-28. Delhi: Pearson Longman.

Casson, L. 1989. The Periplus Maris Erythraei: Text with introduction, translation and commentary. Princeton, NJ: Princeton University Press.

Chakrabarti, D. K. 2005. The archaeology of the Deccan routes: The routes which linked Ganga plain with the Deccan. Delhi: Munshiram Manoharlal.

-. 2010a. The geopolitical orbits of ancient India: The geographical frames of the ancient Indian dynasties. New Delhi: Oxford University Press.

-. 2010b. The ancient routes of the Deccan and the southern peninsula. New Delhi: Aryan Books International.

Chakrabarti, D. K., and N. Lahiri. 1996. Copper and its alloys in ancient India. Delhi: Munshiram Manoharlal.

Chakravarti, R. 1986. Warfare and wealth: early Indian perspective. Calcutta: Firma KLM.

-. 2012. "Pentapotamia and the crossroads of Asia: Politics, state society and linkages (c. second century BCE-300 CE). Presidential address (ancient section).” In B. K. Bhatti (ed.), Punjab History Conference, $43^{\text {rd }}$ session, March 12-14, 2011: Proceedings, 11-29. Patiala: Publication Bureau, Punjabi University.

-. 2016. Exploring early India: Up to c. AD 1300. 3rd ed. New Delhi: Primus.

-. 2017. "Examining the hinterland and foreland of the port of Muziris in the wider perspective of the subcontinent's long-distance networks." In Mathew (2017), 307-338.

Champakalakshmi, R. 1996. Trade, ideology and urbanization: South India 300 BC to AD 1300. Delhi: Oxford University Press.

Chandra, M. 1953. Sārthavāha. Patna: Rashtrabhasha Parishad.

-. 1977. Trade and trade routes in ancient India. New Delhi: Abhinav.

Chattopadhyaya, B. D. 2003a. “'Autonomous spaces' and the authority of state: The contradiction and its resolution in theory and practice in early India." In Studying early India: Archaeology texts and historical issues, 135-152. New Delhi: Permanent Black.

-. 2003b. "Transition into early historic in the Deccan: A note." In Studying early India: Archaeology texts and historical issues, 29-47. New Delhi: Permanent Black. 
-. 2015. “'Unity in diversity’: Voices from the India’s ancient texts.” Social Scientist 43.9-10, 3-28.

Cobb, M. A., ed. 2018. The Indian Ocean trade in antiquity: Political, cultural, and economic impacts. London: Routledge.

Coningham, R. A. E. 1995. "Monks, caves and kings: A reassessment of the nature of early Buddhism in Sri Lanka.” Buddhist Archaeology 27.2, 222-242.

Coningham, R. A. E., M. Manuel, and J. Shoebridge. 2017. "Reconstructing networks of trade and exchange in the Indian Ocean during the early historic period: Case studies from Anuradhapura (Sri Lanka).” In Mathew (2017), 31-51.

Cribb, J. 2000. “Early Indian history." In M. D. Willis (ed.), Buddhist reliquaries from ancient India, 39-54. London: British Museum.

Dash, S. K. 2005. “Monsoons and monsoon climate.” In J. E. Oliver (ed.), Encyclopedia of world climatology, 509-515. New York, NY: Springer.

De Romanis, F. 2012. “On Dachinabades and Limyrike in the Periplus Maris Erythraei.” Topoi 11, 329-340.

De Romanis, F., and M. Maiuro, eds. 2015. Across the ocean: Nine essays on Indo-Mediterranean trade. Leiden: Brill.

Dehejia, V. 1992. "The collective and popular basis of early Buddhist patronage: Sacred monuments, 100 BC-AD 250.” In B. S. Miller (ed.), The powers of art: Patronage in Indian culture, 35-45. Delhi: Oxford University Press.

Devadevan, M. V. 2006. "Lying on the edge of the burning ground: Rethinking Tinais." Journal of the Economic and Social History of the Orient 49.2, 199-218.

Dhavalikar, M. K. 1996. "Sātavāhana chronology: A re-examination.” Annals of the Bhandarkar Oriental Research Institute 77.1/4, 133-140.

Dwivedi, M. 2015. “Colonial imagination and identity attribution: Numismatic cues for defining space.” In H. P. Ray (ed.), Negotiating cultural identity: Landscapes in early medieval South Asian history, 206-238. New Delhi: Routledge.

Falk, H. 2010. "Names and titles from Kuṣāṇa times to the Hūṇas: The Indian material.” In M. Pfisterer, M. Alram, M. Inaba, and D. Klimburg-Salter (eds.), Coins, art and chronology. Vol. 2, 73-89. Vienna: Österreichische Akademie der Wissenschaften.

Fitzpatrick, M. P. 2011. "Provincializing Rome: The Indian Ocean trade network and Roman imperialism.” Journal of World History 22.1, 27-54.

Fuller, D. Q., N. Boivin, R. Allaby, and T. Hoogervorst. 2011. “Across the Indian Ocean: The prehistoric movement of plants and animals." Antiquity 85, 544-558.

Fussman, G. 1987-1988. "Central and provincial administration in India: The problem of the Mauryan Empire." Indian Historical Review 14.1/2, 43-72.

Ghosh, A. 1973. The city in early historical India. Simla: Indian Institute of Advanced Study.

Ghosh, S. 2012. "Migration of the gana-samgha of Punjab." Journal of the Asiatic Society 54.1, 45-54.

Ghoshal, U. N. (1959) 1995. A history of Indian political ideas: The ancient period and the period of transition to the Middle Ages. Delhi: Oxford University Press.

Girija, C. 1976. "Elimalai in Sangam polity." Proceedings of the Indian History Congress 37, 55-61.

Gokhale, B. G. 1966. “Early Buddhist kingship.” Journal of Asian Studies 26.1, 15-22.

Gupta, P. L. 1996. Coins. Delhi: National Book Trust.

Guruge, A. W. P. 1994. "Emperor Aśoka and Buddhism: Unresolved discrepancies between Buddhist tradition and Aśokan inscriptions." In A. Seneviratna (ed.), King Aśoka and Buddhism: Historical and literary studies, 37-91. Kandy: Buddhist Publication Society.

Gurukkal, R. 1993. "Towards the voice of dissent: Trajectory of ideological transformation in early South India." Social Scientist 21.1/2, 2-22.

-. 1995. "The beginnings of the historic period: The Tamil south." In R. Thapar (ed.), Recent perspectives of early Indian history, 237-265. Bombay: Popular Prakashan. 
-. 2008. "The Kosambi effect: A hermeneutic turn that shook Indian historiography." Economic and Political Weekly 43.30, 89-96.

Guy, J., ed. 2014. Lost kingdoms: Hindu-Buddhist sculptures of early Southeast Asia. New York, NY: Metropolitan Museum of Art.

Haerinck, E. 1998. "International contacts in the southern Persian Gulf in the late 1st century BC/ 1st century AD: Numismatic evidence from ed-Dur (Emirate of Umm al-Qaiwain, U.A.E.)." Iranica Antiqua 33, 273-302.

Handa, D. 2007. Tribal coins of ancient India. Delhi: Aryan Books International.

Hansen, V. 2017. The Silk Road: A new history. Oxford: Oxford University Press.

Henige, D. 1986. "Comparative chronology and the ancient Near East: A case for symbiosis." Bulletin of the American Schools of Oriental Research 261, 57-68.

Jahan, S. H. 2010. "Rouletted ware links South and Southeast Asia through maritime trade." SPAFA Journal 20.3, 5-18.

Jayaswal, K. P. 1924. Hindu polity: A constitutional history of India in Hindu times. Vol. 2, Calcutta: Butterworth and Co.

-. 1933. History of India, 150 AD to 350 AD. Lahore: Motilal Banarsidass.

Jayaswal, K. P., and R. D. Banerji. 1929. "The Hathigumpha inscription of Kharavela." Epigraphia Indica 20, 71-89.

Jettmar, K., ed. 1989. Antiquities of northern Pakistan: Reports and studies. Vol. 1, Rock inscriptions in the Indus valley: Text. Mainz: Philipp von Zabern.

Kangle, R. P. (1960-1965) 2014. The Kauțiliya Arthaśāstra. 3 vols. Delhi: Motilal Banarasidass.

Karttunen, K. 2015. Yonas and Yavanas in Indian literature. Helsinki: Finnish Oriental Society.

Kennedy, R. 1976. "The king in early South India, as chieftain and emperor." Indian Historical Review 3.1, 1-15.

Kosambi, D. D. 1956. An introduction to the study of Indian history. Bombay: Popular Book Depot.

Lahiri, N. 1992. The archaeology of Indian trade routes up to c. 200 BC: Resource use, resource access and lines of communication. Delhi: Oxford University Press.

-. 2015. Ashoka in ancient India. Cambridge, MA: Harvard University Press.

Law, B. C. 1955. Historical geography of ancient India. Paris: Société asiatique de Paris.

Lüders, H. 1912. "A list of Brahmi inscriptions from the earliest times to about AD 400 with the exception of those of Asoka." Appendix to Epigraphia Indica 10.

Mabbet, I. W. 1977. "The 'Indianization' of Southeast Asia: Reflections on the historical sources." Journal of Southeast Asian Studies 8.2, 143-161.

Majumdar, R. C. 1960. The classical accounts of India. Calcutta: Firma KLM.

Maloney, C. 1970. "The beginnings of civilization in South India." Journal of Asian Studies 29.3, 603-616.

Mathew, K. S., ed. 2017. Imperial Rome, Indian Ocean regions and Muziris: New perspectives on maritime trade. London: Routledge.

McColl, R. W., ed. 2014. Encyclopedia of world geography. Vol. 1, New York, NY: Facts On File.

Menon, S. M. 2018. "Megaliths: New perspectives for future studies." In R. Korisettar (ed.), Beyond stones and more stones: Defining Indian prehistoric archaeology. Vol. 2, 208-256. Bangalore: Mythic Society.

Moorti, U. S. 1994. Megalithic culture of south India: Socio-economic perspectives. Varanasi: Ganga Kaveri Publishing House.

Morrison, K. D. 1995. "Trade, urbanism, and agricultural expansion: Buddhist monastic institutions and the state in the early historic western Deccan." World Archaeology 27.2, 203-21.

-. 1997. "Commerce and culture in South Asia: Perspectives from archaeology and history." Annual Review of Anthropology 26, 87-108.

Mukherjee, B. N. 1984. Studies in Aramaic edicts of Aśoka. Calcutta: Indian Museum. 
Murphy, C., and D. Q. Fuller. 2017. "The agriculture of early India." Oxford Research Encyclopedia of Environmental Science. http://doi.org/10.1093/acrefore/9780199389414.013.169.

Nayak, G. N., and P. T. Hanamgond. 2010. "India." In E. C. F. Bird (ed.), Encyclopedia of the world's coastal landforms. Vol. 1, 1065-1070. New York, NY: Springer.

Neelis, J. 2000. "Kharoșțīi and Brāhmī inscriptions from Hunza-Haldeikish: Sources for the study of long-distance trade and transmission of Buddhism." In M. Taddei and G. De Marco (eds.), South Asian Archaeology 1997: Proceedings of the fourteenth international conference of the European Association of South Asian Archaeologists, held in the Istituto italiano per l'Africa e l'Oriente, Palazzo Brancaccio, Rome, 7-14 July 1997. Vol. 2, 903-923. Roma: Istituto italiano per l'Africa e l'Oriente.

-. 2011. Early Buddhist transmission and trade networks: Mobility and exchange within and beyond the northwestern borderlands of South Asia. Leiden: Brill.

-. 2013. "Polyvalent perceptions of the Uttarāpatha in history: Archaeological evidence, epigraphic references and literary demarcations." In S. Ghosh, S. Ray Bandopadhyaya, S. Basu Majumdar, and S. Pal (eds.), Revisiting early India: Essays in honour of D. C. Sircar, 13-25. Kolkata: R. N. Bhattacharya.

Olivelle, P. 2005. Manu's code of law: A critical edition and translation of Mānava-Dharmaśāstra. Oxford: Oxford University Press.

-. 2013. King, governance, and law in ancient India: Kauțilya's Arthaśāstra: A new annotated translation. Oxford: Oxford University Press.

Peebles, P. 2006. The history of Sri Lanka. Santa Barbara, CA: Greenwood.

Petrie, C. A., and J. Bates. 2017. “'Multi-cropping,' intercropping and adaptation to variable environments in Indus South Asia." Journal of World Prehistory 30, 81-130.

Prakash, B. 1964. Political and social movements in ancient Punjab. Delhi: Motilal Banarasidass.

-. 1971. Evolution of heroic tradition in ancient Punjab. Patiala: Punjabi University.

Prinsep, J. 1838. "On the edicts of Piyadasi, or Asoka, the Buddhist monarch of India, preserved on the Girnar rock in the Gujerat peninsula and on the Dhauli rock in Cuttack: With the discovery of Ptolemy's name therein." Journal of the Asiatic Society of Bengal 7.1, 219-82.

-. 1858. Essays on Indian antiquities, historic, numismatic and palaeographic, of the late James Prinsep, to which are added his useful tables, illustrative of Indian history, chronology, modern coinages, weights, measures etc. E. Thomas (ed.). London: John Murray.

Rajan, K. 2015. Early writing system: A journey from graffiti to Brāhmī. Madurai: Pandya Nadu Centre for Historical Research.

Randhawa, M. S. 1980. A history of agriculture in India. Vol. 1, Beginning to 12th century. New Delhi: Indian Council of Agricultural Research.

Ray, H. P. 1986. Monastery and guild: Commerce under the Sātavāhanas. Delhi: Oxford University Press.

-. 1988. "Yavana presence in ancient India." Journal of the Economic and Social History of the Orient 31.3, 311-325.

-. 1994a. The winds of change: Buddhism and the maritime links of early South Asia. Delhi: Oxford University Press.

-. 1994b. "Kanheri: The archaeology of an early Buddhist pilgrimage centre in western India." World Archaeology 26.1, 35-46.

-. 1996. "Seafaring and maritime contacts: An agenda for historical analysis." Journal of the Economic and Social History of the Orient 39.4, 422-431.

-. 2003. The archaeology of seafaring in ancient South Asia. Cambridge: Cambridge University Press.

-. 2008. "Interpreting the Mauryan Empire: Centralized state or multiple centers of control." In G. R. Parker and C. M. Sinopoli (eds.), Ancient India in its wider world, 13-51. Ann Arbor, MI: University of Michigan. 
-. 2011. "Writings on the maritime history of ancient India." In S. Bhattacharya (ed.), Approaches to history: Essays in Indian historiography, 27-54. Delhi: Primus.

Ray, H. P., and S. Mishra. 2018. "Introduction." In Bibliography on Sailing to Suvarnabhumi. AIC-RIS. http://ris.org.in/aic/bibliography.

Ray, H. P., and D. T. Potts, eds. 2007. Memory as history: The legacy of Alexander in Asia. New Delhi: Aryan Books International.

Ray, H. P., and C. M. Sinopoli, eds. 2004. Archaeology as history in early South Asia. New Delhi: Aryan Books International.

Raychaudhuri, H. (1923) 1972. Political history of ancient India: From the accession of Parikshit to the extinction of the Gupta dynasty. 7th ed. Calcutta: University of Calcutta.

Raychaudhuri, S. P., and M. Roy. 1993. Agriculture in ancient India: A report. New Delhi: Indian Council of Agricultural Research.

Reddy, A. L. 2016. "Archaeology of Indo-Gulf relations in the early historic period: The ceramic evidence.” In H. P. Ray (ed.), Bridging the Gulf: Maritime cultural heritage of the western Indian Ocean, 53-78. New Delhi: Manohar.

Sahu, B. P. 2001. "Brahmanical ideology, regional identities and the construction of early India." Social Scientist 29.7/8, 3-18.

Sastri, H. 1925-1926. "Brahmi inscription on a wooden pillar from Kirari." Epigraphia Indica 18, 152-157.

Sastri, N. K. A. (1955) 1995. A history of South India: From prehistoric times to the fall of Vijayanagara. 4th ed. Delhi: Oxford University Press.

Sastri, N. K. A., and G. Srinivasachari. 1970. Advanced history of India. Bombay: Allied Publishers.

Schenk, H. 2006. "The dating and historical value of rouletted ware." Zeitschrift für Archäologie außereuropäische Kulturen 1, 59-90.

Seland, E. H. 2014. "Archaeology of trade in the western Indian Ocean, 300 BC-AD 700." Journal of Archaeological Research 22.2, 367-402.

Selby, M. A. 2008. "Representations of the foreign in classical Tamil literature." In G. R. Parker and C. M. Sinopoli (eds.), Ancient India in its wider world, 79-90. Ann Arbor, MI: University of Michigan.

Seneviratne, S. 1981. "Kalinga and Andhra: The process of secondary state formation in early India." In H. J. M. Claessen and P. Skalnik (eds.), The study of the state, 317-338. The Hague: Mouton.

Shrimali, K. M. 1985. History of the Pañcāla. Vol. 1, A study. New Delhi: Munshiram Manoharlal. Sims-Williams, N., and J. Cribb. 1995. "A new Bactrian inscription of Kanishka the Great." Silk Road Art and Archaeology 4, 76-142.

Singh, U. 1996. "Sanchi: The history of the patronage of an ancient Buddhist establishment." Indian Economic and Social History Review 33.1, 1-35.

-. 2008. A history of ancient and early medieval India: From the stone age to the 12th century. Delhi: Pearson Longman.

Singh, V. L. 2005. Mathurā: The settlement pattern and cultural profile of an early historical city. New Delhi: Sundeep Prakashan.

Singhvi, A. K., and R. Krishnan. 2014. "Past and the present climate of India." In V. S. Kale (ed.), Landscapes and landforms of India, 15-23. New York, NY: Springer.

Sircar, D. C. 1965. Select inscriptions bearing on Indian history and civilization. Vol. 1, From the 6th century $B C$ to the 6 th century $A D$. 2nd ed. Delhi: Motilal Banarsidass.

-. (1979) 2000. Aśokan studies. Calcutta: Indian Museum.

Smith, M. 1999. "'Indianization' from the Indian point of view: Trade and cultural contacts with Southeast Asia in the early first millennium CE." Journal of the Economic and Social History of the Orient 42.1, 1-26. 
-. 2005. "Networks, territories, and the cartography of ancient states." Annals of the Association of American Geographers 95.4, 832-849.

Smith, V. A. (1901) 1920. Asoka: The Buddhist emperor of India. 3rd ed. Oxford: Clarendon.

Snead, R. E. 2010a. “Bangladesh.” In E. C. F. Bird (ed.), Encyclopedia of the world's coastal landforms. Vol. 1, 1077-1080. New York, NY: Springer.

-. 2010b. "Pakistan.” In E. C. F. Bird (ed.), Encyclopedia of the world's coastal landforms. Vol. 1, 1059-1064. New York, NY: Springer.

Spate, O. H. K., and A. T. A. Learmonth. (1954) 2017. India and Pakistan: A general and regional geography. London: Routledge.

Srinivasan, T. M. 2016. "Agricultural practices as gleaned from the Tamil literature of the Sangam age." Indian Journal of History of Science 51.2, 167-189.

Subbarayalu, Y. 2014. "Post-Satavahana and post-Sangam polities.” In N. Karashima (ed.), A concise history of South India: Issues and interpretations, 55-63. New Delhi: Oxford University Press.

Subramanian, N. 1966. Sangam polity: The administration and social life of the Sangam Tamils. Bombay: Asia Publishing House.

Swan, B. 2010. "Sri Lanka." In E. C. F. Bird (ed.), Encyclopedia of the world's coastal landforms. Vol. 1, 1071-1075. New York, NY: Springer.

Tandon, S. K., P. P. Chakraborty, V. Singh, and V. S. Kale. 2014. "Geographical and tectonic framework of India: Providing context to geomorphologic development." In Landscapes and landforms of India, 3-14. New York, NY: Springer.

Thapar, R. 1978. "The scope and significance of regional history.” In R. Thapar (ed.), Ancient Indian social history: Some interpretation, 361-376. New Delhi: Orient Longman.

-. 2003. The Penguin history of Early India: From the origins to AD 1300. London: Penguin.

-. 2006. "The Mauryan Empire in early India." Historical Research 79.205, 287-305.

-. (1961) 2013. Aśoka and the decline of the Mauryas. 3rd ed. London: Oxford University Press.

Thomas, R. 2012. "Port communities and Erythraean sea trade." British Museum Studies in Ancient Egypt and Sudan 18, 169-199.

Tomber, R. 2008. Indo-Roman trade: From pots to pepper. London: Duckworth.

Trautmann, T. R. 2009. "Elephants and the Mauryas." In The clash of chronologies: Ancient India in the modern world, 229-254. Delhi: Yoda Press.

Winzeler, R. L. 1981. “The study of the Southeast Asian state.” In H. J. M. Claessen and P. Skalnik (eds.), The study of the state, 455-467. The Hague: Mouton.

Xue, Y., and M. Yanai. 2005. “Asia, climate of south.” In J. E. Oliver (ed.) Encyclopedia of world climatology, 115-120. New York, NY: Springer. 



\section{Kathrin Leese-Messing \\ 4 The Qin and Han Empires}

\section{Introduction}

The early Chinese imperial period comprises the reigns of the short-lived Qin 秦 dynasty (221-207 BCE) and the subsequent, long-lasting Han 漢 dynasty (206 BCE$220 \mathrm{CE}$ ). The early Chinese empire ranks among the largest empires of its time. It was comparable to the Roman Empire in terms of its peak population (up to 60 million) ${ }^{1}$ and territorial size (up to 6.5 million sq. $\mathrm{km}$ ). ${ }^{2}$ One distinguishing feature of its spatial dimensions is that following a short period of rapid expansion, the empire under Qin rule already comprised large parts of what would be the peak of the Han Empire's territorial dimensions, which the latter then kept $^{3}$ (and, during certain phases, further extended) until the early third century CE.

The area that came to be the capital area of both the Qin and Former Han Empires is traditionally referred to as Guanzhong 關中, the 'area within the passes' (map 1). With the fertile lower Wei 渭 River valley at its core, the area is ringed by hills and mountains and was therefore accessible only through a number of passes. From here, several dynasties would unify their empires, and it served as the capital area for 12 dynasties from the Zhou 周 (ca. 1045-770 BCE) up to the Tang 唐 (618907 CE) period.

A traveler leaving the Guanzhong plains toward the east, where the Yellow River (Huanghe 黃河) cuts through the mountains at the Hangu 函谷 Pass, reaches the westernmost edges of the North China Plain. ${ }^{4}$ With the Yellow River at its center, it constitutes China's largest alluvial plain. With its fertile loess soil, but only a moderate amount of precipitation and a relatively short growing season, the North China Plain is particularly suitable for growing drought-resistant and quickly maturing crops like millet and soy beans. The area was home to many prehistoric cultures

1 Bielenstein 1947; Nishijima 1986, 595-596.

2 Turchin 2009, 202; Taagepera 1979, 128. These figures also include, for instance, the territory of the Tarim Basin (comprising about 1 million sq. $\mathrm{km}$ ), in which Han control definitely was of a much more limited scale than in the empire's more central regions. Furthermore, due to its dry climate, only a small proportion of the vast Tarim Basin was populated.

3 The Han initially controlled a smaller territory than the Qin Empire at its peak. They then reconquered the lost territory and eventually went beyond their predecessor's ambitions. See section IV.4 below.

4 The Later Han dynasty would eventually move its capital to the city of Luoyang 洛陽 situated in this region (in the west of modern Henan Province).

Note: I would like to thank Armin Selbitschka and Tsang Wing Ma for valuable comments on an earlier draft of this chapter.

Ә Open Access. () 2020 Kathrin Leese-Messing, published by De Gruyter. (c) BY-NC-ND This work is licensed under the Creative Commons Attribution-NonCommercial-NoDerivatives 4.0 License.

https://doi.org/10.1515/9783110607741-006 

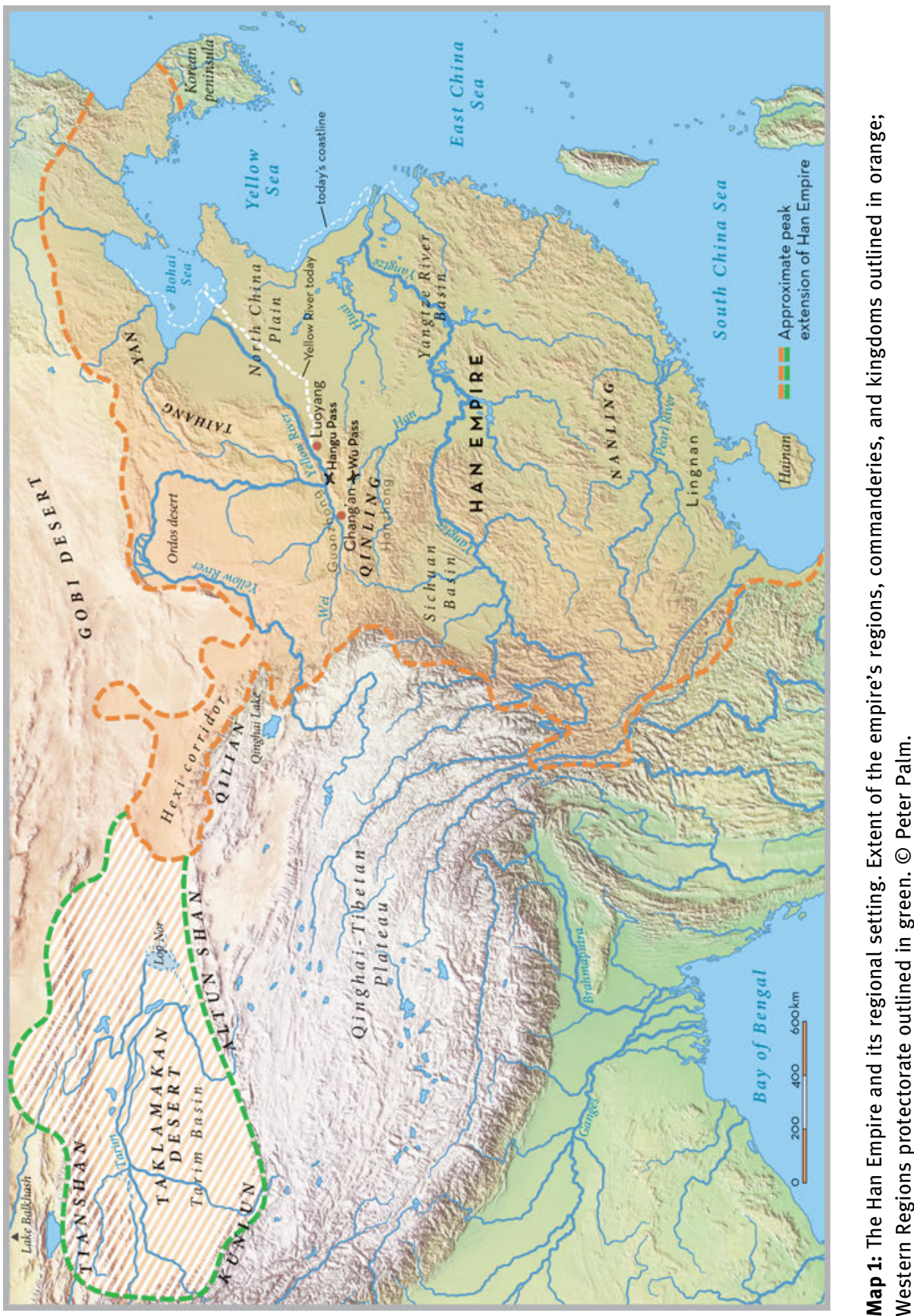
and to the rulers of the Shang 商 (seventeenth to eleventh centuries BCE), known as China's first historical dynasty. The North China Plain is therefore often credited with being the cradle of Chinese civilization, although archaeological findings in other areas have put this myth of a single cultural origin into question. ${ }^{5}$

Toward the north and northwest, the Yan 燕 and Taihang 太行 Mountains separate the North China Plain from areas characterized by steppe, desert, and forest landscapes. During the phase of major expansion in the decades around 100 BCE, the Han Empire expanded its territory northwards to these areas of limited agricultural potential. In the northeast, the empire extended as far as the northern parts of the Korean peninsula. In the north and northwest, the Han got hold of the Ordos, an area enclosed by a large rectangular bend of the Yellow River (the Ordos Loop), and of the so-called Hexi 河西 corridor. The latter is a depression with a width of less than $80 \mathrm{~km}$ and a length of over $960 \mathrm{~km}$, with the Qilian 祁連 Mountains and the Altun Shan to its south, and the Gobi Desert to its north. ${ }^{6}$ The conquest of the Hexi corridor further provided direct access to the Tarim Basin (in modern Xinjiang 新疆 Uyghur Autonomous Region), an endorheic basin dominated by the Taklamakan Desert at its center. Intermittently, the oasis states surrounding the desert areas encountered varying degrees of Han control.

On the southern edges of the North China Plain, the Qinling 秦嶺 Mountains (in the west) and the Huai 淮 River (in the east) demarcate the separation between the areas of the Yellow River and the Yangtze (Changjiang 長江) River Basins. The latter basin was accessible from the Guanzhong capital area via its southeastern gate, the $\mathrm{Wu}$ 武 Pass. The Yangtze River Basin enjoys favorable agricultural conditions, with a climate characterized by abundant rainfall and moderate temperatures that enable a long growing season. Paddy field rice, in combination with beans, vegetables, and fruits, constituted the most important agricultural products of this area. During early imperial times, the land south of the Yangtze River was a region that northern people preferably avoided even though centuries later it evolved into the political, economic, and cultural center of China. The vast majority of the early empires' population lived north of the Yangtze River. The area to its south was often seen as a place of exile, characterized by excessive heat and wetness, disease, and poisonous air. Even though militarily occupied, particularly the subtropical and mountainous area south of the Nanling 南嶺 range including the Pearl River (Zhujiang 珠江) Basin remained largely outside the cultural sphere of the Chinese heartland.

To the southwest of the 'area within the passes' lies an area with considerable geo-strategical importance for the formation of the Chinese empires: the fertile Sichuan 四川 Basin. Surrounded by mountains on all sides, it initially constituted a rather remote area from the outward perspective of the so-called Chinese heartland, even though it had been the home of a highly developed Bronze Age civilization

5 Von Falkenhausen 1995.

6 On the geography of the Hexi corridor, see Chang 2007b, 3-4. 
contemporaneous to the Shang. ${ }^{7}$ During the fourth century BCE, it was made accessible from the Guanzhong area via a network of newly opened mountain roads and evolved into a breadbasket for the forming empire.

From a bird's-eye view, the larger core of the early Chinese empires (including the Guanzhong area, the North China Plain, the Yangtze River Basin, and the Sichuan Basin), is a relatively segregated part of the world. It is surrounded by the high mountains bordering the Qinghai-Tibetan Plateau in the west, by steppe and deserts in the north and northwest, the Pacific Ocean in the east, and a subtropical, mountainous zone to the south. Although these buffer zones limited potential contacts to other centers of civilization in Inner Asia, the Near East, South Asia, and Europe to a certain degree, even in prehistoric times the area that is now central China was never isolated from the rest of the world. Long before the Han Empire's 'penetration to the Western Regions' 通西域 ${ }^{8}$ (via the Hexi corridor into the Tarim Basin and beyond) and the alleged beginning of Silk Road trade, archaeological evidence testifies to long-range intercultural exchange with far-reaching historical impacts: Wheat was introduced to northern China from Western Asia during the mid-fifth millennium BCE, the westward export of Asian millets from China reached Greece by the third millennium BCE, and via the Eurasian steppe, the chariot found its way from Western Asia to the North China Plain, where it was adapted by the Shang at around 1200 BCE. ${ }^{9}$ With the expansion of the early Chinese empires, contacts and exchange intensified in all directions.

The history of the Qin and Han Empires is inapprehensible without taking into account the historical foundations that these empires were built upon. Section II will therefore introduce certain political, institutional, and cultural developments that characterized the pre-imperial polities that had coexisted in the Yellow River and Yangtze River Basins prior to 221 BCE. Thereafter, section III will provide a largely chronological account of the period comprising the rise of the state of Qin, the unification, and the short rule of the Qin Empire, before offering a brief chronological overview of the long-lasting Han period. Finally, section IV will focus on several characteristic institutions of the Qin and Han Empires.

7 On the Sanxingdui 三星堆 culture in Sichuan, see Bagley 2001.

8 This expression is frequently used in Ban Gu's 班固 (32-92 CE) Documents of the Han (Hanshu 漢書) with regard to Emperor Wu 武 (r. 141-87 BCE) of Han and his famous envoy Zhang Qian 張騫 (195-114 BCE).

9 Lightfoot, Liu, and Jonse 2013; Bestel et al. 2014; Barbieri-Low 2000. 


\section{From a Decentralized Network to a Bureaucratic Empire}

\section{II.1 Before Empire: Political Fragmentation versus Cultural Convergence during the Eastern Zhou Period (770-255 BCE)}

By 260 все, the large core area of the later Chinese empires consisted of seven major (and some minor) independent states, whose power and territorial extensions were partly comparable to each other (map 2). Only 40 years later, the whole area was united under the rule of the first Chinese emperor. This fast political unification calls for an explanation that can only be provided by a look at some historical developments characterizing the pre-imperial period.

The centuries preceding the political unification of the Chinese heartland are known as the period of the Eastern Zhou 東周 (770-255 всE). As received literature would make us believe, the Zhou had provided for political stability and moral integrity in their extensive realm before being forced by a neighboring nomadic people to leave their old power base in the Wei River valley in the eighth century BCE. The larger Zhou realm was a territorially decentralized network of individual regional domains, based on a hierarchy of personal and kinship relations that centered on the person of the king. ${ }^{10}$ After the involuntary eastward move of their capital to Wangcheng 王城 (near later Luoyang) in 771 BCE, the Zhou rulers found themselves progressively losing their authority over the other regional lords. ${ }^{11}$ The era of the Eastern Zhou up to the Qin unification is traditionally characterized as a phase of gradual deterioration of the political-ritual order of old. But in fact, the Eastern Zhou period witnessed an unprecedented coalescence of the region nominally still under Zhou rule. ${ }^{12}$ It is arguably with reference to this period that the designation 'China' (as a cultural unit) can be used as a meaningful term in the first place. ${ }^{13}$

During the Eastern Zhou period, which is traditionally divided into the Spring and Autumn (Chunqiu 春秋, 722-481 BCE) and the Warring States (Zhanguo 戰國, 475-221 BCE) periods, this trend was reinforced. Territorial expansion of the individual polities resulted in increasing military and cultural contacts between them. Mili-

\section{Khayutina 2010.}

11 On the Western Zhou and their gradual loss of power, see Li 2006.

12 The roots of this cultural convergence can be traced to the 'ritual revolution' during the ninth century BCE. As archaeological evidence has brought to light, the city-states had standardized their systems of aristocratic display during this period, e.g., by unitizing the number of particular vessels admitted as burial objects according to rank. Rawson 1999; von Falkenhausen 1999.

13 The name 'China' (or any of its linguistic variants) did not exist at that time. Nor was it ever used by any imperial Chinese polity as an autonym. The exonym is most commonly believed to have been derived from 'Qin,' the name of the first imperial dynasty. For one of the alternative suggestions, see Wade 2009. Chinese polities employed their dynastic names or generic terms such as Zhongguo 中國, the 'Central State(s),' as self-references. 


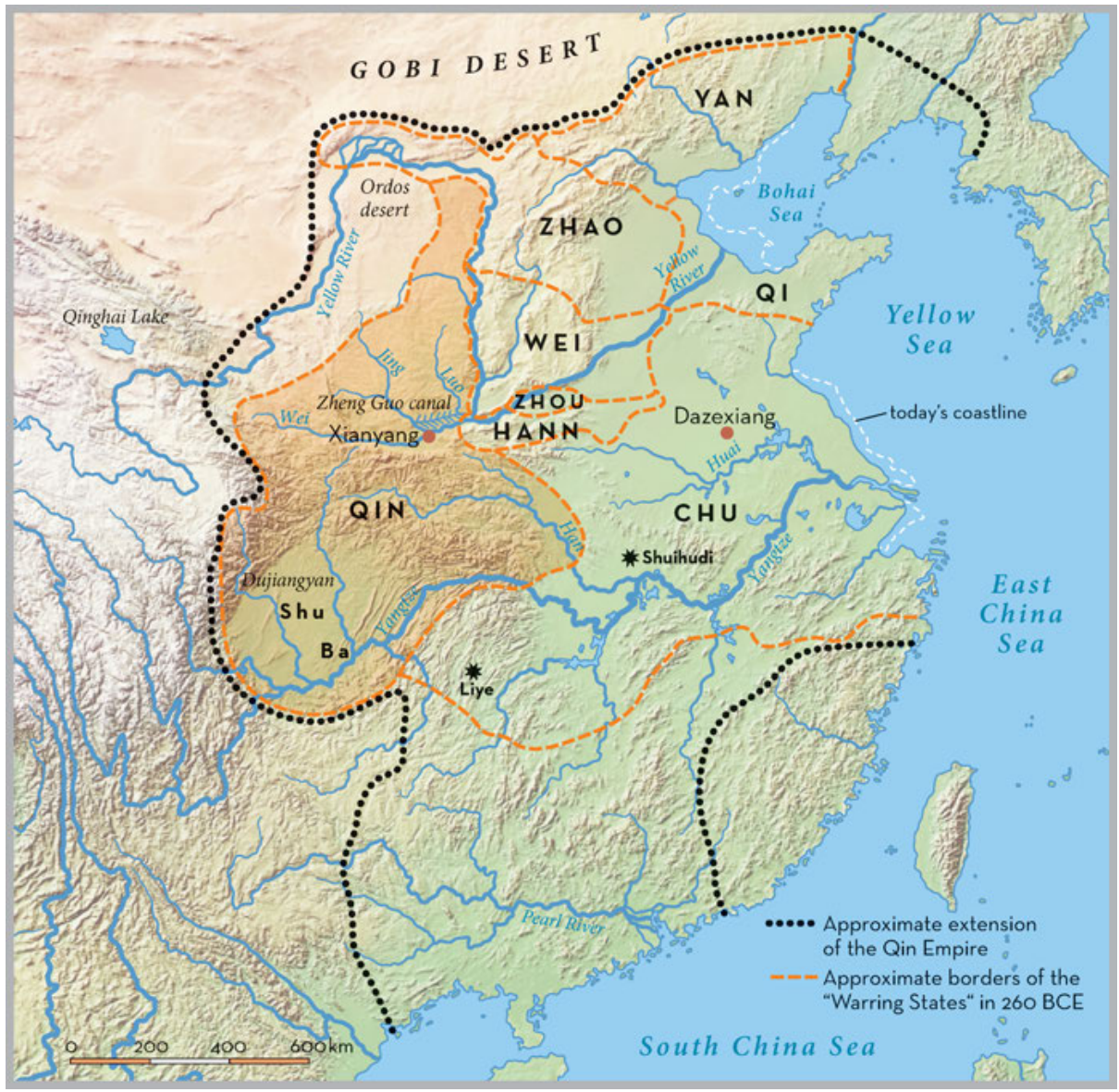

Map 2: The Warring States in 260 BCE and the subsequent extension of the Qin Empire. (C) Peter Palm.

tary confrontations led to drastic changes in the political landscape. While far more than one hundred smaller city-states coexisted under formal Zhou sovereignty in the early Chunqiu period, the number had already decreased to around 20 by the early Warring States era. By 260 BCE, only seven major states were left - albeit much larger and territorially bounded. Amidst the enormous bloodshed caused by these states' incessant warfare, philosophical notions of universal, transcending forces and the idea of political unity were born. ${ }^{14}$ One of these states was the state of Qin 秦, situated at the western margins of the former Zhou ecumene, which finally brought about the first political unification of this vast area under imperial rule.

14 Pines 2000. 


\section{II.2 Toward Empire: General Developments of the Warring States}

Most contemporaries would not have regarded the Qin victory as predictable even only a few decades before the actual unification took place. ${ }^{15}$ The unification was the result of a complex interlocking of certain economic and demographic developments, which served as an important historical foundation of other drastic changes that affected all of the Warring States.

From the fourth century всЕ onward, the emergence of the iron industry made field work much more effective, encouraged the use of draft animals, the construction of large-scale irrigation systems, and extensive deforestation for the reclamation of new farmland. The ensuing increase in agricultural production enhanced trading activities and economic prosperity. An immense growth of population precipitated both interior colonization and exterior expansion of the states. ${ }^{16}$

Demographic growth had manifold implications on Warring States societies, for example with regard to military organization. A development that had started during the Spring and Autumn period with a gradual extension of military service from the nobility and its dependents to the entire population ${ }^{17}$ was now brought to its completion by the new disposability of mass armies. Small formations led by aristocratic warriors, whose 'ritual violence' had characterized the wars up to the Spring and Autumn period, ${ }^{18}$ were now replaced by infantry and cavalry forces comprising hundreds of thousands of peasant levies. They were fighting with technically improved swords and halberds partly made of iron, and with the newly invented and highly effective crossbow. ${ }^{19}$ These trends precipitated a new mode of warfare characterized by large-scale campaigns, long-term sieges, extreme rationalization, and devastating numbers of casualties. It has been argued that the degree of militarization and severity of warfare in Warring States China were higher than anywhere else in the ancient world. ${ }^{20}$

These military changes also heavily affected late Warring States societies in general. Military merit became a primary source of social advancement, which meant new potential for social mobility for the lower levels of society while simultaneously disintegrating the privileges of the old aristocracy. ${ }^{21}$ Experience with the

15 On the changing perception of Qin during the Warring States period, see Pines et al. 2014, 5-6; Pines 2013a.

16 For the development of ironwork in pre-imperial China, see Wagner 1993; 2008, 83-170; von Falkenhausen 2006, 409-410. For the enhancement in agricultural production, see Zhou 2010, 192204, 276-304; Li 2009; Bray 1984, 130-240. For demographic growth, see Ge 2005, 291-300; von Falkenhausen 2006, 244-288.

17 Lewis 2007, 30.

18 Lewis 1990, 15-52.

19 On the crossbow, see Yates 1994, 120-184; Major and Cook 2017, 151.

20 Kiser and Cai 2003, 522-526.

21 An intriguing demonstration of this social mobility by military merit can be seen in an excavated letter sent from the front by two Qin soldiers shortly before the unification. The soldiers ask if 
logistics of huge infantry armies also offered a suitable model for the large-scale hierarchical organizations that came to be the foundation of the bureaucratizing states. $^{22}$

In general, the old social order was essentially dissolved. The former system of lifelong and hereditary posts and fiefs was largely discontinued in favor of a more flexible, merit-based appointment of officials, who were drawn from a widely extended social and geographic range. ${ }^{23}$ Even though meritorious officials could still earn noble titles and corresponding land allocations, these were different from the former aristocratic fiefs. While being permitted to receive tax income from these territories, their new lords - who often dwelled in the capitals, far away from their lands - were largely bereft of their former rights to administer their populations independently or to raise their own troops from them. ${ }^{24}$

Many of the Warring States rulers were members of a new ruling elite and established themselves as absolute monarchs. All of them started adopting the title of king (wang 王) that had thitherto been reserved for the Zhou sovereigns. ${ }^{25}$ The new monarchs competed with each other in recruiting other states' experts on military and administrative matters, as well as in attracting foreign commoners by tax remissions for new land reclamations. ${ }^{26}$ And rather than relying on the old order of personal loyalties, the rulers increasingly came to rely on impersonal, rationalized means of securing their power: bureaucracy and law.

What marked the situation of the polities of the Warring States period is that they were facing competitors of fairly equal strength. ${ }^{27}$ In order to keep up with their rivals, they needed to continuously intensify their measures of control over their states' economic and human resources. Warring States rulers were thus dedicated to extending both military service and tax liability to the entire population. They successively divided their territories into administrative units under direct control of centrally appointed government officials. A two-tiered system of counties (xian 縣) operating under commanderies (jun 郡) evolved into the basis of both mili-

the ranks they had earned on the battlefield had arrived in their home district, since these would increase their families' prestige and legal status (Yates 2009, 33).

22 Kiser and Cai 2003, 517, 522.

23 Pines (2013b, 185) points out that the extent of social mobility varied considerably from state to state. Furthermore, not all posts were meant to be filled according to solely meritocratic principles. Excavated Qin legal statutes from Shuihudi suggest that education at official schools for scribes was permitted only to those whose fathers had already held a post in this profession. See Shuihudi Qin mu zhujian zhengli xiaozu 1990, 63, trans. Hulsewé 1985, 87-88 (A 101). On these restrictions, see also Yates 2011, 345-50; Ma 2017.

24 Lü 1989.

25 An exception was the southern state of Chu, whose rulers had long held their royal title in order to display their repudiation of Zhou suzerainty (Lewis 1999, 603).

26 Lewis 1999, 601.

27 On this important feature as a factor for intense bureaucratization, also from a comparative perspective, see Rosenstein 2009. 
tary recruitment and civil administration. ${ }^{28}$ Peasants would be granted stipulated amounts of land in exchange for taxes, military service, and conscript labor. ${ }^{29}$ The individual household was made the primary unit of landholding and taxation. It ideally consisted of a nuclear farming household cultivating a small plot of land according to its members' labor capacity, so as to keep the maximum acreage in cultivation. Consequently, the individual household also became the basis of elaborate population registers, the maintenance of which became indispensable for the evolving bureaucratic states. ${ }^{30}$

To enforce state control, however, the states' bureaucratic apparatus had to go far beyond record keeping. They needed to be equipped with the judicial means to regulate and sanction their people's actions. Even though it cannot be stated with certainty that all of the Warring States polities promulgated codes of law, several references in received literature as well as some manuscript finds suggest this. ${ }^{31}$ However, the major proportion of both transmitted and excavated legal sources originates from the state of Qin.

Bureaucratization and the ensuing enlargement of officialdom further contributed to the formation of a whole new social stratum, the so-called 'men of service' (shi 士). Mostly stemming from either low aristocratic or nonaristocratic backgrounds, these men increasingly distinguished themselves by their education instead of their ancestry. They came to play a major role as rulers' (would-be) advisors, some of them traveling from state to state in order to find a lord willing to make use of their strategies. ${ }^{32}$ Eminent posts were often given to officials from the other states, not least to limit the power of local aristocrats. In the state of Qin, for exam-

28 On the development of the junxian administrative system, see Han 1986.

29 How far these grants were connected to a recognition of private landownership is a matter of debate. Sterckx $(2015,218,243-244)$ suggests that the Warring States system of land tenure might have come closest to usufruct or a long-term tenancy. On the connection between land tenure and taxation in the Warring States period, see Zhang 张 2013. On the development toward private landownership during the Qin and Han periods, see Zhang 张 2007.

30 The Shiji first records the application of household registers for the year 375 BCE in the state of Qin (Shiji 6.289, trans. Nienhauser 1994a, 173. Note that the translation gives the wrong year due to a confusion of two Qin rulers' names). That the introduction of population registers was not restricted to Qin is suggested by excavated fragments of legal statutes and administrative documents from the states of Wei and Chu (Shuihudi Qin mu zhujian zhengli xiaozu 1990, 174, trans. Hulsewé 1985, 208-209; Roosevelt Weld 1999, 85-87). The earliest extant household registers date to the period of the Qin Empire and were excavated at the Qianling 遷陵 site in modern Liye 里耶 (Hunan Province). See Sanft 2015. For a concise introduction to the Liye finds in general, see Yates 2012. The finds have been only partly published so far: Hunan sheng wenwu kaogu yanjiusuo 2012 and 2017; Chen 2012.

31 Barbieri-Low and Yates 2015, 76-78. On evidence for the Chu legal system, see Roosevelt Weld 1999, 2003.

32 On the rise of the shi, see Pines 2013b, 165-167; Yü 1987, 26-33; Liu 2004. Regarding the archaeological evidence for the social shifts and the emergence of a new "social middle layer" between the Spring and Autumn and the Warring States periods, see von Falkenhausen 2006, 326-399. 
ple, most of the men holding the highest bureaucratic post of chancellor (chengxiang 丞相) were foreigners. ${ }^{33}$

The most crucial educational skill of any official, from an illustrious shi down to a minor clerk, was his ability to read and write. A significant increase and functional broadening of script use not only enabled the copious production of administrative documents, but also the development of a full-grown manuscript culture. The most famous products of this manuscript culture are some transmitted political-philosophical texts that came to be classified under several so-called 'schools' (jia 家), like the Confucians (rujia 儒家), Mohists (mojia 墨家), Daoists (daojia 道家), and Legalists (fajia 法家), all of whose classical representatives were Warring States men. ${ }^{34}$

Of these intellectual currents, the so-called Legalist school is the one with the most obvious impact on the dawn of empire. The texts that received that label retroactively were far from homogenous. ${ }^{35}$ The family resemblances of these compilations would arguably include the conviction that human beings are predominantly selfish and a stress on the importance of laws and punishments, agriculture, warfare, and effective administration. ${ }^{36}$ Despite its retrospective classification (and often condemnation) as Qin ideology, none of the most famous so-called Legalists had been a Qin native. Neither the notion of the basic ideal associated with Legalism 'enrich the state and strengthen the military' (fuguo qiangbing 富國強兵) - nor concrete measures like the promulgation of laws and the promotion of severe punishments, were thus homemade Qin products. ${ }^{37}$ In fact, they rather mirrored the aforementioned developments that characterized the Warring States period in general.

\section{The Qin Empire, its Demise, and the Rise of the Han}

\section{III.1 The Rise of Qin and the Unification of 'All-under-Heaven'}

Sima Qian 司馬遷 (145 or 135-ca. 87 BCE), Han author of the historiographical work Shiji 史記 (The Scribe’s Records), ironically suggested that Qin must have been 'sup-

33 Kiser and Cai 2003, 528; Bodde 1986, 48; Pines 2013b, 185.

34 These classifications have their own history and contain a considerable amount of anachronism when applied to the Warring States period. See (for instance) Smith and Tan 2003; Csikszentmihalyi and Nylan 2003; Zufferey 2003; Goldin 2011.

35 The most important transmitted works that eventually came to be labeled 'Legalist' are The Book of Lord Shang (Shangjun shu 商君書), Master Han Fei (Han Feizi 韓非子), and Master Guan (Guanzi 管子).

36 For a concise introduction to 'Legalist' ideas and texts, see Pines 2018.

37 The impression left by some transmitted texts of Qin itself being ideologically uniform, i.e., committed to 'Legalist' ideals only, is also misleading (Pines et al. 2014, 28). 
ported by Heaven' (tian suo zhu 天所助) in its tremendous achievement of unifying the former Zhou realm. ${ }^{38}$ Presuming there was a little more to it, some potentially distinguishing features in the history of Qin need to be sketched.

While the origins of the Qin ruling house are still obscure, ${ }^{39}$ the picture gets clearer from the eighth century BCE onward. According to the Shiji, Duke Xiang 襄 of Qin (r. 777-766) had been rewarded by the Zhou for his support during the crisis of 771 with the permission to settle in territories of the former Zhou heartland in the 'area within the passes' and with his recognition as regional lord (zhuhou 諸侯). ${ }^{40}$ From 350 всE, Qin had its capital at Xianyang 咸陽 (near modern Xi’an 西安, Shaanxi Province), on the northern bank of the Wei River. In comparison to other states of the former Zhou realm, Qin institutional reforms came rather late. After Duke Xian 獻 of Qin (r. 384-362 BCE) had imported some reforms from the state of Wei 魏, ${ }^{41}$ the process of transforming Qin into a typical Warring States polity was completed under Duke Xian's son, Duke Xiao 孝 of Qin (r. 361-338 BCE), in the famous reforms of Shang Yang 商鞅 (d. 338 BCE). ${ }^{42}$

Having formerly served in Wei, Shang Yang had come to Qin after Duke Xiao had invited foreign experts to help him strengthen his state. ${ }^{43}$ Under Shang Yang's adaptation of practices already common in other states, the Qin state urged people to divide into households consisting of single nuclear families by increasing capitation taxes on households including several adult males (such as father and sons). ${ }^{44}$ Qin's stress on the encouragement of agriculture and its intentness to keep the maximum acreage in cultivation may reflect its status as a rather sparsely populated frontier state with substantial amounts of undeveloped land at its disposal. ${ }^{45}$

The imposition of a system of merit-based ranks on the whole population appears to have been particularly systematic in Qin. In contrast to the other states, where it was still quite common to award fiefs to members of the ruling family,

38 Shiji 15.685; van Ess 2014b, 48.

39 Pines et al. 2014, 11-13.

40 Shiji 5.179, trans. Nienhauser 1994a, 90.

41 Lord Xian had spent most of his life in exile before returning to Qin in 385 BCE and establishing himself as the first powerful Qin ruler after many decades (Lewis 1999, 602).

42 The main source for Shang Yang and his reforms is Sima Qian's Shiji, especially Shang Yang's biography (Shiji 68.2227-39, trans. Nienhauser 1994b, 87-96) and parts of the annals of the state of Qin (Shiji 5.202-205, trans. Nienhauser 1994a, 108-110). As for the work Shangjun shu attributed to Shang Yang, the reforms promoted therein can at most partly be read as going back to Shang Yang himself (Pines 2017, 31-54; Loewe 1993, 368-370). Pines 2017 and Duyvendak 1928 provide English translations of the Shangjun shu.

43 Shiji 68.2227-2229, trans. Nienhauser 1994b, 87-88.

44 Shiji 68.2230. Some entries in excavated household registers from the archive of Qianling County suggest that after the imperial unification, Qin did not universally succeed in this policy of household division. See Hsing 2014, 158 (K43), 159 (K2/23), 164. But even at Qianling, which at that time belonged to the empire's peripheries, extended households do not appear to have been the norm. 45 Pines et al. 2014, 21-23; Lewis 1999, 613. 
Shang Yang reportedly introduced a rule that made the royal kin's regular service to the state a precondition for earning position and status. ${ }^{46}$ More generally, anyone having gained merit in battle was awarded a certain honorary title within a hierarchy of 17 ranks, for which most males were eligible. Postunification population registers from the Qin archive of Qianling 遷陵 County (modern Liye 里耶, Hunan Province), which had formerly belonged to Chu 楚 territory, suggest that the majority of households were indeed headed by accordingly ranked individuals. ${ }^{47}$ Even though ordinary men would usually not be able to rise higher than the eighth rank, this system did mean a considerable increase of social mobility in which Qin is likely to have exceeded the other states. That it also resulted in a highly effective dismantling of the former hereditary aristocracy is corroborated by excavated documentary evidence. ${ }^{48}$ Ranks would come with the right to cultivate a corresponding amount of land, with a certain number of dwellings, a quota of slaves, and an opportunity to remit penalties. ${ }^{49}$ The division of the entire population into units consisting of five households was now extended in that their members were bound by mutual responsibility and surveillance, as neighbors in times of peace and brothersin-arms in times of war. ${ }^{50}$

Contrary to many transmitted sources depicting the Qin as remote and barbarian, archaeological evidence rather suggests a strong proximity to Zhou culture, whose former territories, after all, they had inherited, and with whom they stayed associated by marital ties and periodic visits. ${ }^{51}$ There was one aspect of material culture, however, that indeed qualifies as a distinctive Qin characteristic: As early as the sixth century BCE, Qin rulers would treat themselves to tombs of enormous dimensions. ${ }^{52}$ This tendency eventually culminated in the First Emperor's gigantic

46 Shiji 68.2230, trans. Nienhauser 1994b, 89-90.

47 See Pines 2013b, 200, n. 93. For the Qianling household registers, see the references in n. 30 above.

48 People’s experiences of social mobility are manifest in 'day books' (rishu 日書) excavated from the Qin site at Shuihudi 睡虎地 (in modern Hubei Province), in which predictions of a child’s future show an incredibly wide range of possibilities (from a slave to a high-ranking minister). See Pines et al. 2014, 25-26; Wu 2000, 291-311.

49 Lewis 2007, 32; Loewe 1960, 97-107; Yates 1999.

50 If one member of a unit committed a crime or deserted at war, the other four were likewise punished. Denouncing a neighbor's crime was rewarded like obtaining enemy heads in battle. (Shiji 68.2230, trans. Nienhauser 1994b, 89). See also Loewe 2010a, 304-305, with according evidence from excavated Qin legal texts.

51 Von Falkenhausen and Shelach 2014, 40-47. Regarding the late Warring States period, however, there is some indication of a tendency toward clearer cultural self-definitions among the individual states, and for Qin adopting a sense of its own otherness (Lewis 2007, 42-46; Pines 2005).

52 In a tomb tentatively attributed to Lord Jing 景 of Qin (r. 576-537), the burial chamber itself covers an area of $60 \times 40 \mathrm{~m}$, and is $24 \mathrm{~m}$ deep. Within the burial chamber, the remains of 166 human victims were found accompanying their lord. A later Qin ruler's tomb, dating to the century preceding the unification, is the largest of all known rulers' tombs of the entire Warring States period (Pines et al. 2014, 17, 29; von Falkenhausen 2006, 328-338, 2004, 120-121). 
mausoleum and its world-famous terracotta warriors. This does not imply that Qin's development toward a ruler-centered state took place earlier than in other states. ${ }^{53}$ Its sovereigns' long tradition of immodest self-conception may yet have facilitated later reforms that aimed at creating a ruler-centered state. ${ }^{54}$

While it is difficult to estimate just how decisive Shang Yang's reforms were for Qin's later success, it appears safe to say that from the time of the reforms in the mid-fourth century onward, Qin started to play a major role in the larger political arena. The following century was a confusing era of 'vertical and horizontal alliances' (hezong lianheng 合縱連横), in which Qin would either coalesce with other states, or other states would join forces against Qin. For Qin, this turned out to be a phase of thorough territorial consolidation. ${ }^{55}$

Qin's geo-strategical position proved to be highly favorable. Its core area in the fertile Wei River valley 'within the passes' was only accessible from the other states of the Zhou realm through the Hangu Pass and the $\mathrm{Wu}$ Pass, and was thus comparably easy to defend. ${ }^{56}$ More generally, states like Qin, located at the margins of the former Zhou realm, had a natural advantage over those states situated in the geographic center. The latter ran the risk of being reduced to mere buffer zones, while the growing states around them used their potential to expand their economic bases into less densely populated, non-Zhou territory. In this regard, Qin's accomplishments were without comparison. In 316 BCE, after 130 years of successive conquest, it finally managed to completely occupy the territories of the formerly rather isolated and culturally remote peoples of Shu 蜀 and $\mathrm{Ba} 巴$ who inhabited the fertile Sichuan Basin. The Qin colonized this area by establishing military settlements and sending tens of thousands of settlers, including many convicts, to exploit its resources. They constructed a new city at Chengdu 成都 and heavily invested in the region's agricultural productivity. Both in the Sichuan Basin as well as in the Wei River valley, the Qin implemented several irrigation and flood control projects. ${ }^{57}$

The conquest of Sichuan was a major step toward Qin's rise to power. Nevertheless, for another 50 years, politics within the former Zhou realm were still dominat-

53 The (admittedly sketchy) evidence of the Shiji suggests that like the other states, Qin suffered a deterioration of the sovereign's position during the fifth century, as well as territorial losses and overall political decline in the early fourth century (Pines et al. 2014, 18).

54 For illustrated overviews of Qin Shi Huangdi's mausoleum and his terracotta warriors, see Khayutina 2013; Portal 2007.

55 For a more detailed account of the era of vertical and horizontal alliances (ca. 350-250 BCE), which will be sketched below, see Lewis 1999, 632-641.

56 This geographic advantage was already identified as a major factor for Qin's success by Sima Qian (Shiji 6.277, trans. Nienhauser 1994a, 164).

57 Two famous projects, both of which are still in use, are the Dujiangyan 都江堰 irrigation system on the Min 岷 River northwest of Chengdu (built 256-251 BCE) and the Zheng Guo canal 鄭國渠 (completed in 246 BCE), which turned the alkaline land northeast of the Qin capital into highly productive fields (Shiji 29.1408, trans. Watson 1993, 2:54-55). See further Sage 1992, chs. 4 and 5 (on Dujiangyan); Major and Cook 2017, 184-186; Pines et al. 2014, 18-19. 
ed by other states, some of which were able to considerably expand their territories during this period. It was not until Qin's defeat of Zhao 趙 forces in the Battle of Changping 長平 in 260 BCE that Qin finally took over the dominant position among the still extant states of the former Zhou realm. ${ }^{58}$

After a phase of military reconsolidation and interior quarrels, Qin was able to bundle its strength under King Zheng 政 of Qin, who ascended the throne in 247 BCE. In 230 всE, King Zheng unleashed Qin's final series of campaigns toward the east. Up to 221 BCE, Qin troops subsequently conquered the territories of all its remaining competitors: the states of Hann 韓, ${ }^{59}$ Zhao, Wei, Chu, Yan 燕, and finally, Qi 齊. The actual conquest of the bulk of the Chinese heartland, including the former Zhou realm's most important demographic and economic centers, had thus taken Qin little more than a decade. What factors enabled this fast conquest remains largely unexplained. ${ }^{60}$

Even before this political unification, Warring States elites had shared a certain sense of belonging to one and the same cultural realm, even though there had been both counter movements and disputes on the question of how far this feeling of cultural togetherness was supposed to precipitate into political realities. According to contemporaneous perception, by all means, the final conquest of Qi made it legitimate for Qin to claim that it had finally "united All-under-Heaven" (bing tianxia 并天下). ${ }^{61}$ King Zheng of Qin marked this watershed event by adopting the composite title Huangdi 皇帝 ('August Thearch'), a semi-divinizing designation that Chinese emperors would retain until the end of the imperial era in the early twentieth century. ${ }^{62}$ By naming himself the 'First August Thearch of Qin' (Qin Shi Huangdi 秦始皇帝), the First Emperor clearly presented himself as the founder of a new era.

58 Lewis 1999, 638-641. On the Battle of Changping, see Shiji 73.2333-2335, trans. Nienhauser 1994b, 169-170. See also Miyake 2018, 125-131.

59 In order to avoid confusion with 'Han' 漢, which is the name of a river and region after which the Han dynasty was eventually named, the transcription 'Hann' is used for this state of the Warring States period.

60 Sørensen has criticized Lewis' remark that after the Battle of Changping, "[a]ll that remained was the destruction between 230 and 221 of the remaining six Warring States" (Lewis 2007, 38). Indeed, "all that remained" meant "regrouping and conquering more or less the known world" (Sørensen 2010, 27). Sørensen suggests that certain detrimental events within the eventually subjugated states (like “crop failures, civil war, epidemics, treachery, natural disasters, nomads looting”) may have played an important role, even if our sources are largely silent on them (Sørensen 2010, 14).

61 For example, Shiji 6.235.

$62 \mathrm{Di}$ had been the highest deity of the Shang, whose last rulers adopted the title for themselves. Several mythical culture-heroes of the Warring States period as well as the four highest Qin deities were called di. During an alliance in the early third century BCE, the rulers of Qi and Qin temporarily declared themselves 'Western' and 'Eastern Di.' Huang ('august,' 'splendid'), was used as an epithet for Heaven, and several mythical culture heroes were designated huang (Lewis 1999, 637; 2007, 52). 


\section{III.2 Fifteen Years of Empire (221-207 BCE)}

We learn from Sima Qian that during the first years after the nominal beginning of the imperial era, the First Emperor initiated a series of reforms that were aimed at consolidating his realm's cultural and political unity. Qin administrative structures were now imposed on the whole empire, which was hence divided into at least 36 (but probably more) commanderies (jun $)^{63}$ that were controlled by centrally installed governors (shou 守). The Shiji further mentions measures like the confiscation of the First Emperor's new subjects' weapons, reforms of rituals and nomenclature, as well as the empire-wide standardization of weights and measures, cart axle widths, and the script. ${ }^{64}$

The transmitted depiction of Qin's successive conquest of 'All-under-Heaven' and the implementation of its unifying reforms across the entire empire sound astoundingly neat. But it largely leaves us in the dark, for instance, about the concrete Qin policies of conquest and annexation, and about the methods (and difficulties) of incorporating members of local elites and officialdom into its administration. According to Sima Qian's retrospective evaluation, the Qin's new subjects accepted their new rulers quite readily. He suggests that after the long period of warfare, the "exhausted and worn out" people were simply "longing to settle down to a peaceful life," so that "everyone gave up his preoccupations to look up to the sovereign." 65

As far as previous research has shown, the abovementioned standardization measures were of varying success. ${ }^{66}$ Some excavated sources have further provided indications of the difficulties the Qin must have had in imposing their will on populations of newly conquered territories. ${ }^{67}$ Despite the fact that the Qin could build on the groundwork of the former states' institutions and interconnections, the imple-

63 Shiji 6.239. The alleged number of commanderies varies in different transmitted sources, and previously unknown names of commanderies have been revealed by excavated documents (Hou 2009).

64 Shiji 6.237-240, trans. Nienhauser 1994a, 136-137.

65 Shiji 6.238, trans. Nienhauser 1994a, 168.

66 For instance, epigraphic evidence suggests that the standardization of the script was a gradual process that started before the Qin and extended far into the Han period (Galambos 2004). Qin's decisive attempts at implementing the standardization of weights and measures can be seen in widespread finds of objects bearing identical imperial inscriptions promulgating the standardization (Sanft 2014, 58-63). Some of the excavated weights themselves, however, do show considerable deviations from the norm ( $\mathrm{Wu}$ 1979). As for the new nomenclature, a wooden board from the Qin archive of Qianling County unearthed at Liye contains a comprehensive list of such changes in official designations (You 2013; Venture 2011).

67 In a text excavated from a Qin official's tomb at Shuihudi (on former Chu territory), we find the complaint that "now the legal codes and decrees are complete, but the people do not use them. Dissipated people controlled by local custom do not cease, which means abandoning the ruler's enlightened laws." See Shuihudi Qin mu zhujian zhengli xiaozu 1990, 13. The translation is taken from Lewis 2007, 43-44, where more similar examples are given. An account in the excavated Book of Submitted Doubtful Cases records the case of an open revolt in the southern commandery of 
mentation of bureaucratic centralization on the geographic scale of the Qin Empire must yet have been an enormous challenge. The newly excavated administrative documents from the Qianling County archive (Liye), while also indicating certain problems, generally suggest that Qin efforts and achievements toward this goal were quite impressive. Many of the documents show an "amazing degree of state activism" and more concretely testify, among other things, to an impressively successful implementation of mandatory household registration even in an area quite distant from the Qin homeland. ${ }^{68}$

Qin Shi Huangdi's rule as emperor lasted little more than a decade. According to his annals in the Shiji, his imperial undertakings included the forced resettlement of 120,000 powerful and wealthy households to the capital, his empire's expansion toward the north, including the Ordos Loop, as well as toward the far south, into the areas that now constitute Guangdong Province and Guangxi Autonomous Region, and northern Vietnam. He undertook several inspection tours across his empire and a considerable number of large building projects comprising palaces, roads (including the 'Direct Road,' Zhidao 直道, running from the capital area to the northern border), walls (including parts of the so-called 'Great Wall,' Changcheng 長城), ${ }^{69}$ and his own mausoleum. He further performed new sacrificial rites and conducted several commissions to find immortality drugs. ${ }^{70}$ In 210 BCE, the emperor died unexpectedly on one of his eastern imperial inspection tours. The official and alleged eunuch Zhao Gao 趙高 (d. 207 BCE) and the late emperor's son Huhai 胡亥 (230207 BCE) reportedly conspired to expel the designated heir and invested Huhai instead, who came to the throne as the Second of Qin (Qin Ershi 秦二世). ${ }^{71}$

The Second Emperor's annals ${ }^{72}$ make him look like a complete failure. After putting Zhao Gao in charge of the affairs of state, he reportedly confined himself to undertaking some desperate attempts at imitating his father's display of power, and condemning huge numbers of officials and nobles to death. ${ }^{73}$ During the first year of his reign (209 BCE), a revolt erupted in the east at Dazexiang 大澤鄉 (in the north of modern Anhui Province). It was initiated by Chen Sheng 陳勝 (also known as

Cangwu 篬梧 (also on former Chu territory) shortly after the unification in 221 BCE (Barbieri-Low and Yates 2015, 1332-1358).

68 Pines et al. 2014, 22-23, 28.

69 On the Direct Road and the problems concerning the integration of corresponding historiographical and archaeological evidence, see Sanft 2011. On the archaeology of the Great Wall and the stages of its construction, see Xu 2001.

70 Shiji 6.239-263, trans. Nienhauser 1994a, 137-154.

71 Shiji 6.264-265, trans. Nienhauser 1994a, 154-155.

72 Sima Qian integrated the account of the Second Emperor's rule into the chapter devoted to Qin Shi Huangdi (Shiji 6.266-274, trans. Nienhauser 1994a, 155-162).

73 Sanft $(2018,156)$ suggests that this may have resulted in a fatal loss of both practical expertise and prestige for the Qin ruling house. 
Chen She 涉, d. 208 BCE), originally a peasant laborer from the former Chu state. ${ }^{74}$ The revolts soon spread like wildfire and culminated in the successive reestablishment of Qin's former rival states as kingdoms, whose new lords were partly members of the old (i.e., Warring States) ruling houses. In 207 BCE, Zhao Gao forced the Second Emperor to commit suicide and enthroned the latter's nephew Ziying 子嬰 as king (no more emperor) of Qin. This king's rule came to an end after only fortysix days, however, when Liu Bang 劉邦 (256-195 BCE), a general under the newly reestablished kingdom of $\mathrm{Chu}$, inflicted a decisive defeat on the Qin army and entered the 'area within the passes.' The king of Qin surrendered and was killed in 206 BCE by Xiang Yu 項羽 (232-202 BCE), supreme general (shang jiangjun 上將軍) of $\mathrm{Chu}$, who on his arrival in the former imperial capital divided the territory of the Qin heartland among three former Qin generals. In a breath, and less than fifteen years after the unification, China's first imperial dynasty was history. ${ }^{75}$

The reasons for the Qin Empire's early demise have been debated at least as vigorously as the reasons behind and the extent of Qin's success. Most modern explanations of Qin's decline have echoed earlier assessments provided by Han authors like Sima Qian and Jia Yi 賈誼, (ca. 200-169 BCE). ${ }^{76}$ One of the most prominent explanations claims that the Qin failed to understand that "there is a difference between conquering and retaining” 攻守之勢異也. ${ }^{77}$ Based on Sima Qian's and Jia Yi's depictions, individual people's personal failures have also been suggested as the reason behind Qin's fall. ${ }^{78}$ Others would lift the argument to a more systemic level, blaming the coldheartedness of Qin's 'Legalist' institutional system, with its

74 Sima Qian devoted a whole chapter to Chen Sheng (Shiji 48.1949-1965, trans. Watson 1993, 1:113). In 209 вCE, Chen Sheng acted as a section chief of a group of conscripts whom he convinced to start a rebellion. On Chen Sheng, and for a refutation of the common interpretation of his rebellion as an outgrowth of the Qin regime's allegedly excessive mobilization of manpower, see Dull 1983.

75 Sima Qian integrated the account of the events that culminated in the Qin dynasty's downfall into the annals chapter devoted to Qin Shi Huangdi (Shiji 6.266-275, trans. Nienhauser 1994a, 155163). For a summary see Sanft 2018, 156-159.

76 Toward the end of the part of Shiji 6 that is devoted to Qin Shi Huangdi (Shiji 6.276-284, trans. Nienhauser 1994a, 163-169), Sima Qian cites Jia Yi’s famous essay Guo Qin lun 過秦論 (“On Faulting Qin” or "On Surpassing Qin”). For a summary of some of the traditional as well as some Marxist explanations for Qin's demise, see Bodde 1986, 85-90.

77 Shiji 6.282 (cf. Hanshu 31.1825), trans. Nienhauser 1994a, 168 (providing a divergent translation of the cited phrase, obviously misinterpreting the common collocation “XY之勢異," which always contrasts two opposing circumstances, $\mathrm{X}$ and $\mathrm{Y}$ ). For a recent version of the aforementioned theory, see Lewis 2007, 50.

78 Bodde 1986, 85-86. Many aspects of the First Emperor's alleged personality and way of ruling as depicted in Shiji 6 mirror Sima Qian's description of his own ruler, Emperor Wu of Han, in a striking way. Sima Qian's depiction of the First Emperor's mercilessness, hubris, superstition, and quest for immortality may thus be a partly fictitious backward projection of the historian's critical perception of Emperor Wu. On this matter, see van Ess 2014a. 
severe laws, brutal punishments, and (supposedly) high tax rates, ${ }^{79}$ as it made the population amenable to revolts and kept loyal subjects from truthfully informing their ruler of perilous disturbances. ${ }^{80}$ A recent theory suggests that it was Qin's exploitation of convict and conscript labor in particular that brought about Qin's downfall by creating an unbearable economic pressure on its peasant population. ${ }^{81}$ Others, however, would claim that the main reason for Qin's demise was not systemic but cultural, in that many people in the conquered territories desired to maintain their old identities rather than being absorbed by Qin customs. ${ }^{82}$ Contrary to some positions that criticize the Qin for an alleged overemphasis of military means, Jia Yi and Sima Qian further suggested that the Qin were in fact too careless, and their military insufficiently equipped for the potential threat of rebellion. ${ }^{83}$ In relation to this, they also claimed that one of the Qin's key mistakes was its failure to permit a sufficient number of enfeoffments, because rulers who "possessed [their empire] all by themselves” (gudu er you zhi 孤獨而有之) lacked reliable support in a case of emergency. ${ }^{84}$

While a combination of some of the suggested factors might well have played a role, one has to keep in mind that they are largely based on the information provided by Han officials, who were first and foremost interested in criticizing what they thought were the political mistakes of their own times, and who were using (and possibly manipulating) the case of Qin for constructing a suitable deterrent example. ${ }^{85}$ It is further conceivable that crucial parts of the picture completely evade us simply because we miss corresponding indications in our available sources. ${ }^{86}$ From a very different perspective, but maybe even more importantly, one might also argue that in the end, it was but the Qin ruling house that demised, whereas the empire with its imperial structures and institutions largely endured under the soon-to-follow Han dynasty.

79 Qin tax rates remain largely uncertain. An unlikely high tax rate of "much more than a half" or “two-thirds" (tai ban 泰半/太半) is mentioned in the Hanshu and already in the Huainanzi 淮南子 (Hanshu 24A.1126; Swann 1950, 147; Huainanzi jishi 15.1062). It has, however, long been suggested that this figure might represent a typical case of "anti-Qin propaganda" (Dull 1983, 191-193).

80 Shiji 6.278, trans. Nienhauser 1994a, 164-165 (Sima Qian citing Jia Yi).

81 Shelach 2014. The theory that the Qin conscription system led to the dynasty's downfall has, in contrast, been strongly refuted by Dull 1983.

82 This has been stressed by Dull 1983, 316-317, among others. Loewe 1986b, 110 also considers it a potential factor.

83 See Shiji 6.276, trans. Nienhauser 1994a, 163-164. See also Dull 1983, 299.

84 Shiji 6.283 (Sima Qian citing Jia Yi). The argument on the lack of enfeoffments has also been taken up by Loewe 1986b, 111.

85 For the potential manipulation of Qin history during Han times, see also $\mathrm{n} .78$ above.

86 Recent scholarship paints a more sophisticated picture of the Qin. See, for instance, Sanft 2014, who stresses the cooperative aspects of Qin governance, i.e., its means to encourage people's compliance. 


\section{III.3 Struggle for succession (206-202 BCE)}

During the confusing years of fighting between the fall of Qin and the unification under China's second empire, Xiang Yu and Liu Bang emerged as the protagonists. ${ }^{87}$ Xiang Yu hailed from a noble family whose members had long served the armies of the former kingdom of Chu. After inflicting some serious defeats on Qin troops, Xiang Yu soon became the most prominent military leader. In 206 BCE, he promoted himself to the leader of a confederacy of 18 kingdoms that came into being by a division of the former states. He declared himself Hegemon King of Western Chu ( $\mathrm{X}$ Chu ba wang 西楚霸王) and had the Chu king put to death. ${ }^{88}$

In comparison to Xiang Yu, Liu Bang was of humble origin. As an adult, he came to serve as a local police officer near his home village in the county of Pei 沛 (in the northeast of later $\mathrm{Yu}$ 豫 Region, in the northwest of modern Jiangsu Province). Sima Qian would make fun of Liu Bang's humble background and bad manners, contrasting him with the rulers of old - including the Qin - who had accumulated 'virtue' or 'charisma' (de 徳) over generations and centuries. ${ }^{89}$ Liu Bang started off his military career by taking control of a group of convicts whom he had been ordered to lead to work on Qin Shi Huangdi's mausoleum. ${ }^{90}$ He came to be one of Xiang Yu's confederates, and in 206 BCE, he successfully conquered the Qin capital under Chu command. Xiang Yu apportioned the territory of the Han 漢 River Basin to him, Hanzhong 漢中, located south of the 'area within the passes.' Liu Bang, now 'King of Han' 漢王, soon broke with Xiang Yu and seized the 'area within the passes' in 205 вCE. Liu Bang and his confederates finally defeated Xiang Yu in 202 всE. Xiang Yu committed suicide, and Liu Bang accepted the title 'August Thearch' (Huangdi). ${ }^{91}$ His choice of Qin nomenclature may be taken as a sign of his ambition to step into the footsteps of the First Emperor and adhere to the latter's political vision of a centralized empire.

The new empire's capital city, Chang'an 長安 ('Lasting Peace'), was built just across the Wei River to the south of the former Qin capital. More generally, the Han Empire was largely built on the institutional foundations that the Qin Empire had created. Other than a few decades later when the picture of the evil Qin gained

87 For a detailed account of the interimperial period of fighting, see Loewe 1986b, 110-119. For according primary sources, see the following footnotes.

88 Sima Qian devoted an annals chapter to Xiang Yu (Shiji 7.295-337, trans. Nienhauser 1994a, 179210). On Xiang Yu's family background and the events mentioned above, see Shiji 7.295-320, trans. Nienhauser 1994a, 179-197.

89 On this point, see van Ess 2014b, 47-58.

90 The annals chapter following that of Xiang Yu is devoted to Liu Bang. For Liu Bang's family background and early years, as reported by Sima Qian, see Shiji 8.341-348, trans. Nienhauser 2002, 1-18.

91 For the events from 209 вCE to Xiang Yu's defeat and Liu Bang's promotion as emperor, see the extensive narrative in Shiji 8.349-379, trans. Nienhauser 2002, 18-65. 
ground, early Han protagonists appear to have found Qin's demise quite incomprehensible, if not undeserved. ${ }^{92}$ Yet in opposition to the short-lived and often condemned Qin Empire, the Han Empire came to be one of the most long-lasting and idealized empires within China's entire history. ${ }^{93}$

Before proceeding to the characteristic features and institutions that defined the early Chinese empires, the common division of the Han period, along with a couple of Han emperors associated with some watershed events of the dynasty's history, will be introduced in order to provide a simplified chronological framework of the 400 years of Han rule.

\section{III.4 Chronological Framework of the Han Period}

\section{III.4.1 The ‘Former Han’ 前漢 or 'Western Han’ 西漢 Period (202 BCE-9 CE)}

Liu Bang, often referred to by his temple name Gaozu 高祖 (r. 206 BCE-195 BCE) was the founder of the Former Han dynasty. After his death, his widow, Empress Lü 呂 (Lü Zhi 呂雉), controlled the Han court more or less officially between 195 and 180 BCE. Her rule, together with the reigns of the succeeding Emperors Wen 文 (r. 180-157) and Jing 景 (r. 157-141 BCE) is known as the consolidating phase of the dynasty, characterized by a so-called 'laissez-faire' approach to both domestic and foreign policies.

Emperor $\mathrm{Wu}$ 武 (Liu Che 劉徹, r. 141-87 BCE) ranks among the most famous Chinese emperors of all time. His long rule marked a break with the 'liberal' policies of his predecessors, putting a strong focus on both centralization measures and expansion. Among others, both the introduction of the 'Five Classics' (wu jing 五經) as an educational foundation for high-ranking state officials and the empire's expansion toward Central Asia fall under his rule. Several of his centralizing measures were gradually retracted by his successors, while others were retained even during the Later Han period.

\section{III.4.2 Wang Mang's 王䒭 Xin 新 Dynasty (9-23 CE)}

Wang Mang was originally a Western Han official whose family members had occupied central positions of the state for several decades, before Wang Mang eventually

92 On the latter point, see Dull 1983, esp. 304.

93 Many later dynasties regarded the Han as an exemplary model. Furthermore, it is on grounds of the ancient dynasty's name that the majority of today's Chinese still speak of themselves as belonging to the ethnic group of Han (and are also officially identified as such by the state). Furthermore, the Chinese language is called 'Han language' (Hanyu 漢語). 
seized the throne in $9 \mathrm{CE}$. As emperor of the Xin dynasty, he initiated a couple of profound socio-economic reforms. A fatal combination of peasant revolts and natural calamities contributed to his dynasty's rapid downfall.

\section{III.4.3 The ‘Later Han’ 後漢 or 'Eastern Han’ 東漢 Period (25-220 CE)}

As a rather remote descendant of the Former Han ruling house, Emperor Guangwu 光武 (Liu Xiu 劉秀, r. 25-57 CE) managed to reestablish the Han dynasty in 25 CE. The Han capital was moved from Chang'an eastward to Luoyang 洛陽, outside the former capital area 'within the passes.' ${ }^{4}$ The latter half of the Han period is therefore called the Later Han or Eastern Han period. No Later Han emperor attempted to initiate centralizing efforts with the scope of Emperor Wu's ambitions. Nevertheless, the first decades of the Later Han period are usually interpreted as a phase of economic prosperity and stability. But more generally, the Later Han period is associated with a growing power of local elites, decentralization of economic resources, and gradual weakening of the central government's military authority.

When the last official Han ruler, Emperor Xian 獻 (Liu Xie 劉協, r. 189-220 CE), ascended the throne as a nine-year-old, the Han had already largely forfeited their power, especially after the Yellow Turban Rebellion (Huangin zhi luan 黄巾之乱) had broken out in $184 \mathrm{CE}$. In order to suppress the rebellion, the Han needed to concede considerable self-governing powers to military leaders and local administrators, who eventually evolved into competing warlords. Emperor Xian finally abdicated the throne in favor of Cao Pi 曹丕 (187-226 CE), who came to be the first emperor of the Wei 魏 dynasty (220-265 CE). This event marks the beginning of an era of disunion, during which the northern part of the former empire (including Guanzhong and the North China Plain) eventually came under alternating non-Chinese (i.e., Xiongnu, Qiang, and Xianbei-Tuoba) rule. The period was characterized, among others, by the spread of Buddhism and large-scale southward migration. The Chinese heartland would not be united again until the beginning of the short-lived Sui 随 dynasty (581-618 CE), followed by the long-lived Tang 唐 dynasty (618-907). ${ }^{95}$

94 Several factors may have contributed to the decision for an eastward move. First of all, Emperor Guangwu had restored the dynasty with the help of wealthy landholders whose estates were based in the east. Furthermore, its proximity to the agriculturally productive areas in the empire's east also made Luoyang easier to supply than Chang'an (Lewis 2015, 296).

95 For detailed chronological accounts of the Former Han, Xin, and Later Han periods, see the following four contributions to the Cambridge History of China. Vol 1: Loewe 1986b; Bielenstein 1986; Loewe 1986a; Beck 1986; as well as De Crespigny 2016. 


\section{Imperial institutions}

\section{IV.1 Administrative Structures and Bureaucratic Hierarchies}

Generally speaking, despite particular phases of further expansion, Han emperors were less preoccupied with enlarging their territory than with administering it. As pointed out above, the process of intensive bureaucratization in ancient China had already started during the Warring States period. Long-term bureaucratic experiences collected in individual states could thus be extended to an imperial scale. The question has been raised if the early imperial Chinese administration was "organized in a more systematic and intensive manner" than any other ancient regime before the Byzantine Empire. ${ }^{96}$ But it has also been suggested that the Han system of recruiting officials may be viewed "as a prime example of what [Max] Weber referred to as inefficiency," 97 and that administration in early imperial China was in fact quite similar to that of other ancient empires in being built on a "lean bureaucracy" massively depending on the active collaboration of rural elites. ${ }^{98}$ Comparisons like these are, of course, difficult. Apart from the more general challenge of defining 'bureaucracy' and degrees of its 'efficiency,' the availability of quantifiable data varies considerably from empire to empire. And their interpretation also depends on whether and to what extent comparisons across centuries - like the juxtaposition of Former Han dynasty figures with those of the Later Roman Empire - are considered valid.

While we therefore need to be careful not to rush to general conclusions concerning its efficiency and its relation to local elites, it is safe to say that Han centralized administrative structures exceeded, for instance, the Roman Empire in terms of its penetration to lower administrative levels and the total number of civilian officials. In his Documents of the Han (Hanshu 漢書), the historian Ban $\mathrm{Gu}$ 班固 (32$92 \mathrm{CE}$ ) gives the figure of 130,285 for the entire number of Han officials in 5 BCE. ${ }^{99}$ It contrasts with an estimated 30,000-35,000 civilian officials employed by the Roman state as late as $400 \mathrm{CE}$ (at a time when the Han Empire had long broken apart) with the estimates for earlier periods of the Roman Empire being much lower. ${ }^{100}$ If, however, one were to count in the administrative staff of Roman agents like city administrators, to whom the Roman government left the bulk of the administrative groundwork, these numerical differences would probably be much less dramatic. ${ }^{101}$

96 Loewe 2006, 17. Kiser and Cai 2003, 535, even suggest that the level of bureaucratization in early imperial China remained unchallenged until the late seventeenth century.

97 Xie and Brown 2015, 76.

98 Bang 2009, 108-109. I will come back to these questions in sec. IV.1.4 below.

99 Some Hanshu editions give 130,285, while others (including the Zhonghua shuju edition: Hanshu 19A.743) give 120,285. Scholars usually accept the former figure as correct (Bielenstein 1980, 156, with n. 1 on 205-206). For the Later Han period, a slightly higher estimate (about 153,000) exists for the total number of officials (Loewe 2004, 71).

100 Kelly 2004, 111.

101 Eich 2015, 148. 
Of the total number of Han officials, an estimated 31,000 belonged to the central government in the capital, while about 99,000 officials were either deployed on commandery $(4,000)$ and county $(85,000)$ levels, or in the state's salt and iron agencies (10,000). ${ }^{102}$ All of them received state salaries, the top 16 grades of which were expressed in terms of 'bushels' (shi 石) of grain, but were paid out half in coin and half in unhusked grain. ${ }^{103}$ The leading officials on commandery and county level were centrally appointed and barred by imperial law from serving in their home jurisdictions.

No matter how much value we want to attach to these facts and figures, it is certainly true that the ideal of civil service with its belief in bureaucratic hierarchies and procedures came to be a marked feature of China's socio-political and intellectual tradition during the early imperial period. ${ }^{104}$ It was less the ideals like manliness, freedom, or friendship that this tradition would uphold, ${ }^{105}$ but those of incorruptibility, propriety, and allegiance. If we were to identify the Chinese equivalent to the Roman obsession with the military and its mark on Roman imperial culture, it would have to be the early Chinese empires' obsession with bureaucracy and hierarchy.

\section{IV.1.1 The Structure of the Central Government}

At least in theory, the emperor stood above all bureaucracy. The degree of involvement in directing government policies, however, varied considerably between individual emperors. ${ }^{106}$ The emperor's choices would not rest only on their own judgment, of course, but on the (persuasive or browbeating) influence of imperial relatives, officials, and eunuchs. This is also true for his appointments to senior posts of the central government, the highest levels of which included an executive council, traditionally referred to as the 'Three Excellencies' (San Gong 三公), and the 'Nine Ministers' (Jiu Qing 九卿), all of which the Han dynasty adopted from their Qin predecessors. ${ }^{107}$

102 Loewe 2004, 69-71.

103 The highest official posts were graded at 2,000 bushels, with a further top grade of 10,000 bushels added in 8 BCE. On Han officials' salaries and extant salary lists, see Bielenstein 1980, ch. 5; Barbieri-Low and Yates 2015, 951-1083.

104 Loewe 2006, 35-36.

105 On the role of these ideals in ancient Roman society, see Weaverdyck, ch. 7, sec. II and IV.1.1, this volume.

106 Loewe 2004, ch. 18.

107 The numbers in these traditional designations were not necessarily an indication of the actual number of posts occupied. Very often, only two of the 'Three Excellencies' posts were filled, and there were commonly more than nine ministers. Hanshu (chs. 19A and 19B) and Hou Hanshu (chs. 24 to 28) provide comprehensive lists of bureaucratic posts, salaries, and responsibilities. 
The members of the executive council, in addition to their counseling function, were also entitled to formulate and execute policies. ${ }^{108}$ During the Qin and Former Han periods, the chancellor (chengxiang 丞相) ${ }^{109}$ occupied the most exalted position. ${ }^{110}$ He was officially responsible only to the emperor and entitled to command the entire bureaucracy in the emperor's absence. The power attached to this post, however, diminished considerably during the Later Han period. ${ }^{111}$ The second of the three positions, the imperial counselor (yushi dafu 御史大夫), ${ }^{112}$ served as a deputy for the chancellor and as head of the Censorate (Yushi tai 御史臺), which was meant to maintain disciplinary surveillance over the officialdom. ${ }^{113}$ The third post, the supreme commander (taiwei 太尉), formally represented the highest level of military authority under the emperor, but was not filled on a regular basis. During some periods, regents (designated 'marshal of state,' da sima 大司馬, or 'general-in-chief,' da jiangjun 大將軍) would either replace the post of supreme commander or be appointed separately. The power of a regent, who typically was a close relative of the empress dowager acting on behalf of a child emperor, often came to exceed that of the regular members of the executive council. ${ }^{114}$ The dynastic histories do not leave an impression of a clear-cut division of responsibilities between these senior posts. De facto power hierarchies, both within the executive council and between its members and other offices, also varied immensely over time. ${ }^{115}$

The Nine Ministers each headed a specific governmental department responsible for either ceremonial, administrative, or military matters. Some of the departments' responsibilities mainly concerned the spheres of the palace. Other departments were more deeply connected to the administration of the wider empire, like the legal department headed by the superintendent for trials (tingwei 廷尉) ${ }^{116}$ or the department headed by the superintendent for agriculture ( $d a$ sinong 大司農), with its responsibility for the empire-wide collection of the poll tax and land tax. One example for a highly complex department is that of Lesser Treasury (Shaofu 少府), whose formal responsibilities included the provisions of the imperial palaces and the taxation on lakes and pools, but which was also superordinate to the powerful

108 Giele 2006, 49.

109 Replaced in the Later Han period by the grand minister of the masses ( $d a$ situ 大司徒). In the following, I have largely used the translations of official titles and offices provided by Loewe 2000. For a list of selected posts and their different translations, see Barbieri-Low and Yates 2015, xxiii-1. 110 Formally, the post of grand tutor (taifu 太傅) stood above the level of the executive council. He was officially responsible for the moral guidance of the emperor, but was not regularly appointed (Bielenstein 1980, 5-7).

111 Giele 2006, 50.

112 Replaced in the Later Han period by the title da sikong 大司空.

113 On the post of yushi dafu, see Loewe 2004, 155-175; Giele 2006, 51-52; 62-63.

114 For a summary of the complex history of these posts, see Giele 2006, 53-55.

115 See the examples given by Loewe 2006, 20-22.

116 On which see below, sec. IV.3.2. 
institution of the Imperial Secretariat (Shangshu 尚書). Being in charge of virtually all the documents that passed from and to the throne, the Secretariat's leader was empowered to suppress proposals or reports that he did not want the emperor to know of. Especially during some phases of the Later Han period, this formally subordinate office appears to have been more powerful than those of the Three Excellencies. ${ }^{117}$

\section{IV.1.2 The Structure of Local Administration}

At the beginning of the Han dynasty, Liu Bang had to adopt a less centralist approach to administration than his Qin predecessor. While dividing the western half of his empire into administrative units after the Qin model, he conceded that the eastern (and more populous) half of his empire were to be ruled by his most important followers in the form of relatively independent kingdoms (wangguo 王國). ${ }^{118}$ After only six years, however, nine of the ten kings had been replaced by the emperor's own sons or brothers. ${ }^{119}$ In the long run, and as a response to a seditious Rebellion of the Seven Kingdoms (Qi guo zhi luan 七國之亂) in 154 BCE, the power of the kingdoms was massively curtailed as they were either split up into much smaller territories or terminated altogether. ${ }^{120}$ Even at the initial stage, the central imperial government had appointed the two highest officials within each kingdom. From 145 BCE on, it also assumed the responsibility to appoint other senior officials of the kingdoms, and under Emperor $\mathrm{Wu}$, even a considerable part of the lower officials. After 145 BCE, the kings were also deprived of their former right to raise taxes independently. From then on, they appear to have been permitted to retain only part of the tax so as to meet their living expenses. ${ }^{121}$

Han commanderies, just like their Qin predecessors, were administered by centrally appointed governors (shou 守, from 148 BCE taishou 太守), who enjoyed the same salary grade as the Nine Ministers (2,000 bushels) and good prospects for advancement to senior offices in the capital. Yet central control over the commanderies, whose number leveled off at around one hundred, varied to a large extent. ${ }^{122}$ The governors of some newly established frontier commanderies, whose external boundaries were not necessarily clear, might find themselves rather isolated when

117 Giele 2006, 64-66.

118 These followers had largely already established themselves as the de facto rulers of the lands before Liu Bang officially made them kings. For detailed information on Former Han kingdoms, see Loewe 2004, ch. 11.

119 Loewe 2010a, 306.

120 Loewe 1986b, 141-149; 2004, 360, 370, with the maps on 358 and 359.

121 On the cutback of the kings' rights and power, see Loewe 2004, 361-382.

122 Map 3 shows not the commanderies but the 'regions' (zhou, see below) under each of which several commanderies and kingdoms were subsumed. 
heading about fifty thousand inhabitants of partly alien culture and language. They had to do without the well-established infrastructure that enabled the enforcement of intensive government in the more central commanderies, whose registered populations could comprise 2.5 million people. ${ }^{123}$ The governor's main responsibilities included the maintenance of law and order, control over household registration for the purposes of taxation and of conscript and military service, and the recommendation of future officials. Equally ranked were the commanderies' commandants (wei 尉 or duwei 都尉), whose responsibilities included military defense and the use of conscript servicemen. Frontier commanderies, where military action was of particular significance, were at times administered by commandants instead of governors. ${ }^{124}$

In 106 BCE under Emperor Wu, the post of regional inspector (cishi 刺使) was created for controlling the administration of the commanderies and kingdoms. Every year, a cishi would tour several commanderies and kingdoms subsumed under a certain 'region' ( $\mathrm{zhou}$ 州), ${ }^{125}$ with the task of inspecting the conditions of prisoners and conscript servicemen, assessing officials' performances, and looking out for cases of corruption, bribery, or oppression by powerful local clans (see map 3 for the regions). ${ }^{126}$ The responsibilities and power attached to this office changed considerably during the Later Han, however, when the cishi (eventually renamed as 'sheperds,' $m u$ 牧) evolved into the supreme local administrators and were equipped with considerable military authority. Originally a part of the central administration, the cishi were made an organ of local government in $35 \mathrm{CE}$. With their subordinate staff now being locally recruited, they became increasingly intertwined with powerful local families, a development that thwarted the very idea behind the original cishi institution. ${ }^{127}$ These changes mirrored a general trend of administrative decentralization to the benefit of increasingly influential local magnates, whose power networks, number of dependent farmers, and size of estates grew considerably during this period. ${ }^{128}$

The commanderies and kingdoms were further divided into smaller units called 'counties' (xian 縣) and 'marquisates' (houguo 侯國), ${ }^{129}$ both of which were further

123 Loewe 2006, 38-40.

124 Loewe 2006, 41; Lewis 2000, 37, n. 15.

125 Sometimes also translated as 'province.'

126 Later, in 89 вCE, Emperor Wu also created a new supervisory institution for the central government, the post of the commissioner of the Metropolitan Region (Sili xiaowei 司隸校尉), who was entitled to routinely check up on the conduct of officials in the Metropolitan Region.

127 Crowell 1984, 561.

128 On the growing economic and political power of local magnates during the Later Han period, see Ebrey 1986.

129 There were two other, less frequent units on the county/marquisate level called estates ( $y i$ 邑) and marches (dao 道). Estates were lands providing an income for female members of the imperial clan, and marches were small areas partly inhabited by non-Han people (Hanshu 19A.742). 


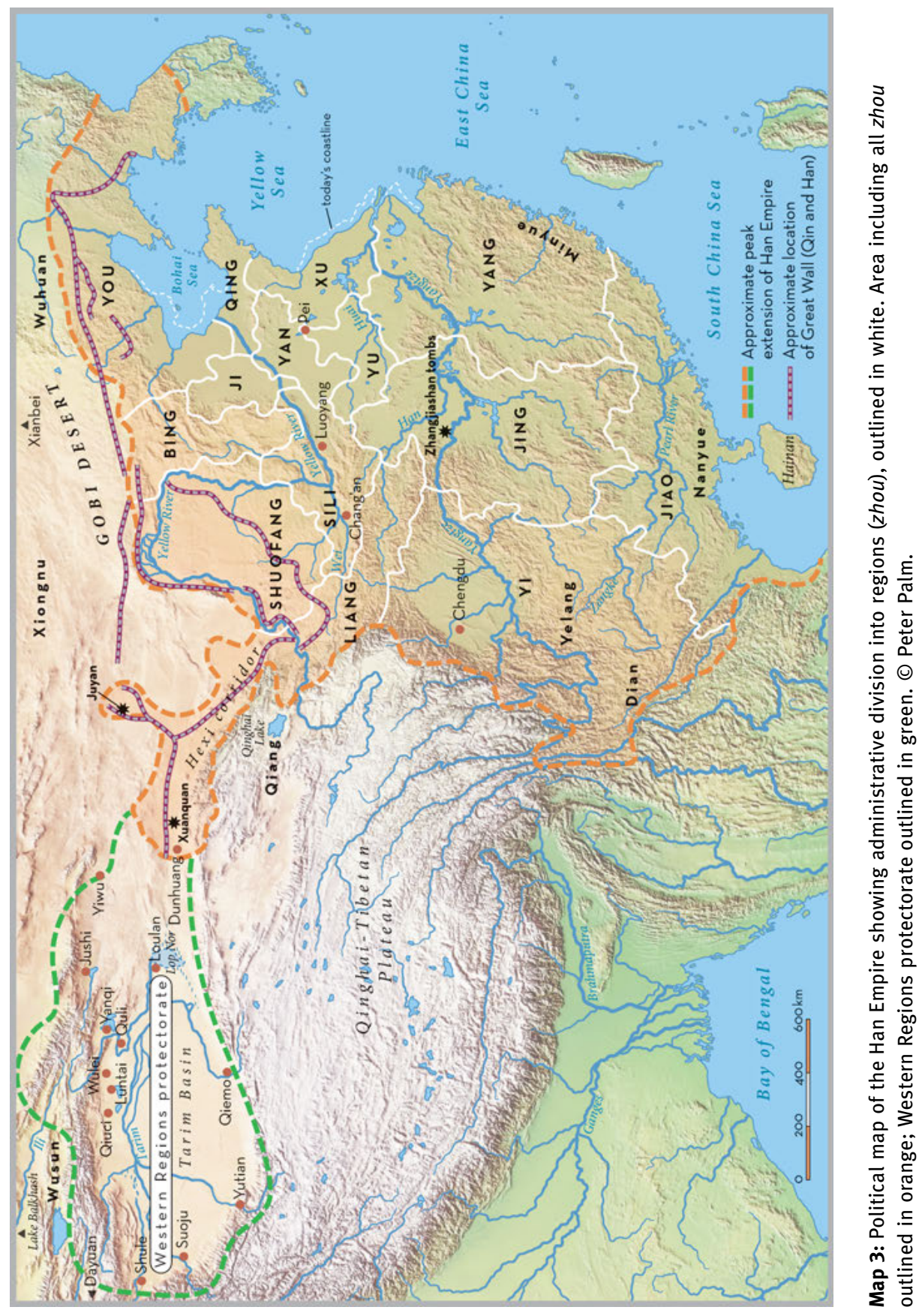




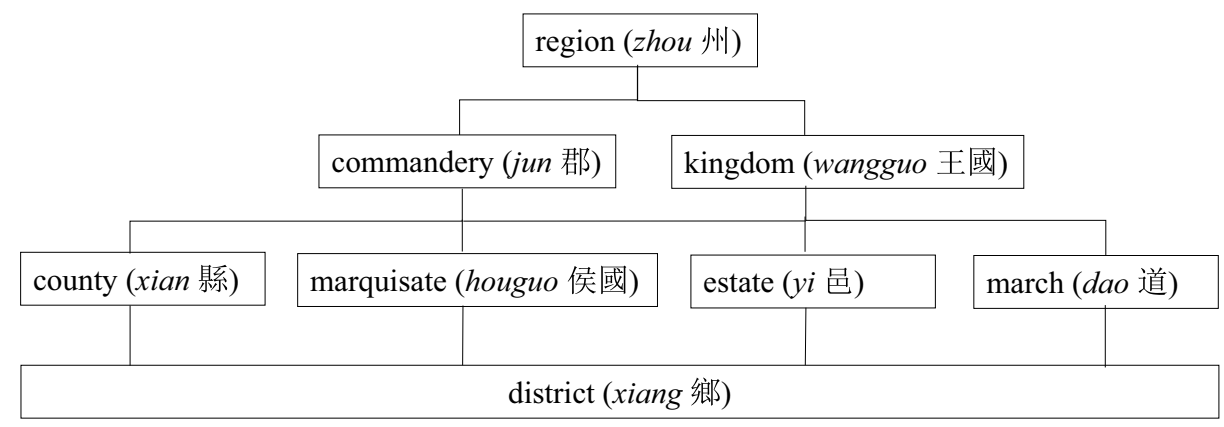

Fig. 1: Structure of higher level administrative units of the Han Empire.

subdivided into 'districts' (xiang 鄉). Counties typically consisted of a town and its surrounding rural area (see fig. 1 for the administrative structure). They were administered by 'magistrates' (ling 令 or zhang 長), who formed the lowest level of officials appointed by the central government. ${ }^{130}$ They were expected to suppress banditry and robbery by patrolling and policing the land, collect the poll and land tax, and render accounts to the commandery, and had considerable legal responsibilities (see section IV.3 below).

Marquisates were usually granted either on a hereditary basis to kings' younger sons, as a reward for merit, or as a mark of favor. ${ }^{131}$ They could be created or closed with comparative ease by the central government and were often short-lived. Their number varied widely, and only few of the Former Han marquisates survived into the Later Han period. Provided with a staff whose titles corresponded to those of county officials, marquises were expected to maintain law and order within their locality and acted as tax collectors for the central government, with the privilege of retaining 200 cash per household for their own use. ${ }^{132}$ Their importance with regard to administrative purposes declined as the number of trained officials grew. The size of marquisates varied from a few hundred households to almost 20,000 households in exceptional cases. Some marquises' incomes may thus have been comparable to the salaries of high-ranking government officials. ${ }^{133}$ From the perspective of the central government, the creation of marquisates could be used as an instrument to satisfy the ambitions of kings' sons, to reduce the power of kings (for instance, by establishing marquisates within existing kingdoms), as a first step to imposing an

130 Ling 令 was the title used for the magistrates of counties with more than 10,000 households, while zhang 長 was used in the case of counties with less than 10,000 households.

131 The Hanshu contains several tables listing a total of 788 Former Han marquisates, 406 of which were granted to kings' sons, 280 for merit, and 102 by favoritism. See the overview in Loewe 2004, 290.

132 Shiji 129.3272, trans. Watson 1993, 2:447-448.

133 Loewe 2004, 286-287. 
administration in newly conquered territories during periods of expansion, and as an appeasement strategy by granting them to leaders of non-Han peoples. ${ }^{134}$

\section{IV.1.3 Honorary Titles}

The Han inherited the Qin's system of honorary ranks (jue 爵) and adapted it to the more civil-based conditions of the unified empire. Holders of the now twenty ranks, which were granted on the basis of a person's military or civil merit, or more generally as an act of the Han government's generosity, enjoyed several economic, legal, and social privileges. According to early Former Han legal statutes, they were entitled to land allocations ranging from 1.5 qing (ca. $7 \mathrm{ha}$ ) for the first, lowest rank to 95 qing (ca. $440 \mathrm{ha}$ ) for the nineteenth, highest rank. However, it appears safe to say that, at least after its initial phase, the Han state never achieved putting this ideal system into practice. ${ }^{135}$ The legal privileges of rank holders included the possibility of mitigating punishments. Holders of the highest ranks were further exempted from military and labor service. The social status that went along with honorary titles was also made visible by the right to wear specific headdresses, and in the seating and distribution of meat and wine at state-sponsored banquets. ${ }^{136}$

The system of honorary titles as a whole is not to be confused with an aristocratic system. According to early Former Han legal statutes, only the title of marquis of the interior (guannei hou 關內侯) and the abovementioned marquis (hou) were hereditary in a strict sense and could thus be regarded as noble titles. ${ }^{137}$ And even these were often short-lived. Heirs whose fathers held the first up to the eighteenth ranks would attain a lower rank on inheritance. But to regard it as a meritocratic system would be equally mistaken. For example, opportunities soon arose for wealthy people to officially buy honorary ranks at a fixed price, ${ }^{138}$ and at least during the Later Han period, it was possible to transfer a rank to a family member.

134 Loewe 2004, 279-324, provides detailed information on Western Han marquisates. A comprehensive study on the local administrative system of Qin and Han times in general is provided by Yan 2007.

135 The state soon appears to have run short of land that could be used for extensive grants. Furthermore, limits on private landholdings came to be virtually removed (Loewe 2010a, 298; Barbieri-Low and Yates 2015, 787; Yang 2003; Gao 2003). On some ineffective attempts at reintroducing limits on private landholding, see Nishijima 1986, 557-559.

136 Loewe 2006, 137-138; Barbieri-Low and Yates 2015, 400-401; Loewe 2010a, 299; Lewis 2007, 110. An extensive treatment of Han honorary titles (though excluding more recent evidence from manuscript finds) is provided by Loewe 1960.

137 Barbieri-Low and Yates 2015, 854-885.

138 For instance, Sima Qian mentions the sale of honorary titles (as well as official posts) as a frequent measure for gaining state revenue during the phase of expansion during Emperor Wu's rule (Shiji 30.1422-1423, trans. Watson 1993, 2:65-66; cf. Hanshu 24B.1159, trans. Swann 1950, 250254). 
Further, certain (yet not fixed) correspondences existed between particular offices or salary grades of officials and particular honorary ranks. ${ }^{139}$

Apart from the possibility of bolstering the imperial budget, the system of honorary titles could fulfill different purposes for the central government. Bestowal of ranks certainly worked as an important incentive for loyal service to the state, but it was also a means of displaying the emperor's bounty and of forging links between the emperor and the common people. This is obvious in several attested cases of general bestowals, in which a rank (or an advancement in rank, respectively) appears to have been granted to every registered household head. ${ }^{140}$ Bestowals were at times also used in order to tempt people to move their homes and, for instance, set up agricultural colonies at the northern frontier. ${ }^{141}$

\section{IV.1.4 Recruitment of Officials and its Social Implications}

With the intensifying administrative control over its growing population, the Han government faced an increasing demand for officials on all administrative levels. Reliance on established elites and on traditional ways of recruitment (such as inheritable eligibility to scribal posts) soon proved untenable, so that new ways of finding suitable candidates from an extended social background became indispensable. Apart from registered traders, who were excluded from office at least during certain periods, all free men came to be at least theoretically eligible for official employment and advancement to high government posts. Concerning their recruitment, some features of the famous civil service recruitment and examination system of late imperial China already appear during the Han period, albeit in a very limited and irregular fashion. ${ }^{142}$ Less favorably put, the Han recruitment system has been described as "crude and open to corruption" - but nevertheless efficient in providing the government "with sufficiently competent candidates for office."143

The bulk of Han officials occupied junior secretarial or technical posts, with their appointments made relatively freely by commissioned officials either of the county or commandery administrations, or under capital ministers. The central government's attempts at controlling junior local officials' qualification, however,

139 Ranks were also granted to commoners not holding an official post, but these would usually not advance beyond the eighth rank. On all these social correspondences, see Loewe 1960, 159162.

140 Loewe (1960, 114, 165-171) provides a list of these occasions. This suggests that at least at certain times, a large proportion of the male population must have held at least the lowest of the twenty honorary ranks, and that rank also correlated with age to a certain degree.

141 Loewe 2006, 136-137.

142 On the late imperial examination system, see Elman 2013.

143 Bielenstein 1980, 132. 
can be seen in some statutory arrangements for the local training and testing of scribes. ${ }^{144}$

With regard to elite officials receiving their appointments at the capital, both the Former and Later Han governments sporadically ordered empire-wide recommendations of promising men, sent commissions to tour the commanderies and kingdoms, and experimented with measures to test candidates' suitability. Ad hoc calls for recommendations were soon to be supplemented by a regularized annual call for each commandery and kingdom to recommend a certain number of promising people who would then be designated 'filially pious and incorrupt' (xiaolian 孝廉). If found suitable, they could be appointed to mid-ranking central or local offices, with a chance of being further promoted up to the highest government posts. This system of annual recommendations was further modified in $92 \mathrm{CE}$ by the introduction of quotas depending on the population size of the administrative units. Several other channels of recommendation existed, with varying degrees of regularity and specification. ${ }^{145}$

Some safeguards against the bluntest forms of nepotism were implemented in the system. Regulations barring those local officials responsible for recommendations, i.e., the commandery governors and county magistrates, from serving in their home jurisdictions are a case in point. Furthermore, if a candidate turned out to be unsuited or was convicted of a crime, his recommendor faced punishment. Probationary periods also existed, and for some channels of recommendation and promotion, candidates underwent examinations on political, technical, or scholarly matters before being admitted to assume office. ${ }^{146}$

That these provisions did by no means prevent local haggling or blackmailing is well attested in many stories and complaints transmitted in historical works. Walter Scheidel is thus right when he argues that "it would be unwise to overestimate the meritocratic dimension of early Chinese officialdom." ${ }^{147}$ Necessarily, the very system of recommendations was intrinsically linked to the principles and practice of favoritism on the basis of both kinship ties and patron-client relationships. And these networks of people - who took on responsibility in local decision-making within and beyond the centrally implemented bureaucratic structures - were something that the central government needed to rely upon and cooperate with rather than fight against in order to maintain stability.

Local networks, on their part, also relied on the bureaucratic system. It was through the advancement of their members in the bureaucratic hierarchy that they

144 Loewe 2004, 217-218; Hulsewé 1959; Barbieri-Low and Yates 2015, 1084-1111.

145 For instance, individual edicts required the recommendation of men with military ability or legal expertise. A particular channel of recruitment (including both recommendations and regular examinations) further evolved for scholarly candidates via the Imperial Academy (Taixue 太學).

146 On the different institutionalized channels of recruitment, see Bielenstein 1980, ch. 6; Loewe 2004, ch. 4; Houn 1956.

147 Scheidel 2009, 19. 
gained opportunities of participating in wide-reaching political decisions at the imperial court. The imperial administrative system further provided the basic channels for interconnecting individual local networks over the space of a vast empire. It also fostered vertical social relationships between members of different economic and social backgrounds, since patrons also needed clients from comparatively humble backgrounds, such as minor clerks serving in local government offices. ${ }^{148}$ By recommending subordinates, a patron not only secured the client's loyalty for the present and future, but also provided real opportunities for these lowly officials to rise up in the bureaucratic and social hierarchy. It is against the background of this dynamic interlocking of bureaucratic structures, local elites, and patron-client links that we need to understand the careers of humble men rising to the highest government posts, examples of which we quite commonly find in the dynastic histories. ${ }^{149}$

Local administrators were further motivated to serve the interests of powerful locals (some of whom were not holding any office) because these could enhance the administrators' reputation - and thus, the career chances for his whole family by certain public acts like the erection of steles. Reputational mechanisms like these were embedded in the recruitment system itself and became especially important during the Later Han period, when the central government ceded some of its administrative powers on the local level. Interestingly, opportunities for rapid social mobility to the highest positions appear to have decreased during this period. ${ }^{150}$

Max Weber held the influential view that the Confucian virtue of filial piety (xiao 孝) acted as a crucial element for the Chinese administrative system to work, as it supposedly made up for its bureaucratic inefficiencies by indoctrinating the Chinese people with an unconditional acceptance of hierarchical, top-down power structures. ${ }^{151}$ But if applied to the Han period, to the very least, this theory would overestimate the role of Confucianism while possibly underestimating the efficiency of the bureaucratic system. It may further underestimate the reciprocal nature of social obligations immanent both in hierarchy-based values like filial piety and in the aforementioned reputational mechanisms.

\section{IV.2 The Empire of Texts and Scribes: Imperial Communication and Record Keeping}

The discovery of large quantities of manuscripts in recent decades have been revolutionary for the study of ancient China, especially in regard to local administration.

148 The significance of these vertical relations tended to decrease at the end of Later Han rule, when wars and the breakdown of imperial administrative structures appears to have forced people to concentrate on local and more horizontal networks in order to assure local safety (Ebrey 1983, 541-542).

149 See Ebrey 1983.

150 Xie and Brown 2015; Ebrey 1986, 631.

151 Weber 1951, 157-159, Weber 1978, 1047-1051. See also Mann 1986, 342-344. 
Several deposits, such as excavated local archives, have brought vast numbers of administrative documents to light. Furthermore, in several local officials' tombs from the Qin and Han periods, administrative texts constitute a considerable part of the grave goods. In the bureaucratic empire, neither life nor death appear to have been imaginable without an extensive availability of texts.

The excavated documents have made us especially familiar with the stratum of local officials - and chiefly among them, the scribes (shi 史) - that have correctly been referred to as the "backbone of the empire." 152 As both proscriptive legal texts and excavated exemplars of administrative files demonstrate, these officials' tasks were connected to an enormous extent of documentation. The communicative system was based on an elaborate system of standardized procedures and forms to gather and transfer information to the capital. ${ }^{153}$ Both Qin and Han laws contained special sets of “Statutes on the Forwarding of Documents" (Xingshu lü 行書律), ${ }^{154}$ and many other statutes minutely prescribe local officials' manifold reporting duties.

The governments of the Qin and Han Empires employed several communication networks including closely spaced courier stations (you 郵) and a looser network of more elaborate postal relay stations ( $z h i$ 置 or $y i$ 驛). Legal statutes prescribe an empire-wide establishment of courier stations at intervals usually ranging from 10 to $30 \mathrm{li}$ (i.e., approx. 4.16 to $12.5 \mathrm{~km}$ ) and required for documents carried by foot couriers to take no longer than one day and one night for a delivery route of $200 \mathrm{li}$ (approx. $83.2 \mathrm{~km}$ ). ${ }^{155}$ Excavated administrative texts from the Qin archive of Qianling County (Liye) demonstrate that officials were required to mark the precise time of a document's arrival or departure: Many documents are time-stamped to the fraction of a (water clock) hour. ${ }^{156}$

Administrative documents excavated from peripheral zones demonstrate that the meticulousness of bureaucratic documentation and imperial communication was by no means restricted to the empire's more central areas. Manuscripts found in northwestern frontier commanderies include, for instance, meticulous accounts of receipt and expenditure of consumables and of various financial matters. ${ }^{157}$

Keeping track of the population was another important aspect of the tasks fulfilled by local government agencies. In Qin household registries excavated at Liye, individuals were identified in terms of their place of residence, name, honorary rank

152 Selbitschka 2018, 467. On the significance of the scribes, see also Ma 2017; Yates 2014.

153 On the communicative modes and procedures involving the court and the emperor, see Giele 2006.

154 For the respective Qin statutes excavated at Shuihudi, see Hulsewé 1985, 85-86; for the early Han statutes excavated at Zhangjiashan, see Barbieri-Low and Yates 2015, 729-752.

155 The documents would usually move from station to station, where the documents would be handed over to the next courier, and so forth (Barbieri-Low and Yates 2015, 729-752).

156 See, e.g., Hunan sheng wenwu kaogusuo 2006, 192 (board no. 16-5); Yates 2012, 302.

157 See Loewe 2010b, 314 (including references to many examples in Loewe 1967); Wang 2004, 47-64. 
(if any), sex, minor/major age status, ${ }^{158}$ membership in five-household units, and health status (if relevant). ${ }^{159}$ Within the Liye corpus, individuals' calender ages were registered in separate files. One of these documents registers an infant as follows: "Zeng: white in color; height: two chi five cun (approx. $58 \mathrm{~cm}$ ); age: five months" (璔晳色, 長二尺五寸, 年五月). ${ }^{160}$ It is possibly the earliest extant example worldwide documenting the registration of such a young child. ${ }^{161}$

Once individuals had been registered in a certain place, they would stay identifiable as residents of this very place irrespective of their concrete physical location. Excavated debt reckonings from the Qin period demonstrate how information on people's identities made its way through the Qin bureaucracy, thereby enabling state agencies to track individual people who were temporarily living far away from their homes, for instance, when doing military service. ${ }^{162}$ In general, moving throughout the empire and beyond its borders (sai 塞) required permission. Travelers' passports were carefully sealed, to be opened, checked, and resealed at each fixed checkpoint. They included information on the individual's place of residence, age, height, skin color, and body marks, as well as on the person's social, legal, and rank status. Separate passports needed to be carried for horses, recording each animal's age, color, and distinguishing brands or markings. ${ }^{163}$ Excavated documents from a Han frontier garrison at Juyan 居延 in the northwestern extension of the empire demonstrate that the officials in charge did not only check passports, but were also required to produce and file registers of the permissions of passage they had granted. ${ }^{164}$

Population registration and control of travel primarily served the goal of tracking the inhabitants' corvée labor and tax obligations. But with the requirement to be updated annually through personal contact with local officials, household registers also made individuals enter into a long-term bond with the state. ${ }^{165}$ Being a member of the ordinary populace came to be so closely associated with registration procedures that by the Former Han period, the expression 'enrolled households and ordered people' (bianhu qimin 編戶齊民) had evolved into a general designation for the common people. ${ }^{166}$

158 Later household registries would comprise calendar ages (Sanft 2015, 257).

159 Sanft 2015, esp. 251, 258.

160 Chen 2012, 178 (no. 8-550); Hunan sheng wenwu kaogu yanjiusuo 2012, 70-71; Sanft 2015, 254-55.

161 Pines et al. 2014, 27-28.

162 Sanft 2015, 260-266.

163 Loewe 2010b, 317-318; Barbieri-Low and Yates 2015, 1128-1129, 1116.

164 See, for instance, the examples given by Loewe 2006, 161-162. See also Loewe 1967, 107-114.

165 Sanft 2014, 129. For the detailed prescriptions in the early Han "Statutes on Households," see Barbieri-Low and Yates 2015, 783-822.

166 See Sanft 2015, 259, and the extensive study on bianhu qimin provided by Du 1990. 


\section{IV.2.1 Cultural Impact}

The empire's bureaucratic structures, hierarchies, and procedures also shaped people's worldviews and beliefs. This is especially obvious in the case of people who were themselves active in local administration and took administrative texts to their graves. They apparently believed that they would need these texts as reference works or to announce their skills in a bureaucratic afterlife.

The origins of a belief in celestial bureaucracies can be traced to the Warring States period. By the Former Han dynasty, manuscript finds attest to a bureaucratization of the netherworld matured to a degree that it bore all signs of a hierarchically ordered, unified empire. With a spirit 'emperor' ( $d i)$ at its top, people would imagine the netherworld to be administered by a host of bureaucrats holding titles such as 'assistant magistrate of the underworld,' 'commander of ordinance for the mounds,' or 'neighborhood head of the gate of the souls.' 167 The titles are only one example of a whole bureaucratic-contractual language set that made it over to the afterworld and minutely mirrored the hierarchy-based procedures of official imperial communication. In many funerary texts from Later Han tombs, it is assured that interactions with the netherworld operate "as prescribed by the laws and ordinances (ru lüling 如律令).”168 One also finds the request for the celestial emperor to accept soybeans and melon seeds "for the taxation underneath," and based on the presentation of a certain drug, there is hope for the deceased that in the netherworld he will be "exempted from the poll tax and corvée conscription."169 It was further assumed that people's being summoned to the underworld before their time was a result of bureaucratic foul-ups in the netherworld's "registers of the dead" (siren $j i$ 死人籍). ${ }^{170}$

Respective funerary texts have most frequently been found in local officials' tombs, but occasionally also in those of nobles and wealthy landowners. ${ }^{171}$ Furthermore, believers of Daoist religious movements like the Way of the Celestial Masters (Tianshi dao 天师道), which evolved during the Later Han period, equally came to believe in a bureaucratic organization of the celestial realm, and were certainly not restricted to very specific social groups. ${ }^{172}$ So while one must be careful not to overinterpret these indications as safe evidence for a common popular religion, it is fair to assume that the belief in a bureaucratically ordered netherworld was not restricted to local officials, but also played a role in wider parts of Han society.

167 Poo 2011, 20.

168 Seidel 1987, 24-25, 39-42. The expression 'as prescribed by the laws and ordinances' was also a stock phrase closing many earthly official documents.

169 Poo 2011, 27.

170 Seidel 1987, 30-34.

171 Guo 2011, 101, and n. 63.

172 Nickerson 1996. 


\section{IV.3 The Legal System}

\section{IV.3.1 Imperial Law}

When Qin Shi Huangdi's chancellor felt the need to stress that his ruler's unification of 'All-under-Heaven' was an unprecedented achievement, he reportedly pointed to two aspects in particular: One was that "[all territory] within the seas [was now] made up of commanderies and counties," and the other one was that "legal principles and ordinances [now] emanated from one single source." ${ }^{173}$ Especially since masses of legal texts have been unearthed during the last few decades, modern scholars have come to agree that the legal system must indeed have played a central role in the early Chinese empires and that it must have constituted a primary prerequisite for the "engine of the imperial bureaucratic state [to be] able to operate as long as it did."174

The new material has shown that the Han comprehensively adopted the Qin legal system. Parallels between the Qin and early Han legal texts excavated at Shuihudi and Zhangjiashan demonstrate that the editors of the Han statutes did not merely model these on the Qin precursors, but literally copied them word-by-word to a large extent. At times, the copyists would even forget to replace certain Qin technical terms with their official Han equivalents. ${ }^{175}$

Furthermore, the excavated documents disproved the formerly widespread conviction that early imperial Chinese legal statutes were mainly focused on criminal matters. ${ }^{176}$ Just to offer a picture of the wide range of contents, among the altogether 28 Han statute sections from Zhangjiashan, we find titles such as "Statutes on Assault” (Zei lü 賊律) as well as “Statutes on Cash" (Qian lü 錢律) and “Statutes on the Exemption from Taxes" (Fu lü 復律). We also find “Statutes on the Establishment of Heirs" (Zhihou lü 置後律), "Statutes on the Establishment of Officials" (Zhili lü 置吏律), and "Statutes on the Composition of Judgments" ( $u$ lü 具律). ${ }^{177}$

In order to offer a first impression of what these statutes looked like, the following example from the "Statutes on Assault" (zei 賊) section is the first and most general one dealing with cases of homicide:

173 平定天下, 海內為郡縣, 法令由一統, 自上古以来未尝有, 五帝所不及。Shiji 6.236; cf. Nienhauser 1994a, 136 (offering a slightly different translation).

174 Barbieri-Low and Yates 2015, 216. Evidence for laws and their implementation is considerably more substantial with regard to the Former than the Later Han period. The following description of the legal system is therefore also subject to this imbalance of source material.

175 Barbieri-Low and Yates 2015, 219-225.

176 Barbieri-Low and Yates 2015, 221.

177 Barbieri-Low and Yates (2015, 210-211) divided the functions of the 28 sections into ten categories, only two of which would be associated with penal law. 
Maliciously killing another person, or killing a person during a fight: cast [the criminal] away in the marketplace. ${ }^{178}$ Should it have been a mistake, as well as killing a person while engaged in horseplay: [order the criminal] to redeem the death penalty. For injuring another person [resulting from the mistake or the horseplay]: remove [the crime from those who are held liable].

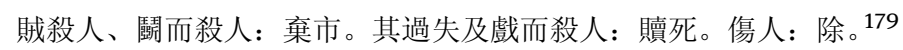

Many subsequent statutes in the same section offer detailed regulations for particular circumstances and scenarios of homicides and bodily injuries. They even cover the case of killing an unborn child by "fighting with or striking a [female] person so that she miscarries” 虍毆變人. In this case - and under the precondition that it was not the woman who had provoked the fight - the offender was to be "shaved and made a bondservant or bondwoman” 耐為隸臣妾. ${ }^{180}$ The same punishment, by the way, applied to a woman who dared to strike her husband - and not in the reverse case.

This hints at an important characteristic of early imperial penal law: The social relationship between offender and victim with regard to kinship and other hierarchies played a crucial role in the judgment of criminal cases. For example, if someone dared to strike a person of higher honorary rank than himself, the fine was to be twice as high as the fine for striking a person who was of the same rank or lower. ${ }^{181}$ The statutes also treat killing or injuring a stranger as belonging to a different crime category than doing the same harm to, for instance, a senior relative. To a certain extent, and again depending on particular kinship relations between offender and culprit, both Qin and Han laws also granted family households their own area of jurisdiction. ${ }^{182}$

Constraining and sanctioning the common people by penal law was but one function of the early imperial legal codes. No less were these intended to regulate the actions of state officials on an empire-wide scale, including regulations concerning official's salaries, duties, and bureaucratic procedures. One statute even determines the number of permitted leave days, depending on the official's post and the distance between his workplace and parental home. ${ }^{183}$

Both Qin and Han statutes often imply a degree of meticulousness that may at times look perplexing. In the Qin legal statutes found at Shuihudi, for example, we find the following statute in the section on currency:

178 During Qin and Han times, being “cast away in the marketplace” (qishi 棄市) was the most common form of the death penalty. It probably meant an individual's beheading by a sword, after which the corpse was left in the marketplace for passersby to behold, as well as to be scavenged by birds and dogs (Hulsewé 1955, 109-112; Barbieri-Low and Yates 2015, 411, n. 9).

179 Barbieri-Low and Yates 2015, 398-399 (no. 16).

180 Barbieri-Low and Yates 2015, 402-403 (no. 25).

181 Barbieri-Low and Yates 2015, 400-401.

182 Lau 2005.

183 Barbieri-Low and Yates 2015, 652-653. 
When there is buying as well as selling, to each [object] the price is to be attached. To small objects, each not worth one cash, it must not be attached.

有賣及買也, 各嬰其賈價; 小物不能各一錢者勿嬰。 184

This level of detail appeared disturbing even to specialists on ancient Chinese law, among whom we find the assertion that the regulations included many dispensable "absurdities." 185 Others have claimed, quite to the contrary, that precisely this attention to detail in legal proscriptions might have been essential to the survival of the system. ${ }^{186}$

\section{IV.3.2 Judicial Personnel}

The smallest units with legal responsibilities were the units of five (wu 伍) mentioned earlier, whose members were obliged to mutual criminal surveillance. ${ }^{187}$ Additionally, locally selected and nonranked village or ward chiefs (zheng 正 or dian 典) were required to report criminal activities among their community members. ${ }^{188}$ Above this level, heavily armed constables (ting zhang 亭長) heading police stations (ting 亭) looked out for and arrested criminals in a fixed jurisdiction. ${ }^{189}$ On the next higher district level, the bailiff of the district (xiangbu sefu 鄉部嗇夫) was required (next to other, nonjudicial tasks) to write up denunciations and forward them to the county court. 190

The most important junior officials for legal matters on county level were the judiciary scribes (yushi 獄史) and scribe directors (lingshi 令史). They were tasked to conduct the majority of investigations and interrogations, and to prepare dossiers for the magistrate or assistant magistrate. The latter would then review these dossiers and (usually) confirm the recommended sentences. The county courts commonly carried out all kinds of punishments. ${ }^{191}$ Sentences in capital cases could only be passed after a review of the verdict by a judicial inspector appointed by the court at the next higher, i.e., commandery level. ${ }^{192}$ The commandery court was likewise

184 Shuihudi Qin mu zhujian zhengli xiaozu 1990, 37, trans. Hulsewé 1985, 53 (A 46).

185 Hulsewé 1981, 22.

186 Barbieri-Low and Yates 2015, 212.

187 Barbieri-Low and Yates 2015, 111-113.

188 At least for Qin times, there is some indication that the selection of village and ward chiefs had to be approved by the assistant county magistrate (Barbieri-Low and Yates 2015, 113).

189 According to Hanshu 19A.743, there were 29,635 such police stations spread over the empire in $2 \mathrm{CE}$.

190 Barbieri-Low and Yates 2015, 116-118.

191 Those sentenced to work as hard labor convicts were pooled by central authorities and transferred to places where their work was needed, i.e., typically to other counties.

192 There are indications that earlier Qin county authorities had been permitted to pass these without further ratification. See Korolkov 2017, 389; Lau and Staack 2016, $224-225$ (II.9), 242 (II.10). 
capable of listening to denunciations, taking statements, and ruling in cases. Its jurisdiction superseded that of the counties in particular cases. ${ }^{193}$

Turning to the central administration in the capital, the highest judge in the empire (below the emperor) was the superintendent for trials. ${ }^{194}$ His ministry was equipped with a sizable and highly trained staff, especially scribes. The ministry's responsibilities included the handling of doubtful cases submitted by commandery courts, the organization and archiving of written laws, and the prosecution of cases directly involving the imperial person or imperial prestige. In addition, the imperial counselor (see section IV.1.1) played an important role in prosecuting major cases, policing the bureaucracy, and creating new legislation. In all judicial matters, the emperor himself had the last word. He could pardon people, decide on doubtful cases that the superintendent for trials felt unable to resolve, and hold trial himself. 195

\section{IV.3.3 Judicial Procedures}

A judicial process commenced when someone was 'held liable' (zuo 坐) for a crime after a commoner's denunciation (gao 告) or an official's discovery of his alleged misdeed. ${ }^{196}$ An arrest of a major suspect usually went along with a 'sealing and guarding' (feng shou 封守) of his property and family. In the case of conviction, his property would be sold, and during some phases of Han rule, the family members of major criminals would be enslaved or even executed alongside the culprit. ${ }^{197}$

Excavated reports of criminal cases suggest that both crime scene investigations and interrogations could be very meticulous and methodical. In cases of suspicious deaths, junior officials such as scribe directors or judiciary scribes were sent out by the county court to investigate the crime scene. A Qin legal model unearthed at Shuihudi describes the case of an apparent suicide by hanging, in which the scribe director meticulously examines both the crime scene and the dead man's body in order to find out whether the latter had rather been strung up by murderers. For these kinds of tasks, some medical understanding was required from scribes dealing with legal matters, and collections of model legal procedures offered guidance in forensic techniques. ${ }^{198}$

193 On the legal institutions on county and commandery levels, see Barbieri-Low and Yates 2015, $118-127$.

194 For a list of different English renderings of titles for judicial personnel, see Barbieri-Low and Yates 2015, XXIII-L, whose own translations I largely follow here.

195 On central legal institutions, see Barbieri-Low and Yates 2015, 129-134.

196 On the rules on denunciations and official accusations with their precise documentary formats, see Barbieri-Low and Yates 2015, 137-142.

197 Hulsewé 1955, 112-122; Barbieri-Low and Yates 2015, 594-606; Ch’ü 1972, 136.

198 Barbieri-Low and Yates 2015, 150-151; Selbitschka 2018, 424-425. 
The pretrial process had to follow standard procedures and involved initial interrogations (xun 訊), statements ( $c i$ 辭) by defendants and witnesses, ${ }^{199}$ crossexaminations (jie 詰), and final inquiries (wen 問). Obtaining confessions through torture by caning was permitted only under certain circumstances and was declared second-rate. This, however, did not necessarily prevent officials from beating confessions out of defendants in order to advance their careers. ${ }^{200}$

The trial ( $j u$ 鞛) was the first stage of the judicial process under the responsibility of the county magistrate or the assistant county magistrate. Being a process of comparing written documents rather than a verbal contest in a courtroom, it mainly consisted in a summation and certification of the facts related to the case. The phase of sentencing (lun 論, literally 'discussion') then involved the determination of guilt according to a particular statute and the matching (dang 當) of an appropriate punishment. The case was completed with an official final report (bao 報). ${ }^{201}$

To be sure, the early empires' legal system was far from being devoid of corruption, personal mistakes, and other irregularities. A uniform phrase commonly found in accusation documents written by low officials says, "I make the official accusation because of personal knowledge of this [crime]; in no respect was I instigated by a senior official [to make this accusation]” 以此知而劾無長吏使. ${ }^{202}$ It clearly demonstrates the government's concerns over instances of wangling between officials of different grades.

Apart from such soft legal safeguard clauses, several more tangible institutions aimed at antagonizing official corruption and judicial errors. One important mechanism of judicial review was that of submitting doubtful cases (zou yan 奏獻). It followed a strict four-step hierarchy: The county magistrate or assistant county magistrate could forward a case they felt unable to decide to the commandery governor. The latter could either report his judgment back to the county for implementation, or transfer the case to the superintendent for trials in the capital, who, if found necessary, could finally forward it to the emperor. The corpus of legal texts excavated at Zhangjiashan includes a corresponding collection of cases in a book entitled Book of Submitted Doubtful Cases (Zouyan shu 奏獻書). ${ }^{203}$

The same work also includes cases that were handled according to other review mechanisms, one of which was the process of personal appeal called 'pleading for

199 Before the officials started to interrogate, they were mandated to inform their subjects of interrogation about the statutes on untruthful testimony and the associated punishments (Barbieri-Low and Yates 2015, 152-154). An excellent study on judicial procedures (in German) is further provided by Lau 2002.

200 Barbieri-Low and Yates 2015, 159.

201 On trials and sentencing, see Barbieri-Low and Yates 2015, 161-170.

202 Barbieri-Low and Yates 2015, 140.

203 For an English translation of this collection, see Barbieri-Low and Yates 2015, 1167-1461. A German translation is provided by Lau and Lüdke 2012. 
trial' (qiju 乞鞓). ${ }^{204}$ These appeals could be lodged after a case had been decided, ${ }^{205}$ either by the convict himself or his immediate family. ${ }^{206}$ Such a step needed to be considered well, however, since in the case of a baseless or carelessly made appeal, the person who had lodged it faced severe (heightening of) punishment. After an appeal had been lodged, the case was transferred to the next higher authority, usually the commandery governor. The latter then appointed a commandery official to reinvestigate the case along the pretrial procedures outlined above. If the appeal was successful, the initial sentence was removed, the defendant's family (if enslaved) was redeemed, and his property (if impounded) was compensated for.

Another form of judicial review was called 'recording of incarcerated persons' (luqiu 錄囚), in which high officials actively sought cases of injustice by reviewing cases and questioning prisoners. This originally rather irregular process was considerably systematized under Emperor $\mathrm{Wu}$ with his establishment of the post of regional inspector (cishi). ${ }^{207}$ According to the Han historical works, their inspection tours and case revisions frequently resulted in overturning unjust sentences and freeing convicts. Considering the fact that the Former Han operated more than 2,000 prisons, however, 13 regional inspectors throughout the empire - who, of course, where themselves not insusceptible to judicial miscarriage - could hardly have uncovered more than a small fraction of actual irregularities. ${ }^{208}$

\section{IV.3.4 Beyond Legal Rationality: Cultural and Economic Aspects of Judiciaries}

In the above, the rationalized, bureaucratic nature of the early imperial judicial system, doubtlessly its outstanding feature, has been stressed. Nevertheless, this system was also deeply culturally embedded, some idiosyncrasies of which surface conspicuously in all kinds of legal regulations, ${ }^{209}$ and partly soften or superimpose its rational structures. One widespread belief that had a strong impact on the judicial system and its penal practice in particular was the notion of a close unity of the human world and the wider cosmos. It was believed that human activities had to be in harmony with the actions of nature. Among others, this idea served as the basis for the requirement for executions to be carried out in the autumn and winter

204 The procedure for this process is laid out in the "Statutes on the Composition of Judgments." 205 The timespan a person had for lodging an appeal varied over time from three months to one year after the decision of the case.

206 A person sentenced to a death penalty could not lodge an appeal on his own behalf; it could only be lodged by his relatives.

207 See above, sec IV.1.2.

208 Barbieri-Low and Yates 2015, 182-185.

209 The legal relevance of certain kinship relations between culprit and victim in judging legal cases, as well as the legal acceptance of a certain degree of private jurisdiction within the sphere of internal family offenses mentioned above would count as important examples. 
months only, since these were considered the months of death and decay. ${ }^{210}$ Many transmitted textual passages suggest that this requirement did have concrete effects on penal enforcement. Han histories inform us about certain legal cases in which the officials in charge show some crude-looking haste trying to have their capital cases closed before the beginning of spring. Other passages refer to people who had been condemned to death and were so lucky as to 'pass beyond winter' ( $y u$ dong 踰冬). The deferral to the next winter obviously opened the door for an individual mitigation of punishment and for the chance of meeting a more general amnesty (she 赦) throughout the year. ${ }^{211}$

Another superimposition of 'rational' legal procedures can be recognized in Han emperors' frequent interference with regular processes in times of droughts or other calamities. Correlative theories of the time ${ }^{212}$ interpreted these as a cosmic reaction to human (and especially the ruler's) misconduct, of which legal injustice or penal overkill were considered important forms. By sending out extraregular commissions to conduct recordings of incarcerated persons or granting amnesties on these occasions of heavenly displeasure, ${ }^{213}$ the emperor and his advisors could soften the strict modus operandi of the bureaucratic legal system with a considerable degree of arbitrariness (or flexibility, if you will). ${ }^{214}$

Certain 'flexibilities' within the system were also made use of for an interference with legal rationality that was based on a very rational, economic calculation. Convict labor, the most common penalty, evidently was such an indispensable resource especially for the Qin, but also for the Han governance, that it is hard to imagine that legal procedures were immune to being tampered with for the sake of gaining the desired number of convict laborers. ${ }^{215}$ Considerations of this sort are quite evi-

210 Historically, this idea was connected to the practical background of a society relying on conscript peasants. Since these were demanded both to fight in battles and to productively work their fields, it made much sense to divide the year into seasons that were devoted to either death and decay (i.e., warfare and punishments) or to growth (i.e., sowing and cultivating). See Lewis 1990, 64-65, 138-146.

211 Hulsewé 1955, 103-109. Furthermore, there were days that were considered more conspicuous than others to engage in certain legal activities. Magistrates were also supposed to abstain from 'polluting' behavior (like sexual activity) when they were to judge cases (Yates 2009, 44).

212 For ancient Chinese correlative theories, see Henderson 1984; Graham 1986.

213 Amnesties were also granted on occasions like an emperor's accession or the installation of an empress (in the hope to create beneficial cosmic conditions), and on the appearance of auspicious omens.

214 On the different forms of general and particular amnesties, see Hulsewé 1955, 225-250; Barbieri-Low and Yates 2015, 184-185. On the role of amnesties in Chinese history in general, see McKnight 1981. For a criticism of his view that the primary reason for Chinese emperors' being so fond of amnesties was a congestion of prisons and courts, see Ebrey 1982.

215 Criminals could be sentenced to different durations of convict labor (from mid-Former Han mostly ranging from four to six years) and different kinds of tasks (ranging from lesser administrative tasks to hard physical labor in mines and construction projects). See Barbieri-Low and Yates 2015, 193-199; Hulsewé 1955, 128-132. Economic considerations possibly also played a role in sever- 
dent when it comes to the use of convicts in military endeavors. For example, when Emperor Wu needed soldiers for his campaign against Chaoxian (Korea) in 109 BCE (see below), he recruited "those people in the empire that had been condemned to death" for this undertaking. ${ }^{216}$ Sima Qian also seems to suggest that Emperor Wu's tightening of laws was targeted at getting a hold of more convict soldiers. ${ }^{217}$ This 'flexible' practice became more institutionalized under the Later Han. An official's memorial from $58 \mathrm{CE}$ explicitly bemoans the manipulation of the legal system for military needs, claiming that many innocent men had been condemned in order to obtain recruits for the frontier. ${ }^{218}$

\section{IV.3.5 Acceptance and Effectiveness of the Legal System}

Allegedly, in the newly founded Han Empire "the net [of the law] let through fishes so large that they could swallow a boat” 網漏吞舟之魚, while during the reign of Emperor $\mathrm{Wu}$, for example, "the net of prohibitions became continually tighter" 禁罔寝密. ${ }^{219}$ As we know from transmitted Han court discussions, there were continuous debates between different camps of central officialdom on how tight this 'net of law' should be (especially in its application on high state dignitaries) and in how far self-administered forms of justice (like blood vengeance or suicide) were supposed to be tolerated. ${ }^{220}$ On the other side of the social hierarchy, resistance against state dominion and the legal system in particular can be seen in the evidently common cases of people 'absconding' (wang 亡) from the state's grid of both residential registration and legal prosecution, which appears to have been a major issue at least during Qin and early Han times. A more active form of resistance is manifest in several known cases of revolts that originated from groups of people that had been sentenced to convict labor. ${ }^{221}$ Also, it is quite obvious that some of the legal statutes could hardly have been implemented in the envisioned form. ${ }^{222}$ Nonetheless, early imperial laws were generally much more than an idealized blueprint.

al reductions of the maximum stroke number in caning punishments. As these were typically adjunct to hard labor punishments, deaths resulting from hundreds of strokes of the bamboo pole had the undesired effect of drying up the pool of convict laborers (Barbieri-Low 2007, 231; Hulsewé 1955, 128-129).

216 Hanshu 6.193.

217 Shiji 30.1421, which has, "The military forces were used up, and [therefore] the laws and ordinances were made stricter and more detailed” 武力進用, 法嚴令具. Regarding both the phrase itself and its context, Watson's (1993, 2:64) translation ("Military achievement was now the key to advancement. The laws were made stricter and more detailed") does not appear quite convincing.

218 Hou Hanshu 48.1597-1598; Lewis 2000, 54-57.

219 Both descriptions are Ban Gu's (Hanshu 23.1101, 1104, trans. Hulsewé 1955, 338, 341).

220 Van Ess 1993, 258-275.

221 See, for instance, Barbieri-Low 2007, 227.

222 Barbieri-Low and Yates 2015, 218-219. 
Indeed, excavated administrative documents from both the Qin and Han dynasties demonstrate that at least during some periods, central parts of the system prescribed in the laws - including household registration, tax collection, labor mobilization, prosecution of crimes, and standardized communication procedures worked with considerable effectiveness. ${ }^{223}$

\section{IV.4 The Role of the Military in Defense and Expansion}

Generally speaking, Han sources (which may not give us the whole picture) tend to treat war as a necessary evil of certain circumstances rather than something that the empire should actively strive for. Territorial expansion had been a consistent feature of the polities of the Warring States period, but not of the Han period, when large-scale conquests were restricted to particular phases. Once the large imperial core had been successfully consolidated, further expansion was also limited on geographical grounds, since the steppe territories to its north proved difficult and extremely expensive to hold once they had been occupied.224 Expansionism was thus less a structural feature of the Han Empire than it was for the Roman Empire, where it was deeply embedded in social structures. ${ }^{225}$ Quite accordingly, the Chinese sources also lack evidence for the cachet of military glory for personal prestige that was so typical for Roman elites. ${ }^{226}$ Nevertheless, pre-imperial military history had important repercussions for the early Chinese empires. ${ }^{227}$ And despite their comparably low-key treatment of military matters, early imperial sources yet attest to an omnipresence of wars of various kinds.

\section{IV.4.1 Major Internal and External Threats}

Turning to concrete military endeavors, the Han Empire came to face three main kinds of threat that provoked solution by force of arms: rebellions by kings, partly

223 Barbieri-Low and Yates 2015, 216.

224 On this point, see Scheidel 2009, 42-43.

225 On this point, see Weaverdyck, ch. 7, this volume.

226 On the comparatively reluctant treatment of Han commanders by the political center (in contrast, especially, to the honors that were granted to Roman commanders), see De Crespigny 1984, 425.

227 For example, it has been argued that the untypically frequent, tense, and long-lasting wars of the pre-imperial period resulted in a matchless loss of aristocratic power, which then facilitated the intense bureaucratization that was to become a characteristic feature of the early empires (Kiser and Cai 2003). From a different angle, the strong impact of the military on administrative matters can also be recognized in the fact that to Han literati, criminal law appeared to be of military origin. It has also been suggested that the system of mutual responsibility originated in the military sphere (Yates 2009, 25, 32). 
messianic agrarian uprisings, and invasions - especially from the north. The first point refers to the potential dissidence of kings in the eastern part of the empire during the first 100 years of Han rule. The most severe military intervention against the kings' power occurred in 154 BCE, when seven kings, as a reaction to centralization measures curtailing their independence and carving their territories, staged a concerted effort against imperial rule. The abovementioned Rebellion of the Seven Kingdoms (Qi guo zhi luan 七國之亂), ${ }^{228}$ which bore a realistic threat of breaking imperial rule, was eventually brought down by the imperial forces within three months. As a reaction to the revolt, the powers of the kingdoms were reduced even more radically during the subsequent decades, with the result that they could no longer pose any serious threat to imperial sovereignty.

As for the second kind of internal threat, rebellions during the Xin and Later Han dynasties tended to originate not from powerful kings, but from various other social groups, including disheartened peasants. The Red Eyebrows (Chimei 赤眉), an agrarian movement partly formed in response to the floods and famines caused by changes in the course of the Yellow River during Wang Mang's reign, ${ }^{229}$ played an important role in the collapse of the short-lived Xin dynasty. A Daoist movement founded in $142 \mathrm{CE}$, the Way of the Celestial Masters (Tianshi dao 天师道), started a successful rebellion in $184 \mathrm{CE}$, culminating in the establishment of an independent theocratic state in Sichuan. ${ }^{230}$ An agrarian crisis further contributed to the Daoistinspired Yellow Turban Rebellion (Huangjin zhi luan 黄巾之乱), which broke out in $184 \mathrm{CE}$ and could be suppressed in $185 \mathrm{CE}$ only at very high cost: Extensive destruction, millions of casualties, and cession of military power to local leaders eventually contributed to the Han dynasty's downfall. ${ }^{231}$

The third major kind of threat came from outside, particularly from the north, and was of a more continuous nature. In a development suspiciously simultaneous to the creation of the Chinese empires, the nomadic empire of the Xiongnu 仦奴 emerged, who at its acme controlled a territory that extended from the Baikal to the Ordos and from Kazakhstan to Manchuria, including parts of northern China, Mongolia, and the oasis states of the Tarim Basin. The Xiongnu may well be regarded as the most difficult challenge the Han ever had to deal with. It came to have tremendous repercussions both on the empire's frontiers and on its internal developments.

228 See above, sec. IV.1.2.

229 On the Red Eyebrows, see Bielenstein 1986, 243-256.

230 On the movement of the Celestial Masters, originally called Way of the Five Pecks of Rice (Wudoumi dao 五斗米道), see Kleeman 2016.

231 On the Yellow Turbans, see Michaud 1958. 


\section{IV.4.2 Dealing with the Xiongnu}

The challenge that the Xiongnu would eventually pose probably had a strong homegrown component. When the Qin general Meng Tian 蒙恬 (d. 210 BCE) invaded the Ordos within the northern loop of the Yellow River in 215 BCE, this probably created a shortage of pastureland for the Xiongnu tribes located in that area. Along with other factors, this contributed to a Xiongnu crisis, to which these responded by reorganizing their tribal union by a centralization of both political and military power. Under their supreme leader, chanyu 單于 Maodun (or Modun 冒頓, r. 209$174 \mathrm{BCE}$ ), the Xiongnu came to engage in military expansion on a large scale, resulting in a territory of Xiongnu sovereignty that by far outstripped that of the Qin. To their south, they recovered the land that the Qin had taken away from them and pushed the border southward. ${ }^{232}$

At the beginning of their rule, the Han suffered a crushing defeat against Xiongnu forces, which resulted in several defections of Han generals and kings. During the following several decades, the Han largely resorted to diplomatic means by repeatedly ratifying treaties of so-called 'peaceful kinship relations' (heqin 和親). These involved contracted marriages of Chinese princesses to the Xiongnu rulers, but also a yearly payment of silk, cloth, grain, and other foodstuff to the chanyu. ${ }^{233}$ This placed the Han in an inferior political position, which most probably mirrored their actual battlefield inferiority at the northern frontier during the early years of the Han period, especially due to their lack of cavalry forces. ${ }^{234}$ Under Emperors Wen and Jing (i.e., between 179 and 141 BCE), border strengthening against the Xiongnu increased by the reinforcement of border garrisons, the incorporation of surrendered Xiongnu within Han military forces, and the creation of a central standing army positioned near Chang'an. But despite several Xiongnu invasions of considerable scale, which were followed by short-term military responses by the Han, the latter generally retained their largely diplomatic, conciliatory approach. In the peace treaties, they granted further concessions to the Xiongnu, like the establishment of markets along the borders. ${ }^{235}$

It was most likely a conjunction of several factors that eventually led to a more aggressive approach to the Xiongnu under Emperor Wu. Decades of costly pay-

232 Di Cosmo 2002, 174-190. To what extent the simultaneous emergence of these two empires correlated is a matter of debate. On this matter, see Brosseder, ch. 5, this volume.

233 Similar approaches to diplomacy had already been adopted by Chinese states before the unification (Selbitschka 2015, 70-81). On the individual components of the Han-Xiongnu heqin agreements, see also Yü 1967, 10-12; Di Cosmo 2002, 193-196.

234 Early Han campaigns against the Xiongnu were still largely made of infantry and charioteers (Chang 1966, 167; Di Cosmo 2002, 190-193, 231). According to the Hanshu, during the early phase of Han rule, Maodun felt so assured of his superiority as to extend a marriage proposal to empress dowager Lü shortly after Liu Bang's death, which she - after an initial fit of rage - politely declined (Hanshu 94.2755).

235 Di Cosmo 2002, 196-201. 
ments, which had failed to result in lasting peace, had accumulated frustration and certainly encouraged rhetoric in favor of a policy shift. ${ }^{236}$ But there were also good reasons for the Han to be more self-confident with regard to their own strength and military power. First, they had accomplished considerable financial solidity and internal consolidation, especially after the defeat of the Rebellion of the Seven Kingdoms in 154 BCE. And second, they now possessed an effective cavalry force and improved military equipment, for instance through the adoption of ironclad armor and metal helmets, as well as the development of multishot crossbows and precision triggers. ${ }^{237}$ But when the shift to a more militaristic stance was initially put into effect, it was obviously still primarily motivated by defensive aims. At this stage, the scale of territorial expansion that finally ensued does not appear to have been envisioned even by the most hawkish warmongers. ${ }^{238}$

\section{IV.4.3 Northern and Northwestern Campaigns under Emperor Wu}

In 139 BCE, Emperor Wu sent out Zhang Qian 張騫 (195-114 BCE) on his famous expedition to the so-called 'Western Regions' (Xiyu 西域) of the Tarim Basin and beyond in order to seek an alliance against the Xiongnu from the Yuezhi 月氏, who had by this time settled in Bactria. ${ }^{239}$ The expedition was a failure, insofar as Zhang Qian got captured and was held captive by the Xiongnu for a decade, and the Yuezhi finally rejected the Han approach. His expedition was nevertheless essential with regard to the knowledge the Han gained about the Tarim Basin and the Central Asian states. ${ }^{240}$ After another renewal of the heqin treaty in 135 BCE, a first offensive military action against the Xiongnu in 133 BCE ended in a humiliating defeat of Han forces. But during the next years, a series of attacks and counterattacks demonstrated the Han's increased ability to mount expensive campaigns and penetrate deeply into Xiongnu territory. The Ordos, which had been under Xiongnu control since the collapse of the Qin dynasty, was now reconquered by the Han, who extended their

236 Often, those who violated treaty arrangements were subordinate Xiongnu leaders or even defected Chinese commanders, over whom the chanyu failed to have sufficient authority to make them abide by treaty conditions. To support the central authority of the Xiongnu ruler over his subordinates may even have been a major rationale behind the early Han's long-term heqin investments (Di Cosmo 2002, 217-226).

237 On these changing preconditions, see Di Cosmo 2002, 228. For a different view, see Psarras 2003, who argues that the offensive shift was only due to augmented Han pride and unrelated to military developments.

238 Di Cosmo 2011, 228.

239 See Morris, ch. 2, sec. III.1, this volume.

240 The central sources on Zhang Qian and his missions are Shiji 123 and the first part of Hanshu 61 (trans. Watson 1993, 2:231-252; Hulsewé 1979, 207-228). On Zhang Qian's missions, see also Morris, ch. 9; Leese-Messing, ch. 12.A, this volume. 
territory north of the Ordos Loop in 127 BCE. Reportedly, 725,000 poor people from the North China Plain were sent to settle there. Figures like this hint at another potential factor in the dynamics of expansion and colonization. Expansion toward certain areas may have promised economic and social relief by providing opportunities for the emigration of people out of areas where agricultural land had become scarce or had been affected by natural disasters. ${ }^{241}$

In 121 BCE, one of the western regional Xiongnu leaders, the Hunye 渾邪 king, surrendered to the Han with his 40,000 followers, who were then moved out of the Hexi area. In 119 BCE, the two famous Han generals Wei Qing 衛青 (d. 106 BCE) and Huo Qubing 霍去病 (140-117 BCE) marched north on two routes, each of them commanding a force of 50,000 cavalrymen and 100,000 infantrymen. Another 100,000 men and 4,000 horses were mobilized as reinforcement. In the North Desert campaign, the Han legions moved 1,400 km, crossed the Gobi Desert, and finally defeated the chanyu's forces. This battle, while also claiming many Han casualties, inflicted decisive damage on the Xiongnu Empire. As a result, Han-Xiongnu battles of the following decades tended to be of a smaller scale and were usually fought farther to the north. ${ }^{242}$

But these initial successes did not bring military campaigns to a halt. Quite the contrary, they were followed by a "general expansionist impulse" aiming at territorial appropiation and in loco administrative rule in all directions. ${ }^{243}$ During the next decades, the 'four commanderies west of the [Yellow] River' (Hexi si jun 河西四郡) were set up in the Hexi corridor and colonized by Han settlers. They came to be the northwestern extension of Liang 涼 Region, with the commandery of Dunhuang 敦煌 situated farthest to the northwest. ${ }^{244}$ The Xiongnu lost control over several polities of this area from which they had formerly received tribute, ${ }^{245}$ and were furthermore separated from their former southwestern allies, the Qiang 㒸 tribes centered in the high plains of modern Qinghai. ${ }^{246}$ At the same time, the Han Empire gained direct access to the Western Regions of the Tarim Basin and beyond. ${ }^{247}$ Military campaigns in the Western Regions began in 108 BCE with an attack on Loulan 樓蘭 and Jushi

241 Chang 2007a, 201-202, 212.

$242 \mathrm{Li} 2013,275$.

243 Di Cosmo 2009a, 203.

244 The commanderies of Jiuquan 酒泉 and Zhangyi 張掖 were both established no later than 104 BCE, Dunhuang 敦煌 was established at some point between 104 and 91 BCE, and Wuwei 武威 between 81 and 67 BCE (Di Cosmo 2002, 20, 246). On the particularities of frontier commanderies, their function, and administration, see Loewe 1967, 59-61.

245 Especially after the successful campaigns of Wei Qing and Huo Qubing, the Xiongnu were forced to transfer their political and economic centers farther to the northwest. They had also lost former ways of revenue from China (through tribute, border raids and frontier trade), so that the oases of the Tarim Basin evolved into essential sources of supply for the Xiongnu.

246 On the Qiang and their alliance with the Xiongnu, see Yü 1986, 422-425.

247 Yü 1986, 389-391. 
車師 (later Turfan) in the eastern part of the Tarim Basin. The next major Han military victory ensued in 101 BCE with the defeat of Dayuan 大宛 (Ferghana), the result of a four-year campaign that was probably the most expensive of the Han dynasty's entire history. ${ }^{248}$ As a reaction to this demonstration of Han military strength, most of the other states of the Western Regions sent envoys to present tribute to the Han court. The defeat of Dayuan also marked the beginning of the Han strategy of establishing agricultural garrisons (which soon came to be termed tuntian 屯田). The first of these colonies, whose soldier-farmers were supposed to supply Han envoys and armies moving westward, were established at Luntai 輪台 (Bügür) and Quli 渠犁 (Korla, both east of Qiuci 龜茲/ Kucha). During the following decades, the existing agricultural garrisons were expanded, and new ones were set up, for instance, in Jushi. They often included the establishment of sophisticated irrigation networks. The Xiongnu, realizing the significance of this strategy, continued to compete with the Han for supremacy in the Western Regions. The situation at the empire's northern borders was by no means settled by the end of Emperor Wu's rule. The Xiongnu's influence decreased, however, during the following decades. ${ }^{249}$

\section{IV.4.4 Moving Beyond 'Defensive Acquisition'}

Most of the Han Empire's territorial expansion took place under the rule of Emperor $\mathrm{Wu}$, or more concretely, from 129 to $90 \mathrm{BCE} .{ }^{250}$ As for the potential reasons behind the expansionist moves, it is important to remember that the different kinds of actors - such as the emperor, court officials and factions, local magnates, generals, and envoys - are each likely to have had their own distinct motives when arguing for or against a certain strategy. And their motives certainly were not static, since some undertakings were encroachments into proverbial terra incognita, not allowing any fixed plans for their outcomes. Furthermore, the main primary sources providing us with hints of potential motives are evidently biased in this regard. ${ }^{251}$

The historiographic sources make very clear that the conquests toward Central Asia meant a heavy fiscal burden rather than an asset for the Han. ${ }^{252}$ It is safe to say that the northwestern expansion was primarily seen as a defensive means aimed

\footnotetext{
248 Yü 1986, 410.

249 The Wusun 烏孫 for a time had both the Xiongnu and Han send princesses to their ruler, and Loulan had to send hostage princes to both the Xiongnu and Han. The Xiongnu also succeeded once in briefly regaining control over Jushi, which had long served as their breadbasket, before the Han regained control over it in 67 BCE, (Yü 1986, 408-411).

250 Chun-shu Chang (2007a, 67) suggests that the territorial expansion under Emperor Wu amounted to approximately 1.6 million sq. miles (i.e., about 2.6 million sq. $\mathrm{km}$ ).

251 On this matter, see Leese-Messing, ch. 12.A, this volume.

252 For some projections based on respective figures given in the dynastic histories, see Chang 2007a, 245-246.
} 
at 'cutting the right arm of the Xiongnu' (duan Xiongnu you bei 斷洶奴右臂) and isolating their allies. Conquering expeditions to the south and southwest, however, can hardly be explained by this rationale. The sources typically point at self-defense (esp. against border raids), vengeance (against 'unruly' or 'overbearing' rulers), and defense of compliant neighbors against other aggressive ones, but of course, these could easily be used as pretexts. Economic considerations may have played a role in some areas to a certain extent, but are not identified as initial motives of military campaigns. ${ }^{253}$ It is quite evident that increased Han military strength, as demonstrated by their first successful campaigns against the Xiongnu, led to a new kind of self-consciousness that made considerable territorial expansion an option in the first place. Apparently, this new perspective came to make parts of the Han court (including Emperor $\mathrm{Wu}$ himself) think that "spreading authority and virtue within the four seas” (威德遍於四海) by “expanding territory for ten thousand miles” (廣地萬里) ${ }^{254}$ was also valid as an end in itself. This ideological or rhetorical shift, along with emperor Wu's personal vanities, ${ }^{255}$ may have made it easier for individuals or groups to advocate certain expansionist moves, but the individual decisions are better explained against the more complex background of particular motives and political situations rather than on pure ideological grounds.

\section{IV.4.5 Northeastern and southern expansion}

Even though a first abortive attempt at establishing Han authority on the Korean peninsula in 128 BCE was reportedly made as a reaction on Xiongnu incursions into the northeastern commandery of Liaoxi (north of the Bohai Sea, in You 幽 Region), ${ }^{256}$ this is not indicated in the case of Emperor Wu's actual campaigns of conquest in 109-108 всE. This resulted in the defeat of the Joseon Kingdom in the northern half of the Korean peninsula and the creation of four new commanderies in that area. ${ }^{257}$

The most powerful enemy in the south was the kingdom of Nanyue 南越, which, however, never posed a threat comparable to that of the Xiongnu in the north. Han

253 For instance, it has been suggested that Han expansion into the Ordos region may have been connected to the aim of controlling existing trade networks and salt resources. The Han government eventually established several salt offices in this region. See Miller 2015, 143-144; Luo and Luo 1995, 59.

254 Shiji 123.1366.

255 For instance, Sima Qian at times associates emperor Wu's interest in exploring unknown territories with his quest for immortality. See, for instance, Shiji 12.476; 123.3179. See also Loewe 1979, ch. 4.

256 Hanshu 6.169, trans. Dubs 1944, 50.

257 These came to be the eastern extension of You 幽 Region. On the expansion to the Korean peninsula, see Byington 2014; Yü 1986, 446-451. 
expeditions against the kingdom of Nanyue were sent out on river ships in 112 BCE as a reaction to the murder of the Nanyue queen dowager, who was of Han origin and had agitated for an incorporation of the kingdom into the Han Empire. The successful military campaign was concluded by the establishment of several commanderies in what came to be termed the Jiao 交 (or Jiaozhi 交趾) Region, which extended into the north of modern Vietnam. ${ }^{258}$ But with its rugged topography and its sparse, ethnically diverse population, the south never came to be viewed as suitable for widespread immigration by the Han. Nevertheless, the Han conquests evidently had a strong impact on the southern peoples' (and especially their elites') political and material culture, as well as on their social structure. ${ }^{259}$

In an attempt to use the southwestern polity of Yelang 夜郎 situated along the Zangke 牂牁 River ${ }^{260}$ for attacks on Nanyue, a new commandery south of the Sichuan Basin had been established in 135 BCE. After a preliminary suspension of further advances in this area, new interest was sparked by Zhang Qian's reports on Daxia 大夏 (Bactria) in which he said he had observed products from the Sichuan Basin that had been brought there via Shendu 身毒 (India) for sale. ${ }^{261}$ A subsequent southwestern expedition, sent out to find a southern route to Bactria by which to avoid the routes under Qiang and Xiongnu dominion, ended in a failure. The actual phase of southwestern conquests started right after the defeat of Nanyue in 112 BCE. As a result, many southwestern local rulers submitted to the Han, and several new commanderies were founded in the south of the Yi 益. Region (modern Yunnan and Guizhou Provinces).

\section{IV.4.6 Major frontier developments after Emperor Wu}

During the decades following the rule of Emperor $\mathrm{Wu}$, the Han were able to consolidate their presence in the Tarim Basin. In 60 or 59 BCE, they established the office of protector-general of the Western Regions (Xiyu duhu 西域都護) with its military headquarters in the city-state of Wulei 烏壘. ${ }^{262}$ Being an adaption of a former Xiongnu office with similar functions, the protector-general, together with his staff, was supposed to act as the chief Han representative in the Western Regions, and ideally maintain Han supremacy over the polities and regulate interactions among them. The number of soldiers under his command is not known, but most likely comprised only a small number. Additionally, the offices of $\mathrm{Wu}$ colonel and Ji colonel $(\mathrm{Wu} J i$

258 On the expansion to the far south, see Yü 1986, 451-455.

259 Allard 2017; Di Cosmo 2009a.

260 This was possibly the designation of the river now known as the Beipan 北盤 River in modern Guizhou Province.

261 Shiji 123.3166, trans. Watson 1993, 2:235-236; Hanshu 61.2689-2690, trans. Hulsewé 1979, 211213.

262 Hill 2015, 1:413-415, n. 20.10. 
xiaowei 戊己校尉) were created in 48 всE. They were seated in Jushi and responsible for the agricultural garrisons of the area, but also for some diplomatic and military undertakings. ${ }^{263}$ An attempt to fully integrate the Western Regions into regular Han administrative structures, for instance by turning them into commanderies, was never made.

In addition to Han diplomatic and military advances, the Xiongnu were further weakened by internal leadership struggles and regionalist divisions. In 51 BCE, the chanyu Huhanye 呼韓邪 agreed to Han peace terms, accepted the status of 'outer vassal' (waichen 外臣), and sent his son to the Han court as a hostage prince. The Han Empire then enjoyed several decades of unprecedented tranquility at the northern borders.

There was a reshuffling of Han-Xiongnu relations during the period of political upheaval beginning at the end of the Former Han, which the Xiongnu were able to take as an opportunity to regain control over the Tarim Basin polities. Generally speaking, the 'expansionist impulse' and quest for in loco administration that had been initiated during the time of Emperor Wu was replaced by a more reluctant treatment of frontier zones in general and the Western Regions in particular under the Later Han. Even upon the invitation of several oasis states, the founder of the Later Han (Emperor Guangwu) refused to reestablish the Western Regions protectorate. Luckily for the Han, the Xiongnu again suffered from internal power struggles, which led to their split in $48 \mathrm{CE}$ into the Northern and Southern Xiongnu. The Southern Xiongnu under Chanyu Bi 比, who were hard pressed not only by their northern counterpart, but also by famine and epidemics, submitted to the Han in $50 \mathrm{CE}$. Bi was ordered to move his court to Han territory, along the Yellow River in the eastern part of the Ordos Loop. ${ }^{264}$ Many Xiongnu were resettled to eight different commanderies on the northern frontier. The Han also forced large numbers of their own population to migrate to the same commanderies, thereby creating mixed Han-Xiongnu settlements. $^{265}$

Even though both the relations to the Northern Xiongnu and to the submitted Southern Xiongnu, to whom the Han government paid large annual subsidies, remained far from smooth, ${ }^{266}$ the power of the Xiongnu had decreased considerably in comparison to the Former Han period. Two major conflicts with the Northern Xiongnu in 73 and $89 \mathrm{CE}$ both ended in the latter's defeat. ${ }^{267}$ The Han reconquered Yiwu and Jushi, and reestablished the offices of protector-general of the Western

263 Yü 1986, 411; Bielenstein 1980, 110.

264 On map 3, this is the region of Shuofang's eastern part. This part, however, was integrated into the region of Bing in $45 \mathrm{CE}$.

265 On the Han-Xiongnu relations of this period, see De Crespigny 1984, 173-227.

266 There were several rebellions attempted by Southern Xiongnu leaders (partly inspired and aided by Han frontier settlers), and wars with the Northern Xiongnu broke out periodically (Yü 1986, 400-405).

267 Yü 1986, 404, 421. 
Regions and of the $\mathrm{Wu}$ and Ji colonels in $92 \mathrm{CE}^{268}$ In $94 \mathrm{CE}$, more than 50 states of the Western Regions sent hostages with tribute to Luoyang. Nevertheless, the Later Han government generally showed a strong tendency toward downgrading its very costly colonies and adminstrative establishment in the Western Regions.

After 15 years of strong Han dominance in the Tarim Basin, the office of protector-general of the Western Regions was permanently abolished in $107 \mathrm{CE}$ and replaced only by lower ranking offices. The Wu and Ji colonels continued to be appointed almost up to the Han's downfall, but the empire considerably reduced its presence in the Western Regions, where it had thus lost its position of dominance by the middle of the second century CE. ${ }^{269}$

After the Xiongnu threat had been largely brought under control, new threats arose, especially during the second century CE. To the north, the pastoralist confederation of the Xianbei 鮮卑 largely took over the Xiongnu's formerly dominating position over the steppes. While the people of the Wuhuan in the northeast largely acted as Han allies, Xianbei raids heavily affected the imperial borders of the You and Bing Regions. Confrontations culminated in a military campaign against the Xianbei in $177 \mathrm{CE}$, which resulted in a humiliating defeat of Han forces. ${ }^{270}$

Another threat came from the Qiang tribes in the west. Their population appears to have increased during this period, and many of them had settled within the imperial borders. When a large-scale Qiang rebellion broke out in $110 \mathrm{CE}$, the Han reacted by largely abandoning several frontier areas belonging to Liang Region. Conflicts continued during the next decades, and in $140 \mathrm{CE}$, large-scale Qiang raids even reached the Metropolitan Region (Sili 司隸). Numerous costly and partly genocidal campaigns $^{271}$ did not result in a long-term stabilization of the area. In $184 \mathrm{CE}$, at a point when the Han dynasty had already been considerably weakened by other rebellions and internal power struggles, large-scale uprisings including Qiang, Xiongnu, Lesser Yuezhi, ${ }^{272}$ and Han people broke out in several areas of Liang Region, which eventually came to play a considerable role in the final fall of the Han Empire. ${ }^{273}$

268 An earlier reestablishment of the offices in $74 \mathrm{CE}$ had been followed by an attack of the protector-general by the states of Yanqi (Karashahr) and Jiuzi (Kucha) in $75 \mathrm{CE}$, after which the posts were abolished again until 92 CE (Bielenstein 1980, 112-113). For a Central Asian perspective on this interlude, see Morris, ch. 2, this volume.

269 Yü 1986, 421.

270 On the Han Empire's relations to the Xianbei and Wuhuan, see De Crespigny 1984, chs. 7-9.

271 The latter is true for the brutal campaigns of Duan Jiong in the late 160s (De Crespigny 1984, 126-146; 2009, 104-105, 109).

272 Reportedly, these were Yuezhi people who had not migrated to Bactria and had partly settled among the Qiang.

273 For an overview of the history of Han-Qiang relations, see Yü 1986, 422-436. For a more extensive treatment, see De Crespigny 1984, 54-172. 


\section{IV.4.7 Composition of Armies and Military Conscription}

The Han Empire took over the Qin's system of universal military conscription. At least in theory, all able-bodied men (except for those who had gained high honorary ranks) aged 23 (originally 20) to 56 (60 during Qin times) were liable for military service as conscripts ( $z u$ 卒). This entailed one year of service (including training) in their home commanderies and another year of service as guards or soldiers, either in the capital, in the commanderies, or at the frontier. After these two years, the conscripts were sent home to resume their civilian lives, forming a local militia under the direction of their home commandery's commandant (duwei) that could be mobilized in case of need. During the Former Han period, the militia was called up for an annual exercise and inspection on the commandery level in the eighth month.

From the very beginning (and as a continuation from Warring States times), the imperial armed forces included both conscripts and paid, partly long-term soldiers (bing 兵). ${ }^{274}$ Elite troops with special training largely bore the burden of direct combat on the frontiers, while the usual conscripts, who probably formed the greater part of the armed forces, were typically employed as carriers and guards. ${ }^{275}$ Apart from the militia in the commanderies, there was also a standing army near the capital, Chang'an, comprising professional combat forces that could be used for suppressing internal rebellions or for fighting at the frontier. During the Later Han, larger permanent forces were also stationed in other permanent camps in the 'area within the passes' and northeast of the new capital, Luoyang. ${ }^{276}$

Since the time of Emperor $\mathrm{Wu}$, forces of paid recruits and, especially, convicted criminals came to be mobilized more frequently. They provided partly long-term troops for frontier garrison duty and lengthy expeditions. In addition, surrendered non-Chinese tribes were increasingly relied upon, especially for frontier defense, but also for some offensive campaigns. ${ }^{277}$

The reliance on the formerly essential system of universal military service further decreased under the Later Han. Emperor Guangwu abolished both the year of service in the commanderies (and thereby, most probably, the period of intensive training) as well as the annual exercises and inspections of the militia. The formerly permanent office of commandant, who had been responsible for the commandery militia, was reduced to a temporary office that was created only for the duration of crisis. ${ }^{278}$ It remains a matter of dispute whether the second year of military service

274 Loewe 2004, 204; Di Cosmo 2002, 233.

275 Lewis 2000, 35-46.

276 At least of one of these large camps was manned by troops recruited from reprieved convicts and former military colonists (Lewis 2000, 51-52).

277 Yü 1967, 14.

278 Some scholars have argued that frontier commanderies continued to have permanent commandants, but this point remains unclear. See the discussion in Lewis 2000, 36-37. 
was abolished as well, or if universal military service was from then on limited to a mere emergency levy. ${ }^{279}$ In general, the changes institutionalized an interior demilitarization and a concentration of forces in the frontier zones, whose inhabitants many of whom were formally subjected non-Chinese people - also had to bear the main burden of military contributions. But both the motives and the repurcussions of these changes are still poorly understood. Lewis suggested that three factors drove emperor Guangwu to his reforms. First, the reforms fit into a campaign to reduce government expenditures at the beginning of the Later Han period. Second, well-trained peasant levies came to be seen as a potential threat to the government, especially after local officials and members of powerful families (including emperor Guangwu himself) had been able to make use of conscripted commandery forces to overthrow Wang Mang's Xin dynasty. And third, in order to secure the distant frontiers, the empire was in need for permanent deployment of troops with local expertise, which the short-term presence of conscripts failed to provide. ${ }^{280}$

Ultimately, the policy of interior demilitarization contributed to a decentralized remilitarization: Semiprivate armies under the control of the increasingly powerful regional inspectors (formerly cishi, later "sheperds”, $m u$ ) and of powerful families evolved. Both of them, along with the increasing military power of non-Chinese inhabitants of the border zones, evidently played active roles in the downfall of the Han dynasty. ${ }^{281}$

\section{IV.4.8 Flexible and Changing Patterns of Integration}

As for the means of Han territorial expansion and for the question how deeply Han 'authority and virtue' were to be imposed on subjugated areas, the empire's approaches were necessarily flexible. Mostly, the strategic pattern in all areas of conquest was a combination of military intervention against the strongest and most obvious hostile powers, and diplomatic relations with the weaker, less assuming ones. Foreign leaders and their associates who were willing to submit were also rewarded and honored by means of gifts and official Han titles. ${ }^{282}$ Marriage relations continued to be used as a diplomatic means even after the alleged renouncement of the heqin strategy under Emperor $\mathrm{Wu}$, and surrendered foreign leaders were at

\footnotetext{
279 Lewis 2000, 36.

280 Lewis 2000, 40-43; See also De Crespigny 1984, 45-53.

281 Lewis 2000, 69-74.

282 According to Hanshu 96B.3928, toward the end of the Former Han period there were 376 official Han titles (ranging from interpreters to generals, marquises and kings) that had been awarded to people from fifty states of the Western Regions. Imperial gifts to the Xiongnu remained substantial even during phases of relative weakness on the part of the Xiongnu. On the Han payments of silk to the Xiongnu between 51 and 1 BCE, see Yü 1986, 396-397.
} 
times required to send children as hostages to the Han court. ${ }^{283}$ At the shifting edges of the empire, varying levels of incorporation into the Han political and administrative system were attempted. While even the frontier zones labeled as 'commanderies' tended to be much less integrated than the commanderies of the interior, this is even more true for areas like the Tarim Basin, in which no commandery administrations were established. Tax levies on surrendered non-Chinese varied considerably over time, from area to area, and from group to group. They tended to be lighter than those demanded from Chinese subjects, with some not being taxed from the time of Emperor Wu's conquest until the early Later Han period. Labor and military service obligations could, however, be heavy at times, and therefore led to several revolts, both in Former and Later Han times. ${ }^{284}$

As for a particular form of integrating frontier zones, from 121 BCE onward, the Han occasionally came to establish 'dependent states' (shuguo 屬國) for areas or states situated outside imperial borders or semiautonomous enclaves within commanderies, whose inhabitants were mainly non-Chinese (e.g., Xiongnu or Qiang). Their leaders had formally recognized Han superiority, and it was hoped that they would remain loyal to the Han and act as buffer zones against more ill-disposed and powerful rivals beyond the borders. At least in part, inhabitants of the shuguo rendered labor or military services to the Han government. The 'dependent states' were integrated into Han administration by the establishment of centrally controlled administrative structures and personnel, albeit on a fairly minimal scale and of basically supervisory nature. In the course of time, however, quite a few of them were transformed into regular commanderies. In other instances, their establishment could be indicative of the decline of central authority: During the Later Han period, several areas that had formerly been part of a commandery came to be declared shuguo. ${ }^{285}$ The policy of letting non-Chinese people settle within the borders in the north and northwest also led to conflicts of interest with Chinese settlers in these areas. This contributed to the latters' massive southward migration out of these frontier zones, which again made their defense a serious problem during the Later Han period. ${ }^{286}$

\section{Conclusion}

After a short introduction of the imperial space of the Qin and Han Empires, this chapter provided an account of important developments of the pre-imperial period.

283 Di Cosmo 2009a, 203; Selbitschka 2015.

284 Yü 1967, 78-89.

285 On the shuguo, see Loewe 1967, 61-64; Bielenstein 1980, 109, esp. n. 139 on 189-190; De Crespigny 1984, 3, esp. n. 4 on 447-449; Yü 1967, 72-78.

286 De Crespigny 1984, 72-75. 
The Qin Empire emerged from a specific historical context in which several roughly equal neighboring polities, the 'Warring States,' competed for power. Their relations were marked by violent wars, but also by increasing communication, exchanges of personnel, and cultural convergence. Furthermore, the individual polities had already developed similar institutions of bureaucratic administration before their political unification in 221 BCE. Both of these historical factors were decisive prerequisites for the emergence of the early Chinese empires.

After the political unification under the First Emperor, the Qin Empire lasted for only 15 years. However, it was soon followed by the long-lived Han Empire. Han rulers, while adopting many Qin institutions, were initially forced to follow a less all-encompassing approach to centralized administration than their predecessors. The fact that the consolidation of power during early Han rule took place as a gradual process over several decades may have contributed to the dynasty's persistence in comparison to the short-lived Qin Empire.

The overview of imperial institutions has focused on a few features of the Qin and Han Empires that can be regarded as especially characteristic. While many of these institutions are fairly well understood due to the ideological and practical emphasis on bureaucratic, rationalized administration, structural questions about the dynamic interactions between different social, economic, and political institutions remain. For example, while the ancient sources occasionally describe how specific foreign and domestic policies influenced each other, we do not fully understand the broader pattern of the interaction between these spheres nor the underlying societal forces that shaped it. Much work remains to be done to integrate political, social, economic, and ideological developments into a more holistic understanding of early imperial society. Recent comparisons between the Roman and the early Chinese empires have provided several imporant insights and impulses in this regard, but further comparative research is necessary to better understand the similarities and particularities of different imperial structures and mechanisms.

This type of research will be particularly rewarding now because the study of early imperial Chinese history is currently in a state of flux. With all the new textual and material evidence being continuously unearthed from tombs and hoards, the picture of the early imperial period is under constant revision. After 2,000 years of almost exclusive reliance on transmitted texts, excavated texts are now revealing fresh and sometimes disturbing insights into the achievements, but also the problems and failures of the Qin and Han Empire's attempts at centralized administration in regional contexts. This is especially true for the imperial peripheries, where the bulk of bamboo and wooden administrative documents have been found. It is, therefore, with regard to the imperial peripheries in particular that current and future research on the history of the early imperial period is likely to provide new and more systematic interpretations of Qin and Han administration. Furthermore, research on several massive finds of material evidence from tombs that have been excavated all over the former Qin and Han territory has only just begun. It is to be 
expected that these new finds, in combination with the potential of new digital humanities approaches, will significantly alter our picture of early imperial social structures.

\section{References}

Allard, F. 2017. "Globalization at the crossroads: The case of southeast China during the preand early imperial period." In T. Hodos (ed.), The Routledge handbook of archaeology and globalization, 454-469. London: Routledge.

Bagley, R. W. 2001. Ancient Sichuan: Treasures from a lost civilization. Seattle, WA: Seattle Art Museum.

Bang, P. F. 2009. "Commanding and consuming the world: Empire, tribute, and trade in Roman and Chinese history." In W. Scheidel (ed.), Rome and China: Comparative perspectives on ancient world empires, 100-120. Oxford: Oxford University Press.

Barbieri-Low, A. J. 2000. "Wheeled vehicles in the Chinese Bronze Age (c. 2000-741 BC)." Sino-Platonic Papers 99.

-. 2007. Artisans in early imperial China. Seattle, WA: University of Washington Press.

Barbieri-Low, A. J., and R. D. S. Yates. 2015. Law, state, and society in early imperial China: A study with critical edition and translation of the legal texts from Zhangjiashan tomb no. 247. 2 vols. Leiden: Brill.

Barfield, T. 2001. "The shadow empires: Imperial state formation along the Chinese-Nomad frontier.” In S. E. Alcock, T. N. D’Altroy, K. D. Morrison, and C. M. Sinopoli (eds.), Empires: Perspectives from archaeology and history, 10-41. Cambridge: Cambridge University Press.

Beck, B. J. M. 1986. "The fall of Han." In D. Twitchett and M. Loewe (eds.), The Cambridge history of China. Vol. 1, 317-376. Cambridge: Cambridge University Press.

Bestel, S., G. W. Crawford, L. Liu, J. Shi, Y. Song, and X. Chen. 2014. "The evolution of millet domestication, middle Yellow River region, north China: Evidence from charred seeds at the late upper Paleolithic Shizitan locality 9 site." The Holocene 24.3, 261-265.

Bielenstein, H. 1947. "The census of China during the period 2-742 AD." Bulletin of the Museum for Far Eastern Antiquities 19, 125-163.

-. 1980. The bureaucracy of Han times. Cambridge: Cambridge University Press.

-. 1986. "Wang Mang, the restoration of the Han dynasty, and Later Han." In D. Twitchett and M. Loewe (eds.), The Cambridge history of China. Vol. 1, 223-290. Cambridge: Cambridge University Press.

Bodde, D. 1986. "The state and empire of Ch'in." In D. Twitchett and M. Loewe (eds.), The Cambridge history of China. Vol. 1, 20-102. Cambridge: Cambridge University Press.

Bray, F. 1984. Science and civilisation in China. Vol. 6, Biology and biological technology. Part 2, Agriculture. Cambridge: Cambridge University Press.

Byington, M. E., ed. 2013. The Han commanderies in early Korean history. Cambridge, MA: Harvard University Korea Institute.

Chang, C. 1966. "Military aspects of Han Wu-Ti's northern and northwestern campaigns." Harvard Journal of Asiatic Studies 26, 148-173.

-. 2007a. The rise of the Chinese Empire. Vol. 1, Nation, state, and imperialism in early China, ca. $1600 B C-A D$ 8. Ann Arbor, MI: University of Michigan Press.

-. 2007b. The rise of the Chinese Empire. Vol. 2, Frontier, immigration, and empire in Han China, $130 B C-A D$ 157. Ann Arbor, MI: University of Michigan Press.

Chen Wei 陳偉, ed. 2012. Liye Qin jiandu jiaoshi (di yi juan) 里耶秦简牍校释 (第一卷) [A critical and annotated edition of the Qin bamboo and wooden slips from Liye. Vol. 1]. Wuhan: Wuhan daxue chubanshe. 
Ch'ü, T. 1972. Han social structure. Seattle, WA: University of Washington Press.

Crowell, W. G. 1984. Review of The bureaucracy of Han times, by Hans Bielenstein. Journal of the American Oriental Society 104.3, 559-562.

Csikszentmihalyi, M., and M. Nylan. 2003. "Constructing lineages and inventing traditions through exemplary figures in early China." T'oung Pao 89.1-3, 59-99.

de Crespigny, R. 1984. Northern frontier: The policies and strategies of the Later Han Empire. Canberra: Australian National University Faculty of Asian Studies.

-. 2009. “Military culture of Later Han.” In N. Di Cosmo (ed.), Military culture in imperial China, 90-111. Cambridge, MA: Harvard University Press.

-. 2016. Fire over Luoyang: A history of the Later Han dynasty, 23-220 AD. Leiden: Brill.

Di Cosmo, N. 2002. Ancient China and its enemies: The rise of nomadic power in East Asian history. Cambridge: Cambridge University Press.

-. 2009a. "Han frontiers: Toward an integrated view." Journal of the American Oriental Society 129.2, 199-214.

-. 2011. "Ethnogenesis, coevolution and political morphology of the earliest steppe empire: The Xiongnu question revisited.” In U. Brosseder and B. K. Miller (eds.), Xiongnu archaeology: Multidisciplinary perspectives of the first steppe empire in Inner Asia, 35-48. Bonn: Vor- und frühgeschichtliche Archäologie, Rheinische Friedrich-Wilhelms-Universität Bonn.

-. 2015. "China-steppe relations in historical perspective." In J. Bemmann and M. Schmauder (eds.), Complexity of interaction along the Eurasian steppe zone in the first millennium CE, 49-72. Bonn: Vor- und frühgeschichtliche Archäologie, Rheinische Friedrich-WilhelmsUniversität Bonn.

Du Zhengsheng 杜正勝. 1990. Bianhu Qimin: Chuantong zhengzhi shehui jiegou zhi xingcheng 編戶齊民：傳統政治社會結構之形成 [Bianhu qimin: The formation of the structures of traditional political society]. Taibei: Lianjing chuban shiye gongsi.

Dubs, H. H. 1944. The history of the Former Han dynasty by Pan Ku. Vol. 2, The imperial annals VI-X. Baltimore, MD: Waverly Press.

Dull, J. L. 1983. “Anti-Qin rebels: No peasant leaders here.” Modern China 9.3, 285-318.

Duyvendak, J. J. L. 1928. The Book of Lord Shang: A classic of the Chinese school of law, translated from the Chinese with introduction and notes. London: A. Probsthain.

Ebrey, P. 1982. Review of The quality of mercy: Amnesties and traditional Chinese justice by Brian McKnight. The Journal of Asian Studies 41.3, 581-582.

-. 1983. "Patron-client relations in the Later Han." Journal of the American Oriental Society 103.3, 533-542.

-. 1986. "The economic and social history of Later Han." In D. Twitchett and M. Loewe (eds.), The Cambridge history of China. Vol. 1, 608-648. Cambridge: Cambridge University Press.

Eich, P. 2015. "The common denominator: Late Roman imperial bureaucracy from a comparative perspective." In W. Scheidel (ed.), State power in ancient China and Rome, 90-149. Oxford: Oxford University Press.

Elman, B. A. 2013. Civil examinations and meritocracy in late imperial China. Cambridge, MA: Harvard University Press.

Galambos, I. 2004. "The myth of the Qin unification of writing in Han sources." Acta Orientalia Academiae Scientiarum Hungaricae 57.2, 181-203.

Gao Min 高敏. 2003. “Cong Zhangjiashan Han jian ‘Ernian Lüling’ kan Xi-Han qianqi de tudi zhidu: Du 'Zhangjiashan Han mu zhujian' zhaji zhi san” 從張家山漢簡《二年律 令》看西漢前期的土地制度一讀《張家山漢墓竹簡》札記之三 [The Han-period 'Ernian Lüling' slips from Zhangjiashan as evidence for the early Western Han system of land tenure]. Zhongguo Jingji Shi Yanjiu 中国经济史研究, no. 3, 143-147.

Ge Jianxiong 葛剑雄. 2005. Zhongguo renkou shi: Daolun, Xian Qin zhi Nanbeichao shiqi 中国人口史 (第一卷) : 导论、先秦至南北朝时期 [Demographic history of China. Vol. 1, 
Introduction, and from pre-Qin times to the Southern and Northern Dynasties]. Shanghai: Fudan daxue chubanshe.

Giele, E. 2006. Imperial decision-making and communication in early China: A study of Cai Yong's Duduan. Wiesbaden: Harrassowitz.

Goldin, P. R. 2011. "Persistent misconceptions about Chinese 'legalism." Journal of Chinese Philosophy 38.1, 88-104.

Graham, A. C. 1986. Yin-Yang and the nature of correlative thinking. Singapore: Institute of East Asian Philosophies.

Guo, J. 2011. "Concepts of death and the afterlife reflected in newly discovered tomb objects and texts from Han China." In A. Olberding and P. J. Ivanhoe (eds.), Mortality in traditional Chinese thought, 85-115. Albany, NY: State University of New York Press.

Henderson, J. B. 1984. The development and decline of Chinese cosmology. New York: Columbia University Press.

Han Lianqi 韩连琪. 1986. “Chunqiu Zhanguo shidai de junxian zhi ji qi yanbian” 春秋战国时代的郡县制及其演变 [The junxian system of the Chunqiu and Zhanguo periods and its development]. Wenshizhe 文史哲 5, 38-47.

Hill, J. E. 2015. Through the Jade Gate - China to Rome: A study of the silk routes 1st to 2nd centuries CE. New updated and expanded edition. 2 vols. Self-published, CreateSpace.

Hanshu 漢書 [Documents of the Han]. 1962. Composed by Ban Gu 班固 (32-92 CE). Beijing: Zhonghua shuju.

Hou Hanshu 後漢書 [Documents of the Later Han]. 1965. Composed by Fan Ye 范瞱 (398-445 CE). Beijing: Zhonghua shuju.

Hou Xiaorong 后曉榮. 2009. Qin dai zhengqu dili 秦代政區地理 [Geography of administrative regions in the Qin period]. Beijing: Shehui kexue wenxian chubanshe.

Houn, F. 1956. "The civil service recruitment system of the Han dynasty." Tsing-Hua Hsueh-Pao 清華學報, 138-164.

Huainanzi jishi 淮南子集釋 [The Huainanzi with collected commentaries]. 1998. Compiled by Liu An 劉安 (ca. 179-122 BCE). Edited by He Ning 何寧. Beijing: Zhonghua shuju.

Hsing, I. 2014. "Qin-Han census and tax and corvée administration: Notes on newly discovered materials." In Y. Pines, G. Shelach, L. von Falkenhausen, and R. D. S. Yates (eds.), Birth of an empire: The state of Qin revisited, 155-186. Berkeley, CA: University of California Press.

Hulsewé, A. F. P. 1955. Remnants of Han law. Vol. 1, Introductory studies and an annotated translation of chapters 22 and 23 of the History of the Former Han Dynasty. Leiden: Brill.

-. 1959. "The Shuo-wen dictionary as a source for ancient Chinese law." In S. Egerod and

E. Glahn (eds.), Studia Serica Bernhard Karlgren Dedicata: Sinological Studies Dedicated to Bernhard Karlgren on his seventieth birthday, October fifth, 1959, 239-258. Copenhagen: Ejnar Munksgaard.

-. 1979. China in Central Asia: The early stage: 125 BC-AD 23: An annotated translation of chapters 61 and 96 of the History of the Former Han Dynasty, with an introduction by $M$. . A. N. Loewe. Leiden: Brill.

-. 1981. "The legalists and the laws of Ch'in." In W. L. Idema (ed.), Leyden studies in Sinology: Papers presented at the conference held in celebration of the fiftieth anniversary of the Sinological Institute of Leyden University, December 8-12, 1980, 1-22. Leiden: Brill.

-. 1985. Remnants of Ch'in law: An annotated translation of the Ch'in legal and administrative rules of the 3rd century BC discovered in Yün-Meng Prefecture, Hu-Pei Province, in 1975. Leiden: Brill.

Hunan sheng wenwu kaogu yanjiusuo 湖南省文物考古研究所, ed. 2006. Liye fajue baogao 里耶发掘报告 [Liye Excavation Report]. Changsha: Yuelu chubanshe.

-, ed. 2012. Liye Qin jian (yi) 里耶秦簡（壹) [The Qin slips from Liye (1)]. Beijing: Wenwu chubanshe. 
-, ed. 2017. Liye Qin jian (er) 里耶秦簡（武）[The Qin slips from Liye (2)]. Beijing: Wenwu chubanshe.

Kelly, C. 2004. Ruling the Later Roman Empire. Cambridge, MA: Belknap Press of Harvard University Press.

Khayutina, M. 2010. "Royal hospitality and geopolitical constitution of the Western Zhou polity." T'oung Pao 96.1-3, 1-73.

-, ed. 2013. Qin: The eternal emperor and his terracotta warriors. Zurich: Neue Zürcher Zeitung Publishing.

Kiser, E., and Y. Cai. 2003. "War and bureaucratization in Qin China: Exploring an anomalous case." American Sociological Review 68.4, 511-539.

Kleeman, T. F. 2016. Celestial Masters: History and ritual in early Daoist communities. Cambridge, MA: Harvard University Asia Center.

Korolkov, M. 2017. "Legal process unearthed: A new source of legal history of early imperial China." Journal of the American Oriental Society 137.2, 383-391.

Lau, U. 2002. "Die Rekonstruktion des Strafprozesses und die Prinzipien der Strafzumessung zu Beginn der Han-Zeit im Lichte des Zouyan shu." In R. Emmerich and H. Stumpfeldt (eds.), Und folge nun dem, was mein Herz begehrt: Festschrift für Ulrich Unger zum 70. Geburtstag, 343-95. Hamburg: Hamburger Sinologische Gesellschaft.

-. 2005. "The scope of private jurisdiction in early imperial China: The evidence of newly excavated legal documents." Asiatische Studien / Études Asiatiques 59.1, 333-352.

Lau, U., and M. Lüdke. 2012. Exemplarische Rechtsfälle vom Beginn der Han-Dynastie: Eine kommentierte Übersetzung des Zouyanshu aus Zhangjiashan/Provinz Hubei. Tokyo: Research Institute for Languages and Cultures of Asia and Africa, Tokyo University of Foreign Studies.

Lau, U., and T. Staack. 2016. Legal practice in the formative stages of the Chinese Empire: An annotated translation of the exemplary Qin criminal cases from the Yuelu Academy Collection. Leiden: Brill.

Lewis, M. E. 1990. Sanctioned violence in early China. Albany, NY: State University of New York Press.

-. 1999. "Warring States: Political history." In M. Loewe and E. L. Shaughnessy (eds.), The Cambridge history of ancient China: From the origins of civilization to 221 BC, 587-650. Cambridge: Cambridge University Press.

-. 2000. "Han abolition of universal military service." In H. van de Ven (ed.), Warfare in Chinese history, 33-76. Leiden: Brill.

-. 2007. The early Chinese empires: Qin and Han. Cambridge, MA: Belknap Press of Harvard University Press.

-. 2015. "Early imperial China, from the Qin and Han through Tang." In A. Monson and W. Scheidel (eds.), Fiscal regimes and the political economy of premodern states, 282-307. Cambridge: Cambridge University Press.

Li, F. 2006. Landscape and power in early China: The crisis and fall of the Western Zhou, 1045-771 $B C$. Cambridge: Cambridge University Press.

-. 2013. Early China: A social and cultural history. Cambridge: Cambridge University Press.

Li Yaguang 李亚光. 2009. Zhanguo nongye shigang 战国农业史纲 [Concise history of Warring States agriculture]. Changchun: Jilin daxue chubanshe.

Lightfoot, E., X. Liu, and M. K. Jones. 2013. "Why move starchy cereals? A review of the isotopic evidence for prehistoric millet consumption across Eurasia." World Archaeology 45.4, 574623.

Liu Zehua 刘泽华. 2004. Xian Qin shiren yu shehui 先秦士人与社会 [The shi and society during the pre-Qin period]. Tianjin: Tianjin renmin chubanshe.

Loewe, M. 1960. "The orders of aristocratic rank of Han China." T'oung Pao 48.1, 97-174.

-. 1967. Records of Han administration. 2 vols. Cambridge: Cambridge University Press. 
-. 1979. Ways to paradise: The Chinese quest for immortality. London: Allan and Unwin.

-. 1986a. "The conduct of government and the issues at stake (AD 57-167)." In D. Twitchett and M. Loewe (eds.), The Cambridge history of China. Vol. 1, 291-316. Cambridge: Cambridge University Press.

-. 1986b. "The Former Han dynasty." In D. Twitchett and M. Loewe (eds.), The Cambridge history of China. Vol. 1, 103-222. Cambridge: Cambridge University Press.

-, ed. 1993. Early Chinese texts: A bibliographical guide. Berkeley, CA: The Society for the Study of Early China and University of California Institute of East Asian Studies.

-. 2000. A biographical dictionary of the Qin, Former Han and Xin periods (221 BC-AD 24). Leiden: Brill.

-. 2004. The men who governed Han China: Companion to a biographical dictionary of the Qin, Former Han and Xin periods. Leiden: Brill.

-. 2006. The government of the Qin and Han Empires: 221 BCE-220 CE. Indianapolis, IN: Hackett Publishing Company.

-. 2010a. "Social distinctions, groups and privileges." In M. Nylan and M. Loewe (eds.), China's early empires: A re-appraisal, 296-307. Cambridge: Cambridge University Press.

-. 2010b. "The operation of the government." In M. Nylan and M. Loewe (eds.), China's early empires: A re-appraisal, 308-320. Cambridge: Cambridge University Press.

Lunheng jiaoshi 論衡校釋 [The Lunheng with collated explanations]. 1990. Composed by Wang Chong 王充 (first century CE). Edited by Huang Hui 黄暉. Beijing: Zhonghua shuju.

Luo Qinkang 罗庆康 and Luo Wei 罗威. 1995. “Han dai yanzhi yanjiu” 汉代盐制研究 [Study on salt administration during the Han period]. Yanye shi yanjiu 盐业史研究, no. 1, 54-63.

Lü Wenyu 吕文郁. 1989. “Caiyi zhi de shuaibai ji qi zai Zhongguo lishi shang de cancun xingtai” 采邑制的衰败及其在中国历史上的残存形态 [The decline of the fief institution and its surviving forms throughout Chinese history]. Jilin Daxue Shehui Kexue Xuebao 吉林大学社会科学学报, no. 4, 84-89.

Ma, T. W. 2017. "Scribes, assistants, and the materiality of administrative documents in Qin-early Han China: Excavated evidence from Liye, Shuihudi, and Zhangjiashan." T'oung Pao 103.4-5, 297-333.

Major, J. S., and C. A. Cook. 2017. Ancient China: A history. London: Routledge.

Mann, M. 1986. The sources of social power. Vol. 1, A history of power from the beginning to $A D$ 1760. Cambridge: Cambridge University Press.

McKnight, B. E. 1981. The quality of mercy: Amnesties and traditional Chinese justice. Honolulu, HI: University Press of Hawaii.

Michaud, P. 1958. "The Yellow Turbans." Monumenta Serica 17, 47-127.

Miller, B. K. 2015. "The Southern Xiongnu in northern China." In J. Bemmann and M. Schmauder (eds.), Complexity of interaction along the Eurasian steppe zone in the first millennium $C E$, 127-98. Bonn: Vor- und frühgeschichtliche Archäologie, Rheinische Friedrich-WilhelmsUniversität Bonn.

Miyake, K. 2018. "The military history of Qin and the composition of its expeditionary forces." Bamboo and Silk 1, 121-151.

Nickerson, P. S. 1996. "Taoism, death, and bureaucracy in early medieval China." PhD diss., University of California, Berkeley.

Nienhauser, W. H., ed. 1994a. The Grand Scribe's Records. Vol. 1, The basic annals of pre-Han China. Bloomington, IN: Indiana University Press.

-, ed. 1994b. The Grand Scribe's Records. Vol. 7, The memoirs of pre-Han China. Bloomington, IN: Indiana University Press.

-, ed. 2002. The Grand Scribe's Records. Vol. 2, The basic annals of Han China. Bloomington, IN: Indiana University Press. 
Nishijima, S. 1986. “The economic and social history of Former Han.” in D. Twitchett and M. Loewe (eds.), The Cambridge history of China. Vol. 1, 545-607. Cambridge: Cambridge University Press.

Pines, Y. 2000. “'The one that pervades the all' in ancient Chinese political thought: The origins of 'the great unity' paradigm.” T'oung Pao 86.4-5, 280-324.

-. 2005. "Biases and their sources: Qin history in the Shiji." Oriens Extremus 45, 10-34.

-. 2013a. "Reassessing textual sources for pre-imperial Qin history.” In Синологи мира к юбилею Станислава Кучеры [Sinologists of the world for the anniversary of Stanislav Kuchera]. Учёные записки Отдела Китая 11, 236-263. Москва: Институт востоковедения $\mathrm{PAH}$.

-. 2013b. "Between merit and pedigree: Evolution of the concept of 'elevating the worthy' in preimperial China." In D. A. Bell and C. Li (eds.), The East Asian challenge for democracy: Political meritocracy in comparative perspective, 161-202. Cambridge: Cambridge University Press.

-. 2017. The Book of Lord Shang: Apologetics of state power in early China by Shang Yang. New York, NY: Columbia University Press.

-. 2018. “Legalism in Chinese philosophy.” In E. N. Zalta (ed.), The Stanford encyclopedia of philosophy. Stanford, CA: Stanford University Metaphysics Research Lab. https:// plato.stanford.edu/archives/win2018/entries/chinese-legalism/.

Pines, Y., L. von Falkenhausen, G. Shelach, and R. D. S. Yates. 2014. “General introduction: Qin history revisited.” In Y. Pines, G. Shelach, L. von Falkenhausen, and R. D. S. Yates (eds.), Birth of an empire: The state of Qin revisited, 1-34. Berkeley, CA: University of California Press.

Poo, M. 2011. "Preparation for the afterlife in ancient China." In A. Olberding and P. J. Ivanhoe (eds.), Mortality in traditional Chinese thought, 13-37. Albany, NY: State University of New York Press.

Portal, J., ed. 2007. The first emperor: China's terracotta army. London: British Museum Press.

Psarras, S.-K. 2003. "Han and Xiongnu: A reexamination of cultural and political relations (I)." Monumenta Serica 51, 55-236.

Rawson, J. 1999. "Western Zhou archaeology.” In M. Loewe and E. L. Shaughnessy (eds.), The Cambridge history of ancient China: From the origin of civilization to 221 BC, 352-449. Cambridge: Cambridge University Press.

Roosevelt Weld, S. 1999. "Chu law in action: Legal documents from tomb 2 at Baoshan." In C. A. Cook and J. S. Major (eds.), Defining Chu: Image and reality in ancient China, 77-97. Honolulu: University of Hawai'i Press.

-. 2003. "Grave matters: Warring States law and philosophy." In C. S. Hsu (ed.), Understanding China's legal system: Essays in honor of Jerome A. Cohen, 122-179. New York, NY: New York University Press.

Rosenstein, N. 2009. "War, state formation, and the evolution of military institutions in ancient China and Rome." In W. Scheidel (ed.), Rome and China: Comparative perspectives on ancient world empires, 24-51. Oxford: Oxford University Press.

Sage, S. F. 1992. Ancient Sichuan and the unification of China. Albany, NY: State University of New York Press.

Sanft, C. 2005. "Six of one, two dozen of the other: The abatement of mutilating punishments under Han emperor Wen." Asia Major 18.1, 79-100.

-. 2011. "Debating the route of the Qin Direct Road (Zhidao): Text and excavation." Frontiers of History in China 6.3, 323-346.

-. 2014. Communication and cooperation in early imperial China: Publicizing the Qin dynasty. Albany, NY: State University of New York Press. 
-. 2015. "Population records from Liye: Ideology in practice." In Y. Pines, P. R. Goldin, and M. Kern (eds.), Ideology of power and power of ideology in early China, 249-269. Leiden: Brill.

-. 2018. "The Qin dynasty." In P. R. Goldin (ed.), Routledge handbook of early Chinese history, 146-159. London: Routledge.

Scheidel, W. 2009. "From the 'Great Convergence' to the 'First Great Divergence': Roman and QinHan state formation and its aftermath." In W. Scheidel (ed.), Rome and China: Comparative perspectives on ancient world empires, 1-23. Oxford: Oxford University Press.

Seidel, A. 1987. "Traces of Han religion in funeral texts found in tombs." In Kan'ei Akizuki 觀英秋月 (ed.), Dōkyō to Shūkyō Bunka 道教と宗教文化, 21-57. Tokyo: Hirakawa shuppansha.

Selbitschka, A. 2015. "Early Chinese diplomacy: Realpolitik versus the so-called tributary system." Asia Major 28.1, 61-114.

-. 2018. "'I write, therefore I am': Scribes, literacy, and identity in early China." Harvard Journal of Asiatic Studies 78.2, 413-477.

Shelach, G. 2014. "Collapse or transformation? Anthropological and archaeological perspectives on the fall of Qin." In Y. Pines, G. Shelach, L. von Falkenhausen, and R. D. S. Yates (eds.), Birth of an empire: The state of Qin revisited, 113-139. Berkeley, CA: University of California Press.

Shiji 史記 [The Scribe's Records]. 1959. Composed by Sima Qian 司馬遷 (145 or 135-ca. 87 BCE). Beijing: Zhonghua shuju.

Shuihudi Qin mu zhujian zhengli xiaozu 睡虎地秦墓竹簡整理小組. 1990. Shuihudi Qin mu zhujian 睡虎地秦墓竹簡 [Bamboo slips from a Qin tomb at Shuihudi]. Beijing: Wenwu chubanshe.

Smith, K., and S. Tan. 2003. "Sima Tan and the invention of Daoism, 'legalism,' et cetera." The Journal of Asian Studies 62.1, 129-156.

Sørensen, B. AE. 2010. "How the first emperor unified the minds of contemporary historians: The inadequate source criticism in modern historical works about the Chinese Bronze Age." Monumenta Serica 58, 1-30.

Sterckx, R. 2015. "Ideologies of the peasant and merchant in Warring States China." In Y. Pines, P. R. Goldin, and M. Kern (eds.), Ideology of power and power of ideology in early China, 211-248. Leiden: Brill.

Swann, N. L. 1950. Food and money in ancient China: The earliest economic history of China to AD 25: Han Shu 24 with related texts, Han Shu 91 and Shih-Chi 129. Princeton, N): Princeton University Press.

Taagepera, R. 1979. "Size and duration of empires: Growth-decline curves, 600 BC to 600 AD." Social Science History 3.3-4, 115-138.

Turchin, P. 2009. "A theory for formation of large empires." Journal of Global History 4.2, 191-217. van Ess, H. 1993. Politik und Gelehrsamkeit in der Zeit der Han (202 v. Chr.-220 n. Chr.): Die Alttext / Neutext-Kontroverse. Wiesbaden: Harrassowitz.

-. 2014a. "Emperor Wu of the Han and the first august emperor of Qin in Sima Qian's Shiji." In Y. Pines, G. Shelach, L. von Falkenhausen, and R. D. S. Yates (eds.), Birth of an empire: The state of Qin revisited, 239-257. Berkeley, CA: University of California Press.

-. 2014b. Politik und Geschichtsschreibung im alten China: Pan-Ma i-t'ung 班馬異同. 2 vols. Wiesbaden: Harrassowitz.

Venture, 0. 2011. "Caractères interdits et vocabulaire officiel sous les Qin: L'apport des documents administratifs de Liye." Études chinoises: Bulletin de l'Association française d'études chinoises 30, 73-98.

von Falkenhausen, L. 1995. “The regionalist paradigm in Chinese archaeology." In P. L. Kohl and C. Fawcett (eds.), Nationalism, politics, and the practice of archaeology, 198-217. Cambridge: Cambridge University Press. 
-. 1999. "The waning of the Bronze Age: Material culture and social developments, 770-481 BC." In M. Loewe and E. L. Shaughnessy (eds.), The Cambridge history of ancient China: From the origins of civilization to $221 \mathrm{BC}, 450-544$. Cambridge: Cambridge University Press.

-. 2004. "Mortuary behavior in pre-imperial Qin: A religious interpretation." In J. Lagerwey (ed.), Religion and Chinese society. Vol. 1, 109-172. Hong Kong and Paris: Chinese University Press and École française d'Extrême-Orient.

-. 2006. Chinese society in the age of Confucius (1000-250 BC): The archaeological evidence. Los Angeles, CA: University of California Cotsen Institute of Archaeology.

von Falkenhausen, L., and G. Shelach. 2014. "Introduction: Archaeological perspectives on the Qin 'unification' of China." In Y. Pines, G. Shelach, L. von Falkenhausen, and R. D. S. Yates (eds.), Birth of an empire: The state of Qin revisited, 37-51. Berkeley, CA: University of California Press.

von Glahn, R. 2016. The economic history of China: From antiquity to the nineteenth century. Cambridge: Cambridge University Press.

Wade, G. 2009. “The polity of Yelang (夜郎) and the origins of the name “China." Sino-Platonic Papers 188.

Wagner, D. B. 1993. Iron and steel in ancient China. Leiden: Brill.

-. 2008. Science and civilisation in China. Vol. 5, Chemistry and chemical technology. Part 11, Ferrous metallurgy. Cambridge: Cambridge University Press.

Wang, H. 2004. Money on the Silk Road: The evidence from eastern Central Asia to C. AD 800, including a catalogue of the coins collected by Sir Aurel Stein. London: The British Museum Press.

Watson, B., trans. 1993. Records of the Grand Historian: Han dynasty. 2nd ed. 2 vols. Hong Kong and New York, NY: Chinese University of Hong Kong Research Centre for Translation and Columbia University Press.

Weber, M. 1951. The religion of China: Confucianism and Taoism. Glencoe, IL: Free Press.

-. 1978. Economy and society: An outline of interpretive sociology. 2 vols. Berkeley, CA: University of California Press.

Wu Xiaoqiang 吳小強. 2000. Qin jian rishu jishi 秦简日书集释 [Collected annotations on the daybooks on Qin bamboo slips]. Changsha: Yuelu chubanshe.

Wu Hung 巫鸿. 1979. “Qin quan yanjiu” 秦权研究 [Study on Qin weights]. Gugong bowuguan yuankan 故宫博物院院刊, no. 4, 33-47, 104.

Xie, Y., and M. Brown. 2015. "Between heaven and earth: Dual accountability of Chinese bureaucrats in Han China." Chinese Journal of Sociology 1.1, 56-87.

Xu, P. 2001. "The archaeology of the Great Wall of the Qin and Han dynasties." Journal of East Asian Archaeology 3.1, 259-281.

Yan Gengwang 嚴耕望. 2007. Zhongguo difang xingzheng zhidu shi: Qin Han difang xingzheng zhidu 中國地方行政制度史: 秦漢地方行政制度 [History of the Chinese local administrative system: The local administrative system of Qin and Han]. Shanghai: Shanghai guji chubanshe.

Yang Zhenhong 楊振紅. 2003. “Qin Han 'mingtianzhai zhi’ shuo: Cong Zhangjiashan Han jian kan Zhanguo Qin Han de tudi zhidu” 秦汉 “名田宅制” 说：从张家山汉简看战国秦汉的土 地制度 [The mingtianzhai system of the Qin and Han: The Han slips from Zhangjiashan as evidence for the systems of land tenure during the Warring States, Qin, and Han periods]. Zhongguo Shi Yanjiu 中国史研究, no. 3, 49-72.

Yates, R. D. S. 1994. Science and civilisation in China. Vol. 5, Chemistry and chemical technology. Part 6, Military technology: Missiles and sieges. Cambridge: Cambridge University Press.

-. 2009. "Law and the military in early China." In N. Di Cosmo (ed.), Military culture in imperial China, 23-44. Cambridge, MA: Harvard University Press. 
-. 2011. "Soldiers, scribes, and women: Literacy among the lower orders in early China." In F. Li and D. P. Branner (eds.), Writing and literacy in early China: Studies from the Columbia Early China Seminar, 339-370. Seattle, WA: University of Washington Press.

-. 2012. "The Qin slips and boards from well no. 1, Liye, Hunan: A brief introduction to the Qin Qianling county archives." Early China 35, 291-329.

-. 2014. "Introduction: The empire of the scribes." In Y. Pines, G. Shelach, L. von Falkenhausen, and R. D. S. Yates (eds.), Birth of an empire: The state of Qin revisited, 141-154. Berkeley, CA: University of California Press.

You Yifei 游逸飛. 2013. “Liye 8-461 hao ‘Qin gengming fang’ xuanshi” 里耶8 - 461號 「秦更名方」選釋 [Selected explanations regarding the 'board of Qin changes in nomenclature' from Liye, nos. 8-461]. Jianbo 簡帛, Bamboo and Silk Manuscripts. http://www.bsm.org.cn/show_article.php?id=1875.

Yü Ying-Shih 余英时. 1967. Trade and expansion in Han China: A study in the structure of Sino-Barbarian economic relations. Berkeley, CA: University of California Press.

-. 1986. "Han foreign relations." In D. Twitchett and M. Loewe (eds.), The Cambridge history of China. Vol. 1, 377-462. Cambridge: Cambridge University Press.

-. 1987. Shi yu Zhongguo wenhua 士與中國文化 [The shi and Chinese culture]. Shanghai: Shanghai renmin chubanshe.

Zhang Jinguang 张金光. 2007. "Pubian shoutian zhi de zhongjie yu siyou diquan de xingcheng: Zhangjiashan Han jian yu Qin jian bijiao yanjiu zhi yi” 普遍授田制的终结与私有地权 的形成: 张家山汉简与秦简比较研究之一 [The end of the system of universal land allocation and the formation of private land ownership: A comparison between the Zhangjiashan Han bamboo slips and the Qin bamboo slips]. Lishi Yanjiu 历史研究, no. 5, 49-65.

-. 2013. “Zhanguo, Qin de fushui: Guojia suoqu de xingcheng” 战国、秦的赋税:

国家索取制的形成 [Zhanguo and Qin taxation: The formation of the state's exaction system]. Jingji Shehui Shi Pinglun 经济社会史评论 6, 5-16.

Zhou Xin 周昕. 2010. Zhongguo nongju tongshi 中国农具通史 [Comprehensive history of Chinese agricultural implements]. Jinan: Shandong kexue jishu chubanshe.

Zufferey, N. 2003. To the origins of Confucianism: The Ru 儒 in pre-Qin times and during the early Han dynasty. Bern: Peter Lang. 


\section{Ursula Brosseder}

\section{The Xiongnu Empire}

\section{Introduction}

The Xiongnu Empire (third century BCE to second century CE) is the earliest and longest lasting of the so-called steppe or nomadic empires witnessed in Inner Asia over the past two millennia. It extended from the Ordos to Lake Baikal and from Manchuria to eastern Kazakhstan with its heartland in Mongolia. What is known about the Xiongnu Empire relies mainly on Chinese chronicles and archaeological evidence. Because it was the first empire in the steppes, and the one that is archaeologically best documented, the Xiongnu case also plays a major role in theoretical approaches to empire formation in Inner Asia.

Historians have convincingly demonstrated that for the Xiongnu Empire circumstances of crisis, exacerbated by Qin incursions into the steppes, initiated processes of state formation through the supplanting of traditional aristocracies. ${ }^{1}$ Historical narratives recount this development as centered around the charismatic leader Modun (r. 209-174 BCE) who killed his father and, after a coup, quickly began conquests to subdue neighboring groups. In the process, the Xiongnu crushed Chinese forces and in 198 BCE secured a treaty, called heqin, involving Chinese princesses and lavish gifts from the nascent Han dynasty for several generations afterward. Xiongnu expansions peaked in the early second century BCE when Modun proclaimed "all the people who draw the bow have now become one family and the northern region has been pacified."2

The Xiongnu Empire endured difficulties when the Han appeasement policy of heqin failed in the middle of the second century BCE and the Han emperor Wudi began to wage war. By the end of his reign ( $87 \mathrm{BCE}$ ) the far western regions, which constituted an important economic base for the Xiongnu, were under the control of the Han. The loss of this neighboring power base exacerbated internal conflicts among Xiongnu leaders that culminated in a civil war (57-47 BCE). After the midfirst century BCE little information about the internal affairs of the Xiongnu exists in the Chinese chronicles. This has often erroneously been interpreted as a decrease in power of the steppe rulers, even though the chanyu Huhanye soon restored sovereignty in the steppes and ushered in an era of revived Xiongnu strength that lasted

1 Di Cosmo 1999.

2 Di Cosmo 2002, 186.

Note: This chapter is a slightly adapted version of Brosseder, U. 2016. "Xiongnu Empire." In M. Mackenzie (ed.), The Encyclopedia of Empire. https://doi.org/10.1002/9781118455074.wbeoe149. (c) 2016 John Wiley \& Sons, Ltd. Reproduction by copyright licence number 4541910378855.

Ә Open Access. (๑) 2020 Ursula Brosseder, published by De Gruyter. (c) BY-NC-ND This work is licensed under the Creative Commons Attribution-NonCommercial-NoDerivatives 4.0 License.

https://doi.org/10.1515/9783110607741-007 


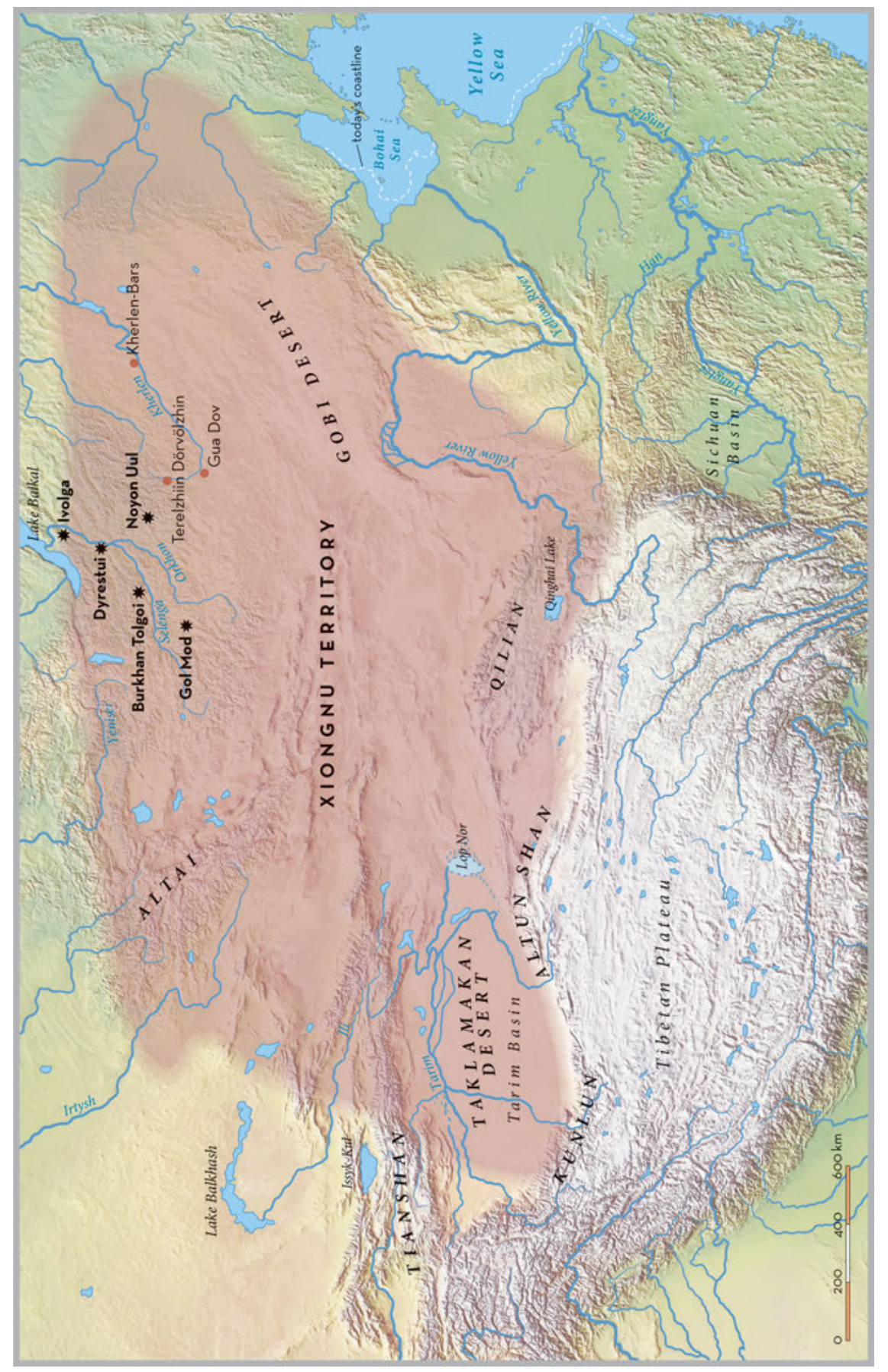

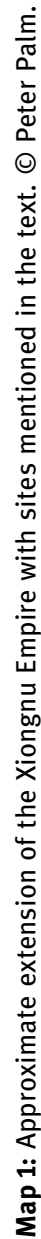


until the end of the first century $\mathrm{CE} .{ }^{3}$ In $50 \mathrm{CE}$, another internal conflict between claimants for Xiongnu rulership led to large factions surrendering in the northern Chinese frontier and establishing a fledgling 'southern' Xiongnu polity, which eventually aided in the destruction of the 'northern' Xiongnu Steppe Empire at the end of the first century CE and remained there until the beginning of the third century. ${ }^{4}$ The combined attacks that finally brought down the Xiongnu Empire included the Han Chinese and other groups, particularly the Xianbei from the eastern flank who are claimed to be the successor empire in the Inner Asian steppes.

What we know about the Xiongnu as a historical phenomenon is based mainly on a few Chinese chronicles - the Shiji, Yantie lun, Hanshu, and Hou Hanshu - dating to between the second century BCE and the fifth century CE. ${ }^{5}$ These provide accounts of the Xiongnu Empire, after its establishment, when it played a major role in the geopolitics of the Qin and Han dynasties. The term 'Xiongnu' was mostly used by Chinese court historians to record diplomatic and military dealings with the northern steppe leaders. It described both a polity and a group of people. The label of Xiongnu does not denote a coherent entity of people with the same language or the same ethnic affiliation. Rather, it refers to numerous peoples or tribes within a political confederation and designates a political entity of groups from distinct regions, with various cultural and social regimes, across a broad territory via a formalized integrative imperial system. ${ }^{6}$ Because of this more sociopolitical meaning, there is no straightforward answer to the question of the origins of the phenomenon known as the Xiongnu.

\section{Characteristics of the Xiongnu Polity}

Another field of debate is the character of the Xiongnu polity, which revolves mainly around the question whether the Xiongnu entity (depending on the criteria applied) qualifies as an early state or a super-complex chiefdom. ${ }^{7}$ Yet it is beyond discussion that it constitutes an empire - in the sense of a political formation that extended far beyond its original territory and integrated a variety of regions and peoples. ${ }^{8}$ Several models have been proposed to explain why and how a comparatively sparse society of pastoralists formed an empire in the Inner Asian steppes. Apart from general theories that emphasize climate change, an inherent militant lifestyle, or economic pressures on pastoralist societies, the most predominant model for the Xiong-

3 Miller 2014.

4 Miller 2015.

5 Di Cosmo 2002; de Crespigny 1984.

6 Brosseder and Miller 2011, 31.

7 Kradin 2011.

8 Di Cosmo 2011. 
nu Empire arose from a geographically oriented approach centered on the relations between China and the steppe. This approach projects a sharp dichotomy between two separate systems that collide in a singular frontier zone. ${ }^{9}$ This frontier zone is central, even 'imperiogenetic,' to theories of steppe dependency or coevolution that explain the formation of steppe empires. Having the centrality of the frontier in mind and based primarily on assumptions of overall deficient steppe social complexities and pastoral economies, Barfield asserts that the Xiongnu depended critically on agriculture from China and formed a secondary phenomenon or 'shadow empire' of China's Qin dynasty. ${ }^{10}$

Such dependency theories have been rejected, or even transformed, by anthropologists in favor of more sophisticated models of coevolution. Although these models also project the frontier zone between China and Inner Asia as still central to formation processes of steppe empires, Turchin deems the Xiongnu Empire the result of long-lasting coevolutionary processes and codependencies on both sides of the frontier that led to the formation of contemporaneous imperial polities. ${ }^{11} \mathrm{Howev}$ er, such polarized perspectives tend to underestimate or neglect developments within steppe societies, and historians and archaeologists alike have begun to propose alternate models that emphasize the internal dynamics of the steppes. ${ }^{12}$

The organization of the unified Xiongnu polity was based on a decimal structure of leadership and an appanage system of territories of the 'left' (east) and 'right' (west). Although scholars have often assumed this structure to reflect Chinese organizational logics, evidence points more to parallels westward in the Achaemenid Empire. ${ }^{13}$ At the top of the political order was the supreme ruler, the chanyu, who belonged to a ruling royal lineage, and the highest political ranks were restricted to this and only a few other secondary lineages, tied to the royal lineage by intermarriage. The uppermost ranks consisted of the 24 Great Chiefs (that is, the 'Chiefs of Ten Thousand Cavalry'), referred to as kings and commanders, which were hereditary positions at the head of a military decimal system and were linked to particular 'left' and 'right' appanages. These were followed by several other ranks of kings, high-order generals, commanders, and officials, some of which were open to other lineages. Each of the Great Chiefs appointed his own subordinate kings and officials, and such lower level leaders within and outside of the recognized system surely represented significant social forces in the steppe polity. ${ }^{14}$ The Xiongnu sought to replicate their political and military titles at the local level to support the hierarchical structures in the center and thus incorporate the elites of conquered

\footnotetext{
9 Di Cosmo 2015.

10 Barfield 2001.

11 Turchin 2009.

12 Honeychurch and Amartuvshin 2006; Di Cosmo 2011.

13 Di Cosmo 2011, 47.

14 Miller 2014.
} 
people. ${ }^{15}$ The elite ranks also included a group of high-ranking appointments amidst the Xiongnu nobility, which included foreigners, such as Chinese defectors, who were directly placed under the authority of the chanyu, indicating a personal entourage of trusted advisors for the latter. ${ }^{16}$

There has been a century-long discussion as to whether the Xiongnu can be deemed the predecessors of the European Huns of the late fourth to early fifth centuries CE. This discussion, however, frequently lacks methodological precision and recurrently conflates different notions of a people, designations of political confederations, and concepts of cultural names that should otherwise remain distinct. While the names 'Xiongnu' and 'Hun' can be linguistically correlated, the written and archaeological evidence that is drawn upon to link the two historical phenomena into a narrative of migration is far too faint to withstand scrutiny. ${ }^{17}$ The archaeological material evidence does not support a narrative that allows for linking these two phenomena. ${ }^{18}$

Apart from the narrative of empire developed via Chinese chronicles of the Xiongnu 'other,' archaeological sources form another critical primary source, independent from the written records, that holds equal potential to elucidate facets of the Xiongnu Empire. The question that firstly affects Xiongnu archaeological studies is how to establish a link between a historically attested political entity and an archaeological culture - a problem that still needs to be completely resolved for the case of the Xiongnu Empire. Researchers have yet to fully define, analyze, and agree upon the collective archaeological culture groups of Late Iron Age southern Siberia, Mongolia, and northern China, much less to distinguish all the elements of what might correlate to the Xiongnu Empire.

Since the 1990s, international investigations of archaeological remains of the Xiongnu period, especially in Mongolia, have grown rapidly. Today thousands of tombs in Mongolia, southern Siberia, and northern China have been documented. However, only a handful of cemeteries - Ivolga, Dyrestui and Burkhan Tolgoi have been excavated sufficiently to allow for intensive analyses. ${ }^{19}$ Furthermore, as most interments were heavily disrupted in antiquity, our knowledge of these graves is quite limited. Moreover, the process of reopening tombs, which is often understood as looting, has yet to be investigated in order to more clearly discern the time frames and processes of disruption. Such studies might elucidate the nature of the grave opening in relation to issues of looting, desecration, or ritual reopening.

The most plausible corpus of archaeological remains in Late Iron Age Inner Asia to be linked to the Xiongnu phenomenon consists of a spread of sites, centered

15 Di Cosmo 2013, 34.

16 Di Cosmo 2013, 30-31.

17 De la Vaissière 2015.

18 Brosseder 2018; Pohl 2018.

19 Brosseder and Miller 2011a. 
mostly in Mongolia, which share similar mortuary expressions as well as numerous artifacts across a wide expanse of territories (map 1). ${ }^{20}$ Progress has recently been made in chronological refinements of this material, allowing us to see a temporal sequence highlighting changes over time - distinctions that are crucial for comparing and combining historical and archaeological narratives. During the second century BCE, a new style of burials appeared in the Mongolian steppes. They are discerned by the large rings or small clusters of stones on the ground surface which demarcate their interments. During the late second to early first centuries BCE, a broad adherence to a group of open-work animal-style belt plaques indicates intense interregional elite communications. The appearance of a homogeneous style of weaponry, namely the massive use of the compound bow with bone strengtheners and large iron arrowheads, as well as a homogeneous assemblage of pottery, points to similar interregional connectivities. Differences in status and/or rank can be observed within these burials and assemblages, but by the late first century BCE (and up through the first century $\mathrm{CE}$ ) monumental terrace tombs containing overwhelmingly ostentatious burial assemblages with numerous exotic goods were erected in the steppes. ${ }^{21}$ As indicated by the exotica, predominantly from China but also from Central Asia and even further west, these elites participated in far-reaching networks. ${ }^{22}$ Through the internal redistribution of goods, some of the exotica were acquired also by lower ranks indicating a wealth-based or prestige goods economy. ${ }^{23}$ The contexts of the transfer are diverse. Those objects manufactured in the Han imperial workshops probably arrived in the bundle of tribute payments from the Han emperor to the Xiongnu chanyu. In times of annual tribute payments, not only a great variety of goods including (special) foodstuffs but also large quantities were transferred to the north. Marriage alliances also brought goods to the Xiongnu courts. Prominently featured in the written records are raiding excursions from the Xiongnu, while border markets were mentioned and constitute yet another way of exchanging goods.

Beyond studies of mortuary arenas, the field of settlement studies for the Xiong$\mathrm{nu}$ is still relatively underdeveloped. Aside from pastoral campsites, identified by small scatters of debris, archaeologists have also unearthed settlements of semisubterranean houses with evidence for some agriculture subsistence and craft production, such as bone working. ${ }^{24}$ Several walled sites with platforms have also been

20 Brosseder and Miller 2011b.

21 Brosseder 2009. Polos'mak and Bogdanov 2016. The most prominent places are Noyon uul and Gol mod (map 1).

22 Miller and Brosseder 2017; Brosseder and Miller 2018.

23 Di Cosmo 1999; Brosseder 2015.

24 Ivolga is still the most intensively studied site (Davydova 1995), followed by Dureny in the Transbaikal area (Davydova and Miniaev, 2003). While there are numerous, yet under-researched settlements, known from Transbaikalia only one larger settlement site, Boroo Gol, which has been investigated, is known from northern Mongolia (Ramseyer 2013). This only reflects the lack of modern research devoted to that area. 
found, though their function is not yet fully understood, more systematic investigation has been conducted at Gua Dov, Terelzhiin Dörvölzhin, and Kherlen Bars. ${ }^{25}$ Because of their architectural layout (a rectangular space enclosed by a rampart), the presence of foreign-inspired architectural elements, and the lack of normal settlement debris, they probably held a central position in society (ritually, economically, politically, and/or socially) on a par with the terrace tombs. In addition, as information on artisans and local production sites is scarce, the economic sectors of Xiongnu society are still poorly understood. Debates on import versus local steppe production of goods and materials are therefore hindered. Yet evidence that aids in the debunking of dependency theories has begun to surface in Xiongnu archaeology, including evidence for local uses of foreign techniques as well as local sources of gold and local sites of intense iron smelting. ${ }^{26}$

Some scholars have attempted to match the historically documented political system of center, left, and right territories to cores and peripheries in distributions of archaeological remains. Yet such correlations, especially with heavy emphases on a handful of elite cemeteries and a dearth of settlement data, remain problematic conjecture at best. Moreover, both the historical and archaeological records point to more complex strata of local elites, ${ }^{27}$ and scholars have yet to elucidate the manners in which they were integrated into the wider polity. Distinctions of 'cultural cores,' 'frontiers,' and the mechanisms of greater or lesser integration of these territories into a political entity, while simultaneously acknowledging regional, cultural, social, and economic diversity, still need to be empirically addressed. Although material expressions of political participation, as well as cultural, social, and economic integration, may highlight different cores and frontiers, we should be wary of outlining precise boundaries of a polity according to an archaeological culture. Instead, it may be more promising to consider varying degrees of interaction and integration within the empire. ${ }^{28}$

Turning again to chronological delineations, radiocarbon dating efforts have shown that some graves in the northern steppes, while appearing very similar to those of the Xiongnu period, date to the second and even third centuries CE, well after the formal collapse of the historically documented Xiongnu Empire. It is in this period that Chinese chronicles have suggested the Xianbei formally ruled over large portions of the steppes that had previously been under Xiongnu control. Recent archaeological research in Mongolia points to a much greater regional (and other?) diversity in mortuary practices in comparison to the previous Xiongnu period. However, this supposition raises numerous questions. In addition to issues of the sometimes problematic correlations between historical polities and archaeologi-

25 Miller et al. 2019.

26 Miller and Brosseder 2013; Sasada and Amartuvshin 2014.

27 Miller 2014.

28 Miller 2015. 
cal cultures, it highlights problems surrounding our understanding of the nature of the collapse of polities.

\section{References}

Barfield, T. J. 2001. "The shadow empires: Imperial state formation along the Chinese-Nomad frontier.” In S. E. Alcock, T. N. D’Altroy, K. D. Morrison, and C. M. Sinopoli (eds.), Empires: Perspectives from archaeology and history, 10-41. Cambridge: Cambridge University Press.

Brosseder, U. 2009. "Xiongnu terrace tombs and their interpretation as elite burials." In J. Bemmann, H. Parzinger, E. Pohl, and D. Tseveendorzh (eds.), Current archaeological research in Mongolia: Papers from the First International Conference on Archaeological Research in Mongolia held in Ulaanbaatar, August 19th-23rd 2007, 247-280. Bonn: Vor- und frühgeschichtliche Archäologie, Rheinische Friedrich-Wilhelms-Universität Bonn.

-. 2015. "A study on the complexity and dynamics of interaction and exchange in Late Iron Age Eurasia." In J. Bemmann and M. Schmauder (eds.), Complexity of interaction along the Eurasian steppe zone in the first millennium CE, 199-332. Bonn: Vor- und frühgeschichtliche Archäologie, Rheinische Friedrich-Wilhelms-Universität Bonn.

-. 2018. "Xiongnu and Huns: Archaeological perspectives on a centuries-old debate about identity and migration." In N. di Cosmo and M. Maas (eds.), Empires and exchanges in Eurasian Late Antiquity: Rome, China, Iran and the Steppe, ca. 250-750, 176-188. Cambridge: Cambridge University Press.

Brosseder, U., and B. K. Miller. 2011a. "State of research and future direction of Xiongnu studies." In U. Brosseder and B. K. Miller (eds.), Xiongnu archaeology: Multidisciplinary perspectives of the first steppe empire in Inner Asia, 19-33. Bonn: Vor- und frühgeschichtliche Archäologie, Rheinische Friedrich-Wilhelms-Universität Bonn.

-. 2018. "Global networks and local agents in the Iron Age Eurasian steppe." In N. Boivin and M. D. Frachetti (eds.), Globalization in prehistory: Contact, exchange and the "people without history', 162-183. Cambridge: Cambridge University Press.

Davydova, A. V. 1995. Иволгинский археологический комплекс 1: Иволгинское городище [Ivolga archaeological complex 1: Ivolga settlement]. Археологические памятники сюнну. Вып. 1. Санкт-Петербур: Фонд «АзиатИКА».

Davydova, A. V., and S. S. Miniaev. 2003. Комплекс археологических памятников у села Дурены [The complex of archaeological sites near the village of Dureny]. Археологические памятники сюнну. Вып. 5. Санкт-Петербур: Фонд «АзиатИКА».

de Crespigny, R. 1984. Northern frontier: The policies and strategy of the Later Han Empire. Canberra: Australian National University.

de la Vaissière, É. 2015. "The steppe world and the rise of the Huns." In M. Maas (ed.), The Cambridge companion to the age of Attila, 175-192. Cambridge: Cambridge University Press.

Di Cosmo, N. 1999. "State formation and periodization in Inner Asian history." Journal of World History 10.1, 1-40.

-. 2002. Ancient China and its enemies: The rise of nomadic power in East Asian history. Cambridge: Cambridge University Press.

-. 2011. "Ethnogenesis, coevolution and political morphology of the earliest steppe empire: The Xiongnu question revisited." In U. Brosseder and B. K. Miller (eds.), Xiongnu archaeology: Multidisciplinary perspectives of the first steppe empire in Inner Asia, 35-48. Bonn: Vor- und frühgeschichtliche Archäologie, Rheinische Friedrich-Wilhelms-Universität Bonn. 
-. 2013. "Aristocratic elites in the Xiongnu Empire as seen from historical and archaeological evidence." In J. Paul (ed.), Nomad aristocrats in a world of empires, 23-53. Wiesbaden: Reichert.

-. 2015. "China-steppe relations in historical perspective." In J. Bemmann and M. Schmauder (eds.), Complexity of interaction along the Eurasian steppe zone in the first millennium CE, 49-72. Bonn: Vor- und frühgeschichtliche Archäologie, Rheinische Friedrich-WilhelmsUniversität Bonn.

Honeychurch, W., and C. Amartuvshin. 2006. "States on horseback: The rise of Inner Asian confederations and empires.” In M. T. Stark (ed.), Archaeology of Asia, 255-278. Malden, MA: Blackwell.

Kradin, N. 2002. "Nomadism, evolution and world-systems: Pastoral societies in theories of historical development." Journal of World-System Research 8, 368-388.

-. 2011. "Stateless empires: The structure of the Xiongnu nomadic super-complex chiefdom." In U. Brosseder and B. K. Miller (eds.), Xiongnu archaeology: Multidisciplinary perspectives of the first steppe empire in Inner Asia, 77-96. Bonn: Vor- und frühgeschichtliche Archäologie, Rheinische Friedrich-Wilhelms-Universität Bonn.

Miller, B. K. 2014. “Xiongnu 'kings' and the political order of the Steppe Empire." Journal of the Economic and Social History of the Orient 57, 1-43.

-. 2015. "The Southern Xiongnu in northern China: Navigating and negotiating the middle ground.” In J. Bemmann and M. Schmauder (eds.), Complexity of interaction along the Eurasian steppe zone in the first millennium CE, 127-198. Bonn: Vor- und frühgeschichtliche Archäologie, Rheinische Friedrich-Wilhelms-Universität Bonn.

Miller, B. K., and U. Brosseder. 2013. "Beasts of the North - Global and local dynamics as seen in horse ornaments of the steppe elite." Asian Archaeology 1, 94-112.

-. 2017. "Global dynamics in local processes of Iron Age Inner Asia." In T. Hodos (ed.), The Routledge handbook of archaeology and globalization, 470-487. London: Routledge.

Miller, B. K., M. Furholt, J. Bayarsaikhan, T. Tüvshinjargal, L. Brandsätter, J. Wright, Ts. Azush, and T. Wunderlich. 2019. "Proto-urban establishments in Inner Asia: Surveys on an Iron Age walled site in eastern Mongolia." Journal of Field Archaeology 44.4, 267-286.

Pohl, W. 2018. "Ethnicity and empire in the western Eurasian steppes." In

N. di Cosmo and M. Maas (eds.), Empires and exchanges in Eurasian Late Antiquity: Rome, China, Iran and the Steppe, ca. 250-750, 189-205. Cambridge: Cambridge University Press.

Polos'mak, N. V., and E. S. Bogdanov. 2016. Ноин-улинская коллекция. Результаты работы российско-монгольской экспедиции, 2006-2012 гг [The Noin-Ula collection: Results of the work of the Russian-Mongolian expedition, 2006-2012]. Новосибирск: ИНФОЛИО.

Ramseyer, D., ed. 2013. L'habitat Xiongnu de Boroo Gol: Recherches archéologiques en Mongolie (2003-2008). Gollion: Infolio.

Sasada, T., and C. Amartuvshin. 2014. "Iron smelting in the nomadic empire of Xiognu in ancient Mongolia.” ISIJ International 54.5, 1017-1023.

Turchin, P. 2009. "A theory for formation of large empires.” Journal of Global History 4, $191-217$. 



\section{The Arsakid Empire}

\section{Introduction: The 'Second Iranian Empire'}

The Arsakid Empire, also known as the Parthian Empire, was a vast entity stretching across central and western Asia that grew out of a small provincial state at the intersection of the Seleukid Empire and the Eurasian steppe. ${ }^{1}$ Its ruling Arsakid dynasty, supported by a Parthian aristocracy, lasted for nearly 500 years. It rose in the mid-third century всE and eventually supplanted Seleukid control in Mesopotamia and Iran, where it came to interact with neighbors from Rome, to the Kushans, to China, before falling to upstart Sasanian successors, who had consolidated power in the Iranian highlands.

Despite its pivotal position, scale, and longevity, historical scholarship on the Arsakid Empire and the Parthian cultural logics that it carried with it as it expanded has been far less extensive than that on either its Mediterranean or East Asian neighbors, or its Iranian predecessors and successors. Sources have been a central hindrance. ${ }^{2}$ There is little material preserving an emic (internal) perspective on Arsakid history, which has led to a reliance on exogenous sources as well as those written hundreds of years later, chiefly by hostile Roman, dismissive Sasanian, or distant Chinese authors. ${ }^{3}$ The source problems are not confined to textual material. Parthian-period archaeology was long confined to excavations of a small number of urban sites, providing only shadowy evidence of broader practices across Arsakid space. ${ }^{4}$ At the same time, the traditional reluctance to incorporate the Arsakid

1 The term 'Arsakid' comes from the name of the ruling dynasty, after the eponymous founder Arsakes. The term 'Parthian' is a geographic, linguistic, and ethnic term derived from the Achaemenid satrapy Parthava (Parthyene), which took on an ethnic meaning in the Roman sources and came to describe an empire far beyond the satrapy. Contemporary scholarship has increasingly adopted the term 'Arsakid' to describe the dynastic period. This choice has been defended as a way of avoiding the ethnic implications of the term 'Parthian,' while at the same time bringing the period into scholarly norms for the study of Iranian empires, which rely on dynastic chronologies. There has been, however, a hesitation to abandon the term 'Parthian,' and the term seems to be settling into a new meaning as "the comprehensive term ... applied to the various and complex cultural manifestations in the countries that fell under Arsacid rule” (Invernizzi 2011, 189). See also Hauser 2012, 1001-1003; de Jong 2013a, 147-148.

2 On sources for the study of economy, see Wiesehöfer, ch. 11, this volume.

3 Boyce 1983; Widengren 1983 provide an overview of transmitted texts from Parthian and Sasanian perspectives. For treatments of source material within regional or evidentiary frameworks, see contributions in Wiesehöfer 1998. For a recent compendium of textual sources, see Hackl, Jacobs, and Weber 2010.

4 The most significant excavations are discussed in Hauser 2012, 1005-1011.

Note: My thanks to Matthew Canepa for his helpful comments on an earlier draft of this chapter.

Ә Open Access. (c) 2020 Lara Fabian, published by De Gruyter. (c) BY-NC-ND This work is licensed under the Creative Commons Attribution-NonCommercial-NoDerivatives 4.0 License.

https://doi.org/10.1515/9783110607741-008 


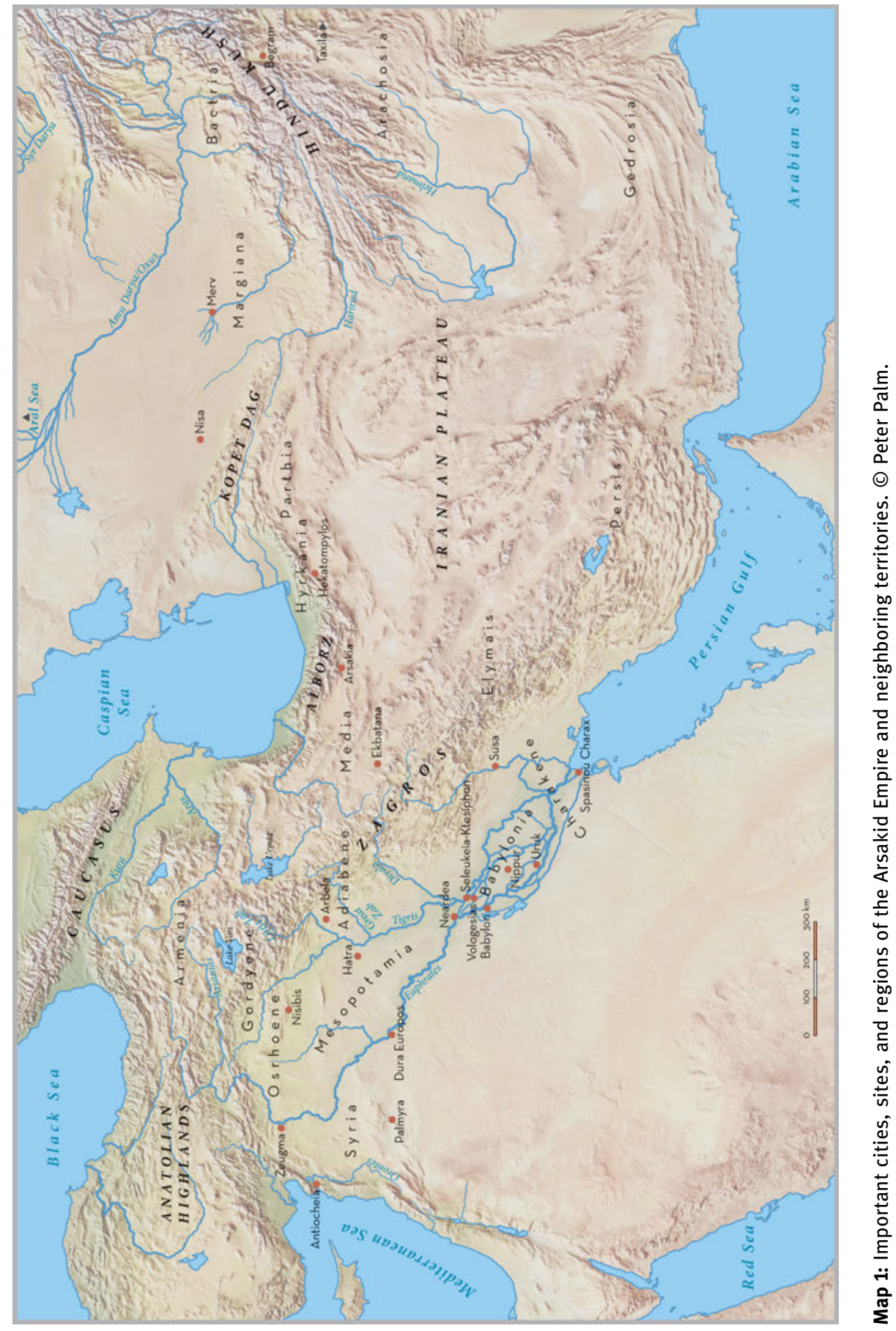


Empire into studies of antiquity also reflects historiographic biases. The Parthians "the stepchildren of ancient history" 5 - have had a difficult time drawing the attention of either Near Eastern or classical historians, while among scholars of the Iranian world, the Arsakid period has often been viewed as a transitional era between the more interesting Achaemenid and Sasanian periods. ${ }^{6}$

\section{I.1 The Space of the Empire}

Arsakid control developed across a range of challenging landscapes. At its greatest extent, it included territories (directly and indirectly ruled) from the edge of Anatolia to northern India, and from the Persian Gulf and Indian Ocean in the south to the Caspian Sea in the north (map 1$).^{7}$

The original heartland of the Arsakid dynasts - the Achaemenid satrapy of Parthava - was in northeastern Iran, within the area of Iran's contemporary Khorāsān provinces, as well as the Transcaspian steppe of southern Turkmenistan. Marked by the Kopet Dag mountains running east-west, and the Karakum and Kavir deserts to the north and south, the fertile area had seen many centuries of interaction between sedentary populations and mobile pastoralist (nomadic) groups. Moreover, the socalled Great Khorāsān Road, a corridor connecting India and Inner Asia to the center of Iran, Mesopotamia and points west, ran through the southern reaches of the territory.

Eventually, Arsakid power spread into Persis and the core of the Iranian Plateau, which had earlier been the seat of the Achaemenid Empire, as well as into the rich agricultural lands of Mesopotamia and its Tigris and Euphrates Rivers. The Arsakids consolidated control along the southern fringe of the Caspian basin, from the temperate Hyrkanian forests and the Alborz Mountains to the edges of the Greater Caucasus Mountains in the northwest, reaching down into the Armenian highlands. Finally, the empire came to include strongholds along the lower Euphrates and coastal territories along the northern edge of the Persian Gulf, stretched in some periods perhaps as far as Arachosia and northern India, although the eastern reaches of the empire are a point of uncertainty. ${ }^{8}$

\section{I.2 Arsakid Contexts: Dualities and Dichotomies}

The relative invisibility of the Arsakid Empire in modern thought is in sharp contrast to its omnipresence in Roman historical narrative, where Arsakid kings were a cen-

5 De Jong 2013a, 144.

6 Hauser 2012, 1001-1002; see also Wiserhöfer, ch. 11.I, this volume.

7 Bivar 1983, 24-27, for a description of Arsakid geography. For the physical geography of the territories of modern Iran, see Fisher 1968.

8 Frye 2004. 
tral foil for centuries. ${ }^{9}$ Despite its visibility, however, the nature of the Arsakid Empire on both a practical and conceptual level was only sketchily outlined by Roman authors, who struggled to fit unfamiliar Parthian practices into their own cultural vocabulary and stumbled over underlying differences in their imperial logics.

The Arsakid Empire can be said to be the second Iranian Empire, in a sequence that began with the Achaemenids and would continue in the Sasanians. Applying this same idea to cultural logics, however, is more problematic. Because of interaction (and intermarriage) between Seleukid and Iranian dynasties, Parthian elites were both conversant with and comfortable within the Greek-infused Hellenistic world, and were a particular vehicle for the spread of 'Hellenistic' sensibilities. ${ }^{10}$ Indeed, one of the recurrent themes of royal presentation among the Arsakids was an appeal to both Achaemenid and Macedonian (that is, Greek) sources in establishing legitimacy. ${ }^{11}$ Furthermore, the history of Arsakid Iran was also entangled with the world of steppe communities along the northern borders. ${ }^{12}$

In an attempt to grapple with these complex heritages, the Arsakid Empire is often simplified into a series of polarized dichotomies. ${ }^{13}$ The development of the empire is framed as a contest between 'Iranian' and 'Hellenic' influences within the Parthian court, while the underlying structural character of the court, the elite, and the army are considered alternately either fundamentally nomadic, or instead sedentary. These issues have been expressed as a set of questions: Did the structure of the Parthian aristocracy emerge from traditional steppe practices, or was it the product of Achaemenid or Hellenistic political systems? Was the Achaemenid Empire the source of Arsakid royal legitimacy, placing the Arsakids within an Iranian continuum, or was it instead the Hellenistic oikoumene from which they drew their power, making them somehow more Greek? In reality, the Arsakid Empire developed in the context of Iranian, Mesopotamian, Central Asian, Mesopotamian, and South Asian traditions. What characterizes the Arsakid Empire, more than any singular notional identity, was its ability to incorporate and accommodate a tremendously wide variety of administrative, structural, and iconographic frameworks as it grew. ${ }^{14}$

9 Lerouge 2007, 11. The importance of Parthians in Roman art and literature has led to a long tradition of studying Mediterranean representations of the Arsakid Empire. For recent contributions, see Landskron 2005; Lerouge 2007; Rose 2005; Wiesehöfer and Müller 2017.

10 Although the Hellenistic, and particularly the Seleukid, kingdoms were themselves borne from the fusion of practices from Greece (carried through Macedonia) with perspectives passed down in the long afterlife of Neo-Babylonian and post-Achaemenid forms of organization and administration (Fowler 2017, n. 29).

11 Shayegan 2011; 2017, 433-436.

12 The question of the depth of Parthian entanglements with pastoralist communities has been a subject of considerable debate. See below, sec. III.1.2 below for an overview of perspectives.

13 On polarization in the scholarship, see Fowler 2005, 129. On the inadequacy of these models with respect to ancient Iran, see Shayegan 2017, 401-403.

14 Keall 1994; Gregoratti 2017a discuss 'flexibility' as a trope of the Arsakid state. 


\section{The Rise and Transformation of the Empire}

\section{II.1 Origins and Origin Stories}

The story of the Arsakid Empire began in the confusing period surrounding the Seleukid Empire's loss of two significant satrapies in Central Asia - Parthia and Bactria. ${ }^{15}$ Although the details are unclear, both secessions appear to have been led by the respective satrapal governors: Diodotos in Bactria and Andragoras in Parthia. ${ }^{16}$ Andragoras's autonomous rule in Parthia was short-lived, as he was soon defeated by Arsakes and his supporters, with the year 247 BCE designated as the starting point of the Arsakid dynasty. ${ }^{17}$

The figure of Arsakes is mysterious and has been so since antiquity. In many of the ancient accounts, Arsakes was not himself a Parthian, but rather an outsider (often said to be from the steppe) who rose to power among the Parthians. ${ }^{18}$ The Roman geographer Strabo provides two such divergent stories about the founder and his followers. ${ }^{19}$ In the first and more elaborate, Arsakes is "a Scythian" who gains the support of the Parni (Aparni), a tribe that was part of the Dahae mobile pastoralist federation, and together with them moves southward into Parthia, conquering it. ${ }^{20}$ In the second version, Arsakes is reportedly "a Bactrian," pushed out by Diodotos and his expansionary desires, who turns his eye to Parthia. ${ }^{21}$ In Justin's third-century CE epitome of Pompeius Trogus, Arsakes is either a man from an unknown background who leads a group of brigands ${ }^{22}$ or a descendent of Andragoras himself. ${ }^{23}$ Finally, there is yet another tradition of Arsakes as a direct descendent of Artaxerxes, the Achaemenid king. ${ }^{24}$ It is difficult to make a cohesive whole out of these conflicting stories, and Hauser suggests that they should be seen, instead, as

15 On the entwined histories of the Arsakid and Bactrian territories, see Lerner 1999. See also Morris, ch. 2, this volume.

16 The chronologies of this period are debated. For an overview of alternate versions of early Arsakid history, see that provided in Bivar 1983, 28-31. For a fuller consideration of the literary sources for this period, see Wolski 1993, 37-51.

17 Wolski and others following him suggest that Arsakes did not actually come to power until 238, and that the date of 247 reflects the beginning of Andragoras's independent rule (Bivar 1983, 29).

18 De Jong 2013b, 30 makes a case for a Parthian ancestry for the Arsakids based on Zoroastrian religion.

19 Strabo 11. 9. 2-3.

20 Strabo 11. 9. 2. As Boyce has pointed out, this tradition of nomadic roots has found favor among contemporary historians. Although she argues against a nomadic character for all of Parthian culture, she does note that the ancient accounts of nomadic roots have "some slight support from what appears to be a genuine Parthian tradition preserved in a Middle Persian text” (1994, 242).

21 Strabo 11. 9. 3.

22 Justinus Epitome of Pompeius Trogus (Just. Epit.) 41. 4. 6-8.

23 Just. Epit. 12. 4 . 2.

24 Arrian Parthica frag. 2. The clearest version of this story comes through Syncellus, a Byzantine author quoting Arrian. Lerouge 2007, 187-192 discusses Arrian’s treatment of Arsakes. 
literary accounts that "employ the typical rhetorical figures and topoi of foundation myths."25

The uncertainties surrounding the early years of the Arsakid dynasty extend beyond the identity of Arsakes. As Strootman has pointed out, there is good reason to question accounts of the rise of the Arsakid dynasty that treat it in "the model of the sovereign nation state" and posit a quick crystallization of a self-conscious empire. ${ }^{26}$ These perceptions simplify the entwined networks of power and kingship that ran through Seleukid and later Arsakid Iran and Central Asia, from which the Parthians emerged and within which they continued to function.

In any case, according to the traditional account, Arsakes was joined in his aggression by his brother, Tiridates, who became king after the death of Arsakes I. More recently, and following the hypothesis of Wolski, many now argue that Tiridates may not have existed, and that the Arsakid throne passed from father (Arsakes I) to son (Arsakes II) around 217 вCE. ${ }^{27}$ Numismatic evidence seems to support this conclusion, although the Arsakid dynastic habit of using the throne-name 'Arsakes' for each monarch complicates matters, and there is not complete agreement. ${ }^{28}$

Iran was, at this point, a space of divided power, with Arsakid, Bactrian, and Seleukid interests vying for control. Although little can be said with certainty about these early decades, textual evidence suggests Arsakid spatial reorganizations, with the creation of new settlements and fortification of old ones. ${ }^{29}$ The early Arsakid dynasts managed to repel the most serious threats to their growing state, with Arsakes II (r. ca. 217 BCE-ca. 191 BCE) offering largely statutory submission to the Seleukid monarch Antiochos III. ${ }^{30}$ Little is known about Arsakid history for several subsequent decades, save some sparse information that Phraates I (r. ca. 176-171) conquered territories around the Caspian's southern shores, marking the earliest steps of the coming period of Arsakid expansion.

\section{II.2 Becoming an Empire}

Mithradates I (r. ca. 171-132 BCE) presided over the rise of the Arsakid state as a significant power. He capitalized on the diminishing cohesion of the Seleukid Empire in the mid-second century всE, expanding Arsakid control deep into Seleukid territory in Media, Babylonia, and Elymais (all conquered between 148 and

25 Hauser 2012, 1003. A fuller discussion of this can be found in Hauser 2005.

26 Strootman 2017, 184.

27 Wolski 1946, 160.

28 Strabo 15. 1. 36. Bivar 1983, 30-31 for example argues for the traditional version of succession transmitted by the classical authors. See also de Jong 2013b, 30.

29 Just. Epit. 41. 5. 1-3.

30 Dąbrowa 2012, 169. 
138 BCE). ${ }^{31}$ Although Mithradates I had widespread success, the victories did not come easily, and Arsakid hold on its new territories was fiercely contested. ${ }^{32}$

Mithradates I's successors, Phraates II (r. 132-126 BCE), Artabanos I (r. 126-123/ 2 BCE) presided over a confusing period of conflict with new and old enemies in both the east and west. The period saw the westward shift of the Arsakid center-ofbalance, from its original core in eastern Iran, toward the denser and more profitable territories of Media and eventually Mesopotamia. ${ }^{33}$ This shift was embodied in the physical transfer of the capital city from its early location at Nisa (mod. Turkmenistan) to Ekbatana (mod. Hamadān, Iran) and then finally to Ktesiphon, near the old Seleukid capital at Seleukeia-Tigris (mod. Baghdad, Iraq). ${ }^{34}$ The imperial recentering coincided with a new set of pressures on the eastern flank of the Arsakid Empire as the Yuezhi mobile pastoralist confederation took control of Bactria. The Yuezhi came into the picture as part of a larger phase of migrations and resettlements precipitated by upheavals farther to the east. ${ }^{35}$ Beyond the Yuezhi, Phraates II found himself facing Seleukid attempts to retake parts of their lost lands in Media and Mesopotamia, as well as incursions from the east by another mobile pastoralist group, the Saka, who proved to be a nagging threat for the next several generations. ${ }^{36}$ In the end, the Seleukid efforts were unsuccessful, and the eastern frontier was stabilized, although these distractions created an opening for the defection of Charakene in the south.

Under Mithradates II (r. 122-91 BCE), the Arsakid Empire entered a period of territorial reclamation and renewed growth. Mithradates retook lost territories in Mesopotamia and Iran, as well as in Central Asia, where it appears that Parthian vassals came to power and became durable allies, although little is known about them. ${ }^{37}$ Mithradates also spread Arsakid interests into Armenia and Anatolia, waging war against Armenia ${ }^{38}$ and likely bringing the rulers in Adiabene, Sophene, Gordyene, and Osrhoene into the Arsakid fold. ${ }^{39}$ By the end of his reign, Arsakid

31 Cuneiform texts have been particularly helpful in clarifying the chronology of Arsakid activities in Mesopotamia in the middle of the second century BCE. Shayegan 2011, 60-120 discusses relevant evidence.

32 See for example the battles between Mithridates I and Demetrios II of Syria, who fought to regain Mesopotamia in 139/138 ВСE, as well as the fierce engagements with the kings of Elymais and Charakene. On Elymais, see Dąbrowa 2014; Potts 1999, 384-391; 2002. On Charakene, see Schuol 2000.

33 Hauser 2012, 1004.

34 Bivar and others have hypothesized that the movement away from Nisa was incited by the vulnerability of the original Arsakid heartland to nomadic raids from the north $(1983,39)$.

35 Morris, ch. 2, this volume.

36 Conflicts with the Saka claimed the lives of not only Phraates II, but also Artabanos I.

37 Frye 2004 discusses this eastern space. See also Morris, ch. 2; Dwivedi, ch. 3, this volume.

38 Strabo 11. 14. 15.

39 The dating of these events is uncertain, and it is possible that some of the territories already were incorporated under Mithradates I. On Adiabene, Sophene, and Gordyene, see Marciak 2017, 128-129, 244, 346-347. 
territory stretched from Dura Europos along the Euphrates in the west to Margiana in the east, and from Hyrkania in the north to Charakene in the south. The developments under Mithradates II were not just territorial, but also cultural. The seat of the empire was securely established in the urbanized context of Seleukeia-Tigris and the manner of Arsakid dynastic titulature changed, including the earliest attestations of the archaizing title 'King of Kings,' (see below).

\section{II.3 Encounters with Rome}

The first recorded diplomatic encounter between the Arsakid and Roman Empires occurred in the mid-90s BCE, when an emissary of Mithradates II met with the Roman governor of Kilikia, Sulla, to propose the establishment of the Euphrates as the border between the Roman and Arsakid spheres of interest. ${ }^{40}$ Despite Mithradates II's attempts, the early decades of the first century BCE were not marked by continued Arsakid expansion or greater political prominence. Instead, the rise in ca. 92 BCE of a powerful rival for the Arsakid throne, Gotarzes, began a period of internal turmoil in the last years of Mithradates II's rule, which only intensified in the struggle over succession after his death. ${ }^{41}$ He was succeeded by Sinatrukes, thought to be a son of Mithradates I, rather than one of his own sons. In the aftermath of this, two lines claiming royal legitimacy rose: the Sinatrukids and the so-called Younger Arsakids, descended from Mithradates II. ${ }^{42}$

During these years, the Roman commanders in the east were occupied by their conflict with Mithridates IV Eupator, the king of Pontos. Tigranes II of Armenia, an Arsakid vassal, used the general unrest to expand his purview, offering extensive support to Mithridates IV in his fight against the Romans. A succession of Arsakid kings (first Sinatrukes and then Phraates III), in contrast, maintained neutrality in the conflict between Pontos and Rome. In exchange for this neutrality, and to encourage its continuation, several Roman generals (first Lucullus and then Pompey) offered their endorsements of the Euphrates as the dividing line between Roman and Arsakid interests. ${ }^{43}$ From the perspective of the Arsakid Empire, these efforts at stabilization were largely ineffective. The dynastic strife inside of the Arsakid world continued apace after the assassination of Phraates III by his two sons, Orodes II and Mithradates III, in 58/7 BCE.

40 Plutarch Life of Sulla (Plu. Sull.) 5. 4-5. The interaction was not without problems: Mithradates II reportedly executed his emissary after hearing that he allowed Sulla to denigrate the power of the Arsakid crown by equating the Arsakid king with a minor (Pontic) king.

41 On the complexities of this period and the role of numismatic data, see Mørkholm 1980; Bivar 1983, 41-45. Assar 2009; Simonetta 2009 discuss ongoing revisions of the chronology based on numismatics.

42 Olbrycht 2016a.

43 Bivar 1983, 45-47. 
This instability eventually drew the attention of Roman authorities, who likely saw an opportunity to expand Rome's holdings in the Near East. Mithradates III provided the proximate cause for Roman intervention, after he requested Roman aid in his conflict against his brother. ${ }^{44}$ Mithradates's request led to the campaign of the Roman general M. Licinius Crassus, who broke the decades-old Euphrates truce as he marched against Orodes II. These were the first open hostilities between the Arsakid and Roman armies. By the time Crassus made it across the Euphrates and past pro-Arsakid territories in Osrhoene, however, Mithradates III had been defeated. Crassus nevertheless attacked, suffering a shattering defeat of the Roman forces at Carrhae in 53 BCE, at the hands of the army of the pro-Orodes Parthian nobleman Suren, described by the ancient biographer Plutarch as first after the king. ${ }^{45}$

In the century following Carrhae, our knowledge of the affairs of the Arsakid Empire suggests considerable dynastic strife, as well as ongoing hostilities between Rome and the Arsakid Empire. The early years of Orodes's reign were spent stabilizing his position. He executed his victorious general Suren, undoubtedly to limit the ambitions of the powerful clan, ${ }^{46}$ and turned his attention to resecuring Armenia, whose king Artavasdes II had entered into an alliance with Crassus. Successful in this endeavor, Orodes sealed the alliance with Artavasdes through a dynastic marriage between an Arsakid prince and Armenian princess, ${ }^{47}$ beginning a centurieslong dynastic relationship between the houses. ${ }^{48}$ Orodes took advantage of his surprising victory as well as unrest precipitated by the Roman civil war between Caesar and Pompey to launch several campaigns into Roman territories in the Near East, first in 51 BCE and then again in 41 BCE. Although Arsakid troops did not intervene in the fighting between Caesar and Pompey, they were on the side of Pompey, ${ }^{49}$ and continued to support his faction after the assassination of Caesar. ${ }^{50}$ In the second Arsakid incursion into Roman territory in 41 BCE, the Arsakid forces were led by Orodes's son Pakoros, as well as by Q. Labienus, a Roman general and supporter of the Republican cause. The two led a temporarily successful invasion of Syria and Judaea, bringing nearly all of the Near East into Arsakid hands. ${ }^{51}$ The Arsakid victory was short-lived though, as both Labienus and Pakoros were killed by Antony's forces, plunging the Arsakid monarchy into renewed dynastic struggle.

\footnotetext{
44 Cassius Dio (Cass. Dio) 39. 56. 2.

45 Plutarch Life of Crassus (Plut. Crass.) 21. 6.

46 Olbrycht 2016a, 23.

47 Plut. Crass. 33. 1.

48 Bivar 1983, 56; Dąbrowa 2018, 80.

49 Supporting, for example, the Pompeian general Q. Caecilius Bassus, who had been cornered by Caesarian forces at Apameia after the death of Pompey.

50 Bivar 1983, 56-57.

51 Schlude and Overman 2017 on the situation in Judaea, interesting because of the ties between Jewish populations under Arsakid rule in Babylonia and those in Judaea.
} 
Orodes II stepped down, passing the throne on to his son Phraates IV (r. 38-3/ 2 вCE). But Phraates did not have universal support from the noble families, many of whom fled to Roman territory and launched (Roman-supported) opposition. In this climate of fractured alliances, Marc Antony began to plan a massive invasion of Media in 36 BCE with the help of, among others, the Armenian king Artavasdes II. Following the defection of Artavasdes and a successful attack on the Roman troops by Arsakid forces under the command of Phraates, however, Antony was forced to retreat. This episode began yet another wave of jockeying for authority in Armenia, which ended with the installation of the pro-Arsakid Artaxes II, son of Artavasdes II. Internal strife in the Arsakid sphere continued. Phraates IV was forced to turn to the so-called Scythian allies to hold on to his throne in the face of opposition from a certain Tiridates, who would eventually flee to Roman territories, but not before abducting Phraates's son, whom he handed over as a hostage to Rome.

The situation between the Roman and Arsakid Empires entered a new phase with the rise of Augustus, who in 20 BCE initiated a diplomatic settlement to the strife in the Near East, which resulted in the return of the Roman military standards and prisoners captured at Carrhae. The moment offered Augustus a tremendous public relations coup: a nearly free and bloodless victory with tangible symbolic ramifications. Although the largely symbolic concessions likely did not cause practical problems for Arsakid rule, Phraates's willingness to bow to Roman demands was seen by his internal opponents as a sign of weakness. ${ }^{52}$ The Armenian noble families, seeing an opening to rid themselves of the Arsakid-supported Artaxes II, murdered him and initiated a new period of Roman-Arsakid feuding in Armenia. These tensions continued until 1 CE, when the son of Phraates IV, Phraatakes (r. 3/ 2 BCE-2 CE) yielded hegemony in Armenia to the Romans. Phraatakes was an unsuccessful king, thought to have been largely the puppet of his mother Musa, an Italic slave who had been given as a gift to Phraates IV by Augustus as part of the peace settlement. ${ }^{53}$ In short order, he was forced out of power by Arsakid aristocrats in 4 CE. For nearly a decade, Arsakid aristocrats and Roman interests vied to impose their chosen candidate on the Arsakid throne.

Eventually, Artabanos II (r. 12-38/9 CE), a member of the Younger Arsakid line who had been ruling in Atropatene and who was likely descended from Mithradates II, came to the throne. This marked the end of the Sinatrukid line on the main Arsakid throne, although a branch of that line is thought to have split off and begun the dynasty of Gondophares ruling in eastern Iran and Northern India, with the support of other Parthian noble houses. ${ }^{54}$ Artabanos, recognizing the danger posed by the strong Arsakid nobility of recent generations, began to take more direct con-

52 Bivar 1983, 66-67; Dąbrowa 2012, 173.

53 Strugnell 2008.

54 Bivar 2007; Olbrycht 2016a, 24. 
trol over Arsakid territories and curry favor among powerful minorities within the empire as a way of diluting the power of the traditional ruling families. ${ }^{55}$

Despite an early attempt to reassert Arsakid influence in Armenia, Artabanos largely accepted the state of affairs. However, following a failed attempt in $35 \mathrm{CE}$ to place his son on the Armenian throne, Artabanos faced opposition from Romebacked nobility, and was forced to find support from eastern 'nomadic' elements of the Arsakid community, retaking kingship at the head of an army of Saka and Dahae. ${ }^{56}$ Another decade-long period of instability followed his death, once again featuring internecine fighting, as well as the continued prominence of the Dahae and Hyrkanians, who supported Gotarzes, one of the sons of Artabanos II.

\section{II.4 Arsakid Stabilization and Transformation}

The rise of Vologases I (r. ca. 51-78/9 CE) marked the beginning of a period of stability and imperial innovation that continued during the rule of his son Pakoros II (r. ca. 77/78-110 CE). ${ }^{57}$ One critical element of this stability was the articulation of a lasting solution to the question of Armenia, which came after the Arsakid victory at the battle of Rhandeia in $62 \mathrm{CE}$. The lead-up to this battle began when the Romanbacked Caucasian Iberians seized the Armenian throne, a move that Vologases rejected as a breach of the previous Roman-Arsakid agreement. In response, he placed his brother, Tiridates, on the throne, sparking the military campaign of Gn. Domitius Corbulo. Corbulo achieved considerable success in his invasion of Armenia, forcing Tiridates out and briefly installing Rome's choice on the throne. However, the Arsakid army was eventually able to out-fight Corbulo's replacement, leading to a victory at Rhandeia that cemented the new state of Armenian affairs: the Arsakid king would appoint his choice for the Armenian crown, who would then be crowned by the Roman emperor. In practice, then, authority over Armenia had transferred to the Arsakid emperor.

This stabilization of the long-contentious Caucasus, interrupted only by an apparent invasion of mobile pastoralists from the North Caucasus in $72 \mathrm{CE},{ }^{58}$ allowed Vologases to turn his sights toward retaking Arsakid territories from Mesopotamia through Elymais, ${ }^{59}$ as well as expanding Arsakid interests farther to the east, through Choresmia and Bactria, in a program continued by Pakoros. Dynastic strife arose again late in the reign of Pakoros II, who was at the time co-regent with his son, Vologases III (r. ca. 110-147), and led to the domination of much of Arsakid

55 Gregoratti 2014, 52-53.

56 Gregoratti 2013, 47-48.

57 For a recent reassessment of this period on numismatic grounds, Olbrycht 2016c.

58 On these mobile pastoralist incursions, see Bosworth 1977.

59 The nature of relations between Elymais and the Arsakid Empire in this period is uncertain, Dąbrowa 2014. 
territory in Mesopotamia by a usurper, Osroes I. Osroes incited Roman involvement in Armenia by crowning Parthamasiris as the king of Armenia without Roman involvement, creating the pretext for Trajan's invasion of Armenia and the Arsakid heartland in Mesopotamia. Roman forces scored significant victories, capturing Ktesiphon for a period, and making their way all the way to the Persian Gulf. But the Roman grip on the territories was short-lived, and entirely abandoned under the Roman emperor Hadrian (r. 117-134). However, the years of unrest had changed the balance of power in the Arsakid realm and seem to have resulted in a split empire, with Osroes controlling the western reaches and Vologases III ruling in the east. By 128/9, Vologases III seems to have reunited the kingdom. ${ }^{60}$

Pressures on the Arsakid Empire from mobile pastoralist neighbors mounted in this period. In $135 \mathrm{CE}$, they faced a renewed invasion from the North Caucasus, once again involving the rulers of Iberia. ${ }^{61}$ At the same time, the Kushans in the east were growing rapidly, forcing a reallocation of Arsakid attention and resources. Tensions with Rome flared again under Vologases IV (r. 147-191/2), who was successful in regaining Arsakid supremacy in Charakene early in his rule. With this victory, he reasserted an important income stream for the Arsakid throne in the form of taxes collected on goods moving through the port territory on the Persian Gulf. But in $161 \mathrm{CE}$, he launched an ultimately unsuccessful campaign into Roman territory, which turned into a victory for Roman forces. This episode led to the definitive loss of Arsakid holdings in Syria, which would never be regained, as well as shifts in control over other parts of northern Mesopotamia.

A renewed Roman campaign into Arsakid lands commenced under the Roman emperor Septimius Severus (r. 193-211), who invaded the Arsakid realm in 197/8 CE. This event had considerable success in expanding Roman control in the territory, despite Severus's failure to capture Mesopotamia proper. The final Roman offensive against the Arsakid Empire commenced under the emperor Caracalla, who took advantage of internal strife between feuding throne claimant brothers. The campaign did not yield any meaningful Roman victories and ended with the assassination of Caracalla in 217, which was followed by opportunistic incursions of Roman

60 For disagreement on this point, contrast the positions of Dąbrowa 2012, 176 with that of Bivar 1983, 93.

61 Cass. Dio 69. 15. 1-3. On these raids, see Bosworth 1977; Perevalov 2006. On the broader question of interactions between these northern pastoralist groups and the Parthians, see particularly Kharmatta 1965. 
territory by the Arsakid army, and a peace settlement including a significant financial payoff by Caracalla's successor. This peace settlement is the last known episode of Roman-Arsakid interaction. Shortly thereafter, an uprising led by Ardašir, the ruler of Persis from a noble family, took hold and spread into Media and Adiabene. From this base, the insurgents were able to overtake Artabanos IV in his seat at Ktesiphon, killing him and claiming both the capital city and the title of 'King of Kings' for Ardašir, inaugurating the Sasanian dynasty who would rule Iran for the next four centuries.

\section{The Shape of Arsakid Rule: The Logics of Arsakid Control}

The Arsakid Empire is marked by its decentralized and multipolar structure, and in this sense has the character of a hierarchal confederation. The course of events within the empire was shaped by tensions between its various internal centers, as well as by the separatist tendencies of its vassal territories and the creation of new power bases like the one that arose in the empire's eastern Indo-Parthian fringe. Although these centrifugal tensions have often been interpreted as indications of imperial weakness, the system forced Arsakid dynasts to rule with flexibility. ${ }^{62}$ Arsakid control was based on a balance between the elements of their system, enacted across the sprawling networks that connected the empire. Three elements of imperial practice are of particular importance in understanding how power flowed across these networks. They are: (1) the image of kingship that emanated from the King of Kings himself, shaping his relationship with the Parthian aristocracy, as well as dependent kings; (2) the coercive power of the Arsakid army that enabled their territorial expansion, as well as the diplomatic ties that emerged in its wake; and (3) the techniques for control of space, which enabled the Arsakid dynasty to shape interaction across their empire.

\section{III.1 Socio-Political Contexts of Arsakid Rule}

At the center of the Arsakid system was a king who enjoyed a form of absolute power, who was invariably a descendent of the founder of the dynasty (or at least, was presented as such), ${ }^{63}$ and who benefited from some sort of ruler cult. ${ }^{64}$ The

62 On the 'weak king' trope, see Hauser 2006, 296. See also Fowler 2010, 57-59 on the notion of 'petty kings' in the Arabic and Persian historical traditions.

63 Strabo 16. 1. 28.

64 On the existence of a ruler cult, Dąbrowa 2009, 2011. 
king was surrounded by a small group of elite families drawn at first from the ranks of the Parthians, which expanded to incorporate local elites in conquered territories as the empire grew. ${ }^{65}$ The socio-political practices of this elite sector of society became increasingly visible in neighboring territories, creating a recognizable elite cultural koine. ${ }^{66}$

\section{III.1.1 Arsakid Kingship: Coin Portraits and Palaces}

The history of the Arsakid dynasty is marked by frequent conflict between different branches of the ruling family and their elite Parthian kinsmen. In this fractious environment, claims of authority and legitimacy by Arsakid kings were critically important. Recombining elements drawn from Achaemenid, Hellenistic, and steppe models, successive generations developed a vision of authority that responded to both internal and external tensions. ${ }^{67}$ That is - the version of kingship that developed within the Arsakid space was neither an incomplete copy of Seleukid approaches, nor a distant recreation of Achaemenid ones, but instead a new practice rooted in the conditions of the Parthian period.

Since we lack synthetic accounts of the Arsakid ideology of rule, central evidence for considering the institution of kingship comes from court art. ${ }^{68}$ Within this body of material, coin portraits offer widespread and diachronic glimpses at imperial representation, while court architecture provides a window into a more private form of imperial representation. ${ }^{69}$

The Arsakid monetary system was bimetallic, with two silver denominations, tetradrachms and drachms, as well as bronzes. ${ }^{70}$ Many coins were issued with mint marks, and a number of the mints have been identified in both Mesopotamia and Iran. The local nature of minting practices in various corners of the Arsakid world

65 Dąbrowa 2013, 54, n. 4 cites Himerus, a Hyrkanian elite who became the satrap of Mesopotamia under Phraates II. For prosopographical data on the aristocratic families, see Karras-Klapproth 1988. Among these elite families, one can add the western Arsakids, the Gondopharids, and the Sūren and Kāren (Olbrycht 2016a, 31).

66 De Jong 2013a.

67 Canepa 2017.

68 On the differences between Arsakid court art and Parthian art, Invernizzi 2011. Many debates about Parthian art more generally can be traced back to Rostovtseff's analysis of the art of Dura, which argues that Parthian art represents an Iranian rejection of Hellenic models (Rostovtzeff 1935), see Dirven 2016 for a summary of debates. For other important discussions, see Ghirshman 1962; Schlumberger 1970.

69 A number of rock reliefs preserve images of Arsakid kings. They appear to be the product of local commission rather than of the Arsakid court itself (Invernizzi 2011, 194), and therefore present indirect evidence about Arsakid dynastic art. On the reliefs, Kawami 1987; Mathiesen 1992.

70 Vardanyan 2001, on the monetary system. Drachms were the most widespread of the denominations. 

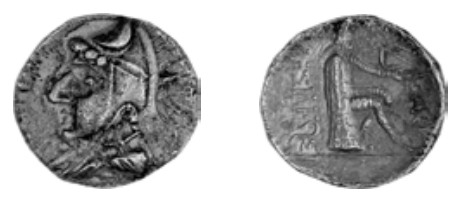

Fig 1: Silver drachm of Parthia, early king, late third/early second century BCE, obv. Head of the king wearing bashlyk, facing left. Rev. Seated archer, right. Diameter $19 \mathrm{~mm}, 3.46$ g., $12 \mathrm{~h}$., Sellwood 4.1. ANS 1944.100.81998. (c) American Numismatic Society.

seems to reflect the decentralized and heterogenous nature of imperial power. The coins generally offer at least one royal portrait, as well as a variety of epigraphic clues about royal titles, packaged as imperially sanctioned royal propaganda. ${ }^{71}$

The earliest Arsakid coins are from the time of Arsakes I and his successors (fig. 1). ${ }^{72}$ These have been seen to demonstrate close affinity to coins of the postAchaemenid fratarak $\bar{a}$ rulers in Persis. ${ }^{73}$ The iconographic language, which includes a left-facing, clean-shaven monarch wearing a pointed tiara, is seen as a divergence from (and perhaps even an active rejection of) Seleukid numismatic vocabulary. ${ }^{74}$ Some early coins of Arsakes I feature the title $\langle\mathrm{krny}\rangle$, interpreted by some as the Middle Iranian term kären in Aramaic script, which appears to be a reanimation of an Achaemenid title - providing early evidence for self-conscious Arsakid recollections of the Achaemenid Empire. ${ }^{75}$ Nevertheless, a divergent reading of the iconographic program of early Arsakid coins suggests a greater interaction with Seleukid idioms - and even posits western Asian roots for some of the characteristic elements - suggesting that it is also possible to read the coins within their most proximate Seleukid imperial context. ${ }^{76}$

Mithradates I at first continued the precedents of his predecessors, ${ }^{77}$ but then adopted a number of Seleukid characteristics on his coins. ${ }^{78}$ On the obverse of these types, the king faces right in Seleukid style, wears a Seleukid diadem and an outfit

71 Sellwood 1980 is the standard reference, and more recently the ongoing work of the Sylloge Nummorum Parthicorum. Examinations of Arsakid coins have a long history within studies of the chronology of Arsakid kingship both in the empire and in vassal states, for example Le Rider 1965; Loginov and Nikitin 1996; Alram 1998; Simonetta 2001; Assar 2006b, $2006 a$.

72 Sellwood 1980, types 1-6.

73 On the fratarakā coinage, Wiesehöfer 2011.

74 Vardanyan 2000; Sinisi 2014. The most visible example of this is the direction of the portrait. Seleukid convention used a right-facing portrait, but the early Arsakid issues flip this to left-facing. 75 Sellwood 1980, type 3.1-2, 4. See Olbrycht 2013, 65-68; Shayegan 2017 for a discussion of this issue. On the term kara-na-, see Shayegan 2011, 170-176; Hyland 2013.

76 Strootman 2017, 187-192.

77 Sellwood 1980, types 7-10.

78 Thus, the use of a diadem rather than a tiara (Sellwood 1980, type 11), the presence of the omphalos instead of a throne, and the flipped direction of the portrait (Sellwood 1980, type 12-13). See Sinisi 2014. 

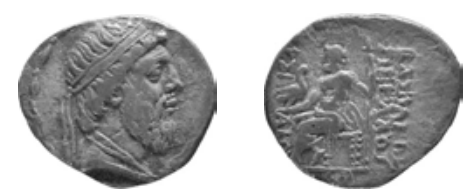

Fig 2: Silver drachm of Mithridates I, 171-138 BCE, from Seleukeia-Tigris, obv. Head of king wearing a diadem, facing right. Rev. Zeus seated, left, holding eagle. Diameter $20 \mathrm{~mm}, 3.27 \mathrm{~g} ., 1 \mathrm{~h}$, Sellwood 13.6. ANS 1944.100.82046. (C) American Numismatic Society.

that evokes a chiton (fig. 2). But the images of Mithridates I's coinage are not purely a quote of Seleukid norms. The king is shown wearing a beard and a hairstyle that is not entirely Seleukid, and in a second image on the reverse, the figure sometimes wears not a chiton, but a trouser-suit, the Parthian costume. ${ }^{79}$ Mithradates I also began to use of the epithet philhellenos on coins minted at Seleukeia. ${ }^{80}$ The term reflects the king's self-presentation as friendly to his new Greek subjects, but at the same time, its use maintains his alterity, since to be 'Greek-loving' is to be explicitly not Greek. ${ }^{81}$ In Mithradates I's coinage, then, we see a response to newfound control of the former Seleukid capital and an adjustment of earlier practice amid changing conditions.

After Mithradates I, many of the more obvious Seleukid borrowings were abandoned, although the use of philhellenos continued. It is in this period that a new royal image emerged, ${ }^{82}$ clear in the costume of the dynasts from this point forward. From the domed tiara of Mithradates II to the combination of the diadem and hairstyle of Orodes II, this image was neither purely Achaemenid nor Seleukid. Next, the coinage of Mithradates II introduced the epithet: 'King of Kings.' This term, never used in the Seleukid court, is seen to indicate a growing Iranian revival among the Arsakid kings and Parthian elites beginning in the first century BCE. ${ }^{83}$

After this, the design of drachms became increasingly fixed, as well as stylized: an obverse featuring a left-facing portrait; a reverse with the image of an archer (e.g., ch. 11, fig. 3b and 3c). ${ }^{84}$ Despite the standardization, by the end of the first century BCE, Arsakid coin issues had begun to diverge into several stylistic schools. ${ }^{85}$ Although it is clear that the overall endeavor of minting was still centrally

79 Curtis 1998 for costume.

80 Wiesehöfer 1996; Dąbrowa 1998 for discussion and earlier bibliography on Arsakid royal epithets.

81 Fowler 2005, 152.

82 Fowler 2005, 147.

83 This is a debated point, Curtis 2007, 15 for the traditional view; Fowler 2005 for an alternative interpretation. On the coinage, Sinisi 2014, 14-15.

84 Sinisi 2014, 14.

85 Sinisi 2014, 23-25. 
planned, the stylistic variation of the later Arsakid coins reflects a pattern of pronounced regionalism that is familiar from other Arsakid contexts.

The coin portraits, then, provide glimpses of the changing Arsakid representations of power and authority, as well as shifting conditions within Arsakid space. Another body of evidence available for considering Arsakid royal ideology and selfpresentation in the first two centuries of the dynasty comes from excavations at Nisa in Turkmenistan, an imperial capital. An ostracon supports the identification of part of the site, Old Nisa, as Mithradatkert, founded by Mithradates I during the period of the Arsakid state's transformation into an imperial power. ${ }^{86}$ Nisa provides a rare window into the cultural context of the Arsakid emperors, showing how they chose to construct the physical seat of their empire.

The site has been excavated since the 1930s, including long-running campaigns in the Soviet period and more recent work by an Italian-Turkmen project. ${ }^{87}$ It is composed of two parts, a large fortified settlement area called New Nisa and the separately fortified area of Old Nisa. ${ }^{88}$ Invernizzi calls the layout of Old Nisa "paratactic" relating this conceptual configuration of space to Achaemenid palace complexes. ${ }^{89}$ He identifies a difference between the building plans, which he attributes typologically to Central Asian Iranian traditions, and building ornamentation, where Greek stylistic vocabularies are in use. ${ }^{90}$ An example of the melding of the two approaches comes from the Round Hall. The structure is thought to be a dynastic shrine, perhaps parallel to the Philippeion at Olympia. ${ }^{91}$ The building's architectural form is not dependent on Greek models though, and indeed the best parallels for the architectural forms of Old Nisa come from Ai Khanum, which similarly developed atop an Achaemenid substrate, layered with (among other things) Central Asian and Seleukid practices. ${ }^{92}$ But the sculptural program, particularly of the Round Hall, featuring monumental clay statues found in an unfortunately fragmentary state, reflects clear familiarity with sculptural forms of the Seleukid world (figs. 3 and 4). ${ }^{93}$ Furthermore, these pieces were sculpted in situ, and therefore reflect the physical presence of artisans likely trained elsewhere in the Hellenistic world at the Arsakid court. ${ }^{94}$ Additional evidence for the extent to which Arsakid court art was entangled with its Seleukid neighbors comes from marble statuettes,

86 Diakonoff and Livshits 1977, 1.2.1: 47, ostracon n. 478. On the debates over the location of Nisa, see Pilipko 1989. The site of Arsakes's earlier capital, known as Asaak (Astauene) is unknown.

87 Pilipko 2001. For the more recent work, see Invernizzi and Lippolis 2008.

88 Canepa 2018, 71-77; see also Invernizzi 2001; Pilipko 2001, 2008.

89 Invernizzi 1997, 112.

90 Invernizzi 2011, 198-199; 2016.

91 Invernizzi 2011, 199.

92 Hauser 2012, 1006-1007; Invernizzi 2016.

93 Although the large-scale terracottas also find affinities with other Central Asian architectural and sculptural practice. On these terracottas elsewhere, Pugachenkova 1971.

94 Bollati 2008. 


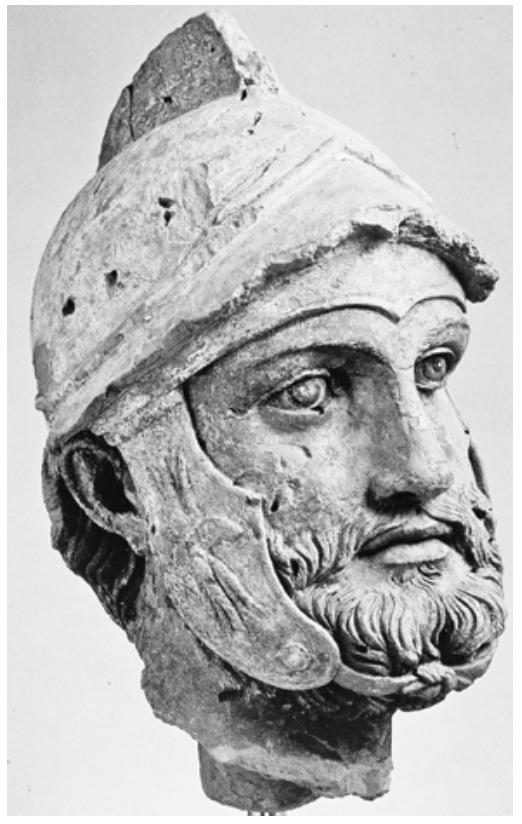

Fig. 3: Head of a warrior in clay, from the Square Hall at Nisa. (c) Centro Scavi Torino.

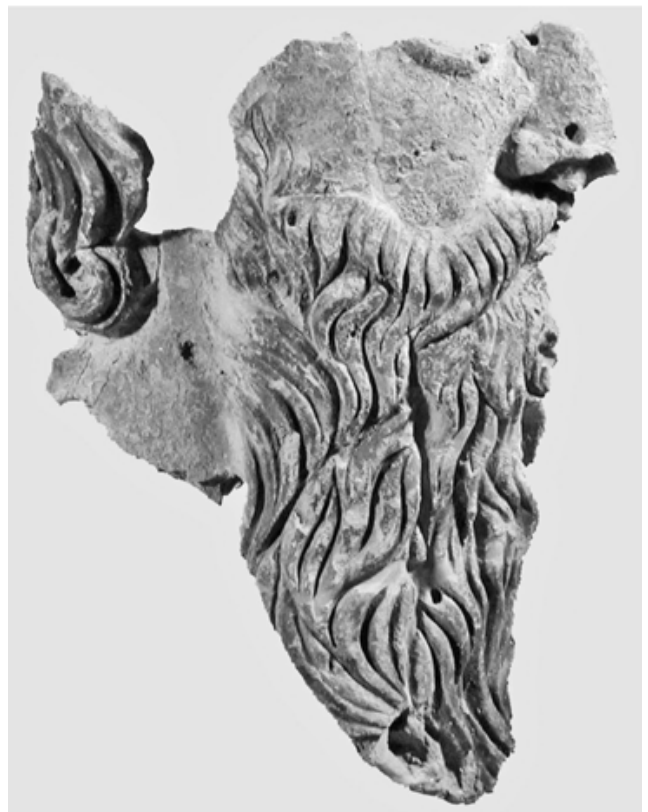

Fig. 4: Part of a clay sculpture, possibly Mithridates I, from the Round Hall at Nisa. (C) Centro Scavi Torino.

metal figurines, and a collection of around 40 ivory rhyta (conical drinking cups) bearing scenes from Greek mythology, all found at Old Nisa. ${ }^{95}$ These objects, often interpreted as imports, could well have been produced by craftsmen working in Central Asia, though ones with a deep familiarity with Seleukid stylistic currents.

In addition to Nisa, literary sources suggest Arsakid capitals and royal residences at a number of other cities, including Ekbatana, ${ }^{96}$ Rhagae, ${ }^{97}$ and Hekatompylos, ${ }^{98}$ as well as eventually Ktesiphon. ${ }^{99}$ Unfortunately, these later capitals have revealed neither Arsakid royal residences nor imperial architecture of the type known from Nisa, so we have a limited understanding of the development of Arsakid imperial architecture or sculptural programs. ${ }^{100}$ Across the sphere of Arsakid interaction, however, a number of other dynastic shrines may be identified, suggest-

95 On the rhyta, Masson and Pugacenkova 1982; Pappalardo 2010.

96 Strabo 16. 1. 16.

97 Athenaios Deipnosophistai 12. 513.

98 Strabo 11. 9. 1; Pliny the Elder Naturalis historia (Plin. HN) 6. 44.

99 Strabo 16. 1. 16; Tacitus Annales (Tac. Ann.) 6. 42. 6. Concerning the various Arsakid capitals and residences, see Chaumont 1973.

100 On the identification of Hekatompylos with Šahr-e Qūmes, near Dāmḡān in Iran, see Hansman and Stronach 1974; Hansman 1981. 
ing that an organized imperial cult became part of kingship among the Arsakids and their contemporaries that marked kingship as explicitly sacral. ${ }^{101}$ This vision of Arsakid kingship is confirmed in the report of the Roman historian Ammianus Marcellinus (ca. 330-395), who describes the deification of Arsakes I upon his death, and the subsequent use of his name as a kingly title with religious undertones. ${ }^{102}$

\section{III.1.2 Aristocratic Identity}

Below the level of the crown, our understanding of the social structure of the Arsakid Empire is hazy. Classical sources do not provide a clear picture of the aristocracy, but tend to differentiate broadly between groups holding varying degrees of freedom, using what seems to be a framework borrowed from the Mediterranean to describe the Parthian system. ${ }^{103}$

Roman sources report a Parthian aristocratic council that served an advisory role within the empire, though the details of its structure and function vary. In one reference, Justin describes an ordo of the nobles who served as military commanders and political leaders, while elsewhere he refers to a Parthian senatus. ${ }^{104}$ Poseidonios apud Strabo describes a bicameral council of the Parthians, ${ }^{105}$ composed of members of the hereditary aristocracy on the one hand, and wise men and priests on the other. ${ }^{106}$

Better evidence for the structure of the aristocracy comes from the Sasanian period, when there is inscriptional evidence for a four-fold division of the elite, with subdivisions delineating the most important noble families. ${ }^{107}$ It is hypothesized that the Arsakid system functioned in a similar way. ${ }^{108}$ The continuities may have

101 On dynastic cult sites, Canepa 2018, 235-239.

102 Ammianus Marcellinus (Amm. Marc.) 23. 6. 4-6. Olbrycht 2016b, 102.

103 Lukonin 1983, 683-684.

104 Just. Epit. 41. 2. 2. The manuscripts for Pomp. Trogus/Justin are confused here: they read either populorum ordo or ipsorum ordo, which has a long history of emendation, including praepositorum ordo or probulorum ordo. See Widengren 1983, 1268 for an argument that populorum ordo is an acceptable Latin version of a term familiar from later Iranian feudalism. The identity of the nobles being referenced in is unclear. Those seeing the Arsakid Empire as strongly nomadic tend to interpret these families as the vestiges of nomadic aristocracy (Olbrycht 1998, 115-117).

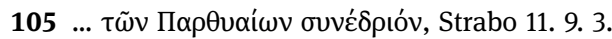

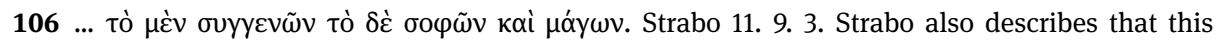
body is responsible for electing the king, chosen from their ranks, although this assertion has been contested, Hauser 2005, 187-192; Lerouge 2007, 250; Wolski 1993, 112.

107 Lukonin 1983, 699.

108 The origin of this internal hierarchy is unclear. Lukonin $(1983,699)$ notes that many of the terms come from known Achaemenid antecedents, suggesting that perhaps the structure can be connected to Achaemenid court practices. Olbrycht (2003, 88-89), however, is skeptical of Achaemenid continuities in the social structure of the Arsakid elite, and suggests that the structures have more in common with steppe mobile pastoralists. 
been quite direct. For instance, several noble families attested in the Sasanian sources - the Sūrens and Kārens - are known to have been important within the Arsakid Empire. ${ }^{109}$ However, the distorted picture in the Greek and Latin sources hinders a total reconstruction of the earlier Arsakid system. ${ }^{110}$

As exemplified in the conflicting stories surrounding the founder of the Arsakid dynasty, the (ethno-)cultural roots of the Parthian lords more broadly have been the subject of much debate, centered around the question of Parthian nomadism. ${ }^{111}$ For a long time, and especially among scholars working in Eastern Bloc countries of the Soviet space, emphasis was placed on their putatively non-Iranian roots and their nomadic character. ${ }^{112}$ However, in the context of modern scholarship, pre-Islamic Iranian cultural belonging is constructed either on linguistic (speakers of an Iranian language), or religious (those who practice Zoroastrianism) grounds. ${ }^{113}$ In both senses, the Parthians fit. The main administrative language of the Arsakid court, Parthian, was an Iranian language, and the dynastic religion of the Arsakids appears to have been an earlier form of Zoroastrianism. ${ }^{114}$

At the same time, it also appears clear that Arsakid power was enabled through close relationships between Parthian aristocrats and members of so-called Scythian mobile pastoralist groups. These alliances - which may indeed have been essentially Parthian cooption of mobile pastoralist mercenaries - are most clearly attested in a coalition that Olbrycht has called the Daho-Hyrkanian group, who maintained considerable autonomy along the Caspian coast and northeastern Iran. ${ }^{115}$ Parthian nobles in alliance with the Dahae presented a formidable base of power, and were the force behind a number of episodes of 'pretenders' to the Arsakid throne through the first century CE. They were also the force behind the ascension of Artabanos II, himself raised among the Dahae. ${ }^{116}$ Although scholars will likely continue to disagree about the depth the Parthians' socio-cultural debt to the nomadic world, the

109 For the Sūrens, see Plut. Crass. 21. 6-7; Tac. Ann. 6. 42. On the Kārens, see Tac. Ann. 12. 10-14. For the families and their appearance in the Sasanian texts, see Lukonin 1983, 704. For debates, see Hauser 2006, 304-307.

110 Compelling arguments have been advanced for parts of the system, see Dąbrowa 2013; Koshelenko 1980; Olbrycht 2003.

111 Some have stressed the predominantly sedentary nature of the Arsakid dynasty and their socio-political world (Boyce 1994; Hauser 2005), while others maintain that nomadic practices had long ramifications (Koshelenko 1966, 1980; Nikonorov 1995; Olbrycht 2003, 2015).

112 It is hard to overlook the role of historiography in this discussion. Much of the archaeological evidence cited in support of nomadic connections was conducted by scholars in the Soviet Union, and therefore more available to russophone scholars. See Fabian, ch. 13, this volume.

113 De Jong 2017.

114 At the same time, there is evidence for the practice of some elements of Zoroastrianism in nonIranian communities within the Arsakid sphere, particularly from the Caucasus, Rapp 2009; Russel 1987.

115 Olbrycht 1998, 161.

116 Tac. Ann. 6. 36. 41-42. 
Dahae demonstrate, at the very least, the ongoing relevance of mobile pastoralist groups in the internal affairs of the Arsakid Empire into the first century CE.

Religion is another category within the Arsakid Empire that shaped the elite, but also cut across other types of social networks. A growing body of evidence, especially from the Nisa ostraca, has demonstrated that the Arsakid kings and elite families practiced Zoroastrianism. ${ }^{117}$ But unlike in the Sasanian period, the religion was not an instrument of state authority. Instead, the practice of Zoroastrianism was more akin to domestic religion, creating a mosaic of locally specific religious instantiations. ${ }^{118}$ Evidence for one such instantiation comes from accounts of elite families in Arsakid Armenia, who included as part of their familial retinue both priests and minstrels connected to the Zoroastrian tradition, who perpetuated both religious and lay knowledge. ${ }^{119}$

At the same time, the empire also accommodated groups that operated within other religious frameworks, which created different networks within the empire. Talmudic sources provide the most abundant evidence for one such group: the Jewish community. Split between Roman and Arsakid space, the accounts suggest that co-religionists bridged the gap between the imperial systems. Their cross-border activity is visible in the Roman historian Josephus's stories about the Arsakid vassal kingdom Adiabene, whose royal family converted to Judaism in the first half of the first century CE. ${ }^{120}$ Finally, cuneiform texts and material evidence also attest to the continuation of older Mesopotamian religious practices. One particularly elucidating example comes from the archive of Rahimesu, documenting the financial administration of a Babylonian temple in 94-93 BCE, where religious practices continued under the Arsakids. ${ }^{121}$

The social practices and political organization of the Arsakid Empire, viewed here through the lenses of kingship, aristocratic self-presentation, and religion, demonstrate the flexibility of the imperial system. Over the course of the centuries, it is possible to identify trends in the ideological frameworks of Arsakid rule, including the intensification of intentionally 'Iranian' representational practices, albeit often ones that represent neo-Persian adaptations and a continued involvement with the mobile pastoralist world. The socio-political system that arose in this context was based on a network of connections between the Arsakid family, their Parthian kinsmen, and a growing circle of elites from Armenia to India.

117 De Jong 2015b, 94-95.

118 De Jong 2008.

119 Boyce 1957, on the gōsān minstrels. On their presence in the court retinue in Armenia, see de Jong 2015a, 127.

120 Josephus Antiquitates Judaicae (Joseph. AJ) 20. 17-96. For Josephus on Adiabene, see Rajak 1998.

121 Van der Spek 1998. 


\section{III.2 Military Force}

A formidable military force facilitated the expansion of both the dynasty and its elite. There are heated debates about the structure of the Arsakid army and the origins of its tactical advantages. ${ }^{122}$ It is clear, however, that military strength played a central role in Arsakid history, from the early days when the Parthians took advantage of the dissolution of Seleukid power, to their later confrontations with Romans and Saka on their borders.

The Parthian military, and particularly its cavalry, is prominent in Roman literary sources, which paint a picture of a mobile fighting force with several specialized heavy-armored troops, most notably the cataphracti/kataphraktoi. ${ }^{123}$ The Parthian armies were also known for their deadly mounted archers, ${ }^{124}$ famous for their ability to shoot backward while at full gallop in the so-called 'Parthian Shot.' ${ }^{125}$ Beyond the esteemed cavalry, the sources also describe infantry of various types, as well as camel-mounted lancemen. ${ }^{126}$

The Parthian army was organized on a decimal system and was what scholars call a composite army. ${ }^{127}$ It included a relatively small standing force under the direct rule of the Arsakid king, ${ }^{128}$ as well as hired mercenaries, especially those drawn from mobile pastoralist communities in the north and northeast of the empire. ${ }^{129}$ Numerically, the strength of the army lay in forces mobilized by the ruling elite in areas under direct Arsakid control, as well as by kings from territories in its suzerainty or in alliance with it. ${ }^{130}$ Within these forces, the sources describe military roles both for the aristocrats themselves and the so-called servi, those dependent on the aristocratic families. Plutarch, for example, provides three separate classes of dependent fighters, the douloi, pelatai and oiketoi, inside of the forces serving one Parthian lord. ${ }^{131}$

122 E.g., Wolski 1981; Hauser 2006; Olbrycht 2015.

123 Plutarch Life of Lucullus (Plut. Luc.) 26-28; Frontinus Strategemata (Frontin. Str.) 2. 2. 4; Appian Mithridateios (App. Mith.) 85. See Potts 2007; Hauser 2006, 300-301.

124 Plut. Crass. 24. 3-27. 1; Tac. Ann. 6. 35. 2.

125 Wissemann 1982 on the 'Parthian shot' in Roman literature.

126 Cass. Dio 40. 15. 2; Appian Bella civilia (App. B Civ.) 2. 18; Herodianos (Hdn.) 4. 14. 3. For more detail on the composition of the army, see Hauser 2006, 297-304.

127 Olbrycht 2016a, 296.

128 Olbrycht (2016a, 299-303) sees the standing forces as specifically a type of 'royal guard,' attested for example in Tac. Ann. 15. 2. 4, as well as in inscriptions, while Hauser considers the standing army to be those "(1) at fortresses for border control and in garrisons and (2) cataphracti ..." (2006, 310-311).

129 Just. Epit. 42. 1. 2; Tac. Ann. 6. 33. 2-3, 6. 36. 3. See Wolski 1965, 107.

130 For an attempt to reconstruct the numerical strength of the Arsakid forces, see Olbrycht 2016a. Although his account differs in many specifics, Hauser 2006, 311 reaches the same conclusion about the proportional scale of the 'standing' vs. levied armies.

131 Plut. Crass. 21; 27. 
That these troops were levied indirectly rather than directly by the Arsakid king has been interpreted as a sign of the weakness of the Arsakid monarch. A central textual locus of this debate is Herodianos 3. 1. 2-3, which describes an episode in which the Arsakid king Vologases V ordered his satrapal commanders to gather troops for battle, rather than relying on either a standing army or mercenaries that he controlled directly. ${ }^{132}$ The organization of the Arsakid army did not follow the Roman model with which Herodianos was familiar, but neither should this system be seen as intrinsically weak. On the contrary, when it functioned well, it enabled the King of Kings to limit military expenditures by procuring troops through indirect channels.

In the early centuries of Arsakid growth, between the reigns of Mithradates I and Mithradates II, the kings were able to use revenues from their newly conquered territories to hire large numbers of mercenary forces. As growth slowed, greater power shifted into the hands of Parthian elites, who increasingly headed fighting forces with the "characteristics of private militias." 133 The Arsakid kings in the late first century BCE and early first century CE were dogged by difficulties arising from these powerful factions, whose interference in imperial succession was a recurrent trope. But eventually, the Arsakid monarchs found a solution, consolidating power within the imperial family. This created a formidable dynastic bulwark stretching from Armenia through northern Mesopotamia and Media, stabilizing the empire and diminishing the power of rival claimant clans. ${ }^{134}$

\section{III.3 Administration, Space, and Movement}

\section{III.3.1 Administration and Territorial Governance}

There does not appear to have been a single, uniform system of territorial control across Arsakid space, nor was there a single policy toward border zones. ${ }^{135}$ Instead, there were several types of territories, including those directly administered by governors appointed from the ranks of the empire's aristocratic families or local elites; frontier regions that seem to have been entrusted to specific caretakers; and allied kingdoms. ${ }^{136}$ The borders seem largely permeable, facilitating a continuation of older networks linking populations across the space.

\footnotetext{
132 Hdn. 3. 1. 2.

133 Gregoratti 2017b, 136-137.

134 Olbrycht 1998, 176-190.

135 In the case of the northern frontiers, recent archaeological work has demonstrated that contrary to previous belief, the Arsakid period did not see the construction of border walls or fortification architecture, unlike in the Sasanian period (Sauer et al. 2012).

136 Wiesehöfer 1999, 99-100 on this formulation. See, for example, the command structures described in Shayegan 2017, 414-415.
} 
A more detailed picture of the Arsakid administrative system in one corner of the empire can be gleaned in Babylonia, where the combination of the Astronomical Diaries and inscriptions provide the richest evidence. In particular, the reports about Babylonia emphasize the importance of cities - a territorial unit with roots in the pre-Arsakid period - within the system. The hierarchy described for Babylonia is multilayered, ${ }^{137}$ with the permanent presence of satrap, as well as generals and garrison commanders with military roles of a more limited operational scope, ${ }^{138}$ all of whom could be presided over by a supreme commander in times of conflict. Some elements of this system appear also to have been in force in Arsakid Dura Europos, suggesting that it may have been common at least in the western Arsakid territories. ${ }^{139}$ A much more granular glimpse into a specific administration/taxation system comes from Nisa, where a collection of ostraca describe officials involved the receipt of taxable foodstuffs (wine) from a specific type of land. ${ }^{140}$ These accounts record the participation of at least three different types of officials, some of whom seem to have had both military and civilian roles within the hierarchy.

An episode of sub-satrapal history from Babylon sheds light on the functioning of this system. ${ }^{141}$ The episode involves two brothers, Anilieos and Asinaios, who edged into power as Jewish rulers in the Babylonian cities of Neardea and Nisibis. Their power grew from ragtag beginnings extracting tribute from local residents after they won a surprising defeat over the Arsakid governor in Babylonia. ${ }^{142}$ In the wake of this upset, rather than siding with his governor or generals, the Arsakid king Artabanos chose to recognize the brothers as the rightful rulers of Babylon, ${ }^{143}$ after which the pair then ruled for 15 years from around the early 20s CE, until they were eventually deposed but by rival Babylonians. In any event, Artabanos's choice to recognize the brothers was an attempt to curb the power of his own officials in the region, ${ }^{144}$ and reflects the complicated flows of power under the Great King.

Beyond lands controlled in these ways, the Arsakid Empire also included a number of vassal kingdoms like Adiabene, Hyrkania, Charakene and Elymais,

137 Shayegan 2011, 208-221.

138 There has been a suggestion that the Arsakid system continued a practice from the Seleukid period, where Greek citizens in major cities had their own general appointed by the king from their number and who was responsible both for the typical administrative duties of the city's protection, but also for raising Greek troops (Shayegan 2011, 213).

139 Shayegan 2011, 215-219.

140 For ostraca related to vineyards and the uzbari ('wzbry) estates, see Diakonoff and Livshits 1977, 1.2.1.

141 Joseph. AJ 18. 310-70. The story is embedded in Josephus's longer moralizing tale of why the Jews at Seleukeia were massacred, but is thought to be historical. See Rajak 1998.

142 Fowler 2007.

143 Joseph. AJ 18. 337.

144 Joseph. AJ 18. 330. 
whose rulers retained considerable autonomy. ${ }^{145}$ De Jong has termed these flanking kingdoms the "Parthian Commonwealth" in recognition of the fact that these spaces were participating not only in a political Arsakid sphere, but more broadly in a culturally Parthian one. ${ }^{146}$ These local dynasts had the right to carry out local and regional functions like appointing judges, setting prices, and collecting duties, and sometimes even minting coinage. ${ }^{147}$ The kingdoms paid tribute and levied troops when requested. ${ }^{148}$ This distributed power structure allowed the empire to grow exceptionally quickly, and spared the central authority from needing to concern itself with the array of minor conflicts that transpired on its borders.

Evidence does not allow for the creation of a universal picture of relationships between the King of Kings and the rulers of the allied kingdoms. However, the glimpses that are possible suggest that Arsakid dynasts held power by balancing the interests of local dynasts with those of other powerful constituent groups within the spaces and harnessing these diverse groups to maintain their own power. The result was a hierarchy that distributed power horizontally across geographically disbursed regional authorities. ${ }^{149}$ There was, however, a shift over time, with local dynasts increasingly replaced by members of the Arsakid family from the time of Vologases I onward, providing greater centralization of power in the royal family, if not in the King of Kings himself. ${ }^{150}$ Thus, by the early second century CE, the son of Pakoros and brother of Vologases II had been installed on the throne in Charakene, while the thrones of Elymais and Media Atropatene both moved into the hands of Arsakid-connected dynasts. ${ }^{151}$

\section{III.3.2 Architecture and Urbanism}

The expansion of the Arsakid Empire also brought material changes to territories under its control. In general, however, as with the structure of the empire itself, there was significant local variation in the nature and extent of the large- and smallscale transformations of material culture. Nevertheless, the spread of imperial architectural forms, and particularly the barrel-vaulted hall or ayvan, would go on to

145 Pliny (HN 6. 112) reports that, in the first century CE, there were 18 kingdoms (regna) of the Parthians, although some have taken the term regna to be the term for Arsakid satrapies more generally (Dąbrowa 2012, 180).

146 De Jong 2013a, 155-159.

147 See, for example, the case of the exilarchs of the Judaeans (Lukonin 1983, 728). On coinage, see also the situation in Fars, Wiesehöfer 2007.

148 Olbrycht 2016a, on the importance of their troops to the overall Arsakid fighting force.

149 Fowler 2010, 75-77 develops the idea of horizontal distribution of power in the context of a hierarchal system.

150 Hauser 2006, 307; Gregoratti 2017a, 101.

151 Gregoratti 2017a, 100-101. 
have long-reaching consequences for the future development of Persian architecture. ${ }^{152}$

There are some textual accounts of Arsakid urban foundations, which report, for example, the early city-building and fortification activities of Arsakes, and the founding of Vologesias by Vologases I. ${ }^{153}$ But most data for understanding Parthian settlement patterns and urbanism are archaeological, and are both laconic and unevenly dispersed. The most intensive work of settlement and urban archaeology of the Arsakid period has been conducted in Mesopotamia. Many of the older cities in the area, such as Seleukeia, Babylon, Nippur, and Uruk, saw at least some growth in the wake of Arsakid expansion, and also considerable ruptures with pre-Arasakid usages of space. ${ }^{154}$ Beyond the spatial renegotiations, the Arsakid period also saw the emergence of distinct and un-Babylonian forms of religious architecture, as in the case of the Gareus temple, constructed in the early second century CE. It combines a Greek dedicatory inscription with a ground plan and decorative details that drew on both Babylonian and Hellenistic traditions. ${ }^{155}$

Outside of Babylonia, some of the strongest archaeological evidence for shifts brought by Parthian presence comes from areas within Elymais, particularly those discovered in the course of long-running excavations at Susa, where the Arsakid period was also one of considerable wealth and expansion. ${ }^{156}$ The productive potential of the city and its hinterland was enhanced by the Arsakid presence, as evidenced by a Greek-language dedicatory inscription to an Arsakid strategos, Zamaspes, set up on behalf of the city's citizenry to commemorate his role in the expansion of irrigation works. ${ }^{157}$ Evidence of expansion and the flourishing of settlement can be seen in Northern Mesopotamia, which saw marked expansion in the scale of previously existing settlements along the Euphrates. ${ }^{158}$ Suggestive of the economic expansion of the Arsakid period, smaller scale Arsakid-period sites in Elymais have been noted to cluster along trade routes, including both the older Achaemenid royal road and routes known to have been in use in the Islamic period. ${ }^{159}$ This pattern is not uniform, however, since farther north in the Dehlorān plain of northern Khūzestān, archaeological survey has demonstrated that Arsakid-period sites were not located along what are presumed to be central routes, but were instead disbursed. ${ }^{160}$

152 See for example the detailed study of regionalism in ceramic styles in Haerinck 1983.

153 Especially Chaumont 1974.

154 For overviews: Canepa 2018, 81-94; Hauser 2012, 1007. For Nippur, see Crawford 1959; Knudstad 1968; Keall 1975. On Uruk, see Adams and Nissen 1972.

155 Kose 1998, 291-335. See also Downey 1988, 137-143.

156 Miroschedji, Desse-Berset, and Kervran 1987, 51.

157 Cumont 1931, 249; Shayegan 2011, 209-211.

158 Hauser 2017b, 238-239.

159 Moghaddam and Miri 2007, 45-48.

160 Neely 2016, 258. 
Beyond the developments in urban systems, a number of sites also demonstrate the development of regional palace architecture or elite villa architecture. ${ }^{161} \mathrm{Al}$ though the dating of many of these structures has presented a persistent problem, new archaeological work, as well as reassessments of earlier excavations, have uncovered a body of elite architecture that is increasingly recognizable as specifically Parthian. These sites set new precedents in architecture - particularly the use of the ayvan, or barrel-vaulted hall - that were influential in the later development of Persian architectural forms. ${ }^{162}$

\section{III.3.3 Movement through the Empire and Trade Relations}

The networks that developed as a result of the complex political system described above covered the land stretching from the edges of the Mediterranean world, through the heartland of the ancient societies of the Near East, and then farther toward Central Asia, India, and China. The Arsakid Empire created conditions that facilitated organized trade across these corridors, although the perception that Parthians were middlemen in direct Roman-Chinese trade is widely rejected today. ${ }^{163}$

Evidence of Arsakid-era movement along east-west routes is preserved in surviving fragments of the work of Isidoros of Charax, known as the Stathmoi Parthi$k o i .{ }^{164}$ The text provides something of an itinerary and a description of Arsakid territories from Zeugma at the eastern edge of Anatolia to Central Asia, moving along the Euphrates corridor to Seleukeia before turning in to the Zagros highlands and the eastern territories of Hyrkania and Khorāsān. ${ }^{165}$ Detailed itineraries from the Achaemenid period attest to the existence of an official 'royal road' running along much of the same path, particularly in Mesopotamia. In both the Achaemenid and Arsakid periods, Seleukeia-Tigris was a node, articulating interactions between the highlands, Mesopotamia, and the Persian Gulf. ${ }^{166}$ The movement of the Arsakid seat to this city in the mid-second century BCE likely reflects its value in this sense. The foundation of Vologesias nearby in the first century CE shows the continued relevance of the area and the desire of the later Arsakid monarchs to direct more of the profits of the trading activity to the royal treasury by circumventing the entrenched interest groups in Seleukeia. ${ }^{167}$

\footnotetext{
161 Canepa 2018, 315-323.

162 Canepa 2018, 316-317.

163 Rezakhani 2010.

164 Isidoros of Charax, born in the capital of Charakene, likely wrote in the early first century CE, Hartmann 2017; Schuol 2017.

165 Hauser 2017a elaborates on the different sections of the text.

166 Strabo 16. 2. 5; Plin. HN 6. 122.

167 Keall 1975 discusses the growing commercial interests of the Arsakid kings in this period.
} 
The role of cities in both Babylonia and Charakene within global trade systems is made clearer in the long-term presence of Palmyrene merchants along the Euphrates. ${ }^{168}$ The Palmyrene traders, who operated lucrative caravan trade across the Syrian desert, left a number of inscriptions at Palmyra attesting to their presence in what might be understood as Palmyrene trading colonies in Arsakid territories in the Tigris-Euphrates basin, particularly in the capital of Charakene, Spasinou Charax (an important node in the Indian Ocean trade routes), as well as Vologesias, Seleukeia, Babylon, and other smaller cities. The epigraphic testimony attests not only to the presence of these merchants, but to their active roles in the civic life of cities under Arsakid control where they engaged in what can be seen as Hellenistic forms of civic generosity. The presence of these Palmyrene communities at Vologesias, well after the Arsakid kings started to take a more active role in managing the trade networks of their empire, demonstrates that the Arsakids did not intend to develop a trade monopoly of their own, but rather an infrastructure through which they could extract profit. The eventual terminus of the Palmyrene trading routes at cities on the coast of the Persian Gulf suggests a maritime component of the Parthian trade infrastructure. ${ }^{169}$

Several accounts from Chinese sources, the Shiji, Hanshu, and Hou Hanshu, also highlight the importance of trade within the Arsakid Empire (Anxi) from a Chinese perspective. ${ }^{170}$ One account from 121 BCE comes from the biography of the emissary Zhang Qian, transmitted in the wake of early direct contacts between the Chinese and Arsakid courts. ${ }^{171}$ In this description, the Arsakid lands are described as vast, cultivated, and developed, with hundreds of towns both large and small, with "trading places" and merchants who "travel in carts and ships" deep into the territory of their neighbors, using silver money minted by the state. ${ }^{172}$

Two later episodes in the Hou Hanshu describe what may be Parthian attempts to control trade across their space by inhibiting the development of direct RomanChinese diplomatic relationships. The first episode dates to ca. $97 \mathrm{CE}$, when the Chinese emissary Gan Ying sought to reach Da Qin, or the Roman Empire. ${ }^{173}$ Gan Ying made it as far as a port called Tiaozhi, identified by some as Charakene. ${ }^{174} \mathrm{He}$ was then told by his Parthian interlocutors that the sea journey was long and risky, and decided not to attempt it. A second account from 166 CE expresses clear eco-

168 Matthews 1984, 166. On the role of Palmyrene trade in the Near East more generally, see Seland 2014.

169 Millar 1998; Seland 2011; Gregoratti 2019. See Dwivedi, ch. 2, sec. VI.2, this volume for a discussion of so-called torpedo jars and their misinterpretation.

170 Posch 1998. On the context of these sources, see also Morris, ch. 9, this volume.

171 Shiji 123, see Posch 1998, 358-359, 2.1.1-2.1.5.

172 Shiji 123.3161.

173 Hou Hanshu 88.2918; see also Gregoratti 2019, 57-59.

174 This identification is much debated. See the recent discussion in Zanous and Yang 2018, 133134. 
nomic motives for Parthian interference in the establishment of direct Roman-Chinese diplomatic relations, saying that the Parthians "put obstacles" in the way of the Romans, wishing themselves "to trade with them [the Romans] in Chinese silk." 175

The question of how far these sources can be extrapolated in an effort to understand Parthian trade interests remains debated. ${ }^{176}$ It seems clear, though, that both Roman and Chinese sources viewed the Parthians as an important link in overland and maritime trade between the Mediterranean and East Asian spheres. How the Arsakid dynasts and Parthian elites themselves understood this position is, unfortunately, less clear.

\section{Conclusion: Arsakid Potentials: (Re)configurations of Networks}

The Arsakid Empire is a slippery phenomenon. Its decentralized structure and diverse communities were a key source of imperial strength, allowing dynasts to draw on diverse models of rule in their imperial project and to pivot quickly when facing changing historical circumstances. These same structural characteristics, however, ensured that centrifugal forces were never far from the surface, threatening to destabilize the imperial network.

Arsakid rule generally allowed the communities under its dominion to retain their own cultural practices, and as a result supported a bewildering diversity within its borders. Arsakid kings, particularly in the early days of imperial expansion, were comfortable integrating local elites from across the empire into their imperial administration. As a result, preexisting networks maintained their relevance and were even elevated as they came to participate in the more expansive political context afforded by the Arsakid hegemony. Although it is possible to glimpse the growth of a Parthian cultural koine (community) in the period, it never entirely supplanted local practices, and there cannot be said to have been a uniform 'Arsakid' cultural program, nor indeed a single Arsakid culture.

The lasting legacy of the empire, however, was far-reaching, stretching well past the borders of the empire, from Anatolia to eastern Central Asia. The empire created a shared political community across this tremendous territory, in which local nodes were empowered to conduct their affairs with relatively little direct oversight. Instead, both diplomacy and trade happened along a web of interactions that connected the Arsakid dynasts to their far-flung kinsmen and nobles, joined by cultural patterns rather than by statutory bonds.

175 Hou Hanshu 99.2920.

176 Alram 2004; Gregoratti 2014; Wiesehöfer 2016; ch. 11, this volume. 


\section{References}

Adams, R. McC., and H. J. Nissen. 1972. The Uruk countryside: The natural setting of urban societies. Chicago, IL: University of Chicago Press.

Alram, M. 1998. "Stand und Aufgaben der arsakidischen Numismatik." In Wiesehöfer (1998), 365-388.

-. 2004. "The history of the Silk Road as reflected in coins." Parthica 6, 47-68.

Assar, G. F. 2006a. "A revised Parthian chronology of the period 91-55 BC.” Parthica 8, 55-104.

-. 2006b. "A revised Parthian chronology of the period 165-91 BC." Electrum 11, 87-158.

-. 2009. "Some Remarks on the chronology and coinage of the Parthian 'Dark Age." Electrum 15, 195-234.

Bivar, A. D. H. 1983. "The political history of Iran under the Arsacids." In E. Yarshater (ed.), The Cambridge history of Iran. Vol. 3.1, 21-99. Cambridge: Cambridge University Press.

-. 2007. "Gondophares and the Indo-Parthians." In V. S. Curtis and S. Stewart (eds.), Age of the Parthians, 26-36. London: I. B. Tauris.

Bollati, A. 2008. "Le sculture in argilla cruda dipinta." In Invernizzi and Lippolis (2008), 167-196. Bosworth, A. B. 1977. "Arrian and the Alani." Harvard Studies in Classical Philology 81, 217-255.

Boyce, M. 1957. "The Parthian Gōsān and Iranian minstrel tradition." Journal of the Royal Asiatic Society 89.1-2, 10-45.

-. 1983. "Parthian writings and literature." In E. Yarsahter (ed.), The Cambridge history of Iran. Vol. 3.2, 1151-1165. Cambridge: Cambridge University Press.

-. 1994. "The sedentary Arsacids." Iranica Antiqua 29, 241-251.

Canepa, M. P. 2017. "Rival images of Iranian kingship and Persian identity in post-Achaemenid western Asia." In R. Strootman and M. J. Versluys (eds.), Persianism in antiquity, 200-222. Stuttgart: Franz Steiner.

-. 2018. The Iranian expanse: Transforming royal identity through architecture, landscape, and the built environment, 550 BCE-642 CE. Berkeley, CA: University of California Press.

Chaumont, M.-L. 1973. "Études d'histoire parthe. II: Capitales et résidences des premiers Arsacides (Ille-ler s. av. J.-C.).” Syria 50, 197-222.

-. 1974. "Études d'histoire parthe. III: Les villes fondées par les Vologèse." Syria 51, 75-89.

Crawford, V. E. 1959. "Nippur, the holy city." Archaeology 12.2, 74-83.

Cumont, F. 1931. "Inscriptions grecques de Suse." Comptes rendus des séances de l'Académie des Inscriptions et Belles-Lettres 75.3, 233-250.

Curtis, V. S. 1998. "The Parthian costume and headdress." In Wiesehöfer (1998), 61-74.

-. 2007. "The Iranian revival in the Parthian period." In V. S. Curtis and S. Stewart (eds.), Age of the Parthians, 8-25. London: I. B. Tauris.

Dąbrowa, E. 1998. “Philhellên: Mithridate ler et les Grecs.” In E. Dąbrowa (ed.), Ancient Iran and the Mediterranean world: Proceedings of an international conference in honour of Professor Józef Wolski held at the Jagiellonian University, Cracow, in September 1996, 9-17. Krakow: Jagiellonian University Press.

-. 2009. "Mithradates I and the beginning of the ruler-cult in Parthia." Electrum 15, 41-51.

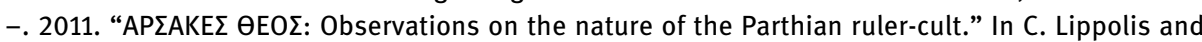
S. de Martino (eds.), Un impaziente desiderio di scorrere il mondo: Studi in onore di Antonio Invernizzi per il suo settantesimo compleanno, 247-253. Florence: Le lettere.

-. 2012. "The Arsacid Empire." In T. Daryaee (ed.), The Oxford handbook of Iranian history, 164186. Oxford: Oxford University Press.

-. 2013. "The Parthian aristocracy: Its social position and political activity." Parthica 15, 53-62.

-. 2014. "A troublesome vassal? Elymais and Parthia (141 BC-AD 228)." Parthica 16, 61-68.

-. 2018. "Arsacid dynastic marriages." Electrum 25, 73-83.

De Jong, A. 2008 [2012]. "Regional variation in Zoroastrianism: The case of the Parthians." Bulletin of the Asia Institute 22, 17-27. 
-. 2013a. "Hatra and the Parthian commonwealth.” In L. Dirven (ed.), Hatra: Politics, culture and religion between Parthia and Rome, 143-160. Stuttgart: Franz Steiner.

-. 2013b. “Religion in Iran: The Parthian and Sasanian periods (247 BCE-654 CE)." In W. Adler and M. A. Sweeney (eds.), The Cambridge history of religions in the ancient world. Vol. 2, 23-53. Cambridge: Cambridge University Press.

-. 2015a. "Armenian and Georgian Zoroastrianism.” In M. Stausberg and Y. S.-D. Vevaina (eds.), The Wiley Blackwell companion to Zoroastrianism, 119-128. Malden, MA: Wiley-Blackwell.

-. 2015b. "Religion and politics in pre-Islamic Iran.” In M. Stausberg and Y. S.-D. Vevaina (eds.), The Wiley Blackwell companion to Zoroastrianism, 83-101. Malden, MA: Wiley-Blackwell.

-. 2017. "Being Iranian in antiquity (at home and abroad)." In R. Strootman and M. J. Versluys (eds.), Persianism in antiquity, 35-47. Stuttgart: Franz Steiner.

Diakonoff, I. M., and V. A. Livshits. 1976-2001. Corpus Inscriptionum Iranicarum. Part 2, vol. 2.1, Parthian Economic Documents from Nisa. 6 vols. London: School of Oriental and Asian Studies.

Dirven, L. 2016. “The problem with Parthian art at Dura.” In T. Kaizer (ed.), Religion, society and culture at Dura-Europos, 68-88. Cambridge: Cambridge University Press.

Downey, S. B. 1988. Mesopotamian religious architecture: Alexander through the Parthians. Princeton, NJ: Princeton University Press.

Fisher, W. B. 1968. "Physical geography.” In W. B. Fisher (ed.), The Cambridge history of Iran. Vol. 1, 3-110. Cambridge: Cambridge University Press.

Fowler, R. 2005. “'Most fortunate roots': Tradition and legitimacy in Parthian royal ideology.” In O. Hekster and R. Fowler (eds.), Imaginary kings: Royal images in the ancient Near East, Greece and Rome, 125-155. Stuttgart: Franz Steiner.

-. 2007. "Kingship and banditry: The Parthian Empire and its western subjects." In T. Rajak (ed.), Jewish perspectives on Hellenistic rulers, 147-162. Berkeley, CA: University of California Press.

-. 2010. “King, Bigger King, King of Kings: Structuring power in the Parthian world.” In T. Kaizer and M. Facella (eds.), Kingdoms and principalities in the Roman Near East, 57-77. Stuttgart: Franz Steiner.

-. 2017. "Cyrus to Arsakes, Ezra to Izates: Parthia and Persianism in Josephus.” In R. Strootman and M. J. Versluys (eds.), Persianism in antiquity, 355-380. Stuttgart: Franz Steiner.

Frye, R. N. 2004. "Parthians in the East." Parthica 6, 129-132.

Ghirshman, R. 1962. Persian art: The Parthian and Sassanian dynasties, 249 BC-AD 651. S. Gilbert and J. Emmons (trans.) New York, NY: Golden Press.

Gregoratti, L. 2013. "The journey east of the Great King: East and West in the Parthian kingdom." Parthica 15, 43-52.

-. 2014. "The Parthian Empire: Romans, Jews, Greeks, nomads and Chinese on the Silk Road." In M. N. Walter and J. P. Ito-Adler (eds.), The Silk Road: Interwoven history. Vol. 1, 43-70. Cambridge: Cambridge Institutes Press.

-. 2017a. "Sinews of the other empire: The Parthian Great King's rule over vassal kingdoms." In H. Teigon and E. Seland (eds.), Sinews of empire, 95-104. Oxford: Oxbow.

-. 2017b. “The Arsacid Empire.” In T. Daryaee (ed.), King of the seven climes: A history of the ancient Iranian world (3000 BCE-651 CE), 125-153. Irvine, CA: UCI Jordan Center for Persian Studies.

-. 2019. "Indian Ocean trade: The role of Parthia." In M. A. Cobb (ed.), The Indian Ocean trade in antiquity: Political, cultural and economic impacts, 66-86. London: Routledge.

Hackl, U., B. Jacobs, and D. Weber, eds. 2010. Quellen zur Geschichte des Partherreiches: Textsammlung mit Übersetzungen und Kommentaren. 3 vols. Göttingen: Vandenhoeck \& Ruprecht.

Haerinck, E. 1983. La céramique en Iran pendant la période parthe (ca. 250 av. JC à ca. 225 après JC): Typologie, chronologie et distribution. Gent: Iranica Antiqua. 
Hansman, J. 1981. "The measure of Hecatompylos." Journal of the Royal Asiatic Society, no. 1, 3-9.

Hansman, J., and D. Stronach. 1974. "Excavations at Shahr-i Qūmis, 1971." Journal of the Royal Asiatic Society, no. 1, 8-22.

Hartmann, U. 2017. "Die Parthischen Stationen des Isidor von Charax: Eine Handelsroute, eine Militärkarte oder ein Werk geographischer Gelehrsamkeit?" In Wiesehöfer and S. Müller (1017), 87-126.

Hauser, S. R. 2005. "Die ewigen Nomaden? Bemerkungen zu Herkunft, Militär, Staatsaufbau und nomadischen Traditionen." In B. Meißner, O. Schmitt, and M. Sommer (eds.), KriegGesellschaft-Institutionen: Beiträge zu einer vergleichenden Kriegsgeschichte, 163-208. Berlin: Akademie-Verlag.

-. 2006. "Was there no paid standing army? A fresh look on military and political institutions in the Arsacid Empire." In M. Mode and J. Tubach (eds.), Arms and armour as indicators of cultural transfer: The steppes and the ancient world from Hellenistic times to the early Middle Ages, 295-319. Wiesbaden: Reichert.

-. 2012. "The Arsacid (Parthian) Empire." In D. T. Potts (ed.), A companion to the archaeology of the ancient Near East. Vol. 2, 1001-1020. Malden, MA: Wiley-Blackwell.

-. 2017a. "Isidor von Charax $\Sigma \tau \alpha \theta \mu o i$ П $\alpha \rho \theta ı$ ikoi: Annäherungen an den Autor, den Routenverlauf und die Bedeutung des Werkes." In Wiesehöfer and Müller (2017), 127-187.

-. 2017b. "Post-imperial Assyria." In E. Frahm (ed.), A companion to Assyria, 229-246. Malden, MA: Wiley-Blackwell.

Hyland, J. 2013. "Vishtaspa krny: An Achaemenid military official in 4th-century Bactria." Achaemenid Research on Texts and Archaeology, no. 2, 1-7.

Invernizzi, A. 1997. "Parthian Nisa: New lines of research." Iran and the Caucasus 1, 107-119.

-. 2001. "Arsacid dynastic art." Parthica 3, 133-157.

-. 2011. "Parthian art - Arsacid art." Topoi 17.1, 189-207.

-. 2016. "A note on architectural traditions in Arsacid Parthia: The round hall at Nisa." In V. S. Curtis, M. Alram, T. Daryaee, and E. Pendleton (eds.), The Parthian and early Sasanian Empires: Adaptation and expansion: Proceedings of a conference held in Vienna, 14-16 June 2012, 83-89. Oxford: Oxbow.

Invernizzi, A., and C. Lippolis, eds. 2008. Nisa Partica: Ricerche nel complesso monumentale arsacide 1990-2006. Florence: Le lettere.

Karras-Klapproth, M. 1988. Prosopographische Studien zur Geschichte des Partherreiches auf der Grundlage antiker literarischer Überlieferung. Bonn: Habelt.

Kawami, T. S. 1987. Monumental art of the Parthian period in Iran. Leiden: Brill.

Keall, E. J. 1975. "Parthian Nippur and Vologases' southern strategy: A hypothesis." Journal of the American Oriental Society 95.4, 620-632.

-. 1994. "How many kings did the Parthian King of Kings rule?" Iranica Antiqua 29, 253-272.

Kharmatta, Іа. 1965. “Из истории алано-парфянских отношений” [From the history of AlanoParthian relations]. Acta Antiqua Academiae Scientiarum Hungaricae 13, 127-147.

Knudstad, J. 1968. "A preliminary report on the 1966-67 excavations at Nippur." Sumer 24, 95-106.

Kose, A. 1998. Uruk: Architektur IV: Von der Seleukiden- bis zur Sasanidenzeit. 2 vols. Mainz: Philipp von Zabern.

Koshelenko, G. А. 1966. Культура Парфии [The culture of Parthia]. Москва: Наука.

-. 1980. "Les cavaliers Parthes: Aspects de la structure sociale de la Parthie." Dialogues d'histoire ancienne 6, 177-199.

Koshelenko, G. A., and V. N. Pilipko. 1994. "Parthia." In J. Harmatta (ed.), History of civilizations of Central Asia. Vol. 2, 131-150. Paris: UNESCO Publications.

Landskron, A. 2005. Parther und Sasaniden: Das Bild der Orientalen in der römischen Kaiserzeit. Vienna: Phoibos. 
Le Rider, G. 1965. Suse sous les Séleucides et les Parthes: Les trouvailles monétaires et l'histoire de la ville. Paris: Geuthner.

Lerner, J. D. 1999. The impact of Seleucid decline on the Eastern Iranian Plateau: The foundations of Arsacid Parthia and Graeco-Bactria. Stuttgart: Franz Steiner.

Lerouge, C. 2007. L'image des Parthes dans le monde gréco-romain: Du début du ler siècle av. J.-C. jusqu'à la fin du Haut-Empire romain. Stuttgart: Franz Steiner.

Loginov, S. D., and A. B. Nikitin. 1996 [1998]. "Parthian coins from Margiana: Numismatics and history." Bulletin of the Asia Institute 10, 39-51.

Lukonin, V. G. 1983. "Political, social and administrative institutions: Taxes and trade." In E. Yarshater (ed.), The Cambridge history of Iran. Vol. 3.2, 681-746. Cambridge: Cambridge University Press.

Marciak, M. 2017. Sophene, Gordyene, and Adiabene: Three regna minora of northern Mesopotamia between East and West. Leiden: Brill.

Masson, M. E., and G. A. Pugacenkova. 1982. The Parthian rhytons of Nisa. C. M. Breton Bruce (trans.), Florence: Le lettere.

Mathiesen, H. E. 1992. Sculpture in the Parthian Empire: A study in chronology. 2 vols. Aarhus: Aarhus University Press.

Matthews, J. F. 1984. "The tax law of Palmyra: Evidence for economic history in a city of the Roman East." Journal of Roman Studies 74, 157-180.

Millar, F. 1998. "Caravan cities: The Roman Near East and long-distance trade by land." In M. Austin, J. Harries, and C. Smith (eds.), Modus Operandi: Essays in honour of Geoffrey Rickman, 275-299. London: Institute of Classical Studies.

Miroschedji, P. de, N. Desse-Berset, and M. Kervran. 1987. "Fouilles du chantier ville royale II à Suse (1975-1977) II: Niveaux d'époques achéménide, séleucide, parthe et islamique." Cahiers de la Délégation archéologique française en Iran 15, 11-143.

Moghaddam, A., and N. Miri. 2007. "Archaeological surveys in the 'Eastern Corridor,' SouthWestern Iran." Iran 45, 23-55.

Mørkholm, 0. 1980. "The Parthian coinage of Seleucia on the Tigris, c. 90-55 BC." Numismatic Chronicle 20, 33-47.

Neely, J. A. 2016. "Parthian and Sasanian settlement patterns on the Deh Luran Plain, Khuzistan Province, southwestern Iran." Iranica Antiqua 51, 235-300.

Nikonorov, V. P. 1995. “К вопросу о парфянской тактике (на примере битвы при Каррах)” [On the question of Parthian tactics (on the basis of the Battle of Carrhae)]. In Военное дело и средневековая археология Центральной Азии, 53-61. Кемерово.

Olbrycht, M. J. 1998. Parthia et ulteriores gentes: Die politischen Beziehungen zwischen dem arsakidischen Iran und den Nomaden der eurasischen Steppen. Munich: tuduvVerlagsgesellschaft.

-. 2003. "Parthia and nomads of Central Asia: Elements of steppe origin in the social and military developments of Arsacid Iran.” In I. Schneider (ed.), Militär und Staatlichkeit. Beiträge des Kolloquiums am 29. und 30.04. 2002, 69-109. Halle (Saale): Orientwissenschaftliches Zentrum, Martin-Luther-Universität Halle-Wittenberg.

-. 2013. "The titulature of Arsaces I, king of Parthia." Parthica 15, 63-74.

-. 2015. "Arsacid Iran and the Nomads of Central Asia - ways of cultural transfer." In J. Bemmann and M. Schmauder (eds.), Complexity of interaction along the Eurasian steppe zone in the first millennium CE, 333-390. Bonn: Vor- und Frühgeschichtliche Archäologie, Rheinische Friedrich-Wilhelms-Universität Bonn.

-. 2016a. "Manpower resources and army organisation in the Arsakid Empire." Ancient Society 46, 291-338.

-. 2016b. "The sacral kingship of the early Arsacids I: Fire cult and kingly glory." Anabasis 7, 91-106. 
-. 2016c. "Vologases I, Pakoros II and Artabanos III: Coins and Parthian history." Iranica Antiqua 51, 215-233.

Pappalardo, E. 2010. Nisa Partica: I rhyta ellenistici. Florence: Le lettere.

Perevalov, S. M. 2006. “Аланский набег 136 г. н. э. в страны Закавказья: проблемные вопросы" [The Alan raid in 136 CE into the countries of the Transcaucasus: Problematic issues]. In Античная цивилизация и варвары, 318-355. Москва: Наука.

Pilipko, V. N. 1989. “К вопросу о локализации Парфавнисы” [On the question of the localization of Parthian Nisa]. Известия Академии наук Туркменской ССР. Серия общественных наук, no. 2, 17-25.

-. 2001. Старая Ниса: Основные итоги археологического изучения в советский период [Old Nisa: The principal results of archaeological research in the Soviet period]. Москва: Наука.

-. 2008. "The central ensemble of the fortress Mihrdatkirt: Layout and chronology." Parthica 10, 35-51.

Posch, W. 1998. “Chinesische Quellen zu den Parthern.” In Wiesehöfer (1998), 355-364.

Potts, D. T. 1999. The archaeology of Elam: Formation and transformation of an ancient Iranian state. Cambridge: Cambridge University Press.

-. 2002. "Five episodes in the history of Elymais, 145-124 BC: New data from the astronomical diaries." In P. Huyse (ed.), Iran: Questions et connaissances: Actes du IVe congrès européen des études iraniennes oraganisé par la Societas Iranologica Europaea, Paris, 6-10 Septembre 1999. Vol. 1, 349-362. Paris: Association pour l'avancement des études iraniennes.

-. 2007 [2012]. "Cataphractus and Kamāndār: Some thoughts on the dynamic evolution of heavy cavalry and mounted archers in Iran and Central Asia." Bulletin of the Asia Institute 21, 149158.

Pugachenkova, G. A. 1971. Скульптура Халчаяна [The sculpture of Khalchaiana]. Москва: Искусство.

Rajak, T. 1998. "The Parthians in Josephus.” In Wiesehöfer (1998), 309-324.

Rapp, S. H. 2009. "The Iranian heritage of Georgia: Breathing new life into the pre-Bagratid historiographical tradition." Iranica Antiqua 44, 645-692.

Rezakhani, K. 2010. "The road that never was: The Silk Road and trans-Eurasian exchange." Comparative Studies of South Asia, Africa and the Middle East 30.3, 420-433.

Rose, C. B. 2005. "The Parthians in Augustan Rome." American Journal of Archaeology 109.1, 21-75.

Rostovtzeff, M. I. 1935. Dura and the problem of Parthian art. New Haven, CT: Yale University Press.

Russel, J. R. 1987. Zoroastrianism in Armenia. Cambridge, MA: Harvard University Press.

Sauer, E. W., H. O. Rekavandi, T. Wilkinson, and J. Nokandeh. 2012. "Innovation at Persia's frontiers: Sasanian campaign bases and defensive barriers." In L. Vagalinski and N. Sharankov (eds.), Limes XXII: Proceedings of the 22nd International Congress of Roman Frontier Studies, Ruse, Bulgaria, September 2012, 327-331. Sofia: National Archaeological Institute with Museum.

Schlude, J. M., and A. J. Overman. 2017. "Herod the Great: A Near Eastern case study in RomanParthian politics." In J. M. Schlude and B. Reubin (eds.), Arsacids, Romans and local elites: Cross-cultural interactions of the Parthian Empire, 93-110. Oxford: Oxbow.

Schlumberger, D. 1970. L'Orient hellénisé: L'art grec et ses héritiers dans l'Asie non méditerranéenne. Paris: Albin Michel.

Schuol, M. 2000. Die Charakene: Ein mesopotamisches Königreich in hellenistisch-parthischer Zeit. Stuttgart: Franz Steiner.

-. 2017. "Isidor von Charax und die literarische Gattung der stathmoi." In Wiesehöfer and Müller (2017), 71-86. 
Seland, E. H. 2011. "The Persian Gulf or the Red Sea? Two axes in ancient Indian Ocean trade, where to go and why." World Archaeology 43.3, 398-409.

-. 2014. "The organisation of the Palmyrene caravan trade." Ancient West and East 13, 197-211.

Sellwood, D. 1980. An introduction to the coinage of Parthia. London: Spink.

Shayegan, M. R. 2011. Arsacids and Sasanians: Political ideology in post-Hellenistic and Late Antique Persia. Cambridge: Cambridge University Press.

-. 2017. "Persianism: Or Achaemenid remembrances in the Iranian and Iranicate world(s) of antiquity.” In R. Strootman and M. J. Versluys (eds.), Persianism in Antiquity, 401-455. Stuttgart: Franz Steiner.

Simonetta, A. M. 2001. "A proposed revision of the attributions of the Parthian coins struck during the so-called 'Dark Age' and its historical significance." East and West 51.1-2, 69108.

-. 2009. "The coinage of the so-called Parthian 'Dark Age' revisited.” Electrum 15, 141-194.

Sinisi, F. 2014. "Sources for the history of art of the Parthian period: Arsacid coinage as evidence for continuity of imperial art in Iran." Parthica 16, 9-60.

Strootman, R. 2017. “Imperial Persianism: Seleukids, Arsakids and Fratarakā.” In R. Strootman and M. J. Versluys (eds.), Persianism in antiquity, 177-200. Stuttgart: Franz Steiner.

Strugnell, E. 2008. “Thea Musa, Roman Queen of Parthia.” Iranica Antiqua 43, 275-298.

Van der Spek, R. J. 1998. "Cuneiform documents on Parthian history: The Rahimesu archive.” In Wiesehöfer (1998), 205-258.

Vardanyan, R. 2000. “Zur Deutung des Königsprofils auf parthischen Münzen.” Archäologische Mitteilungen aus Iran und Turan 32, 253-259.

-. 2001. "Tendenze culturali e ideologiche nell'impero partico riflesse dalla monetazione." Parthica 3, 25-132.

Widengren, G. 1983. "Sources of Parthian and Sasanian history." In E. Yarshater (ed.), The Cambridge history of Iran. Vol. 3.2, 1261-1283. Cambridge: Cambridge University Press.

Wiesehöfer, J. 1996. “'King of Kings' and 'Philhellên': Kingship in Arsacid Iran.” In P. Bilde (ed.), Aspects of Hellenistic kingship, 55-66. Aarhus: Aarhus University Press.

-. 1999. Das frühe Persien: Geschichte eines antiken Weltreichs. Munich: C. H. Beck.

-. 2007. "Fars under Seleucid and Parthian rule." In V. S. Curtis and S. Stewart (eds.), Age of the Parthians, 37-49. London: I. B. Tauris.

-. 2011. "Frataraka rule in Seleucid Persis: A new appraisal.” In A. Erskine and L. Llewellyn-Jones (eds.), Creating a Hellenistic world, 107-122. Swansea: Classical Press of Wales.

-. 2016. "Greeks, Iranians and Chinese on the Silk Road." In S. N. C. Lieu and G. B. Mikkelsen (eds.), Between Rome and China: History, religions and material culture of the Silk Road, 1-17. Turnhout: Brepols.

Wiesehöfer, J., ed. 1998. Das Partherreich und seine Zeugnisse / The Arsacid Empire: Sources and documentation. Stuttgart: Franz Steiner.

Wiesehöfer, J., and S. Müller, eds. 2017. Parthika: Greek and Roman authors' views of the Arsacid Empire / Griechisch-römische Bilder des Arsakidenreiches. Wiesbaden: Harrassowitz.

Wissemann, M. 1982. Die Parther in der augusteischen Dichtung. Frankfurt: Peter Lang.

Wolski, J. 1946. “Arsaces II.” Eos 41, 156-165.

-. 1965. "Le rôle et l'importance des mercenaires dans l'état Parthe." Iranica Antiqua 5, 103-115.

-. 1981. “L'aristocratie foncière et l'organisation de l'armée parthe.” Klio 63, 105-112.

-. 1993. L'empire des Arsacides. Leuven: Peeters.

Zanous, H. P., and J. Yang. 2018. "Arsacid cities in the Hanshu and Houhanshu." Iran and the Caucasus 22.2, 123-138. 



\section{Eli J. S. Weaverdyck \\ 7 The Roman Empire}

\section{Introduction}

The Roman Empire was one of the largest and longest lasting of all the empires in the ancient world. ${ }^{1}$ At its height, it controlled the entire coast of the Mediterranean and vast continental hinterlands, including most of western Europe and Great Britain, the Balkans, all of Asia Minor, the Near East as far as the Euphrates (and beyond, briefly), and northern Africa as far south as the Sahara. The Mediterranean, known to the Romans as mare nostrum ('our sea'), formed the core.

The Mediterranean basin is characterized by extreme variability across both space and time. Geologically, the area is a large subduction zone between the African and European tectonic plates. This not only produces volcanic and seismic activity, it also means that the most commonly encountered bedrock is uplifted limestone, which is easily eroded by water. Much of the coastline is mountainous with deep river valleys. This rugged topography means that even broadly similar climatic conditions can produce drastically dissimilar microclimates within very short distances. In addition, strong interannual variability in precipitation means that local food shortages were an endemic feature of Mediterranean agriculture. In combination, this temporal and spatial variability meant that risk-buffering mechanisms including diversification, storage, and distribution of goods played an important role in ancient Mediterranean survival strategies. Connectivity has always characterized the Mediterranean. ${ }^{2}$

While geography encouraged mobility, the empire accelerated that tendency, inducing the transfer of people, goods, and ideas on a scale never seen before. ${ }^{3}$ This mobility, combined with increased demand and the efforts of the imperial government to mobilize specific products, led to the rise of broad regional specializations, particularly in staple foods and precious metals. ${ }^{4}$ The results of this increased con-

1 It has also been the subject of more scholarship than any other empire treated in this volume. The modern study of the Roman Empire is generally thought to have begun in the eighteenth century with works by the French political philosopher Montesquieu (1734) and the English historian Edward Gibbon (1776-1789). For an overview of the study of the Roman Empire in the twentieth century, see Potter 2006.

2 Horden and Purcell 2000, particularly 175-230. The environmental history of the ancient Mediterranean is entering new territory as more and better data and models become available. See Harris 2013; McCormick et al. 2012 for introductions.

3 For the mobility of people in the Roman empire, see the essays in de Ligt and Tacoma 2016. Recent overviews of the mobility of goods include Wilson and Bowman 2018; Morley 2007.

4 For example, Sicily, Egypt, and North Africa exported grain on a large scale (Erdkamp 2005, 206257; Kessler and Temin 2007). Olive oil for export was produced in North Africa and the Iberian Peninsula (Marzano 2013; Mattingly 1988). Gold and Silver mines were concentrated in the Iberian Peninsula and in the Balkan and Carpathian Mountains (Wilson 2007).

Ә Open Access. () 2020 Eli J. S. Weaverdyck, published by De Gruyter. (c) BY-NC-ND This work is licensed under the Creative Commons Attribution-NonCommercial-NoDerivatives 4.0 License.

https://doi.org/10.1515/9783110607741-009 


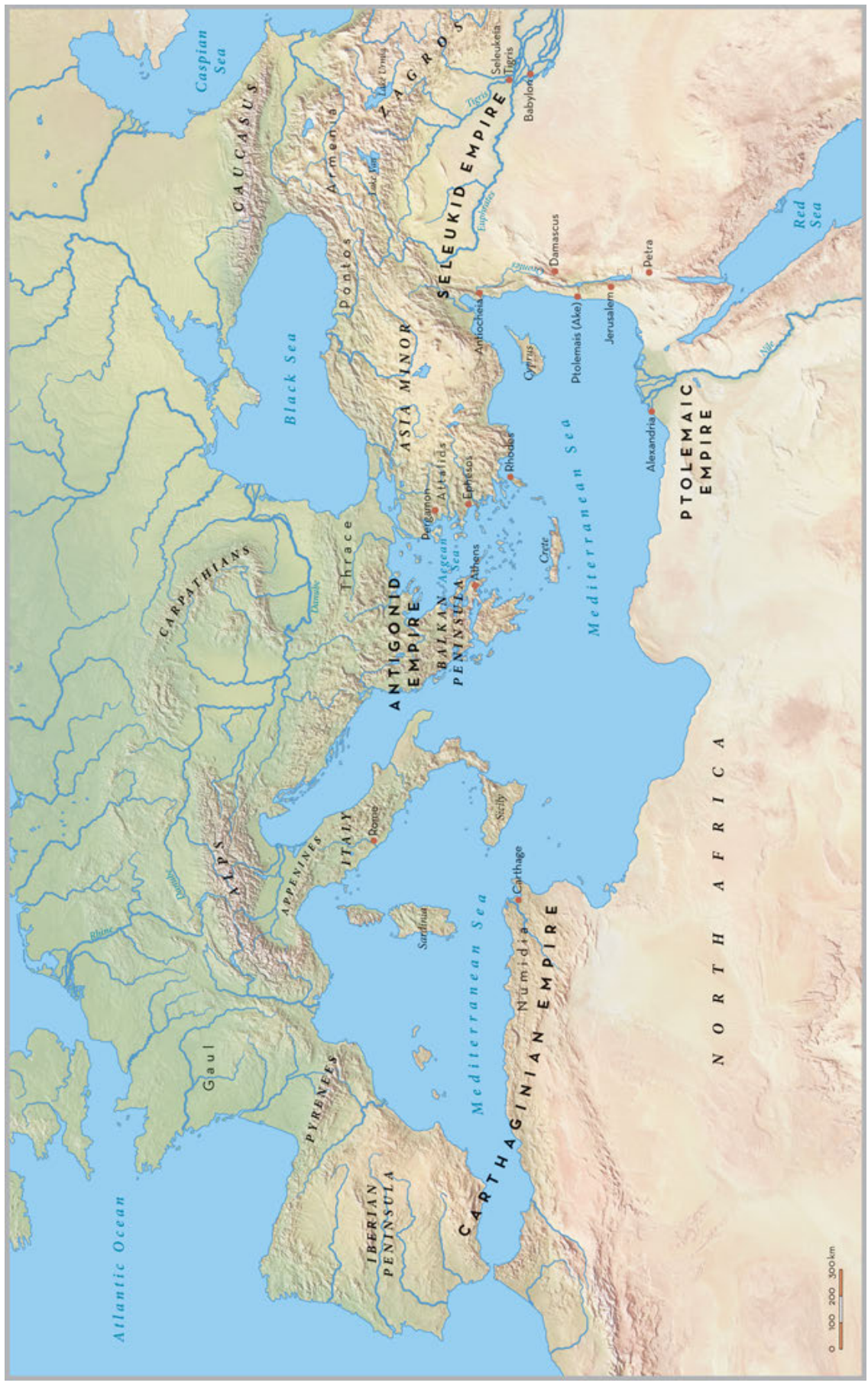

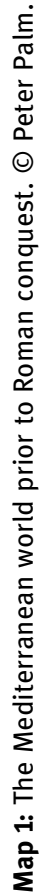


sumption and connectivity are most visible today in the ruins of ancient cities, where certain forms of monumental architecture, built in Roman concrete, are repeated again and again across Europe, northern Africa, and western Asia. ${ }^{5}$

These far-flung remains are the result of a long history of imperial development. Roman history can be divided into several major epochs, only two of which fall within the chronological limits of this handbook: the Republic and the Principate. The city of Rome was ruled according to an oligarchic system of government from the late sixth to the late first century BCE (the Republican period), at which point it became a monarchy (the Principate). Within these epochs a period of social restructuring in the fourth century BCE inaugurated the Middle Republic, an era of stability that lasted until the late second century BCE, at which point further social upheaval took hold and lasted for about a century. This period is known as the Late Republic. In the last third of the first century BCE, one man, Augustus (63 BCE-14 CE), successfully consolidated supreme power in his own person and passed it on to his chosen heir, establishing the rule of Roman emperors. Traditionally, the first three centuries of the Common Era are known as the Principate. The word emphasizes the emperor's status as merely the preeminent citizen, first among equals, princeps. ${ }^{6}$ After a long crisis of government in the third century CE, the empire was refashioned along more authoritarian lines. The period from 300 BCE to $300 \mathrm{CE}$, then, roughly coincides with the Middle Republic, the Late Republic, and the Principate.

Rome acquired its massive empire over centuries of more or less continuous warfare. After a brief discussion of the reasons why Romans were so often willing to go to war, their long-term military success, and the consequences of conquest for the Roman state in section two, section three describes the structures through which the empire was ruled and how these changed over time, particularly between the Republic and the Principate. It begins with the military apparatus that provided the means of physical coercion, then describes the political structures that administered the empire, and finally the infrastructure, both physical and institutional, that supported imperial governance. In addition to the strategies and goals of the central state, the participation of other agents and the impacts of empire are highlighted throughout. The fourth section explores two aspects of society in the ancient Mediterranean that were affected by the Roman Empire and that contributed to its integration. First, it describes long-distance social networks, particularly those based on patronage, those based on Italian origin, and those based on familial ties. Then it discusses the identities through which people understood themselves and related to each other within an imperial context.

5 See Woolf 1998, 112-126 for Roman Gaul; Woolf 2012, 288-300 more generally.

6 The term 'principate' is found in ancient literature. The Roman historian Tacitus makes a point of saying that principatus and libertas (freedom) were irreconcilable until the rise of the good emperor Nerva (Tacitus Agricola [Tac. Agr.] 3. 1). 


\section{Achieving Supremacy: City, State, and Empire}

Roman power was established and, in large part, sustained through military supremacy. ${ }^{7}$ During the Middle Republic, when the Romans defeated the other hegemonic powers in the Mediterranean, they were in the habit of sending out armies every year. At the end of the Late Republic - when powerful generals conquered vast swaths of territory in Europe and the Near East, and when the entire Mediterranean was convulsed by Roman civil wars - the portion of Italian young men serving under arms reached as high as 25 percent. $^{8}$ Under the Principate, the Roman approach to war changed, and the pace of expansion slowed drastically. Nevertheless, the army remained the single largest item of state expenditure, and some emperors still launched campaigns of conquest.

The fact that Rome was a city-state when it acquired its empire sets it apart from the other polities discussed in this volume. Rome's oligarchic internal sociopolitical structure incentivized persistent military aggression. An expansive approach to citizenship and a tolerance for the partial continuation of others' civic structures allowed for the political integration of new territory and provided access to vast reserves of manpower for further wars. Rome's civic ideology, centered on the flexible idea of the res publica, provided the thread of continuity that allowed the empire to survive a traumatic period of civil war and a shift to a monarchic form of government.

Roman expansion can be explained in large part as a consequence of the particular nature of aristocratic competition within the Roman Republic. ${ }^{9}$ Since the middle of the fourth century BCE, the ruling class in Rome was defined primarily by election to office, an honor bestowed by the Roman people on those who had served the state that provided further opportunities to serve and accumulate glory. ${ }^{10}$ The most important form of service was military achievement. Distinction in battle was a valuable asset for candidates and those who held the highest offices achieved further glory by successfully commanding Rome's armies. This encouraged Roman

7 The sources of Roman power have intrigued scholars since the days of Machiavelli in the sixteenth century, and the Roman example has been influential in broader sociological works (e.g., Doyle 1986; M. Mann 1986). Recent overviews of Roman power by Roman historians include Harris 2016; Morley 2010; Woolf 2012, which build on numerous narrower, more detailed investigations. See, for example, influential discussions on the cultivation of loyalty to Rome in the provinces (Ando 2000); the role of honor in binding elites to the imperial system (Lendon 1997); and the position of the emperor (Millar 1977).

8 Brunt 1987, 509-512.

9 Modern debate on Roman imperialism is focused on the extent to which Rome's military aggressiveness during the Republic was unusual and driven by internal factors (Harris 1979) or typical of contemporary Mediterranean city-states in the context of inter-state anarchy (Eckstein 2006). For overviews, see Morley 2010; Hoyos 2013.

10 For the origins of this ethos, see Hölkeskamp 1993; Raaflaub 1996; cf. Eckstein 2006, 229-237. 
commanders to be aggressive during their time in office. Even in defeat, a commander could win glory by living up to the aristocratic ideal of virtus: manly, steadfast courage. ${ }^{11}$ This drove individual generals and the aristocracy as a whole to persist in fighting after losses that might have been war ending for other polities.

Beyond glory, war brought substantial economic benefits that extended beyond the political aristocracy and ensured the support of other segments of society for Roman war making. The most immediate benefit was booty. ${ }^{12}$ After a successful campaign, the spoils of war were paraded through the streets of Rome in a 'triumph,' a grand procession celebrating the victorious general, ${ }^{13}$ who distributed the booty in varying proportions between the soldiers, the treasury, and often construction projects (especially monumental temples) that celebrated the victory. Among the booty were large numbers of slaves. Selling prisoners of war into slavery was common practice in antiquity, and Rome's nearly constant warfare and the huge scale of some campaigns brought massive quantities of slaves into Italy. ${ }^{14}$ Although natural increase and trade would replace warfare as the primary source of slaves, the influx during the Mid-Republic facilitated a new type of market-oriented agriculture practiced especially by elites. ${ }^{15}$ The land acquired was another benefit of conquest. The Romans would often confiscate a portion of their enemies' land, some of which was auctioned off, some rented out, and some distributed to colonists. ${ }^{16}$ Rome established colonies throughout Italy in the Mid-Republic and, in the Late Republic and Early Principate, beyond. ${ }^{17}$ The extraction of resources continued after conquest. In the third and second centuries BCE, the Romans imposed large indemnities - fixed sums to be paid over a specific period of time - on their defeated rivals. ${ }^{18}$ In the second century $\mathrm{BCE}$, it became more common to impose taxes, which were paid in perpetuity. ${ }^{19}$ Captured mines also produced a great deal of revenue. ${ }^{20}$ The exploitation of mines, collection of taxes, and renting of public land were all managed through public contracts auctioned off to groups of individuals called $p u b$ licani, so even public revenues benefited private people. ${ }^{21}$

11 McDonnell 2006; Rosenstein 1990.

12 Kay 2014, 29-35.

13 See Beard 2007 for the Roman triumph.

14 For quantitative estimates of slavery in Republican Italy, see Scheidel 2005, with further literature on the sources of slaves.

15 Hopkins 1978 provides the reference point for modern debate about land, slavery, and the economic impact of Roman conquest on Italy. For a more recent account, see Kay 2014, 133-188.

16 Roselaar 2010, 31-54.

17 The classic account of Roman colonization is Salmon 1969. For more recent perspectives, see the essays in Stek and Pelgrom 2014.

18 Kay 2014, 37-42.

19 Tan 2015.

20 Kay 2014, 43-58.

21 Badian 1972 remains fundamental on publicani. See also Kay 2014, 49-54 (mining); Tan 2017, 40-67 (tax collection). 
Outside of Rome, the complex network of relationships, often antagonistic, between polities of different types and sizes that stretched across the Mediterranean basin enabled, encouraged, and directed Roman war making. ${ }^{22}$ In the third century BCE, the Mediterranean contained a plethora of political actors of various configurations, each with a complex set of relationships and most in some form of subordination to another (map 1). ${ }^{23}$ The ubiquity of substantial power differentials created a lively market for protection, with smaller polities seeking the aid of larger powers against other larger powers. Pleas for assistance by allies were the proximate causes of many of Rome's wars of conquest. It was hazardous to Rome's standing to refuse such a request: if an ally were overrun, the value of Roman friendship was diminished and other allies would be more likely to join a rival hegemon.

The political and economic benefits of warfare and the politically complex Mediterranean context help to explain Roman aggression, but they do not explain Roman success. A habit of persistence in the face of defeat was important, but this was only possible due to the overwhelming manpower advantage that Rome held over its rivals. ${ }^{24}$ The soldiers in Roman armies came not just from the city of Rome but from a network of municipia, colonies, and allies across Italy. In the process of conquering Italy, some defeated cities were absorbed into the Roman state and called municipia. Although the physical infrastructure of these cities remained, and they continued to govern themselves in internal matters, they had no independent foreign relations and their free populations were made Roman citizens. This was unique in the ancient Mediterranean, where access to citizenship was normally closely guarded. Also unique to Rome was the practice of bestowing citizenship on freed slaves (freedmen/women). As a result, Rome had more citizens than any other city-state. ${ }^{25}$ They served in the legions, units of 4,000 to 6,000 men. ${ }^{26}$ Those enemies not incorporated became allies (socii), maintaining an independent political identity but subject to Roman commands and expected to provide troops on request. They served in distinct auxiliary units alongside the legions. Most of the colonies that Rome established in Italy were independent allies (albeit with an especially

22 Gruen (1986) first argued that Roman expansion in the East was driven by involvement in regional politics. Eckstein (2006) developed the idea using modern International Relations theory. Morley (2010) and Woolf (2012) integrate internal and external factors in their accounts of Roman expansion.

23 Von Reden (ch. 1, this volume) describes the most powerful polities in the Eastern Mediterranean and provides further literature.

24 Brunt 1987 is the standard work on Italian demography and Roman manpower in the Republic. More recently, Rosenstein (2004) has provided a model for the demographic sustainability of military recruitment. For an overview of the debate on Italian demography in this period and further literature, see Lo Cascio 2013.

25 Sherwin-White 1973 is fundamental for Roman citizenship. Brunt 1987 provides quantitative estimates. See below, sec. IV.2.4 for more on the meaning of Roman citizenship.

26 For the (variable) size of the legion, see Brunt 1987, 671-676, 687-693. 
close relationship to their metropolis), but some were inhabited by citizens. This arrangement not only expanded Roman manpower, it also integrated distant polities into the Roman Empire without straining the bureaucratic capacities of a citystate.

Rome's allies outside of Italy were also instrumental in its success. ${ }^{27}$ They often fought for Rome, both alongside Roman armies on the battlefield and more independently in a broader campaign. Their diplomatic connections in areas far from Italy could prove invaluable in facilitating troop movements and in mediating new relationships. They also provided invaluable logistical support. They furnished not only supplies and equipment, but transportation, ports, and secure supply bases far from Italy. ${ }^{28}$ This allowed Roman armies to overcome the limitations on campaigning imposed by ancient technology. Allies were often former enemies, those wishing to avoid Roman enmity, or those hoping to benefit from Roman power. Further, each new alliance brought with it a new network of relations stretching into new areas, new potential allies and enemies. Thus, Roman conquest both enabled and invited further conquest.

This dynamic drove Roman state formation. I use the term 'state' loosely to refer to the imagined community of people who identified or were identified as Romans and the institutions that existed, in theory, to serve the interests of that community. The phrase that Latin speakers used to describe this entity most often was res publi$c a,{ }^{29}$ a term that encompasses the affairs that concern the Roman people and demand communal action and the entity that emerges from the interactions of Romans acting as Romans. The flexibility of the concept combined with its ideological power helps explain its continued relevance in ancient political discourse over the centuries, and the durability of the res publica as a symbol helps explain the ability of the Roman Empire to survive in recognizable form through changes in government, ruling dynasty, and even state religion.

The process of conquest strengthened both the state's ideological power and its institutional capacity. ${ }^{30}$ Military service was the primary contribution of both citizens and allies to the Roman state. Outside the city of Rome, it was the main way in which citizens experienced and reproduced the state and their membership in it. For the Italian allies, conscription and campaigning - which involved not only obeying Roman commanders, but the repeated construction of camps that articulated social power relations in the spatial layout of barracks and command centers were the core expressions of Roman domination. ${ }^{31}$ The extension of Roman war

27 See P. J. Burton 2011, 172-205 for the obligations of Rome’s allies.

28 Roth 1999, 169-177 (supply lines), 227-230 (provision of grain).

29 Recently, Moatti's work on the meaning of this phrase and what it reveals about the changing nature of the Roman state has been especially influential (2018).

30 This paragraph is based on Eich and Eich 2005.

31 Polybios (Polyb.) 6. 26-42. 
making both in space and time required the creation of institutions that would later take on civilian administrative functions. In general, Roman political elites of the Mid-Republic were loath to expand the functional capacity of state institutions lest a magistrate use this power to gain preeminence over his peers. ${ }^{32}$ Because war was legitimized as service to the state, and because private armies were dangerous to aristocratic balance, this was the only area in which state institutions were allowed to develop.

The profits from conquest led to civil war and the transformation of Roman government in the first century $\mathrm{BCE}$, but this did not bring an end to the Roman res publica. ${ }^{33}$ As more and more resources poured into Rome, the elites succeeded in capturing most of the profit. They spent this wealth on competition for public office, inflating the costs of election. Candidates began to borrow heavily to finance their campaigns, speculating on the rewards of a successful military command or a profitable governorship. They then exploited their offices to extort money from their subjects, launch campaigns for money and glory, or both. Simultaneously, the enormous expense prevented many from competing for the highest office. A smaller number of men gained more and more power, launching ever greater campaigns to finance their ambition. The scale of these campaigns outstripped any that went before. Julius Caesar conquered vast swaths of northwestern Europe and Pompey campaigned extensively in the East, clearing the Mediterranean of pirates and conquering large parts of southwest Asia. These commands brought great wealth and glory to their generals, which their aristocratic peers sought to contain. In response, the generals led their armies against the city of Rome and against the legions led by their rivals in order to advance their causes. Even when marching on Rome, however, the generals invoked the res publica to legitimize their actions. ${ }^{34}$ Civil wars convulsed Italy and the Mediterranean with increasing frequency from the early 80 s to the late 30s BCE, ending when Octavian, the heir of Julius Caesar, defeated the last of his rivals and became the most powerful man in Rome.

Octavian, later named Augustus, restored the fractured integrity of the res publi$c a$, portraying his regime as a restoration of the old order. ${ }^{35}$ By positioning himself and his household as protectors of the state, he laid the foundations for a monarchical form of government. From this time onward, emperors were closely associated with the res publica, but the relationship was never simple. ${ }^{36}$ The emperor could be

32 This weak state model has been propounded in detail by Tan (2017). The weak state also allowed elites to capture more of the material benefits of conquest and the social benefits of patronizing the lower classes (see below, sec. IV.1.1).

33 For an introduction to the fall of the Roman Republic, see Morstein-Marx and Rosenstein 2006. The account given here is based on Morley 2010, 32-37.

34 Speidel 2010.

35 For an introduction to Augustus and the Augustan period, see Galinsky 2005. Edmondson 2009 collects important scholarship and introduces the historiography.

36 Moatti 2018, 251-298; Ando 2000, esp. 336-405. 


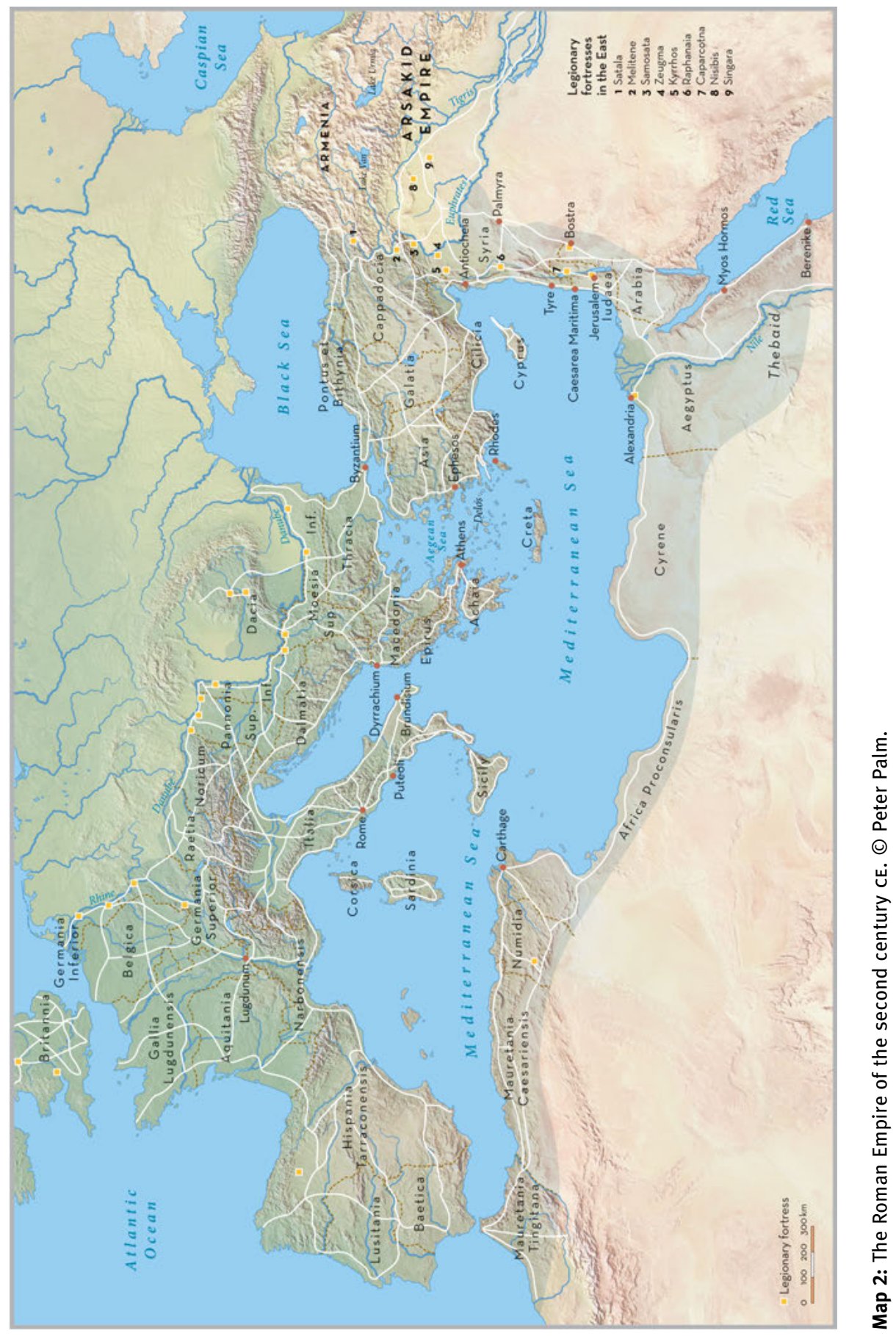


thought of as a supreme magistrate who managed the state on behalf of the people or an embodiment of the state. The res publica was never supposed to be the property of the emperor, but this sometimes had to be articulated explicitly. The flexibility and ambiguity of the relationship allowed usurpers to try, sometimes successfully, to wrest power from the ruling dynasty without necessarily threatening the continuation of the state itself.

The end of the Republic fundamentally altered the dynamics of Roman conquest. ${ }^{37}$ The emperor now sought to monopolize all military glory for himself and his family. By closing off this avenue of aristocratic competition, Augustus removed one of the most powerful incentives that had driven expansion in the past. At the same time, long-term rule by one man allowed for long-term planning of the sort that was impossible under the Republic with its annual rotation of magistrates. The pattern of Augustus's extensive conquests is consistent with a strategic vision for the shape of the whole empire. ${ }^{38}$ For various reasons, then, monarchic rule drastically slowed the pace of Roman conquest after Augustus.

\section{Ruling an Empire}

\section{III.1 The Military}

While the pace of conquest may have slowed, military power remained vitally important to the maintenance of the Roman Empire. The imperial government never completely monopolized violence within the empire, but it did maintain an overwhelming military advantage over all others. It retained a professional, standing army that, while small relative to the size of the empire, could strike quickly and viciously whenever and wherever it was needed. Quick, decisive responses prevented small-scale attacks from encouraging further larger scale attacks. ${ }^{39}$ This required a loyal, highly effective fighting force supported by a reliable logistical apparatus distributed across the empire.

Roman Republican armies were created for specific campaigns and disbanded when the fighting was over, but during the civil wars, armies could remain intact for years, moving from one campaign - or even one commander - to the next. Augustus instituted a standing army, with regular terms of service, pay, and discharge bonuses. He also successfully directed the loyalty of both the common soldiers and the officers to himself and his household. ${ }^{40}$ Soldiering now became a profession. Sol-

37 Cornell 1993.

38 Speidel 2009, 35-44.

39 Goldsworthy 2007.

40 For the evolution of the army from the Republic to the Principate, see Keppie 1984. For Augustus's reforms, see Speidel 2009, 19-51. For the changed political role of the army, see Alston 2007. For overviews, see Le Bohec 1994; Southern 2007. 
diers served for 25 years, the bulk of their adult life, and were paid a respectable salary. Upon discharge, legionaries received a considerable sum of money and auxiliaries received Roman citizenship. ${ }^{41}$ Unlike China, where criminals might be sentenced to military service, in Rome, soldiering was an honorable profession and soldiers were proud of their status. ${ }^{42}$ The military became a distinct community within the empire, united by the conditions of service and consisting not only of soldiers, but their families and the people whose livelihood depended on them. ${ }^{43}$ This community owed its existence to the Roman imperial state and was closely tied to the position of the emperor. While soldiers and officers received pay and position from the emperor, he depended on their backing for his power, and soldiers could appoint new emperors when dissatisfied, as the history of military usurpations reveals. ${ }^{44}$ While they may have rebelled against an individual emperor, though, the soldiers never rebelled against the empire as a whole because they were among the prime beneficiaries of the system.

The standing army allowed for an intensification of imperial power across the empire. Roman officials and tax collectors were often accompanied by soldiers who could physically compel the obedience of subjects. Soldiers were also agents of the Roman state, so failure to obey them was tantamount to rebellion. The killing of a centurion accompanying a tax collector in Egypt led to revolt and widespread, brutal repression, for example. ${ }^{45}$ Not every intensification of power was so destructive. Augustus took great pains to advertise the fact that his reign brought peace and security to the world and he took some steps to make this claim a reality, especially in Rome and Italy. Even before he won sole power, he undertook the eradication of banditry in the Italian peninsula, which had flourished during the chaos of the civil wars. As part of this effort, he established a network of permanent outposts (stationes) manned by soldiers (stationarii) throughout the peninsula. ${ }^{46}$ Under subsequent emperors, and especially in the second century, the practice of spreading outposts and watchtowers along routes begun by Augustus would be implemented throughout the provinces.

41 For terms of service, see Gilliver 2007. For soldiers' salaries, see Speidel 1992; 2014.

42 For China, see Leese-Messing, ch. 4, this volume. For the honorable status of soldiers, see Eck 2014; Potter 2011.

43 For the nature of the military community, see the essays in Goldsworthy and Haynes 1999. Influential earlier works include MacMullen 1963; Saller and Shaw 1984; Shaw 1983. For the army in Egypt, see Alston 1995; for Syria, see Pollard 2000. For soldiers' marriage patterns, see Phang 2001 and, more recently, Greene 2015.

44 Campbell 1984 is the classic account of the relationship between the emperor and the army. For an overview of military usurpations, see Birley 2007.

45 Alston 1995, 86-96.

46 Appian Bella Civilia 5. 132; Suetonius Divus Augustus 32. 1; Tiberius 8, 37. 1; Fuhrmann 2012, 101-103, 203-223. 
These efforts were never completely effective. Banditry was endemic in the Roman world, and travelers were perpetually at risk of theft, assault, and murder. ${ }^{47}$ The Biblical parable of The Good Samaritan is only the most famous example. ${ }^{48}$ Banditry was never eliminated and landscapes characterized by inaccessibility, especially mountains, were notorious as bandit strongholds. ${ }^{49}$ Nevertheless, the Roman state invested resources in trying to curb brigandage in the provinces and the army was instrumental in that attempt. The most famous example predates the Principate: in 67 BсE, Pompey was tasked with clearing the Mediterranean of pirates. ${ }^{50}$ The most complete evidence, however, comes from Egypt, where watchtowers were established in the Nile valley and along the routes linking the Nile to the quarries of the Eastern Desert and the ports on the Red Sea. ${ }^{51}$ The people responsible for manning these watchtowers seem to have been civilians supervised by soldiers. Thus, in addition to the soldiers themselves, the army allowed the government to multiply its manpower resources very efficiently. ${ }^{52}$ These guards were no doubt stationed along routes that were important to the state, guarding the traffic to and from the imperial quarries and the ports that formed a crucial link in the lucrative trade routes to India. At the same time, however, the imperial propaganda of peace and security remained potent. So, for example, in the middle of the second century CE, inscriptions announced that the emperor Antoninus Pius had built four camps (praesidia), 12 watchtowers (burgi) and 109 guard posts (phruri) "for the protection of the province of Thrace." ${ }^{53}$ We have abundant documentary evidence of civilians submitting petitions for aid to stationarii and centurions, which implies that the soldiers manning these posts were seen by provincials as a potential source of assistance. ${ }^{54}$ In both positive and negative ways, then, the army manifested the power of the imperial government in the lives of its subjects.

\section{III.1.1 The Frontiers}

Soldiers were not equally ubiquitous throughout the empire. Rome's military force was deployed to maximize its efficiency and minimize its cost. This entailed matching the size of the military force to the task at hand. A force of around 5,000 men, the Praetorian Guard, was stationed at Rome as the palace guard, along with a

47 Grünewald 2004; Shaw 1984.

48 The Gospel according to Luke (Luke) 10. 25-37.

49 Shaw 1990a; 1990b.

50 For piracy in the ancient Mediterranean, see De Souza 1999.

51 Alston 1995, 80-86.

52 Alston 1995, 80-82; Fuhrmann 2012, 224-225.

53 Gerov 1989, no. 211.

54 Fuhrmann 2012, 201-238. 
smaller force that acted to enforce order in the city. ${ }^{55}$ Small detachments of a few soldiers accompanied officials throughout the empire to add the threat of violence to normal interactions between state representatives and the populace, but most of the army was stationed in the outermost provinces of the empire. Under Augustus, they acted as a mobile strike force, conquering territory and suppressing rebellions in much the same way they had under the Republic. In the course of the first and early second centuries, however, the headquarters of the units gradually became more fixed in locations they would occupy into the third or fourth centuries (map 2). ${ }^{56}$ These were usually located at the outer edge of the territory administered by the Roman government, especially in the European provinces. As a result, heavy militarization became a defining characteristic of the Roman frontiers. ${ }^{57}$

In all frontier zones, the soldiers projected Roman power, discouraging and repressing rebellion both inside and outside of Rome's directly administered territory. Tacitus, in recounting the distribution of troops at the death of Augustus, describes the legions on the Rhine as a reserve against both Germans beyond the Rhine and Gauls who lived on the Roman side of the river. ${ }^{58}$ In general, Rome was rarely at risk of a major invasion that would seriously threaten the territorial integrity of the empire until the third century CE, with the possible exception of the Arsakids (Parthians). ${ }^{59}$ The enemies of Rome in the first two centuries were more likely to inflict damage on a local scale. If unchecked, this could encourage others to raid or rebel, and so the army worked hard to deter and punish such violence. It was difficult to intercept mobile raiders on their way into the empire, so the troops usually attacked them after they were laden with booty. ${ }^{60}$ This was little comfort to the victims of the raiders, and in some places chains of watchtowers, forts, and even linear barriers were constructed to check their incursions. In the late second century, the emperor Commodus advertised to the people of Pannonia Inferior (in modern Hungary) that he had "fortified the whole stretch of the river bank with towers built from the ground up, and with garrisons stationed at suitable points, to prevent surprise crossings by bands of brigands." 61

The security provided by the frontier had real economic and psychological consequences. In Moesia Inferior, the frontier collapsed twice. In the middle of the third century, a series of large- and small-scale raids laid waste to the plain between the

55 Le Bohec 1994, 20-22.

56 This is not meant to imply the existence of an overarching grand strategy in the sense of Luttwak 1976, against which, see Isaac 1990; Mattern 1999; Whittaker 1994. Rather, the distribution of forces was more likely the result of decision makers operating with broadly similar aims adapted to local contexts (Breeze 2011).

57 Von Reden and Speidel, ch. 17, this volume.

58 Tacitus Annales (Tac. Ann.) 4. 5.

59 Fabian, ch. 6, this volume.

60 Goldsworthy 2007, 93-95.

61 ILS 8913, trans. Breeze. 
Balkan Mountains and the Danube, but the Tetrarchic and Constantinian emperors invested in fortifications and campaigned north of the river, eventually reestablishing Roman dominance. The rural economy recovered, with new settlements springing up in agriculturally productive areas. In the late fourth century, the frontier collapsed again and the area faced a mass migration that the empire was powerless to stop. Eventually, the immigrants forged a treaty with the emperor and a semblance of Roman authority was reestablished, but there was no longer a line of forts along the Danube protecting the countryside. Instead, the army fortified strategic population centers and supply depots. Not only did the number of settlements in the countryside plummet, people now lived in areas with easy access to a naturally defensible refuge, leaving the most productive areas empty. ${ }^{62}$

The spatial layout of the frontier varied greatly by region and period (map 2). In Europe, army bases mostly lined the Rhine and Danube Rivers, which eased supply and communications between them while simultaneously creating a surveillance network that could monitor populations and control movement across the frontier. ${ }^{63}$ It also provided the staging ground for expeditions beyond the frontier that enforced and extended Roman supremacy. So, for example, the initial construction of the chain of forts on the lower Rhine in the mid-first century CE has been linked to the conquest of Britain. ${ }^{64}$

In the East, the geography of the frontier was more varied and dynamic. Egypt can be dealt with briefly, as its garrison was relatively stable in size and distribution. This province, crucially important for the grain supply of the capital, contained first two legions and then only one stationed near Alexandria, far from the edge of Roman territory. This megalopolis had to be firmly controlled to ensure traffic flowed smoothly between the Mediterranean and the Nile. From the late first century CE, there were also approximately 5,000 to 7,000 auxiliary soldiers. Some of these were concentrated with the legions near Alexandria, while others were stationed in the region of the First Cataract, protecting Egypt from incursions from the south and preventing uprisings in the Thebaid region. Many soldiers were scattered in smaller outposts, particularly in the Eastern Desert, guarding roads and controlling imperial quarries. A detachment of legionaries from Egypt was even stationed on the Farasan Islands at the mouth of the Red Sea, though their precise function - to suppress piracy and smuggling, to maintain Roman supremacy and control of the Red Sea, or both - is not entirely clear. ${ }^{65}$

The distribution of Roman forces in western Asia was less stable, shifting to address two main phenomena: the strength of the Arsakid Empire in the north and

62 For the effects of the Gothic invasion on the rural economy of the central Danubian Plain, see Poulter 2004; 2013. I identified the widespread shift in settlement location preferences and argued that it could be attributed to lack of security in Weaverdyck 2016.

63 Dobson 2009; Karavas 2005; C. S. Sommer 2009.

64 Polak 2009; van Dinter 2013.

65 Haensch 2012. For the function of the garrison, see Cobb 2018, 118-120 with literature. 
the rebelliousness of local populations, especially the Jews, in the south. ${ }^{66}$ In contrast to Europe, the states that controlled large parts of this area were more centralized, and the rulers of the westernmost states had maintained good relations with Rome since Pompey's eastern campaigns in the 60s BCE at the latest. As a consequence, the initial occupation force was smaller and more concentrated than in the West. Throughout the first and second centuries, their kingdoms were annexed and relations with more distant kings established, so the external borders of Roman provinces also changed more frequently.

Also in contrast to the West, units in the East were more often stationed in cities, so military occupation is much harder to track archaeologically. We know that for most of the first century CE, the province of Syria contained four legions, of which one was stationed at Kyrrhos and one at Raphanaia. In the 50s and 60s CE, a major war erupted over the appointment of the king of Armenia - a perennial bone of contention between Rome and the Arsakids - leading to a major reorganization under Vespasian (r. 69-79 CE): kingdoms were annexed to enlarge the provinces of Syria and Kappadokia, the road network was expanded, fortifications built, and four legions were stationed on or near the Euphrates at Melitene and Satala in Kappadokia, and at Samosata and Zeugma in Syria. ${ }^{67}$ Syria contained a third legion still at Raphanaia, and Judaea, in response to the Jewish revolt of 66-73 CE, contained one in Jerusalem. Vespasian also strengthened the Roman presence in the Black Sea, establishing a fleet and stationing troops in cities on the east coast.

This well-developed military infrastructure, further elaborated by Vespasian's successors, allowed Trajan (r. 98-117 CE) to launch a major invasion of Mesopotamia from 114 to $117 \mathrm{CE}$, although his territorial gains in Mesopotamia and Armenia could not be held. Trajan did, however, annex the Nabataean Kingdom, the last independent kingdom west of the Euphrates, which became the province of Arabia in $106 \mathrm{CE}$. One legion was transferred from Egypt to Arabia's capital, Bostra, and a major road, the Via Nova Traiana, was built to connect this city to the Red Sea. ${ }^{68}$ Following Trajan's Parthian campaigns, legions were shuffled, but the bases remained mostly the same. After the Bar Kokhba revolt in the 130s CE, a second legion was added to Judaea, now called Syria Palaestina, at Caparcotna. The next Parthian war came in the 160s CE and resulted in the occupation of territory across the Euphrates and an extension of Roman control down the river to at least Dura Europos. Another war in the 190s further expanded Roman territory in Mesopotamia and led to the establishment of new provinces across the Euphrates. ${ }^{69}$ Two legions were stationed here

66 Isaac 1990 underpins most recent scholarship on the eastern frontier. Wheeler 2007 is a useful summary that takes a large-scale, strategic perspective. M. Sommer 2005 and Edwell 2008 provide detailed accounts of the Upper and Middle Euphrates frontier. For the Arabian frontier, see Kennedy 2004.

67 Dart 2016; Edwell 2008, 18-20.

68 Speidel 2019.

69 For the provincialization of northern Mesopotamia, see Speidel 2009, 181-210. 
from the 190s, one in Singara near the Tigris, the other possibly in Nisibis, though that is not certain.

Although many details elude us, it seems that the Roman army in the East was intended to control major population centers and important nodes in transportation networks, including crossing points on the Euphrates and oases in the Egyptian and Arabian deserts. ${ }^{70}$ Controlling routes could check major invasions, but the history of Roman aggression suggests a generally offensive rather than defensive stance: control of major river crossings allowed the Romans to threaten, attack, and dominate their neighbors. The old idea that the Arabian frontier was meant to check nomadic incursions has been well refuted. ${ }^{71}$ Rather, control and taxation of the lucrative trade from Arabia, the Indian Ocean, and the East might have been a motivating factor. ${ }^{72}$ Compared to the great riverine frontiers of Europe, Rome's eastern frontier is much less linear and much more focused on the internal population, not only in Judaea but in Egypt as well.

\section{III.1.2 Supplying the Army}

Relative to the population of the empire, which is usually estimated to have contained between 60 and 70 million people in the mid-second century $\mathrm{CE},{ }^{73}$ the size of the army under the Principate was smaller than that of the Republic, numbering probably between 300,000 and 400,000 soldiers, but they were now permanently on duty and many were stationed in areas that had hitherto been sparsely populated. The state's efforts to ensure the supply of these troops with food and equipment had profound and far-reaching economic effects. ${ }^{74}$ The army in northern Europe, in particular, is seen as a transformative force, not only spurring greater agricultural production but introducing new plants, breeds of animals, and technologies affecting both agriculture and communications. ${ }^{75}$ Furthermore, some important Mediterranean staples - particularly olives - do not grow in northern Europe and had to be imported. Supplying these armies, therefore, was a major undertaking that had long-term and far-reaching effects.

Military supplies were acquired and transported to the army through a complex and variable network of exchanges and interactions. ${ }^{76}$ The major point of debate

70 Kennedy 1996; Parker 2006.

71 Isaac 1990, 68-77.

72 Speidel 2016.

73 Hanson 2016, 71 with literature.

74 MacMullen 1963; Wierschowski 1984 are foundational for the economic impact of the army. See also the contributions in Erdkamp 2002 and Blois and Lo Cascio 2007. For military supply, see Roth 1999; Mitthof 2001.

75 Stoll 2016 summarizes many of these themes.

76 I focus here on the supply of troops during peace time, setting aside questions of supply during campaigns. 
has been whether military supplies were acquired through taxation and the extraction of in-kind rents from imperial estates, purchase at a fixed price, or free market purchase and which commodities were obtained in which way. ${ }^{77}$ The problem is that the state acquired goods, in particular grain, in a number of ways, and precise origins are rarely stated in the documentary evidence that survives. So, for example, an ostracon may affirm that a certain person delivered "public wheat" to a soldier, but for the purposes of the people named, who grew the wheat and whether or not they were paid for it is immaterial. ${ }^{78}$ A line from Pliny the Younger's speech in praise of the emperor Trajan shows how blurry the line between purchase and requisition could be: "The fiscus bought whatever it seemed to buy." 79 The implicit comparison is revealing. If requisition was masked as purchase, then purchase was seen as normal. In the same breath, Pliny also notes how extraordinary Trajan was for buying goods at a negotiated price.

Documentary evidence, sparse and unevenly distributed as it is, reveals that there was no single, universal system of acquisition. ${ }^{80}$ The precise mechanisms of supply at work will have depended heavily on contingent circumstances shaped by local ecologies, agricultural practices, social structure, and histories of surplus extraction as well as military need. Supply systems in Egypt and Britain, for example, must have been very different and must have changed over time. A receipt preserved on papyrus shows that, in Egypt, the barley needs of each unit were reported up through the military hierarchy to the praefectus of Egypt, who then distributed the burden of supplying those needs down through the civilian hierarchy until the two met in the form of a low-ranking officer collecting grain from village elders. Although the transaction is described in monetary terms, we hear of no money changing hands. ${ }^{81}$ An earlier papyrus describes barley as having come from the public account of a village and makes no mention of purchase. ${ }^{82}$ In Britain, the wooden writing tablets from the fort of Vindolanda suggest that the needs of the military were met through a more complex and irregular system that included entrepreneurs operating within a free market context. ${ }^{83}$ One letter, addressed to an officer, discusses various business arrangements, including the purchase of a large quantity of grain that has been interpreted as military supply. ${ }^{84}$ The writer has put down a deposit and requires the balance of the price or he risks losing the grain,

77 Summaries can be found in Kehne 2007; Rathbone 2007.

78 O.Petr. 245 with Adams 1995.

79 Pliny Panegyricus 29. 5.

80 For the use of documentary evidence, see von Reden, ch. 8.C, this volume.

81 PAmh. 107 with Adams 1999, 120-121. Note, however, that in Adams's translation, the prefect

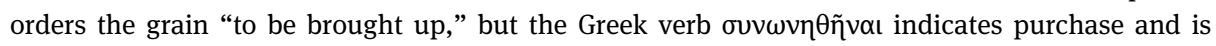
better translated as "to be bought up," as in Campbell 1994, no. 235.

82 SB XIV 12169 with Mitthof 2001, 38-39.

83 Evers 2011; Whittaker 2002.

84 T.Vindol. II, 343. 
the deposit, and his pride. If the writer is engaged in supplying the army, it is notable that this connection does not guarantee access to the grain he is buying. The evidence from Egypt, which had a long history prior to Roman conquest of paying taxes in grain, might be giving a false impression about the prevalence of stateowned grain elsewhere in the empire.

Beyond the local economy of the frontier zones, the soldiers' demand for Mediterranean products led to the modification of long-distance exchange networks and the creation of new ones that had not previously existed. Mediterranean traders had been active in the areas that would become frontier zones long before the influx of soldiers, but the establishment of the military cordon created new demand and, more importantly, made such trade into a structural support of imperial power. The trade in olive oil from Baetica in southern Spain is especially visible because it was transported in a distinctive amphora known as Dressel 20. ${ }^{85}$ While most types of pottery decline in frequency with distance from the place of production, Dressel 20 does not. It is found in very large numbers on the Rhine and in Britain, suggesting directed distribution. There is no evidence that the state ever collected taxes in oil, but there is widespread evidence for the existence of military conductores, people who arranged or entered into contracts for the supply of goods to different units. ${ }^{86}$ Contracts and trade relationships that, once established, were jealously guarded by powerful actors could account for these distributions just as well as state-run redistribution. ${ }^{87}$

Transporting these supplies could be a lucrative business. Not only were the shippers (navicularii) paid for their services, the goods that they transported for the government were not taxed. The temptation to clandestinely mix other goods in with the tax-free portion of the cargo was irresistible, as we learn from a secondcentury edict:

On the subject of property which governors direct to be brought to them for their use, the deified Hadrian wrote to governors saying that when a provincial governor or a legionary commander or a procurator of such a person dispatches someone to make a purchase, he should indicate this in a memorandum signed in his own hand and should send this memorandum to a tax farmer so that anything that is brought in excess of what was ordered can be subject to tax. ${ }^{88}$

Similar edicts demonstrate the persistent difficulty of distinguishing between taxfree and taxable goods. Even the honest navicularius, however, benefited from government contracts beyond the value of the contract itself. In the ancient world, where information on market conditions was difficult to come by, the government

85 The debate about the mechanisms by which Baetican olive oil reached the northern frontier is conveniently summarized in Tchernia 2016, 255-264.

86 Whittaker 1994, 108-113.

87 Tchernia 2016, 97-114, 255-264.

88 Digesta 39. 4. 4. 1, trans. Watson. 
contract ensured a profitable voyage, allowing the merchant to speculate on extra cargo with little risk. The stability and size of the military market, coupled with its ability to operate over long distances and the privileges granted to its suppliers, encouraged the development of a class of business people that was particularly selfaware in western Europe. ${ }^{89}$ This group of people had social contacts throughout the empire and business expertise that allowed them to undertake substantial commercial operations both for the army and for nonmilitary markets as well. In this way, the frontier might have contributed to economic integration and development beyond its own supply needs.

\section{III.2 Political Structures}

The authority of Rome rested on more than the coercive threat posed by the military. Indeed, the empire consisted of a great number of administrative units tied together in a relatively shallow hierarchy through diverse vertical relationships with the imperial center. Compared to the Chinese empires, the Roman state delegated a great deal of responsibility onto relatively autonomous but firmly subordinate political units. These came in a variety of forms. Strabo, writing a geography of the entire Roman world under Augustus, captures this diversity:

Of all of these lands under the Romans, some are ruled by kings, others they themselves hold calling them provinces and sending governors and tax collectors. There are some free cities, some having come as friends from the beginning, and others they themselves set free as an honor. There are also some dynasts and commanders and priests under them: these live according to their ancestral laws. ${ }^{90}$

In addition to the lands that the Romans "hold themselves," there are free cities, kingdoms, and a variety of other places that live by their own laws. In what sense were these places "under the Romans"? The form of Roman dominance differed from case to case, but all acknowledged Roman supremacy, and all were expected to obey Roman commands. The degree of Roman interference in the lives of their subjects also varied, but a general diachronic trend toward greater interference, especially in the Principate, can be observed.

\section{III.2.1 Client Kings}

In Strabo's conception of the empire, monarchies and provinces are parallel forms of Roman control over large territories. The monarchs who ruled these lands are

89 For the negotiatores and navicularii as a social class, see Verboven 2007. Broekaert 2013 provides a prosopography of these people. For the economic benefits of state contracts, see Tchernia 2016, 103-111.

90 Strabo 17. 3. 24. 
often called 'client kings' (queens were rarer) by modern scholars to emphasize their subordination to Rome, but in antiquity the relationship was expressed in terms of friendship and alliance. ${ }^{91}$ This diplomatic language allowed for a great deal of flexibility and diversity. The precise relationship between a king and Rome, as with other allies, varied according to local circumstances. Many were Roman citizens and had grown up in Rome. Herodes and his successors, who ruled Judaea, had no dynastic claim and were entirely dependent on Roman backing for their position, while others had much more powerful, local bases of support. Mithridates VI of Pontos on the southeast coast of the Black Sea and Jugurtha of Numidia in North Africa were both powerful enough in their own right to wage large-scale wars against Rome in the late second and early first centuries BCE. ${ }^{92}$ For the most part, though, Rome's royal allies were loyal and their kingdoms were seen as part of the Roman Empire. ${ }^{93}$ Indeed, territories could be transferred between province and kingdom relatively easily, though it was more common for royal land to become provincial than vice versa. ${ }^{94}$

At the same time, it would be a mistake to regard these kingdoms as simply provinces by another name. There is no unambiguous evidence of kings paying taxes to the Roman treasury, though they might pay indemnities for fixed periods of time, and they expended a great deal of money, ultimately extracted from their subjects, cultivating the favor of powerful Romans both in the Republic and in the Principate. ${ }^{95}$ The Roman state also provided money to some kings. These gifts could ensure loyalty, strengthen the king's position within his kingdom, and allow the king to advance Roman interests, but they could also be protection money, payments to avoid war. ${ }^{96}$ The exchange of money was an ambiguous but normal form of gift exchange that established and maintained social relationships. ${ }^{97}$ For the kings, friendship with Rome provided powerful support against their enemies both inside and outside their kingdom, and enhanced their prestige and influence, especially when they enjoyed close personal relations with powerful Romans. ${ }^{98}$ For the Romans, these relationships provided stability in areas that were difficult to control otherwise - kings were often asked to control bandits - and protection against more distant, hostile groups, but kings could also act as intermediaries between Rome and these groups. ${ }^{99}$ While each king and kingdom was unique, with its own back-

91 Braund 1984 is foundational. Braund 2015; Kemp 2018 are more recent.

92 See von Reden, ch. 1, this volume.

93 Braund 2015, 150-154.

94 Braund 1984, 84-85.

95 Braund 1984, 58-66.

96 Kemp 2018, 97-100 sees a shift from the former to the latter in the late second century CE.

97 Braund 1984, 62-63.

98 Braund 1984, 82-83.

99 Braund 1984, 91-103; 2015. 
ground, goals, and strategies, they all played a role in supporting (usually) Roman power, and this role was distinct from that played by the provinces.

\section{III.2.2 Provinces in the Republic}

The English term 'province' denotes a territorial administrative section of a state or empire. Under the Principate, Roman provinciae conform well to this definition, but this was not always the case. Tracing the changing meanings of the Latin word provincia through time can illuminate the changing nature of the Roman Empire from one based on the military might and the authority of Rome and Roman representatives vis à vis other polities to one based on Roman possession and administration of territories around the Mediterranean and beyond.

In the third and early second centuries, a provincia was a task or responsibility assigned to a magistrate. ${ }^{100}$ Thus, the treasury was the provincia of the urban quaestor. While most provinciae in this period were named for a geographic area, this does not imply that those areas had been or were going to be annexed. ${ }^{101}$ Rather, these geographic provinciae defined the area in which a magistrate was expected to operate and in which his authority superseded that of other, equal magistrates. The borders of a provincia were often vague, but sometimes clear geographical limits were defined, as when the Senate ordered the praetors responsible for the provinciae of Nearer and Farther Spain to fix the boundary between the two in 197 BCE to clarify their areas of competence. ${ }^{102}$ This gradually changed as conquered territories were assigned year after year, and the number of magistrates increased to oversee them. For Cicero, writing in the mid-first century BCE, provincia had a broader range of meanings, including not only a task but also a territory that is in some way owned by the Roman people and continued to exist in the absence of a magistrate as well as the community of people living in that territory. Contemporary authors like Caesar also used the term to refer to a set of legal and administrative norms according to which the territory was governed.

The sense in which the provincia were owned by the Romans is more difficult to tease out because the provincia included numerous subject communities, each with their own relationship to Rome. The provincia of Asia in western Anatolia illustrates the complexity (map 2). ${ }^{103}$ In 134 BCE, the last king of Pergamon died without an heir and left his kingdom to Rome. ${ }^{104}$ After defeating a claimant to the Pergamene throne, the commander and a board of ten commissioners established the

100 The following discussion is based on Richardson 2008. See also Lintott 1993, 22-32.

101 The provincia of Macedonia is a good example, for which see Kallet-Marx 1995, 12-42.

102 Richardson 1986, 77-78.

103 Kallet-Marx 1995, 98-123.

104 For the reasons behind this bequest, see Sherwin-White 1984, 80-92. 
relationships that Rome would have with the various parts of the old kingdom. Many cities were declared free, and large areas were handed over to Rome's allies, but some communities, particularly those that had supported the pretender, were taxed, and formerly royal lands became Roman public land to be sold or rented. Magistrates were sent every year to see to this new provincia, but they did not restrict themselves to the land that was now owned by the Romans nor to the nonfree cities. Indeed, during peacetime, the magistrates seem to have operated primarily out of Pergamon and Ephesos, two free cities. ${ }^{105}$

The shift in the meaning of provincia from a task to a territory owned and administered by the Roman government was exemplified and confirmed by Pompey when, after his military campaigns in the East, he unilaterally created the provincia of Syria and appointed one of his subordinates to govern it because he could find no local candidate able to rule it. The Senate had never before allocated Syria as a provincia, so this was a significant usurpation of its functions, but what is more, the provincia was established explicitly as a territory that would be governed by a Roman magistrate not as a war to be fought or a task to be completed. Never before had a provincia been created after the war had been won, but this would soon become the standard practice. ${ }^{106}$

By the time Augustus took control of the Roman state in the late first century, this territorial administrative meaning was dominant. In $27 \mathrm{BCE}$, the first official attempt to define Augustus's position within the Roman state divided the Roman Empire into provinciae that belonged to the People of Rome and whose governors (as we can now call them) were selected according to traditional practice, and provinciae that belonged to Augustus, who chose representatives (legati Augusti pro praetore) to govern them in his stead. ${ }^{107}$ These are clearly territorial entities existing separate from the magistrates who ruled them, but they also reveal a conception of the provincia as the standard administrative subdivision of the empire. Only now is it appropriate to translate the word as "province." Over time, the provinces would be transferred between senatorial and imperial control, expanded, and subdivided. The provinces had become units of Roman territory.

The emergence of the idea that provinces were territorial sections of Rome's empire had implications for the way they were governed, at least ideally. ${ }^{108}$ The rise of Augustus to supreme power brought the reality closer to that ideal. Roman political thought maintained a theory of beneficent imperialism. ${ }^{109}$ Cicero expressed the

105 Kallet-Marx 1995, 115.

106 Richardson 2008, 106-116.

107 Strabo 17. 3. 25.

108 For provincial administration, see Ando 2006; Bowman 1996; Eck 2000a; Lintott 1993; Richardson 1992.

109 For an introduction to Roman political theory of absolute rule beginning with Cicero in the Late Republic, see Noreña 2009. For the theory of beneficent imperialism in the Republic, see Braund 1998; Brunt 1990, 288-323. 
idea often. In a letter to his brother, who was governing Asia at the time, he says, "In my opinion all who govern others are bound to regard as the object of all their actions the greatest happiness of the governed." 110 As long as provinciae were wars to be won, the inhabitants of the area could be treated as enemies or inconsequential, unless they had formed an alliance with Rome. When they became provinces, part of the Roman Empire, the inhabitants were assumed to be allies and thus ought to be treated well. The utilitarian rationale was that contented subjects were less likely to revolt. ${ }^{111}$

The actual conduct of Republican governors and their subordinates rarely lived up to this ideal. ${ }^{112}$ Starting in the mid-second century BCE, laws were established that allowed for the prosecution of governors by individuals seeking to recover money that had been improperly extorted from them. These laws were amended, revised, and multiplied, but there is little evidence, aside from a few spectacular cases, that they had the effect of ensuring good governance. The plaintiffs had to travel all the way to Rome and secure the services of an aristocratic patron (see below) to represent them in court against another powerful aristocrat. Even then the accused was often acquitted. ${ }^{113}$

Cicero's letter to Quintus, mentioned above, illustrates several aspects of Roman governance and the abuses that Rome's subjects normally suffered. ${ }^{114}$ Cicero dwells at length on Quintus's exercise of self-control in such a wealthy province:

What can be imagined so striking or so desirable as ... that the inhabitants are not being ruined by your progresses, drained by your expenses, agitated by your approach? That there is the liveliest joy, public and private, wheresoever you come, the city regarding you as a protector and not a tyrant, the private house as a guest and not a plunderer? ${ }^{115}$

The role of the governor was still based on that of a military commander who operated without any check on his power. As a governor traveled throughout his province with his entourage, he was entitled to requisition supplies, lodging, and money, and most took full advantage of this privilege. Hosting Roman officials and billeting soldiers could be a heavy burden, and cities would sometimes pay large sums of money to the governor to avoid it. ${ }^{116}$ In addition, cities would vote to give large sums of money as honorific gifts not only to the governor, but to the People of Rome. Cicero boasts of outlawing the voting of money for public spectacles in

110 Cicero Epistulae ad Quintum fratrem (Cic. QFr.) 1. 1. 24, trans. Shuckburgh.

111 See, for example, Livy 8. 13. 16; Sallust Bellum Iugurthinum 102. 6.

112 For the ways Republican Roman officials enriched themselves in the provinces, see Tan 2017, 68-90.

113 Betts and Marshall 2013; Brunt 1990, 53-95.

114 I focus here on Cicero's praise of his brother's exceptionally good government of Asia because it reveals what was considered normal more clearly than his condemnation of Verres's bad government of Sicily in In Verrem (Cic. Verr.) 1 and 2.

115 Cic. QFr. 1. 1. 8-9, trans. Shuckburgh.

116 Cicero, Epistulae ad Atticum 5. 2. 1. 
Rome and of refusing to accept money for a temple and monument in his honor. ${ }^{117}$ Such seemingly 'voluntary' gestures must frequently have been the result of intimidation or coercion. Since the governor would also arbitrate disputes between cities, these honors might also be used to influence future judgments.

Because Asia was a peaceful province, the primary duty of the governor was to settle disputes between allies and Roman citizens. ${ }^{118}$ Indeed, it is in the governor's role as a judge that his power is most manifest:

The entire province mainly depends on the administration of justice. In it we have the whole theory of government, especially of provincial government, clearly displayed: all that a governor has to do is to show consistency and firmness enough, not only to resist favoritism, but even the suspicion of it. ${ }^{119}$

Cicero goes on to contrast the process of litigation in Rome with that in the provinces. In Rome, there are various ways of appealing an unfavorable decision, while in Asia the judge's ruling is final. Nevertheless, there were practical limits on the governor's freedom of action, mainly imposed by Roman politics. The Romans in the provinces consisted of publicani and negotiatores. ${ }^{120}$ Negotiatores were Roman citizens in the province for the purpose of making money and they could be well connected. ${ }^{121}$ Publicani were tax farmers, corporations of investors who bought the right to collect certain taxes for the Republic. ${ }^{122}$ Cicero calls them the chief obstacle to good governance because they had significant political influence in Rome, and their interests were directly opposed to those of the allies. Quintus might be able to restrain "a fraudulent negotiator or a somewhat over-extortionate tax-collector" if he can demonstrate sufficient propriety on the part of himself and his entourage that none can question the integrity of his rulings. ${ }^{123}$ In the end, however, Cicero says nothing of actually restraining the publicani and suggests only that Quintus, after arguing for the reasonability of Roman taxation, beg the cities to cooperate with the publicani as a personal favor.

\section{III.2.3 Provincial Administration during the Principate}

When Augustus came to power and ushered in the monarchy, the form of provincial administration changed little. ${ }^{124}$ The constitutional positions and titles of some offi-

117 Cic. QFr. 1. 1. 10.

118 Cic. QFr. 1. 1. 6-7.

119 Cic. QFr. 1. 1. 20, trans. Shuckburgh.

120 Cic. $Q F r .1 .1 .6-7$.

121 For the meaning of the term negotiator, see below, sec. IV.1.2. For their political influence, see Rauh 1986.

122 See sec. II above.

123 Cic. QFr. 1. 1. 19-20; 1. 1. 7, for the quote.

124 Eck 2009. 
cials in some provinces were new, but this would have mattered little to provincials. Much more important was the fact that there now existed a power greater than the governor. ${ }^{125}$ The effects of this are revealed in an inscription from Cyrene containing five edicts of Augustus. In the first, Augustus establishes a new system for appointing judges in cases between Greeks and Roman citizens. The edict communicates clearly Augustus's access to detailed knowledge about the province and his willingness to bypass the governor and intervene directly:

Since I find that all the Romans in the province of Cyrene are two hundred and fifteen of every age who have a census valuation of twenty-five hundred denarii or more, from whom the judges are (chosen), and that there are conspiracies among these (Romans) - so the embassies of the cities from the province have complained - which have oppressed the Greeks in capital cases, the same people taking turns as accusers and as witnesses for each other, and (since) I myself have found that some innocent people in this way have been oppressed and brought to the ultimate penalty ... 126

The right of appeal, which Quintus's subjects in Asia lacked, was now available even to noncitizen subjects. Later, this right would be reaffirmed, and the emperor would explicitly forbid governors from obstructing such appeals. ${ }^{127}$

Augustus also advertises a willingness to rein in the power of the governor in the interest of the provincials in the fifth edict, which reforms the process by which extortion charges were heard. While this did not completely prevent corruption among the governors, it expressed the idea that the emperor's role was to control his subordinates in the interests of the governed. ${ }^{128}$ By the early third century, the jurist Ulpian could write a treatise on the conduct of governors with a warning that, while a governor was allowed to bring his wife with him, he would be held responsible for any crimes she committed in the province. ${ }^{129}$ While corruption continued, the Principate provided more effective opportunities for redress.

As we have seen, in relatively peaceful provinces, governors probably spent most of their time administering justice. Roman law was well adapted to the problem of solving disputes between Romans and non-Romans. In the ancient Mediterranean world, the legal system that people used depended on their citizenship. This was a serious impediment to commerce across political boundaries, which depends on trust and the existence of enforceable agreements. Often, cities established rules

125 The existence of an emperor also meant that the publicani had less political power, as pointed out by Eck $(2009,234)$. If the farming of taxes was decentralized from Rome to the provinces themselves, as suggested by Brunt $(1990,377)$, this would have further diluted their influence.

126 Sherk 1984 no. 102, 11. 4-11.

127 Dig. 49. 1. 25.

128 Brunt (1990, 53-95) doubts whether this and similar reforms actually made much of a difference, but Ando $(2000,306)$ is more optimistic. For the emperor's role as overseer of his subordinates, see Ando 2000, 362-373.

129 Dig. 1. 16. 4. 
of jurisdiction when they entered into a treaty and the Romans would offer ius commercium - the right to use certain Roman legal actions in Roman courts - to favored allies, but these both required the action of the state. In the third century BCE, when the Romans had extended their power over most of Italy and the interactions between Roman citizens and noncitizens (peregrini) were becoming more common, a solution was found in the person of the praetor.

The praetor, the second most senior annually elected magistrate in Rome, dealt primarily with legal cases. In 224 BCE, a second praetorship was created to handle cases involving peregrini exclusively. The praetor would listen to arguments made by litigants and translate the dispute into a formula that expressed the conflict in Roman legal terminology, the basis on which a decision should be made, and a remedy. The case was then passed to an independent judge who would determine the facts of the matter, issue a verdict, and apply the praetor's remedy. Over time, the praetors' formulas grew into a body of case law called ius honorarium or ius praetorium. By the time of Augustus, it had become the standard procedure of civil litigation. ${ }^{130}$ At some point, probably in the second century BCE, the praetors began to issue edicts at the beginning of their terms specifying the conditions in which they would grant a formula and how it would be written. When the governor went off to his province, he would issue a similar edict, often based on that of the praetor at Rome. These edicts built on previous edicts, but they did not become standardized until the reign of Hadrian (117-138 CE). This procedure was remarkably flexible and could accommodate litigants of various citizenships. ${ }^{131}$

In the provinces, the governor's duty to hear cases, along with the flexibility of the formulary procedure and the power of legal texts, became potent tools that provincials quickly learned to manipulate for their own ends. Legal texts, including the edict of the governor himself, decrees from the Senate or the emperor, responses to petitions, and previous judgments, were published and accessible to all. Using argumentation based on these texts, skilled plaintiffs could harness some of the power of Roman officials because they were supposed to be fair, impartial judges. ${ }^{132}$ This also encouraged the use of Roman-style contracts, which in turn made commerce and long-distance partnerships more predictable. ${ }^{133}$ Thus, Roman law became common throughout the empire in large part through the self-interested actions of the provincials.

In contrast to the well-developed bureaucracy of the Chinese empires, the centrally appointed personnel involved in Roman provincial administration was extremely limited. In addition to the governor himself, a second magistrate, known as

130 Capogrossi Colognesi 2014, 132-138. For the praetorship in the Republic, see Brennan 2000, $125-135$.

131 Richardson 2016.

132 Bryen 2012.

133 Sirks 2018. 
a quaestor, was elected to oversee the finances and had to account for the money received from the treasury to support the governor and his staff. All other officials were either appointed by the Senate or chosen by the governor himself. These included a varying number of high-status legati (who helped to command the army and judged cases as representatives of the governor) and a varied group of lower status functionaries like scribes, messengers, and lictors (a ceremonial body guard that accompanied the governor and carried the insignia of his office). In addition, the governor would be accompanied by a group of friends who, along with the quaestor and the legati, formed the governor's council, which he would consult on major decisions. Finally, governors relied heavily on members of their own household, in particular the slaves who managed their estates. Since the governor was a military commander, the army and its officers could also be considered part of his staff. ${ }^{134}$ Except for the military, this staff was tied directly to the governor, so it remained in the province only as long as the governor himself did. That meant that unless the governor's term was extended, the provincial administration turned over every year. Under the Principate, governors of imperial provinces remained in office for several years at a time, but only rarely long enough for the provincial administrative staff to gain real, local expertise. They necessarily had to rely on locals to provide them with information and advice.

Under the Principate, the administrative apparatus grew slowly but steadily. ${ }^{135}$ Most notable is the proliferation of procurators. The word originally referred to the administrators of large fortunes owned by others, but when Augustus was granted his provinces there were not enough quaestors to fill all the posts, so he sent procurators to take over their duties. Procurators also administered the emperor's increasingly vast private estates throughout all the provinces. There were procurators for individual estates and supervisory procurators that were responsible for all the estates within a province or group of provinces. Because the line between the private estates of the emperor and the public property of the Roman state was extremely blurry, these procurators were de facto public officials, and in the middle of the first century CE they were given the authority to hear legal cases within their domains. ${ }^{136}$ As time went on, procurators were appointed for increasingly specific duties, like the collection of certain taxes. The duties of the procurators varied widely in their nature and geographical scope, so it is likely that most reported directly to the central administration rather than being organized in a strict hierarchy. Unfortunately, the details of this administrative structure are unclear. ${ }^{137}$

134 Lintott 1993, 50-52; Richardson 1992, 580-584.

135 Eck 2000b.

136 Brunt 1990, 163-187.

137 Eck 2000a, 289-291. 


\section{III.2.4 Cities}

The imperial bureaucracy could be so small because most of the mundane tasks of governance were performed by local governments. The basic administrative unit in the provinces was the city, whose magistrates were elected or appointed according to local custom. Coming from the urbanized Mediterranean, the standard (though not the only) form of territorial organization in the Roman imagination was the polis, a territory governed by an urban center. In the eastern part of the empire, where this form of settlement was common, the Roman state ruled through these cities. In the western part, they encouraged the development of this form of urbanism in order to control vast swaths of territory. ${ }^{138}$ This form of rule allowed for minimum investment in the administrative apparatus, as most of the day-to-day administration was carried out by local collaborators. The imperial state simply required the regular payment of taxes of various kinds and the suppression of violence that might disrupt these payments. Nevertheless, over time, the involvement of the central state in local affairs grew more intense as a result of both imperial and local initiatives. The imperial government sought to maintain the financial solvency of the cities on which its rule depended and to maintain its position as the sole source of authority, while both individuals and cities sought to harness imperial power to their own ends.

In the Mid-Republic, Rome's relationships with most of its subordinates outside of Italy was informal and expressed in terms of friendship. These friends were part of the Roman Empire insofar as they obeyed Roman commands when given. Most did not pay tribute, and there were no permanent garrisons. The empire existed through symbolic acts of subordination, such as the dispatching of embassies requesting Roman arbitration in internal and external affairs. In the second half of the second century BCE, small Greek cities began striking treaties with Rome and erecting monuments to the fact. This provided them with protection against their more powerful neighbors and a feeling of civic pride at the special relationship that they enjoyed with such a powerful city. ${ }^{139}$

Roman officials had interfered in the internal affairs of Greek city-states since the end of the Second Macedonian War, when Flamininus set up oligarchic governments, punished pro-Macedonian factions and supported pro-Roman ones. ${ }^{140}$ Afterward, however, they left the actual functioning of those cities in local hands. Greek politicians took advantage of Roman intervention to attack their opponents. In 144/ 3 вСE, for example, an embassy from the city of Dyme approached the governor of

138 For an introduction to Roman urbanism, see Purcell 2010. For urbanization in Gaul, see Woolf 1998, 106-141.

139 Kallet-Marx 1995, 185-198.

140 Livy 34. 48. 2; 34. 51. See Eckstein 2008, 293-295 for the limited scope of these interventions and Kallet-Marx 1995, 66-77 for the nature of Roman political reforms. 
Macedonia to inform him that their political opponents had stirred up social unrest, burning public records and abolishing the constitution that the Romans had given them. The governor ordered that two of the accused be executed and the third sent to Rome. While the judgment was Roman, the embassy was initiated by local Greek politicians, who strategically made their enemies seem like enemies of Rome. In using Roman power for their own benefit, they intensified the Roman presence in Greece. ${ }^{141}$

Some allies, particularly those that had been defeated in battle, were expected to pay regular taxes to Rome. These took various forms and were collected in a variety of ways depending on the circumstances in which the alliance was forged, pre-Roman custom, and ad hoc decisions made by Roman representatives at the time. Spanish communities paid a fixed amount to maintain the Roman troops stationed there, and after the dissolution of the Macedonian kingdom, the four republics that took their place paid an annual tax that was half what they had paid to the Macedonian king. ${ }^{142}$ This sort of taxation blurs the line between allies and subjects and between Roman domination and Roman ownership. As time went on, the allies became less and less unequal partners in a relationship between sovereign powers, and more and more constituent parts within a state that had Rome as its capital. Nevertheless, the imperial government never appointed the magistrates who carried out most of the lower level administrative functions on which the empire relied. ${ }^{143}$

The cities never completely lost their sovereignty, but they always existed in some form of submission to Roman power. Understanding the relationships between the cities and the imperial center is difficult due to the fragmentary nature of our evidence, diachronic change, and a lack of standardization in those relationships. ${ }^{144}$ During the Principate, while most cities had to pay taxes, a few were immune from taxation and allowed to live according to their own laws. The privileges granted by the Roman state became important tools in the maintenance of empire. Cities could petition the governor, the Senate, or the emperor for certain privileges that would enhance their economic well-being or simply enhance their prestige relative to their neighbors. ${ }^{145}$ So, for example, cities in the eastern empire would compete to be named neokoros ('temple warden'), signifying their possession of a temple of the province's cult of the emperor. ${ }^{146}$ Intercity competition now took place within a Roman system. Not only did this prevent wars between cities, but every time a city made a move to try to gain an advantage it reaffirmed the legitimacy of that system.

Cities also reinforced Roman imperial rule through requests for arbitration in matters that went beyond their competence. In the Republican period, the cities of

141 Champion 2007.

142 Cic. Verr. 2. 3. 12; Richardson 1992, 586-589.

143 For a general overview of municipal administration, see Boatwright 2000, 42-52.

144 For the fragmentary nature of both the evidence and reality, see Eck 1999; Nörr 1999, 258.

145 Boatwright 2000, 36-56, 95-107; Edmondson 2015; Millar 1977, 363-463.

146 Burrell 2004. 
Greece sent numerous embassies to the Senate to settle disputes among themselves. Under the Principate the same sorts of conflicts were settled either by the emperor or the governor. In addition, cities could ask governors to step in to enforce the obligations of individuals, such as the payment of debts or fees by officials. ${ }^{147}$ Individuals, in turn, could turn to the governor or the emperor to obtain immunity from office holding and the financial burdens associated with it. ${ }^{148}$ Governors were also called upon to ensure the cities' rights to public lands that had fallen into private hands. Essentially, when a city's authority was not sufficient to deal with a problem, it called upon the central government to step in.

An important area in which imperial officials intervened against the wishes of cities was in the management of civic finances. ${ }^{149}$ Under the Principate, cities were generally forbidden from collecting direct taxes and had to raise money through indirect taxation, public monopolies, the leasing of public land and buildings, endowments, and fees on magistrates. They were also forced to obtain imperial permission to levy new taxes or to increase the size of their council (and thus the fees that were paid by councilors). Governors had the right to audit a city's accounts, unless the city enjoyed the privilege of immunity from such oversight. Sometimes a city's finances were so troubled that the governor or emperor appointed a special magistrate with extraordinary powers to correct them. Occasionally, such an official was appointed to an entire province. This allowed the Roman state to bypass the privileges granted to certain communities without destroying the entire system. These extraordinary officials represent the most intensive expression of central power in municipal affairs, but they were only occasionally appointed and held office for relatively brief periods. ${ }^{150}$ More pervasively, the central state imposed control over cities' largest expenses: public buildings. These buildings were an important part of the intercity competition described above. ${ }^{151}$ Governors were frequently involved in building projects in various capacities, including organizing their financing and maintenance. By the early third century at the latest, it was illegal for a city to build a large, public building without the permission of the emperor, and it was the governor's duty to inspect existing buildings, see that dilapidated ones were repaired, and ensure the completion of any unfinished constructions. ${ }^{152}$

Roman governors had the discretionary power to interfere deeply in municipal administration, but in practice their ability to do so was constrained by time and the personnel at their disposal. The paucity of officials sent out by the imperial government led Peter Garnsey and Richard Saller to describe Roman administration

147 E.g., Pliny Epistulae (Plin. Ep.) 10. 17, 23.

148 E.g., Aelius Aristides Orationes (Aristid. Or.) 50; Eck 2000a, 277.

149 G. P. Burton 2004.

150 G. P. Burton 2004, 336-341.

151 Gleason 2006.

152 Dig. 1. 16. 7. 
as "government without bureaucracy." 153 This fits well with a model of the Roman emperor acting primarily in reaction to situations as they arose. ${ }^{154}$ That notion, however, is being challenged. This stems partly from a greater understanding of Roman administration, and partly from seeing cities and their rulers as integral parts of imperial administration rather than simply its subjects. ${ }^{155}$ The second-century orator Aelius Aristides once told the emperor, "There is no need of garrisons holding acropolises, but the most important and powerful people in each place guard their countries for you." 156 Although delivering a panegyric on the greatness of Rome and therefore downplaying the coercive aspect of Roman rule, his emphasis on the importance of local collaborators is justified.

\section{III.3 Infrastructure}

\section{II.3.1 Roads, Traffic, and Communication}

Monumental works of infrastructural engineering are rightly seen as characteristic of the Roman Empire. Roman roads in particular are renowned for their durability and extensive reach. ${ }^{157}$ It has been estimated that the total length of the network approached 100,000 $\mathrm{km}$ and included more than 1,000 bridges (map 2). ${ }^{158}$ The effect of these roads was to make the overland transportation of large quantities of people and cargo over long distances easier than ever before. Strabo likens Roman roads to rivers, saying, "they have constructed roads through the countryside by adding both cuts through hills and embankments over valleys so that wagons carry as much as a boat." 159 The deep, solid foundations supporting road beds, paved with stone in and around cities but with gravel for most of their length through the countryside, allowed for the overland transport of cargoes that would otherwise require a waterway.

Roads also acted as navigational aids. Hadrian, in an edict that establishes limits on the obligations of cities to provide services for official travelers, says, "No one

153 Garnsey and Saller 2014, 35-55. See also G. P. Burton 2004, 312-317.

154 Millar 1977.

155 Eck 1995-1998; summarized in Eck 2000a; 2000b. See Noreña 2010 on the role of cities in the empire and Ando 2017 on how municipal institutions helped expand Roman infrastructural power. 156 Arist. Or. 26. 64, trans. Behr.

157 Staccioli 2003 provides an accessible overview and references to foundational works. Laurence 1999; Rathmann 2003 treat the roads of Italy and the western provinces respectively. Quilici 2008 treats technological aspects. For Republican period road construction, see Laurence 2013. For the organization of road construction and maintenance in the Principate, see Kissel 2002; Rathmann 2014. For the economic impact of roads, see Hitchner 2012. Purcell 1990; Talbert 2012 investigate roads in the context of imperial power. For bridges, see O’Connor 1993.

158 Kissel 2002, 127.

159 Strabo 5. 3. 8, trans. Talbert. 
shall have the right to take a guide since soldiers do not need to leave the public roads, and since they do not leave they have no need for anyone to show the way. In case the roads become invisible because of a heavy snowfall, only then shall it be allowed to take a guide." 160 The road was a visual signal of the route the soldiers were supposed to be following, which obviated the need for local knowledge. In this way, roads were also useful for non-wheeled traffic, for which the solidity of the roadbed was less important. Milestones giving distances to the nearest cities enhanced their navigational value. In addition to cargo, roads conveyed information that fostered greater connectivity.

For the state, roads served two primary purposes: the movement of armies and their supplies, and rapid communication of information. Large military campaigns often required the improvement of existing routes, or less often, the construction of entirely new ones. ${ }^{161}$ The very first major Roman road, the Via Appia running south from Rome to Campania and across the peninsula to Brundisium, was built in the fourth century BCE to facilitate campaigns in southern Italy. The Via Egnatia, built in the second century BCE to support campaigns in Macedonia, extended the Via Appia beyond Italy, stretching from Dyrrachium to Byzantium. Over time, the network grew, building on preexisting routes wherever possible. ${ }^{162}$ The existence of a well-established road network allowed emperors to move armies around the empire quickly, efficiently, and predictably. Alexander Severus, in the early third century CE, could plan troop movements well in advance, declaring where his army would be on each day so that the cities along the route could have supplies ready. ${ }^{163}$

Not all roads were built specifically for military purposes. The Via Nova Traiana, an early second-century road connecting major cities in the newly incorporated province of Arabia with the Red Sea, was lavishly paved and heavily marked with milestones, suggesting that it served to announce Roman rule. The road would also have served an economic purpose by facilitating imports from the Arabian Peninsula. ${ }^{164}$ The Via Nova Hadriana, in Egypt's Eastern Desert, served primarily an administrative function, facilitating official communication between the Red Sea ports and Hadrian's newly founded city of Antinoopolis. ${ }^{165}$

The rapid communication of information was made possible by the cursus publicus, an institution meant to ensure the swift travel of government agents. ${ }^{166}$ It consisted of a series of inns and stables along with obligations imposed on the people

160 Hauken and Malay 2009.

161 For the construction of roads in preparation for campaigns in the eastern part of the empire, see Kissel 1995, 54-67.

162 Rathmann 2014 argues that emperors used existing infrastructure as much as possible.

163 Scriptores Historiae Augustae, Alexander Severus 45. 2.

164 Speidel 2019.

165 Sidebotham, Hense and Nouwens 2008, 40-41.

166 The best modern account for the early Principate is Kolb 2000, summarized in Kolb 2001. For the third and fourth century, see Lemcke 2016. 
living nearby to supply government agents with vehicles, animals, and services. The system is relatively well attested because the travelers would often abuse their position to demand more from the locals than they were entitled to. The locals would appeal to the emperor or governor for assistance, and he would respond with an edict laying out which travelers were entitled to which services. While lodgings were provided free of charge to travelers on official business, the inns built for this purpose were also available to private people for a fee. Having a safe place to stay for the night significantly lowered the risk, and therefore the cost, of long-distance journeys.

The method of organizing labor that made the cursus publicus possible, in which the imperial government compelled and coordinated the cooperation of local people through local political structures, is typical of the Roman approach to infrastructure construction in general. Roads were generally built and maintained through the labor and funding of local municipalities on the command of the emperor or a governor. ${ }^{167}$ Soldiers represented a labor force that could be used when civilian labor was lacking or when their general felt the need to instill discipline. ${ }^{168}$ The general Corbulo had his men dig a canal connecting the Rhine and the Meuse Rivers both to bypass the dangerous ocean and to keep his men busy. ${ }^{169}$ It was more common for the army to provide supervision or technical expertise. ${ }^{170}$ In the second century, the city of Saldae in North Africa required both. A tunneling project to bring water to the city had failed, so they requested the general of the legion in the area to send Nonius Datus, a surveyor, to plan and supervise the work. He completed the project using soldiers from the fleet and the auxilia. ${ }^{171}$

Other large infrastructure projects were similarly organized. An exchange of letters between Emperor Trajan and Pliny, the governor of Bithynia in Asia Minor, illustrates the process. Pliny tells Trajan about a trade route within the territory of Nikomedia that involves a lake, across which goods are brought cheaply and easily, and a road to the sea, along which transportation is more expensive. He says that the Nikomedians want to connect the lake to the sea, and assures Trajan that there are enough people in the area to provide the labor and that they will eagerly participate because the project will be profitable. He only asks Trajan to send a surveyor or architect to determine the elevation of the lake. Interestingly, to sell Trajan on the idea, Pliny appeals not to the economic benefits, but to Trajan's greatness, magnanimity, and competitive spirit: An earlier king of Bithynia started a canal but could not finish it, giving Trajan a chance to demonstrate his superiority. Trajan

167 Kissel 2002; Rathmann 2014, 211-212.

168 Phang 2008, 201-247. For the social valorization of different types of work done by soldiers, see Phang 2005.

169 Tac. Ann. 11. 20.

170 See Pollard 2000, 242-47 for the application of military labor and specialist skills in Syria. For military specialists in general, see Speidel 2009, 439-450.

171 CIL VIII 2728 = ILS 5795 = Campbell 1994, no. 204. 
responds positively and tells him to write to the governor of Moesia Inferior, the nearest province with a large military presence, for a surveyor. ${ }^{172}$

Emperors showed similar enthusiasm for the construction of harbors, which were considered great works that reflected the care and generosity of the emperor. ${ }^{173}$ The invention of concrete that would set in water using pozzolana, volcanic ash from Puteoli, made it possible to build large harbors in places without favorable natural features. ${ }^{174}$ While Portus, the main harbor of the imperial capital, represents the largest application of this technology, it is also found in harbors much farther away from its source. Most notably, it was used in the port of Caesarea Maritima (modern Israel), built by the Jewish king Herodes in honor of his patron, Augustus. It has been suggested that the pozzolana acted as ballast for grain ships returning from Puteoli - where they had offloaded the grain needed to feed the city of Rome to Alexandria. ${ }^{175}$ Because of the harbor, Caesarea Maritima became an important commercial center in the Eastern Mediterranean. As with the Nikomedian canal, economics and ideology are closely entwined. Herodes's need to honor his patron and Augustus's need to honor and support the populace of Rome, combined with the technological innovation of hydraulic concrete, produced a work of monumental infrastructure with long-lasting and far-reaching economic consequences.

Roman infrastructure was always an important part of imperial power and honor. It not only demonstrated the might of imperial Rome, it also demonstrated the care of the emperor for his subjects. ${ }^{176}$ The subjects, in turn, could appeal to the emperor for assistance in improving their local infrastructure. With the possible exception of infrastructure used exclusively by the army, most of the major infrastructural projects that are associated with the empire were a collaboration - voluntary or otherwise - between central and local agents. The economic benefits of these projects were sometimes recognized, as in the case of the Pliny's lake project in Nikomedia, but they were seen as part of the package of wider social benefits that the emperor could bestow on his subjects in order to enhance his own honor and the honor of Rome. Regardless of motivation, the infrastructural investments made by the Roman Empire served to dramatically increase the economic integration of the Roman world both overland and at sea.

172 Plin. Ep. 10. 41-42, 61-62.

173 See Arnaud 2014 for the role of the emperor in harbor building as compared to cities and private individuals.

174 Blackman 2008 provides a technological introduction to harbors in the ancient world. Brandon et al. (2014) have analyzed hydraulic concrete from numerous sites, while Keay has led a survey of Portus (Keay et al. 2005, Keay and Paroli 2011). De Graauw has compiled an extensive database of ancient harbors (http://www.ancientportsantiques.com/ accessed May 28, 2018). See also the edited volumes, Keay 2012; Höghammar, Alroth and Lindhagen 2016.

175 Wilson, Schörle, and Rice 2012. Portus had not yet been built and the older harbor at Ostia was too small.

176 See Noreña 2011, 37-177 for the ethical profile of the Roman emperor. 


\section{III.3.2 Standardization}

In addition to physical infrastructure, standardized systems of law, measurement, and currency are often cited as factors promoting the integration of the Roman Empire. However, as with the law, Roman imperial officials maintained standards of measurement and currency, but did not seek to impose a universal system throughout the empire in the early imperial period. The spread of Roman institutions that used Roman standards made them common in many areas, but there was never any attempt to suppress the use of old, local systems. ${ }^{177}$

The writings of the Roman land surveyors reveal some tension in the relationship between local and imperial systems. On the one hand, the imperial standard iugerum (an areal unit of measurement) was consistent and trusted by the surveyors themselves: "if there was a dispute whether a versus [a Dalmatian unit of measurement] had 8,640 feet, confidence could nevertheless be placed in the iugera." On the other hand, locals often had more faith in their own units: "Each region follows its own practice so that a trustworthy method can be agreed upon." 178 The land surveyors were often involved in boundary disputes, so maintaining the confidence of local people in the integrity of their work was important, but it was also important that they themselves had faith in their measurements, especially when engaged in infrastructural projects. Thus, they used the imperial system for their own purposes and local systems for others.

The same acceptance of diversity can be observed in coinage. ${ }^{179}$ The Roman monetary system was based on the standard silver denarius. In the western half of the empire, Roman coins issued by imperial mints were the only form of currency from the mid-first century CE. ${ }^{180}$ In the eastern half, several different silver coinages circulated on a regional scale alongside the denarius. ${ }^{181}$ Under the Republic, these regional silver issues resembled older royal coins in appearance but were minted under the auspices of the imperial state. Under the monarchy, the emperor's portrait was combined with the traditional iconography. ${ }^{182}$ The face values of these coins were tied to the denarius, as were their weights, but the denominations of the coins

177 For the lack of standardization of Roman measures, see Cuomo 2007; Riggsby forthcoming, 124-197.

178 Hyginus 1 De condicionibus agrorum 88. 25-26 and Hyginus 1 De generibus controversiarum 92. 24-25, trans. Campbell, quoted in Cuomo 2007.

179 The series Roman Provincial Coinage, beginning with Burnett, Amandry, and Ripollès 1992, provides an authoritative account of coins minted in the Roman provinces. For briefer introductions to the imperial and provincial coinages of the Roman Empire, see contributions in Metcalf 2012. 180 For the rapid disappearance of local currencies in the West, see Burnett, Amandry, and Ripollès $1992,18-19$.

181 Harl 1996, 97-124; Butcher 2012 for the Levant; Geissen 2012 for Egypt.

182 Burnett, Amandry, and Ripollès 1992, 6-9. 
were Greek. ${ }^{183}$ The most commonly produced coin was the tetradrachm, worth four denarii in most places. ${ }^{184}$ In contrast to the denarius, which was essentially pure silver until the reform of Nero in the 60s CE, provincial coins were made of alloyed silver, so their intrinsic value was lower than the denarius. Nero's reform might even have been an attempt to bring the intrinsic value of the denarius and the provincial coinages into closer alignment. ${ }^{185}$ Whether or not these coins were legal tender beyond the region for which they were produced is unclear. It has long been accepted that Egypt had its own self-contained system, but it is possible that the other provincial silver issues were also viewed as foreign currency outside their region. ${ }^{186} \mathrm{Re}$ gional silver coins continued to be produced until the third century CE, at which point the denarius system itself was undergoing substantial transformation. ${ }^{187}$

At Antiocheia in Syria, the imperial government minted a bronze coin that also circulated regionally, but most base metal coinage was minted and used at a local level. ${ }^{188}$ These were produced primarily by individual cities, sometimes paid for by local aristocrats as a public benefaction, and served not only as a form of exchange, but to increase the prestige of the community. ${ }^{189}$ While the cities likely required permission from the emperor or the governor to mint their own coins, the weights and sizes of the coins varied widely from place to place and even between issues. ${ }^{190}$ This suggests the imperial government did not dictate the details of their production. The standard unit of account was the Greek drachm, and it was not until the mid-second century CE that cities started using a unit based on Roman coinage; it took until the third century for this to replace the drachm. ${ }^{191}$ In addition, pre-Roman bronzes often continued to circulate long after conquest. ${ }^{192}$

Thus, in the eastern part of the empire, multiple coinages circulated simultaneously at different geographical scales. Roman precious metal coins were privileged in having a wider circulation and because most imperial taxes were calculated and paid in denarii, but Roman coins never monopolized monetary exchange as they did in the West. ${ }^{193}$ Most transactions were small-scale and would have used locally produced base metal coinage. While higher value provincial coinages were closely

183 Burnett, Amandry, and Ripollès 1992, 26; Butcher and Ponting 2014, 665-686; Harl 1996, 98106; Katsari 2011, 72-74.

184 An Egyptian tetradrachm was worth only one denarius, and a cistophoric tetradrachm from Asia Minor was worth three.

185 Butcher and Ponting 2014, 201-238.

186 Burnett 2005. For Egyptian coinage, see Butcher and Ponting 2014, 606-664; Geissen 2012.

187 Harl 1996, 125-157.

188 See Butcher 2012, 470 for imperial bronzes.

189 Burnett, Amandry, and Ripollès 1992, 3-4, 16-17; Johnston 2012; Rowan 2019, 184-188.

190 For the necessity of imperial permission, see Burnett, Amandry, and Ripollès 1992, 1-5. For the variability of weights and sizes, see Butcher 2012, 474.

191 Yarrow 2012.

192 Rowan 2019, 184-187.

193 See von Reden 2010, 89 for the calculation of taxes in denarii. 
related to denarii in weight and value, they are distinguishable by their iconography, intrinsic value, and their use of Greek denominations. Like the land surveyors, the rulers of the empire seem to have been content to use multiple units of measurement, whether of monetary value or physical parameters, so long as it was possible to convert between Roman and local units. For their own purposes, they preferred Roman standards, but they were also happy to accommodate the standards in which their subjects already had faith.

As with conversion rates between coinages, the provincial census was the mechanism that made its subjects legible to the Roman state and available for exploitation. ${ }^{194}$ While its roots can be found in the Republican census, the provincial census as it existed during the Principate was an innovation of Augustus. In Republican Rome, a censor was elected every five years to conduct a census. All citizens were required to present themselves to the censors or their representatives to declare themselves, their household, and their property. This information allowed the state to rank its citizens into wealth-based classes that formed the basis for voting, determining eligibility for office, the conscription of soldiers, and the payment of taxes. The process required the physical presence of every citizen in Rome, a requirement that became harder and harder to fulfill as Roman citizens spread throughout Italy and then overseas. The regular Republican census seems to have broken down in the second and first centuries BCE. Partial censuses were conducted by Julius Caesar, and there was an attempt to bring the local censuses of Italian cities into synchrony with the Roman census. ${ }^{195}$

Augustus was the first to mandate censuses of noncitizens. The most famous evidence comes from the Gospel of Luke, where the birth of Jesus coincides with a decree of Augustus that the entire world should be registered. ${ }^{196}$ While there is evidence for numerous censuses throughout the different provinces, there is none for a simultaneous census of the entire empire. Nevertheless, the impression that $\mathrm{Au}$ gustus sought a complete record of the inhabitants of the empire may not have been incorrect. ${ }^{197}$ In addition to Syria (which included Judaea at the time), we have direct evidence that censuses were conducted under Augustus in Egypt, ${ }^{198} \mathrm{Gaul}$, and probably in Spain. ${ }^{199}$ Augustus also introduced the practice of registering births and deaths. ${ }^{200}$ In order to extract taxes, the central state needed to know the number of

194 Ando 2000, 350-360; 2017, 140-142; Brunt 1990, 329-335; Lo Cascio 1999; Nicolet 1991, 123147.

195 Nicolet 1991, 131-132. The synchronicity of censuses, if it was ever achieved, did not last long.

196 Luke 2. 1.

197 Nicolet 1991, 134-137.

198 Claytor and Bagnall 2015.

199 Cassius Dio 53. 22. 5; Livy Epitome 134.

200 Nicolet 1991, 132-133. In the city of Rome, deaths were systematically recorded under Julius Caesar. 
inhabitants and the value of the property in each city, and Augustus systematized the process of acquiring this information.

The census, then, was closely tied to Roman taxation and, more generally, Roman domination. Rebellions tended to take place during the organization of new territories into Roman administrative units, and those described as responses to taxation might have been sparked by a census. ${ }^{201}$ For the process of taking the census was burdensome and invasive. The emperor Claudius commended the Gauls for their docility in undergoing what even Romans found onerous. ${ }^{202}$ The early third-century jurist Ulpian describes the kind of information people were expected to provide: in addition to their name and age, they must describe their property, locating their land in Roman administrative space and specifying the area that was dedicated to different types of cultivation and the number of vines and olive trees. Those whose permanent crops had died could claim exemption, but if they had been cut down, the owner would have to justify this action to the census taker. The nationalities, ages, jobs, and skills of all slaves were also recorded, as was the number of tenants. ${ }^{203}$ This level of detail might not have been universal in early censuses, but some form of declaration of property clearly was. This, in turn, defined a person's status in the eyes of the central power. The wealthy would be liable to serve in municipal government and shoulder the attendant financial burdens. Beyond the material consequences, the census forced people to think of themselves and their property in Roman terms. It also required them to adopt record-keeping practices that would be intelligible and authoritative to Roman officials or risk overassessment. The census not only made the persons and property of provincials available for Roman exploitation, it forced those provincials to adopt, at least partially, certain Roman conceptions and habits.

\section{Imperial Society}

The creation and maintenance of Roman political power depended on the structures of both Roman and subject societies. The fact of Roman conquest and rule also transformed these societies, ultimately creating a new, complex, and diverse imperial society that integrated, to a greater or lesser extent and in different ways, millions of people scattered from Britain to Arabia and from Mesopotamia to North Africa. Here, I will discuss two aspects that contributed to the integration of that society: the social networks that spanned it, and the identities through which people understood and negotiated their own place within it.

201 Dyson 1971; 1975.

202 ILS, 212, col. 2, ll. 38-40.

203 Dig. 50. 15. 4. 


\section{IV.1 Networks}

Social networks in the ancient Mediterranean were formed around a variety of different criteria including religion, occupation, place of origin, family, and ties of patronage and friendship. ${ }^{204}$ While some of these networks were organized into corporate bodies, called collegia in Latin, most were not. ${ }^{205}$ While such networks predate the Roman Empire, Roman conquest reshaped them, created new ones, and facilitated the extension of some over great distances. These networks, in turn, bound people to each other and often to the empire in a wide variety of relationships. While all networks were polyvalent, patron-client networks were particularly important to the political integration of the empire, while those based on common origin, occupation, or familial ties had significant economic implications.

\section{IV.1.1 Patron-Client Networks}

Patronage and friendship played an important role in forging both horizontal and vertical links in Roman society. ${ }^{206}$ Both were long-term, social relationships between unrelated parties based on the reciprocal exchange of goods and favors. ${ }^{207}$ Patronage is distinguished from friendship by asymmetry in the status of parties involved, but it is sometimes difficult to differentiate between the two among elites whose precise social positions were constantly under negotiation. Since the term cliens ('client') indicated social inferiority, aristocrats almost never used it to describe each other, preferring the term amicus ('friend'), even when their actions and statuses indicate a patron-client relationship. The ambiguity between patronage and friendship declined with greater social distance between the two parties, but because both relationships were based on an ethic of reciprocity and because the boundary between the two was intentionally obfuscated by the parties involved, a sharp distinction is impossible. Both created long-term relationships that could span great distances and cross ethnic, political, and social boundaries in which each party was morally obligated to support, protect, and honor the other.

204 Introductions to network approaches to ancient Mediterranean history can be found in Malkin 2011 and Malkin, Constantakopoulou, and Panagopoulou 2009, while Collar et al. 2015 review network approaches in archaeology.

205 For collegia, see Perry 2011.

206 Ganter 2015 provides a recent, detailed analysis of Roman patronage. For introductions with guides to further reading, see Deniaux 2006 on the Republican period, and Garnsey and Saller 2014, 173-184 on the Principate. For changes between the Republican and monarchical period, see Winterling 2009, 34-57 and Garnsey 2010. For the economic aspects of patronage and friendship, see Verboven 2002.

207 For the entanglement of affection and reciprocal exchange in Roman friendship, see Verboven 2011. 
By maintaining patronage ties with powerful Romans, local elites could both enhance their standing relative to their neighbors and gain access to the centers of power at Rome. The example of Sextus Roscius, known to us because of Cicero's speech in defense of his son who was accused of parricide, illustrates these relationships and their impact:

Sextus Roscius ... was a citizen of Ameria, by far the first man not only of his municipality, but also of his neighborhood, in birth, and nobility and wealth, and also of great influence, from the affection and the ties of hospitality by which he was connected with the most noble men of Rome. For he had not only connections of hospitality with the Metelli, the Servillii, and the Scipios, but he had also actual acquaintance and intimacy with them ... And of all his property he has left this alone to his son. ${ }^{208}$

Roscius's ties to leading Roman families took the form of both friendship and hospitality, the mutual obligation to host and protect each other while traveling. These relationships not only enhanced his standing locally, they provided protection to his son, who was being accused of Roscius's murder as part of a plot by the dictator Sulla's freedman to seize his estate. Defense before the law was one of the most important services patrons performed for their clients. While the political climate at the time made it dangerous for his patrons to defend the younger Roscius themselves, they arranged for the young Cicero to take on the task. Through inherited personal relationships with the upper echelon of the Roman aristocracy, the younger Roscius secured legal representation and was ultimately acquitted. Thus, the patronage of Romans could protect locals against predation by other Romans. ${ }^{209}$

Patronage also provided the means by which individuals could enter and advance within the Roman aristocracy. Roman military commanders and governors would distribute positions on their staff, which provided opportunities for enrichment and advancement, as favors to their clients or to the clients of others. In the latter case, they were performing a service both for the man who obtained the post and for the one who recommended him for it. In the absence of formalized, impersonal mechanisms for determining competence, positions within the imperial bureaucracy were filled entirely through personal relationships, which as we have just seen, extended beyond Rome into local aristocracies.

An aristocrat's ability to secure positions and favors for others, sometimes through his own competence but much more frequently through his connection to the one making the decision, attracted clients and enhanced his status. In the Republic, posts and other favors were controlled by magistrates or ex-magistrates in the Senate, but under the Principate, the emperor was the ultimate source of these favors. Thus, proximity to the emperor became a source of power and status. Pliny's letter to the emperor Trajan requesting citizenship for a doctor and two freedwomen

208 Cicero Pro Sexto Roscio Amerino 15, trans. Yonge.

209 Deniaux 2006. 
demonstrates how the webs of patronage linked Rome to Bithynia on the Black Sea coast. ${ }^{210}$ Of the doctor, who had cured him, Pliny says, "I can only adequately repay him for the pains and interest he took in my case if you are kind enough to help me. Let me, therefore, entreat you to bestow on him the Roman citizenship." Pliny owes a debt to the doctor for healing him, which he repays by incurring a debt to Trajan. For the bestowal of citizenship, the doctor owes debts to both Pliny and Trajan (unlike financial debts, debts of gratitude are never fully repaid). In the same letter, Pliny requests citizenship for the freedwomen of a distinguished woman who had requested the favor from him, adding yet another link to the chain of patronage. Given the social gulf between Pliny and Trajan, Pliny's ever-accumulating debts could only be repaid through loyal service, public expressions of gratitude, and praise for his patron.

Similar ties of patronage could bind whole communities to powerful Romans. ${ }^{211}$ Civic patronage of Greek cities seems to have begun in the late second century BCE and disappeared gradually in the first century $\mathrm{CE}$, while in the West it continued longer. ${ }^{212}$ Cicero, among others, says that Roman conquerors in the past became patrons of the communities they subjugated, but the historicity of this is debated. ${ }^{213}$ It was more common for cities to request the patronage of a certain person through an official decree and embassy. If the embassy was successful, the city would erect a public inscription attesting to the relationship. As with individuals, patrons would advocate on behalf of their client communities at Rome, offering protection against Roman officials and supporting them in local disputes. In return, communities would honor their patrons, usually with a statue, and provide material support that advanced their patrons' careers. ${ }^{214}$ So, for example, a first-century BCE inscription from the Greek city of Oropos honors three senators as patrons who, it has been argued, intervened on behalf of a local sanctuary in a dispute with Roman publicani about taxation. ${ }^{215}$ The relationship could easily turn extortionate. Verres (a notoriously corrupt governor of Sicily whose crimes we know in detail thanks to two preserved prosecutorial speeches of Cicero) compelled cities to contribute so much money for honorary statues that they petitioned the Senate to be forbidden from erecting statues to any magistrate who was still in the province. ${ }^{216}$ During the Principate, when aristocratic careers depended more on the favor of the emperor, civic

210 Plin. Ep. 10. 5.

211 Canali de Rossi 2001; Eilers 2002; Nicols 2014.

212 For the beginnings of civic patronage, see Eilers 2002, 109-160. There is some debate about whether the decline was caused by a shift in the political economy of the Principate (Eilers 2002, 161-190) or by legal restrictions (Nicols 2014, 207-237).

213 Cicero De Officiis 1. 35; Deniaux 2006, 405; Eilers 2002, 38-60.

214 Deniaux 2006; Nicols 2014, 21-81.

215 Deniaux 2006, 410; Canali de Rossi 2001, 65-66, 140-141.

216 Cic. Verr. 2. 2. 145-146. For a discussion of civic patronage in these speeches, see Nicols 2014, 163-205. 
patronage offered less material benefit to the patrons, but remained a marker of status. The patrons were increasingly local elites who served their clients through public works, among which monumental building projects are the most visible. ${ }^{217}$ As with patronage of individuals, civic patronage provided access to the centers of power at Rome, but the relationship was unquestionably lopsided. Every time a city appealed for relief from an abusive official, it simultaneously reaffirmed Roman supremacy.

\section{IV.1.2 Trade Networks and Negotiatores}

In the ancient Mediterranean, there is a long history of cities establishing distant settlements of merchants who formed social ties within their host communities while maintaining ties to their places of origin. These settlements helped establish trust between local and foreign merchants. ${ }^{218}$ While long-distance connectivity was a feature of the ancient Mediterranean, the rise of Roman power reshaped these networks by establishing new important nodes and by facilitating the extension of Italian networks.

As mentioned above, Italians abroad in a private capacity fell into two overlapping groups during the Republican period: publicani and negotiatores. ${ }^{219}$ The former collected taxes and exploited state-owned resources, while the latter had no official ties to the state. They were private individuals who had gone abroad in search of profit. ${ }^{220}$ They engaged in a variety of business practices, but they are most commonly associated with trade. Cicero famously claimed that no business was transacted in the province of Transalpine Gaul without the involvement of Italian businessmen. ${ }^{221}$ Negotiatores appear in the epigraphic record as either 'Romans' or 'Italians' (terms that are generally assumed to be interchangeable outside Italy) who were either 'doing business in' or 'inhabiting' an area. ${ }^{222}$ Sometimes the specific business is mentioned, but not always.

While many Mediterranean cities had far-flung trade networks, the power of Rome set Italian traders apart. In contrast to other merchant communities, Italian negotiatores did not specify their city of origin in inscriptions. ${ }^{223}$ Adopting an Italian identity, which had no relevance prior to Rome's conquest and unification of the

217 Nicols 2014, 104-115.

218 Terpstra 2013, esp. 70-84 for the illustrative example of a Tyrian merchant settlement in Puteoli.

219 Purcell 2005 provides a good introduction with references to further reading. Brunt 1987, 204233 attempts a quantitative estimate of the number of Italians outside Italy in the Republican period.

220 For a diachronic analysis of the meaning of the term negotiator, see Eberle 2017, 324-343.

221 Cicero Pro Fonteio 11. Cicero uses the phrase "Roman citizens" for rhetorical purposes, but at the time of the speech, Roman citizenship had been extended to all Italians (see below).

222 See Eberle 2017, 331-43 for the precise meanings of the Latin and Greek terminology.

223 Terpstra 2013, 213-214. 
peninsula, might have been advantageous when interacting with Roman magistrates. ${ }^{224}$ How a city treated its resident Roman citizens could affect its relationship to the imperial center. Cicero, while exaggerating, clearly expresses the ideal when he claims that Romans abroad rely on their citizenship for defense, not only before Roman magistrates and among other Romans, but anywhere they travel. ${ }^{225}$ This association could cut both ways. When, in 88 BCE, Mithridates sought to sever the ties between cities in Asia Minor and Rome, he ordered them to massacre all of the Italian inhabitants. ${ }^{226}$ In the aftermath, public acts of favor toward Roman citizens, providing them with feasts, for example, became even more potent statements of loyalty. ${ }^{227}$ Compared to other merchant groups, organizations of Roman traders were more active in the local politics of their host communities. ${ }^{228}$ They can be found honoring patrons in public inscriptions both on their own and with other civic groups. ${ }^{229}$ This prominence was a result of their wealth, informal power that came from association with the hegemonic power of Rome, and presumably some personal connections with powerful Romans, but there is no evidence for official support from the Roman government. ${ }^{230}$

Although they were associated with Rome, negotiatores were not bound by the limits of Roman political or military power. Caesar, describing his conquest of Gaul, mentions them frequently. ${ }^{231} \mathrm{~A}$ distinguishing feature of the northernmost part of Gaul is that merchants visit it less frequently than the parts nearer to the province of Transalpine Gaul. ${ }^{232}$ In one of the very rare instances in which military action was justified by economic concerns, he says that he ordered the conquest of certain groups in the Alps to open the passes through which merchants were accustomed to travel "with great danger and with great tolls." 233 Roman trade networks, then, exceeded the limits of Roman military and political power. They could facilitate military expansion either by providing a reason for war or, probably more commonly, by providing intelligence, ${ }^{234}$ but the activity of Italian negotiatores was important

224 Eberle 2017, 336-338. See below, sec. IV.2.2, for the 'Italian' identity.

225 Cic. Verr. 2. 5. 167.

226 Writing in the second century CE, Appian (Mithridateios 22-23) emphasized hatred for the Italians as motivating the massacre. Terpstra (2013, 215-217) suggests that visiting Roman officials and publicani, rather than negotiatores, were responsible for inciting this hatred, but Kallet-Marx (1995, 155-157) argues that the massacre had as much to do with political alliances as with hatred of Italians.

227 Purcell 2005, 86-89.

228 Terpstra 2013, 214-215.

229 Purcell 2005, 92-94.

230 Terpstra 2013, 207-219.

231 See Brunt 1987, 211 n. 5 for references.

232 Caesar Bellum Gallicum (Caes. BGall.) 1. 1.

233 Caes. BGall. 3. 1.

234 For example, Tacitus argues that Agricola could have conquered Ireland in the late first century CE because its geography was known "through commerce and negotiatores" (Tac. Agr. 24). 
in its own right. Insofar as they extracted resources or generated wealth abroad and transferred it back to Italy, they were practicing "imperialism by other means," extending Rome's economic empire beyond the limits of its politico-military empire. ${ }^{235}$ They also must have contributed to changing cultures of economic exchange and the monetization of parts of Europe, though their precise role in this process is still unclear. ${ }^{236}$

In the Republican period, negotiatores were expected to return to Italy, even if they might stay abroad for an extended period of time. They were conceived of as Roman citizens who had business abroad, but a periodic presence in Italy for things like census declarations was important in constituting the Roman political community. ${ }^{237}$ This changed under Augustus. He established alternative ways of performing one's membership in the Roman polity that could take place in the provinces. He also forced citizens to participate more fully in their local communities. Where Republican officials had seen Roman citizens with business in the provinces and labeled them negotiatores, Augustus created a category that was simply Roman citizens in the provinces and the meaning of negotiatores lost its connection to Italians. ${ }^{238}$ In addition to this terminological shift, cities could now declare their loyalty by honoring Augustus and his household rather than resident Romans, ${ }^{239}$ so the Italian diaspora becomes significantly less visible in the epigraphic record. The change is not just evidentiary, however. Cyclical migration for the purpose of business surely continued, but Julius Caesar and Augustus established numerous colonies that permanently transferred Italians into the provinces. We know of approximately 100 such colonies founded in the second half of the first century BCE, representing perhaps 200,000 to 300,000 colonists in total. ${ }^{240}$ These people probably had social ties that connected them to Italy in the early period, but as time went on, they would have become attenuated. While some of these colonies became important trading centers and Italian businessmen might have settled in them, many must have been more agrarian. Unlike Republican period negotiatores, we should not assume that an old Roman colony was necessarily still part of an Italian social network in the Principate.

Under the monarchy, other networks become more prominent in our evidence. Some, like the ones discussed above that supplied the army, resulted directly from state intervention. The networks of merchants, ship owners, and captains who brought grain to the city of Rome were unusual, both in the size of the market they served and in the interest the government took in their activities. Nevertheless, they established regular, secure links spanning the Mediterranean across which many

235 Eberle 2017, 348.

236 Howgego 2013, 38-44.

237 Eberle 2017, 345-349.

238 Eberle 2017, 343-349, 355-365.

239 Purcell 2005, 87.

240 Brunt 1987, 234-265. 
things other than grain traveled. ${ }^{241}$ Other networks arose indirectly from the activities of the imperial government. Negotiatores, a term no longer associated with Italian origin, are particularly prominent in the northwestern provinces, where they often have ties to the army. ${ }^{242}$ One tombstone illustrates the geographic spread of these networks. ${ }^{243}$ It was erected by a legionary veteran to commemorate his brother, a negotiator purpurarius, a dealer in purple dye who was, therefore, not engaged in military supply. Between the findspot of the inscription, the headquarters of the legion, the place of origin of the deceased, and his place of business, this single inscription attests to a network that spanned most of Gaul. Soldiers and veterans traveled even greater distances upon enlistment, retirement, and sometimes in the course of their careers, maintaining distant relationships and forging new ones. ${ }^{244}$ Some married women from their home communities who traveled to be with their husbands, while others married local women or the female relatives of fellow soldiers. ${ }^{245}$ The army, therefore, served as a vector for population movement and the extension of private social networks over long distances.

\section{IV.1.3 Family Networks}

Social networks based on familial ties are visible to us because of Roman naming practices. Unlike Greek names, which, at best, associate an individual with a parent, Roman names also indicate the patrilineal family group to which an individual belonged. Furthermore, Roman families consisted not only of the kin group, but also included slaves and freedmen (former slaves who had a particular kind of patronclient relationship with their former master). Under Roman law, not only slaves but sons and daughters as well were dependents of the head of the household (the paterfamilias), who was the owner of all of the household's property. He, however, could mandate that his dependents carry out business on his behalf, giving them the use of money or property for this purpose. ${ }^{246}$ Because of the social ties that existed between them and the legal obligations that went with familial relationships - particularly those between master and slave - family members were very commonly used as agents in large-scale business enterprises. ${ }^{247}$

241 For the Roman grain supply, see Erdkamp 2005, 206-257; Kessler and Temin 2007. For the broader implications of this trade, see Lewit 2011; Reynolds 2018; Tchernia 2016, 97-114.

242 Verboven 2007.

$243 A E$ 1982, 709, cited by Verboven (2007, 304).

244 Alston 1999.

245 Greene 2015.

246 Bang 2008, 276-280 provides a convenient overview with references to the relevant laws.

247 Terpstra $(2013,54-56)$ argues that the use of dependents did not solve the problem of enforcement inherent in agency relationships. This, however, ignores the fact that the paterfamilias had at his disposal various means through which to coerce the cooperation of his dependents that could not be applied to other agents. 
By collecting epigraphic and literary attestations of members of a single family, it is sometimes possible to gain a sense of their business practices. So, for example, members of the Annius family, based in Puteoli, appear in Athens, Delos, and Pergamon in the late second and early first centuries BCE. In the beginning of the first century CE, the slave of a later Annius left graffiti in Egypt's Eastern Desert on a major trade route, and Pliny the Elder, writing in the mid-first century CE, says that an Annius had been responsible for collecting the import tax on goods coming into the empire through the Red Sea. He also tells the story of an Annian freedman who was blown off course while sailing around Arabia and ended up in Sri Lanka. Around the same time, the president of the collegium of the perfumers in Rome was an Annius. Annii continue to appear into the second century CE in Rome and Campania, often associated with eastern trade. ${ }^{248}$ The Annii, then, constituted a family network with members who moved from Italy to the Eastern Mediterranean, Egypt, and beyond. For each member that we know about, we must imagine many more whose names are lost, and each individual, in the course of doing business, must have formed relationships with people outside of the family. Based on the previous discussion of merchant communities, it seems likely that some members of the family resided in distant ports for extended periods to maintain local relationships. The Annius family thus constituted the core of a much larger network that spanned vast distances and lasted for centuries. Of course, the Annii were only one among many other similar family networks, most of which have left no identifiable trace.

\section{IV.2 Identities}

The Roman Empire incorporated millions of people, each of whom bore multiple identities, many of which were created or altered by the empire itself. While interest in various types of identities has grown in recent decades, ${ }^{249}$ the question of how the identity of 'Roman' spread throughout the empire has been central to the study of Roman history and archaeology since the late nineteenth century. ${ }^{250}$ The question is deeply entangled with that of the spread of Roman culture in what is often termed "the Romanization debate." 251 The relationship between identity and culture, especially material culture, is complicated by the fact that the use of artifacts associated with one culture does not necessarily imply a self-conscious association with that culture, and by the possibility that objects we associate with Roman culture in the present did not bear that meaning in the past. Nevertheless, the two are related in as much as identities are performed, negotiated, and read through culturally specific

248 This discussion of the Annius family is based on Evers 2017, 91-93.

249 Revell 2016.

250 For an overview, see Morley 2010, 102-155.

251 The current state of the question is well captured by Versluys 2014 - which is intentionally provocative - and the responses to it in Archaeological Dialogues 21.1. 
behaviors and material, sometimes intentionally, but often subconsciously. ${ }^{252}$ When recovering and interpreting these performances of ancient identity, however, it is important to remember that 'Roman' was only one identity among many, and that the relative importance of an individual's identities would vary depending on context. The creation and maintenance of imperial power structures created contexts in which new identities became relevant and the relevance of old identities changed.

\section{IV.2.1 Greek}

The identity of 'Greek' is one of those that changed in relevance with the rise of the Roman Empire. This included both an ethnic Greek identity linked to the Aegean and the Greek cities founded by Alexander the Great and his successors and also an elite cultural and linguistic identity based on education. ${ }^{253}$ This latter identity, centered on the memory of Athens in the fifth and fourth centuries BCE, required not only mastery of a certain set of knowledge, but also a set of behaviors that marked one as cultured or humane rather than barbaric. The most obvious trait was the use of an archaic, Atticizing form of the Greek language that distinguished the educated from the noneducated Greek, but also allowed those who were not ethnically Greek to take on the identity, at least to a certain extent. While this educated identity had roots in the classical and Hellenistic world, the value placed on it and on the Greek past by the Romans (see below) increased its power and perpetuated its performance. Thus, even an identity that was explicitly constructed as the continuation of a past, non-Roman culture can be seen as a product of the Roman Empire. ${ }^{254}$

\section{IV.2.2 Italian}

Roman conquest also created new identities, including that of 'Italian.' The process began in the third century всE, when the Romans' conquest of peninsular Italy was twice threatened by overseas powers. The Romans sought to limit defections by appealing to a geographic unity that bound the allies to Rome and defined the enemy as 'foreign. ${ }^{255}$ At the beginning of the first century вСE, the identity was turned against the Romans when a coalition of allies rebelled. Their Italian identity played an important role not only in unifying the rebels, but in causing the war in the first place. Italians fought alongside Romans in conquering the Mediterranean and were

252 Gardner 2002; Revell 2016, 9-13.

253 Kemezis 2014. See von Reden, ch. 1, this volume for Greek identity in the Hellenistic empires.

254 Whitmarsh 2009.

255 Bispham 2007, 53-68. 
closely associated with imperial power abroad, as we have seen. In Italy itself, Romans and non-Romans alike invested the profits of empire in aggrandizing themselves and their communities - not least by constructing monumental architecture in Hellenistic styles that expressed their elevated status within the Mediterranean. ${ }^{256}$ At the same time, Romans often treated the Italians as subjects. While the causes of the rebellion are controversial, one of them must have been a desire for equality with Romans, an equality justified by their shared Italian identity. ${ }^{257} \mathrm{Al}$ though the Romans won the war, the Italians secured Roman citizenship. A generation later, in the first half of the first century CE, many markers of distinct regional identities within Italy began to disappear. ${ }^{258}$

While the city of Rome was the center of the empire, Italy formed its core. It was not a province and was exempt from taxation on land. Most of the army was staffed increasingly by people from the provinces, but the elite Praetorian Guard stationed in Rome was predominantly Italian until the end of the second century CE. The emperors bestowed special attention on Italy, seeing to its roads and organizing alimentary schemes in the cities to feed children. ${ }^{259}$ At the same time, with political power vested in a mobile emperor, military power concentrated on the edges of the empire, and the increasing participation of provincial elites in imperial administration (see below), Italy's privileged status gradually eroded. Trajan (r. 98-117 CE) was the first emperor born outside of Italy, and he was particularly zealous in patronizing the region. Among other measures, he required senators to invest at least onethird of their property in Italian land, revealing both the ideological primacy of Italy and the increasing provincialization of the imperial elite. Italy's importance slowly diminished until, as part of sweeping reforms at the end of the third century, Diocletian (r. 284-305) subjected Italian land to taxation. Soon after, Rome was replaced by Constantinople as the imperial capital.

\section{IV.2.3 Becoming Roman}

The Romans' conquest of the Mediterranean, particularly Carthage and the Hellenistic monarchies, also had profound effects on what it meant to be Roman. Elite Romans became much wealthier than ever before, but they also began to negotiate a new relationship with Greek culture. In contrast to the other groups with which they came into contact, Greeks were seen as the originators of humanitas, a package of values and high culture that distinguished the civilized elite from the barbarian. ${ }^{260}$

256 Wallace-Hadrill 2008, 73-143.

257 For a good overview of the debate with citations of the most important literature, see Bispham 2016b, who argues for the importance of political equality.

258 Bispham 2016a, 101.

259 Cooley 2016b.

260 See, e.g., Cic. QFr. 1. 1. 27. 
The influence of Greek culture in Rome was not new, but it did intensify in the Late Republic through the increased movement of people between Rome and the Eastern Mediterranean. ${ }^{261}$ The Romans did not become Greeks. Rather, they refined and developed their own unique identity in response to and partial emulation of Greek traditions. Greek techniques of historical investigation were used to uncover and create a more authentic Roman past that served as the basis for contemporary Roman identity. ${ }^{262}$ Greek linguistic theories were used to rationalize the Latin language and purify it of foreign influence. ${ }^{263}$ Even public speaking, long an important part of an aristocrat's public career, was reshaped under the influence of specialized Greek rhetoric, above all by Cicero, who established a new standard of Latin oratory. ${ }^{264}$ Romans saw themselves as competing directly with Greek cultural traditions, which they knew well and mostly respected, but they did so within Greek parameters.

The adoption of Greek customs, particularly those related to the consumption of luxury goods, was often vociferously opposed but never halted. ${ }^{265}$ Luxury was seen by some as a disease imported from the Greek East. Wealth and exotic goods were brought back and paraded in triumphs celebrating the conquests of eastern monarchies. The proper consumption of increasingly rare and expensive exotica was a form of elite competition that simultaneously signaled separation from lower classes, belonging within an aristocracy, and excellence over one's aristocratic peers. Furniture made of rare wood and ivory, perfumes, richly decorated and grand houses, funerary monuments, and sumptuous feasts of variegated delicacies served on ornate dishes all became increasingly popular in a cycle of emulation and distinction. As the cycle progressed, prices declined and cheaper versions of luxuries were consumed by those lower down the social scale in what has been described as a "consumer revolution." 266 It was not only access to these goods that enhanced prestige but the knowledge of how to consume them properly, the lack of which marked one as an interloper. This is the danger of luxury as an elite discourse: it is open to anyone with wealth, so the social meaning of consumption must be vigorously policed by the existing elite. Of course, for the sub-elite, this is an opportunity: if one can learn the code and play the part, one can advance within society.

And advance people did. This is most visible at the top of the social pyramid. Rome's imperial elite consisted of the senatorial and equestrian orders. ${ }^{267}$ These had their origin in the Republican period, but during the civil wars many were killed

261 For this process of Hellenization, see Wallace-Hadrill 2008, 17-28.

262 Wallace-Hadrill 2008, 213-239.

263 Dench 2005, 298-361; Wallace-Hadrill 2008, 64-70.

264 Wallace-Hadrill 2008, 251-258.

265 This paragraph is based on Wallace-Hadrill 2008, 315-355.

266 Wallace-Hadrill 2008, 319-329.

267 Garnsey and Saller 2014, 131-149 provide an overview originally written in the 1980s with an addendum updating the scholarship and bibliography. Duncan-Jones 2016 is more recent and detailed. 
and new members were appointed, so Augustus reformed and reestablished them along new, more formal lines. Both orders had very low levels of intergenerational continuity under the Principate. According to one estimate, only 25 percent of senatorial families persisted for more than one generation. ${ }^{268}$ Similar quantification for the equites is difficult, but there are frequent attestations of shortages of equites in the literary record, especially in the early first century CE. ${ }^{269}$ Lower level and local elites thus had ample opportunity for upward mobility. Membership in these orders spread out from Rome. First, the Italian elites gained access, especially under Caesar and Augustus in the first century CE. ${ }^{270}$ Then, highly urbanized areas with a long history of Roman occupation like southern Gaul and southeast Spain began to contribute substantial numbers in the first and second centuries CE, while North Africa and western Asia Minor contributed more in the second and third centuries. ${ }^{271}$ While Italy remained the core of the Roman Empire, the imperial elite was increasingly drawn from the provinces.

The process of cultural transformation that made this possible is called 'Romanization.' The term and the process are both much debated. ${ }^{272}$ The most influential model explains cultural change among local elites as a strategy to increase personal standing within a new imperial system. ${ }^{273}$ Functionaries wielding imperial power preferred local collaborators who corresponded to their ideas of how elites should act, and local elites adopted Roman cultural forms in order to seize and channel imperial power for their own benefit. The process not only transformed local cultures, but Roman culture as well, creating a new imperial Roman cultural system with common elements and local variants. The evidence for this process can be found in the spread of various cultural elements associated with Rome: the Latin language; Latin literature; inscriptions; an urban-based political structure; public and private architectural forms and styles; decorative techniques including wall painting, marble revetment, and mosaics; the use of terra sigillata, a type of glossy red ceramic with a specific suite of forms for serving and consuming food; and coinage and monetized exchange, to name a few.

The appearance of most of these elements is much more striking in the western part of the empire than in the East. While Latin was the official language of the empire, state officials were happy to use Greek as well, so the Roman Empire, in effect, had two imperial languages. ${ }^{274}$ The eastern part of the empire had also been

268 Garnsey and Saller 2014, 145.

269 Duncan-Jones 2016, 97-99.

270 Syme 1939, 78-96, 349-368 is foundational. See Cooley 2016a, 105-6 for a summary and further literature.

271 Lavan 2016a, 160 provides this summary of older studies. Duncan-Jones 2016, 64-66 argues that the portion of senators from the East was slightly larger throughout the first three centuries CE. 272 Morley 2010, 102-155; Versluys 2014.

273 Millett 1990; Woolf 1998, esp. 63.

274 Wallace-Hadrill 2008, 57-63. 
urbanized and monetized longer than the western provinces. Nevertheless, changes are visible. Among the most obvious are the spread of bath complexes - the architectural infrastructure for a particularly Roman practice of bodily care - and gladiatorial contests - a Roman spectacle centered around one-on-one combat. ${ }^{275}$ But the bath complexes in Greek cities were integrated into gymnasia - the architectural infrastructure for a particularly Greek form of self-definition through exercise and education. ${ }^{276}$ The tombstones of gladiators also demonstrate reinterpretation by describing these men, whose status in Roman society was very low, in the same terms used for the athleticism that marked elite status in Greek society. ${ }^{277}$ This type of adaptation was not unique to the eastern part of the empire, but was typical of imperial Roman culture everywhere. ${ }^{278}$

Indeed, not only were Roman cultural forms adapted for use in locally meaningful contexts, but the expanded geographic awareness and connectivity of the Roman Empire, as well as its administration, stimulated the articulation, transformation, and emphasis of numerous local and regional identities. ${ }^{279}$ The creation of provinces, for example, redrew webs of translocal associations and created new, explicitly imperial collective identities. ${ }^{280}$ The province of Asia is recorded as taking collective action to issue decrees. ${ }^{281}$ When a man from the city of Canatha died in Gaul, his tombstone described him as a 'Syrian,' but later, when the boundaries between the provinces of Syria and Arabia were redrawn to include Canatha in the latter, its citizens described themselves as 'Arabs.'282 'Syrian' and 'Arab' were ethnic labels, and they could function as such, but within the Roman imperial context they were also regional identities. This ambiguity could elide ethnic differences that were more strictly policed outside of the empire, for example, between Syrians and Greeks. ${ }^{283}$ Thus, becoming Roman changed the meaning of numerous other identities as well.

\section{IV.2.4 Roman citizenship}

The political identity of Roman citizens deserves particular consideration. Roman citizenship was a prerequisite for participation in the imperial government at the highest levels and its extension has been seen as emblematic of the integration of

275 Woolf 1994.

276 Woolf 2012, 222-226.

277 C. Mann 2009.

278 Witcher 2017.

279 Andrade 2013; Revell 2009; Whitmarsh 2010.

280 Ando 2010.

281 Ando 2010, 36-37 with literature.

282 Andrade 2013, 110-111.

283 Andrade 2013, 94-121. 
the Roman Empire. ${ }^{284}$ During the Principate, citizenship was gradually extended to more and more non-Italians, especially to auxiliary veterans who were granted it automatically upon discharge. By the beginning of the third century, approximately one-third of the imperial population held it. ${ }^{285}$ Then, in $212 \mathrm{CE}$, the emperor Caracalla issued an edict declaring all free inhabitants of the empire to be citizens. ${ }^{286}$ The value of citizenship, while high, depended on context. Citizenship bestowed material privileges and prestige on its holder, ${ }^{287}$ but it was most important when dealing with people acting as officials of the Roman state and did not necessarily dominate other identities.

The story of the Apostle Paul's troubles in Jerusalem in the mid-first century CE nicely illustrate the place of Roman citizenship alongside other identities. ${ }^{288}$ Paul, having been attacked by a mob, is arrested by the commander of an auxiliary cohort, whom Paul addresses in Greek, thereby proving that he is not a certain Egyptian troublemaker. Paul identifies himself as a Jew and a citizen of Tarsos - "no insignificant city," he specifies - and asks to address the crowd. For this, Paul switches to "the Hebrew language," 289 which placates the crowd somewhat but not completely. When the commander is about to interrogate him through torture, Paul tells him, for the first time, that he is a Roman citizen. The commander, it turns out, bought his citizenship for a good deal of money, but Paul was born into his. Later, at a meeting of the Sanhedrin, he identifies himself as a Pharisee rather than a Sadducee, sowing discord among his prosecutors. In the course of these interactions, Paul deploys an ethnic identity (Jewish), a politico/geographic identity (from Tarsos), two linguistic identities (Greek and Hebrew), a purely political identity (Roman citizen), and a sectarian identity (Pharisee), each time tailoring his strategy to his interlocutor. Even with the Roman military commander, Paul's first recourse is to his ability to speak Greek. Roman citizenship is only used to avoid scourging. The empire was full of people like Paul, bearing multiple collective identities that were relevant in different situations. The lucky ones had Roman citizenship, which could blunt the edge of imperial power should they be so unlucky as to encounter it.

\section{Conclusion}

The Roman Empire was the result of a particular configuration of Roman society with its unrelenting aristocratic competition of service to the state and pervasive

284 Ando 2016; Lavan 2019. Sherwin-White 1973 is fundamental.

285 Lavan 2016b.

286 For the reasons behind this grant, see Blois 2014.

287 Besson 2017.

288 Acts of the Apostles 21. 27-23. 10, discussed by Woolf (2012, 221).

289 Often thought to be Aramaic (Danker 2000, s. v. 'Eßpoîs), but see Buth and Pierce 2014 for the argument that it means Hebrew. 
militarism - and a wider Mediterranean context - with its connectivity, centralizing urban social structure, and political inequality. The former meant that Romans were usually willing to go to war, and the latter meant there were wars to be waged and groups who could be subjugated. The unique nature of Roman subjugation, in turn, provided the means for further conquest. These conquests eventually destroyed the particular configuration of Roman society that had fueled them, but Rome did not fall. The ideological power of the state and the elasticity of the concept of the res publica meant that Rome could be refigured as a monarchy. The process was violent, and some Romans did equate the fall of the Republic with the fall of the Roman state, but most accepted the new regime's message that it was restoring the res publica, or at least accepted that Rome continued in a different form.

Monarchic government resulted in slower conquest and a greater elaboration of state institutions. The professional, standing army played a central part. Soldiers provided the means of coercion in small-scale interactions between state representatives and individuals and in large-scale interactions between Rome and uncooperative groups and polities. The army also multiplied the manpower resources that the state could call upon, as when soldiers oversaw civilians manning guard posts in the Eastern Desert, and when military personnel provided technical and managerial expertise to complete large-scale infrastructural projects. The government's efforts to maintain a standing army that was often stationed in remote areas led to the development of local economies in frontier zones, and to the transformation and creation of long-distance trade networks. Both the army as an institution and the soldiers as individuals relied on the empire for their existence, so the military was not just a tool of the empire, but a powerful constituency with a major stake in its survival.

Compared to the population of the empire, however, the army was small. The constant threat of violence can only partially explain the long-term functioning of the imperial system. Rather, the empire worked because innumerable people in positions of power locally also had a stake in its existence. For some, their power depended directly on imperial support. Others saw an opportunity to advance their wealth and status beyond the local level. For many, the empire guaranteed order, which ensured that their claims to property and position were respected. At a more conceptual level, perhaps a more conscious level, the empire guaranteed civilization. It excluded the barbarians on the outside and domesticated the ones on the inside. For these people, the fall of the Roman Empire was a terrifying prospect.

Others disagreed, of course. There were rebels and bandits who rejected imperial rule. But for most, the pain inflicted by the empire could be localized in particular bad actors: a corrupt governor, an arrogant soldier, or a cruel tax collector. The existence of a distant emperor who evinced a concern for his subjects provided an avenue for redress within the imperial system. For the most part, Roman government was channeled through local power structures, so the mundane experiences of domination that people endured were mediated and not immediately identifiable 
as stemming from Rome. Exceptions, such as the census, could lead to resentment and even rebellion, but these were relatively rare occurrences. In general, imperial officials were content to let their subjects live as they chose, provided their choices did not threaten the empire.

That many chose to adopt certain cultural forms that had roots in the Mediterranean and were similar across the imperial space does not reflect the imposition of a homogeneous, Roman culture. Rather, it reflects the choices made by individuals operating within the imperial system. The adoption of Roman culture, even a Roman identity, did not foreclose other, more particularistic identities relating to place of origin, ethnicity, religion, language, or education. For some, most famously Jews and Christians, these alternative identities put them in conflict with the empire and the imperial reaction was brutal, violent repression. Violence was, after all, a crucial pillar on which the empire stood. But for most, the identities that were most important were compatible with, and occasionally dependent on, the imperial system. Rome gained its empire through violence, but it kept its empire through the collaboration of its subjects.

\section{References}

Adams, C. 1995. "Supplying the Roman army: O. Petr. 245." Zeitschrift für Papyrologie und Epigraphik 109, 119-124.

-. 1999. "Supplying the Roman army: Bureaucracy in Roman Egypt." In Goldsworthy and Haynes (1999), 119-126.

Alston, R. 1995. Soldier and society in Roman Egypt: A social history. London: Routledge.

-. 1999. "The ties that bind: Soldiers and societies." In Goldsworthy and Haynes (1999), 175-196.

-. 2007. "The Military and politics." In P. Sabin, H. van Wees, and M. Whitby (eds.), The Cambridge history of Greek and Roman warfare. Vol. 2, 176-197. Cambridge: Cambridge University Press.

Ando, C. 2000. Imperial ideology and provincial loyalty in the Roman Empire. Berkeley, CA: University of California Press.

-. 2006. "The administration of the provinces." In D. S. Potter (ed.), A companion to the Roman Empire, 177-192. Malden, MA: Blackwell.

-. 2010. “Imperial identities." In Whitmarsh (2010), 17-45.

-. 2016. "Making Romans: Citizens, subjects, and subjectivity in Republican empire." In M. Lavan, R. E. Payne, and J. Weisweiler (eds.), Cosmopolitanism and empire: Universal rulers, local elites, and cultural integration in the ancient Near East and Mediterranean, 169185. Oxford: Oxford University Press.

-. 2017. "The ambitions of government: Territoriality and infrastructural power in ancient Rome." In C. Ando and S. Richardson (eds.), Ancient states and infrastructural power: Europe, Asia, and America, 115-148. Philadelphia, PA: University of Pennsylvania Press.

Andrade, N. J. 2013. Syrian identity in the Greco-Roman world. Cambridge: Cambridge University Press.

Arnaud, P. 2014. "Maritime infrastructure: Between public and private initiative.” In A. Kolb (ed.), Infrastruktur und Herrschaftsorganisation im Imperium Romanum: Herrschafstsstrukturen und Herrschaftspraxis III: Akten der Tagung in Zürich 19.-20. Oktober 2012, 161-179. Berlin: De Gruyter. 
Badian, E. 1972. Publicans and sinners: Private enterprise in the service of the Roman Republic. Ithaca, NY: Cornell University Press.

Bang, P. F. 2008. The Roman bazaar: A comparative study of trade and markets in a tributary empire. Cambridge: Cambridge University Press.

Beard, M. 2007. The Roman triumph. Cambridge, MA: Belknap Press of Harvard University Press.

Besson, A. 2017. "Fifty years before the Antonine Constitution: Access to Roman citizenship and exclusive rights." In L. Cecchet and A. Busetto (eds.), Citizens in the Graeco-Roman world: Aspects of citizenship from the Archaic period to AD 212, 199-220. Leiden: Brill.

Betts, I., and B. Marshall. 2013. "The lex Calpurnia of 149 BC." Antichthon 47, 39-60.

Birley, A. 2007. “Making emperors: Imperial instrument or independent force?” In P. Erdkamp (ed.), A companion to the Roman army, 379-394. Malden, MA: Blackwell.

Bispham, E. 2007. From Asculum to Actium: The municipalization of Italy from the Social War to Augustus. Oxford: Oxford University Press.

-. 2016a. "The civil wars and the Triumvirate." In A. E. Cooley (ed.), A companion to Roman Italy, 90-102. Malden, MA: Wiley-Blackwell.

-. 2016b. “The Social War.” In A. E. Cooley (ed.), A companion to Roman Italy, 76-89. Malden, MA: Wiley-Blackwell.

Blackman, D. J. 2008. "Sea transport, part 2: Harbors." In J. P. Oleson (ed.), The Oxford handbook of engineering and technology in the classical world, 638-670. Oxford: Oxford University Press.

Blois, L. de. 2014. “The constitutio Antoniniana (AD 212): Taxes or religion?” Mnemosyne 67.6, 1014-1021.

Blois, L. de., and E. Lo Cascio, eds. 2007. The impact of the Roman army (200 BC-AD 476): Economic, social, political, religious, and cultural aspects: Proceedings of the sixth workshop of the International Network Impact of Empire (Roman Empire, 200 BC-AD 476), Capri, March 29-April 2, 2005. Leiden: Brill.

Boatwright, M. T. 2000. Hadrian and the cities of the Roman Empire. Princeton, NJ: Princeton University Press.

Bowman, A. K. 1996. "Provincial administration and taxation.” In A. K. Bowman, E. Champlin, and A. Lintott (eds.), The Cambridge ancient history. 2nd ed. Vol. 10, 344-370. Cambridge: Cambridge University Press.

Brandon, C. J., R. L. Hohlfelder, M. D. Jackson, and J. P. Oleson. 2014. Building for eternity: The history and technology of Roman concrete engineering in the sea. Oxford: Oxbow.

Braund, D. 1984. Rome and the friendly king: The character of the client kingship. London: Croom Helm.

-. 1998. "'Cohors': The governor and his entourage in the self-image of the Roman Republic." In R. Laurence and J. Berry (eds.), Cultural identity in the Roman Empire, 10-24. London: Routledge.

-. 2015. “Kings beyond the claustra: Nero's Nubian Nile, India and the rubrum mare (Tacitus, Annals 2.61)." In E. Baltrusch and J. Wilker (eds.), Amici - socii - clientes? Abhängige Herrschaft im Imperium Romanum, 123-159. Berlin: Topoi Excellence Cluster.

Breeze, D. J. 2011. The frontiers of imperial Rome. Barnsley: Pen \& Sword Military.

Brennan, T. C. 2000. The praetorship in the Roman Republic. 2 vols. Oxford: Oxford University Press.

Broekaert, W. 2013. Navicularii et negotiantes: A prosopographical study of Roman merchants and shippers. Rahden: Marie Leidorf.

Brunt, P. A. 1987. Italian manpower: $225 B C-A D$ 14. 2nd ed. Oxford: Clarendon.

-. 1990. Roman imperial themes. Oxford: Clarendon.

Bryen, A. Z. 2012. “Judging empire: Courts and culture in Rome's eastern provinces." Law and History Review 30.3, 771-811. 
Burnett, A. 2005. "The Roman West and the Roman East.” In C. Howgego, V. Heuchert, and A. Burnett (eds.), Coinage and identity in the Roman provinces, 171-180. Oxford: Oxford University Press.

Burnett, A., M. Amandry, and P. P. Ripollès. 1992. Roman provincial coinage. Vol. 1, From the death of Caesar to the death of Vitellius (44 BC-AD 69): Introduction and catalogue. London: British Museum.

Burrell, B. 2004. Neokoroi: Greek cities and Roman emperors. Leiden: Brill.

Burton, G. P. 2004. "The Roman imperial state, provincial governors and the public finances of provincial cities, 27 BC-AD 235." Historia 53.3, 311-342.

Burton, P. J. 2011. Friendship and empire: Roman diplomacy and imperialism in the Middle Republic (353-146 BC). Cambridge: Cambridge University Press.

Butcher, K. 2012. "Syria in the Roman period, 64 BC-AD 260." In Metcalf (2012), 468-484.

Butcher, K., and M. Ponting. 2014. The metallurgy of Roman silver coinage: From the reform of Nero to the reform of Trajan. Cambridge: Cambridge University Press.

Buth, R., and C. Pierce. 2014. "Hebraisti in ancient texts: Does 'Eßpoïotí ever mean 'Aramaic'?" In R. Buth and R. S. Notley (eds.), The language environment of first century Judaea, 66-109. Leiden: Brill.

Campbell, B. 1984. The emperor and the Roman army: 31 BC-AD 235. Oxford: Clarendon.

-. 1994. The Roman army, 31 BC-AD 337: A sourcebook. London: Routledge.

Canali de Rossi, F. 2001. Il ruolo dei patroni nelle relazioni politiche fra il mondo greco e Roma in età repubblicana ed augustea. Munich: K. G. Saur.

Capogrossi Colognesi, L. 2014. Law and power in the making of the Roman commonwealth. L. Kopp (trans.). Cambridge: Cambridge University Press.

Champion, C. 2007. "Empire by invitation: Greek political strategies and Roman imperial interventions in the second century BCE." Transactions of the American Philological Association 137.2, 255-275.

Claytor, W. G., and R. S. Bagnall. 2015. "The beginnings of the Roman provincial census: A new declaration from 3 BCE." Greek, Roman and Byzantine Studies 55, 637-653.

Cobb, M. A. 2018. Rome and the Indian Ocean trade from Augustus to the early third century CE. Leiden: Brill.

Collar, A., F. Coward, T. Brughmans, and B. J. Mills. 2015. "Networks in archaeology: Phenomena, abstraction, representation." Journal of Archaeological Method and Theory 22.1, 1-32.

Cooley, A. E. 2016a. "Coming to terms with dynastic power, 30 BC-AD 69." In A. E. Cooley (ed.), A companion to Roman Italy, 103-120. Malden, MA: Wiley-Blackwell.

-. 2016b. "Italy during the High Empire, from the Flavians to Diocletian." In A. E. Cooley (ed.), A companion to Roman Italy, 121-132. Malden, MA: Wiley-Blackwell.

Cornell, T. 1993. "The end of Roman imperial expansion.” In J. Rich and G. Shipley (eds.), War and society in the Roman world, 139-170. London: Routledge.

Cuomo, S. 2007. "Measures for an emperor: Volusius Maecianus' monetary pamphlet for Marcus Aurelius." In J. König and T. Whitmarsh (eds.), Ordering knowledge in the Roman Empire, 206-228. Cambridge: Cambridge University Press.

Danker, F. W. 2000. A Greek-English lexicon of the New Testament and other early Christian literature. 3rd ed. Chicago, IL: University of Chicago Press.

Dart, C. J. 2016. "Frontiers, security, and military policy." In A. Zissos (ed.), A companion to the Flavian age of imperial Rome, 207-222. Malden, MA: Wiley-Blackwell.

de Ligt, L., and L. E. Tacoma. 2016. Migration and mobility in the Early Roman Empire. Leiden: Brill.

Dench, E. 2005. Romulus' asylum: Roman identities from the age of Alexander to the age of Hadrian. Oxford: Oxford University Press.

Deniaux, E. 2006. "Patronage." In N. Rosenstein and R. Morstein-Marx (eds.), A companion to the Roman Republic, 401-420. Malden, MA: Blackwell. 
De Souza, P. 1999. Piracy in the Graeco-Roman world. Cambridge: Cambridge University Press. Dobson, B. 2009. "The role of the fort." In W. S. Hanson (ed.), The army and frontiers of Rome: Papers offered to David J. Breeze on the occasion of his sixty-fifth birthday and his retirement from Historic Scotland, 25-32. Portsmouth, RI: Journal of Roman Archaeology.

Doyle, M. W. 1986. Empires. Ithaca, NY: Cornell University Press.

Duncan-Jones, R. 2016. Power and privilege in Roman society. Cambridge: Cambridge University Press.

Dyson, S. L. 1971. “Native revolts in the Roman Empire." Historia 20.2/3, 239-274.

-. 1975. "Native revolt patterns in the Roman Empire." In H. Temporini (ed.), Aufstieg und Niedergang der römischen Welt. Part 2, vol. 3, 138-175. Berlin: De Gruyter.

Eberle, L. P. 2017. "Making Roman subjects: Citizenship and empire before and after Augustus.” Transactions of the American Philological Association 147.2, 321-370.

Eck, W. 1995-1998. Die Verwaltung des römischen Reiches in der hohen Kaiserzeit. 2 vols. Basel: Reinhardt.

-. 1999. "Zur Einleitung: Römische Provinzialadministration und die Erkenntnismöglichkeiten der epigraphischen Überlieferung.” In W. Eck (ed.), Lokale Autonomie und römische Ordnungsmacht in den kaiserzeitlichen Provinzen vom 1. bis 3. Jahrhundert, 1-16. Munich: Oldenbourg.

-. 2000a. "Provincial administration and finance." In A. K. Bowman, P. Garnsey, and D. Rathbone (eds.), The Cambridge ancient history. 2nd ed. Vol. 11, 266-292. Cambridge: Cambridge University Press.

-. 2000b. "The growth of administrative posts.” In A. K. Bowman, P. Garnsey, and D. Rathbone (eds.), The Cambridge ancient history. 2nd ed. Vol. 11, 238-265. Cambridge: Cambridge University Press.

-. 2009. "The administrative reforms of Augustus: Pragmatism or systematic planning?" In Edmondson (2009), 229-249.

-. 2014. “Milites et pagani: La posizione dei soldati nella società romana." Rationes Rerum 3, 11-54.

Eckstein, A. M. 2006. Mediterranean anarchy, interstate war, and the rise of Rome. Berkeley, CA: University of California Press.

-. 2008. Rome enters the Greek East: From anarchy to hierarchy in the Hellenistic Mediterranean, 230-70 BC. Malden, MA: Wiley-Blackwell.

Edmondson, J., ed. 2009. Augustus. Edinburgh: Edinburgh University Press.

-. 2015. "The Roman emperor and the local communities of the Roman Empire." In J.-L. Ferrary and J. Scheid (eds.), Il princeps romano: Autocrate o magistrato? Fattori giuridici e fattori sociali del potere imperiale da Augusto a Commodo, 701-730. Pavia: IUSS Press.

Edwell, P. M. 2008. Between Rome and Persia: The middle Euphrates, Mesopotamia and Palmyra under Roman control. London: Routledge.

Eich, A., and P. Eich. 2005. "War and state-building in Roman Republican times." Scripta Classica Israelica 24, 1-34.

Eilers, C. 2002. Roman patrons of Greek cities. Oxford: Oxford University Press.

Erdkamp, P., ed. 2002. The Roman army and the economy. Amsterdam: J. C. Gieben.

-. 2005. The grain market in the Roman Empire: A social, political and economic study. Cambridge: Cambridge University Press.

Evers, K. G. 2011. The Vindolanda tablets and the ancient economy. Oxford: Archaeopress.

-. 2017. Worlds apart trading together: The organisation of long-distance trade between Rome and India in antiquity. Oxford: Archaeopress.

Fuhrmann, C. J. 2012. Policing the Roman Empire: Soldiers, administration, and public order. Oxford: Oxford University Press.

Galinsky, K., ed. 2005. The Cambridge companion to the age of Augustus. Cambridge: Cambridge University Press. 
Ganter, A. 2015. Was die römische Welt zusammenhält: Patron-Klient-Verhältnisse zwischen Cicero und Cyprian. Berlin: De Gruyter.

Gardner, A. 2002. "Social identity and the duality of structure in Late Roman-period Britain." Journal of Social Archaeology 2.3, 323-351.

Garnsey, P. 2010. "Roman patronage." In S. McGill, C. Sogno, and E. Watts (eds.), From the Tetrarchs to the Theodosians: Later Roman history and culture, 284-450 CE, 33-54. Cambridge: Cambridge University Press.

Garnsey, P., and R. Saller. 2014. The Roman Empire: Economy, society and culture. 2nd ed. London: Bloomsbury.

Geissen, A. 2012. "The coinage of Roman Egypt.” In Metcalf (2012), 561-583.

Gerov, B. 1989. Inscriptiones Latinae in Bulgaria repertae. Sofia: In Aedibus Universitatum "Kliment Ohridski".

Gibbon, E. 1776-1789. The history of the decline and fall of the Roman Empire. 6 vols. London: W. Strahan and T. Cadell.

Gilliver, K. 2007. "The Augustan reform and the structure of the imperial army." In P. Erdkamp (ed.), A companion to the Roman army, 183-200. Malden, MA: Blackwell.

Gleason, M. W. 2006. "Greek cities under Roman rule." In D. S. Potter (ed.), A companion to the Roman Empire, 228-249. Malden, MA: Blackwell.

Goldsworthy, A. K. 2007. "War." In P. Sabin, H. van Wees, and M. Whitby (eds.), The Cambridge history of Greek and Roman warfare. Vol. 2, 76-121. Cambridge: Cambridge University Press.

Goldsworthy, A. K., and I. Haynes, eds. 1999. The Roman army as a community: Including papers of a conference held at Birkbeck College, University of London on 11-12 January, 1997. Portsmouth, RI: Journal of Roman Archaeology.

Greene, E. M. 2015. "Conubium cum uxoribus: Wives and children in the Roman military diplomas." Journal of Roman Archaeology 28, 125-159.

Gruen, E. S. 1986. The Hellenistic world and the coming of Rome. Berkeley, CA: University of California Press.

Grünewald, T. 2004. Bandits in the Roman Empire: Myth and reality. J. Drinkwater (trans.). London: Routledge.

Haensch, R. 2012. "The Roman army in Egypt." In C. Riggs (ed.), The Oxford handbook of Roman Egypt, 68-82. Oxford: Oxford University Press.

Hanson, J. W. 2016. An urban geography of the Roman world, $100 B C$ to AD 300. Oxford: Archaeopress.

Harl, K. W. 1996. Coinage in the Roman economy, 300 BC to AD 700. Baltimore, MD: Johns Hopkins University Press.

Harris, W. V. 1979. War and imperialism in Republican Rome: 327-70 BC. Oxford: Clarendon.

-, ed. 2013. The ancient Mediterranean environment between science and history. Leiden: Brill.

-. 2016. Roman power: $A$ thousand years of empire. Cambridge: Cambridge University Press.

Hauken, T., and H. Malay. 2009. "A new edict of Hadrian from the province of Asia setting regulations for requisitioned transport." In R. Haensch (ed.), Selbstdarstellung und Kommunikation: Die Veröffentlichung staatlicher Urkunden auf Stein und Bronze in der römischen Welt: Internationales Kolloquium an der Kommission für Alte Geschichte und Epigraphik in München (1. bis 3. Juli 2006), 327-348. Munich: C. H. Beck.

Hitchner, R. B. 2012. "Roads, integration, connectivity, and economic performance in the Roman Empire." In S. E. Alcock, J. Bodel, and R. J. A. Talbert (eds.), Highways, byways, and road systems in the pre-modern world, 222-234. Malden, MA: Wiley-Blackwell.

Höghammar, K., B. Alroth, and A. Lindhagen, eds. 2016. Ancient ports: The geography of connections: Proceedings of an international conference at the Department of Archaeology and Ancient History, Uppsala University, 23-25 September 2010. Uppsala: Coronet.

Hölkeskamp, K.-J. 1993. "Conquest, competition and consensus: Roman expansion in Italy and the rise of the Nobilitas." Historia 42.1, 12-39. 
Hopkins, K. 1978. Conquerors and slaves. Cambridge: Cambridge University Press.

Horden, P., and N. Purcell. 2000. The corrupting sea: A study of Mediterranean history. Malden, MA: Blackwell.

Howgego, C. 2013. "The monetization of temperate Europe.” Journal of Roman Studies 103, $16-45$.

Hoyos, D, ed. 2013. A companion to Roman imperialism. Leiden: Brill.

Isaac, B. H. 1990. The limits of empire: The Roman army in the East. Oxford: Clarendon.

Johnston, A. 2012. “The provinces after Commodus.” In Metcalf (2012), 453-467.

Kallet-Marx, R. M. 1995. Hegemony to empire: The development of the Roman Imperium in the East from 148 to 62 BC. Berkeley, CA: University of California Press.

Karavas, J. 2005. "Patterns in the distribution of Roman troops and fortifications on the Lower Danube frontier (1st-2nd century AD)." In Z. Visy (ed.), Limes XIX: Proceedings of the XIXth International Congress of Roman Frontier Studies held in Pécs, Hungary, September 2003, 189-199. Pécs: University of Pécs.

Katsari, C. 2011. The Roman monetary system: The eastern provinces from the first to the third century $A D$. Cambridge: Cambridge University Press.

Kay, P. 2014. Rome's economic revolution. Oxford: Oxford University Press.

Keay, S. J., ed. 2012. Rome, Portus and the Mediterranean. London: British School at Rome.

Keay, S. J., M. Millet, L. Paroli, and K. Strutt. 2005. Portus: An archaeological survey of the port of imperial Rome. London: British School at Rome.

Keay, S. J., and L. Paroli, eds. 2011. Portus and its hinterland: Recent archaeological research. London: British School at Rome.

Kehne, P. 2007. "War- and peacetime logistics: Supplying imperial armies in East and West." In P. Erdkamp (ed.), A companion to the Roman army, 323-337. Malden, MA: Blackwell.

Kemezis, A. M. 2014. "Greek ethnicity and the Second Sophistic.” In J. Mclnerney (ed.), A companion to ethnicity in the ancient Mediterranean, 390-404. Malden, MA: WileyBlackwell.

Kemp, J. 2018. “Amicitia, gift-exchange and subsidies in imperial Roman diplomacy.” In M. A. Janković and V. D. Mihajlović (eds.), Reflections of Roman imperialisms, 85-105. Newcastle upon Tyne: Cambridge Scholars Publishing.

Kendall, S. 2013. The struggle for Roman citizenship: Romans, allies, and the wars of 91-77 BCE. Piscataway, NJ: Gorgias.

Kennedy, D. L., ed. 1996. The Roman army in the East. Ann Arbor, MI: Journal of Roman Archaeology.

-. 2004. The Roman army in Jordan. 2nd ed. London: Council for British Research in the Levant. Keppie, L. 1984. The making of the Roman army: From Republic to Empire. London: Routledge.

Kessler, D., and P. Temin. 2007. "The organization of the grain trade in the Early Roman Empire." Economic History Review 60.2, 313-332.

Kissel, T. K. 1995. Untersuchungen zur Logistik des römischen Heeres in den Provinzen des griechischen Ostens (27 v. Chr.-235 n. Chr.). St. Katharinen: Scripta Mercaturae.

-. 2002. "Road-building as a munus publicium.” In Erdkamp (2002), 127-160.

Kolb, A. 2000. Transport und Nachrichtentransfer im römischen Reich. Berlin: Akademie-Verlag.

-. 2001. "Transport and communication in the Roman state: The cursus publicus." In C. Adams and R. Laurence (eds.), Travel and geography in the Roman Empire, 95-105. London: Routledge.

Laurence, R. 1999. The roads of Roman Italy: Mobility and cultural change. London: Routledge.

-. 2013. "Roads and bridges." In J. D. Evans (ed.), A companion to the archaeology of the Roman Republic, 296-308. Malden, MA: Wiley-Blackwell.

Lavan, M. 2016a. “'Father of the whole human race': Ecumenical language and the limits of elite integration in the Early Roman Empire.” In M. Lavan, R. E. Payne, and J. Weisweiler (eds.), 
Cosmopolitanism and empire: Universal rulers, local elites, and cultural integration in the ancient Near East and Mediterranean, 153-168. New York, NY: Oxford University Press.

-. 2016b. "The spread of Roman citizenship, 14-212 CE: Quantification in the face of high uncertainty." Past \& Present 230.1, 3-46.

-. 2019. "The foundation of empire? The spread of Roman citizenship from the fourth century BCE to the third century CE." In K. Berthelot and J. Price (eds.), In the crucible of empire: The impact of Roman citizenship upon Greeks, Jews and Christians, 21-54. Leuven: Peeters.

Le Bohec, Y. 1994. The imperial Roman army. London: B. T. Batsford.

Lemcke, L. 2016. Imperial transportation and communication from the third to the late fourth century: The golden age of the cursus publicus. Bruxelles: Latomus.

Lendon, J. E. 1997. Empire of honour: The art of government in the Roman world. Oxford: Oxford University Press.

Lewit, T. 2011. "Dynamics of fineware production and trade: The puzzle of supra-regional exporters." Journal of Roman Archaeology 24, 313-332.

Lintott, A. 1993. Imperium Romanum: Politics and administration. London: Routledge.

Lo Cascio, E. 1999. "Census provinciale, imposizione fiscale e amministrazioni cittadine nel Principato." In W. Eck (ed.), Lokale Autonomie und römische Ordnungsmacht in den kaiserzeitlichen Provinzen vom 1. bis 3. Jahrhundert, 197-212. Munich: Oldenbourg.

-. 2013. "Population and demographic studies." In J. D. Evans (ed.), A companion to the archaeology of the Roman Republic, 155-165. Malden, MA: Wiley-Blackwell.

Luttwak, E. N. 1976. The grand strategy of the Roman Empire from the first century AD to the third. Baltimore, MD: Johns Hopkins University Press.

MacMullen, R. 1963. Soldier and civilian in the later Roman Empire. Cambridge, MA: Harvard University Press.

Malkin, I. 2011. A small Greek world: Networks in the ancient Mediterranean. Oxford: Oxford University Press.

Malkin, I., C. Constantakopoulou, and K. Panagopoulou, eds. 2009. Greek and Roman networks in the Mediterranean. London: Routledge.

Mann, C. 2009. "Gladiators in the Greek East: A case study in Romanization." International Journal of the History of Sport 26.2, 272-297.

Mann, M. 1986. The sources of social power. Vol. 1, A history of power from the beginning to $A D$ 1760. Cambridge: Cambridge University Press.

Marzano, A. 2013. "Capital investment and agriculture: Multi-press facilities from Gaul, the Iberian Peninsula, and the Black Sea region.” In A. K. Bowman and A. Wilson (eds.), The Roman agricultural economy: Organization, investment, and production, 107-141. Oxford: Oxford University Press.

Mattern, S. P. 1999. Rome and the enemy: Imperial strategy in the Principate. Berkeley, CA: University of California Press.

Mattingly, D. J. 1988. "Oil for export? A comparison of Libyan, Spanish and Tunisian olive oil production in the Roman Empire." Journal of Roman Archaeology 1, 33-56.

McCormick, M., U. Büntgen, M. A. Cane, E. R. Cook, K. Harper, P. Huybers, T. Litt, S. W. Manning, P. A. Mayewski, A. F. M. More, K. Nicolussi, and W. Tegel. 2012. "Climate change during and after the Roman Empire: Reconstructing the past from scientific and historical evidence." Journal of Interdisciplinary History 43.2, 169-220.

McDonnell, M. 2006. Roman manliness: Virtus and the Roman Republic. Cambridge: Cambridge University Press.

Metcalf, W. E., ed. 2012. The Oxford handbook of Greek and Roman coinage. Oxford: Oxford University Press.

Millar, F. 1977. The emperor in the Roman world: $31 B C-A D$ 337. London: Duckworth.

Millett, M. 1990. The Romanization of Britain: An essay in archaeological interpretation. Cambridge: Cambridge University Press. 
Mitthof, F. 2001. Annona militaris: Die Heeresversorgung im spätantiken Ägypten. Vol. 1, Darstellung. Florence: Gonnelli.

Moatti, C. 2018. Res publica: Histoire romaine de la chose publique. Paris: Fayard.

Montesquieu, C.-L. de S. 1734. Considérations sur les causes de la grandeur des Romains et de leur décadence. Amsterdam: J. Desbordes.

Morley, N. 2007. Trade in classical antiquity. Cambridge: Cambridge University Press.

-. 2010. The Roman Empire: Roots of imperialism. London: Pluto.

Morstein-Marx, R., and N. Rosenstein. 2006. "The transformation of the Republic." In

N. Rosenstein and R. Morstein-Marx (eds.), A companion to the Roman Republic, 625-637. Malden, MA: Blackwell.

Nicolet, C. 1991. Space, geography and politics in the Early Roman Empire. Ann Arbor, MI: University of Michigan Press.

Nicols, J. 2014. Civic patronage in the Roman Empire. Leiden: Brill.

Noreña, C. F. 2009. "The ethics of autocracy in the Roman world." In R. K. Balot (ed.), A companion to Greek and Roman political thought, 266-279. Malden, MA: Wiley-Blackwell.

-. 2010. "The early imperial monarchy." In A. Barchiesi and W. Scheidel (eds.), The Oxford handbook of Roman studies, 533-547. Oxford: Oxford University Press.

-. 2011. Imperial ideals in the Roman West: Representation, circulation, power. Cambridge: Cambridge University Press.

Nörr, D. 1999. "Zu den Xenokriten (Rekuperatoren) in der römischen Provinzialgerichtsbarkeit." In W. Eck (ed.), Lokale Autonomie und römische Ordnungsmacht in den kaiserzeitlichen Provinzen vom 1. bis 3. Jahrhundert, 257-302. Munich: Oldenbourg.

O'Connor, C. 1993. Roman bridges. Cambridge: Cambridge University Press.

Parker, S. T. 2006. The Roman frontier in central Jordan: Final report on the Limes Arabicus Project, 1980-1989. 2 vols. Washington, DC: Dumbarton Oaks Research Library and Collection.

Perry, J. S. 2011. “Organized societies: Collegia.” In M. Peachin (ed.), The Oxford handbook of social relations in the Roman world, 499-515. Oxford: Oxford University Press.

Phang, S. E. 2001. The marriage of Roman soldiers (13 BC-AD 235): Law and family in the imperial army. Leiden: Brill.

-. 2005. 'Soldiers' slaves, 'dirty work,' and the social status of Roman soldiers." In J.-J. Aubert and Z. Várhelyi (eds.), A tall order: Writing the social history of the ancient world: Essays in honor of William V. Harris, 203-225. Munich: K. G. Saur.

-. 2008. Roman military service: Ideologies of discipline in the Late Republic and Early Principate. Cambridge: Cambridge University Press.

Polak, M. 2009. "The Roman military presence in the Rhine delta in the period c. AD 40-140." In Á. Morillo Cerdán, N. Hanel, and E. Manso Martín (eds.), Limes XX: XX congreso internacional de estudios sobre la frontera romana: XXth International Congress of Roman Frontier Studies, Léon (España), septiembre, 2006. Vol. 2, 946-953. Madrid: Polifemo.

Pollard, N. 2000. Soldiers, cities, and civilians in Roman Syria. Ann Arbor, MI: University of Michigan Press.

Potter, D. S. 2006. “Introduction.” In D. S. Potter (ed.), A companion to the Roman Empire, 1-19. Malden, MA: Blackwell.

-. 2011. "The Roman army." In M. Peachin (ed.), The Oxford handbook of social relations in the Roman world, 516-534. Oxford: Oxford University Press.

Poulter, A. G. 2004. "Cataclysm on the Lower Danube: The destruction of a complex Roman landscape." In N. Christie (ed.), Landscapes of change: Rural evolutions in Late Antiquity and the Early Middle Ages, 223-254. Aldershot: Ashgate.

-. 2013. "Goths on the Lower Danube: Their impact upon and behind the frontier." Antiquité Tardive 21, 63-76. 
Purcell, N. 1990. "The creation of provincial landscape: The Roman impact on Cisalpine Gaul." In T. Blagg and M. Millett (eds.), The Early Roman Empire in the West, 7-29. Oxford: Oxbow.

-. 2005. "Romans in the Roman world." In Galinsky (2005), 85-105.

-. 2010. "Urbanism." In A. Barchiesi and W. Scheidel (eds.), The Oxford handbook of Roman studies, 579-592. Oxford: Oxford University Press.

Quilici, L. 2008. "Land transport, part 1: Roads and bridges." In J. P. Oleson (ed.), The Oxford handbook of engineering and technology in the classical world, 551-579. Oxford: Oxford University Press.

Raaflaub, K. A. 1996. "Born to be wolves? Origins of Roman imperialism." In R. W. Wallace and E. M. Harris (eds.), Transitions to empire: Essays in Greco-Roman history, 360-146 BC in honor of E. Badian, 273-314. Norman, OK: University of Oklahoma Press.

Rathbone, D. 2007. "Military finance and supply." In P. Sabin, H. van Wees, and M. Whitby (eds.), The Cambridge history of Greek and Roman warfare. Vol. 2, 158-175. Cambridge: Cambridge University Press.

Rathmann, M. 2003. Untersuchungen zu den Reichsstraßen in den westlichen Provinzen des Imperium Romanum. Mainz: Philipp von Zabern.

-. 2014. "Der Princeps und die viae publicae in den Provinzen: Konstruktion und Fakten eines planmäßigen Infrastrukturausbaus durch die Reichszentrale." In A. Kolb (ed.), Infrastruktur und Herrschaftsorganisation im Imperium Romanum: Herrschafstsstrukturen und Herrschaftspraxis III. Akten der Tagung in Zürich 19.-20. Oktober 2012, 197-221. Berlin: Akademie-Verlag.

Rauh, N. K. 1986. "Cicero's business friendships: Economics and politics in the Late Roman Republic." Aevum 60.1, 3-30.

Revell, L. 2009. Roman imperialism and local identities. Cambridge: Cambridge University Press.

-. 2016. Ways of being Roman: Discourses of identity in the Roman West. Oxford: Oxbow.

Reynolds, P. 2018. "The supply networks of the Roman East and West: Interaction, fragmentation, and the origins of the Byzantine economy." In Wilson and Bowman (2018), 353-396.

Richardson, J. 1986. Hispaniae: Spain and the development of Roman imperialism, 218-82 BC. Cambridge: Cambridge University Press.

-. 1992. "The administration of the empire." In J. A. Crook, A. Lintott, and E. Rawson (eds.), The Cambridge ancient history. 2nd ed. Vol. 9, 564-598. Cambridge: Cambridge University Press.

-. 2008. The language of empire: Rome and the idea of empire from the third century $B C$ to the second century $A D$. Cambridge: Cambridge University Press.

-. 2016. "Provincial administration." In P. J. du Plessis, C. Ando, and K. Tuori (eds.), The Oxford handbook of Roman law and society, 111-123. Oxford: Oxford University Press.

Riggsby, A. M. Forthcoming. Mosaics of knowledge: Representing information in the Roman world. Oxford: Oxford University Press.

Roselaar, S. T. 2010. Public land in the Roman Republic: $A$ social and economic history of ager publicus in Italy, 396-89 BC. Oxford: Oxford University Press.

Rosenstein, N. S. 1990. Imperatores victi: Military defeat and aristocratic competition in the Middle and Late Republic. Berkeley, CA: University of California Press.

-. 2004. Rome at war: Farms, families, and death in the Middle Republic. Chapel Hill, NC: University of North Carolina Press.

Roth, J. P. 1999. The logistics of the Roman army at war (264 BC-AD 235). Leiden: Brill.

Rowan, C. 2019. From Caesar to Augustus (c. 49 BC-AD 14): Using coins as sources. Cambridge: Cambridge University Press.

Saller, R. P., and B. D. Shaw. 1984. "Tombstones and Roman family relations in the Principate: Civilians, soldiers and slaves." Journal of Roman Studies 74, 124-156.

Salmon, E. T. 1969. Roman colonization under the Republic. London: Thames and Hudson. 
Scheidel, W. 2005. “Human mobility in Roman Italy, II: The slave population.” Journal of Roman Studies 95, 64-79.

Shaw, B. D. 1983. "Soldiers and society: The army in Numidia." Opus 2, 133-159.

-. 1984. "Bandits in the Roman Empire." Past \& Present 105, 3-52.

-. 1990a. "Bandit highlands and lowland peace: The mountains of Isauria-Cilicia." Journal of the Economic and Social History of the Orient 33.2, 199-233.

-. 1990b. "Bandit highlands and lowland peace: The mountains of Isauria-Cilicia (continued)." Journal of the Economic and Social History of the Orient 33.3, 237-270.

Sherk, R. K., ed. and trans. 1984. Rome and the Greek East to the death of Augustus. Cambridge: Cambridge University Press.

Sherwin-White, A. N. 1973. The Roman citizenship. 2nd ed. Oxford: Clarendon.

-. 1984. Roman foreign policy in the East: 168 BC to $A D$ 1. London: Duckworth.

Sidebotham, S. E., M. Hense, and H. M. Nouwens. 2008. The Red Land: The illustrated archaeology of Egypt's Eastern Desert. Cairo: The American University in Cairo Press.

Sirks, B. 2018. "Law, commerce, and finance in the Roman Empire." In Wilson and Bowman (2018), 53-116.

Sommer, C. S. 2009. "Why there? The positioning of forts along the riverine frontiers of the Roman Empire." In W. S. Hanson (ed.), The army and frontiers of Rome: Papers offered to David J. Breeze on the occasion of his sixty-fifth birthday and his retirement from Historic Scotland, 103-114. Portsmouth, RI: Journal of Roman Archaeology.

Sommer, M. 2005. Roms orientalische Steppengrenze: Palmyra - Edessa - Dura-Europos - Hatra: Eine Kulturgeschichte von Pompeius bis Diocletian. Stuttgart: Franz Steiner.

Southern, P. 2007. The Roman army: A social and institutional history. Oxford: Oxford University Press.

Speidel, M. A. 1992. “Roman army pay scales.” Journal of Roman Studies 82, 87-106.

-. 2009. Heer und Herrschaft im römischen Reich der hohen Kaiserzeit. Stuttgart: Franz Steiner.

-. 2010. "Pro patria mori ...: La doctrine du patriotisme romain dans l'armée impériale." Cahiers du Centre Gustave Glotz 21, 139-154.

-. 2014. “Roman army pay scales revisited: Responses and answers.” In M. Reddé (ed.), De l'or pour les braves! Soldes, armées et circulation monétaire dans le monde romain: Actes de la table ronde organisée par l'UMR 8210 (AnHiMa) à l'institut national d'histoire de l'art (12-13 septembre 2013), 53-61. Bordeaux: Ausonius.

-. 2016. "Wars, trade and treaties: New, revised, and neglected sources for the political, diplomatic, and military aspects of Rome's relations with the Red Sea Basin and India, from Augustus to Diocletian." In K. S. Mathew (ed.), Imperial Rome, Indian Ocean regions and Muziris: New perspectives on maritime trade, 83-128. London: Routledge.

-. 2019. “Rom und die Fernhandelswege durch Arabien.” In A. Kolb (ed.), Roman roads: New evidence - new perspectives. Berlin: De Gruyter.

Staccioli, R. A. 2003. The roads of the Romans. Los Angeles, CA: J. Paul Getty Museum.

Stek, T. D., and J. Pelgrom, eds. 2014. Roman Republican colonization: New perspectives from archaeology and ancient history. Rome: Palombi Editori.

Stoll, 0. 2016. “Melonen, Mähmaschinen und Manager: Limeszonen als transkulturelle (Wirtschafts-)Räume.” In K. Droß-Krüpe, K. Ruffing, and S. Föllinger (eds.), Antike Wirtschaft und ihre kulturelle Prägung: The cultural shaping of the ancient economy, 235-266. Wiesbaden: Harrassowitz.

Syme, R. 1939. The Roman revolution. Oxford: Clarendon.

Talbert, R. J. A. 2012. "Roads not featured: A Roman failure to communicate?" In S. E. Alcock, J. Bodel, and R. J. A. Talbert (eds.), Highways, byways, and road systems in the pre-modern world, 235-254. Malden, MA: Wiley-Blackwell.

Tan, J. 2015. “The Roman Republic.” In A. Monson and W. Scheidel (eds.), Fiscal regimes and the political economy of premodern states, 208-228. Cambridge: Cambridge University Press. 
-. 2017. Power and public finance at Rome, 264-49 BCE. Oxford: Oxford University Press. Tchernia, A. 2016. The Romans and trade. J. Grieve (trans.). Oxford: Oxford University Press. Terpstra, T. T. 2013. Trading communities in the Roman world: A micro-economic and institutional perspective. Leiden: Brill.

Van Dinter, M. 2013. "The Roman limes in the Netherlands: How a delta landscape determined the location of the military structures." Netherlands Journal of Geosciences 92.1, 11-32.

Verboven, K. S. 2002. The economy of friends: Economic aspects of amicitia and patronage in the Late Republic. Brussels: Latomus.

-. 2007. "Good for business: The Roman army and the emergence of a 'business class' in the northwestern provinces of the Roman Empire (1st century BCE-3rd century CE)." In Blois and Lo Cascio (2007), 295-314.

-. 2011. "Friendship among the Romans." In M. Peachin (ed.), The Oxford handbook of social relations in the Roman world, 404-421. Oxford: Oxford University Press.

Versluys, M. J. 2014. "Understanding objects in motion: An archaeological dialogue on Romanization." Archaeological Dialogues 21.1, 1-20.

von Reden, S. 2010. Money in classical antiquity. Cambridge: Cambridge University Press.

Wallace-Hadrill, A. 2008. Rome's cultural revolution. Cambridge: Cambridge University Press.

Weaverdyck, E. J. S. 2016. "Isolation or integration? A spatial analytical approach to the local impact of the Roman army on the northern frontier." PhD diss., University of California.

Wheeler, E. L. 2007. "The army and the limes in the East." In P. Erdkamp (ed.), A companion to the Roman army, 235-266. Malden, MA: Blackwell.

Whitmarsh, T. 2009. "Greece and Rome." In G. Boys-Stones, B. Graziosi, and P. Vasunia (eds.), The Oxford handbook of Hellenic studies, 114-128. Oxford: Oxford University Press.

-, ed. 2010. Local knowledge and microidentities in the imperial Greek world. Cambridge: Cambridge University Press.

Whittaker, C. R. 1994. Frontiers of the Roman Empire: A social and economic study. Baltimore, MD: Johns Hopkins University Press.

-. 2002. "Supplying the army: Evidence from Vindolanda." In Erdkamp (2002), 204-234.

Wierschowski, L. 1984. Heer und Wirtschaft: Das römische Heer der Prinzipatszeit als Wirtschaftsfaktor. Bonn: Habelt.

Wilson, A. 2007. "The metal supply of the Roman Empire." In E. Papi (ed.), Supplying Rome and the empire: The proceedings of an international seminar held at Siena-Certosa Di Pontignano on May 2-4, 2004 on Rome, the provinces, production and distribution, 109-125. Portsmouth, RI: Journal of Roman Archaeology.

Wilson, A., and A. K. Bowman, eds. 2018. Trade, commerce, and the state in the Roman world. Oxford: Oxford University Press.

Wilson, A., K. Schörle, and C. Rice. 2012. "Roman ports and Mediterranean connectivity." In Keay (2012), 367-392.

Winterling, A. 2009. Politics and society in imperial Rome. Malden, MA: Wiley-Blackwell.

Witcher, R. 2017. "The globalized Roman world." In T. Hodos (ed.), The Routledge handbook of archaeology and globalization, 634-651. London: Routledge.

Woolf, G. 1994. "Becoming Roman, staying Greek: Culture, identity and the civilizing process in the Roman East." Cambridge Classical Journal 40, 116-143.

-. 1998. Becoming Roman: The origins of provincial civilization in Gaul. Cambridge: Cambridge University Press.

-. 2012. Rome: An empire's story. Oxford: Oxford University Press.

Yarrow, L. M. 2012. “Antonine coinage.” In Metcalf (2012), 423-452. 
Part II: Evidence 



\section{Sitta von Reden \\ Introduction}

As primary sources are the historian's most important resource, the quantities and diversity of evidence to be considered for the global study of connectivity pose the greatest challenge to world-historical research. The linguistic skills needed for discovering connections and relationships between texts, and assessing their impact, far exceed the capacity of a single scholar. Using non-textual sources in any meaningful and scientifically acceptable way requires further methodological expertise. New methodologies evolve constantly, and the stock of primary evidence increases through archaeological excavation, the discovery of new texts, and the vagaries of the art market. Historians have approached the source problem in different ways. For some critics, world history can never be a field of research, but just a method of instruction that directs students away from limited national perspectives toward broader contexts and connections. ${ }^{1}$ It has also been contended that historians and sociologists not using primary sources are capable of only second-order interpretation. ${ }^{2}$ Others are less pessimistic and practice world-historical research by using primary sources from one tradition, and relying on syntheses in secondary sources for comparative material. ${ }^{3}$ Alternatively, a mix of primary sources, published translations, and secondary sources are consulted to establish a solid historical grounding for research across disciplines. Yet other world historians turn to micro-histories, area studies, or material culture studies in order to reveal the ways the global (or wider) world is used, appropriated, or negotiated on the local level. ${ }^{4}$

These are legitimate interventions and methodological avenues out of a problem that threatens the credibility of world history as a field of research. It is our conviction, however, that the situation is improving. Translations, digitization, and digital communication have radically transformed the conditions of historical research. Only a few decades ago, large corpora of texts and data were enclosed in inaccessible volumes, difficult for outsiders to find, difficult to use, and impossible to read without the appropriate language skills. Over the last 20 years, a tremendous amount of academic energy has been devoted to developing more accessible, multi-language editions of texts, translations, and digital platforms presenting archival material. They have by no means made disciplinary training in reading and evaluating ancient material dispensable, nor have they made the encounter with

1 Weinstein 2012, 63-64.

2 Adas 2012, 232.

3 Weinstein 2012, 73.

4 Pitts and Versluys 2016.

Ә Open Access. () 2020 Sitta von Reden, published by De Gruyter. (c) BY-NC-ND This work is licensed under the Creative Commons Attribution-NonCommercial-NoDerivatives 4.0 License.

https://doi.org/10.1515/9783110607741-010 
the materiality of texts and objects that have survived from ancient worlds dispensable. Yet they enable nonspecialists with greater confidence than ever before, to familiarize themselves with edited texts, translations, and digital resources. The ever-wider availability of primary evidence from different regions of the world bears enormous potential, but also some dangers.

Against this background, the following chapters pursue two slightly contradictory goals. On the one hand, they aim to introduce readers to the scope of and access to, primary sources that can be used for particular questions of economic history in the vast expanse of the Afro-Eurasian region. They aim to offer guidance to the most important texts and editions, archaeological projects, and numismatic methods. They sample methods of interpretation - some of them well established and others more novel - and refer to study aids that in some disciplines are available in great quantity. On the other hand, we want to express a call of caution. We aim to show that at the foundation of the fascinating story of world historical connections and developments there lies a highly fragmentary and fragile body of evidence that is most difficult to make speak to the questions we wish to be answered. Great care must be taken not to overinterpret or decontextualize this evidence, or to appropriate it superficially for our contemporary concerns. Ancient texts usually have their very own argumentative purpose and are not open windows into the past. Archaeological data are by no means 'raw,' but reflect archaeologists' interests and preoccupations; many bodies of material are difficult to date, and are spread unevenly across space and time.

As in the previous section, the chapters deal with different quantities and qualities of evidence. In the case of Greek, Roman, and Chinese sources, both their range and volume is so large that we have divided the chapters into subcategories. In many instances, we have relied on a combination of synthesizing overviews with deeper treatments of selected examples and case studies to bring out specificities in the sources. In the case of Indic sources, there are equally large quantities of texts, coins, visual, and archaeological material, but in each case it is rather controversial how to use them as sources for history and economic history in particular. Thus the discussions of that chapter deal primarily with this question. The history of Central Asia, moreover, is a rather young field of scholarship, given that the evidence is largely archaeological and numismatic. This chapter most comprehensively introduces the reader to the range of projects that are currently taking place, but which to date can simply promise to shed more light on economic questions that so far lie largely in the dark.

\section{References}

Adas, M. 2012. "Comparative history and the challenge of the grand narrative." In D. Northrop (ed.), A companion to world history, 229-243. Oxford: Wiley Blackwell. 
Pitts, M., and M. J. Versluys 2015. "Globalization and the Roman world: Perspectives and opportunities." In M. Pitts and M. J. Versluys (eds.), Globalisation and the Roman world: World history, connectivity and material culture, 3-31. New York: Cambridge University Press. Weinstein, B. 2012. "The world is your archive? The challenges of world history." In D. Northrop (ed.), A companion to world history, 63-78. Oxford: Wiley Blackwell. 



\section{Graeco-Roman Evidence}

\section{Eli J. S. Weaverdyck \\ 8.A Material Evidence}

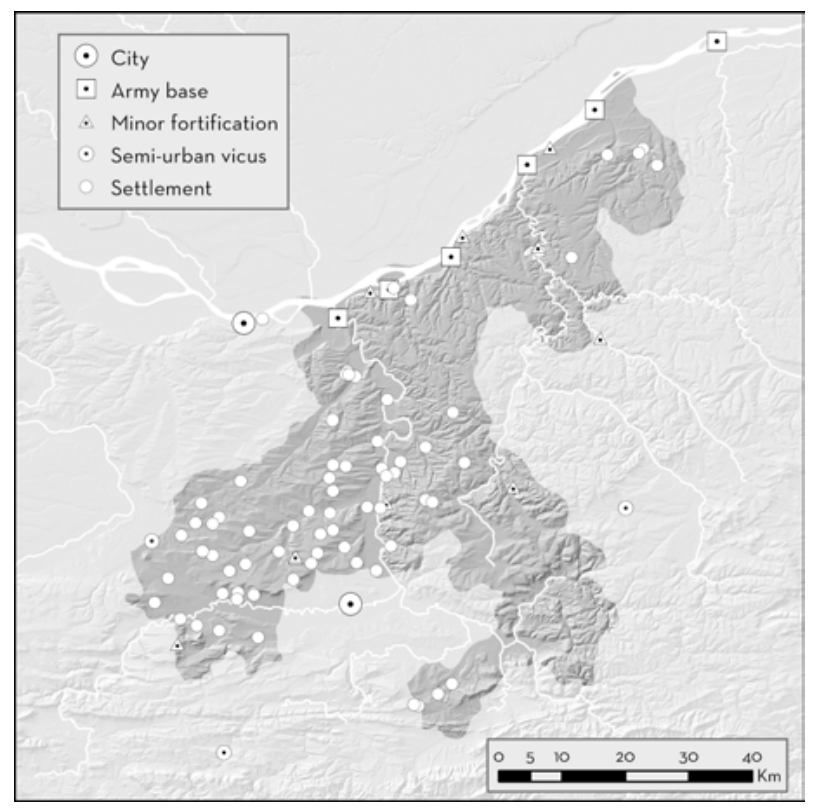

Map 1: Roman settlement in the central part of the Lower Danubian plain, modern Bulgaria. (C) Eli J. S. Weaverdyck.

\section{Introduction}

It might be surprising to use a map to introduce a chapter on the sources of economic history in the Greek and Roman world. Other sources have a longer tradition of scholarship and are much more influential in current debates. This map, however, depicts a landscape as modeled in a geographic information system (GIS). It represents the ways scholars are using modern technology to expand the range of sources

Note: This chapter has benefited from the comments of several specialists. I would like to thank Nicholas Hudson for his comments on section 4 (pottery), Hannah Lau for her comments on section 5.3 (isotopes), and Demetrios Brellas for his comments on section 6 (faunal remains). Any errors remain my own. 
of evidence for economic history. This technology is providing more data and more ways to analyze data than ever before, allowing us to recontextualize and reanalyze information created by previous scholars. A GIS-based analysis of a landscape will illustrate one of the many ways this can be done.

The evidence in this map shows that, in the late second and early third century, in a distant corner of the empire on the edge of the Danube, the Roman economy was booming. Not only was fine pottery being produced by specialist potters and stone being quarried and carved, the map shows that more people were farming the land more intensively than ever before and selling their products in urban markets. ${ }^{1}$ While artifacts and architecture tell us a great deal about the economic activity of a few larger centers, GIS-based analysis of the landscape tells us about the economy of the region as a whole, giving us a broader perspective than would be possible using traditional archaeological evidence.

This chapter cannot cover the entirety of archaeological sources used to write economic history in the ancient Mediterranean in detail. Instead, I try to give an impression of their range while highlighting new sources and techniques. I will provide examples of how different sources have been exploited, emphasizing those that are especially helpful in understanding frontier zone processes. Choosing examples is difficult because ancient economic historians rarely rely on a single type of evidence. There is no single category comprehensive enough to bear the weight of interpretation on its own. Scholars usually start with questions, then collect all the evidence from any source that helps them to craft convincing answers. The examples presented below are of scholarship based primarily, but never exclusively, on one type of evidence. They are meant to illustrate the methods of analysis appropriate to that type, as well as its potential and limitations for economic history. After describing the GIS-based analysis of settlement landscapes, I will discuss digital data and quantification, pottery, human remains, the remains of animals, and air pollution. In parts B and C of this chapter, we discuss written and documentary sources, which enjoy a longer history of scholarship.

\section{Landscapes and GIS}

Geographic information systems are ways of storing, visualizing, and analyzing data with a spatial component. ${ }^{2}$ While spatial data distinguishes GIS from other methods of analysis, it is the linkage of location to other types of information that gives GIS its power. The locational data can be analyzed in the context of information about other phenomena that also have a spatial aspect, like the shape of the terrain, soil

1 Weaverdyck 2016.

2 GIS today refers to computer software, but in principle a GIS need not be digital. Indeed, it is often said that John Snow's contemporary map of the 1854 cholera epidemic in London represents one of the first uses of GIS. 
types, and other archaeological features. Spatial data have been central since the inception of the field of archaeology, and the use of GIS software was quickly and widely adopted when it became available in the 1980s. ${ }^{3}$

For economic historians, the ability to quantify and analyze ancient landscapes is one of GIS's most useful capabilities. Here, the term 'landscape' refers to the physical environment, both natural and cultural, as experienced by its inhabitants. The landscape emerges from the relationship between subjective, strategic actors and their surroundings. By integrating archaeological remains (traces of human behavior) with information about the natural environment, we can begin to reconstruct the landscapes in which people lived, the constraints and opportunities afforded by those landscapes, and the economic strategies that were most likely pursued in the past. ${ }^{4}$

The archaeological data on which landscape archaeology depends come primarily from a combination of extensive and intensive survey. ${ }^{5}$ Extensive survey consists of compiling information about all known archaeological sites in an area and may involve expeditions aimed at discovering new sites. This type of survey can cover a very large area, but will usually only capture the most visible archaeological material, such as architecture or large quantities of pottery. The most serious problem with extensive survey is discovery bias. It can be difficult to know whether the absence of a site in a given place reflects a lack of archaeological material or a lack of investigation. ${ }^{6}$ Intensive survey involves the systematic observation of the ground surface. Often this is done by a group walking in a line at specific intervals and counting and/or collecting archaeological material. This technique facilitates the discovery of smaller sites and permits investigation into small-scale processes of land use. It also allows for systematic sampling of an area, enabling more secure generalizations about the nature of the archaeological material found. Nevertheless, increasing the intensity of survey also means decreasing the area that can be surveyed, which can make it difficult to arrive at sample sizes large enough to support interpretation. ${ }^{7}$

3 Overviews on the use of GIS in archaeology, both monographs and edited volumes, have been published periodically since the late 1980s. Howey and Brouwer Burg 2017 is only the most recent. For precursors from the 1970s, see Clarke 1977; Hodder and Orton 1976.

4 For this definition of 'landscape,' see Ingold 1993. For an introduction to landscape archaeology, see David and Thomas 2008.

5 Remote sensing - the detection of archaeological features through the analysis of satellite imagery, LiDAR data, ground-based subsurface prospection, etc. - is also an important source of evidence, but it cannot be treated here. For introductions, see Parcak 2017; Forte and Campana 2016. Campana 2018 calls for greater integration of different methodologies, including remote sensing and field walking, in landscape analysis.

6 The relationship between archaeological sites and ancient behaviors is not straightforward, but most archaeologists still find the site to be a useful heuristic tool. For the problem of the site, Dunnell 1992.

7 Banning 2002 provides an excellent overview of surface survey methods. For the Mediterranean in particular, the articles collected in Francovich, Patterson, and Barker 2000 and Alcock and Cher- 
Once collected, archaeological data are interpreted to gather information about the distribution of human activity areas - particularly settlements - across the landscape. In agricultural societies, the smallest sites are usually taken to indicate the locations of ancient farming settlements. ${ }^{8}$ Since the daily routines of agriculturalists usually begin and end in settlements, these provide an emic perspective from which to view the ancient environment, a crucial step in reconstructing the ancient experienced landscape.

Site catchment analysis (SCA) is a method of analyzing the landscape surrounding a settlement to understand the resources available to its inhabitants and which economic strategies they might have followed. ${ }^{9}$ Recently, Helen Goodchild has used a version of this technique with GIS analysis to understand Roman agricultural systems in central Italy. ${ }^{10}$ Using ancient agricultural writings and scientific knowledge, she models the agricultural productivity of the landscape under different cultivation regimes. She then estimates production and consumption in the areas around known sites to determine how surpluses might have been generated and how large they might have been. While these models cannot be considered accurate portrayals of the agricultural strategies pursued in antiquity, they are good representations of the web of interconnected factors influencing production. They reveal the limits of what was possible in a given landscape and the consequences of different strategies. They also reveal the extent of regional and local variation in productivity, which can be compared to archaeological evidence about the nature of the settlements. In one area, villas (wealthier rural estates) that were inhabited in both the Late Republic and the Early Principate had better land than the poorer farms with similar occupation histories. However, when comparing new foundations in the Early Principate, the farms actually had better land. This could be related to tenancy arrangements, in which the villa owners were less interested in production around the villa itself than in the productivity of the farms from which they extracted rents, but other explanations cannot be ruled out. In any case, Goodchild's GIS-enabled analysis of site catchments has deepened our understanding of agricultural production in central Italy and raised interesting new questions.

In my analysis of the rural economy on the Lower Danube, I followed a different method. ${ }^{11}$ Rather than starting from ancient and modern agricultural knowledge to deductively estimate the productive capacity of the landscape, I inductively examined the location preferences of settlements. I compared the prevalence of various

ry 2004 introduce the most commonly used methods and issues, including the debate about the value of increasing survey intensity, for which, see especially Fentress 2000; Terrenato 2004.

8 The essays collected in Attema and Schörner 2012 discuss the difficult issue of characterizing small sites.

9 First proposed by Vita-Finzi and Higgs (1970). See also Roper 1979. Farinetti applies the closely related 'community area theory' to Boiotia in Greece (2011).

10 Goodchild 2013; Goodchild and Witcher 2009.

11 See for the following Weaverdyck 2016; Weaverdyck 2019. 
landforms in settlement territories to their overall prevalence in the study area to determine which were favored and avoided at different periods. Interpreting the results in light of Roman agricultural literature, I found that settlements in the Roman period preferred features identified as agriculturally productive, but in Late Antiquity, they favored features associated with defensible locations. This suggests that Roman-period settlers felt safe enough to maximize productive capacity, while those in Late Antiquity compromised productivity for security. Alternatively, the Late Antique settlers could have engaged in agricultural strategies that were less dependent on the condition of the land surrounding their settlement. As with Goodchild's models, my own have generated interesting conclusions while raising further questions.

GIS modelling is also useful for understanding the ways that different places in the landscape interacted, providing evidence about local-scale marketing, for example. If farmers regularly sold their crops at a nearby marketplace or anticipated doing so when they established a farm, most farms ought to minimize the distance to that place while simultaneously maintaining access to productive land. Multivariate statistical analysis can separate the influence of marketplace proximity on settlement patterns from the influence of landscape productivity. Furthermore, by comparing how well different multivariate models fit the observed data, it becomes possible to test hypotheses about the role of different places within an entire marketing system. In the frontier zone of the Lower Danube, for example, I was able to determine that auxiliary forts - despite their access to money and their lack of resident farmers - did not function as marketplaces in the local, rural economy.

By using GIS to analyze archaeological and environmental data, it becomes possible to examine behavior that leaves little trace in the archaeological record. The tools used in agricultural production are rarely found and difficult to date. Local marketing of agricultural surplus involves perishable goods carried in perishable containers. If the location of settlements can be found, however, the landscape can provide hints about production strategies, and if the locations of possible markets can be identified, the importance of marketing in the rural economy can be assessed. Excavation of rural settlements adds valuable detail and nuance, but is extremely costly and only a few sites will ever be excavated. GIS allows us to take advantage of data that would otherwise be too vague to be useful and allows us to draw conclusions that are generalizable to an entire region.

\section{Digital Data and Quantification}

The Roman Empire has enjoyed a long history of scholarship, resulting in a truly massive amount of data compared to other ancient societies. The development of digital technology and the internet is making those data not only more accessible than ever before, but accessible in very different ways. Large encyclopaedias and 
ancient texts reach a wider audience by being available in digital format. ${ }^{12}$ More transformational are the efforts of projects and individuals to create and publish databases. These data are structured and interlinked in a way that makes it easier to query, organize, summarize, and analyze them for the purpose of answering a specific question. Online databases now exist for a range of types of evidence and at a variety of scales. We are still in the early phases of database construction, however, so while the number of databases is growing, the variety in scope, structure, and functionality means that some topics, regions, and periods are better covered than others. The rapid pace at which the field is developing means that any printed overview will soon be out of date, but a few examples of the most widely used databases are described here nevertheless.

Data about ancient places are currently collected by Pleiades. ${ }^{13}$ It started with a focus on the ancient Graeco-Roman world, but is expanding. Ancient geographical data are often fragmented, incomplete, and vague, so Pleiades uses a tripartite data structure that allows it to include the maximum amount of data possible. The three types of data are: place, a conceptual entity like 'the city of Rome'; location, a set of geographic coordinates that might represent the center of the city, the outlines of walls, the forum, and so on; and name, a linguistic identifier of the place. This allows Pleiades to include both unnamed places attested through archaeological remains and places that are attested in ancient sources but lack a known location. Pleiades maintains a Unique Resource Identifier (URI) for every place, which other online resources can use to specify places precisely and link their data to a location. The coin data base Nomisma.org, for example, uses Pleiades's URIs to identify mint locations. Although the website so far provides only simple search capability, the data are downloadable, allowing for use and manipulation in other software.

Like Pleiades, Nomisma seeks to establish stable URIs for a variety of concepts related to a single phenomenon, in this case, coins. ${ }^{14}$ These concepts include things like denomination, material, mint, issuing authority, etc. By using these URIs, different databases of coins and coin types can be integrated. ${ }^{15}$ It also allows users to construct queries about various typological and metrical aspects and quickly generates graphs of the output. So, for example, one can easily create a graph of how the average weight of the denarius changed over a given time period or one showing the relative proportion of different denominations issued by Augustus. Crucially, the data behind these graphs are downloadable in .csv format for verification and further manipulation.

Epigraphic databases segregate Latin from Greek inscriptions, and the coverage of the two is uneven. For Latin inscriptions, the Epigraphik-Datenbank Clauss/Slaby

12 See, e.g., Brill's New Pauly Online (https://referenceworks.brillonline.com/browse/brill-s-newpauly) and the Perseus Digital Library (http://www.perseus.tufts.edu/hopper/).

13 https://pleiades.stoa.org/

$14 \mathrm{http}: / /$ nomisma.org/

$15 \mathrm{http} / / /$ nomisma.org/datasets 
is the most comprehensive to date, with information about 513,521 inscriptions as of this writing. ${ }^{16}$ In addition to simple text searches, available queries include publication, province, place, date range, inscription type, and even personal status. For example, querying by inscription type, province, and date range, one quickly finds that the number of mile stones in the province of Syria dating to each of the first three centuries $\mathrm{CE}$ is 7, 41, and 10. Each entry includes the text, a reference to the original place of publication, precise dating, and find spot. The best resource for Greek epigraphy is the Packard Humanities Institute's Searchable Greek Inscriptions, but the only queries available are for text and region. ${ }^{17}$

Several databases useful for the study of the Roman economy have been constructed and published as part of the Oxford Roman Economy Project (OxREP), a research program that seeks to better understand the Roman economy through the construction, analysis, and publication of quantitative archaeological and documentary data. ${ }^{18}$ The project currently hosts databases about cities, mines, olive oil and wine presses, shipwrecks, stone quarries, and water technology from the entire Roman Empire, and tax rolls from the Egyptian village of Karanis. ${ }^{19}$ They are designed to be easily queried, and visual representations of the data are often available in the form of timelines, maps, or both.

All of these databases are part of a larger quantitative turn in the study of the ancient economy. Although quantitative data have long been used by some economic historians, the popularity of quantification has grown quickly in recent years due to the increased availability of data and the development of new methods to exploit them. ${ }^{20}$ Quantitative evidence is often seen as more empirically sound and amenable to more rigorous analysis than qualitative evidence, but the reasoning is rarely made explicit. After all, humans understand the world in qualitative terms, and numbers in themselves are often meaningless. ${ }^{21}$ The significance of the figures derived from quantitative analysis comes from the interpretive context. Above all, quantification allows for greater precision than qualitative descriptors such as 'large' or 'significant,' which, in turn, allows for comparison on a variety of axes. By reducing complex, unique phenomena to numbers, we can decide whether the Roman economy was more or less productive than, for example, that of classical Greece, the High Middle Ages, or Han China. We might also compare the relative contributions of various factors to a certain phenomenon. Quantification can also

\footnotetext{
16 http://www.manfredclauss.de/

17 http://inscriptions.packhum.org. For papyrological databases, see von Reden, ch. 8.C, this volume.

$18 \mathrm{http}: / /$ www.romaneconomy.ox.ac.uk/

19 http://oxrep.classics.ox.ac.uk/databases/

20 For a historical perspective on quantitative approaches to the ancient economy, see de Callataÿ 2014; von Reden, ch. 8.C, this volume.

21 One is reminded of Douglas Adams's absurdly quantitative answer to the question of "life, the universe and everything" in The Hitchhiker's Guide to the Galaxy (1979).
} 
allow us to compare how well different models fit empirical data, as in the analysis of rural marketing systems described above. Numbers also make it possible to track diachronic change, as in the example of lead and copper pollution below. It is the comparability provided by (more-or-less) precise numbers that makes quantitative analysis more empirically robust than qualitative analysis. Even so, the use to which scholars put these numbers depends heavily on the questions they ask and their theoretical background. Quantification is not a unified methodology or approach. It is a tool, or better, a type of tool, for there are many ways to quantify and many ways of analyzing numbers. ${ }^{22}$

\section{Pottery}

Pottery is ubiquitous in the Mediterranean. ${ }^{23}$ It is the single most commonly encountered type of artifact in any archaeological investigation and therefore has played a large role in the study of the ancient economy. The simple ubiquity and quality of Roman pottery has been taken as evidence for high standards of living. ${ }^{24}$ Most commonly, however, it has been used to identify trade networks and to trace their development over time. Pottery has also been used to study the nature of the exchange mechanisms that distributed it, sometimes over very long distances.

\section{IV.1 Pottery as Data}

Pottery can support these analyses because it is often possible to assign a particular vessel, with more or less precision, to a particular place of origin and chronological period. This is done primarily on the basis of typologies. Ceramic vessels can be classified in a number of ways. At a general level, most archaeologists working in the Mediterranean recognize functional categories like table service, storage and/or transport vessels, cooking pots, and so on. Typologies are more precise classifications, usually built to understand a certain category of material from a specific site or region. They classify material based on several criteria, often including form (the

22 For a theoretically oriented examination of quantification, see Morley 2014.

23 Hayes 1997 provides an introduction to Roman pottery. For manuals on the archaeological study of pottery in general, see Orton and Hughes 2013; Sinopoli 1991. Peacock 1982 is a fundamental study framing Roman pottery production while Peña 2007 is foundational for the use, reuse, and discard of Roman pottery. The study of Greek pottery has historically been dominated by figural vases that largely predate our period, but the foundation of the International Association for Research on Pottery of the Hellenistic Period (IARPotHP) in 2011 shows that interest in this material is increasing (http://iarpothp.org). The essays collected in Fenn and Römer-Strehl 2013 demonstrate the breadth and promise of the field.

24 Ward-Perkins 2005. 
shape of the vessel and its component parts), fabric (the fired clay material from which it is made), subtle indications of production techniques, and surface treatment. ${ }^{25}$ By classifying groups of pottery into types on the basis of well-defined criteria, archaeologists can understand how the pots relate to each other, identifying sets of vessels that share certain production techniques or tracing how types change over time, for example. Vessels that come from a certain potting tradition and share distinctive characteristics are called a 'ware. ${ }^{26}$ In some cases, these have been identified at a large number of sites, and broader typologies describing material from many sites have been constructed. ${ }^{27}$

To mobilize these data, it is necessary to quantify the amount of pottery of different types present in a given assemblage. ${ }^{28}$ This is difficult because the archaeological assemblage consists of broken and incomplete pots. Four measures are commonly used: sherd count, weight, minimum number of individuals (MNI), and estimated vessel equivalent (EVE). Simply counting sherds (broken pieces of pottery) is straightforward but problematic because pots break into different numbers of pieces depending on their physical properties and the processes that have affected them since they stopped being used (these are called 'transformation processes'). These same processes and the collection method employed by archaeologists also affect recovery, meaning that some portion of the sherds from a pot are never found. Thus, all samples are biased, and that bias changes between assemblages that have been submitted to different transformation processes. Weighing pottery types is better because, although the sample is biased toward heavier types, the bias does not vary as much between assemblages, allowing the proportions of different types to be compared across assemblages. MNI is calculated by grouping all sherds that could belong to the same vessel and counting them once. Since most vessels have only one rim and base, these are often used. EVE measures quantity in terms of the fraction of vessels represented, usually using rims. Using a rim chart, one measures the fraction of a circle represented by each rim sherd and sums these to arrive at a total estimated vessel equivalent. Clive Orton has compared these measures and argued that weight and EVE provide the most reliable basis for interassemblage comparison, but sherd count and MNI are still commonly used as well. ${ }^{29}$

25 Typologies can be constructed in a variety of ways using different criteria for different purposes. For overviews, see Orton and Hughes 2013, 190-202 and Sinopoli 1991, 43-67. For a theoretical examination of how archaeological typologies are formed, see Adams and Adams 1991.

26 The term 'ware' is also sometimes used when referring to functional categories, e.g., 'tableware' or 'cookware,' but here it will be used in a narrower sense.

27 The definition of wares and typologies is subject to a great deal of interpretation. Bes (2015, 1126) describes in detail the eight red-slipped wares most commonly found in the Eastern Mediterranean, including a history of their typological definition, which illustrates the process of constructing broad typologies.

28 For an accessible introduction to pottery quantification, see Orton and Hughes 2013, 203-218. Verdan 2011 presents recommendations for standard practices.

29 Orton 1993. 
The place where a type of pottery was produced can be determined in several ways. Scientific analysis of the fabric can reveal the source of the clay and is usually seen as the most certain indication. ${ }^{30}$ Some types of clay, however, are too widely dispersed for fabric analysis to be useful. The excavation of a production center also provides definite evidence for the origin of some types. For many wares and types, however, origin is inferred on the basis of distribution on the assumption that a type will appear most frequently in the area in which it was produced. ${ }^{31}$

In Mediterranean archaeology, pottery is the primary method of dating archaeological deposits. ${ }^{32}$ Pottery forms can be put into a relative sequence within a typology by observing the stratigraphic sequence of deposits in which they are found and by observing subtle differences between otherwise similar pots that mark the evolution of a form over time. Absolute dates come from other artifacts associated with the pottery in a stratigraphic deposit. Coins and wood (dated through dendrochronology, see below) as well as other types of pottery with a better known chronology are common sources of such information.

Another method, used when secure stratigraphic information is not available, is seriation. This technique is based on the assumption that, after it is introduced, types of pottery generally grow and then fade in popularity. Archaeologists quantify the abundance of a type in multiple assemblages and then rearrange the assemblages until the frequency grows and diminishes smoothly. When this is done for multiple types of pottery that occur in a set of assemblages, a larger sequence showing the relative chronology of different types can be built. Additional information is necessary to determine the direction of the sequence and its absolute chronology. ${ }^{33}$

The chronological evidence provided by pottery, then, is indirect, inferred from the identification of a given artifact as an example of a certain type within a typology that itself is dated more or less securely and precisely through association with other remains. Furthermore, many types of pottery remain in use unchanged for a long period of time. It is very rare that pottery can be dated to the quarter century or less; ranges of several centuries are much more common.

One method of dealing with this lack of precision that is becoming more popular is aoristic dating. In this method, a range of possible dates is established for each member of the group under investigation, be it a potsherd, a settlement, or a shipwreck. Then, that member is divided and a fraction assigned to each time-slice within that range such that the total adds up to one. Thus, in a graph showing the frequency of shipwrecks by century, a wreck dated to the second and third century CE would appear as half of a wreck in the second century and half of a wreck in the

30 Orton and Hughes 2013, 150-189; Hunt 2017.

31 Orton and Hughes 2013, 235-245.

32 Sinopoli provides a clear introduction to reconstructing chronologies (1991, 74-81). Orton and Hughes go into more detail (2013, 219-234).

33 There are several more or less statistically sophisticated methods of seriation. For an overview, see Orton and Hughes 2013, 226-232. 
third century. ${ }^{34}$ In this way, the uncertainty inherent in the data is preserved in the analysis.

\section{IV.2 Archaeological Ceramics in the Mediterranean}

Mediterranean pottery differs from that found in many parts of the world in three ways. First, the amount of pottery discovered from archaeological excavations and surface surveys is massive. One not very large project in northern Greece discovered almost 100,000 sherds weighing over half a metric ton in its first season alone. ${ }^{35}$ Recording practices in each project must be tailored not only to address individual research questions, but to deal effectively with the quantity of material given limited resources. This leads to variation between projects that must be accounted for when comparing assemblages.

Second, there are certain broad classes of pottery that are common in the region and enjoy a long history of scholarship. The two most extensively studied functional classes of pottery are transport amphorae and fine table service. ${ }^{36}$ The latter consist of vessels made from fine clay used for serving and consuming food. They are usually covered with a glossy black or red slip, and are often otherwise decorated. ${ }^{37} \mathrm{Am}$ phorae - large jars with a narrow mouth, two handles, and normally a spiked toe were the most common type of shipping container in the ancient Mediterranean used to ship liquids, especially wine and olive oil, and other goods. ${ }^{38}$

34 Keith Hopkins (1980) was the first to use a graph showing the changing frequency of shipwrecks in the Mediterranean as evidence for economic growth. The data were more fully published by Parker in 1992, and OxREP expanded the dataset and published it online (n. 18 above). Wilson (2009) redrew the graph using aoristic dating. For a detailed discussion of chronological uncertainty in quantitative analysis with a focus on settlement patterns, see Crema 2015

35 Arrington et al. 2016, 12.

36 Cooking ceramics - vessels used for food preparation - are equally important, but the history of scholarship on them is much shorter. The essays in Spataro and Villing 2015 provide an overview. 37 For a concise summary of Hellenistic table service, see Hayes 1991. The terms 'terra sigillata' and 'Samian ware' (more common in the UK) refer to ceramics made of fine clay with a glossy red surface. The most recent and comprehensive studies of the vessels and the stamps are Oxé, Comfort, and Kenrick 2000 (Italian sigillata); Hartley and Dickinson 2008-2012 (Gaulish sigillata); Bes 2015 (Eastern Sigillata). The data are also available online in two different databases: https:// www.rgzm.de/samian for the Gallic and Italian material, http://icrates.arts.kuleuven.be/icrates/ for the Eastern Mediterranean.

38 For a useful introduction to Roman amphorae as evidence for economic history, see Peacock and Williams 1986. The online database Roman Amphorae provides an introduction to Roman amphora studies and a catalog of amphora types (http://archaeologydataservice.ac.uk/archives/view/ amphora_ahrb_2005/index.cfm). For an overview of Greek amphora studies, see Eiring and Lund 2004 (with a focus on the Eastern Mediterranean) and Whitbread 1995 (with an emphasis on petrography). 
Third, there are several types of amphorae and table service wares that were produced on a very large scale and distributed over long distances. ${ }^{39}$ The widespread distribution of inexpensive vessels and of containers for inexpensive foodstuffs shows that long-distance trade was not restricted to items with a high valueto-weight ratio, as in other historical contexts. Since the production of pottery formed a relatively small part of the overall economy, we will focus here on its distribution as a marker for more substantial economic activities.

\section{IV.3 Pottery as Evidence for Exchange Networks}

On archaeological sites from Graeco-Roman antiquity, it is common to encounter a great deal of ceramic material with distant and diverse origins. This fact in itself is notable since pottery is not particularly expensive and clay is ubiquitous. No region holds a natural comparative advantage that could explain long-distance pottery trade. Therefore, pottery is usually seen as indicating trade in other goods. For amphorae, this was the contents of the vessel. ${ }^{40}$ For table ceramics, grain or other agricultural products are usually seen as the primary cargo. ${ }^{41}$ In both cases, however, other primary cargoes, such as precious metals, are possible. ${ }^{42}$ Whatever it was, pottery filled in the gaps left by the more important and valuable cargoes that drove exchange. The ceramics that we find are traces of ancient exchange networks, but we have reason to suspect that they are incomplete: literary and documentary evidence show that Egypt exported grain in massive quantities to Rome, but Egyptian pottery is very rare outside of Egypt. ${ }^{43}$ Bearing this in mind, the distribution of pottery provides valuable evidence for broader exchange networks.

This evidence can be used in several ways. When examining a single site, pottery provides some information about the ancient inhabitants' economic connections. It is not valid, however, to assume a direct connection between the places of production and consumption. Trade in the ancient Mediterranean was a heterogene-

39 Modern debate about the organization of Roman ceramic production is based on Peacock 1982. For large-scale production of standardized goods in the Roman world, see Wilson 2008; Jiménez 2017.

40 Many amphora types have been associated with a specific product - usually wine, olive oil, or fish sauce - on the basis of painted inscriptions (tituli picti), literary evidence, close association between amphora production sites and regions or sites known to produce certain products, or the presence of a pitch coating, which prevents wine and fish sauce from soaking through the walls of the vessel but dissolves in oil and renders it inedible. As techniques of residue analysis become more sophisticated, some of these associations are being questioned. Bonifay and Garnier (2007) critically examine the evidence for the contents of North African amphorae. See also Foley et al. 2012; Pecci et al. 2017.

41 Lewit 2011 provides a good overview.

42 Mattingly (1988, 52-53) argues that Spanish olive oil accompanied silver.

43 Lewit 2011. 
ous combination of small-scale, ad hoc tramping and planned journeys with strategically selected cargoes. In both cases, the collection and reexport of goods from harbors was common. ${ }^{44}$ When examining a single class of pottery, the distribution map shows the zone in which that pottery circulated, occasionally shedding light on the route by which it travelled when find spots form a linear pattern.

The best evidence for exchange networks, however, comes from comparing multiple types of pottery from many different sites. If each site provides a sample of the pottery that circulated across the exchange networks in which it was embedded, the comparison of site assemblages can reveal the geographic extent and limits of the various exchange networks. Sites with similar assemblages are seen as participating in similar exchange networks. ${ }^{45}$ By comparing sites that produce large ceramic assemblages spanning several centuries, archaeologists can examine how these exchange networks changed over time. The number of sites with assemblages amenable to this type of analysis is growing. In 1993, Roberta Tomber analyzed assemblages from five sites. ${ }^{46}$ In 2018, Paul Reynolds, while focusing on Beirut (Lebanon) and Butrint (Albania), was able to incorporate comparative data from over 20 other sites. ${ }^{47}$

While various statistical techniques for comparing site assemblages have been suggested, it is more common for scholars to treat pottery quantities as ordinal scale data and to rely on impressionistic comparisons. Both approaches are quantitative in that the object of comparison is a measured quantity, usually the percentage of an entire assemblage or ceramic class accounted for by a particular type of vessel.

Roberta Tomber first proposed the application of multivariate statistics to artifact assemblages in the early 1990s and was able to show, using discriminant analysis, that there were significant differences not only between all five sites she analyzed, but that the three sites in the Western Mediterranean and the two sites in the Eastern Mediterranean formed distinct groups, despite some overlap in their assemblages. ${ }^{48}$ More recently, a team led by Xavier Rubio-Campillo analyzed a massive database of amphora stamps coming from over 1,200 different sites in the Western Mediterranean. ${ }^{49}$ They quantified the similarity of each site to all others and the

44 Horden and Purcell (2000, 123-172) argued that tramping, or 'cabotage,' was the normal method of trade in the ancient Mediterranean, but this view has been challenged (Rice 2016).

45 This is a rather positivist and somewhat simplistic presentation of the logic that ignores complicating factors such as irregularities in the production of pottery and differences in its consumption both between sites and between different places within a site. For a critical examination of the theoretical linkage between archaeological pottery and the Roman economy, see Greene 2005.

46 Tomber 1993. The sites are Carthage (Tunisia), Rome (Italy), Naples (Italy), Benghazi (Libya), and Caesarea Maritima (Israel).

47 Reynolds 2018. This is partially a result of methodological differences but primarily of the massive increase in the amount of archaeological data that has been published in the last 25 years.

48 Tomber 1993.

49 Rubio-Campillo et al. 2018. 
similarity of each site to the others in the same province and compared the two values. Even though the two levels of similarity were very close, they were able to show that within-province similarity was higher than global similarity and that the difference was statistically significant. They concluded, therefore, that provincial borders did impact trade networks. These two examples highlight the primary advantage of statistical analysis: it is able to identify subtle patterns in the data and distinguish significant differences from those that could result from the random element of archaeological sampling.

Paul Reynolds's recent survey of pottery assemblages from around the GraecoRoman world, however, shows that impressionistic comparison has advantages as well. First, it is less dependent on the structure of the data. Rubio-Campillo's analysis works because amphora stamps are a unitary object and quantities can be treated as count statistics. Tomber could only compare sites with similarly large assemblages that spanned similar time frames and were quantified in similar ways. Reynolds could incorporate any data set available and adjust the interpretive weight placed on it to the nature of the data. Thus, some sites appear only when he considers a particular period or a particular type of vessel, while others serve as more consistent and broadly applicable points of comparison. By focusing on which wares dominate, are present in, or are absent from different assemblages rather than on specific quantities, Reynolds also sidesteps some of the problems involved in pottery quantification.

The second advantage is the nuance and fine-grained texture of the interpretations that Reynolds can achieve. So, for example, Reynolds argues that, because the ranges of Black Sea amphorae are similar in Beirut, Athens, and Knossos but Beirut had more Sinopean amphorae, there was a special relationship between these two cities that existed within a more general flow of Black Sea goods into the Aegean and Eastern Mediterranean. He is also able to distinguish a network that brought Aegean cook wares and fine wares into the Adriatic that excluded Black Sea goods, even though the latter were circulating throughout the Aegean. These are just two specific arguments pulled from a larger study that demonstrates the existence and intensification of 'close regional' networks of pottery circulation in the Levant and elsewhere from the second through the seventh centuries CE. If Reynolds had taken a more statistically rigorous approach, these detailed conclusions might have been obscured by larger patterns.

\section{IV.4 Pottery as Evidence for the Nature of Exchange}

Pottery distribution maps have played an important role in debates about the extent to which exchange in the Roman economy was driven by market forces versus political forces. ${ }^{50}$ Transportation costs provide the link between spatial distribution and

50 See Orton and Hughes 2013, 235-241 for an introduction. 
the nature of exchange. In free, market-based exchange, the price of a good includes the cost of moving it from its place of production to the place of exchange. As one moves farther from the place of production, the price rises and the number of people willing to buy it falls. The archaeological result is that sites near the place of production have a higher percentage of a given type of pottery than sites farther away. Deviations from this pattern suggest that transportation costs did not affect consumption, presumably because they were borne or subsidized by the state.

Michael Fulford's analysis of the distribution of several types of Gaulish table ware provide a recent example that also incorporates the function of the sites of consumption. ${ }^{51}$ Fulford plots the spread of terra sigillata from several different production centers in Gaul, using the number of stamps found at different sites as the basis of quantification. With a single exception, none of the distributions follow the pattern predicted by free market exchange. Instead, there are gaps where no pottery is found close to the places of production and large quantities are found farther away, particularly in Britain. Fulford concludes that the state had a hand in organizing the pottery's production and distribution but then must explain why the consumption sites in Britain include not only military bases but civilian and urban sites as well. He suggests that the state also supplied the cursus publicus - the official communication network consisting of inns and changing stations discussed in chapter 7 - with table ware that was then sold to the general public.

On the basis of distribution maps, Fulford cannot say what the relationship between the state, the producers, and the transporters was like, so it is not quite right to say that the pottery is evidence for state redistribution. ${ }^{52}$ If state representatives negotiated contracts with the other parties that involved subsidized transportation and a mutually agreed upon price, then the state acted as a uniquely privileged player within market-based exchange. It is also possible, however, that production or transport were provided at a fixed price or simply as an obligation, in which case the same distributions are produced by nonmarket redistribution or transfer. It is best, then, to interpret pottery distributions as evidence for the influence of transportation costs on consumption. To go further requires other evidence.

Until recently, it was difficult to interpret distribution maps centered on the Mediterranean because sea travel made transportation costs much less dependent on straight-line distance than it is on land. Furthermore, most voyages involved a combination of carriage methods each with different costs and unknown transshipment costs as well. A recent Stanford project has made a major contribution that addresses these problems. ${ }^{53}$ ORBIS is a digital network model of the Roman world

51 Fulford 2018. Peacock and Williams (1986, 61-63) were the first to suggest that consumer site function could be used to distinguish market exchange from state-led redistribution.

52 Fulford does not make this claim here, but distribution maps of oil amphorae have been interpreted in these terms (Weaverdyck, ch. 7, this volume).

53 Orbis.stanford.edu hosts the model and the user interface along with extensive documentation. See Scheidel 2014 for an overview. 
consisting of 632 sites and the links between them. The model makes it possible to calculate the cost of travelling between any two sites in time or money, at different seasons, prioritizing the fastest, cheapest or shortest routes, and using different modes of transportation. The model incorporates a wide variety of factors affecting sea, river, and overland travel, making it possible to construct distribution maps that more accurately reflect the real costs of transportation beyond simple, Euclidean distance. Nevertheless, because of the scale of the model, some simplifications are inevitable, and it is best used to model long-distance traffic. It is also important that users understand how the different parts of the model work together and the effects of the various options available on the calculations. Luckily, ORBIS provides extensive and lucid documentation.

In the last few years, interest in using computer-based models to analyze pottery distributions as evidence for testing larger, more abstract models of the Roman economy has grown. Tom Brughmans and Jeroen Poblome, for example, have constructed an agent-based model (ABM) that simulates the flow of four types of pottery through a social network of traders located at different sites. The aim was to test Peter Bang's vision of a weakly integrated Roman economy against Peter Temin's vision of a strongly integrated one. ${ }^{54}$ Rather than focusing on the spread of pottery across geographic space, they ask what types of networks spread pottery across a large number of sites and what would cause one type of pottery to be spread more widely than others, as observed in the distribution of four types of terra sigillata across the Eastern Mediterranean. They find that wide distributions of pottery are only possible in a network that includes many links between sites, supporting Temin's model over Bang's, and that the dominance of one type over the others could result from differences in the scale of production. ${ }^{55}$

Complex as they are - Brughmans's and Poblome's model contains 17 independent and 15 dependent variables that govern how the social network is constructed and how pottery flows through it - computer models like this require simplification and it is open to debate whether the simplifying assumptions adopted in any particular case are appropriate and useful..$^{56}$ On the other hand, the necessity to simplify is also the greatest benefit of this type of modeling. It requires all of the underlying assumptions and parameters of conceptual models to be stated simply and clearly, allowing others to engage with them. It then shows how changing the values of these parameters affects the outcome in ways that are directly comparable both to other versions of the model with different parameter values and to the observed archaeological record.

54 Brughmans and Poblome 2016.

55 See von Reden, ch. 17, this volume for models of the Roman economy.

56 See Van Oyen 2017 for a constructive critique of Brughmans's and Poblome's model. 


\section{Human Remains}

Human remains have begun to play a major role in debates about the Roman economy as evidence for economic outcomes. ${ }^{57}$ They are a direct, if incomplete, indicator of physical well-being and therefore allow us to approach something akin to ancient quality of life. In addition, they provide valuable evidence for diet and mobility. Skeletal remains also have the advantage of comparability. Unlike culturally determined consumption patterns, human biology is similar across all populations and through time, so we can ask whether the Romans were healthier than, for example, medieval Italians or early modern European populations. ${ }^{58}$ On the other hand, the relationship between economic complexity or performance and biological health is not a simple one. Urbanization and increased population, both linked to economic growth, can cause malnutrition and the spread of disease, producing a population that is simultaneously richer and sicker than before. ${ }^{59}$

\section{V.1 Stature}

Stature has received the most attention recently. ${ }^{60}$ In the modern world, economists have established a correlation between average height and GDP, suggesting that height is positively correlated with economic development. ${ }^{61}$ There are, of course, complications. Adult height is the result of many different, interacting factors. An individual's adult height is the result of sexual dimorphism, genetics, and the conditions in which they grew up. ${ }^{62}$ In periods of stress, the body maintains life at the expense of growth, so children who are malnourished, overworked, or diseased will grow into shorter adults than those who are healthy. At the same time the composition of the diet is consequential: the contribution of dairy, particularly milk, to the

57 Harper 2017, 74-79; Scheidel 2012 with literature. The study of human skeletal remains is called bioarchaeology or osteoarchaeology. For a good introduction to the field, see Larsen 2015. For an overview of bioarchaeology in Roman history, see Sperduti et al. 2018.

58 Kron (2005) was the first to make systematic comparisons between the average height of Roman skeletons and early modern populations. For long-term and large-scale comparisons of stature in Europe, see Koepke 2016; Martella, Brizzi, and Sanna 2018.

59 This happened in the United States in the nineteenth century (Steckel 2013). For Rome, see Harper 2017, 74-79.

60 For an overview of the use of stature in economic history, see Steckel 2013. For the use of stature in Roman history, see Gowland and Walther 2018.

61 Steckel 2013, 408-409.

62 Genetic variation between individuals is controlled by averaging heights across a population. The degree to which genetic differences between populations influence average height is not certain, but recent work on modern populations suggests that environmental factors might be more influential (Stulp and Barrett 2016). 
diet is positively correlated with height. ${ }^{63}$ This could explain why ancient populations in northern Europe, which raised cattle in larger numbers than those around the Mediterranean, were generally taller than their southern European neighbors. ${ }^{64}$ Therefore, average adult stature can be a good indicator of childhood well-being, but a large sample size is necessary to control for genetic variation between individuals, and simple interpretations correlating height and economic prosperity must be avoided.

Estimating height from archaeological remains also presents methodological difficulties. Since whole skeletons rarely survive, height is usually estimated from the length of long bones, especially the femur. However, the ratio between femur length and height is not constant across populations. Using formulas developed for modern populations to estimate the heights of ancient people can be misleading, so analysis should be based on femur length itself. ${ }^{65}$ Furthermore, a femur must be associated with a skull or pelvis so that sexual dimorphism can be controlled in the analysis. This reduces the size of the sample that can be analyzed. As sample size decreases, the probability that any given population's average height will reflect the genetics of its members more than the environment in which they grew up increases. To avoid the problem, researchers can expand the geographic and chronological scale of analysis, but this will blur local and short-term dynamics. In addition, to increase the sample size it becomes necessary to rely on data recorded and published by others, raising the risk of interobserver bias. Nevertheless, the amount of data available is growing rapidly and a consensus is beginning to emerge: the Roman Empire made people short. ${ }^{66}$

\section{V.2 Pathology}

Skeletons also provide evidence that might suggest why this was the case. Malnutrition and some diseases leave traces on the skeleton. Pitting in the crown of the skull (porotic hyperostosis) and in the eye sockets (cribra orbitalia) result from anemia, caused by a variety of stressors including poor diet and unsanitary living conditions. In particular, gastrointestinal parasites, chronic diarrhea, and a diet poor in animal proteins have all been linked to porotic hyperostosis and cribra orbitalia. These kinds of nutritional stresses can also arrest enamel production temporarily, causing visible lines in teeth called linear enamel hypoplasias (LEH). While pitting

63 Stulp and Barrett 2016, 211-212 with literature.

64 Koepke and Baten 2008.

65 Klein Goldewijk and Jacobs 2013.

66 Both Koepke 2016 (relying on others' measurements to assemble a very large database that spanned all of Europe at century-scale resolution) and Giannecchini and Moggi-Cecchi 2008 (relying on their own measurements from archaeological sites in Italy) come to this conclusion. Kron 2005 (relying on heights reconstructed by others) argued that Romans were taller than early modern European populations. 
and LEH provide evidence for stressful conditions, they both have multiple precise causes, so it is usually impossible to tell exactly what led to the pathology. ${ }^{67}$

Both these conditions, pitting and enamel hypoplasia, occur during childhood, and so reflect the conditions in which the individual grew up, much as stature. Nutritional deprivation during adulthood leaves fewer traces on the skeleton, although dental caries (cavities in teeth) indicate a diet rich in carbohydrates and thus an overreliance on grain. ${ }^{68}$ Some diseases, like leprosy or tuberculosis, gradually alter bones, but many others do not. ${ }^{69}$ Routine physical activity, on the other hand, often leads to changes in bone morphology - usually a thickening of loadbearing bones - or pathologies like osteoarthritis in certain joints, making it possible to reconstruct the types of labor that people were engaged in. ${ }^{70}$ This can be particularly helpful in identifying gendered or class-based division of labor. At the same time, age and genetics are also influential causes of these types of pathologies and morphological changes might not be related to occupation, so some caution is warranted in interpreting this type of evidence. ${ }^{71}$

\section{V.3 Isotopes}

Because bones and teeth are living tissue, they preserve chemical traces of the food and water that individuals consumed during their lifetime. This can be used to reconstruct certain aspects of their diet and mobility. ${ }^{72}$ In order to address these issues, archaeologists most frequently assess isotopic forms of four elements: carbon, nitrogen, oxygen, and strontium. The first two provide evidence for diet, the second two for paleomobility. ${ }^{73}$ Here again, the fact that bones and teeth form at different ages strongly affects the way the evidence can be used. Tooth enamel forms in early childhood, while bones remodel over the course of an individual's lifetime and thus may reflect the later years of life. Comparison between isotopic values derived from enamel and bone samples, then, permits archaeologists to assess changes in an individual's diet and mobility over the course of their lifetime.

67 For an overview of these and other skeletal markers of stress and deprivation, see Larsen 2015, 30-57.

68 The other major pathology reflecting adult nutrition is osteoporosis, the resorption of bone tissue as one ages. Bone mass is also affected by mechanical stress, however, complicating the interpretation of these data (Larsen 2015, 57-60).

69 Larsen 2015, 66-114. For an overview of epidemiological studies in Roman history along with a critical analysis of the methodological limitations, see Sperduti et al. 2018, 134-141.

70 Larsen 2015, 178-255.

71 Sperduti et al. 2018, 142-143.

72 For a convenient introduction to chemistry for archaeologists, see Pollard et al. 2007, $217-321$.

73 See Larsen 2015, 301-356 for an introduction, Pollard et al. 2007, 169-191 for the way isotopes are detected and measured and a review of archaeological applications, and Sperduti et al. 2018, 144-153 for the use of isotope analysis in Roman archaeology. 
Isotopes are an attractive source of evidence because they are a biological reflection of normal ancient diets. They are free from the distortions of literary and artistic representation and are equally applicable to powerful and marginalized members of society. Nevertheless, they come with their own complications and problems. First, the information they provide is vague. Not only do isotopes come from various sources that cannot be disentangled, but the isotopic composition of bones and teeth are a composite reflection of the food consumed over a long period of time. Second, the information is incomplete. The carbon and nitrogen in collagen - the organic portion of the bone whose chemistry is less affected by burial conditions - derives largely from proteins, with carbohydrates and lipids contributing a much smaller portion. Thus, isotopes are less helpful for understanding the roles of wheat, barley, wine, and olive oil - staples that form the foundation of the Mediterranean diet. Finally, the isotopic composition of human remains is best understood in relation to the compositions of various potential food sources, which should be measured on a case-by-case basis. Ideally, associated animal and plant remains can be identified and tested, but this is often not the case.

Nevertheless, the fact that isotope analysis provides biologically determined evidence that can be tied to specific individuals at a range of social statuses sets it apart from most other types of evidence for the ancient economy. The technology enabling this type of analysis is advancing, as is our understanding of the way different isotopes move through the food web and through organisms, so we can expect more and better studies in the coming years. With a firm grasp of the nature of the evidence and its limitations, isotopic data can become a powerful tool in the economic historian's toolkit.

\section{Faunal Remains}

Faunal remains - primarily animal bones but also mollusk shells and other remains of nonhuman animals - are a valuable source of information about the ancient economy. ${ }^{74}$ Of these, the most commonly encountered remains in the Graeco-Roman world are those of large, domesticated mammals. This group is composed of cattle, pigs, and the often indistinguishable remains of sheep and goats. These are most often used to study meat consumption and animal husbandry, but bones also provide information about many other topics, including the ways carcasses were processed for meat and other products and even about the relationships between producers and consumers. While these data are collected and analyzed first in the

74 The study of faunal remains is called zooarchaeology or archaeozoology. For an overview of the discipline, see Albarella 2017. Methodological issues are treated in depth in Giovas and LeFebvre 2018. MacKinnon 2007 surveys the study of both human and animal bones within classical archaeology. 
context of a single site, they become most interesting when combined with and compared to data from other sites in regional, supra-regional, cross-cultural, and diachronic analyses. However, this requires a detailed understanding of the formation processes that shaped a site's faunal assemblage as well as the recovery and recording techniques that produced the published data.

Eating meat requires the frequent slaughter of animals, so most animal bones are related to consumption practices. By comparing faunal assemblages across space and time, we can detect regional and diachronic variation in both the types and amount of meat being consumed. ${ }^{75}$ Increased meat consumption is particularly interesting for economic historians because it indicates broad-based prosperity. Meat is an expensive food, so the very poor do not consume very much. At the same time, there is a limit to how much even a very rich person can eat, so large increases in animal bones often indicate a sizeable group of moderately wealthy people rather than a small group of very wealthy people. ${ }^{76}$

The potential value of faunal remains goes beyond consumption patterns, however. ${ }^{77}$ They can also reveal which animal products were being produced. The age and sex distributions of slaughtered animals reflect the purposes for which they were raised. Animals raised for meat will usually be slaughtered as young adults when their growth rate slows. Of course, if pasture, fodder, or stable space are abundant, the age at slaughter might be later than optimal from an economic perspective. ${ }^{78}$ Dairy herds will be dominated by adult females who have given birth, so an assemblage dominated by the bones of slaughtered young animals, particularly young males, indicates that milk was the most important product. Both male and female sheep provide wool throughout their lives, so wool production generally produces an assemblage dominated by older individuals of both sexes. Similarly, cattle that are kept for traction and manure will be killed later in life. ${ }^{79}$

The size, shape, and morphological features of a bone specimen can help determine the species, sex, and part of the animal from which it came. The most common methods to deduce age at death rely on the degree to which teeth have erupted

75 King (1999) gathered data from all over the Roman Empire to trace regional variations in diet. His data were later used by Jongman (2007) to argue for increasing levels of meat consumption both in Italy and the provinces during the Principate.

76 Jongman 2007, 613. This simple correlation between animal bones and prosperity assumes broadly consistent economic strategies and cultural attitudes toward meat consumption. It also glosses over potential shifts in the species being consumed and how different parts of the animal were valued.

77 Groot 2016, 57-67 provides an excellent introduction to the ways in which zooarchaeological data can be used to reconstruct practices of animal production and distribution.

78 The demand for meat must also be taken into account. There is no point slaughtering an animal if no one wants to eat it.

79 Of course, animals can also serve multiple purposes, and factors other than production efficiency influence slaughter patterns - for example, breeding selection or cultural preferences. Thus, real assemblages are more complex than the models summarized here. 
through the mandible and the fusion of long-bone ends. Once these identifications are made, quantification is the next critical step. The two most commonly used estimates are number of identified specimens (NISP) and minimum number of individuals (MNI). ${ }^{80}$ NISP is simply the number of bone fragments that can be assigned to a certain taxon. ${ }^{81} \mathrm{MNI}$ is the smallest number of animals necessary to produce the assemblage. The biggest problem with NISP is that every animal has many bones of which some unknown portion is deposited, and it is usually impossible to tell which bones in an assemblage come from the same individual. ${ }^{82}$ MNI solves this problem, but introduces another, that of aggregation. ${ }^{83}$ The total MNI and the ratios between MNIs for different taxa change depending on whether one calculates them for all bones found at a site or separately for different archaeological contexts, and it is not always clear what the most appropriate units for aggregation are. Since NISP is a simple count of specimens while MNI is a derived measurement, and because it is the more commonly reported statistic, synthetic studies usually rely on NISP rather than MNI when assessing species abundance. ${ }^{84}$

In addition to the demographic profile of the slaughtered animal populations, zooarchaeologists study skeletal elements to understand how animals were processed. Marks left on the bones can reveal which animals were butchered for meat and how they were butchered. A comparison of butchery at urban and rural sites in Roman Britain, for example, showed that urban butchers used cleavers to divide carcasses quickly and skillfully. ${ }^{85}$ The relative ubiquity of different parts of the animal can also reveal specialized production. An abundance of skulls and foot bones has been linked to leather production since hides were transported with the skulls and feet attached. ${ }^{86}$ A large quantity of meat-bearing bones suggests the consumption of joints of meat that had been prepared elsewhere. Similarly, a dearth of such bones could indicate a butchery site from which meat has been removed to be consumed elsewhere. ${ }^{87}$

At the same time, it must be remembered that the presence or absence of both species and skeletal elements might have more to do with what happens between

80 For a detailed discussion of NISP and MNI, see Lyman 2008, 21-82.

81 A taxon is the group to which an organism belongs at any level of classification (e.g., family, genus, or species).

82 Other problems include differential rates of fragmentation, identifiability, and frequency of bones between species.

83 Another significant problem is that there are multiple ways of calculating MNI, and the method used is not always made explicit. MNI also tends to exaggerate the importance of rare species because a species with an NISP of 1 has an MNI of 1, whereas a species with an NISP of 3 might have an MNI of 3, 2 or 1.

84 Lyman $(2008,78-82)$ argues forcefully for the use of NISP over MNI.

85 Seetah 2006.

86 For ancient leather production, see Driel-Murray 2008.

87 For examples, see Groot 2016, 59-62. 
the moment of deposition and the moment of discovery than with ancient behavior. Small or fragile bones - like bird and fish bones or low-density bones from sheep, goats, and pigs - are easily destroyed by erosion or scavengers and easily missed by archaeologists unless the soil is sieved. ${ }^{88}$

The mobility of animals and animal products makes it especially critical to compare faunal assemblages from different sites to fully understand the economics of animal products. Meat production might not yield the signature of young adult bones at the place of production if the animals were driven somewhere else to be slaughtered. By comparing assemblages of production and consumption sites, however, it is possible to draw conclusions about market relations. Maaike Groot has examined faunal assemblages from rural, sacred, urban, and military sites near the Roman frontier on the Lower Rhine. ${ }^{89}$ She not only found a great variety in production strategies on rural sites, she also showed that the species distributions in consumer and producer sites were similar, meaning consumers were eating locally produced meat. Furthermore, cattle were most abundant and therefore the most important source of meat, but the age profile of cattle bones on consumer sites showed a mixture of young and old animals. This means that the farmers were not being forced to supply the most desirable animals to the consumers but were able to use their cattle for labor and manure before sending them to market.

Unlike most types of archaeological material, faunal remains derive directly from ancient food. This makes them invaluable in understanding the production, distribution and consumption of meat. As animals make more than meat, faunal remains are also relevant for the production of leather, wool, bone, glue, grease, and, through manure and labor, even grain. In order to make use of this material the researcher must account for the formation processes, recovery strategies, and methods of quantification and recording that turn bones into data.

\section{Pollution}

The smelting of ore to extract metal causes air pollution, which deposits trace amounts of metals in peat bogs, lakes, and glaciers. Beginning in the 1990s, environmental scientists have identified elevated levels of copper and lead pollution dating to antiquity, which historians have interpreted as evidence for increased mining activity. ${ }^{90}$ In particular, the levels of lead deposited in Greenland ice sheets

88 For the influence of taphonomic processes on skeletal elements, see Faith and Thompson 2018. For their influence on taxonomic representation, see Fisher 2018. For the use of bones as evidence for taphonomy, see Lyman 2008, 264-298.

89 Groot 2016.

90 Scheidel provides citations to all the relevant evidence from the 1990s and 2000s (2009, 47-48, n. 7). The evidence has been used by de Callataÿ 2005; Kehoe 2007; Scheidel 2009; Wilson 2002. 
reflect silver mining, which occurred predominantly in Spain in the Roman period. However, the limited number of samples, the low chronological resolution of the data and uncertainty about the source of the lead have cast doubt on the usefulness of the results. ${ }^{91}$ Recently, however, a new analysis of an ice core from Greenland has addressed these problems. ${ }^{92}$ A team lead by Joseph McConnell at the Desert Research Institute in Reno, Nevada analyzed trace elements in an ice core over $400 \mathrm{~m}$ long. They achieved sub-annual chronological resolution by identifying annual fluctuations in the concentrations of different chemicals and elements. Absolute dates were established by aligning the record with a known volcanic eruption in $1257 \mathrm{CE}$ that left a distinctive concentration of sulfur in the core.

The origin of the lead pollution was confirmed through comparison with published records from peat bogs where a Roman origin had been inferred or supported by isotopic analysis. Because the concentrations of lead followed similar diachronic trends they must have come from the same source, and because lead concentrations declined with distance from southern Spain, that source must have been the Spanish silver mines. McConnell's team also used a newly developed climate model to calculate how sensitive the records from the ice core and the peat bogs were to changes in lead emissions around the world. They found that these sites were much more sensitive to emissions from southwestern Europe and northwestern Africa than other parts of the world like China and that the ratios of lead concentration between the sites was consistent with a source in Spain. On the other hand, the Greenland ice core record was much more sensitive to emissions from Britain, but because archaeological and historical evidence suggests much lower levels of mining in Britain than Spain, they still conclude that the record primarily reflects Spanish mining activity. Nevertheless, the possibility that British mining accounts for some unknown portion of the variation should be kept in mind. ${ }^{93}$

As a result, it is now possible to correlate lead emissions, and thus mining activity in Spain, to historical events. In particular, the civil war of the Late Republic corresponds to a steep decline in lead pollution, which then grew rapidly under Augustus and peaked in the first century CE. Emissions in the second century continued at a slightly lower level until the mid-160s, when they declined precipitously and did not recover until the Middle Ages. This suggests that the Antonine Plague (165-180 CE) can be blamed for decreased silver production - also visible in the declining levels of silver present in Roman coins from this time.

How these new data will be incorporated into scholarship on the Roman economy remains to be seen. ${ }^{94}$ It will be important to keep in mind that fluctuations in

91 Wilson 2014, 156-157.

92 McConnell et al. 2018.

93 The authors also discuss the influence of mines in Germany on the record, McConnell et al. 2018, 5728.

94 For a first attempt, see Manning 2018. 
the deposition of lead pollution in Greenland do not directly reflect fluctuations in total silver production in the Roman Empire because some sources, such as those in Britain, are overrepresented while others, like those in the Balkans, are underrepresented. Further, although the chronological resolution of the data is higher than any other source at our disposal, variations in the atmospheric transmission and deposition of lead undermine any conclusions based on very short-term fluctuations. Finally, silver production is not the same thing as money supply, which also depended on gold and nonmetallic forms of money. ${ }^{95}$

\section{Other Material Evidence}

The selection presented above represents types of data that have historically been prominent within discussions of the Roman economy or are currently rising in prominence. It would be wrong, however, to omit entirely a few other important sources of evidence. These include archaeobotanical remains, stone, and production facilities.

Archaeobotanical evidence, the remains of ancient plants, consists of both palynological data and macro-remains. Palynology is the study of ancient pollen, the grains of which are recovered from soil cores extracted from lakes and wetlands. ${ }^{96}$ Pollen collects in these environments and sinks to the bottom, forming sequences that can span thousands of years. By comparing the prevalence of pollen from trees to that from other plants, one can trace the fluctuating extent of forests and open land. By tracking the prevalence of pollen from specific plant species, including crops but also weeds that are known to grow on the edges of fields, it is possible to trace changes in agricultural regimes over time. At the same time, pollen diagrams are not simple representations of the vegetation in the area around the core. Wind-pollinated species, which produce more pollen that travels farther than insect-pollinated species, are often overrepresented. Furthermore, the chronological resolution of these cores can be coarse, which obscures short-term dynamics.

Macro-remains are larger than pollen. ${ }^{97}$ They include primarily seeds, but also other parts of the plant and provide valuable evidence about the types of crops that were being grown and consumed. They can even shed light on the ways in which crops were processed and stored. Seeds can also reveal the introduction of new crops to an area or, if the species does not grow locally, their importation. Macro-remains also include wood fragments, which can be assigned to a species and sometimes dated dendrochronologically. Sequences of rings that stretch thousands of years into

95 Von Reden, ch. 8.C, this volume.

96 See Izdebski et al. 2016 for a specifically economic application of palynological evidence.

97 Van der Veen 2018. 
the past have been compiled by combining preserved wood samples. The rings in newly discovered samples can then be compared to the master sequence to find the date the tree was felled. Plant macro-remains are usually preserved through charring, but arid and waterlogged environments can also yield well-preserved specimens.

Stone is much more durable than plant remains and can be found in numerous archaeological contexts. ${ }^{98}$ Most of the stone used by people in the ancient world was quarried locally, but some rare types could be imported over long distances, as for example from the quarries in the Eastern Desert of Egypt. These included exotic decorative stones such as marble, porphyry, or alabaster, but also stones with particular utilitarian characteristics. In the ancient Mediterranean, the latter were mostly volcanic stones used for grinding. The origins of these stones can be determined through petrographic and chemical analyses, allowing for the reconstruction of trade networks.

The remains of production facilities have been used to reconstruct the scale on which certain goods were produced. Olive oil and wine presses, which often included large stone elements with characteristic shapes, have long been used for this purpose. ${ }^{99}$ The output of a press can be estimated based on ethnographic comparison, so by counting the number of presses in a region, it is possible to estimate annual production. This type of study has revealed production on a scale that can only be explained by large-scale exports in certain areas, particularly in the southwestern part of the Iberian Peninsula. More recently, fish-salting facilities have proven similarly illuminating. These consist of large vats often made of concrete. Measuring the vats provides an indication of the scale of production, which was also massive in certain areas. ${ }^{100}$

\section{Conclusion}

The range of sources for archaeological evidence about the ancient world is immense and diverse. Each type requires its own set of interpretive techniques to transform remains into useful evidence. Nevertheless, the potential of archaeological evidence is also immense. While those who have the means to consume in larger quantities will usually be overrepresented in the archaeological record, people from all segments of the population could leave traces. Furthermore, these traces can often be directly related to the economic activities in which we are interested. The archaeological record is not evenly distributed across space. Some conditions are

98 Russell 2013.

99 Mattingly (1988), working in North Africa and Spain, was the first to quantify oil production based on presses. Marzano (2013) has examined large-scale pressing facilities around the empire. 100 Wilson 2006; 2014, 157-160. 
more conducive to preservation than others, and some areas have enjoyed a longer, more intensive history of investigation. Nevertheless, archaeological remains can potentially be found almost anywhere. In many places they are the only evidence we have for the ancient economy.

The archaeological record is also growing fast. More people are producing more data from more places than ever before. New techniques are being invented, like DNA analysis, that are producing new types of data, while digital tools allow us to analyze old types of data in new ways. Most radically, perhaps, the internet is making this flood of data widely accessible. Archaeologists and historians are still developing ways to link, organize, and harness these data for the purpose of understanding the past. Just over 30 years ago, Kevin Greene published a book arguing for the relevance of archaeology to the study of the Roman economy. ${ }^{101}$ Today, it would be impossible to write about the ancient economy without archaeology.

\section{References}

Adams, D. 1979. The hitchhiker's guide to the galaxy. London: Pan Books.

Adams, W. Y., and E. W. Adams. 1991. Archaeological typology and practical reality: A dialectical approach to artifact classification and sorting. Cambridge: Cambridge University Press.

Albarella, U. 2017. "Zooarchaeology in the twenty-first century: Where we come from, where we are now, and where we are going." In U. Albarella, M. Rizzetto, H. Russ, K. Vickers, and S. Viner-Daniels (eds.), The Oxford handbook of zooarchaeology, 3-21. Oxford: Oxford University Press.

Alcock, S. E., and J. F. Cherry, eds. 2004. Side-by-side survey: Comparative regional studies in the Mediterranean world. Oxford: Oxbow.

Arrington, N. T., D. Terzopoulou, M. Tasaklaki, M. L. Lawall, D. J. Brellas, and C. E. White. 2016. "Molyvoti, Thrace, archaeological project: 2013 preliminary report." Hesperia 85.1, 1-64.

Attema, P., and G. Schörner, eds. 2012. Comparative issues in the archaeology of the Roman rural landscape: Site classification between survey, excavation and historical categories.

Portsmouth, RI: Journal of Roman Archaeology.

Banning, E. B. 2002. Archaeological survey. New York, NY: Kluwer Academic.

Bes, P. 2015. Once upon a time in the East: The chronological and geographical distribution of terra sigillata and red slip ware in the Roman East. Oxford: Archaeopress.

Bonifay, M., and N. Garnier. 2007. "Que transportaient donc les amphores africaines?" In E. Papi and M. Bonifay (eds.), Supplying Rome and the empire: The proceedings of an international seminar held at Siena-Certosa di Pontignano on May 2-4, 2004 on Rome, the provinces, production and distribution, 8-31. Portsmouth, RI: Journal of Roman Archaeology.

Brughmans, T., and J. Poblome. 2016. "Roman bazaar or market economy? Explaining tableware distributions through computational modelling." Antiquity 90.350, 393-408.

Campana, S. R. L. 2018. Mapping the archaeological continuum: Filling 'empty' Mediterranean landscapes. Cham: Springer.

Clarke, D. L. 1977. Spatial archaeology. London: Academic Press.

101 Greene 1986. 
Crema, E. R. 2015. "Time and probabilistic reasoning in settlement analysis." In J. A. Barcelo and I. Bogdanovic (eds.), Mathematics and archaeology, 314-334. Boca Raton, FL: CRC.

David, B., and J. Thomas, eds. 2008. Handbook of landscape archaeology. Walnut Creek, CA: Left Coast Press.

de Callataÿ, F. 2005. "The Graeco-Roman economy in the super long-run: Lead, copper, and shipwrecks." Journal of Roman Archaeology 18, 361-372.

-. 2014. "Long-term quantification in ancient history: A historical perspective." In F. de Callataÿ (ed.), Quantifying the Greco-Roman economy and beyond, 13-27. Bari: Edipuglia.

Driel-Murray, C. van 2008. "Tanning and leather." In J. P. Oleson (ed.), The Oxford handbook of engineering and technology in the classical world, 483-495. Oxford: Oxford University Press.

Dunnell, R. C. 1992. "The notion site." In J. Rossignol and L. Wandsnider (eds.), Space, time, and archaeological landscapes, 21-41. New York, NY: Plenum.

Eiring, J., and J. Lund, eds. 2004. Transport amphorae and trade in the Eastern Mediterranean: Acts of the international colloquium at the Danish Institute at Athens, September 26-29, 2002. Aarhus: Aarhus University Press.

Faith, J. T., and J. C. Thompson. 2018. "Low-survival skeletal elements track attrition, not carcass transport behavior in quaternary large mammal assemblages." In Giovas and LeFebvre (2018), 109-126.

Farinetti, E. 2011. Boeotian landscapes: A GIS-based study for the reconstruction and interpretation of the archaeological datasets of ancient Boeotia. Oxford: Archaeopress.

Fenn, N., and C. Römer-Strehl, eds. 2013. Networks in the Hellenistic world: According to the pottery in the Eastern Mediterranean and beyond. Oxford: Archaeopress.

Fentress, E. 2000. "What are we counting for?" In Francovich, Patterson, and Barker (2000), 44-52.

Fisher, J. L. 2018. "Influence of bone survivorship on taxonomic abundance measures." In Giovas and LeFebvre (2018), 127-149.

Foley, B. P., M. C. Hansson, D. P. Kourkoumelis, and T. A. Theodoulou. 2012. "Aspects of ancient Greek trade re-evaluated with amphora DNA evidence." Journal of Archaeological Science 39.2, 389-398.

Forte, M., and S. Campana, eds. 2016. Digital methods and remote sensing in archaeology: Archaeology in the age of sensing. New York, NY: Springer.

Francovich, R., H. Patterson, and G. Barker, eds. 2000. Extracting meaning from ploughsoil assemblages. Oxford: Oxbow.

Fulford, M. 2018. "Procurators' business? Gallo-Roman sigillata in Britain in the second and third centuries AD." In A. Wilson and A. K. Bowman (eds.), Trade, commerce, and the state in the Roman world, 301-325. Oxford: Oxford University Press.

Giannecchini, M., and J. Moggi-Cecchi. 2008. "Stature in archeological samples from central Italy: Methodological issues and diachronic changes." American Journal of Physical Anthropology 135.3, 284-292.

Giovas, C. M., and M. J. LeFebvre, eds. 2018. Zooarchaeology in practice: Case studies in methodology and interpretation in archaeofaunal analysis. New York, NY: Springer.

Goodchild, H. 2013. "GIS models of Roman agricultural production." In A. K. Bowman and A. Wilson (eds.), The Roman agricultural economy: Organization, investment, and production, 55-83. Oxford: Oxford University Press.

Goodchild, H., and R. Witcher. 2009. "Modelling the agricultural landscapes of Republican Italy." In J. Carlsen and E. Lo Cascio (eds.), Agricoltura e scambi nell'Italia tardo-repubblicana, 187220. Bari: Edipuglia.

Gowland, R., and L. Walther. 2018. "Human growth and stature." In W. Scheidel (ed.), The science of Roman history: Biology, climate, and the future of the past, 174-204. Princeton, N):

Princeton University Press. 
Greene, K. 1986. The archaeology of the Roman economy. London: Batsford.

-. 2005. "Roman pottery: Models, proxies and economic interpretation." Journal of Roman Archaeology 18, 34-56.

Groot, M. 2016. Livestock for sale: Animal husbandry in a Roman frontier zone: The case study of the civitas Batavorum. Amsterdam: Amsterdam University Press.

Harper, K. 2017. The fate of Rome: Climate, disease, and the end of an empire. Princeton, NJ: Princeton University Press.

Hartley, B., and B. M. Dickinson. 2008-2012. Names on terra sigillata: An index of makers' stamps \& signatures on Gallo-Roman terra sigillata (Samian ware). 9 vols. London: Institute of Classical Studies.

Hayes, J. W. 1991. "Fine wares in the Hellenistic world.” In T. Rasmussen and N. Spivey (eds.), Looking at Greek vases, 183-202. Cambridge: Cambridge University Press.

-. 1997. Handbook of Mediterranean Roman pottery. Norman, OK: University of Oklahoma Press.

Hodder, I., and C. Orton. 1976. Spatial analysis in archaeology. Cambridge: Cambridge University Press.

Hopkins, K. 1980. “Taxes and trade in the Roman Empire (200 BC-AD 400)." Journal of Roman Studies 70, 101-125.

Horden, P., and N. Purcell. 2000. The corrupting sea: A study of Mediterranean history. Malden, MA: Blackwell.

Howey, M. C. L., and M. Brouwer Burg, eds. 2017. “Archaeological GIS today: Persistent challenges, pushing old boundaries, and exploring new horizons." Special issue, Journal of Archaeological Science 84.

Hunt, A. M. W. 2017. The Oxford handbook of archaeological ceramic analysis. Oxford: Oxford University Press.

Ingold, T. 1993. “The temporality of the landscape.” World Archaeology 25.2, 152-174.

Izdebski, A., G. Koloch, T. Słoczyński, and M. Tycner. 2016. "On the use of palynological data in economic history: New methods and an application to agricultural output in central Europe, 0-2000 AD." Explorations in Economic History 59, 17-39.

Jiménez, A. 2017. "Standard time: Typologies in Roman antiquity.” In A. Van Oyen and M. Pitts (eds.), Materialising Roman histories, 75-84. Oxford: Oxbow.

Jongman, W. 2007. “The early Roman Empire: Consumption.” In W. Scheidel, I. Morris, and R. P. Saller (eds.), The Cambridge economic history of the Greco-Roman world, 592-618. Cambridge: Cambridge University Press.

Kehoe, D. 2007. “The early Roman Empire: Production.” In W. Scheidel, I. Morris, and R. P. Saller (eds.), The Cambridge economic history of the Greco-Roman world, 541-569. Cambridge: Cambridge University Press.

King, A. 1999. "Diet in the Roman world: A regional inter-site comparison of the mammal bones." Journal of Roman Archaeology 12, 168-202.

Klein Goldewijk, G., and J. Jacobs. 2013. "The relation between stature and long bone length in the Roman Empire." Research Report 13002-EEF. Research Institute SOM, University of Groningen.

Koepke, N. 2016. "The biological standard of living in Europe from the Late Iron Age to the Little Ice Age." In J. Komlos and I. R. Kelly (eds.), The Oxford handbook of economics and human biology, 70-108. Oxford: Oxford University Press.

Koepke, N., and J. Baten. 2008. "Agricultural specialization and height in ancient and medieval Europe." Explorations in Economic History 45.2, 127-146.

Kron, G. 2005. “Anthropometry, physical anthropology, and the reconstruction of ancient health, nutrition, and living standards." Historia 54, 68-83.

Larsen, C. S. 2015. Bioarchaeology: Interpreting behavior from the human skeleton. 2nd ed. Cambridge: Cambridge University Press. 
Lewit, T. 2011. "Dynamics of fineware production and trade: The puzzle of supra-regional exporters." Journal of Roman Archaeology 24, 313-332.

Lyman, R. L. 2008. Quantitative paleozoology. Cambridge: Cambridge University Press.

MacKinnon, M. 2007. "Osteological research in classical archaeology." American Journal of Archaeology 111.3, 473-504.

Manning, J. G. 2018. The open sea: The economic life of the ancient Mediterranean world from the Iron Age to the rise of Rome. Princeton, NJ: Princeton University Press.

Martella, P., M. Brizzi, and E. Sanna. 2018. "Is the evaluation of millennial changes in stature reliable? A study in southern Europe from the Neolithic to the Middle Ages." Archaeological and Anthropological Sciences 10.3, 523-536.

Marzano, A. 2013. "Capital investment and agriculture: Multi-press facilities from Gaul, the Iberian Peninsula, and the Black Sea region." In A. K. Bowman and A. Wilson (eds.), The Roman agricultural economy: Organization, investment, and production, 107-141. Oxford: Oxford University Press.

Mattingly, D. J. 1988. "Oil for export? A comparison of Libyan, Spanish and Tunisian olive oil production in the Roman Empire." Journal of Roman Archaeology 1, 33-56.

McConnell, J. R., A. I. Wilson, A. Stohl, M. M. Arienzo, N. J. Chellman, S. Eckhardt, E. M. Thompson, A. M. Pollard, and J. P. Steffensen. 2018. "Lead pollution recorded in Greenland ice indicates European emissions tracked plagues, wars, and imperial expansion during antiquity." Proceedings of the National Academy of Sciences 115.22, 5726-5731.

Morley, N. 2014. "Orders of magnitude, margins of error." In F. de Callataÿ (ed.), Quantifying the Greco-Roman economy and beyond, 29-42. Bari: Edipuglia.

Orton, C. 1993. "How many pots make five? An historical review of pottery quantification." Archaeometry 35.2, 169-184.

Orton, C., and M. Hughes. 2013. Pottery in archaeology. 2nd ed. Cambridge: Cambridge University Press.

Oxé, A., H. Comfort, and P. M. Kenrick. 2000. Corpus vasorum Arretinorum: A catalogue of the signatures, shapes and chronology of Italian sigillata. 2nd ed. Bonn: Habelt.

Parcak, S. H. 2017. "GIS, remote sensing, and landscape archaeology." Oxford Handbooks Online. https://doi.org/10.1093/oxfordhb/9780199935413.013.11.

Parker, A. J. 1992. Ancient shipwrecks of the Mediterranean and the Roman provinces. Oxford: Tempus Reparatum.

Peacock, D. P. S. 1982. Pottery in the Roman world: An ethnoarchaeological approach. London: Longman.

Peacock, D. P. S., and D. F. Williams. 1986. Amphorae and the Roman economy: An introductory guide. London: Longman.

Pecci, A., J. Clarke, M. Thomas, J. Muslin, I. van der Graaff, L. Toniolo, D. Miriello, G. M. Crisci, M. Buonincontri, and G. Di Pasquale. 2017. "Use and reuse of amphorae: Wine residues in Dressel 2-4 amphorae from Oplontis Villa B (Torre Annunziata, Italy).” Journal of Archaeological Science: Reports 12, 515-521.

Peña, J. T. 2007. Roman pottery in the archaeological record. Cambridge: Cambridge University Press.

Pollard, M., C. Batt, B. Stern, and S. M. M. Young. 2007. Analytical chemistry in archaeology. Cambridge: Cambridge University Press.

Reynolds, P. 2018. "The supply networks of the Roman East and West: Interaction, fragmentation, and the origins of the Byzantine economy." In A. Wilson and A. K. Bowman (eds.), Trade, commerce, and the state in the Roman world, 353-396. Oxford: Oxford University Press.

Rice, C. 2016. "Shipwreck cargoes in the Western Mediterranean and the organization of Roman maritime trade." Journal of Roman Archaeology 29, 165-192.

Roper, D. C. 1979. "The method and theory of site catchment analysis: A review." Advances in Archaeological Method and Theory 2, 119-140. 
Rubio-Campillo, X., J.-M. Montanier, G. Rull, J. M. Bermúdez Lorenzo, J. Moros Díaz, J. Pérez González, and J. Remesal Rodríguez. 2018. "The ecology of Roman trade: Reconstructing provincial connectivity with similarity measures." Journal of Archaeological Science 92, 37-47.

Russell, B. 2013. The economics of the Roman stone trade. Oxford: Oxford University Press.

Scheidel, W. 2009. “In search of Roman economic growth." Journal of Roman Archaeology 22, 46-70.

-. 2012. "Physical well-being." In W. Scheidel (ed.), The Cambridge companion to the Roman economy, 321-333. Cambridge: Cambridge University Press.

-. 2014. "The shape of the Roman world: Modelling imperial connectivity." Journal of Roman Archaeology 27, 7-32.

Seetah, K. 2006. “Multidisciplinary approach to Roman-British cattle butchery." In M. Maltby (ed.), Integrating zooarchaeology: Proceedings of the 9th conference of the International Council of Archaeozoology, Durham, August 2002, 111-118. Oxford: Oxbow.

Sinopoli, C. M. 1991. Approaches to archaeological ceramics. New York, NY: Springer Science \& Business Media.

Spataro, M., and A. Villing, eds. 2015. Ceramics, cuisine and culture: The archaeology and science of kitchen pottery in the ancient Mediterranean world. Oxford: Oxbow.

Sperduti, A., L. Bondioli, O. Craig, T. L. Prowse, and P. Garnsey. 2018. "Bones, teeth, and history." In W. Scheidel (ed.), The science of Roman history: Biology, climate, and the future of the past, 123-173. Princeton, NJ: Princeton University Press.

Steckel, R. H. 2013. "Biological measures of economic history.” Annual Review of Economics 5.1, 401-423.

Stulp, G., and L. Barrett. 2016. "Evolutionary perspectives on human height variation.” Biological Reviews 91.1, 206-234.

Terrenato, N. 2004. "Sample size matters! The paradox of global trends and local surveys." In Alcock and Cherry (2004), 36-48.

Tomber, R. 1993. "Quantitative approaches to the investigation of long-distance exchange." Journal of Roman Archaeology 6, 142-166.

Van der Veen, M. 2018. “Archaeobotany: The archaeology of human-plant interactions.” In W. Scheidel (ed.), The science of Roman history: Biology, climate, and the future of the past, 53-94. Princeton, NJ: Princeton University Press.

Van Oyen, A. 2017. “Agents and commodities: A response to Brughmans and Poblome (2016) on modelling the Roman economy." Antiquity 91.359, 1356-1363.

Verdan, S. 2011. "Pottery quantification: Some guidelines.” In S. Verdan, T. Theurillat, and A. Kenzelmann Pfyffer (eds.), Early Iron Age pottery: A quantitative approach: Proceedings of the international round table organized by the Swiss School of Archaeology in Greece (Athens, November 28-30, 2008), 165-170. Oxford: Archaeopress.

Vita-Finzi, C., and E. S. Higgs. 1970. "Prehistoric economy in the Mount Carmel area of Palestine: Site catchment analysis." Proceedings of the Prehistoric Society 36, 1-37.

Ward-Perkins, B. 2005. The fall of Rome and the end of civilization. Oxford: Oxford University Press.

Weaverdyck, E. J. S. 2016. “Isolation or integration? A spatial analytical approach to the local impact of the Roman army on the northern frontier." PhD diss., University of California, Berkeley.

-. 2019. "The role of forts in the local market system in the Lower Rhine: Toward a method of multiple hypothesis testing through comparative modelling." In P. Verhagen, J. Joyce, and M. R. Groenhuijzen (eds.), Finding the limits of the Limes: Modelling demography, economy and transport on the edge of the Roman Empire, 165-190. New York, NY: Springer.

Whitbread, I. K. 1995. Greek transport amphorae: A petrological and archaeological study. Athens: British School at Athens. 
Wilson, A. I. 2002. "Machines, power and the ancient economy." Journal of Roman Studies 92, $1-32$.

-. 2006. "Fishy business: Roman exploitation of marine resources." Journal of Roman Archaeology 19, 525-537.

-. 2008. "Large-scale manufacturing, standardization, and trade." In J. P. Oleson (ed.), The Oxford handbook of engineering and technology in the classical world, 393-417. Oxford: Oxford University Press.

-. 2009. "Approaches to quantifying Roman trade." In A. K. Bowman and A. Wilson (eds.), Quantifying the Roman economy: Methods and problems, 213-249. Oxford: Oxford University Press.

-. 2014. "Quantifying Roman economic performance by means of proxies: Pitfalls and potential." In F. de Callataÿ (ed.), Quantifying the Greco-Roman economy and beyond, 147-167. Bari: Edipuglia. 


\section{Eli J. S. Weaverdyck \\ 8.B Transmitted Texts}

\section{Introduction}

The societies of the ancient Mediterranean produced a great deal of writing. Their written words and symbols, communicating everything from simple names, numbers, and lists to great works of literary art, survive today in massive quantities, and these represent a tiny fraction of everything that was originally written. The production of writing in all media probably peaked in or around the second century CE, under the Roman Empire. ${ }^{1}$ While levels of what we would term 'full literacy' in the ancient Mediterranean were low by modern standards, the use of texts was widespread, especially in the Roman world. ${ }^{2}$ Written texts had power, both legal (contracts and legal pronouncements, for example) and social (monumental inscriptions, political graffiti, and letters of recommendation, for example, could all affect one's social standing). The use of writing to convey information and instructions allowed for the administration of large, complex estates and the Roman Empire itself. ${ }^{3}$ Works of linguistic art, originally spoken but recorded and disseminated in written form, were also highly valued. Knowledge of these works served as a marker of cultivation and status, leading to the production and preservation of a large body of literature. ${ }^{4}$ As a result of the value placed on texts and the diversity of ways in which they were used in the past, scholars in the present are able to study the ancient Mediterranean through the utterances of its inhabitants in a way that is paralleled in very few other contexts.

The words of ancient people survive in two different forms: as original texts written in antiquity and as modern texts transmitted through a sequence of copying that stretches back to the original. Texts in the first form are labeled 'documentary sources' and those in the second, 'literary sources.' Here, however, we prefer the term 'transmitted texts,' taken from Sinology, where it is used in contrast to 'excavated texts.' The legal sources, which preserve decrees, descriptions of cases and legal decisions, were not written with aesthetic or rhetorical considerations in mind, and therefore cannot be considered 'literary' in the same way as histories, letters, or even technical literature. This chapter introduces some of the most important transmitted

\footnotetext{
1 Woolf 2009.

2 Harris 1989 is fundamental on levels of literacy in the ancient world. For good introductions to the many ways in which texts were used in the Graeco-Roman world, see the essays collected in Johnson and Parker 2009.

3 Woolf (2009, 51-53) argues that the use of writing for the administration of the Roman state followed its use in the management of private estates. This is in contrast to the sequence in Ptolemaic Egypt (see von Reden, ch. 8.C, sec. III, this volume).
}

4 Habinek 2009.

Ә Open Access. (c) 2020 Eli J. S. Weaverdyck, published by De Gruyter. (c) BY-NC-ND This work is licensed under the Creative Commons Attribution-NonCommercial-NoDerivatives 4.0 License.

https://doi.org/10.1515/9783110607741-012 
textual sources of evidence and discusses how they are used for writing economic history in the ancient Mediterranean. The following chapter discusses documentary texts.

Evidence from transmitted texts poses serious difficulties for the study of economic history. As in any text-based study, it is necessary to consider the agenda of the writer and the context in which they wrote. More problematic are the things that ancient writers did not record. The texts that survive were all written by and for elites usually living near the centers of political power, leaving out large swaths of territory and the majority of the population. Furthermore, the economy was not seen as a distinct sphere of normative behavior in the ancient Mediterranean world. There are no bodies of literature dealing with what we would call macroeconomics the collective production, distribution, and consumption of goods and services within and between populations. Ancient economic thought was focused on individual economic actors, primarily households and, to a lesser extent, political entities, and the ways in which they could acquire wealth. ${ }^{5}$

For ancient writers, wealth was a means to an end, namely subsistence and status, rather than an end in and of itself, and methods of acquiring it were bound up with moral and social considerations. ${ }^{6}$ So, Cato begins his second century BCE treatise on farming thus: "It is sometimes better to obtain wealth through commerce, were it not so hazardous, and likewise to lend money, if it were as honorable."7 For ancient authors, economic activity is bound up in individual morality. The wealth of a community or the Roman Empire as a whole was seen as a reflection of political power wielded well. ${ }^{8}$ While politics and morality were subjects capable of consideration in their own right, the myriad actions and transactions that constitute what we call 'the

5 There are very few works devoted to exploring the ways in which a political entity might raise revenue in the ancient Graeco-Roman world. Xenophon's Poroi is a proposal for ways to raise revenue for Athens in the fourth century BCE and the second book of the pseudo-Aristotelian Oikonomi$k a$ is primarily a collection of anecdotes relating ways that various rulers and cities raised funds. The use of the word oikovopía to refer to these types of revenues is unusual. Normally, it refers more narrowly to household management.

6 Moses Finley argued forcefully for the fundamental difference between ancient and modern economic thought in the 1970s (Finley 1999). Vivenza 2012 provides a useful, recent summary of the ways Romans, in particular, thought about economic matters. Leshem 2016, writing for economists rather than historians, argues that both modern and ancient economic thought consider human behavior as a relationship between means and ends. Whereas modern economics is neutral as to what those ends are, ancient economics consider the worthiness of the ends to be highly important. 7 Cato De agricultura 1. 1. Despite this, Cato was also involved in money lending and other business ventures, as reported by the second century CE biographer, Plutarch (Vita Catonis Maioris 21. 5-8). The examples of similar sentiments could be multiplied. Cicero, for example, says that to preserve and increase wealth is a duty, but only by honorable means (Cicero De officiis (Cic. Off.) 2. 24 (87)). Later, he quotes Cato comparing money-lending to murder (Cic. Off. 2. 25 (89)).

8 See, for example, Pliny, Panegyricus 29. 2-3, Aelius Aristides, Orationes 26. 11-13, and Libanius, Orationes 59. 171 quoted in Wilson and Bowman 2018. See also García Morcillo 2017 for Strabo's connection of communal wealth and quality of government below the imperial level. 
economy' was not. Studying economic history from ancient texts, therefore, requires one to cast a wide net, gathering anecdotes describing economic activities and reconstructing the social and cultural structures within which those activities took place. Luckily, there are profitable fishing grounds within the literary corpus from the ancient Mediterranean. Some of the most frequently used genres and works are introduced here. ${ }^{9}$

\section{Agricultural Manuals}

Since agriculture was considered the most honorable means of acquiring wealth, we possess several treatises on idealized aristocratic farms in Classical Athens and west-central Italy. Xenophon's Oikonomikos, written in the fourth century BCE, is a Socratic dialog on the proper administration of an elite Athenian household that emphasizes the husband and father's training and management of his wife, overseer, and other members of the household. ${ }^{10}$ Roman agricultural writings, in contrast, do not consider marital relations and assume that the readers' agricultural estates are normally managed by a servile overseer (a vilicus). ${ }^{11}$

These works provide a great deal of detail on agricultural techniques. Columella's treatise is the most detailed, covering all aspects of farming including horticulture and animal husbandry. He provides invaluable evidence on the various crops that were commonly planted, human and animal labor inputs for them, sowing rates and yields, and estate management, among other things. Cato, who predates Columella by almost two centuries, provides less detail on techniques, but includes model contracts for various activities and recommendations on how much to feed slaves, which have been used to estimate levels of consumption. ${ }^{12}$ Taken as a whole, the tradition of Roman agricultural writing - which has its roots in the Carthaginian agronomist Mago, whose treatise on the subject was translated into Latin in the second century BCE on the order of the Senate - indicates the intense interest of

9 The Loeb Classical Library is the standard repository of Greek and Latin literature in English translation, with original text and translation on facing pages. It contains all the best-known sources from the Graeco-Roman world (https://www.loebclassics.com/). Legal sources are translated by Watson (1998) and Pharr (1952).

10 Föllinger 2012.

11 The most important surviving works are Cato's De agricultura (second century BCE), Varro's De re rustica (first century BCE), Columella's De re rustica (first century CE), and Palladius's Opus agriculturae (fifth century CE). Pliny the Elder's Naturalis historia (Plin. HN) contains several books that treat agriculture, including book 14 on vines and wine, 15 on fruit trees including the olive, 17 on cultivated trees, 18 on crops, and 19 on flax and garden plants. Vergil's Georgica is a poem on farming that is rarely taken as evidence for ancient practice by modern scholars, but was taken seriously by ancient agricultural writers, as shown by Doody (2007). For overviews of ancient Greek and Latin works on agriculture, see Christmann 2006; White 1970, 14-41. For Roman agricultural writings, see Diederich 2007; White 1973.

12 For one example among many, see Erdkamp 2005, 47. 
elites in maximizing productivity. ${ }^{13}$ From the perspective of modern economics, however, the agricultural writings are incomplete. They contain almost no discussion of the ways in which the produce was distributed and consumed. The Roman agronomists testify to the impressive skill of Roman farmers but not necessarily to a complex understanding of economics.

When using Roman agricultural texts for economic history, one must also be careful in applying their evidence to non-elite farmers and those based outside of Italy. Nevertheless, there are reasons for optimism in this regard. Varro and Columella describe conditions in other parts of the empire. Columella, for example, compares soils in different provinces, probably because his audience owned estates all over the empire. Furthermore, while they focused on cash crops like vines and olives, elites, like smaller producers, also grew staples like grain and legumes to feed their households. ${ }^{14}$ To what extent their advice was followed, of course, is unknown. These writings are a testament to what was possible in ancient agriculture, not what happened in any particular place or time.

\section{Legal Sources}

Roman law codes are also valuable sources for economic history. There are two main sources. The Codex Theodosianus was a collection of decrees and judgements compiled in the fifth century CE under the emperor Theodosius II. Under Justinian in the sixth century, a second compilation also included the Digesta Iustiniani, which contains opinions and treatises written by jurists about legal principles. These sources provide examples of the kinds of contractual relationships and activities that brought people to court. For example, a decision preserved in the Digesta describes a maritime loan that funded a voyage from Berytus in Syria to Brundisium in Italy and back. ${ }^{15}$ The details reveal not only two nodes of a trade route, but how large amounts of money could be moved across the empire, ${ }^{16}$ the roles of slaves in commerce, ${ }^{17}$ and the importance of the sailing season. ${ }^{18}$

13 Plin. HN 18. 22.

14 Erdkamp 2005, 114-118; Morley 2000, 216-218.

15 Modern Beirut and Brindisi. Digesta (Dig.) 45. 1. 122. 1.

16 The loan was made in Syria and used to buy cargo that was sold in Italy. The proceeds could either be used to buy a return cargo or to pay back the loan, in which case the borrower had to pay for the money to be transported to Rome.

17 The loan was made by a slave on behalf of his master and a second slave of the lender accompanied the borrower to look after his master's interests. The legal question that is investigated by means of this example is whether or not the arrangements made by the second slave are legally binding. The answer quoted reveals that masters could specify precisely the scope of their slaves' legal authority.

18 The contract specified that the return journey from Italy to Syria must begin by the thirteenth of September. 
More broadly, the legal sources reveal the institutional framework within which economic activity took place. ${ }^{19}$ The law not only guaranteed property rights, it provided an array of legal tools that facilitated commerce for both Roman citizens and noncitizens. Contracts were standard features of financial relationships and they were enforceable through a legal system that a wide variety of people could access. ${ }^{20}$ More specific institutions like tenancy are described in detail, making it possible to examine things like the economic efficiency of the distribution of risk. ${ }^{21}$ The law codes also reveal persistent attitudes about the proper role of the state in regulating economic activity. ${ }^{22}$ The legal sources are valuable because they both provide anecdotal evidence for economic activity and evidence for the legal structure that shaped that behavior. The full potential of these texts for economic history has yet to be fully realized.

\section{Forensic Oratory}

In both Athens and Rome, elites earned status by pleading cases for others in court. ${ }^{23}$ They recorded and disseminated the speeches they delivered, the best of which were prized as examples of rhetorical excellence. As a result, we possess a substantial body of forensic oratory. In particular, speeches from Demosthenes, an Athenian orator active in the fourth century BCE, and Cicero, a mid-first-century BCE Roman orator, survive in large numbers. ${ }^{24}$ These orators describe, sometimes in detail, the economic circumstances or the activities of their clients, opponents, or others involved in the case when they seemed relevant. So, for example, Cicero, in defending a client against charges of illegal profiteering in Egypt, describes how his ship carried paper, linen, and glass from Egypt to Italy, but because many others were importing similar cargoes, his client lost money on the venture. ${ }^{25}$ This has

19 Kehoe 2007. Bang (2008, 275-281) uses legal sources' testimony on various forms of partnership and investment to argue for the importance of household-based relationships in organizing trade. This is part of a larger argument for his 'bazaar' model of the Roman economy (see von Reden and Speidel, ch. 17, this volume). Sirks 2018 is a more comprehensive and detailed overview of the evidence from a legalistic perspective.

20 For the relevance of the law in everyday life and its accessibility, see Kehoe 2007, 13-25 and Weaverdyck, ch. 7, this volume.

21 Kehoe 2007, 109-119 especially. In general, tenants bore the foreseeable risks and landlords the unforeseeable risks (Dig. 19. 2. 15. 2; 19. 2. 25. 6). Kehoe argues that this is consistent with modern economic theories of maximizing economic efficiency. Kehoe has written extensively on the impact of Roman law on the agricultural economy (1997; 2007; 2013).

22 See most recently Lo Cascio 2018.

23 For an introduction to Greek forensic oratory, see Cooper 2007. For Roman forensic oratory, see van der Blom 2016, 26-33.

24 We have 28 forensic speeches from Cicero and 42 from Demosthenes.

25 Cicero Pro Rabirio Postumo 40. 
been taken as evidence for both the commonness of mixed cargoes in antiquity and the high risk of long-distance trade caused by a lack of communication about market conditions. ${ }^{26}$ Demosthenes reports on the efforts of one group of traders to overcome those risks. ${ }^{27}$ They took out a loan to finance the shipment of grain from Egypt to Athens, but after they set sail, a shipment of Sicilian grain arrived, lowering the price. A partner who had stayed behind sent this information to Rhodes - an important stop on the journey from Egypt to Athens - so the shippers sold their grain on the spot, making a profit but breaking the terms of the original contract. Demosthenes's description suggests that this type of communication was highly unusual. Although the speech and the events it described took place in the late fourth century BCE, it has been taken as evidence for trading conditions in the ancient Mediterranean in general. ${ }^{28}$ When forensic speeches concern particular episodes of economic behavior, they can contain a wealth of valuable detail, but it is important to remember that they provide a snapshot of a moment in one or a few people's careers and that they are meant to persuade a jury.

\section{Collections of Letters}

A body of forensic oratory provides glimpses into the economic behavior of many different elites, but no comprehensive picture of any individual's business activities. Surviving collections of letters from prominent Romans partially make up this deficit, describing (some of) the behavior of one person over a period of time. ${ }^{29}$ One of the most important collections is that of Pliny the Younger, a senator in the late first and early second centuries CE. ${ }^{30}$ Richard Duncan-Jones used scattered references to income, property, and benefactions in Pliny's letters to estimate his total wealth and income, which provides a useful benchmark against which to compare other quantities of money. ${ }^{31}$ More importantly, these letter collections shed light on the mindset with which their authors approached economic problems and the strategies they employed. ${ }^{32}$

In several letters, Pliny describes his rural estates and how he managed them. Pliny frequently declined to exercise his rights to the full extent of the law in order to maintain long-term productive relationships with merchants and his tenants. In

26 Bang 2008, 142; Erdkamp 2005, 177.

27 Demosthenes Orationes 56. 7-11.

28 Erdkamp 2005, 181-185.

29 For Roman epistolography, see Edwards 2005.

30 The letter collections of Cicero (first century BCE), Seneca (first century CE), and Libanius (fourth century CE) also contain useful material.

31 Duncan-Jones 1974, 17-32.

32 Kehoe 1989. 
one letter, he describes how he sold a future grape harvest to multiple merchants, but when the harvest failed he made up part of their losses in accordance with how much they had bought and how much they had already paid. Although it cost him a great deal of money, Pliny says: "it was worth it, for throughout the whole region the unprecedented rebate and the process have won praise. Moreover the purchasers ... have departed under an obligation to me commensurate with their greater honesty and decency." 33 Pliny's letters, although written for publication and therefore depicting their protagonist in the best possible light, provide important evidence for the relationship between wealthy landowners and their socially inferior economic partners. ${ }^{34}$

Although Pliny's letters provide intimate details about one wealthy man's economic activities, their personal nature should be taken into account when using them as evidence for the economy as a whole. For example, some have used Pliny's offhand comments to support an argument about the lack of interregional integration in the Roman economy. In one letter, Pliny complained that he got no profit from an estate in Tuscany due to crop failure and that his estate in the Po valley was unprofitable because of a local glut that drove down prices, but he does not consider transporting the Paduan crops for sale in Tuscany. ${ }^{35}$ When evaluating this statement, however, the larger economic context must be taken into account. The Po drains into the Adriatic, so moving grain from the Po valley to Tuscany would have required either overland transport over the Ligurian Apennines or a sea voyage around the entire Italian Peninsula. Despite their proximity on a map, the two regions are effectively quite distant. ${ }^{36}$ Given that Pliny was probably used to selling to local merchants, as he did with wine, transporting crops to Tuscany would have represented an extraordinary investment. Furthermore, just because Pliny did not move the crops himself does not mean they were not moved. Merchants with access to shipping facilities could have collected cheap produce from all over the Po valley and shipped it in bulk to Tuscany or somewhere else experiencing a shortage. Pliny is only one part of the larger trade in agricultural produce. The fact that he was not prepared to take on the expense of transporting crops between regions does not mean that the regions were isolated from each other. Pliny's letters tell us a great deal about the economic activity of wealthy landowners, no more. As with other transmitted texts, it is dangerous to draw interpretations that exceed the subject matter of the text itself.

33 Pliny Epistulae (Plin. Ep.) 8. 2, trans. Walsh.

34 Plin. Ep. 9. 37 describes how, even after he had lowered their rent, his tenants had gone into so much debt to him that he had decided to institute sharecropping. Pliny would have been within his rights to seize the tenants' property and evict them. In Ep. 3. 19, Pliny considers buying an estate, but the previous owner had seized the property of the indebted tenants and thus destroyed their means of cultivating the land. Remittances of rent also appear in Ep. 10. 8. 5.

35 Plin. Ep. 4. 6. 1-2, cited by Bang (2008, 139).

36 Contra Bang 2008, 139. 


\section{History, Geography, and Encyclopaedia}

From the perspective of the economic historian, the genres of text described so far suffer from a lack of interest in change over time, a deficit exacerbated by the extreme chronological patchiness of works in each particular genre. Ancient histories, on the other hand, were concerned with diachronic change, but the proper subjects for ancient historians were the affairs of state, particularly the military and politics, so they have little to say about economic history. Historians do sometimes describe the fortunes of different cities, but the most important exceptions to their silence on economic matters are the figures they provide for the resources of the state. Tacitus famously summarizes the distribution of Rome's armies, which forms the basis of scholarly estimates of its size and cost at different periods. ${ }^{37}$ This in turn forms a major component of estimates of the tax burden and its effect on the economy. ${ }^{38}$ Histories also provide important evidence for demographic reconstructions of Mid-Republican Italy. Livy, along with a few other historians, reports census figures for the Roman Republic, but what these figures actually represent - all citizens, men, or men of military age - is still a matter of controversy. ${ }^{39}$ In general, the figures preserved in ancient literary sources should be treated with extreme caution since there was a high degree of numerical stylization, ${ }^{40}$ and both the availability of reliable statistics in antiquity and the accuracy of our sources in reporting them are uncertain. ${ }^{41}$

There are two works whose subjects extend beyond the state and beyond elite individuals to encompass the entire inhabited world and therefore contain a wealth of valuable data. These encyclopaedic works are Strabo's Geographika and Pliny's Naturalis historia. Important as they are, neither escapes the problems that characterize the evidence of transmitted texts in general.

The Geographika of Strabo, written in the late first century BCE and early first century CE under Augustus and his successor Tiberius, is a rich source for nuggets of economic data. ${ }^{42}$ The Geographika is a wide-ranging description of all the peoples and places in the inhabited world. Strabo is interested in the foundations of these communities' wealth and he pays particular attention to natural resources and the ways in which they are managed and exchanged. ${ }^{43}$ Therefore, he often mentions the products for which a place is particularly known and the presence of infrastruc-

37 Tacitus Annales 4. 5. Duncan-Jones 1994, 33-37 is one frequently cited example.

38 Most influentially in Keith Hopkins's 'taxes and trade' model (1980; 1995-1996).

39 Brunt 1987; de Ligt 2012; de Ligt and Northwood 2008; Launaro 2011.

40 Duncan-Jones 1997; Scheidel 1996.

41 Duncan-Jones 1997; Scheidel 2016.

42 Roller 2014 is the latest translation into English and the introduction provides a good, concise overview of Strabo's life and the text. For a more detailed treatment of various aspects of the Geographika, see the essays collected in Dueck 2017.

43 García Morcillo 2017. 
ture like harbor facilities and roads. ${ }^{44}$ He is also very useful in identifying hubs of trade. ${ }^{45}$ Of course, the Geographika is not unproblematic. Writing under the pax Augusta (the peace and prosperity provided by Augustus's rule) Strabo stresses that foresight and good governance in general, and the governance of Rome in particular, is the key to converting natural advantages into affluence. ${ }^{46}$ His depiction of the economic success of the core of the Roman Empire is probably somewhat optimistic. Strabo also orders the world along a cultural hierarchy in which distance from the Mediterranean is correlated with increasing barbarity and economic simplicity. ${ }^{47}$ For example, Strabo notes that certain areas do not use coined money and sees this as a sign of backwardness. While this can be taken as evidence that the use of money was seen as normal in the Mediterranean basin, the evidence of coin hoards from these 'barbaric' regions shows that Strabo's testimony cannot be accepted uncritically. ${ }^{48}$ Nevertheless, the Geographika is an invaluable source, particularly for its descriptions of local and regional specialization.

Pliny the Elder's Naturalis historia is another wide-ranging description of the world, organized both geographically and thematically. ${ }^{49}$ The Naturalis historia is a compilation in 37 books of ancient knowledge about nature and its relationship to humanity, much of which is preserved nowhere else. Pliny was both voraciously acquisitive of information and highly moralistic. ${ }^{50}$ Thus, his work provides a rich font of facts on innumerable subjects, many of which have direct bearing on economic questions, but his testimony can also be dismissed as "no more than moralizing archaism." 51 This aspect of the work, however, makes Pliny an excellent source on the cultural meaning of money and commodities in the Roman imagination. ${ }^{52}$ Pliny's ideological stance leads him to emphasize the novel and extreme, which makes him a good source for illustrations of the stupendous wealth acquired by

44 Strabo's description of Tyre on the Levantine coast is a good example (16. 2. 23): The city has two harbors, one open and one closed. It was captured by Alexander but was able to recover due to its seaborne commerce and its purple dye production.

45 Duncan-Jones 1990, 33-34.

46 Strabo states the principle most explicitly at 6. 4. 2. For Strabo's personal ties to the ruling, Roman elite, see Roller 2014, 1-16.

47 Dueck 2010.

48 See, for example, Strabo on the Albanians (11. 4. 4), who, he says, do not use money. However, several coin hoards have been found in the area. Thompson, Mørkholm, Kraay 1973, no. 1737, for example, comes from the site of Qabala in modern Azerbaijan.

49 The last several decades have seen a resurgence of scholarship on Pliny the Elder, which focuses on the nexus of ideology, empire, and science: Beagon 1992; Citroni Marchetti 1991; 2011; Gibson and Morello 2011; Healy 1999; Murphy 2004.

50 See Lao 2011 on the connection between knowledge and luxury in the Naturalis historia.

51 Finley 1999, 202 on Plin. HN 18. 35, where Pliny complains that large estates are ruining Italy. See also Finley 1999, 132 on Plin. HN 6. 101 and 12. 84 where Pliny complains of the great wealth spent on luxuries from the East.

52 Von Reden 2010, 186-198. 
some Roman elites. Pliny's statement that six senators owned half of the land in the province of Africa is one oft-quoted example. ${ }^{53}$ His statement that the finest house in Rome in 78 BCE was not among the finest hundred 35 years later has been taken as evidence for the rapid accumulation of wealth among the elite in the Late Republic. ${ }^{54}$ Pliny also records innovations, like the introduction of exotic plants to Italy and technological inventions that might have had important economic impacts such as the heavy, wheeled plow, the screw-and-lever wine press, the Gallic reaping machine, and hydraulic gold mining. ${ }^{55}$ Pliny's Naturalis historia is a vast compendium of information, but the significance of the facts assembled is rarely self-evident. Pliny's penchant for the wondrous makes it difficult to generalize from his testimony, and his moralizing agenda makes it easy to dismiss many of his claims.

In terms of economic data, the Naturalis historia is emblematic of the literary corpus as a whole. It provides anecdotal evidence scattered unevenly across time and space. There are no statistics and no diachronic sequences. The facts that we do have must be interpreted in the context of heuristic models about their source both the evidentiary basis of the author's claims and their intentions - and models about the economic processes under investigation. The conclusions one reaches depend heavily on those models, but the range of possibilities is not limitless. Through the judicious use of comparative evidence and theoretical models, progress can be made.

\section{Non-elite Literature}

While the people depicted in most ancient literature are elites, we possess several types of sources that provide a wider scope. Rabbinic literature and the New Testament are helpful for the Levant. There is also a tradition of popular literature, works written in a less elevated style about sub-elite characters. Most helpful for the Roman period are Petronius's Satyricon, written in the mid-first century CE, and Apuleius's Metamorphoses or The Golden Ass, written in the mid-second century CE. ${ }^{56}$ They are valuable because they depict the conditions in which the majority of the population lived, at least as it was imagined by their elite authors. Although fictional, they were meant to seem realistic and they treat subjects that were considered too base for the more elevated genres. We hear, for example, about a poor man who

53 Plin. $H N$ 18. 35.

54 Plin. HN 36. 109, cited by, for example, Harris (2007, 524).

55 Plin. HN 18. 171 for the plow, 18. 296 for the reaping machine, 18.317 for the wine press, 33. 7478 for hydraulic mining. Plin. HN 27. 2-3 describes the transfer of plants around the Roman world as one of the greatest benefits of Roman power. References to the exotic origins of various trees are found throughout book 12.

56 For the historical value of the Metamorphoses, see Millar 1981. For the Satyricon as evidence for economic history, see Verboven 2009. 
grows vegetables and goes to sell them in the nearest city every morning before returning to work in his garden, and so learn that market gardening was seen as a realistic strategy for poor cultivators living in an urbanized context. ${ }^{57}$

\section{Conclusion}

The widespread use of texts in antiquity provides a wealth of evidence for the modern scholar of economic history. Because it consists of linguistic expressions made by ancient people, the potential for understanding ancient economic mentalities is qualitatively different for the ancient Mediterranean than it is for contexts that produced less writing. The level of detail, the records of specific economic transactions with precise figures, would similarly be impossible to reconstruct from archaeological evidence alone.

These advantages throw into sharp relief the limitations of the written evidence. They were never recorded for the purposes to which we wish to put them. There was no concept of the economy as a unit of analysis, and so no ancient economic history on which to draw in the way that political historians draw on ancient histories of states. The evidence is highly uneven in its geographical and chronological distribution. This is a result not only of accidents of preservation, but of the original state of the data. Some times and places are simply better attested than others. There are also major obstacles to quantification. As a result of these limitations, it is very difficult, often impossible, to systematize the individual pieces of data into a coherent, diachronic sequence that would support the arguments we would like to be able to make about the ancient economy.

Nevertheless, there is enough evidence to limit the number of possible interpretations. We can get a sense of what was possible and what was, if not impossible, at least highly unlikely. Most importantly, the written evidence can be considered alongside various types of archaeological evidence, which have different sets of strengths and weaknesses, to arrive at a more comprehensive understanding of the ancient economy.

\section{References}

Bang, P. F. 2008. The Roman bazaar: A comparative study of trade and markets in a tributary empire. Cambridge: Cambridge University Press.

Beagon, M. 1992. Roman nature: The thought of Pliny the Elder. Oxford: Clarendon.

Brunt, P. A. 1987. Italian Manpower: 225 BC-AD 14. 2nd ed. Oxford: Clarendon.

57 Apuleius, Metamorphoses 9. 32. 
Christmann, E. 2006. “Agrarian writers.” In H. Schneider, M. Landfester, and H. Cancik (eds.), Brill's new Pauly: Antiquity volumes. Brill Online Reference Works. http://dx.doi.org/10.1163/ 1574-9347_bnp_e108500.

Citroni Marchetti, S. 1991. Plinio il Vecchio e la tradizione del moralismo romano. Pisa: Giardini.

-. 2011. La scienza della natura per un intellettuale romano: Studi su Plinio il Vecchio. Pisa: Serra.

Cooper, C. 2007. “Forensic oratory.” In I. Worthington (ed.), A companion to Greek rhetoric, 203219. Malden, MA: Blackwell.

De Ligt, L. 2012. Peasants, citizens and soldiers: Studies in the demographic history of Roman Italy $225 B C-A D$ 100. Cambridge: Cambridge University Press.

De Ligt, L., and S. J. Northwood, eds. 2008. People, land, and politics: Demographic developments and the transformation of Roman Italy, $300 B C-A D$ 14. Leiden: Brill.

Diederich, S. 2007. Römische Agrarhandbücher zwischen Fachwissenschaft, Literatur und Ideologie. Berlin: De Gruyter.

Doody, A. 2007. "Virgil the farmer? Critiques of the Georgics in Columella and Pliny." Classical Philology 102.2, 180-197.

Dueck, D. 2010. “The geographical narrative of Strabo of Amasia.” In K. A. Raaflaub and R. J. A. Talbert (eds.), Geography and ethnography: Perceptions of the world in pre-modern societies, 236-251. Malden, MA: Wiley-Blackwell.

-, ed. 2017. The Routledge companion to Strabo. London: Routledge.

Duncan-Jones, R. 1974. The economy of the Roman Empire: Quantitative studies. Cambridge: Cambridge University Press.

-. 1990. Structure and scale in the Roman economy. Cambridge: Cambridge University Press.

-. 1994. Money and government in the Roman Empire. Cambridge: Cambridge University Press.

-. 1997. "Numerical distortion in Roman writers." In J. Andreau, P. Briant, and R. Descat (eds.), Économie antique: Prix et formation des prix dans les économies antiques, 147-159. Saint Bertrand-de-Comminges: Musée Archéologique Départemental de Saint-Bertrand-deComminges.

Edwards, C. 2005. “Epistolography.” In S. Harrison (ed.), A companion to Latin literature, 270283. Malden, MA: Blackwell.

Erdkamp, P. 2005. The grain market in the Roman Empire: A social, political and economic study. Cambridge: Cambridge University Press.

Finley, M. I. 1999. The ancient economy: Updated with a new foreword by lan Morris. Berkeley, CA: University of California Press.

Föllinger, S. 2012. “Xenophon, Oeconomicus.” In M. H. Wibier (ed.), Brill's new Pauly. Supplement 1, vol. 5. Brill Online Reference Works. http://dx.doi.org/10.1163/2214-8647_bnps5_ID_0063.

García Morcillo, M. 2017. “Patterns of trade and economy in Strabo's geography.” In Dueck (2017), 137-149.

Gibson, R. K., and R. Morello, eds. 2011. Pliny the Elder: Themes and contexts. Leiden: Brill. Habinek, T. 2009. “Situating literacy at Rome." In Johnson and Parker (2009), 114-140.

Harris, W. V. 1989. Ancient literacy. Cambridge, MA: Harvard University Press.

-. 2007. “The Late Republic.” In W. Scheidel, I. Morris, and R. P. Saller (eds.), The Cambridge economic history of the Greco-Roman world, 511-539. Cambridge: Cambridge University Press.

Healy, J. F. 1999. Pliny the Elder on science and technology. Oxford: Oxford University Press. Hopkins, K. 1980. "Taxes and trade in the Roman economy (200 BC-AD 400)." Journal of Roman Studies 70, 101-125.

-. 1995-1996. "Rome, taxes, rents and trade." Kodai 6/7, 41-75.

Johnson, W. A., and H. N. Parker, eds. 2009. Ancient literacies: The culture of reading in Greece and Rome. Oxford: Oxford University Press. 
Kehoe, D. P. 1989. "Approaches to economic problems in the letters of Pliny the Younger: The question of risk in agriculture." In W. Haase (ed.), Aufstieg und Niedergang der römischen Welt. Part 2, vol. 33.1, 555-590. Berlin: De Gruyter.

-. 1997. Investment, profit, and tenancy: The jurists and the Roman agrarian economy. Ann Arbor, MI: University of Michigan Press.

-. 2007. Law and the rural economy in the Roman Empire. Ann Arbor, MI: University of Michigan Press.

-. 2013. "The state and production in the Roman agrarian economy." In A. K. Bowman and A. Wilson (eds.), The Roman agricultural economy: Organization, investment, and production, 33-53. Oxford: Oxford University Press.

Lao, E. 2011. "Luxury and the creation of a good consumer." In Gibson and Morello (2011), 35-56. Launaro, A. 2011. Peasants and slaves: The rural population of Roman Italy (200 BC to AD 100). Cambridge: Cambridge University Press.

Leshem, D. 2016. "Retrospectives: What did the ancient Greeks mean by Oikonomia?" Journal of Economic Perspectives 30.1, 225-238.

Lo Cascio, E. 2018. "Market regulation and transaction costs in the Roman Empire." In A. Wilson and A. K. Bowman (eds.), Trade, commerce, and the state in the Roman world, 117-132. Oxford: Oxford University Press.

Millar, F. 1981. "The world of the Golden Ass." Journal of Roman Studies 71, 63-75.

Morley, N. 2000. "Markets, marketing and the Roman élite." In E. Lo Cascio (ed.), Mercati permanenti e mercati periodici nel mondo romano: Atti degli Incontri capresi di storia dell'economia antica (Capri, 13-15 ottobre 1997), 211-221. Bari: Edipuglia.

Murphy, T. 2004. Pliny the Elder's Natural History: The empire in the encyclopedia. Oxford: Oxford University Press.

Pharr, C. 1952. The Theodosian code and novels and the Sirmondian constitutions. Princeton, NJ: Princeton University Press.

Roller, D. W. 2014. The geography of Strabo: An English translation, with introduction and notes. Cambridge: Cambridge University Press.

Scheidel, W. 1996. "Finances, figures and fiction." The Classical Quarterly 46.1, 222-238.

-. 2016. "Benford's Law and numerical stylization of monetary valuations in classical literature." Classical Quarterly 66.2, 815-821.

Sirks, B. 2018. "Law, commerce, and finance in the Roman Empire." In A. Wilson and A. K. Bowman (eds.), Trade, commerce, and the state in the Roman world, 53-116. Oxford: Oxford University Press.

Thompson, M., O. Mørkholm, and C. M. Kraay, eds. 1973. An inventory of Greek coin hoards. New York, NY: American Numismatic Society.

van der Blom, H. 2016. Oratory and political career in the Late Roman Republic. Cambridge: Cambridge University Press.

Verboven, K. S. 2009. "A funny thing happened on my way to the market: Reading Petronius to write economic history." In J. R. W. Prag and I. Repath (eds.), Petronius: A handbook, 125-139. Malden, MA: Wiley-Blackwell.

Vivenza, G. 2012. "Roman economic thought.” In W. Scheidel (ed.), The Cambridge companion to the Roman economy, 25-44. Cambridge: Cambridge University Press.

von Reden, S. 2010. Money in classical antiquity. Cambridge: Cambridge University Press.

Watson, A. 1998. The Digest of Justinian. 4 vols. Philadelphia, PA: University of Pennsylvania Press.

White, K. D. 1970. Roman farming. Ithaca, NY: Cornell University Press.

-. 1973. "Roman agricultural writers I: Varro and his predecessors." In H. Temporini (ed.), Aufstieg und Niedergang der römischen Welt. Part 1, vol. 4, 439-497. Berlin: De Gruyter. 
Wilson, A., and A. K. Bowman. 2018. "Introduction: Trade, commerce, and the state." In A. Wilson and A. K. Bowman (eds.), Trade, commerce, and the state in the Roman world, 1-24. Oxford: Oxford University Press.

Woolf, G. 2009. “Literacy or literacies in Rome?” In Johnson and Parker (2009), 46-68. 


\section{Sitta von Reden}

\section{C Documentary Sources}

\section{Introduction}

The use of documentary sources (papyri, coins, and inscriptions) for economic history has a long pedigree. The great German philologist and epigraphist August Boeckh (1785-1875) not only initiated the first corpus of Greek inscriptions (now Inscriptiones Graecae [IG]), but also applied his epigraphical knowledge to writing the first history of Athenian public finance. ${ }^{1}$ Boeckh pioneered ancient economic history as a quantifying discipline. He also reoriented the academic interest from ancient household management to what he regarded as the national economy of Athens. The Russian-born archaeologist Michael Ivanovich Rostovtzeff (1870-1952) likewise used documentary sources to refocus the subject of ancient economic history. More than Boeckh, he demonstrated the potential of this evidence for research on economies beyond Athens and Rome. ${ }^{2}$ Integrating local art, papyri, coins, and inscriptions from the Eastern Mediterranean and the Near East into his research on the Hellenistic and Roman economies, he turned historians' attention away from the centers to places like Egypt, Syria, and the Black Sea. Although his model of the ancient economies is largely obsolete, his evidence is still valuable for the economic history of the Eastern Mediterranean and the Near East. The material of the magisterial five-volume Economic Survey of Ancient Rome (1933-1940), edited by Tenney Frank, had an equally important impact. Moreover, these works did not only focus strongly on documentary evidence, but also argued for the so-called modernist, that is market-oriented, perspective on the Greek and Roman economies. ${ }^{3}$

This perspective fell into disregard with the anti-modernist model of A. H. M. Jones and Moses Finley. ${ }^{4}$ Finley not only emphasized fundamental differences between ancient and modern economies, but also derived his position largely from literary evidence. Unfortunately, Greek and Roman literature overwhelmingly expressed the ideas of Roman and Athenian elites privileging the view from the imperial centers and the rationalities of wealthy landlords. It was only with the return of modernist positions that the use of documentary sources came back in a great way. ${ }^{5}$ Moreover, quantifying trends in archaeological research, a greater integration

\footnotetext{
1 Boeckh (1817) 1967.

2 Rostovtzeff 1926, 1941.

3 Edmondson 2015.

4 See von Reden and Speidel, ch. 17, this volume.

5 See von Reden and Speidel, ch. 17, this volume.
}

Note: Many thanks to Michael Speidel for suggestions and comments on this chapter, and to Andrew Meadows for letting me see forthcoming work.

Ә Open Access. () 2020 Sitta von Reden, published by De Gruyter. (c) BY-NC-ND This work is licensed under the Creative Commons Attribution-NonCommercial-NoDerivatives 4.0 License.

https://doi.org/10.1515/9783110607741-013 
of numismatic, papyrological, and epigraphical research into ancient history, and above all the increasing possibilities of managing large corpora of data digitally spurred the quantitative turn of modern scholarship. ${ }^{6}$ As Weaverdyck emphasizes in the previous chapter, no serious economic historian of the Graeco-Roman world nowadays can ignore the increasing volumes of archaeological data any longer. The same applies to documentary sources. The material is constantly increasing, and new methods of interpretation increase their value as evidence for economic history. Moreover, coins, inscriptions, and papyri each in their way shed light on regions whose economic histories a few decades ago were still largely unknown.

Despite its great potential, documentary evidence bears some particular problems. This concerns, first of all, the uneven spread of coins, inscriptions, and papyri. Papyri mostly come from Egypt; the largest number of inscriptions come from Italy, North Africa, and Asia Minor; and the provenance of large quantities of coins surfacing on the art market is uncertain. This raises the question of the representativeness of individual pieces and groups of documentary evidence beyond their immediate - at times uncertain - geographical and socio-political contexts. Can papyri or local epigraphic sets be used as evidence for the economy and administration of the Hellenistic and Roman Empires in general? Evidence from coins, inscriptions, and papyri, moreover, frequently cluster in particular years, followed by decades or centuries not documented at all, or in very different ways. ${ }^{7}$ Furthermore, many lists and accounts preserved epigraphically or papyrologically lack the information indispensable for economic analysis. Accounts often do not give prices per unit, particular qualities of choice products that might explain higher or lower prices, seasonal, social, or climatic variables of prices and wages, or the specifics of a transaction that might have included agreements concerning the payment of tolls, transport costs, or monetary fees. ${ }^{8}$ If documentary sources are used for quantifying purposes, care must be taken that the specifics of the sample, the size of the sample, and any other particular circumstances of the data are discussed in detail and do not get lost in the generalizing rhetoric of graphs and pie charts.

\section{Coins}

Coins seem to be keys to economic processes. Yet, while numismatic evidence is widely available throughout the Graeco-Roman world and often the only source available, coins are most difficult to use for economic history. ${ }^{9}$ Their potential for

6 See Weaverdyck, ch. 8.A, this volume; and Duncan-Jones 1990; 1994; Bowman and Wilson 2009; de Callataÿ 2014.

7 Rathbone 2014.

8 Reger 1994; Rathbone and von Reden 2015.

9 Metcalf 2012 provides the most up-to-date introductory surveys of major coinages and study aids for research on ancient coinages; for numismatic databases, see Weaverdyck, ch. 8.A, this volume. 


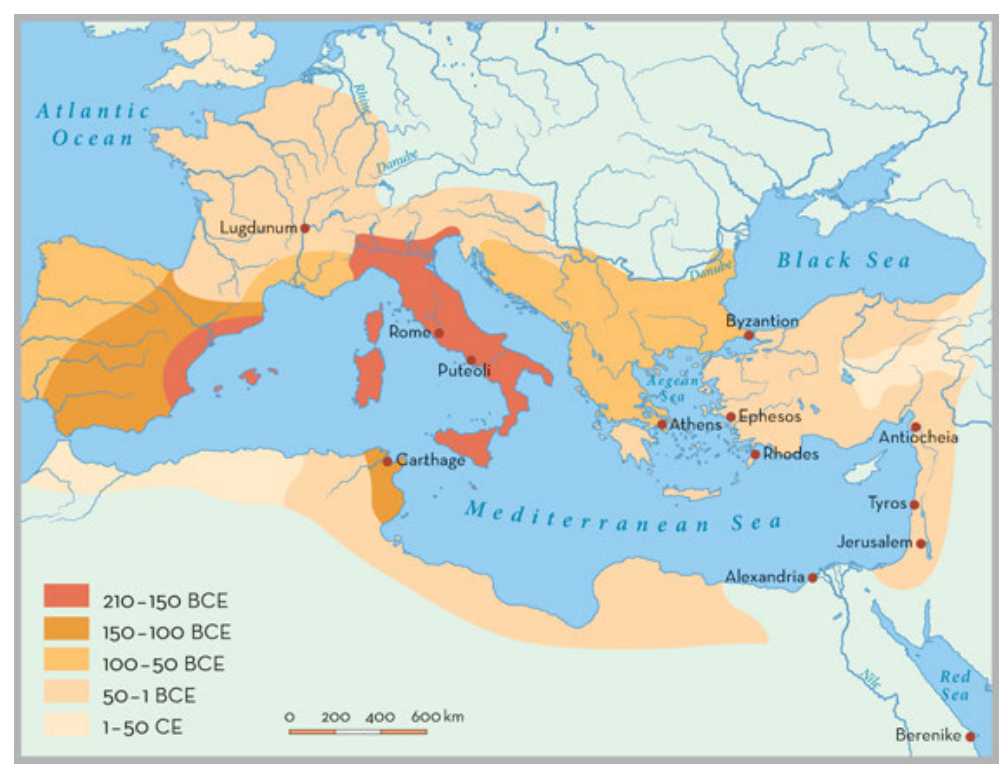

Map 1: Spread of the Roman denarius coinage (after Burnett 1987, fig. 3.1). @ Peter Palm.

quantitative economic research, as well as for studying the contacts, trade, and politics of states is tremendous. But several methodological problems must be kept in mind. Firstly, coins were only one monetary medium alongside many others. There were many alternatives to the use of cash, such as payment in kind (especially grain); payment in uncoined metal pieces and objects (bullion); book money (monetary units not transferred in cash); and the use of foreign coins used alongside local issues or as bullion value. ${ }^{10}$ Measuring coin volumes in circulation, therefore, does not reveal much about a monetary economy which tends to be much larger than the economy in cash. ${ }^{11}$ Secondly, many questions related to the economy in cash are still quite unresolved, such as how different local coinages, and coinages based on different weight standards, were used together. How were foreign coins integrated into the local coin system, and to what extent were old coins demonetized when new coins were issued? Local governments adopted very different policies in these matters. Only under the Roman Empire was an imperial coin system, based on the denarius, developed that integrated all local coinages through fixed exchange rates. Over time, most local precious metal coinages disappeared (see map 1).

Thirdly, it is still controversial whether ancient governments - and the Roman government in particular - minted coins in order to supply their own needs for ar-

10 Harris 2008b for cashless exchange in the Roman world.

11 Woolf 1998 for Roman Gaul; Rathbone 1996 for Roman Egypt; von Reden 2007 for Hellenistic Egypt. 
mies, wages, and infrastructure, or to supply the economy with cash. ${ }^{12}$ This question has implications for our understanding of coin circulation and monetization. Did ancient governments adopt monetary policies that self-consciously fostered monetary development? We also do not know how local coin users reacted to monetary manipulation. Did the precious metal content stipulated by the imperial mint matter to users, or did they tolerate some monetary manipulation without losing trust in the coinage ${ }^{13}$ Fourthly, we have to keep in mind how coins have come down to the present time. Most ancient coins have survived in hoards, that is, from caches saved or hidden, rather than as individual coins being in use. If hoards contain small numbers of certain coins, as is the case for Augustan issues, this is very likely due to intense coin use and peacetime rather than a decline in coin production and circulation. A surge of coins from coin hoards that were not recovered in antiquity are more likely evidence for political crises, warfare, and instability when people hid what they had and never returned back to it. A smaller number of coins are known from archaeological stray finds, that is, from contexts where coins were dropped rather than buried on purpose. Yet these are biased toward base metal coins low in value, as people are more likely to pick up silver and gold than bronze pieces. An exception are the finds from Pompeii. They provide a snapshot of coin use on one particular day in the year 79 CE. 84 coin groups that were buried under the volcanic ashes of the Vesuvius revealed that two-thirds of their total value was struck in gold. ${ }^{14}$ Yet how do we interpret this result? ${ }^{15}$ Thus, when we study distribution patterns of coins, we are heavily dependent on the conditions of recovery, the preservation and composition of the sample, and the interpretability of these factors.

Given these complications, what questions can be answered with numismatic evidence? The presence of coins is usually an indicator for the presence of, or interaction with, goods and people identified with these coins. ${ }^{16}$ Thus, substantial coin finds in rural areas, for example, militate against the notion that monetized exchange was concentrated in urban centers. ${ }^{17}$ The use and imitations of Athenian and Hellenistic coins beyond the regions of direct political influence suggest interaction and monetary exchange, though the nature of the exchange and the ways the coins reached faraway places must be discussed in any particular circumstances. ${ }^{18}$ Roman coins, moreover, can well be shown to have followed Roman armies, and to have contributed to coin use in regions where armies were stationed. ${ }^{19}$ Yet

12 Crawford 1970 contra Lo Cascio 1981; Howgego 1992 for discussion.

13 Howgego 2009.

14 Duncan-Jones 2003.

15 Andreau 2008 for discussion.

16 Finds of individual Roman coins, such as they have been made in (modern) Thailand, Vietnam, China, and Japan, obviously cannot be taken to reflect Roman presence.

17 Howgego 1992.

18 McLaughlin 2016; Nappo 2018.

19 Onken 2003. 
local coin hoards and stray finds have also revealed that in frontier zones Roman coins were not merely concentrated in military settlements, but also increased in local towns that had used their own coinage before Roman armies arrived. ${ }^{20}$

In ideal circumstances, coins can be used to reconstruct circulation patterns and the policies behind them. Thus, for example, the closed currency system of the Ptolemaic Empire where only Ptolemaic coins were permitted in exchange, is attested by the absence of foreign coins in Ptolemaic hoards from the third century BCE onward. ${ }^{21}$ Moreover, on the basis of coin hoards it has been shown that Ptolemaic coins continued to circulate in Phoenician cities after these cities had ceased to be under Ptolemaic control, while the city of Askalon in Palestine, when becoming independent of Seleukid control in 104/3 BCE left the royal type unchanged, merely altering the legend. ${ }^{22}$ These and similar examples help suggest the strong impact of markets relying on the acceptability of coinages in exchange systems that reached beyond the region. Bronze coins, moreover, generally show a rather small local radius of circulation, while silver and gold traveled greater distances and can be found in hoards far away from their area of origin. Such evidence has been used to discuss whether monetary income was generated in different provinces of the Roman Empire than it was spent. ${ }^{23}$

Scholars have successfully calculated the coin output of mints from the evidence of extant dies. Such calculations allow us to see changing volumes of production and to discuss the motivations for and consequences of the increase. ${ }^{24} \mathrm{We}$ have, for example, calculations for coin production in Athens during the sixth and fifth centuries BCE, showing a clear increase in the first years after the foundation of the first Athenian confederacy in 479 всE. ${ }^{25}$ We also have calculations of numbers of coins produced from the Persian treasuries captured by Alexander the Great and put into circulation in the 320 s BCE. ${ }^{26}$ Calculations of total coin production also help us understand the scale of the increase of bronze coinages from the late fourth century BCE onward. ${ }^{27}$ Conversely, increases in imperial coinages have been shown to have led to the gradual decline of local coinages. ${ }^{28}$

Much more problematic than calculating coin production are calculations of volumes of coins in circulation in any particular region, polity, or empire. Keith

20 Katsari 2008.

21 Von Reden, ch.1, this volume.

22 Meadows 2001.

23 Duncan-Jones 1990, 106-107, 172-179; against Hopkins 1980.

24 Crawford 1974; for Hellenistic coinages, de Callataÿ 1997.

25 Meadows 2014; Meadows forthcoming.

26 De Callataÿ 1989; 2005 for revised figures.

27 De Callataÿ 2006, 178-179.

28 Interpretations are controversial, some arguing that local minting was suppressed by force, others by currency competition, Figueira 1998. 
Hopkins famously attempted to calculate such figures for the Roman Empire. ${ }^{29}$ Both the methodology of calculating total coin volumes circulating in a large imperial space such as the Roman Empire from the evidence of extant coins, and the argument that increasing coin volumes must have affected prices is not tenable. ${ }^{30}$ Monetization had reached high levels in the Eastern and Western Mediterranean by the second century BCE, but as we have just pointed out, there were different forms of money in circulation, as well as many local coinages that were only gradually replaced by Roman coins. ${ }^{31}$ An increase in Roman coins might therefore not have increased the absolute number of coins in circulation, let alone the degree of monetization, but simply the number of Roman coins in the empire. Many regions had an insufficient supply of coins for the number of transactions they expressed in monetary terms, so a better supply of coins will have affected neither their monetary economies in principle, nor price formation. Even during the third century CE, it is debatable whether the large increase in the production of coins immediately led to an increase in prices in the Roman provinces. ${ }^{32}$

\section{Papyri and Ostraca}

Papyrology deals with texts surviving on papyrus and some other organic writing materials, such as hides, wood, and wax. ${ }^{33}$ Ostraca (broken potsherds used for everyday writing), though not falling into that category, are also studied by papyrologists. All organic writing materials have a particular history of survival, as their preservation is dependent on particular environmental conditions, such as hyperarid desert zones or volcanic ashes that preserved the material over thousands of years. Thus, despite being the main writing material for formal texts throughout the Graeco-Roman world, papyri - just as hides, wooden, or wax tablets - have survived in only selected areas of the ancient world. Their discovery, moreover, is dependent on archaeological excavation, an interest of archaeologists to excavate texts rather than other material, on accidental finds, and the vagaries of the art market to which many originals were sold in the early days of papyrology during the nineteenth and early twentieth centuries. ${ }^{34}$

29 Hopkins 1980.

30 Von Reden 2002, 161-162 for the debate, and Howgego 2009 for a summary of the numismatic problems.

31 Howgego 1992; Hollander 2007; Katsari 2008.

32 Rathbone 1996; for discussion Howgego 2009.

33 For introductions to particular categories of papyri, study aids, and discussions of issues arising from papyri as historical sources, Bagnall 2009.

34 Cuvigny 2009. 
By far the largest number of papyri come from the dry regions of the Nile valley in Egypt (see map 2). Throughout the Graeco-Roman occupation of Egypt (332 BCE to first the Sasanian and then Arab conquests in the sixth century $\mathrm{CE}$ ) they were written in Greek, Demotic Egyptian, or Coptic, a largely Greek script of rendering Egyptian that became popular from the third century CE onward. Many papyri recording everyday transactions or receipts, moreover, are bilingual documents in both Greek and Demotic. Some pre-Hellenistic papyri in Aramaic and later Roman texts in Latin are extant, but a standardized form of Greek (koine Greek) was used by the immigrants, their descendants, and those who over time adapted to the foreign regime. The habit of fixing contracts and land registers in writing had been practiced during the Pharaonic and Persian periods, but written documentation increased substantially under the Ptolemies and was used for a much wider range of purposes. From about the 260s BCE, the Ptolemaic administration began recording most administrative activities, census returns, formal legal agreements, regulations, and ordinances in writing, while estate holders and private individuals quickly followed suit.

In addition to the ca. 50,000 Egyptian papyri edited so far, some 600 papyri have been excavated in the Middle Euphrates region and the Syrian desert, especially on the site of the city of Dura Europos at the Upper Euphrates (see ch. 1, map 2). In Pompeii and Herculaneum, the eruption of the Vesuvius has preserved burnt parchment containing mostly literary texts, and wax tablets containing, among other things, the accounts of two bankers and business consortia in Pompeii and Puteoli. ${ }^{35}$ The wooden tablets of (ancient) Vindolanda in Britain, sites around modern Carlisle and London, Siebenbürgen in Germany, and (ancient) Vindonissa in modern Switzerland contain official and private correspondence of Roman military camps stationed there in the first century $\mathrm{CE} .^{36}$

Ostraca were used for shorter texts, but contain highly instructive notifications and letters, receipts of taxes, tolls, and rents, as well as acknowledgements of the receipt of trade consignments and ship- or donkey loads. Surprisingly, they are extant almost exclusively from Egypt. ${ }^{37}$ Of particular significance for the study of trade and frontier zone processes are the ostraca from Myos Hormos and Berenike on the Red Sea coast, containing permissions for the passage of goods and people at the customs gate. ${ }^{38}$

Another important collection of ostraca was found at Koptos on the Nile in Upper Egypt, relating to a family-run business of a certain Nikanor owning a caravan

35 TPomp = CIL IV 3340, 1-153 (archive of L. Caecilius Iucundus in Pompeii); Camodeca 1999 (TPSulp = archive of the Sulpicii in Puteoli).

36 Bowman and Thomas 1983; 2003; Speidel 1996.

37 Some 140 ostraca dating to the third century CE were found in a Roman fort at Gholaia (Bu Njem) in Libya, see Marichal 1992.

38 Bagnall, Helms and Verhoogt 2000. 


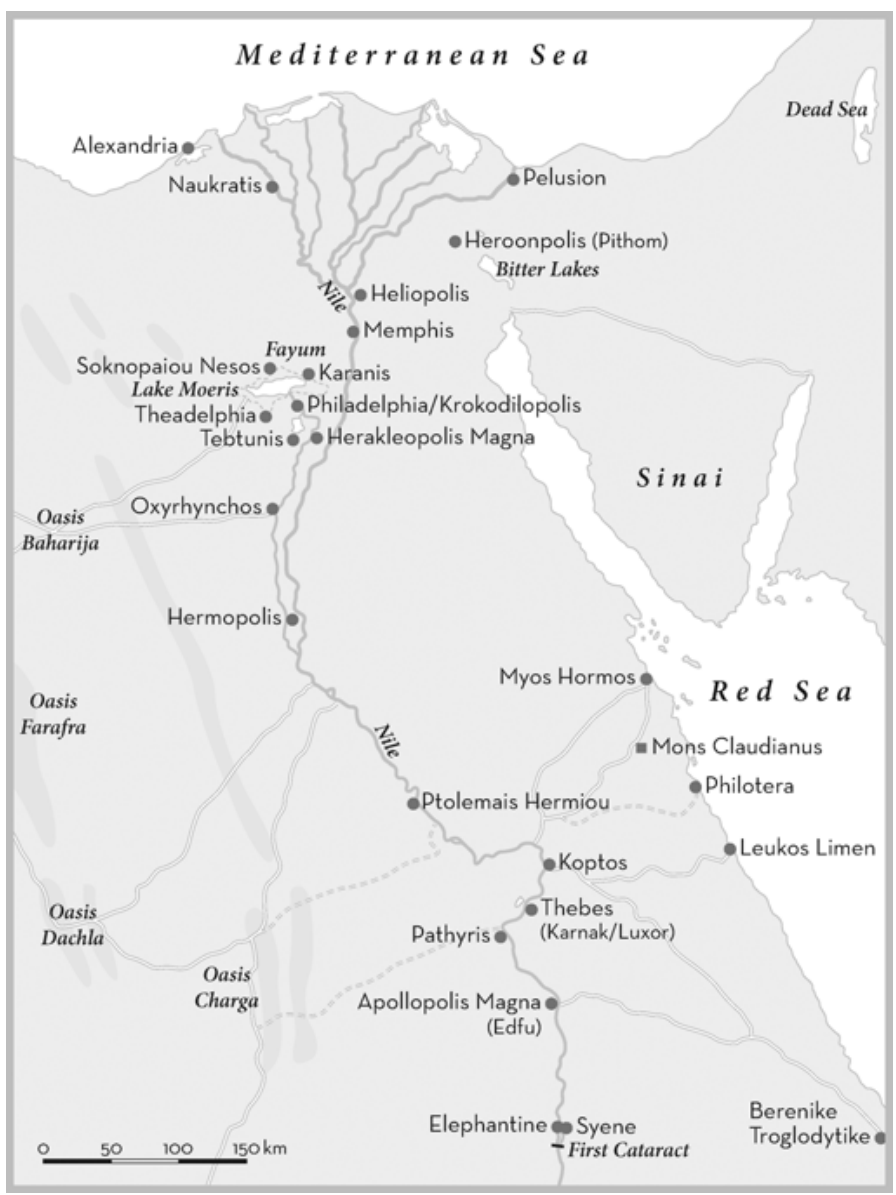

Map 2: Major sites of Graeco-Roman Egypt. (C) Peter Palm.

of at least 36 camels and supplying Roman garrisons in the Eastern Desert and port towns on the Red Sea coast between the years 6 and 62 CE. ${ }^{39}$ More than 10,000 ostraca were found in the Eastern Desert at the Roman forts of Xeron Pelagos and Dios, as well as the quarry of Mons Claudianus that was under the supervision of the Roman army. Adjacent to the quarry were a garrison and quarters for the workers living there with their wives and children. The ostraca from these sites are still in the process of being published. ${ }^{40}$ They contain detailed information about the economic organization of work at the quarry and the supply of the workers with food and goods, as well as the transport of stone, supplies, and other commodities along the routes from the desert to the Nile.

39 Funghi, Messeri and Römer 2012 (= P. Petr. Mus.).

40 O. Claud. I-IV = Bingen, Cuvigny, and Bülow-Jacobson 1992-2009. 
As papyri and ostraca are archaeological finds, they do not document the life of people throughout Egypt. ${ }^{41}$ Much larger numbers of papyri were excavated in Lower than in Upper Egypt, but Greek and Roman occupation was also concentrated largely in the lower Nile valley. The largest number of papyri were excavated or discovered in the Fayum Oasis, which had been an area of intense Greek settlement from the time of Ptolemy II onward and continued to be a center of Graeco-Egyptian settlement in the Roman period. ${ }^{42}$ Extensive excavations of papyri were conducted by the Oxford classicists Bernhard Grenfell (1869-1926) and Arthur Hunt (1871-1934) at Umm al-Baragat (ancient Tebtunis), and by the University of Michigan at Dimai (Soknoupaiou Nesos) and Mom Aushim (Karanis), all of which were thriving local towns established under Ptolemy II. The most spectacular excavation of a waste dump was conducted by Grenfell and Hunt at Oxyrhynchos in the adjacent Oxyrhynchite nome (district), bringing to light about 400,000 fragments, mostly of the Roman period, of which to date merely some 5,500 have been published. Accidental discoveries by Egyptian fellahin and excavators include the archive of Zenon near Madinat al-Fayum (Krokodilopolis/Philadelphia) in 1914 and the archive of Heroninos that was found allegedly in a wooden box, but more likely in a waste dump, near al-Harit (Theadelphia) at the beginning of the twentieth century. In Upper Egypt, significant numbers of papyri relate to second-century BCE Pathyris where a garrison was stationed during the later Ptolemaic period. These papyri in particular reveal a great degree of acculturation between Greeks and Egyptians in the course of the Ptolemaic occupation of Egypt. ${ }^{43}$ Demotic papyri have been discovered in the regions of Edfu (Appolopolis Magna), Karnak/Luxor (Thebes), and also in the Fayum. Substantial numbers of bilingual documents attest to bilingualism both in daily life and in the administration of Egypt during the Ptolemaic period. Very few Romans immigrated into Egypt farther than Alexandria, so Latin never became a dominant spoken or written language in Roman Egypt. Due to the wet conditions in the delta, no papyri are extant from Alexandria, which creates an unfortunate gap, and bias, in the documentation. Chronologically, the second century CE is documented best, due to the increase in written documentation in the Roman Empire, but also because of the extensive excavations in the Oxyrhynchite and Herakleopolite nomes. The numbers of papyri extant from the Hellenistic period are generally smaller, but the third century BCE is better documented than the second and first, as we profit from the find of the Zenon archive, which alone contained 1,800 papyri.

Another methodological problem is posed by the disciplinary separation of ancient history and classical philology on the one hand and Egyptology on the other. Greek papyri are objects of study of Hellenists trained in Greek and Latin, while Demotic documents are often beyond their expertise. As a result, research on Graeco-

41 Habermann 1998.

42 Von Reden, ch. 1, this volume.

43 Lewis 1985, 2001. 
Roman Egypt for a long time represented merely the practices of the ruling elites and those social groups and individuals who adapted to them in the course of time. Only in the last two decades or so, the need for a disciplinary cross-over has been put into practice. Gradually, there are more scholars who combine Greek and Demotic language skills and reveal the degree to which our understanding of the multicultural society of Egypt changes under this perspective. ${ }^{44}$

Papyri offer ample opportunities for both quantitative and qualitative research. Unsurprisingly, most official and private documents represent a local agrarian economy concerned with the use of land, animal husbandry, fishing, textile production, local marketing, and a wide range of other types of agrarian and non-agrarian business in the Nile valley. Alongside administrative documents, land registers, and census lists, a large number of legal documents, such as tenancy, rental and credit agreements, labor and sales contracts, as well as wills, marriage contracts, and divorce settlements are preserved on papyri. ${ }^{45}$ We learn about taxes and tolls, their collection, storage and use, the construction and maintenance of private and public buildings and local infrastructure, in particular the dyke system, about banking, state monopolies (in the Hellenistic period), as well as land and river transport. Coherent sets of papyri (dossiers) allow the reconstruction of the day-to-day running of local administrative offices, temple administrations, banks, and large estates. Thanks to the high standards of editorial work and historical expertise of papyrologists, the commentaries in the printed volumes of papyri are a great source of historical information. ${ }^{46}$ Only a small fraction of this extensive scholarship has yet been synthesized into historical monographs and papers. The groundbreaking work of early twentieth-century papyrologists who tried to make sense of the law, administration, and economy of Graeco-Roman Egypt they reconstructed from the papyri is only gradually being supplemented - without ever being fully replaced - by broader historical approaches that ask new questions, adopt new methods of analysis, and include the ever-growing number of published papyri not yet available to the first generations of papyrologists.

Research tends to focus on groups of papyri (dossiers and archives) that allow insights into particular institutions, regions, or agrarian practices. The long Papyrus Revenue Laws (259/8 BCE), first published by Grenfell at the end of the nineteenth century, was once used to demonstrate, in combination with other papyri, the ex-

44 E.g., Manning 2003; Clarysse and Thompson 2009; Monson 2012; Thompson 2009 for multilingualism in Hellenistic Egypt.

45 Keenan, Manning, and Yiftacht-Firanko 2014.

46 Most editions are now digitized and searchable on various databases conglomerated in the platform www.papyri.info. They contain texts and digital images, but not the translations and commentaries of the print editions. Bibliographical details for the print editions are collected in The Checklist of Editions of Greek, Latin, Demotic and Coptic Papyri, Ostraca and Tablets, also available on papyri.info. 
ploitative fiscal regime and centralized economy of the Ptolemaic state. ${ }^{47}$ It detailed the monopolization of oil production and distribution, as well as the tight regulation of the collection of the tax on vineyards and orchards (apomoira) that was hired out to tax farmers. Subsequently, the same document was used by the Belgian papyrologist Jean Bingen to show that tax farming was in fact a dynamic business for Greek entrepreneurs who, in a royal economy with limited private economic opportunity, made substantial semicommercial profits from the discrepancy between the tax volume calculated by the state and the tax income that could actually be collected from the tax subjects in practice. ${ }^{48}$

The archive of Zenon, a civil immigrant from Kaunos in Asia Minor, who between 259 and 246 BCE managed a large gift estate in Philadelphia and its branch in the Memphite nome, has been the basis for a host of studies on agricultural management and innovation, land development, and monetization in the early years of Ptolemaic rule. ${ }^{49}$ The archive, now spread across several papyrus collections worldwide, contained some 1,800 papyri ranging from receipts and accounts pertaining to the management of the land, the payment of its employees and tenants, the exploitation of the flocks, and commercial affairs, as well as travel and transport to contracts of all kinds, written orders, and the private and business correspondences between Zenon and his friends, superiors, and agents in Philadelphia, Memphis, Alexandria, and locations as far away as Ptolemaic Syria and Phoenicia (fig. 1). ${ }^{50}$ As managers of large estates filled some function in the local administration as well, the archive also reveals much about the fiscal-administrative practice in the Fayum during the early Ptolemaic period.

A smaller group of 50 papyri discovered by the British Egyptologist William Matthew Flinders Petrie (1853-1942) in the late 1880s, contains the business of a royal engineer working on the dyke system in the Arsinoite nome between 262 and 249 вСE. ${ }^{51}$ The papyrologists Willy Clarysse and Dorothy Thompson, moreover, have compiled a large corpus of papyri relating to the poll tax, the main personal tax of Ptolemaic Egypt. ${ }^{52}$ From these documents they were able not only to reconstruct the complicated system of tax assessment, the census on which the poll tax was based, and the system of collection of the tax, but also other questions of significance to the social and economic history of Hellenistic Egypt: its administrative geography, the size of Greek and Egyptian households, the composition of families, and much more.

47 P. Revenue Laws (trans. Bagnall and Derow 2004, no. 114); for the centralized, planned or 'dérigiste’ economy, Rostovtzeff 1941; Préaux 1939.

48 Bingen (1978) 2007.

49 Thompson 1984; 1999; von Reden 2007.

50 Pestmann and Clarysse 1981; Orrieux 1985; Clarysse and Vandorpe 1995.

51 Lewis 2001, 37-45.

52 Clarysse and Thompson 2009. 


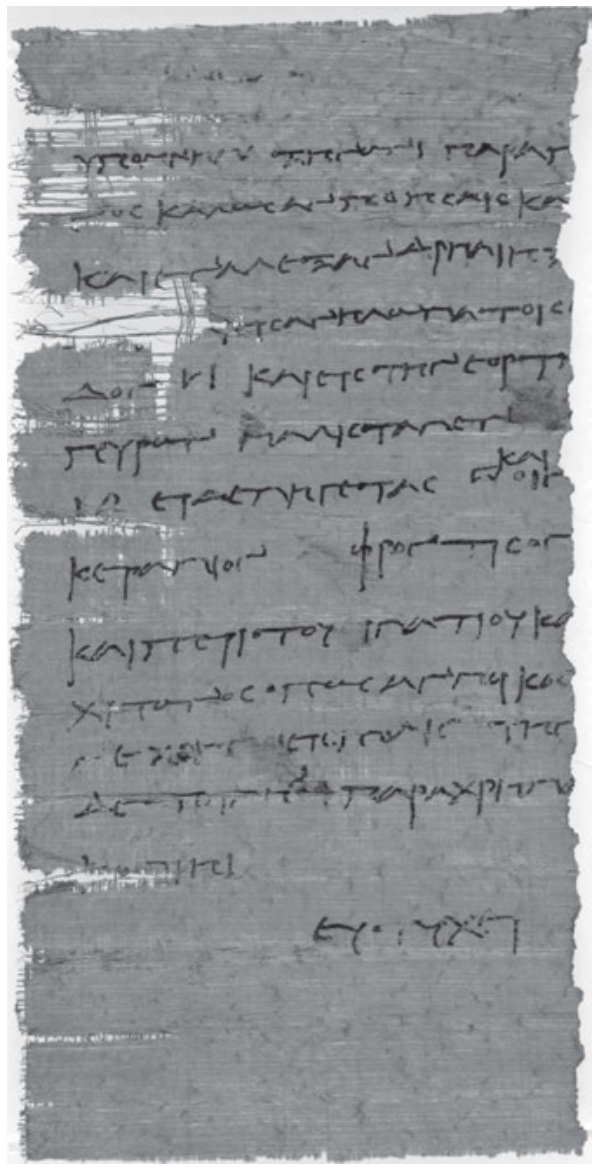

Memorandum to Zenon from ... Will you kindly, as I requested of you in Alexandria also, give those at home 10 drachms for expenses and, if possible, ten artabai [i.e. ca. 400 1] of wheat for the festival or, if not, the six, and a jar of wine? And about the himation [coat] and chiton [frock], see to it that they are brought down to me in town; and you shall receive the price immediately.

May you prosper.

Fig. 1: Memorandum to Zenon, P. Mich. 197 , mid-third century BCE, Philadelphia/Arsinoite nome, University of Michigan Papyrology Collection. Photo and Translation: APIS UM, Creative Commons.

Papyri from the second century BCE are mostly restored from mummy wrappings (cartonage) and are often in a poorer state of preservation than the third-century material. Yet again, Grenfell and Hunt were fortunate to discover in Tebtunis the tombs of 21 sacred crocodiles wrapped and stuffed with the wastepaper of the village office of Kerkeosiris. The papyri date from around 119 to a little after 91 BCE and contain the dealings of the Hellenized Egyptian village scribe Menches and his successor Petesouchos. ${ }^{53}$ Some of the wastepaper had been reused by private people, probably a family, between 105 and 99 вСЕ. The core of the archive relates to the administration of the village's agricultural land, containing land registers and letters to and from the village scribes by their superiors and subordinates. They

53 Vandorpe 2012; Lewis 2001, 104-123; Verhoogt 1998. 
offer detailed insights not only into administrative matters, but the complex system of land management and its royal surveillance in the later Ptolemaic period.

The integration of Demotic papyri into research has made historians move even farther away from the model of a centralized state economy that dominated research on the economy of Hellenistic Egypt well into the second half of the twentieth century. In 2003, Manning published an influential study based on Greek papyri from the Fayum on the one hand, and third- to first-century BCE Demotic texts from Apollopolis Magna (Edfu) and Pathyris on the other. ${ }^{54}$ The comparison of the two corpora of texts revealed a great degree of pre-Ptolemaic institutional continuity in the administration and land tenure regime in Egypt during the first decades of Ptolemaic rule. It showed, furthermore, that the Fayum, so far taken as typical for Ptolemaic Egypt, was an exceptional region because of the particularly effective control of the Ptolemies over the Fayum Oasis and its Greek population. And finally, the comparison of Demotic and Greek evidence helped to question the notion of a strong, centralized Ptolemaic economy. The Ptolemaic administration, rather, was quite dependent on the cooperation of the local Egyptian elites attached to the large temple estates in the Nile valley.

Egypt remained an agrarian economy in the Roman period, while the increase of private property rights and a different fiscal-administrative regime encouraged private economic initiative, as well as probably greater fortunes held in private hands. ${ }^{55}$ This economy has been studied from several socio-economic perspectives and on the basis of different papyrological dossiers. Rowlandson investigated the agrarian economy of Oxyrhynchos and its surrounding villages on the basis of the Oxyrhynchos papyri. She observed that the Roman administration of Egypt was selfconsciously responsible for fostering a class of moderately prosperous, but predominantly small-scale metropolitan landowners. This was achieved by the creation of greater quantities of privately owned land taxed at very moderate rates. ${ }^{56}$ However, despite the substantial material she had at her disposal, it was not possible to distinguish clearly between private and public land, or to prove that there was a greater concentration of land and thus greater prosperity of fewer individuals. 15 years later, Monson elaborated on these findings by first drawing attention to diverse and flexible 'bundles' of property rights that Egyptians, Graeco-Egyptians, Roman citizens, and Alexandrians held in Roman Egypt, and second by correlating population growth and urban development in different regions of Egypt. More than Rowlandson, he emphasized the degree of institutional change in Egypt and the resulting increase in prosperity revealed by the demographic and urban development in Egypt under Roman rule. ${ }^{57}$ The spectacular sums invested into a sea journey to

54 Manning 2003, 65-129.

55 Rathbone 2007; Monson 2012.

56 Rowlandson 1996, 280.

57 Monson 2012. 


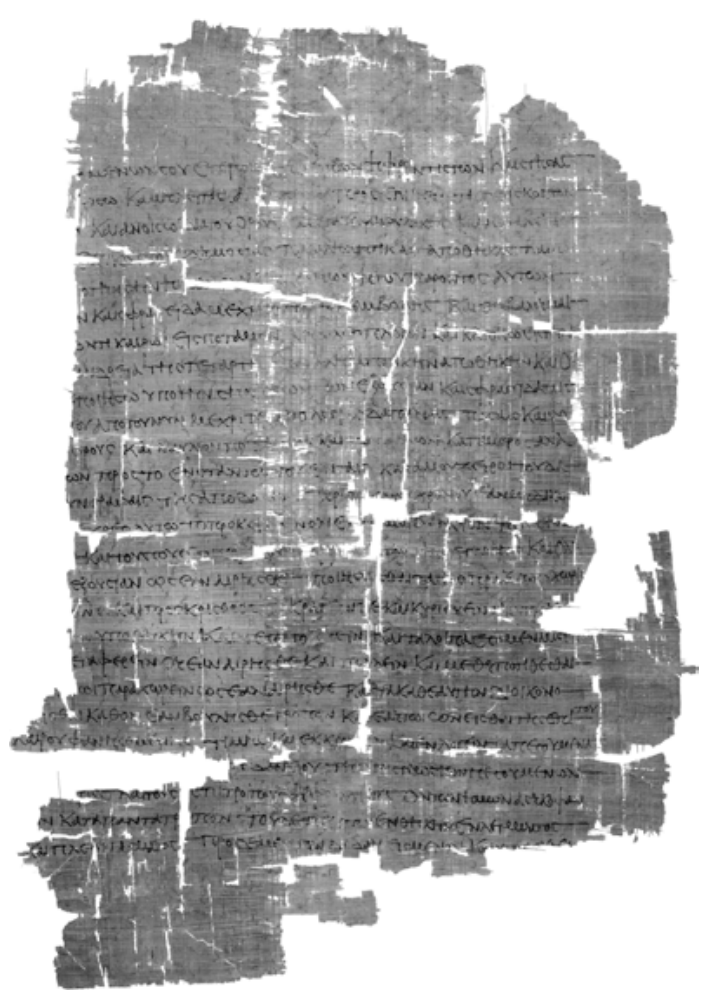

Fig. 2: Muziris Papyrus, SB XVIII 13167, mid-second century CE, Austrian National Library, Vienna. (C) Österreichische Nationalbibliothek, Papyrussammlung.

Muziris in the second century CE, known from a contract preserved on an unprovenanced papyrus purchased by the Austrian National Library in Vienna in 1980 (fig. 2), attest to the outstanding monetary fortunes that were accumulated by some members of the Romano-Egyptian elite under the Roman Empire. ${ }^{58}$

If we are searching for the economy of scale that might explain this monetary wealth, we have to look to the management of large estates. One important body of evidence is provided by the Heroninos archive related to the estate owned by Appianos, a Greek-speaking Egyptian with Roman citizenship rights. The archive probably comprised about 800 to 1,000 documents (many still unidentified and unpublished) and is dated to the first half of the third century CE, when Heroninos was manager of one of the estate's subunits. Roughly 400 published documents of the archive were analyzed by Rathbone in 1992, in a then pioneering study of the profitoriented economic strategies of this large agrarian enterprise. ${ }^{59}$ Rathbone based his

58 Rathbone 2001 for translation and commentary of SB XVIII 13167.

59 Rathbone 1992. 
findings mainly on a detailed analysis of the accounts of the estate, which he realized formed a connected system. They allowed accurate monitoring of the production (and productivity) of the estate's individual units, as well as their marketing of produce. Close reading of the accounts also showed that great attention was paid to the social cohesion of groups of laborers who seem to have worked together in family units. Rathbone's analysis shows how the rather complicated and fragmentary papyrological evidence can be used effectively for economic history, both in quantitative and qualitative ways, and for generating results that suggest neither a market economy similar to modern ones, nor an anti-market mentality that held back large economic players in the Roman economy.

\section{Inscriptions}

In contrast to papyri, inscriptions are available from a large number of sites and regions of the Greek and Roman worlds. ${ }^{60}$ Preserved on monuments, statue bases, tombstones, freestanding slabs (stelai), pottery, metal pieces, and glass, inscribed material is an integral part of most archaeological sites. Rarely are they still found in situ, that is, in the place where they were erected or placed originally, as already in antiquity stone and metal were reused for later monuments and buildings. Official inscriptions tend to be written in the official languages of either standard Latin or Greek, but we have many bilingual or trilingual inscriptions combining a Greek or Latin version with one in either another dominant language (such as Aramaic or Greek in the Roman East), or a local one, such as Lykian, Karian, or Palmyrenian. Many inscriptions, moreover, are written in vernacular Latin, Greek, or other local dialects and help us to appreciate degrees of literacy in different regions and provinces of the Hellenistic and Roman worlds. Given the wide range of inscribed materials and purposes for which they were inscribed, the use of inscriptions as evidence for economic history is as wide-ranging as the reasons for which they were written.

Inscriptions are also spread chronologically and geographically unevenly. There is a significantly larger number of Greek inscriptions extant from the Hellenistic than the Classical period. Epigraphic evidence explodes in the Roman Empire from the first century BCE onward. ${ }^{61}$ Within this period, there is a visible peak in the later second and early third centuries CE. These discrepancies are not a matter of accident, but mark changing epigraphic habits. In the Hellenistic, and even more so in the Roman imperial period, people committed a wider range of issues to stone or other permanent materials. In the Hellenistic cities of the Aegean and Asia Minor,

60 Bruun and Edmondson 2015 for surveys and introductory essays; for Hellenistic epigraphy, McLean 2002; for methodological issues, Bodel 2001; for epigraphic databases, see Weaverdyck, ch. 8.A, this volume.

61 Bodel 2001, 7-15. 
for example, there was an explosion of statues erected in public places with honorific inscriptions adorning their bases or erected next to them, a habit that yet increased under Roman rule.

Geographically, there is a great discrepancy between urban and rural epigraphy. Although we do have inscriptions from rural areas and remote places, public inscriptions are largely an urban phenomenon. Inscriptions are also found in different numbers in different parts of the Hellenistic and Roman Empires. There is a concentration of Greek inscriptions in the Greek mainland, the Aegean (including Cyprus and Crete), and Asia Minor. The epigraphic visibility of Asia Minor continues into the Roman period, but the largest number of surviving inscriptions are from Italy and Rome. North Africa, Spain, and the Lower Danube region (Dacia) have also brought to light abundant epigraphic material, while reasonable quantities are extant from Gaul and Syria. Far fewer inscriptions come from Britain, Kappadokia (central Anatolia), or Raetia (southern Germany).

Some of these discrepancies may be due to varying levels of literacy in the various parts of the Roman world, but the question of how many people and what social groups could read is still controversial. While scholars in the past tended to be pessimistic about levels of literacy in the ancient world (in the order of 10 percent), research over the past 30 years has differentiated the concept of literacy, emphasizing varying levels of reading and writing proficiency, and the interdependence of written and symbolic messages on inscribed monuments. ${ }^{62}$ The archaeological spread of writing utensils in combination with papyrological evidence for primary education in Hellenistic and Roman Egypt suggests that the pessimistic figures of levels of literacy should be corrected upward..$^{63}$

Yet despite the abundance of extant inscriptions, usually published in regional corpora, one must never forget that even at best only a small fraction of the former wealth of inscribed material is extant. Scholars concentrate on certain groups of inscriptions, such as official decrees, edicts, or statutes (called acta by epigraphists) and public or private accounts (also included in the category of $a c t a$ ); or they look at building inscriptions, votive inscriptions, funerary inscriptions, or honorary decrees (so-called tituli). A special category is formed by small inscriptions and stamps on pottery or other items of domestic or everyday use, and by inscribed mile- and boundary stones.

Apart from empirical details regarding place names, occupations, commodity prices, interest rates, taxes, titles to ownership, or water regulations, epigraphic evidence has helped to reconstruct how particular institutions - industrial workshops, mines, customs halls, or road stations - worked in the Hellenistic and Roman Empires. Individual inscriptions or groups of inscriptions have shed light on procedures and regulations that would otherwise be unknown. Many have wider

62 Bodel 2001, 15-19.

63 Morgan 1998; Speidel 2018, 183-184 with further literature. 
than local significance, as similar regulations are often known from several places. The Roman imperial administration in particular developed procedures for the regulation of provincial affairs in a well-organized system of local enquiries and responses from the emperor. Some individual epigraphical texts illuminate the regulations of taxation at imperial borders or instances of price regulation in the Roman Empire. ${ }^{64}$ Edicts preserved in Asia Minor show the imperial concern for transport for military or other purposes. Seemingly insignificant inscriptions that can be studied in bulk, such as stamps on bricks, tiles, storage vessels, or bread (for which the stamping devices have survived) help to reconstruct ceramic production, agrarian practices and landownership, or long-distance trade across the Mediterranean. ${ }^{65}$ The producers' stamps on terra sigillata pottery and oil lamps have allowed historians to understand how the pottery industry was organized in the Roman Empire. A particularly interesting set of bi- and trilingual inscriptions in either Greek and Palmyrenian, or combining these with Latin, are found in Palmyra. The financing and military protection of caravan transport between Palmyra and Spasinou Charax on the lower Euphrates close to the Persian Gulf play a great role in the inscriptions, many of them honoring caravan leaders as benefactors of the city. ${ }^{66}$

Much economic information is owed to the Greek and Roman predilection for fixing on stone accounts and financial aspects of their public and private affairs. The democratic requirement of civic governments and temples to publish their income and expenditure has left us with numerous epigraphic accounts of public or temple income and expenditure, returns of investment in land and credit, expenditure for ritual and temple personnel, as well as the costs of material, labor, and food supply in the course of construction work. ${ }^{67}$ The habit of the Romans to include the status and professions of their deceased family members in funerary inscriptions has provided us with a wide range of occupations of free citizens, foreigners, freedmen, and slaves. Equally revealing are inscriptions surviving on statue bases with which urban populations honored their benefactors, stating in detail the benefactions in money, financial services, public monuments, or buildings for which the honors were due. ${ }^{68}$ Democratic governments published their temple inventories as well as all their laws and regulations on stone, while Roman emperors and local governors made public legal and administrative regulations, including maps and land surveys. ${ }^{69}$

The most valuable epigraphic studies are those that analyze inscriptions in their immediate and wider archaeological contexts, and give details of their physical

64 Cottier et al. 2008; Boatwright 2000, and for the famous price edict of Diocletian, Corcoran 1996.

65 Edmondson 2015.

66 Al As'ad and Gawlikowski 1997; Fox, Lieu, and Ricklefs 2005.

67 Reger 1994.

68 McLean 2002.

69 Edmondson 2015. 


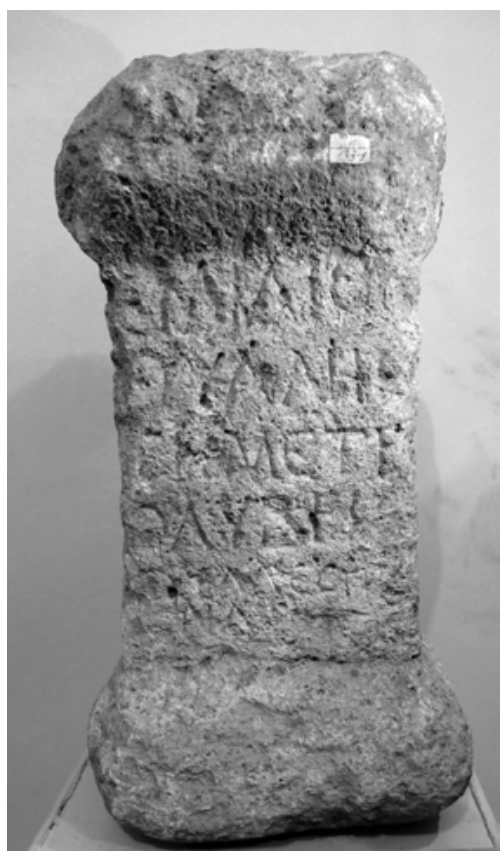

Fig. 3: Altar to Ge Meter Olybris, second century CE, Areni/Armenia, Yeghegnadzor Regional Museum, inv. 133-1. Photo: M. Speidel.

appearance, general purpose, the ways the inscription under consideration was looked at, who could read them, and for whom they were written. A full or fragmentary epigraphic account erected in either a sacred precinct or a public market provides different kinds of information than sums scribbled on the corner of a private room. Good epigraphical research, moreover, is based on either individual texts put into wider and comparative contexts, or bulk material whose chronological and geographical distribution is made transparent.

The importance of contextualization can well be illustrated by the rather inconspicuous inscription shown in fig. 3. This little monument of porous limestone was found in 1978 when a road was built near the modern village of Areni in eastern Armenia. ${ }^{70}$ The village is located at what was also in ancient times a crossroad leading from western Anatolia to Albania or Atropatene. The shape of the monument and a cup-like hole for pouring libations on the top of the flat upper surface identify it as a little altar quite typical for the Roman period. On its front, six lines of Greek are engraved along previously marked lines. The script quite recognizably comes from an amateur's hand and is comparable to those of rural inscriptions known from inner Anatolia. It is an everyday engraving very different in purpose

70 Vinogradov 1992, and Speidel personal communication. 
and function from the professional inscriptions that were erected in urban centers. The text itself gives no hint of its date, but some peculiarities of the letter shapes, also found in other Armenian inscriptions might suggest, though by no means conclusively, that it was engraved sometime in the second century CE. The three lines read: ${ }^{71}$

\begin{tabular}{|c|c|}
\hline 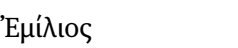 & Emilios \\
\hline 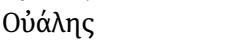 & Ouales \\
\hline 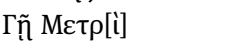 & to Mother Earth \\
\hline 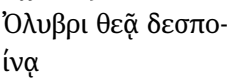 & $\begin{array}{l}\text { Olybris, goddess and mis- } \\
\text { tress }\end{array}$ \\
\hline
\end{tabular}

The altar was thus a dedication to a goddess, possibly intended by Emilios to be worshipped by passersby like himself. A mother goddess with the epiklesis Olybris is not known from any other source, but she might have been the consort of Zeus Olybris who appears more frequently in inscriptions from Kilikia (southern Anatolia), Kappadokia, Syria, and Rome where Zeus Olybris was called a Kilikian god. But who was Emilios Ouales? His mother tongue seems to have been Greek, his religious sentiments affiliate him with Anatolia, and he called himself by a Roman name (Aemilius Valens). The presence of a small, inconspicuous altar on a busy road through Armenia dedicated to an Anatolian goddess by a Greek with a Roman name shows the great mobility and truly global connectedness of people in some areas of the Roman Empire. Some scholars assume that Aemilus Valens was a soldier serving in a legion passing through Armenia at the time of the Roman-Parthian war in 161-167 CE. ${ }^{72}$ But there is no conclusive evidence for this connection other than the general assumption that it was usually soldiers who were mobile, and that it was Roman legionaries who adopted Roman names. But Aemilius might quite as well have been a traveler, a migrant, a trader, a trader accompanying Roman troops, or a veteran using his expert knowledge of the region for some personal business. As it often happens, it is only once a monument is properly contextualized that we can begin asking questions.

\section{Conclusion}

Documentary sources are one of the most important types of sources for economic history. Not only do coins, papyri, and inscriptions lead us into ancient economic practices in far more detail than transmitted texts, but also allow us to investigate places that did not catch the attention of ancient authors. Furthermore, under cer-

71 Supplementum Epigraphicum Graecum (SEG) 42, 1322.

72 Vinogradov 1992. 
tain circumstances they are available in sufficient quantities to make possible quantitative or serial analyses, which are the only ways of assessing economic performance and outcomes.

The last 200 years have seen a vast amount of scholarship devoted to collecting, reading, editing, analyzing, and categorizing Greek and Roman coins, papyri, and inscriptions. Thanks to the continuous effort of numismatists, papyrologists, and epigraphists whose major aim it is to publish the finds that fill national libraries, museums, and university collections worldwide, we are fortunate to have a large number of corpora that present this ever-growing body of material regionally, chronologically, or by collection. To be able to study these corpora, and to understand the language and conventions of documentary sources, remains one of the most important tasks for students of ancient economic history. In recent years, many corpora of documentary sources have been digitized, allowing data searches and serial analyses in quantities that a few years ago would have taken a lifetime. Yet despite these opportunities, one still needs to keep in mind that the raw data provided by documentary sources are but the tiniest fraction of what once was produced. They are extremely selective, circumstantial, and often undated or unprovenanced.

Although documentary sources are best studied as dossiers or series, there is always the chance of squeezing surprising details out of a single find. This holds true as much for exceptional documents such as the Muziris papyrus as it does for fairly ordinary remains such as the small altar in rural Armenia. Most importantly, although coins, papyri, and inscriptions have been presented in this chapter separately, and are usually studied separately by highly trained specialists, they were part of the same ancient world and are best understood, wherever possible, in combination, as well as in conjunction with transmitted texts and archaeological material.

\section{References}

Al As'ad, K., and M. Gawlikowski. 1997. The inscriptions in the Museum of Palmyra: A catalogue. Palmyra and Warsaw: Palmyra Museum and University of Warsaw Institute of Archaeology.

Andreau, J. 2008. "The use and survival of coins and of gold and silver in the Vesuvian cities." In

W. V. Harris (ed.), The monetary systems of the Greeks and Romans, 208-225. Oxford: Oxford University Press.

Bagnall, R. S. 2009. The Oxford handbook of papyrology. Oxford: Oxford University Press.

Bagnall, R. S., and P. Derow, eds. 2004. The Hellenistic period: Historical sources in translation. 2nd ed. Malden, MA: Blackwell.

Bagnall, R. S., C. Helms, and A. M. F. W. Verhoogt. 2000. Documents from Berenike. Vol. 1, Greek ostraka from the 1996-1998 seasons. Brussels: Fondation Égyptologique Reine Élisabeth.

Bingen, J. (1978) 2007. "The Revenue Laws Papyrus: Greek tradition and Hellenistic adaptation." In Hellenistic Egypt: Monarchy, society, economy, culture, 157-188. R. S. Bagnall (ed.). Edinburgh: Edinburgh University Press. Originally published as Le Papyrus Revenue Laws Tradition grecque et adaptation hellénistique. 
Bingen, J., H. Cuvigny, and A. Bülow-Jacobsen, eds. 1992-2009. Mons Claudianus: Ostraca Graeca et Latina. 4 vols. Cairo: Institut français d'archéologie orientale du Caire.

Bodel, J., ed. 2001. Epigraphic evidence: Ancient history from inscriptions. London: Routledge. Boeckh, A. (1817) 1967. Die Staatshaushaltung der Athener. 3rd ed. 2 vols. Berlin: De Gruyter.

Bowman, A. K., and J. D. Thomas. 1983. Vindolanda: The Latin writing-tablets. London: Society for the Promotion of Roman Studies.

-. 2003. The Vindolanda writing tablets. Vol. 2. London: British Museum Press.

Bruun, C., and J. Edmondson, eds. 2015. The Oxford handbook of Roman epigraphy. Oxford: Oxford University Press.

Camodeca, G. 1999. Tabulae Pompeianae Sulpiciorum (TPSulp.). 2 vols. Rome: Edizione Quasar.

Clarysse, W., and D. J. Thompson. 2009. Counting the people in Hellenistic Egypt. 2nd ed. Vol. 1, Population registers (P. Count.). Cambridge: Cambridge University Press.

Clarysse, W., and K. Vandorpe. 1995. Zenon, un homme d'affaires grec à l'ombre des pyramides. Leuven: Presses Universitaires de Louvain.

Corcoran, S. 1996. The empire of the tetrarchs: Imperial pronouncements and government, $A D$ 284-324. Oxford: Clarendon.

Cottier, M., M. H. Crawford, C. V. Crowther, J.-L. Ferrary, B. M. Levick, O. Salomies, and M. Wörrle, eds. 2008. The customs law of Asia. Oxford: Oxford University Press.

Crawford, M. H. 1970. "Money and exchange in the Roman world." Journal of Roman Studies 60, 40-48.

-. 1974. Roman republican coinage. Vol. 2, Studies, plates and indexes. Cambridge: Cambridge University Press.

Cuvigny, H. 2009. "The finds of papyri: The archaeology of papyrology." In Bagnall (2009) 30-58.

de Callataÿ, F. 1989. "Les trésors achéménides et les monnayages d’Alexandre: Espèces immobilisées et espèces circulantes?” Revue des Études Anciennes 91, 259-276.

-. 1997. Recueil quantitatif des émissions monétaires hellénistiques. Wetteren: Éditions Numismatique Romaine.

-. 2005. “L'instauration par Ptolémée ler Sôter d'une économie monétaire fermée.” In F. Duyrat and 0. Picard (eds.), L'exception égyptienne? Production et échanges monétaires en Égypte hellénistique et romaine: Actes du colloque d'Alexandrie, 13-15 avril 2002, 117-134. Cairo: Institut français d'archéologie orientale.

-. 2006. "Greek coins from archaeological excavations: A conspectus of conspectuses and a call for chronological tables.” In P. G. van Alfen (ed.), Agoranomia: Studies in money and exchange presented to John H. Kroll, 177-200. New York: American Numismatic Society.

-, ed. 2014. Quantifying the Greco-Roman economy and beyond. Bari: Edipuglia.

Duncan-Jones, R. 1990. Structure and scale in the Roman economy. Cambridge: Cambridge University Press.

-. 1994. Money and government in the Roman Empire. Cambridge: Cambridge University Press.

-. 2003. "Roman coin circulation and the cities of Vesuvius." In E. Lo Cascio (ed.), Credito e moneta nel mondo romano: Atti degli Incontri di storia dell'economia antica, Capri 12-14 ottobre 2000, 161-180. Bari: Edipuglia.

Edmondson, J. C. 2015. “Economic life in the Roman Empire." In C. Bruun and J. Edmondson (eds.), The Oxford handbook of Roman epigraphy, 671-695. Oxford: Oxford University Press.

Fox, G., S. N. C. Lieu, and N. Ricklefs. 2005. "Select Palmyrene inscriptions." In I. Gardiner, S. N. C. Lieu, and K. Parry (eds.), From Palmyra to Zayton: Epigraphy and iconography, 27-126. Turnhout: Brepols. https://www.mq.edu.au/_data/assets/pdf_file/0018/24525/106178.pdf.

Frank, T., ed. 1933-1940. An economic survey of ancient Rome, 6 vols. Baltimore, MD: Johns Hopkins Press.

Habermann, W. 1998. "Zur chronologischen Verteilung der papyrologischen Zeugnisse." Zeitschrift für Papyrologie und Epigraphik 122, 144-160. 
Habinek, T. 2009. "Situating literacy at Rome." In W. A. Johnson and H. N. Parker (eds.), Ancient literacies: The culture of reading in Greece and Rome, 114-140. Oxford: Oxford University Press.

Harris, W. V. 1989. Ancient literacy. Cambridge, MA: Harvard University Press.

-. 2008. "The nature of Roman money." in W. V. Harris (ed.), The monetary systems of the Greeks and Romans. Oxford: Oxford University Press, 174-207.

Hopkins, K. 1980. "Taxes and trade in the Roman economy (200 BC-AD 400)." Journal of Roman Studies 70, 101-125.

Howgego, C. 1992. "The supply and use of money in the Roman world." Journal of Roman Studies $82,1-31$.

-. 2009. "Some numismatic approaches to quantifying the Roman economy." In A. K. Bowman and A. Wilson (eds.), Quantifying the Roman economy: Methods and problems, 287-295. Oxford: Oxford University Press.

Katsari, C. 2008. "The monetization of the Roman frontier provinces." In W. V. Harris (ed.), The monetary systems of the Greeks and Romans, 242-266. Oxford: Oxford University Press.

Keenan, J. G., J. G. Manning and U. Yiftacht-Firanko, eds. 2014. Law and legal practice in Egypt from Alexander to the Arab conquest: A selection of papyrological sources in translation, with introductions and commentary. Cambridge: Cambridge University Press.

Lewis, N. 1983. Life in Egypt under Roman rule. Oxford: Clarendon.

-. (1986) 2001. Greeks in Ptolemaic Egypt: Case studies in the social history of the Hellenistic world. Oakville, CT: American Society of Papyrologists.

Lo Cascio, E. 1981. "State and coinage in the Late Republic and Early Empire." Journal of Roman Studies 71, 76-86.

Manning, J. G. 2003. Land and power in Ptolemaic Egypt: The structure of land tenure 33230 BCE. Cambridge: Cambridge University Press.

Marichal, R. 1992. Les ostraca de Bu Njem. Tripoli: Grande Jamahira Arabe, Libyenne, Populaire et Socialiste and Département des Antiquitiés.

McLaughlin, R. 2016. The Roman Empire and the silk routes: The ancient world economy and the empires of Parthia, Central Asia and Han China. Barnsley: Pen \& Sword History.

McLean, B. H. 2002. An introduction to Greek epigraphy of the Hellenistic and Roman periods from Alexander the Great down to the reign of Constantine (323 BC-AD 337). Ann Arbor, MI: University of Michigan Press.

Meadows, A. 2001. "Money, freedom, and empire in the Hellenistic world." In A. Meadows and K. Shipton (eds.), Money and its uses in the ancient Greek world, 53-63. Oxford: Oxford University Press.

-. 2014. "The spread of coins in the Hellenistic world." In P. Bernholz and R. Vaubel (eds.), Explaining monetary and financial innovation: A historical analysis, 169-195. New York: Springer.

-. Forthcoming. "The growth of Athenian coinage in the Archaic and early Classical periods." Revue Belge de Numismatique et de Sigillographie.

Metcalf, W. E., ed. 2012. The Oxford handbook of Greek and Roman coinage. Oxford: Oxford University Press.

Monson, A. 2012. From the Ptolemies to the Romans: Political and economic change in Egypt. Cambridge: Cambridge University Press.

Morgan, T. 1998. Literate education in the Hellenistic and Roman worlds. Cambridge: Cambridge University Press.

Nappo, D. 2018. “Money and flows of coinage in the Red Sea trade." In A. Wilson and A. K. Bowman (eds.), Trade, commerce, and the state in the Roman world, 557-78. Oxford: Oxford University Press.

Onken, B. 2003. "Wirtschaft an der Grenze: Studien zum Wirtschaftsleben in römischen Militärlagern im Norden Britanniens.” PhD diss., University of Kassel. 
Orrieux, C. 1985. Zénon de Caunos, parépidèmos, et le destin grec. Paris: Les Belles Lettres.

Pestman, P. W., ed. 1981. A guide to the Zenon archive. 2 vols. Leiden: Brill.

Préaux, C. 1939. L'économie royale des Lagides. Brussels: Édition de la Fondation Égyptologique Reine Élisabeth.

Rathbone, D. 1992. Economic rationalism and rural society in third-century AD Egypt. Cambridge: Cambridge University Press.

-. 1996. “Monetisation, not price-inflation, in third-century AD Egypt?” In C. E. King and D. G.

Wigg (eds.), Coin finds and coin use in the Roman world: The Thirteenth Oxford Symposium on Coinage and Monetary History, 25.-27. 3. 1993: A NATO advanced research workshop, 321-339. Berlin: Gebrüder Mann.

-. 2001. “The 'Muziris' papyrus (SB XVIII 13167): financing Roman trade with India.” In M. Abd-elGani, S. Z. Bassiouni, and W. A. Faray (eds.), Alexandrian studies II in honor of Mostafa el Abbadi, 39-50. Alexandria: Société d'Archéologie d'Alexandrie.

-. 2007. “Roman Egypt.” In W. Scheidel, I. Morris, and R. Saller, (eds.), The Cambridge economic history of the Greco-Roman world, 698-719. Cambridge: Cambridge University Press.

-. 2014. "Mediterranean grain prices c. 300 to 31 BC: The impact of Rome." In H. D. Baker and M. Jursa (eds.), Documentary sources in ancient Near Eastern and Greco-Roman economic history: Methodology and practice, 289-312. Oxford: Oxbow.

Rathbone, D., and S. von Reden. 2015. “Mediterranean grain prices in classical antiquity.” In R. J. van der Spek, B. van Leeuwen, and J. L. van Zanden (eds.), A history of market performance: From ancient Babylonia to the modern world, 149-235. London: Routledge.

Reger, G. 1994. Regionalism and change in the economy of independent Delos, 314-167 BC. Berkeley, CA: University of California Press.

Rostovtzeff, M. I. 1926. The social and economic history of the Roman Empire. Oxford: Clarendon. -. 1941. The social and economic history of the Hellenistic world. 3 vols. Oxford: Clarendon.

Rowlandson, J. 1996. Landowners and tenants in Roman Egypt: The social relations of agriculture in the Oxyrhynchite nome. Oxford: Clarendon.

Speidel, M. A. 1996. Die römischen Schreibtafeln von Vindonissa: Lateinische Texte des militärischen Alltags und ihre geschichtliche Bedeutung. Brugg: Gesellschaft pro Vindonissa.

-. 2018. "Soldiers and documents: Insights from Nubia: The significance of written documents in Roman soldiers' everyday lives.” In A. Kolb (ed.), Literacy in ancient everyday life, 179200. Berlin: De Gruyter.

Thompson, D. J. 1984. “Agriculture.” In F. W. Walbank, A. E. Astin, M. W. Frederiksen, and R. M. Ogilvie (eds.), The Cambridge ancient history. 2nd ed. Vol. 7.1, 363-370. Cambridge: Cambridge University Press.

-. 1999. "New and old in the Ptolemaic Fayum." In A. K. Bowman and E. Rogan (eds.), Agriculture in Egypt: From Pharaonic to modern times, 123-138. Oxford: Oxford University Press.

-. 2009. "The multilingual environment of Persian and Ptolemaic Egypt: Egyptian, Aramaic, and Greek documentation.” In Bagnall 2009, 395-417.

Vandorpe, K. 2012. "Village scribes of Kerkeosiris ('Menches').” ArchID 140/Transmegistos Archives. https://www.trismegistos.org/arch/archives/pdf/140.pdf.

Verhoogt, A. M. F. W. 1998. Menches, komogrammateus of Kerkeosiris: The doings and dealings of a village scribe in the late Ptolemaic period (120-110 BC). Leiden: Brill.

Vinogradov, J. 1997. “The goddess ‘Ge Meter Olybris.' A new epigraphic evidence from Armenia.” East and West 42, 13-26.

Von Reden, S. 2002. "Money in the ancient economy: Some recent research." Klio 84, 141-174.

-. 2007. Money in Ptolemaic Egypt: From the Macedonian conquest to the end of the third century $B C$. Cambridge: Cambridge University Press.

-. 2010. Money in classical antiquity. Cambridge: Cambridge University Press. 



\section{Lauren Morris}

\section{Evidence for Central Asia}

\section{Introduction}

Recent research indicates that smaller scale networks of interaction in prehistoric Central and Inner Asia prefigure the later macro-networks of interaction and exchange of Late Antiquity and the Early Middle Ages now conventionally referred to as the Silk Road(s). ${ }^{1}$ Likewise, archaeobotanical research has highlighted the occurrence of trans-Eurasian exchange via crop transmission through, from, and into Central and Inner Asia during the early third millennium BCE. ${ }^{2}$

Yet it remains difficult to analyze the specific economic developments which occurred in the orbit of the empires controlling Central Asia within the time window of 300 вСЕ-300 CE - that is, the Greek Kingdoms and the Kushan Empire - although these developments should have constituted a key step in generating the heightened connectivity and mobility across Afro-Eurasia by which the Silk Road paradigm is characterized. Perhaps the main hurdle is that the available source profile for this period is simply demanding: it is uneven, obscure, represents a diversity of cultural and intellectual perspectives (both ancient and modern), and often seems too fragmentary and incommensurate to invite the development of broader conclusions.

Thus, the aim of the present chapter is to clarify the shape of this source profile. Rather than aiming for comprehensiveness, I lay out the four main metacategories of data available for studying economic history and development within the purview of the Greek Kingdoms and the Kushan Empire: transmitted texts, coinage, archaeological data, and excavated texts, indicating the potentials and problematics of each throughout.

\section{Transmitted Texts}

\section{II.1 Scope and Problems}

A bewildering diversity of fragments and passages have survived from transmitted texts that have some bearing on Central Asia's economic history during antiquity. None, however, were produced in Central Asia itself, which had no literary tradition

1 See, for example, Frachetti et al. 2017.

2 Such as Spengler et al. 2014; Jones et al. 2016.

Note: Thanks are due to Henry Albery, Olivier Bordeaux, Gunnar Dumke, and Moritz Huber for their comments on earlier versions of this chapter.

Ә Open Access. () 2020 Lauren Morris, published by De Gruyter. (cc))BY-NC-ND This work is licensed under the Creative Commons Attribution-NonCommercial-NoDerivatives 4.0 License.

https://doi.org/10.1515/9783110607741-014 
of its own. The following focuses on information in the two most useful bodies of texts, namely Greek and Latin literature and Chinese historiography, and brings specific issues relating to Central Asia to the fore. It should be noted that Indic literature provides only little usable historical information for the present purposes. This is due to the difficulties in dating information provided in these texts, ${ }^{3}$ as well as in the interpretation of terminology. For example, in early literature and epigraphy the ethnonyms Yavana (as in Sanskrit) and Yona (Pali) first denoted Greeks, especially those living in or beyond the northwestern frontier of India. However, from around the first century всE, this designation slowly expanded to describe other foreigners, including the inhabitants of the Roman East, Arabs, Muslims, and even inhabitants of Southeast Asia. Accordingly, the interpretation of this term depends on the date and geographic orientation of the text in question. ${ }^{4}$ Even when the Indo-Greeks can be clearly identified, the information provided about them may not be historically useful. This is most clearly the case for the Milindapañha, a paracanonical Buddhist text extant in Pali and Chinese versions - but perhaps originally composed in Gāndhārī - which narrates a fictitious dialog between King Menander (Milinda) and the Buddhist monk Nāgasena. ${ }^{5}$ The first book of the text, likely composed between 100 BCE and $200 \mathrm{CE}$, includes a description of the capital of Menander's kingdom, the prosperous town of Sāgala (probably modern Sialkot in the Punjab). The city is painted as well organized and beautiful, with diverse castes and occupations, shops providing a variety of cloth, flowers, perfumes, and jewels, and stocked with abundant produce and warehouses. ${ }^{6}$ Nonetheless, this portrayal has the hallmarks of a conventional literary description of an ideal Indian city, ${ }^{7}$ and is thus of dubious utility.

In contrast, some reality about the historical products of the northwest and regions beyond is likely preserved in the Mahābhärata, a Sanskrit epic composed between the fourth century BCE and the fourth century CE. ${ }^{8}$ This is encountered in the Book of the Assembly Hall in the description of tribute brought to Yudhișthira, the leader of the Pāṇavas in the (partially or entirely) mythologized Kurukșetra War. Among the many peoples and products mentioned, an obscure non-Greek king Bhagadatta reportedly came with the Yavanas, bringing purebred fast horses. ${ }^{9}$ The Kambojas - an enigmatic Iranian people who perhaps lived in the eastern highlands of Afghanistan - are said to have brought fleeces, gold-embroidered furs, deerskin

3 See Dwivedi, ch. 10.A, this volume.

4 Karttunen 2015, 325-337, 409-410. On Yavanas, see further Dwivedi, chs. 3 and 10.A, this volume. 5 For more on the text of the Milindapañha and its historicity, see Fussman 1993; von Hinüber 1996, 82-86.

6 Milindapañha 1. 2, with translation in Horner 1963, 1-3.

7 Schlingloff 2013, 12-15.

8 Brockington 1998, 26-27.

9 Mahābhārata 2. 47. 12-14 
jackets, horses, and camel mares. ${ }^{10}$ The Tukhāras (Tocharoi, see below), among Śakās, Kaṇkās, Romaśas and horned men, brought mahāgama and durāgama horses. Products from the countries of Bālhi (Balkh) and Cīna (China) were also brought, including asses and "textiles of ample size, rich in colors, and good to the touch." 11

Greek, Latin, and Chinese texts were constructed and shaped by their outsider and (often) imperial perspectives on a space at the edges of their known worlds where direct information was limited. The information they do provide is perhaps more useful for understanding the perspectives of the informants, authors, and historical contexts that produced them. Nonetheless, when mined carefully, they provide some indications about demography, urbanization, resource exploitation (including agriculture and pastoralism), trade, mobility, and interregional interaction at a variety of scales.

It should be noted here that information provided by these vastly different literary traditions cannot be simply reassembled to create a coherent bigger picture. Scholars disagree as to the productivity of working with both traditions, most clearly manifested in discussions of the various populations in Central Asia after the collapse of Graeco-Bactrian power. While many have attempted to cohere this information, ${ }^{12}$ others consider the enterprise to be methodologically unsound. ${ }^{13}$

\section{II.2 Greek and Latin Sources}

Snippets of information in this tradition from largely intact sources cover multiple categories. The first is historiography of Alexander the Great's campaigns, being here Curtius Rufus's Historiae Alexandri Magni (first century CE) and Arrian's Anabasis (second century $\mathrm{CE}$ ). There is also universal historiography, such as Polybios's Historiae (second century BCE), Diodoros's Bibliotheca historica (first century BCE), and Justin's Epitome of Pompeius Trogus's Historiae Philippicae (ca. late second century $\mathrm{CE}$, the original from the late first century BCE to early first century $\mathrm{CE}$ ); Diodoros and Pompeius Trogus also dealt extensively with Alexander and his campaigns. Other types of texts are universal encyclopaediae, such as Pliny the Elder's Naturalis historia (first century CE), and treatises on geography such as Strabo's Geographika (first century BCE to first century CE) and Ptolemy's Geographia (early second century $\mathrm{CE}$ ). There are also treatises concerned more specifically with animals or plants, such as Aristotle's Historia animalium (fourth century BCE), Theophrastos's Historia plantarum (late third to early second century BCE) and Aelian's

10 Mahābhārata 2. 47. 3-4.

11 Mahābhārata 2. 47. 21-22, trans. van Buitenen 1975, 117.

12 Recent examples incorporating archaeological evidence are Rapin 2007, 50-64; Abdullaev 2007.

13 Mairs 2014, 155. 
De natura animalium (late second to early third century CE). There are also itinerary texts, being Isidoros of Charax's Stathmoi Parthikoi (ca. first century BCE to first century CE) and the Periplus Maris Erythraei (mid-first century CE), and finally, Late Antique histories and biographies of the earlier Caesars, being the Vita Hadriani of the Historia Augusta, and the Epitome de Caesaribus (both late fourth to early fifth centuries CE).

Contrarily to the case for writing on India, little scholarship thus far has been generated about Graeco-Roman perspectives on Central Asia. ${ }^{14}$ However, Greek and Roman writing on this space is not dissimilar to that on India, which from the fifth century всE onward was largely ethno-geographical in nature, produced by exploration and conquest into distant lands, underpinned by military and intellectual aims, and ultimately shaped by imperialist ideologies. ${ }^{15}$ A particularly strong influence on presentations of Central Asia deriving from early Greek thought is in the description of peoples and places at the peripheries of the known world - far from the center located in Greek civilization - as wild, fabulous, and blessed with great resources, climate, or productivity, a trend which persisted despite the emergence of more empirically oriented writing in the Hellenistic and Roman periods. ${ }^{16}$ Certainly, after Alexander's conquests, Bactria existed in the known world to some extent, if at its fringes. ${ }^{17}$

Several further observations can be made about this corpus. First, the Kushans are virtually unknown here. It is widely accepted, although not directly proven that the Yuezhi (as named in Chinese sources) overlap with the Tocharoi/Tochari mentioned by Strabo among the nomads that removed Bactria from Greek power, ${ }^{18}$ by Justin in listing groups of nomads, ${ }^{19}$ and by Ptolemy among the inhabitants of Bactria. ${ }^{20}$ Later, Bactrians - i.e., people of Bactria-Tokharistan under Kushan rule, or even Kushan envoys - are mentioned in two important contexts. The first is in one of long-distance trade networks, where the author of the Periplus had only vague, indirect knowledge of "a very warlike people, the Bactrians, under a king ..."21 Nonetheless, it is noted elsewhere that commodities from Thina (China) are transported by land through Bactria to Barygaza, and that lapis lazuli (a resource of eastern Bactria-Sogdiana) was available at Barbarikon. ${ }^{22}$ The second context is that

14 See however the appendix to Leriche 2007.

15 Von Reden, ch. 10.B, this volume.

16 Romm 1992.

17 Bactra, for example, is mentioned sometimes among other cities, such as Susa and Babylon, as shorthand for the great but distant cities of Asia in Dio Chrystomos's Orationes (Dio Chrys. Or.) 4. 53. 4-5, and in Chariton 5. 1. 7.

18 Strabo 11. 8. 2.

19 Justin Epitome (Just. Epit.) Prolog 42.

20 Ptolemy Geographia (Ptol. Geog.) 6. 11. 6.

21 Periplus Maris Erythraei (PME) 47.

22 PME 64, 39. 
of two curious references to Bactrian envoys with respect to Hadrian's reign (117$138 \mathrm{CE}$ ) in the Historia Augusta and to Antoninus Pius's reign (138-161 CE) in the Epitome de Caesaribus, both texts composed rather later. In the first, within a favorable review of Hadrian's foreign policy, the "kings" of the Bactrians are reported to have sent envoys to beg for the emperor's amicitia ('friendship'). ${ }^{23}$ In the second reference, they are listed among Indians and Hyrkanians as the distant peoples who sent envoys to the great and powerful emperor. ${ }^{24}$ These are the only direct references we have to potential diplomatic relations between the Kushan and Roman Empires, but while the reliability of the Vita Hadriani is generally well regarded (although the plural "kings" is evidently an error), the latter reference is unverifiable.

Indeed, much of the information provided in this corpus relates to Greek rule in Central Asia, and derives from sources of the early Hellenistic period that are only partially preserved in fragments, survive in citation, or are totally obscure to us. For example, the first time the two-humped camel (C. bactrianus) is associated with Bactria is in Aristotle's Historia animalium, where he compares its physical features to the Arabian camel ( $C$. dromedarius). ${ }^{25}$ This information was drawn upon by Pliny, ${ }^{26}$ and taken to new heights with Aelian, who reported that the longevity of the Bactrian camel is twice as long as others. ${ }^{27}$ In fact, it is likely that C. bactrianus was domesticated much further east than Bactria millennia beforehand, so the origins of its association with Bactria remain obscure. ${ }^{28}$

Elsewhere, the origins of information are more clear. Only in some cases did information from contemporaries of Alexander's conquests survive in antiquity to be partially used as primary sources by later historians. The history written by Alexander's campaign historian Kallisthenes does not survive. ${ }^{29}$ The ethno-geographical work of Aristoboulos of Kassandreia, the junior officer who accompanied Alexander on his campaigns, was used as a primary source by Arrian and survives only in quotation by others. The same is true for the later account of Kleitarchos based on primary accounts, which was used by Diodoros and also by Timagenes, from which Curtius Rufus's account draws. The bematists ('pace measurers') who accompanied Alexander surveyed the itinerary taken (largely coherent with Achaemenid roads) and measured distances by foot between major centers. These measurements were drawn upon by Strabo and Pliny. ${ }^{30}$ However, the differing figures they provide indicate intermediary sources, and the complex genealogy of surviving data about the

23 Scriptores Historiae Augustae Hadrian (SHA Had.) 8.

24 Epitome de Caesaribus (Epit. de Caes.) 15. 4.

25 Aristotle Historia animalium 2. 1. 5; 2. 1. 15.

26 Pliny Naturalis historia (Plin. HN) 8. 26.

27 Aelian De natura animalium (Ael. NA) 4. 55.

28 See Potts 2004, 147.

29 Brill's New Jacoby (BNJ) 124.

30 Strabo 11. 8. 9; 15. 2. 8; Plin. HN 6. 45; 6. 61-62. 
geography of Central Asia from this period is subject to continuing research. ${ }^{31}$ All in all, much of the information on Central Asia in Greek and Latin sources has its origins in Alexander's campaigns.

Furthermore, Eratosthenes's influential Geographika (third century BCE) ${ }^{32}$ was drawn upon in Strabo's treatment of Central Asia. ${ }^{33}$ Likewise, the work of Patrokles, a Seleukid general and explorer, was discussed regarding his famous expedition along the Caspian (Hyrkanian) Sea. ${ }^{34}$ Patrokles wrongly reported that the Oxus emptied into this body of water, creating a navigable route connected also to India, upon which merchandise could be carried eventually to the Black Sea. This report was used by Eratosthenes, cited by Strabo, ${ }^{35}$ and echoed by Arrian. ${ }^{36}$ Similar information was presented by Pliny, but referring to information from the Roman historian and polymath Varro, reportedly obtained by exploration under the direction of Pompey. ${ }^{37}$ The question of the existence of an Oxo-Caspian-Caucasus trade route has provoked prolonged debate in scholarship. ${ }^{38}$

Another important later Hellenistic source was Apollodoros of Artemita's lost Parthika (ca. 50 BCE), which - besides the Arsakid Empire - appears to have dealt extensively with the kings Demetrios and Menander. ${ }^{39}$ Apollodoros was used heavily by Strabo, and was also an important source for Pompeius Trogus.

Particular information of interest for the economy of the Hellenistic period may now be drawn out. The first is the emphasis on the agricultural produce and prosperity of Bactria, which also reflects in part a Greek, land-based idea of wealth. This was painted most explicitly by Strabo, who stated that Bactria produced everything except oil and attributed the growth of Greek power there to the country's fertility. ${ }^{40}$ When Theophrastos attributed the difference in regional grains to their respective soils and their climate, he cited Bactria by way of example: "For in Asia, not far from Bactra they say that in a certain place the corn is so vigorous that the grains grow as large as an olive-stone." 41 This hearsay probably originated in Alexander's campaigns, and was later amplified by Pliny: "It is said that in Bactria the grains of wheat are of such an enormous size, that a single one is as large as our ears of corn." 42 Curtius also described the prosperity and diversity of Bactria at length, al-

31 See foremost Rapin 2017.

32 BNJ 241.

33 Strabo 11. 8. 8; 15. 2. 8-10.

34 BNJ 712.

35 Strabo 12. 7. 3.

36 Arrian Anabasis (Arr. Anab.) 7. 16. 3-4.

37 Plin. HN 6. 17. 52.

38 See discussion in Callieri 2001.

39 BNJ 779.

40 Strabo 11. 11. 1.

41 Theophrastos Historia plantarum (Theophr. Hist. pl.) 8. 4. 5., trans. Hort.

42 Plin. HN 18. 12., trans. Rackham. 
though this also reads as a counterpoint to the horror of the barren Hindu Kush traversed by Alexander just previously:

The land of the Bactriani is of a manifold and rich nature. In one part many trees and vines produce plentiful and mellow fruits, frequent brooks irrigate the rich soil, the milder parts of this they sow with grain, the rest they leave for pasture for the flocks. Farther on a great part of the same land is occupied by sterile sands; because of its frightful dryness the region is uninhabited and produces no fruit ... But where the land is milder it breeds a great multitude of men and horses. ${ }^{43}$

Theophrastos reported further information on Bactrian produce, including a description of a terebinth-like tree with almond-like fruit. ${ }^{44}$ This was drawn upon by Pliny, adding further information from Graeco-Macedonian sources, describing one tree used to manufacture "a kind of linen cloth" cultivated in the plains. ${ }^{45}$ Pliny wrote at particular length on a tree in Bactria that produced the "highly esteemed bdellium," an obscure aromatic resinous gum that was also available in Arabia, India, Media, and Babylon, but often adulterated. ${ }^{46}$

One particularly interesting source for successful indigenous settlement and food-resource strategies in the marginal environment of the Hindu Kush should also be highlighted. This environment and its peoples were encountered prior to Alexander's entrance into Bactria, and quite evidently the Macedonians and later writers found both deeply confusing. The most dramatic iteration of this is provided by Curtius, ${ }^{47}$ which is also infused with Roman values about civilization. Similarities also exist with Strabo's brief account, ${ }^{48}$ reflecting the common origin of their information. In the wintery mountainous environment of the 'Caucasus' (as the Macedonians called the Hindu Kush), its inhabitants - "a rude race of men, especially uncultivated even among barbarians" 49 - are described as living in villages of tapering huts of unbaked brick. They were considered as well supplied in produce except for oil, having concealed their wheat crops in underground pits, called siri (from Gr. siros, silo) for the winter. Crossing the Hindu Kush, due to the lack of vegetation, the Macedonians were - to their horror - forced to eat their pack animals, river fish, and herbs, an ordeal which is represented as the very antithesis of civilization.

References to mineral resources available from Central Asia and its frontiers are difficult to ground in reality. De mirabilibus auscultationibus (On marvelous things heard) reports that the river Oxus brings down enormous quantities of lumps of

43 Curtius Rufus (Curt.) 7 .4. 26-27, 30, trans. Rolfe.

44 Theophr. Hist. pl. 4. 4. 7.

45 Plin. HN 12. 13, trans. Rackham.

46 Plin. HN 12. 19.

47 Curt. 7. 3. 5-14; 7. 4. 22-25.

48 Strabo 15. 2. 10.

49 Curt. 7. 3. 8, trans. Rolfe. 
gold. ${ }^{50}$ Ktesias of Knidos makes passing reference to the deep silver mines of Bactra. ${ }^{51}$ India's northwestern frontier had already obtained a reputation in the Classical period for its abundant gold, especially that which was obtained by gold-digging ants or guarded by griffins. ${ }^{52}$ By the time of Megasthenes, the retrieval of the antgold was linked with the Derdai, ${ }^{53}$ i.e., the Dards of present times. The Dards are traditionally associated with the trade of gold, and appear to have obtained it from unknown sources in the high valleys of the middle and upper Indus. ${ }^{54}$ The immense coverage of gems in Pliny also includes examples from Bactria, including the second best of the 12 varieties of smaragdus, a green stone with proposed identifications as emerald or turquoise, and the (unidentified) eumeces. ${ }^{55}$ It is harder to identify lapis lazuli in Graeco-Roman literature, but it is probably to be seen in references to sappheiros, such as in the Periplus's mention of its export from the port of Barbarikon. ${ }^{56}$

Greek and Roman sources also give a tantalizing image of the extent of urbanization of Bactria under the Greek Kingdoms, but one which faces problems in interpreting. The crux of this are the two references to Bactria's "thousand cities": Strabo, drawing from Apollodoros of Artemita, notes that Eukratides had a "thousand cities [poleis] as his subjects," 57 and Justin, in reference to the political and historical milieu of Parthian rule, makes reference to "the opulent Bactrian Empire, with its thousand cities [urbes]." 58 Although these claims clearly relate to towns and small settlements rather than cities, it is at least evident that the idea of Bactria's population density reached Greek and Latin writers. Indeed, Graeco-Roman sources provide numerous references to Hellenistic period foundations and the names of regions and settlements across this space. ${ }^{59}$ However, due to the difficulties of interpreting Central Asia's historical geography in the Classical tradition, most of these have not been indisputably located.

Information about major routes of intra- and interregional connectivity that were certainly exploited by merchants is also available in Greek writing, including the Periplus mentioned above. Most contested is the description of the itinerary of

50 De mirabilibus auscultationibus (Mir. ausc.) 46.

51 Fragmente der griechischen Historiker $(F G r H) 688$ F 45. 26. For further discussion on this author see von Reden, ch. 10.B, this volume.

52 With origins in Herodotus (Hdt.) 3. 102 and Ktesias FGrH 688 F45. 26, F45h. See discussions in Karttunen 1989, 171-180, who proposes a Central Asian (sensu lato) or Siberian origin for these myths, and Karttunen 1997, 249-250.

53 BNJ 715 F23b.

54 Tucci 1977, 18-20.

55 Plin. $H N$ 37. 61 and 70.

56 PME 39. For the interpretation of sappheiros, see Karttunen 1997, 242, n. 677.

57 Strabo 15. 1. 3, trans. Jones.

58 Just. Epit. 41. 1. 8, trans. Yardley.

59 See further in Morris, ch. 2, this volume. 
the merchant (and agents of) Maes Titianus (ca. $100 \mathrm{CE}$, or perhaps late first century BCE), ${ }^{60}$ repeated in the work of Marinus of Tyre (early second century CE) and used by Ptolemy, ${ }^{61}$ who presented it with his coordinate system where it survives for us today. This itinerary ran from Hierapolis in Syria through Central Asia to the capital of Serike (China). However, the question of the sources and data involved in Ptolemy's mapping of Central Asia, upon which he layered information from Maes Titianus, is extremely complicated and its interpretation remains subject to debate. ${ }^{62}$ Thus, the route from Bactra to the "Stone Tower" and onward to Serike is still disputed, as is the question of whether Maes reached the Stone Tower personally and sent agents thence, or if he even left the Iranian Plateau at all. ${ }^{63}$ It is also worth mentioning here Isidoros of Charax's Stathmoi Parthikoi, a Parthian-era Greek itinerary text of obscure purpose and origins. ${ }^{64}$ In describing distances in schoinoi from Mesopotamia to Alexandria in Arachosia, it preserves something of a Parthian perspective on geography and connectivity.

\section{II.3 Chinese Sources}

Chinese texts dealing with Central Asia provide information of a very different character to that in Greek and Latin sources. ${ }^{65}$ The most significant sources are chapters dealing with the Western Regions (Xiyu 西域) within the three standard histories covering the Han period. These are chapter 123 of the Shiji (The Scribe's Records), compiled by Sima Qian probably by ca. 94 BCE; chapters 61 and 96 in the Hanshu (Documents of the Han), primarily compiled by Ban $\mathrm{Gu}$ and finished by ca. 110$121 \mathrm{CE}$; and chapter 88 in the Hou Hanshu (Documents of the Later Han), compiled by Fan Ye in around the fifth century CE. ${ }^{66}$

Shiji 123 (The Treatise on Dayuan 大宛) recounts Zhang Qian's mission to the west between 138 and 125 BCE. Zhang Qian was tasked by Han Wudi to establish a

60 For Maes's background and date see Bernard 2005, and for a dissenting earlier view of Maes's date, P'iankov 2015, 62.

61 Ptol. Geog. 1. 11. 6-7.

62 For one perspective, see P'iankov 2015.

63 For the first, see Bernard 2005 and the second, Andrade 2015. The Stone Tower is widely (but not indisputably) agreed to be a settlement located near to Daraut-Kurgan in the Kyzyl Suu River valley, for which see Bernard 2005, 953-957.

64 See Wiesehöfer, ch. 11, this volume.

65 For more on Chinese sources, see Leese-Messing, chs. 4 and 12.A, this volume.

66 Regarding translations, that of Shiji 123 in Watson 1993 is widely used but obscures textual difficulties. The translation of Hanshu 61 and 96 in Hulsewé and Loewe 1979 is however heavily annotated with a strong emphasis on textual criticism. The translation of Hou Hanshu 88 in Hill 2015 was achieved in close contact with Central Asianists, and has extensive notes and appendices. Further critical collections of other Chinese sources relating to Central Asia include Zürcher 1968; Thierry 2005; Falk 2015. 
military alliance with the Da Yuezhi 大月氏 against the Xiongnu. Although this alliance was never achieved, Zhang Qian brought back valuable information to the emperor. Shiji 123 thus includes a summary of his report with entries on Dayuan (centered in the Ferghana valley?), the Da Yuezhi (a nomadic group, later sedentary, centered in northern Bactria), Daxia 大夏 (Bactria-Tokharistan), and Kangju 康居 (a nomadic group controlling Chach and much of Sogdiana). Indirectly obtained information on adjacent states was also provided, including the Wusun 烏孫 (a nomadic group located in Semirechye), Yancai 奄蔡 (a nomadic group then located at the lower Syr Darya/Aral Sea?), Anxi 安息 (the Arsakid Empire), Tiaozhi 条支 (the Seleukid Empire, later Charakene), and Shendu 身毒 (northwest India). ${ }^{67}$ These entries note sites of government, distance from the Han capital Luoyang, population numbers, geographical position to neighbors, primary economic modes, and sometimes also customs, physiognomy, and regional products. Certain digressions are also added about political, military, and diplomatic episodes.

Hanshu 96 lays out the geographical and historical context of the Han presence in the far west, followed by a systematic series of entries about peoples and states both in the Tarim Basin and in Central Asia. The latter entries replicate or slightly change those of Shiji 123, sometimes supplying further detail. Hanshu 61 is dedicated to the subjects of Zhang Qian and Li Guangli, treated together for their involvement in the Western Regions. Li Guangli was general in a war waged by the Han against Dayuan (late second century BCE) to obtain the country's reputed horses. Hou Hanshu 88 is similar to Hanshu 96 but more condensed, with some corrections and new information.

Chinese sources also differ from those in Greek and Latin in their chronological coverage, pertaining to the periods after the collapse of Greek rule in Bactria in the late second century BCE and throughout the rule of the Kushans. The Kushans were always called Yuezhi or Da Yuezhi in Chinese texts in recognition of the nomadic origins of the ruling dynasty; as is stated explicitly in Hou Hanshu, "All the kingdoms call [their king] the Guishuang 貴霜 [Kushan] king, but the Han call them by their original name, Da Yuezhi." 68 Additionally, Chinese sources describe states virtually unknown in Greek and Latin writing, foremost Kangju and Dayuan, which played some role in Han foreign policy. Although not under Kushan rule, they are relevant to their history.

A further difficulty is that the information provided in these texts has complex origins and is shaped by intertextuality. Issues with the textual integrity of Shiji 123 have long been raised, culminating in Hulsewé's argument that it is a late reconstruction of a lost chapter, based on information in Hanshu, primarily chapter $61 .^{69}$

67 For the considerable uncertainty and debate about the localization of most of these states and further bibliography, consult the extensive notes and appendices in Hill 2015.

68 Hou Hanshu 88.2921, trans. Hill 2015, 1: § 13.

69 Hulsewé 1975. 
Now, Shiji 123 tends to be treated as a broadly faithful account of Zhang Qian's report and the primary source for Hanshu $61 .^{70}$ The direct sources of Hanshu 96 are less clear, but are above all the product of more intensified contact between the Western Regions and the Han, chiefly as the Han expanded their military power and control into the Tarim Basin states, constituting the Protectorate of the Western Regions. There is also a probable family interest in Hanshu, as Ban Chao (military officer, explorer, and protector general of the Western Regions), was immediately related to the history's three compilers. ${ }^{71}$ Fan Ye's sources are specified to be foremost Hanshu, in addition to a report by General Ban Yong presented to Emperor An in ca. $125 \mathrm{CE}$, which also included information from Gan Ying, an earlier envoy who reached the Persian Gulf in 97 CE. ${ }^{72}$ Additionally, information - even hearsay - circulating in Luoyang during the compilations of Hanshu and Hou Hanshu likely constitutes a source for these texts. ${ }^{73}$

Another important feature of these texts is that they did not cover the outer Western Regions for their own sake, but to convey information of potential use to Han officials, which was thus shaped by the imperial concerns of the Han over time. This is seen, for example, when Zhang Qian's report to Wudi concluded that Dayuan, Daxia, Anxi, "and the others, all great states rich in unusual products whose people cultivated the land ... were militarily weak and prized Han goods and wealth." ${ }^{44}$ This can hardly be read as evidence for a particular demand for Chinese goods. Han attitudes about tributary relations and diplomacy also manifest in these texts. In Hanshu, Han authorities disparage envoys from Jibin 嚺賓 as being merchants in disguise meaning only to trade $\mathrm{e}^{75}$ and from Kangju likewise for a supposed attempt to undertake disguised trade in the markets. ${ }^{76}$ In past scholarship, such passages have been used to argue that foreigners bearing tribute were motivated by economic gain to undertake diplomatic exchanges, although this has recently been problematized. ${ }^{77}$

Perhaps the most significant difficulty is to precisely geographically and historically contextualize the information provided in these texts. Most of the place names and peoples described in Central Asia can be at least approximately placed on the ground, even if their limits are unknown and shifted over time. For example, although the identification of Daxia with Bactria-Tokharistan is widely accepted, its limits are unclear. The extent of Kangju, putatively controlling Chach and much of

70 As in Pulleyblank 1981.

71 Being Ban Biao's second son and brother to Ban Gu and Ban Zhao.

72 Hou Hanshu 88.2931; see Hill 2015, 1: § 28.

73 See Bielenstein 1954 on topoi of early Chinese historiography and Hulsewé and Loewe 1979, 2627.

74 Shiji 123.3166; trans. Watson 1993, 236. See also Hanshu 61.2690.

75 Hanshu 94A.3886.

76 Hanshu 94A.3892-3893.

77 See now Selbitschka 2015 and further discussion in Leese-Messing, ch. 12.A, this volume. 
Sogdiana, is particularly contentious. Dayuan is usually, but not indisputably, located in the Ferghana valley. Jibin certainly referred to Kashmir in later texts, but it is possible that during the Han period it referred instead to Kapisa and Gandhāra. ${ }^{78}$ Localizing cities and micro-regions is yet more difficult. Thus, identifications should always be approached with caution, and it is best practice to retain the Chinese designations as well as information about the precise source in question and period it relates to.

It is also difficult to historically contextualize the information in these texts because time is treated in a fairly loose way. This is seen in the palimpsests of information from different times in Hou Hanshu, such as the entry on Tianzhu/Shen$\mathrm{du}$ (roughly northwest India/north India; Shendu is described as another name for Tianzhu in this passage). ${ }^{79}$ After replicating information from Shiji ${ }^{80}$ and further clarifying this area's extent, some details about administration are provided:

Juandu ${ }^{81}$ has several hundred other towns. An administrator is placed in each town. There are several dozen other kingdoms. Each kingdom has its own king. Although the kingdoms differ slightly, they are still called Juandu. Now they are all subject to the Yuezhi. The Yuezhi killed their kings and installed a general to govern them. ${ }^{82}$

A list of products and commodities available in Shendu follows, then details about envoys from Shendu coming during the reign of Emperor He, concluding with a comment on the growth of Buddhism. This compilation of information creates problems for interpretation. Do the Yuezhi episodes refer to Vima Taktu's conquests extending to Mathura in the late first century CE or Kanishka's across the Gangetic plain? It is impossible to ascertain from here alone how Kushan imperial expansion into north India affected its administration and economy.

However, with the above laid out, Chinese sources ultimately give us insights into demography, subsistence strategies, famous products, merchant activity, and trade routes, and some changes over time can be observed. Demographic estimates tend to be approximate, with figures provided in multiples of 10,000, but with further contact became more precise. For example, in the second century BCE, the Da Yuezhi, being a nation of nomads, were first described as having some 100,000 or 200,000 archer warriors. ${ }^{83}$ Later, in respect to the Kushan period, they are reported to have become settled by migrating to Bactria, with 100,000 households, 400,000 individuals, and 100,000 who could bear arms. ${ }^{84}$

Some curious information on commercial and mercantile activity is also provided. For example, the people of Daxia were described in Shiji as agriculturalists,

78 For all identifications, consult the notes and appendices in Hill 2015.

79 Hou Hanshu 99.2921, trans. Hill 2015, 1: § 15.

80 Shiji 123.3166.

81 Hill's rendering of Shendu.

82 Hou Hanshu 88.2921, trans. Hill 2015, 1: § 15.

83 Shiji 123.3161.

84 Hanshu 96A.3890, repeated in Hou Hanshu 88.2920. 
"poor in the use of arms and afraid of battle, but they are clever at commerce." 85 It is reported with particular interest that their capital, Lanshi 藍市 (Bactra, or Khulm?), has a market, and that Zhang Qian had seen products from Qiong 도 and Shu 蜀 (Sichuan) in Bactria, and was told by merchants that they were purchased from markets in Shendu. ${ }^{86}$ The people of Gaofu 高附 (Kabul) were also characterized as weak but also as excellent traders and very wealthy. ${ }^{87}$ Perhaps most famously, it was reported that the peoples west of Dayuan as far as Anxi speak many languages but are intelligible to each other, being also "expert traders, haggling over fractions of a shu [zhu 銖].”88

\section{Coinage}

\section{III.1 Monetization and Development of Coinages}

A prolific amount of coined money was minted and circulated in Central Asia in antiquity, and numismatic data have long constituted the most significant source for historical research, especially in respect to political history and chronology. ${ }^{89}$ Yet, coins also have great - but hitherto largely unrealized - potential for the study of the economy during this period. The reasons for this are bound up with histories of collecting, scholarly practice, and fundamental problems with data, which will be discussed further below.

It is worth outlining the main strands of the development of coinage in Central Asia, and the most important types of coins. Monetization is generally considered to derive from the Seleukid establishment of mints in Bactria and Sogdiana, although the impact of earlier coin use and the dynamics of the subsequent spread of monetization remain less clear. In the late Iron Age, that is, the Achaemenid period, exchange was presumably transacted primarily in kind, although some early gold and silver coinages - foreign, imperial, and local - were in use. The key example of this is the Chaman-i Hazuri silver hoard, found in a park in Kabul during construction in the 1930s and thought to have been desposited in ca. 380 BCE from its documented contents. ${ }^{90}$ This hoard included jewelry fragments, Greek coins from the western provinces of the Achaemenid Empire, Achaemenid sigloi, Athenian 'owls,' local round punched coins broadly of the same weight as Achaemenid sigloi,

85 Shiji 123.3163-3164, trans. Watson 1993, 235-236.

86 Shiji 123.3166; repeated in Hanshu 61.2689.

87 Hou Hanshu 88.2921.

88 Hanshu 96A.3896, trans. Hulsewé and Loewe 1979, 136.

89 See foremost the seminal but now outdated historiographies of the Greek kingdoms in Tarn 1938 and Narain 1957, methodologically critiqued in Guillaume 1990. It should be noted that limited research has been generated on other forms of money during this period.

90 Curiel and Schlumberger 1953, 31-45. See the discussion in Bopearachchi 1999. 

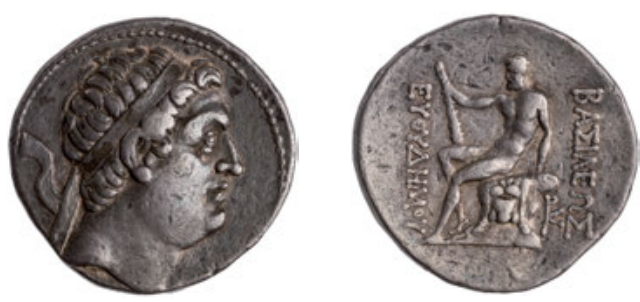

Fig. 1: Silver tetradrachm of Euthydemos I, ca. 230-190 BCE. Diameter 29 mm, 16.48 g. ANS 1995.51.28. ( A American Numismatic Society.

bent and punch-marked bar (also known as 'bent-bar') coinage putatively associated with the Paropamisadai and Gandhāra, and short-bar punch-marked coins also resembling the weight standard of sigloi. Although no mints had been established as a direct result of Alexander's campaigns, some local coinages were minted around the late fourth to mid-third century BCE, such as the imitation Athenian 'owls,' and issues of a certain Sophytes. ${ }^{91}$

During their rule of Bactria and Sogdiana in the first half of the third century BCE, the Seleukids struck coins in gold, silver, and copper, although the locations of their mints remain a point of contention. ${ }^{92}$ Building on this model, Graeco-Bactrian coinage, beginning with Diodotos I, was struck in gold, silver, copper, and - later and rarely - cupronickel. In conformity with other Hellenistic coinage, that of the Graeco-Bactrians was struck to the Attic weight standard (a tetradrachm of $16.80 \mathrm{~g}$ ), the obverses of their gold and silver coins featured royal portraits, and their reverses ordinarily depictions of Greek deities alongside Greek legends giving the ruler's name and sometimes honorific epithets (fig. 1).

Mauryan political control is presumed over the majority of the Paropamisadai, Arachosia and Gandhāra during the third century BCE, and punch-marked coinage appears to have been in use. ${ }^{93}$ This was supplanted by Indo-Greek coinage as the Greek Kingdoms expanded their political control. These coins differed from those circulating in Bactria in several ways. They were usually struck on round or squareshaped silver flans and square-shaped copper flans with weights according to the lower so-called Indian standard (a tetradrachm of $9.80 \mathrm{~g}$ ). The obverses of their silver issues usually featured a royal portrait with a Greek legend. This was also given on the reverse in Gāndhārī (written in the Kharoșthī or, more rarely, Brāhmī script) and accompanied by a deity, sometimes Indic but most often Greek (fig. 2). Copper issues evince a wider diversity of Greek and Indic iconography (fig. 3).

91 See most recently Jansari 2018 for an attribution of the Sophytes coins to a ruler of the Punjab and discussion of other perspectives.

92 Holt 1999, 36-37; Houghton and Lorber 2002, 99-103; Bopearachchi 2004. Naymark 2014 presents evidence for a Seleukid copper mint in Sogdiana.

93 See Dwivedi, ch. 10.A, this volume. 

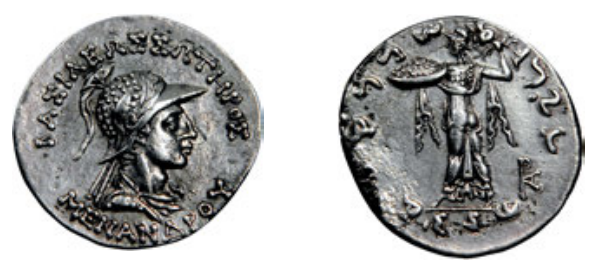

Fig. 2: Silver tetradrachm of Menander I, ca. 165-130 BCE. Diameter $26 \mathrm{~mm}, 9.53 \mathrm{~g}$. ANS 1995.51.124. (@) American Numismatic Society.
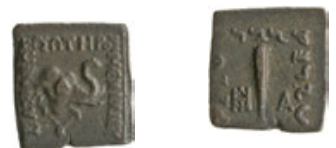

Fig. 3: Copper unit of Menander I, ca. 165-130 BCE, 3.45 g. ANS 1944.100.74666. (c) American Numismatic Society.
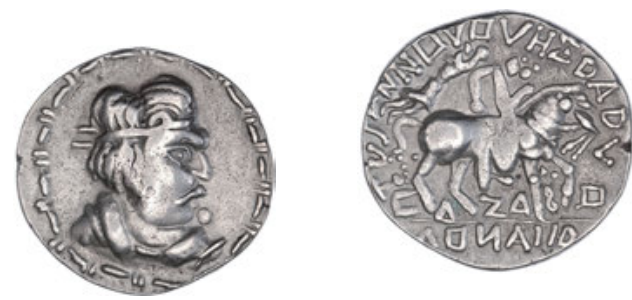

Fig. 4: Silver tetradrachm of 'Heraios', first half of the first century CE. Diameter $29 \mathrm{~mm}, 15.56 \mathrm{~g}$. ANS 1995.51.328. @ American Numismatic Society.

After the end of Greek power in Bactria in the second century BCE, the coins of the last kings were imitated by small local polities of indigenous or nomadic origin. One such example is found in the artistically innovative 'Heraios' coins, featuring a portrait of a mustachioed ruler (fig. 4), although the identification of the issuer is disputed. ${ }^{94}$ Additionally, from the third century вСE onward, local coinages were developed in neighboring territories, including Sogdiana, Chorasmia, and later, Khotan. ${ }^{95}$ Also during the first century BCE until the first century CE in Gandhāra and its adjacent micro-regions, many new rulers - the Indo-Scythians, the Indo-Parthians, Apracarājas, and Kṣatrapas - minted coinages contemporaneously to and after the shrinking sphere of Indo-Greek influence. During this same period, the silver content of higher denomination coins virtually disappeared through widespread debasement.

94 See discussion and references in Morris, ch. 2, this volume.

95 The classification of early Sogdian coinage is subject to continuing research, but for now, see Naymark 2016. For Chorasmian coinage, see Vainberg 1977, and for Sino-Kharoșțīi coins, Cribb 1984; Cribb 1985. 

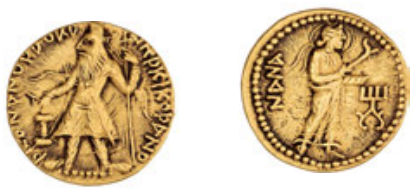

Fig. 5: Gold dinar of Kanishka I, ca. 127-150 CE. Diameter 19 mm, 7.956 g. ANS 1944.100.30743. ( American Numismatic Society.
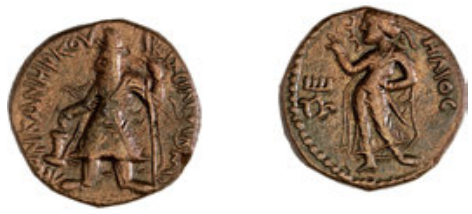

Fig. 6: Copper didrachm of Kanishka I, ca. 127-150 CE. Diameter 21 mm, 8.429 g. ANS 1944.100.34176. ( $\odot$ American Numismatic Society.

Continuing research indicates that the Kushan 'Soter Megas' coinage was developed late in Kujula Kadphises's reign, becoming an imperial coinage under his successors. ${ }^{96}$ During the reign of Vima Kadphises, a new coinage system was developed. Copper coins continued to be struck to the locally modified Attic standard, which was dropping in weight, but gold was struck to a new unit (ca. 8.0 g) conventionally referred to as the dinar. ${ }^{97}$ Thereafter, both gold and copper coins usually featured a depiction of the king in Iranian-Central Asian dress - frequently sacrificing at an altar - and a legend giving the king's name and title on the obverse. On the reverse a deity usually from the Kushan pantheon, was depicted such as Oesho or Nana (fig. 5). ${ }^{98}$ Originally, obverse legends were given in Greek (as in fig. 6), and often replicated in Gāndhārī on the reverse, but early in Kanishka's reign all legends were changed to Bactrian, and the reverse used to label the depicted deity instead. At the same time, a break with Greek-labeled deities in favor of a primarily local Iranian and Zoroastrian-derived pantheon can be seen. Much of the practicalities of Kushan coin production remains unclear, such as the locations of mints which are nonetheless presumed at certain centers. ${ }^{99}$ It is also important to note that while Kushan coinage is attested across the Gangetic plain after Kanishka I's conquests, local coinages circulated simultaneously within this space, and the economic implications of these patterns remain to be explored.

96 See further details and references in Morris, ch. 2, this volume.

97 See further discussion in Morris, ch. 16, this volume.

98 On the Kushan pantheon, see Grenet 2015.

99 Bracey 2012. 


\section{III.2 Sources of Data, Scholarly Traditions, and Problems}

The coinage of the Greek Kingdoms and the Kushans was first rediscovered in Western scholarship of the mid-eighteenth century via small-scale antiquarian collecting practice, with varying success. Theophilus Siegfried Bayer's study of Greek rule in Bactria and India was made with the aid of a silver tetradrachm of Eukratides and a copper coin of Menander (mistakenly attributed to Diodotos) alongside classical sources. ${ }^{100}$ Numismatist Joseph Pellerin made the first publication of a gold dinar of Huvishka, although he was at a total loss to explain it; it would not be recognized as Kushan until over a century later. ${ }^{101}$

Important collections of Graeco-Bactrian, Indo-Greek and Kushan coinage were assembled in the nineteenth century by antiquarian Europeans (usually officers and administrators) in what is now northern Pakistan and Afghanistan. Methods of collection included purchases from agents operating in bazaars, antiquitarian excavations of deposits in 'topes' (often misidentified stūpas), and large-scale surface collecting, such as that undertaken by British antiquarian Charles Masson at Begram. These finds were documented in journals of the time, and many ended up in major public collections, including the British Museum, the Indian Museum at Calcutta, and the Lahore Museum, with catalogs emerging in the last quarter of the nineteenth century. ${ }^{102}$ Comprehensive corpora of the Greek coinages were published in the latter half of the twentieth century, including the present standard reference work of types, Bopearachchi's Monnaies gréco-bactriennes et indo-grecques, Catalogue raisonné (1991) based on the collection of the Bibliothèque nationale de France (BNF), but drawing on other major collections. ${ }^{103}$

Fewer early catalogs of Kushan coinage have been generated. ${ }^{104}$ Robert Göbl's paradigm-shifting System und Chronologie der Münzprägung des Kušanreiches (1984), although now outdated in parts, remains a standard reference work. ${ }^{105}$ However, other contributions, including the publication of Kushan coins in the American $\mathrm{Nu}$ mismatic Society collection and the forthcoming publication of the British Museum collection, contribute important new perspectives and classifications, especially in respect to late Kushan coinage. ${ }^{106}$ Online databases for the collections of the British Museum, the American Numismatic Society, and the BNF also constitute useful research tools.

The contributions of numismatic data from early collections and excavations as well as russophone scholarship, especially that of the Soviet era, have not always

\footnotetext{
100 Discussed in Coloru 2009, 33-40.

101 On the labored historical rediscovery of the Kushans until the 1890s, see Cribb 2007.

102 The first substantial catalog being Cunningham 1884.

103 Bopearachchi 1991. See also the catalogs of Lahiri 1965, Mitchiner 1975 (also covering early Kushan coinage), and Bopearachchi and Rahman 1995.

104 See, however, an early discussion in Cunningham 1890.

105 Göbl 1984, supplemented partially by Göbl 1993.

106 Jongeward and Cribb 2015; Cribb and Bracey forthcoming.
} 
been adequately incorporated into the main strands of scholarship sketched above. Important area-focused publications covering Graeco-Bactrian and Kushan coins include those from private and public collections of Tajikistan and from museum collections in Uzbekistan. ${ }^{107}$

It is worth emphasizing that very few coins in these datasets derive from controlled archaeological excavations or are documented with even a vague sense of provenance. ${ }^{108}$ The vast majority derive from loosely documented hoards or surface finds resulting from erosion or bioturbation. It is often difficult to even ascertain the site or area within which a coin was found, but it is possible in some cases to better quantify and provenance finds from the nineteenth and early twentieth centuries with archival and collections research. ${ }^{109}$ While efforts at archaeological documentation have continued to improve where work can be safely undertaken, political instability has devastated the picture elsewhere. In the last decades, coins found in Afghanistan and Pakistan have exploded onto the antiquities market. ${ }^{110}$ The most significant and contested find is that of the Mir Zakah II hoard (1992/1993) from Paktia province, Afghanistan, estimated to have contained four tons of coins and metallic objects that were subsequently trafficked across the globe. ${ }^{111}$ Accordingly, commercial numismatic publications, in print and online, provide important new data for numismatists. As crucial contextual information remains so rare, methods of analysis that do not require this information have become popular, such as individual die studies.

In Western scholarship, the classification and study of coinage of the Greek Kingdoms and the Kushans has traditionally been undertaken with the aim of shedding light on the political history and the chronology of these polities. Production and monetary policy are often framed as political issues rather than economic ones, and many contemporary specialist numismatic contributions are still oriented toward histories of "battles and treaties." 112 This tradition has coevolved with the paucity of transmitted texts available to answer these questions and the largely contextfree nature of the bulk of available numismatic data. Archaeological approaches to site finds and coin hoards, which shed light on the functions of coins and their patterns of circulation, are conspicuously absent from scholarship but are certainly not impossible. New questions and approaches are required to collect, refigure, and interpret numismatic data from an economic perspective, some examples of which are pointed to below.

107 Zeimal' 1983; Rtveladze and Pidaev 1981.

108 There are important exceptions. The finds from Ai Khanum, for example, are well documented in Bernard 1985.

109 For example, Errington 2001; Naymark 2005.

110 Consult the list of hoards discovered in uncontrolled circumstances between 1990-1998 in Bopearachchi 1999.

111 Bopearachchi 1995, 612-616.

112 As aptly described in Guillaume 1990, 123, n. 39. 


\section{III.3 Approaches}

Metrology - the study of the weight, standard, and content of a coin - is one of the most fundamental purviews of the numismatist. Metrological approaches to Central Asian coinage continue to play an important role in considering more complex issues, such as the existence of monetary networks and connections. Particularly, the study of weight standards of local and imperial coinages together may help to determine the functions of these coinages. An important example of such work is found in Cribb's study of the first-century CE 'Sino-Kharoșthì' coinage of the Kingdom of Khotan. Cribb identified a metrological connection between the weights inscribed in Chinese on the two denominations of these coins and the reduced Atticstandard copper tetradrachms (about $15.5 \mathrm{~g}$ ) circulating in the first century CE in Bactria, Kapisa, and Kashmir. This appears to indicate economic contact between Khotan and the Kushan Empire. ${ }^{113}$

The slow application of archaeometallurgy - the scientific analysis of archaeological metal - in this field has also shed light on putative monetary connections through analysis of the composition of metals in coins. Two longstanding hypotheses regarding monetary connections have accordingly been dismantled. The first is the 'Bactrian nickel theory,' which held that the cupronickel issues of Euthydemos II, Pantaleon, and Agathokles had a similar alloy to Chinese baitong 白銅 (white copper), putatively imported from southwest China. Although disputed many times on other grounds, ${ }^{114}$ the analysis of 28 specimens through atomic absorption spectroscopy and a scanning electron microscope concluded that the composition of these coins derived instead from the use of a nickeliferous copper ore. ${ }^{115}$ The second hypothesis that has been dismantled is that of the Roman provenance of Kushan gold dinars, i.e., that Kushan coinage was produced from melted down Roman aurei. ${ }^{116}$ Through the analysis of trace elements by proton activation analysis, a recent study demonstrated that the high concentration of platinum and palladium in $\mathrm{Ku}$ shan gold coinage rules out a Roman provenance. ${ }^{117}$ The precise origins of Kushan gold remain unknown.

Die studies have recently been incorporated into the methodological repertoire of numismatists in the field, resulting in rapidly expanding datasets. ${ }^{118}$ This method requires the identification of dies (obverse and reverse) and the observation of die

113 Cribb 1984, 149-151.

114 See, for example, Cammann 1962.

115 Cowell 1989.

116 See the discussion in Morris, ch. 16, this volume.

117 Blet-Lemarquand et al. 2009, 51.

118 See Jansari 2018 for the Sophytes coinage; Kovalenko 1996 for Diodotos I and II; Glenn 2015 for Euthydemos I to Antimachos I; Bordeaux 2018 for Diodotos I and II, Euthydemos I, Eukratides I, Menander, and Hippostratos; and Dumke 2019 for the Indo-Greek kings. There are fewer published studies of Kushan coinage, but see Bracey 2009 for Vima Kadphises. 
links between series of coins, ideally from as many specimens as possible. From this it is possible to garner a fuller appraisal of the sequence of production of an entire coinage. The results of such a study may be applied to political or cultural history, but also to economic history, especially through estimations of volumes of coin output, assessed through the estimated number of obverse dies. This was achieved recently by Glenn, who applied the formula established by Esty to calculate the original number of obverse dies used in the coinages of Euthydemos I to Antimachos I. Then, following the method established by de Callataÿ, he clarified the relative (rather than absolute) sizes of these kings' different coinages. ${ }^{119}$

Archaeologically oriented interpretations of numismatic data remain limited thus far, although important inroads have been made. Zeimal' posited that coins with intrinsic metal value (gold and silver) have a wider circulation outside of their monetary system, while finds of copper coins should be interpreted as indicating local circulation and the presence of an issuing authority nearby, thus also political control. ${ }^{120}$ Naymark took up this proposition to argue for a Seleukid (but not GraecoBactrian) presence in Sogdiana through the higher representation of their coins in stray finds. ${ }^{121}$ This is a good starting point, but the role of the small presence of Graeco-Bactrian copper coinage here remains unexplained.

Elsewhere, the interpretation of coin hoards has not been approached very critically, especially in regard to their implications for economic history. One exception is Holt, who has described coin hoards as most often gathered and deposited for safekeeping, implying that they reflect currency in circulation at the time of deposition, make it possible to sequence otherwise undatable coinage, and reveal difficult periods when greater quantities of hoards were left unclaimed. ${ }^{122}$ However, parallel discussions, primarily with respect to Roman coinage, have long disputed the theoretical validity of these propositions. ${ }^{123}$ Indeed, although facing considerable theoretical and methodological challenges, the interpretation of hoards in a Central Asian context has great potential for further research: they resist easy classification into strict utilitarian or ritual boxes, shed light on economic, social, and ritual behavior, and do not mutely reflect neutral economic information but clear selectivity in their composition. ${ }^{124}$

119 On this methodology and further bibliography, see Glenn 2015, 26-31, and further discussion in von Reden, ch. 8.C, this volume.

120 Zeimal' 1978, 178.

121 Naymark 2005.

122 Holt 2005, 138-139.

123 See, for example, Reece 1987, 61-65.

124 Morris forthcoming. 


\section{Archaeological Data}

This category includes data obtained through archaeological excavations and field surveys as well as material culture that has been dislocated from its archaeological context via early collecting practices or more recent illicit excavation. These data can illuminate certain aspects of the economy and economic development, such as regional demography, agricultural production, urbanization, patterns of urbanism, craft production, industry, and intra- and interregional interaction at diverse spatial scales. To better illustrate the potential of the data relating to a Central Asian imperial context, the history of archaeological research and the most relevant projects are first sketched below (see also ch. 1, maps 1-3), followed by a discussion of the problems and questions which arise from them.

\section{IV.1 The Greek Kingdoms and the Kushans: History and Scope of Archaeological Research}

Archaeological research into the Greek Kingdoms and the Kushans originated in two colonialist loci in the nineteenth century: the Punjab, at the limits of British influence in India (now Pakistan), and in Russian Turkestan (now the Central Asian republics). ${ }^{125}$

In the Punjab during the early nineteenth century - beginning in 1830 when Manikyala stūpa was opened - antiquarian collection and excavations were undertaken by British government or East India Company officials in addition to other western Europeans attached to the services of local rulers. ${ }^{126}$ Certain agents, such as Charles Masson, were able to enter southeast and central Afghanistan and document Buddhist monuments and sites. Archaeology in this period was inspired by Graeco-Roman sources on Alexander and his successors, new translations of Chinese sources into European languages, and the development of Buddhism and its art. The Archaeological Survey of India (ASI) was established in 1861, with Alexander Cunningham as its first director, leading to more systematic identification and early excavation of many Buddhist sites and monasteries in the Peshawar valley and around Taxila, and of Buddhist and Jain establishments around Mathura. At the end of the nineteenth century, Alfred Foucher travelled to the northwest, docu-

125 A number of general syntheses are to be recommended here for further information. Mairs 2011 is a comprehensive survey of literature relating to the Hellenistic period, with subsequent updates provided at www.bactria.org. A comparable survey for Kushan archaeology does not exist, but English-language surveys of Soviet archaeological research in Central Asia can be found in Frumkin 1970 and Masson 2011. Staviskij 1986 is a good, if now dated, treatment of Bactria-Tokharistan under the Kushans with a strong emphasis on Soviet research. Pons 2016 surveys Kushan archaeology in India and modern Pakistan.

126 For this and the following, see Errington 2007. 
menting and studying the Gandhāran idiom of Buddhist art produced there which flourished in the Kushan period. Excavations conducted at the turn of the twentieth century by the ASI under John Marshall's directorship began at significant ancient urban centers, including trial excavations at Charsadda's Bala Hisar (probably ancient Puṣkalāvatī) and extensive work in the Taxila micro-region, which featured three cities and Buddhist monuments. ${ }^{127}$ Of the settlements, the fortified city of Sirkap was the best documented, which revealed limited strata dating to the Indo-Greek period and a Kushan-period end to occupation. The putatively Kushan-period fortified city of Sirsukh remains virtually unknown. Around the same time, the Kushan devakula at Māṭ near Mathura was opened by an amateur archaeologist, revealing royal portrait sculptures with Epigraphical Hybrid Sanskrit (EHS) inscriptions. ${ }^{128}$

The collection of antiquities and early excavations in Central Asia under the Russian Empire of the nineteenth century were shaped by different motives and outcomes. ${ }^{129}$ Archaeological excavations began in 1884 in Samarkand (ancient Marakanda) at the enormous multi-period mound of Afrasiab. This city is now known to have been founded in the seventh to sixth centuries BCE and was continuously occupied until the Mongol invasion in 1220, although its antiquity was only realized in Soviet scholarship of the mid-twentieth century. ${ }^{130}$

Archaeological documentation in Afghanistan took off with the founding of the Délégation archéologique française en Afghanistan (DAFA) by Alfred Foucher in 1922, who had negotiated a monopoly on foreign research there. ${ }^{131}$ Although the excavations at the Bala Hissar at Balkh (Bactra) (1923-1925) revealed very little early material, work at other sites was far more productive. Led by Joseph Hackin, excavations at the urban site of Begram (Kapisi and Alexandria in the Caucasus) (1936-1942, 1946), revealed a hoard including artifacts from the Roman Mediterranean, India, and China. ${ }^{132}$ Work at the Kushan bagolango (image-temple) at the site of Surkh Kotal (1952-1963) revealed the remains of royal portrait sculptures and the first monumental inscription in the Bactrian language. ${ }^{133}$ The excavations at Ai Khanum (1964-1978) revealed what remains the only extensively excavated Graeco-Bactrian urban site. ${ }^{134}$ Parallel to this, a Franco-Afghan team surveyed the hinterland of Ai Khanum and the surrounding landscapes of east Bactria (1974-1978) tracing the

127 See Petrie 2013a on Charsadda and Petrie 2013b on Taxila.

128 See the critical discussion in Rosenfield 1967, 140-142.

129 Gorshenina 2004, 16-18.

130 See further bibliography in Grenet 2004.

131 On the early history of the DAFA, see Olivier-Utard 1997.

132 See overview and bibliography in Morris 2017 and further discussion in Morris, ch. 16, this volume.

133 Schlumberger, Le Berre, and Fussman 1983.

134 Published in nine volumes thus far in the Mémoires de la DAFA, vols. 21, 26-31, 33-34, most recently Lecuyot 2013. See Mairs 2011, 26-29 for an annotated bibliography. 
development of irrigated land and settlement patterns over time. ${ }^{135}$ The Soviet invasion of Afghanistan halted operations.

In Pakistan in the mid-twentieth century, Mortimer Wheeler renewed excavations at Charsadda's Bala Hissar (1958), discovering also the nearby urban site of Shaikhan Dheri; excavations were subsequently led there by A. H. Dani (19631964). ${ }^{136}$ The Istituto Italiano per il Medio ed Estremo Oriente (IsMEO, now ISMEO) began work in Pakistan in 1955, contributing especially to extensive research in the Swat valley, including excavations at Buddhist monuments as well as the multiperiod urban site of Barikot (1978-present). ${ }^{137}$ The IsMEO also began excavations in Afghanistan, including at the Buddhist sanctuary of Tapa Sadar near Ghazni (19591976), which had a Kushan phase. ${ }^{138}$ Excavations at Shahr-i Kuhna (Old Kandahar) were also undertaken by the British Society for Afghan Studies (1974-1978). ${ }^{139}$ The same period in north India saw significant excavations at Sonkh in the Mathura district (1966-1974) with well-documented Kushan-period horizons. ${ }^{140}$

Archaeology on a large scale in Soviet Central Asia began in the wake of national demarcation into new Soviet Socialist Republics (1924-1936). Under the leadership of M. E. Masson, the Termez Archaeological Complex Expedition (TAKE) (19361938) began to document sites in the vicinity of Old Termez, which was developed significantly in the Kushan period. The creation of Academies of Sciences in the Soviet Republics during the 1940s and 1950s expanded the scope and resources of archaeological research, which was carried out in cooperation with institutions in Moscow and St. Petersburg. The format of the Kompleksnaia ekspeditsiia (Complex Expedition), i.e., a large-scale interdisciplinary project, would become a prominent mode of subsequent Soviet-era projects. Notably, early attention was also paid to the archaeology of the nomadic populations living in ancient Central Asia through excavations of their kurgans (burial mounds). ${ }^{141}$

The second half of the twentieth century saw the excavation of numerous settlements and religious sites of the Kushan period, especially in southern Uzbekistan. Parts of the citadel of Old Termez and its satellite religious sites were explored, including Airtam and the Kushan/Kushano-Sasanian Buddhist monasteries of Fayaz Tepe and Kara Tepe. In the Surkhan Darya region, excavated sites included the Yuezhi-Kushan period ceremonial edifice at the site of Khalchaian (1959-1963), and the multi-period urban site of Dal'verzintepe (1962-1974). ${ }^{142}$ Archaeological surveys

135 Gardin 1998.

136 Petrie 2013a.

137 Summarized in Colliva 2011, although the chronology of the site's occupation continues to be refined.

138 For an overview, Verardi 2010.

139 See bibliography in Mairs 2011, 35.

140 Härtel 1993.

141 For example in Mandel'shtam 1966.

142 For the sites mentioned here and further bibliography, see Staviskij 1986, Appendix II. 
were also mounted here, producing information about urbanization, hierarchies of settlements, and primary irrigation canals, published later in synthetic form. ${ }^{143}$ The Afghan-Soviet Archaeological Mission (1969-1977) excavated at the urban site of Dil'berdzhin and surveyed part of the Balkh oasis. ${ }^{144}$ Material clearly relating to the Hellenistic period is only minimally visible in the archaeology of this time except, for example, at the Oxus Temple (Takht-i Sangin), excavated during 1976-1979. ${ }^{145}$

Since the collapse of the Soviet Union, projects under the auspices of local Academies of Science and also in cooperation with many international teams have emerged. Those especially relevant to the Hellenistic and Kushan periods include the Franco-Uzbek projects in Sogdiana, with significant renewed excavations at Marakanda-Afrasiab and at the Iron Gate wall near Derbent (MAFOuz de Sogdiane), ${ }^{146}$ and in north Bactria, with continued excavations especially in the vicinity of Old Termez (MAFOuz de Bactriane). ${ }^{147}$ Russian-Uzbek teams cooperate at Kampyrtepa and Uzundara, and Japanese-Uzbek missions are active at Dal'verzintepe and Kara Tepe. The Czech-Uzbek mission in northern Bactria has excavated at the Kushan/Kushano-Sasanian settlement of Jandavlattepa (2002-2006) ${ }^{148}$ and undertaken archaeological surveys of micro-oases. The Italian-Uzbek mission at Samarkand has studied longue durée settlement patterns in the middle Zerafshan utilizing GIS remote sensing combined with pedestrian survey. ${ }^{149}$ More systematic datasets about settlement patterns and land use have also been produced for the Surkhan Darya region from Soviet-era legacy data combined with a GIS-oriented landscape perspective. ${ }^{150}$

The DAFA has resumed minor operations in Afghanistan since 2002, including at Tepe Zargaran near to Balkh (Bactra), finally revealing Hellenistic and Kushanperiod material. ${ }^{151}$ It has also supported rescue archaeology led by the Archaeology Institute of Afghanistan at the extensive Buddhist establishments at the copper source site of Mes Aynak. Illicit excavation, especially in remote or conflict areas, remains widespread, destroying crucial archaeological contextual data. However, the collation and reassessment or legacy data from earlier explorations and excavations in Afghanistan also continues. ${ }^{152}$

143 For example, in Pugachenkova and Rtveladze 1990.

144 Pugachenkova 1976.

145 See bibliography in Mairs 2011, 25.

146 Grenet and Isamiddinov 2001.

147 Leriche and Pidaev 2008.

148 Stančo and Abdullaev 2011.

149 Mantellini 2014.Stride 2007.

150 Stride 2007.

151 Besenval and Marquis 2007.

152 See, for example Fussman, Murad, and Ollivier 2008; Errington 2017. 


\section{IV.2 Problems and Questions}

It is thus evident that archaeological data for Central Asia under the Greek Kingdoms and the Kushans is hardly lacking, but the nature of these data does shape the questions we may ask of them. Foremost, their production has been formed by the complex geopolitical context of this space in the last centuries and accordingly represents diverse intellectual traditions, languages, assessments of chronology, and methodologies. In the cases when work is adequately published, the quality and availability of publications varies. For example, the DAFA excavations at Ai Khanum are still being published over forty years after the premature closure of fieldwork there. Publications of the Soviet era were notorious for having low-quality images and are sometimes still difficult to obtain. In some cases, there are also fundamental problems with published interpretations of data, especially in terms of dating. For example, Marshall's chronology of Sirkap has been subject to major revisions, ${ }^{153}$ but many other sites need similar attention. Thus, what is published often does not lend itself easily to historical interpretation.

Biases in areas of coverage also exist. For example, north and east Bactria and the Swat valley are fairly comprehensively documented, while much of central and southeast Afghanistan is covered only in small pockets. Mountainous regions where petroglyphs reflect human activity and mobility - have been only irregularly archaeologically surveyed. ${ }^{154}$ Specialized studies of material culture, notably ceramics, are also of unequal coverage; the ceramic record of Bactria has long been subject to intense research, ${ }^{155}$ while, comparatively, that of the Paropamisadai has not received sustained attention. This means it is possible to discuss certain economic processes, such as patterns of agricultural production, demography, urbanization, settlement, craft production, urban-rural relationships, and mobility, in some areas but not others.

Our knowledge of urbanism during this period is particularly limited. One reason for this is because many of the famed old urban centers - such as Bactra, Marakanda, Old Kandahar, and Puṣkalāvatī - are buried under many meters of archaeological strata from long histories of occupation. This makes it difficult to reach early levels, let alone to ascertain their structure. Our knowledge is also shaped by the biases of modern research agendas. In Gandhāra and adjacent spaces, for example, archaeological research on the Kushan period has traditionally been oriented toward Buddhist monuments and monasteries and their art rather than settlements. However, the question of economic development might still be approached in such contexts through evidence for the flourishing of donations and investments in these institutions in the first centuries CE.

153 Erdosy 1990.

154 See the contributions in Olivieri 2010.

155 E.g., in Lyonnet 1997; 2012; Maxwell-Jones 2015. 
The application of different methods of analysis and theoretical frameworks will improve the interpretive possibilities of the available data. For example, interest in the analysis of archaeobotanical and zooarchaeological material in Central Asia continues to increase, especially in respect to the Bronze and Iron Ages. ${ }^{156}$ Such data have rarely been systematically collected and analyzed for sites of the subsequent antique period, although this trend does appear to be changing. ${ }^{157}$ The necessity of developing more sophisticated theoretical frameworks in tandem with critically working through difficult archaeological data is particularly evident in respect to the interpretation of foreign artifacts and elements in art. When accurately identified and dated, these objects provide important evidence for interregional connectivity, although the nature of this connectivity is rarely obvious. The discourse about the immense volume of foreign artifacts in the Begram hoard provides a salient example of this. The DAFA excavations at Begram were executed, documented, and published in an idiosyncratic and incomplete manner, and the disparate and confusing nature of Kushan archaeology makes it even more difficult to ground these finds in their specific historical and regional context of Kapisa under Kushan rule. Attracted by the seeming cultural familiarity of these imports - especially those produced in the Roman Mediterranean - and drawing on traditional conceptions of the role of the Kushans as middlemen in Silk Road trade, scholars have frequently interpreted this hoard as representative of broader patterns of commodities traded across this long distance network, with Begram acting as merely a commercial node. ${ }^{158}$

\section{Excavated Texts}

This metacategory of evidence constitutes diverse forms of sources grouped together by virtue of their status as 'excavated,' in the sense that they have been discovered in material form rather than having been transmitted. Their forms vary from official inscriptions to relatively private ephemeral documents written with ink on leather. This corpus includes a range of languages, being written primarily in Greek, IndoAryan languages (foremost Gāndhārī and Epigraphical Hybrid Sanskrit), and Bactrian. Important corpora that bookend the present historical period of interest can also be pointed to, including Achaemenid-era Aramaic documents, as well as Bactrian and Sogdian documents beginning in the early fourth century CE. The following section surveys these sources, grouped linguistically and broadly chronologically, assessing their potentials and limitations. As will be shown, these texts shed light on administration (particularly financial) in the Central Asian empires, in addition to individual mobility and professions.

156 Spengler et al. 2014; Lhuillier and Mashkour 2017; Wu, Miller, and Crabtree 2015.

157 See, for example, Dvurechenskaia 2016.

158 For further discussion, see Morris, ch. 16, this volume. 


\section{V.1 Before the Greeks: Aramaic and Elamite}

Excavated texts from Achaemenid Central Asia are of interest as they demonstrate substantial administrative structures in place that shaped practice in the subsequent Hellenistic period and beyond. Aramaic (rather, Official Aramaic) was an important chancellery language in the multilingual administration of the Achaemenid Empire and accordingly also came into use at its eastern frontiers. Indirect evidence of this has been apparent since the early twentieth century in the use of the Aramaic script in the Aśokan edicts found at Taxila, Old Kandahar, the Laghman valley, and Pul-i Darunta. ${ }^{159}$

Direct evidence of Achaemenid administrative practice in Bactria is found in the Aramaic documents obtained since 2000 by the Khalili collection. Of the first lot, there are 48 dating around the mid-fourth century вСЕ, 29 of which are letters, letter orders, scrap paper, and other documents written with ink on leather, and 18 are split wooden tally-sticks with short inscriptions in ink. This corpus is thought to derive from an archive of Akhvamazda, probably the satrap of Bactria, but this is not clear due to the uncertain provenance(s) of the various documents. ${ }^{160}$ Nonetheless, these documents have thus far shed light on the integration of Bactria into imperial administrative structures through empire-wide bureaucratic protocols, including the training of scribes at a central school ${ }^{161}$ and the use of tally-sticks as credit records for third parties. ${ }^{162}$ They also hint at the diffusion of imperial impact beyond the household economies of this space ${ }^{163}$ and the retention of administrative practice after the collapse of the Achaemenid Empire. ${ }^{164}$ The integration of these documents into the broader study of the documentary record of the Hellenistic and Kushan periods has potential to further illuminate continuities and changes in administrative practice within Central Asia over time. ${ }^{165}$

Two fragments of clay cuneiform tablets with Elamite text, found during excavations in 1977 at Old Kandahar have been recently fully published. ${ }^{166}$ Although

159 See bibliography in Mairs 2011, 41 and further comments on the edicts in Dwivedi, ch. 10.A, this volume.

160 The documents are published in Naveh and Shaked 2012. The first lot was described as found in "either Central Asia, Mesopotamia or Afghanistan" (Naveh and Shaked 2012, ix, 15, 284). See the skeptical remarks in Henkelman and Folmer 2016, 134 n. 2.

161 See a comparison of the letter orders with those from Asharma, Egypt in Folmer 2017.

162 Henkelman and Folmer 2016.

163 Henkelman 2018, 247.

164 Mairs 2014, 43-44; document C4 is dated to year 7 of Alexander.

165 Mairs 2011, 18.

166 Fisher and Stolper 2015. 
their content is limited, they closely resemble material from the Persepolis Fortification Archives in content, shape, and format, demonstrating the existence of an Achaemenid administrative center in Kandahar. ${ }^{167}$

\section{V.2 Greek}

Unsurprisingly, Greek was the chancellery language of the Greek Kingdoms, and Greek texts dominate their rather small documentary record. These include, but are not limited to, records written in ink or incised on ceramic storage vessels from the treasury at Ai Khanum, documentary texts on parchment, graffiti primarily on ostraca (potsherds), legends on coins, and civic, votive, and funerary inscriptions. ${ }^{168}$

The inscribed storage vessels from the treasury at Ai Khanum date from the mid-second century всE. ${ }^{169} \mathrm{Ai}$ Khanum was the regional center of east Bactria as well as a royal city, and thus these texts shed light on financial administration under the Graeco-Bactrians and also provide a regional perspective on economic affairs at a high level of the administrative hierarchy. ${ }^{170}$ Most of these texts (or rather, labels) relate to the contents of the vessels - coined silver, olive oil, and incense, from what is legible - and document the processing of payments, and the deposit of commodities by a variety of individuals with either Greek or local Iranian names. The largest group is a fairly formulaic one relating to the checking and processing of coined silver, which is documented in round sums of 500 drachms and 10,000 kasapanas (Skt. kārșāpaṇas), a denomination of Indian coinage. ${ }^{171}$ One legible example, followed by three similar texts on the same pot (fig. 7), reads:

From Zenon,

they have been counted through

Oxeboakes and Oxybazos, 500 drachms,

it has been sealed by Oxeboakes. ${ }^{172}$

These texts most likely refer to official transactions concerning repeated, consolidated, incoming revenue. They may reflect taxes or tribute extracted by the GraecoBactrian state, including from northwestern India after the conquest of Eukratides. ${ }^{173}$

167 Fisher and Stolper 2015, 20; Henkelman 2018, 244.

168 Consult bibliography in Mairs 2011, 38-43, and the corpus in Rougemont 2012.

169 Collected in Rapin and Grenet 1983; Rougemont 2012, 214-216, Nos. 99-130. See also the discussion in Mairs 2014, 46-51.

170 Mairs 2014, 53.

171 Rougemont 2012, Nos. 101-114, and likely also Nos. 115-116.

172 Rapin and Grenet 1983, 326, No. 4a; Rougemont 2012, No. 101. This jar was found in the city's sanctuary, where it appears to have been moved in the post-palatial period.

173 Rapin and Grenet 1983, 351-354; Mairs 2014, 47-52. For fiscal aspects of these texts, see Bernard 1979; Picard 1984. 


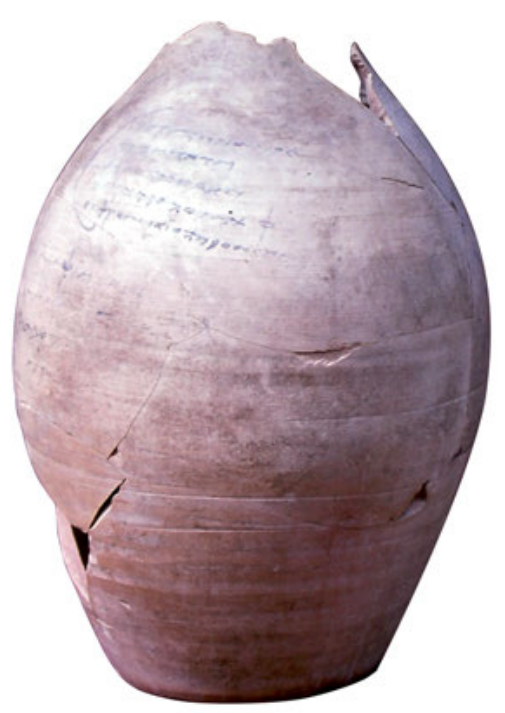

Fig. 7: Ceramic vessel with records of payments in ink, from Ai Khanum, mid-second century BCE, height $41 \mathrm{~cm}$. PO 2752. (C) Délégation archéologique française en Afghanistan, courtesy of Claude Rapin.

A lower level perspective on administration and bureaucracy is seen through three fragmentary texts on parchment from Bactria dating to Graeco-Bactrian rule, which unfortunately have no meaningful archaeological provenance. These relate to dealings of individuals with the state, giving further insight into financial administration under the Graeco-Bactrians. The first is the Asangorna parchment, a tax payment receipt from 171 BCE relating to perhaps a temple or sacred affairs, within which a tax-gatherer (logeutes) acknowledges receipt from another individual of payments due. ${ }^{174}$ This document reveals a complex hierarchy of officials: the tax-gatherer, Menodotos, acted in the presence of an official sent out by two further officials (Demonax and Simos) under the agency of Diodoros, the controller of revenues. ${ }^{175}$ It is likely that this framework derives from a continuation of Seleukid administrative practice in Bactria. ${ }^{176}$ The second is the Amphipolis parchment, dating from the late third or early second century BCE. This is a contract or receipt relating to a sum of 100 drachms of coined silver for, perhaps, Scythian mercenaries. The third text is

174 Rea, Senoir, and Hollis 1994; Bernard and Rapin 1994. For this date (year 4 of the Yavana era) see Rapin 2010.

175 For a general discussion, see Mairs 2014, 46-54.

176 Aperghis 2004, 283. 
very fragmentary, recording the receipt of something for transport by an Archises. ${ }^{177}$ Paleographically, these are indistinguishable from comparable documents from the eastern Hellenistic world and demonstrate clear connectivity through a shared bureaucratic modus operandi. ${ }^{178}$

Although Greek votive and funerary inscriptions of the Hellenistic period are now known from Bactria, Arachosia, and Gandhāra, most do not contain much evidence of direct economic interest. One exception is the funerary epitaph of a certain Sophytos (here a rendering of an Indic name, perhaps Subhūti), putatively found in Kandahar and dating to the second century BCE. In high literary Greek, the epitaph recounts his family's misfortunes, his Greek education, how he found his fortune as a merchant, and his return and restoration of his family's status. ${ }^{179}$ This text attests to the wealth and social status obtainable by a merchant in Arachosia.

Under the early Kushans, Greek was retained for official purposes (as seen on coin legends) until early in the reign of Kanishka I, when it was replaced by Bactrian. The existence of individuals conversant in Greek and Bactrian is seen in the 'signing' of an undated Bactrian inscription on stone at Surkh Kotal in Greek by a Palamedes, presumably the mason. ${ }^{180}$

\section{V.3 Indo-Aryan Languages: Prakrit, Gāndhārī, Epigraphical Hybrid Sanskrit}

Texts in Indo-Aryan languages relevant to Greek and Kushan rule are comprised largely of official and donative inscriptions. They convey limited but important information about diplomacy and mobility, the implementation of new offices through imperial expansion and after regime changes, and the professions of wealthy donors to various religious organizations.

The first text of interest comprises two Prakrit inscriptions written in the Brāhmī script on a stone column erected in ca. 113 BCE in Vidisha (Madhya Pradesh). These describe the erection of the pillar by Heliodoros of Taxila, ambassador of the IndoGreek king Antialkidas to Bhāgabhadra, a local ruler or member of the Śunga dynasty. ${ }^{181}$ This is significant evidence for diplomatic connectivity and mobility under the Indo-Greeks.

A much larger body of texts is found in Gāndhārī, a Middle Indo-Aryan language closely related to Sanskrit, Pali, and various Prakrit dialects. ${ }^{182}$ Gāndhārī de-

177 Clarysse and Thompson 2007.

178 Mairs 2014, 53.

179 Bernard, Pinault, Rougemont 2004, 227-332.

180 Surkh Kotal 3; Curiel 1954, 194-197; Sims-Williams 2012, 78.

181 For an edition see Salomon 1998, 265-267; and discussions in Coloru 2009, 248; Mairs 2014, 117-133.

182 A digital catalog of all known Gāndhārī texts, in addition to bibliographies and dictionaries, is available online at Baums and Glass 2002-. 
veloped in the Peshawar valley during the third century BCE to the third century CE. In the northwest of the Indian subcontinent under the Kushans, it was a major vernacular and literary language, and its use eventually spread with Buddhism northwards into Bactria-Tokharistan and eastward into the Tarim Basin states. ${ }^{183}$ Gāndhārī was written in the Kharoșțī script, which is derived from the Aramaic script; this distinguishes it from other Indo-Aryan languages, which are written in the Brāhmī script and derivatives. Gāndhārī is found most frequently in the legends on reverses of coins, such as bilingual Indo-Greek and early Kushan issues. However, the primary documents of present interest are over five hundred inscriptions that are mostly Buddhist dedicatory or donative records executed on stone or, less commonly metal. ${ }^{184}$ These inscriptions contain occasional mentions of administrative and military offices of foreign origin which appear to have been incorporated into preexisting Indic structures of political hierarchy. These include offices derived from the Greek world, such as strategos and meridarches attested in the decades following the end of Indo-Greek rule, ${ }^{185}$ as well as the kșatrapa and mahākșatrapa of Iranian origin attested prior to and during Kushan rule. ${ }^{186}$ The philological study of such evidence is crucial to clarify the introduction of offices as well as their retention through regime changes.

A similar corpus of texts is found in Epigraphical Hybrid Sanskrit (EHS) inscriptions from around the first to third centuries CE in northern India. This language incorporated characteristics of both Sanskrit and Prakrit, and was written in the Brāhmī script. ${ }^{187}$ Skinner's recent evaluation of EHS inscriptions relating to the Kushan period has gathered a corpus of 252 texts, most from Mathura and environs. ${ }^{188}$ These texts - often accompanying images or inscribed onto architectural objects are primarily dedicatory or donative records from diverse religious contexts: Buddhist, Jain, Naga, and Indic. These inscriptions demonstrate the influx of offices of Iranian origin ${ }^{189}$ and document the professions of donors and their family members. These include, for example, caravan leaders or merchants, ironsmiths, cloak makers, and guild leaders. ${ }^{190}$ These data shed light on the socioeconomic profile of wealthier lay adherents to various religions during the Kushan period in this region, although it must be reiterated that this represents a particular subsection of society rather than a representative sample thereof.

183 Salomon 1998.

184 For editions, see the database in Baums and Glass 2002-. A catalog of reliquary inscriptions is presented in Jongeward et al. 2012.

185 Coloru 2009, 265-266; Falk 2010, 74-76.

186 Falk 2010, 74-76; 78.

187 For further on EHS, see Salomon 1998, 82.

188 Skinner 2017, 3.

189 Falk 2010, 78.

190 For further information, consult the catalog in Skinner 2017. 


\section{V.4 Bactrian}

Bactrian is a Middle Iranian language written in a modified Greek alphabet. It was the native spoken idiom of the region and is first attested in the trilingual inscription of Vima Taktu at Dasht-i Nawur, an apparent proclamation of power etched onto a remote boulder on a ridge of Mount Qarabayu. ${ }^{191}$ The other two languages used in this inscription were Gāndhāri and the so-called 'unknown language' in the undeciphered 'unknown script'; this language may be of Saka origin, and the original language of the Kushans. ${ }^{192}$ Nonetheless, from early in the reign of Kanishka I, Bactrian served as the Kushans' primary imperial language. There are only a few Bactrian texts extant from the Kushan period, but they are packed with historical significance and have revolutionized scholarly understanding of this dynasty, especially the Rabatak foundation inscription, discovered by chance at an unexcavated bagolango in 1993. ${ }^{193}$ Barring the Dasht-i Nawur trilingual, most known Bactrian inscriptions of this era appear to pertain to bagolango contexts in Bactria-Tokharistan. Beyond providing crucial historical and cultural information, these inscriptions also give glimpses into offices at the upper echelons of Kushan rule - such as the amboukao, hasht-walg, and karalrang - and their responsibilities in respect to sacred matters. ${ }^{194}$ The continuing study of these obscure titles will help to develop new hypotheses about their roles in the administration of the Kushan Empire.

There is also limited evidence that Bactrian was used in lower level bureaucratic documentation in this period. During the 1982 excavations at Kampyrtepa - a 3.5 ha fortress settlement thought to have been abandoned in the mid-second century CE thirty slivers of papyri featuring parts of Bactrian words written in ink were found (block 1, room 6), apparently the remnants of an archive of obscure character. ${ }^{195}$ Further quotidian inscriptions exist, incised and inked most frequently on ceramic sherds from Bactria-Tokharistan, seemingly from the same time period and later. ${ }^{196}$

\section{V.5 After the Kushans: Bactrian and Sogdian}

The present lacuna in the documentary record for Bactria-Tokharistan under the Kushans can be mitigated in some way through a relatively recently published corpus of more than 150 unprovenanced Bactrian documents, primarily written in ink

191 The original publication is Fussman 1974. Sims-Williams 2012 provides a useful survey of the major Kushan inscriptions with bibliographic details for reliable editions and translations; see also the silver dish of Nukunzuk in Sims-Williams 2015.

192 Grenet 2015, 205.

193 First publication in Sims-Williams and Cribb 1996. See now Sims-Williams 2004.

194 See further discussion in Morris, ch. 2, this volume.

195 Rtveladze 2012, 234-240.

196 Rtveladze 2013. 
on parchment, which encompass a broad period from the early fourth to the eighth century CE, i.e., the Kushano-Sasanian period to the early Islamic conquest. ${ }^{197}$ Within this corpus, a group of Bactrian letters and broadly 'economic' documents, including tally-sticks, from the early fourth to fifth centuries CE can be singled out for their high potential of contributing indirectly to Bactria-Tokharistan's economic history. These putatively derive from an archive in the city of Rob, which is named in several documents and was located east of Balkh. ${ }^{198}$

The early letters relate the affairs of certain individuals, often involving officials of various standing in a suburb of Rob. They shed light on the roles of these officials, existing administrative divisions, taxation in kind and in coinage, a robust legal system protecting freemen (with hefty fines to be paid to the state when laws are circumvented) and private land ownership. ${ }^{199}$ The tallies refer to various food commodities and are formally very similar to the Aramaic tally sticks of the Achaemenid period, ${ }^{200}$ indicating long-term continuity of local bureaucratic protocols. Although the early letters have only been subject to limited study from an economic and administrative perspective thus far, ${ }^{201}$ further analysis may be able to distinguish which administrative, economic, social, and legal elements derive from practices developed over the longue durée. For example, the marriage contract between Ralik, and the two brothers Bab and Piduk, indicates that this union was made according to the "established custom of the land."202 Fraternal polyandry has been explained from an anthropological perspective as motivated by limited economic opportunities, that is, the desire to retain limited resources and property within a family. ${ }^{203}$

It is worth pointing to a long-known corpus of similarly later but significant documents. These are the Sogdian ancient letters, a collection of personal and private correspondence from Sogdian inhabitants of the Hexi corridor, written on paper in the Sogdian language, dated to the beginning of the fourth century CE. These were found by Aurel Stein in 1907 in the ruins of a Han guard tower west of Dunhuang, and constitute five almost complete letters and numerous further fragments thereof. ${ }^{204}$ These letters shed light on an extensive network of Sogdian diaspora communities (seemingly composed predominantly of merchants and caravan lead-

197 See foremost Sims-Williams 2000.

198 Sims-Williams 2000, 10-17.

199 Generally, Sims-Williams 2000, and see now Sims-Williams and Weber 2018 for the revised chronology of these documents.

200 Henkelman and Folmer 2016, 209-210.

201 See for example Rezakhani 2010.

202 Document A (332 CE), line 15, trans. Sims-Williams 2000, 32-33.

203 Willett 1997.

204 See further Sims-Williams 1985; de la Vaissière 2005, 43-70. Sims-Williams has recently translated or produced completed editions of letters 1, 2, 3, and 5. Consult the bibliography in Sundermann, Hintze, and de Blois 2009, xix. 
ers) living in the Tarim Basin and China, who were also connected with their homeland; Letter 2 was addressed to distant Samarkand. The letters provide details about numerous aspects of the trade of these communities, such as their long-distance financial arrangements and the types of products traded (primarily textiles, musk, wine, pepper, and camphor). They also attest to the continued use of units of measurement introduced by the Greeks to Central Asia, namely the stater (Sogd. styr) weighing about $16 \mathrm{~g}$, used for both commodities and as a monetary unit. ${ }^{205}$ These letters date from just after the period of present concern, but the origins of the Sogdian network are to be sought at least in the preceding century. ${ }^{206}$ Indeed, although Sogdiana lay beyond the northern frontier of Kushan rule, it has been posited that the political stability and economic prosperity achieved in the Kushan Empire attracted Sogdian merchants to emigrate to the cities of Bactria-Tokharistan and northern India, where they drew on the knowledge and experience of other merchants in establishing the network visible in the later Sogdian letters. ${ }^{207}$

\section{Conclusion}

This chapter has aimed to clarify the shape of the complex body of evidence available for the study of the economic history and development of Central Asia under the Greek Kingdoms and the Kushan Empire. Although this corpus poses undeniable difficulties, it nonetheless presents significant and largely unrealized potential for the study of economic questions in this historical context. Information conveyed by Graeco-Roman and Chinese transmitted texts sheds light on many aspects of the economy and its development. An enormous body of numismatic data is available to be exploited, although the perennial lack of contextual data shapes the questions we may ask of it. Yet, the application of new methods and approaches to this corpus has the potential to further illuminate monetary networks, production estimates, and hoarding practices in this historical context. Archaeological data relevant to the Greek Kingdoms and the Kushan Empire were produced between disparate intellectual traditions with different research interests, and much of the published data still have major problems and biases in coverage that make it difficult to define and analyze economic macro-processes from an imperial perspective. Yet, many insights can be gleaned from case studies in better documented micro-regions and from the application of new methods and theoretical approaches. Finally, excavated texts in a number of languages have great potential for further analysis, particularly with

205 See discussion in de la Vaissière 2005, 43-70.

206 See, however, remarks on new global historical phenomena emergent in the fourth century CE in the general introduction to this volume.

207 De la Vaissière 2005, 83-84, 90-91. 
respect to the study of financial administration but also for the formulation of new hypotheses about the origins of phenomena attested only later.

\section{References}

Abdullaev, K. 2007. "Nomad migration in Central Asia." In J. Cribb and G. Herrmann (eds.), After Alexander: Central Asia before Islam, 73-98. Oxford: Oxford University Press.

Andrade, N. 2015. "The voyage of Maes Titianos and the dynamics of social connectivity between the Roman Levant and Central Asia/West China." Mediterraneo Antico 18.1/2, 41-74.

Aperghis, G. G. 2004. The Seleukid royal economy: The finances and financial administration of the Seleukid Empire. Cambridge: Cambridge University Press.

Baums, S., and A. Glass. 2002-. Catalog of Gāndhārī texts. https://gandhari.org/catalog.

Bernard, P. 1979. "Pratiques financières grecques dans la Bactriane hellénisée." Bulletin de la Société française de Numismatique 34, 517-520.

-. 1985. Fouilles d'Aï Khanoum. Vol. 4, Les monnaies hors trésors: Questions d'histoire gréco-bactrienne. Paris: De Boccard.

-. 2005. "De l'Euphrate à la Chine avec la caravane de Maès Titianos (c. 100 ap. n.è.)." Comptes rendus des séances de l'Académie des Inscriptions et Belles-Lettres 149.3, 929-969.

Bernard, P., and C. Rapin. 1994. "Un parchemin gréco-bactrien d'une collection privée." Comptes rendus des séances de l'Académie des Inscriptions et Belles-Lettres 138.1, 261-294.

Bernard, P., G.-J. Pinault, and G. Rougemont. 2004. "Deux nouvelles inscriptions grecques de l'Asie centrale." Journal des Savants 2, 227-356.

Besenval, R., and P. Marquis. 2007. "La rêve accompli d'Alfred Foucher à Bactres: Nouvelles fouilles de la DAFA 2002-2007." Comptes Rendus des séances de l'Académie des Inscriptions et Belles-Lettres 151.4, 1847-1874.

Bielenstein, H. 1954. "The restoration of the Han dynasty." Bulletin of the Museum of Far Eastern Antiquities 26, 1-209.

Blet-Lemarquand, M., G. Sarah, B. Gratuze, and J. N. Barrandon. 2009. "Nuclear methods and laser ablation inductively coupled plasma mass spectrometry: How can these methods contribute to the study of ancient coinage?" Cercetări Numismatice 15, 43-56.

Bopearachchi, 0. 1991. Monnaies gréco-bactriennes et indo-grecques: Catalogue raisonné. Paris: Bibliothèque Nationale.

-. 1995. "Découvertes récentes de trésors indo-grecs: Nouvelles données historiques." Comptes rendus des séances de l'Académie des Inscriptions et Belles-Lettres 139.2, 611-630.

-. 1999. "La circulation et la production monétaires en Asie centrale et dans l'Inde du nord-ouest (avant et après la conquête d'Alexandre)." Indologica Taurinensia 25, 15-121.

-. 2004. "La politique monétaire de la Bactriane sous les Séleucides." In V. Chankowski and F. Duyrat (eds.), Le roi et l'économie: Autonomies locales et structures royales dans l'économie de l'empire séleucide, 349-369. Paris: De Boccard.

Bopearachchi, O., and A. U. Rahman. 1995. Pre-Kushana coins in Pakistan. Karachi: Iftikhar Rasul. Bordeaux, 0. 2018. Les Grecs en Inde: Politiques et pratiques monétaires (IIle s. a.C.-ler s. p.C.). Bordeaux: Ausonius.

Bracey, R. 2009. "The coinage of Wima Kadphises." Gandhāran Studies 3, 25-74.

-. 2012. "The mint cities of the Kushan Empire." In F. López Sánches (ed.), The city and the coin in the ancient and early medieval worlds, 117-132. Oxford: Archaeopress.

Brockington, J. 1998. The Sanskrit epics. Leiden: Brill.

Callieri, P. 2001. "La presunta via commerciale tra l'India e Roma attraverso l'Oxus e il Mar Caspio: Nuovi dati di discussione." Topoi 11.1, 537-546. 
Cammann, S. V. R. 1962. "On the renewed attempt to revive the "Bactrian nickel theory." American Journal of Archaeology 66, 92-94.

Clarysse, W., and D. J. Thompson. 2007. "Two Greek texts on skin from Hellenistic Bactria." Zeitschrift für Papyrologie und Epigraphik 159, 273-279.

Colliva, L. 2011. "The excavation of the archaeological site of Barikot (Bïr-koț-ghwandai) and its chronological sequence." In Ghani-ur-Rahman and L. M. Olivieri (eds.), "Italian Archaeology and Anthropology in Northern Pakistan (1955-2011)." Special issue, Journal of Asian Civilizations 34.1, 157-191.

Coloru, 0. 2009. Da Alessandro a Menandro: Il regno greco di Battriana. Pisa: Fabrizio Serra.

Cowell, M. C. 1989. "Analyses of the cupro-nickel alloy used for Greek Bactrian coins." In

Y. Maniatis (ed.), Archaeometry: Proceedings of the 25th international symposium, 335-345. Amsterdam: Elsevier.

Cribb, J. 1984. "The Sino-Kharosthi coins of Khotan: Their attribution and relevance to Kushan chronology: Part 1." Numismatic Chronicle 144, 128-152.

-. 1985. "The Sino-Kharosthi coins of Khotan: Their attribution and relevance to Kushan chronology: Part 2." Numismatic Chronicle 145, 136-149.

-. 2007. "Rediscovering the Kushans." In E. Errington and V. S. Curtis (eds.), From Persepolis to the Punjab: Exploring ancient Iran, Afghanistan, and Pakistan, 179-210. London: The British Museum.

Cribb, J., and R. Bracey. Forthcoming. Kushan coins: A British Museum catalogue and type corpus. London: The British Museum.

Cunningham, A. 1884. Coins of Alexander's successors in the East: Bactria, Ariana and India. London: Argonaut Inc. Publishers.

-. 1890. "Coins of the Tochari, Kushâns, or Yue-Ti." Numismatic Chronicle 50, 268-311.

Curiel, R. 1954. "Inscriptions de Surkh Kotal.” Journal asiatique 242, 189-197.

Curiel, R., and D. Schlumberger. 1953. Trésors monétaires d'Afghanistan. Paris: Imprimerie Nationale.

de la Vaissière, É. 2005. Sogdian traders: A history. J. Ward (trans.). Leiden: Brill.

Dumke, G. R. 2019. "B $\alpha \sigma ı \lambda \varepsilon \cup \varsigma$ und Mahārāja: Studien zur Herrschaftsausübung hellenistischer

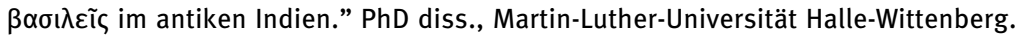

Dvurechenskaia, S.0. 2016. “Предваритеьные итоги изучения костных останков животных из раскопок тарритории крепости Кампыртепа" [Preliminary results of the study of animal bones from the excavations in the territory of Kampyrtepa fortress]. Проблемы Истории, Филологии, Культуры 2, 75-82.

Erdosy, G. 1990. "Taxila: Political history and urban structure." In M. Taddei (ed.), South Asian Archaeology 1987, 657-674. Rome: IsMEO.

Errington, E. 2001. "Charles Masson and Begram." Topoi 11.1, 357-409.

-. 2007. "Exploring Gandhara." In E. Errington and V. S. Curtis (eds.), From Persepolis to the Punjab: Exploring ancient Iran, Afghanistan and Pakistan, 211-226. London: British Museum.

-. 2017. Charles Masson and the Buddhist sites of Afghanistan: Explorations, excavations, collections 1832-1835. London: British Museum.

Falk, H. 2010. "Names and titles from Kuṣāna times to the Hūṇas: The Indian Material." In M. Pfisterer, M. Alram, M. Inaba, and D. Klimburg-Salter (eds.), Coins, art and chronology. Vol. 2, 73-89. Vienna, Österreichische Akademie der Wissensachaften.

-, ed. 2015. Kushan histories: Literary sources and selected papers from a symposium at Berlin, December 5 to 7, 2013. Bremen: Hempen.

Fisher, M. T., and M. W. Stolper. 2015. "Achaemenid Elamite administrative tablets, 3: Fragments from Old Kandahar, Afghanistan." Achaemenid Research on Texts and Archaeology, no. 1, $1-26$.

Folmer, M. 2017. "Bactria and Egypt: Administration as mirrored in the Aramaic sources." In B. Jacobs, W. F. M. Henkelman, and M. W. Stolper (eds.), Die Verwaltung im Achämeniden- 
reich: Imperiale Muster und Strukturen / Administration in the Achaemenid Empire: Tracing the imperial signature, 413-454. Wiesbaden: Harrassowitz.

Frachetti, M. D., C. E. Smith, C. M. Traub, and T. Williams. 2017. "Nomadic ecology shaped the highland geography of Asia's silk roads." Nature 543.7644, 193-198.

Frumkin, G. 1970. Archaeology in Soviet Central Asia. Leiden: Brill.

Fussman, G. 1974. "Documents épigraphiques kouchans." Bulletin de l'Ecole française d'ExtrêmeOrient 61, 1-76.

-. 1993. "L'indo-grec Ménandre ou Paul Demiéville revisité." Journal asiatique 231, 61-138.

Fussman, G., B. Murad, and É. Ollivier. 2008. Monuments bouddhiques de la région de Caboul. 2 vols. Paris: De Boccard.

Gardin, J.-C. 1998. Prospections archéologiques en Bactriane orientale (1974-1978). Vol. 3, Description des sites et notes de synthèse. Paris: Éditions Recherche sur les Civilisations.

Glenn, S. 2015. "Royal coinage in Hellenistic Bactria: A die study of coins from Euthydemus I to Antimachus I." PhD diss., University of Oxford.

Göbl, R. 1984. System und Chronologie der Münzprägung des Kušānreiches. Vienna:

Österreichische Akademie der Wissenschaften.

-. 1993. Donum Burns: Die Kušānmünzen im Münzkabinett Bern und die Chronologie. Vienna: Fassbaender.

Gorshenina, S. 2004. The private collections of Russian Turkestan in the second half of the 19th and early 20th century. Berlin: Klaus Schwarz.

Grenet, F. 2004. “Maracanda/Samarkand, une métropole pré-mongole.” Annales 59.5/6, 10431067.

-. 2015. "Zoroastrianism among the Kushans." In Falk (2015), 203-240.

Grenet, F., and M. Isamiddinov. 2001. "Brève chronique des fouilles de la MAFOUZ (Mission Archéologique Franco-Ouzbèke) en 2000." Cahiers d'Asie centrale 9, 237-242.

Guillaume, 0. 1990. Analysis of reasonings in archaeology: The case of Graeco-Bactrian and IndoGreek numismatics. Oxford: Oxford University Press.

Härtel, H. 1993. Excavations at Sonkh: 2500 years of a town in Mathura District. Berlin: Reimer.

Henkelman, W. F. M. 2018. "Bactrians in Persepolis - Persians in Bactria." In J. Lhuillier and N. Boroffka (eds.), A millennium of history: The Iron Age in southern Central Asia (2nd and 1st millennia BC): Proceedings of the conference held in Berlin (June 23-25, 2014), 223-255. Berlin: Reimer.

Henkelman, W. F. M., and M. L. Folmer. 2016. "Your tally is full! On wooden credit records in and after the Achaemenid Empire." In K. Kleber and R. Pirngruber (eds.), Silver, money and credit: A tribute to Robartus J. van der Spek on the occasion of his 65th birthday, 133239. Leiden: Nederlands Institutt voor het Nabije Oosten.

Hill, J. E. 2015. Through the Jade Gate - China to Rome: A study of the silk routes 1st to 2 nd centuries CE. New updated and expanded edition. 2 vols. Self-published, CreateSpace.

Holt, F. L. 1999. Thundering Zeus: The making of Hellenistic Bactria. Berkeley, CA: University of California Press.

-. 2005. Into the land of bones: Alexander the Great in Afghanistan. Berkeley, CA: University of California Press.

Horner, I. B., trans. 1963. Milinda's Questions. Vol. 1, London: Luzac.

Houghton, A., and C. Lorber. 2002. Seleucid Coins: A comprehensive guide. Part 1, Seleucus I through Antiochus III. New York, NY: The American Numismatic Society.

Hulsewé, A. F. P. 1975. "The problem of the authenticity of Shih-chi ch. 123, the memoir on TaYüan." T’oung Pao 61, 83-147.

Hulsewé, A. F. P., and M. A. N. Loewe. 1979. China in Central Asia: The early stage: 125 BC-AD 23: An annotated translation of chapters 61 and 96 of the history of the Former Han dynasty, with an introduction by M. A. N. Loewe. Leiden: Brill. 
Jansari, S. 2018. "The Sophytes coins: From the Punjab to Bactria and back again." Numismatic Chronicle 178, 71-98.

Jones, H., D. L. Lister, D. Cai, C. J. Kneale, J. Cockram, L. Peña-Chocarro, and M. K. Jones. 2016. "The trans-Eurasian crop exchange in prehistory: Discerning pathways from barley phylogeography." Quaternary International 426, 26-32.

Jongeward, D., and J. Cribb. 2015. Kushan, Kushano-Sasanian, and Kidarite coins: A catalogue of coins from the American Numismatic Society. New York, NY: The American Numismatic Society.

Jongeward, D., E. Errington, R. Salomon, and S. Baums. 2012. Gandharan Buddhist reliquaries. Seattle, WA: University of Washington Press.

Karttunen, K. 1989. India in early Greek literature. Helsinki: Finnish Oriental Society.

-. 1997. India and the Hellenistic world. Helsinki: Finnish Oriental Society.

-. 2015. Yonas and Yavana in Indian literature. Helsinki: Finnish Oriental Society.

Kovalenko, S. 1996. "The coinage of Diodotus I and Diodotus II, Greek kings of Bactria." Silk Road Art and Archaeology 4, 17-74.

Lahiri, A. N. 1965. Corpus of Indo-Greek coins. Calcutta: Poddar.

Lecuyot, G. 2013. Fouilles d'Aï Khanoum. Vol. 9, L'habitat. Paris: De Boccard.

Leriche, P. 2007. "Bactria, land of a thousand cities." In J. Cribb and G. Herrmann (eds.), After Alexander: Central Asia before Islam, 121-153. Oxford: Oxford University Press.

Leriche, P., and C. Pidaev. 2008. Termez sur Oxus: Cité-capitale d'Asie centrale. Paris: Maisonneuve et Larose.

Lhuillier, J., and M. Mashkour. 2017. "Animal exploitation in the oases: An archaeozoological review of Iron Age sites in southern Central Asia." Antiquity 91.357, 655-673.

Lyonnet, B. 1997. Prospections archéologiques en Bactriane orientale (1974-1978). Vol. 2, Céramique et peuplement du Chalcolithique à la conquête arabe. Paris: Éditions Recherche sur les Civilisations.

-. 2012. "Questions on the date of the Hellenistic pottery from Central Asia (Ai Khanoum, Marakanda and Koktepe)." Ancient Civilizations from Scythia to Siberia 18, 143-173.

Mairs, R. 2011. The archaeology of the Hellenistic Far East: A survey. Oxford: Archaeopress.

-. 2014. The Hellenistic Far East: Archaeology, language, and identity in Greek Central Asia. Berkeley, CA: University of California Press.

Mandel'shtam, А.М. 1966. Кочевники на пути в Индию [Nomads on the road to India]. МоскваЛенинград: Наука.

Mantellini, S. 2014. "Settlement dynamics, territory exploitation, and trade routes in the ancient Samarkand oasis (Uzbekistan)." In B. Genito and L. Caterina (eds.), Archeologia delle "Vie della Seta": Percorsi, immagini e cultura materiale. II Ciclo di Conferenze, 6 marzo-22 maggio 2013, 37-59. Naples: Centro Interdipartimentale di Servizi di Archeologia.

Masson, V. M. 2011. “Archaeology V: Pre-Islamic Central Asia.” Encyclopaedia Iranica. Vol. 2.3, 308-317. Available online at http://www.iranicaonline.org/articles/archeology-v.

Maxwell-Jones, C. 2015. "Typology and chronology of ceramics of Bactra, Afghanistan 600 BCE500 CE." PhD diss., University of Michigan.

Mitchiner, M. 1975. Indo-Greek and Indo-Scythian coinage. 9 vols. London: Hawkins.

Morris, L. 2017. "Revised dates for the deposition of the Begram hoard and occupation at the new royal city." Parthica 19, 75-104.

-. Forthcoming. "Hoards from Hellenistic to Kushan Central Asia: Towards some interpretations." In G. Lindström (ed.), Ritual matters: Archaeology and religion in Hellenistic Central Asia: Proceedings of the second meeting of the Hellenistic Central Asia Research Network, Berlin, November 2017. Archäologie in Iran und Turan.

Narain, A. K. 1957. The Indo-Greeks. Oxford: Clarendon.

Naveh, J., and S. Shaked. 2012. Aramaic documents from ancient Bactria (fourth century BCE) from the Khalili collections. London: Khalili Family Trust. 
Naymark [Naimark], А. 2005. “Находки греческих монет в Согдиане” [Finds of Greek coins in Sogdiana]. Нумизматика и Эпиграфика 17, 116-138.

-. 2014. "Seleucid coinage of Samarqand?" Journal of the Oriental Numismatic Society 220, 15-20.

-. 2016. "The coinage of Nakhshab during the first-fourth centuries CE: Towards a new systemization of Sogdian coinages and the political history of Sogd during antiquity." Journal of Inner Asian Art and Archaeology 7, 55-77.

Olivieri, L. M., ed. 2010. Pictures in transformation: Rock art research between Central Asia and the Subcontinent. Oxford: Archaeopress.

Olivier-Utard, F. 1997. Politique et archéologie: Histoire de la Délégation archéologique française en Afghanistan (1922-1982). Paris: Éditions Recherche sur les Civilisations.

Petrie, C. A. 2013a. “Charsadda.” In D. K. Chakrabarti and M. Lal (eds.), History of ancient India. Vol. 3, 512-522. New Delhi: Vivekananda International Foundation and Aryan Books International.

-. 2013b. “Taxila.” In D. K. Chakrabarti and M. Lal (eds.), History of ancient India. Vol. 3, 652663. New Delhi: Aryan Books International.

P'iankov, I. V. 2015. “Maes Titianus, Ptolemy and the 'Stone Tower' on the Great Silk Road.” Silk Road 13, 60-74.

Picard, 0. 1984. “Sur deux termes des inscriptions de la trésorerie d’Aï Khanoum.” In H. Walter (ed.), Hommages à Lucien Lerat. Vol. 2, 679-690. Paris: Les Belles Lettres.

Pons, J. 2016. “Kushan Dynasty VI: Archeology of the Kushans: In India.” In Encyclopaedia Iranica, online edition. http://www.iranicaonline.org/articles/kushan-dynasty-06-archeologyindia.

Potts, D. T. 2004. "Camel hybridization and the role of camelus bactrianus in the Near East." Journal of the Economic and Social History of the Orient 47.2, 143-165.

Pugachenkova, G. A. 1976. “К познанию античной и раннесредневековой архитектуры Северного Афганистана.” [On the understanding of ancient and early medieval architecture of northern Afghanistan]. In Древняя Бактрия. Vol. 1, 125-162. Москва: Наука.

Pugachenkova, G. A., and E. V. Rtveladze. 1990. Северная Бактрия-Тохаристан: Очерки истории и культуры: Древность и средневековье [Northern Bactria-Tokharistan: Essays on history and culture: Antiquity and the middle ages]. Ташкент: Изадельство Фан.

Pulleyblank, E. G. 1981. "Han China in Central Asia.” International History Review 3, 278-286. Rapin, C. 2007. "Nomads and the shaping of Central Asia.” In J. Cribb and G. Herrmann (eds.), After Alexander: Central Asia before Islam, 29-72. Oxford: Oxford University Press.

-. 2010. “L’ère yavana d'après les parchemins Gréco-Bactriens d'Asangorna et d'Amphipolis.” In K. Abdullaev (ed.), Традиции Востока и Запада в античной культуре Средней Азии. Сборник статей в честь Поля Бернара / The Traditions of East and West in the antique cultures of Central Asia: Papers in honour of Paul Bernard, 234-252. Tashkent: “Noshirlik yog'dusi."

-. 2017. "Alexandre le Grand en Asie centrale: Géographie et stratégie de la conquête des Portes Caspiennes à l'Inde." In C. Antonetti and P. Biagi (eds.), With Alexander in India and Central Asia: Moving east and back to west, 37-121. Oxford: Oxbow.

Rapin, C., and F. Grenet. 1983. “Inscriptions économiques de la trésorerie hellénistique d’Aï Khanoum: L'onomastique iranienne à Aï Khanoum.” Bulletin de Correspondence Hellénique 107, 315-381.

Rea, J. R., R. C. Senior and A. S. Hollis. 1994. “A tax receipt from Hellenistic Bactria.” Zeitschrift für Papyrologie und Epigraphik 104, 261-280.

Reece, R. 1987. Coinage in Roman Britain. London: Seaby.

Rezakhani, K. 2010. "Balkh and the Sasanians: The economy of society of northern Afghanistan as reflected in the Bactrian economic documents." In M. Macuch, D. Weber, and D. Durkin- 
Meisterernst (eds.), Ancient and Middle Iranian studies: Proceedings of the 6th European conference of Iranian studies, held in Vienna, 18-22 September 2007, 191-204. Wiesbaden: Harrassowitz.

Romm, J. S. 1992. The edges of the earth in ancient thought: Geography, exploration, and fiction. Princeton, N): Princeton University Press.

Rosenfield, J. M. 1967. The dynastic arts of the Kushans. Berkeley, CA: University of California Press.

Rougemont, G. 2012. Corpus Inscriptionum Iranicarum. Part 2, vol. 1.1, Inscriptions grecques d'Iran et d'Asie centrale. London: School of Oriental and African Studies.

Rtveladze, E. V. 2012. Великий индийский путь: Из истории важнейших торговых дорог Евразии [The great Indian road: From the history of the most important trade routes of Eurasia]. Санкт-Петербург: Нестор-Истоия.

-. 2013. “Неизвестные и малоизвестные бактрийские надписи из северной Бактрии” [Unknown and little-known Bactrian inscriptions from northern Bactria]. In S. R. Tokhtas'eva and L. B. Lur'e (eds.), Commentationes Iranicae: Сборник статей к 90-летию Владимира Ароновича Лившица, 253-267. Санкт-Петербург: Нестор-Истоия.

Rtveladze, E. V., and S. R. Pidaev. 1981. Каталог древних монет Южного Узбекистана [Catalogue of ancient coins of southern Uzbekistan]. Ташкент: Издательство ФАН.

Salomon, R. 1998. Indian epigraphy: A guide to the study of inscriptions in Sanskrit, Prakrit, and the other Indo-Aryan languages. Oxford: Oxford University Press.

Schlingloff, D. 2013. Fortified cities of ancient India: A comparative study. London: Anthem.

Schlumberger, D., M. Le Berre, and G. Fussman. 1983. Surkh Kotal en Bactriane. Vol. 1, Les temples: Architecture, sculpture, inscriptions. Paris: De Boccard.

Selbitschka, A. 2015. "Early Chinese diplomacy: Realpolitik versus the so-called tributary system." Asia Major 28.1, 61-114.

Sims-Williams, N. 1985. "Ancient letters." In Encyclopaedia Iranica. Vol. 2.1, 7-9. Available online at http://www.iranicaonline.org/articles/ancient-letters.

-. 2000. Bactrian documents from northern Afghanistan. Vol. 1, Legal and economic Documents. Oxford: Nour Foundation.

-. 2004. "The Bactrian inscription of Rabatak: A new reading." Bulletin of the Asia Institute 18, 53-68.

-. 2012. "Bactrian historical inscriptions of the Kushan period." Silk Road 10, 76-80.

-. 2015. "A new Bactrian inscription from the time of Kanishka." In Falk (2015), 255-264.

Sims-Williams, N., and J. Cribb. 1996. "A new Bactrian inscription of Kanishka the Great." Silk Road Art and Archaeology 4, 75-142.

Sims-Williams, N., and D. Weber. 2018. Studies in the chronology of the Bactrian documents from northern Afghanistan. Vienna: Österreichische Akademie der Wissenschaften.

Skinner, M. C. 2017. "Marks of empire: Extracting a narrative from the corpus of Kuṣāna inscriptions." PhD diss., University of Washington.

Spengler, R., M. Frachetti, P. Doumani, L. Rouse, B. Cerasetti, E. Bullion, and A. Mar'yashev. 2014. "Early agriculture and crop transmission among Bronze Age mobile pastoralists of Central Eurasia." Proceedings of the Royal Society B: Biological Sciences 281.1783. https://doi.org/ 10.1098/rspb.2013.3382.

Stančo, L., and K. Abdullaev, eds. 2011. Jandavlattepa: The excavation report for seasons 20022006. Vol. 1. Prague: Karolinum.

Staviskij, B. J. 1986. La Bactriane sous les Kushans: Problèmes d'histoire et de culture. Paris: Maisonneuve.

Stride, S. 2007. "Regions and territories in southern Central Asia: What the Surkhan Darya Province tells us about Bactria." In J. Cribb and G. Herrmann (eds.), After Alexander: Central Asia before Islam, 99-117. Oxford: Oxford University Press. 
Sundermann, W., A. Hintze, and F. de Blois, eds. 2009. Exegisti monumenta: Festschrift in honour of Nicholas Sims-Williams. Wiesbaden: Harrassowitz.

Tarn, W. W. 1938. The Greeks in Bactria and India. Cambridge: Cambridge University Press.

Thierry, F. 2005. "Yuezhi et Kouchans: Pièges et dangers des sources chinoises." In 0. Bopearachchi and M.-F. Boussac (eds.), Afghanistan: Ancien carrefour entre l'est et l'ouest, 421-539. Turnhout: Brepols.

Tucci, G. 1977. "On Swāt: The Dards and connected problems." East and West 27.1, 9-104.

Vainberg, В. I. 1977. Монеты древнего Хорезма [Coins of ancient Khorezm]. Москва: Наука.

Van Buitenen, J. A. B., 1975. The Mahābhārata. Vol. 2, The book of the assembly hall. The book of the forest. Chicago, IL: University of Chicago Press.

Verardi, G. 2010. "Issues in the excavation, chronology and monuments of Tapa Sardar." In M. Alram, D. E. Klimburg-Salter, M. Inaba, and M. Pfisterer (eds.), Coins, art and chronology II: The first millennium CE in the Indo-Iranian borderlands, 341-356. Vienna: Österreichische Akademie der Wissenschaften.

von Hinüber, 0. 1996. A handbook of Pāli literature. Berlin: De Gruyter.

Watson, B., trans. 1993. Records of the Grand Historian: Han Dynasty. 2nd ed. Vol. 2. Hong Kong and New York, NY: Chinese University of Hong Kong Research Centre for Translation and Columbia University Press.

Willett, J. 1997. "Tibetan fraternal polyandry: A review of its advantages and breakdown." Nebraska Anthropologist 113, 96-107.

Wu, X., N. F. Miller, and P. Crabtree. 2015. "Agro-pastoral strategies and food production on the Achaemenid frontier in Central Asia: A case study of Kyzyltepa in southern Uzbekistan." Iran 53, 93-117.

Zeimal', Е. V. 1978. “Политическая история Трансоксианы по нумизматическим данным” [Political history of Transoxiana according to numismatic data]. In Культура Востока. Древность и раннее средневековье, 192-214. Ленинград: Аврора.

-. 1983. Древние монеты Таджикистана [Ancient Coins of Tajikistan]. Душанбе: Дониш.

Zürcher, E. 1968. "The Yüeh-chih and Kanișka in the Chinese sources.” In A. L. Basham (ed.), Papers on the Date of Kanișka submitted to the Conference on the date of Kanișka, London, 20-22 April, 1960, 346-390. Leiden: Brill. 



\title{
10 Evidence for Early South Asia
}

\author{
Mamta Dwivedi \\ 10.A Indic Sources
}

\section{Introduction}

Agriculture and animal husbandry, along with trade, constitute economics. It is of benefit because it provides grain, livestock, money, forest produce, and labor. By means of that, he [the king] brings under his power his own circle and his enemy's circle using the treasury and the army. ${ }^{1}$

When a king gathers levies, taxes, duties, gifts, and fines without providing for protection, he will immediately go to hell. ${ }^{2}$

When a man has become educated, he enters the householder stage of life and begins the lifestyle of a man-about-town [nāgaraka], using the money that he has inherited, on the one hand, or obtained from gifts, conquest, trade, or wages, on the other, or from both. ${ }^{3}$

These three quotations come from three different traditions of śāstras: artha (economic pursuit), dharma (religious pursuit), and kāma (pursuit of desire) respectively. ${ }^{4}$ Sâstra is "a verbal codification of rules, whether of divine or human provenance, for the positive and negative regulation of some given human practices." 5 The Sanskrit śāstras are of two types, pauruṣeya (of human origin or compilation) and apauruṣeya (of transcendental or divine origin). ${ }^{6}$ The dharmaśāstras and the arthaśāstras, along with various other treatises, belong to the pauruṣeya (human origin). ${ }^{7}$ Together, the dharmaśāstras also appear as the pervasive regulator of

1 KA 1. 4. 1-2. Trans. Olivelle 2013, 68. For Sanskrit text of the Kauțiliya Arthaśāstra (KA), see Kangle (1960) 2014a.

2 Manusmrti (MS) 8. 307. For Sanskrit text and trans. Olivelle 2005, 183.

3 Kāmasūtra (KS) 1. 4. 1. For Sanskrit text of the Kāmasūtra of Vātsyāyana, see Vātsyāyana 1982. For translation see, Doniger and Kakar 2002, 17. The term nāgaraka has also been translated as a 'cultivated man' or literally just a city dweller.

4 Dharma, artha, and käma are the first three aims and together they make the trivarga. The triple group becomes caturvarga when mokșa (liberation) is added as the fourth term. These four together constitute the purușārtha, goals of human life (Malamoud 1982, 37). For a history purușārtha as a unified concept, see Dwivedi 2016, 48.

5 Pollock 1985, 501.

6 The śāstras of transcendent origin incorporate the four Vedas, the Upavedas, and various ancillaries of the Vedas, Pollock 1985, 502.

7 The other subjects of śāstras include the knowledge of astronomy/astrology, physiology/medicine, grammar, agriculture, domestication of animals, calculations/mathematics, arts, sculptures and architecture, and many more, (Pollock 1985, 502 n. 18).

Ә Open Access. (c) 2020 Mamta Dwivedi, published by De Gruyter. (c) BY-NC-ND This work is licensed under the Creative Commons Attribution-NonCommercial-NoDerivatives 4.0 License.

https://doi.org/10.1515/9783110607741-015 
behavior for the pursuit of dharma, so much so that they can be considered a cultural grammar. They articulate practical and cultural knowledge, mastery over which makes one a competent member of society. ${ }^{8}$ I shall begin the survey of Indic sources with this most important literary genre before treating visual narrative, archaeological remains, epigraphic material, and coinage as sources of economic history.

\section{Sanskrit Śāstras}

As the śāstras are of a prescriptive and normative nature, they do not intend to represent historical events. There are thus two major challenges when dealing with early literary sources: their dating and their grounding in historical reality. Most of the texts have a history of enlargement at various stages. There are numerous layers of redactions hidden below the visible surface, and dates are ascribed only to the final form. Considering these layers necessitates the dating of a text to a range of years, not only decades but centuries apart. The contents of the texts, moreover, are often considered theological and mythical. Thus the study of history based on these texts relies on the historical-critical method, which developed in the field of biblical studies and was only later applied to Indology. This includes literary criticism, tendency criticism, and determining the history of transmission, including the history of redactions. ${ }^{9}$ However, even if they do not provide chronological history nor historical information, they do have historical value. ${ }^{10}$

In recent years, interdisciplinary approaches have proven useful for gaining a better understanding of early Indian texts as historical sources. Such approaches have placed these theological texts in the context of their historical setting by considering words as artifacts. ${ }^{11}$ Moreover, changes in word use over time have been noted. While studying the śāstras, philologists have identified: a) occurrence of foreign words in the texts for their relative dating, b) the embellishment of the language and of its structure, and c) the usage of indeclinable words (avyaya) in the texts. In addition to etymological and stylistic studies, changes in the semantic range of words have been analyzed. These can be understood as representative of

8 Pollock 1985, 500.

9 The historical-critical method is also called text-historical method (Adluri and Bagchee 2014, 1, 11-14). For a criticism of application of these methods on Indic texts, see Adluri and Bagchee 2014. 10 For further discussion on śāstras and other theological texts as historical sources by placing them in historical context, see Olivelle 1993; 2005; 2013. On questions and issues of interpolation and extrapolations in early Sanskrit texts, see Hiltebeitel 1998; 2011.

11 Olivelle 1993, 33. For words as artifact from past societies, see Olivelle 2012, 23. 
historical change and increasing social complexity. ${ }^{12}$ Examples include studies of the terms dāna (gift/donation), ${ }^{13}$ dharma, ${ }^{14}$ and artha (wealth)..$^{15}$

For the present purpose, three śāstras will be discussed as potential sources for economic processes of early India. These are the Kauțilìya Arthaśāstra, the Mānava Dharmaśāstra (also known as the Manusmṛti), and the Vātsyāyana Kāmasūtra. These provide prescriptions regarding the pursuance of artha (livelihood, pursuit of wealth), dharma (religious and social duty), and kāma (pleasure, culture, and education). Tradition has it that these three genres of knowledge treatises have branched off from 'the grand revelation. ${ }^{16}$ Regarding their use as historical sources, scholars have used them in three ways: first, as representations of practice as well as instruction for practice $;{ }^{17}$ second, as reactions to changing social customs determined by non-Brahmanical ideals and practices; ${ }^{18}$ and third as indicators of recommended behavior during extraordinary circumstances. ${ }^{19}$

\section{II.1 The Kauțilīya Arthaśāstra}

The term arthaśāstra means treatise or manual (śāstra) of wealth, economy, and statecraft (artha). It is the science of politics, administration, and economic policy. ${ }^{20}$ The arthaśāstra available to us and most commonly used as historical source is the Arthaśāstra of Kauțilya or the Kauțilìya Arthaśātra (KA). Yet the KA is part of a larger tradition of artha known from several previous authorities. ${ }^{21} \mathrm{~A}$ long tradition of arthaśāstra is further corroborated by the discovery of a birch bark manuscript of

12 Here it is important to distinguish between semantic etymology and historical etymology. As Bronkhorst defines them, a historical etymology is about the origins or early history of a word, while the semantic etymology is about how a word connects with one or more to elucidate its meaning, Bronkhorst 2001, 147-148.

13 Thapar 1978; Nath 1987; Endo 1987; Findly 2003.

14 Horsch 1967; Olivelle 2006; 2009; Hiltebeitel 2011.

15 Dwivedi 2016, 32-56.

16 The grand revelation is 10,000 chapters revealed by Prajāpati. From it, three specialized branches were reproduced into a thousand chapters by: Manu, who compiled the separate treatise on dharma; Brhaspati, who wrote on the artha; and Nandi, who collected those chapters dealing with kāma. See KS 1. 1. 4-17. A similar description is also found in the Mahābhärata (Śāntiparva 59. 8085).

17 Pollock 1985.

18 Olivelle 2005, 42-43.

19 Doniger and Smith 1991, lviii, lix.

20 The $K A$ is variably defined as "the science of resource management and administration" (Ramaswamy 1962), "the science of statecraft or of politics and administration" (Krishna Rao 1953), "textbook of power" (Doniger and Kakar 2002), "science of wealth” (Trautmann 2012), and "Treatise on Success" (Olivelle 2013). It is noteworthy that arthaśāstra in the modern context is the term for economics or political economy in the modern Indian language, Hindi (Vira 1951).

21 Trautmann 2012. 
nìti/arthaśāstra tradition in Kharoșthī script from Bajaur district in Pakistan dated between the first two centuries CE. ${ }^{22}$ The arthaśāstra is also mentioned in various later texts as a science and a topic of education, such as in the Mahäbhärata (third century BCE-fourth century CE) ${ }^{23}$ and in niti (policy and diplomacy) texts from the fourth through the thirteenth century. ${ }^{24}$ Research on the Kautilìya Arthaśātra began in 1905 when the Mysore Government Oriental Library received a copy of the manuscript from an anonymous pandit. ${ }^{25}$

The identification of Kauṭilya with Cāṇakya, also known as Viṣnugupta, the wise mentor and later a minister of Candragupta Maurya, led to the assumption that it may be dated to the late fourth century BCE. The Cānakya-Candragupta tradition was based on a legend recurring in Indic literature in different Sanskrit, Pali, Tamil, and Telugu texts. ${ }^{26}$ Based on this, the $K A$ was considered an administrative guidebook from the Mauryan period. ${ }^{27}$ However, many scholars suggest Cānạkya is fictional, which calls the historicity of Cānạkya/Viṣnugupta into question. ${ }^{28}$ It is also suggested that the text may have been composed between the second and first centuries BCE, with successive enlargements and a major redaction in the first or second century $\mathrm{CE}^{29}$ These debates notwithstanding, there is no denying that the text draws from an earlier tradition of political and economic scholarship and thought.

The $K A$ consists of 15 books (adhikarana) in 180 sections (prakarana), which are divided into 150 chapters (adhyāya) with a total of 6,000 sentences. ${ }^{30}$ The text is mostly prose, with concluding remarks in verses called ślokas, written in the meter of 32 syllables. The first five adhikaranas deal with the administration of the state (tantra), and the following eight deal with relationships with neighboring states $(\bar{a} v \bar{a} p a)$, while the last two are miscellaneous in character. ${ }^{31}$ The text, bring-

22 This is found on the obverse (recto) of fragment 9 of the collection. The manuscript collection was reported in 2006 and found in the ruins of a Buddhist monastery near the Bajaur River in Gandhāra. The same collection also has an interesting legal document recording a loan on fragment 15 (Strauch 2008).

23 Like other early literary works, the dating of the Mahābhärata is also a highly debated subject. Commonly described as an epic, the Mahābhārata is the longest poem in the world, boasting of its encyclopaedic nature about the issues of dharma, artha, kāma, and mokșa. It consists of nearly 75,000 verses. It is suggested that the epic may have consisted of bardic material, which in time grew to include more religious and didactic material, Brockington 1998, 2, 19-21.

24 For a discussion on how the knowledge tradition grew and has reflections in later texts, see Kangle (1965) 2014b, 6.

25 For the impact of the discovery of the $K A$ on the history writing, see Voigt 1966; Mishra 1989.

26 See, Kangle (1965) 2014b, 104-115; Trautmann 1971, 10-67; McClish 2012, 280-286.

27 V. A. Smith 1908, 134; Shamasastry and Narain 1915.

28 Jolly and Schmidt 1923 were the first to suggest the $K A$ post-Mauryan.

29 McClish 2009, 315; Olivelle 2013, 6-25.

30 However, a different manuscript suggests there may have been 180 chapters, (Kangle [1965] 2014b, 19-20; Trautmann 1971, 68-78). Olivelle too, in his translation, divides the work into 180 chapters in total, Olivelle 2013.

31 Olivelle 2012, 24. See also Olivelle, Brick, and McClish 2015, 77, 172. 
ing together the teachings of earlier works in the artha tradition, focuses on the administration of state affairs and thus highlights economic perspectives of the state. Yet it is a guide for kings and the state to protect and facilitate the livelihood $(v \bar{a} r t t \bar{a})$ of every individual. It includes detailed definitions of a state as an organic entity with seven elements (prakrti): king or lord (svāmī), minister (amātya), countryside (janapada), fort (durga), treasury (kośa), army (daṇa), and ally (mitra). Measures are suggested to strengthen all seven elements of a successful state. The state is to regulate and gather resources, channel resources for the maintenance of a strong army, have overt and covert diplomatic policies, and manage resources to avoid and manage calamities. It has often been compared to works of various Western political writings. ${ }^{32}$

The intended audience for the text may have been princes, rulers, and administrative officials. The text includes matters concerning the education of a prince (vijigișu, the potential world conqueror) and how he should conduct himself in the various situations that are likely to arise in the course of his rule. ${ }^{33}$ It also suggests how to hire ministers, ${ }^{34}$ how much their salaries should be, and the various duties of the superintendents (adhyakșas) of different departments. ${ }^{35}$ It recommends the surveillance of artisans, traders, and suspicious people in different offices through the use of secret agents as a measure against potential threats to the state and king. ${ }^{36}$ Among its legal regulations are grounds for litigation, various conditions for the transfer of properties, ways to address issues about the nonpayment of debts, types of punishment, relation between property and owner, and rules governing slave and laborers discussed under the topic of Dharmasthiyam (On Justices). ${ }^{37}$

Kautilya's state is a bureaucratic system with a hierarchy of officials, each with well-charted duties. He enumerates the designated salaries for officials and criteria for setting them in fixed terms. The highest recommended salary is 48,000 panas. Below this scale, Kautilya lists ten further levels of recommended salary scales. Each successive scale is almost half of the immediate higher scale, and the lowest is 60 panas, which is to be given to the attendants and servants. ${ }^{38}$

32 Kautilya's work has been compared with other political theorists like Aristotle, Plato, and more commonly to Machiavelli of the early sixteenth century, and some scholars also called him the Indian Bismarck. In the early twentieth century, scholars felt the need to place the $K A$ amidst the theories of politics and economics. Kautilya's concept of the state was also defined with modern concepts of nation-states. While some saw absolutist tendencies, others found similarities to the social contract theory, state socialism, laissez-faire, and also the welfare state, Dwivedi 2016, 1012.

33 KA 6. 2. 13.

34 KA 1. 5; 1.9.

$35 K A$ bk. 2, Adhyakșapracāra (Tasks of the Superintendent).

$36 K A$ 1. 1. 6; KA bk. 4.

$37 K A$ 1. 1. 5. Trans. Olivelle 2013, 64. See also $K A$ bk. 6.

$38 K A$ 5. 3. 1-17. 
The $K A$ lists all possible avenues of revenue and their elaborate definitions. The samāhartr (Collector/Administrator), for example, is instructed to tap various sources for revenue as follows:

The Collector should oversee the following: fort, province, pit mine, irrigation works, forest, herd, and trade route.

Duties, fines, standardization of weights and measures, city manager, director of the mint, director the passports, liquor, abattoirs, yarn, oil, ghee, sweeteners, goldsmiths, commercial establishment, prostitutes, gambling, building compounds, unions of artisans and craftsmen, temple superintendent, and taxes at the gates are from outsiders - these constitute "fort."

Agriculture, share, tribute, tax, trader, river warden, ferry, boat, port, pasture, road toll, land survey, and capture of thieves - these constitute "province."39

The $K A$ is also valuable for its particularities on money, as it gives the exact amounts of salaries, wages, taxes, duties, and fines. The minimum fine suggested is that of three panas for verbal insult, which is subject to increase depending on the situation. ${ }^{40}$ The maximum fine mentioned in the text amounts to 1,000 panas, however in cases of cheating, hoarding, and pawning, the fines are to be proportionally increased. An example comes from the section on the 'Surveillance of Traders' (Vaidehajarakșaṇam):

For adulterating grain, fat, sugar, salt, perfume, or medicine with substances of similar kind the fine is 12 Paṇas.

For someone presenting for sale or pawn as genuine an article that is not of genuine - whether it is made of wood, metal, or gems; or made of rope, leather, or clay; or made of yarn, bark fiber, or hair - the fine is eight times its price.

For someone presenting for sale or pawn an article that is not of high value as one of high value, an article not belonging to a particular class as one belonging to that class, an article containing fake luster, a sham article, or an article whose container is switched, the fine is 54 Panas if its price is trifling; double that if the price is one Pana; and 200 Panas if the price is two Panas. ${ }^{41}$

These are but a few examples of issues of offices, sources of revenue, and examples of uses of money from the $K A$ itself. It offers a vast coverage of all matters of statecraft and has been of interest to modern historians, and political and economic theorists since its discovery.

\section{II.2 The Mānava Dharmaśāstra or the Manusmrti}

The Mānava Dharmaśāstra is one of the earliest dharmaśāstras and ascribed to the Hindu/Brahmanical tradition in Sanskrit language. The text is dated to the second

39 KA 2. 6. 1-3. Trans. Olivelle 2013, 109.

$40 K A$ 3. 18. 2.

$41 K A$ 4. 2. 17-20. Olivelle 2013, 227. In Kangle's edition the verses are KA 4. 2. 22, 15, 16 respectively, Kangle (1960) 2014a, 132. 
and third centuries CE. ${ }^{42}$ Again, it is of an instructional character, laying down prescriptions and prohibitions to be adhered to by society. Its focus, however, is on dharma, which subsumes the English concepts of 'religion,' 'duty,' 'law,' 'right,' 'justice,' 'practice,' and 'principle.' 43 It can be described as an encyclopaedic organization of knowledge, as it contains details about diverse areas of human activity, including rituals, food habits, marriage, inheritance, adoption, judicial procedures, taxation, punishment, penance, and so on. ${ }^{44}$ The authorship of the text is ascribed to the legendary king Manu, the progenitor of humanity in every epoch of creation and dissolution in the Indian cosmological tradition.

After the Manusmrti (MS), other compositions of dharmaśāstras flourished between 300 and 600 CE. The compilation of śāstras ended by the seventh or eighth century CE and was replaced by a tradition of expert commentaries (tīkās) and essays pertaining to specific topics of dharma (nibandhas). It is through these expert traditions that various dharmaśāstras were recovered and understood. ${ }^{45}$ Nine commentaries on the MS have survived, the earliest being by Bhāruci (ca. seventh century) and Medhātithi (ninth century). Further, nibandhas started in the tenth and eleventh centuries CE and explored legal topics such as litigation, property rights, etc., through citations from older dharmaśāstras. ${ }^{46}$

The MS draws from earlier texts related to aspects of dharma. It includes the domestic rituals and duties to be performed by every householder, as was the case in the earlier texts called dharmasūtras. ${ }^{47}$ However, dharmasūtras were different from dharmaśāstras in that they incorporated vyavahāra, literally meaning interaction. These interactions include aspects of litigation and jurisprudence in relation to disputes arising from economic and social transactions. ${ }^{48}$ The $M S$ recommends

42 Olivelle 2005, 25. Other dates also accepted by some scholars for the compilation of the $M a$ nusmrti $(M S)$ are second century BCE to second century CE (Bühler 1886, cxvii) and second century BCE to fourth century CE (Kane 1968, 330).

43 Doniger and Smith 1991, xviii. To the eyes of the British Company officials and western sanskritists, the śāstric texts appeared as a complete code of law along European lines and therefore ready to be implemented in the court as Hindoo Lawbook in the nineteenth century. The latest texts in the śāstra tradition were in fact compiled as late as the mid-nineteenth century by Hindu Law officers of the High Courts of Bombay, Calcutta, and Madras (Derrett 1973, 6, 9).

44 Doniger and Smith 1991, lxi; Olivelle 2005, 66.

45 Only three survive in their complete form, those ascribed to Viṣṇu, Yājñavalkya, and Nārada, whereas the dharmaśāstras attributed to Bṛhaspati and Kātyāyana were reconstructed from medieval fragments by Rangaswami Aiyangar and P. V. Kane (Olivelle 2005, 66).

46 Olivelle 2005, 69-70.

47 A sūtra (literally 'thread') is a verse from which most nonessential elements have been removed. The sūtra literature falls within the Vedic Supplementary literature and were composed in aphoristic style of verses. These are considered to be designed as a literature of expert tradition to be transmitted orally. The dates for the dharmasūtra texts are cautiously cited as the third to midsecond century BCE (Olivelle 1999, xxiii, xxiv, xxxiv).

48 It is suggested that the vyavahāra aspect of the texts in the dharmaśāstras are derived from the arthaśāstra tradition. Trautmann considers this borrowing to be responsible for the end of the 
that a legal expert should also consider the specific norms of castes, regions, guilds, and families, and only then settle the dispute based on specificities. ${ }^{49}$ To the reader, individual sections often seem to contradict each other, as a result of changing norms and thoughts over a period of time. Contradictions may also stem from the fact that the MS combined different genres (i.e., the dharma with the vyavahāra tradition), and the written form drew on material from different oral traditions. ${ }^{50}$

The $M S$ incorporates within it aspects of litigation (vyavahärapada), the king's duty (räjadharma), and the duties of an individual (svadharma) based on his/her respective social and ritual status. Because it covers the duties and restrictions on every section of society, the intended audience was perhaps larger than that of the $K A$. It has been suggested that the text would have been used in the instruction of young scholars, principally Brāhmaṇas. However, since the medieval commentaries of the text were commissioned mainly under royal patronage, princes may have been another intended audience. ${ }^{51}$

As the räjadharma (the duty of the king) is one of the topics common between the $K A$ and the $M S$, the issues of taxation and its avenues are also referred to in the latter:

The king should levy taxes on traders after taking into consideration the price of purchase and sale, the distance of transport, maintenance and other expenses, and the cost of security.

The king should always assess taxes in his realm after careful consideration so that both he and those who do the work get their fair reward.

As leeches, calves, and bees eat their food a little at a time, so a king should gather annual taxes from his realm a little at a time.

Of livestock and gold, the king shall take a one-fiftieth share; and of grains, an eighth share, or a sixth or twelfth. He shall also take a sixth share of trees, meat, honey, ghee, perfumes, herbs, condiments, flowers, roots, fruits, leaves, vegetables, grass, skins, cane, earthen vessels, and everything made of stone. ${ }^{52}$

Manu lists seven means of acquiring wealth (vittāgama) in accordance with dharma: inheritance (dāya), finding (lābha), purchase (kraya), conquest (jaya), investment (prayoga), work (karmayoga), and accepting gifts from the virtuous (satpratigra-

arthaśāstra tradition as a separate line of work, while the dharmaśāstras continued to be compiled even up till the seventh century CE. It seems to suggest a book-killing book scenario, where the Manusmrti overshadowed the readership of the KA (Trautmann 2012, 16-17). Olivelle also insists on the possibility that the Manusmrti derived the concepts of rājadharma and vyavahāra from the arthaśāstra tradition. He compared similar passages from both the $K A$ and the $M S$, which showed similarities. He also points that it is not possible to understand Manu's vocabulary without reference to the technical terms developed in the arthaśāstra tradition (Olivelle 2005, 48-50).

49 MS 8. 41.

50 Doniger and Smith 1991, lvii-lviii.

51 Olivelle 2005, 66.

52 MS 7. 127-132. Trans. Olivelle 2005, 161. 
ha). ${ }^{53} \mathrm{He}$ also lists ten means of subsistence (daśa jivvanhetavah): learning (vidyā), craft (ślpa), wages and employment (bhrti), service (sevā), cattle-herding (gorakșaṇa), marketing/trade (vipaṇi), agriculture (kṛ̦i), fortitude (dhṛti), begging (bhaik$s ̦ a$ ), and usury (kusìda). ${ }^{54}$ However, not everyone is advised to pursue all forms of livelihood mentioned above. At various instances, the author suggests restricting certain activities to some sections of society. For example:

A Brahmin or a Kṣatriya must never lend money on interest; to pursue the activities dictated by the Law (dharma), however, he may lend to an evil man at a small interest. ${ }^{55}$

The $M S$ thus acts as a guide to social conduct and the roles of an individual based on their ritual status, gender, and economic status, forming an interesting source for the study of economic aspects of individuals and social groups.

\section{II.3 The Kāmasūtra of Vātsyāyana}

Although the subject matter of this text is often taken to be erotic, as a śāstra it may be better defined as a guidebook to attaining the demeanor of a refined city dweller, nāgaraka, who has mastery over various forms of social interaction. The history of the text is poorly understood. It is traditionally attributed to Mallanāga Vātsyāyana, about whom not much is known. It is also possible that the text is a composite work from northern India, dated between the second and fourth centuries CE. ${ }^{56}$ The Kāmasūtra $(K S)$ of Vāstyāyana positions itself with respect to the earlier tradition of works guiding the pursuance of kāma. It presents itself as a specialized treaty that appeared after successive abridgement of the grand revelation dealing with the regulation of the trivarga. ${ }^{57}$ The $K S$ is available to us through the commentary of Yaśodhara called the Jayamangala (ca. thirteenth century), which also makes it possible for us to understand the technical terms and concepts.

The author places the text in the tradition of pursuing puruṣārthas (four goals of human life), by paying homage to the first three in the opening section, namely dharma, artha, and kāma. ${ }^{58}$ Vātsyāyana distinguishes human desires (kāma) from the natural desire of copulation among animals. Because of this difference, the śâstra guides humans on how to acquire proper knowledge and means for success

53 MS 10. 115. For further discussion on acquisition of wealth and on notions about livelihood in śāstras, see Derrett 1957, 70.

54 MS 10. 116.

55 MS 10. 117. Trans. Olivelle 2005, 214.

56 Trautmann 1971, 76, 169-171; Roy 1996, 155.

57 See $K S$ 1. 1. 4-17.

58 KS 1. 1. 1-2. 
in social interactions. ${ }^{59}$ The pursuit of kāma comprises the satisfaction of sexual, emotional, and artistic life. ${ }^{60}$ An example of this can be seen in the lifestyle of a nāgaraka:

He amuses himself by going to festivals, salons, drinking parties, picnics, and group games. On a specific day at half moon or full moon, there is always an assembly of invited guests at the temple of the goddess Saraswati. ${ }^{61}$

The $K S$ is about the art of urbane living. ${ }^{62}$ After finishing his education, a man must focus on cultivating his social life: finding a partner, courting, living with or as a courtesan, and maintaining power in marriage. This includes the subject of wealth and how to succeed in commerce:

Power [artha], in form of wealth, consists in acquiring knowledge, land, gold, cattle, grain, household goods and furniture, friends, and so forth, and increasing what has been acquired. A man learns about it from 'The Tasks of Superintendent,' and from merchants who know about trades and markets. ${ }^{63}$

The text also represents various social and economic groups. One such group is that of the courtesans. They are identified as participants in the economy. The text also contains recommendations for how a courtesan may become rich and discusses the hierarchy among the courtesans on the basis of their skills, popularity, and wealth. It also serves as a guide for how courtesans should manage a successful and wealthy clientele.

Furthermore, the $K S$ talks about auxiliary skills, called 'the sixty-four arts,' which also pertain to women of all social statuses. With training in the sixty-four arts, a veśy $\bar{a}$ (prostitute) may earn a title of gaṇikā (courtesan) and get a place in the public assembly. A princess or daughter of a high official will enjoy her husband's favor over her co-wives. ${ }^{64}$ And a woman may live comfortably on her own when separated from her husband. ${ }^{65}$

The intended readership of the Kāmasūtra is generally considered to be urban social elite, as it revolves around their desires, conduct, and aspirations, and learning the sixty-four arts require both leisure and means. The readers could be princes, barons, high state officials, wealthy merchants, or wealthy courtesans. The nāyaka (male protagonist/actor) is expected to be prosperous and cultured, and is to learn

$59 K S$ 1. 2. 22-24. For a discussion on how Vātsyāyana places the importance on the pursuit of kāma in accordance with dharma, see Rocher 1985, 522.

60 Kane 1968 2.1:8.

61 KS 1. 4. 14-15. Trans. Doniger and Kakar 2002, 19.

62 Doniger 2003, 20.

63 KS 1. 2. 9-10. Trans. Doniger and Kakar 2002, 8. The Adhyakșapracāra (Tasks of Superintendent) is bk. 2 of the $K A$.

$64 K S$ 1. 3. 21.

$65 K S$ 1. 3. 20-21, 23. In different edition these verses are 1. 3. 17, 19, 20. 
the $K S$ along with its ancillary sciences. Material prosperity is emphasized in the text, as poverty is not only considered an obstacle to pleasure, but also to ethics and virtues. ${ }^{66}$

\section{Narratives: Literary to Visual}

The Buddhist narrative tradition forms an important part of the Buddhist scriptural heritage. The two partly overlapping genres of narratives in Buddhist literature are the jātakas and avadānas. The term jātaka literally means 'related to a birth,' but in Buddhist tradition jātakas refer specifically to the stories of the former births of the Buddha in animal and human forms. The jātakas of the Theravāda tradition in Pali come from a collection titled the Jātakatthavannanā ('Explanation and Meanings of the Jätaka'). It contains 547 of the 550 birth stories of the Buddha. ${ }^{67}$ Although the original meaning of the term avadānas (apadāna in Pali) is not clear, it may refer to the accounts of deeds and stories of monks and laity. ${ }^{68}$ Along with their themes, both the avadānas and the jātakas contain elaborate descriptions of city life, market activities, monetary systems, and long-distance travel by land and water routes. ${ }^{69}$

Visual representations on stone reliefs and friezes were also a medium of storytelling in the early Buddhist world. ${ }^{70}$ The visual parallels of the textual narratives start appearing on various stūpas, vihäras, and caityas throughout South Asia from the second century всE. ${ }^{71}$ It is possible that the visual narrative and representation may have found its expression before the written narratives and their canonization.

66 Daniélou 1994, 5. This attitude is also common in some plays composed in early centuries of the Common Era. For a discussion, see Kaul 2011, 217.

67 The Jātakațthavaṇnanā was compiled around 500 CE (Straube 2015, 489). However, it is suggested that the jātaka stories may have already been in the oral tradition from the third century BCE onward. The Jātakatțhavannạana was first edited by V. Fausböll and translated by Rhys Davids, and was published in seven volumes between 1877 and 1897 (Fausböll and Davids 1877-1897). A commonly used translation is available in the six volumes edited by E. B. Cowell with several translators, which were published between 1895 and 1907 (Cowell 1957).

68 Straube 2015, 490-492. One of the earliest works similar to the avadāna genre is the Anavataptagāthā found in old Gāndhārī manuscripts dated as early as the first century CE, a part of the Senior Manuscript Collection now in the British Library. Other than these, the Sanskrit texts avadānas, namely the Mahāvastu and the Jātakamāla by Āryasura, are associated with the Gandhāran region. This association is because they were compiled in what is called Buddhist Hybrid Sanskrit, different from Middle Indic Sanskrit (Salomon 1998, 83).

69 Numerous jātakas refer to voyages undertaken by merchants to Suvarnabhūmi. See Ray and Mishra 2018, 1-4.

70 Dehejia 2007, 285.

71 Stūpas are the mounds, generally hemispherical, built for the veneration of the Buddha and his disciples (Hawkes and Shimada 2009, ix). They are erected to preserve the relics of the Buddha or important monks. The caityas are halls dedicated to prayers, and vihäras are the abode for monks or nuns. 
Both draw from a long oral tradition of transmission. The visual narratives owe their development to donations and the patronage of monks and laity as much as to royal patronage. ${ }^{72}$ The production of visual narratives continued well beyond the third century CE and expanded into other regions of Asia. ${ }^{73}$

The visual representation of narratives is found on the pillars, steles, and arches of various monuments. ${ }^{74}$ While the Buddhist narrative art seems to be a pan-subcontinental phenomenon between the second century BCE and third century CE, different regions are marked by different artistic attributes, such as mode, narrative, and style. ${ }^{75}$ Examples come from various sites at Gandhāra, Sanchi (Madhya Pradesh), Bharhut (Madhya Pradesh), Amaravati (Andhra Pradesh), Nagarjunakonda (Andhra Pradesh), Kanaganahalli/Sannati (Karnataka), as well as the rock-cut caves in Maharashtra and hundreds of other sites.

The visual narratives are studied for the representation of architecture, fashion, scenes of transportations, transactions, royalty, and worship in contexts of city, village, and forests. ${ }^{76}$ The representations of such stories of the Buddha and Bodhisattvas are quite common in the stūpa railings and in rock-cut cave architecture. A famous example is of the story of Anāthapiṇuaka, a rich merchant. ${ }^{77}$ It concerns the purchase of a garden named Jetavana in the ancient city of Śrāvastī (Shravasti, Uttar Pradesh) by Anāthapiṇdaka as a gift for the Buddha. This story is visually depicted at Bharhut, Bodhgaya, Sanchi, Kanaganahalli/Sannati, and Amaravati, often with the label: "Anāthapiṇdaka presents the Jetavana, having bought it for a layer of crores ['10 million']."78 This price is equivalent to the number of coins laid side by side that would cover the whole area.

While the story of Anāthapinduka is quite commonly represented, there are various depictions of the purchase of Jetavana. One example of this story comes from

72 For further discussion on donations and patronage, see below.

73 The visual narrative of birth stories of the Bodhisattvas are also found in Sri Lanka and later in Southeast Asia, Central Asia, and East Asia. See various articles in Agnew 1997; Ray 2007; Skilling 2008.

74 Apart from these, there are various other stylistic representations such as foliate patterns on railing or marking the borders of narrative episodes with musicians and dancers, deities (like Lakșmī, Kubera etc.), mythical and real animals, and auspicious symbols such as svastika, śrīvatsa, and pūrṇaghața.

75 For a discussion on different modes of representation, see Dehejia 1990, 374-376. For a discussion on different styles of depictions and influences, see Desai 1985; Taddei 1999; Behrendt 2003, 56-60; Stoneman 2019, 427-460.

76 Basant 2012, 193-221. The published report of excavation at the stūpa complex at Kanaganahalli (Karnataka) has an interesting illustration of the representations of animals, furniture, ceramics, jewelry etc. (Poonacha 2013).

77 The story is included in textual traditions of different Buddhist schools. Furthermore, these also appear in two biographies of the Buddha in Chinese translations (Zin 2010, 369).

78 The label is from Bharhut, trans. Dehejia. See Coomaraswamy 1935 pl. 51; 1956 p. 26, fig. 67; Marshall, Foucher, and Majumdar (1940) 1983, 122, pl. 34. a2; Dehejia 2007, 290-297; Zin 2010 fig. 1, 2. 


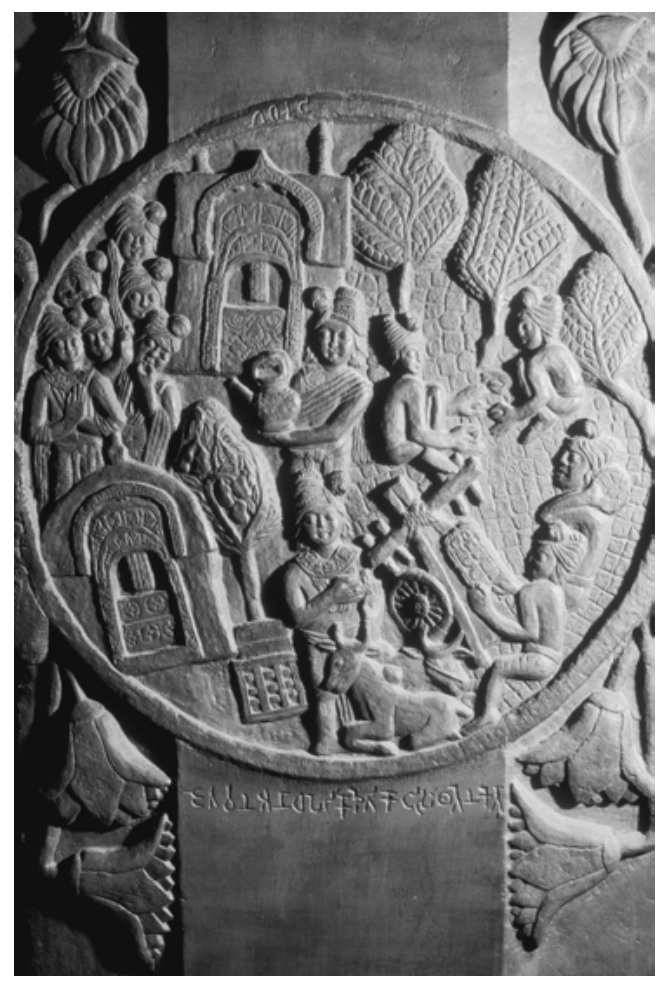

Fig. 1: A medallion on a stūpa railing from Bharhut, ca. second century BCE, depicting the purchase of Jetavana with Brāhmī label: jetavana anādhapiḍiko deti koțisaṃthatena ketā. Indian Museum, Kolkata. Photo: Roland and Sabrina Michaud, akg-images.

a medallion on a stūpa railing from Bharhut (Madhya Pradesh) (see fig. 1). On the left, it depicts figures standing with their hands together. In the middle, Anāthapindaka stands under the mango tree with a water jug in his hand facing toward a monument, which perhaps is the aniconic Buddha. Essential to the narrative is the representation of workers covering the ground with square coins and an unyoked bullock cart at the bottom of the medallion. The reproduction of this story again and again through different narrative methods is a good representative of the importance of the social standing of the merchant, also this is an extraordinary case where the materiality of coins, especially punch marked coins, is represented.

\section{Tamil Anthology}

The Sangam or Cankam is a corpus of literature composed in Tamil in praise of heroic figures, their wars, and love. The Sangam literature comprises eight antholo- 
gies (Ețtuttukai) and ten idylls (Pattupātțu), making a total of 18 works made up of 2,391 poems. ${ }^{79}$ Its compilation is variably dated between 300 BCE and 300 CE. ${ }^{80}$ Based on a later tradition, the compilation is attributed to the patronage of a collegium of scholars in the early centuries CE under the Pāndya dynasty at their capital (Madurai, Tamil Nadu). ${ }^{81}$ Nevertheless, the underlying texts cannot be regarded as court literature. They are more likely bardic in nature and may have been rooted in one or more oral traditions. The recorded authors of various poems are princes, chieftains, peasants, merchants, scholars, monks of different traditions, and so on. The political groups mentioned are the Colas, Pāndyas, and Ceras who controlled the Kaveri valley, the Tamraparni-Vaigai valley, and the western Kaveri region respectively. $^{82}$

For historians, the concept of tinai is a major topic of discussion, and the meaning of the term can only be conjectured. Among the various meanings proposed are concepts as different as 'space,' 'land,' 'abode,' 'genre,' 'genealogy,' and 'situation.' 83 One group of scholars understands tinais as ecological zones in the Tamil region. The five major tinais are: the fertile river valleys, called Marudam; the littoral areas comprised of the coastal and deltaic areas, called Neidal; the hilly region, called Kurinji; the dry pasture lands, called Mullai; and the arid tract, called Palai. If the tinais are understood as ecological zones, each zone has its own range of economic activities, deities, and well defined processes of state formation. ${ }^{84}$

Another view is that the tinais are poetic devices and mythopoeic categories. ${ }^{85}$ There are instances where tinais are associated with seasons and time. The Mullai relates to the season of rain and evening, the Marudam with the last hours of night and the dawn, the Palai as the hot day of midsummer, and the Neidal as sunset. ${ }^{86}$ The economic activities and livelihood are not limited to one ecological zone, there are various overlaps. One example is that of rice cultivation near the coasts, and also the reference to how the farmers enjoy their evening at the beach with tody

79 Manavalan 2014, 43.

80 Zvelebil 1973. Another range of proposed dates is first century BCE to fifth century CE (Hart and Heifetz 2002). However, another study by Tieken (2001) has proposed a medieval date for the literature. He proposed that the literature should be considered a ninth- or tenth-century compilation.

81 The tradition is recorded in a later commentary on Iraiyanār Kalaviyal by Nakkīra (eighth century CE), Zvelebil 1973, 32-33; Manavalan 2014, 43.

82 Chakravarti 2016, 187. For a discussion on polities of the Cola, Pāṇḍas, and Ceras, see Dwivedi, ch. 3, this volume.

83 Devadevan 2006, 199-218.

84 Sastri 1955, 113, 116-117; Champakalakshmi 1996, 28-32; Thapar 2003, 231-233; Gurukkal 1993, 7; Chakravarti 2016, 187-188.

85 Devadevan 2006; Selby 2008.

86 These are the representations of the tinai as poetic themes the Tolkappiyam (951-955) (T. R. S. Sharma 2014b). The Tolkappiyam, literally 'Ancient Book,' may have been the earliest grammatical works. The earliest version of the text may have been a pre-Common Era composition. However, it took its final form in the fifth century CE (Zvelebil 1973, 131, 137-147). 
drinks and fishery. Furthermore, while the Kurunji and Mulai regions are generally considered an abode for raiders, there are also references to people engaging in production and trans-oceanic trade of pepper. ${ }^{87}$

A certain degree of historical anchoring of the Sangam literature can be inferred from a number of port and city names that can either can be related to modern cities because of the continuities of their names, or to sites mentioned in the GraecoRoman Periplus Maris Erythraei (PME) ${ }^{88}$ Thus we hear of Kāñci identified with modern Kanchipuram, Maturai with modern Madurai, or Kāveripaținam with modern Kaveripattinam. Tonti is probably Tyndis and Muciri is Muziris, as both were recorded as located in the kingdom of a certain Keprobotos. ${ }^{89}$

The main themes of the poems are warfare and glory, but they are interwoven with glimpses into economic practices and ideas of wealth. One instance is of a lovelorn man struggling with the idea of leaving the town to gain wealth:

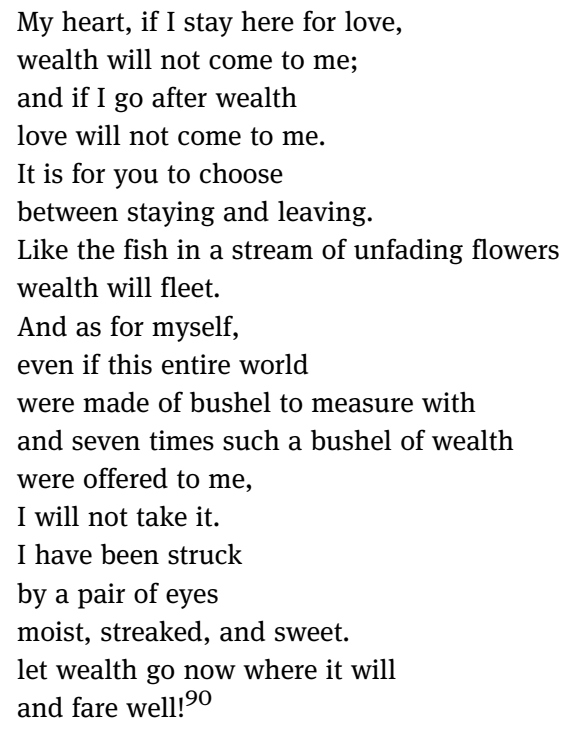

Some poems have vivid descriptions of nature and agricultural settings. One such description is of the life of a farmer:

In the wide paddy field with undiminishing yield the women who reap and gather have cut out the ämpal and neytal flowers numerous grown with paddy crop

87 Devadevan 2006, 204, 207.

88 See von Reden, ch. 10.B, this volume.

89 PME 53-54.

90 Narrinai 16. Trans. T. R. S Sharma 2014a, 94-95. 
and spread in them the threshing field

and got apart the soft red paddy under the feet of fat buffaloes

and the paddy put on heaps with bushels sticking into them

look like the nests of stinging wasps. ${ }^{91}$

There are many descriptions of activities along the shore, such as merrymaking, fishing, storage, exchange, and gifts:

They [the inhabitants] sell fish and bring on boats heaps of paddy which fill the house. The pepper heaped in the house is put into bags which are thrown in confusion on the noisy beach. The gold brought in the ships are brought ashore in the boats which ply in the backwater. The product of the sea and the mountain are mixed together and are given away to guests. In Muciri which belongs to the Kutțuvan who wears a gold garland and where the roar of the sea is heard, toddy flows like water. ${ }^{92}$

Similar accounts have been used to illustrate coastal and inland trade and exchange in peninsular India. The Akanānūru (148) makes references to yavanas (foreigners), whose ships loaded with gold came to Kerala, casting anchor in the river Culli, and returning with loads of pepper. At different instances, they are mentioned as strongly built men who served as palace guards or as merchants who brought lamps of fine workmanship. There are references to them also in the Mullaippāttu, where they are described as wearing toga-like garments and speaking a different language. Interestingly, they are also mentioned as unlearned youngsters who speak 'Northern speech' and are the mahouts of the king's elephants. ${ }^{93}$

\section{Epigraphic Sources}

A vast variety of inscribed material has been preserved in the subcontinent. Inscriptions can be found on boulders, pillars, railings of monuments, pottery sherds, metal vessels, and last but not least, on coins (see section below). The scripts of early inscriptions are mainly Brāhmī and Kharoșțhī, with exceptions from the northwest where there are a few writings in Greek and Aramaic. The languages are Sanskrit, Prakrit, Tamil, and occasionally Greek and Aramaic in the northwest. Sanskrit inscriptions appear earliest on stone from Ayodhya, Ghosundi, and Hathibada in the first century все, ${ }^{94}$ which are later than those in Prakrit and Tamil/proto-Tamil. ${ }^{95}$

91 Patirruppattu 71. Trans. T. R. S. Sharma 2014a, 140-141.

92 Puranānūru 343, lines 1-10, trans. Srinivas Iyenger 1929, 298.

93 Zvelebil 1973, 35, 52, 61.

94 Salomon 1998.

95 Prakrit inscriptions are noted in the Mauryan period (ca. third century BCE). A majority of scholars consider the Aśokan edicts as the earliest examples of writings, while others consider the possibility of a pre-Mauryan origin of writing. For an argument regarding pre-Mauryan origin of writing, see Coningham et al. 1996; Rajan 2015. 
Inscriptions have been one of the most trusted sources used for confirming monetary denominations, personal names, the identification of geographic names, and for establishing political chronology.

The beginnings of epigraphic studies of early India date back to the 1830s, when James Prinsep successfully deciphered Kharoșţhī and Brāhmī scripts. Since then, ancient inscriptions have been transcribed, translated, and published in various volumes of the Epigraphia Indica, the Annual Report on Indian Epigraphy, the South Indian Inscriptions, the Corpus Inscriptionum Indicarum, the Indian Antiquary, the Journal of the Epigraphic Society of India, and more. Recently, there have been attempts to compile digital catalogs of early inscriptions. Two such examples of digital aids are the web catalogs of the epigraphic evidence from the Gandhāran region (the northwestern regions of India, Pakistan, and parts of Afghanistan) and from the Āndhra region (modern Andhra Pradesh, Odisha, and Karnataka). ${ }^{96}$ Below is a general discussion of the types of early epigraphic sources and their scope as sources for economic history.

\section{V.1 Edicts, Eulogies, and Administrative Records}

Royal proclamations inscribed on stone are first attested in the reign of Aśoka (third century BCE) and are of three types: Major Rock Edicts, Minor Rock Edicts, and Pillar Edicts (see map 1). ${ }^{97}$ Most of the inscriptions are in the Prakrit language and Brāhmī script across the subcontinent. Exceptions are found in the northwestern region of the subcontinent, where there are two instances of edicts in Kharoșthi script, two Aramaic edicts, a bilingual Greek and Aramaic edict, and two Prakrit Aramaic edicts.

Above all, these inscriptions have been used to understand events during Aśoka's reign, but they also offer insights into the administrative machinery and reforms, offices, instances of tax exemptions, diplomatic relations with foreign kings, ideological and moral policies, as well as pilgrimage. ${ }^{98}$

An example of the administrative reforms by Aśoka is given in Rock Edict (RE) VI at Erragudi, Andhra Pradesh. The edict proclaims that Aśoka initiated the arrangement by which he was to be informed of affairs of the people at any time of the day, irrespective of where he was. ${ }^{99}$ RE XIII describes Aśoka's conquest of the

\footnotetext{
96 See https://gandhari.org/ and http://hisoma.huma-num.fr/exist/apps/EIAD/index2.html.

97 A collection and translation of the Aśōkan inscriptions may be found in Sircar 1979; Thapar 2012.

98 A pillar inscription in Rummindei refers to Aśoka's pilgrimage to the birth village of the Buddha in 249 BCE, where he declared tax exemption along with reduction of another tax to $1 / 8^{\text {th }}$ (Falk 1998, 20). Further, RE VIII and pillar inscriptions at Rummindei and Nigliva refer to his pilgrimage to Buddhist holy places, Sircar 1979, 65.

99 The edict lists issues to be reported immediately to the king with no delay. For the translation of RE VI, see Sircar 1979, 18-19.
} 


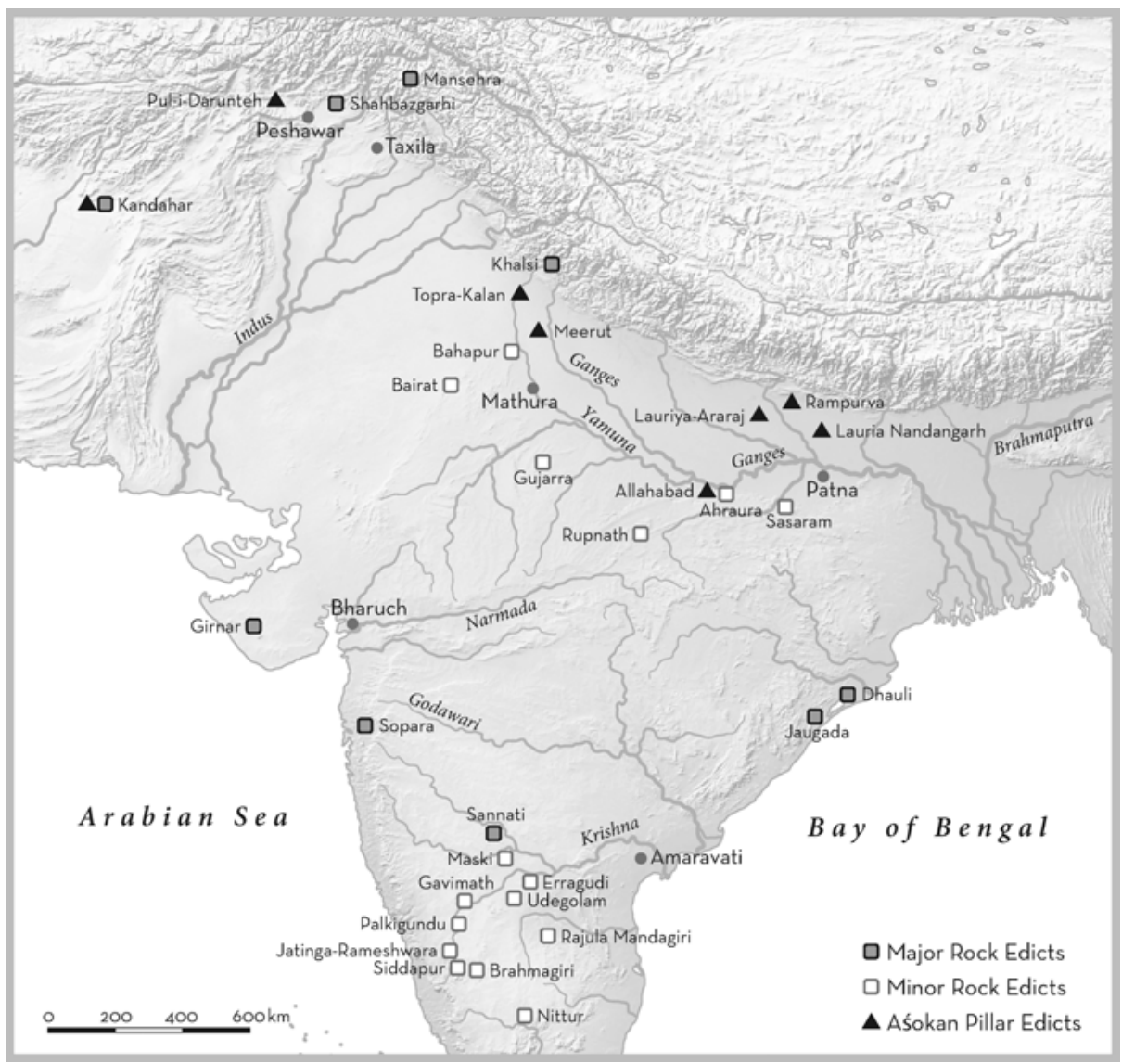

Map 1: Aśokan edicts (uninscribed pillars not shown), based on Falk 2006. () Peter Palm.

region of Kalinga and his remorse for it, which made him follow the path of dhamma, Buddhist teachings.

When he had been consecrated eight years the Beloved of the Gods, the king Piyadassi [Aśoka], conquered Kalinga. A hundred and fifty thousand people were deported, a hundred thousands were killed and many times that number perished. Afterwards, now that Kalinga was annexed, the Beloved of the Gods very earnestly practiced Dhamma, desired Dhamma, and taught Dham$m a$. On conquering Kalinga the Beloved of the Gods felt remorse, for, when an independent country is conquered, the slaughter, death, and deportation of the people is extremely grievous to the Beloved of the Gods and weighs heavily on his mind ... And moreover the Beloved of the Gods has gained this victory on all his frontiers to a distance of six hundred yojanas ... ${ }^{100}$

100 Trans. Thapar 2012, 382-383. 
The Sohgaura (bronze plaque) and Mahasthangarh (stone plaque) inscriptions recording proclamations concerning the prevention of famine in situations of emergency also come from the Mauryan period. They contain instructions for the storage of surplus grains and other products in storehouses as a precaution. However, the authorship of the two inscriptions is unknown, and dating is based just on the paleographical grounds. ${ }^{101}$

A biographical inscription of a post-Mauryan king, Khāravela, comes from a seminatural cavern called Hathigumpha in Udaigiri. It records valuables sent to him consisting chiefly of horses, elephants, men, and chariots. It also refers to his mastery over various administrative duties including finance (gananā) and jurisprudence (vyavahāra), as well as his building activities. He repaired water tanks, canals, and various monuments, and oversaw the construction of a royal residence at the cost of 3,800,000 (units undefined). It also mentions the creation of settlement for 100 masons and various privileges bestowed (anugraha) worth hundreds of thousands, along with tax exemptions (parihära) granted to his subjects on various occasions. ${ }^{102}$

Similar reports of waterworks, repairs, and dedications of wells are found in other inscriptions. At Girnar, the Junagarh inscription of a Saka king named Rudradāman (r. 130-150 CE) records the commissioning of repairs of a dam after its destruction during a storm. The same inscription mentions the construction of the same dam by Candragupta Maurya’s governor, Puṣyagupta, and its later repair by Aśoka's administrator named yavanarāja Tuṣāspa. ${ }^{103}$ Another second-century inscription from Kirari in Chhatisgarh records the commissioning of a water tank in the presence of various officials. ${ }^{104}$

\section{V.2 Individual and Personal Records}

The northwestern region beyond the Indus has yielded more than 5,000 inscriptions written by private individuals in Brāhmī, Kharoșţhi, and Sogdian scripts, with examples also in Bactrian, Tibetan, Chinese, and Hebrew. In addition, there are engraved petroglyphs of stūpas, animals, and human figures. ${ }^{105}$ The dates of these inscriptions vary. The Kharoșthī inscriptions are dated to the first two centuries CE,

101 Due to the archaic nature of the language and fragmentary remains of the paleography, the detailed interpretation has been controversial (Salomon 1998, 111,140). The possible emergency situations mentioned are caused by water, fire, and devastation of crops by parrots. The items that are to be stored include oil, wood, paddy, and probably some coins of certain denomination (Sircar 1965, 82-83).

102 K. P. Jayaswal and Banerji 1929; Sircar 1965, 206-213.

103 Sircar 1965, 169-174; Thapar 2011, 591.

104 H. Sastri 1925; Basu Majumdar 2017b, 120-121.

105 Jettmar 1989. 
while the Brāhmī inscriptions date to $400 \mathrm{CE}$ and much later. They are generally found on boulders and rocks, written alongside or below one another. One example is that of stone no. 18 at Oshibat, a big, isolated boulder covered with more than 125 inscriptions consisting of only personal names. ${ }^{106}$ Other instances mention the names of merchants, sometimes monks, and others. Often, they give references to the profession, official title, religious status, and even hometown of the people. ${ }^{107}$

In the northwest, these inscriptions have been used to understand regional routes of connectivity and travel. One example is Hunza-Haldeikish, located between Gilgit and the modern Chinese border. ${ }^{108}$ This site has more than one hundred inscriptions spread across different passes. The findspots indicate the existence of a dynamic network of capillary routes. These routes perhaps were more important than what are deemed to be major arteries or highways. ${ }^{109}$ As eight of the inscriptions are written in Chinese, some scholars consider this region to be the staging post of the ancient Jibin route mentioned in Chinese sources. ${ }^{110}$

Graffiti and marks on pottery sherds are commonly reported in the South Asian context. Their discovery in sites abroad (as shown above) has important implications for connectivity studies. From Arikamedu, three instances of rouletted ware (RW) sherds with inscriptions in Tamil-Brāhmī and marking the ownership of the wares were reported. ${ }^{111}$ However, among the ceramics carrying Brāhmī script, black and red ware (BRW) and russet-coated BRW dominate at various sites in Tamil $\mathrm{Nadu}$, including Kodumanal, Alagankulam, Uraiyur, Karur, and at Arikamedu in Puducherry. At Kodumanal, which has yielded more than 500 sherds with comprehensible Brāhmī/Tamil-Brāhmī inscriptions, inscribed BRW and russet-coated BRW constitute about 77 percent of the inscriptions. The next most commonly inscribed pottery is RW, constituting about nine percent of the total. ${ }^{112}$ Most of the marks, graffiti, and inscriptions on pots are post-firing marks, which are associated with the vessel's owner rather than that of the potter. Ownership could be of a personal or corporate nature. ${ }^{113}$ Small-scale traders tended to share cargoes, as the risk of loss of a cargo was too great to be incurred by an individual trader. Thus, the items of shared mercantile enterprises needed to be differentiated, and the graffiti or scriptual inscriptions fulfilled that purpose. ${ }^{114}$ The mercantile involvement in the rise and spread of Brāhmī script is commonly acknowledged, at least in Sri Lanka. ${ }^{115}$

106 von Hinüber 1989, 43.

107 von Hinüber 1989, 46; Neelis 2000, 912.

108 Neelis 2000.

109 Neelis 2000, 915-916.

110 Yong 1989. The location of Jibin has been controversial in scholarship (Morris, ch. 9, this volume).

111 Begley 1988, 429; A. L. Reddy 2016, 73.

112 Rajan 2015, 270.

113 Deraniyagala 1972, 129; Coningham et al. 1996, 89-90.

114 Coningham et al. 1996, 89-90.

115 Coningham et al. 1996, 92. 
Inscriptions by individuals outside the subcontinent give us vivid examples of Indian involvement in maritime activities, especially in the much discussed IndoRoman trade. ${ }^{116}$ Six lines of Brāhmī script on an ostracon was discovered in Quseir al-Quadim (Myos Hormos) on the Red Sea in Egypt. ${ }^{117}$ It contains names of three merchants and a list of goods (oil, meat, and wine) in Prakrit. The ostracon, dated to the second or third century CE, presents a case of record keeping in non-Indian style, written in Indian language. ${ }^{118}$ Another inscription that is used to present a case for long existing connection between India and Egypt is a Greek inscription at a temple in Egypt. It mentions a dedication by Sophon, a resident of Egypt, who claims to be an Indian. ${ }^{119}$

An interesting corpus of epigraphic evidence was discovered in 2002 on the island of Socotra, $300 \mathrm{~km}$ off the coast of Arabia. One Kharoșthī and 192 Brāhmī inscriptions were reported from Hoq Cave on the island and are dated between the first and sixth centuries CE. These were found along with various petroglyphs and graffiti. ${ }^{120}$ The inscriptions are mostly devotional in nature, giving names, titles, and sometimes the professions and provenance of the devotees. Some identify themselves as ship captains or ship passengers. ${ }^{121}$ Their mix of ethnicities is an interesting feature. Two devotees give their ethnicity as yavana, a rather indistinct designation for people who at least originally came from regions west of India and most probably were once regarded as Greek. ${ }^{122}$ In one case, the person's name indicates an Iranian origin. Humiyaka bears a Bactrian name related to Iranian ' $\mathrm{Hu}$ maiak.' He left two Brāhmī graffiti in the cave. One of these was accompanied with the Graeco-Bactrian spelling, OMOIAГO. Strauch suggests that it is possible that this Bactrian originally came from northwestern India where a considerable population of Bactrians is attested, but it cannot be excluded that Humijaka was an inhabitant of western India. In any case, the bilingual inscription shows that biscriptuality and bilinguality was common at least in some parts of the Iranian population of India. It can be suggested that this capacity considerably facilitated the trade contacts between westerners and Indians, both in India and on Socotra. ${ }^{123}$

Many Tamil-Brāhmī inscriptions and graffiti on potsherds were found in the Arabian Gulf region, the Red Sea, and southern Arabia. Sherds inscribed with personal names, like nantaikiran, have been found during the excavations of Khor Rori

116 Dwivedi, ch. 15, this volume.

117 Salomon 1991, 731-734; for the identification of Myos Hormos, Whitcomb 1996.

118 Salomon 1991, 734.

119 Salomon 1991, 735-736.

120 For a complete survey and analysis of the inscriptions, see Strauch 2012.

121 Strauch 2012, 347.

122 Strauch 2012, 348. In the inscriptions from western and central India, many donors use the terms yona and yavana to identify themselves (Ray 1988, 314-315).

123 Strauch 2012, 349. 
(southern Arabia). ${ }^{124}$ The potsherds derive from utilitarian vessels, including pots, cooking vessels, lamps and lids, dated as early as the third to the first century BCE. They have been identified variably as BRW, RW, and grey ware with similarities to the pottery assemblages found in southern regions of India and in Sri Lanka. ${ }^{125}$

\section{V.3 Donative Inscriptions}

As in any other ancient society, dāna or gift-giving was of great significance in early Indian society. The question of who should be a donor and who is a worthy recipient was a matter of discussion throughout literary history both in Hindu and Buddhist traditions. ${ }^{126}$ From the first century BCE onward, the term deyadhamma, meaning donation for the sake of acquiring merit, appears as an important part of the Buddhist tradition. ${ }^{127}$ In the context of the Hindu tradition, donations of public utility and charity come under the title of pürtadharma, i.e., merit through donation or giving of pürta ('objects'). The ability of all social classes to be able to acquire religious merit through donation is considered the reason for the high frequency of donative records. The records mention the construction and gifting of various objects of public utility, such as wells, tanks, parks, and temple and cave shelters. ${ }^{128}$ The emergence of monuments in various parts of the subcontinent by the beginning of the first century CE was the result of donations by kings, but more frequently by monks and nuns, and even commoners from different economic and social backgrounds. ${ }^{129}$ This social diversity is visible in the thousands of donative inscriptions found on different monuments, indicating sponsorship of different objects or commissioning of art by different people within the same monument. Common donative objects include, but are not limited to: wells, caves, sculptures, vessels, gardens, commissioning of architectural and landscape work such as railings, sculptures, figures, and money for perpetual endowments (akșayanivi).

Records of the donation of caves and rock shelters come from as early as the third century BCE. The most well-known cave shelters are the Barabara and Nagarjuni caves in Bihar; the Jogimara and Sitabenga caves in Chhattisgarh; ${ }^{130}$ the cave shelter complexes of Kanheri, Karle, Junnar, Nasik, and a cave shelter complex of Aurangabad in Maharashtra; ${ }^{131}$ and Dambulla and Anuradhapura shelters in Sri

124 A. L. Reddy 2016, 73.

125 Pavan and Schenk 2012.

126 Thapar 1978; Nath 1987; Endo 1987.

127 Dehejia 1992, 35.

128 Chakravarti 1996, 185. For the concept on pūrta vis-à-vis ișta, see Kane 1968 2.2:843-914.

129 For the prevalence of monks and nuns as donors, see Schopen 2004, 382; Ray 2018, 29-30.

130 H. Sastri 1925; Basu Majumdar 2017b.

131 Senart 1905; Ray 1987; 1994; Brancaccio 2011. 
Lanka. ${ }^{132}$ There are references to laypersons from different socio-economic backgrounds, such as merchants, fishermen, nuns, and monks. There are also instances where the merits of the donation are transferable to another person, such as a family member, a guild member, or even the king. An example of this comes from a Buddhist rock-cut cave complex in Nasik (Maharashtra), where a cave with several chambers is donated by a merchant:

Success! This cave, a pious gift of the householder Vira, a merchant, a cell of his wife Nandasiri, and a cell of his daughter Purisadattā; the cave thus completed to four cells has been bequeathed to the universal Samgha [Buddhist religious community]. ${ }^{133}$

The Mirjapur stele inscription near Mathura records a donation by a female treasurer. The inscription identifies the donor as Kauśikī Pākșakā, mother of Vasu and wife of Mūlavasu, as treasurer for satrap Śodāsa (ca. 10-25 CE). The gift is listed as twin water tanks, a garden, an assembly hall, a well, a pillar, and stone slabs with the image of goddess Śrī. ${ }^{134}$

One of the most interesting types of donation is the akșayanivi (literally 'perpetual endowment' or 'inexhaustible investment'). ${ }^{135}$ These are donations of capital money - money to be invested - from which the interest ( $v r d d h i)$ is to be used for very specific purposes. It is not the capital itself that is to be enjoyed by the recipient, but just the recurring interest. There are references to these kinds of donations from Mathura, Kanheri, Nasik, and later from sites in Andhra Pradesh. ${ }^{136}$ One such donative inscription is of Ușavadatta from Nasik:

Success! In the year 42, in the month of Vesākha, Ușavadāta, son of Dinika, son-in-law of king Nahapāna, the Kshaharāta Kshatrapa, has bestowed this cave on the Samgha generally, he has also given a perpetual endowment, three thousand - 3000 - kāhāpaṇas, which, for the members of the Samgha of any sect and any origin dwelling in this cave, will serve as cloth money and money for outside life (kuśaṇa); and those kāhāpanas have been invested in guilds dwelling at Govadhana,- 2000 in a weaver's guild, interest one pratika (monthly) for the hundred, (and) 1000 in another weaver's guild, interest three quarters of a padika (monthly) for the hundred; and those kāhāpanas are not to be repaid, their interest only to be enjoyed. Out of them the two thousand - 2000 - at one pratika per cent. Are the cloth money; out of them to everyone of the twenty monks who keep the vassa in my cave, a cloth money of twelve (kähäpanas). As to the thousand which has been invested at an interest of three quarters of a pratika per cent, out of them the money for kuśana. And at the village of Chikhalapadra in the Kāpura district have been given eight thousand - 8000 - stems of coconut trees; and all this has been proclaimed (and) registered at the town's hall, at the record office, according to the custom ....

132 Bandaranayake 1997; Coningham 2006, 453.

133 Senart 1905, 75.

134 R. C. Sharma 1989, 308-310; Quintanilla 2007, 259; Falk 2009, 23.

135 For such endowments in the medieval period, see Borgolte 2014, 70-83.

136 Senart 1905; Sircar 1965, 146, 157-162; Ray 1987, 1994; P. K. M. Reddy 1998, 302; Singh 2004a, 394; Falk 2008.

137 Senart 1905, 82-83. 
Inscriptions on vessels are also found in religious contexts. Examples include a number of Kharoșṭī inscriptions found on donative vessels from Peshawar ${ }^{138}$ and Kashmir Smast, ${ }^{139}$ and those with Brāhmī script from Jetavana Monastery at Anuradhapura. ${ }^{140}$

\section{Archaeological and Architectural Remains}

This section will discuss megalithic remains, ceramics, and shipwrecks from different contexts, with a focus on two issues: how the context and approaches to their study have influenced the understanding of subsistence pattern of people and how the studies have implications on the understanding of regional and long-distance connectivity of South Asia.

Archaeology in the context of South Asia started in the nineteenth century with European antiquarian curiosity about the apsidal Buddhist monuments, called stūpas. Archaeological remains of early India were considered representatives of the Buddhist culture, and the architecture, sculpture, coins, and inscriptions became associated with Buddhism. ${ }^{141}$ Text-based archaeology has been an inherent feature of Indian archaeology, where the main aim of archaeologists has been to locate the cities mentioned in various literary sources. ${ }^{142}$ Another characteristic aspect has been the search for urban centers, identified through various criteria that have changed with developments in scholarship. ${ }^{143}$ In recent understanding, an early historic urban space is marked by a differentiated and heterogeneous population; dynamic public, private, and religious spaces with varied economic, social, and ritual functions; and access to nonlocal goods suggesting long-distance connectivity. $^{144}$

In one study of early historic cities, 63 sites exhibited strong urban tendencies. These urban settlements ranged from 50 to 300 ha. ${ }^{145}$ The largest ones were Chandraketugarh, Kaushambi, Mahasthangarh, Mathura, Paithan, Pataliputra, Shishup-

138 Chhabra 1949-1950, 125.

139 Falk 2008.

140 Ratnayake 1984, 36-44.

141 For the beginning archaeology in India and discussion on the development of scholarship, see Dwivedi, ch. 15, this volume. See also Chakrabarti 1988; 1997; Singh 2004b; Guha-Thakurta 2004; Fogelin 2015; Ray 2018.

142 Chakrabarti 1995, 187-194; J. Menon 2008, 20. The most recent instance of text-based archaeology is the excavation at Pattanam. The site has been identified as the legendary Muziris, even when many scholars question this attribution (Selvakumar 2006; Mathew 2017b).

143 Chattopadhyaya 2003b, 66-68; M. L. Smith 2006.

144 N. Lahiri 1992, 268-323; Morrison 1997, 88; Chattopadhyaya 2003b, 66-68; M. L. Smith 2006, 130; Chakravarti 2009, 139-140.

145 M. L. Smith 2006, 116-119. 
algarh, Ter, and Ujjain. ${ }^{146}$ Recent approaches also identify cities, the process of urbanization, and also the location of the urban, vis-à-vis the rural hinterland. The study of satellite regions and neighboring settlements has demonstrated the great complexity of the landscapes. Often, early historic cities are clusters of closely knit settlements in a limited area. A survey of Kanpur district in Uttar Pradesh showed a cluster of 150 sites, 141 of which experienced an early historic phase. ${ }^{147}$ Mathura has also been identified as a 'settlement locality' with a series of sites in a microregion. ${ }^{148}$ The region of Varanasi also has many related archaeological sites, namely Rajghat, Kotwa, Aktha, and Sarnath. ${ }^{149}$ Similarly, various other complex sites with well-connected clusters of sites are reported from South Asia. The list includes, but is not limited to, Sanchi, Anuradhapura, Tirunelveli, and Tungabhadra valley. ${ }^{150}$

\section{VI.1 Assemblages of Megaliths}

More than 3,000 megalithic sites have been documented since they were first identified and named in the 1820s. ${ }^{151}$ Megaliths are mainly Iron Age structures that continued from ca. the first millenium BCE into the early historical phase of the Deccan, the southern peninsula, and Sri Lanka. ${ }^{152}$ These structures do not conform to the literal meaning of a megalith, which usually means 'built of large stone,' but got their name from European analogies. ${ }^{153}$ These are also referred to by their regional names, such as pandukal, pandu coolies, kodaikal, topikal, etc. ${ }^{154}$

A variety of stone structures constitute the megalithic culture of South Asia. They range from simple erect stones called menhirs to complex arrangements of stone blocks formed into a chambers, cairn circles, and even subterranean porthole cists built of stone slabs. These are generally associated with mortuary practices

146 M. L. Smith 2006, 100.

147 Lal 1984, 145-153, 257-259.

148 Chattopadhyaya 2003b, 68; Härtel 1993.

149 V. Jayaswal 2009, 5.

150 Rea 1904a; Coningham 1995; 1999; Shaw and Sutcliffe 2003; Singh 1996; Basant 2012; Bauer 2015.

151 Babington 1823; S. M. Menon 2018.

152 In South India, the late Iron Age is also associated with the Sangam period, not only based on the archaeological assemblage, but also textual references to burial practices. A reference to urn burial is found even in the Manimekhalai, an epic from later Sangam period, where a widow requests the potter make an urn large enough to include her too. Leshnik 1974, 18-19; Ramanna 1983, 25.

153 Leshnik 1974, 1; S. M. Menon 2018, 210.

154 Pandukal refers to panțu+kal, which in Tamil means old + stones i.e., old graves. Another tradition also associates them with the Pāṇdava brothers of the Mahābhārata, who are said to have taken abode in these stone and rock shelters during their exile (Leshnik 1974, 2-3). The kudaikal and topical were names given to the different varieties of megalithic structures meaning umbrella stone and cap stone respectively (Sudyka 2010, 380). 
and rituals, and they may or may not be associated with burial remains. Some burial sites associated with megalithic remains have also yielded human remains, which have been used to study the food habits of inhabitants during the Iron Age. ${ }^{155}$

Megalithic sites have yielded many artifacts, pottery, metal implements, and grain samples. These remains have been studied to understand the nature of the sites, the connectivity of the site with neighboring and distant areas, as well as the complexity of human interaction with the landscape and bodies of water. ${ }^{156}$ The study of burial pits at the megalithic site in the village of Porunthal (Dindigul, Tamil Nadu) has produced domesticated paddy and millet samples, revealing cereal processing activities and grazing in association with complex burial rituals, which have been found as early as the sixth century всE. ${ }^{157} \mathrm{~A}$ transept cist with paddy remains was found along with potsherds inscribed in Tamil-Brāhmì with a radiocarbon date of 490 всE. ${ }^{158}$ This evidence cast doubt on the old myth about the pastoral nature of the people associated with megalithic burials in South Asia. ${ }^{159}$

There is also evidence for iron production in megalithic sites. In Tamil Nadu, the sites yielding iron ore are Tirunelveli, Madurai, Pudukottai, Coimbatore, and Tiruchirapalli. These regions chiefly contain the magnetite $\left(\mathrm{Fe}_{3} \mathrm{O}_{4}\right)$ and laterite $\left(\mathrm{Fe}_{2} \mathrm{O}_{3}\right)$ types of iron ores and the sites display traditional preindustrial methods of iron extraction and smelting. Kodumanal's megalithic site produced evidence for ferrous crucible processing. ${ }^{160}$ In Sri Lanka, excavations have revealed large-scale iron extraction operations from the third century BCE onward. ${ }^{161}$

\section{VI.2 Pottery, Graffito, and Script}

The history of ceramic studies may be divided into three phases: the study of whole pots from an art historical perspective; the study and analysis of sherds to understand typology both chronologically and spatially; and after 1960, a more holistic contextual approach of the finds. ${ }^{162}$ In recent times, pottery studies have branched

155 Rea 1904a; 1904b. Leshnik 1974, 21-22 on early (sixth century BCE) skeletal finds.

156 Coningham 1995; Bauer 2015.

157 Premathilake et al. 2017.

158 Rajan 2015, 404; Premathilake et al. 2017, 498-499.

159 For recent studies regarding the socio-cultural and political complexities of the megalithic burials, see Coningham 1995; Shaw and Sutcliffe 2003; Bauer 2015.

160 Chakrabarti 1992, 19, 150-151; Srinivasan and Ranganathan 2004, 24-25, 36.

161 Juleff 1998, 3-4.

162 Ray and Achyuthan 2010, 128. Typological study of potteries for their use as chronological markers had been common in Indian history. For instance, the painted grey ware (PGW) were associated with pre-Mauryan chronology, the northern black polished ware (NBPW) commonly gets associated with the Mauryan rule, the pottery found in levels dating from the second century BCE to the third century CE is generally categorized as Śunga-Kuṣāna, and the black and red ware (BRW) got associated with megaliths. 
out to include ethnographic studies, studies on manufacturing technology, the dating of archaeological assemblages, and analyzing the functions of ceramics. ${ }^{163}$ The studies regarding the functions of pottery have been used to understand the economic and social contexts of their use. ${ }^{164}$

Ceramics have been important mostly as a source to determine long-distance trade and interaction in Indian history. The following discussion of studies of rouletted ware (RW) and amphorae shows how the evolution of ceramic studies has altered the course of the discourse on trade. Their finds were long associated with the maritime activities of the Romans in India, and the find sites in south India and Sri Lanka were labeled as Roman trading stations. ${ }^{165}$ More than 120 sites from India and Sri Lanka have reported finds of RW. ${ }^{166}$

In 1945 after the excavation of Arikamedu, a distinctive type of decorated grey ware found at the site was named RW. ${ }^{167}$ The method of decoration appeared similar to the rouletting found in Mediterranean ceramics. ${ }^{168}$ Since the site also contained Mediterranean amphorae and some terra sigillata, the RW was associated with the pottery from the classical world. It was suggested that the finer RW were imported ceramics, and those of softer fabric and coarser rouletting may have been local imitations. ${ }^{169}$ Thus, RW became the identifier of port sites as Roman trading stations. It also became the most important ceramic type for determining the inland trade patterns in the subcontinent, suggesting connections between the eastern coast of India, the northwestern coast of Sri Lanka, and the international routes. This idea only recently fell out of favor. RW as an imported pottery came to be systematically questioned from the 1980s onward based on the difference of the RW from the wares in the west in terms of shape, fabric, surface, color, and scheme of decoration. ${ }^{170}$ Later, the study of RW from Satanikota, Andhra Pradesh (excavated in 1977-80) exhibited a mineral content identical to that of the local black and red ware (BRW) suggesting local production of both. Further studies also concluded that even the RW from different sites were not typologically similar, suggesting varied types within the subcontinent and multiple centers of production. ${ }^{171}$

Further studies from Anuradhapura (Sri Lanka) have suggested that RW falls in the larger grey ware tradition of South Asia dating to 500 BCE-200 CE. Comparative

163 Ray and Achyuthan 2010, 128, 130.

164 Here the reference is to the ceramics and urn for burial rituals (Leshnik 1974, 21-22; Coningham, Knusel, and Mann 2006, 623) and ceramics associated purely with the monasteries and monks (Coningham et al. 2006, 277). Also see Krishnan and Balvally 2017.

165 For study of potteries as a determinant of Roman trade connections, see Wheeler, Ghosh, and Deva 1946.

166 Rajan 2015, 19-23.

167 Wheeler, Ghosh, and Deva 1946; Wheeler 1954.

168 See Weaverdyck, ch. 8.A, this volume for Mediterranean pottery.

169 Wheeler 1954, 149; Wheeler 1976, 48; cf. Begley 1988, 427.

170 Begley 1988, 1992.

171 Begley 1988, 428. 
analysis of the chemical composition of three related potteries (RW, Arikamedu Type 10, and grey ware) from different sites showed significant similarities over time. ${ }^{172}$ As the grey ware predates Mediterranean contact, the common origin of all three must have been indigenous. The study suggested closely related geographical sources for RW and other grey ware, along with consistency in the fabric over a long period of time (500 BCE-200 CE) even among those traded to Berenike (Egyptian coast) to the west and Bali (Indonesian coast) to the east. ${ }^{173}$

As recent studies have disturbed the notions of RW as an imported ware, the Mediterranean origins of other potteries have also been reevaluated. For example, the moldware pottery from the western Deccan is stylistically similar to Hellenistic moldware pottery (Magarian ceramics) and numerous western metal forerunners. However, it has been suggested that the Deccan moldware could date as early as the third century BCE, and that both Deccan and western styles could have been derived from Achaemenid prototypes. ${ }^{174}$ In addition, the reclassification of many 'amphorae' as torpedo jars of Mesopotamian design, and sometimes from the Sasanian period, further questioned the dominance of Rome over maritime activity in the Indian Ocean. ${ }^{175}$

Recent ceramic studies from the Pattanam excavation in Kerala have further confirmed the dominance of local pottery at port sites. These results are even more important for understanding Indo-Roman trade, as Pattanam is considered the legendary port of Muziris known from the PME and the famous Muziris papyrus recording the value of a cargo from Muziris to Koptos in Egypt. ${ }^{176}$ After seven seasons of excavation at Pattanam (2007-2013), the ceramic study has shown that local pottery accounted for about 99 percent of the pottery finds at the site. ${ }^{177}$ The detailed chemical and typological studies of early historical ceramics have challenged the longstanding approach to long-distance trade, suggesting alternative connections and networks developing before the first century CE and the importance of local trade. ${ }^{178}$

Pottery has also been used to illuminate socio-economic practices. The changes in the nature of the earthenware may indicate changes in the social composition of a site over time. In Sri Lanka, a particular flat bowl type of tableware is associated with Buddhist alms bowls and is found in satellite monasteries, but absent in the city cores. At Anuradhapura, this type constitutes 50 percent of the ceramics in 500-300 BCE, declines to 39 percent by the third century CE, and continues to decline to two percent in the medieval period. Such changes are indicative of social, economic, and culinary changes. ${ }^{179}$

172 Ford et al. 2005, 911.

173 Ford et al. 2005, 918.

174 Begley 1992.

175 Tomber 2007, 2008.

176 Rathbone 2001. See also von Reden, ch. 8.C, this volume.

177 Cherian 2011.

178 Pavan and Schenk 2012; Schenk 2015.

179 Coningham et al. 2006. 


\section{VI.3 Underwater Archaeology: Ports and Shipwreck Sites}

Underwater archaeology is one of the most recent developments in the field of South Asian archaeological studies. After the UNESCO Convention on the Protection of Underwater Cultural Heritage (2001), South Asian countries started systematic exploration of maritime spaces and underwater heritage through various international collaborations.

In India, the origins of systematic marine archaeology go back to the foundation of the National Institute of Oceanography in 1981. Since then, government and private collaborations have extended support to offshore marine exploration, which have been carried out in Dwarka, Bet Dwarka, Somnath, Vidyadurg, Malwan, Goa, Lakshadweep Islands, Poompuhar, and Mahabalipuram. ${ }^{180}$ The underwater excavation at Dwarka and the nearby island Bet Dwarka have shown evidence of an ancient harbor. Scholars have identified it as Baraca/Barake of the PME. ${ }^{181}$ Offshore of Bet Dwarka, a concentration of artifacts at the depths of 5-8 $\mathrm{m}$ has been identified as a shipwreck. The site is situated at the mouth of the Gulf of Kachchh where the tidal currents are severe, removing lighter material and preventing organic material from being preserved under sedimentation. This wreck site has yielded amphora sherds, anchors, and a lead ingot, but no timber from the ship itself. ${ }^{182}$

The recently explored shipwreck near Godavaya/Godawaya (southern Sri Lan$\mathrm{ka}$ ) is the first to reveal a variety of well-preserved materials. Carbon 14 analysis of the wood dates the shipwreck to between the second century BCE and first century $\mathrm{CE},{ }^{183}$ making it the oldest shipwreck in the Indian Ocean, possibly predating the Roman engagement in Indian Ocean trade. ${ }^{184}$ Godavaya, situated at the mouth of the river Walawe Ganga, has a strategic position as a port site with access to the hinterland via riverine routes. Moreover, a second-century CE inscription found in the Godavaya temple records the donation of custom duties collected at the port of Godavaya Pattana. The inscription refers to the donation of the custom duties of the port to the vihāra (monastic residence) by King Hamani Abaya. ${ }^{185}$

The shipwreck was first noticed in 1998 during the excavation of the port site at Godavaya. Since then, samples of BRW, quern-like stone objects, two purified glass ingots, and an unidentified copper object were brought to the surface. The ceramics reported include several complete vessels, both large and medium storage jars and a carinated (keeled) cooking vessel, and fragments have also been identified as cooking vessels, plates, and bowls. They are similar to the peninsular and Sri Lankan megalithic BRW. The stone objects discovered could have been four-

180 Tripati et al. 2003; Tripati, Gaur, and Sundaresh 2004.

181 PME 40; Gaur, Sundaresh, and Tripati 2004; 2006.

182 Gaur, Sundaresh, and Tripati 2006, 125.

183 Gaur et al. 2011; Muthucumarana et al. 2014; Bopearachchi, Disanayaka, and Perera 2016.

184 Bopearachchi, Disanayaka, and Perera 2016, 416.

185 Muthucumarana et al. 2014, 43. 
legged querns or small stone benches with possible ritual importance. Similar objects were reported from many places in mainland India and from Sri Lanka. ${ }^{186}$ These objects also carry the engraved symbols of śrivatsa (literally the 'beloved of Śrì'), nandipada (taurine), and mina (fish), which are very common in the iconography of early South Asia and are found in various Hindu, Buddhist, and Jain contexts on stūpa railings and coins. ${ }^{187}$ Artifacts from this shipwreck are indicators of regional connectivity and transport. Further excavations are expected to throw more light on shipbuilding and navigation technology. ${ }^{188}$

\section{Numismatic Sources}

This section is divided into three parts. The first section examines the development of numismatic studies in India. The second section focuses on some salient features of early historic coinage. And ends with a discussion on the importance of the contextual study of the coins, especially those coins found in areas outside their original circulation zone.

\section{VII.1 Numismatics}

The earliest numismatic studies are dated back to the early nineteenth century as a result of the antiquarian interests of the East India Company officials. ${ }^{189}$ One of the earliest attempts of categorizing and cataloguing the collections of early coins was by Alexander Cunningham in 1891. Within the next three decades, museums published five more catalogs of coins. ${ }^{190}$ In 1936, another catalog of pre-Gupta (prefourth century $\mathrm{CE}$ ) coins was compiled by John Allan, which is a comprehensive study of the symbols and legends on the coins of the British Museum collection. ${ }^{191}$ Even though these catalogs were published a long time ago, and many attributions have been questioned and revised, they are still foundational works. ${ }^{192}$ More recent

186 Muthucumarana et al. 2014, 54.

187 Allan 1936; S. Sharma 1990; Handa 2007.

188 Bopearachchi, Disanayaka, and Perera 2016, 411-412, 426.

189 For the brief survey of the development of numismatics in India, see Dwivedi 2015.

190 Dwivedi 2015, 218-219.

191 Allan 1936.

192 Some of the most prominent journals specifically dedicated to numismatic studies are, Numismatic Supplements to the Journal of Asiatic Society of Bengal (Calcutta), Journal of Numismatic Society of India (Varanasi), Numismatic Digest (Bombay, and later Nasik), Numismatic Chronicle (London), Indian Numismatic Chronicle (Patna), Oriental Numismatic Studies (Delhi), Studies in South Indian Coins (Madras/Chennai), Journal of the Academy of Indian Numismatics and Sigillography (Indore) and Numismatic Studies (Delhi). 
corpora include The coinage and history of southern India (2 vols.), ${ }^{193}$ Tribal coins of ancient India, ${ }^{194}$ Ancient trade and early coinage (2 vols.), ${ }^{195}$ Studies in the coinage of the Western Ksatrapas, ${ }^{196}$ and Coins and tokens from ancient Ceylon. ${ }^{197}$

The variety and complexity of the Indian monetary systems are challenging. While the number of coins in the monetary system must have been huge, the denominational structure and size of coin issues, let alone the volume of coins in circulation, is not yet understood. ${ }^{198}$ The absence of coin dies is another challenge in studying Indian monetary systems, as the identification of mint sites is mere speculation. ${ }^{199}$

The role of numismatics in mainstream ancient history thus remains marginal. The primary function of coins in archaeological contexts has been that of dating the archaeological layers or contexts in which they were found. But even this is possible only when the coins are recognizable. If corroded, base metal coins found in excavations often go unnoticed and are not recorded in excavation reports. ${ }^{200}$ Few excavation teams in India have trained numismatists among their members. As a result, lesser known coins remain unidentified and unknown. ${ }^{201}$ For example, the excavations at Rairh and Sanghol that have yielded large numbers of coins were not systematically reported, and thus have not been studied. Often, coins that come out of excavation are left uncleaned and end up in the artifact collection units of the excavation departments or other institutions involved in the excavation. ${ }^{202}$

\section{VII.2 Indic Coins}

The first coined money in the subcontinent, dated to the sixth and fifth centuries вСE, were the bent bar coins from the northwest region and the punch marked coins

193 Mitchiner 1998a.

194 Handa 2007.

195 Mitchiner 2004.

196 Jha and Rajgor 1994.

197 Walburg 2008.

198 However, for attempts at quantification, see R. S. Sharma 1968; Shrimali 1985, 86-87. For a discussion on the difficulty of any form of meaningful quantitative analysis in Indian history, see Chattopadhyaya 2003a, 218.

199 A. M. Shastri 1991. A punch mark die and a Roman coin die have been found from Karur, Tamil Nadu (Radhakrishnan 1994; Krishnamurthy 1996). Based on this find, many scholars have concluded that this could be a minting site, not only for the punch marked coins, but also of the Roman coins found in the subcontinent (Mitchiner 1998b, 72-77; Basu Majumdar 2017a, 405-406).

200 A. N. Lahiri 1990; Gupta 1987.

201 A. N. Lahiri 1990, 213.

202 The coins that came from the Rairh excavation were kept in trunks and gunny bags, and have not been made available for studies. A similar case is the coins excavated from Sanghol that are kept in the Rang Mahal Museum of Punjab, Punjab State Department of Archaeology. There are fewer attempts made to clean and catalog these coins, nor are they being scientifically preserved. 

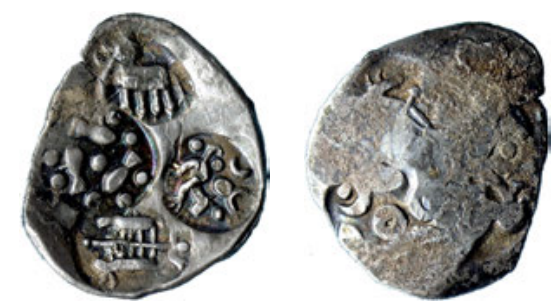

Fig. 2: An example of a silver PMC, Odisha, ca. sixth to third century BCE (not to scale). ANS 1972.30.10. (C) American Numismatic Society.

(PMC) with a wider circulations (fig. 2). ${ }^{203}$ Early coins were produced by three methods: punch marking, casting, and die striking. The die striking method appeared later than punch marking and casting. In punch marking, every symbol is punched separately, while in die striking all the symbols are carved on a single die and are struck on to the coin at once. ${ }^{204}$ Casting required molten metal to be poured into a cavity formed by joining two molds together. ${ }^{205}$

Extensive use of symbols and devices on coins is a common characteristic of Indian coinage tradition (fig. 3). ${ }^{206}$ Many symbols signify mangala (i.e., benediction and auspiciousness), which are also found on pottery, sculpture, and inscriptions. ${ }^{207}$ The function of these symbols has been much discussed. Some suggest that their purpose was to legitimize the coin issue, as some devices served as heraldic emblems. ${ }^{208}$ Others have suggested that they had some function in benediction, ${ }^{209}$ or were a succinct means of communication, as symbols can convey much within a very small space. ${ }^{210}$

Coins with legends, called inscribed in contrast to uninscribed, first appear in the second century BCE. The introduction of writing on coins was probably influenced by contemporary Western coins. ${ }^{211}$ From the second century BCE onward, a large number of coin issuing groups appeared in northern India. Their issues, known as tribal coins, circulated along with the Indo-Greek, Indo-Parthian, and Kuṣāṇa coins with overlaps in areas of circulation.

203 Cribb 2005; Morris, ch. 9, this volume.

204 Srivastava 2008.

205 Prakash and Singh 1968, 90-91.

206 Allan 1936; Mitchiner 1973; Cribb 2005. Fig. 3 is a biscriptual coin of Kunindas, attributed to Amoghabhūti (Handa 2007, 58-60). This coin is a good representative of extensive use of symbols and devices on Indic coins.

207 Many of these symbols date back to the Bronze Age (S. Sharma 1990; Cribb 2005, 16).

208 A. K. Jha 1991, viii.

209 Sarkar and Pande 1999, 2-3.

210 Y. Shastri 1999.

211 A. N. Lahiri 1964; Cribb 2005, 8. 

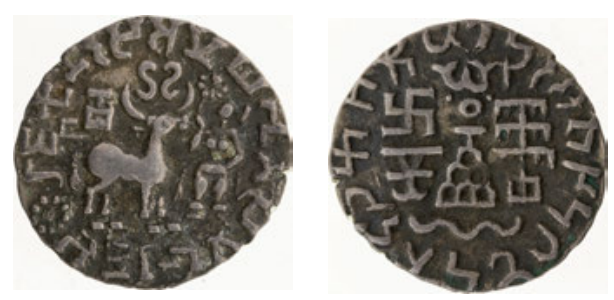

Fig. 3: Silver drachm of Amoghabhūti (Kuṇinda), 150-100 BCE (not to scale). ANS 1944.100.51664. () American Numismatic Society.

The coins of the Indo-Greeks, Indo-Parthians, and Kuṣāna regularly bore the names of rulers and certain deities. ${ }^{212}$ In contrast, the inscribed coins of indigenous issues had four types of inscription: (i) names of specific cities; ${ }^{213}$ (ii) guild names, naigama or negamā, gadhikānam; ${ }^{214}$ (iii) the name of a king, chief, or deity; ${ }^{215}$ and (iv) references to janasya, ganasya, or janapada, tying it to republican or clan-based society. ${ }^{216}$

Some coins reveal connections between different groups and regions. The northwestern coins of the Kunindas, Audumbaras, and Ārjunāyanas contain both Brāhmī and Kharoșthị scripts. ${ }^{217}$ In the Deccan, the Sātavāhanas also issued bilingual coins in Tamil and Prakrit, suggesting connections to the north as well as the south. ${ }^{218}$ The coin design of the Sātavāhanas, which featured a royal portrait on one side and a divine image on the other, is considered the result of Hellenistic influence. Some Sātavāhana also bear counter-strikes, which have been used to establish the relative chronology of the Kṣatrapa and Sātavāhana rulers in the first century CE. ${ }^{219}$ It is often believed that counter-striking was an indication of political rivalry, showing contestation of and superiority over the other ruler. But it could also have been an efficient means of continuing monetary supply when political authority changed legitimately. Counter-striking is a swift method of announcing political change to the money user without the need of melting down, refining, and refabricating the coins. This, however, has been more specifically found to be the case in the Kșatrapa and Sātvahana coins, where Nahāpana overstruck the Sātavāhana coins. Later, his coin issues were further overstruck by Gautamīputra Sātkarṇi (fig. 4). ${ }^{220}$

212 See Morris, ch. 9, this volume.

213 Allan 1936.

214 Bajpai 1976, 50, 52-53.

215 Shrimali 1985; Handa 2007; Bhandare 2016.

216 Allan 1936; Sharan 1972; Y. Shastri 1999; Handa 2007.

217 Allan 1936; Handa 2007.

218 Panneerselvam 1969; Thapar 2011, 583.

219 Cribb 2000, 43-46; Bhandare 2011.

220 Bhandare 1999, 39, 74-76, 134-136. 

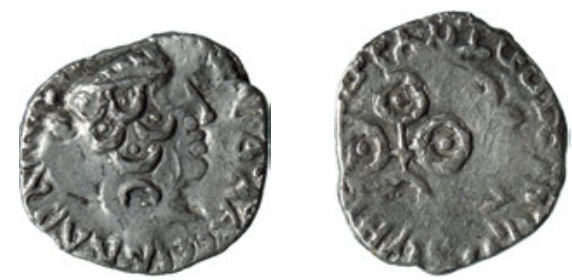

Fig. 4: Counter-struck silver drachm of Nahāpana/Gautamīputra, Girinagara, 119-126 CE (not to scale). ANS 1944.100.55902. @ American Numismatic Society.

The functionality of the monetary system in the early Indian context is based on the concept of continuity of coin design and not dependent on the issuing authority. ${ }^{221}$ As a result, various coins circulated long after the decline of the dynasties that issued them. There was probably also no royal monopoly on the issuing of coins. It has been argued that when dynastic authorities were not in a position to issue their own coins, local goldsmiths minted imitations in order to meet monetary demand.222 The longevity of circulation of a coin type and the issuance of similar coins is explained by local conservatism and a long monetary tradition. ${ }^{223}$ For example, the PMC circulated until well into the early medieval period. Some types of Mālavas, Sātavāhana, Kṣatrapas, and Kuṣāṇa coins circulated until the fourth and fifth centuries $\mathrm{CE}$ in crude imitation forms. ${ }^{224}$

\section{VII.3 Contexts of Coin Finds: Money, Treasure, and Ritual Objects}

Coins have been found as surface finds, in excavations, and in hoards. The discovery of coins in foreign contexts has various implications. However, their use as valid media of exchange is limited to a specific region. This regiospecificity is an inherent consequence of the monetary functions of coins. ${ }^{225}$ In the Indian subcontinent, however, coins are found in large numbers outside their regiospecific contexts, especially in the southern peninsula and Sri Lanka. Examples are Roman gold coins found in peninsular India and Sri Lanka, and the early north Indian inscribed and uninscribed coins found in Sri Lanka in large numbers. Given their large numbers, can

\footnotetext{
221 Cribb 2005, 14-16.
}

222 Sircar 1965, 207.

223 Sircar 1968, 206-208; Cribb 2005, 14-16.

224 Sircar 1968, 206-207; A. M. Shastri 1992, 292; Gokhale 2004, 109. An indicative if this tradition is also found in the PME. The PME $(47,9)$ mentions old drachms of the Indo-Greek kings Apollodotos and Menander (second century BCE) still in use at Barygaza in the first century CE.

225 Bhandare defines regiospecificity as "a numismatic phenomenon in which, for a given issuing authority, the type/types of the coins it issues are peculiar to a particular geographic area" (Bhandare 2006, 83-84). 
these be called coins in their foreign contexts? Did they have a monetary role as currency or as bullion? Or did they also fill extra-economic roles in the society? ${ }^{226}$

PMCs are often understood as all-purpose money. Based on the existence of silver-plated imitations of the northern issues, it is evident that the northern PMCs influenced Sri Lankan ones. Like genuine PMCs, these may have circulated alongside locally produced ingots, suggesting that both had monetary functions. The monetary role of the PMCs in Sri Lanka is also attested in inscriptions and texts by the regular use of the terms kahāpana (Pali) and kahāvana (Sinhalese). ${ }^{227}$ Kahāpana (Skt. kārșāpana) is a commonly used term in India that connotes a quantifiable monetary unit. Many Sātavāhana inscriptions refer to payments in certain numbers of kahāpanas.

While the PMCs may have been all-purpose money, other coin types from mainland India and Rome may not have had monetary functions. ${ }^{228}$ The presence of coin-like objects may not always mean the presence of a monetary economy, or more precisely, the use of those coin-like objects as money. Nonmonetary functions of these coins can be identified based on the coins themselves and the context in which they were found. ${ }^{229}$ More specifically, the inscribed and uninscribed coins found in Sri Lanka may have been ornaments, since a standard weight pattern cannot be established. These coin-like objects are made of pure lead, which is easy to cast, were possibly cast at a very small scale in households or on individual request by goldsmiths and silversmiths.

The situation of inscribed and uninscribed coins in Sri Lanka is different from that in India. First, coins found in India are made of copper and lead alloys, which require specialized skill in metal working as well as furnaces attaining the high melting temperature needed for alloy manufacture. Second, the casting methods used in India could produce greater numbers of coins than in Sri Lanka, where we find molds for casting only one or eight coins at a time. Furthermore, the presence of a large variety of other lead artifacts and of miniature objects made of bronze and silver at Anuradhapura has been used to show the nonmonetary role of the coin-like objects. That coins are commonly found in the ritual contexts, such as stūpa deposits or in relic caskets, highlights their religious functions as well. ${ }^{230}$

The case of Roman coins in India raises similar questions. Roman coins have been of great interest since the beginning of antiquarian studies in the late eighteenth century. An important corpus had already been assembled by $1904 .{ }^{231}$ Roman and Byzantine coins found in India date from as early as the Augustan period

226 For bibliographic details on the study of Roman coins found in India and its impact on the questions of Indo-Roman trade, see Darley 2015.

227 Walburg 2008, 46-48, 307-310.

228 Walburg 2005, 2008, 307-317.

229 Walburg 2008, 108-114.

230 Walburg 2005, 42-108.

231 Sewell (1904) 1997. See also Turner 1989. 
(27 BCE-14 CE) to as late as the rule of Leo III (the eighth century CE). ${ }^{232}$ The coins most commonly found are silver denarii of Augustus and Tiberius, alongside gold aurei of the first to second centuries and solidi of the fifth century. ${ }^{233}$ Four features are common to Roman coins in South Asia: slash marks; countermarks, often identified as small punch marks; piercing or perforation for ornamental use and; imitations using gold or silver plating over a copper or lead core. They have been reported from almost 170 sites. The limited number of finds of Roman coins from the northern region comes from Buddhist stüpa deposits. In southern regions, they have been found in hoards as well.

The contextualization of the Roman coin finds reveals their relationship with Buddhist sites and local bodies of water. ${ }^{234}$ Further, they suggest that the role of the Roman coins in the subcontinent did not remain the same over centuries. Rather, the coins of the fourth century CE exhibit closer relationships with sacred sites than those of the three preceding centuries. The discovery of coins in ritual contexts, however, does not suggest that coins ceased to be of any economic value. Rather, it suggests that the society of the early historic and early medieval India allows for a fuzzy distinction between economic, ritual, and social contexts. ${ }^{235}$

\section{Conclusion}

We started with a discussion of literary sources, which were theological in nature. Even the archaeological, epigraphic, and numismatic sources have very close connections with religion and religious practices. The archaeological and architectural remains are primarily related to religious structures (stūpas and megalithic burial remains), even the indicators of urbanism (i.e., burnt brick structures, coins, inscriptions, and sculptures). In the South Asian context, these varied sources above all allow us to study economic processes with regard to social values and beliefs that underwrite ritual practices, thus highlighting the interconnectedness between ritual and economic activities. The study of economic history in South Asia, therefore, requires one to adopt the approach of 'ritual economy.' This approach emphasizes the interdependence of economy, power, and human agency as contributors to society and social change. ${ }^{236}$

232 Bhatia 1997, 667-669.

233 Ray 2008, 194, 197.

234 Darley 2015.

235 Darley 2015.

236 More about the concept of ritual economy and the need for this approach may be found in Wells and McAnany 2012; Hardenberg 2017. 


\section{References}

Adluri, V., and J. Bagchee. 2014. The nay science: A history of German Indology. Oxford: Oxford University Press.

Agnew, N., ed. 1997. Conservation of ancient sites on the Silk Road: Proceedings of an international conference on the conservation of grotto sites. Los Angeles, CA: Getty Conservation Institute.

Allan, J. 1936. Catalogue of coins of ancient India in the British Museum. London: British Museum. Babington, J. 1823. "Descriptions of the Pandoo coolies of Malabar." Transactions of the Literary Society of Bombay 3, 324-330.

Bajpai, K. D. 1976. Indian numismatic studies. New Delhi: Abhinav.

Bandaranayake, S. 1997. “The Dambulla rock temple complex, Sri Lanka.” In Agnew (1997), 46-55.

Basant, P. K. 2012. The city and the country in early India: A study of Malwa. New Delhi: Primus.

Basu Majumdar, S. 2017a. "Money matters: Indigenous and foreign coins in the Malabar coast (second century BCE-second century CE)." In Mathew (2017a), 395-423.

-. 2017b. "State formation and religious processes in the north-south corridor of Chhattisgarh (from first century BC to eight century AD)." Studies in People's History 4.2, 119-129.

Bauer, A. M. 2015. Before Vijayanagara: Prehistoric landscapes and politics in the Tungabhadra basin. New Delhi: Manohar.

Begley, V. 1988. "Rouletted ware at Arikamedu: A new approach.” American Journal of Archaeology 92.3, 427-440.

-. 1992. "Ceramic evidence for pre-Periplus trade on the Indian coasts." In V. Begley and R. D. de Puma (eds.), Rome and India: The ancient sea trade, 157-196. Delhi: Oxford University Press.

Behrendt, K. 2003. The Buddhist architecture of Gandhära. Leiden: Brill.

Bhandare, S. 1999. "Historical analysis of the Satvahana era: A study of coins." PhD diss., University of Mumbai.

-. 2006. "Numismatics and history: The Maurya-Gupta interlude in the Gangetic plain." In P. Olivelle (ed.), Between the empires: Society in India 300 BCE to 400 CE, 67-112. Oxford: Oxford University Press.

-. 2011. "Linking the past: Overstruck coins and the chronology of the Satvahanas." In S. Bhandare and S. Garg (eds.), Felicitas: Essays in numismatics, epigraphy and history in honour of Joe Cribb, 53-63. Mumbai: Reesha Books International.

-. 2016. "Money and the monuments: Coins of the Sada dynasty of the coastal Andhra region." In A. Shimada and M. D. Willis (eds.), Amaravati: The art of an early Buddhist monument in context, 37-45. London: British Museum.

Bhatia, P. 1997. "Roman and Byzantine coin-finds from India, Pakistan and Afghanistan." In F. R. Allchin and D. K. Chakrabarti (eds.), A source-book of Indian archaeology. Vol. 2, 666-708. New Delhi: Munshiram Manoharlal.

Bopearachchi, O., S. Disanayaka, and N. Perera. 2016. "The oldest shipwreck in the Indian Ocean.” In M.-F. Boussac, J.-F. Salles, and J.-B. Yon (eds.), Ports of the ancient Indian Ocean, 411-434. Delhi: Primus.

Bopearachchi, 0., and R. M. Wickremesinhe. 1999. Ruhuna: An ancient civilization re-visited: Numismatic and archaeological evidence on inland and maritime trade. Nugegoda: R. M. Wickremesinhe.

Borgolte, M., ed. 2014. Enzyklopädie des Stiftungswesens in mittelalterlichen Gesellschaften. Vol. 1, Grundlagen. Berlin: De Gruyter.

Brancaccio, P. 2011. The caves at Aurangabad: Transformations in art and religion. Leiden: Brill.

Brockington, J. L. 1998. The Sanskrit epics. Leiden: Brill.

Bronkhorst, J. 2001. “Etymology and magic: Yāska's Nirukta, Plato's Cratylus, and the riddle of semantic etymologies." Numen 48.2, 147-203.

Bühler, G. 1886. The laws of Manu. Delhi: Motilal Banarsidass. 
Chakrabarti, D. K. 1988. A history of Indian archaeology from the beginning to 1947. New Delhi: Munshiram Manoharlal.

-. 1992. The early use of iron in India. New Delhi: Oxford University Press.

-. 1995. "Buddhist sites across South Asia as influenced by political and economic forces." World Archaeology 27.2, 185-202.

-. 1997. Colonial Indology: Sociopolitics of the ancient Indian past. New Delhi: Munshiram Manoharlal.

Chakravarti, R. 1996. "Kutumbikas of early India." In V. K. Thakur and A. Aounshuman (eds.), Peasants in Indian history. Vol. 1, 179-198. Patna: Janaki Prakashan.

-. 2009. "Relationship and interactions in the economic sphere." In B. D. Chattopadhyaya (ed.), History of science, philosophy and culture in Indian civilization. Vol. 2.5, 129-156. Delhi: Pearson Longman.

-. 2016. Exploring early India: Up to c. $A D$ 1300. 3rd ed. New Delhi: Primus.

Champakalakshmi, R. 1996. Trade, ideology and urbanization: South India 300 BC to AD 1300. Delhi: Oxford University Press.

Chattopadhyaya, B. D. (1988-1989) 2003a. "Trends of research on ancient Indian economic history." In Studying early India: Archaeology, texts and historical issues, 159-171. Originally published in Journal of Ancient Indian History. New Delhi: Permanent Black.

-. 2003b. "Urban centres in early Bengal: Archaeological perspectives." In Studying early India: Archaeology, texts and historical issues, 47-71. New Delhi: Permanent Black.

Cherian, P. J. 2011. "Pattanam archaeological site: The wharf context and the maritime exchanges." In M. Staniforth (ed.), The 2011 Asia-Pacific Regional Conference on Underwater Cultural Heritage Proceedings. The MUA (Museum of Underwater Archaeology) Collection. http://www.themua.org/collections/items/show/1204.

Chhabra, B. C. 1949-1950. "Peshawar potsherds with Kharoshthi writings." Epigraphia Indica 28, 449-453.

Coningham, R. A. E. 1995. "Monks, caves and kings: A reassessment of the nature of early Buddhism in Sri Lanka." Buddhist Archaeology 27.2, 222-242.

-, ed. 1999. Anuradhapura: The British-Sri Lankan excavations at Anuradhapura Salagha Watta 2. Vol. 1, The site. Oxford: Archaeopress.

-, ed. 2006. Anuradhapura: The British-Sri Lankan excavations at Anuradhapura Salgaha Watta 2. Vol. 2, The artefacts. Oxford: Archaeopress.

Coningham, R. A. E., F. R. Allchin, C. M. Batt, and D. Lucy. 1996. "Passage to India? Anuradhapura and the early use of the Brahmi script." Cambridge Archaeological Journal 6.1, 73-97.

Coningham, R. A. E., L. Ford, S. Cheshire, and R. Young. 2006. "Unglazed ceramics." In Conningham (2006), 127-331.

Coningham, R. A. E., C. Knusel, and S. Mann. 2006. "Human remains.” In Conningham (2006), 619-627.

Coomaraswamy, A. K. 1935. La sculpture de Bodhgayā. Paris: Éditions d'art et d'histoire.

-. 1956. La sculpture de Bharhut. Paris: Vanoest.

Cowell, E. B., ed. (1895-1907) 1957. The Jātaka, or stories of the Buddha's former births: Translation from the Pāli by various hands under the editorship of E. B. Cowell. 6 vols. London: Luzac.

Cribb, J. 2000. "Early Indian history." In M. Willis (ed.), Buddhist reliquaries from ancient India, 39-54. London: British Museum.

-. 2005. The Indian coinage tradition: Origins, continuity and change. Nashik: Indian Institute of Research in Numismatic Studies.

Daniélou, A., trans. 1994. The complete Kāma Sūtra. Rochester, VT: Park Street.

Darley, R. 2015. "Self, other and the use and appropriation of Late Roman coins in peninsular India (4th to 7th centuries CE)." In H. P. Ray (ed.), Negotiating cultural identity: Landscapes in early medieval South Asian history, 60-84. New Delhi: Routledge. 
Dehejia, V. 1990. "On modes of visual narration in early Buddhist art." Art Bulletin 72.3, 374-392.

-. 1992. "The collective and popular basis of early Buddhist patronage: Sacred monuments, 100 BC-AD 250." In B. S. Miller (ed.), The powers of art: Patronage in Indian culture, 35-45. Delhi: Oxford University Press.

-. 2007. "Questioning narrativity and inscribed labels: Buddhist Bharhut, Sannati, and Borobudur." In H. P. Ray (ed.), Sacred landscapes in Asia: Shared traditions, multiple histories, 285-308. New Delhi: Manohar.

Deraniyagala, S. U. 1972. "The citadel of Anuradhapura 1969: Excavations in the Gedige area." Ancient Ceylon 11, 149-168.

Derrett, J. D. M. 1957. "The right to earn in ancient India: A conflict between expediency and authority." Journal of the Economic and Social History of the Orient 1.1, 66-97.

-. 1973. A history of Indian literature. Vol. 5.1, Dharmaśästra and juridical literature. Wiesbaden: Harrassowitz.

Desai, D. 1985. Erotic sculpture of India: A socio-cultural study. 2nd ed. New Delhi: Munshiram Manoharlal.

Devadevan, M. V. 2006. "Lying on the edge of the burning ground: Rethinking Tinais." Journal of the Economic and Social History of the Orient 49.2, 199-218.

Devendra, S., and R. Muthucumarana. 2013. "Maritime archaeology and Sri Lanka: Globalization, immigration, and transformation in the underwater archaeological record." Historical Archaeology 47.1, 50-65.

Doniger, W. 2003. “The Kamasutra: It isn't all about sex." Kenyon Review 25.1, 18-37.

Doniger, W., and S. Kakar, trans. 2002. Vatsyayana Kamasutra. Oxford: Oxford University Press.

Doniger, W., and B. K. Smith, trans. 1991. The laws of Manu: With an introduction and notes. London: Penguin.

Dwivedi, M. 2015. "Colonial imagination and identity attribution: Numismatic cues for defining space.” In H. P. Ray (ed.), Negotiating cultural identity: Landscapes in early medieval South Asian history, 206-238. New Delhi: Routledge.

-. 2016. "Understanding Artha: Pursuit of wealth in the Ganga-Yamuna Doab." PhD diss., Jawaharlal Nehru University.

Endo, T. 1987. Dāna: The development of its concept and practice. Colombo: Gunasena.

Falk, H. 1998. The discovery of Lumbinī. Lumbini: Lumbini International Research Institute.

-. 2008. "Money can buy me heaven: Religious donations in late and post-Kushan India." Archäologische Mitteilungen aus Iran und Turan 40, 137-148.

-. 2006. Aśokan sites and artefacts: A source-book with bibliography. Mainz: Philipp von Zabern.

-. 2009. "The pious donation of wells in Gandhara." In G. J. R. Mevissen and A. Banerji (eds.), Prajñādhara: Essays on Asian art, history, epigraphy and culture in honour of Gouriswar Bhattacharya, 23-36. New Delhi: Kaveri.

Fausböll, V., and R. Davids, trans. 1877-1897. The Jātaka together with its commentary being tales of the anterior births of Gotama Buddha. 7 vols. London: Trübner.

Findly, E. B. 2003. Dāna: Giving and getting in Pali Buddhism. Delhi: Motilal Banarsidass.

Fogelin, L. 2015. An archaeological history of Indian Buddhism. Oxford: Oxford University Press.

Ford, L. A., A. M. Pollard, R. A. E. Coningham, and B. Stern. 2005. "A geochemical investigation of the origin of rouletted and other related South Asian fine wares." Antiquity 79.306, 909920.

Gaur, A. S., R. Muthucumaran, W. M. Chandraratne, B. C. Orillandeda, M. Manders, S. Karunarathna, P. Weerasinghe, A. M. A. Dayananda, T. Zainab, A. Sudaryadi, K. B. A. Ghani, J. Wahjudin, and N. Samaraweera. 2011. "Preliminary assessment of an early historic (2000 year old) shipwreck at Godawaya, Sri Lanka." Bulletin of the Australasian Institute for Maritime Archaeology 35, 9-17.

Gaur, A. S., Sundaresh, and S. Tripati. 2004. "An ancient harbour at Dwarka: Study based on the recent underwater explorations." Current Science 86.9, 1256-1260. 
-. 2006. "Evidence for Indo-Roman trade from Bet Dwarka Waters, west coast of India." International Journal of Nautical Archaeology 35.1, 117-127.

Gokhale, V. D. 2004. "Coins from the excavation at Sanjan - 2002." Journal of Indian Ocean Archaeology 1, 107-112.

Guha-Thakurta, T. 2004. Monuments, objects, histories: Institutions of art in colonial and postcolonial India. New York, NY: Columbia University Press.

Gupta, P. L. 1987. "Numismatists and archaeologists." Puratattva 18, 85-88.

Gurukkal, R. 1993. "Towards the voice of dissent: Trajectory of ideological transformation in early South India." Social Scientist 21.1-2, 2-22.

Handa, D. 2007. Tribal coins of ancient India. New Delhi: Aryan Books International.

Hardenberg, R., ed. 2017. Approaching ritual economy: Socio-cosmic fields in globalised contexts. Tübingen: University of Tübingen.

Hart, G. L., and H. Heifetz, trans. 2002. The four hundred songs of war and wisdom: An anthology of poems from classical Tamil: The Purananuru. New York, NY: Columbia University Press.

Härtel, H. 1993. Excavations at Sonkh: 2500 years of a town in Mathura District. Berlin: Reimer.

Hawkes, J., and A. Shimada. 2009. "Approaches to the study of Buddhist stūpas: An introduction." In J. Hawkes and A. Shimada (eds.), Buddhist stupas in South Asia: Recent archaeological, art-historical, and historical perspectives, xi-xli. New Delhi: Oxford University Press.

Hiltebeitel, A. 1998. "Empire, invasion, and India's national epics." International Journal of Hindu Studies 2.3, 387-421.

-. 2011. Dharma: Its early history in law, religion, and narrative. Oxford: Oxford University Press.

Horsch, P. 1967. "From creation myth to world law: The early history of Dharma." J. L. Whitaker (trans.). Journal of Indian Philosophy 32.5/6, 423-448.

Jayaswal, K. P., and R. D. Banerji. 1929. "The Hathigumpha inscription of Kharavela." Epigraphia Indica 20, 71-89.

Jayaswal, V. 2009. Ancient Varanasi: An archaeological perspective (excavations at Akhta). New Delhi: Aryan Books International.

Jettmar, K., ed. 1989. Antiquities of northern Pakistan: Reports and studies. Vol. 1, Rock inscriptions in the Indus valley: Text. Mainz: Philipp von Zabern.

Jha, A., and D. Rajgor. 1994. Studies in the coinage of the Western Ksatrapas. Nashik: Indian Institute of Research in Numismatic Studies.

Jha, A. K. 1991. "Introductory address." In A. K. Jha (ed.), Coinage, trade and economy: 3rd International Colloquium, January 8th-11th 1991, vii-x. Nashik: Indian Institute of Research in Numismatic Studies.

Jolly, J., and R. Schmidt, trans. 1923. Arthaśāstra of Kautilya. Lahore: Moti Lal Banarsi Das.

Juleff, G. 1998. "Ancient iron and steel production at Samanalawewa." Sabaragamuwa University Journal 1.1, 3-9.

Kane, P. V. 1968. History of Dharmaśāstras. 5 vols. Poona: Bhandarkar Oriental Research Institute. Kangle, R. P. (1960) 2014a. The Kauțilīya Arthaśāstra. 2nd ed. Vol. 1, Sanskrit text with a glossary. Delhi: Motilal Banarsidass.

-. (1965) 2014b. The Kauțilīya Arthaśāstra. 2nd ed. Vol. 3, A Study. Delhi: Motilal Banarsidass. Kaul, S 2011. Imagining the urban: Sanskrit and the city in early India. London: Seagull.

Krishna Rao, M. V. 1953. Studies in Kautilya. Mysore: H. Venkataramiah.

Krishnamurthy, R. 1996. "A Roman coin die from Karur, Tamil Nadu.” Studies in South Indian Coins 6, 43-48.

Krishnan, K., and R. Balvally. 2017. "Assessing the early historic Indian Ocean trade through ceramics." In Mathew (2017a), 231-268.

Lahiri, A. N. 1964. "Who struck the first Indo-Greek bilingual coin." Proceedings of the Indian History Congress 26, 142-149. 
-. 1990. "What the numismatist expects from archaeologists." In A. Ray and S. Mukherjee (eds.), Historical archaeology of India: A dialogue between archaeologists and historians, 1-3. Delhi: Books \& Books.

Lahiri, N. 1992. The archaeology of Indian trade routes up to c. 200 BC: Resource use, resource access and lines of communication. Delhi: Oxford University Press.

Lal, M. 1984. Settlement history and rise of civilization in Ganga-Yamuna Doab (from 1500 BC to 300 AD). Delhi: B. R. Publishing.

Leshnik, L. S. 1974. South Indian 'megalithic' burials: The Pandukal complex. Wiesbaden: Franz Steiner.

Malamoud, C. 1982. "On the rhetoric and semantics of purușārtha." In T. N. Madan (ed.), Way of life: Kings, householder, renouncer: Essays in honour of Louis Dumont, 33-54. New Delhi: Vikas.

Manavalan, A. A. 2014. "The Cańkam literature." In T. R. S. Sharma (2014a), 40-68.

Marshall, J., A. Foucher, and N. G. Majumdar. (1940) 1983. The monuments of Sāñchī. Vol. 1, Text. Delhi: Swati.

Mathew, K. S. ed. 2017a. Imperial Rome, Indian Ocean regions and Muziris: New perspectives on maritime trade. London: Routledge.

-. 2017b. "Introduction." In Mathew (2017a), 9-30.

McClish, M. 2009. "Political Brahmanism and the state: A compositional history of Arthaśāstra." PhD. diss., University of Texas.

-. 2012. "Is the Arthaśāstra a Mauryan document?" In P. Olivelle, J. Leoshko, and H. P. Ray (eds.), Reimagining Aśoka: Memory and history, 280-309. New Delhi: Oxford University Press.

Menon, J. 2008. "Archaeology of early historic South Asia: A review." In G. Sengupta and S. Chakraborty (eds.), Archaeology of early historic South Asia, 313-336. New Delhi: Pragati and Centre for Archaeological Studies and Training.

Menon, S. M. 2018. "Megaliths: New perspectives for future studies." In R. Korisettar (ed.), Beyond stones and more stones: Defining Indian prehistoric archaeology. Vol 2, 208-256. Bangalore: Mythic Society.

Mishra, S. C. 1989. "A historiographical critique of the Arthaśāstra of Kauțilya.” Annals of the Bhandarkar Oriental Research Institute 70.1/4, 145-162.

Mitchiner, M. 1973. The origins of Indian coinage. London: Hawkins.

-. 1998a. The coinage and history of southern India. Part 1, Karnataka - Andhra. London: Hawkins.

-. 1998b. The coinage and history of southern India. Part 2, Tamil Nadu - Kerala. London: Hawkins.

-. 2004. Ancient trade and early coinage. 2 vols. London: Hawkins.

Morrison, K. D. 1997. "Commerce and culture in South Asia: Perspectives from archaeology and history." Annual Review of Anthropology 26, 87-108.

Muthucumarana, R., A. S. Gaur, W. M. Chandraratne, M. Manders, B. R. Rao, R. Bhushan, V. D. Khedekar, and A. M. A. Dayananda. 2014. "An early historic assemblage offshore of Godawaya, Sri Lanka: Evidence for early regional seafaring in South Asia." Journal of Maritime Archaeology 9.1, 41-58.

Nath, V. 1987. Dāna: Gift system in ancient India (c. 600 BC-c. AD 300): A socio-economic perspective. Delhi: Munshiram Manoharlal.

Neelis, J. 2000. "Kharoștị and Brāhmī inscriptions from Hunza-Haldeikish: Sources for the study of long-distance trade and transmission of Buddhism." In M. Taddei and G. De Marco (eds.), South Asian archaeology 1997: Proceedings of the fourteenth international conference of the European Association of South Asian Archaeologists, held in the Istituto italiano per l'Africa e l'Oriente, Palazzo Brancaccio, Rome, 7-14 July 1997. Vol. 2, 903-923. Rome: Istituto italiano per l'Africa e l'Oriente.

Olivelle, P. 1993. The Āśrama system: The history and hermeneutics of a religious institution. Oxford: Oxford University Press. 
-, trans. 1999. Dharmasūtras: The law codes of Āpastamba, Gautama, Baudhāyana, and Vasiștha. Oxford: Oxford University Press.

-, trans. 2005. Manu's code of law: A critical edition and translation of the Mānava-

Dharmaśāstra. Oxford: Oxford University Press.

-. 2006. "Explorations in the early history of the Dharmaśāstras." In P. Olivelle (ed.), Between the empires: Society in India 300 BCE to 400 CE, 169-190. Oxford: Oxford University Press.

-, ed. 2009. Dharma: Studies in its semantic, cultural and religious history. Delhi: Motilal Banarsidass.

-. 2012. "Material culture and philology: Semantics of mining in ancient India." Journal of the American Oriental Society 132.1, 23-30.

-, trans. 2013. King, governance, and law in ancient India: Kauțilya’s Arthaśāstra. Oxford: Oxford University Press.

Olivelle, P., D. Brick, and M. McClish, eds. 2015. A Sanskrit dictionary of law and statecraft. Delhi: Primus.

Panneerselvam, R. 1969. "Further light on the bilingual coin of the Sātavāhanas." Indo-Iranian Journal 11.4, 281-288.

Pavan, A., and H. Schenk. 2012. "Crossing the Indian Ocean before the Periplus: A comparison of pottery assemblages at the sites of Sumhuram (Oman) and Tissamaharama (Sri Lanka)." Arabian Archaeology and Epigraphy 23.2, 191-202.

Pollock, S. 1985. "The theory of practice and the practice of theory in Indian intellectual history." Journal of the American Oriental Society 105.3, 499-519.

Poonacha, K. P. 2013. Excavations at Kanaganahalli (Sannati), Taluk Chitapur, Dist. Gulbarga, Karnataka. New Dehli: Director General, Archaeological Survey of India.

Prakash, S., and R. Singh. 1968. Coinage in ancient India: A numismatic, archaeochemical and metallurgical Study of ancient Indian coins. New Delhi: Research Institute of Ancient Scientific Studies.

Premathilake, R., K. Anupama, K. Rajan, K. Prasad, G. Orukaimani, and V. P. Yathees Kumar. 2017. "Implications of phytolith records from an early historic megalithic burial site at Porunthal in southern India." Journal of Archaeological Science: Reports 11, 491-506.

Quintanilla, S. R. 2007. History of early stone sculpture at Mathura, ca. 150 BCE-100 CE. Leiden: Brill.

Radhakrishnan, P. 1994. "A punch marked die from Karur." Studies in South Indian Coins 4, 51-56.

Rajan, K. 2015. Early writing system: A journey from graffiti to Brāhmī. Madurai: Pandya Nadu Centre for Historical Research.

Ramanna, H. S. 1983. Megaliths of South India and South East Asia: A comparative study. Madras: New Era Publications.

Ramaswamy, T. N. 1962. Essentials of Indian statecraft: Kautilya's Arthasastra for contemporary readers. New York, NY: Asia Publishing House.

Ratnayake, H. 1984. Jetavanaramaya project, Anuradhapura: First archaeological excavation and research report. Colombo: Central Cultural Fund, Ministry of Cultural Affairs.

Rathbone, D. 2001. "The 'Muziris' papyrus (SB XVIII 13167): Financing Roman trade with India." In M. Abd-el-Gani, S. Z. Bassiouni and W. A. Faray (eds.), Alexandrian Studies II in Honor of Mostafa el Abbadi, 39-50. Alexandria: Société d'Archéologie d'Alexandrie.

Ray, H. P. 1987. "Early historical urbanization: The case of the Western Deccan.” World Archaeology 19.1, 94-104.

-. 1988. "Yavana presence in ancient India." Journal of Economic and Social History of the Orient 20, 311-325.

-. 1994. "Kanheri: The archaeology of an early Buddhist pilgrimage centre in western India." World Archaeology 26.1, 35-46. 
-, ed. 2007. Sacred landscapes in Asia: Shared traditions, multiple histories. New Delhi: Manohar.

-. 2008. Colonial archaeology in South Asia: The legacy of Sir Mortimer Wheeler. New Delhi: Oxford University Press.

-. 2018. Archaeology and Buddhism in South Asia. London: Routledge.

Ray, H. P., and H. Achyuthan. 2010. “Defining 'Kushan' pottery.” In H. P. Ray (ed.), Sanghol and the archaeology of Punjab, 128-142. New Delhi: Aryan Books International.

Ray, H. P., and S. Mishra. 2018. "Introduction.” In Bibliography on Sailing to Suvarnabhumi. AIC-RIS. http://ris.org.in/aic/bibliography.

Rea, A. 1904a. "An account of excavation conducted during the year 1903-04." Annual Report of Archaeological Survey of India 1, 18-25.

-. 1904b. "Prehistoric antiquities in Tinnevelly." Annual Report of Archaeological Survey of India 1, $111-140$.

Reddy, A. L. 2016. "Archaeology of Indo-Gulf relations in the early historic period: The ceramic evidence." In H. P. Ray (ed.), Bridging the Gulf: Maritime cultural heritage of the western Indian Ocean, 53-78. New Delhi: Manohar.

Reddy, P. K. M. 1998. “God, trade and worship: A glimpse into the religion of early Āndhradeśa." East and West 48.3/4, 291-311.

Rocher, L. 1985. “The Kāmasūtra: Vātsyāyana's attitude toward Dharma and Dharmaśāstra.” Journal of the American Oriental Society 105.3, 521-529.

Roy, K. 1996. “Unravelling the Kāmasūtra." Indian Journal of Gender Studies 3.2, 155-170.

Salomon, R. 1991. "Epigraphic remains of Indian traders in Egypt." Journal of the American Oriental Society 111.4, 731-736.

-. 1998. Indian epigraphy: A guide to the study of inscriptions in Sanskrit, Prakrit, and the other IndoAryan languages. Oxford: Oxford University Press.

Sarkar, H., and B. M. Pande. 1999. Symbols and graphic representation in Indian inscriptions. New Delhi: Aryan Books International.

Sastri, H. 1925. "Brahmi inscription on a wooden pillar from Kirari." Epigraphia Indica 18, 152-157.

Sastri, K. A. N. 1955. A history of South India: From prehistoric times to the fall of Vijayanagara. Delhi: Oxford University Press.

Schenk, H. 2015. "Role of ceramics in the Indian Ocean maritime trade during the early historical period." In S. Tripati (ed.), Maritime contacts of the past: Deciphering connections amongst communities, 143-181. New Delhi: Delta Book World.

Schopen, G. 2004. "What's in a name: The religious functions of the early donative inscriptions." In Buddhist monks and business matters: Still more papers on monastic Buddhism in India, 382394. Honolulu, HI: University of Hawai'i Press.

Selby, M. A. 2008. "Representations of the foreign in classical Tamil literature." In G. Parker and C. M. Sinopoli (eds.), Ancient India in its wider world, 79-90. Ann Arbor, MI: University of Michigan Press.

Selvakumar, V. 2006. "Public archaeology in India: Perspectives from Kerala." India Review 5.3/4, 417-446.

Senart, E. 1905. "The inscriptions in the caves of Nasik." Epigraphia Indica 8, 59-96.

Sewell, R. (1904) 1997. "Roman coins found in India." In F. R. Allchin and D. K. Chakrabarti (eds.), A source-book of Indian archaeology. Vol. 2, Settlement, technology and trade, 617-647. Originally published in Journal of the Royal Asiatic Society. New Delhi: Munshiram Manoharlal.

Shamasastry, R., and V. Narain, eds. 1915. Kauțilīya Arthaśāstra. Mysore: Sri Raghuvir.

Sharan, M. K. 1972. Tribal Coins: A study: The Yaudheyas, the Mālavas, the Audumbaras, and the Kunindas. Bodh Gaya: Abhinav.

Sharma, R. C. 1989. “New inscriptions from Mathura." In D. M. Srinivasan (ed.), Mathurāa: The cultural heritage, 308-315. New Delhi: Manohar.

Sharma, R. S. 1968. "Coins and problems of early Indian economic history." Proceedings of the Indian History Congress 30, 103-109. 
Sharma, S. 1990. Early Indian symbols: Numismatic evidence. Delhi: Agam Kala Prakashan.

Sharma, T. R. S., ed. 2014a. Ancient Indian literature: An anthology. Vol. 3, Tamil and Kannada. New Delhi: Sahitya Akademi.

-. 2014b. “Tolkāppiyam.” In T. R. S. Sharma (2014a), 71-72.

Shastri, A. M. 1991. "Presidential address." In A. K. Jha (ed.), Coinage, trade and economy: 3rd International Colloquium, January 8th-11th 1991, xi-xxiii. Nashik: Indian Institute of Research in Numismatic Studies..

-, ed. 1992. The age of the Vākātakas. New Delhi: Herman Publishing House.

Shastri, Y. 1999. Prācīna Bhārata Mem Yaudheya Ganarājya. New Delhi: Prachīn Bharatīya Shodha Parișad.

Shaw, J., and J. V. Sutcliffe. 2003. "Water management, patronage networks and religious change: New evidence from the Sanchi Dam complex and counterparts in Gujarat and Sri Lanka." South Asian Studies 19.1, 73-104.

Shrimali, K. M. 1985. History of the Pañcāla, Vol. 1, A study. New Delhi: Munshiram Manoharlal.

Singh, U. 1996. "Sanchi: The history of the patronage of an ancient Buddhist establishment." Indian Economic and Social History Review 33.1, 1-35.

-. 2004a. "Cults and shrines in early historical Mathura (c. 200 BC-AD 200)." World Archaeology 36.3, 378-398.

-. 2004b. The discovery of ancient India: Early archaeologists and the beginnings of archaeology. Delhi: Permanent Black.

Sircar, D. C. 1965. Select inscriptions bearing on Indian history and civilization. 2nd ed. Vol. 1, From the 6 th century $B C$ to the 6 th century $A D$. Delhi: Motilal Banarsidass.

-. 1968. Studies in Indian coins. Delhi: Motilal Banarsidass.

-. 1979. Aśokan studies. Calcutta: Indian Museum.

Skilling, P., ed. 2008. Past lives of the Buddha: Wat Si Chum: Art, architecture, and inscriptions. Bangkok: River Books.

Smith, M. L. 2006. "The archaeology of South Asian cities." Journal of Archaeological Research 14.2, 97-142.

Smith, V. A. 1908. The early history of India. 2nd ed. Oxford: Clarendon.

Srinivas lyengar, P. T. 1929. History of the Tamils: from the earliest times to 600 AD. Madras: C. Coomarasawmy Naidu and Sons.

Srinivasan, S., and S. Ranganathan. 2004. India's legendary wootz steel: An advanced material of the ancient world. Bangalore: National Institute of Advanced Studies and Indian Institute of Science.

Srivastava, P. 2008. "Die striking mode of fabrication of coins: Its origin in India." Journal of the Numismatic Society of India 70, 28-31.

Stoneman, R. 2019. The Greek experience of India: From Alexander to the Indo-Greeks. Princeton, N): Princeton University Press.

Straube, M. 2015. “Narratives: South Asia.” In J. A. Silk (ed.), Brill's encyclopedia of Buddhism. Vol. 1, Literature and Languages, 489-506. Leiden: Brill.

Strauch, I. 2008. "The Bajaur collection of Kharoșțī manuscripts: A preliminary survey." Studien zur Indologie und Iranistik 25, 103-136.

-, ed. 2012. Foreign sailors on Socotra: The inscriptions and drawings from the cave Hoq. Bremen: Hempen.

Sudyka, J. 2010. "The 'megalithic' Iron Age culture in South India: Some general remarks." Analecta Archaeologica Ressoviensia 5, 359-401.

Taddei, M. 1999. "Oral narrative, visual narrative, literary narrative in ancient Buddhist India." In A. Cadonna (ed.), India, Tibet, China: Genesis and aspects of traditional narrative, 71-86. Florence: L. S. Olschki.

Thapar, R. 1978. "Dāna and Dakṣiṇā as forms of exchange." In Ancient Indian social history: Some interpretations, 94-108. New Delhi: Orient Longman. 
-. 2003. The Penguin history of Early India: From the origins to AD 1300. London: Penguin.

-. 2011. "Inscriptions as historical writing in early India: Third century BC to sixth century AD." In A. Feldherr and G. Hardy (eds.), The Oxford history of historical writing. Vol. 1, Beginnings to $A D$ 600, 577-600. Oxford: Oxford University Press.

-. 2012. Aśoka and the decline of the Mauryas. 3rd ed. Oxford: Oxford University Press.

Tieken, H. J. H. 2001. Kāvya in South India: Old Tamil Can்kam poetry. Groningen: Forsten.

Tomber, R. 2007. “Rome and Mesopotamia: Importers into India in the first millennium AD." Antiquity 81.314, 972-988.

-. 2008. Indo-Roman trade: From pots to pepper. London: Duckworth.

Trautmann, T. R. 1971. Kauțilya and the Arthaśāstra: A statistical investigation of the authorship and evolution of the text. Leiden: Brill.

-. 2012. Arthaśāstra: The science of wealth. New Delhi: Penguin.

?ls content-type="author"?>Tripati, S., G. Parthiban, K. H. Vora, Sundaresh, and S. N. Bandodker. 2003. "Lead ingots from a shipwreck off Poompuhar, Tamil Nadu, east coast of India: Evidence for overseas trade and their significance." International Journal of Nautical Archaeology 32.2, 225-237.

Tripati, S., A. S. Gaur, and Sundaresh. 2004. “Marine archaeology in India." Man and Environment 29.1, 28-41.

Turner, P. J. 1989. Roman coins from India. London: Royal Numismatic Society.

Vātsyāyana. 1982. Kāmasūtram. Yaśodharaviracita 'Jayamañgalā' vyākhyāsahitaṃ. Vārāṇasī: Caukhambhā Saṃskṛta Saṃsthāna.

Vira, R. 1951. Hindi-English dictionary of technical terms. Nagpur: International Academy of Indian Culture.

Voigt, J. H. 1966. “Nationalist interpretation of Arthaśāstra in the historical writing.” In S. N. Mukherjee (ed.), South Asian Affairs, no. 2: The movement for national freedom in India, 46-66 Oxford: Oxford University Press.

von Hinüber, 0. 1989. "Brāhmī inscriptions on the history and culture of the upper Indus valley." In Jettmar (1989), 41-72.

Walburg, R. 2005. “The earliest inscribed 'coins' from Tissamahārāma: Why they are not truly coins." In U. Franke-Vogt and H.-J. Weisshaar (eds.), South Asian Archaeology 2003: Proceedings of the seventeenth international conference of the European Association of South Asian Archaeologists, 7-11 July 2003, Bonn, 369-378. Aachen: Linden Soft.

-. 2008. Coins and tokens from ancient Ceylon. Wiesbaden: Reichert.

Wells, E. C., and P. A. McAnany, eds. 2012. Dimensions of ritual economy. Bingley: Emerald. Wheeler, R. E. M. 1954. Rome beyond the imperial frontiers. London: Bell.

-. 1976. My archaeological mission to India and Pakistan. London: Thames and Hudson.

Wheeler, R. E. M., A. Ghosh, and K. Deva. 1946. "Arikamedu: An Indo-Roman trading station on the east coast of India." Ancient India no. 2, 17-124.

Whitcomb, D. 1996. "Quseir al-Qadim and the location of Myos Hormos.” Topoi 6.2, 747-772.

Yelle, R. A. 2013. The language of disenchantment: Protestant literalism and colonial discourse in British India. Oxford: Oxford University Press.

Yong, M. 1989. “The Chinese inscriptions of the 'Da Wei' envoy of the 'sacred rock of Hunza.'” In Jettmar (1989), 139-157.

Zin, M. 2010. “The purchase of Jetavana in an Amaravati-relief.” In P. Callieri and L. Colliva (eds.), South Asian archaeology 2007: Proceedings of the 19th international conference of the European Association of South Asian Archaeology, Ravenna, Italy, 2-6 July 2007. Vol. 2, 369-373. Oxford: Archaeopress.

Zvelebil, K. 1973. The smile of Murugan on Tamil literature of South India. Leiden: Brill. 



\section{Sitta von Reden}

\section{B Graeco-Roman Indography}

\section{Introduction}

India entered the intellectual horizon of the Greeks in the course of the Persian period. ${ }^{1}$ As early as the late sixth century, Skylax from Karyanda in Asia Minor was called into service by the Persian king Darius who wished to gather information about the country he intended to conquer. ${ }^{2}$ Circumnavigation (periplous) and 'leading around' (periegesis) were the means by which such knowledge was gathered, generating numerous treatises under these titles, though only a fraction of them is transmitted. Their origin in circumnavigation and travel explains why these treatises were not just ethnographies, but paid attention to geography, distances, and conditions of travel.

Ethno-geographical writing developed certain patterns that over centuries remained relatively unchanged, despite the fact that the relationship of the Mediterranean to distant worlds changed through conquest and trade. ${ }^{3}$ One typical feature was concerned with contact zones. Although many ethnographers had never traveled to the countries they described, the regions that they explored were adjacent to familiar political spaces. Second, despite the very different nature of the contact zones, and the contacts Greeks and Romans had with them, ethno-geographical writing shared a canon of common themes. Regardless of whether the people and countries observed were befriended or inimical, praised or abhorred, there were expectations regarding a catalog of features to be treated. These included descriptions of the land, rivers, climate, plants, and animals, together with the land's agrarian and mineral wealth, the origins of people, their appearance, size and political institutions (including the political rule of women). We also find comments on the nature and size of cities, housing styles, dress, sexual habits, marriage customs, funerary rites, religion, education, weapons, and methods of warfare. The repetition of themes becomes apparent when one considers what was not described unless it was exception, paradoxical, or noteworthy: public architecture, administration, agricultural and crafts, urban development, and other observations that economic historians would like to have.

Third, not only were similar themes covered, but similar observations made: certain tribes built no temples or made no images of their gods, fought particularly fiercely, had strange but functional physiologies that fitted their strange lives, or did

1 For the following, Karttunen 1989; Romm 1992; Parker 2008; Roller 2016; Stonemann 2019; and the contributions to the volumes in Wiesehöfer 2011 and Wiesehöfer, Brinkhaus, and Bichler 2016. 2 Herodotus (Hdt.) 4. 44; Romm 1992, 84-94.

3 Murphey 2004, 78-79; and in greater detail, Parker 2008, 69-120.

Ә Open Access. (C) 2020 Sitta von Reden, published by De Gruyter. (c) BY-NC-ND This work is licensed under the Creative Commons Attribution-NonCommercial-NoDerivatives 4.0 License.

https://doi.org/10.1515/9783110607741-016 
things exactly opposite to the usual practice. Typical of the narratological method of ethno-geographical writers was also the desire to give each town, tribe, or river a proper name, which has led to much debate about their location and identification with archaeological sites. ${ }^{4}$ And finally, from its inception, ethno-geographical writing engaged with its own tradition. Predecessors were praised or blamed for their accurate or inaccurate observations, their credulity or exaggeration, or their opinion and judgements. ${ }^{5}$ This has brought down to us large numbers of ethnographic fragments that have not been transmitted independently. ${ }^{6}$ But despite the critical engagement of later authors with the veracity of empirical detail, there was no apparent progress made toward more tenable, less exotic facts about the countries described. Change of emphasis and critical comments were related to changing selfperceptions, changing expectations of the audiences, and the changing rhetoric of conveying authoritative knowledge. But they were not what we might expect to be steps toward critical evaluation of empirical data.

However, the campaigns of Alexander and the ethnographies written in its aftermath created a revised vision of India. ${ }^{7}$ Nearchos and Onesikritos, Alexander's naval commanders, and Aristoboulos, Alexander's military engineer, reported firsthand observations that included new regions. Taprobane (Sri Lanka), for example, was not known to the Greeks before the Hellenistic period. ${ }^{8}$ Megasthenes, moreover, who was probably a native of Asia Minor and sent to the court of the Mauryan king Chandragupta by Seleukos I in the late fourth century, established the Ganges, rather than the Indus, as the biggest river of India. ${ }^{9}$ Also, he was the first one who proposed that there was an inhabited world beyond India. ${ }^{10}$ Yet there were continuities that linked Hellenistic Indography to its former tradition. India was vast, now covering one third of the entire world. ${ }^{11}$ It had the largest and largest number of rivers. ${ }^{12}$ It was particularly fertile, and some fruits grew by themselves; ${ }^{13}$ there were

4 Parker 2008, 120.

5 Karttunen 1989, 121.

6 Parker 2016, 99. The Roman Alexander historian Arrian (second century CE) built his Indika on Eratosthenes, Megasthenes, and Nearkhos (Wirth and von Hinüber 1985, 1077).

7 Karttunen 1989, 90; Stoneman 2019, 129-288. The fragments and of the most important representatives of the Hellenistic ethnographic tradition can be found with translations and commentaries in Brill's New Jacoby (BNJ) 133 (Nearchos); BNJ 134 (Onesikritos); BNJ 715 (Megasthenes); BNJ 716 (Daimachos); and BNJ 241 (Eratosthenes).

8 Commentary ad BNJ 716 (Daimachos) F 2b; cf. Roller 2016, 125.

9 The date of the journeys and the date of Megasthenes's Indika are controversial. Roller ad BNJ 715 (Megasthenes) agues for a time before 312/11; Kosmin (2014, 261-271) following an earlier consensus, suggests that a date close to the end of the fourth century BCE is more likely.

10 Kosmin 2014, 38-41; for the world beyond Roller 2016, 126 with reference to seres (silk people), not necessarily to be identified with China, mentioned in the fragments of Megasthenes.

11 Arrian Anabasis (Arr. Anab.) 5. 6. 2.

12 Arr. Indika (Ind.) 5. 2-3.

13 Diodoros (Diod.) 2. 36. 5. 
large gold resources; ${ }^{14}$ and the people of Taprobane, now a new edge of the world, had strange social habits and a different rhythm of life. ${ }^{15}$

\section{Roman Indography}

Megasthenes was one of the main authorities for authors writing about India during the Roman Empire. ${ }^{16}$ Extensive portions have survived in Strabo, Arrian, and Diodoros, while Pliny the Elder used some of his material in his relatively brief survey of the subcontinent. ${ }^{17}$ Joining together fragments and quotes from previous Indographies, they do not provide much more than a renegotiation of previous information with the intention of making them serve Roman imperial ends. In Roman eyes India was both an 'other' and part of the extended Roman Empire, a view that was legitimized by the conquests of Alexander. ${ }^{18}$ Among its surprising otherness was the fact that, despite its fertility and wealth, it never expanded like the Roman Empire. Yet the reliance of the Roman authors on their predecessors was so extensive that their texts have been regarded just a mosaic of fragments joined together by critical comments on their veracity and authority. ${ }^{19}$

Nevertheless, there are some new emphases and a greater openness to information derived from commercial travel. ${ }^{20}$ Strabo was still reluctant to add such information to his geography, while Claudius Ptolemy, writing 150 years later, made direct reference to the observations of merchants. A clear indication that the geographer included such information is that he mentions local products and articles of trade in those parts of his geographical catalog delineating the coasts of the Indian Ocean beyond the Ganges and Taprobane up to the Bay of Bengal. ${ }^{21}$ Pliny incorporated Roman trade with India into his scathing attack on the destructive force of luxury, money, and profit that runs through his work: In no year did India absorb less than 50 million sesterces from 'our empire' (imperium nostrum), sending back merchandise to be sold at a hundred times its costs. It was therefore, he says, that the total route from Egypt to India was worth describing. ${ }^{22}$ Thus in order to

14 Arr. Ind. 15. 6.

15 Strabo (Strab.) 15. 1. 57; Arr. Ind. 9. 1-8; Pliny Naturalis historia (Plin. HN) 7. 2. $29=$ BNJ 715 F $13 a-d$.

16 Strab. 15. 1; Arr. Ind.; Diod. 2. 35-42; Plin. HN 6. 21-24; Karttunen 1989, 96-102; Parker 2008, 42-48; Kosmin 2014, 31-53; Roller 2016; Ruffing 2016; Wiesehöfer, Brinkhaus, and Bichler 2016.

17 Parker 2008; Dandrow 2017.

18 Whittaker 1998.

19 Parker 2008, 113-116.

20 Parker 2008, 118.

21 Ptolemy Geographia (Ptol. Geog.) 2. 1, with Berggreen and Jones 2000, 27; Parker 2008, 310.

22 Plin. HN 6. 101; cf. 12. 84 (including imports from Arabia), and Tacitus Annales (Tac. Ann.) 3. 53 on Emperor Tiberius exporting money to India to buy gemstones; Parker 2002 and von Reden 2010, 188-198, for the connection between money, gold, and luxury in Pliny's work. 
identify new developments in the intimations of India, we need to turn to the most extraordinary surviving text about the subcontinent, the Periplus Maris Erythraei ('Circumnavigation of the Erythrian Sea').

The Periplus Maris Erythraei (PME) was written in the second half of the first century CE by an anonymous writer whose identity or profession is not revealed by the author himself. ${ }^{23}$ Since he uses the Egyptian calendar and has his journey start in Egypt, his origin from Egypt is undisputable. He very likely belonged to the Greek-speaking class of Graeco-Egyptians living a fairly prosperous and culturally Greek oriented life in either Alexandria or some metropolis in the Nile valley. The diversity of his observations and a good acquaintance with the navigation of the Erythrean Sea - spanning from the Red Sea via the Persian Gulf to the Indian Ocean - renders it likely that the author gathered his information from firsthand observation.

In plain language, the $P M E$ describes the routes of trade from Myos Hormos in the northern part of the Red Sea, down the African coast up to a place called Rapta, back to the southern Arabian coast from where the route crosses over to the southern Iranian coast, and southward along the Indian coastline. It passes the southern tip of the subcontinent and the northern coast of Sri Lanka, then turning north along the eastern Indian coast up to the mouth of the Ganges. Descriptions of the markets contain details of what could be imported and exported, as well as referring to legal and social conditions in the markets frequented. Yet such details become more cursory as the journey moves farther north along the coast of India, and may no longer have been based on personal observation. Strange peoples enter the text in the final sections, such as the Kirradai who are "wild men" with flattened noses, or the Bargysoi, "horse faces," who are said to be cannibals. ${ }^{24}$ The journey stops at the border of Thina (probably a Greek rendition of the Sanskrit version of China), ${ }^{25}$ the regions beyond which "because of the extremes of storm, bitter cold, and difficult terrain, and also because of some divine power of the gods" are no longer explored. ${ }^{26}$

The narrative procedure of listing places and distances of travel suggest the author's familiarity with periplous literature. His interest in flora, fauna, large rivers, foreign tribes, and wondrous, huge animals reveal that he was familiar with the conventions of the ethno-geographic genre and with previous literary descriptions of India. ${ }^{27}$ The hinterland behind Dachinabades, for example, “contains many barren areas, great mountains, and wild animals of all kinds - leopards, tigers, ele-

23 Text, translation and commentary in Casson 1989, from which all subsequent translations are taken with minor adaptations. Sections 38-66, that is, almost half of the treatise deal with Indian harbors.

24 PME 62.

25 Casson 1989 commentary ad 64. 21.

26 PME 63.

27 Ruffing 2017. 
phants, enormous serpents, hyenas, and a great many kinds of monkeys as well as a great many populous tribes up to the Ganges." ${ }^{28}$ And vessels coming from Bakare, a little farther south, "get an indication that they are approaching land from the snakes that emerge to meet them; these are also black in color, but shorter and with dragon-shaped head and blood-red eyes." 29 Itineraries, commodities, and markets are the major concern of the author, but navigation is difficult in many places, ${ }^{30}$ and the account of India is interlaced with intimations of danger, warfare, and past conquest. Thus, at the very beginning of navigation into the Indian region, one reads:

Immediately after the gulf of Bakare is the gulf of Barygaza and the coast of the region of Ariake, the beginning both of Manbano's realm and of all India ... The metropolis of the region is Minnegara, from which great quantities of cloth are brought to Barygaza. In the area there are still preserved to this very day signs of Alexander's expedition, ancient shrines and the foundations of encampments, and huge wells. ${ }^{31}$

And he carries on:

Inland of Barygaza there are numerous peoples: the Aratrarioi, Arachusioi, Gandaraioi, and the peoples of Proklais in whose area Bekephalos Alexandria is located. And beyond these is a very warlike people, the Bactrians, under a king ... Alexander setting out from these parts penetrated as far as the Ganges but did not get to Limyrike [Kerala] and the South of India. Because of this, there are to be found on the market in Barygaza even today old drachms engraved with the inscriptions, in Greek letters, of Apollodotos and Menander, rulers who came after Alexander. ${ }^{32}$

The backdrop given to the local harbor towns is not strictly necessary for understanding trade in India. It places the pursuit of commercial exchange into ethnographical as well as imperial memories and the ruins of conquest.

The Periplus tells us much about the nature of trade along the Indian coast. Scholars have put the names of the ports and their suggested distances on a map. Inventories of the goods brought to and taken from each locality can be made: textiles, garments, unguents, metals glassware, pearls, ivory, nard, dyes, spices, slaves, and so on. We learn about sailing seasons, and the connection of harbors via rivers to the hinterland. Individual harbors are described as either controlled by a local king, open to foreigners, or reserved for local trade. Yet most importantly, the image conveyed by the Periplus is one of local trade networks in which commodities, both local and more valuable, are imported and exported by a large number of traders of many origins. Harbors are connected with the hinterland by various

\footnotetext{
28 PME 50.

29 PME 55.

30 E.g., PME 38, 40, 43, 45, 46.

31 PME 41. For Barygaza, see ch. 3, map 1, this volume.

32 PME 47.
} 
means, and both the people filling the harbors, and the kings controlling their hinterland, tend to be described as cooperative rather than hostile. In these observations lies the greatest potential of the Periplus as a historical source for Indo-Roman trade. But this source is still permeated by the idea that Roman power, through the conquests of Alexander, reached as far as the edges of the world.

\section{Conclusion}

Though Graeco-Roman Indography is easily accessible to modern minds in many places, it provides both problematic and instructive evidence for trans-imperial relationships in the period covered in this volume. Like any literary genre, it followed particular conventions and themes that authenticated the texts, their observations, and their generic origin. From the earliest writings of Skylax to Pliny and beyond, ethno-geographical treatises were literary texts, above all serving Greek and Roman interests, self-reflection, entertainment, and imagination. Marvelous and paradoxical features were not only essential ingredients of the genre, but literary devices for distancing lands and people as well as fitting them into a cosmological, geographical, and imperial world order. In this function, Greek and Roman writing about India cannot be taken as source for Indian history, even less so for its deeper economic structures. Trade and the consumption of Indian goods increased Indian presence in Rome from the time of Augustus onwards. Yet, except for the PME, it caused little factual change in the Indographic genre whose essential features remained indebted to its Hellenistic predecessors. However, the concepts through which Indo-Roman relationships were conveyed to Roman audiences were no longer just exploration, conquest, and dominance by civilization, but in addition money and trade. A new moralizing voice gained force in the discourse about Roman imperial relationships with the distant periphery. India had ceased to be an unproblematic 'other' at the edge of the inhabited world. Quite on the contrary, the desire of the Roman elite for Indian luxuries, combined with the Indian craving for Roman money, had, according to Pliny, the potential of destroying the whole empire.

\section{References}

Berggren, J. L., and A. Jones. 2000. Ptolemy's Geography: An annotated translation of the theoretical chapters. Princeton, NJ: Princeton University Press.

Casson, L. 1989. The periplous maris Erythraei. Princeton, NJ: Princeton University Press.

Dandrow, E. 2017. “Ethnography and identity in Strabo's Geography.” In D. Dueck (ed.),

The Routledge companion to Strabo, 113-124. London: Routledge.

Karttunen, K. 1989. India in early Greek literature. Helsinki: Finnish Oriental Society. 
Kosmin, P. 2014. The land of the elephant kings: space, territory, and ideology in the Seleucid Empire. Cambridge, MA: Harvard University Press.

Murphy, T. M. 2004. Pliny the Elder's 'Natural history': The empire in the encyclopedia. Oxford: Oxford University Press.

Parker, G. 2002. "Ex oriente luxuria: Indian commodities and Roman experience." Journal of the Social and Economic History of the Orient 45, 41-95.

-. 2008. The making of Roman India. Cambridge: Cambridge University Press.

-. 2016. "Roman Megasthenes. Towards a reception history.” In Wiesehöfer, Brinkhaus, and Bichler (2016), 119-128.

Roller, D. W. 2015. Ancient geography: The discovery of the world in classical Greece and Rome. London: I. B. Tauris.

-. 2016. "Megasthenes: his life and work.” In Wiesehöfer, Brinkhaus, and Bichler (2016), 119128.

Romm, J. S. 1992. The edges of the earth in ancient thought: Geography, exploration, and fiction. Princeton, NJ: Princeton University Press.

Ruffing, K. 2016. “Die Ausbildung des literarischen Indienbildes bei Megasthenes." In Wiesehöfer, Brinkhaus, and Bichler (2016), 165-190. Wiesbaden.

-. 2017. “Der Periplus Maris Erythraei und die Ethnographie der Erythra Thalassa.” In R. Rollinger (ed.), Die Sicht auf die Welt zwischen Ost und West (750 v. Chr.-550 n. Chr.) / Looking at the world from the East and the West (750 BCE-550 CE), 185-196. Wiesbaden: Harrassowitz.

Stoneman, R. 2019. The Greek experience of India: From Alexander to the Indo-Greeks. Princeton: Princeton University Press.

von Reden, S. 2010. Money in classical antiquity. Cambridge: Cambridge University Press.

Whittaker, C. R. 1998. "'To reach out to India and pursue the dawn:' The Roman view of India." Studies in History 14.1, 1-20.

Wiesehöfer, J., ed. 2011. Ktesias' Welt / Ctesias' world. Wiesbaden: Harrassowitz.

Wiesehöfer, J., H. Brinkhaus, and R. Bichler, eds. 2016. Megasthenes und seine Zeit / Megasthenes and his time. Wiesbaden: Harrassowitz.

Wirth, G., and O. von Hinüber, eds. 1985. Arrian: Der Alexanderzug - Indische Geschichte. Zurich: Artemis. 



\section{Evidence for Arsakid Economic History}

\section{Introduction}

\section{I.1 Methodological Problems I: Tradition, Research, and Popular Views}

For anyone who is concerned with the history, culture, and economy of the ancient Iranian empires there is a serious problem: The views of the inhabitants of their heartlands, that is, above all the Iranian highlands, have passed down to us in Late Antique or Early Islamic versions only. Exceptions are royal announcements, inscriptions, coins, images, and administrative documents. The reason for the lack of nonofficial source material is the decidedly oral character of the Iranian tradition. ${ }^{1}$ Texts related to religious ritual, like the Avesta, may have preserved large parts of original ideas and the original shape of its oral presentation. The more secular parts of the tradition, however, were subjected to fundamental change and adaptation. The complete disappearance of the Achaemenid kings from the socalled Iranian National History, which probably happened in Parthian times, can hardly be explained otherwise. The Arsakids were also denied their fair share of the historical tradition by the last Sasanian kings. We can actually speak of Iranian literature only since the late Sasanian period, when a wealth of historical, religious, geographical, didactic, and entertaining literature emerged in Iran - probably initiated not least by the rivalling secular and religious book cultures of the West. ${ }^{2}$

This means that the history of pre-Islamic Iran must be reconstructed to a considerable extent from foreign and later, that is, broken and partly hostile or biased, traditions: the Greek, Babylonian, Elamite, Egyptian, and Aramaic ones during the Achaemenid period; the Graeco-Latin, Babylonian, Aramaic, Middle Persian-Sasanid, and Chinese ones under the Arsakids; and the Graeco-Latin, Armenian, Syriac, and Arabic ones in Sasanid times. In the context of the history of events as much as in the history of structures, this requires a high degree of source-critical vigilance and some effort not to succumb to the horror vacui by forming airy hypotheses. It must always be remembered, moreover, that in the Achaemenid and Arsakid periods Iran, rather than Mesopotamia, which is much better represented in written sources, formed the heart of the empire. However, dealing with non-Iranian traditions opens up ways to a better understanding of alien perceptions of Iranian institutions as well as to uncovering the reasons for the emergence of stereotypical ideas and topical distortions in this very foreign tradition. Besides, in the last decades,

\footnotetext{
1 Huyse 2008.

2 For the literature of pre-Islamic Iran, see Emmerick and Macuch 2009.

Ә Open Access. (c) 2020 Josef Wiesehöfer, published by De Gruyter. (cc)BY-NC-ND This work is licensed under the Creative Commons Attribution-NonCommercial-NoDerivatives 4.0 License.

https://doi.org/10.1515/9783110607741-017
} 
apart from an abundance of individual studies, excellent editions of the respective sources have been published. ${ }^{3}$

Quite apart from the inadequacies of the sources, research on the history of preIslamic Iran continues to suffer from several problems, both in academic and popular historiography. First, the tradition of essentialist-holistic and stereotypical notions of the ancient Near East contrasted with images of the Graeco-Roman world, Europe, and the Occident (Abendland) that are just as topical though quite different and more positive or 'progressive'4 is still unresolved. Second, there is clearly a political abuse of ancient Iranian history and its traditions in the form of historical myths both in Iran and in the West (see below). Third, there is an unfortunate disciplinary separation in research and academic teaching between Near Eastern studies and ancient history where Iran - not only for practical linguistic reasons - comes into view only at times when Iran and the Mediterranean powers entered into war with each other, or when the Graeco-Macedonians or Romans ruled over the Near East. It is only in recent decades that transcultural approaches in history and forms of inter- or even transdisciplinary cooperation have managed to cross these borders. ${ }^{5}$ Last but not least there is the infertile debate about the value of certain traditions - Greek and Roman versus 'Oriental' sources - which often enough makes us forget that not only historical realities, but also forms and images of peoples' dealings with the unfamiliar and the foreign are historically relevant and worth investigating.

Moreover, the history of the relations between the Iranian empires and the Greek poleis, the Macedonian kingdoms, or the Roman and East Roman Empires is still written mostly from the Western point of view, that is, as part of the history of Greece and Rome. It continues to be presented - not least for reasons of European self-assurance - as a history of constant confrontations between the states of the West and the East, or as an encounter between a foreign and a Western, or anachronistically called 'European,' world allegedly close to us Europeans. Often enough, this is based on ancient models that also constructed Eastern 'others' as a kind of counterworld. ${ }^{6}$ A reference to the pair of opposites of 'Greek (that is: European) freedom' versus 'Oriental despotism,' or to the Battle of Salamis at the presumed

3 Achaemenid royal inscriptions: Schmitt 2000; 2009; Sasanian royal inscriptions: Back 1978; Huyse 1999. Other sources: Achaemenids: Kuhrt 2007; Parthians: Hackl, Jacobs, and Weber 2010 (cf. the review Hartmann 2011); Sasanians: Dodgeon and Lieu 1991; Greatrex and Lieu 2002; Dignas and Winter 2007.

4 Wiesehöfer 2006; 2007; 2017a.

5 See, e.g., the Achaemenid History Workshops published in Sancisi-Weerdenburg et al. 1987-2010; Wiesehöfer 1998; Curtis and Stewart 2005; 2007; 2008; Wiesehöfer and Huyse 2006; Gyselen 2009; 2010 (Sasanians); Curtis and Simpson 2010; Jacobs and Rollinger 2010; Henkelman and Redard 2017 (Achaemenids); Jacobs, Henkelman, and Stolper 2017; Wiesehöfer and Müller 2017 (Parthians). 6 See von Reden and Speidel, ch. 17, this volume. 
end of the Graeco-Persian Wars as the 'birth cry of Europe' may suffice to illustrate this rather fundamental bias in European historiographical traditions. ${ }^{7}$

A scheme of succession of world empires, furthermore, was laid down in Greece by the authors Herodotus and Ktesias, ${ }^{8}$ later living on in the European idea of a translatio imperii, and in its salvific-historical manifestations dating back to the book of Daniel as an idea for structuring history. ${ }^{9}$ To this day, with clear chiliasticapocalyptic references, it is still virulent in Western fundamentalist circles. Together with Hegel's idea of a teleological world history, this sequential history has attributed the role of a childhood stage of world history to the ancient Near Eastern cultures and empires, including the Iranian ones, and torn apart the links of the European cultures with the East and the later Islamic Near East. The role of the ancient Iranian empires in these narratives, however, is not limited to that of being the great adversary or partner of the Greeks and Romans. Iranian history also became relevant, among other things, by the fact that the political unification of the Near East under the Greek and Roman aegis permitted cultural, religious, ideological, and economic developments that radiated both to the West and to the East, and into the imperial territories themselves. ${ }^{10}$

Finally, it is not only in Europe that a fair appreciation of the historical role of the Iranian empires is lacking until today. Even in today's nation state of Iran, which is only a part of Ancient Iran, its evaluation is biased. On the one hand, the Teispids/Achaemenids, and Kyros as the alleged founder of the idea of human rights, were reimported to Iran from the Western tradition only under the Pahlavis, and are considered by the Iranian elites both in and outside Iran as historical benefactors. ${ }^{11}$ On the other hand, the Sasanians, strongly anchored in the Iranian tradition, are understood in the same circles - on the basis of the Iranian mythical tradition as great adversaries of the Turanians in the East (often enough equated with the Turks), the inhabitants of Rum in the West (Greeks and Romans or Europeans), and sometimes also of the Arabs in the South. ${ }^{12}$ And thus, it is not surprising that still today Alexander's campaigns and the appearance of the Arab Muslims - like the so-called Mongolian invasion - appear to some Iranians as world-historical caesuras which endangered the survival of 'Iranianness' to the extreme. Only thanks to the extraordinary tradition and talent of the Iranian inhabitants those catastrophes

\footnotetext{
7 Nippel 2013. For the concept of oriental despotism and the related neo-Marxian concept of the Asiatic mode of production, see Manning 2010, 36-45; and, in this volume, Dwivedi, ch. 15; Fabian, ch. 13; Morris, ch. 16.

8 See von Reden, ch. 10.B, this volume.

9 Kosmin 2019, esp. 139-162.

10 On these trends, see Wiesehöfer 2005; 2006. A dissertation by M. Oellig (Kiel) on the genesis of the scheme of the sequence of world empires has just been completed.

11 Wiesehöfer 1999.

12 Wiesehöfer 2005.
} 
did not impair the unchangeable core of 'Iranianness.' The Parthians, by the way, are almost unknown in both East and West.

\section{I.2 Methodological Problems II: The Arsakid Empire in Time and Space}

The Arsakids were not just, as Pompeius Trogus in Augustan times has it, heirs of the Macedonian Empire alongside the Romans. Nor were they, as represented in Roman art, barbaric enemies and fascinating inhabitants of an orbis alter, inferior and yet ultimately indomitable, as Trajan, Septimius Severus, and Caracalla had to experience painfully. ${ }^{13}$ Political and economic contacts and agreements were therefore advisable and profitable for both sides, as for example with regard to the Armenian question in the time of Nero, and for trade in the time of Hadrian and Antoninus Pius. Eurasia presented itself in the time of the Seleukids and Parthians as a "world of cultural entanglement, wherein cultural processes ... [took] place on an intra-cultural level (within the same cultural sphere) rather than on an inter-cultural one (between different monolithic cultures), and in which emplaced localities ... [were] formed through intra-cultural appropriation and recontextualization of translocal elements," as a new work on "Eurasian localisms" has rightly emphasized. ${ }^{14}$ Regionally shared goods, techniques, and cultural practices were exchanged and recontextualized on the local level "for social purposes, which may or may not have been imbued with ethnic significance." 15

Usually, the beginnings of intensive and allegedly continuous East-West connections, which, since the nineteenth century, have been summarized under the problematic term of 'Silk Roads,' are transferred to the period of interest here. However, the notion of Silk Roads by land and sea as clearly identifiable continuous trade routes between China on the one hand and the Roman Empire, Byzantium, or Europe on the other is historically unsupportable. ${ }^{16}$ The testimonies from China show a particular Eastern interest in certain parts of Central Asia, not least the Ferghana valley, in possible allies in this very area and the border regions of Iran, also in economic and cultural ties with the people living there. But they only rarely mention Rome and even more rarely show an interest in getting in touch with what Western scholars normally call 'the West.' ${ }^{17}$ On the other hand, we can certainly see on the Roman side an interest in economic contacts with China, but - apart from a problematic case from Marcus Aurelius's reign - we know nothing about the fact

13 See Weaverdyck, ch. 7, this volume.

14 Hoo forthcoming.

15 Hoo 2018, 179.

16 Rezakhani 2010; see also von Reden and Speidel, ch. 17, this volume.

17 Leese-Messing, chs. 5 and 12.A, this volume. 
that such a situation really came about. The concept commonly found in research literature of the inhabitants of Syria, Mesopotamia, Iran, and Central Asia being pure intermediators for goods moving between the Roman Empire and China "is an anachronistic and largely Eurocentric view of world history." 18 By degrading Palmyrenians, Charakeneans, Parthians, and Sogdians to pure middlemen whose task was to ensure the flow of goods between Han China and the Roman Empire, i.e., the two greatest empires of antiquity, historical Silk Road studies have deprived themselves of their greatest potential. The world east of the Euphrates was merged economically into the western part of the Silk Road, while Central Asia became an essentialized concept, organized either around the problem of the relationship between 'nomads' and sedentary peoples, or as the connecting link between the world empires of Rome and China. ${ }^{19}$

\section{I.3 General Research Trends in Arsakid History}

The military conflicts between Rome and the Arsakid Empire used to be the main focus of historical attention, but a change of perspective has taken place since the 1990 s. $^{20}$ Without neglecting the previous research focus, problems of the local tradition, studied on the basis of written as well as numismatic and archaeological sources and material (see below), the structure of the Arsakid Empire, including the relationship between the center and particular local powers, regional studies, ${ }^{21}$ and the literary image of the Parthians ${ }^{22}$ shifted to the foreground. Another new focus has been on the Parthian connections to, and interactions with Central Asia, China, and other eastern polities, including the Parthian role as either producers or mediators of goods and ideas. ${ }^{23}$ The Arsakids' dealings with their Greek and Babylonian subjects $^{24}$ and the Arsakid share in the promotion of Greek paideia ${ }^{25}$ have also attracted much interest.

As far as the end of Arsakid rule in the 220s CE is concerned, no longer the structural instability of the ruling power but a bundle of highly contemporary factors are taken into consideration. Among these were the reemerging disputes be-

18 Rezakhani 2010, 433.

19 See also Morris, ch. 16, this volume.

20 Most important general literature on the history of the Arsakid Empire: Schippmann 1980, Wiesehöfer 2004a, 115-149; 2014; 2015a, 92-96; Huyse 2005; Brosius 2006, 79-138; Hackl, Jacobs, and Weber 2010; Shayegan 2011; Hauser 2012; 2013; Jacobs 2014; bibliography: www.parthia.com. A textbook on the Parthians, edited by R. Shayegan, is in preparation.

21 Hackl, Jacobs, and Weber 2010; Schuol 2000; Marciak 2014; 2017; Luther 2015; Potts 2016.

22 Hauser 2005; Lerouge 2007; Wiesehöfer and Müller 2017.

23 Wiesehöfer 2004b; 2016.

24 Dąbrowa 2011 (cf. the review Kettenhofen 2012); Grajetzki 2011; Wiesehöfer 2015b; Olbrycht 2017.

25 Wiesehöfer 2000; Olbrycht 2014; Hoo forthcoming. 
tween Rome and the Arsakid Empire at the beginning of the third century, the throne dispute between Artabanos IV and Vologases VI, and the increasing ambitions of the early Sasanians in Fars. And even though we have only a few meaningful testimonies for the period of transformation, it cannot be doubted that the Sasanians, despite setting some new accents, imitated the Arsakids in many respects, taking over many politically established Arsakid institutions and functionaries in order to give their new rule the necessary stability.

\section{Sources on the Economic Conditions in the Arsakid Empire}

If one tries to weigh the evidence of the Arsakid period according to its local, temporal, and content-related proximity to the object of investigation, priority should be given to the following documents: 1 ) inscribed ostraca (sherds) from the old Arsakid centers Nisa in today's Turkmenistan and Shahr-i Qumis (Hekatompylos?) in Iran; 2) on parchment from Avroman in Western Iran; 3) on parchment and papyrus from Dura Europos in Syria; 4) in cuneiform script on clay tablets from Babylonia; as well as 5) to the work Stathmoi Parthikoi of the Arsakid subject Isidoros of Charax; 6) to the results of archaeological surveys, especially from the Susiane or from Eastern Iran; 7) to the Arsakid coins; this group of sources is then followed by the foreign tradition; not least 8) the particularly significant inscriptions from Palmyra as well as information provided 9) by Chinese historiography and 10) Greek, Latin, as well as Christian and Jewish literature. ${ }^{26}$ In the remaining part of this brief survey, I shall look at each of these categories of evidence in turn.

\section{II.1 Ostraca from Nisa and Shahr-i Qumis}

In Nisa, the original Arsakid residence in Turkmenistan (near present-day Ashgabat), Soviet excavators found more than 2,000 ostraca from nine wine cellars ( $m a$ dustan) with 2,758 texts from a 'record office.' These texts dating mostly to the 70s and 60s BCE mainly provide details about deliveries of wine to the palace from the vineyards of various estates, temples or private people, or give information on the allocation of food to those employed there. Many of them mention Arsakid officials with their names and titles, from a wine supplier up to the satrap. The ostraca are probably to be interpreted as provisional notes for the identification of the contents of the vessels, which were to be followed up by a summary on some other writing

26 For a general overview of the sources, see Wiesehöfer 1998; and of the economically relevant testimonies, see Hackl 2010. 


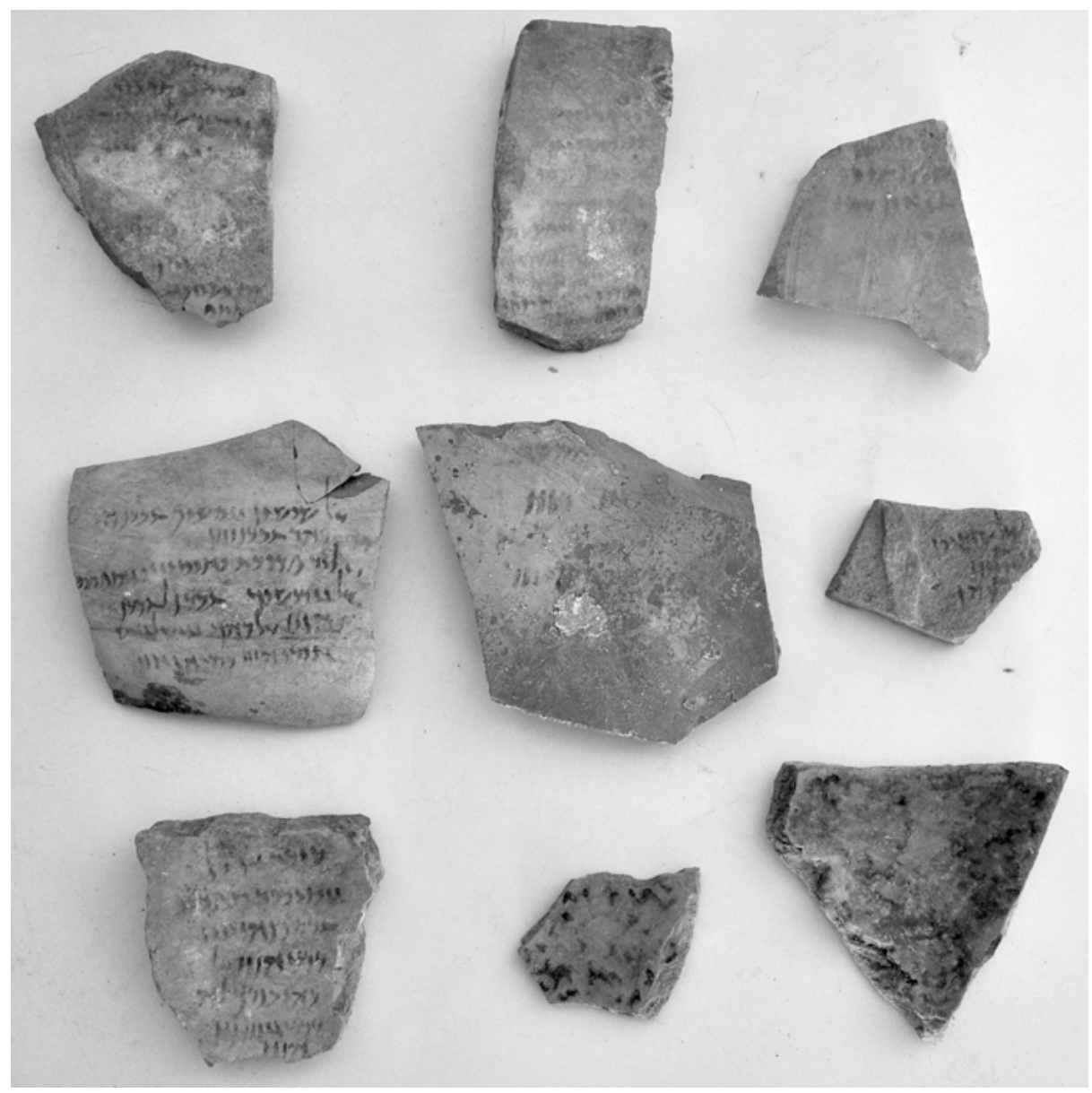

Fig. 1: Ostraca from a storehouse in the SW corner of Nisa (excavated between 2008 and 2015). (c) Archive of Centro Scavi Torino - CRAST.

material, perhaps leather. In addition to palaeographical, historical linguistic, and onomastic information ${ }^{27}$ they offer evidence on viticulture, wine varieties, wineries, administration and taxation, and the relevant terminology. In addition, the Nisa ostraca provide particulars on the calendar, on questions of chronology, religion, and the genealogy of individual kings. ${ }^{28}$ It seems, moreover, that a number of estates and vineyards were not only named after living and deceased Arsakid kings,

27 For personal names in Arsakid epigraphical sources, see Schmitt 2016.

28 Editions: Diakonoff and Livshits 1976-2001; Morano 1996; Livshits and Pilipko 2004; Livshits 2006; Morano 2008; 2013; Weber 2010b (selection with German translation); commentaries: Schmitt 1998, 168-170; Weber 2010b. 
but that the goods delivered from the estates "supported some sort of cult for the memory and the benefit of the king's soul." 29

\section{II.2 Documents from Avroman}

In 1909, a farmer found a vessel in a cave of the Kuh-i Salan Mountains near Shari Owraman (Hawraman, Avroman) in the Iranian part of Kurdistan. The vessel contained several ancient texts from Parthian times written on parchment now kept in the British Museum. The three texts are private documents and contain purchase or lease contracts for parts of a vineyard. The first two documents are available as double documents in two versions of the text, however, with partly significant deviations. The extant parts are written in Greek language on the back of document 1,

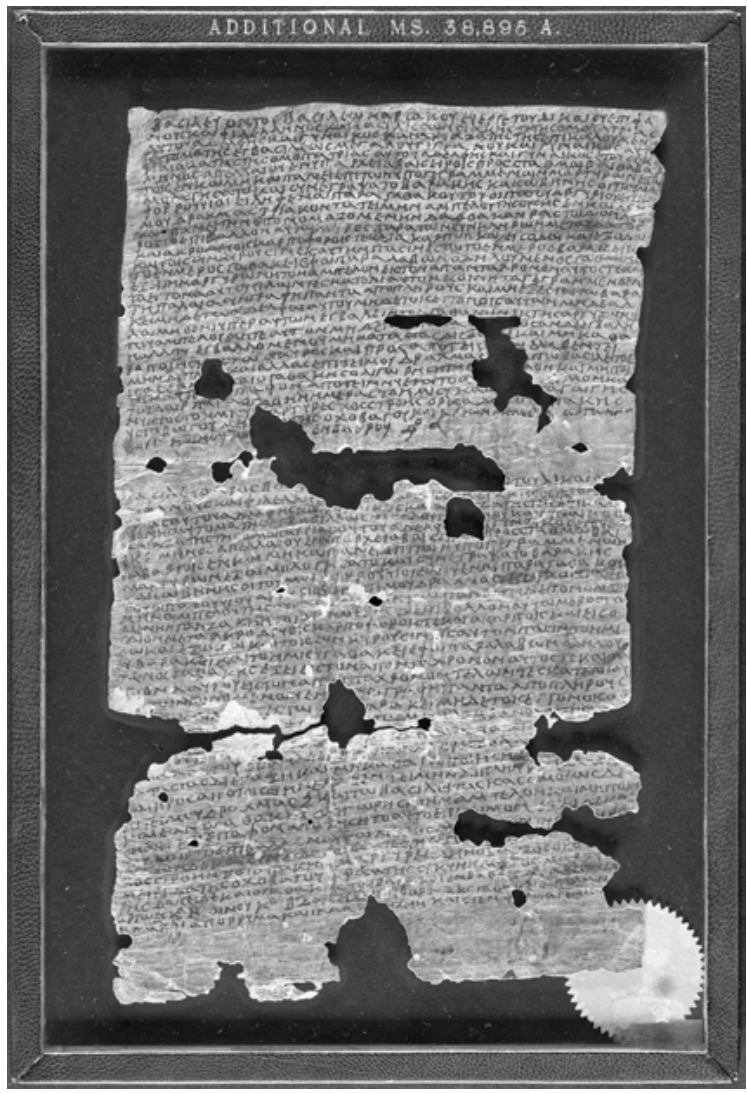

Fig. 2: Avroman Document I (Additional Manuscript 38895a f001r). () British Library.

29 Canepa 2018, 237-238. 
yet there are five Parthian text lines that unfortunately are hardly legible. The third document is written in Parthian language. Documents 1 and 2 refer to the vineyard Dadbakan in a place called Kophanis (Kopanis). Document 3 relates to the "half vineyard Asmak, which is near the farmland" and which is sold by Pataspak, the son of Tiren from Bod, to Avil, the son of Bashnin, and his brother, for 65 drachms. The documents are important sources for the legal and documentary system in the Arsakid Empire, the position of Greek as an administrative language and a lingua franca there as well as for the history of the Parthian script and language and for Parthian onomastics. ${ }^{30}$ On the basis of the references these documents give to the kings and their wives, it has recently been shown that the three documents belong to the Arsakid era. Document 1 can now be dated quite precisely to the month of November 24 BCE, document 2 to the year $43 / 4 \mathrm{CE}$, and document 3 to approximately December 52 CE. ${ }^{31}$

\section{II.3 Documents from Dura Europos}

The parchments and papyri from Dura Europos, which was under Arsakid control between 116 BCE and 164/5 CE, contain some important detail for the economic and administrative history of the Arsakid Empire. Especially interesting for the present purpose are the two parchments, PDura 18 and 19, in which a tax collector (praktor), settled in an urban context, is mentioned, as well as PDura 20, in which the "strategos of Mesopotamia and Parapotamia" and "Arabarch" Manesos also functions as tax collector (paraleptos) and is supported by his subordinate, the eunuch Phraates, the "chief of the tax system" (arkapates). ${ }^{32}$ Two less significant ostraca with name lists in the Parthian script from Shahr-i Qumis and others from Tureng Tepe, Nippur, Qosha-depe (booking entries on flour), Kunja-kala, and the Merv oasis conclude this group of records. ${ }^{33}$

\section{II.4 Tablets from Babylonia}

The late cuneiform written tradition from Babylon contains texts with religious, astronomical-astrological, historiographical, economic, and administrative content.

\footnotetext{
30 Editions: Documents 1-2: Minns 1915; Rougemont 2012, no. 73-74; Document 3: Haruta 2001, 125, 128; Livshits 2010, 164-165; Documents 1-2 (with German translation): Thommen 2010a; Document 3: Weber 2010a; commentaries: Weber 2010a; Thommen 2010a; Luther 2018.

31 Luther 2018.

32 Editions: Welles, Fink, and Gilliam 1959; Cotton, Cockle, and Millar 1995; Thommen 2010b (PDura 18 and 20 with German translation); commentaries: Millar 1998a; Hackl 2010, 123; Thommen 2010b.

33 Schmitt 1998, 170-171; Schmitt 2016, passim (with further literature published in the meantime).
} 
Yet it must be considered that cuneiform came out of use as a writing system in Arsakid times, that the extant material is incomplete, and that we therefore run the risk of concluding from the absence of texts that institutions or traditions were also absent or deliberately abandoned. Among the 'economic texts,' mainly originating from Uruk and Babylon and dating to Arsakid times, are the so-called Astronomical Diaries with dated quantitative observations from the Neo-Babylonian period up to the first century CE. In addition to observations of the moon, the planets Mercury, Venus, Mars, Jupiter, and Saturn, comets, the weather and the water level of the Euphrates, special local events, and the price in silver of a fixed number of foodstuffs and export products are also mentioned, among them fish, barley, mustard, cress, sesame, and wool. ${ }^{34}$ The cuneiform texts also include the tablets of the socalled Rahimesu Archive, all of which date back to just two years, 94-93 CE or 154155 Arsakid Era and 218-219 Seleukid Era. It has been noted that

in fact, all texts belonging to his archive are terse and stereotyped lists of income and expenditures which consist of an introductory statement giving the amount of the income collected in a certain sanctuary for a specific period of time. This introduction is followed by a varying number of specific expenditures ... and the remainder of the silver (i.e., the balance) that was deposited with Rahimesu ... The transactions recorded in these lists were exclusively conducted in silver and thus mark the last phase of the general trend of an increasing monetization of economic exchange that can be observed in the course of the first millennium $\mathrm{BC}$... [T] he right to the collection of temple income was farmed out to private businessmen against the obligation of paying out salaries for temple personnel and meeting other expenses of the temples such as the acquisition of supplies for the upkeep of the offering system. ${ }^{35}$

Information on money, prices, wages, and agricultural production (wheat, rye, dates) is not the least of the factors that make these archival texts invaluable sources for economic questions.

\section{II.5 The Stathmoi Parthikoi}

The Stathmoi Parthikoi of Isidoros (early first century CE) from the city of Spasinou Charax (the capital of Charakene), lists in its first part 31 places on the route between Zeugma-Euphrates and Seleukeia-Tigris (see ch. 6, map 1). ${ }^{36}$ It gives accurate distances between them up to a total of 171 schoinoi. ${ }^{37}$ In the second part it describes

34 Editions: Hunger 1988-1996; 2001; 2006; 2014; Böck 2010 (selected documents with German translation); commentaries: van der Spek 1997-1998; Böck 2010.

35 Hackl 2016, 87-88; editions, translations, and commentary of the published texts in van der Spek 1998 with new additions in Hackl 2016.

36 For editions, see Hartmann 2017, 87 n. 1; for the most important recent literature, Hartmann 2017; Hauser 2017; Schmitt 2017; Schuol 2017; Hartmann 2018, 446-450 (in each case with further literature); Morris, ch. 9, this volume.

37 The schoinos was of variable length, but on average, a length of $10.5 \mathrm{~km}$ can be used (Der Neue Pauly, s. v. schoinos). 
the regions further east up to Alexandria-Arachosia. However, the number of places is much smaller, they are almost exclusively larger cities with hardly any distance data given between them apart from the total distance of 700 schoinoi. For a long time, scholars assumed some practical purpose of the work as either the description of an overland trade route, a semiofficial Parthian itinerary, or the result of military exploration and preparation for Roman campaigning. However, there is much to suggest that we are dealing with a nonuniform compilation of texts, which in the first part described the course of the central east-west route from Zeugma to Seleukeia, oriented toward the Seleukid city foundations, and in the second part offered an "abstract geographical description of the regions between eastern Assyria and the Kushan Empire." 38 It rather bears witness to the spread of geographical knowledge in Arsakid Mesopotamia and Babylonia in the first century CE. ${ }^{39}$

\section{II.6 Archaeological Surveys}

Among the archaeological surveys of particular economic and historical significance, those from Susa and the surrounding Susiane are particularly noteworthy. As far as the city is concerned, its growing prosperity in Arsakid times is shown by a remarkable increase in land reclamation, and significant improvements in the irrigation network. ${ }^{40}$ The excavations at Nisa and in other parts of Northeastern Iran are also becoming increasingly important in economic terms. ${ }^{41}$

\section{II.7 Coins}

Arsakid coins are among the most important primary sources for the history of the Arsakid Empire. They have been studied intensely for the valuable information they hold about the succession of Arsakid rulers and about Arsakid mints. In addition, their images and legends contain important information about ruler ideology and representation, traditional costumes and armament, religious conditions, language policy, and much more. ${ }^{42}$ Yet they have also a great and largely unexplored poten-

38 Hauser 2017, 165.

39 Hauser 2017, 165.

40 Wenke 1975-1976, 115-131.

41 Cf., e.g., Lippolis and Manassero 2015.

42 Overview: Sinisi 2012; coins and 'Parthian Art': Sinisi 2014. In the project Sylloge Nummorum Parthicorum (SNP), in which a volume has already been published, the collections of Arsakid coins in the Münzkabinett of the Staatliche Museen zu Berlin, in the Department of Coins and Medals of the British Museum (London), in the American Numismatic Society (New York), in the Cabinet des Médailles of the Bibliothèque nationale de France (Paris), in the National Museum of Iran (Tehran) and in the Münzkabinett of the Kunsthistorisches Museum (Vienna), and supplementary material from coin trade publications shall be published. In addition, the system and chronology of the Arsakid coinage - separated by mints - will be examined in detail for the first time. 
a)
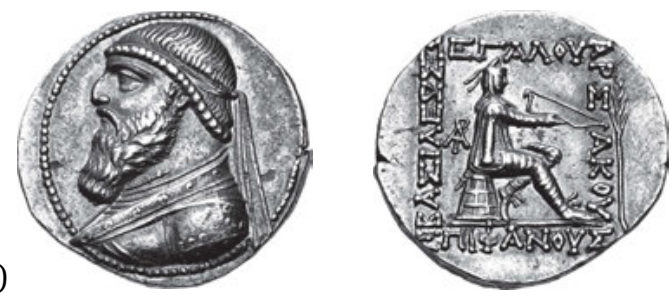

b)
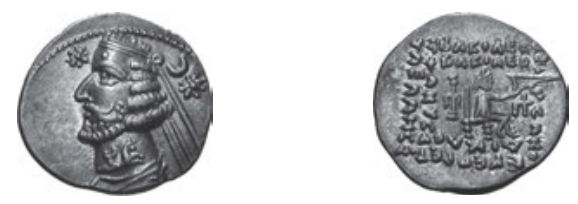

c)
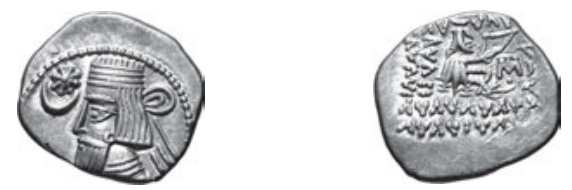

Fig. 3: Arsakid Coins: a) Tetradrachm of Mithradates II with a monogram on the reverse (a magistrate's monogram?) (Classical Numismatic Group 106 (13-9-2017), lot 533, 30 mm., 15.89 g., $12 \mathrm{~h}$, Sellwood 24.5 corr). (C) Classical Numismatic Group; b) Drachm of Orodes II from Rhagae with the relevant mintmark (Agora Auctions, Numismatic Auction 40 (8-9-2015), lot 53, 19.8 mm., 4.10 g., 1h, Sellwood 48.10). () Agora Auctions; c) Drachm of Artabanus II from Mithradatkart with the relevant mintmark (Classical Numismatic Group E-auction 400 (28-6-17), lot 455, 19 mm., 3.85 g., 12h). @ Classical Numismatic Group.

tial for the analysis of monetary and economic conditions in Iran and its neighboring countries, such as coin circulation, coin deterioration, and conditions of hoarding.

\section{II.8 Palmyrene Caravan Inscriptions}

Among the foreign sources, two corpora are of particular importance, especially for questions of trade by land and by sea. One is the so-called corpus of the Palmyrene caravan inscriptions, the other the historiography of the Han dynasty, discussed in the following section. The corpus of the Palymyrene caravan inscription is a group of 34 honorary inscriptions for people who have rendered outstanding services to the safe arrival of the caravans in Palmyra. The inscriptions are often bilingual in both Palmyrenian and Greek. ${ }^{43}$ Among other things, they provide information on

43 Fox and Lieu 2005; for discussions, Young 2001, 236-275; Millar 1998b. 
the scope of Palmyrene economic activity beyond the borders of the Roman Empire, Palmyrene presence in Seleukeia-Tigris, at Babylon, Vologesias (where even a temple for the Augusti is attested), ${ }^{44}$ as well as Forat and Spasinou Charax. They provide vivid evidence for transimperial exchange in the Gulf area, with the Arsakids, their Charakenean and other vassals in Mesopotamia as well as the Palmyreneans as important agents in that trade. At the same time this group of evidence calls for clarifying more precisely the relations between the great imperial powers, these great powers and their own and foreign subjects, and the historical circumstances under which these contacts were established and maintained, and the question of a possible active Arsakid policy of trade. ${ }^{45}$

\section{II.9 Chinese Historiography}

There were three phases of Han Chinese contacts with the Arsakid Empire (Anxi): the diplomatic journeys of Zhang Qian and the ensuing presence of China in Dayuan (Ferghana) (ca. 126-91 BCE), the Protectorate of the Western Regions (59 BCE-9 CE), and the periods of intensive military presence in the Tarim Basin under Dou Gu (73-77 CE), and Ban Chao and his son Ban Yong (91-123 CE). ${ }^{46}$ Chinese sources such as Sima Qian's Shiji, Ban Biao's Hanshu, and Fan Ye's Hou Hanshu provide information on urban development, rice and wheat cultivation, wine production, as well as trade and coinage of the Arsakid Empire. ${ }^{47}$

\section{II.10 Graeco-Roman Texts}

The Periplus Maris Erythraei (PME) is the most important testimony on Arsakid trade from the perspective of the Roman Empire. ${ }^{48}$ Beyond its character as some technical manual on navigation and trade in the Red Sea, it testifies to the penetration of literary concepts into the world of merchants, as well as to that of perceptual patterns of the latter into literary circles. ${ }^{49}$ Of interest to us here are the descriptions of the shipping route from the Indian port of Barygaza (Bharuch) via Omana to Spasinou Charax and Apologos at the Shatt al-Arab and to Kane in Arabia, respectively, and the hint that from ports of the Arsakid Empire "pearls in large quan-

44 Speidel 2016, 110-114.

45 Important inroads into these questions have been made by Gregoratti 2010 and Hartmann 2018.

46 See Leese-Messing, ch. 4; Morris, ch. 9, this volume.

47 Leslie and Gardiner 1996, passim; Posch 1998. Texts relating to Parthia are collected by Golze and Storm 2010.

48 See von Reden, ch. 10.B, this volume.

49 Edition: Casson 1989; Thommen 2010c (selections [ch. 35f., 38] with German translation); for the character of the work, Ruffing 2017 (with the older literature). 
tities ..., local garments, wine, dates in large quantities, gold and slaves” had been transported both to Barygaza and to Arabia, in addition "from Omana to Arabia local boats tied together, which are called madarate." 50 However, whether or not the "large ships" sent out from Barygaza, loaded with "copper, teak, beams, seedlings, sandalwood, and ebony trunks," or the incense shipments from Kane to Omana were unloaded in ports under Arsakid control, cannot be said.

Several authors living and writing under the Roman Empire, in particular Pompeius Trogus (preserved in Justin), Strabo, Pliny the Elder, Josephus, Tacitus, Arrian, and Herodianos expressed their views on the Parthians. Yet only rarely do they provide reliable information on the economic conditions in the Arsakid Empire, such as observations on agricultural production, import and export products, or artisan production sites. ${ }^{51}$ However, the importance of the latter can be gleaned from the mere mention of pearl fishing, mining, special armament, traditional costumes, and local writing materials (parchment) that suggest extensive local manufacture. Late Christian and Jewish texts give indications of traders and merchants, including Jews, who transported 'goods of silk.' The Song of the Pearl from the Acts of Thomas also mentions valuable Parthian import and export products. ${ }^{52}$

\section{Conclusion}

If one systematizes the economically relevant information that our sources provide, then the following picture emerges. First, the hazards of transmission and loss of material determine the state of the extant source material, which can only offer glimpses into a few aspects of complex economic contexts. The priority of the spoken over the written word in the core territories of the empire, unprocessed or fragmented fields of research, and ideologically biased views from outside make the situation even more difficult.

Second, the Arsakid Empire is still, like in our foreign sources, primarily seen along ethnic or Orientalist lines and as the great adversary of Rome. Like the territorial states of Central Asia or the Arsakid 'vassal kingdoms,' the Arsakid Empire is fixed on its role as a mediator of ideas and goods between East and West, between the great empires of China and Rome, which are often compared. The same applies to the Arsakid Empire's role as predecessor of the much better attested Sasanian

50 PME 35-36.

51 Selections: Hackl, Jacobs, and Weber 2010, vol. 2; for Greek and Roman views of the Parthians and their institutions and customs, see, e.g., the contributions in Wiesehöfer 1998; Wiesehöfer and Müller 2017; for economically relevant information, Hackl 2010.

52 Doctrina Addae: Zehnder 2010a (selections with German translation); Song of the Pearl: Zehnder 2010b (selections with German translation). 
Empire, which itself, in Late Antiquity, denied the Arsakids their role in world history. ${ }^{53}$

Third, in contrast to the Achaemenid and Sasanian Empires, there is until today a lack of decidedly economic-historical analyses of the Arsakid Empire, even though it has to be admitted that the task will encounter severe problems of research.

Fourth, economically relevant information is chronologically and spatially unequally distributed. Some data are transferable across time and space, but others are not, or only partly so.

Fifth, most of the information relates to a) trade, especially long-distance trade, and goods traded (Chinese historiography; Periplus; Christian-Jewish literature; Palmyrene inscriptions); b) urbanism and demography (Chinese historiography; Susa surveys et al.; Isidoros); c) agricultural (Nisa ostraca and archaeology; Babylonian texts) and craft production (Greek and Latin authors; Nisa archaeology); d) water management (Nisa ostraca; Susiane surveys; Astronomical Diaries; Isidoros); e) prices and wages (Babylonian texts); f) taxes and duties (Dura parchments; Palmyrene inscriptions; Greek and Latin authors; Jewish texts); and g) general economic conditions (Chinese historiography; Babylonian texts; Greek and Latin authors; coins).

\section{References}

Back, M. 1978. Die sassanidischen Staatsinschriften: Studien zur Orthographie und Phonologie des Mittelpersischen der Inschriften zusammen mit einem etymologischen Index des mittelpersischen Wortgutes und einem Textcorpus der behandelten Inschriften. Leiden and Tehran: Brill and Bibliothèque Pahlavi.

Böck, B. 2010. "Schriftquellen mit Übersetzung und Kommentar: Keilschriftliche Texte: Astronomische Tagebücher." In Hackl, Jacobs, and Weber (2010), vol. 3, 45-127.

Brosius, M. 2006. The Persians: An introduction. London: Routledge.

Canepa, M. P. 2018. The Iranian expanse: Transforming royal identity through architecture, landscape, and the built environment, 550 BCE-642 CE. Berkeley, CA: University of California Press.

Casson, L. 1989. The Periplus Maris Erythraei: Text with introduction, translation, and commentary. Princeton, NJ: Princeton University Press.

Cotton, H. M., W. E. H. Cockle, and F. Millar. 1995. "The papyrology of the Roman Near East: A survey." Journal of Roman Studies 85, 214-235.

Curtis, J., and S. J. Simpson, eds. 2010. The world of Achaemenid Persia: History, art and society in Iran and the ancient Near East. London: I. B. Tauris.

Curtis, V. S., and S. Stewart, eds. 2005. Birth of the Persian Empire. London: I. B. Tauris.

-, eds. 2007. The age of the Parthians. London: I. B. Tauris.

-, eds. 2008. The Sasanian era. London: I. B. Tauris.

Dąbrowa, E. 2011. Studia Graeco-Parthica: Political and cultural relations between Greeks and Parthians. Wiesbaden: Harrassowitz.

53 Wiesehöfer 2017b. 
Diakonoff, I. M., and V. A. Livshits. 1976-2001. Corpus Inscriptionum Iranicarum. Part 2, vol. 2. 1, Parthian Economic Documents from Nisa. 6 vols. London: School of Oriental and Asian Studies.

Dignas, B., and E. Winter. 2007. Rome and Persia in Late Antiquity: Neighbours and rivals. Cambridge: Cambridge University Press.

Dodgeon, M. H., and S. N. C. Lieu, eds. 1991. The Roman eastern frontier and the Persian Wars, $A D$ 226-363: A documentary history. London: Routledge.

Emmerick, R. E., and M. Macuch, eds. 2009. The literature of pre-Islamic Iran. London: I. B. Tauris.

Fox, G., S. N. C. Lieu, and N. Ricklefs. 2005. "Select Palmyrene inscriptions." In I. Gardiner, S. N. C. Lieu, and K. Parry (eds.), From Palmyra to Zayton: Epigraphy and iconography, 27-126. Turnhout: Brepols.

Golze, U., and K. Storm. 2010. "Schriftquellen mit Übersetzung und Kommentar: Chinesische Texte." In Hackl, Jacobs, and Weber (2010), vol. 3, 482-511.

Grajetzki, W. 2011. Greeks and Parthians in Mesopotamia and beyond, 331 BC-AD 224. London: Bloomsbury.

Greatrex, G., and S. N. C. Lieu, eds. 2002. The Roman eastern frontier and the Persian Wars. Part 2, AD 363-630: A narrative sourcebook. London: Routledge.

Gregoratti, L. 2010. “The Palmyrenes and the Arsacid policy.” Вопросы эпиграфики: Сборник статей 4, 21-37.

Gyselen, R., ed. 2009. Sources pour l'histoire et la géographie du monde iranien (224-710). Leuven: Peeters.

-, ed. 2010. Sources for the history of Sasanian and post-Sasanian Iran. Leuven: Peeters.

Hackl, J. 2016. "New additions to the Rahimesu archive: Parthian texts from the British Museum and the World Museum Liverpool." In K. Kleber and R. Pirngruber (eds.), Silver, money and credit: A tribute to Robartus J. van der Spek on the occasion of his 65th birthday on 18th September 2014, 87-106. Leiden: Nederlands Instituut voor het Nabije Oosten.

Hackl, U. 2010. “Das Partherreich im Spiegel der Schriftquellen: Die inneren Verhältnisse im Partherreich: Handel und Wirtschaft." In Hackl, Jacobs, and Weber (2010), vol. 1, 111-124.

Hackl, U., B. Jacobs, and D. Weber, eds. 2010. Quellen zur Geschichte des Partherreiches: Textsammlung mit Übersetzungen und Kommentaren. 3 vols. Göttingen: Vandenhoeck \& Ruprecht.

Hartmann, U. 2011. "Review of U. Hackl, B. Jacobs, and D. Weber, Quellen zur Geschichte des Partherreiches: Textsammlung mit Übersetzungen und Kommentaren.” Humanities - Sozialund Kulturgeschichte 14.03. 2011, www.hsozkult.de/publicationreview/id/rezbuecher-14169.

-. 2017. "Die parthischen Stationen des Isidor von Charax: Eine Handelsroute, eine Militärkarte oder ein Werk geographischer Gelehrsamkeit?” In Wiesehöfer and Müller (2017), 87-125.

-. 2018. "Wege durch Parthien - Straßen, Handelsrouten und Kommunikation im Arsakidenreich." In B. Woytek (ed.), Infrastructure and distribution in ancient economies, 445-472. Wien: Österreichische Akademie der Wissenschaften.

Haruta, S. 2001. "A new translation of the Avroman parchment no. 3 (British Library Or. 8115).” Oriento 44, 125-134.

Hauser, S. R. 2005. “Die ewigen Nomaden? Bemerkungen zu Herkunft, Militär, Staatsaufbau und nomadischen Traditionen der Arsakiden.” In B. Meißner, O. Schmitt, and M. Sommer (eds.), Krieg, Gesellschaft, Institutionen: Beiträge zu einer vergleichenden Kriegsgeschichte, 163208. Berlin: Akademie-Verlag.

-. 2012. “The Arsacid (Parthian) Empire.” In D. T. Potts (ed.), A companion to the archaeology of the ancient Near East, 1001-1020. Malden, MA: Wiley-Blackwell.

-. 2013. "The Arsacids (Parthians)." In D. T. Potts (ed.), The Oxford handbook of ancient Iran, 728-750. Oxford: Oxford University Press. 
-. 2017. "Isidor von Charax $\Sigma \tau \alpha \theta \mu$ oì П $\alpha \rho \theta$ ıкоí - Annäherungen an den Autor, den Routenverlauf und die Bedeutung des Werkes." In Wiesehöfer and Müller (2017), 127-187.

Henkelman, W. F. M., and C. Redard, eds. 2017. Persian religion in the Achaemenid period / La religion perse à l'époque achéménide. Wiesbaden: Harrassowitz.

Hoo, M. 2018. "Ai Khanum in the face of Eurasian globalisation: A translocal approach to a contested site in Hellenistic Bactria." Ancient West and East 17, 161-186.

-. Forthcoming. Eurasian localisms: Towards a translocal approach to Hellenism and inbetweenness in central Eurasia, c. 300 BCE-1 CE. Stuttgart: Franz Steiner.

Hunger, H., ed. 1988-1996. Astronomical diaries and related texts from Babylonia. Vols. 1-3. Vienna: Österreichische Akademie der Wissenschaften.

-, ed. 2001. Astronomical diaries and related texts from Babylonia. Vol. 5, Lunar and planetary texts. Vienna: Österreichische Akademie der Wissenschaften.

-, ed. 2006. Astronomical diaries and related texts from Babylonia. Vol. 6, Goal year texts. Vienna: Österreichische Akademie der Wissenschaften.

-, ed. 2014. Astronomical diaries and related texts from Babylonia. Vol. 7, Almanacs and normal star almanacs. Vienna: Österreichische Akademie der Wissenschaften.

Huyse, P. 1999. Corpus Inscriptionum Iranicarum. Part 3, vol. 1, texts 1, Die dreisprachige Inschrift Šābuhrs I. an der Ka'ba-i Zardušt (ŠKZ). 2 vols. London: School of Oriental and African Studies.

-. 2005. La Perse antique. Paris: Les Belles Lettres.

-. 2008. "Late Sasanian society between orality and literacy." In Curtis and Stewart (2008), 140155.

Jacobs, B. ed. 2014. Parthische Kunst - Kunst im Partherreich. Düsseldorf: Wellem.

Jacobs, B., and R. Rollinger, eds. 2010. Der Achämenidenhof / The Achaemenid Court. Wiesbaden: Harrassowitz.

Jacobs, B., W. F. M. Henkelman, and M. W. Stolper, eds. 2017. Die Verwaltung im Achämenidenreich: Imperiale Muster und Strukturen / Administration in the Achaemenid Empire: Tracing the imperial signature. Wiesbaden: Harrassowitz.

Kettenhofen, E. 2012. Review of Studia Graeco-Parthica: Political and cultural relations between Greeks and Parthians, by E. Dąbrowa. Humanities - Sozial- und Kulturgeschichte 20. 02. 2012, www.hsozkult.de/publicationreview/id/rezbuecher-17304.

Kosmin, P. 2019. Time and its adversaries in the Seleucid Empire. Cambridge, MA: Harvard University Press.

Kuhrt, A. 2007. The Persian Empire: A corpus of sources from the Achaemenid period. 2 vols. London: Routledge.

Lerouge, C. 2007. L'image des Parthes dans le monde gréco-romain: Du début du ler siècle av. J.-C. jusqu'à la fin du Haut-Empire romain. Stuttgart: Franz Steiner.

Leslie, D. D., and K. H. J. Gardiner. 1996. The Roman Empire in Chinese sources. Rome: Bardi.

Lippolis, C., and N. Manassero. 2015. "Storehouses and storage practices in Old Nisa (Turkmenistan)." Electrum 22, 115-142.

Livshits, V. A. 2006. "Three new ostraca documents from Old Nisa." In M. Compareti, P. Raffetta, and G. Scaria (eds.), Ėrān ud Anērān: Studies presented to Boris Il'ic Maršak on the occasion of his 70th birthday, 403-406. Venice: Cafoscarina.

-. 2010. "The Avroman parchment III in Parthian." Anabasis 1, 159-174.

Livshits, V. A., and V. N. Pilipko. 2004. "Parthian ostraca from the central building complex of Old Nisa." Ancient Civilizations from Scythia to Siberia 10, 139-181.

Luther, A. 2015. "Das Königreich Adiabene zwischen Parthern und Römern.” In E. Baltrusch and J. Wilker (eds.), Amici - socii - clientes? Abhängige Herrschaft im Imperium Romanum, 275300. Berlin: Edition Topoi.

-. 2018. "Zu den Dokumenten aus Avroman." Gymnasium 125, 155-177. 
Manning, J. G. 2010. The last Pharaohs: Egypt under the Ptolemies, 305-30 BC. Princeton, NJ: Princeton University Press.

Marciak, M. 2014. Izates, Helena, and Monobazos of Adiabene: A study on literary traditions and history. Wiesbaden: Harrassowitz.

-. 2017. Sophene, Gordyene, and Adiabene: Three regna minora of northern Mesopotamia between East and West. Leiden: Brill.

Millar, F. 1998a. "Dura-Europos under Parthian rule.” In Wiesehöfer (1998), 473-492.

-. 1998b. "Caravan cities: The Roman Near East and long distance trade by land." In M. M. Austin, J. Harries, and C. J. Smith (eds.), Modus operandi: Essays in honour of Geoffrey Rickman, 119-137. London: Institute of Classical Studies.

Minns, E. H. 1915. "Parchments of the Parthian period from Avroman in Kurdistan." Journal of Hellenic Studies 35, 22-65.

Morano, E. 1996. "Two new ostraka from Nisa." In Convegno internazionale sul tema: La Persia e l'Asia Centrale da Alessandro al X secolo: In collaborazione con l'Istituto italiano per il Medio ed Estremo Oriente, 139-145. Rome: Academia Nazionale dei Lincei.

-. 2008. "Iscrizioni partiche da Nisa Vecchia su ostraka e intonaco." In A. Invernizzi and C. Lippolis (eds.), Nisa Partica: Ricerche nel complesso monumentale arsacide 1990-2006, 344-350. Florence: Le Lettere.

-. 2013. "On some recently found ostraca from Old Nisa." In S. Tokhtasev and P. Luria (eds.), Commentationes Iranicae: Vladimiro f. Aaron Livschits nonagenario donum natalicium, 111117. St. Petersburg: Nestor-Historia.

Nippel, W. 2013. "Der Diskurs über die orientalische Despotie im 18. und 19. Jahrhundert: Von Montesquieu zu Marx." In N. Zenzen, T. Hölscher, and K. Trampedach (eds.), Aneignung und Abgrenzung: Wechselnde Perspektiven auf die Antithese von 'Ost' und 'West' in der griechischen Antike, 465-484. Heidelberg: Verlag Antike.

Olbrycht, M. J. 2014. "Parthians, Greek culture and beyond." In K. Twardowska, M. Salamon, S. Sprawski, M. Stachura, and S. Turlej (eds.), Within the circle of ancient ideas and virtues: Studies in honour of Professor Maria Dzielska, 129-141. Cracow: Historia Iagellonica.

-. 2017. "Greeks in the Arsacid Empire." In Wiesehöfer and Müller (2017), 3-27.

Posch, W. 1998. “Chinesische Quellen zu den Parthern.” In Wiesehöfer (1997), 355-364.

Potts, D. T. 2016. The archaeology of Elam: Formation and transformation of an ancient Iranian state. 2nd ed. Cambridge: Cambridge University Press.

Rezakhani, K. 2010. "The road that never was: The Silk Road and trans-Eurasian exchange." Comparative Studies in South Asia, Africa and the Middle East 30.3, 420-433.

Rougemont, G. 2012. Corpus Inscriptionum Iranicarum. Part 2, vol. 1.1, Inscriptions grecques d'Iran et d'Asie centrale. London: School of Oriental and African Studies.

Ruffing, K. 2017. "Der Periplus Maris Erythraei und die Ethnographie der Erythra Thalassa." In R. Rollinger (ed.), Die Sicht auf die Welt zwischen Ost und West (750 v. Chr. -550 n. Chr.) / Looking at the world from the East and the West (750 BCE-550 CE), 185-196. Wiesbaden: Harrassowitz.

Sancisi-Weerdenburg, H. et al. 1987-2010, eds. Achaemenid History. 15 vols. Leiden: Nederlands Instituut voor het Nabije Oosten.

Schippmann, K. 1980. Grundzüge der parthischen Geschichte. Darmstadt: Wissenschaftliche Buchgesellschaft.

Schmitt, R. 1998. "Parthische Sprach- und Namenüberlieferung aus arsakidischer Zeit.” In Wiesehöfer (1997), 163-204.

-. 2000. Corpus Inscriptionum Iranicarum. Part 1, vol. 1, texts 2, The Old Persian inscriptions of Naqsh-i Rustam and Persepolis. London: School of Oriental and African Studies.

-. 2009. Die altpersischen Inschriften der Achaimeniden. Wiesbaden: Reichert. 
-. 2016. Iranisches Personennamenbuch. Vol. 2, Mitteliranische Namen. Fascicle 5, Personennamen in parthischen epigraphischen Quellen. Vienna: Österreichische Akademie der Wissenschaften.

-. 2017. "Isidors Stathmoi Parthikoi aus Sicht der iranischen Toponomastik." In Wiesehöfer and Müller (2017), 189-220.

Schuol, M. 2000. Die Charakene: Ein mesopotamisches Königreich in hellenistisch-parthischer Zeit. Stuttgart: Franz Steiner.

-. 2017. "Isidor von Charax und die literarische Gattung der stathmoi." In Wiesehöfer and Müller (2017), 71-85.

Shayegan, M. R. 2011. Arsacids and Sasanians: Political ideology in post-Hellenistic and Late Antique Persia. Cambridge: Cambridge University Press.

Sinisi, F. 2012. "The coinage of the Parthians." In W. E. Metcalf (ed.), The Oxford handbook of Greek and Roman coinage, 275-294. Oxford: Oxford University Press.

-. 2014. "Sources for the history of art of the Parthian period: Arsacid coinage as evidence for continuity of imperial art in Iran." Parthica 16, 9-59.

Speidel, M. A. 2016. "Augustus-Tempel in Indien und im Partherreich? Zur Tabula Peutingeriana und zum römischen Kaiserkult ausserhalb des Römischen Reiches." In A. Kolb and M. Vitale (eds.), Kaiserkult in den Provinzen des Römischen Reiches: Organisation, Kommunikation und Repräsentation, 101-121. Berlin: De Gruyter.

Thommen, L. 2010a. "Schriftquellen mit Übersetzung und Kommentar: Griechische und lateinische Texte: Inschriften, Pergamente und Papyri: Iran: Griechisches Pergament von Avroman, Nr. I-II." In Hackl, Jacobs, and Weber (2010), vol. 2, 467-476.

-. 2010b. "Griechische und lateinische Texte: Inschriften, Pergamente und Papyri: Syrien: Dura Europos: Griechisches Pergament aus Dura Europos: P. Dura 18 und 20." In Hackl, Jacobs, and Weber (2010), vol. 2, 445-452.

-. 2010c. "Schriftquellen mit Übersetzung und Kommentar: Griechische und lateinische Texte: Literarische Texte: Periplus Maris Erythraei.” In Hackl, Jacobs, and Weber (2010), vol. 2, 300-302.

Van der Spek, R. J. 1997-1998. "New evidence from the Babylonian astronomical diaries concerning Seleucid and Arsacid history." Archiv für Orientforschung 44/45, 167-175.

-. 1998. "Cuneiform documents on Parthian history: The Rahimesu archive: Materials or the study of the standard of living." In Wiesehöfer (1998), 205-258. Stuttgart: Franz Steiner.

Weber, D. 2010a. "Schriftquellen mit Übersetzung und Kommentar: Parthische Texte: Avrōmān III (Tafel VII)." In Hackl, Jacobs, and Weber (2010), vol. 2, 566-567.

-. 2010b. "Schriftquellen mit Übersetzung und Kommentar: Parthische Texte: Nisa-Dokumente." In Hackl, Jacobs, and Weber (2010), vol. 2, 494-561.

Welles, C., R. O. Fink, and J. F. Gilliam. 1959. The excavations at Dura-Europos: Final report. Vol. 5.1, The parchments and papyri. New Haven, CT: Yale University Press.

Wenke, R. J. 1975-1976. "Imperial investments and agricultural developments in Parthian and Sasanian Khuzistan, 150 BC-AD 640." Mesopotamia 10/11, 31-221.

Wiesehöfer, J. ed. 1998. Das Partherreich und seine Zeugnisse / The Arsacid Empire: Sources and documentation. Stuttgart: Franz Steiner.

-. 1999. "Kyros, der Schah und 2500 Jahre Menschenrechte: Historische Mythenbildung zur Zeit der Pahlavi-Dynastie." In S. Conermann (ed.), Mythen, Geschichte(n), Identitäten: Der Kampf um die Vergangenheit, 55-68. Hamburg: E.B.-Verlag.

-. 2000. “'Denn Orodes war der griechischen Sprache und Literatur nicht unkundig...': Parther, Griechen und griechische Kultur." In R. Dittmann, U. Löw, P. Matthiae, R. Mayer-Opificius, and S. Thürwächter (eds.), Variatio delectat: Iran und der Westen: Gedenkschrift für P. Calmeyer, 703-721. Münster: Ugarit.

-. 2004a. Ancient Persia from 550 BC to 650 AD. 3rd ed. London: I. B. Tauris. 
-. 2004b. "Vermittler zwischen Ost und West: Die Parther." In T. Stöllner, R. Slotta, and

A. Vatandoust (eds.), Persiens antike Pracht: Bergbau, Handwerk, Archäologie, 2, 408-415.

Bochum: Deutsches Bergbau-Museum.

-. 2005. Iraniens, Grecs et Romains. Paris: Association pour l'Avancement des Études Iraniennes.

-. 2006. "Statt einer Einleitung: 'Randkultur' oder 'Nabel der Welt'? Das Sasanidenreich und der

Westen: Anmerkungen eines Althistorikers." In Wiesehöfer and Huyse (2006), 9-28.

-. 2007. "Alte Geschichte und Alter Orient, oder: Ein Plädoyer für Universalgeschichte." In

R. Rollinger, A. Luther, and J. Wiesehöfer (eds.), Getrennte Wege? Kommunikation, Raum

und Wahrnehmung in der Alten Welt, 595-616. Heidelberg: Verlag Antike.

-. 2014. "Parther und Sasaniden: Imperien zwischen Rom und China." In M. Gehler and R.

Rollinger (eds.), Imperien und Reiche in der Weltgeschichte: Epochenübergreifende und globalhistorische Vergleiche. Vol. 1, 449-478. Wiesbaden: Harrassowitz.

-. 2015a. Das frühe Persien: Geschichte eines antiken Weltreichs. 5th ed. Munich: C. H. Beck.

-. 2015b. "Greek poleis in the Near East and their Parthian overlords." In A. M. Kemezis (ed.), Urban dreams and realities in antiquity: Remains and representations of the ancient city, 328-346. Leiden: Brill.

-. 2016. "Greeks, Iranians and Chinese on the Silk Road." In S. N. C. Lieu and G. B. Mikkelsen (eds.), Between Rome and China: History, religions and material culture of the Silk Road, 1-17. Turnhout: Brepols.

-. 2017a. "Alte Geschichte und internationale Geschichte." In B. Heider-Wilson, W. D. Godsey, and W. Mueller (eds.), Internationale Geschichte in Theorie und Praxis: International history in theory and practice, 65-79. Vienna: Österreichische Akademie der Wissenschaften.

-. 2017b. "Ērān ud Anērān: Sasanian patterns of worldview." In R. Strootman and M. J. Versluys (eds.), Persianism in Antiquity, 381-391. Stuttgart: Franz Steiner.

Wiesehöfer, J., and P. Huyse, eds. 2006. Ėrān ud Anērān: Studien zu den Beziehungen zwischen dem Sasanidenreich und der Mittelmeerwelt. Stuttgart: Franz Steiner.

Wiesehöfer, J., and S. Müller, eds. 2017. Parthika: Greek and Roman authors' views of the Arsacid Empire / Griechisch-römische Bilder des Arsakidenreiches. Wiesbaden: Harrassowitz.

Young, G. K. 2001. Rome's eastern trade: International commerce and imperial policy, 31 BC$A D$ 305, London: Routledge.

Zehnder, M. 2010a. "Schriftquellen mit Übersetzung und Kommentar: Aramäische Texte: Literarische Texte: Die Doctrinae Addae." in Hackl, Jacobs, and Weber (2010), vol. 3, 209-218.

-. 2010b. "Schriftquellen mit Übersetzung und Kommentar: Aramäische Texte: Literarische Texte: Thomasakten und Perlenlied." In Hackl, Jacobs, and Weber (2010), vol. 3, 237-261. 


\title{
12 Qin and Han Evidence
}

\author{
Kathrin Leese-Messing \\ 12.A Transmitted Texts
}

\section{Introduction}

Society obviously must have farmers before it can eat, foresters, fishermen, miners, etc., before it can make use of natural resources; craftsmen before it can have manufactured goods; and merchants before they can be distributed. But once these exist, what need is there for government directives, mobilizations of labor, or periodic assemblies? Each man has only to be left to utilize his own abilities and exert his own strength to obtain what he wishes. Thus, when a commodity is very cheap, it invites a rise in price; when it is very expensive, it invites a reduction. When each person works away at his own occupation and delights in his own business, then, like water flowing downward, goods will naturally flow forth ceaselessly day and night without having been summoned, and the people will produce commodities without having been asked.

故待農而食之, 虞而出之, 工而成之, 商而通之。此寧有政教發徵期會哉? 人各任其能, 竭其力, 以得所欲。故物賤之徵貴, 貴之徵賤, 各勸其業, 樂其事, 若水之趨下, 日夜無休時, 不召而自來, 不求而民出之。1

This advice was not written by some eighteenth- or nineteenth-century classical economist. The fact that it might well be is astounding in itself, considering that it was an ancient Chinese historian, Sima Qian 司馬遷 (145 or 135-ca. 87 BCE), who recorded it more than 2,000 years ago. Not quite without reason, this passage has often been described as an ancient precursor of Adam Smith's (1729-1790) 'invisible hand.' It has even been suggested, albeit wrongly, that it was his knowledge of Sima Qian's ideas that inspired Adam Smith in developing this notion. ${ }^{2}$ The question of how far the ancient author's ideas are in fact comparable to modern theories of competitive, self-regulating markets is, to be sure, much more complex than this isolated quotation could possibly suggest. But apart from this particular question, the quotation illustrates very well the high degree of interest and sometimes sophistication that several ancient Chinese works reveal with regard to economic considerations. In early imperial China, economic circumstances as well as policies such as currency reforms, price stabilization schemes, or the introduction of state monopolies, were acknowledged as important factors for a state's well-being, and contem-

1 Shiji 129.3254, trans. Watson 1993, 434.

2 Young 1996; McCormick 1999; Chiu and Yeh 1999.

Note: I would like to thank Armin Selbitschka for valuable comments on an earlier draft of this chapter.

Ә Open Access. (C) 2020 Kathrin Leese-Messing, published by De Gruyter. (c) BY-NC-ND This work is licensed under the Creative Commons Attribution-NonCommercial-NoDerivatives 4.0 License.

https://doi.org/10.1515/9783110607741-018 
porary writers felt no compulsion to keep their silence in this regard. In general, therefore, sinologists can hardly complain about a lack of sources dealing with economic matters. As for the generic categories of texts to be considered, there are historical narratives as well as descriptive, documentary, and normative texts. They contain economic theories, historical events (such as the implementation of economic measures by the state), officials' criticisms of contemporaneous economic policies, and economically relevant figures (such as state budgets, government expenditure, tax rates, and commodity prices). Excavated texts in particular provide further information on imperial laws (including those on currencies and marketplaces) and on local economic administration (such as the local management of conscript labor and of agricultural frontier garrisons).

This chapter will introduce the most important early imperial texts for economic history that have come down to us via traditional transmission. These are texts that were verifiably written during ancient times, and were then subsequently copied. But their earliest full extant copies usually date from the Song 宋 (960-1297 CE) or later periods. These books became part of China's rich literary tradition, some of them having accumulated commentaries whose dates of composition range from Han 漢 (206 BCE-220 CE) times to the modern age. The following introduction to these texts will proceed by traditional genres, starting with the mostly narrative, but partly also essayistic historiographic sources covering the Han period. It will then move to politico-philosophical works falling under the traditional literary category of 'masters' ( $z i$ 子), before finally turning to technical manuals. ${ }^{3}$

\section{The Standard Histories}

\section{II.1 The Nature of the Standard Histories}

The history of the Han period is covered by three historiographic works which later came to be acknowledged as belonging to the quasi-canonized so-called 'standard histories’ (zheng shi 正史) of imperial China. ${ }^{4}$ Sima Qian’s The Scribe’s Records (Shiji 史記), which founded this genre, covers a long period from mythological rulers such as the Yellow Emperor (Huang D $i$ 黃帝), who supposedly ruled during the third millennium BCE up to and including the Han emperor Wu's 武) reign (141-87 вCE). ${ }^{5}$

3 For the non-transmitted texts, excavated from tombs and deposits, see Ma, ch. 12.B, this volume. 4 The last of these standard histories, whose basic structures remained largely consistent with Sima Qian's and Ban Gu's early models, covers the Ming 明 period (1368-1644) and was compiled during the Qing 清 period (1644-1911).

5 Whereas the Shiji is different from its successors in not being confined to one single dynasty, its larger part is concerned with the Han dynasty up to Emperor Wu with an even stronger focus on the latter's reign (under which Sima Qian served and, possibly, died). 
Ban Gu's 班固 (32-92 CE) Documents of the Han (Hanshu 漢書) ${ }^{6}$ covers the entire Former (or Western) Han period (206 BCE-9 CE) and Wang Mang's 王莽 Xin 新 dynasty (9-23 CE). Fan Ye's 范瞱 (398-445 CE) Documents of the Later Han (Hou Hanshu 後漢書) ${ }^{7}$ covers the Later (or Eastern) Han period (25-220 CE). As for the Hou Hanshu, a fairly large time gap separates the period covered by the work and the time of its compilation in the first half of the fifth century CE. Its author Fan Ye did, however, base his work on earlier histories that had been compiled under circumstances more comparable to those of the Shiji and Hanshu.

All standard histories are of a predominantly biographical nature. Their largest sections consist of officials' and other individuals' biographies or memoirs (zhuan 傳 or liezhuan 列傳). ${ }^{8}$ Each of these standard histories further includes a first section that contains the emperors' annals (ji 紀 or benji 本紀). They are more annalistic in style but may also be called biographical in the broadest sense. In addition, each of the three Han histories contains a section of so-called treatises (shu 書 or $z h i$ 志) in partly essayistic, partly narrative style. They are concerned with particular objects of government, institutions, and other politically relevant matters - such as, for example, imperial rituals, astronomy, the administrative and judicial systems, literature, geography, and economy. Moreover, both Shiji and Hanshu each include a section consisting of 'tables' (biao 表), ${ }^{9}$ while the Shiji alone has another section on 'hereditary households' (shijia 世家), a homage to the older aristocratic system that Emperor Wu eventually dismantled. ${ }^{10}$

Unlike many later standard histories, neither of the three Han histories was written by imperial order. All of them arose - at least initially - from their authors' private initiative. Nevertheless, all three authors were officials of the central court. This proximity to the emperor and to central government institutions is important to keep in mind as it has particular implications for the nature of their works: Firstly, the authors had access to the palace archives, and they made extensive use of them. Quotations of official documents such as imperial edicts and memorials to

6 Alternatively translated as Book of (the) Han.

7 Alternatively translated as Book of (the) Later Han.

8 The translation 'biography' for zhuan makes sense in most cases, but it must be noted that a few zhuan are not concerned with individuals' lives, but with foreign peoples and polities (see below). A more literal translation of zhuan would be 'tradition' or 'record.'

9 The biao provide information in a chronological and tabular form on, e.g., each year's enfeoffments and assignments to high government posts.

10 As for the general writing style, within individual chapters (except for the largely essayistic treatises), the historians are inclined to rarely interrupt their narratives by inserting personal remarks or evaluations. Yet, the majority of chapters do include - specially denoted - final evaluative passages (or, to a lesser degree, introductions) of varying length, in which the authors classify events and place them in larger historical contexts, judge people's behavior and evaluate their personalities. On the early development of the historiographic genre, see Leese-Messing 2016, 52114. 
the throne ${ }^{11}$ make up a considerable part of their historiographic works. They can be regarded as being informed by official documents to a large extent, even though the historians are likely to have manipulated these in one way or another. Secondly, their positions at court not only made their authors adopt a focus on the center of the empire and its history, but also came along with direct participation in court factionalism. This had a strong impact on the authors' depiction of particular events and people. At the same time, the historians' attitudes toward the court's current policies and ideological trends were by no means uncritical. For example, and quite to the contrary, Sima Qian was one of the most passionate critics of the prevailing political trends of his time and of his ruler, Emperor Wu, in particular. The degree of delicate involvement in political affairs of all three authors may also be indicated by the fact that each of them eventually came to be charged with capital crimes. Sima Qian was the 'luckiest' of the three by getting off with castration, whereas both Ban $\mathrm{Gu}$ and Fan Ye were executed. ${ }^{12}$

One peculiarity of imperial Chinese historiography is that it was to some extent shaped by an ideal of 'transmitting but not creating' (shu er bu zuo 述而不作). ${ }^{13}$ The extensive reproduction of official documents in historiographic works may be seen as one aspect of this tendency. A more disturbing outgrowth of this may be perceived in the extreme extent to which Ban Gu modelled his Hanshu on Sima Qian's Shiji. He not only fundamentally adopted the form of individual chapter types and the overall structure of the Shiji, but he even largely copied the latter's contents for the time period on which both works overlap, that is, the second and early first centuries BCE. But the superficial similarity of the accounts can be profoundly misleading. By rearranging the sequence of sentences or passages, by subtly changing the wording, or by concluding a largely reproduced chapter with a strongly divergent evaluation, Ban $\mathrm{Gu}$ manages to express views that are diametrically opposed to those of his predecessor. Without taking a very close look at the details of both texts and the historical contexts in which they were written, these significant differences are prone to be overlooked. Generalizing attributions of allegedly typical ideological or political attitudes of Han historians are therefore to be taken with a grain of salt. ${ }^{14}$

11 Memorials to the throne were an official way of communicating with the emperor in written form. They could theoretically be submitted by any of his subjects across the empire and were formally presented to the emperor by government officials.

12 For basic information on the Shiji, Hanshu, and Hou Hanshu, their authors, and their composition, as well as for references to classical studies of these works, see Hulsewé 1993a; 1993b; Knechtges 2010a; 2010b.

13 The expression is found in Lunyu 論語 7.1, where it is attributed to Confucius (551-479 вCE). See Lunyu zhengyi 論語正義, 251. Even though the original context of the expression was a different one, Han authors related it (in varying manners and interpretations) to textual qualities.

14 See van Ess 2014 for a comprehensive and detailed comparison of the overlapping contents of Shiji and Hanshu. With regard to a more specific topic, Chin 2010 offers an intriguing analysis of the differences between Sima Qian's representation of frontier relations in his account on the Xiong$\mathrm{nu}$ 匈奴 in comparison to other Han authors such as Ban Gu. 
Pieces of information on various aspects of economic history are scattered all over the three 'standard histories' of the Han period, ${ }^{15}$ but there are several chapters that are more generally concerned with economic matters. These will be introduced in the following subsections.

\section{II.2 The Economic Treatises (Shiji 30 and Hanshu 24)}

One of the eight treatises that Sima Qian decided to include in his pioneering work bears the title "Treatise on the Balanced Standard" (Pingzhun shu 平準書). ${ }^{16}$ The chapter deals with economic challenges and policies from the beginning of the Han period up to Emperor Wu. The period of the latter's rule, which Sima Qian experienced in person, makes up the larger part of the chapter. The concrete economic challenges to the Han government that Sima Qian refers to in his chronological account include depleted state funds (especially due to military spending), price inflation (partly resulting from the private casting of coins), social and regional inequalities regarding the distribution of wealth and goods, tax evasion, high transportation costs for tax collection, and regional hunger crises (caused by natural disasters).

The government measures taken in response and recorded by Sima Qian include tax reforms (especially tax increases for merchants, but also tax exemptions for newly reclaimed land or newly conquered territories), repeated currency reforms (including moderate changes in weight and design of bronze coins, but also introduction of highly overvalued currencies), the sale of honorary titles and official posts, and the resettlement of impoverished people. He further writes about the introduction of state monopolies (coin casting, salt and iron production), the establishment of a state-run transportation or logistics system called 'equitable delivery' (junshu 均輸) for a more effective and rational distribution of tax revenues, and the establishment of a 'balanced standard' (pingzhun 平準) system, under which government agencies were to buy up goods when cheap and sell them when expensive in order to control prices and to replenish the treasury.

The following passage discusses the introduction of a government monopoly on the casting of coins under Emperor Wu. It may serve as a vivid example of how the

\footnotetext{
15 In addition, contents relevant for the history of the Han period (including economic matters) are also to be found in other historiographic works that were not quasi-canonized as 'standard histories' - such as Xun Yue's 荀悅 (148-209 CE) Hanji 漢紀 and Yuan Hong's 袁宏 (328-376 CE) Hou Hanji 後漢紀. Furthermore, Chen Shou's 陳壽 (233-ca. 297 CE) Sanguo zhi 三國志, a 'standard history' mainly covering the period of disunion following the Han dynasty's downfall, also stretches back to the Later Han period and includes a highly important chapter on foreign relations (Sanguo zhi 30).

16 For an English translation of this chapter (Shiji 30), see Watson 1993, 61-85; for an English translation of Ban Gu's equivalent chapter (Hanshu 24), see Swann 1950, 109-359.
} 
chapter tends to treat economic problems and policies, and what kind of information one can expect to find therein:

In the commanderies and kingdoms there was so much illegal coin casting going on that the cash had become extremely numerous and light in weight. [In 116 BCE,] the high officials therefore asked that the officials in the capital who were in charge of casting metal be ordered to cast coins with red rims, each of which would be worth five of the five-shu cash presently in circulation. No taxes or other payments to the government were to be accepted unless made in these coins ... Two years later, the red-rimmed coins had become worthless, the people having managed to use them while cleverly evading the intention of the law. They were declared impractical and withdrawn from circulation. With this an order was issued forbidding any further casting of coins in the commanderies and kingdoms. All casting was to be done by three offices set up in the Shanglin Park. Since there were already a number of coins in circulation, it was ordered that no cash other than those cast by the three offices should be accepted as legal tender anywhere in the empire. All copper coins previously cast in the commanderies and kingdoms were withdrawn from circulation and melted down, the copper being turned over to the three offices. After this there were fewer and fewer people who attempted to cast their own cash, since the cost of making a passable imitation did not repay the effort. Only highly skilled professional criminals continued to produce counterfeit coins.

郡國多㚣鑄錢, 錢多輕, 而公卿請令京師鑄鐘官赤側, 一當五, 賦官用非赤側不得行。 $[\cdots]$ 其後二歲, 赤側錢賤, 民巧法用之, 不便, 又廢。於是悉禁郡國無鑄錢, 專令上林三官 鑄。錢既多，而令天下非三官錢不得行，諸郡國所前鑄錢皆廢銷之，輸其銅三官。而民 之鑄錢益少，計其費不能相當，唯真工大姦乃盜為之。17

Ban Gu's “Treatise on Food and Commodities” (Shihuo zhi 食貨志, Hanshu 24), while generally sticking closely to the contents of Sima Qian's treatise concerning the second century BCE, is different from the latter in that it splits these contents up into two sections, i.e., 'food' (shi) and 'commodities' (huo), and in that it prefaces them with several passages on pre-imperial economic policies. To the economic history of the time period between Emperor Wu's rule and the end of the Former Han period (for which, of course, Sima Qian's treatise did not provide a model), Ban Gu dedicated only one single passage, which is followed by an again detailed (and critical) account of the economic policies under Wang Mang. The differences in arrangement of the two texts are not to be regarded as unimportant subtleties. Sima Qian's account of the economic policies undertaken during Emperor Wu's reign reads like the depiction of a downward spiral. Ban Gu's rearrangement of passages, in contrast, smoothes out much of his predecessor's underlying criticism. ${ }^{18}$

\section{II.3 The Biographical Chapters on the 'Money Makers' (Shiji 129 and Hanshu 91)}

Both Sima Qian and Ban Gu incorporated into their histories a chapter called "Memoirs of Money Makers" or, more literally, "Memoirs of [Those Whose] Goods In-

17 Shiji 30.1435, trans. Watson 1993, 76-77 (with modifications).

18 Van Ess 2014, 567-587. Fan Ye's Hou Hanshu does not contain an economic treatise. 
creased” (Huozhi liezhuan 貨值列傳). ${ }^{19}$ Although Ban Gu took over the chapter from his predecessor, he sharply criticized Sima Qian for having "praised benefit and profit” (chong shili 崇勢利) when dealing with these people. ${ }^{20}$ So while the biographical details on wealthy people are almost identical in both authors' chapters, their interpretations reveal two very different attitudes toward the value of profit seeking and wealth. Sima Qian's multifaceted chapter - of which the individuals' biographies only make up a minor part - reads like a plea for the pursuit of wealth. It acknowledges profit seeking as a fundamental human quality not to be oppressed, while depreciating mediocre people's behavior of "praising poverty and lowliness while talking big about humaneness and righteousness” 長貧賤, 好語仁義 as a disgrace. ${ }^{21}$ Sima Qian appears to have envisioned wealthy merchant families - with some of whom he maintained personal and kinship connections - as a potential replacement of the former aristocracy. Considering them as prospective pillars of society and counterweigths to imperial power, he floats the idea of them being the “uncrowned nobles" (su feng 素封). ${ }^{22}$ As the introductory quote to this chapter, taken from the 'money makers' account, demonstrates, he was opposed to strong governmental interference in trading activities. Ban $\mathrm{Gu}$, in contrast, shows a much more positive attitude toward state intervention. His family played an active role in the military defense of Later Han presence in the northwest and therefore endorsed the government's measures to increase treasury funds. He expresses strong moral concerns over private profit seeking, implicating wealthy business people in criminal activities. ${ }^{23}$

The chapters on the money makers provide plenty of information about the range of means by which people of the second century BCE were able to accumulate fortunes. ${ }^{24}$ Among the people mentioned in the chapters, the most common generator of wealth was the engagement in iron ore production during the pre-monopoly era. Others accumulated fortunes by trading in salt and fish, speculation in grain, investment in land, and money lending. Still others made their fortunes by what Sima Qian regarded as rather unconventional means to that end, that is, agricul-

19 An English translation of Shiji 129 is provided by Watson 1993, 433-453. A new and thoroughly annotated translation of this chapter by Stephen Durrant is now available in Nienhauser 2019, pp. 261-307. An English translation of Hanshu 91 (in combination with Shiji 129) is provided by Swann 1950, 413-453. For two overviews of earlier interpretations of Shiji 129, see L'Haridon 2015; Ruan 1996. Fan Ye's Hou Hanshu does not include a chapter on 'money makers.'

20 Hanshu 62.2738.

21 Shiji 129.3272, trans. Watson 1993, 449 (with modifications).

22 Shiji 129.3272, 3283. Cf. Watson 1993, 447, 454.

23 For a comprehensive comparison of Sima Qian's and Ban Gu's chapters on the 'money makers,' see van Ess 2014, 587-618.

24 Apart from wealthy people of the early Han period, both the Shiji and the Hanshu accounts also include pre-imperial examples. 
ture, ${ }^{25}$ selling fat, sauce, or dried sheep stomachs, working as mobile traders, blade sharpeners, horse doctors, or even as gamblers or grave robbers. ${ }^{26}$ On a more general level, both authors describe a society in which economic profit seeking among the populace played a considerable role. According to their description, private business ventures had the potential of accumulating immense wealth. This is also manifest in two other passages in which Sima Qian lists dozens of particular possessions $^{27}$ and annual sales, ${ }^{28}$ which he associates with the expectation of twenty percent profit and of making people economically equal to "a marquis enfeoffed with 1,000 households."29

A considerable part of Sima Qian's chapter is devoted to the description of different regions of the empire and their economic potential. ${ }^{30}$ This, for instance, is how Sima Qian describes the area of the Sichuan Basin:

\begin{abstract}
South [of the capital area] are the commanderies of Ba and Shu, which also contain rich fields and produce large quantities of gardenias [for making dye], ginger, cinnabar, copper, iron, and bamboo and wooden implements. In the south these commanderies control the [recently subjugated] regions of Dian and Po, the latter noted for its young slaves. Nearby on the west are the regions of Qiong and Zuo, the latter famous for its horses and oxtails. Though the area is hemmed in on all four sides by natural barriers, there are plank roadways built along the sides of the mountains for 1,000 li so that there is no place that cannot be reached. All these roads are squeezed together into one in the narrow defile running between the Bao and Ye rivers. By means of such roads, areas which have a surplus may exchange their goods for the things which they lack.
\end{abstract}

南則巴蜀。巴蜀亦沃野，地饒炧、薑、丹沙、石、銅、鐵、竹、木之器。南御滇整，梀來 僮。西近邛笮，笮馬、暆牛。然四塞，棧道千里，無所不通，唯襄斜綰豰其口，以所多 易所鮮。31

In a similar manner, Sima Qian provides descriptions of other regions, typically mentioning major cities, natural resources and handicraft products, soil quality, population density, and the role of merchants. In some cases, he also includes re-

25 Sima Qian does acknowledge agriculture (the 'root', ben 本) as the primary means to make a living at low risk. When it comes to sources of considerable wealth, however, he sees engagement in trade and handicrafts (the 'branches,' $m o$ 末) as the most promising, albeit riskier, activities (Shiji 129.3272; 3274, trans. Watson 1993, 449).

26 Shiji 129.3282, trans. Watson 1993, 453-454.

27 Such as the possession of "pasture lands producing fifty horses, 100 head of cattle, 500 sheep, or 500 marshland swine a year," or of "1,000 chestnut trees in Yan or Qin," "1,000 citrus trees in Shu, Han, or Jiangling," or "1,000 mu of mulberries or hemp in Qi or Lu" (Shiji 129, trans. Watson 1993, 448).

28 Such as "1,000 jars of pickles and sauces," "100 slaves," "1,000 rolls of embroidered or patterned silk," or "30,000 catties of salted fish" (Shiji 129, trans. Watson 1993, 449-450).

29 Shiji 129; Watson 1993, 448.

30 Ban Gu shifted large parts of these contents to his "Treatise on Geography” (Dili zhi 地理志, Hanshu 28), of which there is no precursor in the Shiji.

31 Shiji 129.3261-2, trans. Watson 1993, 441 (with modifications). 
marks on roads and interregional trading connections. ${ }^{32}$ It is interesting to note that similar to the case of the Sichuan Basin quoted above, several descriptions of other frontier regions mention lucrative trade with 'barbarian' peoples whose territories had recently been conquered by Emperor Wu. For example, regarding the region north of the capital area, there were supposedly "profits to be gained among the Qiang people” 西有羌中之利, and as for the northeastern region, it is pointed out that "on the north [it] adjoin[ed] the Wuhuan and Fuyu tribes, and on the east it control[led] the profits derived among the Huimo, Chaoxian, and Zhenpan peoples [of the recently subjugated regions of southern Manchuria and northern Korea]" 北鄰烏桓、夫餘, 東綰穢貉、朝鮮、真番之利. ${ }^{33}$ The northwestern Hexi corridor and the so-called Western Regions (Xiyu 西域) of the Tarim Basin, including the routes to and from Central Asia, are not included in these accounts of regional economic potentials. Yet if we regard one of the primary goals of Sima Qian's chapter as providing a guide to where to find uncrowned nobles, that is, wealthy families that had the potential of becoming the future pillars of the empire, then the omission of these sparsely populated and only partially integrated steppe and desert regions is less surprising. It does not reflect the potential importance of trading activities in these regions to the empire.

\section{II.4 The Treatises on the Waterways (Shiji 29 and Hanshu 29)}

Both Shiji and Hanshu contain one chapter on imperial water management projects entitled “Treatise on the Waterways” (Hequ shu 河渠書 and Gouxu zhi 溝洫志, respectively). ${ }^{34}$ The two chapters are almost identical for the period covered by the Shiji, after which the Hanshu account continues until the end of Wang Mang's reign. ${ }^{35}$ They provide accounts of both successful and abortive hydraulic projects on a major scale, several of which were realized by labor forces of several tens of thousands of workers. ${ }^{36}$ The overlapping purposes of the projects included facilitation of the transport of taxes in kind, agricultural irrigation, and flood control. The accounts testify to major public works having been conducted both near to and far away from the capital.

32 Furthermore, Sima Qian's descriptions of regions typically include geo-deterministic remarks on their inhabitants' prevalent character traits.

33 Shiji 129.3262; 3265; Watson 1993, 441, 443 (with modifications).

34 For an English translation of Shiji 29, see Watson 1993, 53-85. Needham (1971, 211-378) provides a study of the history of premodern Chinese hydraulics, including translations of several passages from Shiji 29 and Hanshu 29. Fan Ye's Hou Hanshu does not comprise a treatise on water management.

35 Both chapters do include several passages on pre-imperial times, but the bulk of each account is dedicated to projects undertaken during the Han period.

36 For the time after Emperor Wu's reign, the Hanshu does not mention any public works of such scale, but rather minor projects initiated by local administrators. 
Considerable parts of the chapters' accounts on Han dynasty projects are made up of quotations from high officials' memorials to the throne recommending particular public works. Among other matters, these elaborate on transaction costs to be minimized, such as the amount of time and risk involved when shipping tax grain from a certain region to the capital. The following account of the construction of a transportation canal running south of the Wei River may serve as a case in point:

\begin{abstract}
At this time [133 вCE] Zheng Dangshi, who was serving as superintendent for agriculture, said to the emperor, "Up to now grain from east of the pass has been brought to the capital by being transported up the Wei River. The operation requires six months to complete and the course is over $900 \mathrm{li}$ (about $375 \mathrm{~km}$ ) and beset with dangerous places. Now if we were to dig a canal from the Wei River, beginning at [the capital] Chang'an and following along the Southern Mountains [eastward] to the Yellow River, the distance could be reduced to something over 300 li (about $125 \mathrm{~km}$ ). We would have a much easier route for transporting grain, and the trip could be accomplished in three months. Moreover, the people living along the canal could utilize the water to irrigate over 10,000 qing of farmland. Thus we would reduce the time and labor required to haul grain and at the same time increase the fertility of the lands within the passes and obtain a higher yield." Approving the plan, the emperor ordered Xu Bo, a water engineer from Qi, to plot the course of the transport canal and called up a force of several ten thousands of laborers to do the digging. After three years of labor, it was opened for use in hauling grain and proved extremely beneficial. From this time on grain transport to the capital gradually increased, while the people living along the canal were able to make considerable use of the water to irrigate their fields.
\end{abstract}

是時鄭當時為大農，言曰：「異時關東漕粟從渭中上，度六月而罷，而漕水道九百餘里， 時有難處。引渭穿渠起長安, 并南山下, 至河三百餘里, 徑, 易漕, 度可令三月罷; 而渠 下民田萬餘頃, 又可得以溉田：此損漕省卒，而益肥關中之地，得穀。」天子以為然，令 齊人水工徐伯表，悉發卒數萬人穿漕渠，三歲而通。通，以漕，大便利。其後漕稍多， 而渠下之民頗得以溉田矣。37

Several further projects were concerned with the transportation costs for tax grain reaching the capital from the east. Another official under Emperor $\mathrm{Wu}, \mathrm{Pan} \mathrm{Xi}$, suggested that it would be more efficient to construct a system of canals irrigating a formerly uncultivated region along the Yellow River north of the capital area and use its yields instead of transporting masses of grain from the east to the capital. He argued that

Every year over 1,000,000 piculs (about 20,000 cubic meters) of grain are transported [to the capital] from the area east of the mountains. It must be shipped through the dangerous narrows at Dizhu Mountains [i.e., Sanmenxia], where much of it is lost, and the cost of transportation is very high.

漕從山東西, 歲百餘萬石, 更砥柱之限, 敗亡甚多, 而亦煩費。38

37 Shiji 29.1409-1410, trans. Watson 1993, 55-56; cf. Hanshu 29.1679, trans. Needham 1971, 273.

38 Shiji 29.1410, trans. Watson 1993, 56 (with modifications); cf. Hanshu 29.1680. 
Passages such as this are important, among other reasons, because they provide certain quantitative data, such as the volume of annual grain transported from the North China Plain to the capital. Pan Xi's irrigation project is said to have failed because the Yellow River changed its course. Consequently, "the water did not flow into the canals properly and the farmers who worked newly opened fields were unable to produce enough to repay the cost of planting” 渠不利, 則田者不能償種. Considering the information that "several tens of thousands of laborers" 卒數萬人 had worked on this project "for several years" 數歲, 39 the example further illustrates the risk that was involved in large-scale public undertakings, as well as the expenditure involved for the state's treasury.

The unpredictability of the Yellow River had even greater effects on the area of the North China Plain in the east, where breaking banks and dikes repeatedly caused flood disasters of literally historic dimensions. The Shiji and Hanshu accounts of these incidents reveal a good deal of the complexities involved in flood control measures: Local or personal interests could at times be at odds with and prevent public action for the common good, just as interests of flood protection could be at odds with those of irrigation. The accounts further attest to the complexity of economic considerations - regarding, e.g., budgetary policies, estimation of labor forces, distribution of tax revenues for emergency relief, and migration management - that were at play when the central government faced the task of dealing with flood disasters in the eastern part of the empire.

The historiographic accounts of imperial water management offer fascinating and detailed insights into the ways the Qin and Han Empires dealt with their massive challenges regarding infrastructure and resource extraction. ${ }^{40}$ It is interesting to see, moreover, how these challenges were reflected in historiographic writing. The two parallel chapters in Shiji and Hanshu belong to those rare examples in which Sima Qian and Ban Gu convey a fundamentally congruent view. Both of them clearly acknowledged the importance of the state's efforts in expanding waterways and finding effective measures of flood control. ${ }^{41}$ Both the practices and their historiographic reception further invite comparisons with other imperial polities. The Mediterranean Sea, for example, was a highly important space for trade, communication, and travel in the Greek and Roman worlds. The Greek and Roman states spent much effort to make it safe and navigable, if rather in the form of fighting piracy and hostile powers that impinged on the secure transport of goods and peo-

39 Shiji 29.1410, trans. Watson 1993, 56 (with modifications); cf. Hanshu 29.1680.

40 On the more general implications of these challenges for the Qin and Han Empires, see Lewis 2015.

41 The subtle changes that Ban Gu made with regard to the time period covered in both chapters and with regard to his evaluative comments do not touch upon this general view, but rather consist of personal side blows against Sima Qian. On the parallels and subtle differences between the two chapters, see van Ess 2014, 563-567. 
ple across the sea. And as in the Chinese case these efforts provided themes for historiographic accounts that praised the beneficial effects of these efforts. ${ }^{42}$

\section{II.5 The Accounts on Foreign Peoples}

All three Han histories contain several chapters on foreign peoples, including both ethnographic descriptions and chronological accounts of diplomatic relations and military conflicts. These chapters are relevant to economic history in that they include information on the economic bases and commodities of neighboring regions and polities, their interest in Han products (and vice versa), and frequent references to gift exchange or extorted payments in the context of diplomatic relations. They also comprise remarks on tax relations, border markets, customs barriers, legal restrictions on foreign trade, and contraband. Furthermore, they include the central historical accounts of the Han envoy Zhang Qian's 張騫 (185-114 BCE) missions to Central Asia and the empire's expansion toward the northwest, as well as accounts of long-distance connections to polities reaching as far as the Roman Empire, India, and Japan, including occasional references to economic activities. ${ }^{43}$

These chapters have been at the center of debates over the reasons why the Han Empire expanded its contacts, areas of influence, and territories toward Central Asia and other directions. Opinions on this matter range from assuming economic motives as being crucial for all sides to the view that they were mutually of a truly diplomatic nature, with economic motives playing a marginal role and private trading activities being hardly more than a side effect. Others have stressed ideological purposes with regard to the Chinese side, while arguing that diplomacy served as a "cloak for trade" for some polities of the Western Regions. ${ }^{44}$ Rather than jumping

42 For the Roman efforts, see Weaverdyck, ch. 7, sections III.1 and III.3.1, this volume.

43 Both Shiji and Hanshu include accounts of the Xiongnu (Shiji 110 and Hanshu 94), the southern peoples of the Southern Yue (in modern Guangdong, Guangxi, and Yunnan in southern China, and parts of northern Vietnam), Eastern Yue (in modern Zhejiang and Fujian in southeastern China), and Southwestern Yi (in modern Sichuan, Yunnan, and Guizhou), as well as Chaoxian on the northern Korean peninsula (Shiji 113-116 and Hanshu 95), and the so-called Western Regions of the Tarim Basin and beyond (Shiji 123 and Hanshu 96). The account on Zhang Qian, which is incorporated into Shiji 123, was remodeled by Ban Gu as an individual biography (in Hanshu 61). The Hou Hanshu contains a different set of accounts, i.e., on the Eastern Yi 東夷 (Korean peninsula, including a short account of Japan), the Southern Man 南蠻 and Southwestern Yi 西南夷, the Western Qiang 西㒸, the Western Regions 西域, the Southern Xiongnu 南匈奴, and the Wuhuan 烏桓 and Xianbei 鮮卑. An English translation of the individual Shiji chapters on foreign peoples is provided by Watson 1993, part 2. For an English translation of Hanshu 61 and 96, see Hulsewé 1979. An English translation of the account on the Western Regions of the Hou Hanshu is provided by Hill 2015. For extensively annotated accounts of the chapters on the Western Regions in Shiji, Hanshu, and Hou Hanshu, see Yu 2005. For an analysis of these chapters, see Yu 2013.

44 The latter view has been highly influential ever since Yü Ying-shih published his pioneering work on the relationship between Han foreign policies and external trade (Yü 1967). For the "cloak 
to general conclusions about long-term motivations, it is better to read these chapters closely and ask what they have to say about the motivations of particular actors, or groups of actors, in particular situations with regard to particular regions, and under particular (and changing) historical circumstances. Approaching the texts from a micro-perspective reveals a rather complex ensemble of individual factors and historical situations rather than an all-encompassing picture about Han ideology.

For example, Emperor Wu's initial interest in several polities of the Western Regions was clearly connected to his hopes to get hold of their fine horses. Rather than being just a personal fancy or a desire for 'heavenly horses' (tian ma 天馬) that had some ideological value as tributary gifts, his interest might have largely resulted from a loss of allegedly more than 100,000 horses in a battle against the Xiongnu in 119 BCE, which must have rendered the Han army virtually unable to fight. ${ }^{45}$

Another example is a passage which reveals the social motivation of envoys for making an expedition. Sima Qian tells us the following:

After Zhang Qian achieved honor and position by opening up communications with the lands of the west, ${ }^{46}$ all the officials and soldiers who had accompanied him vied with one another in submitting reports to the emperor telling of the wonders and curiosities, profits and harms of the foreign states and requesting to become envoys ... The envoys were all sons of poor families who handled the government gifts and goods that were entrusted to them as though they were their private property, intending to make a cheap deal [out of them] in order to privately bag the profit (in the foreign states). ${ }^{47}$ The foreign states on their part were disgusted

for trade" argument, see 59, 144. Liu Xinru argues that after the first military confrontations between the Han and the Xiongnu, "[t]he interests of both sides shifted to trade and protecting trade routes," and that Emperor Wu decided to occupy the Hexi corridor "in order to protect a newly established trade route" (Liu 2010, 9, 11). Earlier, Frederick J. Teggart had even argued that Han expansionism had been fueled by a desire to find new outlets for the empire's overproduction of silk (Teggart 1939, 148-233). For the view that most Han endeavors were neither ideologically nor economically motivated, but that they were primarily based on realpolitik and diplomacy, see Selbitschka 2015.

45 On horses as motives for military action, see, e.g., Hulsewé 1979, 132-134, n. 332; Creel 1965, esp. 660. There are several references to foreign 'heavenly horses' in Shiji 123 and in Hanshu 61 and 96.

46 Sima Qian quite frankly writes that Zhang Qian himself had advocated for a mission to the Wusun "because he had lost his title of marquis" 既失侯, 因言曰, thereby suggesting that Zhang Qian, sensing a chance for rehabilitation, might very well not have been quite honest in his arguments in favor of the undertaking (Shiji 123.3168; cf. Hanshu 61.2691).

47 Watson $(1993,242)$ translates "looked for opportunities to buy goods at a cheap price in the foreign countries and make a profit on their return to China." The Chinese text, however, says nothing about the envoys buying goods or about them making their profit on their return to China (even though they may have done that as well). The original text rather suggests that the envoys sold the aforementioned presents and goods that had been entrusted to them by the Han government and which they "handled as though they were their private property." The final "in the foreign states” (wai guo 外國) is syntactically awkward and might well be due to dittography, as the next sentence starts with wai guo as well. The Hanshu parallel accordingly omits the former wai guo. 
with the envoys invariably talking about the value [of goods], and, estimating that the Han armies would be too far away to be able to make it to [their countries], refused to supply the Han envoys with food and provisions in order to make things difficult for them.

自博望侯開外國道以尊貴，其後從吏卒皆爭上書言外國奇怪利害，求使。 $[\cdots]$ 其使皆貧 人子，私縣官齊物，欲賤市以私其利外国。外國亦厭漢使人人有言輕重，度漢兵遠不能 至，而禁其食物以苦漢使。48

While Sima Qian may have exaggerated this point in order to make the expansionist strategy of the emperor appear ill conceived, there is no good reason to believe that his remarks on the envoys' motives were not grounded in some general truth. The passage suggests that diplomacy could indeed be used as a 'cloak for trade,' but in this case by the Chinese envoys. It demonstrates how diplomatic missions and trading activities, involving both governmental and private interests, could be intertwined, with their particular goals being at odds with one another. ${ }^{49}$ In a similar manner, foreign states of the far west such as Jibin 罰賓 (Kashmir) or Kangju 康居 (Sogdiana), on their part, were accused by the Chinese side of sending "traveling merchants and men of low status" as pseudo-envoys, whose only interest was doing business "under the pretext of making offerings" 以獻為名, ${ }^{50}$ or of sending a hostage prince just because they "wish[ed] to conduct trade and create a pretense through fine verbiage” 欲賈市為好辭之詐. ${ }^{51}$ It is important to note, however, that large and remote states such as Jibin and Kangju would naturally have been less interested

This reading would thus not specify where the envoys sold the goods. But even in this case, the most intuitive reading would be that they sold them in the foreign countries they visited.

48 Shiji 123.3171. Cf. Hanshu 61.2695, where Ban Gu left out the remark on the envoys' poor family background while largely adopting the rest of these statements. The last sentence quoted above is difficult with regard to the interpretation of the expression yan qing zhong 言輕重, with the literal meaning of qing zhong being 'light and heavy' (see section III.2 below). Watson (1993, 242), following a traditional commentator, translates (quite freely) "each of the Han envoys told some different story" (my emphasis). Van Ess (2014, 358, n. 125), following another commentator, takes yan qing zhong to mean "jdn. übervorteilen" ('to fleece s. o.'). Considering that the sentence before is talking about the envoys' marketing goods and seeking profit, I would suggest that the most contextually fitting (and generally well-attested) interpretation of qing zhong in this case would simply be 'cheap and expensive' or 'non-valuable and valuable,' that is, the prices or values (of goods), as already indicated as an alternative translation to the parallel Hanshu passage by Hulsewé 1979, 222-223, n. 842. On the passage above, see also Yü 1967, 137-138, who uses Watson's translation.

49 Other actors' motives for advocating northwestern expeditions and wars could again be totally different: A court faction of southerners, for example, appears to have pleaded for military action in the north not because of any alleged (public or private) benefits of such an undertaking, but simply because they wanted to prevent any further military engagement in the southern regions, fearing that in the latter case, southern locals would have to carry the load. On these events, see van Ess 2014, 343-344.

50 Hanshu 96.3886 (with reference to Jibin, i.e. Kashmir); cf. Hulsewé 1979, 109.

51 Hanshu 96.3893 (with reference to Kangju, i.e., Sogdiana); cf. Hulsewé 1979, 128 (with a slightly different translation). 
in purely diplomatic relations with China than many of the rather small states of the Tarim Basin. The latter were not only neighbors to larger and more powerful city-states, but also dangerously close to the two giant empires of the Han and the Xiongnu. For them, reliable diplomatic relations - which ideally provided a certain measure of safety from military confrontation - would have tended to be much more essential. Nevertheless, here as well we have to take into account that the description of the foreign envoys' behavior was Sima Qian's personal interpretation, which fit well into his general attempt at ridiculing his emperor's passionate attempts at expanding his authority to distant lands.

On a more general note, the historiographic sources suggest that in the north and northwest, foreign relations tended to be an economic burden, rather than an asset, both for the Han Empire and at least some of the Tarim Basin city-states. Based on figures given in the Hou Hanshu, Yü Ying-shih has estimated the Eastern Han government's annual payments to the Xianbei 鮮卑, Xiongnu 匈奴, Qiang 㒸, Wuhuan 烏桓, and the city-states of the Tarim Basin to have amounted to 750 million in cash value, or to "about one third of the annual government payroll or 7 percent of the total revenue of the empire." 52 The scale of expenses used for diplomatic relations, moreover, was a matter of dispute at the Han court. ${ }^{53}$ It should be noted, however, that the payments to all Tarim Basin polities together amounted to only one tenth of these figures (74.8 million cash), while almost one third (270 million cash $)^{54}$ was dedicated to the Xianbei. These were the Han's most powerful pastoralist neighbors at that time, having taken over large parts of the former Xiongnu territory to the north of the Han Empire.

Apart from other costly obligations, ${ }^{55}$ some Tarim Basin polities on their part appear to have been particularly burdened by the Han government's expectation for them to supply the latter's frequent and highly manned missions with "cattle, sheep, corn, cut fodder, guides, and interpreters” 牛羊穀媰荠, 導譯. ${ }^{56}$ In anticipation of one such mission, the rulers of Further Jushi (Jushi Hou 車師後) decided to surren-

52 Yü 1967, 61-64, quotation from 64.

53 In 3 BCE, when the Xiongnu chanyu asked for a permission to personally visit the Han court, many court officials pleaded to turn down this request on the grounds of the costs the visit would involve. The emperor, however, decided not to heed their advice. He had been persuaded by Yang Xiong 揚雄 (53 BCE-18 CE) that, despite of the high costs involved, the damage caused by a denial of the chanyu's request would be far more detrimental. Hanshu 64B.3812-3816.

54 Other than the total estimate of annual payments (which could only take into account ballpark figures for the unreported amount of annual payments to the Qiang and Wuhuan), the above two figures are reported explicitly in a memorial to the throne quoted in Hou Hanshu 45.1521.

55 Such as expenses for gifts presented to the Han court, contributions of fertile lands for Han military garrisons, and bribes to Han officials (Yü 1967, 51, 145-147).

56 Hanshu 96.3925, trans. Hulsewé 1979, 193. Sima Qian provides some summarizing figures for the frequency and size of missions during Emperor Wu's rule: Reportedly, between five and more than ten missions to foreign states were sent out each year, with the larger ones including up to several hundred envoys (Shiji 123.3170, trans. Watson 1993, 275). 
der to the Xiongnu in $10 \mathrm{CE}$, assuming that their economic situation would not allow for the impending expenses. ${ }^{57}$ On the other hand, the sources do suggest at least temporary dependencies on Han goods in the case of some of the predominantly pastoralist northern neighbors. It appears that from the latter's point of view, relations to the Han Empire - as a means of receiving certain desired products through gift exchange or of getting access to border markets - tended to be economically desirable.

The dynastic histories draw a complex picture as regards the reasons for Han expansion and for particular external policies. Many factors must be considered, such as the proximity and accessibility of the individual foreign polities, their pastoralist or nonpastoralist lifestyle, and their short-term economic situations. Moreover, changing forms of demands, changing levels of information, changing regional power structures, fluctuating assertiveness of the Han and other polities' governments, as well as individual motives on different operating levels had massive impacts on foreign policy decisions. The sources, however, do not suggest that the Han government envisioned establishing a flourishing long-distance network of trade for the sake of either themselves or for any merchants.

\section{II.6 Concluding Remarks on the Source Value of the Dynastic Histories}

Despite the fact that dynastic histories include a large amount of economic reflection and detail, they pose challenges to their readers. Firstly, the information we get from these chapters is distributed unevenly over time, with the absence of chapters on economy, water management, and 'money makers' in the standard history of the Later Han period (i.e., in Fan Ye's Hou Hanshu) being only the most obvious weakness. ${ }^{58}$ Secondly, the authors of these texts were biased not only in the general sense of writing from the perspective of the imperial center, but also in particular ways. Sima Qian disapproved of many of his ruler's centralist, interventionist, and expansionist initiatives, and his accounts often involved his personal archenemies or friends. Thus his presentation is likely to be selective, or at least overemphasizing some aspects while underemphasizing or withholding others. Thirdly, much information on economic matters, despite their apparent clarity, reveals ambiguities on closer inspection. Imprecision and other peculiarities have for generations and even centuries left scholars debating both the authors' standpoints and the implications of the policies themselves they suggest. The histories' remarks on the nature of the policies of 'equitable delivery' and the 'balanced standard' are a case in point: Their

57 Hanshu 96.3925, trans. Hulsewé 1979, 192-193.

58 As has already been mentioned, the Shiji and the Hanshu accounts themselves each feature a strong focus on particular periods within their larger time frames. 
very terseness accounts for the fact that up to today, scholars keep struggling with questions about the scope, practical implications, and interdependency of these measures. ${ }^{59}$

All these limitations notwithstanding, the historiographic works remain among the most important sources for early imperial history in general and economic history in particular. They are also indispensable with regard to the interpretation of newly excavated texts, since many of the latter's concrete and detailed contents would be hardly intelligible without the framework that is provided by, and only by, the transmitted historiographic works.

\section{Politico-Philosophical 'Masters' (zi 子)}

\section{III.1 The Discourses on Salt and Iron (Yantie lun 鹽鐵論)}

The legacy of Emperor Wu's rule, with its shift toward expansionism, centralism, and economic interventionism, provoked the genesis of yet another quasi-historiographic work that is of crucial importance for our understanding of Han economic thinking and policies: The Yantie lun is an account of a court debate that was held in 81 BCE, a couple of years after Emperor Wu's death, on the empire's future political agenda. It was without much doubt compiled during the reign of emperor Xuan 宣 (r. 74-49 BCE) by a man named Huan Kuan 桓寬. The political issue from which the work derived its title was the question of whether or not the state should maintain its monopolies on salt (yan) and iron (tie) that had been introduced under Emperor Wu's rule. This question, however, was tightly connected with a set of other controversial issues, many of which were of economic significance, such as military spending, the coinage monopoly, centralized logistics, price stabilization schemes, and taxation. Comprising sixty chapters, the text presents opinions on all these matters in the form of a dialog between two opposing parties: the 'grandee' (dafu 大夫), usually identified with the interventionist policy maker Sang Hongyang 桑弘羊 (ca. 152-80 BCE), ${ }^{60}$ and his critics, typically represented by the unnamed 'learned scholars' (wenxue 文學). ${ }^{61}$

59 See, for instance, the diverging interpretations of the 'equitable delivery' system offered by Wang 王 1994 and Yi 亦 1994.

60 The policies implemented by Sang Hongyang under Emperor Wu included the introduction of state monopolies as well as the 'equitable delivery' and 'balanced standard' systems. Later, from 87 to 80 BCE (which includes the time when the debates took place), he held the eminent post of imperial counselor or secretary grandee, yushi dafu 御史大夫. Sima Qian's “Treatise on the Balanced Standard" (see above) notoriously ends with the former sheep breeder Bu Shi's request for Sang Hongyang to be "boiled alive" (Shiji 30.1442, trans. Watson 1993, 83).

61 Occasionally, the text refers to other, equally unnamed speakers such as the 'worthy' (xianliang 賢良) or the 'chancellor's scribe' (chengxiang shi 丞相史). While one needs to take into account that each of these may have referred to the distinctive views of particular people or groups, the attitudes 
It is, however, hard to say in what ways Huan Kuan interfered with the source material that may have been at his disposal. It is uncertain to what extent the text reflects the duality and wording of the actual debate or rather the author's modified (that is, organized, sharpened, shortened, extended, biased, or even fictionalized) version of it. ${ }^{62}$ That the author did interfere with his material at least to a certain extent is suggested by the fact that the learned scholars always have the last word within the individual chapters, and that the grandee faction (in contrast to the learned scholars) is explicitly said to have been left dumbfounded on occasion. Nevertheless, at least from a modern reader's perspective, the grandee's arguments do not appear to have been altered in a way that made them look generally illogical or otherwise bereft of their persuasive power.

Especially in Western scholarship, the opposing opinions that the Yantie lun reveals have often been read from an overly ideological point of view. Such an approach suggests that it was the learned scholars' allegedly 'Confucian' ideology, which they found in allegedly 'Confucian' texts, ${ }^{63}$ and the grandee's allegedly 'legalist' doctrine, that shaped their opposing political views. ${ }^{64}$ Most importantly, approaches focusing merely on ideology neglect the practical motives and socioeconomic backgrounds that lay behind these disputes. Trying to track these down while acknowledging the largely rhetorical nature of the debate's philosophical and moralizing underpinnings - promises to be a much more fruitful approach to the disputes found in the Yantie lun, and, indeed, many other Han texts. People must have had good reasons to advocate for or against military engagement in a certain place or at a certain time, in favor of or against a certain treatment of merchants, a particular form of taxation, or the government's control over coinage and the production of iron and salt. All these depended on their own or their supporters' socioeconomic background, regional or local roots and networks, their role in the bureaucracy, or their potential involvement in military matters, trading activities, and

attributed to the worthy are largely concordant with those articulated by the learned scholars, while the chancellor's scribe's opinions resemble those of the grandee.

62 It has been argued that some sections appear more likely to have been "cit[ed] from what was originally an independent piece of writing" (Loewe 1993, 477) rather than from a record of oral speech. It has further been suggested that chapters 42-59 were written at a later date since they are different in style. For this argument, see Lai 1996.

63 It has been suggested that the notion of Han era 'Confucianism' (at least in the sense of an ideology) should be abandoned altogether. See, e.g., van Ess 1993b, 291; Beck 1977, 329-330.

64 The most typical example of this perspective is Kroll 1978. Chinese scholarship in the PRC, in contrast, while typically being deeply entrenched in the respective politics and ideological vocabulary of the day, has traditionally been more (though not generally) devoted to questions about the socio-economic background of the debate (Vogel 2002, 90-102). Vogel himself, however, is rather inclined to stress the alleged significance of "ideology" and of a belief in certain "principles of cosmic world order," and to advocate Kroll's approach of "understanding Sang Hongyang's economic ideas not as an isolated economic attitude, but as an organic part of his entire world view, so as to take him seriously as a philosopher" (Vogel 2002, 83-83, 102). 
power struggles between mighty clans. It is therefore not conducive, for example, to fall for the learned scholars' line: The fact that their rhetorical vocabulary puts stress on 'humaneness' (ren 仁), 'righteousness' ( $y i$ 義), and 'mercy' (en 恩) does not imply that their standpoint was necessarily more idealistic, ethically founded, more commiserative with the 'common people' in general, or less concerned with realpolitik than the grandee's faction. ${ }^{65}$ It is more useful to ask which parts of society they may have envisioned as the central beneficiaries of the 'mercy' and 'humaneness' arising from the concrete politico-economic measures they advocated. A very similar laissez-faire-like political agenda to the one which the learned scholars of the Yantie lun advocated while invoking so-called Confucian texts had typically been supported by people with a preference for texts of a more 'Daoist' nature only slightly earlier (such as, for instance, Sima Qian). ${ }^{66}$ Meanwhile, however, Emperor Wu's establishment of the Five 'Confucian' Classics (wu jing 五經) as a formal textual standard for high officials' education (but not as a state ideology) at the Imperial Academy (Taixue 太學) had begun to leave its mark on the rhetorical style of political discussions. To put it simply, it had turned the formerly 'Daoist' conservatives into 'Confucian' conservatives, with their political standpoints largely preserved. ${ }^{67}$

In contrast to many, especially Eastern Han texts, in which political controversies are increasingly shrouded by the surface of philological disputes, the arguments of the two Yantie lun parties are often quite straightforward and - thanks to the dialogical form - well defined. Furthermore, many disputes are contested on the basis of purely economic rationales by both parties. The following, for instance, is an example of how they discuss the matter of the state's involvement in economic matters by means of its 'balanced standard' and 'equitable delivery' policies:

The grandee said: "Formerly the lords in the commanderies and kingdoms sent in their respective products as tribute. The transportation was vexatious and disorganized; the goods were usually of distressingly bad quality, often failing to repay their transport costs. Therefore, transportation officers have been provided in every commandery and kingdom to assist in the delivery and transportation and for the speeding of the tribute from distant parts. So the system came to be known as 'equitable delivery.' A Receiving Bureau has been established at the capital to monopolize all the commodities, buying when prices are low, and selling when pri-

65 Even Michael Loewe, who otherwise emphasizes the political nature of the debate, speaks of "the two points of view of the idealist and the realist" (Loewe 1974, 98).

66 Possibly in continuation to this legacy, the learned scholars still quote Laozi on several occasions, whereas the grandee faction does not invoke him at all.

67 On the political dimension of scholarly debates during the Han period, see Loewe 1974; van Ess 1993b. On the conservatives' (or reformists') rhetorical shift from a 'Daoist' to a 'Confucian' framework, see van Ess 1993a, 24-25. While I concede the point that the political camps, their sets of opinions, and their connection to particular texts were less bipolar and less stable than some of van Ess's assertions suggest, his central approach, that is, trying to identify practical (e.g., political, social, economic) motives behind the 'ideological' underpinnings or scholarly debates, remains valid and highly relevant for modern-day research on Han political, intellectual, social, and economic history. For a critical and thought-provoking review of van Ess 1993b, see Gentz 2003. 
ces are high, with the result that the government suffers no loss and the merchants cannot speculate for profit. This is therefore known as the 'balanced standard.' With the balanced standard, people are safeguarded from unemployment; with the equitable delivery, people have evenly distributed labor. Both of these measures are intended to equilibrate all goods and convenience the people, and not to open the way to profit and provide a ladder to popular misdemeanor."

大夫曰: 「往者, 郡國諸侯各以其方物貢輸, 往來煩雜, 物多苦惡, 或不償其費。故郡國 置輸官以相給運，而便遠方之貢，故曰均輸。開委府於京師，以籠貨物。賤即買，貴則 賣。是以縣官不失實, 商賈無所貿利, 故曰平準。平準則民不失職, 均輸則民齊勞逸。 故平準、均輸，所以平萬物而便百姓，非開利孔而為民罪梯者也。」

The learned scholars said: "The ancients in levying upon and taxing the people would look for what the latter were skilled in, and not seek for those things in which they were not adept. Thus the farmers contributed the fruits of their labor, the weaving women, their products. Now the government leaves alone what the people have and exacts what they have not, with the result that the people sell their products at a cheap price to satisfy demands from above. Recently in some of the commanderies and kingdoms they ordered the people to make woven goods. The officers then caused the producers various embarrassments and bargained with them. What was collected by the officers was not only the silk from Qi and E, or cloth from Shu and Han, but also other goods manufactured by the people which were mischievously sold at a standard price. Thus the farmers suffer twice over while the weaving women are doubly taxed. We have not yet seen that your delivery is 'equitable.' As to the second measure under discussion, the government officers swarm out to close the door, gain control of the market and corner all commodities. With commodities cornered, prices soar; with prices rising, the merchants make private deals by way of speculation. Thus powerful officials and rich merchants store up goods and accumulate commodities waiting for a time of need. Nimble traders and unscrupulous officials buy in cheap to get high returns. We have not yet seen that your standard is "balanced."”

文學曰：「古者之賦稅於民也，因其所工，不求所拙。農人納其穫，女工效其功。今釋 其所有, 責其所無。百姓賤賣貨物, 以便上求。間者, 郡國或令民作布絮, 吏恣留難, 與之為市。吏之所入，非獨齊、阿之縑，蜀、漢之布也，亦民間之所為耳。行姦賣平， 農民重苦, 女工再稅, 未見輸之均也。縣官猥發, 闣門擅市, 則萬物并收。萬物并收, 則物騰躍。騰躍, 則商賈侔利。自市, 則吏容姦。豪吏富商積貨儲物以待其急, 輕賈姦 吏收賤以取貴，未見準之平也。68

Discussions like these significantly add to our understanding of economic policies and their implications, regarding which we would otherwise have to rely largely on the often terse or even cryptic references found in the dynastic histories. Other passages show the two parties' differing opinions on whether or not expansion had turned out to be beneficial for the Han from a 'balance of trade' (or 'balance of exchange') perspective. This is the grandee's opinion on the matter:

Now the treasures of the mountains and marshes and the reserves of the equitable delivery system are means of holding the balance of natural wealth and controlling the principalities.

68 Yantie lun jiaozhu, 4, trans. Gale 1967, 9-11 (with modifications). 
$\mathrm{Ru}$ and Han gold and other petty articles of tribute ${ }^{69}$ are means of inveigling foreign countries and snaring the treasures of the $\mathrm{Hu}$ and the Qiang. So [in exchange for] a piece of Chinese plain silk, we get Xiongnu articles worth several pieces of gold and thereby reduce the resources of our enemy. Mules, donkeys and camels enter the frontier in unbroken lines; horses, dapples and bays, and prancing mounts come into our possession. The furs of sables, marmots, foxes and badgers, colored rugs and decorated carpets fill the Imperial Treasury, while jade and auspicious stones, corals and crystals, become the state's treasures. That is to say, foreign products keep flowing in, while useful [resources] are not dissipated.

汝、漢之金, 纖微之貢, 所以誘外國而釣胡、芫之寶也。夫中國一端之縵, 得匈奴累金 之物, 而損敵國之用。是以騾驢馲駝, 銜尾入塞, 驒騱騵馬, 盡為我畜, 鼠貂狐貉, 采斿

文罧, 充於內府, 而璧玉珊瑚琉璃, 咸為國之寶。是則外國之物內流, 而利不外泄也。

The learned scholars, however, take a very different view:

Now mules and donkeys are not as useful as cattle and horses. Sable and marmot furs, wool and felt goods do not add substance to silk. Beautiful jades and corals come from mount Kun. Pearls and ivory are produced in Guilin. These places are more than ten thousand li distant from the Han [i.e., Chang'an]. Calculating the labor for farming and silk raising and the costs in material and capital, it will be found that one article of foreign import costs a price one hundred times its value, and for one handful, ten thousand weight of grain are paid. As the rulers take delight in novelties, extravagant clothing is adopted among the people below. As the rulers treasure the goods from distant lands, wealth flows outward.

今騾驢之用, 不中牛馬之功, 鼠貏斿罰, 不益錦綈之實。美玉珊瑚出於昆山, 珠㙨犀象出 於桂林, 此距漢萬有餘里。計耕桑之功, 資財之費, 是一物而售百倍其價也, 一揖而中 萬鍾之粟也。夫上好珍怪，則淫服下流，貴遠方之物，則貨財外充。 ${ }^{70}$

Passages of this kind provide insights on several issues: For instance, and most generally, they depict both parties as arguing on purely economic grounds. More specifically, they attest to people's conception of diplomatic gifts from an economic point of view: The value of gifts is here traded off against each other with the ultimate intent of striking a bargain. The discussion further suggests that the output of this kind of exchange was thought to consist primarily of luxury items. The circle of beneficiaries of this kind of exchange will have been largely restricted to the emperor and the people close to him. This so-called trade with foreign polities is pictured here as a trade through a very tight bottleneck.

To be sure, the Yantie lun confronts us with the question of its value as a historical source. It is by no means certain to what extent the dialogs as presented were related to the actual debates that took place a couple of decades earlier. But in comparison to other sources, such as the Guanzi introduced in the next section,

69 The sentence before makes it clear that these products were demanded by the Han court as tributary taxes from certain regions within the empire and transported across the empire by the state's 'equitable delivery' (junshu) system. The term 'tribute' is therefore used here (like elsewhere) with reference to something that the Han court gets, not to something that it pays.

70 Yantie lun jiaozhu, 28-29, trans. Gale 1967, 14-16 (with modifications). 
these problems appear rather marginal. The Yantie lun therefore needs to be credited with being one of the most illuminating transmitted sources for economic policy and deliberation in the Han period. Its comprehensive contents continue to offer ample potential for future research.

\section{III.2 The Qingzhong 輕重 Chapters of the Guanzi 管子}

It is uncontested that parts of the politico-philosophical work Master Guan (Guanzi) deserve to be counted among the most important ancient Chinese works on economic thinking. Whether it should be treated as a source for the early imperial period under question, however, has long been a matter of debate. The work was traditionally attributed to and named after Guan Zhong 管仲 (720-645 BCE), who is known as the chancellor and most important adviser of Duke Huan 桓 of Qi 齊 (d. 643 BCE). The latter went down in history as the first of five 'hegemons' ( $b a$ 霸) that consecutively led the states of the Chunqiu period. His predominance is typically attributed to Guan Zhong's strategies. Many chapters of the Guanzi are presented in the form of dialogs between Guan Zhong and Duke Huan, with the former answering the latter's questions. Scholars nowadays generally agree that the Guanzi was neither written by Guan Zhong himself nor by any other single author, but that it is a multiauthored product with a rather complex textual history, parts of which can be dated to the Han period.

In its received version, the Guanzi contains a group of chapters (chs. 68-85) which are primarily concerned with economic matters and are commonly referred to as the Qingzhong chapters. ${ }^{71}$ Qingzhong 輕重 literally means 'light and heavy,' but it may also be interpreted as 'inexpensive and expensive' or 'invaluable and valuable,' 'value and devalue,' or even 'devalue what is considered valuable.' The specific meaning of both the compound and its two parts in particular contexts (within the Guanzi and elsewhere) is often contested. But as a more general term, it is usually associated with the notion of a ruler's use of economic strategies, such as the manipulation of exchange ratios, in order to consolidate state power.

As in the case of other parts of the Guanzi, the framing contents of the Qingzhong chapters are not set in a unified empire, but in a particular state (that is, Qi) that competes with its neighbors on both military and economic grounds. This alone, however, does not rule out the possibility of an early imperial dating. Modern scholars disagree on whether the Qingzhong chapters should be primarily read as Warring States or Former Han texts. ${ }^{72}$ Regarding both linguistic evidence and histori-

71 Of these, chs. 80-85 actually bear the term qingzhong in their headings.

72 In his introduction to Guanzi Qingzhong pian xin quan (1979, 3-50), Ma Feibai 馬非百 furthermore suggested that the Qingzhong chapters were produced during the interregnum of Wang Mang (r. 9-23 CE). For a summary of the different hypotheses regarding the dating of the Qingzhong chapters, see Rickett 1985, 2:346-357. In his Economic History of China, von Glahn (2016, esp. 120- 
cal contexts that the chapters' contents suggest, arguments for both scenarios can be found. The multiauthor and multilayer hypothesis is therefore to be assumed for these chapters as well, even though they are more homogenous as a group than the Guanzi text as a whole. Furthermore, the contents of the Qingzhong chapters are notoriously difficult to understand. The extent of the difficulties involved, however, is hardly noticeable for non-Chinese speakers accessing the English translation by Allan Rickett, ${ }^{73}$ whose (albeit careful and marked) incorporation of Chinese commentators' suggestions for character emendations, omissions, and insertions, glosses over substantial uncertainties and inconsistencies within the received text.

The Qingzhong chapters generally convey the ideal of a strong ruler who knows how to use economic principles (such as the interdependency of certain values) to control the flow of goods and money. The following passage from the chapter "The State's Store of Grain” (Guo xu 國蓄) may serve as an example:

Indeed, when things are plentiful, they will be cheap; when they are scarce, they will be expensive. When they are spread about, they will be valued lightly (qing); when they are concentrated, they will be valued highly (zhong) ${ }^{74}$ Knowing this to be so, the prince pays attention to his country's surpluses and shortages and manages its wealth and goods. When grain is cheap, he exchanges money for food. When hemp and silk cloth are cheap, he exchanges money for clothing. He pays attention to the relative value (qingzhong) of things and manages them in order to maintain price stability. Therefore, the expensive and cheap may be harmonized, and the prince reaps his profits.

夫物多則賤，寡則貴。散則輕，聚則重，人君知其然，故視國之羡不足而御其財物; 穀賤則以幣予食, 布帛賤則以幣予衣, 視物之輕重而御之以准。故貴賤可調, 而君得 其利。75

State policies aimed at controlling prices by "buying when cheap and selling when expensive," which were eventually put into practice in Emperor Wu's 'balanced standard' (pingzhun) scheme mentioned above, are frequently recommended within the Qingzhong chapters. Apart from the hope of making a profit for the state, the fear that is regularly mentioned as underlying such policies is that "should the lord fail to maintain control [over prices] by these policies, the people will eventually control them” 君不守以筮, 則民且守. ${ }^{76}$ This concern is often particularly connected to the fear of merchants controlling prices by engaging in hoarding and speculation.

The Qingzhong chapters demonstrate that quite a variety of ideas on the ideal form of taxation were floating around: Taxes were supposed to be fair in order to

123) treats the Qingzhong chapters as a Former Han source. Chin 2014 also uses it for her analysis of Han economic thinking.

73 Rickett 1985.

74 In this sentence, my translation diverges from Rickett's, who renders qing and zhong as "supply will exceed demand," and "demand will exceed supply," respectively.

75 Guanzi Qingzhong pian xin quan, 241-242, trans. Rickett 1985, 2: 384 (with modifications).

76 Guanzi Qingzhong pian xin quan, 160, trans. Rickett 1985, 2: 366 (with modifications). 
prevent social inequalities and concentration of power among the populace, and acceptable to prevent people from tax evasion, e.g., by migration. Furthermore, several chapters are primarily concerned with the idea of indirect taxation, mainly on salt and iron. ${ }^{77}$ The Qingzhong chapters also suggest a considerable awareness of the undesirable effects of certain levies, as manifest in the following (originally rhyming) mnemonics: ${ }^{78}$

Placing a special tax on houses and verandas means harming construction (成 dj'eng). Placing a special tax on the six domestic animals means killing the living. (生 sreng). Placing a special tax on cultivated fields means restricting their cultivation (耕 kreng). Placing a special tax on adult males means a falsifying of their true numbers (情 $d z j i e n g$ ). Placing a special tax on households favors those blessed with abundance (贏 rieng).

以室庶籍, 謂之毀成。以六畜籍, 謂之止生。以田畧籍, 謂之禁耕。以正人籍, 謂之離 情。以正戶籍, 謂之養贏。79

Yet another remarkable Qingzhong passage has been suggested to imply a "recognition of the quantity theory of money and its value." ${ }^{80}$ Even though the association with the theoretical approach of early modern monetary economics may be contestable, the passage does demonstrate a strong awareness of money being an important standard for measuring the wealth of a country in quantitative terms:

Duke Huan questioned Guanzi, saying, "May I ask about the proportionate [calculation of] money [supply]?” Guanzi replied, "To begin with, base [your calculation] on [the units of] tracts and households consisting of three such tracts, with one chariot per six-square li area and twenty-eight men providing for one chariot. As for a proportionate [calculation of] money [supply], [one then needs to calculate] how many fields of high and low productivity there are in each six-square $l i$ area, how much grain these will produce, what the price of grain will be, how much money will be needed in each six-square li area on average, and how much money will be needed in the case of high grain prices. For a proportionate [calculation of] money [supply], one then issues the money in the country [in such a way that] the money corresponds to the amount of the emerged [i.e., arable] land of the whole country. This is called 'the proportionate [calculation of] money [supply].”

桓公問管子曰:「請問幣乘馬？」管子對曰:「始取夫三大夫之家，方六里而一乘，二十 七人而奉一乘，幣乘馬者，方六里。田之美惡若干，穀之多宣若干，穀之貴賤若干， 凡方六里用幣若干, 穀之重, 用幣若干, 故幣乘馬者, 布幣於國, 幣為一國陸地之數, 謂之幣乘馬。」81

77 These are chapters $72,74,75$, and 76.

78 Reconstructed ancient pronunciations for the characters at the end of each line are given in brackets. In modern Chinese pronunciations, the lines rhyme only partially.

79 Guanzi Qingzhong pian xin quan, 241, trans. Rickett 1985, 2:382-383 (including the ancient phonetic reconstructions).

80 Rickett 1985, 2:406.

81 Guanzi Qingzhong pian xin quan, 383-384; my translation deviates from the one provided by Rickett 1985, 2: 416-417. 
Interesting as these and many other passages may be, the question of dating the Qingzhong chapters remains a serious issue. It often remains unclear whether certain historical backgrounds and particular economic challenges suggested by the chapters refer to Warring States or early imperial realities. Yet it is a notable fact that many Han people must have found them relevant for their own times. This is suggested both by references to the Qingzhong chapters within Han sources and by the similarities between some of the economic measures described in the chapters and those that were actually implemented during the Han period according to the dynastic histories. At least in this regard, the Qingzhong chapters can claim considerable source value for the Han period.

\section{Manuals}

Several works of a more technical nature offer valuable insights into early imperial economic history, if in a very different way than the histories and politico-philosophical treatises. Some sections of mathematical handbooks, for instance, contain valuable material for economic history. Of the two transmitted mathematical manuals from the early imperial period, the Nine Chapters on the Mathematical Art Uiuzhang suanshu 九章算術) is of particular importance in this regard. Each of its nine chapters assembles sample mathematical problems along with their solutions (by clearly stated algorithms) for a particular topic area. Some of the titles of these topic areas already indicate an economic context: The chapter "Millet and Rice" (Su mi 粟米), for instance, is devoted to mathematical problems concerning pricing issues and the exchange of goods at different rates. ${ }^{82}$

The following section will introduce another kind of technical literature, that is, agricultural manuals. Two works of particular importance for the study of agricultural history are Fan Shengzhi's 氾勝之 (first century BCE) Documents of Fan Shengzhi (Fan Shengzhi shu 氾勝之書) ${ }^{83}$ and Cui Shi's 崔定 (second century CE)

82 For an English translation of the Jiuzhang suanshu, see Shen, Crossley, and Lun 1999. For a thoroughly annotated French translation, see Chemla and Guo 2004. The second transmitted mathematical work from the early imperial period, the Gnomon of the Zhou (Zhoubi 周髀, later entitled Zhoubi suanjing 周髀算經), is mainly concerned with astronomical and calendrical calculations. On this work, see Cullen 1996. Another mathematical treatise from the early Western Han period has been excavated from a Western Han local official's tomb at the Zhangjiashan site. It bears the title Writings on Reckoning (Suanshu shu 等數書). Parts of its contents closely parallel those of the Jiuzhang suanshu and similarly touch upon practical economic issues. For English translations of this excavated work, see Cullen 2004; Dauben 2008.

83 Two English translations of the reconstructed Fan Shengzhi shu are available: One is provided by Shi 1974. A revised version based on the latter translation is provided by Hsu 1980, 280-294. The literary catalog of Ban Gu's Hanshu lists a work entitled Fan Shengzhi comprising 18 chapters (pian). It is the only (even fragmentarily) surviving text out of nine items listed under the section of agricultural works in Hanshu 30.1743. 
Monthly Instructions for the Four Classes of People (Simin yueling 四民月令) ${ }^{84}$ Both of them have come down to us only as fragments, that is, through (often extensive) citations in other works. ${ }^{85}$

The Documents of Fan Shengzhi constitute a Former Han agricultural handbook with a strong focus on the activities on the field, such as plowing, sowing, fertilizing, and harvesting. It provides detailed and often quantified advice regarding the cultivation of particular crops, such as the amount of seed to be used, the depth of pits to be dug, ${ }^{86}$ or the crop yield to be expected. Interestingly, the text also incorporates the following estimates regarding the monetary profit to be gained from the cultivation of gourds:

Each [bottle gourd] vine yields three fruits, so each pit yields twelve fruits, one $m u$ produces 2,880 fruits, and $10 \mathrm{mu}$ produces 57,600 dippers. Each dipper is worth 10 cash; so the total value is 576,000 cash. ${ }^{87}$ You will have used 200 shi of silkworm manure, which together with cattle and manpower spent in cultivation will cost 26,000 cash. The remainder is 550,000 cash, exclusive of the profits from the fattened pigs and bright candles.

一本三實, 一區十二實, 一畧得二千八百八十實, 十畧凡得五萬七千六百瓢。漂直十錢, 並直五十七萬六千文。用䖯矢二百石, 牛耕、功力, 直二萬六千文。餘有五十五萬。肥 猪、明燭，利在其外。 88

As for the second agricultural handbook, the Monthly Instructions are a Later Han calendrical guide for a rural patriarch to the seasonal economic, social, and ritual activities of his farming household. ${ }^{89}$ The recommendations suggest to have been meant neither for a very wealthy landlord's large estate nor that of a poor peasant's petty farm. They rather suit a moderately well-off farming family whose members were personally involved in basic agricultural work, but who also enjoyed some social standing within the local community. They could afford the help of (an un-

84 An English translation of Shih Sheng-han's reconstruction of the Monthly Instructions is provided by Hsu 1980, 115-128. These agricultural treatises or guides are not the only early imperial texts devoted to the more practical and technical aspects of agriculture, however. Some chapters of works belonging to the politico-philosophical 'masters', like the aforementioned Guanzi, as well as the Lüshi chunqiu 呂氏春秋, also contain relevant material (Bray 1984, 48, note c).

85 One of the works that extensively quotes from both texts is the Qimin yaoshu 齊民要術 from the sixth century CE. There is some indication that the reconstructed text of the Monthly Instructions actually represents a large part of the original text (Ebrey 1974, 180-181).

86 On the pit-farming method that the Fan Shengzhi shu describes, see Hsu 1980, 117-118.

87 In the first reference to monetary value in this passage ("10 cash"), the Chinese text uses the ordinary expression qian 錢, whereas in the following instances within the passage, it uses wen 文. The usage of the latter term in reference to cash is quite common in texts from the period of disunion after the Han dynasty onward, but does not appear to be common in Han texts. This alone does not rule out a Han dating of the text or even of this particular passage, but it would suggest that a certain degree of precaution is in order.

88 Shi 1974, 24-25, trans. Hsu 1980, 288 (with modifications).

89 On the Simin yueling, see Ebrey 1974; Loewe 1968, 175-179. 
specified number of) nonfamily working hands ${ }^{90}$ and to occasionally "dispense virtue by relieving those in need” 布德, 振贍窮乏 (first and foremost among their extended kin). ${ }^{91}$ Apart from the many details on rural life, farming technology, and seasonal agricultural work concerning a great variety of crops, the Monthly Instructions picture a farmer's livelihood that was not restricted to pure subsistence farming. The text frequently advises certain time periods for buying and selling particular goods. Most of the items were to be both bought and sold (in different months, respectively), which suggests that seasonal price fluctuations were taken into account. ${ }^{92}$ The text also incorporates seasonal recommendations concerning the preservation and processing of food, such as the preparation of different sauces and vinegars, or of "cakes to be made as provisions for those who come and go" 作粠, 以供入出之糧. ${ }^{93}$ Much advice is further concerned with sericultural activities, which are presented as constituting a highly important field of work on the farm, and as one largely undertaken by women. ${ }^{94}$

The source value of these agricultural manuals is certainly impaired by their fragmentary nature and dubious transmission. Moreover, it remains largely unclear to what extent the depicted agricultural way of life and its economic activities can be regarded as typical for Han farms in general, or for particular types of farms, or for agriculture in certain regions. Nevertheless, the handbooks provide us with illuminating insights into Han rural life and a wide range of corresponding economic activities, including trade. They offer important alternative perspectives and pie-

90 The text leaves open whether these were tenants, hired workers, or slaves. On discussions regarding this question, see Ebrey 1974, 200-201.

91 In the context of recommending relief for the poor, the text admonishes to neither "endure other people's poverty if you have savings," nor "exhaust the family's accumulated riches because you covet a good name” 無或蕴財, 忍人之窮; 無或利名, 憼家繼富, which may be taken as a further indication of the family's socio-economic standing (Simin yueling, third month, trans. Ebrey 1974, 192; cf. Hsu 1980, 220). Cui Shi himself came from a well-established family from Anping 安平 in modern Henan, some of whose members were famous writers. Cui Shi held the position of grand administrator of Wuyuan 五原, a rather problematic commandery on the northern border, for a few years. His biography in the Hou Hanshu describes him as relatively poor and states that he started a brewing business to make a living after the expenditures on his father's funeral had left him bankrupt. In a political essay that has been partly transmitted, Cui Shi mentions his own experiences with teaching people how to spin and weave hemp in order to improve their standard of living (Hou Hanshu 52.1725-1731; Ebrey 1974, 175-179).

92 The goods mentioned to be sold over the course of the year include unhusked millet, glutinous millet, soya and lesser beans, hemp, wheat, sesame, seed wheat and/or barley, thick silk, silk, and silk floss. The goods mentioned to be bought include firewood, charcoal, hempen cloth, huskless and regular barley, scrap silk wadding, wheat, silk floss, hempen and silk cloth, straw, thick and thin silk, leather shoes, glutinous millet, unhusked millet, soya and lesser beans, hemp seeds, and non-glutinous rice (Ebrey 1974, 198-199).

93 Cf. Hsu 1980, 222.

94 On women's role in agriculture and sericulture during the early imperial period, see Hinsch 2011, 71-76. 
ces of information that are typically excluded in sources like the standard histories and their center-focused point of view.

\section{Conclusion}

Ancient Chinese authors' interest in economic policies as an important aspect of statecraft puts modern research on early imperial economic history in a comparably comfortable position with regard to the availability of transmitted textual evidence. But while these texts provide us with a surprising amount of economic detail and reflection on economic practices of the state and other economic actors, these transmitted sources tend to be biased toward the perspectives of the imperial center. Apart from some technical manuals that seem to reflect agrarian and other practices of a well-to-do, but not exceptional social class, transmitted texts do not offer much evidence on economic processes at the grassroots level. Luckily, however, recently excavated texts from tombs and local government archives are able to provide us with such long-awaited information. However, while having opened up a completely new perspective on local economies and practices, many of these excavated texts have also corroborated parts of the general picture that the transmitted sources convey. In particular, they tend to confirm the high degree of influence the imperial administration exerted on local and small-scale economic practice.

\section{References}

Beck, B. J. M. 1977. Review of Hsün Yüeh (AD 148-209): The life and reflections of an early medieval Confucian, by Chi-yun Chen. T'oung Pao 63.4/5, 324-330.

Bray, F. 1984. Science and civilisation in China. Vol. 6, Biology and biological technology. Part 2, Agriculture. Cambridge: Cambridge University Press.

Chemla, K., and S. Guo. 2004. Les neuf chapitres: Le classique mathématique de la Chine ancienne et ses commentaires. Paris: Dunod.

Chin, T. T. 2010. “Defamiliarizing the foreigner: Sima Qian's ethnography and Han-Xiongnu marriage diplomacy." Harvard Journal of Asiatic Studies 70.2, 311-354.

-. 2014. Savage exchange: Han imperialism, Chinese literary style, and the economic imagination. Cambridge, MA: Harvard University Asia Center.

Chiu, Y. S., and R.-S. Yeh. 1999. "Adam Smith versus Sima Qian: Comment on the Tao of markets." Pacific Economic Review 4.1, 79-84.

Creel, H. G. 1965. "The Role of the horse in Chinese history." American Historical Review 70.3, 647-672.

Cullen, C. 1996. Astronomy and mathematics in ancient China: The Zhou bi suan jing. Cambridge: Cambridge University Press.

-. 2004. The Suàn shù shū: 'Writings on reckoning': A translation of a Chinese mathematical collection of the second century $B C$, with explanatory commentary. Cambridge: Needham Research Institute. 
Dauben, J. W. 2008. "Suan Shu Shu: A book on numbers and computations: English translation with commentary." Archive for History of Exact Sciences 62.2, 91-178.

Ebrey, P. 1974. "Estate and family management in the Later Han as seen in the Monthly Instructions for the Four Classes of People." Journal of the Economic and Social History of the Orient 17.2, 173-205.

Gale, E. M., trans. 1967. Discourses on Salt and Iron: A debate on state control of commerce and industry in ancient China, Chapters I-XXVIII. Taibei: Ch'eng Wen.

Gentz, J. 2003. Review of Politik und Gelehrsamkeit in der Zeit der Han (202 v. Chr.-220 n. Chr.): Die Alttext/Neutext-Kontroverse, by Hans van Ess. Database of Research on Chinese Philosophy in Foreign Languages: German. https://www.research.ed.ac.uk/portal/files/ 45058495/Hansrez_final.pdf.

Guanzi Qingzhong pian xin quan 管子輕重篇新詮 [The Qingzhong chapters of the Guanzi with new explanations]. 1979. Attributed to Guan Zhong 管仲 (720-645 BCE). Annotated and edited by Ma Feibai 馬非百. Beijing: Zhonghua shuju.

Hanji 漢紀 [Annals of the Han]. 2002. Composed by Xun Yue 荀悅 (148-209 CE). In Liang Hanji 兩漢紀. Beijing: Zhonghua shuju.

Hanshu 漢書 [Documents of the Han]. 1962. Composed by Ban Gu 班固 (32-92 CE). Beijing: Zhonghua shuju.

Hill, J. E. 2015. Through the Jade Gate: China to Rome: A study of the silk routes 1st to 2nd centuries $C E$. New updated and expanded edition. 2 vols. Self-published, CreateSpace.

Hinsch, B. 2011. Women in early imperial China. 2nd ed. Lanham, MD: Rowman and Littlefield.

Hou Hanshu 後漢書 [Documents of the Later Han]. 1965. Composed by Fan Ye 范曄 (398-445 CE). Beijing: Zhonghua shuju.

Hou Hanji 後漢紀 [Annals of the Later Han]. 2002. Composed by Yuan Hong 袁宏 (328-376 CE). In Liang Hanji 兩漢記. Beijing: Zhonghua shuju.

Hsu, C. 1980. Han agriculture: The formation of the early Chinese agrarian economy (206 BC$A D$ 220). J. L. Dull (ed.). Seattle, WA: University of Washington Press.

Hulsewé, A. F. P. 1979. China in Central Asia: The early stage, 125 BC-AD 23: An annotated translation of chapters 61 and 96 of the History of the Former Han Dynasty, with an introduction by M. A. N. Loewe. Leiden: Brill.

-. 1993a. “Hanshu 漢書.” In M. Loewe (ed.), Early Chinese texts: A bibliographical guide, 129136. Berkeley, CA: Society for the Study of Early China and University of California Institute of East Asian Studies.

-. 1993b. “Shiji 史記.” In M. Loewe (ed.), Early Chinese texts: A bibliographical guide, 405-414. Berkeley, CA: Society for the Study of Early China and University of California Institute of East Asian Studies.

Knechtges, D. R. 2010a. “Han shu 漢書.” In D. R. Knechtges and T. Chang (eds.), Ancient and early medieval Chinese literature: A reference guide. Part 1, 339-345. Leiden: Brill.

-. 2010b. “Hou Han shu 後漢書.” In D. R. Knechtges and T. Chang (eds.), Ancient and early medieval Chinese literature: A reference guide. Part 1, 372-379. Leiden: Brill.

Kroll, J. L. 1978. “Toward a study of the economic views of Sang Hung-yang.” Early China 4, 11-18.

Lai Jiancheng 賴建成. 1996. “Yantie lun de jiegou fenxi yu yizao wenti” 《鹽鐵論》 的結構分析與臆造問題 [An analysis on the structure of the Yantielun and the question of fabrication]. Zhongguo Wenhua 中國文化 14, 159-167.

Leese-Messing, K. 2016. Tradition im Wandel. Historiographiegeschichtliche Studien zu Chen Shous 陳壽 Sanguo zhi 三國志. Wiesbaden: Harrassowitz.

Lewis, M. E. 2015. "Early imperial China, from the Qin and Han through Tang." In A. Monson and W. Scheidel (eds.), Fiscal regimes and the political economy of premodern states, 282-307. Cambridge: Cambridge University Press. 
L'Haridon, B. 2015. "The merchants in Shiji: An interpretation in the light of later debates." In H. van Ess, O. Lomová, and D. Schaab-Hanke (eds.), Views from within, views from beyond: Approaches to the Shiji as an early work of historiography, 171-192. Wiesbaden: Harrassowitz.

Liu, X. 2010. The Silk Road in world history. Oxford: Oxford University Press.

Loewe, M. 1968. Everyday life in early imperial China during the Han Period, 202 BC-AD 220. London: Batsford.

-. 1974. Crisis and conflict in Han China, 104 BC to AD 9. London: Allen and Unwin.

-. 1993. “Yen t'ieh lun 鹽鐵輪." In M. Loewe (ed.), Early Chinese texts: A bibliographical guide, 477-482. Berkeley, CA: Society for the Study of Early China and University of California Institute of East Asian Studies.

Lunyu zhengyi 論語正義 [The Correct Meaning of the Analects]. 1990. Compiled by Liu Baonan 劉寶楠. Beijing: Zhonghua shuju.

McCormick, K. 1999. "Sima Qian and Adam Smith.” Pacific Economic Review 4.1, 85-87. Needham, J. 1971. Science and civilisation in China. Vol. 4, Physics and physical technology. Part 3, Civil engineering and nautics. Cambridge: Cambridge University Press.

Nienhauser, W. H., ed. 2019. The Grand Scribe's Records. Vol. 11, The Memoirs of Han China, Part 4. Bloomington, IN: Indiana University Press.

Rickett, W. A. 1985. Guanzi: Political, economic, and philosophical essays from early China: A study and translation. 2 vols. Princeton, NJ: Princeton University Press.

Ruan Zhisheng 阮芝生. 1996. “Huozhi yu liyi: Shiji Huozhi zhuan xilun”貨殖與禮義： 《史記貨殖列傳》析論 [Goods increasing and rightousness: Interpreting the Huozhi liezhuan of the Shiji]. Taida Lishi Xuebao 臺大歷史學報 19, 1-49.

Sanguo zhi 三國志 [Treatise on the Three Kingdoms]. 1959. Composed by Chen Shou 陳壽 (233ca. 297 CE). Beijing: Zhonghua shuju.

Selbitschka, A. 2015. "Early Chinese diplomacy: Realpolitik versus the so-called tributary system." Asia Major 28.1, 61-114.

Shen, K., J. N. Crossley, and A. W.-C. Lun. 1999. The Nine Chapters on the Mathematical Art: Companion and commentary. Oxford and Beijing: Oxford University Press and Science Press.

Shi, S. 1974. On "Fan sheng-chih shu": An agriculturist book of China written by Fan Sheng-chih in the first century $B C$. 3rd printing. Beijing: Science Press.

Shiji 史記 [The Scribe's Records]. 1959. Composed by Sima Qian 司馬遷 (145 or 135-ca. 87 BCE).

Swann, N. L. 1950. Food and money in ancient China: The earliest economic history of China to $A D$ 25: Han shu 24 with related texts, Han shu 91 and Shih-chi 129. Princeton, N): Princeton University Press.

Teggart, F. J. 1939. Rome and China: A study of correlations in historical events. Berkeley, CA: University of California Press.

van Ess, H. 1993a. "Die geheimen Worte des Ssu-ma Ch'ien." Oriens Extremus 36.1, 5-28.

-. 1993b. Politik und Gelehrsamkeit in der Zeit der Han (202 v. Chr.-220 n. Chr.): Die Alttext / Neutext-Kontroverse. Wiesbaden: Harrassowitz.

-. 2014. Politik und Geschichtsschreibung im alten China: Pan-ma i-t’ung 班馬異同. 2 vols. Wiesbaden: Harrassowitz.

Vogel, H. U. 2002. "Das Yantie lun: Ereignisse und Interpretationen.” In E. von Mende, B. Schefold, and H. U. Vogel (eds.), Huan Kuan, Yantie lun: Vademecum zu dem Klassiker der chinesischen Wirtschaftsdebatten. Vol. 2, 77-105. Düsseldorf: Verlag Wirtschaft und Finanzen.

von Glahn, R. 2016. The economic history of China: From antiquity to the nineteenth century. Cambridge: Cambridge University Press.

Wang Zijin 王子今. 1994. “Xi Han junshu zhidu xin yi” 西汉均输制度新议 [A new discussion on the equitable delivery system of the Western Han period]. Shoudu Shifan Daxue Xuebao 首都师范大学学报, no. 2, 52-57. 
Watson, B., trans. 1993. Records of the Grand Historian: Han dynasty. 2nd ed. Vol. 2. Hong Kong and New York, NY: Chinese University of Hong Kong Research Centre for Translation and Columbia University Press.

Yang, H., and G. Yang. 1979. Selections from Records of the Historian. Beijing: Foreign Languages Press.

Yantie lun jioazhu 鹽鐵論校注 [The Discourses on Salt and Iron with Collated Commentaries]. 1992. Composed by Huan Kuan 桓寬 (first century BCE). Commentaries compiled by Wang Liqi 王利器. Beijing: Zhonghua shuju.

Yi Jie 亦捷. 1994. “Xi Han junshu guan que you jingshang zhineng” 西汉均输官确有经商职能: 与王子今同志商榷 [The equitable delivery offices of the Western Han period did have the function of regulating trade: A response to comrade Wang Zijin]. Shoudu Shifan Daxue Xuebao 首都师范大学学报, no. 3, 68-69.

Young, L. 1996. "The Tao of markets: Sima Qian and the invisible hand." Pacific Economic Review $1.2,137-145$.

Yu Taishan 余太山. 2005. Liang Han Wei Jin Nanbei chao zhengshi Xiyu zhuan yaozhu 兩漢魏晉南北朝正史西域傳要注 [The records on the Western Regions in the standard histories of the Han, Wei, Jin, and Nanbei chao, with essential commentaries]. Beijing: Zhonghua shuju.

-. 2013. "A History of the relationship between the Western and Eastern Han, Wei, Jin, Northern and Southern Dynasties and the Western Regions." Sino-Platonic Papers 131. Originally published in 2004. http://www.sino-platonic.org/complete/spp131_chinese_dynasties_ western_region.pdf.

Yü, Y.-S. 1967. Trade and expansion in Han China: A study in the structure of Sino-Barbarian economic relations. Berkeley, CA: University of California Press. 



\section{B Excavated Texts}

\section{Introduction}

At the time of cultivating the fields, I do not wish to levy the black-headed ones.

田時殹 (也), 不欲興黔首。1

This passage is seen on the front side of three published wooden documents found from the well no. 1 at the Liye 里耶 site in Hunan Province, which was the office of Qianling County 遷陵縣 in the Qin 秦 State and Empire. The passage is part of an instruction given by a governor (shou 守) of Dongting Commandery 洞庭郡, ${ }^{2}$ named $\mathrm{Li}$ 禮, on mobilizing laborers for the transportation of armaments from Dongting Commandery to the Capital Area and other commanderies in 220 BCE. During the reform of official terminologies held after the Qin unification in 221 BCE, the term min 民 ('commoner') was changed to qianshou 黔首 ('black-headed one'). ${ }^{3}$ In his instruction, Governor Li refers to an ordinance (ling 令) that stipulates that when levying laborers for delivery and transportation, officials must first mobilize the forced laborers and people who were paying off fines, redemption-fees, or debts by their labor; only when there was an urgent matter that could not be delayed, the officials could levy the black-headed ones for government service. ${ }^{4}$ Governor Li adds the above-quoted passage in order to explain his intention behind the instruction, which was passed from Dongting Commandery to Qianling County on March 30 , right in the middle of a peak season in agricultural production.

Governor Li's instruction shows us two basic principles of the state economy during the Qin. First, the Qin placed agricultural production, also known as 'the fundamental occupation' (benye 本業), as a higher priority than other types of production, which appears to be in line with the records in transmitted texts such as

1 Hunan sheng wenwu kaogu yanjiusuo 2007, 192-194, board nos. 16-5, 16-6; 2017, 242, board no. 9-2283. Translation after Ma 2015. All translations are my own unless stated otherwise.

2 Dongting does not appear in any transmitted records as a Qin commandery. Chen 2003 suggests that it was located between modern Hunan, Hubei, and Sichuan Provinces. The Qin and Han local administrative structure had four levels: commandery (jun 郡), county (xian 縣), district (xiang 鄉), and village ( $l i$ 里), see Yen 1961.

3 Note that it was also during this reform that the title 'king' (wang 王) was changed to 'emperor' (huangdi 皇帝). For the Qin reform of legal and administrative terminologies, see Chen 2014.

4 An ordinance was a form of law during the Qin and Han dynasties, see Barbieri-Low and Yates 2015, 68-88.

Note: I would like to thank Maxim Korolkov, Thies Staack, and Tong Chun Fung for their helpful comments.

Ә Open Access. (C) 2020 Tsang Wing Ma, published by De Gruyter. (c) BY-NC-ND This work is licensed under the Creative Commons Attribution-NonCommercial-NoDerivatives 4.0 License.

https://doi.org/10.1515/9783110607741-019 
those in the Book of Lord Shang (Shangjun shu 商君書). ${ }^{5}$ Second, and more importantly, it reflects the Qin priority of mobilizing laborers. Considering the commoners or black-headed ones the major labor force in agricultural production, the Qin did not want to overburden them with additional labor tasks such as transportation of armaments during the agricultural season. The government would rather assign these tasks to forced laborers who were mainly criminals and prisoners of war, and people who were paying off fines, redemption-fees, or debts by their labor. ${ }^{6}$ This new evidence questions the stereotyped traditional view that the Qin had brutally and irrationally exploited the commoners, who were also the potential farmers. ${ }^{7}$

Two decades before the excavation of the Liye materials in 2002, the late historian Jack L. Dull had already raised doubts about the traditional image of the Qin dynasty, but unfortunately, he was not able to see how the newly excavated materials may support his arguments. ${ }^{8}$ The last few decades have witnessed an unprecedented growth of ancient texts excavated from archaeological sites in mainland China. ${ }^{9}$ The above-mentioned one is just one of the many examples showing how the newly excavated texts can add to or reshape our knowledge of the early Chinese empires. This chapter will briefly introduce the excavated texts that can shed light on the economic history of early imperial China. Our discussion is selective and focuses on the genres of legal, administrative, and economic texts. ${ }^{10}$

\section{Archaeological Contexts and Written Contents}

The 'excavated texts' mentioned in this chapter refer to those texts which were archaeologically excavated, randomly discovered, or illegally looted from tombs or other sites in mainland China in recent years, mainly preserved in the forms of bamboo, wooden, or silk manuscripts. ${ }^{11}$ The discovery of these texts began with the wave of European expeditions in Central Asia and northwestern China in the late

5 Pines 2017. Von Glahn categorizes the Qin as a "military-physiocratic state” $(2017,85)$.

6 As Barbieri-Low argues, "The government made conscious cost-benefit analyses when employing various pools of labor for a given project, taking into account the nature of the work, the season of the year, and the overall cost to the peasant-based economy” (2007, 26). See also Ma 2015.

7 Note that before the modern excavation of the Qin texts, most of the Qin sources were transmitted through the texts composed or compiled in the Han 漢 dynasty, which often include Han criticism of the Qin dynasty, Pines et al. 2014. A few exceptions include those Qin stele inscriptions which represent the Qin official portrayal of the First Emperor, for which see Kern 2000.

8 Dull 1983.

9 See also Ma, ch. 14, this volume.

10 Other genres include religious, literary, philosophical, and medical texts. For more details on the genres, see Giele 2003; Pian and Duan 2006.

11 On relatively rare occasions, they were written on early forms of paper as well. For the uses of paper in the early imperial periods, see Wang 2012. 
nineteenth and early twentieth centuries. Since 1901 when Sir Aurel Stein (18621943) first discovered around 40 pieces of Chinese wooden documents at the Niya 尼雅 ruins (in Xinjiang Province) until now, archaeologists (and tomb looters) have discovered more than 200,000 bamboo and wooden boards and slips (including fragments) in mainland China. ${ }^{12}$ The earliest major findings such as those from Dunhuang 敦煌 were mostly discovered by European expeditions at the frontier military sites in northwestern China. ${ }^{13}$ After the establishment of the People's Republic of China in 1949, the state-organized archaeological teams completely took over the role of the European expeditions in the excavations of ancient Chinese texts. ${ }^{14}$

Despite suffering from the political instability during the Cultural Revolution (1966-76), the 1970s witnessed a significant growth in the discoveries of ancient texts, such as those from the sites at Shuihudi 睡虎地 and Mawangdui 馬王堆. Major findings were not confined to the frontier military sites. Archaeologists have discovered a significant quantity of ancient texts from a number of tombs across mainland China (with a concentration in the Yangtze River valley), which has attracted wide attention among scholars of early China. ${ }^{15}$

Another major change happened in 1996 when archaeologists first discovered around 100,000 bamboo and wooden slips and boards dated to the Three Kingdoms period (220-280 CE) from well no. 22 at Zoumalou 走馬樓 in Changsha 長沙, Hunan Province. About 70,000 pieces are inscribed with characters. Since then at least six groups of documents have been found in wells (jing 井) or storage pits (jiao 空) in the nearby area in Changsha, as well as several groups of documents from wells in southern China. These documents were local administrative documents before they were discarded as trash in wells. Given their specific archaeological context, these texts now constitute a new category in the study of unearthed Chinese texts. ${ }^{16}$ Because the archaeological context is a crucial factor in determining the nature of these excavated texts, we will discuss the texts by the categories of archaeological sites and select some examples to illustrate their value as sources of economic history under each category. ${ }^{17}$

12 A few wooden documents were found in the northern Korean Peninsula where the eastern border of the Han Empire had been, for example Yun 2009.

13 As early as the 1920s, Chinese scholars started to organize archaeological teams to excavate ancient texts in northwestern China. However, the formation of the Chinese-Swedish archaeological team in the excavation of Juyan material in 1930s suggests that European archaeologists still played a significant role in the excavations of ancient texts during that time.

14 Since then, no Western archaeologists have participated in the excavations of ancient Chinese texts in mainland China.

15 It is worth noting that, in 2000, the University of Hamburg organized a workshop specifically on early Chinese 'tomb texts.' For an introduction to this workshop, see Richter 2003.

16 Ling 2015, 455-472.

17 For an introduction to the excavated early Chinese texts in chronological order, see Pian and Duan 2006, 379-348. For the importance of the archaeological contexts in studying the excavated texts, see Giele 2010. 


\section{Frontier Documents}

The invasions of the steppe group the Xiongnu 匈奴 was the major security problem of the northwestern border of early imperial China. During the first 70 years of the Han dynasty, due to the economic and societal damage caused during the late Qin civil war and the internal conflict between the central government and regional kingdoms, China was unable to conduct aggressive campaigns against the Xiongnu. With the accumulation of wealth during the reigns of his grandfather (Emperor Wen 文, r. 180-157) and father (Emperor Jing 景, r. 157-141 BCE), Emperor Wu 武 (r. 14187 BCE) successfully strengthened central control over local governments and turned to an offensive foreign policy. During his reign, the Han forces retrieved the lands which were formerly occupied by the Xiongnu in modern Gansu Province and the Inner Mongolia Autonomous Region and established four commanderies (Jiuquan 酒泉, Zhangye 張掖, Dunhuang and Wuwei 武威) in these areas which later became known as the Gansu or Hexi corridor. ${ }^{18}$

On the northwestern defense lines, the Han forces built chains of watchtowers (sui 燧) to defend against the invasions from the Xiongnu, set up checkpoint-like passes (guan 關) to control the mobility of people, and established a postal relay system to facilitate communication between the central government and frontier zone. ${ }^{19}$ The 'frontier documents' were found at the archaeological sites of the fortified constructions on the defense lines, where environmental conditions such as dry weather helped preserve the documents. Most of them were discarded as waste in trash heaps at the sites. ${ }^{20}$ Mostly dated between the mid-Western Han and early Eastern Han periods, the majority of these documents were of an administrative nature (with a small amount of private documents such as personal letters of officials and soldiers). ${ }^{21}$ They include registries of personnel, such as officials, conscripts, and convicts; account books of various types of daily military and administrative tasks; tallies for verifying and recording the transfers of money or commodities; records of disbursement of clothing and grain rations; official documents sent between officials of different statuses; and copies of imperial instructions, which directly shed light on the daily operation of the frontier system and the local economic activities.

\section{III.1 Evidence for the State-Organized Agricultural Production on the Frontier}

The frontier administration was different from that in the interior regions of the empire. The wooden slips and boards excavated from the watchtowers and frontier

18 For more on this background, see Loewe 1967; Yü 1967; Di Cosmo 2002.

19 For these fortified constructions and their terminologies, see Lien 2015, 21-33.

20 Giele 2010, 122-123.

21 For private letters excavated from these sites, see Giele 2015. 
offices at Juyan 居延, the Inner Mongolia Autonomous Region, and Dunhuang, Gansu Province show that on the northwestern frontier, the chief commandant (duwei 都尉) of the commandery, appointed by the central government, was the official in charge of the military administration. Several company commanders (hou 候), who were at the same rank as county magistrates (xianling 縣令) in the interior regions, were serving under him. Each company commander was in charge of a number of headquarters ( $b u$ 部), each of which supervised several watchtowers located on the defense lines. ${ }^{22}$

Parallel to the military administration was an agricultural administration. In order to avoid the high transportation cost of grain from the interior regions and ensure that there were enough supplies for the military campaigns in the northwest, the Han government enforced a system of agricultural garrisons or colonies (tuntian 屯田) on the northwestern border. ${ }^{23}$ The agricultural magistrates (nongling 農令 or nongzhang 農長) of the Offices of the Agricultural Fields (tianguan 田官) were in charge of the agricultural production in the garrisons. At the end of each year, the agricultural office had to submit an account book on the amount of agricultural fields (kentain 狠[塱]田) that had been cleared for cultivation to the higher authority for evaluation. ${ }^{24}$ From the registries found from Juyan, we know that the conscripted soldiers ( $z u$ 卒) constituted the major labor force of this state-organized agricultural production. A registry of an agricultural conscript (tianzu 田卒) reads: "Agricultural conscript Zhang $\mathrm{Wu}$, of the rank gongshi, from Fan Village, Fugou County, Huaiyang Commandery, age twenty-seven.” 田卒淮陽郡扶溝反里公士張誤年 廿 七 $^{25}$ (fig. 1).

Most of the registries of agricultural conscripts follow the same format, listing their personal information such as place of origin (village, county, and commandery), order of rank (jue 爵), ${ }^{26}$ name, and age. ${ }^{27}$ This evidence offers an opportunity to look into the composition of the population of agricultural conscripts in the Juyan area. These conscripts were mainly from the interior regions of the Han Empire, and formed a large proportion of the immigrant population on the frontier. According to Suzuki Naomi's 鈴木直美 recent research, the average age of these agricultural conscripts was 29, which is in line with the average age of the overall conscripted soldiers in the Juyan area. ${ }^{28}$ After the reform of the conscription system held during

22 For the Han defense system on the northwestern border, see Loewe 1967, 1:74-77; Chen 1980, 37-96.

23 For an overview of this system, see Liu 1988; Tong 2014.

24 Jiandu zhengli xiaozu 2014, slip no. 113.6+139.24.

25 Jiandu zhengli xiaozu 2017, slip no. 514.31A.

26 A rank (jue 爵) holder during the Han dynasty enjoyed certain privileges, including using his rank to reduce punishment (Barbieri-Low and Yates 2015, 876).

27 Some registries might have additional information such as the clothing issued by the government to the conscripts, see Loewe 1967, 2:261-273.

28 These figures are based on 570 registries of conscripted soldiers, of which 156 are agricultural conscripts (Suzuki 2017, 144). 


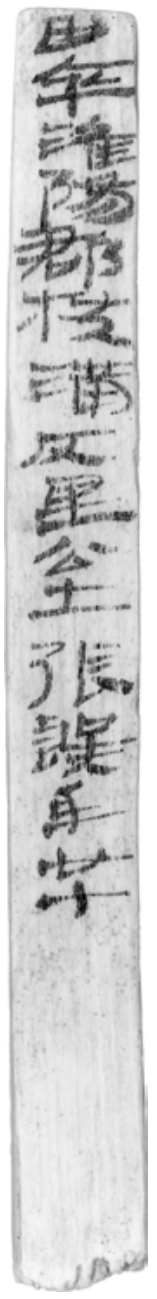

Fig. 1: A registry of an agricultural conscript from the Han dynasty, slip no. 514.31A from EdsenGol, Inner Mongolia Autonomous Region. (C) Institute of History and Philology, Academia Sinica.

the reign of Emperor Jing (r. 157-141 BCE), it was mandatory for adult males who reached age 23 to enlist for government service and military conscription. ${ }^{29}$ However, not every adult male would serve himself. For one who did not want to serve, he could choose to pay a certain amount of money to hire someone to take his

29 Before the reform, subject to the rank of their fathers and the rank they might hold, young men who reached the ages between 20 and 24 were mandatory to enlist for government service and military conscription. For the details, see section III.5 below. 
place through the arrangement of the local government. ${ }^{30}$ The Juyan and Dunhuang materials preserve this kind of record in detail. An example reads:

Agricultural conscript Gao Qianqiu, who is at the age of twenty-six, of the rank shangzao, from Jing Village, Xinping County, Huaiyang Commandery, hires $\mathrm{Hu} \mathrm{Bu}$, who is at the age of twentyfour, of the rank shangzao, from Si Village, Ningping County, [Huaiyang Commandery,] to substitute for him.

田卒淮陽郡新平景里上造高千秋年廿六 取寧平駆里上造胡部年廿四為庸 ${ }^{31}$

The hiring of substitute conscripts during the Qin and Han periods was under the government's supervision. According to a Qin law preserved in the collection held by the Yuelu Academy 萨麓書院, a conscripted soldier who wanted to have someone substitute for him must first report to the government. ${ }^{32}$ As seen in the Juyan and Dunhuang materials, the Han must have inherited this system. Almost all the conscripted soldiers and their substitutes were from the same county or commandery and held the same rank. This must be the result of the local government's arrangement, which shows the high degree of state control over the use of labor forces in the agricultural production on the frontier. ${ }^{33}$

\section{III.2 Records on Economic Activities on the Frontier}

In the frontier area, the local residents, the conscripted soldiers, the officials and their families, and the convicts who were sent to the northwest for hard labor punishment together formed a local community, within which economic activities occurred daily. The frontier documents preserve many records concerning the sale of commodities, lending of money, hiring of laborers, and legal cases regarding economic affairs among the members of this community. An example of the sale of clothing (fig. 2) reads:

In the second year of Jianzhao [of the reign of Emperor Yuan] (37 BCE), on the Bingxu day of the leap month, Scribe Director of Jiaqu Company Dong Zifang purchased a fur robe at the price of 750 cash from garrison soldier Yin Wei. They agree to make the full payment by spring. The witness (lit. the one by the side) is Du Junjuan.

\section{建昭二年閏月丙戌甲渠令史董子方買鄣卒殷威装一領直七百五十約至春錢里已旁人杜君} 隽 34

30 Transmitted texts suggest that the amount of money an adult male had to pay to hire a substitute conscript to serve on the frontier was 300 cash for three months (Shiji 106.2823). This amount might have changed subject to inflation or changes of the conscript system over time. For more on the wages of laborers, see Shi 2012.

31 Gansu jiandu bowuguan et al. 2013, 70, slip no. 73EJT26:9.

32 Chen 2015, 128, slip nos. 1414-1, 1298.

33 Lai and Ma 2011, 55. For hired laborers in general, see Ma 2012.

34 Jiandu zhengli xiaozu 2014, 78, slip no. 26.1A. Translation modified from Scogin 1990, 1347; Zhang 2010, 15. 


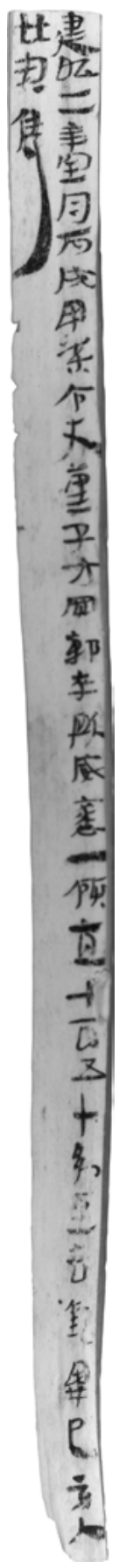

Fig. 2: A record of the sale of clothing on the Han frontier in $37 \mathrm{BCE}$, slip no. 26.1A from EdsenGol, Inner Mongolia Autonomous Region. (C) Institute of History and Philology, Academia Sinica. 
While the garrison soldiers would receive clothing from the local government, the officials on the frontier would have to provide their own. ${ }^{35}$ Such transaction records show that some soldiers would rather trade the clothes received from the government for money. ${ }^{36}$ To avoid any arguments in the future, a third party was present to witness the writing of the agreement, like Du Junjuan in the above example.

However, even with the written agreement, conflicts between the two parties could still occur. In addition, in some cases, there was only an oral agreement. When arguments occurred, one or both of the parties would seek help from the local authorities. An excellent example is a legal case composed of 33 wooden slips found during the excavation of Juyan documents in the 1970s. It tells us that Company Commander $\mathrm{Su}$ 粟 filed a lawsuit in $28 \mathrm{CE}$ against commoner Kou En 寇恩 for failing to fulfill the terms of their employment agreement. Su originally hired Kou En to sell fish in a nearby county called Lude 解得 and agreed to pay Kou En one ox and 27 bushels of grain for selling 5,000 fish at the price of 400,000 cash. However, eventually, Kou En could only bring back 320,000 cash. To make up the difference, Kou En gave the goods he had recently purchased to Su's wife. His son Qin 欽 also caught fish for Su for three months and ten days. Whereas Kou En thought that he had already fulfilled his part in the agreement, Su was not satisfied with the result and brought a lawsuit against him. ${ }^{37}$ Such a case shows us the economic relationship among the members of the local community on the Han northern frontier, and the conflicts that might have occurred among them.

\section{III.3 Routine Records from a Han Postal Station on the Diplomatic and Trading Route}

To facilitate communications between different regions within the empire, the Han government had established a postal relay system which served four major functions: (1) the transmission of official documents; (2) the provision of room and board for travelers; (3) the provision of horses and carriages for transportation; and (4) the establishment of stables to house and care for animals used in the postal service. ${ }^{38}$ From 1990 to 1992, Chinese archaeologists discovered about 23,000 wooden slips at the Xuanquan 懸泉 site (near the city of Dunhuang), which had been a postal station (zhi 置) located on the diplomatic and trading route between Han China and Central Asia. The Xuanquan postal station was under the administration of Xiaogu 效穀

35 Different from the conscripted soldiers, despite receiving monthly salaries and grain rations, the frontier officials did not receive clothing and salt from the government (Zhao 2012, 278-281).

36 The Han government had once prohibited the transaction of government-issued clothing (Zhao 2012, 351-352).

37 Scogin 1990, 1362-1365; Zhang 2010, 1-2.

38 Lien 2015, 33; Sanft 2008-2009. 
County. ${ }^{39}$ The documents found at the site provide direct evidence for studying the daily operation of the Han postal relay system and the visits of foreign delegations from the states in Central Asia.

As reported by the excavators, the Xuanquan documents mention the names of at least 24 states in Central Asia, such as Loulan 樓蘭, Yuezhi 月氏, Dayuan 大宛, Yutian 于闐 and Jingjue 精絕. ${ }^{40}$ The size of these foreign delegations could be huge. A document shows that a delegation of 1,074 members was sent from Yutian; another document records that there were 479 visitors from different states such as Jingjue on their way back home. ${ }^{41}$ By presenting a passport (zhuan 傳) issued by the local government, these foreign visitors were able to receive free food and accommodation in the Xuanquan postal station. ${ }^{42}$ The Xuanquan documents include many records of the issuing of food to these foreign visitors. A typical example reads as follows:

Issued 2 dou and 4 sheng ( 4 liters and 800 milliliters) of millet to feed three envoys of the Great King of Wusun. Each of them ate two meals and for each meal ate 4 sheng (800 milliliters) of millet. [They headed] west.

出粟二斗四升, 以食烏孫大昆彌使者三人, 人再食, 食四升, 西。43

Following Yü Ying-shih's argument about the Han tributary system, ${ }^{44}$ Jidong Yang has suggested that the foreign visitors seen in the Xuanquan documents might not come for purely diplomatic or political purposes. Some of these visitors were actually 'merchants' who 'sold' camels (tuotuo 橐佗) or other goods to the Han government. Although the documents often use the term fengxian 奉獻 or xian 獻 ('to contribute' or 'to offer') to refer to these actions, the Han emperor might have 'paid' for the camels in the form of imperial gifts. ${ }^{45}$ Such an argument has now faced criticism. Scholars such as Armin Selbitschka point out that the argument was made mainly based on the biased account in Chinese transmitted texts. There is no clear record showing that these foreign visitors were granted imperial gifts in return of their tributes. ${ }^{46}$ Regardless of the real motives, the records of the foreign tributes offered to the Han court provide new evidence for the exchange of goods between Central Asia and Han China.

39 Hao and Zhang 2009, 23; Sanft 2008-2009, 129.

40 Hao and Zhang 2009, 194.

$41 \mathrm{Hu}$ and Zhang 2001, 110, 114.

42 Yang 2015, 427.

$43 \mathrm{Hu}$ and Zhang 2001, 143.

44 Yü has argued that the foreign delegations "took the tribute as a cloak for trade" $(1967,144)$. He suggested that it was this economic interest that motivated them to visit Han China. Under such a tributary system, these foreigners offered tributary goods to the Han emperor in exchange for generous imperial gifts; see also von Glahn 2017, 155.

45 Yang 2015, 429.

46 Selbitschka 2015, 103. 


\section{III.4 Tomb Texts}

The earliest evidence of burying texts in tombs can be seen in the southern region of China from the Warring State period (475-221 ВCE). Enno Giele has summarized six possible motives for entombing texts: (1) to benefit the deceased directly and personally based on the belief that the deceased will continue their life in the netherworld as in the real world; (2) to address others in the netherworld either to enlist their help and protection or to ward off their evil influences; (3) to demonstrate an attitude, a status, an achievement, a will, etc., to the living and future generations, hoping for their reverence, praise, compliance, or eventual emulation; (4) to store away or hide texts that should no longer circulate among the living but that were also cherished enough not to be destroyed altogether; (5) to fill in unused, empty space inside the coffin; and (6) as accidentally present objects, which is to say manuscripts that had been converted into parts of funerary objects. ${ }^{47}$ Examining the literary elements of a legal case book from the Zhangjiashan Han tomb, Anthony J. Barbieri-Low and Robin D. S. Yates recently argued that such a text could have provided personal enjoyment in the tomb occupant's afterlife, which appears to be in line with the first motive summarized by Giele. ${ }^{48}$

The tomb occupants range from regional lords (e.g. Lord of Haihun 海昏侯, owner of tomb no. 1 at Guodunshan 墎墩山, Jiangxi Province) to local officials (e.g. Scribe [shi 史] Xi 喜, owner of tomb no. 11 at Shuihudi, Hubei Province) to commoners (e.g. Zhu Ling 朱凌 and her husband, owners of tomb no. 101 at Xupu 胥浦, Jiangsu Province). Noticeably, the texts found from the tombs of the local legal and administrative officials are similar in nature. In most cases, legal or administrative texts constitute the majority of the entire corpus. These texts could be ones that the tomb owners had used in the course of their careers during their life, or ones modeled thereafter. Other genres of texts found in these tombs, such as calendars, mathematical and medical texts, are believed to be related to their official duties as well (tab. 1). ${ }^{49}$ For the purpose of this chapter, we will look at those tomb texts that shed light on the economic history of the early Chinese empires.

47 Giele 2003, 428-434.

48 Barbieri-Low and Yates 2015, 107-110.

49 Yates 2014, 144. 


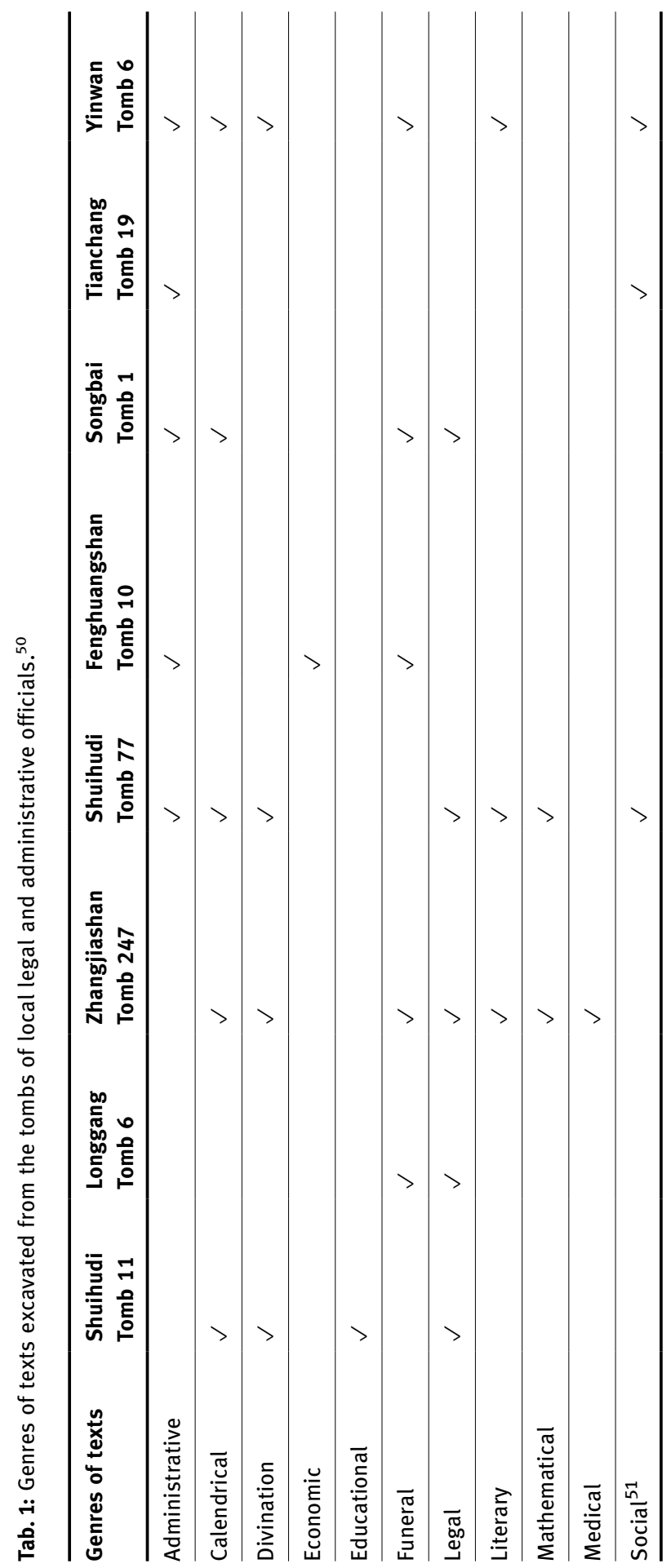

$\Xi \quad$

월

क

ड़

吾

崩

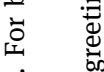

䒿 चี

论 造

है त्ञّ

‡

:

苞

¿

की है

क छ

\&

:

$+$

ฮँ

齐 .

표

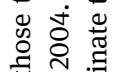

을

ซ

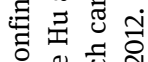

. 4 类

品 品

호 호 ᄚ

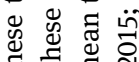

$\Xi \Xi$ छ

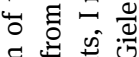

.웜

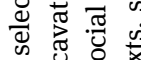

क

击 


\section{III.5 Legal Texts on Economic Policies and Activities}

The two most important and richest legal text collections with a clear archaeological context are those found in tomb no. 11 at Shuihudi and tomb no. 247 at Zhangjiashan 張家山, both in Hubei Province. ${ }^{52}$ The Shuihudi legal texts are composed of a selection of 18 categories of Qin laws, a selection of Qin legal model forms (shi 式), and a selection of commentaries on the Qin laws. The year of the final compilation of the legal collection was after 217 всE, but some of the entries could be dated back to the time before the Qin unification. The Zhangjiashan legal texts contain a selection of statutes and ordinances compiled in 186 BCE, titled Statutes and Ordinances of the Second Year (Ernian lüling 二年律令), and a legal case book, titled Book of Submitted Doubtful Cases (Zouyan shu 奏獻書). Similarly, these two texts also contain entries which could be dated back to an earlier period. ${ }^{53}$ The third significant group of texts is held by the Yuelu Academy in mainland China. ${ }^{54}$ The collection contains Qin statutes and ordinances and legal cases dated to the reign of the First Emperor of Qin (r. 220-210 вCE), also known as Qin King of Zheng (r. 247-220 вСE) before the Qin unification, which were believed originally to have been stored in a tomb in Hubei Province. ${ }^{55}$ Scholars believe that the owners of these tombs were scribes or low-ranking legal officials who had worked in local administration and that the texts buried in their tombs were related to their legal duties during their life. ${ }^{56}$

In these collections, 'statutes' (lü 律) such as those under the titles “Granaries" (Cang 倉), “Cash” (Qian 錢), “Agriculture” (Tian 田), “Abscondence” (Wang 亡), “Passes and Markets” (Guan shi 關市), “Households” ( $\mathrm{Hu}$ 戶), “Enrollment” (Fu 傅), “Levies” (Xing 興), “Government Service” (Yao 徭), and “Finance” (Jinbu 金布) and 'ordinances' (ling 令) under the title “Fords and Passes” (Jinguan 津關) provide direct insight into issues like the Qin and early Han economic policies, management of land and labor resources, taxation and household systems, government control of currencies, and the restriction of population movements. The following will use the

52 For the complete translations of the legal texts from these two tombs, see Hulsewé 1985; Barbieri-Low and Yates 2015.

53 Ma 2017, 298-299, n. 4.

54 Chen 2009.

55 For an English translation of the Yuelu legal case, see Lau and Staack 2016. The Yuelu manuscripts were purchased on the antiquities market in Hong Kong in 2007. Despite their undeniable value as primary sources, Western scholars have different opinions on the use of such unprovenanced texts in scholarly research, Goldin 2013; Lau and Staack 2016, 12-14; Foster 2017. In addition, a smaller Qin legal collection was archaeologically excavated from tomb no. 6 at Longgang 龍崗, Hubei, Hu and Li 2004, 287-293. Two other groups of Han legal texts, which were found in tomb no. 336 at Zhangjiashan and tomb no. 77 at Shuihudi, have not been fully published yet, Jingzhou diqu bowuguan 1992; Xiong, Chen, and Cai 2018. Note that earlier archaeological reports usually refer Zhangjiashan tomb no. 336 to no. 136.

56 Barbieri-Low and Yates 2015, 98-110. For more on scribes in the Qin and early Han periods, see Ma 2017. 
example of resource management to illustrate the value of these legal texts as sources for economic history.

The Qin and Han governments placed a consistently strong emphasis on agricultural production. The "Statutes on Agriculture" in the Shuihudi and Zhangjiashan collections demonstrate a strong influence of the tradition of 'monthly ordinances' (yueling 月令), which consists of monthly requirements, prohibitions, and taboos based on the agricultural calendar. ${ }^{57}$ The "Statutes on Agriculture" also suggest that the Qin and early Han rulers had maintained a system of distributing government-owned land to their subjects. ${ }^{58}$ The "Statutes on Households" in the Zhangjiashan collection preserves detailed regulations on a 'named-field' (mingtian 名田) system in the early Han period, under which commoners, nobles, and even former convicts and mutilated persons were supposed to be granted land for homesteads and agricultural fields according to their rank. ${ }^{59}$

Apart from the land resources, the Qin and Han government intentionally extracted usable human resources. The detailed legal regulations on hard labor punishment throughout these collections show us the ways in which the early Chinese empires turned convicts into usable human resources for the functioning of the state. ${ }^{60}$ Besides, as mentioned earlier, adult males in Han China were obligated to enroll for government service and military conscription. The Zhangjiashan legal texts preserve the details of an early Han conscription system. The "Statutes on Enrollment" stipulates that, depending on the rank of their fathers and the rank they might hold, young men would have to enroll for service at the ages of 20, 22, or 24. With a formal request for retirement, they would be released from service between the ages of 58 and 66 according to the rank they held. The conscripted laborers were a significant portion of the human resources of the Han Empire, even though the system which provided these conscripted laborers had undergone several changes over the Han period. ${ }^{61}$ As seen in the frontier documents introduced above, the soldiers conscripted from this system were the major military force defending against invasions by the Xiongnu on the Han northern frontier.

\section{III.6 Taxation and Population Records}

In addition to the legal texts, archaeologists found a number of account books and registers on taxation and population in the tombs of local officials. Among these, a

57 Barbieri-Low and Yates 2015, 693. An actual example of monthly ordinances dated to 5 CE was inscribed on the southern wall of room F26 in the Xuanquan station, Sanft 2008-2009.

58 Hulsewé 1985, 23; Barbieri-Low and Yates 2015, 696-697.

59 Barbieri-Low and Yates 2015, 792-793.

60 For the development of hard labor punishment, see Tu 1990, 261-316.

61 The influence of rank in the conscription system disappeared as time went by. After the reform implemented during the reign of Emperor Jing, all young men were supposed to enroll at the age 
famous collection was found in tomb no. 9 at Fenghuangshan 鳳凰山. Archaeologists excavated six wooden tablets and around 170 bamboo slips dated to the early Han period (160s-150s BCE). ${ }^{62}$ The owner of the tomb is believed to be a district(xiang 鄉) level official, named Zhang Yan 張偃, who was supposed to be responsible for tax collection. ${ }^{63}$

In Zhang Yan's tomb, archaeologists found tax records of three villages (li 里) Shiyang 市陽, Zheng 鄭, and Dangli 當利 - which were in Xi 西 District of Jiangling 江陵 County, Nan 南 Commandery (in modern Hubei Province). The types of tax include poll tax (suanfu 算賦), hay and straw tax (chugao 㫚毫), land tax (tianzu 田租), and labor service, which show the composition of the tax burden of a household in the early Han society. ${ }^{64}$ Even more interestingly, the collection includes a multi-bamboo-slip document, titled Account book of the disbursement of grain of Zheng Village (Zheng Li linbu 鄭里庰簿), which lists the heads of 25 households, the number of persons in each household, the number of persons who are "capable of fieldwork" in each household, the amount of land held by each household, and the amount of grain loaned to each household. An entry is translated as follows: "Head of household: Pian; capable of fieldwork: 4 persons; household members: 5 persons; fields: $30 \mathrm{mu}$ (1.38 hectares) + p loan: 3 shi (60 liters).” 戶人駢能田 四人口五人田卅畧 + 貸三石. ${ }^{65}$ With these records, we can calculate that there was a high ratio of 2.78 capable field workers per household. We can also find out that the average number of household members was between 4.48 and 4.60 , which is in line with the number of a typical Han household - 'family of five' (wukou zhi jia 五口之家) - described in transmitted texts. ${ }^{66}$ The surprisingly low average area of fields (24.68 $\mathrm{mu}$ [1.14 hectares]) held by each household suggests that the early Han government, at least in the Jiangling region, did not strictly implement the laws of land distribution as specified in the Zhangjiashan Han legal statutes introduced earlier. ${ }^{67}$

It is not accidental that these tax records were found in the tomb of a districtlevel official. Each year, the local governments were supposed to report to the central government about the overall performance of the administration for annual evaluation. This administrative process was called "the forwarding of accounts" (shangji 上計). The tax records of Xi District were the primary sources for drafting an annual account book of Jiangling County, which would be included in the ac-

\footnotetext{
of 23 regardless of what rank their father or they might have held (Barbieri-Low and Yates 2015, 833-835).

62 Qiu 1974.

63 Hsing 2014.

64 Von Glahn 2017, 109.

65 Hubei sheng wenwu kaogu yanjiusuo 2012, 111. Note that the marks on the slip were probably to verify the receipt of loan.

66 For the size of Han families, see Lai 1995.

67 For the calculation of these numbers, see Hsing 2014, 169-170; von Glahn 2017, 111.
} 
count book of Nan Commandery submitted to the central government. In the tombs of other local officials, such as tomb no. 1 at Songbai 松柏 in Hubei Province and tomb no. 19 at Tianchang 天長 in Anhui Province, archaeologists have also found a number of taxation or population documents. These documents, since they represent different levels of local administration, would help reconstruct a hierarchy of documents corresponding to the bureaucratic hierarchy. ${ }^{68}$

\section{III.7 Economic Documents on Property Inheritance}

The 'tomb text' category also includes economic documents showing the financial situation of a household or an individual. A notable one is a will (xianling quanshu 先令券書) written on 16 bamboo slips found in a joint burial in Xupu, Jiangsu Province. According to Li Jieman 李解民, the owner of coffin A is a woman named Zhu Ling 朱凌 who was the head of the household, while the owner of coffin B is Zhu Ling's husband who had passed away long before Zhu Ling. ${ }^{69}$

The 'will' very possibly is an excerpt of the original will. It states that, suffering from a recent illness and considering herself close to death, Zhu Ling requested the elders in the county and district and the district and village officials to make a will for her. Zhu Ling had given birth to six children and been married to three different husbands. As the head of the household, she could decide on the division of her property after her death. The will states that she originally gave a certain number of fields to two of her daughters who suffered from poverty and did not hold any property. Considering now her younger son, named Gongwen 公文, who had moved out from the household for a long time, recently committed a crime of injuring people and was sentenced to hard labor punishment, Zhu Ling (referred to as 'old woman' [yu 嫗] in the will) decided to retrieve the fields from the two daughters and give them to Gongwen. Zhu Ling specifically made very clear in the will that Gongwen was not allowed to sell the land to others.

This particular case shows us the economic and social rights a woman (also a widow) could have enjoyed in early imperial China, which appears to be much higher than one could expect in the stereotyped 'traditional China. ${ }^{70}$ Moreover, the drafting of the will appears to be highly consistent with that regulated in the Zhangjiashan early Han laws. The "Statutes on Households" states that:

When an ordinary person wishes to make a will, dividing his or her agricultural fields, homestead, male and female slaves, and valuable items, the Bailiff of the District is to listen person-

68 Ma 2018b.

$69 \mathrm{Li} 2005$. As in the cases of many other excavated texts, the reconstruction and interpretation of the text has been widely debated. For other interpretations, see Chen and Wang 1987; Hinsch 1998. 70 For more on women in early imperial China, see Hinsch 2011. 
ally to his or her directives and, in every case, is to write it up in a tripartite contract tally and immediately report it up [to the County Court], just as with the household registers.

民欲先令相分田宅、奴婢、財物, 鄉部嗇夫身聽其令, 皆參辨券書之, 輶上如戶籍。 ${ }^{71}$

The will found in Zhu Ling's tomb shows, on the one hand, that women could enjoy economic rights comparable to men under the imperial laws, and on the other hand, that state power had penetrated into the economic life of a household. The government had to keep track of the changes of the financial situation of a household, which actually was the basic unit of the state taxation system.

\section{Well/Storage Documents}

The third category of excavated texts is those recovered from wells or storage pits in a local administrative area. The majority of these texts were original documents that were dropped in abandoned wells or storage pits as trash. Archaeological and textual evidence attest that the Qin and Han government would dispose of or discard documents that were considered no longer relevant to current business after a certain period of time. This was mainly due to the mounting pressure that the accumulated documents would put on storage and archiving capacities. ${ }^{72}$ Yet the reason(s) that the local officials chose (or were ordered) to drop the unwanted documents in abandoned wells or storage pits rather than to destroy them by fire, or to recycle them for other purposes, or to simply discard them in trash heaps as the Han soldiers did on the frontier, remain unclear. ${ }^{73}$ One of the possible reasons might be the fear of causing uncontrollable fire when burning a considerable amount of bamboo or wooden documents. A Qin legal statute from the Shuihudi site states that no one is allowed to enter into archives and storehouses with fire. Other excavated texts also show that scribal officials in local government were ordered to take shifts to inspect the storehouses (possibly including archives) and make sure that there was no fire or water leaking. ${ }^{74}$ Legal and administrative documents both attest that the government was well aware of the possibility of fire in certain areas of

71 Translation modified from Barbieri-Low and Yates 2015, 801.

72 Hsing 2011. By examining the documents excavated from an archive room (F23) at the Pochengzi 破城子 site, Wang Guihai 汪桂海 reasons that the duration of keeping documents in an archive was about 13 years. This number appears to be very close to that suggested by Song Shaohua 宋少華 who argues that the local administration of the $\mathrm{Wu}$ 吳 Kingdom (222-280 CE) would have to remove unwanted documents every 10 years (Wang 1999, 227-232; Song 2008, 261).

73 A small number of the documents found in well no. 1 at Liye had apparently been burned. It remains a question why the officials did not burn all of them, but rather dropped them in an abandoned well.

74 Ma 2018a. 
buildings. In fact, the burning of a considerable amount of wooden documents resulting in a serious disaster is a not uncommon occurrence in history. ${ }^{75}$

Regardless of the reason(s) for dropping unwanted documents in unused wells or storage pits, this practice appears to be a particular feature of the southern region, possibly due to ground water levels that allowed the opening of plenty of wells. ${ }^{76}$ So far, almost all of the 'well/storage documents' have been found in Hunan Province. ${ }^{77}$ In the city of Changsha, at least six groups of official documents, covering the periods from the Western Han to the Three Kingdoms (second century BCEthird century CE), were found in wells or storage pits in the office of Linxiang 臨湘 County. ${ }^{78}$ Other discoveries in Hunan Province include the famous Qin archive found in well no. 1 at Liye; several groups of documents, dated from the late Warring States to the Three Kingdoms periods (third century BCE-third century CE), found in 11 wells at Tuzishan 兔子山; ${ }^{79}$ and two groups of documents, separately dated to the Three Kingdoms and Western Jin (late third-early fourth century CE) periods, found in wells no. 4 and no. 10 at Suxianqiao 蘇仙橋. ${ }^{80}$ The total number of texts in this category now amounts to more than 150,000 pieces (including the uninscribed slips and boards), possibly making it the largest of the three categories introduced in this chapter. The following will focus on introducing the local archives excavated from Liye and Changsha.

\section{IV.1 Administering a Newly Conquered Qin Area: Evidence from the Liye Archive}

As many scholars would admit, although the Qin (221-207 BCE) only lasted for 15 years in Chinese history, its influence is profound and incomparable. It created an

75 In England in 1834, due to the pressure caused by the large quantity of wooden tally sticks accumulated in the tally room at the exchequer, the Lords of Treasury decided to have most of the tallies destroyed. The workers were supposed to burn the tallies in an iron stove in the House of Lords. However, eventually, the fire not only destroyed all the tallies as expected but also burned the House of Lords and nearby buildings to the ground (Baxter 1989, 81-2).

76 According to Song Shaohua, the major excavator of the Zoumalou material, because of the sufficient ground water in the city of Changsha, even today, the residents will choose to open a new well rather than clear the dirt when the well water gets polluted. Yet he also added that archaeologists did not survey the level of ground water in Changsha. Personal communication with Song on August 10, 2011 at the Changsha Bamboo Slips Museum.

77 The only exception is a group of about a hundred wooden slips excavated from well no. 264 in the palace of the Nanyue 南越 Kingdom, in the city of Guangzhou 廣州. Unlike those excavated from Hunan Province, the 'well' is actually a manhole (shajing 沙井) within a drainage system in the palace, Guangzhou shi wenwu kaogu yanjiusuo et al. 2006.

78 Changsha shi wenwu kaogu yanjiusuo 2016, 5-7.

79 The documents found in well no. 9 at Tuzishan have recently been announced in Hunan sheng wenwu kaogu yanjiusuo 2016.

80 Zheng el at. 2013. 
unprecedented imperial system that was succeeded and modified by the following dynasties, which lasted until the early twentieth century. The 30,000 pieces of wooden slips and boards (about 17,000 inscribed with Chinese characters) excavated from well no. 1 at Liye, Hunan Province, open a window for us to look at how the Qin enforced their legal regulations in a newly conquered area (xindi 新地). Liye was under the control of the State of Chu 楚 during the Warring States period. One year before the Qin final unification, the Qin army conquered this area. During the Qin period, it was under the administration of Qianling County. The dating of the Liye documents (222-208 BCE) basically coincides with Qin rule in the area until the fall of the empire. ${ }^{81}$

The southwestern frontier of the Qin was not any safer than the northwestern frontier of the Han. Despite lacking a strong enemy such as Xiongnu, the old Chu area in southern China was always an unsecured area under Qin rule. ${ }^{82}$ This is attested by the mentions of 'rebels' (fankou 反寇) in the Liye documents. ${ }^{83}$ In brief, these documents reveal the difficulties and problems that the Qin encountered while ruling Qianling County, which actually was an under-cultivated area and constantly struggled with the shortage of human resources.

As discussed earlier, the Qin intentionally prioritized agricultural production over other types of economic activities. Local officials were ordered to regularly report on the amount of land that had been cleared for farming to the higher authority. ${ }^{84}$ However, a multi-slip document found at Liye reveals that while Qianling became a Qin county in 222 BCE, it was only in 218 BCE that responsible officials ordered 'laborer-servants' (tuli 徒隸) to cultivate the land:

Now, Qianling was made a county in the $25^{\text {th }}$ year [of the reign of the First Emperor of Qin] (222 BCE) and its agricultural fields [started to be] cultivated in the $29^{\text {th }}$ year (218 BCE). These fields should have been cultivated from the $26^{\text {th }}$ year $(221 \mathrm{BCE})$ through the $28^{\text {th }}$ year $(219 \mathrm{BCE})$, [Bailiff of] Convict Labor Yan and the others mistakenly did not order [laborer-servants] to cultivate them.

今遷陵廿五年為縣, 廿九年田。廿六年盡廿八年當田, 司空厭等失弗令田。

'Laborer-servant' is a general term that can refer to several types of forced laborers. The Liye archive preserves a number of documents titled 'Account Book of Laborers' (tubu 徒簿 or zuotubu 作徒簿) which show the assignments of various manual tasks to these laborer-servants. ${ }^{85}$ One of the tasks was to be sent to the Office of the Agri-

81 For a brief introduction to the Liye material, see Yates 2012. For the Qin enforcement of laws in Qianling County, see Yates 2018.

82 The anti-Qin rebellions during the fall of the empire were mostly generated in the Chu area, Dull 1983.

83 Hunan sheng wenwu kaogu yanjiusuo 2017, for example, board no. 9-2287.

84 Hunan sheng wenwu kaogu yanjiusuo 2017, board no. 9-40.

85 For the 'Account Book of Laborers' from Liye, see Korolkov 2015. 
cultural Fields (tianguan 田官) to engage in agricultural production. This particular document shows that the land in Qianling County was still under-cultivated even though it had already been incorporated into Qin territory four years earlier. ${ }^{86}$

Since more than half of the Liye material remains unpublished, we do not know if Qianling County maintained a system of agricultural garrisons or colonies like the one described in the Han frontier documents, but it clearly engaged soldiers in agricultural production. The Liye archive includes an enormous number of tallies (quan 券), which record the transfers of grain, money, and commodities between two or more parties. ${ }^{87}$ Several of them record that garrison conscripts (tunshu 屯戍) received grain rations from the Office of the Agricultural Fields, which was the agency in charge of agricultural production in Qianling County. ${ }^{88}$ Moreover, by submitting a formal request, local residents would be permitted to clear land for farming. A newly published Liye slip, however, suggests that the land in Qianling was not only under-cultivated but also underpopulated. The slip shows that a district in Qianling County lacked sufficient black-headed ones to cultivate its land. ${ }^{89}$ This situation matches exactly the description that "the people are not sufficient for its land” (ren bu cheng tu 人不稱土) in the Book of Lord Shang, a collection of essays attributed to the reformer of the Qin State, Shang Yang 商鞅, during the reign of Duke Xiao 孝 (r. 361-338 BCE). ${ }^{90}$

\section{IV.2 Records on the Economic Development of Changsha}

The documents excavated from the wells or storage pits in the city of Changsha can help reconstruct a historical chronology of the city's development. According to transmitted records, the jurisdiction of Changsha had undergone several changes from the third century BCE to the third century CE, but the location of the office of Linxiang County appears to be quite consistent throughout that period. ${ }^{91}$ Archaeological evidence also attests that the present Wuyi Square 五一廣場 and nearby area was probably the office of Linxiang County, where six groups of documents dated to different periods were found. ${ }^{92}$ Although there are gaps between the dating of these excavated texts, they represent the changes of the city from the mid-Western Han to the late Eastern Han to the Three Kingdoms period (tab. 2).

86 For a translation and interpretation of this document, see Ma 2015.

87 For a discussion on these tallies, see Ma 2017.

88 Hunan sheng wenwu kaogu yanjiusuo 2017, for example, slip no. 9-761.

89 Hunan sheng wenwu kaogu yanjiusuo 2017, slip no. 9-2119.

90 Pines 2017, 266. For the management of human resources in Qianling County, see Ma 2015.

91 Shiji 6.239-40; Hanshu 1b.53; 5.141; 28b.1639; Sanguozhi 47.1119; 48.1177.

92 He 1998. 
Tab. 2: Timeline of the historical changes of Changsha with the dating of excavated texts from Changsha.

\begin{tabular}{|c|c|c|}
\hline \multicolumn{2}{|c|}{$\begin{array}{l}\text { Historical changes of Changsha from the third } \\
\text { CEntury BCE to third CEntury CE as seen in } \\
\text { transmitted records }\end{array}$} & $\begin{array}{l}\text { Dating of the excavated texts from the wells } \\
\text { or storage pits in Changsha }\end{array}$ \\
\hline $221 \mathrm{BCE}$ & $\begin{array}{l}\text { The First Emperor of Qin unified the } \\
\text { empire and made Changsha a } \\
\text { commandery }\end{array}$ & \\
\hline 202 BCE & $\begin{array}{l}\text { Emperor Gao 高 of Han enfeoffed } \\
\text { Wu Rui 吳䓎 as the King of } \\
\text { Changsha and made Linxiang } \\
\text { County the capital of the Kingdom }\end{array}$ & \\
\hline $157 \mathrm{BCE}$ & $\begin{array}{l}\text { Emperor Wen 文 of Han abolished } \\
\text { Changsha Kingdom }\end{array}$ & \\
\hline \multirow[t]{2}{*}{$156 \mathrm{BCE}$} & Emperor Jing 景 enfeoffed his & \\
\hline & $\begin{array}{l}\text { son Liu Fa 劉發 as the King of } \\
\text { Changsha. Linxiang County } \\
\text { remained the capital of the }\end{array}$ & $\begin{array}{ll}125- & \text { About 2,000 bamboo and wooden } \\
120 \text { BCE } & \text { slips and boards found in well no. } 8 \\
& \text { at Zoumalou 走馬樓 }\end{array}$ \\
\hline
\end{tabular}
Kingdom

\begin{tabular}{ll}
\hline $9 \mathrm{CE}$ & $\begin{array}{l}\text { Wang Mang 王莽 changed } \\
\text { Changsha Kingdom to Tianman } \\
\text { Commandery 填蠻郡 and Linxiang } \\
\text { County to Fumu County 撫睦縣 }\end{array}$ \\
\hline $25 \mathrm{CE}$ & $\begin{array}{l}\text { Emperor Guangwu 光武 restored } \\
\text { the Han Empire and reestablished } \\
\text { Changsha Commandery. }\end{array}$
\end{tabular}

\begin{tabular}{|c|c|c|c|}
\hline & & \multicolumn{2}{|r|}{ Wuyi Square 五一廣場 } \\
\hline & & c. $106 \mathrm{CE}$ & $\begin{array}{l}\text { A few hundred wooden and bamboo } \\
\text { slips and boards found in six wells } \\
\text { in Kewen Building 科文大廈 }\end{array}$ \\
\hline & & $\begin{array}{l}171- \\
184 \mathrm{CE}\end{array}$ & $\begin{array}{l}426 \text { wooden slips and boards found } \\
\text { in well no. } 7 \text { at Dongpailou 東牌樓 }\end{array}$ \\
\hline & & $\begin{array}{l}173- \\
181 \mathrm{CE}\end{array}$ & $\begin{array}{l}257 \text { wooden slips and boards found } \\
\text { in nine wells at Shangdejie 尚德街 }\end{array}$ \\
\hline \multirow[t]{2}{*}{$214 \mathrm{CE}$} & \multirow{2}{*}{$\begin{array}{l}\text { Sun Quan 孫權 occupied Changsha } \\
\text { Commandery. }\end{array}$} & & \\
\hline & & $\begin{array}{l}220- \\
237 \mathrm{CE}\end{array}$ & $\begin{array}{l}\text { About } 100,000 \text { wooden and bamboo } \\
\text { slips and boards found in well }\end{array}$ \\
\hline \multirow[t]{2}{*}{$229 \mathrm{CE}$} & \multirow{2}{*}{$\begin{array}{l}\text { Sun Quan declared himself Emperor } \\
\text { of Wu }\end{array}$} & & no. 22 at Zoumalou 走馬樓 \\
\hline & & & \\
\hline $280 \mathrm{CE}$ & $\begin{array}{l}\text { The Conquest of the Wu Kingdom by } \\
\text { the Western Jin }\end{array}$ & & \\
\hline
\end{tabular}


As with the Liye material, the documents found in the wells or storage pits in Changsha were local archives before they were discarded and thus reveal the daily operation of the county administration. For example, the Wuyi Square material includes legal cases regarding the registration (zhan 占) of the 'floating population' (liumin 流民). One of these cases shows that, according to an imperial decree, the 'floating population' who did not want to return to their registered location were now allowed to reregister at the place where they were currently living, which fits well with the record in the History of the Later Han (Hou Hanshu 後漢書). ${ }^{93}$ More intriguing are the Zoumalou $\mathrm{Wu}$ documents. Although these documents date to after the fall of the Han Empire, the taxation system recovered from them could be, at least in part, inherited from the southern region of the Eastern Han dynasty. ${ }^{94}$ Scholars also suggest that the legal processes revealed in the Eastern Han excavated materials appear to be closer to those in the Zoumalou documents than in the Qin and early Han materials. ${ }^{95}$ Parts of these six groups of texts are now being published gradually. Their full publication should be able to shed light on many economic issues, such as the financial administration, population, taxation, mobility, and resource management, of Linxiang County from the mid-Western Han to the Three Kingdoms period, which allows for a study of the longue durée economic history of Changsha.

\section{Concluding Remarks: The Materiality of Texts}

This brief introduction could not fully explore the great value of the newly excavated texts as sources of economic history. One particular aspect that calls for attention is the materiality of texts. The major writing materials in early imperial China were bamboo and wood, which were made in different shapes, lengths, and widths to accommodate different needs. Treating these bamboo and wooden documents as objects rather than texts can further explore the economic messages recorded and conveyed through the material features of these documents. To name one example, the notches (kechi 刻齒) carved on the wooden tallies from Liye and Juyan served a similar function as the writing did. ${ }^{96}$ These notches were shaped in different forms to represent different numbers (fig. 3).

As the tallies were to verify the transfers of money, grain, and commodities, the amount represented by the notches on a pair of tallies must match the one written on them. Therefore, as the producer and reader of these documents, scribes in the Qin and Han Empires needed not only to know how to use a writing brush ( $b i$ 筆)

93 Changsha shi wenwu kaogu yanjiusuo et al. 2015, board no. CWJ1(1):85; Hou Hanshu 4.191.

94 Ling 2015. So far, the only English introduction to these documents is Lu 2014.

$95 \mathrm{Xu} 2015$.

96 Momiyama 2015, 17-61; Zhang, Okhawa, and Momiyama 2015, 53-69. 


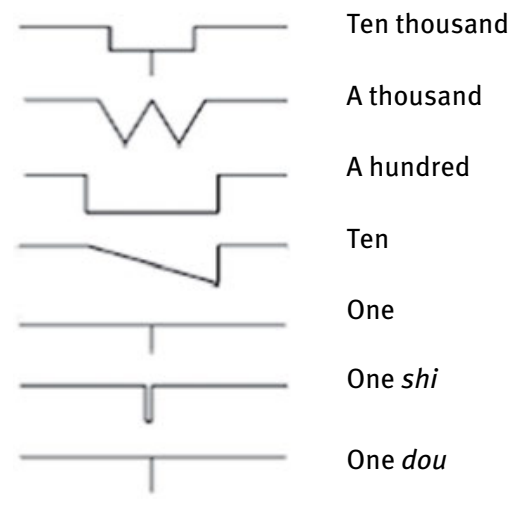

Fig. 3: 'Notch languages' (the shapes of notches) as seen on the Liye wooden tallies. (Adapted from Zhang, Okhawa, and Momiyama 2015, 54.) One shi $=20$ liters; one dou $=2$ liters.

to write Chinese characters on a wooden or bamboo document, but also to master a writing knife (shudao 書刀) to modify the material features, such as shapes, marks, notches and lines, to transmit information for administrative purposes. ${ }^{97}$ In this regard, a thorough investigation of the messages hidden in the material features of the wooden and bamboo texts would certainly contribute to our understanding of the economic history of the early Chinese empires.

\section{References}

Barbieri-Low, A. J. 2007. Artisans in early imperial China. Seattle, WA: University of Washington Press.

Barbieri-Low, A. J., and R. D. S. Yates. 2015. Law, state, and society in early imperial China: A study with critical edition and translation of the legal texts from Zhangjiashan tomb no. 247. 2 vols. Leiden: Brill.

Baxter, W. T. 1989. "Early accounting: The tally and checkerboard." Accounting Historians Journal 16.2, 43-83.

Changsha shi wenwu kaogu yanjiusuo 長沙市文物考古研究所. 2016. Changsha shangdejie Dong Han jiandu 長沙尚德街東漢簡牘. Changsha: Yuelu shushe.

Changsha shi wenwu kaogu yanjiusuo 長沙市文物考古研究所et al. 2015. Changsha wuyi guangchang Dong Han jiandu xuanshi 長沙五一廣場東漢簡牘選釋. Shanghai: Zhongxi shuju.

Chen Kanli 陳㑆理. 2014. “Liye Qin fang yu ‘shu tong wenzi””里耶秦方與 “書同文字”. Wenwu 文物, no. 9, 79-81.

Chen Mengjia 陳夢家. 1980. Han jian zhuishu 漢簡綴述. Beijing: Zhonghua shuju.

Chen Ping 陳平 and Wang Qinjin 王勤金. 1987. “Yizheng Xupu 101 hao Xi Han mu xianling quanshu chu kao” 儀徵胥浦101號西漢墓《先令券書》初考. Wenwu 文物, no. 1, 20-25.

97 Ma 2017. 
Chen Songchang 陳松長. 2009. "Yuelu Shuyuan suo cang Qin jian zongshu” 嘼麓書院所藏秦簡綜述. Wenwu, no. 3, 75-88.

-, ed. 2015. Yuelu shuyuan cang Qin jian (si) 嶽麓書院藏秦簡(肆). Shanghai: Shanghai cishu chubanshe.

Chen Wei 陳偉. 2003. “Qin Cangwu, Dongting er jun chu lun” 秦蒼梧、洞庭二郡㑇論. Lishi yanjiu 歷史研究, no. 5, 168-72.

Di Cosmo, N. 2002. Ancient China and its enemies: The rise of nomadic power in East Asian history. Cambridge: Cambridge University Press.

Dull, J. L. 1983. “Anti-Qin rebels: No peasant leaders here.” Modern China 9.3, 285-318.

Foster, C. J. 2017. "Introduction to the Peking University Han bamboo strips: On the authentication and study of purchased manuscripts." Early China 40, 167-239.

Gansu jiandu bowuguan 甘肅簡牘博物館 et al. 2011-2016. Jianshui jinguan Han jian 肩水金關漢簡. 5 vols. Shanghai: Zhongxi shuju.

Giele, E. 2003. "Using early Chinese manuscripts as historical source materials." Monumenta Serica 51, 409-438.

-. 2010. "Excavated manuscripts: Context and methodology." In M. Nylan and M. Loewe (eds.), China's early empires: A re-appraisal, 114-134. Cambridge: Cambridge University Press.

-. 2011. "Evidence for the Xiongnu in Chinese wooden documents from the Han period." In U. Brosseder and B. K. Miller (eds.), Xiongnu archaeology: Multidisciplinary perspectives of the first steppe empire in Inner Asia, 49-75. Bonn: Vor- und frühgeschichtliche Archäologie, Rheinische Friedrich-Wilhelms-Universität Bonn.

-. 2015. "Private letter manuscripts from early imperial China." In A. Richter (ed.), A history of Chinese letters and epistolary culture, 403-474. Leiden: Brill.

Goldin, P. R. 2013. "Heng Xian and the problem of studying looted artifacts." Dao 12, 153-160.

Guangzhou shi wenwu kaogu yanjiusuo 廣州市文物考古研究所 et al. 2006. “Guangzhou shi nanyueguo gongshu yizhi Xi Han mujian fajue jianbao"

廣州市南越國宮署遺址西漢木簡發掘簡報. Kaogu 考古, no. 3, 3-13.

Hanshu 漢書. 1962. Composed by Ban Gu 班固 (32-92 CE). Beijing: Zhonghua shuju.

Hao Shusheng 郝樹聲 and Zhang Defang 張德芳. 2009. Xuanquan Han jian yanjiu 懸泉漢簡研究. Lanzhou: Gansu wenhua chubanshe.

He Xuhong 何旭紅. 1998. “Changsha Han 'Linxiang gucheng' ji qi ‘gongshu’ weizhi kaoxi” 長沙漢 “臨湘故城” 及其 “宮署” 位置考析. Nanfang Wenwu 南方文物, no. 1, 96-100.

Hinsch, B. 1998. “Women, kinship, and property as seen in a Han dynasty will.” T'oung Pao 84.1/ 3, 1-20.

-. 2011. Women in early imperial China. 2nd ed. Lanham, MD: Rowman \& Littlefield.

Hou Hanshu 後漢書. 1965. Composed by Fan Ye 范瞱 (398-445 CE). Beijing: Zhonghua shuju. Hsing I-tien 邢義田. 2011. “Handai jiandu de tiji, zhongliang he shiyong: yi zhongyanyuan shiyusuo cang juyan hanjian wei li” 漢代簡牘的體積、重量和使用一一以中研院史語所藏居延漢簡為例. In Hsing I-tien Di bu ai bao: Handai jiandu 地不愛寶：漢代簡牘, 1-50. Beijing: Zhonghua shuju.

-. 2014. "Qin-Han census, tax and corvée administration: Notes on newly discovered materials." In Pines, Shelach, von Falkenhausen, and Yates (2014), 155-186.

Hu Pingsheng 胡平生 and Li Tianhong 李天虹. 2004. Changjiang liuyu chutu jiandu yu yanjiu 長江流域出土簡牘與研究. Wuhan: Hubei jiaoyu chubanshe.

Hu Pingsheng 胡平生 and Zhang Defang 張德芳. 2001. Dunhuang Xuanquan Han jian shicui 敦煌懸泉漢簡釋粹. Shanghai: Shanghai guji chubanshe.

Hubei sheng wenwu kaogu yanjiusuo 湖北省文物考古研究所, ed. 2012. Jianglin Fenghuangshan Xi Han jiandu 江陵鳳凰山西漢簡牘. Beijing: Zhonghua shuju.

Hulsewé, A. F. P. 1985. Remnants of Ch'in law: An annotated translation of the Ch'in legal and administrative rules of the 3rd century BC, discovered in Yün-meng Prefecture, Hu-pei Province, in 1975. Leiden: Brill. 
Hunan sheng wenwu kaogu yanjiusuo 湖南省文物考古研究所. 2007. Liye fajue baogao 里耶發掘報告. Changsha: Yuelu shushe.

-. 2016. “Hunan Yiyang Tuzishan yizhi jiu hao jing fajue jianbao”湖南益陽兔子山遺址九 號井發掘簡報. Wenwu 文物, no. 5, 32-48.

-. 2017. Liye Qin Jian (er) 里耶秦簡 (武). Beijing: Wenwu chubanshe.

Jiandu zhengli xiaozu 簡牘整理小組. 2014-2017. Juyan Han jian 居延漢簡. 4 vols. Taipei:

Zhongyang yanjiuyuan lishi yuyan yanjiusuo.

Jingzhou diqu bowuguan 荊州地區博物館. 1992. “Jiangling Zhangjiashan liangzuo Han mu chutu dapi zhujian” 江陵張家山兩座漢墓出土大批竹簡. Wenwu 文物, no. 9, 1-11.

Korolkov, M. 2012. “'Greeting tablets' in early China: Some traits of the communicative etiquette of officialdom in light of newly excavated inscriptions." T'oung Pao 98.4/5, 295-348.

-. 2015. "Convict labor in the Qin Empire: A preliminary study of the 'registers of convict laborers' from Liye.” In Fudan daxue lishi xi 復旦大學歷史學系 et al. (eds.), Jianbo wenxian yu gudai shi: Di er jie chutu wenxian qingnian xuezhe guoji luntan lunwenji 簡帛文獻與古代史: 第二届出土文獻青年學者國際論壇論文集, 132-156. Shanghai: Zongxi shuju.

Lai, Ming Chiu. 1995. "Family morphology in Han China: 206 BC-AD 220.” PhD diss., University of Toronto.

Lai Ming Chiu 黎明釗 and Ma Tsang Wing 馬增榮. 2011. “Han jian buji zaitan: Yi 'zu yongzuo mingji’ wei li” 漢簡簿籍再探: 以「卒傭作名籍」為例. Journal of Chinese Studies 53, 33-56.

Lau, U., and T. Staack. 2016. Legal practice in the formative stages of the Chinese Empire: An annotated translation of the exemplary Qin criminal cases from the Yuelu Academy Collection. Leiden: Brill.

Li Jiemin 李解民. 2005. “Yangzhou yizheng xupu jianshu xin kao” 揚州儀徵胥浦簡書新考. In Changsha shi wenwu kaogu yanjiusuo 長沙市文物考古研究所 (ed.), Changsha Sanguo Wu jian ji bainian lai jianbo faxian yu yanjiu guoji xueshu yantaohui lunwenji 長沙三國吳簡 暨百年來簡帛發現與研究國際學術研討會論文集, 449-457. Beijiing: Zhonghua shuju.

Lien, Y. E. 2015. "Reconstructing the postal relay system of the Han period." In A. Richter (ed.), A history of Chinese letters and epistolary culture, 15-52. Leiden: Brill.

Ling Wenchao 凌文超. 2015. Zoumalou Wu Jian caiji bushe zhengli yu yanjiu 走馬樓吳簡採集簿 書整理與研究. Guilin: Guangxi shifan daxue chubanshe.

Liu Guanghua 劉光華. 1988. Han dai xibei tuntian yanjiu 漢代西北屯田研究. Lanzhou: Lanzhou daxue chubanshe.

Loewe, M. 1967. Records of Han administration. 2 vols. Cambridge: Cambridge University Press. Lu, Y. 2014. "Managing locality in early medieval China: Evidence from Changsha." In W. Swartz, R. F. Campany, Y. Lu and J. J. C. Choo (eds.), Early medieval China: A sourcebook, 95-107. New York, NY: Columbia University Press.

Ma Tsang Wing 馬增榮. 2012. “Qin Han shiqi de guyong huodong yu renkou liudong” 秦漢時期的僱傭活動與人口流動. Journal of Chinese Studies 中國文化研究所學報 54, $1-28$.

-. 2015. "Qin management of human resources in light of an administrative document from Liye, Hunan Province." Paper presented at the 19th Annual Southeast Early China Roundtable, University of Tennessee, Knoxville, October 30-November 1.

-. 2017. "Scribes, assistants, and the materiality of administrative documents in Qin-early Han China: Excavated evidence from Liye, Shuihudi, and Zhangjiashan.” T'oung Pao 103.4/5, 297-333.

-. 2018a. “Handai difang xingzheng zhong de zhifu zhidu” 漢代地方行政中的直符制度. Jianbo 簡帛 16, 253-277.

-. 2018b. "Between the state and his superior: The anxiety of being a low-ranked scribe in the Qin and Han bureaucratic hierarchy.” Paper presented at the 22nd Biennial 
Conference of the European Association for Chinese Studies, University of Glasgow, Glasgow, August 29-September.

Momiyama Akira 籵山明. 2015. Shin kan shutsudo moji shiryō no kenkyū: keitai, seido, shakai 秦漢出土文字史料の研究: 形態・制度・社会. Tōkyō: Sōbunsha.

Pian Yuqian 駢宇騫 and Duan Shu’an 段書安. 2006. Ershi shiji chutu jianbo zongshu 二十世紀出土簡帛綜述. Wenwu chubanshe.

Pines, Y. 2017. The Book of Lord Shang: Apologetics of state power in early China. New York, NY: Columbia University Press.

Pines, Y., G. Shelach, L. von Falkenhausen, and R. D. S. Yates, eds. 2014. Birth of an empire: The state of Qin revisited. Berkeley, CA: University of California Press.

Qiu Xigui 装錫圭. 1974. “Hubei Jiangling Fenghuangshan shi hao Han mu chutu jiandu kaoshi” 湖北江陵鳳凰山十號漢墓出土簡牘考釋. Wenwu 文物, no. 7, 49-63.

Richter, M. 2003. "Hamburg tomb text workshop: Introduction." Monumenta Serica 51, 401-408.

Sanft, C. 2008-2009. "Edict of monthly ordinances for the four seasons in fifty articles from 5 CE: Introduction to the wall inscription discovered at Xuanquanzhi, with annotated translation." Early China 32, 125-208.

Scogin, H. T. Jr. 1990. "Between heaven and man: Contract and the state in Han dynasty China." Southern California Law Review 63.5, 1326-1404.

Selbitschka, A. 2015. "Early Chinese diplomacy: Realpolitik vs. the so-called tributary system." Asia Major 28.1, 61-114.

Shiji 史記. 1959. Composed by Sima Qian 司馬遷 (145 or 135-ca. 87 BCE). Beijing: Zhonghua shujiu.

Shi Yang 石洋. 2012. “Ryōkan yōka hensen kōshyō” 両漢雇価変遷考証. Tōyōshi kenkyū 東洋史研究 71.2, 1-28.

Song Shaohua 宋少華. 2008. “Changsha chutu de jiandu ji xiangguan kaocha” 長沙出土的簡牘及相關考察. In Bu Xianqun 卜憲群 and Yang Zhenhong 楊振紅 (eds.), Jian bo yanjiu er ling ling liu 簡帛研究二 $\mathrm{O}$ 六. Guilin: Guangxi shifan daxue chuban she.

Suzuki Naomi 鈴木直美. 2017. “Kan dai furontia keiseisha no purofïru: Kyoen Kankan, Katamizukaneseki Kankan ni miru sotsu no nenrei ni chakumoku shite" 漢代フロンテイア形成者のプロフィール一居延漢簡・肩水金関漢簡にみる卒の年齢 に着目して一. In Takamura Takeyuki 高村武幸 (ed.), Shūen ryōiki kara mita Shin Kan teikoku 周縁領域からみた秦漢帝国, 137-172. Tokyo: Rokuichi Shobō.

Tong Chun Fung 唐俊峰. 2014. "Xi Han hexi tianguan de zuzhi yu xingzheng: yi Juyan, Jianshui diqu de tianguan wei zhongxin” 西漢河西田官的組織與行政：以居延、肩水地區的田 官為中心. Journal of Chinese Studies 中國文化研究所學報 59, 87-120.

Tu Cheng-sheng 杜正勝. 1990. Bianhu qimin: Chuantong zhengzhi shehui jiegou zhi xingcheng 編戶齊民: 傳統政治社會結構之形成. Taipei: Lianjing chuban shiye gongsi.

von Glahn, R. 2017. The economic history of China: From antiquity to the nineteenth century. Cambridge: Cambridge University Press.

Wang Guihai 汪桂海. 1999. Han dai guanwenshu zhidu 漢代官文書制度. Nanning: Guangxi jiaoyu chubanshe.

Wang Yuanlin 王元林. 2012. “Kaogu xue shiye xia de jian zhi bingyong shidai: jiantan guzhi de qiyuan yu shiyong” 考古學視野下的簡紙並用時代: 兼談古紙的起源與使用. In Zhang Defang 張德芳 (ed.), Gansu sheng di er jie jiandu xue guoji xueshu yantaohui lunwenji 甘肅省第二屆簡牘學國際學術研討會論文集, 359-374. Shanghai: Shanghai guji chubanshe.

Xiong Beisheng 熊北生, Chen Wei 陳偉 and Cai Dan 蔡丹. 2018. “Hubei Yunmen Shuihudi 77 hao Xi Han mu chutu jiandu gaishu” 湖北雲夢睡虎地 77 號西漢墓出土簡牘概述. Wenwu 文物, no. 3, 43-53.

Xu Chang 徐暢. 2015. “Xin kan Changsha Zoumalou Wu jian yu Xu Di gemi an sifa chengxu de fuyuan” 新刊長沙走馬樓吳簡與許迪割米案司法程序的復原. Wenwu 文物, no. 12, 71-83. 
Yang, Jidong. 2015. "Transportation, boarding, lodging, and trade along the early Silk Road: A preliminary study of the Xuanquan manuscripts." Journal of the American Oriental Society 135.3, 421-432.

Yates, R. D. S. 2012. "The Qin slips and boards from well no. 1, Liye, Hunan: A brief introduction to the Qin Qianling county archives." Early China 35, 291-329.

-. 2014. "Introduction: The empire of the scribes." In Pines, Shelach, von Falkenhausen, and Yates (2014), 141-154.

-. 2018. "Evidence for Qin law in the Qianling county archive: A preliminary survey." Bamboo and Silk 1, 403-445.

Yen Keng-wang 嚴耕望. 1961. Zhongguo difang xingzheng zhidu shi jia bu: Qin Han difang xingzheng zhidu 中國地方行政制度史甲部: 秦漢地方行政制度. Taipei: Zhongyang yanjiuyuan lishi yuyan yanjiusuo.

Yü, Ying-shih. 1967. Trade and expansion in Han China: A study in the structure of Sino- Barbarian economic relations. Berkeley, CA: University of California Press.

Yun Yong-gu 尹龍九. 2009. “Heijō shutsudo 'Rakurō-gun shogen yonen kenbetsu toguchi-bo' kenkyū” 平壤出土「樂浪郡初元四年縣別戶口簿」研究. Hashimoto Shigeru 橋本繁 (trans.). Chūgoku shutsudo shiryō kenkyū 中國出土資料研究 13, 205-236.

Zhang Chunlong 張春龍, Ohkawa Toshitaka 大川俊隆, and Momiyama Akira 籵山明. 2015. “Liye Qin jian kechi jian yanjiu: Jianlun yuelu Qin jian shu zhong de wei jiedu jian” 里耶秦簡刻齒簡研究——兼論嶽麓秦簡《數》中的未解讀簡. Wenwu, no. 3, 53-69, 96.

Zhang Zhaoyang. 2010. "Civil laws and civil justice in early China.” PhD diss., University of California.

Zhao Chongliang 趙寵亮. 2012. Xingyi shubei: Hexi Han sai lizu de tunshu shenghuo 行役戌備: 河西漢塞吏卒的屯戍生活. Beijing: Kexue chubanshe.

Zheng shubin 鄭曙斌 et al. 2013. Hunan chutu jiandu xuanbian 湖南出土簡牘選編. Changsha: Yuelu shushe. 



\section{C Material Evidence: Lacquerware}

\section{Introduction}

Besides transmitted and excavated texts, a vast amount of material evidence is available for the study of the economic history of early imperial China, ranging from numismatic sources to settlement archaeology. Instead of giving a cursory overview of all the various kinds of material evidence, this section will provide an extended introduction to one specific type of material object, that is, lacquerware (qiqi 漆器). Lacquer objects from the Han 漢 period (206 BCE-220 CE) are of particular value for economic history in several regards: Firstly, lacquer objects were unique to China for the period under consideration. Secondly, they serve as crucial evidence for local economic production processes. Thirdly, they constitute one of the most illuminating indicators of long-distance exchange across Eurasia. And fourthly, large quantities of lacquer objects have been unearthed during the last few years. These new finds, parts of which still await complete publication, leave ample room for future research, especially with regard to interdisciplinary approaches and the study of long-distance exchange networks.

Tombs of the elite in the Han period were typically conceived of and designed as afterlife dwellings for the deceased, in which discrete chambers (such as private chambers, a main hall, or a kitchen) held various kinds of objects associated with their respective functions. The deceased were accordingly equipped with items they would need to throw lavish banquets, for which the use of exquisite tableware was regarded essential. In many of these tombs, individual pieces or whole sets of lacquer tableware therefore make up typical components of the tomb inventory. ${ }^{1}$

The most common Han-period lacquer objects that have been discovered include various types of cups (especially 'eared cups,' erbei 耳杯, i.e., oval cups with handles, fig. 1a) and platters (pan 盤). But other kinds of objects such as lacquered boxes, chariots, furniture, elements of weaponry, and coffins have also been found.

1 Han lacquer art was built on a tradition that went back to the Neolithic. The oldest known object is a lacquer-painted bowl discovered during excavations of the Hemudu 河姆渡 culture (50004000 BCE) in modern Zhejiang Province. During the Shang 商 period (ca. 1600-1045 BCE), lacquered ritual vessels were used, fragments of which have been discovered. Lacquer vessels of various kinds and in larger numbers were found in tombs of the Warring States period (475-221 BCE) (Frick, Kieser, and Prüch 2019, 2-3).

Note: I would like to thank Armin Selbitschka for valuable comments on an earlier draft of this chapter.

Ә Open Access. ( 2020 Kathrin Leese-Messing, published by De Gruyter. (cc)BY-NC-ND This work is licensed under the Creative Commons Attribution-NonCommercial-NoDerivatives 4.0 License.

https://doi.org/10.1515/9783110607741-020 
The cores of lacquer vessels were usually made of ramie fabric or wood ${ }^{2}$ (or a combination of both), with the ramie-cored objects being more time- and lacquer-consuming and thus more expensive. ${ }^{3}$ The cores were covered by several layers of lacquer, the main ingredient of which was the sap of the Chinese lacquer tree (Toxicodendron vernicifluum, formerly Rhus verniciflua). Lacquered products stand out due to their glossy finish and extreme durability. For practical reasons, most of the lacquer vessels are red and black in color. ${ }^{4}$ Their decors vary over time and among different production facilities as regards sophistication, quality, and motifs, with the more typical ones including spirals, birds, dragons, and clouds. Some of the objects were further equipped with gilded or silvered metal mounts, made of a bronze alloy of copper and tin. ${ }^{5}$ Some, moreover, exhibit gold or silver foil inlays that were pasted on the objects' motifs with lacquer, a technique commonly referred to as pingtuo 平脫 ${ }^{6}$

Lacquer objects offer valuable insights into production processes, which will be introduced in section II. The fact that lacquer objects were not only found in Han tombs, but also in a number of archaeological sites across Eurasia further indicates their source value for long-distance exchange. This aspect will be demonstrated in section III.

2 Analyses of individual samples of lacquer vessels proved the wood to be either that from the Chinese chestnut (Castanea mollissima) or from the Populus genus, possibly Populus maximimowiczii (Satō 1962, 300-307).

3 See Barbieri-Low 2001, 271-272. Ideal locations for the growth of lacquer trees and the setting of the lacquer coating provide temperatures between 25 and $30^{\circ}$ celsius and a relative humidity between 75 and 85 percent. Today, these conditions exist only in the provinces of Hubei, Hunan, and Sichuan. While in regard to pre-imperial times lacquer production is often reported in early Chinese texts for northern areas such as the modern provinces of Shandong and Henan, a partial southward shift (to areas such as the upper reaches of the Yangtze River and the Sichuan Basin) is already perceivable for the Han period. Raw lacquer can, however, be transported in airtight containers to areas of less favorable climatic conditions for final application, where artificial heat and humidity then needs to be provided for the drying process of the lacquer coating. Since at least Qin times, humid 'shade rooms' (yinshi 陰室) were used in order to enable lacquer production during the dryer seasons and in areas outside the humid southern zone (Barbieri-Low 2001, 270-271, 283-284).

4 The first lacquer layer applied to the objects was a relatively thick ground layer probably formed by a mix of raw lacquer and ashes or dark soils. On top of this, a non-pigmented covering layer and two overlapping, pigmented ornamental layers were applied. The chemistry of the lacquer fluid limited the applicable pigments to ferrous oxide, lampblack, cinnabar, and orpiment. Since the latter was rare, the color palette of lacquer objects was usually restricted to black and red (BarbieriLow 2001, 269, 275-280). On the technical and chemical aspects of Chinese lacquer production, see also Burmester 1988; McSharry et al. 2007.

5 For a comprehensive study of the decors and motifs of Western Han lacquers, see Prüch 1997, chs. 2 and 3. For two extensive studies on lacquer objects and sets from the Zhanguo, Qin, and Han periods see Hong 2006b; Chen 2007.

6 Pirazzoli-t’Serstevens 2009, 37-38. 


\section{Lacquerware as Evidence for Production Processes, Labor Division, and Quality Control}

Some of the lacquerware production facilities during Han times were not ordinary, small-scale workshops, but exhibited several typical features of 'factories.' Their staff included professional managers and accountants who would procure material and tools, set the stylistic agenda, organize and supervise a force of specialized workers, and control the facility's output and finances. Advanced production and management techniques were applied, including quality control, multi-tiered management models, and 'assembly-line' mass production supported by the use of machines, molds, and jigs. ${ }^{7}$

While some insights into production processes can be gained from technical analyses and from the partially streamlined shapes, dimensions, and design patterns of the vessels, ${ }^{8}$ the most crucial evidence is provided by quality control and accounting inscriptions found on some of the lacquer objects. ${ }^{9}$ On some vessels that were probably produced in smaller, local production facilities (commonly referred to as 'private workshops,' see below), brief inscriptions, brandings, or seals have been found. ${ }^{10}$ The longest inscriptions, however, are found on vessels explicitly identified as having been produced in state-run workshops. Following standardized patterns, they are typically incised on relatively hidden parts of the vessels (for instance the bottom rim) with a script size of a few millimeters (fig. 1b). The writing styles range from perfunctory and irregular in execution to artistic calligraphy, depending on both the time period and the production site. ${ }^{11}$ As for their contents, the

7 Ledderose 2000, 75; Barbieri-Low 2001, 7-9, 22, 267, 340; 2007, 76-83. Many of these techniques were not an innovation of the Han period, but went back to practices in various Qin and preimperial manufactories (Barbieri-Low 2001, 31-38; Li 1957; Satō 1962, 329-358; Hulsewé 1985b; Yamada 1990; Zuo 1986, 108).

8 For instance, on vessels decorated in the imperial 'Ornate Shu Style' (prominent in objects from the Western Workshop of Shu Commandery ca. 44-20 BCE), the use of turntables in the lacquering process is indicated by minute holes in the center of some lacquer platters as well as the flawlessly executed red lacquer bands encircling the inside and outside of platters. Some of the vessels produced in the Chang'an factories further indicate the use of transfer stamps or stencils for creating spiral designs, whereas those made in the Sichuan workshops appear to have been drawn by hand only (Barbieri-Low 2001, 302, 304).

9 Inscriptions are also found on other objects such as bronze vessels, lamps, weapons, and agricultural tools.

10 See Satō 1987; Prüch 1997, 82 (n. 184), 83; Hong 2006a, 156-158. See also below, section III.1.2. 11 Early Western Han inscriptions tended to be similar to those of the Warring States period in both their brevity and perfunctory writing style. It is especially from 30 BCE onward that far greater importance was attributed to the artistic value of the inscriptions, with the most carefully incised inscriptions being those from the Sichuan imperial workshops. Those from the workshops at Chang'an remained comparably crude. On the calligraphic style of the inscriptions, see BarbieriLow 2001, 245-253. 
following inscription found on an eared cup decorated with a bird design may serve as an example. It was unearthed from the tomb of a Western Han marquis's wife in modern Hunan Province (Yaoziling, tomb no. 2):

\begin{abstract}
Made in the $3^{\text {rd }}$ year of the Yuanyan era $[10 \mathrm{BCE}]$ at the Workshop of Guanghan Commandery [in modern Sichuan Province], for imperial use. A black and red lacquered, decorated, woodcored eared cup with gilt bronze mounts, capacity 1 sheng and sixteen yue [approx. $360 \mathrm{ml}$ ]. Made by: core carver Rong, lacquerer Zheng, topcoat lacquerer $\mathrm{Hu}$, gilder $\mathrm{Xu}$, design painter Zun, red lacquerer Wei, touch-up artisan Shun, master artisan He. Managed by: accessory scribe for workshop inspection Long, factory chief Jun, assistant factory chief Shang, lacquer bureau head Shang, probationary scribe director $\mathrm{Wu}$.

元延三年, 廣漢郡工官造, 乘與。髹涑畫, 木, 銅耳黄塗棓, 容一升十六篇。素工戎, 髹工真，上工護，銅耳黄塗工诩，畫工尊，汐工威，清工順，造工賀造。護工卒史隆， 長骏, 丞尚, 掾商, 守令史武主。12
\end{abstract}

The information that inscriptions of this kind provide us with thus include: 1) the year of production, ${ }^{13}$ 2) the name of the production facility, in the case above: one of the two imperial workshops in modern Sichuan, ${ }^{14}$ 3) the utilization category ("for imperial use"), ${ }^{15}$ 4) a description of the object, including materials, colors, shape/ vessel category, 5) the capacity of the vessel, 6) the names and specified tasks of the workers participating in the production process, ${ }^{16}$ and 7) the names and titles of managers and supervisors.

The inscription above lists eight artisan workers and five people responsible for managing and supervising tasks. Since the people who gathered and processed the raw materials are not included, one may assume that at least 20 individuals were involved in the production of one single cup of this quality. ${ }^{17}$ By comparing inscriptions of a particular workshop, it is possible to deduce more general insights, for

12 Hunan sheng wenwu kaogu yanjiusuo and Yongzhou shi Zhishan qu wenwu guanlisuo 2001, 53 (no. 77); trans. Liu 2019b, 162-163 (no. 22), with modifications. Note that in Liu's translation, the sequence of the first sentences is different from the Chinese original. This has been adjusted here. 13 On excavated lacquer objects with inscriptions referring to state-run workshops, the years of production indicated range between 85 BCE and 102 CE. See the chronological list provided in Liu 2019b.

14 The various workshops will be introduced in section III.1.

15 For the interpretation of this term (chengyu 乘與), see Barbieri-Low 2001, 136, n. 86. At least 51 lacquer objects are known whose inscriptions include this information. See Liu 2019a, 46.

16 In contrast to the pieces made in the two imperial workshops in modern Sichuan (of which the above inscription is an example), those from the Chang'an workshops usually only mention the master artisan instead of the full roster of workers.

17 Criticism of the dissipation of labor for the production of lacquer vessels (which, according to the critics, should rather be used for agricultural work) is indicated in a passage of the Discourses on Salt and Iron (Yantie lun 鹽鐵論), in which we find the complaint that "for one single cup or bowl, the labor of one hundred people is used”一杯棬用百人之力 (Yantie lun jiaozhu 29.356). 

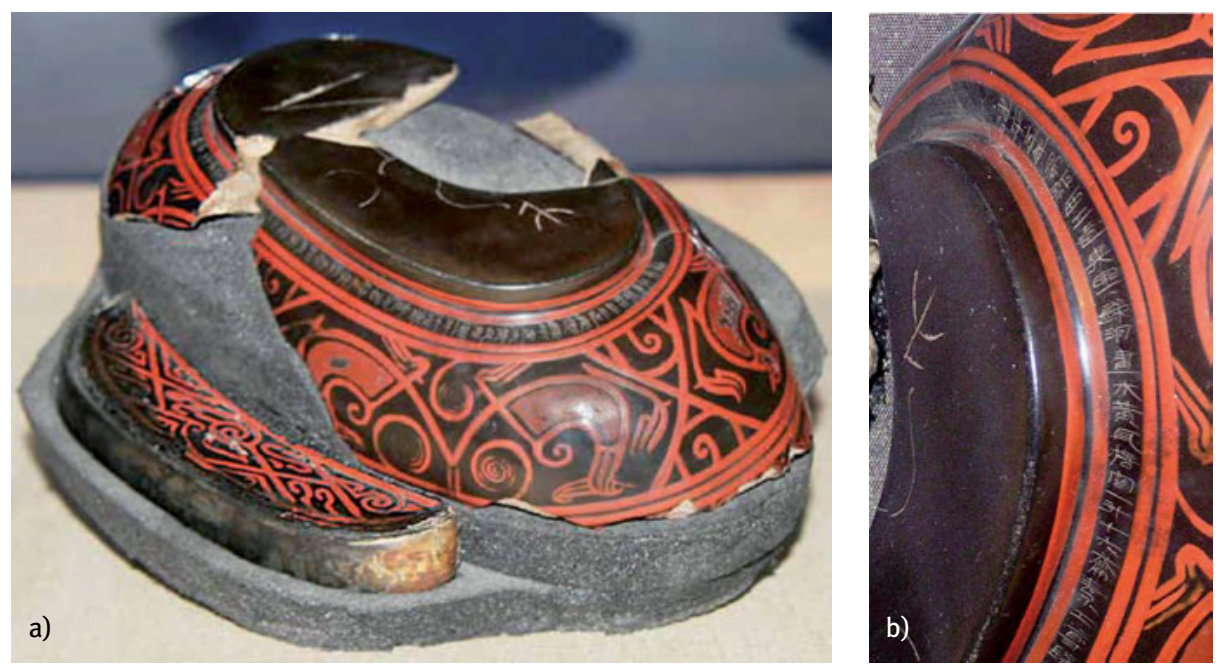

Fig. 1: a) Lacquered eared cup (erbei) from a Xiongnu tomb at Tszurumte, Noyon Uul. National Museum of Mongolian History, inv. no. A-242. b) Detail of inscription. Photos courtesy of Julia Elikhina and Sergei S. Miniaev.

example, on the degree of specialization associated with particular production steps, ${ }^{18}$ the tenure of workers, ${ }^{19}$ and changes over time in the division of labor. ${ }^{20}$

18 Sometimes, a particular name (presumably belonging to one particular worker) occurs with reference to different production steps from one year to the next or even on a single object. This indicates that moving between different activities was possible and even common for part of the workforce. The possibility cannot quite be ruled out, however, that different people with the same surname were involved. The inscriptions also indicate that, at least in the Western Workshop, a larger number of ground-layer lacquerers appear to have been employed than any other type of artisan, and that in comparison to artisans responsible for other production steps, the ground lacquerers rarely undertook other tasks. The job of ground-layer lacquerer appears to have involved less skill than the other tasks but was very laborious and time-consuming. It has therefore been suggested that ground-layer lacquerers might have been corvée laborers conscripted from local private lacquer workshops for a month or so each year (Barbieri-Low 2001, 292). In contrast, the fact that for any given year only one name is ever recorded as a touch-up artisan (qinggong 清工) on the pieces from the Western Workshop of Shu indicates that the workshop may have employed only one of them at any given time. The master artisan's tasks also seem to have been rather exclusive (Barbieri-Low 2001, 314, 318).

19 For instance, a gilder named $\mathrm{Gu}$ 古 appears in inscriptions of products from the Western Workshop of Shu as early as 4 BCE and as late as 4 CE, and a zhou artisan (probably red-lacquerer) named Rong 戊 appears on inscriptions dated between 4 BCE and 8 CE (Barbieri-Low 2001, 301, 312).

20 The inscriptions on vessels from the Western Workshop of Shu indicate a considerable increase in the division of labor over the course of the first century BCE, which may have been related to both the increased complexity of the vessels produced during this period (including different materials like wood, ramie, lacquer, and bronze) and an attempt to adapt to the demands of mass pro- 
But why were all these inscriptions made in the first place? The evidence available indicates that they were made for the purpose of quality control. We know from excavated legal texts from the Qin period that state-run production facilities underwent annual inspections (xing 省) in which their products were evaluated according to their quality. If graded 'unacceptable' (dian 殿), all people involved in the working and managing process were fined or - in the case of convicts flogged. ${ }^{21}$ This inspection system was apparently continued by the Han. Some inscriptions on Han products (including lacquer objects made at the Chang'an imperial workshops) explicitly refer to an 'inspection' as the final step in the production and supervision process. ${ }^{22}$

Some vessels from imperial workshops further include additional inscriptions on the underside referring to their primary place of consumption, such as the 'Eunuch Office' (zhongguan 中官), which was probably responsible for banquets in the women's quarters in the imperial palace at Chang'an, the 'Provisioner's Office' (taiguan 太官), which catered the emperor's banquets and had three thousand slaves at its staff, or the 'Palace of Everlasting Joy' (Changle shi 長樂室) of the Grand Empress Dowager during Wang Mang's reign (9-23 CE). ${ }^{23}$ Two of these secondary inscriptions, found on parts of two platters unearthed from a tomb in what is now North Korea (corresponding to the former Han commandery of Lelang 樂浪), further refer to serial numbers. One of them, whose primary inscription gives the year of production as $8 \mathrm{CE}$, reads:

The provisioner of the Palace of Everlasting Joy in the first month of the first year of the Shijianguo era [Jan. 15 - Feb. 13 in $9 \mathrm{CE}$ ] received number 2,173 of 3,000.

常樂大官, 始建國元年正月, 受第二千一百七十三至三千。24

The highly standardized, 'assembly line' mass production in Han factories as attested by the imperially produced lacquer objects was the culmination of a long workshop tradition that had been encouraging specialization and standardization for

duction by applying assembly line production processes (Barbieri-Low 2001, 329-330). For the contents of inscriptions found on lacquer objects in general, see also Hong 2006c.

21 Shuihudi Qin mu zhujian zhengli xiaozu 1990, 83-85; Hulsewé 1985a, 110-112 (C11-C14).

22 See the inscriptions on lacquer objects from the Tribute workshop (Gonggong 供工), the Imperial Workshop (Kaogong 考工), and the Workshop of the Right (Yougong 右工) listed in Liu 2019b. Inscriptions on objects from the two workshops in modern Sichuan only refer to inspections during the reign of Wang Mang.

23 Barbieri-Low 2001, 160, n. 19, 7, n. 5. For individual examples, see Barbieri-Low 2001, 6-7, 160, n. 19; Liu 2019b, 154-155, nos. 5 and 8, 162-163, nos. 23 and 24, 168-169, no. 36.

24 See Kayamoto and Machida 1974, 104, no. 49; trans. Liu 2019b, 188-189, no. 71; Barbieri-Low 2001, 6-7, 435. For the second platter fragment with an inscription of this kind (which refers to the reception date as $9 \mathrm{CE}$, but is missing the rim with the primary inscription referring to, among others, the year of production), see Barbieri-Low 2001, 438, no. 2.82. 
many centuries. ${ }^{25}$ As for Qin and Han times, it is not only manifest in lacquer production, but also in the mass production of, for instance, identical and interchangeable metal components (for weapons and vehicles). The production of Qin Shihuang's terracotta warriors has also been shown to be an example of "module and mass production." ${ }^{26}$ In the case of lacquer, the physical properties of the material which involved drying phases of at least two days for each layer - further encouraged a fine labor division. Bureaucratic culture, with its insistence on defined tasks and titles, may have further added to this predilection. ${ }^{27}$ In this regard, it is moreover striking that the management structure and concrete title designations given on the lacquer inscriptions mirror those of local administration on county (xian 縣) level. ${ }^{28}$

\section{Lacquerware as Evidence for Long-Distance Exchange}

The inscriptions on lacquer objects produced in state-run workshops provide us with quite precise information about their place of production and sometimes also about their primary place of consumption. Even for some of the other presumably privately produced objects, there are some useful indications as to where they were most likely produced. Interestingly, many of the objects were found a great distance from both of their indicated places of production and primary consumption. This section will first give an overview of the known production sites before turning to the find spots and the related question of how the objects may have ended up in these places.

\section{III.1 Production Sites}

\section{III.1.1 State-run Factories}

Most of the longer inscriptions found on lacquer objects explicitly refer to certain state-run workshops. Among the four most commonly mentioned imperial work-

25 The method of casting (rather than hammering) large numbers of bronze vessels from the second millennium BCE onward is an early example of a production technique that encouraged labor division.

26 See Ledderose 2000, ch. 3.

27 On all these factors, see Barbieri-Low 2001, 338-339. On early imperial bureaucracy and bureaucratic culture, see Leese-Messing, ch. 4, sections IV.1 and IV.2, this volume.

28 Barbieri-Low 2001, 341-348. On the macro-organization of different kinds of Han imperial workshops within the political, economic, and geographic structure of the Han Empire, for which received texts like the Han dynastic histories are the most important source, see Barbieri-Low 2001, 
shops are two facilities at the Western Han capital, Chang'an: the Imperial Workshop (Kaogong 考工, until 104 BCE: Kaogong shi 室) and the Tribute Workshop (Gonggong 供工). They appear to have been similar to each other with regard to their management structure as well as their product ranges, which apart from lacquer objects also included bronze vessels, lamps, and weapons. Their products seem to have been made primarily for the palaces in- and outside of Chang'an, and possibly for use as imperial gifts in particular. ${ }^{29}$ According to the Documents of the Later Han (Hou Hanshu 後漢書), the Imperial Workshop employed a director, two assistants, and 109 subordinate officials during the Later Han period. ${ }^{30}$

The vessels of highest quality - which are also those bearing the longest inscriptions - were not the vessels made at Chang'an, however, but those produced in two regional (but also state-run) workshops in what is now Sichuan Province. These were the Western Workshop of Shu Commandery (Shu Jun Xigong 蜀郡西工) in Chengdu 成都 and the Workshop Office of Guanghan Commandery (Guanghan Jun Gongguan 廣漢郡工官) in Zitong 梓潼. Like the workshops at Chang'an, they not only specialized in lacquering, but further produced other luxury objects for the imperial court, such as gilt bronzes and book knives. The majority of lacquer objects whose inscriptions refer to 'imperial use' (chengyu 乘與) are products of the Shu and Guanghan facilities. ${ }^{31}$ In Ban Gu's 班固 (32-92 CE) Documents of the Han (Hanshu 漢書), they are mentioned as two out of nine 'workshop offices' (gongguan 工官) that were spread over different parts of the Han Empire. ${ }^{32}$ Their locations in the Sichuan Basin had the twofold advantage of being close to raw materials and of having longstanding traditions in the production of luxury products such as lacquerware.

\section{III.1.2 Other Production Sites}

Other than in the cases introduced above, the provenance of the large majority of lacquer objects is more difficult to determine, as they either do not bear any inscrip-

ch. 1. On lacquer production and management processes from the Warring States to the Han period, see Hong 2006 .

29 Barbieri-Low 2001, 68, 251. Several inscriptions on lacquer and bronze vessels further refer to a facility called the Workshop of the Right (yougong 右工), which was possibly also situated in the greater Chang'an area. Its roster of officials appears to have been similar to the two workshops at the capital mentioned above. It is not mentioned in any transmitted text. On all three workshops, see Barbieri-Low 2001, 68-69, 74-76.

30 Hou Hanshu 25.3581, including the commentary citing the Hanguan 漢官. See also Bielenstein 1980, 37-38.

31 Only a small portion of the objects produced in the Chang'an workshops are identified as cheng$y u$ ware (Hong 2006a, 155).

32 They are mentioned in individual 'original commentary' entries throughout the "Treatise on Geography” (Dili zhi 地理志), Hanshu 28A, each saying “[place X] has a workshop office” (you gongguan 有工官). Inscribed products have been unearthed from six out of these nine facilities. 
tion at all, or their inscriptions do not refer to a (identifiable) place of production. Furthermore, the line between private workshops and state-run workshops is often much more difficult to draw than some studies may suggest. In the case of some facilities occasionally mentioned in inscriptions, location or status (or both) remain doubtful. One case in point is a production site that several inscriptions refer to as the 'Southern Workshop Office' (Nan Gongguan 南工官). While its designation as a 'workshop office' is congruent with the aforementioned system of local - but obviously state-run and centrally controlled - production facilities mentioned in the Hanshu, the latter does not list it among these. ${ }^{33}$ What is more, inscriptions referring to the 'Southern Workshop Office' use the regnal years of the local king of Jiangdu 江都, Liu Fei 劉非 (who is also the tomb occupant), ${ }^{34}$ for dating the production of the objects, which speaks in favor of interpreting the 'Southern Workshop Office' as a local workshop under the control of this king. ${ }^{35}$ But to what extent this production site as well as some others deserve to be called 'private workshops,' or to what extent they were subject to the central government's control or finance, is as yet all but certain. ${ }^{36}$ The question how broad their spectrum of consumers was and to what extent they were produced commercially for a wider market also remains largely unsolved. Lacquer pieces with simple brandings, seals, or very short inscriptions referring to single craftsmen or simple trademarks (like 'House of Wang' 王家) more clearly suggest that they may have been facilities deserving to be named 'private' or 'semi-dependent' workshops. ${ }^{37}$ As for the many more lacquer objects not bearing

Other than the two mentioned above, most of the other workshop offices specialized in the production of weapons (Barbieri-Low 2001, 84-85).

33 There is a great deal of uncertainty about what it meant for a workshop to be called a 'workshop office.' Even the early Hanshu commentators appear to have been confused about the meaning of the term and what kind of workshops were subsumed under this designation. See Ru Chun's 如淳 and Yan Shigu's 顏師古 remarks on the meaning of the "three workshop offices" mentioned in Gu Yong's 貢禹 memorial in Hanshu 72.3070-3071, commentary no. 4.

34 Liu Fei was a half-brother of Emperor Wu 武 (r. 141-87 BCE). His kingdom, Jiangdu, was located in what is now the province of Jiangsu, in the east of the Han Empire.

35 Similarly, of the approximately 3,000 lacquer objects found in the tomb of the king of Changyi 昌邑, Liu He 劉賀, a large number were inscribed with regnal years referring to this very kingdom, which was located in modern Shandong Province. See Liu 2019a, 55; Jiangxisheng wenwu kaogu yanjiusuo 2016, 55-58. Liu He was a grandson of Emperor Wu. After having inherited the title King of Changyi from his father in 88 BCE, he came to rule as Han Emperor for about one month in 74 BCE before being deposed again. He was then demoted to Marquis of Haihun 海昏.

36 There are indications (both from transmitted texts and from archaeological evidence) that the degree of central state control over local workshops changed over time, but the concrete implications of these changes remain largely unclear. For indications of such changes, see Qian 2016. For a concrete example of a certain lacquer object that different scholars have variously attributed to either private or imperial production sites, see the case of the Noyon Uul 'Shanglin' cup discussed below, including n. 51 .

37 Liu 2019a, 55-56; Hong 2006a, 156-158. The latter suggests, however, that even the 'private' or 'independent' workshops "might have been rigorously regulated by the state" (158). 
any according inscriptions, their provenance can only be conjectured on the basis of their find spots and certain design features. These are at times associated with certain regions due to local clusters of objects with particular shapes or decorations (such as gold foil inlays).

While all these issues are in need of further research, the combined evidence of both scattered inscriptions and local clusters strongly suggest that in the Han Empire's eastern and southern parts (in today's Henan, Shandong, Jiangsu, Jiangxi and Hunan Provinces), local centers of lacquer production with varying and changing degrees of independence existed beyond the famous state-run facilities under firm control of the central government. ${ }^{38}$

\section{III.2 Find Spots and Potential Ways of Distribution}

Since the first Han lacquer vessels were discovered in the early twentieth century near Dunhuang and in southern Manchuria, thousands of lacquer products and lacquer fragments have been found in tombs all over the former Han territory and in many archaeological sites across Eurasia, with the hitherto westernmost finds stemming from tombs at the necropolis of Ust'-Al'ma (Crimean peninsula) and at Sokolova Mogila (Ukraine, over 6,000 km from Chang'an). ${ }^{39}$ The first Han lacquer objects bearing inscriptions were found in 1916 in a tomb near modern Pyongyang, North Korea, in an area corresponding to the Han frontier commandery of Lelang. ${ }^{40}$ Since then, more than 80 lacquer objects have been discovered which bear inscriptions referring to state-run production sites. Apart from further finds in North Korea, more have been unearthed from tombs at the Noyon Uul (Noin Ula) and Gol Mod sites (in Mongolia) as well as at Tsaram (in Buriatiia, southern Russia), all of which are located in areas associated with the Xiongnu Empire. ${ }^{41}$ Of the several lacquer objects found at Begram (in Afghanistan, about 3,600 km from Chang'an), two have been attributed to one or the other state-run workshop on the basis of their designs, although they are not inscribed. ${ }^{42}$ Within the territory of today's People's Republic of China, pieces of lacquerware with inscriptions referring to imperial workshops

38 Liu 2019a, 50-56.

39 On the latter finds, see Prüch 2019; Brosseder 2015, 259, 291.

40 Even today, the North Korean finds make up the majority of lacquer objects with imperial inscriptions. A groundbreaking illustrated collection of early finds of inscribed lacquers was published in 1943 by Umehara Sueji.

41 Pirazzoli-t’Serstevens 2009; Chistyakova 2011 (Noyon Uul); Yeruul-Erdene and Otani 2015 (Gol Mod); Pirazzoli-t'Serstevens 2007 (Tsaram). On the difficulties of preserving lacquer objects found in Xiongnu tombs, see Waugh 2006. For Noyon Uul and Gol Mod, see ch. 5, map 1.

42 On the Begram finds, see Pirazzoli-t’Serstevens 2001 and Zhang 2011, who disagree about whether the two objects in question were products of the Western Workshop of Shu Commandery (Pirazzoli-t'Serstevens) or one of the workshops at Chang'an (Zhang). For a critical assessment of Zhang's attributions regarding object typology and dates, see Morris 2017, 164-171. 
have been found in the provinces of Guizhou and Hunan (corresponding to the southwestern peripheries of the Han Empire), Gansu (the north-western periphery of the Han Empire), and in Jiangsu and Henan (in the east of the Han Empire). Some of the tombs from which the objects were unearthed could be identified as those of middle- to high-ranking officials or nobles (including close relatives of emperors). ${ }^{43}$

Curiously, other than non-inscribed objects or those bearing inscriptions from local, presumably private workshops, none of the mass-produced imperial lacquer objects has so far been unearthed from locations close to their production sites, that is, in or near the Western Han capital Chang'an or in Sichuan. More generally, the imperially produced objects found in locations in the larger core of the Han Empire are clearly outnumbered by the imperially produced lacquers found in the former Han Empire's peripheries and beyond. ${ }^{44}$ This has led many scholars to the conclusion that the Han court's redistribution practices - in the form of lavish bestowals of luxury objects to foreign leaders and barbarian chieftains as diplomatic gifts must have played the central role in the distribution of these luxury items. ${ }^{45}$

The question of distribution is more difficult to answer with regard to the vast majority of lacquer objects, that is, those without inscriptions referring to state-run production facilities. Lacquer objects whose inscriptions or designs are commonly interpreted as evidence for certain local, more-or-less 'private' production centers have been found both close to the alleged production sites as well as a great distance away from them. In many tombs both in- and outside the former Han territory, one finds them side-by-side with lacquer objects explicitly made in government workshops in Chang'an and Sichuan. This suggests that the tomb owners would have gotten hold of them via different pathways of distribution that were operating side-by-side inside of the Han Empire. ${ }^{46}$ Looking beyond the Han Empire's borders, it is recognizable that the further one gets to the west of the Eurasian steppes, the more lacquer finds tend to be non-inscribed, presumably privately produced objects, especially lacquer boxes. ${ }^{47}$

43 For the geographic distribution of attested private and imperial Western Han lacquer workshops as well as find spots of both types of lacquer products, see the maps in Liu 2019a, 31 (for workshops and finds in Han and Xiongnu territories) and Brosseder 2015, 258 (for Eurasian finds beyond the Han territory). The latter article includes a helpful and comprehensive list of Han lacquer finds in Eurasia, giving site names, locations, contexts, and references to image publications (288-291). For a compilation of 87 inscriptions on lacquer objects referring to imperial production facilities, see Liu 2019b.

44 Liu 2019a, 45-46. The Korean (Lelang Commandery) finds are still by far the most numerous. One has to keep in mind, however, that future excavations, which might also include the hitherto unexcavated Western Han imperial tombs near Chang'an, bear the potential of considerably changing the picture.

45 Pirazzoli-t'Serstevens $(2009,39)$, refutes the idea that lacquer objects from imperial workshops were available on the market. She argues that if this had been the case, more objects with the characteristic inscriptions would have been found in tombs in the Han Empire's core territory.

46 Pirazzoli-t’Serstevens 2009, 38.

47 Brosseder 2015, 258, figs. 27 and 28, 259. 
Lacquer objects - most typically, toilet boxes - whose designs and decorations (such as gold-foil inlays) have been suggested to be typical of certain eastern and southern regions of the Han Empire and the Han kingdom of Guangling 廣陵 (in modern Jiangsu Province) in particular, have been found, for example, at Noyon Uul, in North Korea (Lelang), at Begram, and at Ust'-Al'ma on the Crimean peninsula. ${ }^{48}$ If the attribution of provenance is correct, ${ }^{49}$ the question is how these products from presumably private workshops, perhaps associated with certain local nobles in the east or south of the Han Empire, made their way to the various sites across Eurasia. How did they get out of the Han Empire's territory in the first place? Should we imagine that they were sold in a local market close to their production site? Would they then have been transported from one trading post to the next until they ended up in a border market, from where they were further redistributed? Or should we rather imagine their distribution to have worked more directly, via a "network of connected elites" 50 that operated across borders in addition to - or in circumvention of - the official diplomatic activities of the central government? Alternatively, should Chang'an (or Luoyang, respectively) be seen as a nodal point, through which locally produced lacquer products that had been acquired by the court were redistributed in connection to the imperial government's management of foreign relations? All these possibilities do not exclude each other; a mixture of different types and routes of distribution is certainly possible. Some scholars, however, have made suggestions regarding particular objects, two examples of which will be introduced in the following.

The first concerns a lacquer eared cup unearthed at Noyon Uul (barrow no. 6), which features two inscriptions. One of them, incised at its foot, refers to a production date (ninth month, i.e., Oct./Sept. of 2 всE) and the names of two artisans and one inspector. The second one was painted in red on the underside and says 'Shanglin’ 上林, which was the name of an imperial park west of Chang'an. Several features of the quality control inscription as well as certain design features have been suggested by some scholars to have been atypical of imperial products. ${ }^{51}$ Accepting

48 For the provenance of the relevant lacquer objects from these sites, see Pirazzoli-t'Serstevens 2009, 37 with n. 12 (Noyon Uul); Zhang 2011, 10-11 (Begram); and Prüch 2019, $24-28$ (Ust'-Al'ma, North Korea). A large collection of color images of the lacquer finds from Guangling tombs can be found in Yangzhou bowuguan 2004.

49 Prüch, for example, has emphasized that such attributions of provenance must be regarded as tentative: "Whether the Ust'-Al'ma boxes were produced in the Jiangsu area, in the factories of today's Sichuan area, or in the imperial workshops at Xi'an cannot be determined with absolute certainty" (Prüch 2019, 29).

50 Prüch 2019, 29.

51 The lack of a reference to a production site, the inclusion of a specific month (instead of just the year) for the date of production, and the small number of workers are atypical for inscriptions referring to the most commonly mentioned imperial workshops at Chang'an and in Sichuan. The sketchily incised bird on the bronze mount and the use of thin lines instead of thick lines in relief for the painted decoration (which otherwise uses the same motifs found on imperial objects) have 
the two (though controversial) hypotheses that the cup was produced in a private workshop and that the painted inscription refers to the Shanglin Park as an indication of its place of usage, ${ }^{52}$ while further taking into account that the cup was finally deposited in a Xiongnu (possibly a chanyu's) tomb, one may hypothesize the following sequence of steps: The cup was made at a private workshop and acquired by the Han court for the use at a palace of the Shanglin Park. From there it was given away, possibly as an imperial gift to a member of a Xiongnu mission visiting the palace. ${ }^{53}$ As a matter of fact, Hanshu 94B.3817 explicitly mentions that the chief Xiongnu leader of this period, Chanyu Wuzhuliu 烏珠留 (r. 8 BCE-13 CE) was accommodated in a palace in Shanglin Park during his visit at Chang'an in 1 BCE. ${ }^{54}$ In any case, this example speaks in favor of interpreting Chang'an as a nodal point of cross-border distribution, potentially also for privately produced lacquerware.

The second example concerns several lacquer boxes discovered in various nonChinese sites such as Noyon Uul, Begram, and Ust'Al'ma. Scholars have attributed these boxes to production sites that were presumably located in or near the Guangling Kingdom in modern Jiangsu Province. One of the sites of this region in which similar (presumably locally produced) objects have been unearthed in large quantities is the tomb of Liu Jing 劉荊 (d. $67 \mathrm{CE}$ ), ${ }^{55}$ king of Guangling. Interestingly, his diverse tomb assemblage also included fragments of a blue ribbed bowl made from

also been suggested as evidence for private production (Pirazzoli-t’Serstevens 2009, 36-37; Liu 2019a, 43-44). Chistyakova $(2011,85)$ even argues that the (admittedly rather crude-looking) inscription on this cup was not made by a Han Chinese artisan, but rather "another artisan who was simply following the Chinese model." Other scholars, however, believe that the design of the cup is, by contrast, typical of the imperial workshops at the capital and believe that it was produced in one of these (e.g., Louis 2006-2007, 50-51). Barbieri-Low suggests that the painted inscription refers to the place where the cup was used (2001, 125, n. 64, and 352), but furthermore argues that it was also produced at an imperial workshop called 'Shanglin' (76, n. 79). That 'Shanglin' was indeed also the name of a production site is clear from respective references in quality control inscriptions on certain bronze vessels. Except for the fact that in the incised quality control inscription on the cup from Noyol Uul, the reference to 'Shanglin' as the production site is missing, the inscription is strikingly similar to those on the bronze vessels that explicitly refer to the 'Shanglin' workshop as their production site. For example, they similarly refer to the month of production. See the examples 1.6 and 1.7 provided in Barbieri-Low 2001, 390. This shows that the cup might well have been produced in an imperial (albeit less well known) workshop after all.

52 It has been suggested that the style of the 'Shanglin' inscription is similar to another one, also saying 'Shanglin,' painted on the underside of a lacquer platter that was found in tomb no. 1 at Sanyangdun, Yancheng, in Jiangsu Province (Pirazzoli-t’'Serstevens 2009, 37; Hong 2006c, 335). For the controversies, see n. 51 above.

53 Pirazzoli-t’Serstevens 2009, 36-37, 38-39; Louis 2006-2007, 50-51.

54 Louis (2006-2007, 51), therefore, suggests that the cup might have been produced for this event. The tomb occupant of barrow no. 6 might indeed have been Chanyu Wuzhuliu himself, but this attribution remains speculative (Pirazzoli-t'Serstevens 2009, 39).

55 Liu Jing was a son of the founder of the Eastern Han dynasty, Emperor Guangwu 光武 (r. 25$57 \mathrm{CE}$ ). 
mosaic glass, which has been shown to be one of the very rare finds of Western glass of the Western Han period. Ribbed bowls of this type (type E184, Isings form 17) were widely distributed in the Roman Empire and were also found in the Black Sea area and Mongolia, among other places. In contrast to other glass vessels found in China, this type has not been found in sites commonly associated with the 'maritime Silk Road,' but rather appear to have been distributed via the land routes that led through Central Asia and Xiongnu territory. ${ }^{56}$ In combination with the evidence of lacquerware, which appears to have travelled along the same routes in the opposite direction, this might be interpreted as an indication of cross-border networks in which Chinese local elites from the Han Empire's eastern parts might have played an active role beyond the diplomatic operations of the central Han court.

\section{Conclusion}

The above introduction has sought to demonstrate how the multidimensional source value of Han lacquer objects has contributed to our understanding of various economic processes, including local production and long-distance distribution. Taking into account that large quantities of such vessels continue to be discovered, lacquer objects promise to evolve into an even more valuable field of research in the near future. Assuming that refined technical and analytical approaches to both provenance identification, and also distributional mechanisms and networks will accompany these ongoing finds, many of the uncertainties that characterize analyses hitherto may eventually be minimized. A comparatitive analysis with finds of other Chinese products discovered in different parts of Eurasia, such as bronze mirrors and silks, as well as with non-Chinese objects moving in the opposite direction from the steppes and the far west, then promises to allow for more precise and revealing insights, especially with regard to long-distance exchange networks. ${ }^{57}$

\section{References}

Barbieri-Low, A. J. 2001. "The organization of imperial workshops during the Han dynasty."

PhD. diss., Princeton University.

-. 2007. Artisans in early imperial China. Seattle, WA: University of Washington Press.

56 Brosseder 2015, 261-264. For other types of glass bowls found in Han tombs that are either associated with the 'maritime silk road' or were produced locally in the southern regions of the Han Empire, see Borell 2010.

57 See Brosseder 2015 for a groundbreaking and comprehensive synopsis of archaeological finds of objects (of several different kinds) that moved in different directions along the Eurasian Steppe belt. 
Bielenstein, H. 1980. The bureaucracy of Han times. Cambridge: Cambridge University Press.

Borell, B. 2010. “Trade and glass vessels along the maritime Silk Road." In B. Zorn and A. Hilgner (eds.), Glass along the Silk Road from 200 BC to AD 1000, 127-142. Mainz: RömischGermanisches Zentralmuseum.

Brosseder, U. 2015. "A study on the complexity and dynamics of interaction and exchange in Late Iron Age Eurasia.” In J. Bemmann and M. Schmauder (eds.), Complexity of interaction along the Eurasian steppe zone in the first millennium CE, 199-332. Bonn: Vor- und frühgeschichtliche Archäologie, Rheinische Friedrich-Wilhelms-Universität Bonn.

Burmester, A. 1988. "Technical studies of Chinese lacquer." In N. S. Brommelle and P. Smith (eds.), Urushi: Proceedings of the 1985 Urushi Study Group, 163-187. Marina del Rey, CA: Getty Conservation Institute.

Chen Zhenyu 陈振裕. 2007. Zhanguo Qin Han qiqi qun yanjiu 战国秦汉漆器群研究 [Study on lacquer sets of the Warring States, Qin, and Han periods]. Beijing: Wenwu chubanshe.

Chistyakova, A. N. 2011. "Lacquer cups of the Western Han dynasty (Noin Ula, Mongolia): An analysis of inscriptions." Archaeology, Ethnology and Anthropology of Eurasia 39.4, 83-89.

Frick, P., A. Kieser and M. Prüch. 2019. “Introduction.” In P. Frick and A. Kieser (eds.), Production, distribution and appreciation: New aspects of East Asian lacquer ware, 1-9. Leiden: Brill.

Hanshu 漢書 [Documents of the Han]. 1962. Composed by Ban Gu 班固 (32-92 CE). Beijing: Zhonghua shuju.

Hong Shi 洪石. 2006a. "Production and management of the lacquer industry during the Warring States, Qin and Han periods.” Chinese Archaeology 6.1, 152-158.

-. 2006b. Zhanguo Qin Han qiqi yanjiu 战国秦汉漆器研究 [Study on lacquer objects from the Zhanguo, Qin, and Han periods]. Beijing: Wenwu chubanshe.

-. 2006c. “Zhanguo Qin Han shiqi qiqi shang de wenzi neirong tanxi” 战国秦汉时期漆器上的文 字内容探析 [Investigation in the meaning of the inscriptions of lacquer objects from the Warring States, Qin, and Han periods]. In Handai kaogu yu Han wenhua guoji xueshu yantaohui lunwenji 汉代考古与汉文化国际学术研讨会论文集 [Proceedings of the International Symposium on Han archaeology and Han culture], 329-339. Jinan: Qi Lu shushe.

Hou Hanshu 後漢書 [Documents of the Later Han]. 1965. Composed by Fan Ye 范曄 (398-445 CE). Beijing: Zhonghua shuju.

Hulsewé, A. F. P. 1985a. Remnants of Ch'in law: An annotated translation of the Ch'in legal and administrative rules of the 3rd century BC discovered in Yün-meng prefecture, Hu-pei province, in 1975 . Leiden: Brill.

-. 1985b. "The influence of the 'legalist' government of Qin on the economy as reflected in the texts discovered in Yunmeng county." In S. R. Schram (ed.), The scope of state power in China, 211-235. London: School of Oriental and African Studies.

Hunan sheng wenwu kaogu yanjiusuo 湖南省文物考古研究所 and Yongzhou shi Zhishan qu wenwu guanlisuo 永州市芝山區文物管理所. 2001. “Hunan Yongzhou shi Yaoziling er hao Xi Han mu” 湖南永州市鷂子岭二號西漢墓 [Tomb No. 2 at Yaoziling, municipality of Yongzhou, Hunan Province]. Kaogu 考古, no. 4, 45-62.

Jiangxi sheng wenwu kaogu yanjiusuo 江西省文物考古研究所, ed. 2016. “Nanchang shi Xi Han Haihun hou mu” 南昌市西汉海昏侯墓 [The tomb of the Western Han Marquis of Haihun, Nanchang city]. Kaogu 考古, no. 7, 45-62.

Kayamoto Tojin 榧本杜人 and Machida Akira 町田章. 1974. “Kandai kinenmei shikki shūsei” 漢代紀年銘漆器聚成 [Collection of Han-period lacquers with dated inscriptions]. In Rakurō kanbo kankōkai 樂浪漢墓刊行繪 (ed.), Rakurō Kanbo 樂浪漢墓 [Han tombs in Lelang], 96122. Nara: Rakurō Kanbo Kankōkai.

Ledderose, L. 2000. Ten thousand things: Module and mass production in Chinese art. Princeton, N): Princeton University Press. 
Li Xueqin 李学勤. 1957. “Zhanguo shidai de Qin guo tongqi” 战国时代的秦国铜器 [Qin bronze vessels of the Warring States period]. Wenwu cankao ziliao 文物参考资料, no. 8, 38-40, 53.

Liu, Y. 2019a. "Emblems of power and glory: The Han-period Chinese lacquer wares discovered in the borderlands." In P. Frick and A. Kieser (eds.), Production, distribution and appreciation: New aspects of East Asian lacquer ware, 30-63. Leiden: Brill.

-. 2019b. "Han-period official lacquers excavated from archaeological sites." In P. Frick and A. Kieser (eds.), Production, distribution and appreciation: New aspects of East Asian lacquer ware, 152-195. Leiden: Brill.

Louis, F. 2006-2007. "Han lacquerware and the wine cups of Noin Ula." Silk Road 4.2, 48-53.

McSharry, C., R. Faulkner, S. Rivers, M. S. P. Shaffer and T. Welton. 2007. "The chemistry of East Asian lacquer: A review of the scientific literature." In "Reviews in Conservation 8." Supplement, Studies in Conversation 52.51, 29-40.

Morris, L. 2017. “The Begram hoard and its context." PhD. diss., Ludwig-Maximilians-Universität München.

Pirazzoli-t’Serstevens, M. 2001. "Les laques chinois de Begram: Un réexamen de leur identification et de leur datation." Topoi 11.1, 473-484.

-. 2007. "A Chinese inscription from a Xiongnu elite barrow in the Tsaraam cemetery." Silk Road $5.1,56-58$.

-. 2009. "Chinese lacquerware from Noyon uul: Some problems of manufacturing and distribution." Silk Road 7, 36-41.

Prüch, M. 1997. Die Lacke der Westlichen Han-Zeit. Frankfurt: Peter Lang.

-. 2019. "From east to west: The journey of Han-dynasty lacquer boxes to the Crimean Peninsula." In A. Kieser and P. Frick (eds.), Production, distribution and appreciation: New aspects of East Asian lacquer ware, 10-29. Leiden: Brill.

Qian Yanhui 钱彦惠. 2016. “Mingwen suo jian Xi Han zhuhou wang qiwu de shengchan jigou: Jianlun Xi Han gongguan de shezhi yu guanli” 铭文所见西汉诸侯王器物的生产机构: 兼论西汉工官的设置与管理 [Inscriptions as evidence for the organization of manufacturing objects for the Western Han feudal lords: Including a discussion on the establishment and management of the gongguan system]. Dongnan wenhua 东南文化, no. 3, 40-46.

Satō Taketoshi 佐藤武敏. 1962. Chūgoku kodai kōgyōshi no kenkyū 中国古代工業史の 研究 [Study on the ancient Chinese manufacturing industry]. Tōkyō: Yoshikawa Kōbunkan.

-. 1987. “Shin Kan sho no shikki no seisan ni tsuite 秦漢初の漆器の生産について” [Qin and early Han lacquer production]. Koshishunjū 4, 3-16.

Shuihudi Qin mu zhujian zhengli xiaozu 睡虎地秦墓竹簡整理小組. 1990. Shuihudi Qin mu zhujian 睡虎地秦墓竹簡 [Bamboo slips from a Qin tomb at Shuihudi]. Beijing: Wenwu chubanshe.

Umehara Sueji 梅原末治. 1943. Shina Kandai kinenmei shikki zusetsu 支那漢代紀年銘漆器図說 [Illustrated catalogue of the Han period Chinese lacquers with datable inscriptions]. Kyōto: Kuwana Bunseidō.

Waugh, D. C. 2006. "The challenges of preserving evidence of Chinese lacquerware in Xiongnu graves." Silk Road 4.1, 32-36.

Yamada Katsuyoshi 山田勝芳. 1990. “Offices and officials of works, markets and lands in the Ch'in dynasty." Acta Asiatica 58, 1-23.

Yangzhou bowuguan 扬州博物馆, ed. 2004. Han Guangling guo qiqi 汉广陵国漆器 [Lacquer objects from the Han kingdom of Guangling]. Beijing: Wenwu Chubanshe.

Yantie lun jiaozhu 鹽鐵論校注 [The Discourses on Salt and Iron with collated commentaries]. 1992. Composed by Huan Kuan 桓寬 (first century BCE). Commentaries compiled by Wang Liqi 王利器. Beijing: Zhonghua shuju.

Yeruul-Erdene, C., and I. Otani. 2015. "The Chinese inscription on the lacquerware unearthed from tomb 20, Gol Mod I Site, Mongolia." Silk Road 13, 104-108. 
Zhang, L. 2011. "Chinese lacquerwares from Begram: Date and provenance." International Journal of Asian Studies 8.1, 1-24.

Zuo Decheng 左德承, ed. 1986. Yunmeng Shuihudi chutu Qin-Han qiqi tulu 云梦睡虎地出土 秦汉漆器图录 [Catalogue of Qin-Han lacquer ware excavated from Shuihudi, Yunmeng]. Wuhan: Hubei meishu chubanshe. 

Part III: Historiographies 



\section{Lara Fabian \\ Introduction}

Research on Afro-Eurasian empires and their economies in antiquity has unfolded within diverse communities of scholars who approach the topic of the ancient world from a number of different research traditions. Because of the scale of the subject and the diversity of approaches, these scholarly communities have interacted in sporadic and often superficial ways. Despite the increasingly global nature of scholarship, they remain halting conversation partners today.

In this handbook, we integrate knowledge from across the landscape of studies on Afro-Eurasian history in order to develop our own new understanding of economic developments in the space. As we do this, we find ourselves faced with data and interpretations predicated on different understandings of history. The vision of the 'Silk Road' in Chinese scholarship differs quite sharply from what lives in the mind of historians writing in the Western European tradition. A German Hellenistic historian's understanding of the Bactrian kingdom is perhaps unrecognizable from the perspective of a Russian-trained archaeologist working in Central Asia. Superficially, these differences appear to be explained by a focus on different bodies of evidence. In fact, the differences run deeper, reflecting the diverse research traditions that undergird scholarship. These genealogies of knowledge are powerfully formative, since history and archaeology are processes of cultural sedimentation, where each layer builds on what came before it.

Research traditions in this sense are the constellations of institutional and social networks that surround individual scholars and give structure to the worldview through which they study the past. Discussions of how research traditions structure studies of the ancient world have been ongoing for decades, although they have received more explicit attention from archaeologists than ancient historians. ${ }^{1}$ Choices about where and what to excavate, as well as how to organize, categorize, and present data shape the archaeological record. As such, the 'archaeological record' is not a neutral reflection of the past, but rather a creation of modernity that reflects the priorities and interests of the scholars involved in its creation, and that goes on to affect the shape of future research. ${ }^{2}$ Although the material character of archaeology makes these issues particularly present and relevant, historiographical research has highlighted a similar process of interpretational accumulation in ancient historical scholarship, in which educational networks and disciplinary conventions clearly shape normative spheres of inquiry. ${ }^{3}$ Finally, research agendas are also informed

1 For example, Trigger 1984; Díaz-Andreu and Champion 1996.

2 Patrik 1985; Shanks and Tilley 1987; Schlanger 2002; Murray 2012; Wylie 2017.

3 See for example the papers collected in Lianeri 2011.

Ә Open Access. () 2020 Lara Fabian, published by De Gruyter. (cc)BY-NC-ND This work is licensed under the Creative Commons Attribution-NonCommercial-NoDerivatives 4.0 License.

https://doi.org/10.1515/9783110607741-021 
by what might best be termed 'identity relationships' that link communities of researchers to the populations and pasts that they study.

As we examine these research traditions, however, we need to take care not to essentialize them: there never has been a single 'Western European' vision of the Roman Empire any more than there has been a single 'Chinese' vision of ancient China. Instead, research traditions are shifting phenomena with fuzzy borders and overlapping spheres of activity. Furthermore, these traditions are not parallel in structure: some are rooted in a particular modern nation-state or research language, while others are bound together by a specific disciplinary approach.

A complete treatment of all the historical traditions that study economies and their connectivities in ancient Afro-Eurasia is impossible. The following chapters are selective and do not run strictly parallel. The two on Chinese/Japanese and Indian historiography - in which the 'Silk Road' and transcontinental exchange have played relatively minor parts in research on the ancient periods - concentrate on economic history writing without treating questions of connectivity. Dominant paradigms in Western Graeco-Roman historiography, meanwhile, include both economic and trans-regional approaches which, in combination with the more abundant historiographical research, allows this chapter to touch on both sets of questions. The chapter discussing Russian scholarship, in contrast, had to deal with the fact that for most of the twentieth century, economic questions have been enmeshed with materialist approaches to history and archaeology more generally, making it problematic to treat traditions of economic history in isolation. Finally, the chapter on Central Asia traces why comparatively little scholarship has been generated about its ancient economic history, showing instead the impact of the 'Silk Road' paradigm on receptions of the Kushan economy. Thus, we focus on a set of examples that highlight the fact that different questions have been important to different communities of scholars and demonstrate how these priorities, preconceptions, and contexts have shaped understanding.

\section{References}

Díaz-Andreu, M., and T. Champion, eds. 1996. Nationalism and archaeology in Europe. Boulder, CO: Westview Press.

Lianeri, A., ed. 2011. The western time of ancient history: Historiographical encounters with the Greek and Roman pasts. Cambridge: Cambridge University Press.

Murray, T. 2012. "Writing histories of archaeology." In R. Skeates, C. McDavid, and J. Carman (eds.), The Oxford handbook of public archaeology, 135-152. Oxford: Oxford University Press.

Patrik, L. E. 1985. "Is there an archaeological record?" Advances in Archaeological Method and Theory 8, 27-62.

Schlanger, N. 2002. "Ancestral archives: Explorations in the history of archaeology." Antiquity 76.291, 127-131.

Shanks, M., and C. Y. Tilley. 1987. Re-constructing archaeology: Theory and practice. Cambridge: Cambridge University Press. 
Trigger, B. G. 1984. "Alternative archaeologies: nationalist, colonialist, imperialist." Man 19.3, 355-370.

Wylie, A. 2017. "How archaeological evidence bites back: Strategies for putting old data to work in new ways.” Science, Technology, \& Human Values 42.2, 203-225. 



\section{Lara Fabian}

\section{Russian Perspectives on Eurasian Pasts}

\section{Russia and Eurasia}

For the last three centuries, the ancient pathways running across the Eurasian steppe belt have fallen along the southern fringes of the Russian Empire and its proximate successors, the Soviet Union, and now the Russian Federation, as well as a constellation of post-Soviet states. There has been a long and robust research tradition about Eurasia within the Russian academic sphere - the intellectual space anchored in St. Petersburg and Moscow, but extending far beyond. The Russian school of research on ancient Eurasia, as a result of direct and regular contact with the diverse territories of the Black Sea, the western and eastern reaches of the Eurasian steppe, and Central Asia, offers a wide-angle view on historical, social, and economic developments across the sweeping territory (map 1). It is a perspective

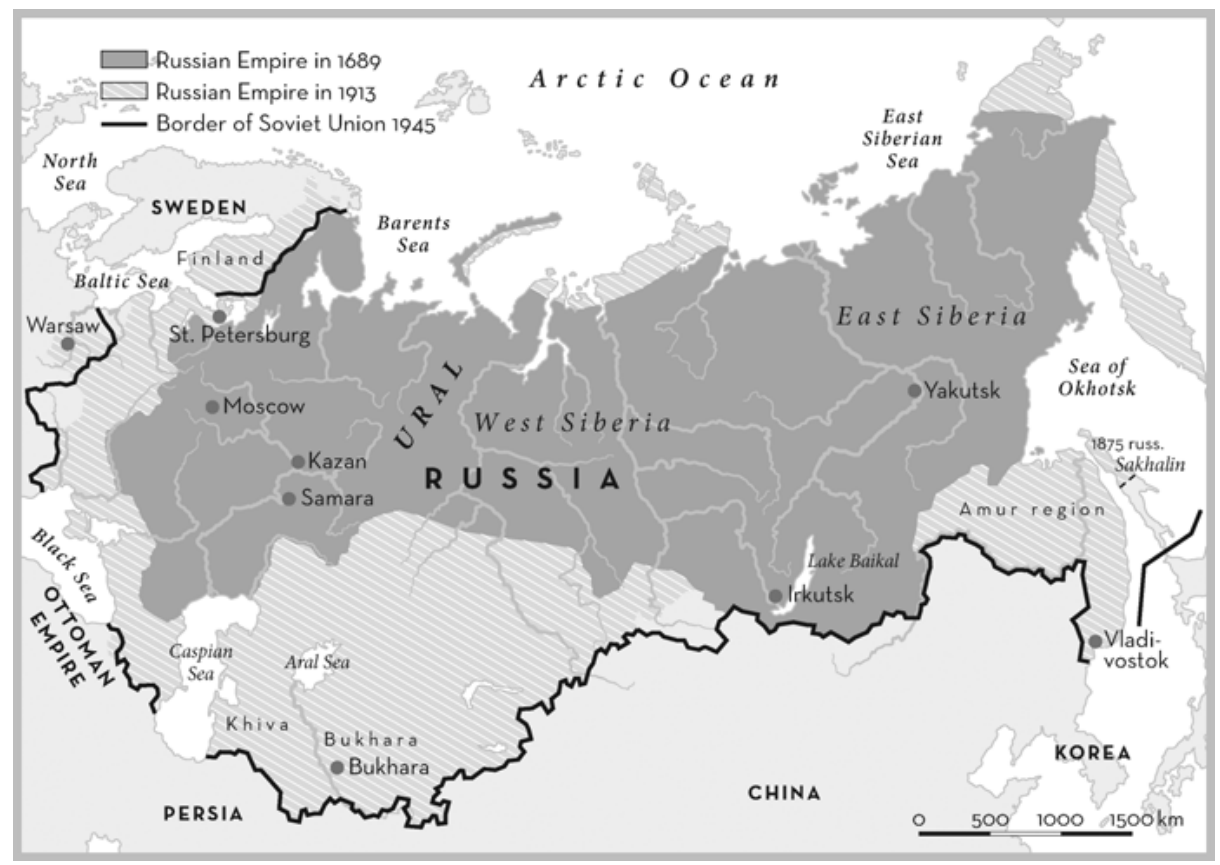

Map 1: Territorial extent of the Russian Empire $(1689,1913)$ and the Soviet Union (1945). (C) Peter Palm.

Note: Thanks to Sergei Krikh and Bruce Grant for their helpful comments on this chapter.

Ә Open Access. (c) 2020 Lara Fabian, published by De Gruyter. (c) BY-NC-ND This work is licensed under the Creative Commons Attribution-NonCommercial-NoDerivatives 4.0 License.

https://doi.org/10.1515/9783110607741-022 
unlike that found in any other 'national' tradition studying the region, shaped by a distinct set of imperial rhythms and social and intellectual currents.

For much of the twentieth century, anglophone work on antiquity treated Russian scholarship on these spaces and their economies as, at best, a footnote: either hopelessly derivative or unforgivably Marxist. ${ }^{1}$ Motivated by both these ideological preconceptions and hampered by issues of accessibility (physical and linguistic), dominant paradigms of historical thought in the anglophone and Western European worlds overlooked research conducted within the Russian framework, generating meaningful gaps in our understandings of ancient Eurasia's connectivities. ${ }^{2}$

\section{I.1 The Prism of Rostovtzeff}

For studies of ancient economic history, however, the works of the historian Michael Ivanovich Rostovtzeff (1870-1952) stand as a visible exception. Rostovtzeff came of age in the Russian Empire. At 47, he emigrated to England and then to the United States in the wake of the Russian Revolution. Along the way and in the midst of considerable personal precarity, he wrote the first of his two seminal studies of the ancient economy, Social and Economic History of the Roman Empire (1926). ${ }^{3}$ Along with his later Social and Economic History of the Hellenistic World (1941), it dominated discourse on the ancient economy in the Western European and Anglo-American spheres for the next half century, while also playing an important role in discussions in the Soviet Union. ${ }^{4}$

Rostovtzeff came by his career naturally: the son of a classicist father who was a teacher and imperial educational administrator. Born in Zhitomir, he spent his early life in Kiev attending the same school where both his father and grandfather had taught. He eventually studied at St. Petersburg University, which remained the center of his academic life until he left Russia. ${ }^{5}$ Maintaining close relationships with German academics in these early years, Rostovtzeff pursued wide-ranging interests. ${ }^{6}$ He published studies on classical antiquity that foreshadowed his Englishlanguage treatises, but also explored other strands of research, ranging from the

\footnotetext{
1 It is easy to overgeneralize, but for a sense of the midcentury polemic, see Miller 1956. Consider, however, Mongait (1955) 1961, and the generally positive review in Glaesser 1957.

2 The later Soviet period saw an increase in interest in Soviet science among foreign scholars. On archaeology, see Klejn 1977; Trigger 1978. On ancient history, see Raskol'nikova 1975.

3 Bongard-Levin 1997 offers the most detailed recontextualization of Rostovtzeff. In English, see Wes 1990 and Bongard-Levin 1999.

4 On Rostovtzeff in Western European scholarship, see von Reden and Speidel, ch. 17, this volume. For Rostovtzeff in Soviet ancient economic discourse, see Krikh 2013b, ch. 3.2.

5 See Wes 1988; Zuev 1997b, 50-54 on Rostovtzeff's early life.

6 Kreucher 2005.
} 
Iranian background of the Scythians to studies of coins from the Black Sea coast. ${ }^{7}$ He left Russia in 1918, apparently intending to return, but he never did. ${ }^{8}$ Following a difficult period in Oxford, Rostovtzeff moved to America, and by 1925 settled in to a prominent post at Yale University. He spent the rest his career there, publishing voluminously throughout the 1920 s and 1930s. His trajectory, then, led from the Kiev of his youth, through the late Russian imperial academia where he matured, and finally to the American universities where he spent his latter years.

For an anglophone audience, Rostovtzeff represents a rare point of contact between the Russian and Western European intellectual traditions in the twentieth century. The scholarship that he offered to his anglophone readers was something new. As the historian and historiographer Momigliano wrote of his first encounter with The Social and Economic History of the Roman World as a university student in the late 1920s:

\begin{abstract}
We were accustomed to books on ancient history where the archaeological evidence, if used at all, was never presented or explained to the reader. Here a lavish series of plates introduced us directly to the archaeological evidence, and the caption of each plate really made us understand what one could learn from apparently insignificant items. ... Learning we knew, but here was overwhelming learning on out-of-the-way subjects. And of course the main novelty was the text itself. ... Rostovtzeff delighted and surprised us by what seemed to us his uncanny gift of calling things ancient to life. He guided us through the streets of Rome, Pompeii, Nîmes, and Trèves and showed us how the ancients had lived. ${ }^{9}$
\end{abstract}

For well over half a century, scholars have tried to understand what accounts for Rostovtzeff's paradigm-shifting work. The question of his Russian 'roots' has played a central role in the discourse from the beginning.

I begin this chapter with mention of Rostovtzeff in order to point out the relevance of Russian intellectual history, even to those who have little interest in Russia as such, but I hesitate on this point. It is parochial to suggest that nonspecialists should be interested in Russian scholarship of antiquity only insofar as it helps to understand a figure who became a 'household name' internationally. The Russian tradition offers a long, vibrant, and varied history of research on the ancient world, much of which is directly relevant to contemporary debates about ancient Eurasian. This justifies serious engagement with Russian intellectual history.

There is a more compelling reason for beginning this chapter with a discussion of Rostovtzeff, which is his reception by later scholars. Upon closer consideration, Rostovtzeff is a prism refracting myriad images of himself and his research according to the preconceptions and interests of those who study him. ${ }^{10}$ Take, for example, two opinions among anglophone scholars of how 'Russian' Rostovtzeff's later schol-

7 Zuev 1997a provides the most complete bibliography. See also Welles 1956; Andreau 1989.

8 Bongard-Levin 1999, 9.

9 Momigliano 1954, 334.

10 On Rostovtzeff as a refractor, see Krikh 2009. 
arly production was. In the eyes of Momigliano, "it would be wrong to assume that [Rostovtzeff] had reached intellectual maturity before leaving Russia," 11 while according to Bowerstock, "Rostovtzeff's intellectual formation was essentially complete by the time he turned thirty." 12 Considering the reception of Rostovtzeff among a wider variety of scholars, including both Soviet-period and contemporary Russians, the images multiply. He is a stark modernizer, or a passionate defender of Russian values, or an opponent of the Bolsheviks; each interpretation shapes the understanding of his scholarship. ${ }^{13}$

Over the last 30 years, studies based on increasingly accessible archival records have fleshed out our understanding of Rostovtzeff's numerous and overlapping social and historical contexts, and provide a fuller and more sound basis for reconstructing his personal biography and legacy. ${ }^{14}$ And yet, rather than leading to a single unified vision of the man, this recent research demonstrates how elusive such a reconstruction is. The example demonstrates the complexities of tracing intellectual history, even at the level of a single individual. The problems multiply exponentially when considering the intellectual history of entire research traditions. And yet, as is the case with Rostovtzeff himself, there is both a value in and a necessity to this project if we hope to understand the shape of contemporary research.

\section{I.2 Scope of Chapter}

Within the Russian context, a number of fields have been involved in the study of ancient Eurasia, although the boundaries and disciplinary structures have changed over time. These include broadly classical studies, ${ }^{15}$ Oriental studies, ${ }^{16}$ Slavic stud-

11 Momigliano 1954, 335.

12 Bowersock 1974, 17.

13 Krikh 2009.

14 Chiefly Bongard-Levin 1997. See also: B. D. Shaw 1992; Emmons 2003; Krikh 2006a; Andreau and Bérélowitch 2008; Alipov 2009; Meyer 2009; Tunkina 2014.

15 The term ancient (classical) studies (antikovedenie) came into use in the nineteenth century, describing the study of ancient classical empires materially, historically, and textually. The term most closely parallels the German Altertumswissenschaft - a sign of the close connections between Russian and German scholarship. For Russian-language overviews of the trajectory of the field, see Tunkina 2002; Frolov 2006. On the twentieth century, see Krikh 2013b; Ladynin 2016. It is through the work of Graham (1961a; 1961b) that the anglophone world became acquainted with the study of classical philology in the Soviet Union. On Graham, see Karpiuk and Kulishova 2015.

16 Russian Oriental studies (vostokovedenie) - often called 'Orientology' by anglophone scholars has been the subject of relatively more research among anglophone scholars, resulting in more synthetic English-language works, e.g., Schimmelpenninck van der Oye 2010; Tolz 2011; Kemper and Conermann 2011; Kemper and Kalinovsky 2015. In Russian, a wealth of new information can be found in the five volumes of Naumkin et al. 1997-2014. 
ies, ${ }^{17}$ and eventually archaeology. ${ }^{18}$ Each has approached historical, cultural, and economic questions through its own disciplinary lens. The body of scholarship generated within these disciplines - the intellectual traditions - are united by a shared academic culture and a shared academic language, but they nevertheless offer multiple of perspectives on the Eurasian past.

Before moving further, we need address two issues of vocabulary. The first is the word 'Eurasia,' which has been used by archaeologists and historians as replacement for the no-longer-accurate term 'Soviet' and the problematic 'post-Soviet': a spatial notion describing the territory stretching from the Mediterranean Sea to the Pacific Ocean. Problematically, however, the term carries marked political overtones within the context of contemporary geopolitics that scholars of antiquity should recognize, even as we continue to use the word. ${ }^{19}$

Furthermore, we must consider why and on what grounds we define the intellectual tradition under discussion as 'Russian': do we mean here research conducted by Russian scholars, as opposed to the many non-Russians who have nevertheless been engaged in scholarly enterprise in the Russian Empire and Soviet Union? Or do we rather mean work carried out within a Russian political context - and if so, how do we fit post-Soviet work into this frame? Or instead, do we more narrowly mean those writing in Russian, excluding other regional practices of history writing that developed along the edges of Russian space, from the Balkans to Central Asia, particularly over the last half century? We might, furthermore, ask on what grounds we divide this research tradition from those of neighboring areas in Central and Western Europe, which share deep roots; or why we foreground it, rather than the variety of Persian, Turkic, and Arabic traditions that grew alongside it.

On the one hand, we run the risk of essentializing this tradition - reinforcing a sense of Russian exceptionalism and downplaying the many ways in which it is a constituent part of other approaches to antiquity. ${ }^{20}$ On the other hand, Russian imperialism and colonialism did create a unique configuration of relationships between imperial scholars and their ancient (and modern) subjects, foregrounding

17 Slavic studies (slavistika, slavianovedenie) became the largest field of study within the Imperial Academy of Sciences, although its relationship to the subject under consideration here is complex. On the history of the field, see Lapteva 2005; 2012.

18 The development of Russian archaeology has been treated most extensively by Klejn (recently 2011; 2014). Klejn 2012 offers an English-language translation, to which I will refer where possible. Klejn is an important figure in archaeological method and particularly theory, and was one of the early voices introducing anglophone audiences to Soviet and Russian archaeology (Klejn 1977; 1993; Bulkin, Klejn, and Lebedev 1982). Biographical and autobiographical works help to put his research into perspective (Klejn 2010; Leach 2015). His is not, however, the only position on archaeological historiography. On nineteenth- and twentieth-century archaeology, see Platonova 2008; 2010, and also Formozov 1995; 2004.

19 Bassin 2008; Glebov 2008; Shnirelman 2009.

20 Khalid 2000, 697. 
historical narratives that are absent in treatments of the same populations by scholars working in other traditions. Furthermore, the Soviet Union shaped twentiethcentury research in unique and dramatic ways.

'Russian' - perhaps, better, russophone - scholarship about antiquity (defined according to any of the possible definitions offered above), therefore, merits contextualized discussion. Research in this framework was written by scholars from a variety of personal backgrounds, in a number of languages. It was generated within a patchwork of disciplines and political contexts. It has never offered a monolithic view of the past, but rather demonstrates the consistent presence of discrepant narratives.

Here I consider the institutional frameworks for studying Eurasia's antiquity, as well as relevant socio-cultural discourses, moving roughly chronologically. I highlight three recurring themes that shaped research on connectivity and economic development, although not all are explicitly economic: (1) approaches to space; (2) perceptions of self and social location; and (3) and models of social and economic structure.

\section{Rise of an Empire, Rise of a Self-Conscious Past}

Russian research on ancient Eurasia grew alongside the creation and expansion of the Russian Empire, with the early stages emerging under Peter the Great (16821725). ${ }^{21}$ We can scarcely talk about a formal school of scholarship on Eurasia in this period. But a scholarly community began to develop in the new capital city of St. Petersburg, from which the scientific and bureaucratic apparatus of the empire looked east and west to understand Russia's position in the world and chart a course forward. ${ }^{22}$

\section{II.1 Pre-Petrine Contexts}

It is, however, a mistake to start the story with Petrine Russia, ignoring the history of cultural interactions that played out in the Rus' heartland of the later Russian Empire long before Peter the Great. On a local level, these relationships brought sedentary agriculturalists and mobile pastoralists into contact, and in a broader sense, created encounters of European and Asian spheres of interest. ${ }^{23}$ This early

21 Shchavelev 1998 discusses early engagements with archaeology.

22 Examples of pragmatic Petrine use of scientific exploration come from the field of cartography, see D. J. B. Shaw 1996; A. V. Postnikov 2014.

23 Scholarship on the early history and cultural affiliations of Rus', and particularly on the relative 'influence' from Scandinavia, Byzantium, and the steppe have raged for generations. For a recent overview in English, see Dvornichenko 2016. A valuable if contested picture on the place of Rus' 
history of Russia, and later popular and scholarly receptions and interpretations of it, has had long-lasting ramifications on Russian imaginations of the past, which in turn informed scholarship.

Pre-Mongol Rus' (between the late ninth and mid-thirteenth centuries) was oriented in a religio-political sense toward Byzantium. This reality framed local traditions about Mediterranean antiquity within Eastern Mediterranean narratives. ${ }^{24} \mathrm{At}$ the same time, the Rus' were engaged in geopolitical entanglements well past the Mediterranean sphere, including the Varangians (Vikings), the Khazar khaganate in the North Caucasus, and other neighboring steppe pastoralists. ${ }^{25}$ The subsequent centuries are traditionally understood as a period of cultural stagnation and isolation for Muscovite Rus', ${ }^{26}$ despite Mongol influence emanating from Central Asia, as a vassal of the Golden Horde (1283-1480). Of course, the situation was more complicated than this negative portrayal suggests. Access to Mongol trade networks provided broad opportunities for the Slavs and brought them into even closer connection with Eurasia's steppe. ${ }^{27}$

Subsequently, in the period of Muscovite independence and the early days of the Russian Tsardom, negotiations with the steppe frontier increased as Muscovy extended its territory through a process of gradual colonization. ${ }^{28}$ Although classical learning of the type familiar from Europe's Christian centers played a limited role in Muscovite Russia, ${ }^{29}$ hagiographic literature and a fragmentary, translated classical textual tradition brought a Christianized vision of antiquity into Russian cultural fabric. A version of Alexander the Great, for example, appeared in both religious and secular contexts in seventeenth-century Russia, ${ }^{30}$ while the official genealogy of Ivan IV (1530-1584) was said to trace its way back to Augustus. ${ }^{31}$ There was the idea, promoted by some seventeenth-century Muscovite elite, that Moscow stood as the 'Third Rome,' the inheritor of the apostate Latin church and the conquered Byzantium. ${ }^{32}$ It was with the key reconfigurations of Peter the Great, however, that self-conscious knowledge about the Graeco-Roman world became central

can be found in Raffensperger 2012. Archaeology has played an important role in these discussions, see Shepard 2016.

24 Franklin 1992; Thomson 1995 discuss understandings and uses of classical antiquity in Kievan Rus'.

25 On Rus' relationships with pastoralists, see Golden 1991.

26 For an introduction to the Mongol period, see Halperin 1985.

27 Schimmelpenninck van der Oye 2011, 19.

28 Sunderland 2004, 17-34.

29 A small number of Slavonic translations of classical texts were produced (Thomson 1995, 312313). Latinity was nevertheless present across the seventeenth century, see Okenfuss 1995; Vorob'ev 1999.

30 V. V. Postnikov 2006.

31 Madariaga 2005, 32-34.

32 See e.g., Poe 2001; Sinitsina 1998. 
to the development of a new age within Russia, and its presentation to internal and external audiences.

\section{II.2 Early Scholarly Infrastructure}

The Petrine era brought shifts both in the rhetorical presentation of Russia and in the scientific infrastructure of the state. ${ }^{33}$ The infrastructural epicenter was the new St. Petersburg Academy of Sciences, which codified 'historical science' as one of the foundational scholarly aims of the new age in Russia. Research here included interdisciplinary scientific-geographic expeditions sent to distant corners, which set paradigms for state-sponsored research - within which the Great Eurasian Steppe featured prominently. ${ }^{34}$ Additionally, there was an aggressive program of manuscript acquisition and translation of ancient texts into Russian, which finally introduced significant works through secular channels. ${ }^{35}$ The Kunstkamera, which opened as Russia's first public museum in 1714, marks another insititional innovation.

The study of classical antiquity along philological, material, and historical lines was central to this phase of research, but both Sinology and Oriental studies also played a role. The Prussian polymath Theophilus (Gottlieb) Siegfried Bayer who was brought to the Imperial Academy of Science exemplifies these interests. First coming as specialist in classical studies, his interests shifted to the east. Over the course of his career, he published prolifically on historical themes ranging from ancient defensive architecture in the Caucasus and Chinese linguistics to the question of the Scythians and the development of Russia. ${ }^{36}$ Much of this early work at the Imperial Academy was conducted by non-Russian scholars, particularly Germans. ${ }^{37}$ The diffusion of their rarified research was limited, and with few students, they left a relatively shallow mark on later scholarship. Nevertheless, the Petrine era created a foundation for historical and cultural research that would only expand.

By the end of the eighteenth century, Greeks and Romans figured prominently in the cultural imagination of elite Russians. ${ }^{38}$ Influential eighteenth-century scholar Mikhail Vasil'evich Lomonosov (1711-1765) framed Russian history in explicitly Roman terms, drawing straightforward equivalencies between Russian and Graeco-

33 On imperial rhetorical allusions to Mediterranean antiquity, see Wes 1992, 33-36.

34 On scientific attention to the steppe, see Sunderland 2004, 36.

35 Frolov 2006, 48.

36 Dubowoj 1985; Lundbaek 1986.

37 The Orientologist Georg-Jacob Kehr is another example (Schimmelpenninck van der Oye 2010, 33-35).

38 The place of Latin in grammar schools, for example, was politicized, see Okenfuss 1995, 198230. On classics in Russian higher education, see Pozdeeva 1962. 
Roman mythical heroes. ${ }^{39}$ Mikhail Ivanovich Popov (1742-ca. 1790), a poet of the era, presented Slavic mythology in a long-running agonistic struggle with Greek and Roman myth, no less grand, but with its own individual (and superior) character. ${ }^{40}$ Even more explicitly, historian Nikolai Mikhailovich Karamzin, author of an epic history of Russia, wrote the following lines in another epic poem:

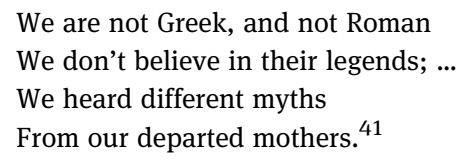

The discourse of Russianness as articulated with respect to both classical and Slavic pasts expanded in the next century, alongside the scientific exploration of these histories.

\section{Russian Expansion and the Nineteenth Century}

In the context of the nineteenth-century Russian Empire, Russian studies of ancient Eurasia developed along axes that were alternately complementary, parallel, and contradictory. In archaeology, large-scale excavations of Greek and Roman sites began on Russian soil, generating vast quantities of new material for study by experts in Russia's imperial cities. In history, there was a growing interest in a different, nonclassical past among Russia's elites: that of the Slavic world. Finally, the field of Oriental studies was formalized within the Russian academy.

Global comparative research shows that reconstructions of the past are shaped by modern imperial and nation-building projects. Historical interest in a given region tends to follow in the footsteps of colonial expansion, which is optimistically credited with 'opening' new spaces to scholarly activity. This general model holds true in the Russian case. From the Black Sea to the Caucasus and Central Asia, Russian scientific research followed the expansion of the empire. ${ }^{42}$ However, one cannot fully understand the nineteenth-century developments in Russia without reference to the debates about the nature of Russian identity that simmered through the century and beyond.

39 Lomonosov argued that "in Russian history, one finds heroes and deeds that are fully comparable to those of the Greeks and the Romans" (trans. Baehr 1978, 3). See also Kahn 1993.

40 Segel 1973, 56. See Lebedev 1992, 62-66 on research into Slavic material culture in this period. 41 From Karamzin's 1795 “Il'ia Muromets.” Quoted, in part, in Lebedev 1992, 62.

42 For an example of the connection between military campaigns and scholarship, see Bayer (1728), which reports on antiquities discovered by an aristocrat accompanying Peter the Great's 1722 campaign against Persia. 


\section{III.1 The Cultural Backdrop: East and West in Russian Politics and Art}

Because the ideas of 'East' and 'West' are so fundamental in scholarly reception of ancient Eurasia, it is worth considering how these issues have played out in the Russian context.

\section{III.1.1 Slavophiles and Westernizers}

Ninteenth-century Russian intellectuals were preoccupied with where to place Russia within the global East-West dichotomy. Was Russia part of the West, part of the East, or something else entirely? The mid-nineteenth-century iteration of this debate - the Slavophile/Westernizer discourse ${ }^{43}$ - had sharp consequences for Russian Oriental and classical studies.

The acephalous and heterodox Slavophile (slavianofil'stvo) and Westernizer (zapadnichestvo) movements pitted elites with a western gaze (the Westernizers) against those who valorized the pre-Petrine past and its putatively pure Slavic roots (the Slavophiles). At stake was the relationship between the pasts and the futures of both Russia and 'the West' - articulated as two distinct cultural spheres. The Slavophiles, inspired by Russia's rich Orthodox heritage and holding to a narrative of Slavic descent, believed it was harmful for Russia to follow Western developmental models. They argued that older collectivist Slavic practices should guide the next stage of Russian progress, rather than imported individualistic paradigms. Westernizers, in contrast, believed that Russia was and had always been European. They blamed what they saw as Russia's cultural stagnation on its fractious medieval history, and especially the Mongol invasions. For them, the path to a stronger Russia lay in the adoption of European intellectual and practical frameworks.

\section{III.1.2 Literary Constructions of Identity and Frontiers}

This Slavophile-Westernizer debate positioned Russia as the meeting point and interpreter between East and West. The imagined locations of the ancient Mediterranean past, the Slavic world, and Eurasian steppe came to play a role in Russian cultural self-perception. The result was a wide range of perspectives about to what extent and in what ways Russia was (or was not) the inheritor of these pasts. Russia's territorial fringes became especially entangled in these discourses.

A clear example of the role of frontiers in the construction of identity - and one explicitly engaging with a variety of heritages - comes from the most famous Rus-

43 See Tolz 2001, 76-94 for an introduction to the terms of debate. 
sian poet, Alexander Pushkin. ${ }^{44}$ In "To Ovid" (K Ovidiiu), Pushkin explores the contrasts between himself and his Roman interlocutor Ovid. The two men, separated by two millennia, each served an exile along the coast of the Black Sea, having antagonized his respective emperor. ${ }^{45}$ Pushkin begins by addressing Ovid and his legacy:

Ovid, I live near the quiet shores To which you once brought your banished native gods And where you left behind your ashes.

Your joyless lament made these lands famous,

Your tender-voiced lyre has not gone mute. ${ }^{46}$

Continuing, Pushkin layers his perception of the zone over Ovid's. Although Ovid characterized the exilic land as a snowy wilderness, ${ }^{47}$ Puskhin found the winter storms entirely normal, and, in fact, rather brief. ${ }^{48}$ Pushkin plays with the inversion of the authorial relationships to the Pontic - south from Pushkin's home, but north from Ovid's. Pushkin is not without sympathy for Ovid, but neither does he entirely identify with him:

As an austere Slav, I have not shed any tears,

But I understand them. A self-willed exile,

Unsatisfied with the world, life, and myself,

I, with a meditative spirit, have now visited

This land, where you once lived out a sad eternity. ${ }^{49}$

In the southern borderlands of the Russian Empire, Pushkin finds a tie to classical antiquity against which he can measure his own experience. The challenges he faced in accommodating his vision of the Black Sea with that of Ovid exemplify the issue facing Russian intellectuals confronting the traces of classical antiquity more broadly. How should they articulate their place with respect to both ancient models and modern contexts?

\section{III.2 Research along the Frontiers}

Frontiers were at the center of Russia's nineteenth-century history. ${ }^{50}$ It has been said that Russian archaeology "formed and grew just as the archaeology of the bor-

44 Formozov 2000 discusses Pushkin's engagements with antiquity. See also Layton 1994 for Russian literary engagements with the frontiers in more depth.

45 For discussions of this poem in English, see Sandler 1989, 41-56; Hokanson 2005.

46 Pushkin, “To Ovid,” 1. 1-5, trans. Sandler 1989, 42.

47 Pushkin, “To Ovid,” 1. 8-10.

48 Pushkin, “To Ovid,” 1. 64-66.

49 Pushkin, “To Ovid,” 1. 54-58, trans. after Sandler 1989, 43. Sandler uses 'severe' instead of 'austere' in 1.54 for Pushkin's surovyi. Pushkin, it should be noted, was not in a self-willed exile. 50 See Bassin 1993 for a comparison of various ways of understanding 'frontiers' in nineteenthcentury thought, in Russia and beyond. 
derlands, the archaeology of the frontier." 51 The same can be said of broader research on Eurasian antiquity. Although the questions asked within each discipline and space differed, there are fundamental points of similarity: nineteenth-century Russian archaeologists, historians, and Orientologists were tasked with studying their own territorial edges, and converting those spaces into Russia.

Each frontier provided scholars the chance to develop new and different connections to Russia's many pasts. These connections, in turn, were reformulated as justifications for Russian expansionary activities. For imperial authorities seeking to control the Black Sea region newly acquired from the Ottoman Empire, for example, the area's deep Christian roots provided a logical entry point that privileged Russian territorial claims. Thus, the vice admiral of the Black Sea Fleet, Aleksei Samuilovich Greig, developed an archaeological project in the newly incorporated Crimean peninsula to memorialize the purported baptismal site of Prince Vladimir, the tenth-century prince who brought Christianity to the Rus' ${ }^{52}$

Later in Central Asia, Russian colonial officials appropriated the figure of Alexander the Great, finding in him a parallel for their conquest of the region and conducting excavations to prove his presence. ${ }^{53}$ At the same time, Russian scholars also cast doubt on just how 'civilized' Alexander's civilizing mission had been and questioned its importance for local historical developments. ${ }^{54}$ In nearly all cases, it was on the frontiers that these questions were negotiated. ${ }^{55}$

\section{Disciplinary Crystallizations}

Within these social currents, the concrete details of Eurasian antiquity came to be studied in ever more organized disciplinary structures. These fields established approaches to Eurasian antiquity that have remained important up to the present.

\section{IV.1 Archaeology and Ancient History}

A significant force in the development of homegrown studies of the ancient past came from archaeological excavations. Although archaeological collections had

51 Smirnov 2011, XX.

52 There, Grieg discovered a fifth- to sixth-century Christian basilica, "unambiguously" demonstrating the Christian past of the area (Smirnov 2011, 211). On the ideological project of this work, see Kozelsky 2004.

53 Russians were not alone in this: the British drew parallels with Alexander the Great in their claims to India. On the limits of this appropriation in the Russian context, see Gorshenina 2017. For a more on the historiography of Central Asia, see Morris, ch. 16, this volume.

54 Gorshenina 2017, 177.

55 Even in the Caucasus - perhaps the most restless of Russia's colonial frontiers - nineteenthcentury writings cast Russia as the protector of an ancient local past, which had been under the shadow of the barbarian overlords (e.g., Kruze 1835, 425). 
been gathered on Russian soil since the Petrine era, extensive archaeological work began only after Catherine II's Russo-Turkish War (1768-1774), which led to the Russian acquisition of coastal territories along the Black Sea. Archaeological interests expanded from the Black Sea coast eastward into new imperial territories, reaching Central Asia and eventually the Caucasus, while also expanding within nonperipheral areas of European Russia and older frontiers like Siberia.

Much of the earliest work was of limited scientific quality from a contemporary point of view, and was indeed little more than treasure-hunting. ${ }^{56}$ Excavations in the Pontic were occasionally under the direction of military commanders, a pattern familiar to other colonial contexts. The Russian academic centers of the period the Academy of Sciences and the State Hermitage Museum - had little involvement with archaeological practice in this period. Interested antiquarians, who created organized and powerful amateur societies, however, conducted methodologically innovative fieldwork. ${ }^{57}$ Regardless of who did the work, the rich Greek and Roman artifacts found along the Black Sea coast fueled new interest in the study of classical antiquity within the academic system and generated an expanding body of publications.

Advances in the study of material culture occurred within a system of increasingly rigorous philological and historical scholarship. Leading figures in the newly reorganized imperial education system, Aleksei Nikolaevich Olenin (1764-1843) and Sergei Semenovich Uvarov (1786-1855), ensured that classics was central among humanities disciplines. ${ }^{58}$ The educational frameworks that emerged were informed by continued close relationships with German scholars, several of whom became foundational figures in Russian universities. ${ }^{59}$

As the archaeological sphere of inquiry spread from the Pontic shores eastward and the study of classics assumed a more formal position in the university system, the role of amateurs diminished. The founding of the Imperial Archaeological Commission in 1859 was a key stage in this process, setting out the goals of Russian archaeology for the first time. ${ }^{60}$ The Commission was the central organizing body for all archaeological investigations in the Russian Empire, and eventually came to

56 Lebedev 1992, 75.

57 These associations held rights to excavate in particular zones, financed their own work, and published their own journals. The best projects took an "ecosystemic" approach, considering local topography and monumental landscapes alongside geological, botanical, historical, ethnographic, and linguistic information (Tunkina 2003, 310).

58 Lebedev 1992, 73-75; Frolov 2015, 140.

59 Frolov 2016.

60 The goals of the Commission were: "1) search for objects from antiquity, predominantly those related to domestic (otchestvennaia) history and the lives of the peoples who lived once in the territory that is today occupied by Russia; 2) the collection of evidence about both the people in the state and the various monuments of antiquity; 3) scientific assessment of the antiquities that are discovered" (Tikhonov 2009, 7). 
be responsible for all permits and archaeological oversight, organized into three sectors: Slavic and Russian archaeology; archaeology of the Orient; and classical and Byzantine archaeology. This was followed by the founding of the Moscow Archaeological Society in 1864. Under the direction of Aleksei Sergeevich Uvarov (1828-1884), this association sponsored All-Russian Archaeological Congresses, which created a unified archaeological knowledge frameworks and an empire-wide system for disseminating the details of archaeological finds. ${ }^{61}$ Over time and against the backdrop of Emperor Nicholas II's (1825-1855) restructuring of the Russian academic system, the Society and its Congresses expanded archaeological work into the imperial provinces. ${ }^{62}$ This period saw methodological and theoretical advances within Russian archaeology broadly, with theories of cultural evolution, diffusion, and change entering the lexicon of Russian practice, although these new currents had less impact in the sphere of 'classical archaeology' in Southern Russia, which remained more traditional in its approaches. ${ }^{63}$

Epigraphic research, which bridged the material and textual worlds, grew in the mid- and late nineteenth century. Fedor Fedorovich Sokolov (1841-1909), an ancient historian at St. Petersburg Imperial University, is credited as the first of the Russian school to turn attention to and inspire interest in epigraphic research. ${ }^{64}$ Issues of socio-economic development also began to occupy a central role in this period: an interest that has been credited to the rapid pace of economic development in late nineteenth-century Russia, and the attendant radical social changes. ${ }^{65}$ Rostovtzeff pursued these subjects in his post-emigration work.

The work of Vasilii Vasil'evich Latyshev (1855-1921), a prominent figure in prerevolutionary classics who published a catalog of inscriptions for the North Black Sea and compiled a sourcebook of Greek and Latin descriptions of the Pontic and Caucasus regions, demonstrates the strength of late imperial scholarship. ${ }^{66}$ Latyshev's biography and training, furthermore, provide a window into the international character of classical studies during this time. ${ }^{67}$ Born in 1855 , he had a classical education at a provincial school, received pedagogical training in St. Petersburg at the Historical and Philological Institute, and was then nominated by the Ministry of Education to travel to Greece and study with Ulrich Köhler and Paul Foucart, the directors of the German Archaeological Institute and French School at Athens, re-

61 Lebedev 1992, 94-105 outlines of A. S. Uvarov's accomplishments.

62 Fifteen Congresses were held from 1869 until 1911, each coinciding with large-scale local excavations, see Komarova 1990.

63 Lebedev 1992, 142. Notably, this extensive work on 'Scythian' monuments (including that on the Kimmerians and the Sarmatians) formed a key part of research in Southern Russia in the late nineteenth century, with far-reaching consequences for ancient history, see Lebedev 1992, 144-146. 64 Frolov 2015, 141-142.

65 Frolov 2006, 312.

66 Latyshev 1890-1906; 1885-1901. See Lebedev 1992, 188-190 for context.

67 Tunkina 1999; Frolov 2006, 218-263. 
spectively. By Latyshev's time, Russian specialists in antiquity had the potential to participate in mainstream European classical scholarship, although much research, nevertheless, remained rooted in Russian networks.

Later opinions on this period were divided - normative Soviet scholarship criticized much of the late imperial work. But others looked back on this era wistfully. In the words of one such scholar, it was a "blooming of the splendid sunset of humanistic culture that marked the last decades in the life of Old Russia." 68

\section{IV.2 Scythian Archaeology and Slavic History}

While the study of classical, particularly Greek, monuments continued to be of importance in the second half of the nineteenth century, there were growing nationalist sentiments and a concomitant interest in the origin of the Slavs. ${ }^{69}$ By the 1850 s, Slavic archaeology itself had acquired a central place within archaeological infrastructure. ${ }^{70}$ One advocate was Aleksei Ivanovich Voitsekhovich, the Ober-procurator of the Holy Synod, who took control of the Russian Archaeological Society in 1850, and advocated for research on Slavic and Orthodox sites. ${ }^{71}$ Scholars developed narratives of the Slavs that placed them as the teleological conclusion of a long line of steppe residents stretching back to the Scythians, and eventually the Sarmatians. ${ }^{72}$

The increasing interest in Slavic history brought new attention to the question of Scythian origins. A growing body of archaeological research on Scythian sites often but not always conducted in the context of work in South Russia mentioned above, and thus as part of 'classical archaeology' - laid the groundwork for these discussions. Excavations of Scythian kurgans were a central focus, with significant work conducted in the lower Dnepr basin and the Taman' Peninsula (e.g., by I. Zabelin). By the end of the nineteenth century, Aleksandr Sergeevich Lappo-Danilevskii (1863-1919) had published on the social organization of Scythian populations. ${ }^{73}$ Periodizations of the various groups and subgroups of archaeological material were well underway at this time, complemented by serious archaeological research that continued throughout the early twentieth century.

In addition to his interests in Graeco-Roman socio-economic history, Rostovtzeff was also a central figure among Scytho-Sarmatian researchers. ${ }^{74}$ He posited an Ira-

\footnotetext{
68 Frolov 2006, 247.

69 Shnirelman 1996, 223.

70 The roots of this lay in the 1820s, when the first imperial archaeological surveys had gone in search of the Eastern Slavs, especially the work of Khodakovskii in Novogorod, see Formozov 1974; Saunders 1982.

71 On research on Orthodox monuments, see Kosykh 2009.

72 Mordvintseva 2013, 205.

73 Lappo-Danielevskii 1887.

74 For two approaches to Rostovtzeff on the Scythians and Sarmatians, see Meyer 2009, and Mordvintseva 2013, 205-207.
} 
nian basis for Scythian style - breaking with many of his nineteenth-century predecessors - and argued that long-distance migrations from the east had brought this material (and these people) to the Black Sea. ${ }^{75}$ Embedded in this theory are two ideas worth consideration: (1) long-distance human migrations as a central vector for cultural transmission; and (2) the steppes of Southern Russia as territory that easily accommodated this type of human movement. ${ }^{76}$ Both of these ideas are echoed in imperial Russian perceptions of medieval history, and particularly in the interaction between Muscovy and the Turko-Mongolian Golden Horde. ${ }^{77}$

\section{IV.3 Oriental Studies}

In tandem with the growth of Slavic history and archaeology, the mid-nineteenth century also saw the expansion of Oriental studies. Universities created faculties for the study of Asian languages in the early nineteenth century. ${ }^{78}$ By midcentury, the central Oriental studies faculty relocated from peripheral Kazan to the seat of imperial power in St. Petersburg. The growth of Oriental studies can be correlated (in some cases directly) with the sentiment that Russia was an ideal mediator between the Near East, Asia, and Western Europe. This was framed in terms of the East-West debates, and also as a natural outgrowth of Russia's geopolitical position. ${ }^{79}$

The department in St. Petersburg had no peers at other European universities, inasmuch as it was a stand-alone faculty devoted only to Oriental studies. ${ }^{80}$ Scholars found themselves in a tug-of-war between factions who saw the department principally as a scholarly enterprise, and those more interested in the pragmatic benefits of preparing Russians for service in the imperial borderlands. ${ }^{81}$ This field had a profoundly practical side: the investigation of non-Russians inside of the Russian territory, particularly those living in "Russia's own Orient." 82

Vasilii Vasil'evich Grigor'ev (1816-1881) was a central figure of midcentury Oriental studies who embodies both of these tendencies. ${ }^{83}$ Grigor'ev, a historian,

75 Rostovtzeff 1922, 11-12.

76 Although with some caution, see Rostovtzeff 1922, 8.

77 Frachetti 2011, 199.

78 Schimmelpenninck van der Oye 2010, 95.

79 The future imperial education minister, S. S. Uvarov wrote: "Russia, lying next to Asia, and mistress of the entire northern part of this continent, shares with the other powers the moral interest that guides their noble enterprises; but she possesses moreover a political interest so clear, so powerful, that a mere glimpse at a map is enough to convince. Russia rests, so to say, on Asia. An arid border of immense dimensions puts her in contact with nearly all of the peoples of the Orient" $(1810,8)$.

80 Schimmelpenninck van der Oye 2010, ch. 8 on the institutional framework.

81 Schimmelpenninck van der Oye 2010, 198.

82 Tolz 2011.

83 On Grigor'ev, see Knight 2000a. 
advocated for the development of a specifically Russian approach to the East in a theoretical, scholarly sense. ${ }^{84}$ But he also harnessed his knowledge about the borderlands in service of the empire, becoming an imperial administrator in the Orenburg region near the modern Russian-Kazakh border. He was not alone in occupying both scholarly and administrative roles; the ties between the scholarly and administrative communities were close throughout the period. At the same time, as recent work on Russian Orientalism has pointed out, the nature of these scholars' engagements with the state (and their perspectives on the non-Russian communities they studied) varied widely, demonstrating the complexity of Orientalist formulations. ${ }^{85}$

Grigor'ev did not accomplish his grand scholarly vision of creating a distinctly Russian approach to Oriental studies, but Baron Viktor Romanovich Rozen (18641908), the most prominent of his students, did. The Rozen School of Oriental studies was rooted in studying the polyfocal cultural interactions that characterize Russia's frontiers, and it presented opposition to the idea of an East-West binary. ${ }^{86}$ Rozen's research fundamentally addressed the question of how to integrate Russia's many ethnic groups into a unified whole. ${ }^{87}$ Despite Rozen's nationalist leanings, ${ }^{88}$ his disciplinary outlook was decidedly Western-facing. Trained partly in Germany, he promoted closer ties between Russian scholars and Oriental studies communities elsewhere in Europe after his ascension to the position of dean of the Faculty of Oriental Studies in St. Petersburg in $1893 .{ }^{89}$

Rozen School academics, like Nikolai Iakovlevich Marr (1864-1934), articulated opposition to the perceived arrogance of European approaches to Oriental studies already in the late imperial period. ${ }^{90}$ Vasilii Vladimirovich Bartol'd (1869-1930) even developed an extended critique of the categorical divides between 'East' and 'West' that underpinned Oriental studies. ${ }^{91}$ Both Marr (a specialist on the Caucasus) and Bartol'd (a historian of Central Asia) went on to become central figures in post-

84 Tolz 2011, 33.

85 There has been a sharp debate over whether Grigor'ev's professional development demonstrates or refutes the existence of an Orientalist gaze à la Said in the Russian context. See Khalid 2000; Knight 2000a; 2000b. For discussions about Russian Orientalism, much of which has unfolded among scholars based in the Anglo-American academic sphere, see especially: Campbell 2002; Etkind 2002: Gerasimov 2002; Knight 2002: Schimmelpenninck van der Oye 2002.

86 On Rozen, see Tolz 2008.

87 As Tolz (2011, 9-10) has pointed out, neither Rozen nor his most prominent disciples were ethnic Russians, and their own personal histories likely shaped their perspectives on both ethnicity and empire.

88 As a proponent of Russian as a scholarly language, for example (Schimmelpenninck van der Oye 2010, 186).

89 This effort began earlier, see Schimmelpenninck van der Oye 2011, 186-189.

90 Tolz 2011, 55. Marr is an extremely important and polarizing figure (both as a linguist and archaeologist). See especially Alpatov 1991; Platonova 1998.

91 Tolz 2011, 50-53. 
revolutionary Oriental studies and archaeology - a context in which their critiques of European scholarly approaches took on new (Marxist) weight.

\section{IV.4 Prerevolutionary Conclusions}

By the First World War and the Russian Revolution, which dramatically reshaped the political context of scholarship, Russian study of the spaces of the ancient Silk Roads had matured along diverse axes. Russian approaches in classical studies were, in general, in keeping with dominant international paradigms, and particularly with those of German academics. Nevertheless, the practical focus of the discipline in Russia produced a subtly different vision of classical antiquity in which the Black Sea played a major role, and in which steppe populations were more visible. Russian Oriental studies, in contrast, charted a path that was self-consciously different from that which was pursued elsewhere in Europe - developing a Russian vision of not just 'the Orient,' but of the concept of 'an Orient' itself. Nevertheless, both classical scholars and late imperial Orientologists felt they were part of a European research community and enjoyed close relationships with their international colleagues. These connections would wither and disappear under the pressures of totalitarianism, with lasting consequences.

\section{Responses to Revolution}

In the years just after the revolution in 1917, rapidly shifting political structures and entirely new pressures from Bolshevik authorities altered disciplinary development. Studies of this period traditionally emphasize ruptures between pre- and postrevolution historical thought. ${ }^{92}$ There is currently, however, a reevaluation of this paradigm from the post-Soviet perspective. This work has brought to the fore many continuities across the chasm of political change and has focused attention instead on the complex processes of adaptation faced by scholars.

Furthermore, it is critical to acknowledge that the postrevolution years were quite simply perilous times for intellectuals. Bolshevik power was harsh, and the first waves of political repression began early, targeting specific individuals as well as perceived elites and intellectuals. Beyond the tremendous personal costs to individuals and their families, this state terror shaped the course of scholarship directly, since the work of disgraced scholars (and of their associates) was deemed subversive and was no longer read or cited. ${ }^{93}$

92 Historiographic work about postrevolution classical studies has been limited, and in the main presents a narrative of decline and intellectual stagnation; see Frolov 2006, 247. Studies on archaeology and Oriental studies have been more abundant and varied. For example, Volkov 2015.

93 On this construction of cause and effect, see Krikh 2016a, 194. 


\section{V.1 Early Developments}

In the wake of the Russian Revolution and the foundation of the Soviet Union, great swaths of the prerevolutionary scholarly infrastructure were dismantled or restructured, often causing disruptions in scholarly activity. In rarer cases, prerevolutionary structures morphed into new Soviet formulations, assuming new titles to emphasize their Marxist underpinnings, but seeing few other initial changes - at least during Lenin's New Economic Policy (1921-1928). Fields viewed as directly relevant to the revolutionary project came more quickly under the aegis of the party. ${ }^{94}$ Scholars meanwhile scrambled in the face of institutional renegotiations to secure their futures amid the turmoil of the period - and some took advantage of new opportunities. Central members of Rozen's Oriental studies school, for example, forged close relationships with Bolshevik authorities, creating a "revolutionary alliance," 95 in which imperial scientific knowledge about Russia's various 'Easts' helped consolidate the new internationalist state. As a result, Oriental studies came to occupy a place of considerable importance within the world of Soviet policy. ${ }^{96}$ At the same time, the participation of Orientologists in this system should not be overstated. There was widespread dislike of the new regime among mainstream metropolitan scholars, even if key figures accommodated themselves to the new political winds. ${ }^{97}$

The situation was different in ancient history. Marx himself was, of course, interested in antiquity; and the classical world played an important role in his philosophical framework. ${ }^{98}$ Nevertheless, although a very specific idea of historical progress lies at the heart of Marxist thought, the formal academic study of classical antiquity was not a priority for the early Soviet state. Ancient historians in general maintained a fairly high degree of autonomy in the 1920s, with many operating on the fringes of Marxist paradigms. This was even true for scholars espousing Marxist positions, like the ancient historian Aleksandr Il'ich Tiumenev (1880-1959), who advocated Marxist history while basing his own writings in the 1920s on non-Marxist historical models developed in Germany around the same period. ${ }^{99}$ Furthermore, although Russian universities continued to teach ancient languages rigorously throughout the Soviet period, there was certainly a minimization of the field, tainted by its roots in the Western European academies and the social circumstances of

\footnotetext{
94 Thus, Oriental studies and ethnography saw a faster course of ideological rearticulation than ancient history and archaeology. On ethnography, see Gadjiev, Kohl, and Magomedov 2007, 122.

95 Hirsch 2005, 21.

96 On the development of Soviet Oriental studies, see Kemper and Conermann 2011; Kemper and Kalinovsky 2015, as well as Battis 2015; Cronin 2015.

97 On the (long) list of Orientologists who were repressed, see Vasil'kov and Sorokina 2003. See also Rodionov 2011.

98 Nippel 2018.

99 Krikh 2013b, 78-79.
} 
prerevolutionary leaders, with their ties to the aristocracy. ${ }^{100}$ Slavic studies suffered similarly due to its close association with the Orthodox church. Work dropped off precipitously and Slavic researchers faced harsh repression. ${ }^{101}$ That discipline, however, resurged in the 1930s and 1940s, and would become a key player in Soviet discussions of ethnogenesis.

Archaeology fell somewhere in the middle. As the discipline of material culture, it found a natural place within the paradigms of Soviet science, given the Marxist interest in articulating a historical materialist presentation of history. Thus, the Russian Academy for the History of Material Culture was quickly founded under the aegis of Lenin in 1919 to move the Imperial Archaeological Commission's work in a new direction. ${ }^{102}$ The discipline, however, had difficulty articulating a clear vision of precisely what this new direction should be. After the turmoil of the immediate postrevolution years, the late 1920s saw robust archaeological research, including the resumption of work at important Black Sea classical sites, and contributions in palaeoethnology. ${ }^{103}$ The 1920 s also witnessed the establishment of archaeological commissions based in the republics of the USSR, expanding the structures of the imperial period and creating an explosion of local ethnographic and archaeological museums. ${ }^{104}$

\section{V.2 The Creation of New Scholarly Norms}

The revolutionary era created new historical questions and changed institutional research frameworks. But during the early 1920s, the Soviet state had not yet developed a clear enough sense of its own priorities to systematize its perspective on the past. ${ }^{105}$ It also lacked an apparatus to uniformly enforce any new ideological bent. After a period of theoretical diversity and experimentation in the 1920s, an increasingly political cadre of postrevolutionary scholars began to create a Soviet Marxist history and history of material culture, eventually with a decidedly Stalinist slant. This perspective was different in scope, structure, and intent from prerevolutionary disciplines. ${ }^{106}$

100 For a view that emphasizes the diminished scale of postrevolutionary classical studies, see Frolov 2015, 144-148.

101 Goriainov 1990; Curta 2001. Byzantine studies were similarly affected, for the same reasons. 102 Soon renamed the State Academy for the History of Material Culture. The most accessible English survey of this period is in Klejn 2012. For a different reading, see Platonova 2010.

103 Platonova 2010, 180-184.

104 Formozov 1995, 31. See, e.g., the establishment of research centers in the Caucasus and Central Asia.

105 Ladynin 2016, 11-12.

106 This was a complicated time with opposing camps of archaeologists and other partisans fighting in Moscow and Petersburg, whom Klejn characterizes as "ideological enthusiasts, at first with little experience of either Marxism or archaeology” $(2012,18)$. On rival scholarly communities, see Metel' 2017. 
The 1930s development of archaeology is best understood as a product of the shifting norms that circulated within Soviet Marxist circles. The Academy for the History of Material Culture's activities were of central importance. The academy was run by N. Ia. Marr and headed by party-affiliated managers (for example, S. N. Bykovskii and F. V. Kiparisov), who advanced a new Marxist model of material culture studies. Their influence eventually spread beyond the Academy, as seen in the case of Vladislav Iosifovich Ravdonikas (1894-1976), who went on to become chair of the archaeology department at Leningrad State University. ${ }^{107}$

This generation found typological studies untenable, saying that the "naked artefactology" that characterized prerevolutionary work was a "product of bourgeois evolutionism, a method which fetishized objects and biologized history." 108 The dominant prerevolutionary interpretive framework, the cultural-historical model, also fell out of official favor at this time, as it was associated with bourgeois formalism. ${ }^{109} \mathrm{~A}$ host of new theories began to circulate, which integrated Marxist perspectives with studies of ancient material. The most influential for our purposes is the model of stadiality, the 'theory of stages,' discussed below. In the following decade, though, Stalin's purges eliminated even some of the most ardent Marxist voices, as numerous members of the Academy of Material Culture were arrested in the mid-1930s. Afterward, the pendulum swung quickly away from theoretical explorations, toward the explication of factual details of the past.

\section{V.3 Post-War Evolutions}

Following the Second World War, and particularly the death of Stalin in 1953, the broader context of humanitarian scholarship changed once again. Oriental studies developed largely under Vasilii Vasilievich Struve's (1889-1965) influence and his research on slavery in the ancient Near East. Struve's work concerned ancient Mesopotamia, but subsequent controversies with Igor' Mikhailovich D'iakonoff (19151999) in the 1950s and 1960s filtered into ancient studies more broadly. ${ }^{110}$ Classical antiquity became the purview of a larger scholarly community who worked, among other places, at reconstituted university departments. Influential participants included representatives of the old guard (S. A. Zhebelev, V. S. Sergeev and N. A. Mashkin), as well as the new (A. V. Mishulin). ${ }^{111}$ In general, research continued to

107 Ravdonikas was not simply a party functionary, but an archaeologist who rose quickly from relative obscurity largely through condemnation of the older generation (especially Gorodtsov). Platonova 2002 provides a nuanced treatment. See also Klejn 2012, 216-232.

108 Klejn 2012, 23.

109 Despite doctrinal protests, both of these models remained central to archaeology in the USSR.

110 On the controversies between Streuve and D'iakonoff, see Krikh 2016b.

111 Ladynin 2016, 16-18. 
center on marginalized groups like the populist masses and slaves, although it lost some of its earlier polemic. ${ }^{112}$ The bottom-up perspective on social life visible in the work of Elena Mikhailovna Shtaerman (1914-1991) represents the late-stage development of Soviet thought on classical society. ${ }^{113}$

The scale of archaeological fieldwork expanded. ${ }^{114}$ Although ideological orthodoxy remained after the 1960s 'thaw,' there was increasing intellectual diversity and methodological and theoretical advancements. ${ }^{115}$ Questions of Slavic prehistory were taken up from a number of positions (e.g., B. A. Rybakov and M. I. Artamonov, advancing the perspectives of autochthony and migration/diffusionism, respectively). Central Asian sites were studied in the framework of the Khorezm expedition (S. P. Tolstov), ${ }^{116}$ as well as by excavations at Nisa (M. E. Masson), and at Panjakent (B. Marshak), among others. In the South Caucasus, relevant research was conducted at necropoleis of Samtavro (A. N. Kalandadze, A. M. Apakidze, and others), and Mingechevir (S. M. Kaziev, P. M. Vaidov, and others), as well in the Armenian highlands (B. B. Piotrovsky). Excavations at Black Sea coastal settlements also continued, as well as work in the North Caucasus. This research produced material-historical syntheses of the polities located along the Eurasian corridors, bringing greater structure to regional understandings. ${ }^{117}$

At the same time, there were persistent divisions in research between the 'center and the periphery' in Soviet scholarship in these years. ${ }^{118}$ 'Periphery' in this sense has both a physical and an institutional valence - including both scholars based outside of the metropolitan centers of Moscow and Leningrad, but also those whose approaches were not normative within these spaces. Soviet-period research was neither a uniform nor linear phenomenon, and understandings and applications of precisely what constituted 'Soviet' thought varied between these research spheres and over time.

112 On slavery and slave revolts, for example, see section VI.2 below.

113 As she says in the introduction to an earlier synthetic work, Moral' i religiia ugnetennykh klassov Rimskoi imperii, "In the Roman Empire, the role of nonmainstream classes was especially great" $(1961,7)$. See Krikh 2013b for a discussion of Shtaerman's approach to ancient history.

114 E.g., Klejn 2012, maps 1-5.

115 Klejn 2012, 38-44, for a survey of this period.

116 Arzhantseva 2013 provides a theoretical perspective on work at Khorezm.

117 E.g., the works of Kamilla Vasil'evna Trever: Trever, Iakubovskii, and Voronetz 1950; Trever 1959.

118 Krikh 2017, on the idea of the 'periphery' and its role. 


\section{Soviet Models of Ancient Societies and Economies}

Recent work on Soviet studies of antiquity makes the point that on balance, the organism of Soviet historical science was not interested in debate. ${ }^{119}$ Instead, it aimed to 'solve' the problems of history. It hoped to reach definitive conclusions about the past through a search for verity (istina) - a sort of platonic truth - and a commitment to orthodoxy. ${ }^{120}$ Once an optimal solution was found, the work of scholars lay not in testing that hypothosis, but rather illustrating it through specific case studies. Additionally, the Soviet Marxist historical approach was not only Marxist in its theoretical leanings, but also in its discursive style and manner of narrative construction. ${ }^{121}$ In this final section of the chapter, I consider three facets of Sovietperiod scholarship that are necessary for understanding Soviet research on the spaces of Eurasia: 1) how the economy was conceived; 2) how social structure and change was modeled; and 3) how personal and collective self-understanding intersected with these social and economic frameworks, particularly in the field of archaeology.

\section{VI.1 The Place of the Economy}

For scholars outside of the Soviet Union, there is a temptation to imagine Soviet scholarship on the ancient economy as Marxist in an uncomplicated way. Such an assumption overestimates the status of economic questions in Soviet thought on antiquity. ${ }^{122}$ On the contrary, as Krikh has recently commented, despite Soviet economocentrism, “... in Soviet science, the economic history of antiquity is transmuted into political history with a slight economic tinge." 123

Understanding this situation requires an appreciation of two discourses. The first pitted Soviet scientists against non-Soviet researchers. In general, Soviet researchers sought to define themselves oppositionally to 'bourgeois history' either for personal ideological reasons, or perhaps more commonly for professional reasons. With respect to the economy, Rostovtzeff was a central target of Soviet scholar-

119 These issues have been explored most directly by Krikh. For an overview in English, see Krikh 2016 .

120 Krikh and Metel' 2014, 7-25.

121 In a related example, Lozny 2017 argues for a distinct discourse of "communist archaeology" (understood differently from Marxist archaeology) that spread throughout the USSR and its sphere of influence.

122 Cf. Marxist scholarship on the ancient economy generated outside of the Soviet Union, see Sullivan 1975; B. D. Shaw and Saller 1981; Morley 1999.

123 Krikh 2013b, 137. 
ly derision, with his research on ancient economies stressing the 'modern' characteristics of the ancient economic landscape. ${ }^{124}$ His position created ample ground for criticism by Soviet contemporaries, who parodied his interpretations as retrojections of capitalism. At the same time, Soviet scholars were interacting with - and even borrowing from - the ideas they encountered in foreign scholarship, including Rostovtzeff's. ${ }^{125}$ It is through this vector that the poles of primitivism and modernism, so critical to twentieth-century debates about the ancient economy in nonSoviet spheres, were also central subjects of debate within midcentury Soviet scholarship. ${ }^{126}$

The second discourse concerned the true and correct interpretation of MarxistLeninist thought on society and the economy, and its relationship to historical scholarship. The Soviet government eventually addressed the question of the "proper' way to write history, demonstrating the centrality of historical narrative-building within governance. ${ }^{127}$ Along the way, a rigid model for understanding historical evolution became doctrinal and precluded investigations into alternative forms of economic evolution. Thus, explicitly economic questions, although putatively central to Soviet Marxist historical understandings, played a marginal role in Soviet research on Eurasian antiquity.

\section{VI.2 Societal Structure and Change}

The influential model of historical evolution with roots in Marx's writings that came to dominate historical thought by the 1930 s is the five-stage system (piatichlenka). ${ }^{128}$ This model posited that all of history was a single process of development through five categorical socio-economic structures: tribal, slave-owning, feudal, capitalist, and, finally, communist. The ascendance of the linear model obviated the need for debates about ancient socio-economic organization. The essential economic questions were, after all, already answered.

The ancient worlds of Greece and Rome occupied a single categorical stage: that of a slave-owning society. As Engels wrote, "Without slavery, no Greek state, no Greek art and science, without slavery, no Roman Empire." ${ }^{129}$ In the field of ancient history, therefore, the issue of slavery as an economic model became a topos. ${ }^{130}$ The

124 Krikh 2013a, 140-186, which insists that it is impossible to trace the paths of the transfer of ideas.

125 E.g., the work of the historian Ranovich, see Krikh 2013b, especially 148-166.

126 Krikh and Metel' 2014, 65-85 discuss one vector for interaction: reviews of foreign literature in major Soviet journals.

127 Yilmaz 2015, 13-15.

128 Loosely adapted from the works of Marx and Engels, debates remain about the roots of the idea. It emerged from the halls of GAIMK over the course of the 1920s (Formozov 2006, 162-163).

129 Engels, Anti-Dühring, part 2, sec. 4 ([1877] 1962, 168).

130 For broad surveys of the subject in scholarship, see Krikh 2013b, 116-132; also Rubinsohn 1987. 
discussion of slave revolts became more lively still after 1933, when Stalin explained the fall of the classical world as the result of "revolutions of slaves that liquidated the class of slave-owners and the slave-owning system as a form of exploitation of the working masses." 131 The problem, of course, was that this assertion did not match the history of slave revolts within the Roman world, which were considerably earlier than the putative transition between the slave-owning means of production of antiquity and the subsequent medieval feudal system.

Finding ways to support Stalin's claim, or at least to accommodate it, became several ancient historians' focus in the 1930s and 1940s. ${ }^{132}$ Even after Stalin's death, there were attempts to widen or reformulate the global slave-revolt hypothesis, considering for example the Social Wars to be a demonstration of a peasant rebellion against their overlords. ${ }^{133}$ Despite considerable effort, however, ancient historians failed to build a durable theoretical apparatus for studying classical antiquity according to the five-stage system, although their rigorous work on slavery is of continuing relevance. ${ }^{134}$

Positioning the ancient Near East within the five-stage development system presented an even larger problem. Dominant understandings in early Soviet years posited that either a feudal or, more particularly, an 'Asiatic mode of production' governed life in the ancient Near East rather than a slave-owning one. ${ }^{135}$ This concept emerges in a shifting and convoluted form from Marx. The term, in essence, describes a system where the state held a monopoly on infrastructural development (and particularly on hydrological management, although alternately on military power), which sustained largely self-sufficient and autonomous local communities. An important commonality in Marx's various presentations of the 'Asiatic mode of production' is the absence of private land ownership, thus inhibiting the development of a land-owning class.

Debates about the 'Asiatic mode of production' raged in the 1920s and early 1930s. The concept had wide-reaching political consequences for Soviet Marxist understandings of the world, and the debates attracted considerable attention at the center of Marxist philosophy and the Soviet leadership. Eventually, the concept was

131 Trans. and references, Tolz 1997, 80. On the broader cultural currents, and the ways in which Stalin's statement fit into (and failed to conform to) historical understandings, see Krikh 2013b, 119; Voloshin and Trandofilov 2015.

132 See especially Korzheva 1976; Krikh 2006b; see also Tolz 1997, 80-81. Sharova 2017 discusses slave revolts in textbooks (which were subject to state scrutiny and therefore offer insight into 'official' thought).

133 Ladynin 2016, 24, discussing the work of Utchenko (1965).

134 Heinen 2010. The work of the American ancient historian, Grace Kazakevich, who moved to the Soviet Union in 1949 after her husband was accused of espionage, deserves mention here. Her works on slavery, while somewhat out of step with later Soviet scholarship, were nevertheless important. See Kazakévich and Kamen 2008; Karpiuk 2016.

135 On the Asiatic mode of production, see Dunn 1982; Fogel 1988. 
determined incompatible with the proper interpretation of Marx, and the subject was stricken from debate for the next several decades, reemerging only in the 1960s. This caused a problem for specialists in the ancient history of the Near East, who had to fit the ancient societies into accepted paradigms of economic evolution. Struve proposed a solution. He reclassed the societies of the Near East as slave-owning on the basis of descriptions of labor patterns in Sumerian texts. ${ }^{136}$ Despite the many infelicities of this argument and controversy around it, it became the cornerstone of mainstream research on the ancient Near East for the next generation.

Struve's refashioning of the Near East into a slave-owning society is but one example of the way that the canonical five-stage model shaped research about antiquity. Beyond ancient history, the five-stage system also shaped archaeological thought. A central question became explaining the cause of changes from one stage to the next. The 'theory of stadial development' mentioned earlier provided a tool to study such structural changes through material culture. Developed on the basis of an idiosyncratic linguistic theory advanced by Marr, ${ }^{137}$ 'stadiality theory' held that all changes in society and culture were actually caused by 'technological innovations,' which is to say the restructuring of economic systems. ${ }^{138}$ As Marr wrote, stadiality theory explained that what appear to be ethnic differences between tribal groups were actually class differences. ${ }^{139}$

Stadial models (at least, as interpreted in the 1930s) ruled out human migrations as a cause of social and linguistic change, and demanded autochthony. ${ }^{140}$ Thus, for example, Rostovtzeff's Scythian and Sarmatian migration hypothesis was firmly rejected as "artificial." 141 At the same time, ethnic arguments that claimed evolutionary connections between the past and the present were viewed for a time as a type of "bourgeois nationalism." 142 In the words of Yilmaz, "Everyone was autochthonous in a spatial sense and at the same time did not bear a single ethnic root."143

\section{VI.3 Ethnicity and Social Location}

The idea of autochthony and perceptions of ethnicity more broadly, however, were in flux during Soviet rule. Over time, it became increasingly acceptable for histori-

136 Krikh 2016a; 2016c.

137 Velmezova 2007 contextualizes Marr's linguistic theory.

138 Klejn 2012, 24; see also Platonova 2010, 253-258. Through the vector of V. Gordon Childe, this idea made its way into global archaeological theory in the 1930s (Trigger 1989, 334-353), and anticipated the theoretical development of New Archaeology (Trigger 1978, 162).

139 Dolukhanov 1995, 124.

140 Slezkine 1996, 843. See e.g., Ravdonikas 1932.

141 Mordvintseva 2013, 208. Although the foremost Scythian scholar in the late 1920s, Boris Grakov, continued to draw on migration theories in his writings (Mordvintseva 2013, 207).

142 Shnirelman 1996, 231.

143 Yilmaz 2015, 9. 
ans and particularly archaeologists to talk about ethnogenesis, which earlier had been suspect. ${ }^{144}$ This discourse, which had percolated for generations, came to the fore over the first decades of Soviet rule. ${ }^{145}$ The concept of 'nationality' was operationalized as 'national consciousness' to develop the new Soviet nationalist identities for all of the citizens of the Soviet Union. ${ }^{146}$

These frameworks took hold quickly in the late 1930s, and applied both to Russian self-perception (generating a resurgence of interest in Slavic history) and to the panorama of national identities of the union-republics. ${ }^{147}$ The effect was a rapid retreat away from Marr's idea of telling history without ethnicity to a version of history entangled much more deeply with ethnic categorization. Eventually, Marr was denounced by Stalin's own pen, ending the supremacy of stadiality, and opening the way for new discussions about both ethnicity and migration as causes of social change. ${ }^{148}$

The roots of the ethnogenetic turn have been traced by some to the situation in the 1940s, when the threat from Germany spurred a "growth of national selfconsciousness, the expression of national pride and the fostering of the best indigenous traditions." 149 This threat was paired with the damage of the war years, which saw tremendous loss of life among young scientists, as within the larger society. ${ }^{150}$ An articulation of Russian heritage free of outside influence, consequently, grew in popularity. ${ }^{151}$ Archaeological explorations were instrumental in this process, tracking the relationships between the Scythians, Sarmatians, and Slavs, and providing the Slavs with unambiguous ancestors in the steppe. ${ }^{152}$ Here, the concept of an 'archaeological culture,' with roots in Russian imperial scholarship, provided the theoretical link between a particular material assemblage, a territorial space, and a historic population.

Eventually, archaeologists working in the various republics also began to incorporate ideas of 'national ethnogenesis' into their works on local populations, bolstered by a rehabilitation of the kraevedenie (local studies) movement. ${ }^{153}$ As ethnogenetic explanations based on archaeological cultures matured, the boundaries

144 Interest in ethnic history lasts into the present day. See Laruelle 2008 for a case study.

145 E.g., Klejn 2012, 135-138.

146 Hirsch 2005.

147 Slezkine 1996, 852.

148 The piece was likely authored by Marr's opponent A. Chikobava (Smith et al. 1998, 178).

149 Bulkin, Klejn, and Lebedev 1982, 276. See the discussion in Kenig, Tikhonov, and Korusenko 2013, 155-159.

150 See Formozov 2006, 76-79.

151 Among these was a new iteration of the long-running Normanist/anti-Normanist controversies on the role of the Vikings in early Russian history, see Melnikova 2013.

152 Shnirelman 1995, 234. Iablonskii 2003; Raevskii 2003 offer a glimpse into the development of discourse of steppe enthnogenesis.

153 Donovan 2015. 
between 'historic tribal populations' and modern nationalities began to dissolve. Given the fractious histories of many of the spaces along the southern Soviet border, the archaeological search for national origins found fertile ground.

At the same time, and somewhat contradictorily, discussions of migration grew in the later years, entering debate after 1960 and assuming a place of prominence, particularly in understanding Eurasia's numerous mobile pastoralist communities. As a result, long-distance migrations have been widely accepted as a normal feature of steppe pastoralism and are used to explain changes in material culture, with varying degrees of nuance.

\section{VI.4 Eurasian Mosaic}

If nineteenth-century Russian archaeology was about frontiers, then twentiethcentury scholarship was, in a certain sense, about borders. Using the administrative system of the USSR to corral data from antiquity, the borders of the Soviet Socialist Republics were used to delineate research territories and became the fundamental unit for data organization for everything from archaeological reports to specialist publications. Within each republic, furthermore, research focused on historical research problems tied to the history of the peoples living within that territory, setting proscribed boundaries both spatially and conceptually. ${ }^{154}$

This scholarship presents a mosaic of images of the past rather than a single totalizing whole. Researchers studying the Eurasian past were under pressure from the central Soviet science structures, and also from the regional research communities in their local republics. Explanatory models for human development - and chiefly the concept of autochthony and that of human migrations - went in and out of vogue in the later years of the Soviet Union. Economic models, meanwhile, downplayed the presence of market economies in these spaces. Although these spaces - from the Black Sea, across the Caucasus, and into Central Asia - were interacting with each other, and with the ancient empires they bordered, the emphasis within archaeological and historical studies in the late twentieth century focused on historically particular, often local, phenomena within each region. It is these overlapping, intertwined, and often conflicting factors that have come together to form the research landscape today.

\section{Contemporary Currents}

Prerevolutionary Russian scholarship established a historical narrative rooted in the wide-open spaces of the imperial frontiers, but stopped short of developing a united

154 Shnirelman 2001, 6. E.g., Alikberov 2015, 24. 
vision of Eurasian antiquity based on this perspective. Soviet research, in contrast, explicity sought to tease out the deeper meaning of ancient history on a global scale, but its focus on a limited number of explanatory paradigms hampered progress. Today, almost thirty years after the end of the Soviet Union, we can only begin to talk about tendencies in post-Soviet ancient Eurasian history. This period began with yet another shift in structure to the practice of science in Russia - one that diminished the position of history, and thus archaeology, vis-à-vis state power. ${ }^{155}$ Today, however, we can speak of robust continuing work in the fields of archaeology and history in the Russian Federation, as well as participation in international scholarly communities. We can also note a particular interest in historiography, which is broadening and deepening our understanding of the various strands of Russian thought about the past.

Scholarship about the space of Eurasia more broadly is increasingly multivocal, but also increasingly fragmented. Much of this work is being generated not within Russia itself, but instead in the former union-republics, now states in their own right. The 1990s were difficult in many of these areas, where border conflicts and widespread economic privation had tremendous consequences for scholars. The academic and scientific infrastructure that existed in these spaces in the Soviet period has not been easy to replace, and funding for research remains a pressing problem.

Nevertheless, each country is in the process of developing its own independent practice of history outside of the Soviet context and an institutional framework to support it. ${ }^{156}$ Some of these traditions still look toward Russia, while others look elsewhere. The publishing landscape is far more diverse, but also atomized. Russian is no longer the primary scholarly language in some areas, as increased publishing in local languages and in English change the picture. Both domestically run archaeological projects and international collaborations have increased, generating considerable new data, and also profoundly divergent interpretations.

\section{References}

Alikberov, А. К. 2015. “Кавказская Албания и лезгинские народы: актуальные проблемы, новые дискурсы” [Caucasian Albania and the Lezgian peoples: Relevant issues and new discourses]. In A. K. Alikberov and M. S. Gadjiev (eds.), Albania Caucasica, 16-27. Москва: Институт востоковедения РАН.

Alipov, Р. А. 2009. “Историк М. И. Ростовцев: научный успех эмигранта” [The historian M. I. Rostovtzeff: The scientific success of the emigrant]. Новый исторический вестник 19.1, 128133.

155 Guliaev and Beliaev 1995 provide a view of institutionally mainstream scholars from after the transition.

156 E.g., Solonari 2003; Laruelle 2010. 
Alpatov, V. М. 1991. История одного мифа: Марр и марризм [The history of one myth: Marr and Marrism]. Москва: Наука.

Andreau, J. 1989. "Bibliographie des oeuvres de Rostovtseff." In M. I. Rostovtseff, Histoire économique et sociale du monde hellénistique, 1273-1303. O. Demange (trans.). Paris: Robert Laffont.

Andreau, J., and W. Bérélowitch, eds. 2008. Michel Ivanovitch Rostovtzeff. Bari: Edipuglia.

Arzhantseva, І. А. 2013. “Имперская археология и археологические империи: советская Хорезмская археологическая экспедиция" [Imperial archeology and archaeological empires: The Soviet Khorezm archaeological expedition]. Этнографическое обозрение, no. 4, 65-87.

Baehr, S. L. 1978. "From history to national myth: Translatio imperii in eighteenth-century Russia." Russian Review 37.1, 1-13.

Bassin, M. 1993. "Turner, Solov'ev, and the 'frontier hypothesis': The nationalist signification of open spaces." Journal of Modern History 65.3, 473-511.

-. 2008. "Eurasianism 'Classical' and 'Neo': The lines of continuity." In T. Mochizuki (ed.), Beyond the empire: Images of Russia in the Eurasian cultural context, 279-294. Sapporo: Slavic Research Center.

Battis, M. 2015. "Soviet Orientalism and nationalism in Central Asia: Aleksandr Semenov's vision of Tajik national identity." Iranian Studies 48.5, 729-745.

Bayer, T. S. 1728. "De muro Caucaseo." Commentarii Academiae Scientiarum Imperialis Petropolitanae, no. 1, 425-464.

Bongard-Levin, G. M. 1999. "M. I. Rostovtzeff in England: A personal experience of West and East.” In G. R. Tsetskhladze (ed.), Ancient Greeks west and east, 1-45. Leiden: Brill.

-, ed. 1997. Скифский роман [The Scythian novel]. Москва: РОССПЭН.

Bowersock, G. W. 1974. "The social and economic history of the Roman Empire by Michael Ivanovitch Rostovtzeff." Daedalus 103.1, 15-23.

Bulkin, V. A., L. S. Klejn, and G. S. Lebedev. 1982. "Attainments and problems of Soviet archaeology." World Archaeology 13.3, 272-295.

Campbell, E. 2002. “К вопросу об ориентализме в России (во второй половине XIX веканачале XX века)" [On the question of Orientalism in Russia (in the second half of the 19th century-early 20th century)]. Ab Imperio, no. 1, 311-322.

Cronin, S. 2015. "Introduction: Edward Said, Russian Orientalism and Soviet Iranology." Iranian Studies 48.5, 647-662.

Curta, F. 2001. "Pots, Slavs and 'imagined communities': Slavic archaeologies and the history of the early Slavs." European Journal of Archaeology 4.3, 367-384.

Dolukhanov, P. M. 1995. "Archaeology in Russia and its impact on archaeological theory." In P. J. Ucko (ed.), Theory in archaeology: A world perspective, 321-336. London: Routledge.

Donovan, V. 2015. “'How well do you know your Krai?' The kraevedenie revival and patriotic politics in late Khrushchev-era Russia." Slavic Review 74.3, 464-483.

Dubowoj, S. M. 1985. "Gottlieb Siegfried Bayer (1694-1738): From Königsberg to the Imperial Academy of Sciences in St. Petersburg." Canadian Slavonic Papers / Revue canadienne des slavistes 27.2, 123-139.

Dunn, S. P. 1982. The fall and rise of the Asiatic mode of production. London: Routledge and Kegan Paul.

Dvornichenko, А. Y. 2016. "The place of the Kievan Rus in history." Вестник СанктПетербургского университета. Серия 2. История, по. 4, 5-17.

Emmons, T. 2003. "The problem of 'Russia and the West' in Russian historiography (with special reference to M. I. Rostovtsev and P. N. Miliukov)." In C. Evtuhov and S. Kotkin (eds.), The cultural gradient: The transmission of ideas in Europe, 1789-1991, 95-108. Lanham, MD: Rowman and Littlefield. 
Engles, F. (1877) 1962. “Anti-Dühring.” In Karl Marx, Friedrich Engels: Werke. Vol. 20, 5-303. Berlin: Dietz.

Etkind, A. 2002. “Бремя бритого человека, или Внутренняя колонизация России” [The shaved man's burden, or the inner colonization of Russia]. Ab Imperio, no. 1, 265-298.

Fogel, J. A. 1988. "The debates over the Asiatic mode of production in Soviet Russia, China, and Japan." American Historical Review 93.1, 56-79.

Formozov, А. А. 1974. “Пушкин и Ходаковский” [Pushkin and Khodakovskii]. Прометей 10, 108-113.

-. 1986. Страницы истории русской археологии [Pages of the history of Russian archaeology]. Москва: Наука.

-. 1995. Русские археологи до и после революции [Russian archaeologists before and after the revolution]. Москва: Институт археологии РАН.

-. 2000. Пушкин и древности. Наблюдения археолога [Pushkin and antiquity: Observations of an archaeologist]. Москва: Языки русской культуры.

-. 2006. Русские археологи в период тоталитаризма: Историографические очерки [Russian archaeologists in the period of totalitarianism: Historiographic essays]. 2nd ed. Москва: Знак.

Frachetti, M. D. 2011. “Migration concepts in Central Eurasian archaeology.” Annual Review of Anthropology 40.1, 195-212.

Franklin, S. 1992. “Greek in Kievan Rus'.” Dumbarton Oaks Papers 46, 69-81.

Frolov, E. D. 2006. Русская наука об античности. Историографические очерки [Russian research on antiquity: Historiographic sketches]. Санкт-Петербург: Издательство СанктПетербургского университета.

-. 2015. “Петербургская историческая школа: традиции классицизма и последствия модернизации” [The Petersburg historical school: Traditions of classicism and the consequences of modernism]. Вестник Санкт-Петербургского университета. Серия 2. История, по. 4, 136-149.

-. 2016. “Academic links between Russia and Germany in the 18th-19th centuries.” Вестник Санкт-Петербургского университета. Серия 2. История, по. 3, 57-67.

Gadjiev, M., P. L. Kohl, and R. G. Magomedov. 2007. "Mythologizing the remote past for political purposes in the North Caucasus.” In B. Grant and L. Yalçın-Heckmann (eds.), Caucasus paradigms: Anthropologies, histories and the making of a world area, 119-142. Berlin: LIT.

Gerasimov, І. 2002. “От редакции: Обновление российской империи и парадоксы ориентализма" [From the editors: Modernization of the Russian Empire and paradoxes of Orientalism]. Ab Imperio, no. 1, 239-248.

Glaesser, G. 1957. “Archaeology in the USSR.” East and West 8.1, 77-99.

Glebov, S. 2008. "Wither Eurasia? History of ideas in an imperial situation.” Ab Imperio, no. 2, 345-376.

Golden, P. B. 1991. "Aspects of the nomadic factor in the economic development of Kievan Rus'." In I. S. Koropeckyj (ed.), Ukrainian economic history: Interpretive essays, 58-101. Cambridge, MA: Harvard University Press.

Goriainov, A. N. 1990. “Славяноведы-жертвы репрессий 1920-1940-х годов. Некоторые неизвестные страницы из истории советской науки” [Slavic studies - victims of the repressions of the 1920s-1940s: Some unknown pages from the history of Soviet science]. Советское славяноведение, по. 2, 78-89.

Gorshenina, S. 2017. "Alexandre le Grand et les Russes: Un regard sur le conquérant porté depuis l'Asie centrale." In C. Antonetti and P. Biagi (eds.), With Alexander in India and Central Asia: Moving east and back to west, 152-193. Oxford: Oxbow.

Graham, H. F. 1961a. "Soviet classical scholarship and the Black Sea region." Classical Journal 56.5, 194-202. 
-. 1961b. "The classics in the Soviet Union." Classical World 54.7, 205-213.

Guliaev, V. I., and L. A. Beliaev. 1995. “О современном состоянии археологии в России (полемические заметки)" [On the current state of archeology in Russia (polemical notes)]. Российская археология, по. 3, 97-105.

Halperin, C. J. 1985. Russia and the Golden Horde: The Mongol impact on Medieval Russian history. Bloomington, IN: Indiana University Press.

Heinen, H. 2010. "Aufstieg und Niedergang der sowjetischen Sklavereiforschung: Eine Studie zur Verbindung von Politik und Wissenschaft." In H. Heinen (ed.), Antike Sklaverei: Rückblick und Ausblick: Neue Beiträge zur Forschungsgeschichte und zur Erschließung der archäologischen Zeugnisse, 95-138. Stuttgart: Franz Steiner.

Hirsch, F. 2005. Empire of nations: Ethnographic knowledge and the making of the Soviet Union. Ithaca, NY: Cornell University Press.

Hokanson, K. 2005. “'Barbarus hic ego sum': Pushkin and Ovid on the Pontic shore.” Pushkin Review 8, 61.

lablonskii, L. T. 2003. “Археология и скифология в этноисторической реконструкции” [Archaeology and Scythology in ethnohistorical reconstruction]. Российская археология, no. 4, 71-79.

Kahn, A. 1993. "Readings of imperial Rome from Lomonosov to Pushkin." Slavic Review 52.4, 745-768.

Karpiuk, S. G. 2016. “Эмили Грейс (Эмилия Львовна Казакевич), американский филологклассик и советский историк" [Emily Grace (Emilia Kazakevich), American philologistclassicist and Soviet historian]. Вестник древней истории 76.1, 141-161.

Karpiuk, S. G., and O. V. Kulishova. 2015. “Хью Грэхем, «индианский эксперимент» и советское антиковедение 50-60-х годов" [Hugh Graham, 'the Indiana experiment' and Soviet ancient studies in the 50's and 60's]. Вестник древней истории, no. 3, 209-217.

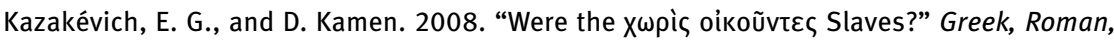
and Byzantine Studies 48.4, 343-380.

Kemper, M., and S. Conermann, eds. 2011. The heritage of Soviet Oriental studies. London: Routledge.

Kemper, M., and A. M. Kalinovsky, eds. 2015. Reassessing Orientalism: Interlocking Orientologies during the Cold War. London: Routledge.

Kenig, A. V., S. S. Tikhonov and M. A. Korusenko. 2013. "The development of ethnoarchaeological thought in Russian archaeology." In A. Marciniak and N. Yalman (eds.), Contesting ethnoarchaeologies: Traditions, theories, prospects, 145-171. New York, NY: Springer.

Khalid, A. 2000. "Russian history and the debate over Orientalism." Kritika 1.4, 691-699.

Klejn, L. S. 1977. "A panorama of theoretical archaeology." Current Anthropology 18.1, 1-42.

-. 1993. "To separate a centaur: On the relationship of archaeology and history in Soviet tradition." Antiquity 67.255, 339-348.

- [Klein]. 2010. Трудно быть Клейном. автобиография в монологах и диалогах [Hard to be Klejn: An autobiography in monologs and dialogues]. Санкт-Петербург: Нестор-История.

- [Klein]. 2011. История археологической мысли. Курс лекций [A history of archaeological thought: Lecture course]. 2 vols. Санкт-Петербург: Петербургского государственного университета.

-. 2012. Soviet archaeology: Trends, schools, and history. K. Windle and R. Ireland (trans.). Oxford: Oxford University Press.

- [Klein]. 2014. История российской археологии: учения, школы и личности [A history of Russian archaeology: Teachings, schools and personalities]. 2 vols. Санкт-Петербург: Евразия.

Knight, N. 2000a. "Grigor'ev in Orenburg, 1851-1862: Russian Orientalism in the service of empire?” Slavic Review 59.1, 74-100. 
-. 2000b. “On Russian Orientalism: A response to Adeeb Khalid.” Kritika 1.4, 701-715.

-. 2002. "Was Russia its own Orient? Reflections on the contributions of Etkind and Schimmelpenninck to the debate on Orientalism." Ab Imperio, no. 1, 299-309.

Komarova, I. І. 1990. “Московское археологическое общество и его роль в развитии местных краеведческих организаций России" [Moscow Archaeological Society and its role in the development of local regional history organizations in Russia]. In Археографический ежегодник 1989, 80-87. Москва: Наука.

Korzheva, K. P. 1976. "Spartacus's rebellion in Soviet historiography." Soviet Studies in History 15.1, 67-97.

Kosykh, V. I. 2009. “Церковно-археологические общества Русской Православной Церкви (конец XIX-начало XX вв.)" [The religious-archaeological societies of the Russian Orthodox Church (end of 19th-beginning of 20th century)]. Ученые записки Забайкальского государственного университета. Серия: Филология, история, востоковедение, по. 3 , 121-126.

Kozelsky, M. 2004. "Ruins into relics: The monument to Saint Vladimir on the excavations of Chersonesos, 1827-57." Russian Review 63.4, 655-672.

Kreucher, G. 2005. Rostovtzeffs Briefwechsel mit deutschsprachigen Altertumswissenschaftlern: Einleitung, Edition und Kommentar. Wiesbaden: Harrassowitz.

Krikh, S. В. 2006а. Упадок древнего мира в творчестве М.И. Ростовцева [The decline of the ancient world in the works of M. I. Rostovtzeff]. Омск: Издательство ОмГУ.

-. 2006b. “«Революция рабов» в советской историографии 30-х годов XX века” ['The Slave revolution' in Soviet historiography during the 30's of the 20th century]. Диалог со временем, по. 17, 224-236.

-. 2009. “МИ Ростовцев: быть в образе и быть образом” [М. I. Rostovtzeff: Being in the similtude and being an image]. Новое литературное обозрение, nо. 95, 146-162.

-. 2013а. “Специфика древней экономики: советская историография в контексте мировой исторической науки" [Specification of the ancient economy: Soviet historiography in the context of global historiographical sciences]. In Древность и Средневековье: вопросы истории и историографии: материалы II Всероссийской научной конференции студентов, аспирантов и молодых учёных (Омск, 25-27 октября 2012 г.), 6-14. Омск: Издательство Омского государственного университета.

-. 2013b. Образ древности в советской историографии [The image of antiquity in Soviet historiography]. Москва: Красанд.

-. 2016a. "Assyriology and Stalinism: Soviet historiography and the invention of slavery in the ancient Near East." Journal of Ancient Near Eastern History 3.2, 191-209.

-. 2016b. “И. М. Дьяконов против В. В. Струве: полемика на полях Шумера” [I. M. D’iakonoff vs V. V. Struve: Polemics in the fields of Sumer]. Вестник древней истории, no. 4, 10111029.

-. 2016с. "В.В. Струве и марризм" [V. V. Struve and Marrism]. In Советский ландшафт древней ойкумены: отечественная наука о древнем Востоке и античности в 1920-1980-е гг. Вестник Университета Дмитрия Пожарского, по. 4, 47-72.

-. 2017. “Феномен периферийности в советской историографии” [The phenomenon of peripherality in Soviet historiography]. Вопросы истории 10, 164-169.

Krikh, S. B., and O. V. Metel'. 2014. Советская историография древности в контексте мировой историографической мысли [Soviet historiography of antiquity in the context of global historiographical thought]. Москва: Ленанд.

Kruze, F. 1835. “О важности южнокавказских областей России в отношении антикварном и о Птолемее, главном писателе в рассуждении географии сей страны” [On the importance of the South Caucasus regions of Russia in relation to antiquity, and on Ptolemy, the most important author in the discourse about the geography of this territory]. Журнал министерства народного просвещения 5.3, 423-439. 
Ladynin, I. А. 2016. “Особенности ландшафта (насколько марксистской была «советская древность»?)" [Features of the landscape (how Marxist was "Soviet antiquity"?)]. Советский ландшафт древней ойкумены: отечественная наука о древнем Востоке и античности в 1920-1980-е гг. Вестник Университета Дмитрия Пожарского 2.4, 9-32.

Lappo-Danielevskii, A. S. 1887. “Скифские древности” [Scythian antiquity]. Записки отделения русской и славянской археологии 4, 352-543.

Lapteva, L. P. 2005. История славяноведения в России в XIX веке [The history of Slavic studies in Russia in the 19th century]. Москва: Индрик.

-. 2012. История славяноведения в России в конце XIX-первой трети XX века [The history of Slavic studies in Russia at the end of the 19th-first third of the 20th century]. Москва: Индрик.

Laruelle, M. 2008. "The concept of ethnogenesis in Central Asia: Political context and institutional mediators (1940-50)." Kritika 9.1, 169-188.

-. 2010. "National narrative, ethnology, and academia in post-Soviet Uzbekistan." Journal of Eurasian Studies 1.2, 102-110.

Latyshev, V. V., ed. 1885-1901. Inscriptiones antiquae orae septentrionalis Ponti Euxini Graecae et Latinae. 4 vols. Санкт-Петербург: Типография Императорской Академии наук.

-. 1890-1906. Известия древних писателей, греческих и латинских, о Скифии и Кавказе [Accounts of ancient Greek and Latin authors about the Scythians and the Caucasus]. 3 vols. Санкт-Петербург: Типография Императорской Академии наук.

Layton, S. 1994. Russian literature and empire: Conquest of the Caucasus from Pushkin to Tolstoy. Cambridge: Cambridge University Press.

Leach, S. 2015. A Russian perspective on theoretical archaeology: The life and work of Leo S. Klejn. Walnut Creek, CA: Left Coast.

Lebedev, G. S. 1992. История отечественной археологии. 1700-1917 гг. [A history of domestic archaeology: 1700-1917]. Санкт-Петербург: Издательство Санкт-Петербургского Университета.

Lozny, L. R. 2017. "Sickle, hammer, and trowel: Theory and practice of archaeology under Communism." In L. R. Lozny (ed.), Archaeology of the Communist era: A political history of archaeology of the 20th century, 9-58. New York, NY: Springer.

Lundbaek, K. 1986. TS Bayer (1694-1738): Pioneer sinologist. London: Curzon.

Madariaga, I. de. 2005. Ivan the Terrible. New Haven, CT: Yale University Press.

Melnikova, E. 2013. “The 'Varangian problem': Science in the grip of ideology and politics.” In R. Taras (ed.), Russia's identity in international relations: Images, perceptions, misperceptions, 42-52. London and New York, NY: Routledge.

Metel', O. V. 2017. “Коммунистическая академия как центр советской исторической мысли (1918-1936 гг.)" [The Communist Academy as the center of Soviet historical thought (19181936)]. In Актуальные проблемы исторических исследований: взгляд молодых ученых: сборник материалов Всероссийской молодежной научной школы-конференции (14-16 сентября 2017 г.). Новосибирск: Институт истории СО РАН.

Meyer, C. 2009. "Rostovtzeff and the classical origins of Eurasianism." Anabases 9, 185-197.

Miller, M. O. 1956. Archaeology in the U. S.S.R. New York, NY: Praeger.

Momigliano, A. 1954. "MI Rostovtzeff." Cambridge Journal 7, 334-346.

Mongait, A. L. (1955) 1961. Archaeology in the USSR. 2nd ed., M. W. Thompson (trans.). Baltimore, MD: Penguin. Originally published as Археология в СССР.

Mordvintseva, V. 2013. "The Sarmatians: The creation of archaeological evidence." Oxford Journal of Archaeology 32.2, 203-219.

Morley, N., ed. 1999. "Marx and antiquity." Special issue, Helios 26.2.

Naumkin, V. V. et al., eds. 1997-2014. Неизвестные страницы отечественного востоковедения [Unknown pages in Russian Oriental studies]. 5 vols. Москва: Восточная литература. 
Nippel, W. 2018. “Marx and antiquity.” In D. Allen, P. Christesen, and P. Millett (eds.), How to do things with history: New approaches to ancient Greece, 185-208. Oxford: Oxford University Press.

Okenfuss, M. J. 1995. The rise and fall of Latin humanism in early-modern Russia: Pagan authors, Ukrainians, and the resiliency of Muscovy. Leiden: Brill.

Platonova, N. І. 1998. “Николай Яковлевич Марр - археолог и организатор археологической науки” [Nikolai lakovlevich Marr - archaeologist and organizer of archaeological research]. Археологические вести 5, 371-382.

-. 2002. “Панорама отечественной археологии на ‘великом переломе’(по страницам книги ВИ Равдоникаса 'За марксистскую историю материальной культуры')” [The panorama of Russian archeology at the 'great turning point' (in the pages of the book by VI Ravdonikas 'Towards a Marxist history of material culture')]. Археологические вести 9, 261-278.

-. 2008. "The phenomenon of pre-Soviet archaeology: Archival studies in the history of Russian archaeology - methods and results." In N. Schlanger and J. Nordbladh (eds.), Archives, ancestors, practices: Archaeology in the light of its history, 47-58. New York: Berghahn.

-. 2010. История археологической мысли в России. Вторая половина XIX - первая треть XX века [A history of archaeological thought in Russia: Second half of the 19th century through first third of the 20th century]. Санкт-Петербург: Нестор-История.

Poe, M. 2001. "Moscow, the Third Rome: The origins and transformations of a "pivotal moment."” Jahrbücher für Geschichte Osteuropas n.s. 49.3, 412-429.

Postnikov, A. V. 2014. История географического изучения и картографирования Сибири и Дальнего Востока в XVII-начале XVIII века в связи с формированием русско-китайской границы [The history of geographical study and mapping of Siberia and the Far East in the 17th-early 18th century in connection with the formation of the Russian-Chinese border]. Москва: Ленанд.

Postnikov, V. V. 2006. “Образ Александра Македонского в русской материальной культуре” [The image of Alexander of Macedon in Russian material culture]. Вестник Дальневосточного отделения Российской академии наук, по. 3, 141-147.

Pozdeeva, I. V. 1962. “Изучение древней истории и древних языков в Московском университете в 50-70-е гг. XVIII в.” [The study of ancient history and ancient languages at Moscow University during the $50 \mathrm{~s}-70$ s of the 18th century]. Вестник древней истории, no. 3, 3-23.

Raevskii, D. S. 2003. “Об историографии скифской проблемы в современном освещении (некоторые замечания к дискуссии)” [On the historiography of the Scythian problem in a modern light (some comments on the discussion)]. Российская археология, по. 2, 64-71.

Raffensperger, C. 2012. Reimagining Europe: Kievan Rus' in the Medieval world. Cambridge, MA: Harvard University Press.

Raskol'nikova, M. 1975. La recherche en Union Soviétique et l'histoire économique et sociale du monde hellénistique et romain. Strasbourg: AECR.

Ravdonikas, V. I. 1932. “Пещерные города Крыма и готская проблема в связи со стадиальным развитием Северного Причерноморья” [Cave cities of Crimea and the Gothic problem in relation to the stadial development of the northern Black Sea region]. Известия ГАИМК $12,5-106$.

Rodionov, M. 2011. “Profiles under pressure: Orientalists in Petrograd/Leningrad, 1918-1956." In Kemper and Conermann (2011), 47-57.

Rostovtzeff, M. I. 1922. Iranians and Greeks in South Russia. Oxford: Clarendon.

-. 1926. The social and economic history of the Roman Empire. 2 vols. Oxford: Clarendon.

-. 1941. The social and economic history of the Hellenistic world. 3 vols. Oxford: Clarendon.

Rubinsohn, W. Z. 1987. Spartacus' uprising and Soviet historical writing. J. G. Griffith (trans.). Oxford: Oxbow. 
Sandler, S. 1989. Distant pleasures: Alexander Pushkin and the writing of exile. Stanford, CA: Stanford University Press.

Saunders, D. B. 1982. "Historians and concepts of nationality in early nineteenth-century Russia." Slavonic and East European Review 60.1, 44-62.

Segel, H. B. 1973. "Classicism and classical antiquity in eighteenth- and early-nineteenth-century Russian literature." In J. G. Garrard (ed.), The eighteenth century in Russia, 48-71. Oxford: Clarendon.

Schimmelpenninck van der Oye, D. 2002. “Ориентализм - Дело Тонкое” [Orientalism - a subtle matter]. Ab Imperio, no. 1, 249-264.

-. 2010. Russian Orientalism: Asia in the Russian mind from Peter the Great to the emigration. New Haven, CT: Yale University Press.

-. 2011. "The imperial roots of Soviet Orientology." In Kemper and Conermann (2011), 29-46.

Sharova, A. V. 2017. “'Революция рабов’ в учебных изданиях ЕA Косминского” [The 'Slave revolution' in the textbook editions of E. A. Kosminsky]. In M. D. Bukharin (ed.), Scripta antiqua. Вопросы древней истории, филологии, искусства и материальной культуры 6 , 421-450.

Shaw, B. D. 1992. "Under Russian eyes." Journal of Roman Studies 82, 216-228.

Shaw, B. D., and R. P. Saller. 1981. "Editors' introduction." In M. I. Finley Economy and society in ancient Greece, ix-xxvi. London: Chatto and Windus.

Shaw, D. J. B. 1996. "Geographical practice and its significance in Peter the Great's Russia." Journal of Historical Geography 22.2, 160-176.

Shchavelev, S. P. 1998. “Становление археологического интереса в России XVII века (ранние находки древностей в районе Курска в отражении приказного делопроизводства)" [Formation of archaeological interest in Russia in the 17th century (early finds of antiquities in the area of Kursk in light of department records)]. Российская археология, nо. 2, 188194.

Shepard, J. 2016. "Back in Old Rus and the USSR: Archaeology, history and politics." English Historical Review 131.549, 384-405.

Shnirelman, V. A. 1995. "From internationalism to nationalism: Forgotten pages of Soviet archaeology in the 1930s and 1940s." In P. L. Kohl and C. Fawcett (eds.), Nationalism, politics and the practice of archaeology, 120-138. Cambridge: Cambridge University Press.

-. 1996. "The faces of nationalist archaeology in Russia." In M. Díaz-Andreu and T. Champion (eds.), Nationalism and archaeology in Europe, 218-242. Boulder, CO: Westview.

-. 2001. The value of the past: Myths, identity and politics in Transcaucasia. Osaka: National Museum of Ethnology.

-. 2009. "To make a bridge: Eurasian discourse in the post-Soviet world." Anthropology of East Europe Review 27.2, 68-85.

Shtaerman, Е. М. 1961. Мораль и религия угнетенных классов Римской империи (Италия и Западные провинции) [Morality and religion of the oppressed classes of the Roman Empire (Italy and the Western provinces)]. Москва: Издательство Академии наук СССР.

Sinitsyna, N. V. 1998. Третий Рим: Истоки и эволюция концепции [Third Rome: The origins and evolution of the concept]. Москва: Индрик.

Slezkine, Y. 1996. "N. Ia. Marr and the national origins of Soviet ethnogenetics." Slavic Review $55.4,826-862$.

Smirnov, A. S. 2011. Власть и организация археологической науки в Российской империи: очерки институциональной истории науки XIX-начала XX века [State power and the organization of archaeological sciences in the Russian Empire: Research on the institutional history of science in the 19th and early 20th century]. Москва: Институт археологии РАН.

Smith, G., V. Law, A. Wilson, A. Bohr and E. Allworth. 1998. Nation-building in the post-Soviet borderlands: The politics of national identities. Cambridge: Cambridge University Press. 
Solonari, v. 2003. “Creating a 'people': A case study in post-Soviet history-writing.” Kritika 4.2, 411-438.

Sullivan, J. P., ed. 1975. "Marxism and the classics." Special issue, Arethusa 8.1.

Sunderland, W. 2004. Taming the wild field: Colonization and empire on the Russian steppe. Ithaca, NY: Cornell University Press.

Thomson, F. J. 1995. "The distorted mediaeval Russian perception of classical antiquity: The causes and consequences." In A. Welkenhuysen, H. Braet, and W. Verbeke (eds.), Mediaeval Antiquity, 303-364. Leuven: Leuven University Press.

Tikhonov, I. L. 2009. “Императорская Археологическая Комиссия: структура и кадровый состав” [Imperial Archaeological Commission: Structure and personnel]. Российская археология, по. 4, 5-17.

Tolz, V. 1997. Russian academicians and the revolution: Combining professionalism and politics. Basingstoke and London: MacMillan Press and St. Martin's Press.

-. 2001. Russia: Reader in Russian history. London and New York, NY: Arnold and Oxford University Press.

-. 2008. "European, national, and (anti-) imperial: The formation of academic Oriental studies in late Tsarist and early Soviet Russia.” Kritika 9.1, 53-81.

-. 2011. Russia's own Orient: The politics of identity and Oriental studies in the late imperial and early Soviet periods. Oxford: Oxford University Press.

Trever, К. V. 1959. Очерки по истории и культуре Кавказской Албании IV в. до н. э.-VII в. н.э. [Studies on the history and culture of Caucasian Albania: 4th century BCE-7th century CE]. Москва: Издательство Академии наук СССР.

Trever, K. V., A. I. lakubovskii and M. E. Voronetz. 1950. История народов Узбекистана [A history of the peoples of Uzbekistan]. Том 1. Ташкент: Издательство АН УзССР.

Trigger, B. G. 1978. “No longer from another planet.” Antiquity 52.206, 193-198.

-. 1989. A history of archaeological thought. Cambridge: Cambridge University Press.

Tunkina, I. V. 1999. “В. В. Латышев: Жизнь и учёные труды (по материалам рукописного наследия)” [V. V. Latyshev: Life and scientific works (on the basis of manuscript evidence)]. In Рукописное наследие русских византинистов в архивах Санкт-Петербурга, 172-288. Санкт-Петербург: Д. Буланин.

-. 2002. Русская наука о классических древностях юга России (XVIII-середина XIXв.) [The Russian science of classical antiquities of southern Russia (18th-mid-19th centuries)]. Санкт-Петербург: Наука.

-. 2003. "The formation of a Russian science of classical antiquities of southern Russia in the 18th and early 19th century.” In P. G. Bilde, J. M. Højte, and V. Stolba (eds.), The cauldron of Ariantas: Studies presented to A. N. Ščeglov on the occasion of his 70th birthday, 303364. Aarhus: Aarhus University Press.

-. 2014. "Rostovtzeff entre archéologies russe et allemande avant 1914." In H. Eristov and F. Monier (eds.), L'héritage germanique dans l'approche du décor antique: Actes de la table ronde organisée à l'Ecole normale supérieure le 23 novembre 2012, 97-114. Bordeaux: Ausonius.

Utchenko, S. L. 1965. Кризис и падение Римской республики [The crisis and fall of the Roman Republic]. Москва: Наука.

Uvarov, S. S. 1810. Études de philologie et de critique. Paris: Didot Frères.

Vasil'kov, I. V., and M. I. Sorokina. 2003. Люди и судьбы. Биобиблиографический словарь востоковедов - жертв политического террора в советский период (1917-1991) [Реople and destinies: Bibliographical dictionary of Orientalists - victims of political terror in the Soviet period (1917-1991)]. Санкт-Петербург: Петербургское востоковедение.

Velmezova, E. 2007. Les lois du sens: La sémantique marriste. Bern: Peter Lang.

Volkov, D. V. 2015. "Rupture or continuity? The organizational set-up of Russian/Soviet Oriental studies before and after 1917." Iranian Studies 48.5, 695-712. 
Voloshin, D. A., and A. A. Trandofilov. 2015. “К вопросу об историографических предпосылках сталинской “теории революции рабов”" [On the question of the historiographic preconditions for the Stalinist 'theory of the revolution of Slaves']. Научно-методический электронный журнал Концепт 30, 541-545.

Vorob’ev, I. К. 1999. Латинский язык в русской культуре XVII-XVIII веков [Latin language in Russian culture of the 17th-18th centuries]. Саранск: Издательство Московского университета.

Welles, C. B. 1956. "Bibliography: M. Rostovtzeff." Historia 5.3, 358-381.

Wes, M. A. 1988. "The Russian background of the young Michael Rostovtzeff." Historia 37.2, 207-221.

-. 1990. Michael Rostovtzeff, historian in exile: Russian roots in an American context. Stuttgart: Franz Steiner.

-. 1992. Classics in Russia 1700-1855: Between two bronze horsemen. Leiden: Brill.

Yilmaz, H. 2015. National identities in Soviet historiography: The rise of nations under Stalin. London: Routledge.

Zuev, V. I. 1997а. “Материалы к биобиблиографии М.И. Ростовцева” [Materials for the bio-bibliography of M. I. Rostovtzeff]. In Bongard-Levin (1997), 200-232.

-. 1997b. “М.И. Ростовцев. Годы в России. Биографическая хроника” [M. I. Rostovtzeff: The years in Russia: Bibliographic chronicle]. In Bongard-Levin (1997), 50-83. 


\section{The Qin and Han Economies in Modern Chinese and Japanese Historiographies}

\section{Introduction}

The late nineteenth and early twentieth centuries witnessed some fundamental changes in the East Asian world, not only in terms of political, institutional, societal, and economic aspects, but also of historiography. The defeat of China by the Western powers during the two Opium Wars (1839-1842 and 1856-1860) shocked the entire East Asian world. Some Chinese politicians and intellectuals began to realize the urgent need for reform. The Westernization Movement (also known as the Self-Strengthening Movement) which took place from 1861 to 1895 , covering aspects such as diplomacy, military, and industrial production, was a response to the challenges posed by Western powers. However, the movement eventually ended in the Sino-Japanese War with the defeat of China in 1895, which seemed to suggest that Japan was more successful in its modernization scheme than China. One of the results of this war was the shift in intellectual and cultural exchange between China and Japan.

China had long been the cultural center of the East Asian World and deemed a model by its neighbors, such as Japan and Korea. Already in the seventh century, Japan had developed a tradition of kundoku 訓読 ('reading by gloss'), which combines reading and translation of Chinese texts into a single integrated act. The early Japanese could use this method to comprehend Chinese texts as well as produce new texts. ${ }^{1}$ During the Tokugawa 徳川 period (1600-1868), kangaku 漢学 (Chinese learning), which was mainly based on Confucian ( $r u$ 儒) learning, had formed the basis of the mainstream ideology among the educated in Japan. Although the defeat of China during the Opium Wars greatly surprised the Japanese, it did not stop them from learning from the Chinese and absorbing Western knowledge through Chinese works. A significant shift in intellectual and cultural exchange between these two countries occurred after the defeat of China during the Sino-Japanese War. Many Chinese intellectuals turned to see the 'modernized' Japan as their new model. ${ }^{2} \mathrm{New}$ ideas and terminologies from the West flooded into China through the translations

\footnotetext{
1 Lurie defines kundoku as a complex of practices that "associate logographs of Chinese origin with Japanese words and transpose the resulting words into Japanese order while adding necessary grammatical elements, thereby producing an actual or imagined vocalization in Japanese” (2011, 175).

2 See Wang 2003; Chen 2007 for this background.
}

Note: I am grateful to Kwok-leong Tang for his helpful comments.

Ә Open Access. (c) 2020 Tsang Wing Ma, published by De Gruyter. (c) BY-NC-ND This work is licensed under the Creative Commons Attribution-NonCommercial-NoDerivatives 4.0 License.

https://doi.org/10.1515/9783110607741-023 
of Japanese work. The Western concepts of 'economy' and 'history', which were translated in Japanese as keizai 経済 and rekishi 歴史, were introduced to China along with this flood. ${ }^{3}$

From the early twentieth century on, the study of Chinese history in China and Japan had undergone several changes as responses to the contemporary political and intellectual environment. The aim of this chapter is not to offer a comprehensive literature review of modern scholarship on Qin 秦 and Han 漢 (221 BCE-220 CE) economic history, ${ }^{4}$ which is almost an impossible task given the limited length of this chapter, but rather to contextualize the writing of Qin and Han economic history in the development of modern Chinese and Japanese historiographies, so as to show the changes of concerns and methodologies in this field. Part one situates the studies of Chinese economic history in the transformations of Chinese and Japanese historiographies at the turn of the twentieth century. Part two examines the studies of Qin and Han socioeconomic history under Chinese Marxist historiography. Part three discusses the publishing of the Food and Commodities Semimonthly (Shihuo banyuekan 食貨半月刊) and the development of Qin and Han economic history in Taiwan and Hong Kong. The chapter concludes with a section introducing the new trends in the studies of early Chinese economy which are due mainly to the remarkable growth of the discoveries of ancient texts in recent decades.

\section{Transformations of Historiographies: Xin shixue (New Historiography) in China and Tōyōshi (Eastern History) in Japan}

After the defeat of China during the Sino-Japanese War, Chinese intellectuals realized that they needed a more comprehensive reform, which gave rise to the Hundred Days' Reform in 1898. Although the reform only lasted for about one hundred days due to factors including the internal conflict among the imperial families, it urged

3 Masini 1993, 183, 186. Both of these compounds were originally Chinese (jingji 經濟 and lishi 歷史 ) and later assimilated into the Japanese writing system. In classical Chinese, jingii is an abbreviation of jingshi jimin 經世濟民 ('to manage the realm and save the people') while lishi refers to lidai zhi shi 歷代之史 ('history of different dynasties'). When the concepts of 'economy' and 'history' were introduced to Japan, just as other Western concepts, the Japanese chose to use kanbun 漢文 ('Chinese writing') to translate them. Mehl 2000, 53 indicates that the Japanese during the Meiji era considered kanbun a language of the educated people and it was clearer and more concise in translating foreign language work.

4 There are several literature reviews which can serve this purpose. See Li 1999 for a general review on ancient Chinese economic history; Yamada 1993, 15-26 for Qin and Han fiscal history; Zhang 2006, 10-23 for Han settlements and cities; Kakinuma 2011, 3-39 for early Chinese monetization, etc. 
Chinese intellectuals to reconsider the practical function of traditional Chinese historiography in the face of threats by the Western powers. On the contrary, the war made the Japanese aware of their achievement in the Westernization movement and led to the rise of Japanese imperialism. Along with these changes came the transformation of Chinese studies from kangaku ('Chinese learning') to tōyōshi 東洋史 ('Eastern history') in Japan. The following considers two prominent figures in modern Chinese and Japanese historiographies, Liang Qichao 梁啟超 (1873-1929) and Katō Shigeshi 加藤繁 (1880-1946), to demonstrate the changes regarding concerns and methodologies in the writing of Chinese economic history.

In 1902, Liang Qichao’s famous essay “New Historiography” (Xin shixue 新史學) was serialized in the New Citizen Journal (Xinmin congbao 新民叢報), which formally launched an attack on the traditional Chinese historiography. As one of the leaders of the Hundred Days' Reform, Liang was exiled to Japan after the failure of the reform. Inspired by Western historiography, Liang criticized that the Chinese traditional historical writings, which are mainly presented in the annalistic and biographical styles, had four problems: Firstly, they only paid attention to the imperial courts but not the entire nation, thus the so-called 'Twenty-Four Standard Histories' (ershisi shi 二十四史) were not 'history' but nothing more than the history of 24 imperial houses. Secondly, they only focused on prominent figures, but not the people as a group. Thirdly, they emphasized ancient times rather than modern times. Fourthly, they merely narrated facts but did not study historical causality, thus offered no meaningful advice for the need of present issues. ${ }^{5}$ Modern historians consider Liang Qichao's criticism of traditional Chinese historiography as a 'revolution' in modern Chinese historiography, which redefined the meaning of 'history." 6

In fact, the advocate of "New Historiography" also influenced the writing of economic history. Liang was one of the first Chinese scholars during his time who were aware of Western economic studies. He himself had written an essay titled " $\mathrm{A}$ Brief History of the Origin and Changes of Economic Studies" (Shengji xue xueshuo yange xiaoshi 生計學學說沿革小史). ${ }^{7}$ In “New Historiography,” he criticized that traditional Chinese historiography concentrated on political history and failed to develop other fields of history such as literary, ethnic, economic, and religious history. ${ }^{8}$ Since Ban Gu's 班固 introduction of “Treatise on Food and Commodities" (Shihuo zhi 食貨志) in the History of the Han (Hanshu 漢書), Chinese official historians adopted this genre of historical writing to record economic matters and included it in the official compiled history. The term shihuo ('food and commodities') was commonly

5 Liang 1926, 34.25b-28a. For analyses of Liang's historical ideas, see Xu 2003, 9-60; Wang 2001, $42-50$.

6 Xu 2003, 9-60.

7 Liang 1926.

8 Liang 1926, 34.29b. Liang's knowledge of Western economic studies was acquired through Japanese translations. Masini 1993, 183 points out that he was familiar with the meaning of the Japanese term keizai ('economy'). 
used as one of the general terms referring to economic matters in historical writings during the imperial period. ${ }^{9}$ Yet such a genre was not scholarly research of economic history in the modern sense but merely represented the dynastic views on economic policies and activities. During the twentieth century, an apparent change in the writing of economic history occurred, in which Chinese historians stopped following the traditional genre of "Treatise on Food and Commodities" and assimilated the Japanese translation of the Western concept of economy into the writing of economic history, the so-called jingji shi 經濟史 in Chinese. It might not be a direct result of Liang's advocacy of "New Historiography," but it had undoubtedly urged scholars to reevaluate the value of traditional Chinese historiography when facing the challenges posed by Western powers.

As most scholars have indicated, Liang's Japanese experience had a clear influence on his historical ideas. ${ }^{10}$ In fact, the most influential work on Qin and Han economic history during the early twentieth century was completed by Japanese scholars, of whom Katō Shigeshi was a pioneer in this field. Unlike China, Japan had been aware of Western knowledge since the Tokugawa period, during which the study of Western knowledge had formed an independent field called rangaku 蘭学 ('Dutch learning'). ${ }^{11}$ Since the Meiji 明治 restoration in 1868 until the SinoJapanese War in 1895, Japan had undergone a more comprehensive Westernization movement than China. The defeat of China signified the success of this movement and gave rise to Japanese imperialism during the late nineteenth and early twentieth centuries. In the meantime, the discipline of Chinese studies in Japan had also transformed from kangaku ('Chinese learning') to tōyōshi ('Eastern history'). ${ }^{12}$ Regarding this transformation, Margaret Mehl describes the following: "While kangaku was based on the assumption that China was the source of civilization, tôyōshi

9 Ban Gu elaborated the terms shi (food) and huo (commodities) as such: "The former may be said to be the excellent grains and [other] edibles produced by the agriculturalists. The latter may be defined as textiles, woven of vegetable fibers and of silk, of which wearing apparel can be made; as well as metals, knife [money], tortoise shells, cowries [etc.], with which wealth may be divided, benefits distributed, and [what the people] have exchanged for [what they] have not” 食謂農殖嘉 穀可食之物, 貨謂布帛可衣, 及金刀鬼貝, 所以分財布利通有無者也 (Hanshu 24a.1117, trans. Swann 1950, 109-10).

10 For example, Q. Edward Wang argues that Meiji intellectual Fukuzawa Yukichi's 福沢諭吉 (1835-1901) advocacy of 'histories of civilization' (bummeishiron 文明史論) provided a new perspective for Liang to understand Chinese history, see Wang 2001; 2003.

11 The Dutch were the only Westerners who were allowed to enter Japan during the Tokugawa period and they also became the only channel for the Japanese to learn about the West. See Katagiri 1982 for more on rangaku.

12 Many scholars including Katō himself attribute the founding of tōyōshi to Naka Michiyo 那珂通世 (1851-1908), who proposed to divide world history in the middle school curriculum into seiyōshi 西洋史 ('Western history') and tōyōshi in 1894 (Katō 1948, 50). The study of kokushi 国史 ('Japanese national history') was an independent discipline which does not belong to either seiyōshi or tōyōshi. 
recognized indebtedness to China, but also claimed Japanese superiority over contemporary China." ${ }^{13}$ Compared to kangaku scholars, tōyōshi scholars incorporated the traditional training of kangaku and Western methodologies in studying China. ${ }^{14}$ Born in 1880, Katō Shigeshi grew up along with this transformation. ${ }^{15}$ His studies of Chinese economic history demonstrate his training in both the kangaku and tōyōshi traditions.

While Qing kaojuxue 考據學 ('evidential research') formed Katō Shigeshi's fundamental knowledge of Chinese texts, ${ }^{16}$ his education of Western historiographies, such as Leopold von Ranke's (1795-1886) objective writing of history, differentiated him from the traditional kangaku scholars. As a son of a family with samurai antecedents during the Meiji period, Katō followed the path of his contemporaries and received the typical kangaku education when he was young. ${ }^{17}$ Katō then entered into the Tokyo Imperial University 東京帝国大学 (the modern-day University of Tokyo 東京大学) and studied Shina ('Chinese') History 支那史學科 with the first generation of tōyōshi scholars, including Naka Michiyo and Shiratori Kurakichi 白鳥庫吉 (1865-1942). ${ }^{18}$ From 1918 to 1919, Katō’s influential essay on Han fiscal history, titled "The Distinction of the State Finances and the Imperial House Finances during the Han Dynasty and a Look at the Imperial House Finance" (Kandai ni okeru kokka zaisei to teishitsu zaisei to no kubetsu name ni teishitsu zaisei ippan 漢代に於ける 国家財政と帝室財政との区別並に帝室財政一斑), was serialized in the Journal of Eastern Studies (Tōyō gakuhō 東洋学報). Adopting the contemporary terminologies kokka 国家 ('state') and teishitsu 帝室 ('imperial household'), Katō argued that the Western Han treasury was divided into two parts, treasury of the state and treasury of the imperial household, which were operated by different government agencies. He closely examined the incomes and expenses of the state's and imperial house's treasuries and investigated the abolishment of the imperial household's treasury during the reign of Emperor Guangwu 光武 (r. 25-57). This research explored the public and private spheres of the financial administration during the Western Han period. Despite being challenged and supplemented by contemporary and later scholars,

13 Mehl 2000, 64.

14 Mehl adds: "Perhaps more importantly, they lacked the reverence for China as the source of all learning, and their studies were separated from moral training” (2000, 64).

15 For academic biographies of Katō Shigeshi, see Katō 1948, 145-237; Egami 2015, 145-51.

16 Kaоjuxue ('evidential research') was the dominant academic discipline during the Qing period (1644-1912). Kaojuxue scholars emphasized an empirical approach, which was based on philology and textual criticism, in studying classical knowledge. Many Meiji kangaku scholars had been deeply influenced by this empirical approach. See Elman 2011 for more on Qing kaojuxue.

17 Mehl 2000, 61 points out that kangaku was regarded as the hallmark of good education during Meiji Japan compared to classical education in Europe.

18 Shiratori had studied with Ludwig Rieß (1861-1928), who was a student of Leopold von Ranke, at the Tokyo Imperial University. In an unfinished article on the methodology of Chinese economic history, Katō also showed that he was familiar with European economic terminologies and history (Katō 1948, 13-26). 
Katō's view formed the foundation of the studies of early Chinese economic history in Japanese scholarship. ${ }^{19}$

Katō's other works on Qin and Han economic history include essays on the ancient Chinese land system, Han poll tax and coinages, and annotated translations of the two most important transmitted texts on early Chinese economy - "Treatise on the Balanced Standard” (Pingzhun shu 平準書) of the Grand Scribes' Records (Shiji 史記) and “Treatise on Food and Commodities" of the History of Han. ${ }^{20}$ As shown in Yamada Katsuyoshi's 山田勝芳 (b. 1944) review, Katō’s attention paid to Han fiscal history has left apparent imprints on the work achieved by later scholars including Miyazaki Ichisada 宮崎市定 (1901-1995), Hiranaka Reiji 平中苓次 (1907-1973), Masubuchi Tatsuo 増淵龍夫 (1916-1983), Yoshinami Takashi 好並隆司 (1929-2010), and Yamada himself. ${ }^{21}$ Katō's influence in the writing of early Chinese economic history had already spread to the Chinese academic circle during the first half of the twentieth century. Early in the 1930s, Katō's argument for the division of the state and imperial household finances had been cited by Chinese scholars such as Zhou Yunxi 周等溪. ${ }^{22}$ Katō's essays on early Chinese economic history are included in the first volume of his book Shina keizaishi kōshō 支那經濟史考證, which was translated by $\mathrm{Wu}$ Jie 吳杰 into Chinese in 1959, just a few years after it was published in Japan. ${ }^{23}$

Since Katō's pioneering work in early Chinese economic history, Japanese scholars continued to make remarkable contributions to the field. Apart from the names mentioned above, Hamaguchi Shigekuni 浜口重国 (1901-81) clarified the conflicting records about the practice of Han labor service in transmitted texts, which was later proved mostly correct by Hirose Kunio 広瀬薰雄 (b. 1975) with the help of newly excavated texts in 2010. ${ }^{24}$ Utsunomiya Kiyoyoshi's 宇都宮清吉 (1905-98) detailed analysis of The Contract for a Youth (Tongyue 僮約) text reveals the manor economy of the southwestern region during the first century всE. ${ }^{25}$ Nishijima Sadao 西嶋定生 (1919-1998) offered a comprehensive account on Western Han social and economic history, which is still one of the works most accessible in the West. ${ }^{26}$ Other important works include Watanabe Shinichirō 渡邊信一郎 (b. 1949) on Han financial logis-

19 This long essay was later revised and included in Katō 1952-1953, 1: 35-156.

20 Katō 1942.

21 Yamada 1993, 15-26.

22 Zhou 1936, 8-9.

23 Katō 1959.

24 Hamaguchi 1966, 459-486; Hirose 2010, 269-332.

25 Utsunomiya 1955, 256-374. For an English translation of The Contract for a Youth, see Wilbur 1943, 383-92.

26 This study is included in the Qin and Han volume of The Cambridge History of China. Note that Nishijima's chapter in that volume is a translation of his Japanese essay written in 1967. A revised Japanese version of Nishijima's essay had already been incorporated into his book published in 1981 whereas the English translation based on the old Japanese version came out in 1986 due to the delay of the publishing of the Qin and Han volume; Nishijima 1981; 1986. 
tics and labor forces, Shigechika Keiju 重近啓樹 (b. 1951) on Qin and Han taxation and labor service system, Sahara Yasuo 佐原康夫 (b. 1958) on Han cities and markets, and most recently, Kakinuma Yōhei 柿沼陽平 (b. 1980) on early Chinese monetization. $^{27}$

\section{The Study of the Qin and Han Socioeconomic History under Chinese Marxist Historiography}

The flourishing of economic history writing in China, however, had to wait until the 1920s-1930s. From 1928 to 1933, many Chinese activists and historians participated in a debate on Chinese social history under Karl Marx's (1818-1883) economic model, the so-called 'Chinese social history controversy' (Zhongguo shehui shi lunzhan 中國社會史論戰). ${ }^{28}$ Although this debate was given credit for the rise of socioeconomic history (shehui jingji shi 社會經濟史) in China, it had been criticized that it had generated a trend of historical interpretation which assumed that the Europeanexperience-based Marxist theory was universally true and tailored Chinese historical materials to fit into the Marxist model. ${ }^{29}$ Such a trend became more dominant after the establishment of the People's Republic of China (PRC) in 1949; since then, Marxism has become the orthodox ideology in China. Chairman Mao Zedong 毛澤東 (1893-1976) stated clearly that historians should follow Marxist-Leninist models to study Chinese history. ${ }^{30}$ The studies of Chinese history in mainland China were therefore closely related to politics, a trend that reached its peak during the Cultural Revolution (1966-1976). Chinese historians who were engaged in the studies of Qin and Han economic history would inevitably have to respond to the questions regarding the placement of Qin and Han society in the Marxist model.

Marxist theory arrived in China in the late 1890s, but it did not receive wide attention among Chinese intellectuals until the late 1910s. Inspired by the Russian Revolution in 1917, discussion on Marxist theory and its application to Chinese history flourished through the introduction by Chen Duxiu 陳獨秀 (1879-1942) and Li Dazhao 李大釗 (1889-1927) in the magazine New Youth 新青年 (Xin qingnian) during the New Culture Movement. ${ }^{31}$ In searching for a new strategy in confronting the Nationalists (guomindang 國民黨), the nature of Chinese society under the Marxist model became a hotly debated topic among the Communists (gongchandang 共產黨)

27 Watanabe 2010; Shigechika 1999; Sahara 2002; Kakinuma 2011.

28 He 1937; Dirlik 1978; Lu 1979.

29 Dirlik 1978; Lu 1979.

30 Lu 1979, 29.

31 Japanese work on Marxist theory had served as the conduit through which Chinese intellectuals acquired their knowledge of Marxist theory (Dirlik 1978, 21). 
after 1927.32 From 1931 to 1933, the Reading Magazine (Dushu zazhi 讀書雜誌) published four special volumes on the topic 'Chinese social history controversy,' discussing how to correctly understand Marxist theory and properly apply the Marxist fivestage model (namely, primitive, slave, feudal, bourgeois, and socialist societies) to the development of Chinese history. ${ }^{33}$ Arif Dirlik argued that it caused a paradigm shift in the interpretation of historical changes in China: "Where previous historians had marked time according to political (whether individual, dynastic, or institutional) or intellectual changes, Marxist historians turned to transformations in the socioeconomic structure as the criteria for determining significant historical change." 34 The debate on Chinese social history in the 1930s did not reach a consensus and continued with another controversy on the periodization of ancient Chinese history in the 1950s. ${ }^{35}$ Many Marxist historians including Guo Moruo 郭沫若 (1892-1978), Fan Wenlan 范文瀾 (1893-1969), Jian Bozan 翦伯贊 (1898-1968), Lü Zhenyu 呂振羽 (19001980) and Hou Wailu 侯外盧 (1903-1987) had participated in the 1950s discussion. ${ }^{36}$

Regarding the placement of Qin and Han society in the Marxist model, the discussion centered on whether it was in the stages of feudal or slave society. Despite the diverse opinions of the periodization of Chinese history, participants of the debate generally agreed that the Chinese feudal society was based on a self-sufficient natural economy, while the money economy was the driving force leading to the destruction of this feudal society. The problem was determining when this feudal stage began. ${ }^{37}$ In 1958, Guo Moruo's periodization finally gained official recognition. The Ministry of Education of the PRC government adopted Guo's periodization in the higher education curriculum. He argued that the transition from the Spring and Autumn (771-476 BCE) to Warring States (475-221 BC) periods was the turning point of Chinese society, transforming from a slave to a feudal society. ${ }^{38}$ This periodization implied that the feudal stage lasted throughout the entire Chinese imperial period without any significant changes. To claim the political legitimacy of this view, Guo referred to a quote from Chairman Mao: "China was [in the stage of] a feudal society since the Zhou-Qin period” 自周秦以來, 中國是一個封建社會. ${ }^{39}$ In Guo’s interpretation, 'Zhou-Qin' refers to the transition from Zhou to Qin periods, which is around 475 BCE. ${ }^{40}$

32 Lu 1979; Dirlik 1978; Liang 2003 for more on this background.

33 Wang and $\mathrm{Lu} 1990$.

34 Dirlik 1978, 9.

35 Lu 1979, 141-166.

36 Li 1999, 131.

37 Liang 2005, 11-12.

$38 \mathrm{Lu}$ 1979, 7; He 2006, 2930-2939.

39 Guo 1954, 13.

40 Guo's views on the transition period from slave to feudal societies had changed several times, from around 770 BCE, to 206 BCE, to 475 BCE (Guo 1954, 2). 
Guo's periodization by no means represented a scholarly consensus on this issue, ${ }^{41}$ but since then most studies on Chinese socioeconomic history in mainland China labeled Qin and Han society as a feudal society. Two multivolume works on Chinese economic history, with the same title, Socioeconomic History of Feudal China (Zhongguo fengjian shehui jingji shi 中國封建社會經濟史), both refer Qin and Han society to the feudal stage in the Marxist model, even though they have different opinions on the beginning of the feudal society in Chinese history. ${ }^{42}$ Such a view was readdressed in a nine-volume government-sponsored work on Chinese economic history published in 1999, in which the chief editor Lin Ganquan 林甘泉 (19312017), a Marxist historian who specialized in Qin and Han economic history, rejected the idea that Qin and Han societies was still in the stage of a slave society. Incorporating newly excavated texts in recent decades, Lin distinguished convicted laborers from government-owned slaves and attested that the latter were only rarely engaged in large-scale agricultural production. According to his analysis, the major producers in the Qin and Han society were no longer slaves but peasants, who served an exploitative class of landlords as tenants and hired laborers. ${ }^{43}$ This view appears to be consistent with that proposed by Guo Moruo in the 1950s. ${ }^{44}$

The influence of the Marxist interpretation of history in modern Chinese historiography is profound and long-lasting. After the enthronement of Marxism as the orthodox ideology of the PRC government, Marxist writings replaced Confucian classics to become the new canons for scholars to seek for authority. A. F. P. Hulsewé observed that "Although the true scholar has recognized certain historical phenomena to be sui generis, he still finds himself compelled to find the right passage in the canon which should be applied in this particular case." 45 Chinese Marxist concepts such as historical materialism, production modes, feudal land ownership, and class struggle became indispensable analytical tools in studying Qin and Han economic history. Yet it does not mean that no real progress was made in this field. For example, Li Jiannong’s 李劍農 (1880-1963) comprehensive treatment of the Qin and Han economic history, Peng Xinwei’s 彭信威 (1908-1967) historical overview of Chinese

41 Other propositions include those which argued that the feudal society started during: 1 . the Western Zhou (ca. 1045-771 BCE) (Fan Wenlan); 2. the Qin-Han transition (Hou Wailu); 3. the Wei 魏 period (220-265 CE) (Tong Shuye 童書業 [1908-1968]). For various ideas on the periodization of Chinese history, see Lu 1979, 141-166.

42 While Fu 1981-1989 considers the Western Zhou as the beginning of the feudal society, Tian and Qi 1996 refers the Warring State period to the beginning of the feudal stage in China.

43 Lin 1999, 85-106.

44 Guo 1954. Note that the debate on the periodization of Chinese history also existed in postwar Japan as a response to the failure of Japanese imperialism. The debate had mainly divided into two camps, one was composed of scholars based at Kyoto University 京都大学 and one was at the University of Tokyo. Most members of these camps considered the Qin and Han periods as the ancient period of Chinese history, despite holding different views regarding the end of this period, Gao 1986. For an English account of this debate, see Tanigawa 1985, part 1.

45 Hulsewé 1968, 120. 
currencies, and Sun Yutang's 孫毓棠 (1911-1985) essays on Han textile industry and military service are still the foundation in the modern scholarship of early Chinese economy. ${ }^{46}$

As will be addressed in the following section, participants of the 'Chinese social history controversy' in the 1930s had already noticed the problems inherent in mechanically applying the Marxist model to Chinese history. Even after 1949, when Marxist theory became the orthodox ideology in China, some scholars such as Chen Zhi 陳直 (1901-1980) continued to follow an empirical approach to study Qin and Han economic history. ${ }^{47}$ This empirical approach was revived after the late 1970 s when the PRC's government shifted the focus from politics to economy. Many historians turned to a more evidence-based research approach while still adopting a Marxist framework. To name a few examples, Huang Jinyan 黃今言 (b. 1937) provided a comprehensive understanding of the Qin and Han taxation and labor service system; ${ }^{48}$ Zhang Jinguang's 張金光 (1936-2013) study of the Qin institutional history covered aspects including the land system, taxation, labor- and household system, all of which are considered fundamental to understanding Qin economic history. ${ }^{49}$ There were also at least two collaborative works devoted to the collection of sources for Qin and Han economic history published in the 1980s. ${ }^{50}$

The abovementioned nine-volume Chinese economic history edited by Lin Ganquan in 1999 is another good example. In his preface to this multivolume work, while acknowledging Marxist theory as the guiding principle, $\mathrm{Wu}$ Chengming 吳承明 (1917-2011) also emphasized the significance of an empirical approach to conducting historical studies. ${ }^{51}$ Although some Chinese Marxist key concepts appear repeatedly throughout the volume devoted to the Qin and Han periods, it basically outlines the scope of Qin and Han economic history in modern Chinese scholarship during that time. ${ }^{52}$ It was also able to incorporate younger generation historians such as Wang Zijin 王子今 (b. 1950), Ma Yi 馬怡 (b. 1952) and Yang Zhenhong 楊振紅 (b. 1963), who later became the major scholars in the field, as well as their new

46 Li 1962; Peng 1954; Sun 1995.

47 Chen 1958.

48 Huang 1988.

49 Zhang 2004, which was in fact completed in 1987 as stated by the author in his preface.

$50 \mathrm{Fu}$ and Wang 1982; Xie and Zhou 1985.

51 Lin 1999, 1-7.

52 Apart from the theoretical introduction, the rest of the 21 chapters respectively represent a subfield in Qin and Han economic history, which include: 1. Distribution of population; 2. Land and irrigation; 3. Agriculture; 4. Animal husbandry; 5. Forestry and fishing; 6. Land ownership system; 7. Land management system; 8. Inheritance and trading of land; 9. Handicraft; 10. Relations of production in handicraft; 11. Commerce and cities; 12. Prices of commodities; 13. Currencies; 14. Taxation; 15. Labor service; 16. Fiscal institution; 17. Economic policies of the feudal state; 18 . Transportation; 19. Social classes and their statuses and assets; 20. Consumption by different classes; and 21. Economies of ethnic minorities. 
findings in the writing of Qin and Han economic history. ${ }^{53}$ As will be addressed in the final section, the revival of this empirical approach has also benefited from the discoveries of ancient manuscripts in recent decades.

\section{Food and Commodities Semimonthly and the Development of Early Chinese Economic History in Taiwan and Hong Kong}

Already in the 1930s, one of the active participants in the 'Chinese social history controversy,' Tao Xisheng 陶希聖 (1899-1988) had questioned the Marxist interpretation of Chinese history. Dissatisfied with the trending approach which mechanically applied Marxist 'formula' to study Chinese history, Tao founded the Food and Commodities Semimonthly in 1934. Although this semimonthly journal lasted for only two years and seven months due to the Japanese invasion in 1937, it initiated another trend of socioeconomic historical studies which advocated a more evidencebased research approach. The influence of the Food and Commodities Semimonthly was more apparent in Taiwan 臺灣 and Hong Kong 香港 after 1949 when Tao Xisheng and one of his major students at the Peking University 北京大學, Quan Hansheng 全漢昇 (1912-2001), retreated to Taiwan with the Nationalist government. ${ }^{54}$ The journal resumed publication in 1971 in Taiwan on a monthly basis and lasted for another 17 years, during which it met with the new trend in Taiwan which emphasized using social science methods in the study of socioeconomic history. The development of the studies of Qin and Han economic history in Taiwan and Hong Kong after 1949 can only be fully understood within this context.

Despite being a Nationalist, Tao Xisheng was also interested in the Marxist economic model. ${ }^{55}$ After participating in a few years of intense debate on the application of Marxist theory to Chinese history, Tao felt satiated by the endless discussions

53 For example, the volume adopts Ma Yi's view that the enrollment of labor service under the Qin had changed from being based on a person's height to his age in 231 BCE. This argument provides a better way to understand the conflicting records on the age of enrollment seen in transmitted and excavated texts (Lin 1999, 701-708).

54 This does not mean that Tao and his journal had left no influence in mainland China. Another major student of Tao at the Peking University in the 1930s was He Ziquan 何茲全 (1911-2011) who had several articles published in the journal. He had studied and worked at Columbia University and Johns Hopkins University in the late 1940s but decided to return to mainland China in 1950. He later became one of the major scholars focusing on the socioeconomic history of China at the Beijing Normal University 北京師範大學, where he had trained a number of scholars including Hou Xudong 侯旭東 (b. 1968) who is now the head of the Department of History at Tsing Hua University 清華大學.

55 Dirlik calls him “a Guomindang Marxist” (1996, 236). 
of the Marxist approach and returned to more evidence-based methods. ${ }^{56}$ In his "Editorial" to the first issue of the Food and Commodities Semimonthly, Tao stated clearly that the purpose of founding this journal was to provide a platform for scholars who were engaged in Chinese economic and social history to share their thoughts and methodologies and to present the questions and sources they had collected. He claimed that it was dangerous to treat a methodology (by which he meant the Marxist model) as a conclusion and he would rather concentrate on collecting historical sources. ${ }^{57}$ A typical example of this approach is Ma Feibai's 馬非百 (1896-1984) Sources for Qin and Han Economic History (Qin Han jingjishi ziliao 秦漢經濟史資料), which was serialized in seven different issues of the journal, collecting sources for the history of handicraft, commerce, agriculture, currency system, population and land, slavery system, and taxation system during the Qin and Han periods. ${ }^{58}$ Yet this does not mean that the journal neglected the importance of methodologies in studying economic history. In fact, Chinese translations of Western and Japanese work on social science and historical studies constituted a significant portion of this journal. ${ }^{59}$ In addition, the journal did not entirely exclude articles which were engaged in the debate on the periodization of Chinese history. ${ }^{60}$

Whereas most submissions to the Reading Magazine emphasized the backwardness during the imperial period of China (referred to as the feudal stage in the Marxist model, see above), articles published in the Food and Commodities Semimonthly covered different eras of imperial China and demonstrated the historical changes throughout the imperial period. ${ }^{61}$ From 1934 to 1937, 23 articles (including two Chinese translations of Japanese works) focusing on the Qin and Han periods, covering aspects such as fiscal institutions, slavery, taxation, land system, currencies, irrigation, and land clearing, were published in the journal. These articles represented a more evidence-based approach compared to the Marxist conceptualized treatment of Qin and Han economy in the 1930s. It should be mentioned that the influence of this journal had also spread to Japan. Tao had claimed that the Japanese market accounted for about 60 percent of the sales for each issue of the journal. ${ }^{62}$

56 Liang 2003, 300-310.

57 Shihuo banyuekan 1.1 (1934). Such a research focus corresponds to that advocated by Fu Sinian 傅斯年 (1896-1950), the founder of the Institute of History and Philology, Academia Sinica 中央研究院歷史語言研究所. Fu had famously stated that: “[we must] go all the way to Heaven above and Yellow Spring below, using our hands and feet, to search out the stuff of history" 上窮碧落下黃泉, 動手動腳找東西 (Wang 2000, 77). This statement was likely inspired by one made by G. M. Trevelyan (1876-1962): “Collect the facts of the French Revolution! You must go down to Hell and up to Heaven to fetch them" (Xu 2003, 245).

58 In Shihuo banyuekan 2.8 (1935); 2.10 (1935); 3.1 (1935); 3.2 (1935); 3.3 (1936); 3.8 (1936); 3.9 (1936). 59 See the index in Shihuo banyuekan 6.1 (1937).

60 For example, He Ziquan had at least two articles elaborating his thoughts on the feudal society during the Wei and Jin periods published in the journal from 1934 to 1936 (He 2006, 2-3).

61 Liang 2003, 324-326.

62 Tao Xisheng's "Editorial” in Shihuo yuekan 1.1 (1971). For the influence of this journal in Japan, see also Yamada 1993, 18; Kakinuma 2011, 5. 
It is also worth mentioning that the Food and Commodities Semimonthly offered a platform for junior scholars, most of whom were actually Tao's students during that time, to share their new thoughts on economic history. Among Tao's students in the 1930s, Quan Hansheng, who taught in Taiwan and Hong Kong after 1949, later became a prominent figure in the studies of Chinese economic history. Adopting Bruno Hildebrand's (1812-1878) distinction of economic phases, Quan had famously argued that China entered into the phase of natural economy along with the collapse of the Han Empire. He attributed the destruction of Han money economy to the economic damage caused by the collapse of the empire and the remarkable decrease in the supply of copper for the production of coins. Regarding the decrease in the supply of copper, Quan added that the importation of Buddhism from India during the Eastern Han period had caused the consumption of large amounts of copper for the casting of Buddha statues. ${ }^{63}$ As noted by Kakinuma Yōhei, this observation has become one of the influential theories in the modern scholarship of early Chinese monetization. ${ }^{64}$ Since this study mainly focuses on the natural economy during the medieval period of China, Quan did not provide an extensive discussion on the money economy during the Han period. This gap was later filled by Song Xuwu 宋敘五 (1934-2016), one of Quan's students in the New Asia College 新亞書院 in Hong Kong, who offered a comprehensive study of Western Han currencies and its money economy under Quan's guidance in 1971.65

When the journal resumed publication on a monthly basis in Taiwan in 1971, Tao reemphasized the importance of social science methods in the study of socioeconomic history. ${ }^{66}$ This emphasis corresponded to the new trend in Taiwan which was actually initiated by Xu Zhuoyun 許倬雲 (b. 1931) in the 1960s and 1970s. ${ }^{67}$ Originally residing in Wuxi 無錫 in Jiangsu 江蘇 province, Xu Zhuoyun and his family retreated to Taiwan after 1949. He was the first generation of scholars in Taiwan who studied abroad and then returned for teaching. From 1962 to 1972, Xu taught and conducted research at the National University of Taiwan 國立臺灣大學 and the Institute of History and Philology, Academia Sinica, during which he introduced social science methodologies and American University curricula to his Taiwanese colleagues and students. ${ }^{68}$ Educated at the University of Chicago from 1957 to 1962, $\mathrm{Xu}$ was able to study with the major economists and sociologists of the time, such

\footnotetext{
63 Quan 1948.

64 Kakinuma 2011, 7.

65 See Song 2002 for a revised version of this research.

66 Tao Xisheng's “Editorial” in Shihuo yuekan 1.1 (1971). The managing editor was Tao Xisheng's son, Tao Jinsheng 陶晉生 (b. 1933), who received his doctoral degree from Indiana University and returned to Taiwan for teaching from 1969 to 1976. Xu Zhuoyun and Tao Jinsheng were two of the major sources of American social science methodologies in 1960s and 1970s Taiwan (Du 2002, 31). $67 \mathrm{Du} 2002,20-32$.

68 Xu 2011, 299-332.
} 
as Bert F. Hoselitz (1913-1995) and Peter Blau (1918-2002). ${ }^{69}$ In his dissertation, which was published under the title Ancient China in Transition in 1965, he adopted a quantifying approach to analyze the social mobility of different classes of people during the transition from the Spring and Autumn to Warring States periods. ${ }^{70}$ His second book, published in 1980, Han Agriculture, demonstrated the association of intensive farming of small-farm operations with a market economy in Han China. ${ }^{71}$ Both of these studies were considered examples of successful integration of social science and historical studies during that time. Before his return to America in the early 1970s, Xu also helped found the journal Thought and Words (Si yu yan 思與言) in 1963, which to this day is devoted to the studies of social science in Taiwan. ${ }^{72}$ But even more important was Xu's influence on his students and the younger generation of scholars. ${ }^{73}$

As Xu's major student in the 1960-1970s, Du Zhengsheng 杜正勝 (b. 1944) developed his interest in the social and economic history of ancient China. His work on Qin and Han economic history could be best represented by his monumental book, Registered Households and Equal People (bianhu qimin 編戶齊民). ${ }^{74}$ Intrigued by the huge change during the Zhou-Qin transition, Du sought to recover the life of the general public from an institutional perspective. Although Du self-identified this book as social and political history, it actually touched on most of the economic aspects during the transition period, including household registration, military conscription, land tenure system, and agricultural economy. The book title, Registered Households and Equal People, demonstrates Du's major argument: during the ZhouQin transition, the special status and privileges of the nobility were eliminated due to the destruction of the Western Zhou hierarchical system. Being registered on government records, the free people now became equal as subjects of the ruler. The establishment of this household registration system was mainly due to the rising needs of enrolling adult males for military service during the Spring and Autumn and Warring States periods. Given the influence of this book, the term bianhu qimin (registered households and equal people) has now become a common term in referring to the free population during the Qin and Han periods in modern scholarship. This book sets an example for conducting research into social and economic history of ancient China from an institutional perspective.

$69 \mathrm{Xu} 2011,181-186$.

70 Hsu 1965.

71 Hsu 1980.

$72 \mathrm{Xu}$ 2011, 286-297.

73 See Zhang Xiurong's 張秀蓉 article in Xu 2011, 598-607.

$74 \mathrm{Du} 1990$. 


\section{Research on Qin and Han Economic History in Light of the Newly Excavated Ancient Texts}

As introduced in chapter 12.B above, the ancient Chinese texts excavated from the ground in recent years ${ }^{75}$ have reshaped our knowledge of early Chinese economy. Before the significant growth in the discoveries of ancient texts in the 1970s, scholars in the early twentieth century had already noted the importance of newly excavated materials in studying Chinese history. Wang Guowei 王國維 (1877-1927), the renowned scholar at Tsing Hua University, had proposed a research approach called 'method of dual attestation' (erchong zhengju fa 二重證據法), which emphasized using new materials excavated from the ground to examine the transmitted texts. ${ }^{76}$ Following this method, historians such as Chen Zhi in mainland China and Lao Gan 勞翰 (1907-2003) in Taiwan incorporated the Han texts excavated from Juyan 居延 and Dunhuang 敦煌 in the early twentieth century and Han transmitted texts to study the history of the Han dynasty. Their work touched on economic aspects including prices of commodities, coinages, salary grades of frontier officials, slavery, the conscription system, resource management, and economic life on the Han northern frontier. ${ }^{77}$ Yet since the Han wooden documents from Juyan and Dunhuang can only adequately represent the frontier situation, the influence of the unearthed texts in the studies of Qin and Han economic history before the 1970s remained limited.

The 1970s were an important decade in the history of the discoveries of ancient manuscripts in mainland China. There were significant finds almost every year, including the ancient texts excavated from tomb nos. 1 and 3 at Mawangdui 馬王堆 in 1972-1974, tomb nos. 8, 9, 10, 167, 168 and 169 at Fenghuangshan 鳳凰山 in 19731975, fortification sites in the Juyan area in 1974, and tomb no. 11 at Shuhuidi 睡虎地 in $1975 .{ }^{78}$ In response to these findings, the State Administration of Cultural Heritage of the PRC's government organized specialists in groups (the so-called 'research group' [zhengli xiaozu 整理小組]) to preserve and study these manuscripts. As remarked by Li Xueqin 李學勤 (1933-2019), these government-organized research groups provided a shelter for scholars to stay away from the intense political movement during the Cultural Revolution. ${ }^{79}$ Since the reading and transcription of the ancient Chinese graphs required specialized knowledge, the study of Qin and Han

\footnotetext{
$75 \mathrm{Ma}$, ch. 12.B, this volume, offers a more extensive introduction to these findings. This chapter mainly focuses on the changes of concerns and methodologies in Chinese and Japanese historiographies due to these new findings.

76 Wang 1994, 2.

77 Chen 1958; Lao 1976. Note that Chen Zhi is also famous for using artifacts in his examination of transmitted texts.

78 For these findings, see Pian and Duan 2006, and Ma, ch. 12.B, this volume.

79 See Li Xueqin's preface in Pian and Duan 2006, 2.
} 
economic history was not confined to historians. We can observe that paleographers always formed the core of these research groups and they were the first scholars who had access to these ancient manuscripts after the archaeologists in charge of the excavations. Their work demonstrates the significance of paleography in advancing our knowledge of Qin and Han economic history. Frequently, different readings of a single word or term on an excavated text would lead to a variety of interpretations of an economic problem.

The first systematic study of Chinese graphs was finished by an Eastern Han scholar Xu Shen 許慎 (40-121 CE) who compiled the first dictionary in Chinese history, the Explaining the Graphs and Analyzing the Characters (Shuowen jiezi 說文解字). The study of ancient Chinese scripts belonged to the discipline of epigraphy (jinshixue 金石學) during the Song 宋 dynasty (960-1279) and it reached its peak under the Qing evidential research (kaojuxue). At the turn of the twentieth century, the discoveries of Shang 商 oracle bone inscriptions and Han frontier wooden slips and tablets offered firsthand materials for the study of modern paleography (guwenzi xue 古文字學). Starting with Luo Zhenyu 羅振玉 (1866-1940) and Wang Guowei, paleographers stood on the frontline of the studies of ancient Chinese manuscripts. ${ }^{80}$ Nowadays, major research centers on ancient Chinese manuscripts such as those at Wuhan University 武漢大學 (headed by Chen Wei 陳偉 [b. 1955]), Fudan University 復旦大學 (headed by Liu Zhao 劉釗 [b. 1959]) and Tsinghua University (formerly headed by Li Xueqin) ${ }^{81}$ are all under the leadership of renowned scholars specialized in paleography.

A number of new questions and issues related to Qin and Han economic history were raised by these specialists. For example, according to the records in the Liye 里耶 Qin wooden tablets, Li Xueqin argued that the term tuli 徒隸 (laborer-servants), which represents the Qin major governmental labor force, refers to three types of forced laborers: bond servants and bondwomen (lichenqie 隸臣妾), wall-builders and grain-pounders (chengdan chong 城旦春), and gatherers of firewood for the spirits and sifters of white grain (guixin baican 鬼薪白粲). Li’s observation once again brought scholarly attention to the discussion of the nature and composition of forced labor during the Qin period. Examining the inscriptions on Juyan and Dunhuang wooden slips, seals, and roof tiles, another renowned scholar Qiu Xigui 荹錫圭 (b. 1935) has carefully recovered the system of Qin and Han government-organized agricultural production. ${ }^{82}$

As the newly excavated texts are usually held by different academic institutions across mainland China, only a small number of scholars have direct access to the original materials before their full publication. Scholars who are not included in the research group normally need to wait for a long time to see the full publication of

80 Luo and Wang 1993.

$81 \mathrm{Li}$ passed away in 2019 when I was in the middle of revising this chapter.

82 Li 2003; Qiu 1997. 
the materials. For example, the full publication of the legal texts found in tomb no. 247 at Zhangjiashan 張家山, which were originally excavated in 1983, appeared only in 2001. Another example is the Han wooden documents excavated from Jianshui 肩水 golden pass in Ejina 額濟納 River valley in 1974, which were finally published between 2011 and 2016. ${ }^{83}$ Scholars who have no direct access to the original materials have to develop their own advantages based on their historiographical traditions to study these manuscripts.

Initiated by Mori Shikazō 森鹿三 (1906-1980) at the Kyoto University in 1951, Japanese scholars formed long-term reading seminars to study these excavated ancient manuscripts. The participants of the reading seminar on Juyan wooden slips and tablets at the Kyoto University in the 1950s-60s included Fujieda Akira 藤枝晃 (1911-1998), Ōba Osamu 大庭脩 (1927-2002), Nagata Hidemasa 永田英正 (b. 1933) and British scholar Michael Loewe (b. 1922), all of whom later became authorities in the field. Differently from their contemporary Chinese colleagues (such as Lao Gan), who mainly focused on the written content of the excavated texts and used them to examine the transmitted texts, the Kyoto reading seminar led by Mori Shikazō paid particular attention to the excavation locations and material features of these texts. As noted by Fujieda Akira, this research approach was inspired by Japanese 'ancient manuscript studies' (komonjogaku 古文書学). ${ }^{84}$

A large number of ancient manuscripts is preserved in Japan, especially those from the seventeenth century onward. Japanese ancient manuscript studies emphasize the close examination of the original materials, including aspects such as preservation status, appearance, handwritings, and written formats of the manuscripts. Due to this research emphasis, Momiyama Akira 籵山明 (b. 1953) claims that Japanese ancient manuscript studies could therefore be identified as a sub-branch of historical studies, museum studies, or even field studies. ${ }^{85}$ Without direct access to the original materials, the first and second generations of Japanese scholars of the Juyan wooden manuscripts examined the excavation locations, written content and material features of these manuscripts based on the archaeological report. ${ }^{86}$ Using this method, Nagata Hidemasa categorized and identified different types of Han frontier account books and recovered the terminologies and written formats seen in these account books. ${ }^{87}$ Following this research emphasis, later Japanese scholars such as Tomiya Itaru 冨谷至 (b. 1952) and Momiyama Akira kept paying attention to the material features of the unearthed ancient texts, which was often neglected by

\footnotetext{
83 The delay in publication of the excavated texts appears to have greatly improved since the late 1990s. But there are still some materials which were excavated more than 30 years ago but still have not yet been fully published. For example, scholars are still waiting for the full publication of the legal texts excavated from tomb no. 336 at Zhangjiashan in the 1980s.

84 See Fujieda Akira's preface in Nagata 1989.

$85 \mathrm{Su}$ and Chen 2017.

86 Michael Loewe's foreword in Ōba 1993.

87 Nagata 1989.
} 
their contemporary Chinese colleagues. ${ }^{88}$ Examining the notches carved on the Juyan and Dunhuang wooden tallies held by the Academia Sinica in Taiwan and the British Museum in the United Kingdom, Momiyama Akira achieved groundbreaking research results in 1995. He successfully deciphered the numerical meaning represented by different shapes of these notches, which explored the administrative and economic messages hidden in the material features of these manuscripts. ${ }^{89}$

The reading seminar tradition and the insights drawn from Japanese ancient manuscript studies have now become an advantage for Japanese scholars who are engaged in the studies of excavated Chinese manuscripts. Much individual research is actually based on the collaborative work of the reading seminars. ${ }^{90}$ The reading seminar tradition also offers a chance for graduate students and junior scholars to study with the senior scholars in the field. In response to the rapid increase of unearthed ancient manuscripts, it appears that scholars in mainland China, Taiwan, and Hong Kong have started to adopt this reading seminar tradition. For example, responding to the call by Xing Yitian in 2005, scholars and graduate students in Taiwan formed a reading seminar to study the legal texts excavated from tomb no. 247 at Zhangjiashan once every month. In Beijing, under the guidance of Ma Yi and Zhang Rongqiang 張榮強 (b. 1973), since 2008 graduate students and junior scholars at various academic institutes have gathered together to study the newly excavated texts. They have already finished reading the Juyan materials excavated in the 1970s. Due to the new findings from the Wuyi square 五一廣場 in Changsha 長沙, scholars and graduate students at the Department of History at the Chinese University of Hong Kong have recently formed a new reading seminar under the direction of Li Mingzhao 黎明釗 (b. 1956). These reading seminars emphasize cross-checking of the writings of the original materials on the photos against the transcriptions provided in the archaeological reports and paying attention to the preservation status and material features of the ancient Chinese manuscripts. It can be expected

88 Xing Yitian 邢義田 (b. 1947) is one of the few scholars who has paid enough attention to the material features of ancient Chinese manuscripts. This is probably due to his comprehensive training of Roman epigraphy and history at the University of Hawai'i with Michael P. Speidel (b. 1937); e.g., Xing 2011, 1-50. Since the discovery of the meaning of the lines carved on the verso side of bamboo manuscripts by Sun Peiyang 孫沛陽 in 2011, Chinese scholars started to put significantly more energy into the study of the materiality of ancient manuscripts, Sun 2011.

89 For a revised version of this study, see Momiyama 2015, 17-61.

90 There are now at least two active reading seminars of excavated ancient Chinese texts in Japan which are respectively led by Miyake Kiyoshi 宮宅潔 (b. 1969) at the Kyoto University and A. H. Hafner 陶安あんど (b. 1968) at the Meiji University 明治大学. Some of the research results of the reading seminar participants are now available on their official websites. See Shin dai shutsudo moji shiryō no kenkyū 秦代出土文字史料の研究: http://www.shindai.zinbun.kyoto-u.ac.jp/index.html; Chūgoku kodai kan doku no ōdan ryōiki teki kenkyū 中国古代簡牘の横断領域的研究: http:// www.aa.tufs.ac.jp/users/Ejina/contempory.html. 
that these reading seminars will be the places where many new issues and problems in the studies of Qin and Han economic history are raised in the future. ${ }^{91}$

\section{Conclusion}

The discussion above contextualized the writing of Qin and Han economic history in the development of modern Chinese and Japanese historiographies. The cultural interaction between China and Japan can be traced back to the third century when Japan was still under the formation process of an early state. ${ }^{92}$ But this sort of interaction was not equal as Japan always played the role of cultural receiver while China stood as the source of civilization. This situation completely changed in the late nineteenth century when Japan defeated China during the Sino-Japanese War. The shift in intellectual and cultural exchange between China and Japan also changed the ways they viewed Chinese history. The establishment of tōyoshi as a new discipline in Japan and the revolution of traditional Chinese historiography were direct responses to such changes. As discussed above, research into Qin and Han economies in mainland China, Taiwan, Hong Kong, and Japan then followed different paths in the last century as responses to the political and intellectual changes. During the Cultural Revolution, scholars in mainland China were isolated from the outside world due to intense political movement. The direct interaction between scholars in mainland China and Japan gradually resumed when the PRC's government changed their focus on economy rather than politics from the late 1970s onward. We can observe that the intellectual and cultural exchange between China and Japan in recent years no longer flows in one direction, neither merely from China to Japan nor from Japan to China. Chinese and Japanese historians are able to exchange their thoughts and methodologies on Qin and Han economies while developing their own advantages based on their historiographical traditions.

\section{References}

Chen Guowei 沈國威. 2007. “Shidai de zhuanxing yu Riben tujing” 時代的轉型與日本途徑. In Wang Fansen王汎森 (ed.), Zhongguo jindai sixiang shi de zhuanxing shidai 中國近代思 想史的轉型時代, 241-270. Taipei: Lianjing chuban shiye gufen youxian gongsi.

Chen Zhi 陳直. 1958. Liang Han jingji shiliao luncong 兩漢經濟史料論丵. Xi'an: Shanxi renmin chubanshe.

91 The study of Chinese excavated texts may be usefully compared to the first 100 years of Greek papyrology where an equally strong collaborative editorial energy, and historical expertise, went into the publication of the vast material. See von Reden, ch. 8.C, this volume; Keenan 2009.

92 Piggott 1997. 
Dirlik, A. 1978. Revolution and history: The origins of Marxist historiography in China, 1919-1937. Berkeley, CA: University of California Press.

-. 1996. "Social formations in representations of the past: The case of 'feudalism' in twentiethcentury Chinese historiography." Review (Fernand Braudel Center) 19.3, 227-267.

Du Zhengsheng 杜正勝 (= Tu Cheng-sheng). 1990. Bianhu qimin: Chuantong zhengzhi shehui jiegou zhi xingcheng 編戶齊民: 傳統政治社會結構之形成. Taipei: Lianjing chuban shiye gongsi.

-. 2002. “Xin shixue zhi lu: Jian lun Taiwan wushi nian lai de shixue fazhan” 新史學之路: 兼論臺灣五十年來的史學發展. Xin shixue 新史學 13, 21-42.

Egami Namio 江上波夫. 2015. Jin dai Riben hanxue jia: Dongyang xue de xipu di yi ji 近代日本 漢學家: 東洋學的系譜・第一集. Lin Qingzhang 林慶彰 (trans.). Taipei: Wanjuan lou.

Elman, B. 2011. "Early modern or late imperial philology? The crisis of classical learning in eighteenth century China." Frontiers of History in China. 6.1, 3-25.

Fu Zhufu 傅築夫. 1981-1989. Zhongguo fengjian shehui jingji shi 中國封建社會經濟史. 5 vols. Beijing: Renmin chubanshe.

Fu Zhufu 傅築夫 and Wang Yuhu 王毓瑚, eds. 1982. Zhongguo jingjishi ziliao: Qin Han Sanguo bian 中國經濟史資料: 秦漢三國編. Beijing: Zhongguo shehui kexue chubanshe.

Gao Mingshi 高明士. 1986. Zhan hou Riben di Zhongguo shi yanjiu 戰後日本的中國史研究. Taipei: Mingwen shuju.

Guo Moruo 郭沫若. 1954. Nuli zhi shidai 奴隸制時代. Beijing: Renmin chubanshe.

Hamaguchi Shigekuni 浜口重国. 1966. Shin Kan Zui Tō shi no kenkyū 秦漢隋唐史の研究. Tokyo: Tōkyō Daigaku Shuppankai.

He Ganzhi 何幹之. 1937. Zhongguo shehuishi wenti lunzhan 中國社會史問題論戰. Shanghai: Shanghai Shenghuo shudian.

Hanshu 漢書. 1962. Composed by Ban Gu 班固 (32-92 CE). Beijing: Zhonghua shuju.

He Ziquan 何茲全. 2006. He Ziquan wen ji. 何茲全文集. 5 vols. Beijing: Zhonghua shuju. Hirose Kunio 広瀬薰雄. 2010. Shin Kan ritsuryō kenkyū 秦漢律令研究. Tokyo: Kyūko Shoin. Hsu, Cho-Yun. 1965. Ancient China in transition: An analysis of social mobility, 722-222 BC. Stanford, CA: Stanford University Press.

-. 1980. Han dynasty China. Vol. 2, Han agriculture: The formation of early Chinese agrarian economy (206 BC-AD 220). J. L. Dull (ed.). Seattle, WA: University of Washington Press.

Huang Jinyan 黃今言. 1988. Qin Han fuyi zhidu yanjiu 秦漢賦役制度研究. Nanchang: Jiangxi jiaoyu chubanshe.

Hulsewé, A. F. P. 1968. "Chinese communist treatment of the origins and the foundation of the Chinese Empire." In A. Feuerwerker (ed.), History in communist China, 96-123. Cambridge, MA: MIT Press.

Kakinuma Yōhei 柿沼陽平. 2011. Chūgoku kodai kahei keizaishi kenkyū 中国古代貨幣経済史研究. Tokyo: Kyuko Shoin.

Katagiri Kazuo. 1982. "The rise and development of Dutch learning (Rangaku 蘭学) in Japan.” Acta Asiatica 42, 1-17.

Katō Shigeshi 加藤繁, trans. 1942. Shiki heijunsho kanjo shokukashi 史記平準書・漢書食貨志. Tokyo: Iwanami Shoten.

-. 1948. Chūgoku keizaishi no kaitaku 中國經濟史の開拓. Tokyo: Ogiku Shoin.

-. 1952-1953. Shina keizaishi kōshō 支那經濟史考證. 2 vols. Tokyo: Toyo Bunko.

-. 1959. Zhongguo jingjishi kaozheng: Di yi juan 中國經濟史考證・第一卷. Wu Jie 吳杰 (trans.). Beijing: Shangwu yinshuguan.

Keenan, J. G. 2009. "The history of the discipline." In R. Bagnall (ed.), The Oxford handbook of papyrology, 59-78. Oxford: Oxford University Press.

Lao Gan 勞翰 (= Lao Kan). 1976. Lao Gan xueshu lunwenji: Jiabian 勞榦學術論文集：甲編. Taipei: Yiwen yinshuguan. 
Li Genpan 李根蟠. 1999. “Ershi shiji de Zhongguo gudai jingji shi yanjiu”二十世紀的中國 古代經濟史研究. Lishi yanjiu 歷史研究, no. 3, 126-150.

Li Jiannong 李劍農. 1962. Xian Qin liang Han jingji shigao 先秦兩漢經濟史稿. Beijing: Zhonghua shuju.

Li Xueqin 李學勤. 2003. “Chudu Liye Qin jian” 初讀里耶秦簡. Wenwu 文物 no. 1, 73-81.

Liang Gengyao 梁庚堯. 2003. “Cong ‘Dushu zazhi’ dao ‘Shihuo’ banyuekan: Zhongguo shehui jingji shi yanjiu de xingqi” 從《讀書雜誌》到《食貨》半月刊: 中國社會經濟史研 究的興起. In Zhou Liangkai 周樑楷 (ed.), Jiewang erbian 結網二編, 285-340. Taipei: Dongda tushu gufen youxian gongsi.

-. 2005. "Lishi wei tingzhi: Cong Zhongguo shehui shi fenqi lunzheng kan Quan Hansheng de Tang Song jingji shi yanjiu” 歷史未停滞: 從中國社會史分期論爭看全漢昇的唐宋經 濟史研究. Taida lishi xuebao 臺大歷史學報 35, 1-53.

Liang Qichao 梁啟超. 1926. Yichou zhongbianyinbingshi wenji 乙丑重編飲冰室文集. Shanghai: Zhonghua shujiu.

Lin Ganquan 林甘泉. 1999. Zhongguo jingji tongshi: Qin Han jingji juan 中國經濟通史: 秦漢經濟卷. Beijing: Jingji ribao chubanshe.

Lu Yaodong 逯耀東. 1979. Zhonggong shixue de fazhan yu yanbian 中共史學的發展與演變. Taipei: Shibao wenhua chuban shiye youxian gongsi.

Luo Zhenyu 羅振玉 and Wang Guowei 王國維. 1993. Liusha zhuijian 流沙墜簡. Beijing: Zhonghua shuju.

Lurie, D. B. 2011. Realms of literacy: Early Japan and the history of writing. Cambridge, MA: Harvard University Asia Center.

Masini, F. 1993. The formation of modern Chinese lexicon and its evolution toward a national language: The period from 1840 to 1898. Berkeley, CA: University of California Project on Linguistic Analysis.

Mehl, M. 2000. “Chinese learning (Kangaku) in Meiji Japan (1868-1912).” History 85, 48-66.

Momiyama Akira 籵山明. 2015. Shin kan shutsudo moji shiryō no kenkyū: keitai, seido, shakai 秦漢出土文字史料の研究：形態・制度・社会. Tokyo: Sobunsha.

Nagata Hidemasa 永田英正. 1989. Kyoen Kankan no kenkyū 居延漢簡の研究. Kyoto: Dohosha. Nishijima Sadao 西嶋定生. 1981. Chūgoku kodai no shakai to Keizai. 中国古代の社会と経済. Tokyo: Tōkyō Daigaku Shuppankai.

-. 1986. "The economic and social history of Former Han." In D. Twitchett and M. Loewe (eds.), The Cambridge history of China. Vol. 1, 545-607. Cambridge: Cambridge University Press.

Ōba Osamu 大庭脩, ed. 1993. Kankan kenkyū no genjō to tenbō 漢簡研究の現状と展望. Suita: Kansai Daigaku Shuppanbu.

Peng Xinwei 彭信威. 1954. Zhongguo huobishi 中國貨幣史. Shanghai: Qunlian chubanshe.

Pian Yuqian 駢宇騫 and Duan Shu'an 段書安. 2006. Ershi shiji chutu jianbo zongshu 二十世紀出土簡帛綜述. Beijing: Wenwu chubanshe.

Piggott, J. R. 1997. The emergence of Japanese kingship. Stanford, CA: Stanford University Press. Qiu Xigui 装錫圭. 1997. “Cong chutu wenzi ziliao kan Qin he Xi Han shidai guanyou nongtian de jingying” 從出土文字資料看秦和西漢時代官有農田的經營. In Zang Zhenhua 㶓振華 (ed.), Zhongguo kaogu xue yu lishi xue zhi zhenghe yanjiu 中國考古學與歷史學之整合研究, 429478. Taipei: Zhongyang yanjiuyuan lishi yuyan yanjiusuo.

Quan Hansheng 全漢昇 (= Chuan Han-Sheng). 1948. “Zhonggu ziran jingji” 中古自然經濟. Zhongyang yanjiuyuan lishi yanjiusuo jikan 中央研究院歷史語言研究所集刊 10, 73-173.

Sahara Yasuo 佐原康夫. 2002. Kandai toshi kikō no kenkyū 漢代都市機構の研究. Tokyo: Kyūko Shoin.

Shigechika Keiju 重近啓樹. 1999. Shin Kan zeieki taikei no kenkyū 秦漢稅役体系の研究. Tokyo: Kyūko Shoin.

Song Xuwu 宋敘五 (= Sung Shee-wu). 2002. Xi Han huobishi 西漢貨幣史. Hong Kong: Chinese University Press. 
Su Junlin 蘇俊林 and Chen Hongyin 陳弘音. 2017. “Riben Dongyang Wenku yanjiuyuan Nishan Ming: Zai jianduxue, guwenshuxue, fazhishi yu Qin Han shi zhijian” 日本東洋文庫研究 員籵山明: 在簡牘學, 古文書學, 法制史與秦漢史之間. Wenhuibao 文匯報. February 3, 2017, W10.

Sun Peiyang 孫沛陽. 2011. “Jiance bei huaxian chutan” 簡冊背劃綫初探. Chutu wenxian yu gu wenzi yanjiu 出土文獻與古文字研究 4, 449-462.

Sun Yutang 孫毓棠. 1995. Sun Yutang xueshu lunwenji 孫毓棠學術論文集. Beijing: Zhonghua shuju.

Swann, N. L. 1950. Food and money in ancient China: The earliest economic history of China to AD 25: Han Shu 24 with related texts, Han Shu 91 and Shih-chi 129. Princeton, NJ: Princeton University Press.

Tanigawa Michiol. 1985. Medieval Chinese society and the local "community." J. A. Fogel (trans.). Berkeley, CA: University of California Press.

Tao Jinsheng 陶晉生, et al., eds. 1971-1988. Shihuo yuekan 食貨月刊. Taipei: Shihuo yuekan she.

Tao Xisheng 陶希聖, ed. 1934-1937. Shihuo banyuekan 食貨半月刊. Peiping: Xin shengming shujiu.

Tian Changwu 田昌五 and Qi Xia 漆俠, eds. 1996. Zhongguo fengjian shehui jingji shi 中國封建社會經濟史. 4 vols. Jinan: Qilu shushe.

Utsunomiya Kiyoyoshi 宇都宮清吉. 1955. Kandai shakai keizaishi kenkyū 漢代社会経済史研究. Tokyo: Kōbundō.

Wang, Fan-sen. 2000. Fu Ssu-nien: A life in Chinese history and politics. Cambridge: Cambridge University Press.

Wang Guowei 王國維. 1994. Gushi xinzheng: Wang Guowei zuihou de jiangyi 古史新證: 王國維最後的講義. Beijing: Qinghua daxue chubanshe.

Wang Lixi 王禮錫 and Lu Jingqing 陸晶清, eds. 1990. Zhongguo shehuishi de lunzhan 中國社會史的論戰. Shanghai: Shanghai shudian.

Wang Qingjia 王晴佳. 2003. “Zhongguo jindai ‘xin shixue’ de Riben beijing: Qing mo de 'shijie geming' he Riben de “wenming shixue” 中國近代「新史學」的日本背景：清末的

「史界革命」和日本的「文明史學」. Taida lishi xuebao 臺大歷史學報 32, 191-236.

Wang, Q. E. (= Wang Qingjia). 2001. Inventing China through history: The May Fourth approach to historiography. Albany, NY: State University of New York Press.

Watanabe Shinichirō 渡邊信一郎. 2010. Chūgoku kodai no zaisei to kokka 中國古代の財政 と國家. Tokyo: Kyūko Shoin.

Wilbur, C. M. 1943. Slavery in China during the Former Han dynasty, 206 BC-AD 25. Chicago, IL: Field Museum of Natural History.

Xie Guihua 謝桂華 and Zhou Nianchang 周年昌, eds. 1985. Qin Han wujia zilao jilu 秦漢物價資料輯錄. In Zhongguo gudai shehui jingjishi ziliao 中國古代社會經濟史資料. Vol. 1. Fuzhou: Fujian renmin chubanshe.

Xing Yitian 邢義田 (= Hsing I-tien). Di bu ai bao: Handai jiandu 地不愛寶：漢代簡牘. Beijing: Zhonghua shuju.

Xu Guansan 許冠三. 2003. Xin shixue jiushi nian 新史學九十年. Changsha: Yuelu shushe.

Xu Zhuoyun 許倬雲 (= Cho-Yun Hsu). 2011. Jiashi, guoshi, tianxiashi: Xu Zhuoyun bashi huigu 家事、國事、天下事: 許倬雲八十回顧. Hong Kong: Chinese University Press.

Yamada Katsuyoshi 山田勝芳. 1993. Shin Kan zaisei shūnyū no kenkyū 秦漢財政収入の研究. Tokyo: Kyuko Shoin.

Zhang Jihai 張繼海. 2006. Han dai chengshi shehui 漢代城市社會. Beijing: Shehui kexue wenxian chubanshe.

Zhang Jinguang 張金光. 2004. Qin zhi yanjiu 秦制研究. Shanghai: Shanghai guji chubanshe.

Zhou Yunxi 周筠溪. 1936. “Xi Han caizheng zhidu zhi yiban” 西漢財政制度之一班. Shihuo banyuekan 食貨半月刊 3.8, 8-36. 


\section{Trends in Economic History Writing of Early South Asia}

\section{Introduction}

Economic history writing in India had its origin in the controversies over the effects of British rule and its consequences for the Indian economy. ${ }^{1}$ Within the first three decades of the twentieth century, it became an established discipline, with economic processes in the ancient period also receiving some attention. This essay will present the major trends of economic history writing within the wider context of Indian historiographical traditions. ${ }^{2}$

Indian historiography experienced several phases of dominant schools of history writing: imperialist/colonial, nationalist, Marxist, post-structural, postcolonial, etc. However, a strict evolutionary account of schools of historical scholarship would be inappropriate. First, it would assume that these schools were successive to one another, and may give an impression of hidden commonalities running through all these modes of historiography. Second, it would obscure many overlaps among these schools. Third, some practitioners have continued to work with a method deemed obsolete by fellow historians and, fourth, it would elide the question of why particular positions or methods were more stable than others. ${ }^{3}$ Considering these problems, the current chapter attempts to chart out the trends in history writing of India without assuming a chronological succession of different schools of thought.

\section{Beginnings and Developments in History Writing}

\section{II.1 The Scientific West and the (Missing) History of India}

The aim of the earliest enthusiasts of the Indian past was to make India legible to the West. In this process, colonial and scientific motives became merged, making it

\footnotetext{
1 Habib 2009, 3; Seshan 2007, 164-166. The earliest works included various essays and monographs by M. G. Ranade (1842-1901, one of the founding members of the National Congress Party), Dadabhai Naoroji (1825-1917, Parsi scholar and Liberal Party member of the British Parliament) and Romesh C. Dutt (1848-1909, civil servant).

2 Morris and Stein 1961; Sharma and Jha 1974; Chakravarti 2001; Chattopadhyaya 2003, 217-232; Ray 2011; Basant 2012, 4-54.

3 For further discussions on issues of historiography, see Chattopadhyaya 2003, 3-4; Seshan 2007, 158-160.
}

Ә Open Access. () 2020 Mamta Dwivedi, published by De Gruyter. (c) BY-NC-ND This work is licensed under the Creative Commons Attribution-NonCommercial-NoDerivatives 4.0 License.

https://doi.org/10.1515/9783110607741-024 
difficult to distinguish between the two. ${ }^{4}$ Some notions and understandings of the Indian people and their religion had already interested Western audiences through the works of the Jesuits, followed by the Dutch and German Protestants. Already before the administration of India under the British East India Company, three comprehensive Sanskrit grammars had been produced in the seventeenth and eighteenth centuries by Jesuit missionaries. ${ }^{5}$ In the 1770 s Governor General Warren Hastings provided the impetus for the production of Orientalist knowledge, aiming to understand the laws, norms, and customs of the natives. His Judicial Plan of 1772 resolved to adhere to laws in "the Shaster with respect to Gentoos" and "Koran with respect of Mahometans." 6 This was the period when ancient texts were explored, and Indologists interested in knowing about India's past translated many works. Hastings's patronage of the production of the Purānārthaprakāśa, an abstract of history from the Sanskrit purānas, in 1784 was a clear move toward it. ${ }^{7}$ The aim was to bring forth the true and pristine understanding of the past as presented in the ancient books.

Inquiries into the Indian past by Western antiquarians and scholars started through individuals' interests in exploring material treasures and cultural difference. They started with translation exercises and geographical surveys, and eventually developed history writing as an institutional field of inquiry. Modern academic disciplines, especially philology and archaeology, were introduced in order to understand India's historical past. They took a more organized form with the formation of the Asiatic Society (1784) under the presidency of William Jones at Calcutta. From 1788, the Society published its transactions, called Asiatick Researches, which were to appeal to all the "naturalists, chemists, antiquaries, philologers, and men of sciences from different parts of Asia" to "commit their observations to writing, and sending them to the Asiatic Society at Calcutta."8 However, to the enthusiasts of factual history, the purānas soon appeared to be disappointing because of their lack of credible history. The succession of kings that was extracted from the purānas had no place in Western historical chronologies, as the Indic concept of time could not be linked to Western concept of history and chronology. To the Western minds of the eighteenth century, for whom the world was only a few thousand years old, references to millions of years in Indian traditional chronologies seemed useless. ${ }^{9}$

4 Trautmann and Sinopoli 2002, 494.

5 The three complete Sanskrit grammars were composed by Fathers Heinrich Roth (1620-1668), Johann Ernst Hanxleden (1681-1732) and Jean-François Pons (1698-1752?). These have been preserved in European libraries and monasteries as the earliest tangible products of cross-cultural and intellectual interchange (Van Hal 2016, 99).

6 Rocher 1994, 220-221.

7 Trautmann and Sinopoli 2002, 496; Rocher 1983, 48-72.

8 These words of William Jones became the credo of the Asiatic Society. This was quoted on the cover pages of the Journal of the Asiatic Society of Bengal.

9 Trautmann 2009 25-52, 155-188. It was with the time revolution of the 1850s and 1860s, along with Charles Darwin's works (1859 and 1871) on the theory of evolution, that the proposed human 
The early nineteenth-century scholars were baffled and simultaneously disenchanted by the disparity they saw between the material remains and the descriptions in the texts. This became the main reason for early antiquarians to declare that Indians lacked a "sense of history." The fact that ancient Indian literature failed to establish a political chronology that could be tested against and corroborated by the Western chronology led them to refer to the texts as unhistorical and mythological. ${ }^{10}$ James Mill's 1817 History of British India made a strong case for justifying British rule in India by referring to Indian stagnation and inability to change. Furthermore, the works of Max Müller in the 1850s, including A History of Ancient Sanskrit Literature in 1859, had put forward the image that Indians were unconcerned with the material world and that their thoughts and ideas were focused more toward the religious and transcendental sphere. The indigenous literary texts are described as "religious and semi-religious," which "threw only a very dim light on secular affairs." 11 Their value as historical sources was further reduced because their composition could not be assigned to any single period in time. ${ }^{12}$ In all, this pointed to a lack of scientific temperament and spirit of enterprise. The scientific and dynamic Occident had come into contact with a stagnant and religious Orient. This idea was reiterated in the new educational policy under Governor General William Bentinck during his office between 1828 and 1836. He favored Western knowledge over indigenous forms of learning, and thus the government funding for printing ancient texts almost stopped. ${ }^{13}$

The image of a stagnant and primarily rural India gained further currency from the mid-nineteenth century onward with Karl Marx's conceptualization of the Asiatic mode of production. ${ }^{14}$ India served as a fine example through which he explained it. Among the characteristics of the Asiatic mode of production were the absence of private ownership of land, as all land was state owned; the predominance of village economy with occasional towns functioning more as military camps or administrative centers than commercial hubs; self-sufficient and closed village economies meeting their own agricultural needs and manufacturing essential goods; a lack of surplus for exchange, fostered by the state that collected large shares of the surplus used by a despotic ruler for his luxurious life; complete subjugation of rural communities; and control over the irrigation works by the state. Further developments of the Marxist approach to the Indian past were to dominate the narrative of Indian history even much later, as we will see below.

history could be dated beyond a few thousand years. Until then the biblical narrative provided a short chronology of human history.

10 Yelle 2013, 3-70.

11 Majumdar 1960, xi.

12 Majumdar 1960, xi.

13 Seed 1952.

14 See also Fabian, ch. 13, this volume. 
While the Hindu texts were considered devoid of historical fact, the only respite scholars could draw was from Buddhist literary sources, especially the Pali chronicles of Sri Lanka. These texts gave them the additional satisfaction of relating the information from texts to the material evidence of monuments like stūpas, vihāras, and other extant buildings. Moreover, Western Indologists could corroborate the information they gained from Buddhist texts with the accounts of Chinese pilgrims like Faxian (early fifth century CE) and Xuanzang (seventh century CE).

The early nineteenth century was also the period of exploration and research. Central Asia was explored by Captain Alexander Burnes, Kabul by Charles Masson, the Punjab region by Jean-Baptiste Ventura and Claude Auguste Court, and Sarnath by Alexander Cunningham. This spurt of explorative energy led to the first collections of coins and other antiquities, mostly from Buddhist sites. Various geographical surveys by officials of the East India Company had brought to light a variety of material remains, most notably the inscribed stone edicts soon to be attributed to Aśoka, but also the copper plate inscriptions, architectural remains, and coins. James Prinsep deciphered two ancient scripts of India between 1834 and 1835. These scripts were named Brāhmī and Kharoșțīi. The decipherment enabled the identification of the Aśokan edicts, as well as the identification of the Kuṣānas, Indo-Greeks and many other ruling dynasties from their numismatic issues. ${ }^{15}$

Alexander Cunningham, often regarded as the father of Indian archaeology, found material remains to be reliable sources offering some glimpses of the past. His inclination is visible in the proposal he made to increase archaeological investigation instead of engaging in texts only. ${ }^{16}$ Pointing to the absence of any reference to Buddhism in the Brahmanical texts, he considered that separate research on Buddhist history was important. Cunningham had proposed establishing a centrally organized body that would introduce a systematic process of explorations and excavations of Buddhist sites. His endeavors resulted in the establishment of the Archaeological Survey of India (ASI) in 1861. Throughout his writings, he showed a special interest in what he called "the Buddhist period of India." For the study of the geography of the period, he used the paths followed by Alexander during his campaigns in the northwest and the travels of the Chinese pilgrim Xuanzang. ${ }^{17}$

Enthusiasts of history also relied on the identification of historical figures and places known from Graeco-Roman sources, one example being Alexander of Macedonia. ${ }^{18}$ For Indologists searching for historical facts, the classical Western accounts had better value as historical sources, because they had ascribable dates and accounts of a nonreligious nature. Alexander's campaigns appeared as the only undisputed historical point of reference, and his account of India as the only reliable

15 Dwivedi 2015, 210-211.

16 Cunningham 1848.

17 Cunningham 1871, 104.

18 Potts and Ray 2007. 
source of history. By the beginning of the twentieth century, the two historical phenomena that marked Indian civilization were the Buddha and Alexander. This was clearly visible in V. A. Smith's famous work from 1908, The Early History of India.

\section{II.2 Restoring Indian Past: Beginnings of Economic History Writing}

The turn of the twentieth century brought two revolutionary discoveries that changed the course of Indian history writing. One was the discovery of the Kautiliza Arthaśāstra (KA) in 1905; the other was the archaeological discovery of the Indus Valley Civilization of the Bronze Age in the 1920s. The latter pushed back the antiquity of India as a civilization to the third millennium BCE, while the $K A$ proved ancient Indians as capable of scientific and rational thought.

The $K A$, a political and economic manual dated to the Mauryan period, represented a model of a well-developed centralized state. ${ }^{19}$ The text was used to study the Mauryan fiscal economy, and demolished the long held assumption of an everapolitical India of social stagnation, lacking a sense of history, and ruled by Oriental despotism. ${ }^{20}$ The Indian political past was now considered on par with that of the European civilizations, and there were parallels to be drawn with the Greek and Roman political philosophies. The practice of drawing parallels was quite typical in early conventional interpretations of the $K A$ and must be seen as a reaction to the European superiority complex and obsession with the unique greatness of ancient Greece and Rome in the field of politics and economics. ${ }^{21}$ The traditional Indian political understanding could now be compared with the political theories of Machiavelli, Plato, Aristotle, and other Western political thinkers. ${ }^{22}$

These two findings influenced indigenous history writing in the early part of the twentieth century as well. Indian scholars set out to "restore to Indians their lost past, and instil in them a sense of pride in their own ancient heritage," and explicitly prove "that India had traditions, especially of government, no less than those of Britain, and therefore was capable of governing itself." 23 The newly discovered $K A$ was one of the important reasons that various works on economic history, with special reference to the fiscal economy, were being written between the 1930s and 1940s. The scholarship that was produced to restore the image of India's past has been named the nationalist school of history. They brought related topics into

19 See Dwivedi ch. 10.A, this volume. For an evaluation of the use of the text to study the monetary system of the Mauryan period, see Bhandare 2012.

20 Voigt 1966, 51, 65. For Oriental despotism, see below. See also Fabian, ch. 13; Morris, ch. 16, this volume.

21 Voigt 1966, 51.

22 Keith (1920) 2002, 452-453; Krishna Rao 1953.

23 Seshan 2007, 155-178. 
discussion such as agrarian structures, property ownership, urbanism, city planning, and long-distance trade. These will be discussed later in this chapter.

The early twentieth century also saw a participation of many Marxist scholars in the writing of Indian history. The earliest critique of the idea of the West along cultural, political, and evolutionary economic lines came from Marxist Orientalism. As the West represented modern commerce, world trade, territorial acquisition, and capitalist rationality, a contrast and opposition to this was drawn with Asia, especially India, in the narratives of the leftist Orientalists. Theodor Lessing's Europa und Asien (1915) was a work against Eurocentricism. He argued for the comparative study of the Chinese, Indian, Islamic, Jewish, and Persian civilizations, which presented rich and sophisticated "cultural wholes." ${ }^{24}$ Criticism of Eurocentric approaches also became favorable among Indian scholars.

It was mainly the Marxist criticism of Eurocentrism that attracted the Indian scholars to the idea of economic determinism in history writing. Marxist and neoMarxist approaches appeared in the 1940s, however they gained prominence only after independence. Two of the earliest proponents of Marxist methods of history writing were D. D. Kosambi and Mohammad Habib. Mohammad Habib took up the study of the medieval period, challenging the prevalent notion that the medieval Indian state was a theocratic one. D. D. Kosambi was the first to move the focus of history from political events and dynasties to the study of Indian society and economy. He was the first scholar to apply methods of structural functionalism, placing the religious texts in their temporal and social context. His contribution also lies in the bridging of historical archaeology and history, considered until then to be a mismatch. His methods focused on contextualizing sites and settlements in their surroundings in order to understand the continuities of traditions. He was also among the earliest scholars to have brought into use literary sources that had been disregarded earlier because of their religious content and lack of facts or empirical data. To a large extent, Kosambi's work marked a turning point in Indian historiography away from the positivist method that had been used by both imperialist and nationalist historians.

\section{II.3 From Economic to Cultural History and Other Criticisms}

Edward Said's Orientalism, published in 1978, fundamentally reshaped the historiography of Third World countries. It questioned the Western methods of writing the past, and in particular the concepts and theories produced in the colonial period. It also led to a certain decline in economic history writing in favor of cultural studies, marginalizing questions of the political economy of the state. Cengiz Kurlı noticed

24 For a detailed discussion, see Manjapra 2014, 175-179. 
the shift in Ottoman studies from economic to socio-cultural aspects. ${ }^{25}$ As historical agency had been recast as indigenous, the scope and questions of the studies are more focused on regional and local processes, moving away from the grand empirebased Eurocentric models.

In the Indian context, state-centric economic history was also regarded as obsolete by Tirthankar Roy in the 1990s. His criticism was directed above all against Marxist methods of economic history writing. The period between 1950 and 1990 had been a phase of socialist leaning, leading to economists seeing a great relevance in history. The collaboration of historians and economists was a marked phenomenon of this period. Yet economic history underwent a decline during the post-socialist period and the shift of India to a modern market economy. ${ }^{26}$ Works on the modern/ colonial economic history of India had placed the colonial state at the center. The state had also been an important focus of Marxist historiography. Not only did this model see empires as agents of economic change, but any absence of powerful political structures or states was regarded as correlating with rural, self-sustained, and closed economies, in all their negative senses. It was after the publication of two volumes of The Cambridge Economic History of India in 1982 that the relevance of state-centric economic history came to be questioned. One of the reviewers of the volumes accused the authors of being stuck in the methodologies of the 1960s and suggested that the economic history writing elsewhere had moved on. ${ }^{27}$ Since the discipline of economics abandoned the paradigm of political economy in the phase after economic liberalization, historians of a Marxist conviction and reformist economists had little to say to each other. Yet this does not mean that the state has become immaterial to the study of economic history. Rather, the state is seen to be important to any discourse of long-term economic change. Roy perceives the relationship between economics and history that created state-centric history both as a product of the political needs of the period and as a tool for inspiring public policy:

\footnotetext{
The belief in politically induced market failure served as a strong link between the past and the present in the Nehruvian era. Economists and historians both invested 'market failure' with foundational status in their respective analytical systems. Economists and historians agreed that markets and the open economy were instruments that needed to be restrained, if used at all. Historians thereby gave meaning to a regime that intervened heavily to restrain market forces and international relations ... Historiography, in other words, supported the political establishment. The ruling historiography, furthermore, was singularly compatible with the ruling economic sentiment that upheld an insular and state-dominated development strategy. ${ }^{28}$
}

The echoes of postcolonial narratives influenced the study of ancient history as well. Various authors raised questions about the ways history was written and the

25 Kirli 2014.

26 Roy 2004, 3238.

27 Perlin 1988.

28 Roy 2004, 3240. 
problems associated with the methods and theories within their fields. Postmodernism and postcolonialism brought about a loss of the sense of absoluteness of Western accounts of history. In an important essay on general ancient history writing, titled "The study of early India," B. D. Chattopadhyaya identified many problems of the colonial and West-centric approaches to history. ${ }^{29}$ He pointed to the disjuncture between precolonial modes of history writing and the ways Indology developed in the eighteenth century, and how this had affected the shaping of the cultural consciousness of India itself. The major premises that seemed to govern our historical thinking today were all rooted in the colonial past. Neither the itihāsa-purāna tradition, which is representative of the historical thought of early India, nor, for that matter, the Islamic distinction between a pre-Islamic barbaric past and the birth of a true history with the rise of Islam can explain how history is categorized and periodized in the present time. ${ }^{30}$ Although Chattopadhyaya stresses the difference of Indian sources and methods of historiography, he does not argue for a correct indigenous perspective vis-à-vis colonial ones. 'Eastern' and 'Western' ideological approaches were difficult to disentangle, and perhaps this is not required. While he acknowledges the limitations and hegemonic aspects of colonial historiography, he does not imply that only Indians should produce their own 'national' histories. In fact, he warns that in doing so there would be the great danger of inverting hegemonization, that is, reverse hegemonism. Reverse hegemonism is the assumption of a natural cultural and spiritual superiority of Indians. This, too, would be undesirable according to Chattopadhyaya.

Over the last decade, historiographical studies have very consciously placed scholarship and ideas in their historical contexts. These include discipline-reflexive or discipline-critical studies. One example is the collection of essays by Trautmann. ${ }^{31}$ These essays explore the encounters of Western rationalism and Indian philosophies. They illustrate how Western scholars struggled with the Indian concepts of time, history, chronology, and identities. Various essays position Western philologists and historians in their social, religious, and ideological background.

Another interesting work is that of Robert Yelle. ${ }^{32}$ Questioning the secular and rational nature of science, and of the historical disciplines in particular, he does not consider rationality and rationalism devoid of religion. Rather, what was commonly regarded as rationality represented the inheritance of one particular religious culture, Protestant Christianity. The study of colonial encounters helped to add some historical perspective to inherited ideas, which were neither rational, nor secular, nor universal, nor ineluctable. ${ }^{33}$ Demonstrating how the Indian past, literature, and

29 Chattopadhyaya 2003, 3-5.

30 Chattopadhyaya 2003, 4.

31 Trautmann 2009.

32 Yelle 2013.

33 Yelle 2013, $x$. 
religion were viewed by its outsiders, he shows the non-secular nature of Indology in British India. Indian religion, moreover, was confronted with comparable criticism as applied to Catholic and Jewish religions by Protestants in between the seventeenth and nineteenth centuries.

Another discipline-reflexive work is that of Adluri and Bagchee. ${ }^{34}$ Adluri and Bagchee question history as an enlightened, nonpolitical, and nonideological science. They explain how the claim that history was scientific and rational dominated the narratives about Europe's encounter with the Orient. Focusing on the discipline of Indology, and German Indology in particular, Adluri and Bagchee argue that these works were radically theological, though capturing the imagination of Indologists throughout the globe as being objective and scientific. One example for Adluri and Bagchee is the method of textual criticism. This method aimed to establish the original version of a text free of later corruptions. But this approach to Sanskrit texts was entirely inappropriate, being informed instead by neo-Protestant biblical studies and text exegesis, where the establishment of the true word of the Bible formed the primary intellectual and spiritual goal. ${ }^{35}$

\section{Topics and Questions in Indian Economic History}

The theories and frameworks of the history writing of early India draw heavily from the models and methods adopted from the study of history, but other disciplines, such as archaeology, anthropology, economics, sociology, philology and linguistics, philosophy, etc., were also influential. Although my discussion here focuses on economic history writing between $300 \mathrm{BCE}$ and $300 \mathrm{CE}$, it is difficult to separate issues related to this period from those of the centuries before and after. ${ }^{36}$ For example, the study of urban centers and processes of urbanization in ancient India needs to be contextualized within the concepts of first urbanization (the Bronze Age Indus Valley Civilization), second urbanization (sixth century BCE to fourth century CE), and another phase of urbanization with the coming of Islam (eight/nineth to eleventh/thirteenth century $\mathrm{CE}$ ). Moreover, centralization and feudalization of econo-

34 Adluri and Bagchee 2014.

35 Adluri and Bagchee trace the origin of textual criticism to Johann Salomo Semler (1725-1791). Whereas orthodoxy taught that the Bible and the dogma were absolute, Semler suggested that there were in fact different temporal and spatial layers. With this approach, the content of the books of the Bible were localized and temporalized. This was done in order to be able to free the Bible of its local and temporal components and to identify its true content for "the moral betterment of humanity" (Adluri and Bagchee 2014, 12-14).

36 Some works discussing the development of economic history writing about ancient India are: Morris and Stein 1961; Sharma and Jha 1974; Chakravarti 2001; Chattopadhyaya 2003, 217-232; Ray 2011; Basant 2012, 4-54. 
mies were discussed in the context of debates over state formation processes and the rise and fall of empires more generally. And finally, research on foreign contacts and their economic impact was informed by research on other historical periods and projected onto ancient times using various modern theoretical approaches.

It is important to draw attention to the problem of periodization in Indian history at this juncture. What demarcates a transition and the beginning of a new period is still baffling historians. ${ }^{37}$ The Indian past was presented to the world for the first time by James Mill in 1817. He distinguished three periods, Hindu, Muslim, and British. Over a period of time this came to be replaced by another scheme of periodization, ordering history into ancient, medieval, and modern periods. The new method indicated that the transition from one period to another was no longer related to political transformation alone, but to the socio-economic shifts that were brought about by them. Transformation was framed in terms of the economic, social, and political dynamics of the period, and processes of urbanization and ruralization were alligned with the rise and fall of empires. However, the underlying notion of transition remained the same as in Mill's scheme: the medieval period and the economic changes brought about by it were marked by the coming of Muslim rule, and the modern period began with rule of the British from the mid-eighteenth century onward.

The ancient period is further subdivided into protohistoric (Bronze Age or Indus Valley Civilization), early historic (sixth century BCE to fourth/sixth century CE), and early medieval (seventh to eleventh/thirteenth centuries). The period of $300 \mathrm{BCE}$ to $300 \mathrm{CE}$ thus falls into the middle of the early historic phase. Even though poorly defined, the term 'early historic' has been commonly accepted in academic writing. Yet R. S. Sharma was the first to point to the ambiguity of the term 'early' and the problems of definition arising from its use. ${ }^{38}$ To him the use of the terms 'early historical' and 'early medieval' in archaeological reports was an advancement over previous attempts of periodization; however, their precise meaning in terms of chronology, concept, and material culture remained unexplained. This problem was also raised by B. D. Chattopadhyaya in relation to archaeological sites. He criticized especially the sweeping use of 'early historic' across the subcontinent where particular characteristics of material culture occurred at different times. The lack of definition of what cultural assemblage qualified a period or stratum as being early historic made the terminology highly ambiguous. As a result, there is always the possibility of stretching the term far beyond the concerns and technicalities of archaeology. ${ }^{39}$

37 This can be seen in a recent publication that attempts to disentangle the problems of periodization and questions regarding defining transitions in course of South Asian history (Seshan and Kumbhojkar 2018).

38 Sharma 1987, 3.

39 Chattopadhyaya 2008, 12. 


\section{III.1 Studies in Agricultural Society and Urban Spaces}

The nineteenth- and early twentieth-century capitalist perspectives on global history put special emphasis on the urban. As mentioned above, British writing on Indian history above all had conceived of early Indian society as mainly rural, agrarian, and stagnant. This was conceptualized in Marx's Asiatic mode of production and was reiterated by V. A. Smith in 1908. While some scholars agreed to the model proposed, others found it difficult to accept. These views were challenged within two decades by Indian scholars, who were then termed 'Nationalist' historians.

One of the earliest economic histories dealing with issues of agriculture was the compilation of six lectures by Samaddar published in 1922. He relied heavily on Indic sources, the Vedas, śāstras and sūtras, the two epics (the Mahābhārata and the Rāmāyaṇa), the Buddhist jātakas, and especially the newly discovered $K A$. The revenue and agrarian systems in ancient northern India were the subject of two publications by U. N. Ghoshal just a few years later. ${ }^{40}$ These were closely followed by Gangopadhyaya, who extensively used the $K A$ to refute various notions of exploitative state machinery and heavy taxation as suggested in the model of the Asiatic mode of production and Oriental despotism. ${ }^{41} \mathrm{He}$ also used the dharmaśāstras to show the presence of private ownership of land. While private ownership of land is now generally accepted, the question of whether water management was a state enterprise or controlled by local communities is still unsettled.

Postindependence socio-economic history writing argued against the generalized views of Indian society as an essentially rural and stagnated economy. The dharmasūtras and dharmaśāstras were brought to bear on private landownership, and the Buddhist texts became important for showing commercial activities and centers, thus challenging the notion of a stagnant, self-sustained agrarian village economy. The sixth century BCE in northern India came to be described as a dynamic urban phase where and when urbanization was closely associated with socioreligious diversity, a flourishing economy, and the emergence of trade centers. ${ }^{42}$ To a large extent, economic history writing of India at that time focused on trade, centers of exchange, and the growth of towns and cities as a result of urbanization processes. Yet, even though scholarship from the mid-twentieth century started to show the subcontinent's urban potential, the hinterland, agrarian history, and rural landscape continued to be regarded as economically stagnant and immutable. The expansion of agriculture was seen as a sign of feudal tendencies concomitant with a decline in foreign trade. ${ }^{43}$ The phases of early historical urbanization, both the

40 Ghoshal (1929) 1972; 1930.

41 Gangopadhyaya 1932.

42 Sharma 1983a, 89-135; Wagle 1995; Thapar 1992, 70-115.

43 The fourth and fifth centuries CE are seen as the period of decline in the urban centers as a result of the end of the Indo-Roman trade. Named the 'early medieval period,' it has been studied as a phase of feudalism (Sharma 1983a; 1987; Sahu 2001). 
'second urbanization' of the sixth century and the 'secondary urbanization' of the post-Mauryan period, from the second century BCE onward, were determined with reference to increasing commercial trade and monetization. These indicators of a burgeoning economy, however, were studied mostly in the nonagrarian sector.

The expansion of agriculture is not only a topic of economic interest, but also related to social and political questions. Most scholars of ancient India associate the emergence of imperial states in the Ganga valley with its fertile alluvial plains. The development of uncultivated areas was regarded as a technique of territorial expansion in the process of state formation, while agricultural expansion was correlated with increasing social complexity. In Marxist narratives, it was understood especially in terms of development of social hierarchies and an exploitative class system (more precisely the varna). The varna system, commonly translated as and equated to a 'class system,' consists of four socio-ritual hereditary groups with specific economic and social functions as prescribed in the normative texts, especially the dharmaśāstras. Social formations were studied in the light of exploitative hierarchical relations in which most of the manual labor was in the hands of the lowest socio-ritual group, the śüdras (literally meaning 'small' or 'minute'). ${ }^{44}$ These were considered the servile class who were to serve the other three higher varnas (brāhmaṇa, kṣatriya, and vaișya). Agricultural laborers were possibly also śūdras.

Other scholars focused on the issues of productivity and did not engage in the debates about state formation. One example is the work of M. S. Randhawa. ${ }^{45}$ His survey of agriculture is more encyclopaedic, starting from prehistory and moving on to types of agricultural production, allied activities, and technological progress from the third century BCE onward. The period between the first century BCE and the third century CE, in particular, was a period of technical advancement that saw better water management and the development of new practices like sharecropping, commercial cropping, multicropping, etc. ${ }^{46}$

Irrigation was another well-discussed issue in economic history. One group of scholars emphasized the role of the central state in the building and managing of irrigation works. Agricultural revenue was the main source of income for the administrative machinery in charge of the maintenance of irrigation. ${ }^{47}$ Others suggested a more community-based management of irrigation works and related it to the patronage of Buddhist monasteries. Further, monastic landlordism in Sri Lanka and their exchange relation with the laity suggested similar tendencies in areas of Gujarat and Madhya Pradesh. The expansion of Buddhist networks is also associated with the introduction of rice cultivation in central India, which requires a more consist-

44 Some works that prominently argue about the class antagonism and social constitution of the peasant society are: Sharma 1983a; 1990; Thapar 1992.

45 Randhawa 1980.

46 Randhawa 1980. See also Gopal and Srivastava 2008.

47 Ghoshal 1930; Sharma 1983b; Chakravarti 2008. 
ent irrigation system. ${ }^{48}$ Instances of the donation of wells and water tanks from Mathura ${ }^{49}$ and Gandhāra, ${ }^{50}$ as well as the presence of tanks at Kashmir Smast, ${ }^{51}$ link the water management with ritual and monastic sites. In the context of southern India and Sri Lanka, recent studies have related ancient water tanks and reservoirs more closely to settlements and mortuary sites, although their association with agriculture is not denied. ${ }^{52}$ Sri Lanka, apart from tanks, had a method called the Tank Cascade system, which is based on recycling and reuse of water through a network of small to large tanks. ${ }^{53}$

\section{III.2 Definitions of Urban Space and Urbanization}

During the 1970s and 1980s, studies in early Indian urbanization became more rigorous. These studies echoed the debates over technological determinism, on the one hand, and the importance of socio-cultural factors, on the other, which had been at the center of intellectual concerns of Western scholars in the 1950s and 1960s. Within the Indian context, the two sides of the debate related urban development to either increased agricultural surplus achieved by the use of iron technology, ${ }^{54}$ or to socio-cultural and political aspects that affected the allocation of resources. ${ }^{55}$ Even though these differences are no longer very stark, history writing may still be cate-

48 Shaw and Sutcliffe 2003b; 2003a; Shaw 2007; Shaw et al. 2007.

49 Inscription nos. 84 and 149b in Lüders 1913.

50 Falk 2009.

51 Kashmir Smast is located on the southern slopes of the northern peripheral mountain chains of the Peshawar basin in modern Pakistan. The dates of the tanks are very tentative, see Khan 2006, 29-31; 2011, 96.

52 Bauer and Morrison 2008; Morrison 2009, 3-6.

53 Brohier 1934. See also Geekiyanage and Pushpakumara 2013.

54 Kosambi (1956) 2009; (1955) 2002; Sharma 1974. In R. S. Sharma's formulation, the state and urbanism originate together and owe their beginnings to the use of iron for advanced food production techniques, which created agricultural surplus. This surplus, in turn, maintained priests, administrators, professional soldiers, the capital consisting of the ruler's establishment, artisans, traders, etc. (Sharma 1983a, 16). Urbanization was studied through various perspectives such as the simultaneous emergence of urban centers, long-distance trade routes, state formation, and often monetization. Economic determinism was also used to explain ruralization of the economy, decline of urban centers, decentralization and fragmentation of the state, and their reflection in the economy through demonetization. These were the attributes ascribed to the beginning of feudalism in India, when the decline of Indo-Roman trade was considered a reason for the decline of urban centers and monetary economy.

55 A reference to the social complexity and criticism to the economic determinism was first visible in a work of Ghosh (1973), where he argued that economic aspects are to be seen as a social product. Other criticism came from Chakrabarti (1972a; 1972b; 1992), who pointed to the dangers to implanting the Western models of enquiry in the Indian context, and urged scholars to look at the sociopolitical uniqueness of the Indian context. 
gorised into two groups: those arguing for economic determinism, and those emphasizing socio-cultural and religious factors.

The definition of 'urban' has been another issue. The use of archaeological material to trace urbanization is not new. Gordon Childe identified various determinants of urbanization in historical contexts. ${ }^{56}$ The criteria included fortification; varied crafts; luxury items of precious and semiprecious stones; the presence of script and forms of writing; indications of towns and cities in long-distance overseas trade routes; and coinage, both imperial and local. After his study, many scholars tried to apply similar criteria to understand urbanization processes in the early historical period. In response to Childe, R. S. Sharma cautioned the students of history. ${ }^{57} \mathrm{He}$ criticized the practice of identifying a site as urban just on the basis of size and population, as to him it was "the quality of material life and the nature of occupation" that was to be emphasized. Neither a large population nor the size of a settlement itself automatically qualified a site as urban. However, to a large extent the markers of urbanization in India are nuanced adaptations of Childe's characteristics. The common features in material remains that are used as identifiers of an urban site are as follows: the presence of fortification and ramparts along with coins; ${ }^{58}$ increasing and common use of iron implements; ${ }^{59}$ text, exotic ceramics, coins, glass, and nonlocal raw materials; ${ }^{60}$ burnt brick structures, ring well, and other water storing facilities; ${ }^{61}$ and foreign influences in art. ${ }^{62}$ Additionally, an urban site is expected to have a differentiated and heterogeneous space, including distinct spaces for roads, artisanal areas, religious shrines, and other types of community spaces, along with residential buildings. ${ }^{63}$

Recently, archaeologists and anthropologists have started looking at urbanization as a wider process rather than merely as an event at a given archaeological site. D. K. Chakrabarti explored the aspects of connectivity and networks by looking not only at archaeological sites but also the connectivity, routes, and corridors between urban centers. ${ }^{64}$

R. Chakravarti approached urban contexts through economic hierarchies and social processes within a space. Descriptions of cities in texts help with the visualization of processes of wealth production, accumulation, and distribution. According to Chakravarti, "cities in the early historical period are not to be regarded as a loose

56 For the ten-point model to identifying urban sites, see Childe 1936.

57 Sharma 1987, 5.

58 Morrison 1997, 90.

59 Allchin 1995.

60 Lahiri 1992.

61 Sharma 1987; Lal 1986.

62 Chakravarti 2009, 139-140.

63 Chattopadhyaya 2003, 68.

64 Chakrabarti 2010. The trade routes mentioned by Chakrabarti, however, are based on possible routes in modern times, which could be questioned. 
agglomeration of traits (i.e., exchange and administrative centers) but should be viewed as a manifestation of a process which transformed the society from a more or less egalitarian phase into a sharply class differentiated one."65

\section{III.3 Connectivity, Trade, and Empire}

As a legacy both of colonial history writing and the Marxist theory of Oriental despotism, any trade that was prolific had conventionally been viewed as trade in luxury items controlled by imperial states. The emphasis had been on grand trade networks or trade routes, which proliferated during periods of imperial expansion and declined thereafter. ${ }^{66}$ Examples were the Mesopotamian trade of the Bronze Age, Indo-Roman trade during the early Common Era, Arab trade of the medieval period, and European trade of the modern period. The trading networks of India were considered to be sporadic phenomena. After a period of booming expansion and then cooling down, a phase of ruralization followed, with later wave of urbanization leading to the reemergence of new, different trade networks. Minimal or no continuity was seen between the Harappan (Bronze Age) trade and that of the early historic period. Equally, the economic changes in the early medieval period were regarded as rather unconnected to the trade networks of the early historic period.

For a long time, specialists of Indian economic history had worked with a model of economic determinism and a focus on state-centric economic history. In 1973, Colin Renfrew argued that ancient trade was integrally linked to early state formation processes. ${ }^{67}$ The theory of trade as an agent of change also gained currency in Indian historiography. Its impact is widely prevalent in Indian economic as well as cultural historiography. Trade was associated especially with the concept of 'secondary state formation' as well as the process of 'secondary urbanization' in the hinterland of the Indian subcontinent. ${ }^{68}$ Both processes were interconnected. In the theory of secondary urbanization, urban regions impart urban traits to regions with which they come into contact. The secondary state formation model suggests that a developed state machinery propells the political structure of other pre-state societies into state formation. In the Indian context, for example, the Mauryan Empire is seen as such a state. After the Mauryas, the majority of India, if not the entire subcontinent, is seen to have gone through secondary urbanization and secondary state formation.

Empires were ascribed not only the role of uniting geography, but also of homogenizing economic systems and bringing about cultural unity. The Mauryan Em-

65 Chakravarti 2007, 39.

66 For a review and critique of this historiographic trend, see Ray 2003, 12-15; 2011; Ray and Mishra 2018.

67 Renfrew 1975.

68 Seneviratne 1981; Chattopadhyaya 2003, 66-102; Basu Majumdar 2017. 
pire is generally thought to have filled this role by centralizing the state, and thus the fiscal regime. ${ }^{69}$ Any connection of the center with a less developed region brought urban as well as administrative change to this region. This role was also ascribed to the Kuṣāna rule. This understanding is also owed to a wider tradition of archaeological research that associated artifacts with people and changes in pottery styles with changes of polities. For example, the Ganga valley in the first millennium BCE was characterized first by the "ochre colored pottery ware people," who were replaced by the "painted gray ware people," replaced in turn by the "northern black polished ware people" associated with the Mauryan polity. ${ }^{70}$ The pattern is followed in the identification of pottery type and sculpture as the 'Sunga and Kuṣāna types.' Based on these pottery types ${ }^{71}$ and on the size of the bricks, specific cultural phases, and more precisely, political phases are identified, which can be problematic. ${ }^{72}$ The Indian south, too, has commonly been understood through the model of secondary state formation as a result of Tamil contacts with the Mauryan Empire bringing about a complex state system and urbanization. ${ }^{73}$

A departure from economic determinism and state-centric economic history can be seen in the works that focus on the regional and interregional processes. The grand theories and histories of empires and their kings often overlook regional power nodes and social functionaries such as merchants, small landowners, and religious agents. ${ }^{74} \mathrm{~A}$ greater focus on regional processes, instead, sees economic transformations or urbanization in relation to the "dynamics of political and social power and in the changing religious landscape." $75 \mathrm{~K}$. D. Morrison has recommended considering the important role of religious groups regulating the long-distance travels. An example of this approach is the archaeological research in the Tungabhadra valley. The survey and excavation were aimed to investigate non-elite sites from the prehistoric to the medieval periods, landscapes of settlement, roads, temples, and agricultural facilities. ${ }^{76}$

69 Thapar 2006. For criticism, see M. Smith 2005; Ray 2008b.

70 Sinopoli, Johansen, and Morrison 2009, 11.

71 In the case of the early-historical site of Sanghol in Punjab, Ray (2010) raised a similar issue. The pottery cultures like the painted grey ware (PGW) and the northern black polished ware (NBPW) are considered styles of pottery uniquely associated with specific cultural-ethnic groups. A common example is that of Śunga-Kușāna pottery comprising the bowl, lid, inkpot, etc., without looking at internal diversity. On the basis of this kind of undifferentiated evidence, wider hypotheses about uniform urban town planning and state formation (Mani 1987). "The centralized Kushan Empire is seen as providing a foundation for the proliferation of urban settlements.” (Ray 2010, 7). 72 The introduction of burnt bricks is considered a distinct feature of Kuṣāna's standardization. Burnt bricks are associated with the urban enclaves under their rule. Ray points at the problem of such ascription. At Mathura, where 14 mounds were excavated, evidence for baked bricks is definitely pre-Kuṣāna (Ray 2010, 8-9).

73 Champakalakshmi 1996.

74 M. Smith 2005, 836; Ray 2008b, 11.

75 Morrison 1997, 88.

76 Out of the 12 monographs relating to this site, Bauer (2015) deals with the study of the economic and political complexities as visible from the landscape of the region in the early historic period. 
In several publications, H. P. Ray has proposed the study of economic questions together with social developments, in particular the close linkages of monasteries and other religious institutions with trade and credit systems. ${ }^{77}$ The settlement of Arikamedu, $4 \mathrm{~km}$ from Puducherry, grew along with the development of regional coastal networks related to the growth of trade in fish, pepper, and paddy, rather than in association with any central political elite, or as a Roman colony. ${ }^{78}$ Maritime activity had long been studied through references to foreigners in literature and their involvement in trade in luxury goods. For a long time, these methods resulted in the assumption that trade was controlled by the state. Representation of India in the Alexander historiography was the entry point for many scholars for the study of ancient India. ${ }^{79}$ Here India appeared above all as a source of luxury products for export. Ray and others have shown, by contrast, that this trade was based on much wider networks of local trade, having developed independently and trafficking in subsistence items such as timber, cloth, metal, dried fish, salt, medicines, and ritual commodities. $^{80}$

\section{III.4 Indo-Roman Trade}

The study of Indo-Roman trade has a tradition of more than a century. It was part of the broader history of the Indian Ocean associated with the commercial activities dominated by Roman actors. The presence of smaller networks of connectivity in the Persian Gulf and the Red Sea have been commonly accepted by most scholars from the fifth and fourth century BCE onward. ${ }^{81}$ However, studies of such networks have been controversial and have revolved around questions of initiative and agency, types of sources, and the nature of engagement between India and the Roman Empire.

Trade relations between India and Egypt from the third century BCE onward had already been pointed out by R. K. Mookerji in 1912. He suggested that, with the start of Roman control over Egypt from the first century BCE onward, Indian trade relations extended to the Mediterranean. Warmington's work in 1928 made Roman trade with India a matter of debate by emphasizing the Roman initiative of this trade and the Roman dominance in the Indian Ocean. Most of his findings and propositions did not remain unchallenged, although they were echoed for years. Even his contemporary, archaeologist R. G. Collingwood, had questioned his as-

77 Ray 1986; 1994a; 1994b; 2003.

78 Ray 2006, 119; 2008a, 193.

79 For a discussion on the nature of this literature, see von Reden, ch. 10.B, this volume.

80 Ray 2003, 6, 82-125; Fuller et al. 2011; Seland 2014, 386.

81 Salles 1998, 58, 66; Cobb 2018, 42. 
sumptions on navigation techniques and Graeco-Roman claims to the discovery of the monsoon winds. ${ }^{82}$

The dominance of Roman activity in the Indian Ocean was established by various finds of Mediterranean pottery at Indian sites, like Roman amphorae, terra sigillata, and what came to be called rouletted ware. After excavation of the port site of Arikamedu in 1945, Mortimer Wheeler concluded that the site was an emporion and was a merchant colony of the empire. ${ }^{83}$

In the 1980s and 1990s the dominant role of Romans in the maritime activity of the Indian Ocean was severely challenged. V. Begley's study of pottery from Arikamedu clearly contradicted the idea of Roman emporia in the Indian subcontinent. ${ }^{84}$ During this time, H. P. Ray provided a compelling new model and method of study in her monograph Winds of Change. ${ }^{85}$ She rooted maritime activity beyond trade within the religious and social context of Buddhism and Hinduism. Her subsequent works also placed maritime activity in the local cultural and religious milieu, as well as advocating for a connectivity of South Asia, Africa, and Southeast Asia older than Indo-Mediterranean connections. ${ }^{86}$ Her work has been influential for many other scholars since then.

Apart from the matters of origins and agency, the questions of what was traded and who benefited from Indo-Roman trade became an issue of discussion. The scholarship about who benefited economically from the trade may be grouped into four positions. ${ }^{87}$ The view with the longest pedigree is that the balance of trade was unfavorable for Rome, but favored India. There was an enormous inflow of gold and silver coins as attested by both Tamil sources and a famous statement by the Roman author Pliny the Elder. Another view states just the opposite: that the trade favored the Mediterranean, Egypt, and West Asia, while the outflow of coin was not a major factor for the Roman economy. Yet another view emphasizes that the concept of a balance of trade was rather alien to ancient states and could not be estimated without detailed statistics. A final point of view questions arguments about balances of trade altogether, as the trade was based simply on the demand of com-

82 Collingwood 1930; see also Evers 2017 for a brief survey of early research on Indo-Roman trade. 83 Wheeler, Ghosh, and Deva 1946; Wheeler 1954. The glorification of the Roman Empire was also glorification of the British Empire, as to a great extent the hegemonic ideas of the British Empire were validated by the claims of them as the sole inheritors of the Roman imperial mantel. The representation of the Roman dominance on their contemporaries was used to validate the British domination over others in modern time. Recent works demonstrate how the echoes of Roman imperialism were used by the British imperialists to justify their imperium. The Victorian and Edwardian traditions also had an influence on the archaeological practices even in the twentieth century. Study of Roman monuments and artifacts helped to draw the discipline of archaeology into the sphere of imperial discourses (Hingley 2000, 1-16; Ray 2008a, 187-217; Parchami 2015).

84 Begley 1983.

85 Ray 1994b.

86 Apart from various articles, two important monographs relating to this topic are Ray 2003; 2015.

87 Cobb 2018, 272-286 for further literature on these positions. 
modities from the Roman Empire to India and vice versa. Cobb suggests that silver and gold, especially in coined form, are unlikely to have been the main commodities of trade, since other commodities filling the ships, such as wine, oil, pottery, metal ore, glassware, wheat, barley, slaves, etc., had their own demand. They should not be regarded as ballast, or secondary to silver and gold coins, but as forming the greater portion of the ships' loads in total value. ${ }^{88}$

There are further arguments for dropping the labels 'Indo-Roman' or 'RomanIndian trade' for the commercial relation between the Mediterranean and South India. ${ }^{89}$ Thus Gurukkal has pointed to the fact that merchants from Roman Egypt traded with local merchants on the southwestern Indian coasts, which does not imply that trade was between two states. He points particularly to the (perhaps debatable) fact that South India was a pre-state society with little potential for stateorganized trade. Furthermore, he questions whether all transactions can be called trade. Trade and markets are neoclassical concepts, and there were very different forms of exchange contributing to the movement of goods between the Indian Ocean and the Red Sea. R. Chakravarti, while strongly supporting Gurukkal's views of dropping the labels, points out that the Roman commercial presence in India had no significant effect on local political and economic development, which should rather be sought in local dynamics. ${ }^{90}$

\section{III.5 Connectivity, Ports, and Hinterland}

The importance of maritime connections between South Asia, Indochina, and Southeast Asia, and their relationship to the wider question of commercial hinterlands of the Indian Ocean trade has often been emphasized by scholars. Even one of the earliest works on maritime connectivity explored Indian exchange relations with Southeast Asia. ${ }^{91}$ Recent works have also emphasized the need to look for communities and small participants to understand the seafaring traditions. ${ }^{92}$ The role of the Bay of Bengal in maritime relations has been studied by looking at the movement of ideas, people, and material objects. ${ }^{93}$ Salles explains the nature of the port

88 Cobb 2018, 272-286.

89 Gurukkal 2016.

90 Chakravarti 2017, 333-338; Chakravarti 2007 also emphasized the study of regional centers of exchange, such as puțabhedana, maṇapikas, and pențha, which offer glimpses into the complexity of market places.

91 Mookerji 1912. For more recent works on South and Southeast Asian maritime relations, see the edited volumes by Kulke, Kesavapany, and Sakhuja 2009; Manguin, Mani, and Wade 2011.

92 Ray 1994b; Ray and Salles 1996; Ray 2003; Ray and Mishra 2018.

93 With reference to the movement from the east coast of materials including (but not limited to) glass, flora and fauna, pottery, minerals, and metal, see Kanungo 2004; Fuller et al. 2011; Murphy et al. 2018; Tripati 2011; Tripati, Patnaik, and Pradhan 2017; Ray and Mishra 2018. 
sites on the Bengal coast as local distribution centers. He points out that the ports could be considered as centers in the sense of a Polaniyan 'port of trade,' which were centers of distribution in a frontier zone. ${ }^{94}$

The study of relationships between ports and inlands has been a dynamic field of research in the historiography of connectivity. Begley repositioned the site of Arikamedu from a standalone Roman emporion to a series of interrelated settlements along the Gingee River. Port sites like Korkai and Kaveripattinam have also been studied with respect to their connections with inland regions. ${ }^{95}$

Deloche has emphasized the importance of the fluvial connectivity of the ports, more so since the famous ports of ancient period, often understood as coastal ports, are rather at the mouth of riverine estuaries. ${ }^{96}$ The need for connectivity with inland regions is also one of the important concerns of the early ports. An example is that of the Palghat (Palakkad) Gap, which allows for a land route between two chains of hills (the Nilgiris and Anaimallai), connecting the west of the hills with the east. The Palghat Gap allows an easy passage to the east where three minor rivers drain into the Kaveri River, allowing the channelling of traffic across India from the Arabian Sea to the eastern coast of India. ${ }^{97}$ The geographic location of the corridor also reduces the need for navigation around the southern tip of the subcontinent through the shallow waters of the Gulf of Mannar, and even around the island of Sri Lanka (see ch. 3, map 1).

Further decentralization of ports and coastal locations has been recently advocated. ${ }^{98}$ Thus, the use of the term 'hinterland' to define the interior regions of southern India and the use of 'foreland' for the ports has been criticized. The commodities that passed into different regions through the Indian Ocean ports were not the produce of the littoral region. The most important commodities such as spices, timber, textile, gemstones, and metal were instead obtained from the upland and interior regions in the peninsula. The inhabitants of the inner regions had their own sociopolitical and historical contexts as well as complexities, which shaped their engagement with the merchants. The presence of traditional exchange networks and the participation of the inner land in them has been advocated by bringing the presence of nonlocal items excavated from inland sites into focus. The mortuary remains found in excavations have shown increasingly differentiated practices of production and consumption, as well as settlement configurations. ${ }^{99}$

94 Salles 2004 questions the attribution of Wari-Bateshwar (in Bangladesh) as an administrative center, economic hub, and entrepôt. Salles's criticism of the site has the potential of challenging the centralization of coastal ports in the narrative of undifferentiated long-distance exchange relations. For the concept of the port-of-trade as frontier zone space of exchange, see Curtin 1984; von Reden and Speidel, ch. 17, this volume.

95 Begley 1983.

96 Deloche 1983; 1994, 5-128.

97 Deloche 2010.

98 Bauer 2016.

99 Bauer 2016. 


\section{III.6 Merchants, Monks, and Voyagers}

While most work has concentrated on trade routes and trade connections, some important work has brought the human aspect of the movements into focus. Chandra raised the question of who was moving. ${ }^{100}$ Sea voyages and long-distance trade were conducted by caravans under the leadership of the sārthavāha. Based on the śāstras, scholars have identified the vaiśya varna (one of the four socio-ritual classes) as the merchants of the society. Their participation in the movement and trading activities, however, was not based on individual initiative, but they were organized, or organized themselves, as groups. There were various types of 'guilds' (śrenis), professional communities that have been discussed in detail by K. K. Thaplyal. ${ }^{101}$ Guilds as forms of social organization in early India were first studied by the German Indologist R. Fick, who dealt mainly with social or caste relationships prevalent in early northeastern India based on the Buddhist jātakas. ${ }^{102}$

The relation between Buddhism and urbanism has been an issue of discussion since the 1800s. However, the role of monks and monasteries as networks of exchange has been emphatically emphasized in more recent works. Kosambi had noticed the importance of Buddhist monasteries as centers of wealth and recognized their influence beyond religious matters. ${ }^{103}$ However, Ray developed the thesis of Buddhist patronage of long-distance merchants. ${ }^{104}$ The networks of connectivity and mobility facilitated through monasteries in connection with the traditional northern and southern routes, Uttarāpatha and Dakșin̄āpatha, have also been studied. ${ }^{105}$

People did not move just for reasons of trade, and trade may have been only one aspect of people's journeys. The movement of slaves between India and the Mediterranean is one example of such movements. ${ }^{106}$ Other types of people on the move were pilgrims. Ray suggests the possibility of Kanheri being a destination with pilgrim traffic because of its location on the trans-oceanic and overland long-distance routes. ${ }^{107}$ Sanchi is also suggested to have been a pilgrim site where pilgrims made donations. ${ }^{108}$ Overseas pilgrimage to the island of Socotra, usually regarded as stopover for traders in the Indian Ocean, might be indicated by the finds of lamps, frankincense, religious engravings, and small water tanks for ritual purposes. ${ }^{109}$ The religious importance of the island in later periods might also raise the

100 Chandra 1953; 1977.

101 Thaplyal 1996.

102 Originally published as Die Sociale Gliederung im Nordöstlichen Indien zu Buddhas Zeit in 1897, the work was translated by S. K. Maitra in 1920. See Fick (1920) 1987.

103 Kosambi (1955) 2002, 450-475.

104 Ray 1986; 1994a; 1994b.

105 Neelis 2011.

106 Cobb 2018, 195-196, 231; Hain forthcoming.

107 Ray 1994a.

108 Basant 2012, 191.

109 Kulshreshtha 2018. 
question of whether or not religious ritual was just a subsidiary activity of the earlier travelers who left their graffiti there. ${ }^{110}$ Wink argued that Socotra or Suquṭās was perhaps derived from the Sanskrit Dvippa Sukhatara, 'blessed isle,' and that this, too, might have had some significance as a pilgrim site. ${ }^{111}$

\section{Conclusion}

This chapter has focused on various issues and questions of historiography that developed over the course of time. One has to be careful not to treat different research agendas as successive stages in history writing. Many methods and theories have been contemporaneous, and similar research interests were spurred by different theoretical aims or preconceptions. This concerns the purpose of history writing in and about India as much as changes in the perceptions of sources, narratives of trade and urbanization, and regional approaches to economic history writing. My aim has not been to discard the chronological aspect of scholarship. Many issues in the economic, political, and intellectual historiography of early historic India have been abandoned, while others are recurring, and various questions are raised again and again. Also, decline of one dominant theory does not mean an end of its allied approaches. The end of colonialism did not mean the end of its methods and questions. Marxist views on the history of social struggle and centralized economic processes have not receded into the background even after its diminishment on a global platform. And today, even as we move away from state-centric economic history toward more holistic socio-cultural approaches, the practice of economic history writing continues.

\section{References}

Adluri, V., and J. Bagchee. 2014. The nay science: A history of German Indology. Oxford: Oxford University Press.

Basant, P. K. 2012. The city and the country in early India: A study of Malwa. New Delhi: Primus.

Basu Majumdar, S. 2017. "State formation and religious processes in the north-south corridor of Chhattisgarh (from first century BC to eighth century AD)." Studies in People's History 4.2, 119-129.

Bauer, A. M. 2015. Before Vijayanagara: Prehistoric landscapes and politics in the Tungabhadra basin. New Delhi: Manohar.

-. 2016. "Provincializing the littoral in Indian Ocean heritage: Coastal connections and interior contexts of the southern Deccan." In H. P. Ray (ed.), Bridging the gulf: Maritime cultural heritage of the western Indian Ocean, 101-119. New Delhi: Manohar.

110 For a discussion on inscriptions at Socotra, see Dwivedi, ch. 10.A, this volume.

111 Wink 1991, 45. 
Bauer, A. M., and K. D. Morrison. 2008. "Water management and reservoirs in southern India and Sri Lanka.” In H. Selin (ed.), Encyclopedia of the history of science, technology, and medicine in non-Western cultures. 2nd ed. 2207-2214. Berlin: Springer.

Begley, V. 1983. “Arikamedu reconsidered.” American Journal of Archaeology 87.4, 461-481.

Bhandare, S. 2012. “From Kauțilya to Kosambi and beyond: The quest for a 'Mauryan/Aśokan' coinage.” In P. Olivelle, J. Leoshko, and H. P. Ray (eds.), Reimagining Aśoka: Memory and history, 93-128. New Delhi: Oxford University Press.

Brohier, R. L. 1934. Ancient irrigation works in Ceylon. 3 parts. Colombo: Government Publications Bureau.

Chakrabarti, D. K. 1972a. "Concept of urban revolution and the Indian context." Puratattva 6, 27-31.

-. 1972b. "Beginning of iron and social change in India." India Studies: Past and Present 14, 329-338.

-. 1992. The early use of iron in India. Delhi: Oxford University Press.

-. 2010. India: An archaeological history: Palaeolithic beginnings to early historic foundations. New Delhi: Oxford University Press.

Chakravarti, R. 2001. “Introduction.” In R. Chakravarti (ed.), Trade in early India, 1-101. New Delhi: Oxford University Press.

-. 2007. Trade and traders in early Indian society. New Delhi: Manohar.

-. 2008. "Agricultural technology in early medieval India (c. AD 500-1300)." Medieval History Journal 11.2, 229-258.

-. 2009. "Relationship and interactions in the economic sphere." In B. D. Chattopadhyaya (ed.), History of science, philosophy and culture in Indian civilization. Vol. 2.5, 129-156. Delhi: Pearson Longman.

-. 2017. "Examining the hinterland and foreland of the port of Muziris in the wider perspective of the subcontinent's long-distance networks." In K. S. Mathew (ed.), Imperial Rome, Indian Ocean regions and Muziris: New perspectives on maritime trade, 307-338. London: Routledge.

Champakalakshmi, R. 1996. Trade, ideology and urbanization: South India 300 BC to AD 1300. Delhi: Oxford University Press.

Chandra, M. 1953. Sārthavāha. Patna: Rashtrabhasha Parishad.

-. 1977. Trade and trade routes in ancient India. New Delhi: Abhinav.

Chattopadhyaya, B. D. 2003. Studying early India: Archaeology, texts, and historical issues. New Delhi: Permanent Black.

-. 2008. "Early historical in Indian archaeology: Some definitional problems." In G. Sengupta and S. Chakraborty (eds.), Archaeology of early historic South Asia, 3-14. New Delhi: Pragati.

Childe, V. G. 1936. Man makes himself. London: Watts and Co.

Cobb, M. A. 2018. Rome and the Indian Ocean trade from Augustus to the early third century CE. Leiden: Brill.

Collingwood, R. G. 1930. "Review of: E. H. Warmington, The commerce between the Roman Empire and India." Antiquity 4.15, 384.

Cunningham, A. 1848. "Proposed archaeological investigation." Journal of Asiatic Society of Bengal 17, 535-536.

-. 1871. The ancient geography of India. London: Trübner and Co.

Curtin, P. D. 1984. Cross-cultural trade in world history. Cambridge: Cambridge University Press.

Deloche, J. 1983. "Geographical considerations in the localisation of ancient sea-ports of India." Indian Economic and Social History Review 20.4, 439-448.

-. 1994. Transport and communications in India prior to steam locomotion. Vol. 2, Water transport. J. Walker (trans.). Delhi: Oxford University Press.

-. 2010. "Roman trade routes in South India: Geographical and technical considerations (c. 1st cent. BC-5th cent. AD)." Proceedings of Indian National Science Academy 45.1, 33-46. 
Dwivedi, M. 2015. "Colonial imagination and identity attribution: Numismatic cues for defining space.” In H. P. Ray (ed.), Negotiating cultural identity: Landscapes in early medieval South Asian history, 206-238. New Delhi: Routledge.

Evers, K. G. 2017. Worlds apart trading together: The organisation of long-distance trade between Rome and India in antiquity. Oxford: Archaeopress.

Falk, H. 2009. "The pious donation of wells in Gandhara." In G. J. R. Mevissen and A. Banerji (eds.), Prajñādhara: Essays on Asian art, history, epigraphy and culture in honour of Gouriswar Bhattacharya, 23-36. New Delhi: Kaveri.

Fick, R. (1897) 1920. The social organization in north-east India in the Buddha's time. S. K. Maitra (trans.). Calcutta: University of Calcutta.

Fuller, D. Q., N. Boivin, R. Allaby, and T. Hoogervorst. 2011. "Across the Indian Ocean: The prehistoric movement of plants and animals." Antiquity 85, 544-558.

Gangopadhyay, R. 1932. Some material for the study of agriculture and agriculturists in ancient India. Serampore: N. C. Mukherjee and Co.

Geekiyanage, N., and D. K. N. G. Pushpakumara. 2013. "Ecology of ancient tank cascade systems in island Sri Lanka." Journal of Marine and Island Cultures 2.2, 93-101.

Ghosh, A. 1973. City in early historical India. Simla: Indian Institute of Advanced Study.

Ghoshal, U. N. 1930. The agrarian system in ancient India. Calcutta: University of Calcutta.

-. (1929) 1972. Contributions to the history of the Hindu revenue system. 2nd ed. Calcutta: Saraswat Library.

Gopal, L., and V. C. Srivastava, eds. 2008. History of Science, Philosophy and Culture in Indian Civilization. Vol. 5.1, History of agriculture in India (up to c. 1200 AD). New Delhi: Centre for Studies in Civilizations.

Gurukkal, R. 2016. Rethinking classical Indo-Roman trade: Political economy of Eastern Mediterranean exchange relations. New Delhi: Oxford University Press.

Habib, I. 2009. "Economics and the historians." Social Scientist 37.5/6, 3-20.

Hain, K. Forthcoming. "The prestige markers: Mediterranean slave women in India." Slavery and Abolition.

Hingley, R. 2000. Roman officers and English gentlemen: The imperial origins of Roman archaeology. London: Routledge.

Kanungo, A. K. 2004. "Glass beads in ancient India and furnace-wound beads at Purdalpur: An ethnoarchaeological approach." Asian Perspectives 43.1, 123-150.

Keith, A. B. (1928) 2002. The development and history of Sanskrit literature. Delhi: Sanjay Prakashan.

Khan, N. M. 2006. Treasures from Kashmir Smast: The earliest Śaiva monastic establishment. Peshawar: University of Peshawar Department of Archaeology.

-. 2011. "Hydrological setup at Kashmir Smast: Exploration and excavation at the Kashmir Smast field campaign 2006/2007: A preliminary report." Gandhāran Studies 5, 89-114.

Kırl, C. 2014. "From economic history to cultural history in Ottoman studies." International Journal of Middle East Studies 46.2, 376-378.

Kosambi, D. D. (1955) 2002. Combined methods in Indology and other writings. B. Chattopadhyaya (ed.). New Delhi: Oxford University Press.

-. (1956) 2009. An introduction to the study of Indian history. 2nd ed. Delhi: Popular Prakashan.

Krishna Rao, M. V. 1953. Studies in Kautilya. Mysore: H. Venkataramiah.

Kulke, H., K. Kesavapany, and V. Sakhuja, eds. 2009. Nagapattinam to Suvarnadwipa: Reflections on the Chola naval expeditions to Southeast Asia. Singapore: Institute of Southeast Asian Studies.

Kulshreshtha, S. 2018. "Practices of faith: Coastal shrines on the rim of the western Indian Ocean." Paper presented at Knowledge Traditions of the Indian Ocean World, Ashmolean Museum, Oxford, 29-30 November 2018. 
Lahiri, N. 1992. The archaeology of Indian trade routes up to c. 200 BC: Resource use, resource access and lines of communication. Delhi: Oxford University Press.

Lal, M. 1986. "Iron tools, forest clearance and urbanisation in the Gangetic Plains." Man and Environment 10, 83-90.

Lüders, H. 1913. "A list of Brahmi inscriptions from the earliest times to about AD 400 with the exception of those of Asoka." Appendix to Epigraphia Indica 10.

Majumdar, R. C. 1960. The classical accounts of India. Calcutta: Firma K. L. Mukhopadhyay.

Manguin, P.-Y., A. Mani, and G. Wade, eds. 2011. Early interactions between South and Southeast Asia: Reflections on cross-cultural exchange. New Delhi: Manohar.

Mani, B. R. 1987. The Kushan civilization: Studies in urban development and material culture. Delhi: B. R. Publishing.

Manjapra, K. 2014. Age of entanglement: German and Indian intellectuals across empire. Cambridge, MA: Harvard University Press.

Mookerji, R. 1912. Indian shipping: A history of the sea-borne trade and maritime activity of the Indians from the earliest times. Bombay: Longmans, Green and Co.

Morris, M. D., and B. Stein. 1961. “The economic history of India: A bibliographic essay.” Journal of Economic History 21.2, 179-207.

Morrison, K. D. 1997. "Commerce and culture in South Asia: Perspectives from archaeology and history." Annual Review of Anthropology 26, 87-108.

-. 2009. Daroji valley: Landscape history, place and the making of dryland reservoir system. New Delhi: Manohar.

Murphy, C., A. Weisskopf, W. Bohingamuwa, G. Adikari, N. Perera, J. Blinkhorn, M. Horton, D. Q. Fuller, and N. Boivin. 2018. "Early agriculture in Sri Lanka: New archaeobotanical analyses and radiocarbon dates from the early historic sites of Kirinda and Kantharodai (Kandarodai)." Archaeological Research in Asia 16, 88-102.

Neelis, J. 2011. Early Buddhist transmission and trade networks: Mobility and exchange within and beyond the northwestern borderlands of South Asia. Leiden: Brill.

Parchami, A. 2015. "The echoes of Rome in British and American hegemonic ideology." In K. Nicolaïdis, B. Sèbe, and G. Maas (eds.), Echoes of empire: Memory, identity and colonial legacies, 105-122. London: I. B. Tauris.

Perlin, F. 1988. "Disarticulation of the world: Writing India's economic history: A review article." Comparative Studies in Society and History 30.2, 379-387.

Randhawa, M. S. 1980. A history of agriculture in India. Vol. 1, Beginning to 12th century. New Delhi: Indian Council of Agricultural Research.

Ray, H. P. 1986. Monastery and guild: Commerce under the Sātavāhanas. Delhi: Oxford University Press.

-. 1994a. "Kanheri: The archaeology of an early Buddhist pilgrimage centre in western India." World Archaeology 26.1, 35-46.

-. 1994b. The winds of change: Buddhism and the maritime links of early South Asia. Delhi: Oxford University Press.

-. 2003. The archaeology of seafaring in ancient South Asia. Cambridge: Cambridge University Press.

-. 2006. "Inscribed pots, emerging identities: The social milieu of trade." In P. Olivelle (ed.), Between the empires: Society in India 300 BCE to 400 CE, 113-144. Oxford: Oxford University Press.

-. 2008a. Colonial archaeology in South Asia: The legacy of Sir Mortimer Wheeler. New Delhi: Oxford University Press.

-. 2008b. "Interpreting the Mauryan Empire: Centralized state or multiple centers of control." In G. Parker and C. M. Sinopoli (eds.), Ancient India in its wider world, 13-51. Ann Arbor, MI: University of Michigan Press. 
-. 2010. "Introduction." In H. P. Ray (ed.), Sanghol and the archaeology of Punjab, 1-19. New Delhi: Aryan Books International.

-. 2011. "Writings on the maritime history of ancient India." In S. Bhattacharya (ed.), Approaches to history: Essays in Indian historiography, 27-54. Delhi: Primus.

-. 2015. Beyond trade: Cultural roots of India's ocean. New Delhi: Aryan Books International.

Ray, H. P., and S. Mishra. 2018. "Introduction." In Bibliography on Sailing to Suvarnabhumi. AIC-RIS. http://ris.org.in/aic/bibliography.

Ray, H. P., and J.-F. Salles, eds. 1996. Tradition and archaeology: Early maritime contacts in the Indian Ocean: Proceedings of the international seminar Techno-Archaeological Perspectives of Seafaring in the Indian Ocean 4th cent. BC-15th cent. AD. New Delhi, February 28-March 4, 1994. New Delhi: Manohar.

Renfrew, C. 1975. "Trade as action at a distance: Questions of integration and communication.” In J. A. Sabloff and C. C. Lamberg-Karlovsky (eds.), Ancient civilization and trade, 3-59. Albuquerque, NM: University of New Mexico Press.

Rocher, R. 1983. Orientalism, poetry, and the millennium: The checkered life of Nathaniel Brassey Halhed, 1751-1830. Delhi: Motilal Banarsidass.

-. 1994. "British Orientalism in the eighteenth century: The dialectics of knowledge and government." In C. A. Breckenridge and P. van der Veer (eds.), Orientalism and the postcolonial predicament: Perspective on South Asia, 215-249. Philadelphia, PA: University of Pennsylvania.

Roy, T. 2004. "Economic history: An endangered discipline." Economic and Political Weekly 39.29, 3238-3243.

Sahu, B. P. 2001. "Brahmanical ideology, regional identities and the construction of early India." Social Scientist 29.7/8, 3-18.

Said, E. W. 1978. Orientalism. New York: Pantheon.

Salles, J.-F. 2004. "Archaeology and history of Bangladesh: Recent perspectives." In H. P. Ray and C. M. Sinopoli (eds.), Archaeology as history in early South Asia, 185-218. New Delhi: Aryan Books International.

Samaddar, J. N. 1922. Lectures on economic condition of ancient India. Calcutta: University of Calcutta.

Seed, G. 1952. "Lord William Bentinck and the reform of education." Journal of the Royal Asiatic Society 84.1/2, 66-77.

Seland, E. H. 2014. "Archaeology of trade in the western Indian Ocean, 300 BC-AD 700." Journal of Archaeological Research 22.4, 367-402.

Seneviratne, S. 1981. "Kalinga and Andhra: The process of secondary state formation in early India." In H. J. M. Claessen and P. Skalnik (eds.), The study of the state, 317-338. The Hague: Mouton.

Seshan, R. 2007. "Writing the nation in India: Communalism and historiography." In S. Berger (ed.), Writing the nation: A global perspective, 155-178. London: Palgrave Macmillan.

Seshan, R., and S. Kumbhojkar, eds. 2018. Re-searching transitions in Indian history. London: Routledge.

Sharma, R. S. 1974. "Iron and urbanization in the Ganga basin." Indian Historical Review 1, 93-103.

-. 1983a. Material culture and social formations in ancient India. Madras: Macmillan India.

-. 1983b. Perspectives in social and economic history of early India. New Delhi: Munshiram Manoharlal.

-. 1987. Urban decay in India, c. 300-c. 1000. Delhi: Munshiram Manoharlal.

-. 1990. Súdras in ancient India: A social history of the lower order down to circa AD 600. 3rd ed. Dehli: Motilal Banarsidass.

Sharma, R. S., and D. N. Jha. 1974. "The economic history of India up to AD 1200: Trends and prospects." Journal of the Economic and Social History of the Orient 17.1, 40-80. 
Shaw, J. 2007. Buddhist landscapes in central India: Sanchi Hill and archaeologies of religious and social change, $c$. third century $B C$ to fifth century $A D$. London: British Association for South Asian Studies.

Shaw, J., and J. V. Sutcliffe. 2003a. "Ancient dams, settlement archaeology and Buddhist propagation in central India: The hydrological background." Hydrological Sciences Journal 48.2, 277-291.

-. 2003b. "Water management, patronage networks and religious change: New evidence from the Sanchi dam complex and counterparts in Gujarat and Sri Lanka." South Asian Studies 19.1, 73-104.

Shaw, J., J. V. Sutcliffe, L. Lloyd-Smith, J.-L. Schwenninger, M. S. Chauhan, O. P. Misra, and E. Harvey. 2007. "Ancient irrigation and Buddhist history in central India: Optically stimulated luminescence dates and pollen sequences from the Sanchi dams." Asian Perspectives 46.1, 166-201.

Sinopoli, C. M., P. Johansen, and K. D. Morrison. 2009. "Changing cultural landscapes of the Tungabhadra valley, South India." In S. E. Falconer and C. L. Redman (eds.), Polities and power: Archaeological perspectives on the landscapes of early states, 11-41. Tucson, AZ: University of Arizona Press.

Smith, M. 2005. "Networks, territories, and the cartography of ancient states." Annals of the Association of American Geographers 95.4, 832-849.

Smith, V. A. 1908. The early history of India. 2nd ed. Oxford: Clarendon.

Thapar, R. 1992. From lineage to state: Social formations in the mid-first millennium $B C$ in the Ganga valley. 2nd ed. Delhi: Oxford University Press.

-. 2006. "The Mauryan Empire in early India." Historical Research 79.205, 287-305.

Thaplyal, K. K. 1996. Guilds in ancient India: A study of guild organization in northern India and western Deccan from circa $600 B C$ to circa 600 AD. Delhi: New Age International.

Trautmann, T. R. 2009. The clash of chronologies: Ancient India in the modern world. Delhi: Yoda Press.

Trautmann, T. R., and C. M. Sinopoli. 2002. "In the beginning was the word: Excavating the relations between history and archaeology in South Asia." Journal of the Economic and Social History of the Orient 45.4, 492-523.

Tripati, S. 2011. "Ancient maritime trade of the eastern Indian littoral." Current Science 100.7, 1076-1086.

Tripati, S., S. K. Patnaik, and G. C. Pradhan. 2017. "Maritime trade contacts of Odisha, east coast of India, with the Roman world: An appraisal." In K. S. Mathew (ed.), Imperial Rome, Indian Ocean regions and Muziris: New perspectives on maritime trade, 215-230. London: Routledge.

Van Hal, T. 2016. "Protestant pioneers in Sanskrit studies in the early 18th century: An overlooked chapter in South Indian missionary linguistics." Historiographia Linguistica 43.1/2, 99-144.

Voigt, J. H. 1966. "Nationalist interpretation of Arthaśāstra in the historical writing." In S. N. Mukherjee (ed.), South Asian Affairs, no. 2: The movement for national freedom in India, 4666. Oxford: Oxford University Press.

Wagle, N. K. 1995. Society at the time of the Buddha. 2nd ed. Bombay: Popular Prakashan.

Warmington, E. H. 1928. The commerce between the Roman Empire and India. Cambridge: Cambridge University Press.

Wheeler, R. E. M. 1954. Rome beyond the imperial frontiers. London: Bell.

Wheeler, R. E. M., A. Ghosh, and K. Deva. 1946. "Arikamedu: An Indo-Roman trading station on the east coast of India." Ancient India 2, 17-124.

Wink, A. 1991. Al-Hind: The making of the Indo-Islamic world. Vol. 1, Early medieval India and the expansion of Islam 7th-11th centuries. Leiden: Brill.

Yelle, R. A. 2013. The language of disenchantment: Protestant literalism and colonial discourse in British India. Oxford: Oxford University Press. 



\title{
Lauren Morris
}

\section{Constructing Ancient Central Asia's Economic History}

\section{Introduction}

In the global history of the ancient world, conceptions of Central Asia are entangled with ideas about long-distance transit trade. This is particularly true in respect to the Kushans and their pre-imperial predecessors, the Yuezhi. ${ }^{1}$ Two excerpts from recent contributions make this clear. The first derives from Benjamin's treatment of the development of the Silk Roads from 100 BCE-250 CE, framed through the contributions of empires of Eurasia during this period:

\begin{abstract}
Along with bales of Chinese silk, [the items in the Begram hoard] are examples of the sort of high-value trade goods that were passing back and forth along the Silk Roads during the height of their operation, through major commercial nodes such as Begram and the Kushan Empire. Although we lack many of the details about how that trade was actually conducted, its astonishing diversity and value, along with the critical role the Kushans played in it, is indisputable ... Despite the fact that the Kushans constructed an essentially land-based empire, at least two of the major trade routes that passed through their territory headed toward ports along the west coast of South Asia, some of which probably came under their direct control during the Great Kushans period. ${ }^{2}$
\end{abstract}

The second is Falk's philologically oriented paper, which proposes new locations for the realms controlled by the five yabgus of the Yuezhi:

\begin{abstract}
The five yabghus were not the heads of five geographically divided groups of animal breeders inside northern Bactria, but commanded five trade routes also outside Bactria, starting in the middle of the first century B.C., at the latest. All five yabghus and their predecessors had been busy trading or protecting traders for a long time before Kujula took over the authority of the other four yabghus ... With these profitable "external" activities over a huge area and a long period, an assault by Kujula on Gondophares in the Peshawar Valley, blocking "free" trade, looks almost inevitable. ${ }^{3}$
\end{abstract}

Although very different in scope and method, it is remarkable that a particular longstanding topos can be clearly discerned in both works: the notion that external transit trade was central to the power and prosperity of the Kushan Empire (and now also the Yuezhi), a point largely attributed to the geography that they commanded, which putatively entailed control of important trans-regional and long-

1 For background information, see Morris, ch. 2, this volume.

2 Benjamin 2018, 201-203.

3 Falk 2014, 34.

O Open Access. (c) 2020 Lauren Morris, published by De Gruyter. (cc) BY-NC-ND This work is licensed under the Creative Commons Attribution-NonCommercial-NoDerivatives 4.0 License.

https://doi.org/10.1515/9783110607741-025 
distance trade routes. More succinctly, we might refer to this postulate as that of 'Kushan middlemen.'

But what are the origins of this idea? It finds no explicit support in the textual or documentary evidence available to us, as compared to the parallel case of the fourth-century Sogdian letters and the concomitant conception of Sogdian traders. ${ }^{4}$ Instead, the present chapter proposes that the notion of Kushan middlemen - although emphatically not outright incorrect - has much less to do with reality than with the curious way the economic history of ancient Central Asia and its empires has been constructed. The roots of this run deep into the complex geopolitics of the late nineteenth and twentieth centuries in Russian Turkestan, Afghanistan, and northwest India. The limited scholarship that does exist constitutes occasional, disjointed perspectives produced across different scholarly spheres at the fringes of disciplines, which have difficulty talking to each other. This chapter thus addresses two related questions. First, I analyze the shape of various approaches to the economic history of ancient Central Asia, particularly under the Greek Kingdoms and the Kushan Empire, and inquire into why such little scholarship has been generated in this field. Second, I consider the origins, development, and critiques of the notion of Kushan middlemen, and ask why external, long-distance trade is still frequently framed as the source of economic growth during the Kushan Empire.

\section{Approaches}

\section{II.1 Geopolitical and Disciplinary Origins}

As signaled above, little intensive scholarship has been generated on the economic history of ancient Central Asia, and even less so in respect to the Greek Kingdoms or the Kushan Empire. What does exist can hardly be referred to as a single field with clear discourses and disputes. This is obviously due in part to the limited evidentiary basis for such a project, particularly the paucity of transmitted textual evidence, which has long hindered the resolution of fundamental disputes about chronology and political history that continue to preoccupy many scholars today. ${ }^{5}$

However, the practicalities and ideologies of knowledge production about Central Asia have been shaped more decisively by its colonialist, imperialist, and nationalist geopolitical context during the nineteenth and twentieth centuries. In the nineteenth century, the Punjab became a frontier province of the British Raj, and western Turkestan - roughly the later Soviet and now independent republics of Turkmenistan, Uzbekistan, Tajikistan, Kyrgyzstan, and Kazakhstan - lay within the Russian Empire. Influence in Afghanistan was contested between the British and

4 See discussion in Morris, ch. 9, this volume.

5 See further in Morris, ch. 9, this volume. 
Russian Empires during this century as part of a broader political and diplomatic struggle described by modern historians as the 'Great Game.' Concomitant with colonial control of the Punjab, vigorous research by (foremost British) Europeans was initiated into the campaigns of Alexander, Hellenistic and Kushan numismatics, and the archaeology, art, and epigraphy of Buddhism in Gandhāra. ${ }^{7}$ Russian Oriental studies was concerned especially with the history of Islamic Turkestan primarily through written sources, although burgeoning archaeological excavations at Afrasiab and collection of antiquities were also practiced. ${ }^{8}$

In the 1920s in independent Afghanistan, Amanullah Khan sought heightened diplomatic relations with France in the context of his modernization program. These relations were cemented with the establishment of the Délégation archéologique française en Afghanistan (DAFA) in 1922, which held a monopoly on archaeological research until the 1960s. ${ }^{9}$ After the Russian Revolution in 1917, Russian Turkestan was demarcated into new Soviet republics (between 1924-1936), which entailed the production of new histories to bolster their status. Indian independence and the partition creating Pakistan in 1947 resulted in the allocation of much of the Punjab to the new modern state, and scholars of both domains devised new histories of their past. ${ }^{10}$ The Soviet Union's invasion of Afghanistan in 1979 virtually halted archaeological research in the subsequent decade of conflict between the Afghan $\mathrm{Mu}$ jahideen and Soviet Armed Forces. The collapse of the Soviet Union was followed by an upheaval in research in the new Central Asian republics, which was eventually followed by intensified international collaboration in archaeological research projects. Afghanistan suffered civil war throughout the 1990s, leading to the US-led intervention in 2001. These decades have been marked by devastating destruction and illicit excavation of cultural heritage.

The complex modern political history of this space has also clearly influenced scholarly disciplinary receptions of its ancient history. In particular, the contested claims as to the most correct historical approach to the easternmost Greek Kingdoms are well documented. ${ }^{11}$ William Woodthorpe Tarn's monumental The Greeks in Bactria and India (1938) explicitly oriented itself against hitherto prevailing scholarly associations of Bactria with Indian history and culture, evidently born from the development of scholarly interest in the Greek Kingdoms of Central Asia in the context of British control of the Punjab. Tarn wrote: "It is unfortunate that in Britain,

\footnotetext{
6 On the 'Great Game,' see Hopkirk 1990; Sergeev 2013.

7 The orientation of scholarship toward Buddhism was an innovation established by Alexander Cunningham. For more, see Dwivedi, ch. 15, this volume.

8 For further discussion on Russian Oriental studies, see Fabian, ch. 13, this volume. On early collecting practices in Russian Turkestan, see Gorshenina 2004. On archaeology of the period, see Gorshenina 2012.

9 On the political context of the formation of the DAFA, see Olivier-Utard 1997, 17-44.

10 See further discussion on postindependence scholarship in Dwivedi, ch. 15, this volume.

11 See discussions in Guillaume 1990; Mairs 2006, 22; and Holt 2012, 70-75.
} 
and I think everywhere, the story of the Greeks in India has been treated as part of the history of India alone. For in the history of India the episode of Greek rule has no meaning; it is really part of the history of Hellenism, and that is where its meaning resides." 12

The implications of Tarn's perspective are clear throughout his monograph, as he drew repeated links between the Seleukids and Graeco-Bactrian kings, to the extent of even claiming (for example) kinship between Eukratides and Antiochos IV. Yet, his approach proved influential in subsequent scholarship. Awadh Kishore Narain's The Indo-Greeks (1957) was put forward as a rebuttal to Tarn, not only in points of reconstruction of political history, but in its central premise. Narain stated clearly that the history of the Indo-Greeks "is part of the history of India and not of the Hellenistic states." ${ }^{13}$ Narain's trajectory exemplifies the difficulties of viewing any individual scholar as the product of an essentialized intellectual tradition: he received British training in the form of his tutelage from $R$. B. Whitehead of the Peshawar Museum and held a doctorate from the School of African and Oriental Studies (SOAS) in London. Yet, it is difficult not to read a fundamental culturalhistorical rift between the memory of British India and new Indian nationalism into the Tarn-Narain dispute. ${ }^{14}$ Other appraisals also existed, although they have featured less prominently in historiography. For example, in Soviet scholarship, the focus on autochthony in ethnogenesis led scholars to de-emphasize any contribution of the Hellenistic world to Central Asia. However, Tadzhiki: Drevneishaia, drevniaia i srednevekovaia istoriia (1972) by Bobodzhan Gafurovich Gafurov ${ }^{15}$ criticized this approach, as well as the Western overemphasis of the contribution of the Hellenistic period to this space, arguing instead that the Graeco-Bactrian Kingdom is better assessed as part of Central Asia's history. ${ }^{16}$

The modern reception of the Kushans has not been subject to a similar critical historiography. However, from the early twentieth century their rule was seen in many quarters as emphatically belonging to Indian history and associated with the spread of Buddhism. ${ }^{17}$ More recently, Rezakhani has presented the Kushans as part of the history of what he refers to as "East Iran."18 Ultimately, the study of the Greek Kingdoms and the Kushan Empire has existed at the disciplinary fringes of Western scholarship on the Graeco-Roman world, Indian historiography, Soviet Oriental

12 Tarn 1938, xx.

13 Narain 1957, 18.

14 As put very firmly by Guillaume 1990 , 475. Yet, as Holt $(2012,75)$ reiterates, Narain later considered the conflict between his own and Tarn's approach to have been overstated.

15 In Tajik, Bobojon Ghafurov. As this chapter engages with Gafurov's work in Russian, the Russian version of his name is retained here.

16 Gafurov 1989, 160. See further discussion below.

17 See, for example, Kennedy 1912a, 666, in embodying early scholarly receptions of Kanishka as a Buddhist king, even claiming that he "never reigned outside of India."

18 Rezakhani 2017, 3-4. 
studies, and Iranian studies, and this has affected how the economic history of Central Asia has been produced.

\section{II.2 Western Perspectives}

The most extensive explanation of the economy of Hellenistic Bactria from a 'Western' perspective remains its treatment in Michael Ivanovich Rostovtzeff's threevolume Social and Economic History of the Hellenistic World (1941). ${ }^{19}$ This was a work largely produced within an American academic context during Rostovtzeff's professorship at Yale, published by Oxford's Clarendon Press, and relying on Tarn's premise that the Graeco-Bactrian Kingdom should be seen within the framework of Hellenistic history. However, as Fabian makes clear, Rostovtzeff's work had an immense debt to his intellectual training and career under the Russian Empire. ${ }^{20}$ In reference to Bactria, this is seen in his assertion of lively trade links with Siberia and South Russia, and his novel attribution of Hellenistic jewelry and metalwork found there by archaeologists of the Russian Empire to Bactrian manufacture. ${ }^{21}$ This case reminds us that intellectual traditions do not exist as reified and pure entities.

Nonetheless, Rostovtzeff's treatment was still relatively cursory. After the customary complaint about the source material, he described the rich natural resources of Bactria and Sogdiana known from Graeco-Roman sources, their agricultural and pastoral potential, and their poverty in precious metals (an assertion deriving from Tarn). ${ }^{22}$ He emphasized, however, that "Bactria's real source of wealth ... was the transit trade along the caravan roads that crossed the country, connecting India with the Iranian lands and brought them with Mesopotamia and Syria."23 The Begram hoard was also cited as evidence for the persistence of terrestrial caravan routes between India and Syria, with Rostovtzeff also claiming that (Hellenistic) Bactrian coinage "was destined to become and did become the instrument of the caravan trade of Bactria and India." 24 This notion of caravan trade was connected to Rostovtzeff's 'modernist' ideas about supply and demand in the Mediterranean. ${ }^{25}$

Today, the study of ancient Central Asia's economic history remains a virtual non-priority in Western scholarship, despite the creation of relevant new datasets through the archaeological study of irrigation ${ }^{26}$ and renewed interest in agropasto-

19 Rostovtzeff 1941, 542-551.

20 Fabian, ch. 13, this volume.

21 Rostovtzeff 1941, 546.

22 Rostovtzeff 1941, 543.

23 Rostovtzeff 1941, 545.

24 Rostovtzeff 1941, 545-547.

25 See further in von Reden and Speidel, ch. 17, this volume.

26 See, for example, the results of the eastern Bactria survey (1974-1978) in Gardin 1998. 
ral strategies in northern Central Asia during the Bronze Age. ${ }^{27}$ With the gradual publication of Graeco-Bactrian documentary evidence excavated at Ai Khanum and from the antiquities market, scholars have recently (and appropriately) noted parallels with the financial administration of other eastern Hellenistic kingdoms, ${ }^{28}$ but these are not extensive studies. ${ }^{29}$ One helpful step forward is found in Étienne de la Vaissière's Histoire des marchands sogdiens (2002), ${ }^{30}$ which also considered the earlier development of Sogdian merchant diasporas in China attested from the early fourth century CE.

\section{II.3 Indian Perspectives}

Although scholarship on the economic history of India has a rich tradition, ${ }^{31}$ few contributions deal specifically with the local impact of Greek and Kushan conquest and putative control in areas of northwest and north India. This point is not helped by the fact that the shape and extent of Greek and Kushan rule in this space remains obscure. ${ }^{32}$ Nonetheless, some currents can be highlighted. Narain's classic treatise on the Greek Kingdoms reiterated that the presence of Indo-Greek coins beyond the Punjab was evidence of their "commercial success" rather than evidence of IndoGreek rule. ${ }^{33}$ Concurrently, the 1950s-1990s was a period in which India's economic history was increasingly interpreted from a Marxist perspective, and dominated by state-centric and Eurocentric imperial approaches, with a broader aim of informing policymaking in independent India. ${ }^{34}$ These trends frame the sole monograph that is dedicated to considering Kushan expansion into India from an economic perspective, Bratindra Nath Mukherjee's short Economic Factors in Kusāṇa History (1970). Here, Mukherjee criticized the prominence of the study of chronology in political history, aiming instead to analyze the motivation of Kushan expansion into India through "the prospect of economic gain, as the love for gain is an inborn instinct of man." 35 This was executed through two case studies. The first alleged that Kushan expansion into the lower Indus was motivated by a desire to control its coastal port, thus profiting from lucrative silk trade through the taxation of merchants and increasing the flow of international trade. ${ }^{36}$ The second case study argued that Ka-

27 See, e.g., Spengler et al. 2014.

28 For example, Aperghis 2004, 278, 282-283; Coloru 2009, 266-269.

29 The most comprehensive discussion of trade, agricultural production, and crafts in contemporary Western scholarship on the Greek Kingdoms is Coloru 2009, 269-275.

30 Published in English translation as de la Vaissière 2005.

31 See Dwivedi, ch. 15, this volume.

32 Morris, ch. 2, this volume.

33 Narain 1957, 88-89.

34 Dwivedi, ch. 15, this volume.

35 Mukherjee 1970, 9.

36 Mukherjee 1970, 11-21. 
nishka's conquests in the Malwa region (central India) were motivated by the control of its diamond mines, due to their putative significance in Indo-Roman trade. ${ }^{37}$ Although the factual bases of both arguments are dubious, ${ }^{38}$ it is more interesting that Mukherjee's approach was not only influenced by developments in Indian historiography, but by another trend growing in importance in Western scholarship, that highlighted the putative role of the Kushans in long-distance Silk Road and Indo-Roman trade (see below). That Mukherjee studied at SOAS and Cambridge should reiterate that there is some artifice to assigning scholars to certain intellectual traditions.

Otherwise, in Indian scholarship, explanations of the Kushan Empire's impact on the economy of northwestern and north India manifested primarily in debates during the 1970s and 1980s about the nature and causes of urbanization in early historic South Asia. Buddha Rashmi Mani, for example, influentially attributed a phase of urban growth in northwest India to the Kushan period, detected especially by the appearance of baked bricks, ${ }^{39}$ although the archaeological classification of such phenomena as explicitly 'Kuṣāna' has been since criticized. ${ }^{40}$ In the last decades, state- or empire-centric approaches to the economy have fallen out of fashion in favor of studies of local processes and on the agency of regional actors.

\section{II.4 Russian Perspectives}

The intellectual tradition of the Russian Empire and the Soviet Union (here, glossed as 'Russian' $)^{41}$ has produced substantially more scholarship about ancient Central Asia's economic history than competing traditions. ${ }^{42}$ Yet, as academics under the Russian Empire in the late nineteenth century began engaging with historical socioeconomic development, only medieval and later periods of Central Asia's history came onto the radar. This is because the discipline of Russian Oriental studies was foremost concerned with the analysis of written sources, which in the Central Asian context were primarily written in Arabic, Persian, and Turkic languages. During this

37 Mukherjee 1970, 22-36.

38 There is still no strong evidence that the Kushans ever controlled the lower Indus. The Chinese toponym Shendu 身毒 is not stable; it may have originally indicated the lower Indus, but grew over time to refer to northern India (Hill 2015, 1: 368-371). The textual support for the Malwa proposition derives from a Tibetan Buddhist history written in the seventeenth century. The author (Tāranātha) stressed that the king 'Kanika' associated with the mines and Kanishka were not identical, which Mukherjee perhaps rightfully rejected. There is no other evidence for Kushan conquests or control over Malwa.

39 Mani 1987, 40, 53-62.

40 E.g., in Ray 2010, 7.

41 See further in Fabian, ch. 13, this volume.

42 The present discussion does not treat emerging post-Soviet perspectives, which are still crystallizing into an intellectual tradition distinct to that of the Soviet era. 
time, important critiques of Euocentrism in European Oriental studies were fermented, particularly by Vasilii Vladimirovich Bartol'd (1869-1930). ${ }^{43}$ Bartol'd also transformed the historical study of Central Asia. In his work, he eschewed the prevailing scholarly conception of a dichotomy of barbaric nomadic populations of the steppe and settled civilizations in southern oases. Instead, Bartol'd treated the development of Central Asian nomadic and sedentary worlds as syncretic, and advocated for a regional conception of Central Asia (i.e., of Turkestan) as a unit of historical analysis. ${ }^{44}$ One important work of his in this vein was $K$ istorii orosheniia Turkestana (1914), ${ }^{45}$ which engaged with a range of ancient and medieval literary sources to survey the development of agriculture and artificial irrigation throughout this entire region up to the Russian conquest.

Scholarship of the decades following the 1917 revolution was shaped not only by wider debates in Soviet Oriental studies informed by nascent interpretations of Marxist ideology and applications of historical materialism, but also by characteristics specific to the space of Central Asia shaped by Soviet attempts to control it. National demarcation of Central Asia into republics was achieved between 19241936. Leningrad Orientalists were accordingly pressured to produce new meta-histories of the respective republics reaching back to prehistory in order to strengthen the historical validity of the new republics in place of a united Turkestan feared by the Bolsheviks. ${ }^{46}$ These meta-histories came to serve as the primary vehicle for writing on ancient Central Asia's economic history in subsequent decades. For the present purposes, the most relevant works are those dealing with the peoples of Uzbekistan and Tajikistan. These include the brief monograph Drevniaia kul'tura Uzbekistana (1943) by Sergei Pavlovich Tolstov (1907-1976), ${ }^{47}$ the multivolume coauthored Istoriia narodov Uzbekistana (1950), ${ }^{48}$ and the multivolume works on the Tajik people by Bobodzhan Gafurovich Gafurov (1908-1877), the first being Istoriia tadzhikskogo naroda $v$ kratkom izlozhenii (1947), ${ }^{49}$ and the second being Tadzhiki: Drevneishaia, drevniaia i srednevekovaia istoriia (1972). ${ }^{50}$ Short contributions of interest also appeared in journals, chiefly Vestnik drevnei istorii, and edited volumes.

The content of these works were informed by scholarly debates of the 1920s and 1930s about the nature of socio-economic formations in prerevolutionary Oriental

43 Tolz 2011, 88-91.

44 Bustanov 2015, 37.

45 Reprinted in Bartol'd 1965.

46 On the production of Soviet nationalist meta-histories in Central Asia and the competing (but ultimately unsuccessful) regional histories, see Bustanov 2015, 36-88.

47 Tolstov 1943.

48 Trever, Iakubovskii, and Voronets 1950.

49 First published in 1947 in Tajik, followed by an expanded Russian translation in 1949, with a second edition in 1952 (Gafurov 1952), and a third edition in 1955.

50 First published in Moscow, with a second edition published in Dushanbe, as Gafurov 1989. 
societies and their development. ${ }^{51}$ When it became widely agreed that ancient Oriental societies could fit into the scheme of five formations (piatichlenka) - primitive communism, slavery, feudalism, capitalism, and communism - scholars asked if this applied to nomadic societies too. When Tolstov argued in 1933 that nomadic societies of Central Asia from the second century BCE did indeed pass through the slave-ownership phase, ${ }^{52}$ this became widely accepted. Additionally, burgeoning autochthonous explanations of ethnogenesis conceptually grounded the inclusion of the study of prehistoric and ancient societies into Central Asian republican metahistories. Drawing on Marr's "Japhetic theory" for the Central Asian context, the Orientalist and historian Aleksandr Iur'evich Iakubovskii (1886-1953), in a commissioned brochure $K$ voprosu ob etnogeneze uzbekskogo naroda (1941), asserted that the conditions of the formation of a people do not begin with the historical appearance of their contemporary name. ${ }^{53}$ This postulate was taken up in other republican meta-histories which located the origins of contemporary peoples in antiquity, such as in Tolstov's pamphlet on Uzbekistan, and Gafurov's writing on the Tajiks. ${ }^{54}$

In the postwar years, scholars refined their ideas about the specifics of ancient Central Asia's slave-owning formation and its development, also touching on questions of production and monetary circulation. Although archaeological research had been undertaken on amateur and professional levels since the late nineteenth century, the 1937 initiation of the multidisciplinary Khorezmian Archaeological-Ethnographic Expedition led by Tolstov produced a vast amount of new archaeological data about this region that could be drawn upon to solve problems of the past. ${ }^{55}$ It was particularly the project's documentation of historical irrigation that allowed the study of the creation and maintenance of irrigation canals to take a more central role in explanations of socio-economic development.

Tolstov drew on data from the project combined with written evidence to forward the first in-depth explanations of ancient Central Asia's supposed slaveowning system. ${ }^{56}$ In light of extended archaeological work, he developed several influential ideas in the monograph Drevnii Khorezm (1948). This included the periodization of 'Antichnyi Khorezm' that extended from the mid-first millennium BCE (beginning with the construction of large irrigation canals, the origin of the state, and Chorasmia's inclusion into the Achaemenid Empire) to the mid-first millennium CE (the 'Kushan-Afrigid Culture,' ending with a crisis of the slave-owning formation in a parallel fashion to Europe). ${ }^{57}$ This periodization, which was subsequently ex-

51 See the discussion in Fabian, ch. 13, this volume.

52 Tolstov 1934, 179, 185.

53 Iakubovskii 1941. On ethnogenesis in Soviet historiography of Central Asia, see Laruelle 2008.

54 Tolstov 1943, 5; Gafurov 1989, 173.

55 For this expedition and its political implications, see Arzhantseva 2015.

56 Tolstov 1938a, 182-187. See also Tolstov 1938b, 47-49.

57 Tolstov 1948, 32-33. 
tended to the rest of Central Asia, ${ }^{58}$ was accompanied by presumptions about its slave-holding socio-economic formation. Paraphrasing Engels's claim of the crucial contribution of slavery to Greece and Rome in antiquity, Tolstov wrote, "we can say that if there were no slavery, the rich irrigation culture of the East could not have come about." 59 This thesis became a formula adopted by subsequent research: "once there was irrigation - there was slavery."60 More immediately controversial was Tolstov's claim that free or serf labor did not contribute to the mass of labor required in the construction of large canals, which he thought were solely constructed and maintained by a specialized "huge mass of slaves" not otherwise engaged in other agricultural labor. ${ }^{61}$ By the mid-1950s, a number of scholars had questioned the factual basis of such claims. Foremost, Belenitskii cast doubt on the specific contribution of slaves to irrigation in this period, underlining the overlooked role of the community. ${ }^{62}$

Although it remained widely accepted that some form of slave-owning formation characterized ancient Central Asia, scholars asked more specific questions about economic development and the extent of monetization. Trever's contribution to the history of the Uzbek peoples described the existence of a developed monetary economy by the end of the first century всE$^{63}$ while Gafurov underplayed the existence of such, pointing instead to small-scale trade in kind. ${ }^{64} \mathrm{~A}$ specialist numismatic study by the prominent archaeologist Vadim Mikhailovich Masson added some concreteness to the debate. Although conceding that subsistence farming was the basis of the economy throughout Central Asia's ancient period, Masson highlighted the widespread and early use of silver tetradrachms after the Seleukid period, explaining this as a high value coinage used for expensive foreign trade items. He also interpreted the more widespread circulation of copper coinage during the Kushan period as evidence for small-scale 'retail' trade in domestic markets. Finally, he suggested with reference to Engels that commodity exchange and 'monetary relations' developed from outside inward. ${ }^{65}$

In scholarship of the decades following the death of Stalin, a tangible opening of ideas can be detected, combined with more rigorous analysis of sources and application of Marxist theory. For one, critiques of the slave-holding society formation of the ancient Near East and Orient had finally established that subdivisions of this formation were necessary, and that slave-holding should be framed as part of a

58 This periodization was criticized in E. V. Zeimal' 1987 for presuming a certain set of socio-economic factors and not appreciating the uneven development across Central Asia during this period.

59 Tolstov 1948, 173.

60 As put in T. I. Zeimal' 1971, 176.

61 Tolstov 1948, 173; and more explicitly in Tolstov 1958, 115.

62 Belenitskii in Tolstov 1955, 506-508.

63 Trever, Iakubovskii, and Voronets 1950, 107.

64 Gafurov 1952, 89.

65 Masson 1955. 
larger economic system. ${ }^{66}$ In the 1960 s too, scholarship of selected prerevolutionary Orientalists began to be rehabilitated through recognition of their empirical significance. This occurred, for example, in Bartol'd's case with the publication of the nine volumes of his reprinted Sochineniia ('Writings,' 1963-1977). The study of historical irrigation also increased in sophistication during this period, notably with work on Khorezm and the Bukhara oasis. ${ }^{67}$

Gafurov's Tadzhiki (1972, $2^{\text {nd }}$ ed. 1989) is emblematic of the state of knowledge production in the late Soviet period. ${ }^{68}$ A classic in Tajik history, the paradigmatic quality of this work is underlined in the dispute about its authorship. ${ }^{69}$ Gafurov, a statesman and scholar, is representative of the specific marriage of politics and history found in the Soviet intellectual context. Born in Tajikistan, he studied at the Moscow Institute of Journalism and the Institute of History of the Soviet Academy of Sciences before returning to Dushanbe to take up party administrative positions. He became first secretary of the Central Committee of the Communist Party of Tajikistan, established Tajikistan's first State University (1948), inaugurated its National Academy of Sciences (1951), and also served as the director for the Institute of Oriental Studies in Moscow, all the while publishing historical scholarship.

Outwardly, Tadzhiki still looks and mostly reads like a nationalist meta-history, but its preface did note Central Asia's historical cultural unity, ${ }^{70}$ hearkening back to Bartol'd's ideas and reflecting the tentative shift in the administration at the time toward regionalist histories. ${ }^{71}$ The section of Tadzhiki of interest here is "Predki tadzhikov v epoku razvitiia rabovladel'cheskikh otnoshenii" (The ancestors of the Tajiks in the era of the development of slave-holding relations), which covers Central Asia under the Achaemenids to the Kushans. Like its intellectual predecessors, this section came after a treatment of prehistory as a primitive communal system, and before another on the supposed emergence of feudal relations in Late Antiquity (ca. fourth century CE).

Some points in Gafurov's treatment of the Greek Kingdoms are remarkable. ${ }^{72}$ First, he seriously engaged with Western research and historical scholarship, including the scholarship of Tarn and Narain, and the DAFA excavations at Balkh and

66 D'iakonov 1966, 47-52.

67 See, respectively, Andrianov 1969; Mukhamedzhanov 1978.

68 Gafurov 1989.

69 Foremost debated on digital platforms in the last decade. The archaeologist Boris Anatol'evich Litvinskii was credited as editor of Tadzhiki, but in a memoir published online on Fergana.Ru in 2009, he indicated that he and numismatist Elena Abramovna Davidovich (also Litvinskii's wife) actually authored the text. Although explicit statements to this effect were later removed from the article (see now Ianovskaia 2009), the claim was criticized by Tajik academics (see, for example, Ikrami 2009).

70 Gafurov 1989, 3-10.

71 Bustanov 2015, 70-76.

72 For the following, Gafurov 1989, 158-160. 
Ai Khanum. Although Gafurov considered that Western scholars had exaggerated the role of 'Greek-Hellenistic' culture in Central Asia's development, he also criticized Soviet scientists for denying that it had any impact at all. He found a middle ground by suggesting that a new impetus was given to Central Asia's slave-holding system due to close contacts with the Hellenistic world, but underscored that the origins and development of the Graeco-Bactrian Kingdom were due to the historical and geographical conditions of Central Asia. Further specific points of historical interpretation can also be highlighted. ${ }^{73}$ For example, Gafurov asserted that the description of Sāgala in the Milindapañh ${ }^{74}$ constitutes evidence for a developed craft industry under the Greeks, with craft and commerce mainly in the hands of the local population. Gafurov also associated the Graeco-Macedonian conquest of Sogdiana with increased production and quality of crafts through a "mutual enrichment of cultures," and highlighted the importance of agricultural production. Additionally - clearly influenced by Masson, although he is not cited - Gafurov regarded the abundance of coinage of the Greek Kingdoms as evidence for developed commodity circulation through high-volume international trade (especially with the Hellenistic world) and smaller scale domestic trade.

Gafurov was able to draw on much more archaeological data for his synthesis of the economy under the Kushans. ${ }^{75}$ Acknowledging that the main agricultural regions had already been developed prior to the advent of Kushan power, he noted the construction of new canals along (for example) the Vakhsh River. Development was highlighted in several arenas: in the technology of agricultural production, in craft production, and in the monetary system. Unusually, in comparison to other intellectual traditions (see below), it was taken as self-evident that mining was carried out on a large scale under the empire, and that Central Asian mines were the main suppliers for the gold ore used for Kushan coinage.

Most interesting is Gafurov's treatment of Central Asia's role in external longdistance trade. ${ }^{76}$ Although the idea of the Silk Road is mentioned in passing as "flowing through" this space, Gafurov proposed that raw metal ore and metalwork may have been exported. He also emphasized Romano-Central Asian ties through (limited, contested) finds of Roman products and coins, and asserted that Central Asian exports to China were significant. He also interpreted the possible presence of Bactrian merchants in Alexandria (like Sogdians in Dunhuang) as indicative of the establishment of trading posts, pointed to possible trade with the Ural-Volga and Sarmatian tribes, and the export of Bactrian textiles. Ultimately, Central Asia was not seen here as a thoroughfare, but an active locus of importing and exporting, with its own merchants traveling great distances.

73 For the following, Gafurov 1989, 143, 147-148.

74 Discussed further in Morris, ch. 9, this volume.

75 Gafurov 1989, 201-206.

76 Gafurov 1989, 205-207. 
Gafurov's concluding discussion represents a nuanced perspective on the slaveholding formation of this period. ${ }^{77}$ Against Tolstov, he pointed to the unevenness of slave-holding and economic development across Central Asia during antiquity. The oases of Sogdiana, Chorasmia, Bactria-Tokharistan, and Ferghana were seen as relatively developed (compared to mountainous areas), and accordingly engaged more in slave-holding. He also emphasized the contribution of free commune members to labor, especially in agriculture. A class struggle was envisaged as emanating from the rich military nobility and priesthood, putatively owning slaves, large tracts of land, and trading caravans.

In sum, the Russian intellectual tradition has made a comparatively substantial contribution to the study of ancient Central Asia's economic history. Certainly, early postrevolutionary scholarship was almost purely ideological and theoretical, as it grappled with the interpretation and application of Marxist doctrine. However, as scholarship became more empirically rigorous, its strength lay in synthesis and explanation, asking unique questions of economic development from a localized bottom-up perspective. This intellectual tradition later produced more nuanced understandings of what a slave-holding formation really looked like in ancient Central Asia. It emphasized the importance of developments in artificial irrigation and agricultural production, syncretism between nomadic pastoralists and oasis-dwelling agriculturalists, the extent of monetization and its implications for the development of commodity exchange both within and external to a state, advances in craft production, and entertained the possibility of Central Asia's mineral resources. Ultimately, Central Asia under the Kushans was framed as an active agent in the external importation and exportation of raw materials and finished products, with its own highly mobile merchants.

\section{On the Origins of Kushan Middlemen}

As we have seen, limited scholarship has been generated on the economy of ancient Central Asia. Yet, certain assertions are frequently made about the role of the Yuezhi and Kushans as traders or middlemen, appearing both in scholarship on Silk Road and Indo-Roman trade (mostly produced from a Western Romano-centric perspective), as well as specialist treatments of the Kushans. Seeking the origins of the notion of Kushan middlemen, the following examines two highly visible bodies of material culture repeatedly mobilized in this discourse: Kushan gold coinage and the Begram hoard.

77 Gafurov 1989, 232-240. 


\section{III.1 Roman Aurei and The Secret of Kanishka}

In the late nineteenth century, Alexander Cunningham of the Archaeological Survey of India published a set of influential observations about Kushan gold coinage, which was struck to a weight standard of ca. $8.0 \mathrm{~g}$. Having studied the weights of all such coins available to him and noticing a general metrological similarity with Roman aurei, he posited that Kushan gold coins had been restruck on Roman aurei, and that the heavy use of gold in Kushan coinage derived from heightened commerce between Rome and India at the time of the Roman Empire. Cunningham did, however, suspect that the weight standard of Kushan gold coinage was fixed by the internal economics of their own empire, through a ratio relationship to silver coinage of pre-Kushan rulers, presumably remaining in circulation. ${ }^{78}$ Finally, he proposed that, although the name of the Kushan gold unit was not known, because gold coins of the Gupta Dynasty (ca. 320-550 CE) were referred to in epigraphic evidence as dinars, it was thus likely that Kushan gold coins had the same name as they preserved the weight of early Roman imperial "denarii aurei." ${ }^{29}$ Cunningham's ideas were quickly taken up by other numismatic authorities of the time and further elaborated. For example, Robert Sewell suggested that this theory also explained the paucity of Roman coin finds in northern India in comparison to the south. ${ }^{80}$

A paper published in 1912 by James Kennedy, a historian and member of the Indian Civil Service, took these ideas into some wild new directions. ${ }^{81}$ In The Secret of Kanishka, ${ }^{82}$ Kennedy explained that the new gold coinage putatively introduced by Kanishka (in fact introduced by Vima Kadphises) was part of the history of longdistance silk trade, relying on many complex, if now clearly erroneous, conceptions of Kushan and regional chronologies, socio-linguistics, religious practice, and numismatics. Still, it is worth outlining Kennedy's central ideas. ${ }^{83}$ Arguing that Kanishka struck gold coins "not to supply local wants, but for the purposes of foreign trade," he correctly disputed the precise metrological cohesion between Roman aurei and Kushan dinars, but suggested Achaemenid and Macedonian precedents for their weight standard instead. He further claimed that the gold used for Kushan dinars, "certainly not indigenous," was brought by Messenian merchants, and that the use of Greek in Kushan coin legends (in fact, Bactrian, from early in the reign of Kanishka) was intended as a lingua franca for foreign traders.

78 Cunningham 1888, 219.

79 Cunningham 1888, 218.

80 Sewell 1904, 596. This frequently-discussed discrepancy may have been caused by many other factors.

81 Kennedy 1912a; Kennedy 1912b.

82 The titular secret being that Kanishka's gold coinage proved that he ruled in the mid-first century BCE, which has been thoroughly proven false by subsequent research (see Morris, ch. 2, this volume).

83 For the following, see Kennedy 1912b, 983-984. 
Scholarship of the next decades, particularly written from a Romano-centric perspective, disputed Kennedy's metrological arguments, but further developed his emphatic link between Kushan dinars and external long-distance trade, in addition to claims as to the foreign origins of Kushan gold. Warmington's classic monograph The Commerce between the Roman Empire and India (1928) cited the similarity of the weight, metal, and purity of Roman aurei and Kushan dinars as "a very test of a lively commerce." ${ }^{84}$ Although he rejected a Roman origin of the gold and conceded that some might have come from India, he suggested that the majority of Kushan gold used for coinage derived from gold exported from Arabia and was imported in the form of bullion via Barygaza. ${ }^{85}$

Similar ideas were also expressed in one of the first specialist monographs on the Kushans, van Lohuizen-de Leeuw's The "Scythian" Period (1949). ${ }^{86}$ Van Lohuizen-de Leeuw maintained that the Kushan gold standard derived from that instituted by Augustus, encountered via contact with Roman aurei seen during Vima Kadphises's (historically dubious) expansion to coastal harbors that was putatively motivated by "trade considerations." 87 This argument was based on the incorrect assumption that Vima Kadphises (ca. 110-127) ruled prior to the Neronian reforms of 64-68 CE, after which otherwise the metrological correspondence between the coinages certainly could not tally. ${ }^{88}$

Only in 1960 was the question of the metrological correspondence between the Roman aureus and Kushan gold dinar seriously addressed again. Numismatist Malcolm MacDowall agreed with Kennedy that there was never a precise correspondence between the two coinages. He pointed out that even in the case of pre-Neronian aurei, the seemingly small weight difference of $0.4 \mathrm{~g}$ was significant in the case of gold coinages (equivalent to more than two days' pay for a Roman soldier in the first century CE). MacDowall thus argued that the coinages did not freely circulate together, and that Kushan dinars were probably "exchanged principally in large scale commercial transactions by international traders." ${ }^{89}$ Ultimately, he interpreted Kushan dinars as introduced as multiples of preexisting copper denominations for large-scale commercial transactions to replace local silver coinage that had eventually collapsed prior to Kushan rule. ${ }^{90}$

\section{III.2 Explaining the Significance of the Begram Hoard}

The discovery of the Begram hoard by archaeologists of the DAFA during 1937 and 1939 was a turning point for Kushan archaeology. Begram is a partially excavated

84 Warmington 1928, 298-299.

85 Warmington 1928, 270, 298-299.

86 For the following, see Van Lohuizen-de Leeuw 1949, 365-366.

87 Van Lohuizen-de Leeuw 1949, 365-366.

88 Under Nero, the weight of the aureus was reduced from 40 to 45 aurei per Roman pound.

89 MacDowall 1960, 67-68.

90 MacDowall 1960, 74. 
(1936-1942; 1946) urban site located around $60 \mathrm{~km}$ north of Kabul, which was the location of the regional capital of the Paropamisadai (variously, Alexandria in the Caucasus and Kapisi), and located in the ancient microregion of Kapisa. At the socalled 'New Royal City' (a southern fortified area dominated by habitations), excavations revealed two sealed rooms in the center of a repurposed elite residence. In these rooms, over 400 individual objects were recovered, which originated from across Afro-Eurasia. ${ }^{91}$ Objects from the Roman Mediterranean included elaborate glass vessels of numerous different manufacturing and decorative techniques, ${ }^{92}$ bronze basins, technologically elaborate bronze 'aquariums' with mobile elements, figurines, plaster casts produced from high-relief metalwork with Graeco-Roman imagery, and vessels of alabaster, porphyry, and rock crystal. From the Indian subcontinent (the precise place of manufacture remains disputed) ${ }^{93}$ were footstools, furniture legs, and panels from chairs that had been adorned with elaborately carved decorative ivory and bone panels. From China, lacquered boxes and cups produced in both private and state workshops dating to the late Former Han and Xin dynasties were also found. ${ }^{94}$

The finds from the first hoard room in 1937 were rapidly published. However, the deaths of the three main archaeologists - Joseph Hackin, Ria Hackin, and Jean Carl - in 1941 led to the posthumous publication of the finds from 1939 only in 1954, and ultimately caused many significant documentation problems that hinder a precise appraisal of the hoard's archaeological context and chronology. This central problem has shaped most of the subsequent debate about the find. ${ }^{95}$ Joseph Hackin's interpretation of the nature and wider significance of the hoard was very cautious; in his last writing, dated to 1940, he remarked simply that this find was evidence for wide connectivity under the Kushans during the first to second centuries CE. ${ }^{96}$ It was his colleagues and successors at the DAFA who explicitly suggested that the Site II structure was a palace, and that the hoard objects were the abandoned and concealed precious possessions of a Kushan king or lord fleeing a Sasanian invasion. ${ }^{97}$

Archaeologist Mortimer Wheeler's interpretation of the find in Rome Beyond the Imperial Frontiers (1954) was even bolder. He asserted: "the easiest explanation is doubtless the correct one. The store was probably a Customs depot for the receipt of dues in kind collected by the kings or viceroys of Kapisa from the caravans which traversed the adjacent highway in the luxury traffic of Orient and Occident." 98 Al-

91 For the primary publications of the hoard finds see Hackin 1939; Hackin 1954.

92 See conveniently the survey in Whitehouse 2001.

93 See the discussion in Rosen Stone 2008.

94 For the most recent survey, see Zhang 2011.

95 Discussed at length in Morris 2017.

96 Hackin 1954, 11-15.

97 Ghirshman 1946, 28; Foucher 1954.

98 Wheeler 1954, 163-164. 
though not usually directly cited, ${ }^{99}$ Wheeler's general supposition that the Begram hoard is symptomatic of wider patterns of long-distance trade rather than a phenomenon of consumption specific to the Kushan context has come to resonate in subsequent scholarship. Indeed, although numerous scholars of the latter twentieth century still more prudently considered the hoard as broad evidence for the prosperity and cosmopolitanism of the Kushan Empire and the nature of goods acquired through trade, ${ }^{100}$ this has been widely supplanted by Sanjyot Mehendale's reinterpretation of the find, which is in fact not entirely distant to that of Wheeler.

Mehendale has argued that the hoard objects were not especially precious in the sense that they could only be associated with royal wealth, that the hoard objects all date to the first century $\mathrm{CE}$, and that the hoard itself may have been a traders' stock accumulated for commercial purposes (or impounded) awaiting further distribution. She has also suggested the possible inclusion of unworked material in the hoard was indicative of local craft activities. ${ }^{101}$ Ultimately, Mehendale cast Begram as a commercial transit and manufacturing center "at the heart of the Silk Roads.”102

\section{III.3 Crystallization into Doctrine}

From the 1960s to the present, certain interpretations as to the origins and metrology of Kushan dinars and the significance of the Begram hoard have crystallized (despite the scholarly non-consensus seen above), establishing a historiographical doctrine about the economic significance of external transit trade for the Kushan Empire. For example, Robert Göbl - the leading specialist on Kushan numismatics during his lifetime - accepted the Roman origin of Kushan gold, in addition to his well-known arguments for typological links between Roman and Kushan coinage. ${ }^{103}$ Likewise, John Rosenfield's groundbreaking monograph, The Dynastic Arts of the Kushans, repeated the assumption that the Kushan gold derived largely from melted-down Roman aurei. ${ }^{104} \mathrm{He}$ also stated clearly: "much of the prosperity of the $\mathrm{Ku}$ shan Empire must have rested on its trade with the West, for its merchants served as middlemen taking cargoes coming from China when they entered the Kushanshahr from the Tarim Basin."105

Similar assertions were made in generalist discussions of Silk Road and IndoRoman trade, produced in increasing volumes in the latter half of the twentieth

99 See however, Thorley 1979, 187-188.

100 For example, MacDowall and Taddei 1978, 257; Raschke 1978, 632; Frye 1984, 284.

101 Mehendale 1996; Mehendale 1997, 6.4; Mehendale 2011.

102 Thus the title of Mehendale 2011.

103 Already in Göbl 1960.

104 Rosenfield 1967, 19-23.

105 Rosenfield 1967, 21. 
century. Boulnois's monograph on the Silk Road and Miller's on the spice trade of the Roman Empire both characterized the Kushans as middlemen. ${ }^{106}$ Srivastava's study of trade and commerce in India claimed that the initiation of Kushan gold coinage on a Roman pattern was to "encourage traders" and was aimed at an "international market” of (especially Roman) merchants. ${ }^{107}$ John Thorley's articles in Greece and Rome about the development of trade between Rome and China described the Kushans as middlemen, ${ }^{108}$ and again considered Kushan gold coinage as intended to facilitate trade with Rome. Following Wheeler's interpretation of Begram as a customs post; Thorley even went so far as to speculate that the Kushans had a government monopoly on silk trade via a center such as Begram. ${ }^{109}$

Finally, in 1978, Manfred G. Raschke (an economist and ancient historian) decisively confronted several of these ideas, explaining the economy under the Kushans and their role in long-distance trade in an entirely different manner. Raschke pointed to the Begram hoard as evidence for luxury imports under the Kushan period, describing Central Asia and northwest India as particularly suitable markets for Roman goods due to the region's Hellenistic heritage. ${ }^{110}$

Even more significantly, Raschke also considered the various 'middlemen' of Rome's eastern trade, including Chinese agents, Parthians, Sogdians, and the Kushans - "the middlemen par excellence." He attacked underlying assumptions about the role of these agents in long-distance trade:

A most delicate subject this, and one which calls forth liberal and Marxist scholars' deepest
economic prejudices. It is accepted doctrine that the middlemen were the villains in Rome's
Eastern trade. Simple drones who contributed nothing to the value of the product, they used
their geographic position to sap the financial strength of the Roman Empire and by the prod-
ucts they sold they corrupted the morals of its nobility. This picture bears little resemblance
to the evidence. ${ }^{111}$

Acknowledging the evident prosperity of the Kushan period, Raschke however pointed out that the basis of this was not transit trade, but rather advanced irrigated agricultural production, acknowledging the contribution of Soviet research to this issue. ${ }^{112}$

Yet, only Raschke's criticism of the villainous casting of middlemen seems to have been taken up in subsequent scholarship, as later contributions nonetheless increasingly emphasized the significance of the Kushan contribution to transit trade. For example, Xinru Liu's study of Yuezhi-Kushan migration and settlement

106 Boulnois 1966; Miller 1969, 234-235.

107 Srivastava 1968, 179-191.

108 Thorley 1969; Thorley 1971.

109 Thorley 1979.

110 Raschke 1978, 632-633.

111 Raschke 1978, 637.

112 Raschke 1978, 640. 
in Bactria attributes the Kushan's capacity as the "cosmopolitan broker of Eurasian trade" to their Yuezhi heritage and "trading skills," for which the Begram hoard is also mobilized as evidence. ${ }^{113}$ Similarly, in The Silk Road in World History (2010), she claimed that the Kushans became prosperous from the geography of their empire as trade passed through their territory, in addition to their patronage of Buddhist institutions, and (the old story) that the Kushans had based their gold dinars on the Roman aureus to accommodate their Roman trading partners. ${ }^{114}$

At the beginning of this chapter, we have already seen the idea of the Yuezhi desire to control "trade routes" as a "profitable" activity in Falk's study. ${ }^{115}$ It is also worth emphasizing that Benjamin's appraisal of the Kushans' contribution to Silk Road trade, cited also at the beginning of this chapter, depended heavily on Mehendale's interpretation of Begram as a commercial node and point of redistribution. ${ }^{116}$ The same is true for Graf's recent coverage on the Silk Road within the edited volume Trade, Commerce, and the State in the Roman World (2018). ${ }^{117}$

\section{Conclusion: Beyond Transit Trade}

As we have seen, the notion of Kushan middlemen originated in precarious hypotheses that became crystallized in both generalist treatments of long-distance trade and specialist studies of the Kushans. Although this notion ought to be further critically reassessed, it should suffice to note for now that factual problems continue to undermine its basis. For example, recent analysis of the trace elements in Kushan gold coinage has finally ruled out the theory that they were produced from melted down Roman aurei. ${ }^{118}$ A study of some overlooked coins found in the Begram hoard has demonstrated that the assemblage must have been deposited after the midthird century CE, which means that the chronological foundation of Mehendale's argument is no longer valid. ${ }^{119}$ Furthermore, scholars of Han lacquerware (such as those found at Begram) continue to emphasize the limited range of circulation and extremely high value of this class of material objects in Chinese and foreign diplomatic contexts. ${ }^{120}$

Yet, scholarly discourse is not simply driven by evidence, and it is worth finally considering why the notion of Kushan middlemen - certainly a historiographical

113 Liu 2001, 272-276.

114 Liu 2010, 42-61.

115 Falk 2014.

116 Benjamin 2018.

117 Graf 2018.

118 Blet-Lemarquand et al. 2009, 51.

119 Morris 2017.

120 Pirazzoli-t’Serstevens 2001; Pirazzoli-t'Serstevens 2009; Zhang 2011. 
construct, if not wholly fictitious - continues to retain such appeal when other explanations of economic development under the Kushans and their participation in long-distance trade might be proposed. For this, I offer three concurrent explanations.

The first is that scholars now recognize the centrality of the space of the Kushan Empire within the Eurasian landmass, their location between the well-documented empires of Rome and China, and their significance for global history despite major documentary difficulties. Accordingly, the ever-increasing emphasis placed on the "critical role" played by the Kushans in long-distance transit trade ${ }^{121}$ may be explained as an attempt to account for the power, prosperity, and importance of this mysterious empire in some way; in the end, it is best to have the pivotal Kushans in the Silk Road story somewhere, rather than not at all. The second explanation is, as clarified above, two particular classes of material evidence - Kushan gold coinage and the Begram hoard - have long remained extremely visible in scholarship, and traditional interpretations of their significance appear to support the notion of Kushan middlemen.

However, the final, most significant reason why this notion continues to hold such appeal is because there is no highly developed discourse on the economic history of ancient Central Asia and its empires, and accordingly a broader lack of engagement with the relevant knowledge produced by Soviet scholarship. I emphasize the significance of Soviet research here because anyone seeking to obtain a different perspective on economic development under the Kushan Empire would need only to look in this direction. Of course, this can be forgiven in some part due to linguistic boundaries and the frequent difficulty of obtaining Soviet-era scholarship; although this task can remain difficult even today, before the fall of the USSR it could be insurmountably so. Nonetheless, Soviet scholarship characterized the Kushan period of Central Asia by agricultural prosperity through artificial irrigation, advances in technologies of agricultural and craft production, expanding urbanization, highly developed monetization and commodity exchange, the exploitation of local mineral resources, and the active importation of foreign commodities and exportation of their own. Naturally, these claims need to be reassessed and further nuanced as research progresses, but the fact remains that Soviet scholarship produced a completely different vision of the economy of the Kushans, which could certainly challenge and nuance prevailing narratives in Western scholarship.

Ultimately, the truth probably lies somewhere in the middle: the prosperity of the Kushan Empire, although in need of better quantification, is likely entangled between all of the factors raised in this chapter. Only once the origins, life, and persistence of the many disparate relevant ideas are clearly spelled out, can specialist research reassess their veracity.

121 Benjamin 2018, 202. 


\section{References}

Andrianov, В. V. 1969. Древние оросительные системы приаралья [Ancient irrigation systems of the Aral Sea area]. Москва: Наука.

Aperghis, G. G. 2004. The Seleukid royal economy: The finances and financial administration of the Seleukid Empire. Cambridge: Cambridge University Press.

Arzhantseva, I. 2015. "The Khorezmian expedition: Imperial archaeology and Faustian bargains in Soviet Central Asia." Public Archaeology 14.1, 5-26.

Bartol'd, V. V. 1965. “К истории орошения Туркестана” [On the history of irrigation in Turkestan]. In Сочинения. Vol 3, 97-233. Москва: Наука.

Benjamin, C. 2018. Empires of ancient Eurasia: The first Silk Roads era, 100 BCE-250 CE. Cambridge: Cambridge University Press.

Blet-Lemarquand, M., G. Sarah, B. Gratuze, and J.-N. Barrandon. 2009. "Nuclear methods and laser ablation inductively coupled plasma mass spectrometry: How can these methods contribute to the study of ancient coinage?" Cercetări Numismatice 15, 43-56.

Boulnois, L. 1966. The Silk Road. D. Chamberlin (trans.). London: Allen \& Unwin.

Bustanov, A. K. 2015. Soviet Orientalism and the creation of Central Asian nations. London: Routledge.

Coloru, 0. 2009. Da Alessandro a Menandro: Il regno greco di Battriana. Pisa: Fabrizio Serra.

Cunningham, A. 1888. "Coins of the Indo-Scythians." The Numismatic Chronicle and Journal of the Numismatic Society 8, 199-248.

de la Vaissière, É. 2005. Sogdian traders: A history. J. Ward (trans.). Leiden: Brill.

D’iakonov, I. М. 1966. “Основные черты экономики в монархиях древней Западной Азии” [The main features of the economy in the monarchies of ancient Western Asia]. Народы Азии и Африки, по. 1, 44-58.

Falk, H. 2014 [2018]. "The five Yabghus of the Yuezhi." Bulletin of the Asia Institute 28, 1-43.

Foucher, A. 1954. "L'oeuvre archéologique de J. et R. Hackin en Afghanistan." In Hackin (1954), $1-3$.

Frye, R. N. 1984. The history of ancient Iran. Munich: C. H. Beck.

Gafurov, B. G. 1952. История таджикского народа в кратком изложении: С древнейших времен до Великой Октябрьской социалистической революции 1917 г. [The history of the Tajik people in summary: From ancient times until the Great October Socialist Revolution of 1917]. 2nd ed. Москва: Государственное издательство политической литературы.

-. 1989. Таджики: Древнейшая, древняя и средневековая история. Книга Первая. Издание второе [Tajiks: The most ancient, ancient, and medieval history]. 2nd ed. Vol. 1. Душанбе: Ирфон.

Gardin, J.-C. 1998. Prospections archéologiques en Bactriane orientale (1974-1978). Vol. 3, Description des sites et notes de synthèse. Paris: Éditions Recherche sur les civilisations.

Ghirshman, R. 1946. Begram: Recherches archeologiques et historiques sur les Kouchans. Cairo: Institut français d'archéologie orientale.

Göbl, R. 1960. "Roman patterns for Kushana coins." Journal of the Numismatic Society of India 22, 75-96.

Gorshenina, S. 2004. The private collections of Russian Turkestan in the second half of the 19th and early 20th century. Berlin: Schwarz.

-. 2012. "L'archéologie russe en Asie centrale en situation coloniale: Quelques approches." In P. Burgunder (ed.), Études pontiques: Histoire, historiographie et sites archéologiques du bassin de la mer Noire, 183-222. Lausanne: Université Lausanne.

Graf, D. F. 2018. "The Silk Road between Syria and China." In A. Wilson and A. K. Bowman (ed.), Trade, commerce, and the state in the Roman world, 443-530. Oxford: Oxford University Press. 
Guillaume, 0. 1990. "Naive anthropology in the reconstruction of Indo-Greek history." Indian Economic \& Social History Review 27.4, 475-482.

Hackin, J. 1939. Recherches archéologiques à Begram: Chantier no. 2 (1937). 2 vols. Paris: Les Éditions d'art et d'histoire.

-. 1954. Nouvelles recherches archéologiques à Begram (ancienne Kâpici) (1939-1940): Rencontre de trois civilisations, Inde, Grèce, Chine. 2 vols. Paris: Imprimerie Nationale and Presses Universitaires.

Hill, J. E. 2015. Through the Jade Gate - China to Rome: A study of the silk routes 1st to 2 nd centuries CE. New updated and expanded edition. 2 vols. Self-published, CreateSpace.

Holt, F. L. 2012. Lost world of the golden king: In search of ancient Afghanistan. Berkeley, CA: University of California Press.

Hopkirk, P. 1990. The Great Game: On secret service in High Asia. London: John Murray.

lakubovskii, A. I. 1941. К вопросу об етногенезе узбекского народа [On the question of the Uzbek people's ethnogenesis]. Ташкент: Узфан.

lanovskaia, М. 2009. “Борис Литвинский: «Мы подарили таджикскому народу первую полноценную историю»" [Boris Litvinskii: "We gave the Tajik people the first full history']. Фергана.Py, March 17. https://web.archive.org/web/20180723164238/https:// www.fergananews.com/articles/6098.

Ikrami, D. 2009. “Кто на самом деле написал ‘Таджики’? (ответ Б. Литвинскому)” [Who really wrote 'Tajiks'? (answer to B. Litvinskii)]. ЦентрАзия, April 16. https://web.archive.org/web/ 20160611173522/http://www.centrasia.ru/newsA.php?st=1239875040.

Kennedy, J. 1912a. "The secret of Kanishka." Journal of the Royal Asiatic Society 44.3, 665-688.

-. 1912b. "The secret of Kanishka (concluded from p. 688)." Journal of the Royal Asiatic Society 44.4, 981-1019.

Laruelle, M. 2008. "The concept of ethnogenesis in Central Asia: Political context and institutional mediators (1940-50)." Kritika 9.1, 169-188.

Liu, X. 2001. "Migration and settlement of the Yuezhi-Kushan: Interaction and interdependence of nomadic and sedentary societies." Journal of World History 12.2, 261-292.

-. 2010. The Silk Road in world history. Oxford: Oxford University Press.

MacDowall, D. W. 1960. "The weight standards of the gold and copper coinages of the Kushana dynasty from Kadphises to Vasudeva." Journal of the Numismatic Society of India 22, 62-74.

MacDowall, D. W. and M. Taddei. 1978. "The pre-Muslim period." In F. R. Allchin and N. Hammond (eds.), The Archaeology of Afghanistan: From earliest times to the Timurid period, 233-299. London: Academic Press.

Mairs, R. 2006. “'Hellenistic India.” New Voices in Classical Reception Studies 1, 19-30.

Mani, B. R. 1987. The Kushan civilisation: Studies in urban development and material culture. Delhi: B. R. Publishing.

Masson, V. M. 1955. “Денежное хозяйство древней Средней Азии по нумизматическим данным" [Monetary economy of ancient Central Asia according to numismatic evidence]. Вестник древней истории, по. 2, 37-47.

Mehendale, S. 1996. "Begram: Along ancient Central Asian and Indian trade routes." Cahiers d'Asie centrale 1/2, 47-64.

-. 1997. "Begram: New perspectives on the ivory and bone carvings." PhD. diss., University of California, Berkeley.

-. 2011. "Begram: At the heart of the silk roads." In F. Hiebert and P. Cambon (eds.), Afghanistan: Crossroads of the ancient world, 131-144. London: British Museum Press.

Miller, J. I. 1969. The spice trade of the Roman Empire, 29 BC-AD 641. Oxford: Clarendon.

Morris, L. 2017. "Revised dates for the deposition of the Begram hoard and occupation at the New Royal City." Parthica 19, 75-104. 
Mukhamedzhanov, A. R. 1978. История орошения Бухарского оазиса: с древнейших времен до начала XX в. [History of irrigation of the Bukhara oasis: From ancient times to the beginning of the 20th c.]. Ташкент: Издательство Фан.

Mukherjee, B. N. 1970. The economic factors in Kushāna history. Calcutta: Pilgrim.

Narain, A. K. 1957. The Indo-Greeks. Oxford: Clarendon.

Olivier-Utard, F. 1997. Politique et archéologie: Histoire de la Délégation archéologique française en Afghanistan, 1922-1982. Paris: Éditions Recherche sur les Civilisations.

Pirazzoli-t'Serstevens, M. 2001. “Les laques chinois de Begram: Un réexamen de leur identifiation et de leur datation.” Topoi 11.1, 473-484.

-. 2009. "Chinese lacquerware from Noyon uul: Some problems of manufacturing and distribution." Silk Road 7, 36-41.

Raschke, M. G. 1978. "New studies in Roman commerce with the East.” In H. Temporini (ed.), Aufstieg und Niedergang der römischen Welt. Part 2, vol. 9.2, 604-1363. Berlin: De Gruyter.

Ray, H. P. 2010. “Introduction.” In H. P. Ray (ed.), Sanghol and the archaeology of Punjab, 1-19. New Delhi: Aryan Books International.

Rezakhani, K. 2017. ReOrienting the Sasanians: East Iran in Late Antiquity. Edinburgh: Edinburgh University Press.

Rosen Stone, E. 2008. "Some Begram ivories and the South Indian narrative tradition: New evidence." Journal of Inner Asian Art and Archaeology 3, 45-59.

Rosenfield, J. M. 1967. The dynastic arts of the Kushans. Berkeley, CA: University of California Press.

Rostovtzeff, M. I. 1941. The social and economic history of the Hellenistic world. 3 vols. Oxford: Clarendon.

Sergeev, E. 2013. The Great Game, 1856-1907: Russo-British relations in Central and East Asia. Baltimore, MD: Johns Hopkins University Press.

Sewell, R. 1904. "Roman coins found in India." Journal of the Royal Asiatic Society 36.4, 591-637.

Spengler, R., M. Frachetti, P. Doumani, L. Rouse, B. Cerasetti, E. Bullion, and A. Mar'yashev. 2014. "Early agriculture and crop transmission among Bronze Age mobile pastoralists of Central Eurasia." Proceedings of the Royal Society B: Biological Sciences 281.1783. https://doi.org/ 10.1098/rspb.2013.3382.

Srivastava, B. 1968. Trade and commerce in ancient India: From the earliest times to C. AD 300. Varanasi: Chowkhamba Sanskrit Series Office.

Tarn, W. W. 1938. The Greeks in Bactria and India. Cambridge: Cambridge University Press.

Thorley, J. 1969. "The development of trade between the Roman Empire and the East under Augustus." Greece and Rome 16, 209-223.

-. 1971. "The silk trade between China and the Roman Empire at its height, circa AD 90-130." Greece and Rome 18, 71-80.

-. 1979. "The Roman Empire and the Kushans." Greece and Rome 26, 181-190.

Tolstov, S. P. 1934. “Генезис феодализма в кочевых скотоводческих обществах” [The genesis of feudalism in nomadic pastoral societies]. Известия ГАМИК 103, 171-199.

-. 1938а. “Основные вопросы древней истории Средней Азии” [Main questions of the ancient history of Central Asia]. Вестник древней истории, no. 1, 176-203.

-. 1938b. “Тирания Абруя: Из истории классовой борьбы в Согдиане и тюркском каганате во второй половине VI в. н.э.” [The tyranny of Abrui: from the history of class struggle in Sogdiana and the Turkic Kaghanate in the second half of the 6th century CE]. Исторические Записки 3, 3-53.

-. 1943. Древняя культура Узбекистана [Ancient culture of Uzbekistan]. Ташкент: Издательство УзФАН.

-. 1948. Древний Хорезм. Опыт историко-археологического исследования [Ancient Khorezm: Experience of historical and archaeological research]. Мосвка: Издание МГУ. 
-, ed. 1955. Материалы объединенной научной сессии, посвященной истории Средней Азии и Казахстана в дооктябрьский период [Materials of the Joint Scientific Section devoted to the history of Central Asia and Kazakhstan in the pre-October Revolution period]. Ташкент: Издательство АН УзССР.

-. 1958. “Работы Хорезмской археолого-этнографической экспедиции АН СССР в 1949-1953 гг." [Works of the Khorezm Archaeological-Ethnographic Expedition, USSR Academy of Sciences in 1949-1953]. In Труды Хорезмской археолого-этнографической экспедиции, vol. 2, 7-258. Москва: Издательство АН СССР.

Tolz, V. 2011. Russia's own Orient: The politics of identity and Oriental Studies in the late imperial and early Soviet period. Oxford: Oxford University Press.

Trever, K. V., А. I. lakubovskii, and M. Е. Voronets. 1950. История народов Узбекистана. Том 1. С древнейших времён до начала XVI века [The history of the peoples of Uzbekistan. Vol. 1, From ancient times to the beginning of the XVI century]. Ташкент: Издательство АН УзССР.

Van Lohuizen-de Leeuw, J. E. 1949. The "Scythian" period: An approach to the history, art, epigraphy and palaeography of North India from the 1st century $B C$ to the 3rd century $A D$. Leiden: Brill.

Warmington, E. H. 1928. The commerce between the Roman Empire and India. Cambridge: Cambridge University Press.

Wheeler, R. E. M. 1954. Rome beyond the imperial frontiers. London: G. Bell and Sons.

Whitehouse, D. 2001. "Begram: The glass." Topoi 11.1, 437-449.

Zeimal’, E. V. 1987. “К периодизации древней истории Средней Азии (середина I тысячелетия до н.э. - середина I тысячелетия н.э.)" [On the periodization of the ancient history of Central Asia (the middle of the 1st millennium BC-the middle of the 1st millennium AD)]. In Центральная Азия: новые памятники письменности и искусства, 149-157. Москва: Наука.

Zeimal', T. I. 1971. “Древние и средневековые Каналы вахшской долины” [Ancient and Medieval channels of the Vakhsh valley]. In Страны и народы Востока. Средняя и центральная Азия. География, Этнография, История 10, 37-57. Москва: Наука.

Zhang, L. 2011. “Chinese lacquerwares from Begram: Date and provenance.” International Journal of Asian Studies 8.1, 1-24. 


\section{Economy, Frontiers, and the Silk Road in Western Historiographies of Graeco- Roman Antiquity}

\section{The Mediterranean and Trans-imperial Exchange}

Although the last few years have seen a surge of publications on Indo-Roman trade and Silk Road exchange, ${ }^{1}$ the trans-imperial trade connections of the Hellenistic and Roman Empires have never been central to the field of Graeco-Roman history. The Greeks and Romans were Mediterranean societies. Their involvement in Asia beyond Asia Minor was the result of colonization, annexation, and conquest, but not central to their cultural formation, empire building, and economy. ${ }^{2}$ The Mediterranean perspective of studies on Greek and Roman culture, that explains itself by the origin of Graeco-Roman history in Greek and Latin philology, gained further momentum by a new interest in Mediterranean connectivity that developed in the wake of the English translation of Fernand Braudel's La Méditerranée et le monde méditerranéen à l'époque de Philippe II (1949) in 1972. Since then, Graeco-Roman culture and economy could be even more convincingly, and more comprehensively, located in the Mediterranean Basin. ${ }^{3}$ The subject of ancient history was no longer defined just by the languages, but instead by geographical, cultural, and economic cohesion of the ancient Mediterranean. In 2000, Horden and Purcell published a volume full of knowledge and insight about ecologies, microclimates, nutrition, settlement patterns, and systems of travel and exchange that gave life to the Mediterranean as a connected human landscape. In an often-quoted phrase, they summarized the Mediterranean's most important characteristics as fragmentation and connectivity: "We have identified extreme topographical fragmentation as one of two environment ingredients - along with the connectivity provided by the sea itself - in a distinctly Mediterranean history." 4

The unity of the Mediterranean is a construct, but it has some natural basis: The region was the home of particular vines, the European olive, and certain types of wheat typically consumed by Greeks and Romans; it was a unified climatic zone and it was relatively easily navigable. The very uneven distribution of natural re-

1 Matthew 2015; de Romanis and Maiuro 2015; McLaughlin 2016; Evers 2017; Wilson and Bowman 2018 (part III); Cobb 2018; 2019.

2 See, however, Fitzpatrick 2011 with a different emphasis. For the Mediterranean orientation of the Hellenistic Empires, see von Reden, ch. 1, this volume.

3 See, however, Burkert (1984) 1992; Morris and Manning 2005, 17 for further dissenting voices.

4 Horden and Purcell 2000, 175.

Ә Open Access. (c) 2020 Sitta von Reden and Michael Speidel, published by De Gruyter. (cc) BY-NC-ND This work is licensed under the Creative Commons Attribution-NonCommercial-NoDerivatives 4.0 License.

https://doi.org/10.1515/9783110607741-026 
sources, especially metals, and its diverse microclimatology encouraged a system of Mediterranean-wide trade. ${ }^{5}$ Yet the Mediterranean is also a political instrument. In an important colloquium four years after the publication of Corrupting Sea, Herzfeld called the Mediterranean a civilizational ideal, a "strategy of self-stereotyping," and part of the "politics of humiliation" in a global national hierarchy. ${ }^{6}$ Bagnall in the same colloquium emphasized the ambivalent place of Graeco-Roman Egypt in this socio-geographical scheme. Despite Egypt's extended Mediterranean coast, he argued, it never fully belonged to the category of a Mediterranean society, nor Graeco-Roman Egypt to the realm of ancient history proper. ${ }^{7}$

Greeks and Romans themselves anchored their cultural belonging in the Mediterranean Sea. Contacts and exchange between Asia and Egypt had been intense from the times of the Bronze Age onward - not least mediated by Greek settlement on the Ionian and Levantine coasts, the Egyptian delta, and Cyprus. ${ }^{8}$ But it was in the aftermath of the Persian Wars that a strong sense developed (forced to emphasize unity) that Greeks lived as free citizens in city-states in a manner that came to be seen as typical of Greece and the Aegean Sea, while Persians were by nature subjects. ${ }^{9}$ In this self-imagination, barbarians neither participated in, nor were affected by, the more advanced culture of poleis. Geographical and medical writers placed Greek civilization in the world's temperate central zones, while people either more savage or softer, but in any case less civilized, inhabited the climatically more extreme regions toward the edges of the world. ${ }^{10}$ As the Macedonians conquered Asia and Egypt, kings and immigrants were drawn to the Mediterranean coast lines: Alexandria in Egypt was founded on the Mediterranean, and soon replaced Memphis as the royal capital; the Seleukids shifted their political core from the Persis to Babylonia and connected it via roads and colonial foundations to the newly built capitals Antiocheia and Seleukeia on the Syrian coast. ${ }^{11}$ Even long after the expansion of the Roman Empire, Rome never ceased to be the uncontested center of the Roman Empire. It was not only the seat of the emperor, but also the center of the orbis terrarum that could be grasped conceptually and geographically only from a central and elevated vantage point. ${ }^{12}$ A monument called the Golden Milestone (milliarium aureum) erected by Augustus in 20 BCE in the center of the city symbolized Rome's central position in its world: all roads led here.

5 Harris 2005, 5-6.

6 Herzfeld 2005, 48, 52, 59; also Morris and Manning 2005, 19-22 for the politics of the Mediterranean paradigm.

7 Bagnall 2005.

8 Most recently Broodbank 2013 on these connections and their role in the formation of Mediterranean unity.

9 Cartledge 1993, 36-63.

10 See von Reden, ch. 8 B, this volume.

11 See von Reden, ch. 1, this volume.

12 Murphy 2004, 129-164. 
Economic history and theory furthered Mediterranean unity. In a famous passage introducing his influential The Ancient Economy (1973), Moses Finley defended a unitary perspective on the Graeco-Roman economy with reference to its difference from those of the ancient Near East, the Babylonians, Phoenicians, Egyptians and Persians:

The Near Eastern economies were dominated by large palace or temple complexes, who owned the greater part of the arable virtually monopolized anything that can be called 'industrial production' as well as foreign trade ... and organized the economic, military, political and religious life of the society through a single complicated, bureaucratic, record-keeping operation for which the word 'rationing,' taken very broadly, is a good one-word description. None of this is relevant to the Greco-Roman world until the conquests of Alexander the Great and later the Romans incorporated large Near Eastern territories. At that point we shall have to look more closely at this Near Eastern kind of society. ${ }^{13}$

He left the issue at that point, since, as he argued, if he were to define 'ancient' to embrace both worlds, there was not a single topic that could be discussed "without resorting to disconnected sections, employing different concepts and models." Finley conceded that there were forms of private landownership and labor also in the Near East, and there were also independent craftsmen and traders in the towns. Yet it was not possible to elevate these people to driving forces in the economic development of the Near East, whereas the Graeco-Roman economy was essentially one of private property. ${ }^{14}$

While Finley did not discuss the factors that changed the Near Eastern and Egyptian economies after the Macedonian conquest, the editors of the more recent Cambridge Economic History of the Greco-Roman World (CEHGRW) emphasized the justification of Graeco-Roman unity in a broader sense. The division between east and west in antiquity was overstated, but there were very real differences between "most of the economic systems of Egypt and the Near East, in which temples, palaces and redistributive bureaucracies performed crucial functions, and those of the Greeks and Roman societies, where they generally did not". ${ }^{15}$ However, the category of Graeco-Roman economy was dislocated from its Mediterranean home, insofar as Greek and Roman institutions and practices were exported to other regions. ${ }^{16}$ Both before the Classical period (479-336 BCE) but especially after it, there were many connections and interpenetrations of these essentially different systems. Accounts of the pre-Hellenistic Near East, Seleukid Asia, Ptolemaic and Roman Egypt as well as the Roman frontier zones were naturally included in the CEHGRW. They demonstrated the gradual transformation, continuity, and change under Graeco-Roman presence. No uniform picture emerged from these regional views. However, and

13 Finley (1973) 1985, 28.

14 See Baker and Jursa 2014; Jursa 2014.

15 Morris, Saller, and Scheidel. 2007, 8.

16 Bingen (1978) 2007. 
simplification permitted, the conclusion of most chapters was that the impact of Graeco-Roman institutions, private property rights, monetization, technological knowledge, and the logistics of transport and trade led to an increase in market exchange and economic performance. ${ }^{17}$ Some authors were hesitant to attribute increased performance just to Graeco-Roman institutional change: Monetization and monetary tribute of the Near East began in the age of Dareios; experimentation with new, more marketable agrarian produce built on pre-Hellenistic trends in Egypt; and army presence in Roman frontier zones had very different kinds of impact in different provinces. ${ }^{18}$ Yet it was Graeco-Roman presence and their institutions and forms of knowledge that led to new economic practices and levels of performance.

In a thought-provoking study, suggestively entitled The Roman Bazaar (2008), Bang criticized this approach to the Graeco-Roman economy. Its overly Western outlook, which centralized markets, private property, and individuals as driving forces of economic development, in fact projected dynamics that had in fact emerged much later in the context of the European nation state into the imperial world of antiquity. The economic development of tributary empires had a different logic. To ignore this put one in danger of reinforcing European orientalism, which belittled the prosperity of Asian empires before European colonialism. ${ }^{19}$ The market model, characterized by monetary exchange, private property rights, and rational choice, was deeply impregnated by the universalist claims of classical political economy that developed in Early Modern Europe. Competition between independent nationstates and governments, international opportunities for competitive investment of commercial capital, and mercantilist politics were typical for this historically unique state system. The Roman Empire, in contrast, was not part of a competitive state system, nor were its provinces autonomous states. It resembled rather more the early modern tributary empires of Asia, the Ottomans, the Mughals, or China of the Ming and Ch'ing dynasty. Inter-state competition was a much weaker dynamic in these, and also in the Roman Empire. "The Roman state was already the most powerful and had much less in need to privilege commercial groups; it could concentrate on taxing its vast population, particularly the peasant masses."20

The authors of the Cambridge Economic History of the Greco-Roman World approached the ancient economy from its centers. The main subjects of inquiry were the city-states of Greece and Italy where the development of free peasantries, private property rights, and monetization had played an undeniably positive role for economic performance before the Hellenistic period. The impact of the imperial expansion of the Greek world from the late fourth century BCE, and of the Roman world from the late third century BCE, continued to be viewed (as in Graeco-Roman history

17 Shown more thoroughly for Roman Egypt by Monson 2012.

18 Van der Spek 2007; Manning 2007; Cherry 2007.

19 Bang 2008; Morris 2010 for a long-term analysis.

20 Bang 2008, 12. 
more generally) from the perspective of the old and new Greek and Roman centers. The Hellenistic capitals and later the city of Rome profitted from the economic development of the conquered land, and in turn these regions developped under the influence of the Greeks and Romans. Contacts beyond the Graeco-Roman Empires, moreover, played a relatively subordinate role. In a chapter discussing the Seleukid economy of the third to first centuries BCE, van der Spek, for example, raised the question of whether trade with Central Asia increased in the Seleukid Near East, but found no positive evidence. ${ }^{21}$ Rathbone, writing on Roman Egypt (first to third centuries CE), was well acquainted with the spectacular value of trade between Egypt and India in the first century CE. Nevertheless, he saw the impact of this trade to be limited to a small elite of financiers in Italy and Alexandria, and the manufacturing industries in Alexandria and Koptos where the import of perfumes, textiles and spices generated processing industries. ${ }^{22}$ Imports from Arabia and India, and their visible traces in Palmyra and the ports of the Red Sea coast, receive due attention in Morley's and Alcock's accounts of trade in the Roman Empire and the Eastern Mediterranean respectively. But once again, they are described as separate phenomena. Although profoundly affecting Palmyra as a nodal city on the routes to the Gulf and further on, Roman imports served the consumption and financial interests of just a small Italian and Roman elite. ${ }^{23}$ Lo Cascio emphasized the low state rate of the Roman fiscal economy, while not discussing the potentially huge fiscal income from external trade and frontier zone development. ${ }^{24}$ In the dominant models of the Graeco-Roman economy, trade and exchange with India, Central Asia and further east were no more than comparable to the modern drug trade: highly profitable for some, and stimulating complex exchange networks, but with little impact on economy and society as a whole. The focus on the economic principles of the imperial cores, and the resultant lack of integrating peripheral zones into research on the economies of the Hellenistic and Roman Empires, made it difficult to even raise the question of their impact.

For a long time, research on long-distance trade with India, the Arabian Peninsula, Central Asia and beyond was the concern of academic subgroups, particularly archaeologists and papyrologists whose interest in Egypt, Arabia, and India led them to transcend mainstream ancient history. ${ }^{25}$ In 1954, Mortimer Wheeler published what then was regarded an authoritative study of Roman trade beyond its frontiers. ${ }^{26}$ Wheeler had been Director General of the Archaeological Survey of India

21 Van der Spek 2007, 423.

22 Rathbone 2007, 711.

23 Morley 2007a, 583-584; Alcock 2007, 689-690, both marking it as an aside of Roman trade.

24 Lo Cascio 2007; Bowman and Wilson 2018 for a different assessment of the fiscal income derived from cross-border trade.

25 Pioniering studies were Rawlinson 1916, Charlesworth 1924, and Warmington 1928, but their interest in trade was limited; see Evers 2017, 4.

26 Wheeler 1954. 
between 1944 and 1948, and after partition functioned as archaeological advisor to the newly formed government in Pakistan. In his Presidential Address to the Oxford meeting of the British Association in September 1954 entitled "Colonial Archaeology," he stressed that the theme of his lecture related to the safeguarding of cultural, historical, and archaeological heritage in Britain's colonial territories. ${ }^{27}$ More than 20 years later, Raschke, an ancient historian and Harvard-trained economist, was commissioned to write a chapter for the multivolume Aufstieg und Niedergang der römsichen Welt (1978). Raschke was eager to emphasize that there was no coordinated trade between Rome and the East. The silk trade was indirect, a series of uncoordinated exchanges starting with the Chinese tribute payments to the Xiongnu via enterprising merchants in Central Asia who sold their goods to Parthians and Indians until they reached the Roman borders in Syria and Egypt. ${ }^{28}$ This view that Eastern trade reached Rome at the end of a series of disconnected enterprises embedded in local exchange systems and consumption centers was adopted again 20 years later by Young. Archaeological projects in the Eastern Desert, the Red Sea ports and sites along the coast of the Arabian Peninsula have stimulated debate over the conditions of Indo-Roman trade, its development and decline, and the communities and people both involved in and driving it. ${ }^{29}$ Yet the crucial question of precisely how external contacts and exchanges affected local, and possibly also wider, systems of trade and exchange was not answered in any systematic or analytical way. Textual and archaeological research in combination suggest a complicated assemblage of local and long-distance exchange networks peopled by different communities and economic agents from all regions involved. ${ }^{30}$

The idea of a 'Silk Road' was adopted by the geographer and geologist Ferdinand von Richthofen (1833-1904) and came to symbolize the vitality of trans-Eurasian trade long before the modern period. ${ }^{31}$ Yet, both the term and the idea behind it have been met with much skepticism among ancient historians. Its romantic allusion to camel trains and caravan cities has popular appeal, but little analytical power. Its underlying assumptions of traders linking supply and demand at either end of the long route is certainly mistaken, as Raschke, Young, and many others have shown. ${ }^{32}$ Most scholars have toned down the term by referring to a number of 'silk routes' in inverted commas and including into this category multiple pathways on the way as well as maritime trade routes between India and Egypt where silk played a subordinate role. Some scholars insist that, in contrast to the maritime trade routes, evidence for overland movement of goods from China through Central Asia

27 Ray 2008, 1; Tomber 2008, 13-14.

28 Raschke 1978, e.g., 605.

29 Proceedings of the Red Sea Project I-V; Tomber 2008; Sidebotham 2011; Sidebotham and GatesFoster 2019; Cuvigny 2003.

30 Tomber 2008; Thomas 2009; Sidebotham 2011; Evers 2017.

31 Galli 2017, 4; Brown 2018, 98-99; and von Richthofen 1877-1912.

32 Wiesehöfer, ch. 11, this volume; Graf 2018; Cobb 2018. 
and Mesopotamia before Late Antiquity (ca. 400-ca. 650 CE) was scant, fragmentary, incoherent, and did not add up to a continuous well-frequented route from China to the Mediterranean coast. ${ }^{33}$

Both as a consequence of growing interests in global contexts and fruitful controversies over the Mediterranean character of the Graeco-Roman economy, the insularity of research on trans-imperial exchange is gradually dissolving. Thus, Evers asked in his 2017 publication:

What if the Mediterranean is better perceived of, at least for the purpose of some studies, not as a unit, but as part of a greater whole, such as the Eurasian landmass, or, as in this study, the periphery of the Indian Ocean? In this case, we need to think about the historiographical consequences of shifting Rome from being the center, to being $a$ center in the peripheral west of Eurasia, which is really just a late consequence of old and new discussions about the implications of postcolonialism and globalization for our interpretation of the Roman Empire ... [T]he old ways of writing about Indo-Roman trade die hard, infusing studies with a 'Romanocentric' bias as regards the sources singled out for analysis, in turn emphasizing Roman carriers of the trade and a Roman chronology for trade in the Indian Ocean. ${ }^{34}$

Less globally oriented, but equally forceful, Bowman and Wilson in their latest volume of the Oxford Roman Economy Project (OxRep) have called for a better integration of external trade into the Roman trade system:

It is our contention, in fact, that external trade, with the east whether via Palmyra and the Silk Road(s) or with the Arabian peninsula and India, and with (and even across) the Sahara, should be considered not merely as an exotic sideshow, but as a fundamental part of the Roman trade system from the reign of Augustus onward, important not only for the quantities of exotic imports that it introduced, but also for the fiscal revenue that the 25 per cent customs dues yielded..$^{35}$

The two statements address very different problems. Evers asks us to rethink the position of the Roman Empire in a global post-imperial world, in which the Romans no longer were the central players. He questions the role of Rome as the initiator of global interaction, its rhythms and directions, as well as the autonomy of the Roman Empire in a multi-imperial orbit. He also qualifies, if not yet explicitly, the centrality of the city of Rome in a 'hublike' imperial structure within which the center dominated its peripheral regions to channel resources to the core. ${ }^{36}$ Addressing the social and economic organization of Indo-Roman trade in which more than

33 Millar 1998; Sartre 2000; Ball 2000; disputed by McLaughlin 2014; 2016, and Graf 2018; for the latest assessment, Gregoratti 2019.

34 Evers 2017, 4 and 5; also Fitzpatrick 2011, and Ball 2007.

35 Bowman and Wilson 2018, 13; Wilson 2015.

36 Motyl 2001 for this model of imperial structure; Scheidel 2012, 27-28 for discussion. According to Hopkins 1995-1996, Morley 2007a, and Morris, Saller, and Scheidel 2007, the city of Rome as a consumption center was the single most important factor driving economic performance, trade and market development in the Roman Empire. 
one empire or polity was involved, Evers draws our attention to the multifaceted assemblage of regions, communities and frontier regions that were involved. These were not just middlemen and transit zones in Indo-Roman trade, but active participants in the construction of the system. Bowman and Wilson, by contrast, do not question the dominating role of the Roman Empire and the centrality of Rome in Indo-Roman trade. They emphasize the fiscal and financial interest the Roman state took in the income derived from this trade. But they urge us better to integrate external trade into our understanding of the ancient economy. They invite us to think more carefully about the role external trade played in the state budget, and in the complex connection between tax income, coin supply, and military expenditure. ${ }^{37}$

The two issues, though related, lead into different and unconnected traditions of ancient historical research. The one concerns the nature of the ancient economy, the other relates to the political construction of the Roman Empire and its relation to its frontiers. Both contribute to the issues at stake. In order to answer the questions raised in this handbook, we will need to bridge these two fields of study: What were the dynamics of the ancient economy, which sources of income were generated, and how did ancient governments engage in the development of the economy? To what extent did the Roman interest in its border zones extend beyond preparing for warfare, defending possessions, supplying troops and exploiting resources? How were economic frontiers integrated into the Roman Empire and its economy? Did the Roman state identify economic interests in connection with its frontiers, and which measures did it take to pursue and defend such interests?

Studies of both the ancient economy and of the Roman frontiers have generated an enormous amount of scholarship, of a highly detailed as well as conceptual kind, which can only be discussed in their broadest outlines here. Yet, although they are in many respects closely related, the traditions of research have little overlap. ${ }^{38}$ To a significant extent this was a consequence of very diverse historiographic developments, as these themes were pursued by two distinct groups of specialists without much direct scholarly exchange.

\section{Sitta von Reden}

\section{Trends in the Historiography of the Graeco-Roman Economy}

\section{II.1 The Ancient Economy and European Modernity}

Ancient economic history developed as a subject of academic research in connection with the emergence of European capitalism and the field of classical political

37 Bowman and Wilson 2018, 14.

38 Cf. e.g., Young 2001; Sidebotham 2011; Speidel 2016. 
economy within philosophical inquiry in the late eighteenth century. It was pioneered by the groundbreaking study Die Staatshaushaltung der Athener (1817) of the Berlin classical philologist August Boeckh, which was rapidly translated into English as The Public Economy of Athens (1827). Boeckh compiled all available literary and epigraphic data about prices, wages, interest rates, public income, and expenditure, and framed them with discussions of demography, agriculture, manufacture, commerce, money and credit, mining, slavery, nutrition, clothing, and total costs of living in Athens. He thereby defined a subject area for ancient economic history that was strongly influenced by the national economies emerging in Western Europe at the time and the theoretical reflection about them in Scottish moral philosophy. ${ }^{39}$ Well into the eighteenth century, economic theory had been shaped by the classical separation of agrarian household management (oikonomia) on the one hand, and commerce (Gk chrematistike, lat. commercium), on the other. ${ }^{40}$ It was only in the Scottish enlightenment, culminating in Adam Smith's An Inquiry into the Nature and Causes of the Wealth of Nations (1776) that there developed an integrated notion of political economy. It connected these fields and constituted the relationship between consumption, agrarian as well as commercial production, and market distribution as the joint foundations of national wealth. Smith, however, regarded his economic model, and its underlying principle of the profit-seeking individual, as typical not only for contemporary national economies, but as universally valid. This universal claim gave the study of economic history a teleological direction toward Western economic liberalism that has never vanished. ${ }^{41}$

However, the universalizing claims of economic theory immediately met with critical response. The maximizing principle of human behavior in particular was called into question. According to Adam Smith, individuals served the interests of others not out of a sense of benevolence or charity, but out of self-interest and calculation. ${ }^{42}$ The term homo oeconomicus, which still stands for the maximizing principle today, was coined by John Stuart Mill as a critical objection against the notion of the profit-seeking individual, as it so strongly contradicted the classical concept of mankind as homo politicus. Accordingly, the market of the invisible hand that Smith envisioned as not just a distribution mechanism but as the basic means of political integration, was questioned. The German Historical School of National Economics that developed around Wilhelm Roscher (1817-1894) responded to the universalistic model of the Scottish enightenment scholars by relating the economy of the present to a historical process of gradual emergence. In the subsequent generation of scholars around Gustav Schmoller (1847-1930), economic theories were de-

39 Schneider 1988.

40 Burkhardt, Oexle, and Spahn 1992.

41 Bang 2008; Morley 2009, 21-46.

42 Smith (1776) 1961, 26-27. 
veloped on the basis of empirical historical investigations, from which the preconditions of modern capitalism were derived.

Classical economics was developed further by the Neoclassical School. Influential economists such as Léon Walras (1834-1910) in France, Carl Menger (1840-1921) in Germany and Alfred Marshal (1842-1924) in Britain theorized the market as a price formation mechanism based on supply and demand (equilibrium). ${ }^{43}$ Constituting equilibrium as the principle goal of markets, and markets the center of economic analysis, they transformed economics into a science based on quantifiable data and mathematical models. The maximizing principle was developed further into the concept of rational choice according to which economic agents always strive to make decisions to their best advantage, and thus make choice available for marginal cost calculation. To this day, neoclassical economic theory forms the basis of mainstream economics. For the investigation of precapitalist and non-Western economies, however, there remain only two options. Either the principles of modern economic theory are assumed to be generally valid, or they are regarded as the outcome of modern capitalism and largely useless for understanding precapitalist economies.

Since these controversies, the question of what constitutes economic history has been central to Graeco-Roman economic historians. If economic history is defined as the study of markets whose price formation processes are to be examined, ${ }^{44}$ it is very difficult to gather appropriate data. As we shall see below, ancient historians nevertheless have attempted to do so. At the other end of the spectrum are anthropological and cultural approaches that have developed in opposition to the neoclassical paradigm. They define an economy most broadly as the sum of activities that secure material livelihoods. ${ }^{45}$ Relationships, social values, and local models of meaning are at the center of such approaches and have led to historical research that may be regarded as much as cultural as economic history. ${ }^{46}$ While cultural approaches to the Graeco-Roman economy were en vogue during the 1990s, and led to much collaboration between anthropologists, literary critics, and ancient historians, in the last 20 years the pendulum has swung back to economic history in the neoclassical sense. ${ }^{47}$ However, neoclassical approaches have become more accommodating to historians of premodern economies in the course of the debates over Neo-Institutional Economics (NIE). For NIE economists, rational choice, the calculating individual, and market development are still essential to the analysis of economic processes. However, the institutional (that is, normative and legal) contexts of markets and the normative conditions of rational choice are given greater

43 Roll 1956.

44 Roll 1956, 373.

45 Polanyi 1977, 230.

46 Carrier 2012, 4-7.

47 Morris 1994; Morris and Manning 2005. 
prominence. ${ }^{48}$ This has offered new opportunities for studying the variable institutional influences on markets and behavior in historical perspective. Douglass North (1920-2015), a Nobel Prize winning economist, was particularly influential in redefining economic history as the task of identifying institutional and organizational conditions that explain structure and performance of historical economies through time. ${ }^{49}$ This approach had a major impact on research into ancient economic history in the twenty-first century.

\section{II.2 The Bücher-Meyer Controversy and the Ancient Economy}

Given its close connection with the emergence of Western modernity, ancient economic history has been concerned with its own theoretical assumptions more intensively than any other branch of ancient history. Its role in shaping modern thought and the role of Europe in the global cultural scheme came to the fore in the controversy between the national economist of the Historical School Karl Bücher (18471937) and the ancient historian Eduard Meyer (1855-1930). ${ }^{50}$ Bücher developed a model of European history that established a development of stages from the "closed domestic economy" of antiquity via the "city economy" of the Middle Ages to the "national economy" of modern times. ${ }^{51}$ With this model he met sharp criticism from Meyer, who defended the modernity of the ancient economy in the neoclassical sense. In his response to Bücher, Meyer sketched a picture of the gradual development of the Greek economy from the eighth century BCE onward toward a capitalist market economy. Trade, commerce, money, and market-oriented production drove a dynamic economy in classical Athens that reached its climax with banks and high volumes of credit in the fifth and fourth centuries BCE. ${ }^{52}$ The landowning aristocracy was replaced by an aspiring industrial bourgeoisie by the late fifth century. In his five-volume Geschichte des Altertums (1884-1902) Meyer compared the seventh to fifth centuries BCE in Greece to the fourteenth to sixteenth centuries CE in Europe. His colleague Julius Beloch largely adopted this model in his three volumes of Griechische Geschichte (1893-1904).

The dispute between Bücher and Meyer, introduced into ancient history by Moses Finley as the 'primitivist-modernist debate,' was highly influential for research on the ancient economy up to the early 1990s. ${ }^{53}$ In fact, Bücher and Meyer were concerned with more than the question of whether the ancient economy was primitive or modern. Meyer placed trade and markets at the center of ancient eco-

48 North 1990; Frier and Kehoe 2007; Bresson (2007-2008) 2016.

49 North 1981, 3.

50 Finley 1979 for a collection of key texts in English translation.

51 Bücher 1893.

52 For a rival of ancient capitalism, Bresson 2014; critically Bang 2008, 45.

53 Andreau (1995) 2001; Cartledge 1998; Nafissi 2005. 
nomic performance in the sense of the classical and neoclassical economy; Bücher, on the other hand, understood the economy as a part of political and social community-building in the agrarian household, the city, and the nation state. ${ }^{54}$ His concern was about structures rather than economic performance.

The extent to which the controversy over the ancient economy was implicated in contemporary debates over national economic performance and the welfare state is shown by the work of the sociologist Max Weber (1864-1920). ${ }^{55}$ Engaging with the methodological and historical conflicts of the Bücher-Meyer controversy in a long handbook article Agrarverhältnisse des Altertums (translated into English 70 years later as Agrarian sociology of ancient civilizations), he constructed a threesector model with a natural economy in the rural sector, a surplus production sector based on slave labor on large Roman estates, and a commercial sector in the cities. ${ }^{56}$ Important methodological change occurred between the second and third editions of this article. Weber abandoned the historical approach to economic systems and presented instead a theory of ideal types which was to have a great influence on the social sciences of the twentieth century. The three-sector model gave way to a more conceptual approach in which household economy, the slave mode of production, and the economy of cities were just mental constructs ('ideal types') for heuristic analytical purposes. ${ }^{57}$ Weber's sociological study on the ancient world initially had little influence on ancient history in Germany. Then, Johannes Hasebroek, a student of Eduard Meyer's, took up Weber's and Bücher's project and emphasized the profound influence of state and city-state social structures on ancient economies. One of Hasebroek's central ideas in his Staat und Handel im Alten Griechenland (1928) was that people without citizenship rights and landed property dominated trade and commerce. The outsider role of people involved in trade and commerce marginalized economic matters in politics, and thus prevented the emergence of a modern economy. Hasebroek's interest once again was concerned with economic structures rather than performance, and of emphasizing difference rather than similarity between ancient and modern economic behavior.

Yet it was Fritz Heichelheim (1901-1968) and the Russian émigré Michail Rostovtzeff (1870-1952) who dominated Western ancient economic history until the 1960s. They focused not so much on the Greek city-state, but rather on the development of interconnected markets and trade in the Hellenistic and Roman Empires. Heichelheim argued that the expansion of Greek culture in the Hellenistic period after the conquests of Alexander and the resulting demand for Greek luxury goods in Hellenistic royal courts and cities led to a massive increase in long-distance trade. This stimulated the creation of an economic area integrated by supply and demand from

54 Wagner-Hasel 2004.

55 Nafissi 2005; Eich 2006; Bang 2008.

56 Weber 1897.

57 Weber 1904 on the concept of ideal types. 
the Western Mediterranean to the Near East. ${ }^{58}$ It was no coincidence that one year after the Great Depression, Heichelheim published a study on economic cycles in the Hellenistic world on the basis of variations in wages, prices, and interest rates from Egypt, Delos, and Uruk. ${ }^{59}$ Less concerned with price data and economic scales, Rostovtzeff envisioned the Hellenistic and Roman Empires as dynamically moving toward a capitalist world economy. ${ }^{60}$ Against the background of his own experience of the modernization process of late imperial Russia, and a magisterial knowledge of ancient archaeological, epigraphical and papyrological evidence from Southern Russia, Syria, Egypt, and the Mediterranean, he designed a grand panorama of the Hellenistic and Roman economies driven by dynamic urban bourgeoisies, yet eventually held back by the primitiveness of the agrarian sector. ${ }^{61}$

\section{II.3 Polanyi, Substantivism and Finley's Ancient Economy}

The work of the Austro-Hungarian economist Karl Polanyi (1886-1966), who had emigrated in 1933 and lived in America from 1940, played a central role in anthropological discussions about alternative economic systems from the postwar period until the 1990 s and beyond. ${ }^{62}$ Shocked by the collapse of capitalism in the late 1920 s, he led an almost emotional campaign against the universal claims of liberal market economics. Instead, he developed an anthropological vision of market-less, simple or even socialist social formations prior to the triumphal advance of liberal markets. In precapitalist societies, economic behavior had been 'embedded' in social and political institutions. A self-interested homo oeconomicus that was free of social and ethical concerns of justice and fair exchange was an invention of capitalist society, as was an autonomous economic process that was socially "disembedded."63

Strongly influenced by leading anthropologists like Richard Thurnwald, Bronislaw Malinowski and Marcell Mauss, Polanyi developed an anthropological model of economic development that was based on modes of exchange and forms of social integration. These regulated the flow of goods in precapitalist societies: household exchange, 'reciprocity' (interpersonal mutual exchange based on ideas of fairness and justice), and state 'redistribution. ${ }^{64}$ Only in the course of the 'Great Transformation' during the early industrial age did market exchange develop into the fourth principle of integration (see Adam Smith, above). ${ }^{65}$ Polanyi later abandoned house-

\footnotetext{
58 Heichelheim 1938.

59 Heichelheim 1930.

60 Rostovtzeff 1939-1944; (1926) 1957.

61 Rostovtzeff (1926) 1957, esp. 538.

62 Humphreys 1978, 31-75; Nafissi 2005, 127-190.

63 Polanyi 1977.

64 Polanyi 1957b.

65 Polanyi 1944.
} 
hold exchange as an early form of social and economic integration. His model of economic development was also not a strictly evolutionary one. Thus there were forms of reciprocity and redistribution in capitalist societies, and market 'elements' could also develop in precapitalist societies. Moreover, in an influential article on the pseudo-Aristotelian Oikonomika, he argued that Aristotle had discovered political economy as a field of theory and planning independently of society and politics. ${ }^{66}$ Essential for the character of an economy was, instead, the question of which institutions were crucial for integrating a society or state. Moreover, market elements rarely if ever remained uncontrolled in preindustrial societies. He and his colleagues observed a certain type of commercial harbor in many contemporary African and historical societies, which he modelled into the concept of 'port-oftrade. ${ }^{67}$ These ports housed one or more trading communities, hedged in and protected by official or state control both for their own preservation and for the social protection of the local society. In contrast to the modern 'formalist' concept of the economy defined by the profit motive and market principle, Polanyi postulated a 'substantive' economic concept. It was grounded in the necessity for humans to provide a livelihood for themselves within a communal context, rather than doing so with their own advantage in mind.

While Polanyi exerted little direct influence on ancient economic historians of his time, his anti-modernist stance strongly resonated in Moses Finley's The Ancient Economy (1973), one of the most influential works of ancient history in the twentieth century. ${ }^{68}$ Theoretically eclectic and not particularly novel in any of its detail, The Ancient Economy designed an overall model of the ancient economy that combined well-selected source material into a radically new approach to the ancient economy. It was an attack both against the modernizing assumptions of earlier economic historians, and against the positivistic method of data collection that characterized their research. He also argued strongly against Marxist positions which had infiltrated economic history not only in Eastern Europe but also Western Germany, Italy, France and Britain during the 1960s and early 1970 s. ${ }^{69}$ In return, he offered a powerful framework for the analysis of the structural differences between the ancient and modern economies. These included the predominance of the agrarian household over market exchange; the importance of social status as against economic class; a particular kind of hierarchical social relationships in which slave labor dominated production; a particular relationship between town and countryside; and the priority of politics over economics, the latter being nonexistent as a separate discourse, or unit of analysis, in ancient states.

66 Polanyi 1957a.

67 Polanyi 1963; cf.1957a.

68 Finley had collaborated with Polanyi at Columbia University, but it came to an end with the expulsion of Finley from Rutgers University, Nafissi 2005, 209-214.

69 Nafissi 2005, 205-208 for Finley’s Marxist orientation during his early career. 
According to Finley, the ancient economy was a subsistence economy characterized by domestic self-sufficiency and the ideal of political autarky. The basis for all wealth was agriculture. Due to the availability of slave labor, the productivity of this agricultural domain never increased substantially, nor was it made more efficient through significant technical development. There was no economic growth in real terms. Within the economy as a whole, trade played only a minor role. Land transport was expensive, while sea transport risky and, with a few exceptions, concentrated on the import of luxury goods for consumption by a small elite. Cities did not specialize in any branch of production or manufacture that would have stimulated the division of labor, markets, and trade. Cities, in contrast to their industrialized counterparts, were political-religious centers of administration and representation, rather than centers of production. There were no rational individuals who made cost-benefit calculations in order to effectively increase the productivity of their land, or reinvested any profit in order to increase profitability through technological improvement or agricultural intensification. Wealth and surplus were invested into conspicuous consumption for the purpose of maintaining status and power. Loans were also used for consumption purposes only, to finance monetary dowries, or to compensate for temporary liquidity problems. Money was not capital but coinage, the minting of which was aimed at the self-representation of poleis and not at facilitating trade. In general, the politics of the states and their weak bureaucracies were directed toward self-representation, as well as the coverage of their own above all military - expenditure, and finally the allocation of honorary positions. There was neither an economic policy nor economic theory.

Finley's model of a 'primitive' non-dynamic economy has been more frequently criticized than praised. However, his insistence on approaching the ancient world conceptually, rather than arguing with selected quantities of evidence and common sense, has transformed research in ancient history beyond the ancient economy. And while many archaeologists, numismatists, and ancient historians have called into question the largely literary foundation to Finley's claims, with all the implications of social and geographical biases and stylization therein, no economic historian of the ancient world nowadays can go back to the descriptive positivism of much of pre-Finleyan economic history writing.

\section{II.4 Back to Economic Growth: The Work of Keith Hopkins and Beyond}

As early as 1978, Keith Hopkins wrote an essay on the question of economic growth in antiquity. ${ }^{70}$ In 1980 he published another influential article that developed a new methodological approach for studying the ancient economy, a new model for the

70 Hopkins 1978; cf. 1983. 
study of economic growth, and a model for the political economy of the Roman Empire. ${ }^{71}$ But he did not return to the modernist alternative. Hopkins proposed that in the long period from the first millennium BCE until the end of the second century $\mathrm{CE}$, there had been economic growth in the Graeco-Roman region, which accelerated in the Roman Empire from the second century BCE onward. This growth had several reasons: (1) an increase of agricultural production as a result of the increase of the area under cultivation; (2) population growth and an increase in population density; (3) an increase in the proportion of the population that was not active in the agricultural sector; (4) an increase in the production volume per capita; (5) an increase in production for tax purposes; and (6) a redistribution of taxes from more productive to less productive areas of the Roman Empire and to the Roman frontiers. Methodologically, Hopkins broke new ground by trying to provide quantitative evidence volumes of coinage and shipwrecks - for his theses. His taxes-and-trade model also suggested new ways of thinking about the relationship between the city of Rome, its provinces and the armies stationed to secure the Roman frontiers. ${ }^{72}$

Hopkins's hypotheses still form the starting point of many archaeological and historical research projects on the ancient economy. At first, however, his quantifying methodology, still in its infancy, was criticized from several angles. From a numismatic point of view, it was questioned whether the evidence from coin hoards could be extrapolated to quantify coin volumes in circulation and degrees of monetization. ${ }^{73}$ Shipwreck evidence, because of recovery rates and the constraints of maritime archaeology, also does not lend itself easily to long-term analyses of the rise and decline of seaborne trade. ${ }^{74}$ A large number of studies, moreover, took issue with Hopkins's circulation and integration model (thesis 6). ${ }^{75}$ This was based on the assumption that taxes in the Roman Empire were levied primarily in money, which was rightly called into question. Other forms of monetary and nonmonetary taxes and tributes were raised, forming a substantial part of the empire's income. The question of the extent to which the Roman Empire formed an economically integrated zone during the Roman Empire is still controversial. Adherents to the integration model of the Roman market economy include Temin and Geraghty. But despite their attempts, data are not sufficiently robust to prove an integrated market economy that was based primarily on the laws of supply and demand. ${ }^{76}$

The publication of the Cambridge Economic History of the Greco-Roman World marked a turning point in research on the ancient economy. Not only did it organize the current state of knowledge into a comprehensive multiauthored set of re-

71 Hopkins 1980.

72 Hopkins (1995-1996) 2001 discussed this relationship with a new emphasis on the city of Rome as a consumption center driving trade and economic performance (see also above, n. 36).

73 E.g., Duncan-Jones 1989; Howgego 1992.

74 Kitchen 2001.

75 E.g., Jongman 1988; Howgego 1994; Woolf 1992.

76 Rathbone and von Reden 2015. 
gional and chronological surveys, but it also set a new common agenda for the study of the ancient economy. Based on the neo-institutional approach to economic history developed by Douglass North, the editors defined the task of economic history as to explain economic performance through time. While being cautious not to overemphasize economic growth in terms of per capita increase in productivity, ${ }^{77}$ they suggested that the population of the Mediterranean perhaps doubled between ca. 800 BCE and $200 \mathrm{CE}$ and that there was a measurable increase in per capita consumption over the long-term. ${ }^{78}$ Emphasizing explanation and quantification rather than description and evaluation, they proposed a social science approach to economic history in contrast to the traditional humanistic methodology that characterized most ancient history writing. Already in 2005, Morris and Manning had developed a methodological catalog for such an approach. They suggested, (1) to make definitions of key terms and underlying assumptions clearer; (2) to be more explicit about processes and model building; (3) to present clear propositions and testable implications; (4) to be explicit about methods and standards of falsification; (5) to break large problems down to smaller, more answerable questions; (6) to specify causal relationships; (7) to quantify wherever possible; and (8) to formulate descriptions and explanations in ways that can be generalized to allow comparisons between different regions and periods. ${ }^{79}$

Neo-institutional economics, moreover, offered a number of conceptual tools and models with which economic performance could be explained. Central among these are institutional change, in particular the structure of property rights, the nature of transaction costs, the role of the state as well as the development of knowledge, including technological change, communication, and transport costs. Not all authors of the CEHGRW followed the call, and not all sets of ancient evidence easily lend themselves to answering the questions that neo-institutional economic poses, but the approach, and the volume of knowledge that the CEHGRW assembled, marked a starting point for increasingly scientific, quantitative, and comparative research in ancient economic history. As a result, economic historians have made greater use of the ever-increasing body of documentary evidence (papyri, coins, and inscriptions), and of new quantifiable data generated by archaeological research.

Parallel to, but not in tandem with, the development of the social science orientation of ancient economic history, archaeological science underwent fundamental changes. Since the 1960s, anthropological archaeologists under the umbrella term of New or Processual Archaeology had explored new theoretical and empirical

77 Per capita increase of productivity, according to classical economic theory, is the only basis for economic growth in real terms, while aggregate increase of wealth may be the result just of more efficient mobilization or concentration of wealth. If approached from classical economic theory, the only growth that matters is per capita increase of productivity; see Saller 2001 for discussion.

78 Morris, Saller, and Scheidel 2007, 6-11.

79 Morris and Manning 2005, 35. See now Canevaro, Erskine, Gray, and Ober 2018. 
methods in order to gain a more rigorous understanding of settlement structures, cultivation methods, subsistence strategies, energy provision, consumption patterns, trading behavior, forms of long-distance interaction and exchange, migration, and their ecological and environmental condition. ${ }^{80}$ Prehistoric archaeology, that is, archaeology in regions where written evidence is scarce or absent, has opened up new areas and landscapes for economic research. Maritime archaeology, archaeobotanical research, skeletal analyses, and paleoclimatology offer new opportunities for assessing more precisely the directions and scales of trade, standards of living, the productivity of human landscapes, maritime technologies, and the economic consequences of climate change. The volumes of the OxRep as well as their website have assembled bodies of quantitative evidence and tested new methods of analyzing large corpora of archaeological and documentary data. The intent of this work is to gain a more differentiated understanding of regional diversity and the conditions of economic performance related to agriculture, settlement, urbanization, and trade. $^{81}$

Globalization has changed how academics think. As Manning and Morris wrote in 2005, "Finley's was an ancient Mediterranean of divisions, rigid structures, and powerful institutions; Horden's and Purcell's is one of mobility, connectivity, and decentring." 8220 years further on, the laboratory in which Greek and Roman historians analyze mobility, connectivity, and decentering has become bigger.

\section{II.5 The Ancient Economy Turning Global}

For a variety of academic and contemporary reasons, there has been an increasing interest in global comparison, global trade, and global networking processes. ${ }^{83}$ Some Bronze Age archaeologists argue that the Afro-Eurasian region, or some zones within it, formed a world system as early as the third millennium BCE, ${ }^{84}$ that is, that they formed a space in which places interacted sufficiently to shape each other's economic and cultural development. ${ }^{85}$ Historians of later periods, including Immanuel Wallerstein himself, were rather more hesitant to identify world systems in the ancient world. ${ }^{86}$ Yet the concepts of world systems theory have profoundly influenced postcolonial, globalization, and empire studies. ${ }^{87}$ The discussion in ancient

80 Binford 1962; Clarke 1968; Renfrew and Bahn 1991; Wells 1992.

81 Bowman and Wilson 2009; 2011; 2013; 2018; Weaverdyck, ch. 8.A, this volume.

82 Morris and Manning 2005, 21-22.

83 With a particular focus on an economic issue, Monson and Scheidel 2015.

84 Sherrat and Sherrat 1993; Woolf 1990; Morley 2007b. For a stimulating summary of the original model, see Wallerstein 2004.

85 Kardulias and Hall 2008, 274-275; cf. Chase-Dunn and Hall 1997; Kuzmina and Mair 2008.

86 Chase-Dunn and Hall 1997, 41-75; Woolf 1990; cf. Wallerstein 1974, 15-16.

87 Morley 2007b; el-Ojeili 2014; Pitts and Versluys 2015. 
history about world systems stimulated debate over the significance of imperial peripheries and their role in transimperial exchange. The pioneering study by Philipp Curtin already focused on what he called trade diasporas in border zones: tightly organized merchant communities of the same cultural origin that provided protection and security for those engaging in commercial activities with the host community. ${ }^{88}$ More recently, scholars have described how host communities in border zones (both ecological and imperial) select or reject outside groups on the basis of their own needs or benefits. ${ }^{89}$ Research on frontier zone and borderland processes between ecologically different communities have qualified the picture of external trade as an unproblematic in- and outflow of goods between empires. ${ }^{90}$

Frontier zones as regions of economic development and cross-border contact have been studied mostly in connection with the Roman army. The military securing of frontiers shifted large numbers of soldiers to the borders of the Roman world. ${ }^{91}$ The question of the supply of these armies with food, equipment and other daily requirements has led to intensive research on the impact of the presence of the Roman legions as a local economic factor of frontier zones. Were soldiers supplied through requisition, local trade, trade over long distance, or the development of agrarian land in the frontier region? In what ways did the presence of soldiers and their demands encourage cross-border exchange either in the form of trade or diplomatic exchange of gifts? Answers vary, depending on the nature of the frontier, the nature of the supplies, and the evidence available. ${ }^{92}$ Frontier zones in Britain, North Africa, along the Danube, and the Eastern Desert have been researched intensely. The amount of economic and infrastructural development in North Africa and Egypt are particularly well studied, but they were of a very different kind, undertaken for different reasons, and with different effects. In North Africa, the evidence for agrarian development, the development of the olive industry and the export of olives had massive effects on markets throughout the Roman Empire. In the case of the Egyptian Eastern Desert, the development of roads, praesidiae (forts), and wells in connection with the exploitation of stone from Mons Claudianus and Porphyrites much facilitated the transport of luxury goods from the Red Sea harbors, Arabia, and India. ${ }^{93}$ The questions of how and in what ways these infrastructures affected markets and consumption within and outside the Roman Empire - or in Bowman and Wilson's terms, in what ways they were part of a trade system - are only beginning to be asked.

88 Curtin 1984, 1-3.

89 Morris 1999; Kardulias 2007; Kardulias and Hall 2008; Shaw 1990 and Purcell 2017.

90 Ray 2003; Thomas 2012.

91 See Weaverdyck, ch. 7 this volume, and Speidel below.

92 Cherry 2007, 726-733.

93 Cobb 2019; Schneider 2019. 


\section{Michael Speidel \\ III Historiographic Trends in Roman Frontier Studies}

\section{III.1 Introduction}

Rome's borders, and the eminent importance the Romans assigned to them are as old as the city itself. Tradition maintained that Rome's founder, King Romulus, personally ploughed the original line of the city's religious boundary, the pomerium, and built a wall around the earliest settlement. Both Rome's boundary and its protection were therefore considered to be essential to the very existence of the city from its earliest days onward. This is also borne out by the introduction of the new god Terminus, soon identified as an aspect of Rome's supreme god Jupiter, during the reign of Romulus (or that of his successor king Numa), as this god protected boundary markers and guaranteed peace.

The Roman Republic that was established after the last king was overthrown continuously expanded the often seemingly ill-defined boundaries of Roman power and influence, moving them ever further away from the city which thereby turned into an imperial capital. By the reign of Augustus (30 BCE-14 CE), Virgil, the poet of Rome's national epos, purported the empire to be one "without borders." 94 By the end of Augustus's reign, Roman expansion came to a near halt and the newly established standing army was moved to the Rhine, the Danube, and to the Euphrates, as well as to strategic positions in the Near East, Egypt, and North Africa. Before a century was over, durable fortresses and defenses were erected and proclaimed to protect the empire. With comparatively minor adjustments, but with the addition of Britain under Claudius in 43 CE and Dacia under Trajan in 106, these remained operational until around the early years of the fifth century CE when foreign invasions, civil wars, and weakened defenses wrenched control of the former frontiers from the central government and set the scene for the collapse of the Western Empire.

Boundaries, frontiers and defense systems thus played a very visible and important role throughout Roman history. In order to understand the directions of modern historiographic trends, it is essential to realize that the surviving ancient narratives and other written sources have deeply influenced the ways in which modern historians thought about Rome's borders and frontiers. Thus, ancient historiography only rarely focuses on the history of frontiers and frontier zones as a subject in its own right. On the few occasions when frontiers are mentioned, it is almost exclusively in the context of military conflicts with Rome's external neighbors. Unless these 'barbarians' beyond the frontiers were allied with the empire, ancient historiography tended to portray them as hostile and bellicose, some to the point that "they do

94 Virgil, Aeneid (Virg. Aen.) 1. 279; Harris 2016. 
not even understand what peace is." 95 In modern historiography, frontiers therefore became a subject of military history. During the Republican period, however, in which Rome expanded primarily at the expense of communities in Italy and Greece, Carthage in North Africa, Spain, and the Hellenistic kingdoms in the East, outer borders hardly ever surface in the ancient texts and are thus missing in modern accounts. Perhaps the reason for their near absence in historical texts was that Rome, rather than setting new external borders, usually took over those of the powers it subjugated. Exceptional mentions of boundaries are few, though one might note the so-called Ebro treaty of ca. 226 BCE, according to which the river Iber was identified as the border between the sphere of influence of Carthage and Rome on the Iberian Peninsula. The Carthaginian breach of this treaty is said to have caused the Second Punic War (218-201 BCE).

\section{III.2 Changing Perspectives}

Evidently, this episode and its sources have been thoroughly studied by modern historians. Yet only the more-or-less static frontiers of imperial Rome suggested themselves forcefully to modern scholars as a complex subject worthy of intensive scholarly attention in a time when the rising European colonial powers began to view their own 'civilizing mission' as one that followed in Roman footsteps. When the focus of scholarly interest first fell on imperial frontiers, they began to be studied within the broad narrative frame of an epic clash of cultures in which one (the Greeks and Romans) was eminently superior and had the divine mission to push back the other, inferior culture (the 'barbarians' beyond the frontiers) or at least to keep it at bay. The significance of the empire's frontiers was thus seen to lay in their function as a dividing line between what was understood to be the civilized world on the one side and a world on the other in which civilization was absent. Such views were of course deeply rooted in the transmitted narratives from the ancient world, in which humanitas ('civilization') was a wholly Roman concept and contrasted sharply with the strange, ferocious and irrational ways of the 'barbarians.'96 Yet, within the empire, humanitas could be acquired through a process of assimilation. Hence, modern historiography believed that those peoples, communities, and landscapes absorbed and subjugated to Roman control eventually transformed as a whole. They adopted Roman ways of life, architecture, and culture, learned Latin and thus elevated to a higher degree of civilization, in a process Theodor Mommsen referred to by the term "romanization". 97

95 Tanta barbaria est ut nec intellegant pacem, Florus (Flor.) 2. 29, in the early second century CE on the Sarmatians.

96 Woolf 1998, 54-67.

97 Mommsen 1885, ch. 2. 
At any rate, it is perhaps hardly a coincidence that the interpretation of the empire's northern frontier in Britain that the eminent English historian Edward Gibbon (1737-1794) advanced set the tone for much of the ensuing discourse:

This wall of Antoninus, at a small distance beyond the modern cities of Edinburgh and Glasgow, was fixed as the limit of the Roman province. The native Caledonians preserved in the northern extremity of the island their wild independence, for which they were not less indebted to their poverty than to their valour. Their incursions were frequently repelled and chastised; but their country was never subdued ... The masters of the fairest and most wealthy climates of the globe turned with contempt from the gloomy hills assailed by winter tempests, from lakes concealed in a blue mist, and from cold and lonely heaths over which the forest deer were chased by naked barbarians. ${ }^{98}$

Independence was the only positive aspect of their existence, but even that was owed to their own ignorance, brutality and greed as well as to the unwillingness of the civilized to welcome the wild and naked into their world. Rome's downfall was understood as a consequence of its failure to ultimately keep the 'barbarians' out.

Cold, poverty and a life of danger and fatigue fortify the strength and courage of barbarians. In every age they have oppressed the polite and peaceful nations ... who neglected, and still neglect, to counterbalance these natural powers by the resources of military art ... The splendid days of Augustus and Trajan were eclipsed by a cloud of ignorance, and the barbarians subverted the laws and palaces of Rome. ${ }^{99}$

According to the traditional view, imperial Rome established its external borders from the very beginning with the intention to defend the empire and to keep the 'barbarians' out. ${ }^{100}$ The significance of its frontiers was seen to have shifted over the centuries from open, moving zones of an expanding empire to closed, static lines of defense. The physical barriers, natural or erected, that surrounded the provincial territory came to be understood as military, moral, ideological and cultural barriers separating civilization and law from barbarism and lawlessness. ${ }^{101}$ This largely remained to be the case even after the discovery of a gate through Hadrian's Wall already in 1848 gave rise to criticism of the wall's supposed impermeability. ${ }^{102}$ To some, however, the existence of a gate suggested that "the people north of it [the Wall] were not very formidable" after all. ${ }^{103}$ To most, however, Rome's boundaries continued to be above all a geopolitical subject, a major part of the empire's military infrastructure, and one that needed to be studied within the framework of Roman army studies. The end of the frontiers, and indeed the fall of the Western Empire in

98 Gibbon 1776, 1.

99 Gibbon 1781, 637 and 640.

100 Rice Holmes 1928-1931, 2:164-165; Syme 1934, 352-354; Wells 1972, 152.

101 Alföldi 1952; Miller and Savage 1977.

102 Breeze 2018a, 166.

103 Anonymus 1898, 49. 
$476 \mathrm{CE}$, naturally found their explanations within this narrative frame. Allegoric floods and dykes (thus natural disasters against man-made protections) determined the narratives of these developments. The recruitment of increasing numbers of foreign, even 'barbarian' soldiers and mercenaries into the Roman army, an ensuing decline of military discipline, and neglect to defend the borders were the main reasons believed to have led to the fall of the Western Empire in $476 .{ }^{104}$ Such views shaped and sometimes dominated the debate about Roman frontiers until the later twentieth century and are still regularly discussed in attempts to describe the current state of Roman frontier studies. ${ }^{105}$

Such were the insights most nonspecialists took away, and often still do, from the published literature on Roman frontiers or from their own studies of the written sources and archaeological remains. Thus, for instance, Lord Curzon of Kedleston, Britain's viceroy of India from 1899 to 1905, who was praised for his attempts to bring stability to the Indian frontier, was inspired by the history of Rome's frontiers, even though he later erroneously claimed that scholars had "almost wholly ignored" the subject. ${ }^{106}$ According to him, the Roman Empire was "nowhere so like our own as in its Frontier policy and experience." In his view, India's northwest frontier could therefore compare "point by point with its ancient counterpart and prototype, the frontier system of Rome.” C. Collin Davies, the historian and author of a classic study on British India's north-west frontier even concluded: "Rome fell because her dykes were not strong enough to hold back the flood of barbarian inroads."107 Rudyard Kipling's descriptions of Hadrian's Wall in Puck of Pook's Hill (1904) and of its meaning for the Roman Empire were inspired by the same images, and the British experience of empire.

The study of Rome's desert frontiers, too, was influenced by nineteenth-century European imperial history and colonial experience. Thus, Lord Curzon explained the absence of linear frontier barriers and legionary and auxiliary fortresses strung out on from the edges of the deserts in North Africa and the Near East by referring to Napoleon I, who judged that the desert was sufficient barrier and the most effective kind of frontier. ${ }^{108}$ The French in North Africa, believing in their 'mission civilisatrice,' saw themselves as heirs to the Romans. ${ }^{109}$ With respect to the North African frontier zones, their focus was set on the relations and interactions between the nomadic and the sedentary populations. Hence, interpretations of the Roman barriers in North Africa, the so-called Fossatum Africae, almost invariably "relate to observations of French colonial officials on transhumance in the land between the

104 Von Domaszewski 1914, 256; $1967^{2}, 88$.

105 E.g., James 2005; Hingley 2017; Breeze 2018a and b.

106 Curzon 1907, 4-5; ibid. 8 and 54 for the following quotations; cf. Whittaker 2004.

107 Davies 1932, 2.

108 Curzon 1907, 15-16; cf. Birley 2002a, 2.

109 Baradez 1949, 362. 
desert and the cultivated areas, either supporting or challenging their interpretations."110

Yet, even within Europe, interpretations of imperial Rome's frontiers were anything but irrelevant as they could take on hotly debated political dimensions. This is perhaps most evident in the centuries-long dispute about the meaning of the Roman Rhine frontier for French or Roman rule over the Alsace. ${ }^{111}$ Famously, this dispute was fueled by the discovery, in the sixteenth century, of Tacitus's Germania, which provided a Latin text of great authority to counterbalance Julius Caesar's claim that the Rhine marked the borders of Gaul. When France's defeat in the Franco-Prussian War of 1870/71 led to its loss of Alsace and Lorraine, two eminent ancient historians of their respective countries, Numa Denis Fustel de Coulanges and Theodor Mommsen, publicly exchanged arguments, based in part on their knowledge of the ancient sources, for and against the Rhine as the border between France and Germany.

From a structural perspective, however, the academic study of the Roman frontiers developed as a branch of Roman archaeology with a strong input by ancient history, and was initiated in the nineteenth century in Britain and Germany. The beginnings of research on imperial frontiers in Britain (mainly of course Hadrian's Wall), is closely tied to the name of John Collingwood Bruce, a Newcastle clergyman who produced a long series of publications about Hadrian's Wall and who initiated the tradition of an organized walk along the Wall, the so-called Pilgrimage that began in 1849 and has continued every 10 years since 1886 except for the war years. ${ }^{112}$ Scientific studies of the Wall were carried out and published by the local English and Scottish archaeological societies. In Germany, after half a century of debate, the centralized state-run Reichslimeskommission (RLK) was established in 1892 under the leadership of the newly united country's leading ancient historian Theodor Mommsen. The Kommission was funded and supported by the new German imperial government in order to work out the route and document the remains of the Roman frontier, its defenses as well as its associated forts and military installations north of the Alps on the territory of the Kaiserreich. Kaiser Wilhelm II publicly expressed his support of this enterprise by extending his patronage for the reconstruction of the Roman fortress at the Saalburg. Between 1894 and 1937 the RLK, which in 1902 passed under the directorship of Ernst Fabricius, professor of ancient history in Freiburg, published the results of its work in 56 installments of its publication series Der obergermanisch-rätische Limes des Römerreichs. This major achievement had its clear impact on future studies of the Roman frontiers as it appears to have encouraged a reducing of the subject to linear barriers and strings of heavily garrisoned forts.

110 Wells 1991, 478; Breeze 2018a, 165.

111 Whittaker 2004, 187-189.

112 Birley 2002a, 1. 
The two world wars not only interrupted many archaeological and historical projects and studies as well as ties between colleagues of different nations, they also had various other impacts on the ways scholars began to interpret Roman frontiers. ${ }^{113}$ Trench warfare in particular appears to have inspired interpretations of Roman warfare and defense lines after the First World War. ${ }^{114}$ On the whole, however, the Roman army's role as a fighting force was marginalized after the Second World War as a field of scholarly research, above all in German speaking academia. The appalling war experiences many archaeologists and historians of the Roman frontiers had personally suffered or witnessed, as well as the emergence of the Iron Curtain, now began to influence Roman frontier studies. ${ }^{115}$ Thus, the study of all forms and aspects of violence including the study of battles, military equipment and techniques were considered repugnant and distasteful. ${ }^{116}$ Instead, questions pertaining to the structures and organization of the army and to the military organization of the frontiers now took center stage. ${ }^{117}$

Since 1949, Roman frontier studies have developed largely (though not exclusively) through the medium of the (usually) triennial international Roman Frontier Studies Congress or Limes Congress, which convenes at changing locations with access to archaeological sites on the Roman frontiers. Initiated by Eric Birley from Durham University, the later Life President of the Congress, with the intention to promote the exchange of British and foreign scholars working on Roman frontiers, the Limes Congress has become one of the oldest periodic conventions in the studies of the ancient world. Initially, the dominant tradition displayed through these Congresses was to uncover (by excavation and survey), to record, and to reconstruct the physical remains of infrastructure of the Roman army in the frontier regions of the empire. Organizational questions regarding the Roman army, imperial wars and military infrastructure, chronologies, archaeological typologies, and general augmention of our databases of archaeological and historical information on such matters were the prime objectives of the presentations at the Limes Congresses. ${ }^{118}$ Soon, however, the global political situation of the time began to show its impact on the way in which scholars thought about Roman imperial frontiers. Cold War logic, in any event, was in full accord with the main statement of an influential paper presented by Eric Birley in 1955 on Hadrianic frontier policy at the second Congress in Carnuntum, Austria in which the author argued that it was an intention of Roman frontiers to protect the empire's inhabitants from foreign attacks and of the Roman

113 Whittaker 2004, 186.

114 Breeze 2018a.

115 Alföldi 1952.

116 James 2002, 12-14.

117 James 2002, 13-14, 21; Breeze 2018a, 166.

118 Birley 2002a. 
army to provide the safety that was necessary for the economic exploitation of the lands. ${ }^{119}$

Also much-inspired by Cold War thinking was Edward N. Luttwak's The Grand Strategy of the Roman Empire from 1976. The author, a modern US strategist and outsider to studies of the ancient world, was the first to offer a coherent narrative of the Roman Empire's military strategy along its frontiers based on the available archaeological and historical sources (mainly fortification placement and transmitted military operations). His reconstructions of Roman Grand Strategy were heavily inspired by assumptions relevant to Cold War scenarios and the defense of the West against threats from the communist East rather than by concepts and structures from the Roman world, and have therefore been widely rejected by historians of the Roman Empire. ${ }^{120}$ Luttwak's book was nevertheless highly influential as the rejection of its conclusions sparked not only a lively (often heated) debate among those engaged in Roman frontier studies about the empire's frontier strategy. ${ }^{121}$ But it also raised new questions of how to define this field of study. ${ }^{122}$ It substantially increased efforts to understand the history of the imperial frontiers and the role of the army in order to include new and different aspects to the hitherto predominant (though never entirely exclusive) studies of the frontiers as military defenses of the empire against external threats along physical barriers. In particular, the cultural and economic impact of the army's presence, the daily life of its soldiers, and the various ways in which they were a burden on the population of the frontier zones became an increasingly popular research subject. ${ }^{123}$

In the wake of these developments, a group of initially mainly British ancient historians and archaeologists began to voice criticism of the traditions of the Limes Congresses, calling for a move away from the study of Roman fortifications and military strategies against external threats, as well as from the constraints imposed by the traditional set of written sources, and for the development of a broader concept of Roman frontiers that gives priority to wider social and economic aspects. ${ }^{124}$ The traditional approach toward Roman frontier studies as represented by the Limes Congress was accused of being "unduly narrowly focused and obsessively concerned with pointless minutiae," "introverted," "far too parochial for its own (or anybody else's) good," "predominantly conservative," and "permanently suspicious of innovation, especially in theory," while being mostly preoccupied with the wrong kind of questions. ${ }^{125}$ The effects of Rome's frontiers on the local populations and

119 Birley 1956.

120 Mann 1979; Millar 1982; Isaac 1990; Whittaker 1994, 62-66.

121 Wheeler 1993; Breeze 2011; Breeze 2018b.

122 Isaac 1990.

123 E.g., Bowman 1994; Birley 2002b; Erdkamp 2002.

124 Isaac 1990; Whittaker 1994; Elton 1996; Mattingly 1997; James 2005; Gardner 2013; Gardner 2017.

125 James 2005, 499, 501-502; Breeze 2018b, 2. 
the threat by external forces were considered far less significant than previously thought. ${ }^{126}$ The processes and results of 'romanization' were reinvestigated and found to be far more complex and diverse than many had previously held. ${ }^{127}$ Even the view, accepted since Gibbon, that the pax Romana meant general peace and prosperity within the empire was challenged with reference to attested domestic and juridical violence. ${ }^{128}$ Although much of the critique and call for innovation was no doubt justified and resulted in fruitful debates and inspiring new contributions, they were not always free of exaggerations and omissions of existing alternative views, particularly in other national traditions and their publications.

Since the 1980s and 1990s, increased attention has thus been directed toward the complexities of the interactions between native peoples under Roman domination and the representatives of the empire. As a result, it became increasingly common to study frontiers not so much as fortified linear military barriers but as zones of a specific nature in which cultural, social, and economic aspects played a prominent role. ${ }^{129}$ Theory and models came to be favored, ${ }^{130}$ which unsurprisingly also encouraged cross-cultural and cross-temporal comparative studies, ${ }^{131}$ as well as studies investigating interpretations of the Roman army with regard to contemporary theories of migration and globalization. ${ }^{132}$ It is now generally accepted that Roman frontiers cannot be understood in isolation from socioeconomic and cultural processes along, far behind, and far beyond the frontiers themselves. ${ }^{133}$ It has also been suggested that the frontier zone along the edge of the empire was indeed an important factor for the development and prosperity of the Roman state. ${ }^{134}$

\section{III.3 Long-Distance Trade and the Frontiers}

In addition to supplying the army, trade movement across the Roman frontier existed at all times. Mortimer Wheeler explored this important subject in his Rome beyond the Imperial Frontiers in 1954. It was recently again the subject of a collection of articles. ${ }^{135}$ The long-distance overland and maritime trade routes through Egypt, the Red Sea, the Arabian Peninsula and Mesopotamia had to cross Roman borders

126 Isaac 1990; Elton 1996; Whittaker 2004, 45-46.

127 Woolf 1998; 2014; Mattingly 2004; Versluys 2014.

128 Woolf 1993.

129 Isaac 1990; Whittaker 1994; Whittaker 2004; cf. James 2005; Hekster and Kaizer 2012; Hingley 2017.

130 Birley 2002a, 7; Hingley 2017.

131 Miller and Savage 1977; Breeze 2008; McWilliams 2011; cf. Hingley 2017, 2; Breeze 2018b, 3.

132 Hingley 2017; Breeze 2018a, 165.

133 Birley 2002a, 3; James 2005, 501.

134 Whittaker 1994; Whittaker 2004; cf. Speidel 2016, esp. 165.

135 Wells 2013. 
and frontier zones. Therefore, studies investigating trade between the Roman Empire and South Arabia, East Africa or India usually engage with questions pertaining to the Roman army and the empire's frontiers. ${ }^{136}$ In particular, the army's role in safeguarding trade routes and traders as well as its involvement in the collection of tolls and taxes have been repeatedly studied. ${ }^{137}$ Moreover, the mechanisms and effects of cross-border mobility on the Roman frontiers has received attention. Seen to be largely a result of trade and military activity, these types of mobility centralized the Roman frontiers as spaces which aggregated and disseminated information about various parts of the world, as far away as China. ${ }^{138}$ However, trade between the Roman Empire and the East is only rarely investigated by the same scholars who engage in Roman frontier studies or Roman army studies. Moreover, specialized and distinct academic disciplines often deal with just one side of Rome's former borders, for example in the Arabian Peninsula, Nubia, or North Africa, and lack sufficient knowledge of the sources, methods, institutions, and concepts of the other. Both of these obstacles stand in the way of a comprehensive and universal study of the frontier zones of the Roman Empire, which therefore remain under-researched in many of the respective areas.

\section{References}

Alcock, S. 2007. "The Eastern Mediterranean.” In Scheidel, Morris, and Saller (2007), 671-697.

Alföldi, A. 1952. "The moral barrier on Rhine and Danube." In E. Birley (ed.), The Congress of Roman Frontier Studies 1949, 1-16. Kendal: Titus Wilson \& Son.

Andreau, J. (1995) 2001. “Twenty years after Moses I. Finley's The Ancient Economy." In Scheidel and von Reden (2001), 33-52. Originally published as "Vingt ans après L'Économie antique de Moses I. Finley."

Anonymus 1898. "Report of a visit to Hadrian's Wall." Proceedings of the Society of Antiquaries of Newcastle upon Tyne 8, 46-53.

Austin, N. J. E., and N. B. Rankov. 1995. Exploratio: Military and political intelligence in the Roman world from the Second Punic War to the Battle of Adrianople. London: Routledge.

Baker, H. D., and M. Jursa, eds. 2014. Documentary sources in ancient Near Eastern and GrecoRoman economic history. Oxford: Oxbow.

Bagnall, R. S. 2005. "Egypt and the concept of the Mediterranean." In W. V. Harris (ed.), Rethinking the Mediterranean, 339-347. Oxford: Oxford University Press.

Ball, W. 2000. Rome in the East: The transformation of an empire. London: Routledge.

Bang, P. F. 2007. "Trade and empire: In search of organizing concepts for the Roman economy." Past and Present 195, 3-52.

-. 2008. The Roman bazaar: A comparative study of trade and markets in a tributary empire. Cambridge: Cambridge University Press.

136 Esp. Young 2001; Sidebotham 2011; Seland 2016; Cobb 2018; Nappo 2018.

137 Cuvigny 2003; Speidel 2016; Cobb 2018.

138 Lee 1993; Austin and Rankov 1995; Kolb and Speidel 2017. 
Baradez, J. 1949. Fossatum Africae: Recherches aériennes sur l'organisation des confins sahariens à l'époque romaine. Paris: Arts \& Métiers graphiques.

Binford, L. R. 1962. “Archaeology as anthropology.” American Antiquity 28, 217-225.

Bingen, J. (1978) 2007. "The Revenue Laws Papyrus: Greek tradition and Hellenistic adaptation.” In Hellenistic Egypt: Monarchy, society, economy, culture, 157-188. R. S. Bagnall (ed.). Edinburgh: Edinburgh University Press. Originally published as Le Papyrus Revenue Laws Tradition grecque et adaptation hellénistique.

Birley, A. R. 2002a. “Fifty years of Roman frontier studies.” In P. Freeman, J. Bennett, Z. T. Fiema, and B. Hoffmann (eds.), Limes XVIII: Proceedings of the XVIIIth International Congress of Roman Frontier Studies, held in Amman, Jordan (September 2000). Vol. 1, 1-11. Oxford: Archaeopress.

-. 2002b. Garrison life at Vindolanda: A band of brothers. Stroud: Tempus.

Birley, E. 1956. "Hadrianic frontier policy.” In E. Swoboda (ed.), Carnuntina: Ergebnisse der Forschung über die Grenzprovinzen des römischen Reiches: Vorträge beim internationalen Kongress der Altertumsforscher, 25-33. Graz: Böhlau.

Bowman, A. K. 1994. Life and letters on the Roman frontier: Vindolanda and its people. London: British Museum Press.

Bowman, A. K., and A. Wilson, eds. 2009. Quantifying the Roman economy: Methods and problems. Oxford: Oxford University Press.

-, eds. 2011. Settlement, urbanization, and population. Oxford: Oxford University Press.

-, eds. 2013. The Roman agricultural economy: Organization, investment, and production. Oxford: Oxford University Press.

-, eds. 2018. Trade, commerce, and the state in the Roman world. Oxford: Oxford University Press.

Breeze, D. 2008. “To study the monument: Hadrian's Wall 1848-2006.” In P. T. Bidwell (ed.), Understanding Hadrian's Wall: Papers from a conference held at South Shields, 3rd-5th November, 2006, to mark the publication of the 14th edition of the 'Handbook to the Roman Wall,' 1-4. South Shields: Arbeia Society.

-. 2011. The frontiers of imperial Rome. Barnsley: Pen \& Sword Military.

-. 2018a. "The role of Zeitgeist in understanding Roman frontiers." in C. S. Sommer and S. Matešić (eds.), Limes XIII: Proceedings of the 23rd International Congress of Roman Frontier Studies Ingolstadt 2015: Akten des 23. Internationalen Limeskongresses in Ingolstadt 2015. Vol. 1, 164-167. Mainz: Nünnerich-Asmus.

-. 2018b. "The value of studying Roman frontiers." Theoretical Roman Archaeology Journal 1, 1-17.

Bresson, A. 2014. "Capitalism and the ancient Greek economy." In L. Neal and J. Williamsen (eds.), The Cambridge history of capitalism. Vol. 1, 43-74. Cambridge: Cambridge University Press.

-. (2007-2008) 2016. The making of the ancient Greek economy: Institutions, markets, and growth in the city-states. S. Rendall (trans.). Princeton, NJ: Princeton University Press. Originally published as L'économie de la Grèce des cites. 2 vols.

Broodbank, C. 2013. The making of the Middle Sea: A history of the Mediterranean from the beginning to the emergence of the classical world. London: Thames \& Hudson.

Brown, P. 2018. “'Charismatic' goods: Commerce, diplomacy, and cultural contacts along the Silk Road in Late Antiquity." In N. Di Cosmo and M. Maas (eds.), Empires and exchanges in Eurasian Late Antiquity, 96-107. Cambridge: Cambridge University Press.

Bücher, K. 1893. Die Entstehung der Volkswirtschaft. Tübingen: Mohr.

Burkert, W. (1984) 1992. The orientalizing revolution: Near Eastern influence on Greek culture in the early Archaic age. M. E. Pinder (trans.). Cambridge, MA: Harvard University Press. Originally published as Die orientalisierende Epoche in der griechischen Religion und Literatur. 
Burkhardt, J., O. Oexle, and P. Spahn. 1992. "Wirtschaft." In O. Brunner, W. Conze, and R. Koselleck (eds.), Geschichtliche Grundbegriffe: Historisches Lexikon zur politisch-sozialen Sprache in Deutschland. Vol. 7, 511-594. Stuttgart: Klett.

Canevaro, M., A. Erskine, B. Gray, and J. Ober. eds. 2018. Ancient Greek history and comtemporary Social Science. Edinburgh: Edinburgh University Press.

Carrier, J. G. 2012. “Introduction.” In J. G. Carrier (ed.), A handbook of economic anthropology. 2nd ed., 1-12. Cheltenham: Edward Elgar.

Cartledge, P. 1993. The Greeks: A portrait of self and others. Oxford: Oxford University Press.

Chase-Dunn, C., and T. D. Hall, eds. 1997. Rise and demise: Comparing world-systems. Boulder, CO: Westview.

Cherry, J. 2007. "The frontier zones." In Scheidel, Morris, and Saller (2007), 720-741.

Clarke, D. L. 1968. Analytical archaeology. London: Methuen.

Cobb, M. A. 2018. Rome and the Indian Ocean trade from Augustus to the early third century CE. Leiden: Brill.

-. 2019. "From the Ptolemies to Augustus: Mediterranean integration into the Indian Ocean trade." In M. A. Cobb (ed.), The Indian Ocean trade in antiquity: Political, cultural and economic impacts, 17-51. London: Routledge.

Curtin, P. D. 1984. Cross-cultural trade in world history. Cambridge: Cambridge University Press.

Curzon, G. N. 1907. Frontiers. Oxford: Oxford University Press.

Cuvigny, H., ed. 2003. La route de Myos Hormos: L'armée romaine dans le desert orientale d'Égypte. 2 vols. Cairo: Institute français d'archéologie orientale.

Davies, C. C. 1932. The problem of the north-west frontier 1890-1908: With a survey of policy since 1849. Cambridge: Cambridge University Press.

De Romanis, F., and M. Maiuro, eds. 2015. Across the ocean: Nine essays on Indo-Mediterranean trade. Leiden: Brill.

Duncan-Jones, R. 1989. "Mobility and immobility of coin in the Roman Empire." Instituto Italiano di Numismatica 36, 121-137.

Eich, A. 2006. Die politische Ökonomie des antiken Griechenland (6.-3. Jahrhundert v. Chr.). Cologne: Böhlau.

El-Ojeili, C. 2014. "Wallerstein: The modern world-system: Four decades on." Critical Sociology 40.1, 1-22.

Erdkamp, P., ed. 2002. The Roman army and the economy. Amsterdam: J. C. Gieben.

Elton, H. 1996. Frontiers of the Roman Empire. London: Batsford.

Evers, K. G. 2017. Worlds apart trading together: The organisation of long-distance trade between Rome and India in antiquity. Oxford: Archaeopress.

Finley, M. I. (1973) 1985. The ancient economy. London: Chatto \& Windus.

Finley, M. I., ed. 1979. The Bücher-Meyer controversy. New York, NY: Arno.

Fitzpatrick, M. P. 2011. "Provincializing Rome: The Indian Ocean trade network and Roman imperialism." Journal of World History 22, 27-54.

Frier, B. W., and D. F. Kehoe. 2007. "Land and economic institutions." In Scheidel, Morris, and Saller (2007), 113-144.

Galli, M. 2017. "Beyond frontiers: Ancient Rome and the Eurasian trade networks." Journal of Eurasian Studies 8, 3-9.

Gardner, A. 2013. "Thinking about Roman imperialism: Postcolonialism, globalisation and beyond?" Britannia 44, 1-25.

-. 2017. "Roman Britain from the outside: Comparing western and northern frontier cultures." In S. González Sánchez and A. Guglielmi (eds.), Romans and barbarians beyond the frontiers: Archaeology, ideology and identities in the north, 34-47. Oxford: Oxbow.

Gibbon, E. 1776. The history of the decline and the fall of the Roman Empire. Vol. 1, London: Strahan \& Cadell. 
-. 1781. The history of the decline and the fall of the Roman Empire. Vol. 3, London: Strahan \& Cadell.

Graf, D. 2018. "The Silk Road between Syria and China.” In A. Wilson and A. K. Bowman (eds.), Trade, commerce, and the state in the Roman world, 443-532. Oxford: Oxford University Press.

Gregoratti, L. 2019. “Indian Ocean trade: The role of Parthia.” In M. A. Cobb (ed.), The Indian Ocean trade in antiquity: Political, cultural and economic impacts, 52-72. London: Routledge.

Harris, W. V. 2005. "The Mediterranean and ancient history." In W. V. Harris (ed.), Rethinking the Mediterranean, 1-44. Oxford: Oxford University Press.

-. 2016. Roman power: A thousand years of empire. Cambridge: Cambridge University Press. Hasebroeck, J. 1928. Staat und Handel im alten Griechenland. Tübingen: Mohr.

-. 1931. Griechische Wirtschafts- und Gesellschaftsgeschichte. Tübingen: Mohr.

Heichelheim, F. M. 1930. Wirtschaftliche Schwankungen der Zeit von Alexander bis Augustus. Jena: Fischer.

-. 1938. Wirtschaftsgeschichte des Altertums. 2 vols. Leiden: Sijthoff.

Hekster, O., and T. Kaizer, eds. 2012. Frontiers in the Roman world: Proceedings of the ninth workshop of the international network Impact of Empire (Durham, 16-19 April 2009). Leiden: Brill.

Herzfeld, M. 2005. "Practical Mediterraneanism: Excuses for everything from epistemology to eating." In W. V. Harris (ed.), Rethinking the Mediterranean, 45-63. Oxford: Oxford University Press.

Hingley, R. C. 2017. "Introduction: Imperial limits and the crossing of frontiers." In S. González Sánchez and A. Guglielmi (eds.), Romans and barbarians beyond the frontiers: Archaeology, ideology and identities in the north, 1-7. Oxford: Oxbow.

Hopkins, K. 1978. "Economic growth and towns in classical antiquity." In P. Abrams and E. A. Wrigley (eds.), Towns in societies: Essays in economic history and historical sociology, 3577. Cambridge: Cambridge University Press.

-. 1980. "Taxes and trade in the Roman Empire (200 BC-AD 400)." Journal of Roman Studies 70, 101-125.

-. 1983. “Introduction.” In P. D. A. Garnsey, K. Hopkins, and C. R. Whittaker (eds.), Trade in the ancient economy, ix-xxv. Berkeley, CA: University of California Press.

-. (1995-1996) 2001. “Rome, taxes, rents, and trade." In Scheidel and von Reden, 190-230.

Horden. P., and N. Purcell. 2000. The corrupting sea: A study of Mediterranean history. Malden, MA: Blackwell.

Howgego, C. 1992. "The supply and use of money in the Roman world, 200 BC to AD 300." Journal of Roman Studies 82, 1-31.

-. 1994. "Coin circulation and the integration of the Roman economy." Journal of Roman Archaeology 7, 5-21.

Humphreys, S. C. 1978. Anthropology and the Greeks. London: Routledge and Kegan Paul. Isaac, B. 1990. The limits of empire: The Roman army in the East. Oxford: Clarendon.

James, S. 2002. "Writing the legions." Archaeological Journal 159, 1-58.

-. 2005. "Limesfreunde in Philadelphia: A snapshot of the state of Roman frontier studies." Britannia 36, 499-502.

Jongman, W. 1988. The economy and society of Pompeii. Amsterdam: J. C. Gieben.

Jursa, M. 2014. "Introduction.” In H. D. Baker and M. Jursa (eds.), Documentary sources in ancient Near Eastern and Greco-Roman economic history, 1-6. Oxford: Oxbow.

Kardulias, P. N. 2007. "Negotiation and incorporation on the margins of world systems: Examples from Cyprus and North America." Journal of World Systems Research 31, 55-82.

Kardulias, P. N., and T. D. Hall. 2008. "Archaeology and world systems analysis.” World Archaeology 40, 572-581. 
Kitchen, K. 2001. "Economics in ancient Arabia: From Alexander to the Augustans." In Z. H. Archibald, J. Davies, V. Gabrielsen, and G. J. Oliver (eds.), Hellenistic economies, 157-173. London: Routledge.

Kolb, A., and M. A. Speidel. 2017. "Imperial Rome and China: Communication and information transmission." M. D. Elizalde and W. Jianlang (eds.), China's development from a global perspective, 28-56. Newcastel upon Tyne: Cambridge Scholars Publishing.

Kuzmina, E. E., and V. H. Mair, eds. 2008. The prehistory of the Silk Road. Philadelphia, PA: University of Philadelphia Press.

Lee, A. D. 1993. Information and frontiers: Roman foreign relations in Late Antiquity. Cambridge: Cambridge University Press.

Lo Cascio, E. 2007. "The early Roman Empire: The state and the economy." In Scheidel, Morris, and Saller (2007), 619-650.

Mann, J. C. 1979. "Power, force and the frontiers of empire." Journal of Roman Studies 69, 175-183.

Manning, J. G. 2007. “Hellenistic Egypt.” In Scheidel, Morris, and Saller (2007), 434-459.

Mathew, K. S., ed. 2015. Imperial Rome, Indian Ocean regions and Muziris: New perspectives on maritime trade. London: Routledge.

Mattingly, D. 2004. "Being Roman: Expressing identity in a provincial setting." Journal of Roman Archaeology 17, 5-26.

Mattingly, D., ed. 1997. Dialogues in Roman imperialism: Power, discourse, and discrepant experience in the Roman Empire. Portsmouth, RI: Journal of Roman Archaeology.

McLaughlin, R. 2014. The Roman Empire and the Indian Ocean: The ancient world economy and the kingdoms of Africa, Arabia and India. Barnsley: Pen \& Sword Military.

-. 2016. The Roman Empire and the Silk Routes: The ancient world economy and the empires of Parthia, Central Asia and Han China. Barnsley: Pen \& Sword History.

McWilliams, A. 2011. "All quiet on the eastern front." In D. Mullin (ed.), Places in between: The archaeology of social, cultural and geographical borders and borderlands, 13-22. Oxford: Oxbow.

Millar, F. 1982. "Emperors, frontiers and foreign relations." Britannia 13, 1-23.

-. 1998. "Caravan cities: The Roman Near East and long distance trade by land." In M. M. Austin and G. Rickman (eds.), Modus operandi: Essays in honour of Geoffrey Rickman, 275-299. London: Institute of Classical Studies, University of London.

Miller, D. H., and W. W. Savage. 1977. "Ethnic stereotypes and the frontier: A comparative study of Roman and American experience." In D. H. Miller and S. O. Steffen (eds.), The frontier: Comparative studies, 109-137. Norman, OK: University of Oklahoma Press.

Mommsen, T. 1885. Römische Geschichte. Vol. 5, Die Provinzen von Caesar bis Diocletian. Berlin: Weidmann.

Monson, A. 2012. From the Ptolemies to the Romans: Political and economic change in Egypt. Cambridge: Cambridge University Press.

Monson, A., and W. Scheidel, eds. 2015. Fiscal regimes and the political economy of premodern states. Cambridge: Cambridge University Press.

Morley, N. 2007a. "The early Roman Empire: Distribution.” In Scheidel, Morris, and Saller (2007), 570-591.

-. 2007b. Trade in classical antiquity. Cambridge: Cambridge University Press.

-. 2009. Antiquity and modernity. Malden, MA: Wiley-Blackwell.

Morris, I. 1994. "The Athenian economy 25 years after The Ancient Economy." Classical Philology 99, 351-366.

-. 1999. "Negotiated peripherality in Iron Age Greece: Accepting and resisting the East." In P. N. Kardulias (ed.), World-systems theory in practice: Leadership, production, and exchange, 6384. Lanham, MD: Rowman \& Littlefield. 
-. 2010. Why the West rules - For now: The patterns of history, and what they reveal about the future. New York, NY: Farrar, Straus and Giroux.

Morris, I., and J. G. Manning. 2005. “Introduction.” In J. G. Manning and I. Morris (eds.), The ancient economy: Evidence and models, 1-44. Stanford, CA: Stanford University Press.

Morris, I., R. Saller, and W. Scheidel. 2007. “Introduction.” In Scheidel, Morris, and Saller (2007), 1-12.

Motyl, A. J. 2001. Imperial ends: The decay, collapse, and revival of empires. New York, NY: Columbia University Press.

Murphy, T. 2004. Pliny the Elder's Natural History: The empire in the encyclopedia. Oxford: Oxford University Press.

Nafissi, M. 2005. Ancient Athens and modern ideology: Value, theory and evidence in historical sciences: Max Weber, Karl Polanyi and Moses Finley. London: Institute of Classical Studies, University of London.

Nappo, D. 2018. I porti romani nel Mar Rosso da Augusto al tardoantico. Naples: FedOA Press. North, D. C. 1981. Structure and change in economic history. New York, NY: W. W. Norton \& Co.

-. 1990. Institutions, institutional change and economic performance. Cambridge: Cambridge University Press.

Pitts, M., and M. J. Versluys, eds. 2015. Globalisation and the Roman world: World history, connectivity and material culture. Cambridge: Cambridge University Press.

Polanyi, K. 1944. The great transformation. New York, NY: Rinehart.

-. 1957a. "Aristotle discovers the economy." In Polanyi, Arensberg, and Pearson (1957), 64-96.

-. 1957b. "The economy as an instituted process." In Polanyi, Arensberg, and Pearson (1957), 243-269.

-. 1963. "Ports of trade in early societies." Journal of Economic History 23, 30-45.

-. 1977. The livelihood of man. New York, NY: Academic Press.

Polanyi, K., C. M. Arensberg, and H. R. Pearson. 1957. Trade and market in the early empires: Economies in history and theory. New York, NY: Free Press.

Purcell, N. 2017. "Mountain margins: Power, resources and environmental inequality in antiquity." P. Derron, and S. von Reden (eds.), Économie et inégalité: Ressources, échanges et pouvoir dans l'Antiquité classique: Huit exposés suivis de discussions: 22-26 août 2016, 75-105. Geneva: Fondation Hardt.

Raschke, M. G. 1978. “New studies in Roman commerce with the East.” In H. Temporini (ed.), Aufstieg und Niedergang der römischen Welt. Part 2. Vol. 9.2, 604-1378. Berlin: De Gruyter.

Rathbone, D. 2007. “Roman Egypt.” In Scheidel, Morris, and Saller (2007), 698-719.

Rathbone, D., and S. von Reden. 2015. “Mediterranean grain prices in classical antiquity." In R. J. van der Spek, B. van Leeuwen, and J. L. van Zanden (eds.), A history of market performance: From ancient Babylonia to the modern world, 149-235. London: Routledge.

Ray, H. P. 2003. The archaeology of seafaring in ancient South Asia. Cambridge: Cambridge University Press.

-. 2008. Colonial Archaeology in South Asia. The legacy of Mortimer Wheeler. Oxford: Oxford University Press.

Renfrew, C., and P. Bahn. 1991. Archaeology: Theories, methods and practice. London: Thames and Hudson.

Rice Holmes, T. R. 1928-1931. The architect of the Roman Empire. 2 vols. Oxford: Clarendon.

Roll, E. 1956. The History of economic thought. London: Faber and Faber.

Rostovtzeff, M. 1941. The social and economic history of the Hellenistic world. 2 vols. Oxford: Clarendon.

-. (1926) 1957. The social and economic history of the Roman Empire. 2nd ed. Oxford: Clarendon.

Saller, R. 2001. "Framing the debate over growth in the ancient economy." In Scheidel and von Reden (2001), 251-269. 
Sartre, M. 2000. "Syria and Arabia." In A. K. Bowman, P. D. R. Garnsey, and D. W. Rathbone (eds.), The Cambridge ancient history. 2nd ed. Vol. 11, 635-663. Cambridge: Cambridge University Press.

Scheidel, W. 2012. "Studying the state." In P. F. Bang and W. Scheidel (eds.), The Oxford handbook of the state, 5-60. Oxford: Oxford University Press.

Scheidel, W., and S. von Reden, eds. 2001. The Ancient Economy. Edinburgh: Edinburgh University Press.

Scheidel, W., I. Morris, and R. Saller, eds. 2007. The Cambridge economic history of the GrecoRoman world. Cambridge: Cambridge University Press.

Schneider, H. 1988. "Schottische Aufklärung und antike Gesellschaft." In P. Kneissl and V. Losemann (eds.), Alte Geschichte und Wissenschaftsgeschichte: Festschrift für Karl Christ, 431-464. Darmstadt: Wissenschaftliche Buchgesellschaft.

Schneider, P. 2019. "Erythrean pearls in the Roman world: Features and aspects of luxury consumption (late second century BCE-second century CE)." In M. A. Cobb (ed.), The Indian Ocean trade in antiquity: Political, cultural and economic impacts, 135-157. London: Routledge.

Seland, E. H. 2016. Ships of the desert and ships of the sea: Palmyra in the world trade of the first three centuries CE. Wiesbaden: Harrassowitz.

Shaw, B. 1990. "Bandit highlands and lowland peace: The mountains of Isauria-Cilicia." Journal of the Economic and Social History of the Orient 33, 199-270.

Sherrat, A., and S. Sherrat. 1993. "The growth of the Mediterranean economy in the early first millennium BC." World Archaeology 24, 361-378.

Sidebotham, S. E. 2011. Berenike and the ancient maritime spice route. Berkeley, CA: University of California Press.

Sidebotham, S. E., and J. Gates-Foster. 2019. The archaeological survey of the desert roads between Berenike and the Nile Valley: Expeditions by the University of Michigan and the University of Delaware to the Eastern Desert of Egypt, 1987-2015. Boston, MA: American Schools of Oriental Research.

Smith, A. (1776) 1961. An inquiry into the nature and causes of the wealth of nations. London: Methuen.

Speidel, M. A. 2016. "Fernhandel und Freundschaft zu Roms Amici an den Handelsrouten nach Südarabien und Indien." Orbis Terrarum 14, 155-193.

Syme, R. 1934. "The northern frontiers under Augustus.” In S. A. Cook, F. E. Adcock, and M. P. Charlesworth (eds.), The Cambridge ancient history. Vol. 10, 340-381. Cambridge: Cambridge University Press.

Thomas, R. I. 2012. "Port communities and the Erythraean Sea trade." British Museum Studies in Ancient Egypt and Sudan 18, 169-199.

Tomber, R. 2008. Indo-Roman trade: From pots to pepper. London: Duckworth.

Van der Spek, R. J. 2007. “The Hellenistic Near East.” In Scheidel, Morris, and Saller (2007), 409-433.

Versluys, M. J. 2014. "Understanding objects in motion: An archaeological dialogue on Romanization.” Archaeological Dialogues 21, 1-20.

von Domaszewski, A. 1914. Geschichte der römischen Kaiser. 2nd ed. 2 vols. Leipzig: Quelle \& Meyer.

-. 1967. Die Rangordnung des römischen Heeres. 2nd ed. by B. Dobson. Cologne: Böhlau.

von Richthofen, F. 1877-1912. China: Ergebnisse eigener Reisen und darauf gegründeter Studien. 5 vols. Berlin: Reimer.

Wagner-Hasel, B. 2004. “Le regard de Karl Bücher sur l'économie antique et le débat sur théorie économique et histoire." In H. Bruhns (ed.), L'histoire et l'économie politique en Allemagne autour de 1900, 159-183. Paris: Maison de Science de l'homme. 
Wallerstein, I. M. 1974. The modern world-system: Capitalist agriculture and the origins of the European world-economy in the sixteenth century. New York, NY: Academic Press.

-. 2004. World-systems analysis: An introduction. Durham, NC: Duke University Press.

Weber, M. 1897. “Agrarverhältnisse im Altertum.” In J. Conrad et al. (eds.), Handwörterbuch der Staatswissenschaften. Suppl. Vol. 2, 1-18. Jena: Fischer.

Weber, M. 1904. "Die 'Objektivität' sozialwissenschaftlicher und sozialpolitischer Erkenntnis.” Archiv für Sozialwissenschaften 19, 22-87.

Wells, B., ed. 1992. Agriculture in ancient Greece: Proceedings of the seventh international symposium at the Swedish Institute at Athens, 16-17 May 1990. Stockholm: Åström.

Wells, C. M. 1972. The German policy of Augustus: An examination of the archaeological evidence. Oxford: Clarendon.

-. 1991. "The problems of desert frontiers." In V. A. Maxfield and M. J. Dobson (eds.), Roman frontier studies 1989: Proceedings of the 15. International Congress of Roman Frontier Studies, 478-481. Exeter: University of Exeter Press.

Wells, P., ed. 2013. Rome beyond its frontiers: Imports, attitudes and practices. Portsmouth, RI: Journal of Roman Archaeology.

Wheeler, M. 1954. Rome beyond the imperial frontiers. London: Bell and Sons.

Wheeler, E. L. 1993. "Methodological limits and the mirage of Roman strategy: Part I \& II." Journal of Military History 57.1, 7-41 and 57.2, 215-240.

Whittaker, C. R. 1994. Frontiers of the Roman Empire: A social and economic history, Baltimore, MD: Johns Hopkins University Press.

-. 2004. Rome and its frontiers: The dynamics of empire. London: Routledge.

Wilson, A. 2015. "Red Sea trade and the state." In De Romanis and Maiuro (2015), 13-32.

Wilson, A., and A. K. Bowman. 2018. "Introduction: Trade, commerce and the state." In Wilson and Bowman (2018), 1-26.

Woolf, G. 1990. "World systems analysis and the Roman Empire." Journal of Roman Archaeology 3, 44-58.

-. 1992. "Imperialism, empire and the integration of the Roman economy." World Archaeology 23, 283-293.

-. 1993. “Roman peace." In J. Rich and G. Shipley (eds.), War and society in the Roman world, 171-194. London: Routledge.

-. 1998. Becoming Roman: The origins of provincial civilization in Gaul. Cambridge: Cambridge University Press.

-. 2014. "Romanization 2.0 and its alternatives." Archaeological Dialogues 21, 45-50.

Young, G. K. 2001. Rome's eastern trade: International commerce and imperial policy, $31 B C-A D$ 305. eLondon: Routledge. 



\section{Index}

accounting $108,278,358,371,441,533,543$, 559, 635

Achaemenid Empire 15, 60, 207, 477

- conquest of Central Asia 53, 677

- continuities in Arsakid Empire 207-208, 218, 220

- continuities in Central Asia 73, 84, 109, 407-408

- continuities in Hellenistic Empires 18, 20-21, 27-29, 32, 34, 38, 41, 46, 695

- influence on Xiongnu Empire 198

Achaia 46

adhyakșa (superintendent) 111, 427

Adiabene 211, 217, 225, 228

Adluri, V. 649

administration (by region)

- in the Arsakid Empire 223-224, 227-229, 481, 483, 485

- in Central Asian Empires 73-74, 80, 86-88, 392, 412

- in Hellenistic Empires 27-29, 363

- in Indian polities 103, 108-110

- in the Qin and Han Empires 150-163

- in the Roman Empire 259-271

- in the Xiongnu Empire 198

administration (subject), see also adhyakșa; bureaucratization; legal system; officials; taxation

- central 151-153, 167, 293, 499, 532-533, 543

- financial, see also state budget, 73-74, 270, $344,373,496,408-409,550,623-624$, 674

- frontier, see frontier

- in the Kauṭilīya Arthaśāstra 426

- local 103, 112, 153-157, 160, 163, 228, 268$271,290,293,541,543-544,550,651$

administrative documents 228, 477

administrative units 136, 153, 156, 262, 655

Aegean (Sea) 15, 18, 20, 25, 28, 31, 44, 48, 694

Aelian 383

Aelius Aristides 270-271, 344

Afghanistan 21, 59, 397-398, 401-405, 566, 670-671

Agathokles 65, 67, 399

agriculture, see also animals; farms; irrigation; peasants; production; subsistence, 21 ,
$40,97,113,139,198,392,423,428,503-$

$504,522,541-542,548,630,632,651-$

653, 656, 701, 707

- double-cropping 97

- garrisons, see tuntian

- innovation 32, 39, 135, 256, 652

- interaction with steppe groups 207

- magistrates, see nongling/nongzhang

- market oriented 245

- multi-cropping 97

- patronage of 107

- in steppe context 198, 200

- surplus, see production

agronomic literature 314-315, 345-346, 521524

Ai Khanum, see also treasury, 27, 35-37, 67, 70, 72, 221, 405, 408

documentary evidence from 674

Akanānūru 438

akșayanivi (perpetual endowment) 444-445

Albania (Caucasus) 351

Alexander IV 23

Alexander Severus 272

Alexander the Great 18, 53, 66, 71, 98, 101, $287,361,644-645,671$

- in ancient historiography $383,385-387$, 644,657

- in modern reception 479, 587, 592

Alexandria (Egypt) 26-27, 35-37, 39, 254, 274, 365, 367, 694, 697

Alexandria in the Caucasus 402, 684

allies, see also socii, 48, 247, 260, 266, 269 , 427

- allied kingdoms, in Arsakid Empire 228-229, 490

All-Russian Archaeological Congress 594

alluvial plain 95, 97-99, 113, 129, 652

Altun Shan 131

Amaravati 434

amicitia (friendship) 260, 268, 279, 385

amphorae, see ceramics

Amu Darya, see Oxus

Anaimallai Hills 660

Anāthapiṇụaka 434-435

Anatolia 21, 25, 44-45, 374

Andragoras 209 
animals, see also camels; cattle; elephants; goats; horses; pigs; sheep, 79, 135, 441, 469,472

- husbandry 331

Annius family 286

Antialkidas 65, 69, 410

Antigonid Empire 15, 31

Antigonos Gonatas 24-25

Antigonos Monophthalmos 23

Antimachos I 58, 64-65, 67

Antiocheia-Ishtar 36

Antiocheia-Orontes 27, 36-37, 48, 276

Antiochos I 35, 55

Antiochos III 45, 66, 210

Antiochos IV 672

Antipatros 23

antiquarians 397, 452, 593, 642-643

Antoninus Pius 252, 385, 480

anugraha (privileges) 441

Anuradhapura 107-108, 115, 447, 449, 450, 457

Anxi, see also Arsakids, 78, 81, 232, 390-391, 393, 489

Apameia 27, 36

Apollodoros of Artemita 55-56, 386, 388

Apollodotos I 58, 64-65, 67, 473

Apollonopolis Magna, see Edfu

apomoira (tax) 31, 367

Apracarājas 395

Apuleius 352

arabarch (magistrate) 485

Arabia 119, 255, 272, 286, 291, 443-444, 489-490, 711, 719

Arabian Desert 256

Arabian Peninsula 2, 39, 272, 286, 697, 719, 720

Arabian Sea 61, 95, 118-119, 660

Arabs 48, 479

Arachosia 21, 55, 57, 62-63, 66-70, 73, 85, 101, 394, 410, 487

arājaka (anarchy) 109

Aramaic, see language

archaeobotany, see archaeology

Archaeological Survey of India 401, 487, 682

archaeology, see also colonial, and by region, 362, 650, 656, 709

- archaeobotany 97, 335-336, 381, 406

- archaeometallurgy 119, 399

- Buddhist monuments 401-405

- and Graeco-Roman economic history 311337
- isotope analysis 329-330

- maritime 27, 320-321, 451-452, 708, 710

- New Archaeology 606, 709

- radiocarbon dating 201, 448

- survey 36, 230, 313, 482, 491, 642

- zooarchaeology 406

architecture 221-223, 229-230, 243, 288, 290, 402-405, 434, 469

archives (ancient), see also cuneiform texts; Heroninos Archive; Qianling County Archive; Zenon Archive, 499, 524

Ardashir I/Ardašir 74, 82, 217

area within the passes, see Guanzhong

Areni (Armenia) 374

Argeads (dynasty of Alexander III) 23-24

Aria 21

Ariana 55-56, 61

Arikamedu 119, 442, 449-450, 657-658, 660

aristocracy 4, 30, 84, 289

- Chinese 30, 84, 289, 503

- competition 70, 244, 245, 292

- ideals, see virtus

- Parthian 208, 214-215, 217-218, 223-225, 227

- Roman 244-245, 248, 288-290

- Xiongnu 201

Aristotle (Pseudo) Oikonomika 40, 344, 706

Arius 66, 73

arkapates (chief of the tax system) 485

Armenia, see also Areni, 25, 47, 211, 213, 225 , 255

- Arsakid-Roman disputes over 214-215

- Trajanic invasion of 216, 255

army (by region)

- in the Arsakid Empire 217, 226-229

- in Central Asian Empires 70, 72-73, 81, 86

- in Hellenistic Empires 22-23, 28, 47, 72

- in Indian polities 101, 105, 109-111, 114

- in the Qin and Han Empires 172-184

- in the Roman Empire 244, 250-259, 267, 273, 285

- in the Warring States 135-136

- in the Xiongnu Empire 197

army (by subject) see also mercenaries, 6, 373, 375, 427, 548, 696

- cavalry 71, 73, 86, 111, 135, 174-176, 226

- finances 41, 227, 532, 707

- in Greek Indography 111

- infantry 72, 111, 135-136, 176, 226

- in the Kauṭilīya Arthaśāstra 110-111, 423 
- logistical support $136,256-259,272,529-$ 530, 533

- mass 135

- protection of trade routes 720

- recruitment 111, 170-171, 182-183

- service 35, 136-137, 154, 157, 162, 182-184, 251, 542, 632

- size of 86, 111, 135, 176, 226, 256, 293

- standing 101, 110, 182, 226, 250, 293

Arrian 383, 386, 471

Arsakes I 66, 209-210, 219, 223

Arsakes II 210

Arsakid Empire = Parthian Empire, see also architecture; climate; epigraphy; Hellenization; kingship; Nisa; physical geography, 11, 48, 56-57, 66, 68, 70, 8384, 253-255, 390

- archaeology of 205, 221-223, 230-231

- court art 218, 221-222

- foreign sources on $205,477-479$

- regionalism/localism in 221, 229-230, 480

Arsakid era 58

Arsinoe II 31-32, 47

Arsinoe (Red Sea) 39

Arsinoite nome 367-368

Artabanos I 211

Artabanos II 214-215, 224, 228

Artabanos IV 217, 482

Artavasdes II 213-214

Artaxes II 214

artha (economic pursuit, wealth) 423, 425 , 427, 431-432

Arthaśāstra see Kauțilīya Arthaśāstra

artisans 427, 560, 568

Asangorna parchment 64, 73, 409

Ashgabad 482

Asia (Roman provincia) 117, 261-263, 291

Asia Minor 25, 34-35, 39, 273, 283, 290, 371

Asiatic mode of production 479, 643, 651

- Soviet-Marxist interpretations of 605-606

Asiatic Society 642

Aśoka Maurya, see also edicts, 101, 105, 109111, 113-116

- policy, see dhamma, see also bherighoșa; dhammaghoșa

- titles, see devānampiya; piyadasi

Assyria 487

Astronomical Diaries, see cuneiform texts

Athens 17-18, 24, 30, 37, 39, 286-287, 348, 701, 703
Atropatene 214, 229

Augustus, see also edicts, 214, 243, 248, 250253, 259, 262, 264, 274, 277, 284, 290, 458, 474, 587, 694, 712, 714

Aurangabad 444

javadāna(s) 433

Avil, son of Bashnin 485

Avroman parchments 482, 484-485

ayvan (barrel-vaulted hall) 229, 231

Azes era 58

Babylon 21, 26, 40, 230, 232, 485-486, 489

Babylonia, see also Mesopotamia, 15, 19, 21, $24-25,33,46-47,210,228,230,481-$ 482

Bactra 61, 66, 71, 73, 82, 85-86, 383, 386, 388-389, 393, 402, 404-405, 413

Bactria, see also Daxia; letters, 19, 21, 25, 35, $44,53,55-57,60-61,66,68,73,175,179$, 210-211, 384, 393-395, 399, 402, 404405, 407-409, 669, 673

- agricultural prosperity of $55,62,386-387$

- Bactria-Tokharistan 56, 61, 74, 77, 81-83, 85, 384, 390-391, 411-414, 681

Badakhshan 63

Bagchee, J. 649

bagolango (image temple), see also devakula, 81-82, 84, 402

Baikal (lake) 173, 195

Bajaur Manuscript collection 426

balanced standard, see pingzhun

balance of trade, see trade

Bali 450

Balkan 241, 254, 335, 585

Balkh, see Bactra

bamboo manuscripts, see also excavated texts, 185, 530-531, 543-545, 549-551

Ban Biao 391, 489

Ban Chao 78-80, 86, 391, 489

Ban Gu 150, 498-513, 564, 621

Ban Yong 489

banditry 251-252, 260, 293

Bang, P. F. 326, 347, 349, 696

banks (trapezai) 33, 336, 703

barbarians $140,288,293,505,567,712-715$

Barbarikon 384, 388

Barfield, T. 62-63, 198

Barikot 403

barley, see also grain, 62

Bartol'd, v. v. 597-598, 676, 679 
Barygaza $=$ Bharuch 112, 384, 473, 489-490

basileia, see kingship

basilikon, see treasury

battles

- Actium 47

- Carrhae 213

- Changping 142

- Cynoskephalae 45

- Ipsos 24

- Kurupedion 24

- North Desert campaign 176

- Pydna 46

- Raphia 45

- Rhandeia 215

Bayer, T. S. 397,588

bdellium 387

Begley, V. 658, 660

Begram 86, 397, 402, 566, 568-569, 669, 684

- hoard 58-59, 402, 406, 669, 673, 683-688

Beloch, J. 703

benefaction $27-29,31,41,157-158,274,276$, 282

Bengal (bay) 95, 97, 118, 471

Benjamin, C. 669, 687-688

Bentinck, W. 643

Berenike I 30

Berenike Troglodytika 36-37, 39, 119, 363

Bessos 19, 53

Bharhut 434-435

Bharuch, see Barygaza

bherighoșa (declaration of war) 102, 111

$\mathrm{Bi}$, Chanyu 180

biblical studies 424, 479, 649

bilingualism, see also inscriptions;

multilingualism, 363, 371, 439, 484-485

Bingen, J. 367

biography 232, 499, 508

biology, see also bones, 327

Bisitun Inscription 82,84

Bithynia 25, 46, 273, 281

Bitter Lakes 39

Black Sea $=$ Pontos 20, 46, 48, 255, 260, 281, $357,581,589,591-592,596,598$

- study of $583,593-594,600,602$

Bod 485

Bodh Gaya 434

Boeck, A. 357, 701

Bolsheviks 584, 598-599, 676

bones

- human 327-330

- mammal 330-333 booty 67, 245

Book of Lord Shang, see Shangjun shu

border zones, see also frontier, 109, 115, 162, $174,183,227,373,442,608,698,712$

- markets 174, 508, 512, 568

Boroo Gol 200

Boubastis Canal, see Pithom Canal

boundaries

- boundary stones 372

- pomerium (Rome) 712

- of satrapies 60-61

Bowman, A. 241, 699-700

Braudel, F. 693

Bṛhadratha (king) 102

Briant, P. 15

British Raj 641, 650, 670

Bronze Age, see also Indus Valley Civilization, 53, 62, 131, 406, 645, 649$650,655,674$

brother-sister marriage, see marriage

Bruce, J. C. 716

Brughmans, T. 326

Brundisium 272

Bücher-Meyer controversy 703-705

Buddha 115, 433-435, 439, 645

Buddhism 58, 70-71, 81, 86, 108, 110, 116, 119-120, 149, 392, 401, 411, 631, 644, $658,661,671-672$

Buddhist, see also archaeology; dhamma; literature; monasteries; stūpa

- art 58, 401-402, 434-435

- chronicles 108, 111, 644

- monks 115, 433-434, 436, 445, 661

- narrative literature $68,81,109,382,433-$ 434

- nuns 115, 445

budgetary policies, see state budget

bullion 41, 359

bureaucracy 136, 150-152, 160, 183, 266, 268, 271, 280, 409, 514

bureaucratic afterlife 163

bureaucratization 136-138, 150

- cultural impact of $151,163,563$

burgi (watchtower) 252

Burkhan Tolgoi (cemetery) 199

Burnes, A. 644

butchery 332

Byzantium, Russian affiliation with 587

cabotage, see tramping

Caesar, G. Julius 213, 248, 261, 277, 283-284, 290 
Caesarea Maritima 274

cakravarti (universal monarch) 105, 110

Cambridge Economic History of the GraecoRoman World 695-696, 708

camels 364, 517

- Bactrian 385

Cāṇakya-Candragupta tradition 426

canals, see infrastructure

Canatha 302

Candragupta Maurya = Chandragupta Maurya 101-102, 111, 115-116, 118, 426, 441, 470

capitalism $603-604,643,646,651,700,702$, 705

cannibals 472

Caracalla 216-217, 292, 480

caravan, see also trade

- leaders 411, 414, 661

- routes 232

Carthage 45, 323, 288, 713

Caspian Sea 207, 210, 224, 386

Catherine II 593

Cato 344-345

cattle 328, 330-331, 333, 423, 428, 430, 432, 511, 517

Caucasus (region) 588-59, 592-593, 602

Caucasus Indicus, see Hindu Kush

cavalry, see army

cave inscriptions

- Karle 444

- Nagarjuni 109, 444

- Nanaghat 105

- Nasik 444-445

- Sitabenga 103, 444

- Socotra 44, 443, 661-662

- Sri Lanka 445

Celts 25

cemeteries, see also tombs 21, 199-201, 448, 602

census, see also registration of population 277-278, 284, 294, 350

Central Asia, see also Greek Kingdoms of Central Asia; Kushan Empire, 2-3, 14, 16, 19, 45, 148, 177, 210, 231, 480-481, 490, $508,570,577,581,585,589,592-593$, 644, 669-682, 684-688, 697-698

- definitions of 59-61

- historical products 382-383, 387-388

centralization, see also decentralization; state formation, $101,108,143,144,147-149$, $151,153,174,229,367,369$ centurion 251

ceramics, see also ostraca, 118-119, 200, 318326, 448, 450-451, 654

- amphorae 321-324, 449-451

- black and red ware (BRW) 442, 444, 449, 451

- chronology 320-321, 448

- classifications 449-450, 656

- as data 318-321, 405

- inscribed 372-373

- moldware 450

- northern black polished ware (NBPW) 100

- rouletted ware (RW) 118-120, 442, 444, 449-450, 658

- storage vessels 119,451

- terra sigillata 290, 321, 325-326, 373, 449, 658

- torpedo jars 232, 450

Ceras 105-106, 436

Chach 79, 390-391

Chakrabarti, D. K. 654

Chakravarti, R. 654, 659

Chandra, M. 661

Chandragupta, see Candragupta Maurya

Chang'an 147, 149, 174, 182, 506, 517, 562, 564, 567-569

Changsha 531, 546, 548-550, 636

chanyu 174, 198, 200, 569

Charakene 216, 228-229, 232, 481, 486, 489

Charax Spasinou, see Spasinou Charax

chariots 105, 111, 132, 441, 557

Charsadda 402-403

Chattopadhyaya, B. D. 648-650

checkpoints 162,532

Chen Duxiu 625

Chen Sheng/Chen She 144

Chen Zhi 628, 633

Chengdu 141

chengxiang (chancellor) 152

chiefdom 108, 197-199, 455

chiefs $10,108,111,114,436$

Chief of the Ten Thousand Cavalry 198

Childe, V. G. 606, 654

children 152, 162, 184, 364

China 59, 199, 251, 259, 698

Chinese Empires (Qin and Han), see also historiography (ancient); kingship; legal systems; literature; physical geography; Qin Empire, 14, 231-233, 389, 480-481, 490, 529-551, 557-570, 578, 619-637 
Chinese social history controversy (Zhongguo shehui shi lunzhan) 625-626, 628-629

Chorasmia $=$ Khorezm 57, 395, 677, 681 chrematistike (art of acquiring money) 701

Christians 294, 642

Chu (state of the Warring States period) 136$137,140,142-145,147,547$

Chunqiu period 133, 135, 518

Cicero, M. Tullius 261-264, 280-283, 289, 344, 347

circulation, see also coinage; money, 276, 400, 708

cishi (regional inspector) 154, 169, 183

cities, see also urbanization, 27, 72, 106-107, $222,228,230,232,243,259,268-271$, 281, 284, 360, 469, 487, 491, 548, 651, $654,704,707$

- foundation of $36,40,53,66,71-72,230$

- life in 423, 432-433, 655

citizenship 246, 265, 280-281, 291-292

city-state, see polis

civil war (Roman Late Republic) 213, 248

Clarysse, W. 367

Claudius (Roman emperor) 278, 712

Claudius Ptolemy 471

cleruchs (military settlers) 34

client kings 20, 259, 261

climate 21, 358, 469, 693, 710

- Arsakid Empire 207, 486

- Central Asia 62-63

- change 197

- Mediterranean 241, 693-694

- South Asia 97

- Qin and Han Empires 129, 131

Cobb, M. 659

Codex Theodosianus 346

Coele-Syria, see Syria and Phoenicia

coevolution 174, 198

coinage (by regions)

- in the Arsakid Empire 218-221, 229, 487489

- Athenian, see also weight standard, 17, 393394

- Bactrian nickel theory 399

- denarii 275-276, 359, 458

- dinars 80, 396-397, 399, 682-683, 685, 687

- drachms in the Arsakid Empire 220

- drachms in Central Asia 64, 74, 394, 399

- drachms in the Roman Empire 276, 277
- in early South Asia 434, 438, 453-458

- Graeco-Bactrian 63-64, 70-71, 394, 397398, 400

- in Hellenistic Empires 17, 27-29, 31, 33, 3943, 55

- Indo-Greek 63-64, 67, 70-71, 394, 397, 455, 644

- janapadas 455, 654

- kārșāpaṇas 74, 408, 445, 457

- Kushan 63, 76, 79-80, 394-399, 455-456, $678,682-683,685-687$

- paṇa 427-428

- Ptolemaic 32, 34, 43-44, 276

- in the Qin and Han Empires 48, 501-502, $624,631,633$

- Roman coins in India and Sri Lanka 456458, 682

- in the Roman Empire $275-277,400,682-$ 683, 685-687

- Seleukid 17, 27-29, 31, 393-394, 400

- shekels 42

- Sino-Kharoșthī 395, 399

- in South Asia 452-458

coinage (subject), see also currency; demonetization; monetization; money; standardization

- base metal 44, 46, 63, 85, 218, 276, 361, 394-395, 400, 453, 631

- cast 454, 457

- circulation 361

- closed currency system 43, 276

- counterfeit 502

- cupronickel 394, 399

- gold 41-44, 55, 63, 80, 335, 352, 360-361, 393-394, 396-397, 399-400, 456-458, $517,658-659,680-683,686-688$

- hoards 43, 185, 351, 360-361, 398, 400, 456, 458, 708

- iconography 42, 70, 78, 219-221, 277, 487

- imitations 69, 77, 360, 394-395, 456-458, 502

- inscribed (Indian) 455, 457

- legends on $67,71,82,219,394,396,408$, 411, 452, 682

- manipulation of $44,276,360,395$

- metrology 399, 682-683

- mint marks 218

- mints 55, 218, 393-394, 396, 487

- monopoly 456, 501, 513

- overstrikes 455 
- political symbolism 41

- portraits 218-221, 394-396

- posthumous Alexander 42

- production 220-221, 361

- punch marked 394, 453-454, 456-457

- trust in 455

- volume 362

- weight standard 17, 39-41, 43, 64, 82, 394395, 399, 682

coin-like objects 457

Colas 99, 105-107, 436

Cold War 582, 717-718

collegia (corporate bodies) 279, 286

Collingwood, R. G. 657

colonial

- archaeology, see also antiquarians 397, 401, 589, 593, 642

- discourse 59, 98-100, 119-120, 641-645, 648, 655

- officials 401, 592, 596-597, 644

- philology 424, 642

colonialism 585, 592, 641, 648, 662, 713

colonization $45,116,119,135,141,176-177$, 587, 693, 657-658

Columella 345-346

commandant, see wei/duwei

commandery, see jun

commentary tradition 429,498

commercial production, see production

commercium 266, 701

commodities, see goods

Commodus 253

communication network 112-113, 153, 160162, 172, 473

- cursus publicus 272-273, 325

- postal stations 161, 532, 537-538

comparative method, see also interdisciplinary research, 13, 710, 719

concrete, Roman 274

conductores 258

Confucianism 138, 160, 514-515, 619, 627

connectivity $1,2,5,57,119,241,272,282$, $381,388,406,654-655,657,659,684$, 693, 710

conscripts $171,183,532,633$

- agricultural 533-535

- laborers 137, 146, 154, 157, 162-163, 172, 184, 529-530, 561, 624

- soldiers 182-183, 533, 535, 542

Constantinople 288 consumer revolution 289

consumption $4-5,289,562-563,660,710$

- meat 62, 331

contracts, see also tally systems, 245, 258$259,325,343,345,347,363,366-367$, 464

convict(s) 167

- laborers 141, 169-171, 542, 547, 634

- soldiers 171, 182, 251

Corbulo 273

core-periphery model 15, 201

Corinth 18

Corinthian League 17-18, 23

corporation, see guilds

corruption 154, 158-159, 168, 263-265, 281

county, see xian

Court, C. A. 644

court, royal 29, 40, 62, 704

Crassus, M. Licinius 213

credit (loans), see also debt; money, 4, 40, 366, 373, 407, 503, 625, 657, 701, 703

Crete 44, 372

Crimean peninsula 568,592

Cultural Revolution 531, 625, 633, 637

cuneiform texts 225, 485-486, 491

- Astronomical Diaries 228, 486, 491

- Rahimesu Archive 225

Cunningham, A. 401, 452, 644, 682

currency, see also coinage; money, 457, 541, 630-631

- reform 395-396, 486, 497, 501-502, 682683

cursus publicus, see communication network Curtin, P. 711

Curtius Rufus 383, 385-387

Curzon, G. 715

customs duties $30,358,363,366,423,451$, $508,684,686,720$

Cyprus 15, 24-25, 34, 39-40, 44, 47-48, 265, 372, 694

Cyrene (Kyrenaika) 15, 34, 39, 47-48, 115, 265

da sinong (superintendent for agriculture) 152, 506

Dachinabades, see Dakșināpatha

Dacia 372, 712

Dahae 78, 209, 215, 224

Dakṣināatha (southward route) 105, 112-113, 661

Dal'verzintepe $77,85,403-404$ 
dāna (donation, gift) 115, 425, 444

Danube 312-315, 372

- as frontier 254, 712

Daoism 138, 173, 515

Darius I 28, 53, 60, 82, 84, 469, 696

Darius III 19, 53, 60

Dasht-i Nawur inscription 80, 412

Daxia, see also Bactria, 179, 390-393

Dayuan, see also Ferghana, 177, 389-393, 489

Dazexiang 144

de Callataÿ, F. 400

de la Vaissière, É. 674

debt, see also credit, 162, 224, 270, 281, 349, 427, 529-530, 673

Deccan 95, 99-105, 111, 113, 447, 450, 455

decentralization 149, 154, 160, 183, 649, 653, 660

defense systems, see fortifications; frontier

Délégation archéologique française en

Afghanistan (DAFA) 402, 404-406, 671, 679,683

Deloche, J. 660

Delos 286, 705

Delphi 30

Demetrios I (Graeco-Bactrian king) 55, 66-67, 71, 386

Demetrios I Poliorketes 24, 56

Demetrios II (Graeco-Bactrian king) 67

Demetrios II Nikator 211

demography, see also population, 246, 392, 401, 491, 701

demonetization 359, 653

Demosthenes 347

demotic (language) 363, 365-366, 369

dendrochronology 335

dependency theory 198, 201

dependent states, see shuguo

desert, see also under individual deserts, 21, 62, 131-132, 207, 362, 364

- frontier 715

devakula (house of the gods), see also bagolango, 80, 82, 84, 402

devānampiya (title of Aśoka) 100, 108-109

Devānampiya Tissa 107-108

dhamma (Buddhist teaching) 100, 102, 104, 111, 440

dhammaghoșa (declaration of dhamma) 102, 111

dharma (religious pursuit, duty), see also rājadharma; svadharma, 423-425, 429431 dharmaśāstra, see śāśtras

D'iakonoff, I. M. 601

diaspora 284, 413, 674, 711

diet 327-330

Digesta lustiniani 346

digital data and methods 186, 315-317, 323324, 326, 358, 376

- Epigraphik-Datenbank Clauss/Slaby 316

- Nomisma 316

- ORBIS 325-326

- Pleiades 316

- Searchable Greek Inscriptions (PHI) 317

Diocletian, see also edicts, 288

Diodoros (Siculus) 383, 385, 471

Diodotos I 55, 65-66, 209

dioiketes 33-34

Dionysos 43

Dioscorides $=$ Socotra, see also cave inscriptions, 443, 661-662

diplomacy, see also envoys; gifts; nīti; trade, 69, 76, 78-82, 174, 180, 183, 197, 217, 260, 385, 390-391, 410, 427, 508512, 537-538, 568

- as a 'cloak for trade' 391, 508, 510

Direct Road (Zhidao) 144

discipline-reflexive studies (of South Asia) 648 Discourses on Salt and Iron, see Yantie lun district, see xiang diversity 40-41, 107-108, 146, 154, 179-189, $201,233,259,275,710$

- cultural 13, 28, 33, 247, 381

- ecological 1, 6, 62, 97, 121

- social 470

- religious 651

donations, see also benefaction; dāna; doreia; gifts; inscriptions, 28, 35, 84, 115, 405, 444-445, 451, 661

Dongting Commandery 529

doreia (gift estate) 30, 35, 367

doriktetos ge/chora (spear-won land) 28, 70

Dou Gu 489

Drangiana 21, 60, 67

dry farming regions 62

Du Zhengsheng (Tu Cheng-sheng) 632

Dunhuang 176, 413, 531, 533, 535, 566, 633, 634,636

Dura Europos, see also papyri, 228, 255, 363, 482, 485, 491

Dureny 200

Dushu zazhi 626 
Duṭthagāmani 107-108

Dwarka 451

dykes 715

dynasty building 19, 23, 31, 99

Dyrestui (cemetery) 199

East Africa 720

East India Company (British) 401, 452, 642, 644

Eastern Desert 252, 254, 256, 272, 286, 293, 336,711

Ebro treaty 713

ecology 6, 20-22, 62, 114, 121, 257, 436, 693

economic determinism 646, 653-656

economic development 28, 45, 706

- growth 135, 149, 670, 707-710

economic models, see also Asiatic mode of production; Marxism

- modernism 357, 604, 675

- primitivism 604, 703

- Soviet, see also five-stage model, 578, 603604,608

- state-centric (India) 647, 655-656, 662

economy, see also subsistence

- closed 643

- concept of, China 620

- concept of, Graeco-Roman 344, 578

- national 1, 3, 7, 357, 701, 703-704

Edfu = Apollonopolis Magna, 365

edicts 266, 273, 372, 439

- ancient Chinese 499

- Aśokan 98, 100, 102, 104-105, 110, 113, 115, 407, 439, 644

- Augustan 265

- Caracallan 292

- Diocletian 373

- Hadrianic 271

- prostagmata (prescripts) 29

Egypt 17-19, 24, 32-33, 37, 47, 115, 241, 251252, 254, 257-258, 276-277, 286, 322, $347-348,357,362-371,443,657-658$, 698, 705, 712, 719

- Mediterranean society 694

- Pharaonic 29

Eisenstadt, S. 4

Ekbatana 19, 21, 211, 222

Elamite, see language

elephants $25,27,43,73,86,102,110-111$, $438,441,473$ elites, see also aristocracy; local, 136, 158, 632, 657

- military 19, 27

Elymais 210, 228-230

emperorship 142, 147, 151, 167

empire, see also core-periphery model; and under individual empires

- competition 15, 22, 25

- decline 145-146, 149, 173, 181, 183

- definitions of 3,13, 56

- expansion of, see also imperialism, 19, 27, 47-48, 66-68, 78, 80-81, 99, 129, 144, $148,150,172,195,210-212,226,229$, 233, 244-250, 293, 508-512, 516, 586, 589,696

- formation, see also state formation, 13, 5556, 78, 99

- ideal (in Indian historiography) 99

- memories 13

- revenue, see also taxation 28, 35, 45-48, 74, 157-158, 176, 245, 428, 511, 651-652, 699

- universal 13, 20, 22, 24-27, 44, 48, 134

- vs. nation state 4, 13, 696

empirical approach (on Chinese economic history) 628-630

emporion (port-of-trade) 106, 658, 706

Empress (Dowager) Lü 148

Engels, F. 604, 678

envoys, see also Zhang Qian, 47, 79-80, 82, $132,177,384-385$, 389-393, 508-512, 538.

Ephesos 262

Epigraphical Hybrid Sanskrit, see language 87 epigraphy (by regions), see also inscriptions

- in the Arsakid Empire 230, 488-489

- in Central Asian Empires 86-87, 406-412

- in China 634, 636

- in Hellenistic Empires 17, 34, 44

- in the Roman Empire 286, 371-374

- in Russia 594

- in South Asia 105, 382, 438-446

epigraphy (subject), see also inscriptions, 371-374

- epigraphic habit 290

- rural 374

- urban 268, 281

Epiros 24, 115

Epitome de Caesaribus 384-385

equitable delivery, see junshu 
Eratosthenes 61, 386, 470

Ernian lüling (Statutes and Ordinances of the Second Year) 541

Erythrean Sea 472

ethnicity 224, 291-292, 606-609

ethno-class $28,30,37$

ethnogenesis $600,606-608,677$

ethnography $384,508,600$

euergetism, see benefaction

Eukratides I 67-68, 70, 72, 77, 388, 397, 408, 672

Euphrates 2, 21, 38, 48, 207, 230-231, 255, $363,481,486,712$

- as a border 212-213, 255-256

Eurocentrism/West-centric 478-479, 481, 646-648, 681

Euthydemos I 65-66, 394

excavated texts, see also bamboo manuscripts; papyri; wooden manuscripts, $185,406-$ 412, 524, 529-551, 620

- administrative documents $161,172,185$, 407-410, 530

- delays in publication (China) 548, 550, 634635

- legal documents 137, 164-172, 530, 537, $539,541-542,550,562,635,636$

- in the study of the economy $530,624,633-$ 637

- tomb texts $163,530,539-545,633,635-636$

exchange, see also trade; transimperial exchange

- long-distance 29, 322-324, 516-517, 557, 578

- networks 3, 200, 231-233, 258, 259, 266, 282-285, 322-324, 512, 514, 557-558, $568,657,660$

expansionism, see empire

expenditure, military $41,227,501,513,700$, 707

Falk, H. 58, 687

Fan Shengzhi shu (Documents of Fan Shengzhi) 521-522

Fan Ye 389, 391, 499, 512

Farasan Islands 254

farmers, see peasants

farms/farming settlements $154,314,522-523$, 632

Fars/Persis 19, 207, 217, 219

Faxian 117, 644
Fayum (oasis) 36-39, 48, 367, 369

Fenghuangshan 540, 543, 633

Ferghana, see also Dayuan, 177, 390, 392, 480,681

festivals 28, 31-32, 44, 432

feudalism, see also five-stage model, 223 , 604, 626-627, 653

Fick, R. 661

filial piety, see xiao

Finley, M. I. 357, 695, 703, 706-707

First Cataract (region) 254

First Emperor of Qin, see Qin Shi Huangdi

fiscal regime, see taxation

fishing 437-438, 445, 503, 657

five-stage model (piatichlenka), see also Marxism

- in Central Asian studies 677

- in China 626

- in Soviet thought 604-606

Flamininus, T. Q. 268

flood, see also inundation, 141, 173, 505, 507, 715

Food and Commodities Semimonthly (Shihuo banyuekan) 620, 629-631

forensic oratory 347-348

forest 103, 113, 131, 423, 428, 434

fortifications $71,252-253,532,588,645,712$, 718

- Antonine Wall 714

- Fossatum Africae 715

- fortress settlement 412

- Great Wall (Changcheng) 144

- Hadrian's Wall 714

- Iron Gate Wall (near Derbent) 71, 404

- legionary fortress 716

- watchtowers 252, 413, 532-533

France 59, 397, 671, 702, 706

Frank, T. 357

frontier, see also border zones; port-oftrade, 6, 198, 201, 587, 608, 700, 708, $712-720$

- administration 153-154, 161-162, 179-181, 183-184, 228-229, 257-258, 532-535, 633

- defense 71-72, 182, 253-256

- desert 256, 715

- documents 257, 532-538, 635

- economy 256-259, 293, 535-537

- garrisons, see also tuntian, 71, 162, 174, 253,531 
- modern perceptions of $590-592,608,713-$ 719

- regions/zones 505, 695, 700, 711

Fulford, M. 325

Gafurov, B. G. 672, 676, 678-681

Gallic reaping machine 352

Gan Ying 232, 391

gana-samgha (political conglomeration) 99, 102-103, 120

Gandhāra 25, 55, 57, 67-70, 73-74, 78, 83, 87, 392, 394-395, 405, 434, 439, 653

- art 116

Gāndhārī, see language

Ganga 56, 68, 74, 81, 95, 103, 396, 470-471, 473

Ganga-Yamuna valley 100, 112, 121, 652, 656

Ganges, see Ganga

Gangopadhyaya, R. 651

Gansu corridor, see Hexi corridor

Gaozu, see Liu Bang

Garden 353, 434, 444-445

Garnsey, P. 270

Gaul 277-278, 282-283, 290-291, 325, 372

Gautamīputra Śātkarṇi 455

Gedrosia 21, 25, 60, 101

gender 329, 431

geographic information systems (GIS) 311-315, 404

geographical treatises, see also Eratosthenes;

Ptolemy; Strabo, 350, 487

geography, see physical geography

Germany (modern) 334, 363, 372, 597, 599, 607

- ancient history in 716

- economic history in 702, 704, 706

Gibbon, E. 241, 714, 719

gift estate, see doreia

gifts, see also donations, 30, 116, 183, 195, 214, 423, 425, 434, 438, 444-446, 564, 569

- diplomatic 101-102, 260, 391, 517, 567

- gift exchange 260, 279, 508, 512

Gilgit 117, 442

gladiators 291

glass 119, 371, 451, 570, 654, 659, 684

globalization

- ancient 1, 290

- modern 1, 699, 710

- studies 710

- theory 719 goats 330

Gobi Desert 131, 176

Göbl, R. 685

Godavaya 451

Gol Mod 566

gold, see also coinage, $63,117,388,430,432$, 438, 458, 471, 490, 658, 680

Golden Horde 587, 596

Gondophares, dynasty of, see also IndoParthians, 214

Goodchild, H. 314

goods $109,443,473,532,535,548,550,659-$ 660

- exotic 289, 654, 684

- prestige/luxury 67, 118, 221-222, 289, 414, 473-474, 489-490, 516-517, 564, 567, $657,684,686,697$

Gotarzes 212, 215

government, see administration

governors 441

- Arsakid, see also satrap 227

- Hellenistic, see also strategos, 29

- of a Qin/Han commandery, see shou/taishou

- Roman provincial 262-267

Graeco-Bactrians, see also Greek Kingdoms of Central Asia, 55-56, 58, 64-66, 70-71, 408-409, 443, 672

graffiti 408, 442-443

grain, see also barley; millet; rice; wheat, 119 , 151, 174, 241, 254, 257-258, 274, 284, $322,329,333,346,423,428,432,448$, 503, 506-507, 517, 519-520, 532-533, 548,550

granaries, see storehouses

Great Britain 645, 714, 716

Great Game 671

Great Khorāsān Road 207

Great Transformation 705

Great Wall, see fortifications

Greece 269, 491, 645, 694

Greek (language), see language

Greek Kingdoms of Central Asia 54, 65, 408410, 670, 674

- archaeology of 401-406

- historiography of 57-58, 669-672, 679

Grigor'ev, V. V. 596-597

Gua Dov 201

Guangling Kingdom 568-569

Guangwu di (Emperor Guangwu of Later Han) $149,180-183,549$ 
Guanzhong (area within the passes) 129, 131132, 139, 141, 147, 149, 182

Guanzi (Master Guan) 518-521

guilds 411, 430, 445, 455, 661

Gulf of Kachchh 451

Gulf of Mannar 660

Guo Moruo 626-627

Gurukkal, R. 659

gymnasion (Greek building) 27, 35, 72, 291

Habib, M. 646

Hadrian 216, 258, 266, 271, 385, 480

Hadrian's Wall, see fortifications

Han Empire, see Chinese empires

Hangu Pass 129, 141

Hanshu (Documents of the Han) 76, 86, 150, 197, 232, 390-391, 489, 498-513, 564$565,621,624$

- relation to the Shiji 390-391, 500, 502-503

harbors $=$ ports, see infrastructure

Hasebroek, J. 704

Hastings, W. 642

Hathigumpha inscription 104, 107, 115, 441

health 162

Hebrew, see language

Heichelheim, F. 704

Heliodoros pillar 69, 410

Hellenistic influence

- on art 35, 221

- on kingship 109, 208, 218

Hellenization

- in the Arsakid Empire 218

- in the Hellenistic Empires 18, 36

- in the Roman Empire 288-289

Hellespont $=$ Propontis 19, 25

Henige, D. 98

heqin (peaceful kinship relations) 174-175, 183, 195

Herakleopolite nome 365

Herakles 17, 42-43

Hermaios 65, 69

Herodes 260, 274

Herodianos 226-227, 490

Heroninos Archive 365, 370

Hexi corridor 76, 131-132, 176, 413, 505, 532

Himalayas 21, 95, 106, 116

Hindu Kush 55, 60-61, 63, 387

Hinduism 67, 71, 658

hinterland 97, 112, 118, 230, 447, 451, 472, $651,655,659$

- concept of 117,660
Hissar range $61,71,74$

Historia Augusta 384-385

historiography (ancient), see also Alexander the Great, Hanshu, Hou Hanshu, Shiji 4, 5

- Chinese 195, 489, 498-513

- Graeco-Roman 44, 289, 350-351, 382-383, 391

homo oeconomicus 701,705

Hopkins, K. 362, 707-708

Horden, P. 693, 710

horses, see also army, 111, 162, 176, 382-383, 390, 441, 504, 509, 517

hostages $177,180,184,214,510$

Hou Hanshu (Documents of the Later Han) 78 , 197, 232, 389, 392, 489, 499, 512, 550, 564

houguo (Han marquisate) 154, 156-157

household 40, 200, 432, 545, 628, 701, 704706

- householder/household head 423, 429, 445

- paterfamilias (head of household) 285

- registers 137, 140, 144, 154, 158, 161-162, 172, 277, 550, 632

- Roman 285

- royal 32

- size 137, 139, 367, 543

- units of five households 140, 182, 166

Huai (river) 131

Huhai, see Qin Ershi

Huhanye, Chanyu 180

human resources, see also labor; laborers, 136, 542

Hundred Days' Reform 620-621

Hunza-Haldeikish 442

Huo Qubing 176

Huozhi liezhuan ("Memoirs of Money

Makers") 503, 502-505

Huvishka 79, 82-83, 397

Hydaspes (river) 20

Hyrkania 207, 212, 215, 218, 228, 231, 385

lakubovskii, A. I. 677

Iber (river), as frontier 713

Iberia (Caucasus) 215-216

ideal type analysis, see also Weber, Max, 704

identity 3, 29, 41, 48, 114-115, 286-292, 294

- Chinese 133, 142, 146

- Greek 31, 48, 106, 116, 287, 443

- Italian 282, 287-288

- non-Roman 287-288 
- Roman 286, 288-291

- sectarian (Pharisee) 292

illicit excavation 398, 401, 404, 671

Illyria 45

Imperial Academy (Taixue) 159, 515

Imperial Archaeological Commission 593, 600

Imperial history (China) 621-622

Imperial Secretariat (Shangshu) 153

imperialism, see also empire, 22, 176, 178, 284

- beneficent 262-263

India, see also Shendu; South Asia; Tianzhu, $2,5,13,15,39,45,55-56,59-60,67,73$, $80-81,85,95,179,215,720$

- traditional names of 103, 112

Indian Ocean 95, 97, 118, 232, 450-451, 657661

Indicization 119

Indo-Gangetic Plains, see also Ganga-Yamuna valley, 95

Indography $101,103,106,111,114,384$, 469474, 644

Indo-Greeks, see also Greek Kingdoms of Central Asia, 55-56, 64-65, 67-70, 73, $99,102,410,672,674$

Indology 424, 641-645, 648-649

Indo-Parthians 217, 395

Indo-Roman trade, see trade

Indo-Scythians, see also Śakas, 58, 69-70, 84, 87, 98-99, 105, 395

Indus 95, 117, 441, 470

- lower 674

- region 22

- upper 63

Indus Valley Civilization 645, 649-650, 655

inflation 501-502, 516, 535

infrastructure 271-274, 507

- bridges 271

- canals 273-274, 506-507

- embankments 271

- military 714

- ports $108,114,118-120,274,428,437,449-$ $451,490,658-660$

- river 48

- roads 113, 132, 144, 271, 288, 385, 504, 656

Inner Asia 59, 195, 381, 532, 593

inscriptions, see also cave inscriptions; edicts; epigraphy; and under individual inscriptions

- bi/multilingual 28, 30, 115, 371, 412, 439, 443, 488-489
- on Chinese lacquer objects 559-569

- donative 115, 410-411, 444-446

- funerary $285,373,410$

- honorific 283,373

- on pottery $442-443,448$

- royal $80,439-441$

- on seals 106

- Tamil-Brāhmī 119, 442-443, 448

institutional change 3

intellectual traditions $405,577-578,584-586$, $609,620-621,641,673,675,680-81$

interdisciplinary research, see also comparative method, 4, 119, 424, 449, 557, 649

inter-imperiality $1,2,4$

interventionism 503, 512-513

inundation, see also floods, 95

- Nile 31, 33

Iran 60, 113, 119, 205, 207, 210-211, 214, 217218, 224, 477-482, 487-488

Iranian

- artistic traditions 221, 225

- historical narratives 478-480

- influence on kingship 82-85, 208, 218

Iranian Plateau 207, 389

iron $63,104,117,119,135,151,448,501,503-$ $504,513-514,519,653-654$

Iron Age

- in Central Asia 62

- in Indian Subcontinent 104, 448

Iron Gate wall near Derbent, see fortifications irrigation, see also infrastructure, 20, 33, 62 , $97,135,141,177,230,403-404,428,487$, 505-507, 630, 643, 652-653, 673

- study of in Russian Empire 676

- study of in USSR 677-679, 686, 688

Isidoros of Charax 231, 384, 389, 482, 486487, 489

Islam, early 648-649

Italy 245-246, 277, 284, 286-288, 290, 314, 696-697, 706

itihāsa-kāvya (historical poetry) tradition 106 itihāsa-purāṇa (Indic historical tradition) 648 iugerum (land measure) 275

ius (law)

- commercium 266

- honorarium 266

- praetorium 266

Ivolga (cemetery) 199

ivory $1,115,117,222,289,473,517,684$ 
jade $76,80,517$

Jainism 411

janapada 98, 102-103, 109, 455

- coins, see coinage

- as countryside 427

- kopa (revolt) 110

Japan 619-625, 630, 635-637

Japanese Westernization 622

Japhetic theory 606,677

jātakas 109, 120, 433, 651, 661

Jaxartes (river) 20, 60, 390

Jerusalem 255, 292

Jetavana 434

Jewish Revolt 255

Jews 225, 228, 255, 292, 294, 490

Jia Yi 145-146

Jiao Region (Jiaozhou) 179

Jibin, see also Kashmir 78, 117, 391-392, 442, 510

Jingdi (Emperor Jing of Han) 148, 174, 532, 534, 549

Jingjue 538

Jiuzhang suanshu (Nine Chapters on the Mathematical Art) 521

Jones, W. 642

Joseon kingdom 178

Josephus 225, 490

Judaea 40, 213, 255, 260, 277

Judaism, see Jews; Jewish literature

Judicial Plan of 1772642

jue (honorary titles), see ranks

jun (commandery) 136, 143, 151, 153-154, 164, 166-167, 182, 184

Junagarh inscription 441

junshu (equitable delivery) 501, 512-513, 515516

Jushi (later Turfan) 176-177, 180, 511

Justin (Epitome of Pompeius Trogus) 66-67, 209, 223, 383-384, 386, 388, 490

Juyan 162, 531-537, 550, 633-639

Kabul 62-63, 117, 393, 644

Kakinuma Yōhei 625, 631

Kalinga 99, 102, 104, 107, 440

- ruler of, see Khāravela

kāma (pursuit of desire) 423, 425, 431-432

Kambojas 116, 382

Kampyrtepa 71, 85, 88, 404, 412

Kanaganahalli 434

Kandahar 60-61, 85, 403, 405, 407-408, 410
Kane (Arabian peninsula) 489

kangaku ('Chinese learning') 619, 621-623

Kangju 79, 390-391, 510

Kanishka I 58, 76, 79, 81-82, 84, 392, 396, 412, 682

kaojuxue (evidential research) 623, 634

Kapisa 62, 78, 87, 392, 399, 402, 406, 684

Kappadokia 25, 46-47, 255, 375

karalrang (margave) 82, 86-87, 412

Karamzin, N. M. 589

Karanis 365

Kāren (family) 224

Karle, see cave inscriptions

Karnak see Thebes (Egypt)

kārșāpaṇa, see coinage (by region), see also paṇa

Kashgar 79-81, 117

Kashmir Smast 653

Kassandros 23-24, 30

Katō Shigeshi 621-624

Kauśāmbī 81, 446

Kauțilīya Arthaśāstra, see also administration; army; treasury, 108-111, 113, 423, 425428, 430, 651

Kaveri valley 95, 104, 106, 436, 660

Kazakhstan 59-60, 173, 670

Kerkeosiris 368

Khalchaian 77-78, 86, 403

Khāravela 107, 115, 441

- royal titles of 104

Kherlen Bars 201

Khor Rori 443

Khorezm, see Chorasmia

Khorezmian Archaeological-Ethnographic Expedition 602, 677

Khotan 116-117, 395, 399

Kilikia 48, 212

King of Kings (title) 19, 23, 80, 84, 212, 217, 220, 227, 229

kingship (by region)

- in the Arsakid Empire 217-219, 221-223

- in Central Asian Empires 59, 70-71, 83

- Early Roman 712

- in Hellenistic Empires 19, 26-32, 70-71

- in Indic tradition, see also cakravarti; vijigīșu, 108-111

- in the Qin and Han Empires, see wangguo

- in the Warring States 136

kingship, ideology of 26, 41, 44, 217

kinship 27, 108, 115, 133, 159, 165, 169, 174, 503, 672 
Kipling, R. 715

Kirari inscription 441

Kırlı, C. 646-647

Kleopatra VII 23, 47

Kodumanal 104, 442, 448

Kokcha 63

Kolchis 47

Koptos 363, 450, 697

Korea 619

Korean peninsula 178, 505, 531, 562, 566, 568

Korkai 660

Kosambi, D. D. 646, 661

Kosambi effect 646

Krishna valley 95, 105, 112

kșatrapa (title) 87, 411

Kșatrapas, see also Western Kșatrapas, 395

Ktesias 388

Ktesiphon 211, 216, 222

Kujula Kadphises 56, 69, 76, 78-80, 396, 669

Kunāla 116

Kunja-kala 485

kurgans (burial mounds) 403, 595

Kuṣāṇa(s), see Kushan Empire; Yuezhi

Kushan Empire, see also coinage, 3, 55, 75, $79,99,102-103,216,399,414,656,669-$ $670,672,674$

- archaeology of $85,401-406$

- historiography of $57-59,578,669-673,680$

- as middleman 406, 669-670, 681-687

Kushan era $58,81-82$

Kushano-Sasanian Kingdom 56-57, 74, 82-83, 403-404, 413

Kyrenaika 25, 44, 47

Kyrgyzstan 59, 670

Kyros 479

labor 329, 423, 498, 505-509, 516-517, 529$530,541,625$

- division of $329,559,561,563$

- female 516, 523, 544

- management 273-274, 293, 373, 529-530, 535

- slave $140,245,704$

laborers, see also conscripts; convicts; slavery, 505-507

- servants (tuli) 547-548, 634

- wage 41

lacquer boxes $557,567-568,684$

lacquerware 557-570, 684 land, see also, cleruchs; donation; gifts; property rights, $20,32,45,109,432,624$, 628,630

- allocation 136-137, 140, 157, 542

- development 27, 136, 139, 367, 487

- management 343, 348-349, 367, 369, 541

- ownership 101, 137, 288, 369, 544, 632, 651, 656

- registers $32,278,363,366,368$

- royal 32-35, 260, 262, 267

- survey $275,373,428$

$-\operatorname{tax} 19,30-31,40,152,156,288,369,543$

landscape 13, 21, 61, 95-97, 103, 313-315, 404, 444, 448, 651, 656, 693

language, see also lingua franca

- Aramaic 53, 73, 115, 292, 406-407, 413, 438, 439

- Bactrian 80, 82, 84, 86, 88, 402, 406, 412413

- Coptic 363

- Demotic 363, 365-366

- Elamite 53, 407

- Epigraphical Hybrid Sanskrit 402, 406, 411

- Gāndhārī 64, 80, 84, 87, 382, 394, 396, 406, 410-412

- Greek 20, 27, 33, 39, 48, 55, 82, 84, 115, 287, 290, 292, 371, 382, 394, 396, 406, 408-410, 412, 438-439, 443, 484-485, 488

- Greek dialects 39

- Hebrew 292, 441

- Latin 290, 382

- Middle Persian 87, 209, 219

- Pali 382, 426, 433, 457, 644

- Palmyrenian 371, 488

- Parthian 224, 485

- Prakrit 69, 117, 410, 438-439, 443, 455

- Sanskrit 58, 84, 382, 438

- Sogdian 67, 406, 413-414, 441

- Tamil 105, 438, 455

Laodikeia 27, 36

Lao Gan (Lao Kan) 633, 635

lapis lazuli 63, 384, 388

Lappo-Danilevskii, A. S. 595

law, see ius; legal systems

Latyshev, V. V. 594-595

lead deposits, Greenland 334

legal systems

- Chinese law 137, 146, 152, 157, 163-172, 502, $529,535,541-542,544-545,550$ 
- contracts 3, 174, 245, 258-259, 266, 325, $343,345,347,363,366-367,370,409$, 413, 464, 484, 545

- Hellenistic law 17, 36, 39, 45

- litigation, see also vyavahāra, 166-171, 264-266, 280, 427, 429-430, 535, 537

- Roman law 265-266, 285, 343-347

- in śāstras see vyavahāra

Legalism 138, 145

legati (military officials) 262, 267

legumes 129, 131, 163, 346

Lelang 562, 566, 568

Leo III 458

Lessing, T. 646

letters

- in Achaemenid administration 73, 407

- Bactrian 88, 412-413

- in Han China 135, 532, 540

- to Hellenistic kings 31

- on papyri and ostraca 363, 368

- in Roman Empire 257, 263, 273, 280-281, 343, 348-349

- Sogdian 413-414, 670

Levantine coast 694

Li Dazhao 625

Li Xueqin 633-634

Liang Qichao 621-622

Liang Region (Liangzhou) 176, 181

libraries 27, 35, 45, 376, 642

Libya $19,323,363$

limes, see frontier

Limes Congress (Roman Frontier Studies

$$
\text { Congress) 717-719 }
$$

Limyrike 112, 473

Lin Ganquan 627-628

ling (ordinances) 163-164, 529, 541

ling/zhang (magistrate of a Qin/Han county) 156, 166

lingshi (scribe director) 166-167, 560

lingua franca 363

Linxiang County 546, 548-550

lists $60,143,151,343,358,366,392,428$, 443, 485-486, 508

literacy 138, 343, 372

literature (ancient)

- Buddhist 68, 81, 109, 382, 433-434

- Chinese 205, 482, 491, 497-524

- Christian 482, 490, 642, 648-649

- Greek 17, 205, 224, 383-389

- Indian 382
- Iranian 205, 477

- Jewish 213, 225, 482, 490

- Latin 205, 224, 290, 383-389, 646

- Sangam 105-106, 110-114, 116, 435-438, 658

- Sanskrit 103, 112, 116, 382, 423-433, 642644, 649, see also śāstras

- value of 343

litigation, see legal system

Liu Bang (Emperor Gaozu of Han) 145, 147148, 153, 549

liumin, see migration

Livy 350

Liye 137, 140, 143-144, 161-162, 529-530, 545-548, 550-551, 634

Lo Cascio, E. 697

loans, see credit

local

- autonomy 99

- dialects/vernacular 39, 371, 411

- economic practice, see also market, 524, 532

- elites 143, 149-150, 154, 177, 268-271, 280282, 290, 293, 568

localism 27, 480

Lomonosov, M. V. 588-589

Loulan 176

lü (legal statutes) 164-166, 171, 541

Lü Zhi, see Empress (Dowager) Lü

Luoyang 129, 133, 149, 181-182, 390-391, 568

Luttwak, E. N. 718

luxury 289

- attitudes towards 289, 351, 516-517

- goods, see goods

Lydia 19

Lysimachos 23-24

Ma Feibai 518, 630

Ma Yi 628

Maccabean revolt 46

Macedonia 24, 46, 269, 272

- Macedonian Empire (under Alexander) 20, 25

- Roman provincia 261, 268

Madurai 106, 436-437, 448

Maes Titianus 389

Magadha 99-102, 104

magistrate (of a Han county), see ling/zhang

Mahābhārata 103, 106, 382, 426, 651

Mahasthangarh 441

Malwa 675

Manchuria 173, 195, 505, 566 
Manesos 485

Manning, J. G. 369, 709-710

manuals

- administrative, see Kauțilīya Arthaśāstra; Manusmrti; śāstras

- ancient Chinese 521-524

- economic 645

- technical 485

manuscripts, see also Bajaur Manuscript collection; papyri; silk manuscripts

- Chinese, see excavated texts

- Sanskrit 117, 425-426

Manusmrti 110, 423, 425, 428-431

Mao Zedong 625-626

Marc Antony 47, 214

Marakanda-Afrasiab, see also Samarkand 67, $71,402,405,671$

Marcus Aurelius 480

maritime, see also ships; technology; trade

- activity 103, 106, 118, 449, 658-659, 661

- loans 346, 348

- studies 638

market 37, 257-258, 433, 541, 659, 702

- border, see border zones

- economy 324-326, 608, 632, 647

- local 7, 315, 333, 366, 568

- model 497, 701, 704, 706, 708

- rural 318

- urban 312

marquisate (Han), see houguo

Marr, N. Ia. 597-598, 601, 606-607, 677 marriage 174, 183, 366, 429, 469, 707

- brother-sister 47

- dynastic 19, 23, 27, 32, 66, 79, 200, 213

marshal of state (da sima) 152

Marx, K. 599, 604-606, 625, 643, 651

Marxism, see also five-stage model; Japhetic theory; Orientalism; stadiality

- anti-Marxist Western historiography 718

- Chinese historiography 620, 626-629

- criticism of Eurocentrism 646

- Indian historiography, see also Kosambi effect, 99, 643, 646-647, 662, 674

- Soviet historiography 582, 598-601, 603604, 676-681, 706

mass production, see production

Masson, C. 397, 401

Masson, V. M. 678

Māṭ 80, 82

materiality of texts $550-551,635$
Mathura 80, 115-116, 392, 401-403, 411, 445, 653

Mauryan Empire 22, 55, 101-102, 104, 426, $441,645,655-656$

- army 101, 111

- dynasty 99, 113

- pottery, see ceramics - northern black polished ware

- as state 101, 103, 656

Mawangdui 531, 633

McConnell, J. 334

meat, see consumption

Media 19, 21, 47, 61, 211, 214, 217, 224, 229

medical texts 117

Mediterranean

- connectivity with East Asia 15, 233

- ecology 20-21, 241-244, 246, 248

- idioms adopted by the Arsakids 223

- political and economic space 3, 252, 254 , $256,258,261,265,268,274,279,282$, 284, 286-289

- in Russian historiography 587, 590

- Seleukid orientation toward 38

- trade with India 657-661

mediterraneanism 693-696

megalithic sites (South Asia) 104, 117, 447448, 458

Megasthenes 113, 388, 470-471

Mehendale, S. 685, 687

Memphis 40, 367

Menander I 56, 65, 67-68, 71, 382, 386, 395, 397,473

Menches 368

mercenaries 28-29, 41-42, 73-74, 224, 226227, 409, 715

merchants, see traders

meridarches (civil local governor) 73, 411

Merv (oasis) 485

Mes Aynak 63, 404

Mesopotamia, see also Babylonia, 2, 21, 205, 207, 211, 218, 231, 255, 481, 485, 699, 719

metals, see also gold; iron, 63, 428, 438, 448, 457, 490, 558, 657, 660, 694

metropolis (central city) 30, 37, 48, 472-473

Metropolitan Region (Sili) 154, 181

Meyer, E. 703-704

Middle Persian, see language

migration, see also resettlement, 29, 35, 76, $149,180,184,254,284,507,550,694$, 710,719

- cyclical 284

- long-distance 596 
- of slaves 661

- Soviet approaches to 602, 606-608

milestones 272

Miletus 37

Milindapañha 68, 382, 680

militarization 135

military service, see army

military history 172

- Roman army studies 713-715, 720

Mill, J. S. 62, 97, 129, 132, 448

millet, see also grain, $62,97,129,132,448$, 521

minerals $113,387,673,680-681$

mingtian ('named field' system) 542

mining 63, 241, 333-335, 352, 372, 404, 490, 680

Mithradates I (Arsakid king) 210-211, 219-221

Mithradates II (Arsakid king) 211-212

Mithradates III (Arsakid king) 212-213

Mithridates IV (Pontic king) 212

Mithridates VI (Pontic king) 46, 260, 283

mobile pastoralists, see also kurgans, 62, 173 , 181, 211, 215-216, 224, 384, 448, 511-512, 587, 608

- archaeology of 68, 403

- and the Arsakid Empire 208-209, 215-216, 223-226

- campsites 200

- and Central Asian empires 56, 74, 76, 79, 84

- historiography of 676

- relationships with sedentary communities 57, 207, 481, 586, 676, 715

- and the Xiongnu Empire 195-202

mobility, see also migration

- goods 5-6

- money 346

- people 27, 29, 241, 285, 289, 329, 375, 381, 550,720

- social 87, 135-136, 140, 159-160, 289-290

Modun, Chanyu 174, 195

Moeris (lake) = Birket Qarun 38

Moesia Inferior 253-254, 274, 312, 314-315

Momiyama Akira 635-636

Mommsen, Th. 713, 716

monarchy, see also kingship

- Hellenistic 29-32

- Roman 248-250, 275, 280, 293

- in South Asia 105, 107-108, 110, 121

- Warring States 136 monasteries 405, 450, 652-653, 661

- monastic landlordism 652

- role in trade networks $117,652,657,661$, 687

monetization, see also demonetization, 55, $284,290,351,360,362,393,486,631$, $652-653,678,681,696,708$

money, see also coinage, 335, 423, 428, 444, 456-457, 486, 631

- all-purpose 457

- capital 445, 696

- credit, see also credit (loan), 431, 535

- in kind 41, 359

- monetary reform, see currency

- transfer of 532, 548, 550

Mongolia 60, 173, 199, 201, 566, 587, 590

monks, see Buddhist

monopolies, see also coinage, 63, 232, 270, $366,456,497,501,513,605,630$

Monson, A. 369

monsoon 97, 658

Mons Claudianus 711

Mons Porphyrites 711

Mookerji, R. K. 657

Mori Shikazō 635

Morley, N. 697

Morris, I. 709-710

Morrison, K. D. 656

Moscow Archaeological Society 594

mountains, see also under individual ranges, 20-21, 62, 129, 131-132, 207, 472

Muciri, see Muziris

Mukherjee, B. N. 674-675

Müller, M. 643

multilingualism, see also bilingualism; inscriptions, 28

municipia 246

Musa 214

museum (ancient) 45

Muziris, see also Pattanam, 119, 437-438, 450

Muziris papyrus 370, 376, 450

Myos Hormos = Quseir al-Quadim 39, 363

Nabataean Kingdom 255

Nagapattinam 434

nāgaraka (man-about-town) 423, 431-432

Nagarjunakonda 434

Nagata Hidemasa 635

Nahapāna 445, 455

Naka Michiyo 623 
Nanling range 131

Nannan 106

Nanyue 178-179

Narain, A. K. 672, 674, 679

Nasik, see cave inscriptions

nationalist historiography (India) 641, 645646, 651

navicularii (shippers) 258

navigation, see also maritime - activity, 118 , $452,658,660$

nāyaka (protagonist) 432

Nearchos 470

Nedun 106

negotiator (business man) 282-285

Nektanebo 32

Neoclassical economics 659, 702, 704

Neo-institutional economics 702-703, 709

Nero 276, 480

networks, see also exchange; patron-client, 154, 159-160, 223, 225, 279-286, 654, 657

- approach 6, 279

- familial 286

- long-distance 112, 217

- urban 37, 231

New Historiography (in China), see Xin Shixue Nikanor Archive 363

nigama, see guilds

Nikomedia 273-274

Nile, see also inundation

- delta 39, 694

- valley 363, 365-366

Nilgiri Hills 660

Nine Ministers (Jiu Qing) 151-153

Nippur 230, 485

Nisa 211, 221-222, 228, 482-484, 487, 491, 602

Nishijima, S. 624

nìti (policy and diplomacy) 426

Niya 117, 531

nomads, see mobile pastoralists

nomos/nome (district) 33, 365, 367

nomarch (nome governor) 33

nongling/nongzhang (agricultural magistrate) 533

Nonius Datus 273

normative texts, see also śāstras, 498

North Africa 241, 273, 290, 712, 715, 720

North Caucasus 215-216, 587, 602

North China Plain 129, 131-132, 149, 176
North Desert campaign, see battles

North, D. 703, 709

Noyon Uul 561, 566, 568-569

Nubia 39, 45, 720

Nukunzuk 81-82, 84, 87

Numidia 260

numismatics, see also coinage, 358-362, 452453, 487-488, 583, 671, 685

- die studies 398-400

- Central Asia 393, 397-400

- South Asia 452-458, 644

- study of in USSR 397-398

nuns, see Buddhist

Octavian, see Augustus

Oḍi dynasty 70

Offices of the Agricultural Fields, see tianguan officials, see also adhyakșa

- control of 154, 165, 266-267

- donations made to 30

- frontier 86-87, 550, 633

- making donations 84

- number of 150-151, 266, 270-271

- recruitment/appointment of 136-137, 151, 153-154, 156, 158-160, 164, 267, 280

- salaries of $151,153,156,158,427-428,486$, 633

oikonomia (household management) 701

oikonomos (financial magistrate) 33, 35

oikoumene (inhabited world) 24, 208

olive 346,693

olive oil 74, 241, 256, 258, 336, 408

Olympias 23

Omana 489-490

Onesikritos 114, 470

Opium Wars 619

oral tradition 433-434, 477, 490

ORBIS see digital data methods

orbis terrarum (the whole world) 694

ordo (Roman status group) 180, 223

Ordos 131, 144, 173-176

Oriental despotism 479, 643, 645, 651, 655

Orientalism, see also Marxism; Russian

Empire; USSR, 490, 596-597, 646

- Orientalist knowledge 642

Orodes II 213-214

Orontes (river) 27, 36-37, 48

Oropos 281

Oshibat 442

Osroes I 216 
ostraca

- in Brāhmī script from Egypt 443

- from Central Asia 408, 412

- from Egypt 362-365

- from Nisa 221, 225, 228, 482-484, 491

- in Parthian script 485

outposts (stationes) 251

Ovid, reception of in Russia 591

Oxford Roman Economy Project 317, 699

Oxo-Caspian-Caucasus trade route 386

Oxus (river) 61, 71, 387, 404

Oxyrhynchite nome 365

Oxyrhynchos, see also papyri, 365, 369

paddy, see rice

Pahlavi (dynasty) 479

Pakistan 60, 397-398, 401, 403, 698

Pakoros I 213

Pakoros II 215-216

Palakkad (Palaghat Gap) 104, 660

paleographers (in the study of the ancient

Chinese economy) 634

Pali, see language

Palladius 345

Palmyra 2, 232, 481, 488, 697

Palmyrene caravan inscriptions 232, 373, 482, 488-489, 491

palynology 335

Pamir 21

Pāṇḍya 99, 105-107, 436

Pāṇini 103, 112

Panj 63

Pannonia Inferior 253

Pantaleon 65, 67, 399

papyri 88, 358-376, 412, 709

- from cartonage 368

- from Dura Europos 485

- from Oxyrhynchos 369

- Muziris, see Muziris Papyrus

Papyrus Revenue Laws 366

paraleptos (tax collector) 485

parihāra (tax exemption) 441

Parni/Aparni 209

Paropamisadai 55, 57, 62, 67-69, 101, 394, 405,684

Parthia 25, 44, 48, 66, 209

Parthian (language), see language

Parthian Commonwealth 29

Parthian Empire, see Arsakid Empire

Parthian Shot 226
Parthian Stations, see Isidoros of Charax

passports 162

pastoral communities, see mobile pastoralists

Patala 20

Pāțaliputra 68, 81

pathology 328-329

patronage 434,661

- royal $71,100,115,430,434$

patron-client

- networks 159, 279-282

- relationships 159-160, 274, 279-282

Pattanam 119, 450

Paul (apostle) 292

paurușeya (of human origin) 423

pax Romana 251-252, 351

Pearl River (Zhujiang) 131

peasants 135, 154, 436-437, 522

Pella 26

Peloponnese 48

Peng Xinwei 627

People's Republic of China (PRC) 531, 566, 625

peregrini (noncitizens) 265-266

Pergamon 25, 45-46, 261, 286

periphery, see also core-periphery model, 1-2, 27, 567, 697

periplous (circumnavigation) 469

Periplus Maris Erythraei 86, 112, 118, 384, 437, 450-451, 472, 489-491

Persepolis 19, 23, 38, 42, 408

Persian Gulf 21, 118, 207, 216, 231-232, 391, 472, 657

Persian Wars 18

Persis, see Fars/Persis

Peshawar 62, 83, 117, 401, 411

Peter the Great 586-587

petroglyphs, see also graffiti, 405, 441, 445

Pharisee 292

Philadelphia (Fayum) 36, 365-367

philhellenos (epithet) 220

Philip II 18-19, 23

Philip III 22-23

Philip V 45

philos (friend) 29, 40

Phoenician cities 18, 361

Phraatakes 214

Phraates (eunuch) 485

Phraates I 210

Phraates II 211

Phraates III 212-213

Phraates IV 214 
phruri (guard posts) 252

phrouarchos (garrison leader) 34

Phrygia 46

physical geography (by region), see also ecology; landscape

- in the Arsakid Empire 207

- in Central Asian Empires 60

- in Hellenistic Empires 20-21

- in the Qin and Han Empires 129-132, 141

- in the Roman Empire 241

- in South Asia 95-97

piatichlenka, see five-stage model

pigs 330

pilgrimage $644,661-662$

pingzhun (balanced standard) 501, 512-513, 515-516, 519

Pingzhun shu ("Treatise on the Balanced

Standard") 501-502, 624

piracy 45,507

Pithom (= Bubastis) Canal 28, 39

Pithom stele 28, 31

piyadasi (title of Aśoka) 100

plants 97,472

Pleiades, see digital data and methods

Pliny, the Elder 11, 281, 285-286, 345, 351, $352,383,385-387$

Pliny, the Younger 257, 273, 280, 348-349

Plutarch 111, 344

Po Valley 349

Poblome, J. 326

Polanyi, K. 705-706

polycentricity (of Hellenistic Empires) 15

polis $35,37,40-41,244,247,268,694,704$

political economy, see Smith, Adam

pollen analysis, see palynology

pollution 333

polyandry 413

Polybios 47, 66

Pompeii 360, 363

Pompeius Trogus, see Justin (Epitome of Pompeius Trogus)

Pompey, Gn. Publius 47, 212-213, 248, 252, 255, 262, 386

Pontos (kingdom) 25, 47, 212, 260

Pontos, see Black Sea

Poompuhar 451

Popov, M. I. 589

population $104,443,550,630,654$

- growth 135, 369, 708-709

- registers, see registration of population

- size 129, 154 port-of-trade (concept), see also emporion, 660

ports, see infrastructure

Portus 274

Porunthal 448

postal system, see communication network postcolonial studies $641,648,699,710$

post-Soviet 581, 585, 598, 609

pottery, see ceramics

poverty $21,241,331,352-353,433,501,503$, 509-510, 520, 522-523, 544, 714

praesidia (camps) 711

praetor (high legal official) 261, 266

Praetorian Guard 252

Prakrit, see language

praktor (tax collector) 485

pre-state society 107,659

price $166,362,430,486,491,498,633$

- fluctuation 325, 523

- stabilization 497, 501, 513, 515, 519

priests $30-31,39,83,223,225,259$

Principate 243, 260, 270, 280-281, 290, 292

Prinsep, J. 100, 644

procession

procurator (imperial delegate) 267

production 660

- agricultural 314-315, 346, 482-484, 490491, 522-523, 529-530, 533, 542, 547$548,634,652,708$

- commercial 565

- costs 558

- craft 469, 490-491, 630, 695

- facilities, see workshops

- management 559-560, 563-564

- market oriented 522, 565, 703

- mass 322, 336, 559, 562-563, 567

- slave mode of, see also five-stage model; slavery, 704

- surplus $3-4,99,643,653,707$

- steppe 201

propaganda 44, 146, 219, 252

property rights $20,369,427,429,544-545$, $643,646,651,695-696$

- inheritance $423,430,544-545$

Propontis, see Hellespont

prostagmata, see edicts

prostitution 428,432

protection $246,268,281$

- of markets and trade routes $373,509,669$, 711,720

- money 260 
protector-general of the Western Regions (Xiyu duhu) 78-79, 179, 181

province (provincia) 261-267, 291, 696, 708, 714

provincialization 255, 288

Ptolemais Hermiou 36-37

Ptolemy (geographer) 112, 383-384, 389, 471

Ptolemy I 23, 25

Ptolemy II 28, 31-32, 39, 47, 365

Ptolemy IV 47

Ptolemy VIII 47

publicani (tax-farmers) 245, 264, 281-282

punch marked coins, see coinage

Punic Wars 288, 713

Punjab 57, 63, 68-69, 74, 83, 382, 401, 670671

purāṇas 98, 105, 642

Purcell, N. 693, 710

purușārtha (goals of human life) 423, 431

Pushkin, A. 591

Puṣkalāvatī 402, 405

Puṣyagupta 441

Puṣyamitra Śunga 102

Puteoli 274

Qi (state of the Warring States period) 142,518

Qiang 176, 178, 181, 184, 505, 511, 517

Qianling County Archive 137, 139-140, 143$144,161,166,529-530,546-548$

qianshou (black-headed ones) 529-530, 548

Qilian Mountains 131

Qin (state of the Warring States period) 134, 137-142

- unification by Qin 133, 135, 142, 145

Qin Empire, see also Chinese empires, 143$146,174,530,546-548$

- demise 144-146

Qin Ershi (Second Emperor of Qin) 144

Qin Shi Huangdi, see also terracotta warriors, 140, 142-144, 147, 164, 185, 541, 549, 563

Qinghai-Tibetan Plateau 132

qingzhong ('light and heavy') 518-521

Qinling Mountains 131

Qosha-depe 485

quaestor (Roman magistrate) 261, 267

quality control (ancient China) 559, 562, 568

Quan Hansheng 631

quantification 317-318, 323-324, 357-358, $366,371,702,708-709$

- of bones 332
- of coin volumes 359, 400, 453

- of pottery 319

quantity theory of money 520

quarries 252

Rabatak inscription $76,81-82,87,102,412$

Raetia 372

Rahimesu Archive, see cuneiform texts

rājadharma (king's duty) 110

Randhawa, M. S. 652

rangaku ('Dutch learning') 622

rank 133, 200, 277, 533-535, 543

- honorary 29, 40, 139-140, 157-158, 162, 165

- military 29, 34

Rapta

Raschke, M. G. 686, 698

Rathbone, D. 370, 697

Ravdonikas, V. I. 601

Ray, H. P. 108, 657-658, 661

Reading Magazine (Dushu zazhi) 626, 630

Rebellion of the Seven Kingdoms (Qi guo zhi luan) 153, 173, 175

rebellions/revolts, see also janapada - kopa; Jewish Revolt; Maccabean Revolt, 20, 46, 145-146, 149, 153, 171-173, 181, 184, 251, 253-255, 260, 278, 287-288, 293, 547, 605

reciprocity 279,705

record keeping 137, 160-162, 443, 482, 485

Red Eyebrows (Chimei) 173

Red Sea (= Erythrean Sea) 118-119, 252, 254 , 272, 286, 443, 472, 489, 657, 659, 711, 719

redistribution 257-258, 324-325, 567-568, 654, 660, 695, 705, 708

regents (in the Han Empire) 152

regional inspector, see cishi

regionalism 695

registration of population; see also census; household, 137, 154, 161-162, 277, 542544, 550, 632

Reichslimeskommission 716

religion, see also Buddhism; Christians; Hinduism; Judaism; Russian Orthodox; Zoroastrianism, 71, 82, 84, 225, 228

- religious politics, see also ruler cult, 27, 30

Renfrew, C. 655

Republic, Roman 243-244, 248, 250, 256, 260-264, 268-269, 275, 277, 280, 284, 289,293 
res publica 247-248, 250, 293

resettlement, see also migration, 144,176 , 180, 184, 501

resistance, see rebellion

resource management $25,118,469,542,550$, 633, 653

revenue, imperial, see empire

Reynolds, P. 324

Rhagae 222, 488

Rhakotis see Alexandria

Rhine 253, 258, 273

- as frontier $254,273,333,712,716$

Rhodes 348

rice, see also grain, 97, 131, 436-438, 448, 489, 521, 652, 657

rivers, see infrastructure see also under individual rivers

roads, see infrastructure

Roman Empire, see also Republic, Roman, 7, $13,129,150,151,172,185,212-215,226$, 233, 480-481, 490, 578, 645, 657-659, 708

- as model for conceptualizing India 645,715

Romanization 286, 290-291, 294, 713, 719

Rome (city) 45-46, 48, 253, 272, 277, 281, 481, 697-698, 708, 713

Rowlandson, J. 369

Rosetta Stone 30, 46

Rostovtzeff, M. I. 357, 594, 603-604

- life 582-583

- reception 583-584

- on Scythians 595, 606

- works 582, 673

Roy, T. 647

Rozen, V. R. 597-598

ruler cult see also emperorship; kingship; monarchy, 19, 30, 48, 71, 84, 140, 217, 222-223, 484

Rum, see also Rome, 479

Rus' 586-587, 592

Russia 705

Russian Empire, see also epigraphy; Orientalism, 585-586

- archaeology in, see also All-Russian Archaeological Congress; Imperial Archaeological Commission, 402, 589, 591-595, 673

- classical studies in 588, 593-595, 598, 673

- early research in 586,588

- identity debates in, see also Slavophile; Westernizer, 589-591
- Oriental studies in $588-589,594,596-598$, 671, 675-676

- Slavic studies in 589, 594-595

- Turkestan in the 59, 401, 670, 676

Russian Orthodox (religion) 587, 590, 595, 600

Russian Revolution 598-599, 671

sacrifice 31

Sāgala $68-69,382,680$

Said, E. 597, 646

Śaka era 58, 98

Sakas/Śakas, see also Indo-Scythians, 68, 78, $99,211,215,226,383$

salaries, see officials

Saldae 273

salt $151,178,428,501,503,513-514,520,537$, 560,657

Samarkand, see also Marakanda-Afrasiab, 35, 402, 404, 414

Sanchi 115-116, 434, 447, 661

Sang Hongyang 513-514

Sangam, see also literature

- polities 105-107

Sannati 434

Sanskrit, see language; literature; manuscripts; purānas; śāstras

Sanskritization 100

saptānga (seven elements of state) 108

Sardis 35

Sarmatians 595, 606-607

sārthavāha, see caravan leader

Sasanian Empire 56, 82-83, 205, 207-208, $217,479,481-482,491,684$

- kings 52, 74, 82-83, 477

śāstras, see also Manusmṛti, 120, 423-433, 651, 661

Satanikota 449

Sātavāhana 99, 105, 111, 119, 455-457

Śātkarṇi 105, 455

satrap (ruler of a satrapy), see also kșatrapa, 19, 20-21, 23, 32, 34, 53, 55, $73,85,228,407,445,482$

satrapy (Persian administrative unit) 20-23, 61, 66, 73, 98-99, 102

- Arachosia 60

- Anatolia 23

- Bactria 24, 44, 53, 60, 209, 407

- Egypt 19, 34

- Parthia/Parthava 44, 207, 209

Sattagydia 60 
Scheidel, W. 159

scribes, see also lingshi; yushi, 158-159, 161, 166-167, 267, 407, 541, 545, 550

script

- Aramaic 219, 407, 411

- Brāhmī 69, 83, 100, 120, 410-411, 438-439, 441-443, 448, 455, 644

- cuneiform 407, 486

- Kharoșțhī 100, 117, 394, 411, 438-439, 441 , 443, 455, 644

- Parthian 485

Scythians, see also Indo-Scythians; Rostovtzeff, M. I.; Sakas/Śakas

- Arsakes as 209

- studies of 583, 588, 595-596, 606-607

- 'Scythian' mercenaries 73

- 'Scythian' monuments 594

- 'Scythian' period 683

seafaring tradition, see maritime - activity

Searchable Greek Inscriptions, see digital data and methods

seasonal capitals 62

Second Emperor of Qin, see Qin Ershi

Second Macedonian War 268

second urbanization, see urbanization

secondary state, see state formation

Seleukeia-Eulaios, see also Susa, 36

Seleukeia-Pieria 27, 36

Seleukeia-Tigris 24, 26, 36-37, 220, 231-232, 486, 489, 697

Seleukid Empire 2, 34, 55, 64, 66, 70-72, 73 , 205, 209-210, 219, 226, 409, 672

Seleukos I 24-25, 35, 55, 102, 470

Self-Strengthening Movement 619

senate (Roman) 261-262, 280-281, 288-290

senatus (Arsakid) 223

Septimius Severus 216, 480

sericulture, see also silk, 517, 523

settlement, see also cities, 35-40, 61, 72, 104, $107,109,200,230,314,388,447,646$, $654,656,660,710$

- foundations $38,45,71-72,441,694$

- studies 313-315

- villages 434, 651

Sextus Roscius 280

shadow empire 198

Shar-i Owraman, see Avroman

Shahr-i Qumis/Šahr-e Qūmes

(Hekatompylos?) 222, 482, 485

Shang Yang 139-140, 548
Shangjun shu 530, 548

Shanglin Park 568-569

Sha-i Owraman, see Avroman

Sharma, R. S. 650-654

Shatt al-Arab 489

sheep 330-331, 504, 511

shekel, see coinage

Shendu, see also India, 179, 390, 392-393, 675

shi (men of service) 137

Shihuo zhi ("Treatise on Food and Commodities") 502, 621-622, 624

Shiji (The Scribe's Records) 138, 143, 197, 232, 389-392, 489, 498-513, 624

ships/shipping, see also maritime activity, 232, 347, 363, 443, 451, 490, 659

- grain 274

- owners 284

- river 179

shipwreck evidence, see archaeology maritime

Shtaerman, E. M. 602

shou/taishou (governor of a Qin/ Han commandery) 143, 153-154, 159, 168-169, 529

shuguo (dependent states) 184

Shuihudi 136, 140, 143, 164-165, 167, 531, 539-542, 545, 633

Siberia, see Inner Asia

Sichuan 141, 173, 393, 560, 564, 567

Sichuan Basin 131-132, 141, 179, 504, 564

Sicily 281

Silk Road(s), see also trade, 5, 132, 381, 406, 480-481, 577-578, 675, 680-681, 685, $693,698-700$

silk, see also sericulture, 79, 174, 233, 490, 517, 698

- manuscripts 530

Sima Qian 138, 143, 145-146, 389, 497-513, 515

Simin yueling (Monthly Instructions for the Four Classes of People) 522-523

Sinatrukes 212

Sino-Japanese War 619-620, 622, 637

Siwa, oracle 19

sixty-four arts 432

Skylax of Karyanda 469

skeleton, see bones

slavery, see also five-stage model; labor; migration; trade, $140,267,278,345,427$, 504 
- Chinese scholarship on 626-627, 630, 633

- economic impact 245

- freed slaves 246, 280-281, 285-286

- involved in commerce 346

- revolts 602

- slave-holding formation (Central Asia) 677$678,680-681$

- Soviet scholarship on 601-602, 604-606, 678

- trade and deportation 46, 245, 661

- Western scholarship on 701-704

Slavic history, see also Russian Empire; USSR, 587, 589-590

Slavophile 590

śloka (32 syllable verse) 426

Smith, Adam 497, 701-702, 705

Smith, V. A. 645,651

social mobility, see mobility

social science methods (China) 629

socii (Roman allies) 246

Socotra, see Dioscorides

Śoḍāsa 445

Sogdian (language), see language

Sogdiana $19,21,55,57,61,67,79,390,392-$ $395,404,414,673,680-681$

soil, types of, see also alluvial plain, 95, 97, 113, 129, 312, 335, 382, 504

Soknopaiou Nesos 365

Sokolov, F. F. 594

Sokolova Mogila 566

Song of the Pearl 490

Song Xuwu (Sung Shee-wu) 631

Sophytos inscription 410

soter (cult name/saviour) 24, 30, 43, 80, 396

Soter Megas 80, 396

South Asia, see also climate; epigraphy; India, kingship; physical geography, 15, 95, 231, 578, 675

Southeast Asia 118-120, 658

Soviet Union, see USSR

Spasinou Charax 232, 373, 486, 489

sport, see also gymnasion, 30, 45

Spring and Autumn period 626, 632

śrenii, see guilds

Śrī-Campā 74

Sri Lanka, see also South Asia, 97, 100, 105, 107-109, 114, 119, 121, 286, 442, 444, 447-452, 456-457, 470-472, 644, 652653,660

Śrī Sātkarṇi 105
St. Petersburg/Leningrad 581, 586, 602

- Academy of Sciences 588, 593

- University 582, 594, 596-597, 601

stadiality $601,606,608$

Stalin, J. 601, 605, 607, 678

standard histories, see zheng shi

standardization 275-278, 562

- of coinage $218-219,275-277$

- of script 143

- of weights and measures 32, 143, 275

state budget, see also administration -

financial; empire - revenue, 498, 501, 503, 507, 511

state formation, see also empire; pre-state society, 99, 101, 118, 195, 247-248, 293, 436, 650, 652

- centralized state, see also centralization, 99, $141,143,147,151,512,645-649,656$

- secondary 99-100, 103, 105, 655-656

Stathmoi Parthikoi, see Isidoros of Charax

statues $18,30-31,80,221,281,371-373$

stature, see also bones, $162,327-328$

Stein, A. 413, 531

stele, see also Pithom stele, 160, 371, 434, 445

steppe 62, 131-132, 172, 196-202, 205, 581, 587-588, 590, 596, 598, 607

- societies (Mongolian) 195-202

stone, see quarry

storage pits $531,545-550$

storehouses 33, 441, 545

Strabo 55, 61, 68, 73, 114, 209, 259, 271, 350, 383-387, 471

strategos (military/civil governor) 29, 34, $40,73,230,411,485$

Strauch, I. 443

Struve, V. V. 601,606

stūpa (monument for housing relics) 115, 397 , 401, 433-435, 441, 452, 457-458, 644

subsistence $62,118,200,392,431,446,523$, $643,651,657$

- economy 707,710

- farming 523, 678

substantivism 706

Successors (diadochi) 17, 26, 35, 44, 98-99, 287, 401

- Wars of the Successors 22-24, 26-27, 44, 55

Śunga dynasty 69, 102, 105

superintendent for agriculture, see da sinong superintendent for trials, see tingwei 
supreme commander, see taiwei

Sūrens 224

Surkh Kotal 82-83, 402, 410

Surkhan Darya 403-404

surplus, see production

Susa 36, 113, 230, 482, 487, 491

Suvarnabhūmi 120

svadharma (personal duty) 430

Swat 73, 95, 117, 403, 405

syncretism 28, 71, 676, 681

Syr Darya, see Jaxartes

Syracuse 37

Syria 2, 15, 19, 21, 25, 34, 38, 45, 47-48, 115 , 213, 216, 251, 255, 262, 276-277, 291, 357, 372, 375, 389, 481, 698

Syria and Phoenicia $=$ Coele-Syria/Syria-

Palestine 17, 19, 24-25, 34, 45, 48, 367

Syrian Wars 45

tableware, see also ceramics, 557

Tacitus 243, 253, 283, 350, 490

- Germania 716

Taihang Mountains 131

Taiwan 629, 631-633, 636-637

taiwei (supreme commander) 152

Tajikistan 59, 398, 670, 676-677, 679

Takht-i Sangin 77, 404

Taklamakan Desert, see also Tarim Basin, 131 tally systems

- Chinese tallies (quan) 532, 546, 548, 550551, 636

- tally-sticks in Bactria 73, 407, 413

Tamil, see language

Tamilakam 105-106, 112

Tamraparṇi = Tambapanni = Taprobane, see also Sri Lanka, 107, 114

- valley (Thamirabarani) 106, 114, 436

Tao Xisheng 629-631

Tarim Basin 58-59, 80-81, 129, 131-132, 173, 175-177, 179-181, 184, 390-391, 411, 414, 489, 505, 511, 685

Tarn, W. W. 671-673, 679

taxation (by region) see also land; tribute

- in the Arsakid Empire 216, 228, 483, 485

- in Central Asia 73-74, 408-409

- in early South Asia 136-137, 146, 152-154, 156, 162-164, 172, 184, 423, 428, 430

- in Hellenistic Empires, see also apomoira 15, 35, 39-41, 363, 366

- in Qin and Han Empires 491, 498, 513, 519$520,541-545,550,628,630$
- in Roman Empire 245, 259-260, 262, 264 , 269-270, 277-278, 281, 286, 696, 700, 708,720

taxation (by subject)

- exemption, see also parihära, 30, 136, 269 , 439, 501

- imperial strategy 3-4

- in kind 33, 41, 257-258, 359, 413, 505, 684

- monetary 413, 502

- poll tax 152, 156, 163, 543, 624

- tax farming 367

Taxila 62, 69, 73, 78, 87, 117, 401-402, 405, 407, 410

technology 6, 271

- farming 523, 680

- manufacturing 449

- maritime 119, 452

- military 247

- technological improvement 4, 274, 352, 653

- water 271

teeth 328-331

Temin, P. 326, 708

temple 20, 30-31, 72, 225, 230, 366, 369, 373, 443, 451, 469, 482, 486, 489, 654

tenancy $137,278,314,347,349,363,366$, 523, 627

- royal tenants 32

Terelzhiin Dörvölzhin 201

Termez 77, 85-86, 403-404

terracotta warriors 141,563

terra sigillata, see ceramics

Tetrarchy 254

textiles, see also sericulture; silk, 1, 383, 414, 473, 622, 676, 680, 697

- textile industry 628

Thaplyal, K. K. 661

Thar Desert 20

Theadelphia 365

theater 35, 72

Thebaid (region) 254

Thebes (Egypt) 365

Thebes (Boiotia) 18

Theophrastos 383, 386-387

Theravāda tradition, see also Buddhist, 107, 433, 644

Thessaly 25

'Third Rome' 587

Thompson, D. 367

Thrace 19, 29, 44, 252

Three Excellencies (San Gong) 151-153 
tianguan (Office of the Agricultural Fields) 533, 548

Tianzhu, see also India, 80, 392

Tiaozhi 232, 390

Tiberius 350, 458, 471

Tigranes II 212

Tigris 21, 38, 48, 207

tinai (mythopoetic physiographic division) 113-114, 436-437

tingwei (superintendent for trials) 152, 167

Tiridates (Arsakid king) 210

Tiridates (Armenian king) 214-215

Tirunelveli 447-448

Tiumenev, A. I. 599

Tissa (Sri Lankan king) 109

Tocharians/Tocharoi 56, 383-384

Tokugawa period (scholarship) 619, 622

Tolstov, S. P. 676-678, 681

Tomber, R. 323

tombs, see also cemeteries

- ancient Chinese 140-141, 161, 163, 185, 530-531, 539-545, 557-558, 560, 562, $565-567,569,633,635$

- terrace 199-201

- tombstones 285, 291, 371

Tōyōshi 620, 625

trade, see also exchange; maritime - activity; Silk Road(s); transimperial exchange, 45, $48,118,135,266,363,423,431,489$, $491,646,655,657,662,694,697,701$, 711

- and diplomacy 233, 391, 508-512, 568

- balance of 516-517, 658

- caravan 1, 39, 232, 364, 373, 488-489, 661, 673

- Indo-Roman 106, 116, 119, 252, 256, 286, 443, 449-450, 471, 655, 657-659, 675, 681, 693, 697, 699

- long-distance 231, 450, 480, 491, 654, 669$670,673-674,680,682-688,710$

- maritime 114, 118-120, 232-233, 346, 480, 488-490, 570, 657-659

- routes, see also Dakṣiṇāpatha; Oxo-CaspianCaucasus trade route; Uttarāpatha, 104, 112-113, 117, 119, 230-233, 433, 449, 451, 537-538, 568, 570, 587, 654, 656, 661, 669,720

- tramping/cabotage 323

traders/merchants, see also negotiator, 115 , $119,158,232,258-259,282,349,392-$
393, 410-411, 427, 432, 434-436, 442$443,490,501,504,510,512,656,660-$ 661

- Sogdian 481, 670, 674, 680

- attitudes toward 158, 391, 503, 514, 516, 519,597

Trajan 255, 257, 273, 280-281, 288, 480, 712, 714

transaction records 537

Transbaikalia 200

transimperial exchange, see also exchange long-distance, 232-233, 489, 566-570, 719

transmitted texts

- and the study of Chinese economic history $624,633,635$

- criticism of $512-513,524$

transport 47-48, 258, 358, 366-367, 373, 507, 707

- costs 273, 324-326, 349, 501, 506, 515

Trautmann, T. R. 648

travelers, see also pilgrimage, 103, 112, 115, 162, 443, 661

treasury, see also banks; empire revenue, 456

- of Ai Khanum 63, 67, 72, 74, 408

- Han 503, 507, 517, 546, 623

- in the Kauțilīya Arthaśāstra 109, 111, 423, 427

- Persian 42

- royal (to basilikon) 34

Treatises on the Waterways (Hequ shu, Gouxu zhi) 505-508

tribute $64,67,79-80,82,174,176-177,181$, 229, 391, 408, 428, 515, 517

- in Athenian confederacy 42

trivarga (first three goals of human life) 423 , 431

Tsaram 566

Tungabhadra 447, 656

tuntian (agricultural garrisons) 177, 180, 537, 548

Turchin, P. 198

Tureng Tepe 485

Turfan, see Jushi

Turkmenistan 59, 207, 211, 221, 482, 670

Turks 479

Tuṣāspa 441

Tuscany 349 
Ujjain 87, 119

Ulpian 265, 278

underwater archaeology, see archaeology maritime

Uraiyur 104, 106, 442

urbanization 35-36, 85-86, 98-99, 268, 369, $388,404-405,447,649,651,653-656$ $662,675,710$

- second(ary) 100, 652, 655

Uruk, see also Antiocheia-Ishtar, 36, 230, 486, 705

Ușavadatta 445

USSR (Union of Soviet Socialist Republics), see also economic models; irrigation; Marxism; Orientalism; slavery, 581, 585586, 599, 608

- archaeology in 403-405, 600-602, 607, 609,677

- ancient history in 599, 601-602, 609

- demarcation of Central Asian republics 59, 403, 617, 676

- invasion of Afghanistan 671, 403

- Oriental studies 599, 601, 676-679

- peripherality, in science 602

- republican meta-histories (Central Asia) 676-679

- scientific institutions in 403,599-601,609, 679

- Slavic studies in $600,602,607$

Ust-Al'ma 568-569

Uttarāpatha (northward route) 112-113, 661

Uvarov, A. S. 594

Uvarov, S. S. 593,596

Uzbekistan 59, 398, 404, 670, 676-677

Vakhsh 77, 680

van der Spek, R. 697

Varanasi 447

varṇa (socio-ritual status) 652

Varro 346, 386

vassal kingdoms, see client kings

Vasudeva I 79, 62

Vātsyāyana Kāmasūtra 423, 425, 431-433

ventar/vendar (chiefs, crowned kings) 106, 197

Ventura, J.-B. 644

Vergil 345

Verres 263, 281

Vespasian 255

Via Appia 272

Via Egnatia 272
Via Nova Hadriana 272

Via Nova Traiana 255, 272

victory $29-30,44,46,78,103,106,135,177$, 213-216, 245, 440

Vietnam 119-120, 144, 179

vihāra (monastic residency) 117, 433, 451, 644 vijigișu (the potential world conqueror) 109 , 427

villas 231,344

villages, see settlement

Vima Kadphises 76, 79-81, 396, 682-683

Vima Taktu 79-80, 82, 85-87, 392, 412

Vindolanda 257, 363

Vindonissa 363

vineyard, see wine

virtus (virtue) 245

Voitsekhovich, A. I. 595

Vologases I 215-216, 230

Vologases III 215

Vologases IV 216

Vologases VI 482

Vologesias 230-232, 489

Von Ranke, L. 623

Von Richthofen, F. 698

vyavahära (jurisprudence) 429-430, 441

wages, see also laborers; officials, 423, 428, 431, 486, 491

Wallerstein, I. 710

wangguo (Han kingdoms) 153, 156, 173

Wang Guowei 633-634

Wang Mang 148, 173, 183, 499, 502, 549, 562

Wang Zijin 628

warfare, see also army, victory, 27, 81, 103 , $111,134-135,138,143,170,172,185,197$, 437

Warmington, E. H. 657

Warring States period 133-142, 150, 163, 172, $182,185,518,539,546-547,626,632$

water management, see also irrigation 115 , 141, 372, 441, 448, 491, 505-508, 605, 651-654

Way of the Celestial Masters (Tianshi Dao), 163,173

wealth, see also luxury, $289,348,351,425$, 471, 654, 661, 701, 707

- attitudes toward 437, 502-503

- means of acquiring 345, 430, 503-504

Weber, Max, see also ideal type analysis, 150, 160, 704 
Wei (river) 129, 133, 139, 141, 147, 176, 506

Wei (state of the Warring States period) 137, 139,142

Wei Qing 176

wei/duwei (commandant) 154, 182, 533

weight standard, see standardization

wells 444-445, 654, 711

- find spot of Chinese manuscripts 529, 531, 545-550

Wendi (Emperor Wen of Han) 148, 174, 532, 549

Western Kșatrapas, see also Kșatrapas, 105, 455

Western Regions (Xiyu) 132, 177-176, 179-181, 389-391, 505, 508

- protectorate 78, 179-180, 391

Westernization Movement, see also SelfStrengthening Movement, 619, 621

Westernizer (in Russia) 590

wheat, see also grain, 62, 97, 132, 486, 489, 659,693

Wheeler, M. E. 403, 658, 684, 686, 697, 719

Wilson, A. 241, 699-700

wine $116,336,346,352,414,443,482-484$, 489,490

- vineyards 484-485

Wink, A. 662

women, see also Buddhist - nuns; labor;

Musa, and under individual names, 165 , 364, 469

- economic and social rights of $544-545$

- empresses 148, 152

- princesses 195

- queens 31, 45, 105, 260

wooden manuscripts, see also excavated texts, 185 , 530-532, 537, 543, 545-547, 549- 551, 633-635

wool 486

workshops, see also production

- Han imperial 200, 559-560, 562-564, 566567

- private 559, 563-567, 569

World Systems Theory, see also dependency theory, 710

World War I 598, 717

World War II 601, 717

Wu Ji xiaowei (Wu colonel and Ji colonel) 180181

Wu Pass 131, 141
Wudi (Emperor Wu of Han) 145, 148, 153-154, $157,169,171,174-179,183,195,389,498$, $500-501,509,513,515,532$

Wuhuan 181, 505, 511

Wusun 390

Wuzhuliu, Chanyu 569

Xenophon 344-345

xian (county) 136, 151, 154, 156, 164, 166, 563

Xianbei 149, 181, 197, 201, 511

Xiandi (Emperor Xian of Later Han) 149

xiang (district) 156

Xiang Yu 145, 147

Xianyang 139

xiao (filial piety) 160

Xin dynasty $148-149,173,183$

Xinjiang 59

Xin Shixue (New Historiography) 620-621

Xiongnu 2, 76, 173-181, 184, 509, 511, 517, 570

- origins of 197, 199

Xu Zhuoyun (Cho-yun Hsu) 631-632

Xuanquan 537-538

Xuanzang 81, 644

yabgu (allied prince) 74, 76-78, 669

Yan Mountains 131

Yancai 390

Yangtze (Changjiang) 131-132, 531

Yantie lun (Discourses on Salt and Iron) 197, 513-518, 560

Yaśodhara 431

Yaudheya 102-103

yavana (western people), see also Indo-Greeks; yona, 106, 115-116, 382, 438, 441, 443

Yavana era 58

Yelang 179

Yelle, R. 648

Yellow River (Huanghe) 129, 131-132, 173-174, 176, 180, 506-507

Yellow Turban Rebellion (Huangjin zhi luan) 149,173

yona (western people, Ionians), see also yavana, 69, 115-116, 382

Young, G. 698

Yü, Y.-S. 508, 511, 538

Yuelu Academy collection 541

Yuezhi/Da Yuezhi, see also Kushan Empire; Tocharians, 56, 69, 74, 76-78, 85-86, $175,181,211,384,390,392,669,681$, 686

Yugapurāna 68 
yushi (judiciary scribe) 166-167

yushi dafu (imperial counselor) 152, 167

Yutian 538

Zagros Mountains 21, 231

Zeimal', E. V. 400, 678

Zenon (of Kaunos) 365, 367-368

Zenon (in Bactria) 408

Zenon Archive 365-366

Zeugma-Euphrates 255

Zeus 19, 375
Zhang Qian 175, 179, 232, 389-391, 393, 489

Zhangjiashan 164, 168, 541-544, 635-636

Zhao Gao 144-145

zheng shi (standard histories) 389, 498-513, 621

zhou ('region') 154

Zhou (period) 129, 133-142, 626, 632

Zoroastrianism 82-83, 224-225, 396

Zoumalou 531, 549-550

Zouyan shu (Book of Submitted Doubtful Cases) 168 